\title{
Abrahão Sanovicz: o projeto como pesquisa
}

\section{Volume 1}

Helena Aparecida Ayoub Silva

Tese apresentada à Faculdade de Arquitetura e Urbanismo

da Universidade de São Paulo para obtenção de grau de Doutor.

Orientador: Prof. Dr. Eduardo de Almeida

São Paulo, 2004 

Diva.

Eduardo, Marcelo e Roberto. 
AUTORIZO A REPRODUÇÃO E DIVULGAÇÃO TOTAL OU PARCIAL DESTE TRABALHO, POR QUALQUER MEIO CONVENCIONAL OU ELETRÔNICO, PARA FINS DE ESTUDO E PESOUISA, DESDE QUE CITADA A FONTE.

ASSINATURA:

E-MAIL: lena.ayoub@uol.com.br

Silva, Helena Aparecida Ayoub

S586a Abrahão Sanovicz: o projeto como pesquisa - Vol I / Helena Aparecida

Ayoub Silva. - São Paulo, 2004.

Volume 1: il.

Tese (Doutorado) - FAUUSP.

Orientador: Eduardo Luiz Paulo Riesencampf de Almeida.

1. Arquitetura moderna - Brasil 2. Sanovicz, Abrahão Velvu,

1934-1999 I. Título

CDU $72.036(81)$

Capa: Reprodução da prova escrita apresentada por Abrahão Velvu Sanovicz para o Concurso de

Livre Docência do Departamento de Projetos da Faculdade de Arquitetura e Urbanismo da

Universidade de São Paulo, realizado em 1997 e reprodução de desenho de Abrahão Velvu Sanovicz. 


\section{Agradecimentos}

Ao Eduardo de Almeida, meu orientador, pelo apoio e incentivo constantes.

Aos professores Rebeca Scherer e Arnaldo Antônio Martino, pelos comentários durante o exame de qualificação.

Ao Julio Roberto Katinsky, pelos esclarecimentos e incentivo.

À Diva Sanovicz, à Lucia Suane, ao Nachman Falbel ao Edson Elito, ao João Honório de Mello Filho e ao Paulo Mendes da Rocha, pelo apoio.

Aos bibliotecários e funcionários das diversas bibliotecas consultadas, pela acolhida e auxílio inestimáveis.

Ao Atílio Brunacci pela cuidadosa revisão do texto do Volume 1.

À Ana Carolina Corberi Famá Ayoub Silva, Gustavo André Jorge Rodrigues, Gustavo Madalosso Kerr, Igor Dias Rogovschi,
Mayra Aquino Ferreira, Sabrina Studart Fontenele e Thiago Corberi Famá Ayoub Silva, pela dedicação e apoio.

Ao Dailson de Jesus Alves pela dedicação, apoio e esmero na execução dos desenhos.

À Camila Lisboa e à Mariana Alves de Souza pelo projeto gráfico.

Aos amigos Aragão Rambelli, Dirceu Furquim, Lélio Bittencourt, Mauro Magliozzi, Milton Norio Sogabe e Mirela Geiger de Mello pelo incentivo, proveitosas conversas e sugestões.

Aos colegas, professores da FAUUSP e da Anhembi Morumbi, pelo privilégio do convívio e do debate cotidiano.

Por fim, ao João Roberto Rodrigues, meu companheiro, pela presença, leituras e discussões. 

de arquitetura e sua atuação como professor, permite identificar em seus projetos, aquela que foi sua principal tese: o projeto como pesquisa.

Abrahão, nascido em Santos SP, em 1933, formou-se arquiteto, em 1958, pela Faculdade de Arquitetura e Urbanismo da Universidade de São Paulo, onde foi professor de 1962 a 1999, atividade que exerceu até os últimos dias de sua vida.

Ao estabelecer as determinações que orientaram o arquiteto a cada obra analisada; ao explicitar as condições e reflexões que o levaram à realização das propostas; ao investigar o que há de comum, permanente ou essencial na postura de Abrahão Sanovicz quando elabora seus projetos; e, ainda, ao investigar como ocorreu a síntese dos conhecimentos na invenção do objeto - a arquitetura; busca-se a compreensão da totalidade do processo de elaboração do projeto. 

his work in architecture and his performance as professor, allow us to identify among his projects the one that was his main proposition: the project as a research.

Abrahão was born in Santos (SP) in 1933, he graduated as bachelor in Architecture in 1958 by the Faculdade de Arquitetura e Urbanismo in the Universidade de São Paulo, where he worked as professor from 1962 until 1999, work he performed untill the very last days of his life.

Through the establishment of the procedures that would guide the architect for each work analysed; clarifying the conditions and reflections that conducted to the accomplishment his proposals; investigating the common grounds, enduring or essential in Abrahão Sanovicz's attitude when creating his projects; and moreover, through the investigation of how the synthesis of all knowledge in the creation of the object - the Archictecture; we will search a wide understanding of the whole elaboration process of the project. 



\section{Sumário}

Introdução

Formação

Projetos

Docência

Conclusão

Referências Bibliográficas

Bibliografia
01

07

63

271

289

295

303 

Introdução

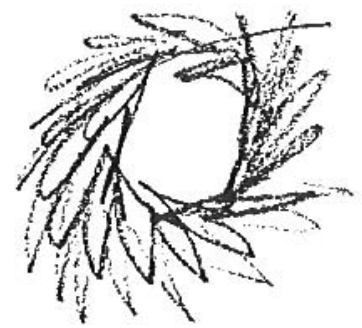



A sistematização da prática na arquitetura como forma de produzir novos conhecimentos tem sido uma preocupação constante em todas as épocas.

A evolução dos conhecimentos científicos e tecnológicos fez com que a maioria dos campos disciplinares, que correspondiam a práticas profissionais, ampliasse a reflexão sobre seu fazer. Possibilitou a criação de instrumentos conceituais que, além da função explicativa, colocavam novas questões: a relação entre a prática e a teoria (operacionalidade) e a relação entre a ética e a prática (legitimidade).

Tal realidade teve importante conseqüência no desenvolvimento do saber arquitetônico, muitas vezes recorrendo-se a disciplinas aparentemente estranhas ao seu próprio fazer (semiótica, teoria geral dos sistemas, ciências cognitivas, cibernética, informática, entre outras) para sua explicação e aprofundamento.

Tais constatações orientaram a escolha inicial do tema de pesquisa para o programa de doutorado: "A Questão do Método na Arquitetura".

O objetivo era aprofundar os temas levantados e discutidos no programa de mestrado, entendendo que a "pesquisa é sempre a mesma", ou seja, aquela que complementa a formação do professor de projeto e realimenta sua atuação profissional.
Em abril de 1999, época da inscrição para o doutorado, sob a orientação do professor Dr. Abrahão Velvu Sanovicz, procurava-se aprofundar a discussão do método na arquitetura, a partir da análise de projetos e obras da arquitetura contemporânea brasileira. A idéia era revelar os processos percorridos pelos arquitetos na realização dessas obras.

Todavia, o orientador faleceu e a pesquisa sofreu uma pequena alteração no que se referia ao seu objeto. Definiu-se um novo recorte: a questão do método seria enfocada a partir da análise da obra do arquiteto e professor Abrahão Sanovicz, e não mais versaria sobre obras da arquitetura contemporânea.

Com efeito, a importância de sua contribuição profissional pode ser aquilatada pelos seguintes valores: o seu intenso comprometimento com formação de gerações de arquitetos; o volume de produção e inovação nos campos da arquitetura e do desenho industrial; e a preocupação no registro de suas certezas e convicções. Aquilatada também, pela conduta atuante nos órgãos representativos dos arquitetos, principalmente o Instituto de Arquitetos do Brasil.

Na realização da pesquisa, um novo enfoque pareceu-nos mais apropriado: uma questão que Abrahão sempre defendeu passou a ser assumida como tema do doutorado: "o projeto como pesquisa". 
Acrescente-se a essa questão o pressuposto de que o projeto de arquitetura seria aqui tratado na justa medida de seu comprometimento social e, consequentemente, histórico. Aliás, nosso ex-orinetador assim ensinava:

O projeto, em geral, é demonstração e exercício da soberania. É através dele que podemos contribuir para racionalizar os caminhos para o desenvolvimento, o que só poderá ser alcançado através do contínuo exercício profissional dos técnicos brasileiros. Este cuidado com o projeto nada mais é do que a visão histórica, com a devida antecipação, do desejo de equipar nossas cidades (edificações e urbanização), nossa paisagem (estradas, pontes, viadutos, planos regionais) com obras esteticamente belas, programática e tecnologicamente funcionais, para que nossas cidades e seus entornos se tornem agradáveis para o uso e a vida (SANOVICZ, apud Katinsky, 1983, p. 945)

Dessa maneira, a análise dos processos percorridos por Abrahão para a realização de seus projetos servirão de ponto de partida para serem identificados os elementos que confirmam os estudos materializados na presente tese.

A análise do percurso que baliza nosso estudo pode ser aqui sintetizada nas seguintes propostas: estabelecer as determinações que orientaram o arquiteto a cada obra analisada; explicitar as condições e reflexões que o levaram à realização das propostas; identificar o que há de comum permanente ou essencial - na postura de Abrahão Sanovicz quando elabora seus projetos; e, ainda, investigar como ocorreu a síntese dos conhecimentos na invenção do objeto a arquitetura. Em suma, busca-se a compreensão da totalidade do processo de elaboração do projeto.

Esse processo é aqui abordado da mais ampla maneira, posto que incorpora sua formação e contribuição didática à análise da sua atividade de profissional do projeto. Não há como tratar um dos temas sem o entendimento dos outros.

Cabe salientar que a questão do "projeto como pesquisa", ou seja, a pesquisa em arte e em arquitetura, tem sido objeto de estudo de diversos autores. Assim é que há quem coloque a prática do projeto como método próprio de investigação e produção de conhecimento em arquitetura, como, por exemplo, constatamos nas palavras do professor José Cláudio Gomes:

O objeto é o projeto. Isto é: o operar artístico. O fazer de arte. Nem é a reflexão "sobre" o projeto, ou "a respeito", mas a própria fabricação de algo que, ao se constituir, reflete sobre o objeto constituído: sobre o projeto. Portanto, o objeto da pesquisa em projeto não pode ser algo que Ihe seja externo ao próprio ato projetual (GOMES, 1990, p. 29).

O professor Arnaldo Martino, por sua vez, em texto avulso, preparado para discussão pelo Grupo de Disciplinas de Projeto de Edificações do Departamento de Projetos da 
Faculdade de Arquitetura e Urbanismo da Universidade de

São Paulo, argumenta:

O projeto elaborado com intenção criadora, percorre em seu caminho a indagação, o questionamento, o entendimento, a escolha, a proposta e a formalização das idéias enquanto expressão artística. Estes caminhos, embora pautados por sistematizadas metodologias, envolvem grande número de dados e de novas situações e têm seus percursos dificilmente repetidos. Cada caso, cada projeto em Arquitetura pode revelarse um fato novo. A ação de projetar, a obra realizada, geram novos conhecimentos, que se acumulam como experiência e base para outros projetos. Então, o projeto assim desenvolvido, isto é, simultaneamente ao objetivo da obra, tem por finalidade a descoberta de novos conhecimentos e enquanto processo (contínuo, plural, etc.) em arquitetura. Deveria ser compreendido como uma das suas formas mais importantes e legítimas de pesquisa. (MARTINO, 1985, s.p.)

Abrahão Sanovicz sempre compartilhou essas idéias, que ficaram consignadas em textos, entrevistas e, até, na maneira como deixou organizado seu acervo de projetos.

Ao pressuposto baseado no comprometimento social e histórico que integra a carreira profissional de Abrahão, podemos acrescentar ainda como principal justificativa do presente trabalho: o empenho em explicitar, na obra do arquiteto, a unidade da teoria com a prática, no domínio da elaboração do projeto de arquitetura, visando o ensino, a formação e a atuação profissional.
O trabalho é constituído por dois volumes.

O primeiro, a tese, desenvolve-se em três capítulos:

- Formação: são apresentados aspectos relativos à sua formação, a partir da reflexão do significado da exposição da obra de Sanovicz realizada na Faculdade de Arquitetura e Urbanismo da Universidade de São Paulo - FAUUSP em 1997.

- Projetos: foram selecionados e analisados os projetos considerados mais significativos no sentido de melhor exprimir a tese "o projeto como pesquisa".

- Docência: de sua carreira docente foram identificadas suas principais preocupações. Encerra o capítulo o relato sobre a exposição final comemorativa do cinqüentenário da FAU, que teve como curador Abrahão Sanovicz.

O segundo volume reúne documentos que deram suporte à pesquisa e que complementam as reflexões apresentadas na tese. 



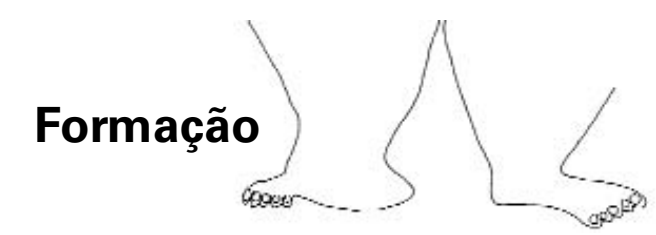

O aprendizado da arte

Pássaro da Liberdade

O aprendizado da arquitetura 


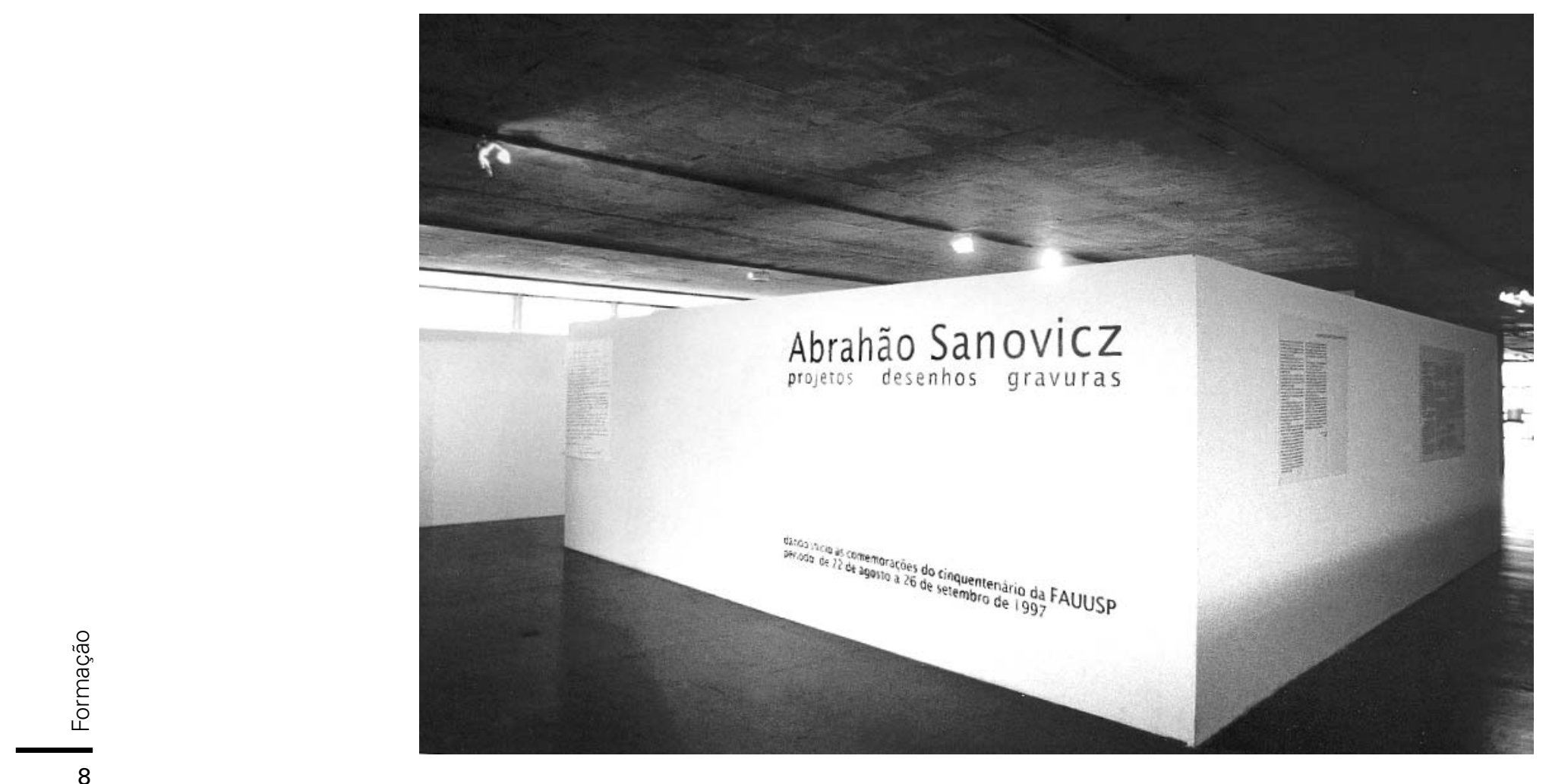


Por iniciativa dos alunos do Grêmio da Faculdade de Arquitetura e Urbanismo - GFAU, foi realizada na Faculdade de Arquitetura e Urbanismo da Universidade de São Paulo FAUUSP a exposição da obra do professor Abrahão Velvu Sanovicz.

Foi o primeiro dos eventos comemorativos do cinqüentenário dessa Faculdade. Sua realização teve o apoio da Associação dos Ex-Alunos e da Diretoria da FAUUSP.

Os textos da professora Odiléa Toscano e do professor Eduardo de Almeida, registrados a seguir, nos relatam alguns traços da arte do professor Abrahão. Eles foram extraídos do catálogo que apresentava a referida exposição.

Relata-nos a professora Odiléa:

FAU Maranhão: formandos de 1958

Não éramos apenas uma classe, mas uma família permitida pelo número restrito de alunos.

Todos desenhávamos - que futuros arquitetos devem ser, de alguma forma, desenhistas - mas alguns de nós trabalhávamos para além das tarefas da escola ...

Criamos os "artistas de domingo," e a mania de rabiscar já fazia parte de nosso cotidiano.

Abrahão seguiu quase que sistematizando esse saudável hábito e, em conseqüência, temos aí os "desenhos de reunião, nenhum tempo perdido".

Passando das figuras humanas e nus, dos registros de vegetação, ao desenho do arquiteto inventando espaços $e$ explicando outros, Abrahão imprime sua visão vigorosa e 
singular dos temas que o preocupam. Seu traço gestual colorido e livre vai organizando objetos e temas com fluência e generosidade, sem economia.

A despeito da unidade que caracteriza seus desenhos, permitem uma classificação - embora flexível - por temas, escala, maneira de direcionar os gestos e criar tensões e mesmo pela subjetividade de alguns deles.

Escolher desenhos para essa mostra foi tarefa complicada de um tirar e por mais complicado ainda. Os alunos se encarregaram dela. Ajudei pouco.

É olhar, decifrar e fruir (TOSCANO, O., 1997).

Professor Eduardo, por sua vez registrou:

A obra de Abrahão Sanovicz fala de todos nós, colegas da FAU e arquitetos formados nos anos 50 em São Paulo, embora talvez nenhum outro arquiteto daquela geração tenha manifestado com seus projetos um compromisso tão forte com a cultura brasileira (presença de Mário de Andrade...) e uma disciplina tão rigorosa no exercício do "ato de projetar". Trabalhando e pensando como um arquiteto de nosso tempo ele questiona seu papel na História, povoando seu universo de referências essenciais: Breuer, Mies, Wright, Terragni, Lúcio (Costa, é lógico), Oscar (mais ainda Reidy e outros "cariocas"). Artigas (respeitosamente) e muito, mas muito Le Corbusier. E ainda Picasso, as gravuras de Segall, os "Stabile" de Calder. Completam o quadro, suas preocupações com as questões do design, (que aprofundou com Nizzolli em Milão), e da comunicação visual (com Buffoni em São Paulo). Alimentando esse universo com sua sensibilidade e seu conhecimento teórico e técnico, Abrahão Sanovicz realiza uma arquitetura forte, coerente, precisa e admirável, não apenas pela sua obstinação em evitar os "efeitos especiais", a grandiloqüência o discurso vazio mas, principalmente pelo rigoroso cuidado em trabalhar com o desenho da construção do espaço, elevando-o a nível da verdadeira obra de Arte (ALMEIDA, E., 1997)
Exposição Abrahão Sanovicz - 1997

FAUUSP | Salão Caramelo

vistas gerais

oto: Cândida Maria Vuolo
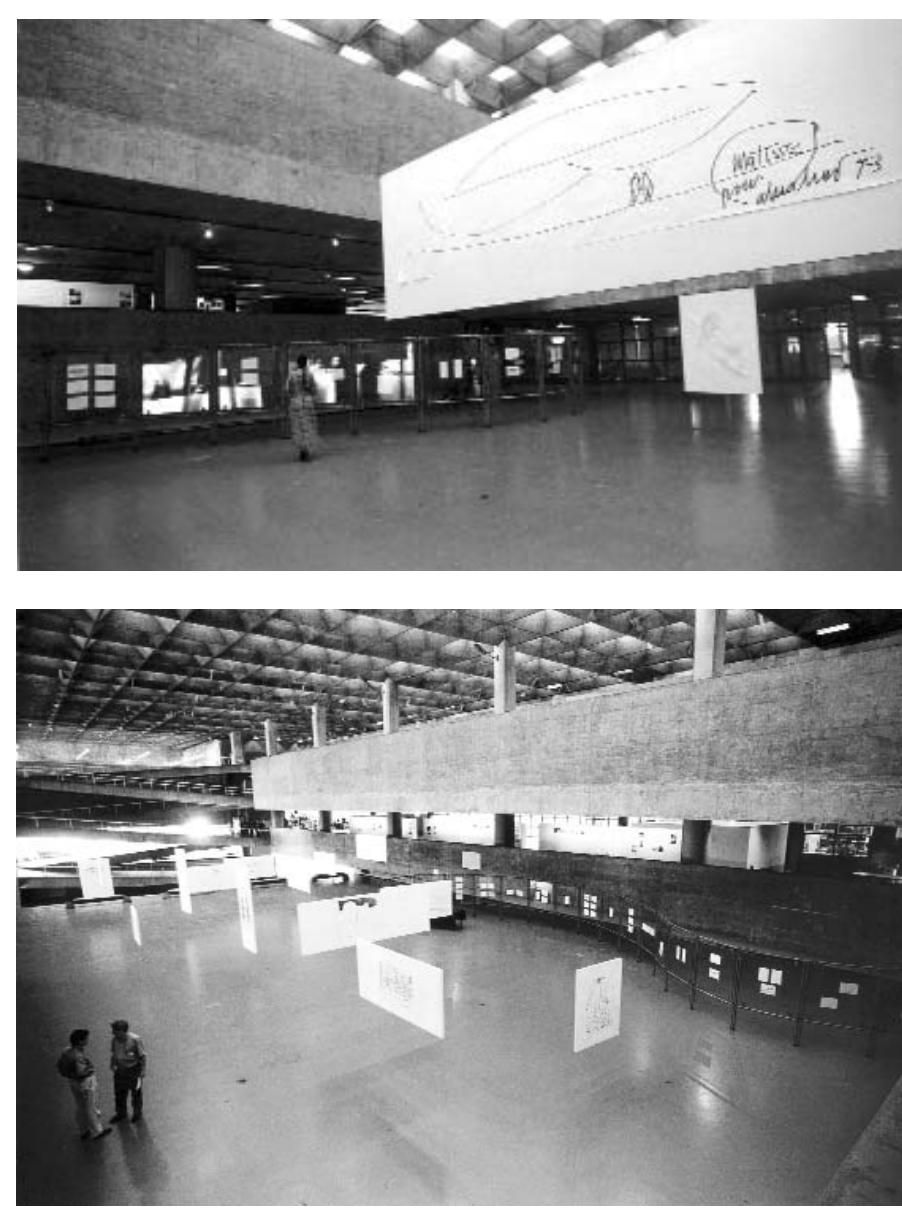

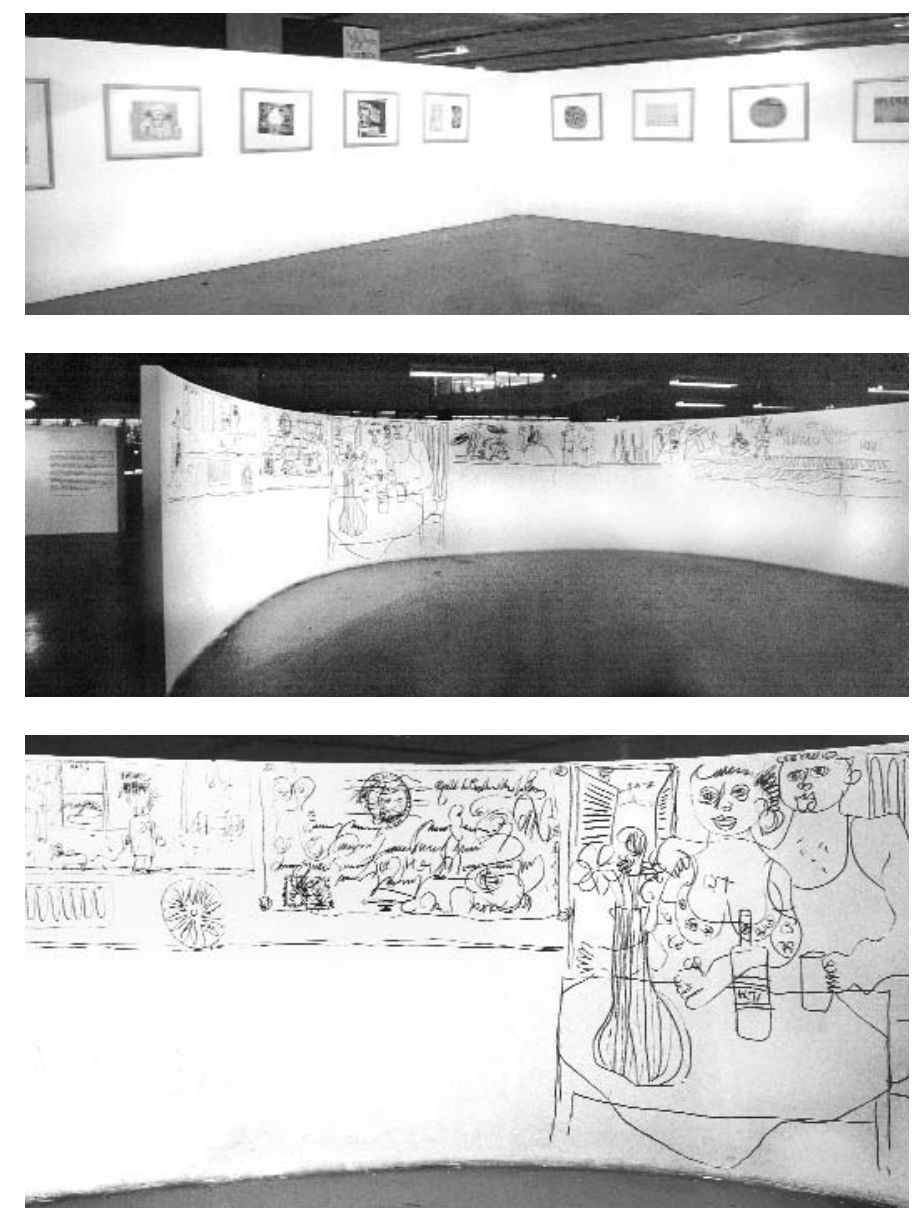

A escolha feita pelos alunos foi a mais apropriada, já que, sem dúvida, identificaram quem tão bem poderia representar a Escola, pela diversidade de sua atuação.

Com efeito, a organização espacial proposta por Abrahão Sanovicz e equipe de alunos foi a que melhor interpretou o espaço - e dele se apropriou - do prédio projetado por João Batista Vilanova Artigas para a Faculdade. Reforçando sua continuidade espacial, criou espaços apropriados para discussões sobre os projetos fixados nas paredes brancas; conformou "salas tradicionais" onde eram expostas as gravuras; fez no Caracol um painel onde desenhou "cenas do dia a dia" e da vida na FAU; montou uma parede transparente e sinuosa, no Salão Caramelo, junto à empena do Museu onde estavam, no dizer de Odiléa Toscano, "os desenhos de reunião - nenhum tempo perdido"; e, os "desenhos de figuras humanas, nus e registros de vegetação" que, ampliados ao máximo, foram fixados sobre grandes painéis brancos pendurados na grelha da cobertura, dando ao Caramelo uma nova escala. 


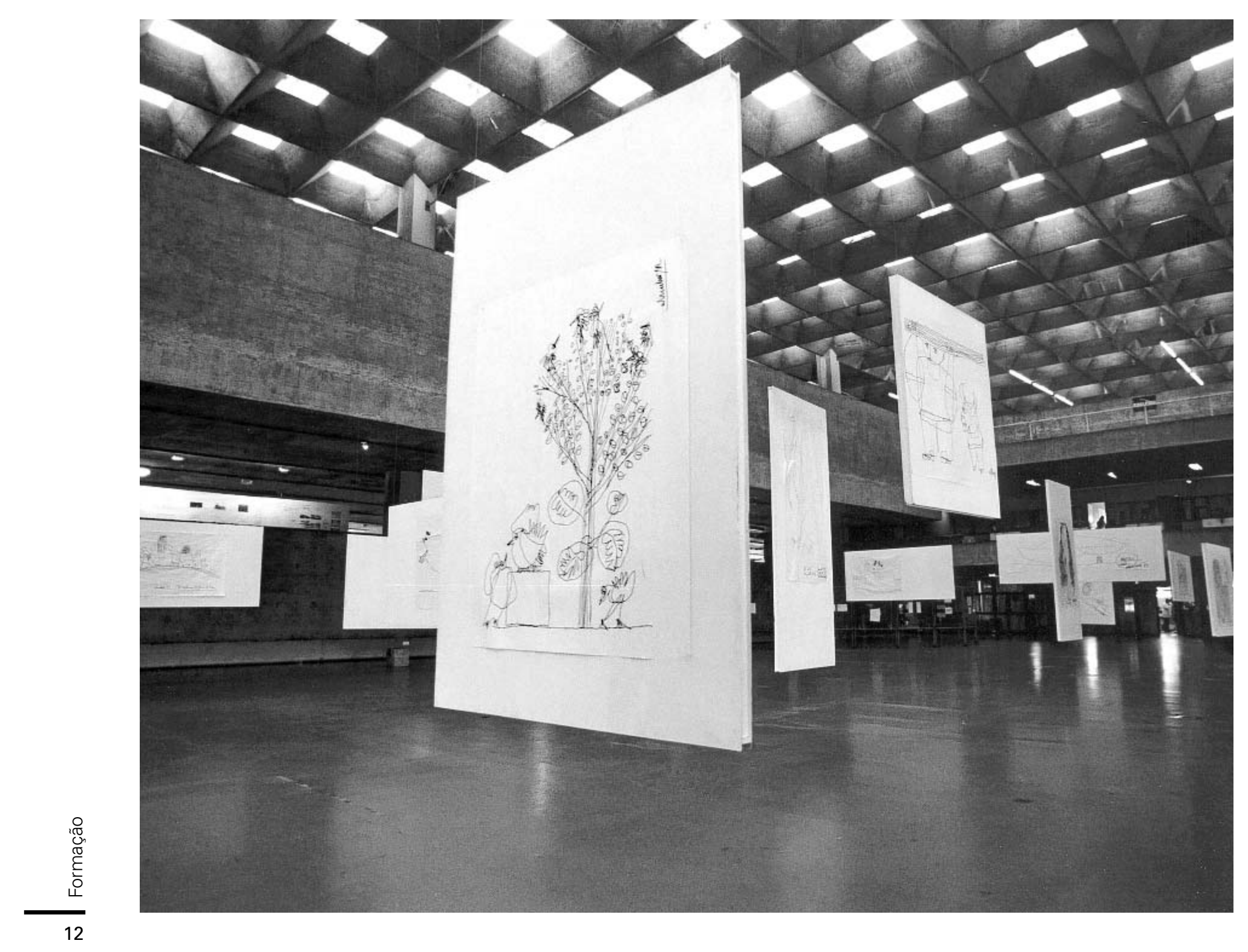




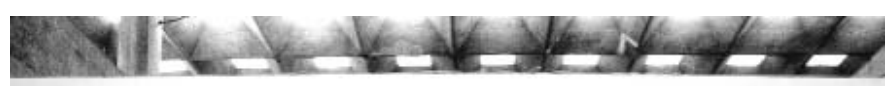
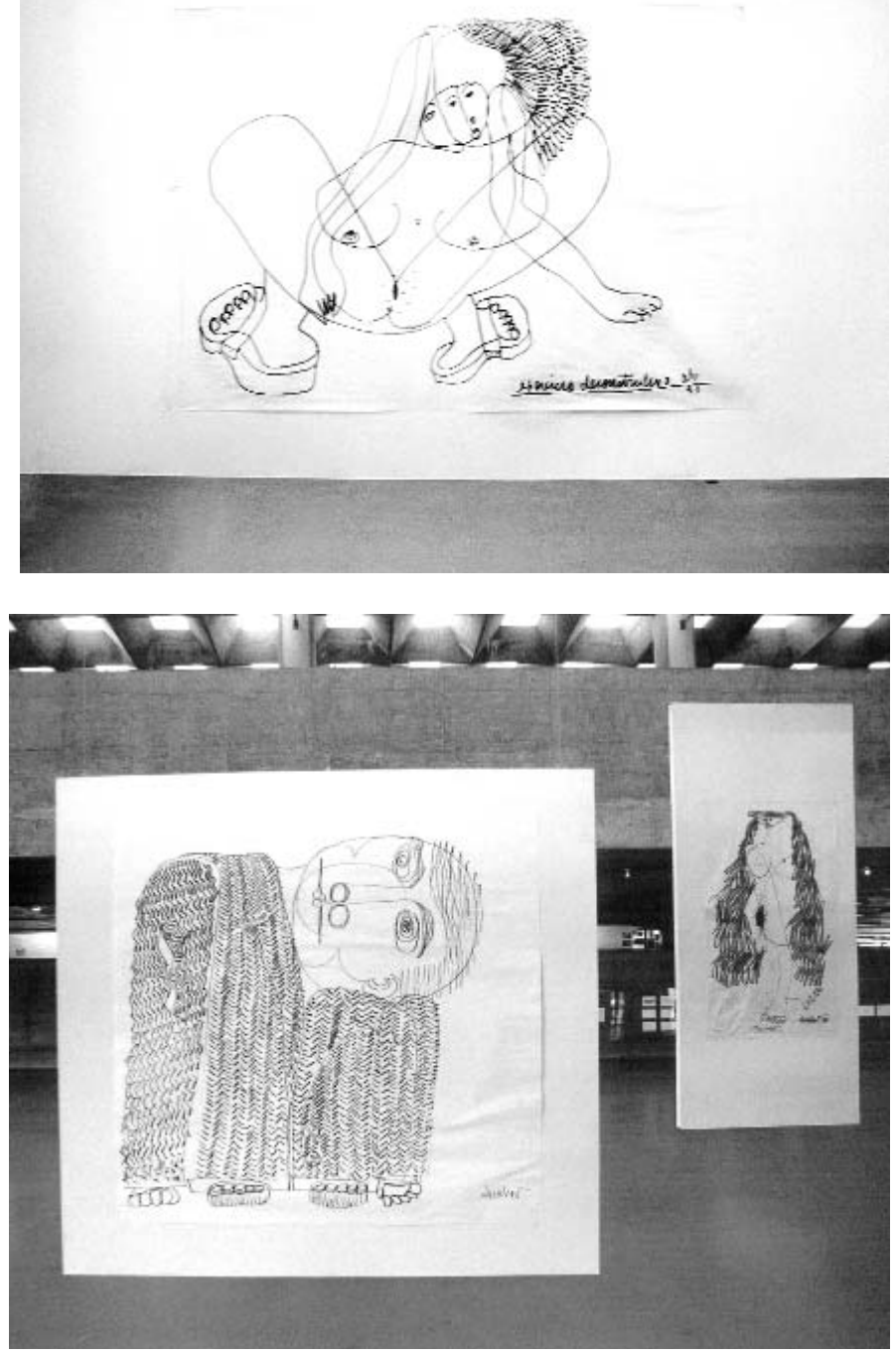
Exposição Abrahão Sanovicz - 1997

FAUUSP | Museu

foto: Cândida Maria Vuolo
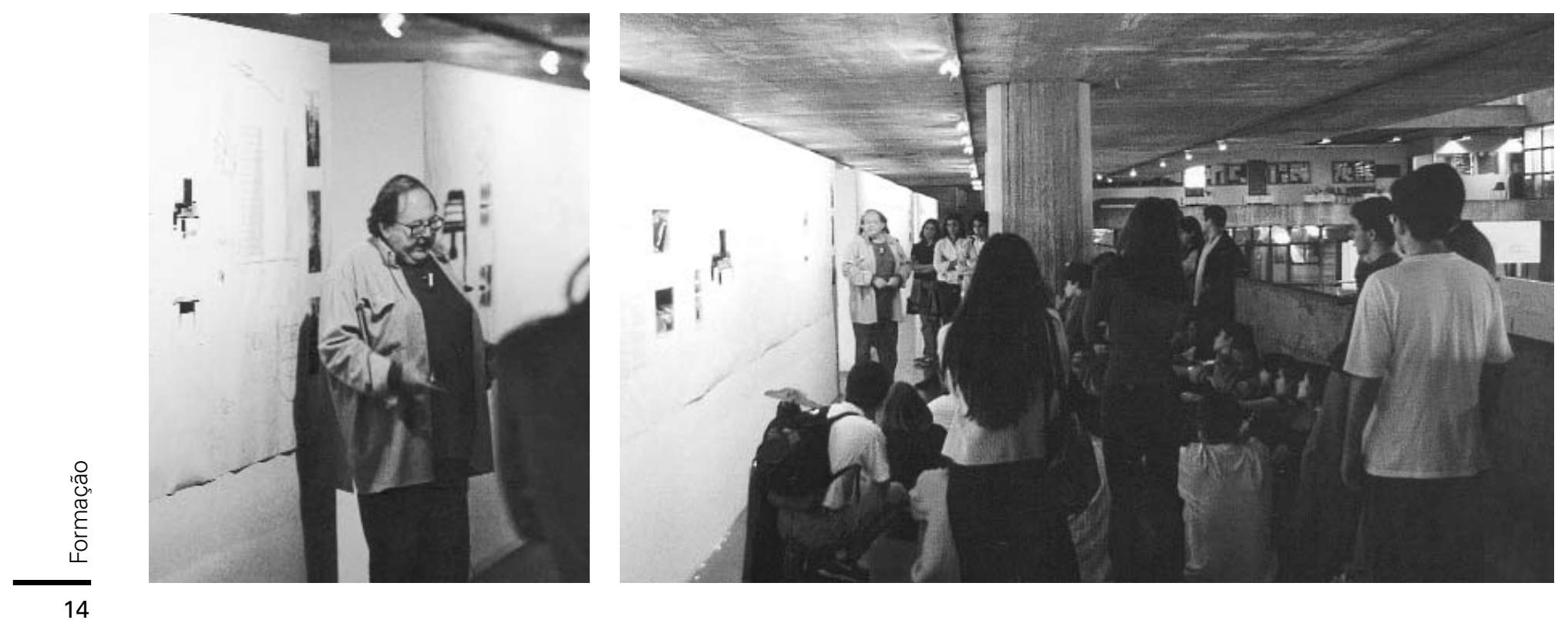


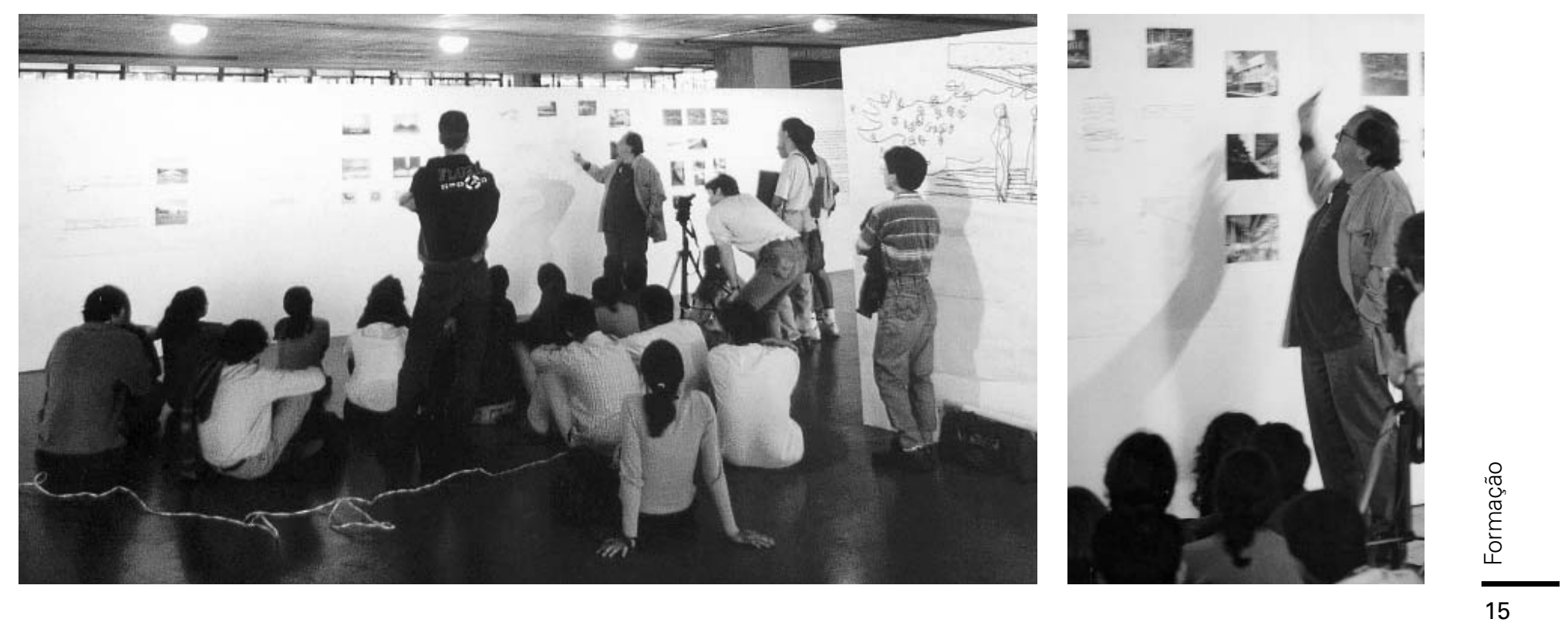


Com esse projeto para uma exposição, a equipe idealizadora reafirmou as intenções de Vilanova Artigas para a FAU, cuja essência Miguel Antonio Buzzar, em sua dissertação de mestrado sobre a obra de Artigas no período entre 1938 e 1967, toma emprestado de Manfredo Tafuri:

[...] a arquitetura, pela sua própria natureza, permite já aquela tomada de consciência por parte da coletividade, que Brecht exigia ao seu público: uma fruição que consinta o relaxamento e a reflexão por parte das pessoas interessadas na realização cênica. Isto é arquitetura, cidade e teatro épico pretendem todos uma extrema transparência dos processos que conduziam à sua elaboração, para os revelar a quem acompanhe com distanciação as suas narrações (TAFURI,

1979, apud BUZZAR, 1996, p. 117).

Aliás, a obra de Abrahão Sanovicz, cobrindo quase quatro décadas de atividade profissional nos campos da arquitetura, do urbanismo, do desenho industrial, na comunicação visual e nas artes plásticas, é, inegavelmente a expressão do profissional que sempre se desejou formar na FAUUSP.

A trajetória desse arquiteto é permeada de inquietações que remontam à sua adolescência.
Perspectiva Vila Residencial Porto Primavera

fonte: acervo biblioteca da FAUUSP

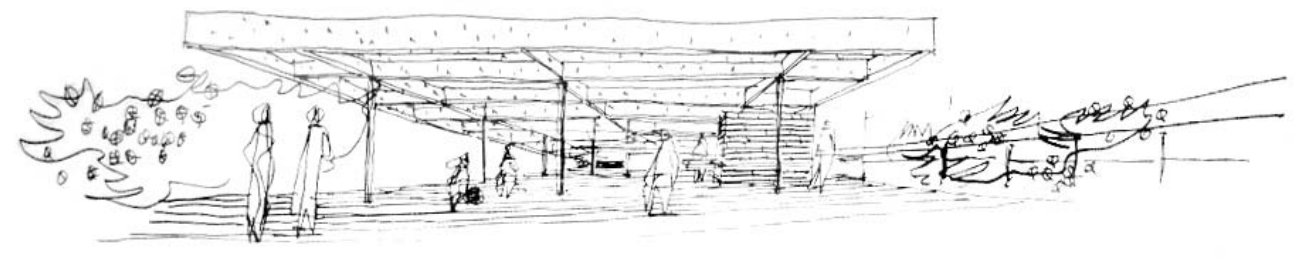


Abrahão Sanovicz nasceu em Santos em 1933, no bairro de Vila Mathias, onde viveu até os 17 anos.

Enquanto cursava o ginásio, estimulado pela família freqüentou um curso de desenho técnico e trabalhou em um escritório de desenho, onde teve seus primeiros contatos com a arquitetura.

Nesse escritório, era responsável pelas aprovações de projetos. Com isso, era obrigado a ir freqüentemente a São Paulo para verificar os processos junto ao Departamento de Engenharia Sanitária da Secretaria de Saúde do Estado. Aproveitava as viagens para visitar as exposições de arte e arquitetura que aconteciam no Museu de Arte São Paulo MASP.

Em 1950, tendo completado o ginásio, muda-se para São Paulo a fim de freqüentar a Escola Técnica Federal, curso de técnico em edificações - equivalente ao antigo científico com vistas ao vestibular em arquitetura. Acreditava que, cursando a escola técnica, poderia, em suas palavras, "queimar etapas" na faculdade.

$\mathrm{Na}$ oportunidade de uma série de entrevistas concedidas a Catharine Gati, pesquisadora do Centro Cultural São Paulo - CCSP, entre 1987 e 1988, Abrahão declarou:
Em Santos, já conhecia as revistas "Acrópole" e "Habitat", e também a obra de Niemeyer, que já naquela época (final dos anos 40), trazia todo esse carisma próprio dele (talvez, não fosse bem compreendido, mas já despertava a sensação de ser alguém que apresentava uma qualidade muito especial). Ele havia projetado a Pampulha, o Pavilhão da Feira de Nova York, além de outros projetos. Foi, enfim, quando eu conheci as primeiras obras modernas. Santos contava com alguma coisa moderna sendo construída. Assim, o que me chamou mais a atenção foram duas casas do Artigas, uma na ilha Porchat e outra na rua Castro Alves (isso, talvez, me tenha influenciado até hoje, a casa que projetei para mim, por exemplo, é justamente uma casa-caixote). Na ilha Porchat, havia também duas casas projetadas por Oswaldo Bratke. Como jovem, tinha toda essa inquietação e acompanhava tudo isso com muito interesse, as publicações, o que se construía etc. Essa aproximação com a arquitetura se deu quase naturalmente (DPCA, 1987 - 1988)

A vivência em ambientes e eventos artísticos que ocorreu nesse período não só foi decisiva na formação do arquiteto Abrahão Sanovicz, como também, e ao mesmo tempo, alimentou uma inquietação que o marcou definitivamente, como confessou na referida entrevista:

"Apesar de sofrer uma grande dúvida a vida inteira entre seguir a vida de artista (ou seja, pintor ou desenhista) ou fazer arquitetura, acabei me definindo pela arquitetura" (DPCA, 1987 - 1988) 


\section{O aprendizado da arte}

O interesse pela arte levou Abrahão Sanovicz a procurar, no ano de 1952, a recém-criada Escola de Artesanato do Museu de Arte Moderna de São Paulo - MAM. Concorreu a uma vaga como bolsista cuja obtenção permitiu freqüentar o curso à noite.

Ainda em entrevista com Catharine Gati, discorreu sobre a vida em São Paulo no período:

Na época, anos 50, São Paulo era uma maravilha, tinha uma escala ótima, com seus quase 3,5 milhões de habitantes. Já era uma metrópole, já não tinha mais a garoa, mas o movimento cultural era muito intenso: os novos museus, Museu de Arte Moderna MAM e Museu de Arte São Paulo MASP; a primeira Bienal; a criação da cinemateca. Era uma ebulição artística: as revistas estimulavam polêmicas sobre arte.

A vida cultural girava em torno da Praça da República.

Muito de arte se produziu no período, novas escolas, o grupo concreto, os tachistas, o rebatimento aqui das discussões que aconteciam nas escolas européias.

Acredito que esta explosão tenha sido preparada, e sempre encontramos, de alguma forma, a figura de Mario de Andrade envolvido nessas manifestações (DPCA, 1987 - 1988).

Resgatar o histórico da constituição da Escola de Artesasalientado na citação, e que remonta à criação do MAM.

Paulo Mendes de Almeida, em sua obra De Anita ao
Museu, apresenta como a pré-história do MAM a Semana de Arte Moderna de 1922, "rebelião no terreno das artes e do pensamento", que encontrou ressonância nacional no campo da literatura: "vozes entusiásticas, de início isoladas, se arregimentavam em grupos, deitando manifestos como era de moda, e lançando jornais e revistas" (ALMEIDA, P., 1976, p. 213).

Contudo, no campo das artes plásticas, foi somente em São Paulo que se formaram movimentos coletivos organizados, ainda que, no Rio de Janeiro dois importantes acontecimentos devam ser mencionados: a XXXVIII Exposição Geral de Belas Artes, organizada por Lucio Costa em 1931 - conhecida como o "Salão Revolucionário" ou "Salão dos Tenentes" - aberta pela primeira vez a artistas de orientação moderna; também em 1931, a criação do Núcleo Bernardelli, constituído por jovens artistas que não aceitavam o tipo de ensinamento ministrado pelos mestres da Escola Nacional de Belas Artes. Tidos como a ala moderada do modernismo, entre eles estavam José Pancetti, Milton Dacosta, Joaquim Tenreiro e Yoshiya Takaoka.

\subsection{A Sociedade Pró-Arte Moderna}

Na capital paulista, um desses movimentos organizados resultou na Sociedade Pró-Arte Moderna - SPAM, fundada 
em fins de 1932. Tinha como programa fundamental estreitar as relações entre artistas e "as pessoas que se interessavam por toas as suas manifestações", no dizer de Almeida (1976, p.42). Para tanto, promoveriam exposições, concertos, conferências, reuniões literárias. Instalariam sede social com salão de exposições, sala de leitura e ateliê para os artistas. Um jornal seria criado A Vida de SPAM, com direção de Alcântara Machado, Mário de Andrade e Sergio Milliet.

O quadro dos trinta e nove membros fundadores, compunha-se de representantes de todas as artes, excetuando-se o teatro e o cinema. Eram eles Anita Malfalti, Antonio Gomide, Camargo Guarnieri, Chinita Ullman, Gregori Warchavichik, Guilherme de Almeida, Lasar Segall, Mário de Andrade, Paulo Mendes de Almeida, Paulo Prado, Paulo Rossi Osir Sergio Milliet, Victor Brecheret, Tarsila do Amaral, entre outros.

Para obter fundos a fim de cumprir o programa proposto para a SPAM, realizou-se um baile carnavalesco, em fevereiro de 1933, nos salões do Trocadero, à Rua Conselheiro Crispiniano, denominado "Carnaval na Cidade de SPAM". Com projeto e direção de arte de Lasar Segall, houve a colaboração de muitos outros artistas na confecção da decoração e fantasias. A música ficou a cargo do maestro Camargo Guarnieri. O convite, desenhado por Segall, contou com versos de Mário de Andrade.

O baile divulgou o nome da Sociedade Pró-Arte Moderna, ampliou o quadro social e auferiu renda suficiente para que fosse alugada metade do quinto andar do Palacete Campinas à Praça da República.

Enquanto a sede era reformada, decidiram realizar a Primeira Exposição de Arte Moderna da SPAM, aberta ao público em 28 de abril de 1933, apresentando uma centena de obras. O local escolhido para a exposição foi o piso térreo de um edifício à Rua Barão de Itapetininga, onde hoje se encontra a Galeria Guatapará.

Sobre a exposição, comentou o referido Paulo Mendes de Almeida:

Pode dizer-se, sem exagero, ter sido a mais importante mostra de arte moderna até então realizada em toda a América do Sul. Ali figuraram, ao lado dos artistas da SPAM, peças de grandes pintores e escultores contemporâneos, pertencentes a coleções particulares de São Paulo, notadamente as de D. Olivia Guedes Penteado, Samuel Ribeiro, Paulo Prado, Mário de Andrade e Tarsila do Amaral. Pela primeira vez, com certeza, o grande público via, "em pessoa", um Picasso ou um Léger, um Lipchitz ou um Brancusi. Dos artistas estrangeiros expostos era a seguinte a relação: Lhote, Léger, Picasso, Chirico, Csako, Delaunay, Dufy, Foujita, Gleizes, Juan Gris, Marie, Laurencin, Sara Afonso, Vuillard, Pompon, Brancusi, Lipchitz e Le Corbusier. Como se vê, um razoável acervo, em que aparecem alguns dos principais nomes em evidência no momento. Exibir tal coleção ao publico, constituiu, naquela 
altura, empresa quase temerária, pois que a hostilidade, então existente contra a arte moderna, punha em risco autênticas preciosidades (ALMEIDA, P., 1976, p. 56)

Em agosto desse mesmo ano, inaugurou-se a sede: um grande salão de exposições, de concertos e de conferências; com palco cênico e iluminação apropriada; ateliê, onde eram realizadas sessões com modelo vivo; biblioteca e sala de leitura; secretaria; e bar.

Em fins de 1933, ocorreu mais uma exposição também com grande repercussão, desta vez participaram artistas radicados no Rio de Janeiro: Portinari, Di Cavalcanti, Cardoso Júnior, Guignard, Lechovsky, Octavio Pinto, Rothkirk, Silvia Meyer, Teruz, Zangert e Cecília Meireles.

Todavia, logo a SPAM se encontrou em dificuldades financeiras. Um novo baile de carnaval foi realizado, "Uma Expedição às Selvas da Spamolândia", dessa vez em um rinque de patinação à Rua Martinico Prado, de novo sob os cuidados de Lasar Segall que transformou o espaço numa enorme selva.

A festa restabeleceu as finanças da instituição, mas, D. poucos meses depois, por desentendimentos entre os diretores, foi convocada uma assembléia no início de 1935, declarando extinta a Sociedade.

\subsection{O Clube dos Artistas Modernos}

Contemporâneo à Sociedade Pró-Arte Moderna, surgiu o Clube dos Artistas Modernos - CAM, que tinha como figura central o polêmico arquiteto e artista Flávio de Carvalho. Sabendo que as tratativas para a constituição da SPAM seriam um pouco demoradas, e porque suspeitava que teria um caráter elitista, ele entendeu ser mais prático fundar o CAM em novembro de 1932.

Concorreu para isso o fato de dividir com $\mathrm{Di}$ Cavalcanti, Carlos Prado e Antonio Gomide um imóvel na Rua Pedro Lessa, $n^{\circ}$. 2, junto ao Viaduto Santa Ifigênia, onde mantinham seus ateliês.

Não se limitou a realizar exposições de artes Realizou, da mesma forma, exposições de cartazes soviéticos, de desenhos de loucos e de crianças. Organizou concertos de música moderna, de recitais de cantos populares, conferências e palestras.

Em pouco tempo, o CAM tornou-se ponto de encontro obrigatório para quem estivesse na cidade ou que tivesse algum interesse pelas artes.

Em novembro de 1933 o Clube instalou no térreo desse imóvel o "Teatro de Experiência", com capacidade para 275 espectadores; foi inaugurado com a peça "Bailado do Deus 
"Bailado do Deus Morto" (Flávio de Carvalho) fonte:www.antaprofana.com.br/Grupos 1.2.htm visitada em 12/12/2003

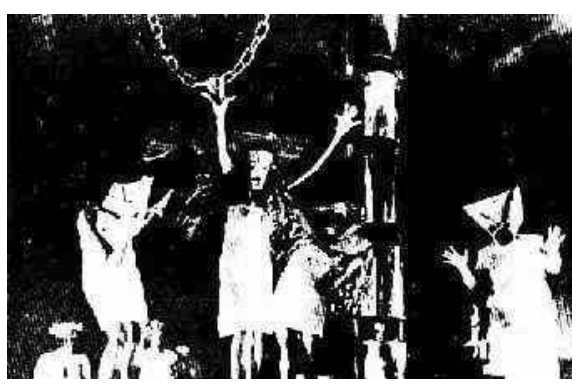

Hotel Esplanada

fonte:www.patrimoniosp.com.br/sampa hotelesplanada.html visitada em 12/12/2003

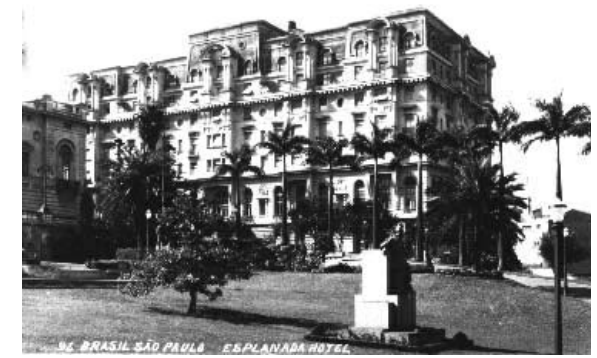

Morto", de autoria de Flávio de Carvalho. Depois da terceira apresentação, o teatro foi fechado pela polícia. Essa intervenção policial gerou protestos de intelectuais, mas sem que houvesse qualquer repercussão.

Tal fato causou sérios prejuízos ao CAM, que se extinguiu logo depois.

Cumpre salientar, no entanto, que a Sociedade Pró-Arte Moderna e o Clube dos Artistas Modernos se completavam, como atestam as palavras de Paulo Mendes de Almeida:

A primeira, um tanto aristocrática, porém mais sólida, mais "séria", no bom sentido da palavra. O CAM, democrático, largado, mas apresentando, indiscutivelmente, uma vivacidade maior. Um grande e vibrante movimento de arte e de inteligência que dificilmente se repetirá (ALMEIDA, P. 1976, p. 84).

\subsection{O Salão de Maio}

Um evento importante para criação do Museu de Arte Moderna - MAM e, conseqüentemente, para a Escola de Artesanato, foi o Salão de Maio. Idealizado pelos cronistas e críticos de arte Quirino da Silva e Geraldo Ferraz, em 1937, foi criado para exibir a produção dos artistas modernos que não tivessem um espaço próprio de exposição.

Realizado no grillroom do Hotel Esplanada, em 25 de 
maio de 1937, o primeiro salão teve expostas obras de trinta artistas brasileiros ou estrangeiros aqui residentes, destacando-se os que depois iriam colaborar com a Escola de Artesanato: Tarsila do Amaral, Nelson Nóbrega e Livio Abramo.

Acompanhando a mostra, foram realizadas várias conferências como de Anton Giulio Bragaglia - fundador do teatro experimental italiano - sobre "As Tendências Modernas da Cenografia", e a de Flávio de Carvalho, denominada "O Aspecto Mórbido e Psicológico da Arte Moderna".

O evento obteve grande êxito e repercussão junto aos meios culturais e artísticos.

Com o Salão de Maio, recolocava-se a discussão sobre a arte moderna versus a arte acadêmica, que dominava o mercado. A segunda edição do Salão aconteceu em 27 de junho de 1938, novamente no Esplanada Hotel. Um catálogo acompanhava a exposição, com textos assinados por Sérgio Milliet, Mário de Andrade, Jorge Amado, Flávio de Carvalho, Lasar Segall e Vittorio Gobbis.

Destaque especial se deveu à presença de artistas ingleses surrealistas e abstratos, como Ceri Richards, Ben Nicholson e Penrose. De igual modo de artistas mexicanos,
Catálogo do $2^{\circ}$ Salão de Maio - 1938

fonte: ZANINI, 1983, p. 584

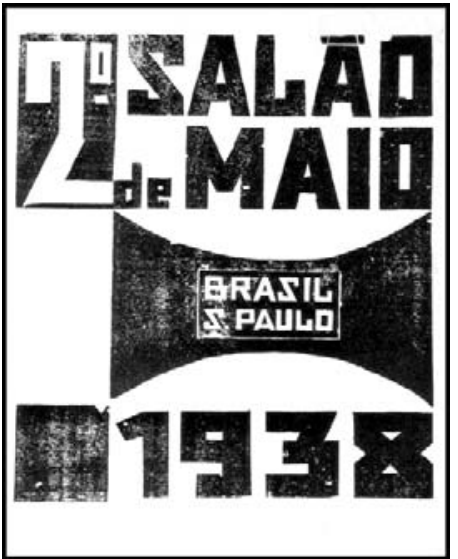


Palacete Santa Helena

fonte: SIMÕES, 1990, p. 26

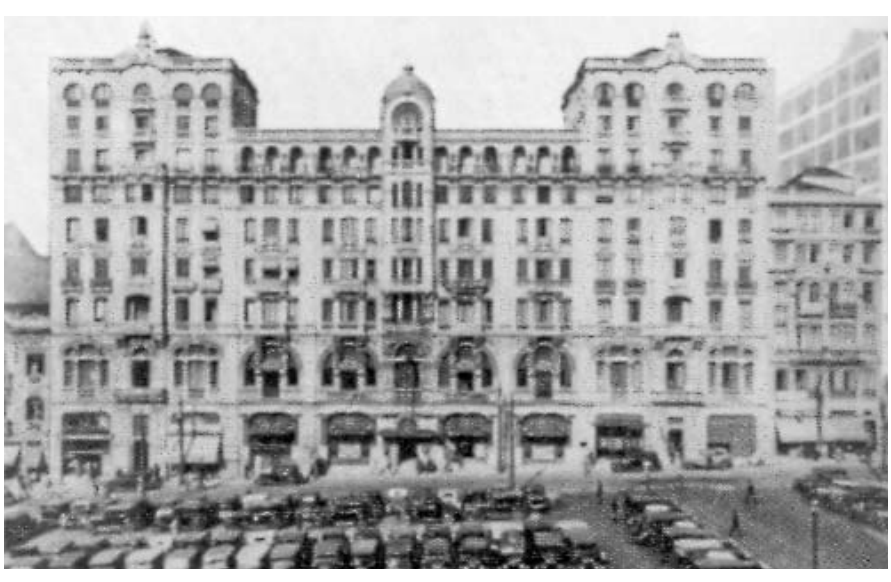

como o gravador Leopoldo Mendez e o pintor Díaz de Leon, além de uma expressiva participação nacional.

O terceiro e último Salão, agora realizado na Galeria Itá, contou com a participação de trinta e nove artistas, incluindo pintores, desenhistas, gravadores e arquitetos. Houve também participação estrangeira, como Alexander Calder, Alfredo Magnelli e Josef Albers.

Para Mendes de Almeida a representação de artistas estrangeiros nos Salões de Maio antecipava-se às futuras Bienais do Museu de Arte Moderna, "justificando-se sua inclusão, sob esse aspecto também, naquela série de movimentos coletivos de irrecusável e inestimável função pioneira e precursora" (ALMEIDA, P., 1976, p. 84).

\subsection{A Família Artística Paulista}

Enquanto se idealizava o Salão de Maio, outro importante movimento acontecia na cidade: A Família Artística Paulista - FAP.

A FAP contou com a participação de vários artistas, dentre os quais os do Grupo Santa Helena.

O Grupo Santa Helena surgiu da união espontânea de alguns artistas que, inicialmente, tinham seus escritórios ou ateliês no antigo Palacete Santa Helena, que foi demolido no 
início da década de 1970 para a construção da Estação Sé do Metro. Lá o grupo desenvolvia diferentes atividades profissionais, mas se organizaram em função do seu interesse artístico. Criaram ali um ambiente de troca de conhecimentos técnicos, sessões de modelo vivo, de organização de excursões aos subúrbios da cidade, nos fins de semana, para pintura ao ar livre. Era onde os artistas discutiam sobre a participação em exposições e salões de arte, ou sobre a remessa de obras para esses eventos. Todavia estavam relativamente afastados do meio artístico da época. Foi com as exposições organizadas pela Família Artística Paulista que o Grupo ganhou visibilidade.

A Família Artística Paulista absorveu a contribuição do modernismo, mas não rompeu com a tradição artística. Demonstrava certa reação ao vanguardismo e experimentalismo - característicos de outros grupos artísticos da época - mas revelava um grande interesse pelo estudo da técnica e pelo aperfeiçoamento do métier. Essa preocupação com o ofício era estimulada pelas figuras dos artistas Paulo Rossi Osir e Vittorio Gobbis que, segundo Mário de Andrade, eram "homens capazes de conversar sobre as diferenças de pinceladas de um Rafael e de um Ticiano e sabendo o que é ligar uma cor à sua vizinha" (ANDRADE, 1971, p. 155). Já para Geraldo Ferraz - um dos idealizadores do Salão de Maio - citado por Leite (1999) eram "tradicionalistas, defensores do carcamanismo artístico da Paulicéia, a morrer de amores pelos processos de Giotto e Cimabue".

Por esta época, Paulo Rossi Osir abre uma empresa de azulejaria, a Osiarte. Com a finalidade de produzir os azulejos desenhados por Candido Portinari para o Ministério de Educação e Saúde, recebia seguidas encomendas de arquitetos e artistas, além de produzir alguns padrões criados por ele próprio. Assim agindo questiona, os comentários de Geraldo Ferraz. Mediante sua preocupação com o aprimoramento do métier, e graças ao seu rigor técnico, viabilizava a possibilidade de um novo meio de manifestação artística. ${ }^{1}$

A Família Artística Paulista realizou três exposições: a primeira em novembro de 1937, no Hotel Esplanada, com a participação dos artistas plásticos Aldo Bonadei, Alfredo Volpi, Anita Malfatti, Arnaldo Barbosa, Arthur Krug, Clóvis Graciano, Francisco Rebolo Gonzales, Fúlvio Pennacchi, Hugo Adami, Humberto Rosa, Joaquim Figueira, Manuel Martins, Mario Zanini, Paulo Rossi Osir e Valdemar da Costa, entre outros.

Dois anos depois, a segunda exposição teve lugar no Automóvel Clube, na Rua Libero Badaró, 287, onde estavam 
expostos, além de nomes já conhecidos da primeira mostra, vários outros que só então aderiam à Família: Candido Portinari, Alfredo Ruilio Rizzotti, Domingos Viegas de Toledo Piza, Renée Lefevre, Nelson Nóbrega, Ernesto de Fiori e João Batista Vilanova Artigas.

No ano de 1939, após visita à exposição organizada pela Família Artística Paulista, Mário de Andrade identifica e tenta conceituar pela primeira vez a existência de uma "Escola Paulista", caracterizada por seu modernismo moderado. Enfatiza, como elemento de unificação entre os expositores, a preocupação com o apuro técnico, a volta à tradição do fazer pictórico e o interesse pela representação da realidade concreta. Faz também algumas críticas:

Ora, pois o que falta a toda esta paulista família? Falta o estouro, falta o estalo de Vieira, falta a coragem de errar. O verdadeiro estádio de cultura não é propriamente saber, mas saber ignorar em seguida. Toda esta nossa forte e consangüínea Família Paulista já sabe eruditamente pintar, mas ainda não aprendeu a coragem de ultrapassar a sabença e conquistar aquele trágico domínio da expressão pessoal, sem o qual não existe arte. Todos estes artistas já sabem caminhar com firmeza, mas é lastimável que na terra que criou a Vasp, a única empresa nacional de aviação, eles não se arrisquem a voar (ANDRADE, 1971, p. 155)

Sobre esse texto de Mário de Andrade, Flávio Motta, no artigo "Textos Informes: A Família Artística Paulista", observa:
Ora, o Mário de Andrade era bem uma expressão de 22. E verdade que era renovador ou um "revolucionário metodizado" procurando dar sentido e organização tanto ao mundo das coisas como aos processos de agir no Brasil. Foi muito provavelmente - e isso vale como hipótese de trabalho - pelo mesmo respeito ao trabalho que reconheceu o novo na Família Paulista. E esse novo, temos para nós, é um novo tido como uma nova situação para o homem nos processos de transformação. Esse admirável reconhecimento que um poeta erudito faz de um grupo de artistas simples em arte e em origem, nos dá a chave, um outro ângulo de verificação do problema da Família Artística, ao mesmo tempo que restabelece uma tese proposta pelo próprio Mário de Andrade, qual seja, a relação erudito e popular. Aliás, essa tese, especialmente para os arquitetos, é da maior valia. Poderíamos a guisa de exemplo, formulá-la a partir da seguinte consideração:

1. Em que medida determinadas formas ou determinadas soluções, ou ainda determinados símbolos são elaborados para responder a um determinado contexto?

2. Como esses símbolos, transferidos para outro contexto, ainda mantêm a referência a alguns significados originais?

3. Em que medida, quando esses elementos são usados já sem recorrência aos seus significados originais, mas como simples "matéria prima" - a serviço de uma cultura com sentido novo e fundamento popular?

Aí está portanto, outra ordem de consideração, de preocupação que poderia esclarecer e dinamizar uma análise da "linguagem" das nossas obras de arte, para que não falte a essa "razão analítica em movimento" um sentido histórico. Num certo sentido, com o encontro do erudito com o popular, o que se busca é compreender as direções de uma história já feita e uma por fazer ou se fazendo (MOTTA, F., 1971, p. 140).

A terceira e última exposição ocorreu em 1940, no Rio de 
Janeiro, com novas participações que incluíam, entre outros, os nomes dos artistas plásticos Carlos Scliar, Paulo Sangiuliano, Vicente Mecozzi e Bruno Giorgi. Pouco depois a Família Artística Paulista deixava de existir, sobrepujada pelo aparecimento de novos movimentos. Cumpriu, pois, sua missão, como escreveu Paulo Mendes de Almeida:

Ela inseriu, de maneira definitiva, na lista de nossos melhores artistas, meia dúzia de nomes pelo menos, que servirão para recomendá-la aos exegetas da evolução das artes plásticas no País. Lembrar Volpi, Zanini, Rebolo, Bonadei ou Graciano, aqui mencionados sem preocupações de hierarquia, é lembrar a Família - aquela "Paulista Família", em cujo seio se formaram e foram revelados ao mundo da paleta e do pincel (ALMEIDA, P., 1976, p. 125 e 126).

Nesse mesmo período, organizou-se um outro importante grupamento de artistas de origem japonesa, com afinidade de interesses com o Grupo Santa Helena. Criaram um espaço de discussão que promovesse o aprimoramento técnico e a divulgação de suas obras. Organizados de 1935 a 1972, com intervalo nas atividades no período da Segunda Guerra Mundial, o Grupo Seibi, como era chamado, era integrado originalmente por Hajime Higaki, Shigeto Tanaka, ণ্ Th Takahashi, Tamaki, Tomoo Handa e Yoshiya Takaoka; mas logo teve a adesão de Tomie Ohtake, Manabu Mabe e Flávio Shiró, entre outros.
Em 1941, Quirino Silva organizou o "1º Salão de Arte" da Feira Nacional de Indústrias, acontecimento inédito, onde, segundo Paulo Mendes de Almeida:

Os homens da produção, os homens da indústria e do comércio, os homens de negócios, em suma, vinham ao encontro dos artistas, propiciando-lhes, dentro de sua organização um lugar para uma parada das artes plásticas

(ALMEIDA, P., 1976, p. 186).

A exposição foi realizada no Parque da Indústria Animal, na Água Branca. Mesmo com critérios pouco rigorosos para escolha das obras, apresentou um panorama bastante amplo e representativo dos meios artísticos.

Em 1947 apareceria novo movimento associativo, o chamado Grupo dos 19, que realizaria uma única exposição, com a presença de jovens pintores, entre os quais Aldemir Martins, Antonio Augusto Marx, Lothar Charoux, Flávio Shiró, Jorge Mori, Marcelo Grassmann, Maria Leontina, Mário Gruber, Otávio Araújo, Odetto Guersoni e Luís Sacilotto.

Antes disso, em 1945, foi inaugurada a seção de arte da Biblioteca Municipal, como conseqüência do projeto para um museu de arte moderna em São Paulo que tinha como idealizadores, desde o final dos anos de 1930, Mário de Andrade e Sérgio Milliet. 
Sobre essa proposta, comenta Lisbeth Rebollo Gonçalves:

A idéia de um Museu de Arte Moderna veiculada por Mário de Andrade e Sérgio Milliet tem, porém, um lado mais amplo: vai além da aglutinação de artistas e aproximação do "público de arte moderna", voltando-se para a comunidade em geral. O objetivo é a formação cultural do público em compasso com a contemporaneidade. Não é "festa", mas uma ação organizada dentro da plataforma modernista de atualizar a inteligência artística brasileira, dentro também de uma orientação política que impregna a intelectualidade paulista voltada para os ideais liberais democráticos, depois da Revolução de 1932. A idéia de criar um Museu de Arte Moderna tem mais a ver com a política cultural que favoreceu o surgimento do Departamento de Cultura. Aliás, tanto Mário como Sérgio pensam o museu ligado ao Departamento. Para Mário, sua forma seria a de um museu popular, de reproduções para Sérgio, o Museu preserva o sentimento tradicional da instituição que compõe um acervo significativo e propicia ao público o contato com os bens culturais. Mário quer a "desaristocratização da obraprima", vê o museu popular "com o destino de por as suas coleções ao alcance de qualquer compreensão", através de reproduções. Sérgio quer o modelo tradicional de museu, mas prega a necessidade paralela de uma ação pedagógica (GONÇALVES, 1992, p.77).

\subsection{O Museu de Arte Moderna}

Em 1946, a cidade de São Paulo recebeu do presidente do Museum of Modern Art de Nova York - MoMA, Nelson Rockfeller, a doação de sete obras de arte para a constituição de um museu. Inicialmente, ficam sob a guarda do Instituto de Arquitetos do Brasil - IAB; depois vão para a Biblioteca
Municipal, onde, nesse mesmo ano, são expostas ao público.

Amplia-se, então, o empenho para a criação do Museu de Arte Moderna. São realizadas reuniões no IAB, com a participação de artistas, intelectuais e empresários. O jornalista Assis Chateaubriand, fundador dos "Diários e Emissoras Associados" e o industrial Francisco Matarazzo Sobrinho são sensibilizados pela campanha.

$\mathrm{Na}$ entrevista de Vilanova Artigas a Lisbeth Rebollo Gonçalves está registrado:

Mas, ao que consta, a decisão de acolher o apoio de Matarazzo se dá com o aval americano. Segundo depõe o arquiteto Vilanova Artigas, a palavra final que leva ao encaminhamento do processo de criação do Museu de Arte Moderna de São Paulo sob a liderança de Matarazzo surge numa reunião de Nova lorque, da qual ele participa, quando bolsista nos Estados Unidos. Carleton Sprague Smith é o porta-voz de Rockfeller, falando do seu interesse pela participação daquele empresário no projeto (GONÇALVES, 1992, p. 77)

Abre-se, assim, o processo para se constituir o Museu de Arte Moderna de São Paulo. Matarazzo Sobrinho e sua esposa, Yolanda Penteado, começam comprar importantes obras de arte internacionais, visando a criação de um acervo para o Museu.

A 15 de junho de 1948, sessenta e oito pessoas comparecem para assinar a ata de constituição do MAM. Na lista 
predominam os nomes de arquitetos: entre eles, Aldo Calvo, Carlos Cascaldi, Eduardo Kneese de Mello, Galiano Ciampaglia, Gilberto Junqueira Caldas, Giuseppe Severo Giacomini, Gregori Warchavchik, João Batista Vilanova Artigas, Jacob Maurício Ruchti, Léo Ribeiro de Moraes, Luís Saia, Manilo Cosenza, Miguel Forte, Roberto de Cerqueira César, Roger Henri Weiler, Rino Levi, Salvador Candia e Virgílio Isola.

As palavras de Paulo Mendes de Almeida a esse respeito:

Havia uma razão para isso, dado que, entre as artes plásticas, foi a arquitetura aquela em que as novas tendências e concepções mais cedo conseguiram encontrar acolhida junto ao grande público. Os arquitetos, portanto, sentiam de modo mais concreto, se assim se pode dizer, as vantagens até mesmo materiais de uma arregimentação (ALMEIDA, P., 1976, p. 205).

Maria Cecília França Lourenço, em sua obra Museus Acolhem o Moderno, comenta:

A implantação dos MAMs, após a Segunda Guerra Mundial, colabora para fomentar modificações nas condições culturais e também, coaduna-se com alguns ideais político-econômicos relacionados ao fenômeno da metropolização, industrialização, desenvolvimentismo e alianças com os Estados Unidos. Nesse panorama, São Paulo assume papel ímpar pela concentração de atividades econômicas, em especial na questão industrial, enquadrando-se a abertura do MAM como parte explicitadora de uma imagem que se almeja atingir (LOURENÇO, 1999, p. 103)

Se a constituição do MAM ocorreu em junho de 1948 suas atividades se iniciaram em março de 1949, com sede à Rua 7 de abril, nº. 230, no prédio dos Diários Associados. Nesse local funcionava, desde 1947, o Museu de Arte São Paulo - MASP. O MAM teve projeto de adaptação do espaço de Vilanova Artigas e modelo museográfico do Museum of Modern Art - MoMA de Nova York.

Maria Cecília Franca Lourenço, acima citada, servindo-se da documentação fotográfica existente nos arquivos do MAM, assim descreve o projeto de Artigas:

Privilegiando a circulação em " $U$ ", bastante despojada se comparada ao modelo dos museus novecentistas, caracterizado pela concentração de peças e horror ao vazio. As obras são dispostas com base em painéis, funcionando como fundo neutro, paralelos às paredes para as pinturas e formas geométricas regulares para esculturas, com cuidado de projetar vitrines inclinadas para fruição adequada de desenhos e gravuras (LOURENÇO, 1999, p.109).

Pelos seus estatutos, o Museu de Arte Moderna tinha os seguintes objetivos:

a. Adquirir, conservar, exibir e transmitir à posteridade obras de arte moderna do Brasil e do Estrangeiro; b. incentivar o gosto artístico do público, por todas as maneiras que forem julgadas convenientes, no campo da plástica, da música, da literatura, e da arte em geral, oferecendo a seus sócios e membros a possibilidade de se receber gratuitamente ou com descontos, todos os serviços organizados da associação, nas condições estabelecidas pelo Regulamento Interno (NASCIMENTO, 203, p.249). 
O conselho de administração era composto por Villanova Artigas, Luís Saia, Sérgio Milliet, Antonio Candido Mello e Souza, Almeida Salles, Lourival Gomes Machado e Mário Bandeira, entre outros. A direção artística coube a Leon Dégrand.

Dégrand, francês conhecido por difundir a arte abstrata praticada em seu país, organizou a exposição inaugural "Do Figurativismo ao Abstracionismo", onde se aprofundava a discussão que começara anos antes, sobre a oposição entre a arte figurativa, tida como retrógrada, e a arte abstrata, considerada "a vanguarda" das artes plásticas.

Aracy Amaral, em sua obra Arte Para Que?, assim comenta o evento:

Sintomaticamente, porém, essa exposição abre as atividades do museu que trazendo as bienais internacionais para São Paulo, a partir de 1951, seria o mais eficaz veiculador das novas informações internacionalistas, em particular o abstracionismo, que florescia tanto no Rio como em São Paulo, a partir desse estímulo externo, e fazendo surgir na capital paulista, a partir dos anos 50, dois grandes grupos: 0 dos abstracionistas vinculados ao "Atelier Abstração", de Samson Flexor, e o dos abstracionistas geométricos, liderados por Waldemar Cordeiro, a partir do manifesto "Ruptura" (AMARAL, 1987, p. 237).

Em 1950, já sob a direção do filósofo e crítico de arte Lourival Gomes Machado, coube ao MAM organizar a participação brasileira na Bienal de Veneza. Foi, talvez, em função dessa participação, que se resolveu a criação de uma Bienal no Brasil.

Em 21 de outubro 1951 inaugurou-se a I Bienal do Museu de Arte Moderna de São Paulo, com vinte e três países participantes. O evento ocupou o belvedere do Parque Trianon, onde havia um antigo salão de baile. Aproveitandose da estrutura do salão, Eduardo Kneese de Mello e Luís Saia, ambos que assinaram a ata de constituição do MAM, projetaram um polígono de madeira perfazendo uma área de cinco mil metros quadrados, de maneira a poder receber as 1.854 obras expostas.

O êxito da I Bienal confirmou a capacidade de realização da equipe do MAM se constituindo no mais importante evento artístico no Brasil.

O projeto do MAM apresentava-se com um caráter didático. Isso fazia parte das intenções de estreita identidade com o que Mário de Andrade e Sérgio Milliet propagavam há mais de uma década, ou seja, educar o público, acostumado com os valores estéticos tradicionais, para o novo conceito de arte moderna. Nesse sentido, eram freqüentes palestras e conferências, organizadas como atividades paralelas às exposições. 
Como menciona Vera D'Horta: "logo é sentida a necessidade de se ensinar, na prática, o que era arte moderna" (D'HORTA, 1995, p. 31).

\subsection{A Escola de Artesanato}

Em julho de 1950, a imprensa paulista divulgava a criação da Escola de Iniciação Artesanal e Artística do MAM.

Foi festejada por muitos intelectuais como a instituição que viria substituir a primeira escola de arte moderna de São Paulo, a "Escola Livre de Artes Plásticas", criada no MASP por Flávio Motta e pelo artista plástico Poty (Napoleon Potyguara Lazzarotto). Com vida efêmera, a Escola Livre permaneceu funcionando alguns meses, em 1949.

A proposta da Escola do MAM era despertar nos jovens o amor pelo ofício e constituir-se como um centro de pesquisa em arte, sem se ligar a princípios rígidos ou doutrinas estéticas exclusivistas.

As informações que seguem foram obtidas pela leitura de artigos e notícias de alguns jornais da época (décadas de 1940 e de 1950). São recortes de jornais que fazem parte do Arquivo Histórico Wanda Svero,Fundação Bienal de São Paulo, e da coleção de recortes de jornais de Lucia Suane, viúva de Nelson Nóbrega.

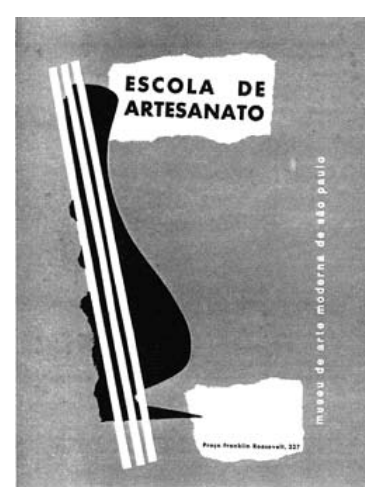

Folheto de divulgação da

Escola de Artesanato

fonte: acervo de Lucia Suane

Convite da exposição de alunos da Escola de Artesanato em junho de 1953 fonte: acervo de Lucia Suane
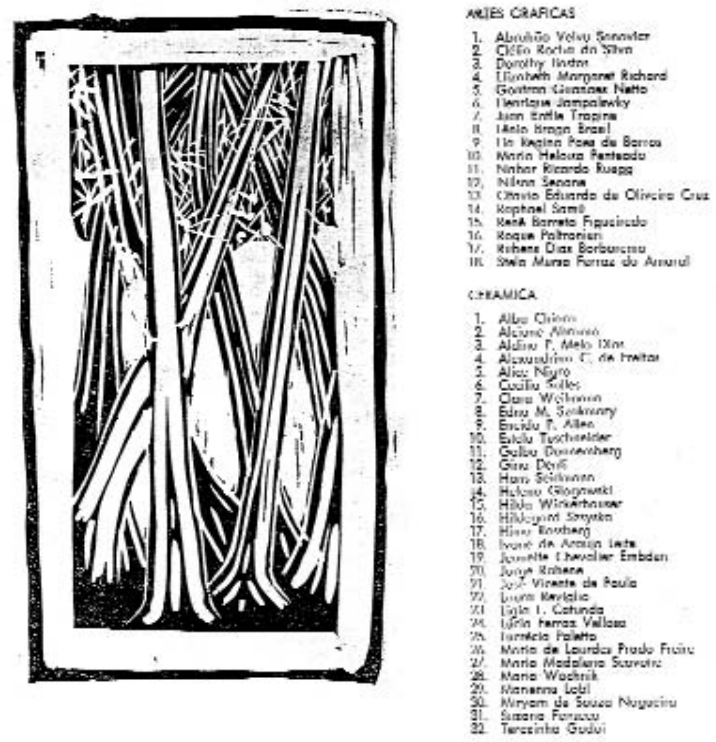

ESCOLA DE ARTESANATO DO

MUSEU DE ARTE MODERNA

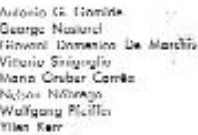


Desenhos de Abrahão Sanovicz Escola de Artesanato

fonte: acervo de Diva Sanovicz

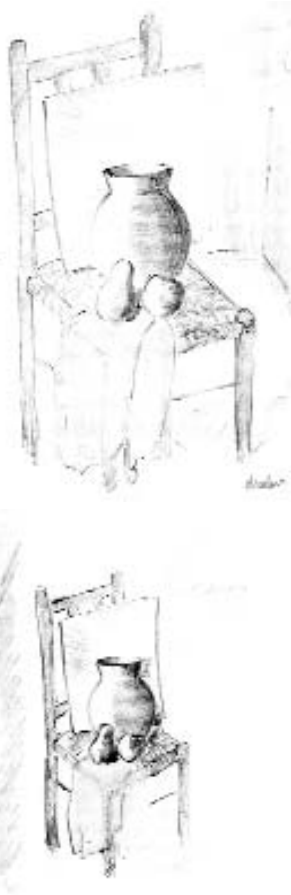

Os cursos de artes plásticas nela ministrados tinham como objetivo principal, a aplicação prática e profissional da arte escolhida pelo aluno. Já os cursos artesanais, por sua vez, eram mantidos em constante referência com as artes plásticas afins.

Assim, os cursos de desenho e pintura visavam o ensino da pintura mural e decorativa; o curso de cerâmica possibilitava a iniciação à escultura ou a criação de componentes para a construção civil, como revestimentos e louças. O de artes gráficas se dedicava à gravura e programação visual. Mantinha-se, dessa forma, o ensino do ofício, ao mesmo tempo preservando e estimulando as fontes puras da criação artística.

Havia o entendimento de que se fazia urgente formar equipes de artistas especializados a fim de que, com o amor ao seu ofício, pudessem ser o contraponto da produção mecânica industrial, conservando nos objetos por eles criados, emoção e sensibilidade.

Como método de ensino, adotava-se o aprendizado direto de mestre a discípulo, em convivência no ateliê, o que acentuaria ainda mais a ligação entre o elemento profissional e o artístico.

A previsão inicial era que esta escola iniciasse suas 
atividades já no segundo semestre de 1950. Porém, somente em 10 de junho de 1952 foi inaugurada a Escola de Artesanato - EDA, à Praça Roosevelt, nº. 227, sob a direção do pintor Nelson Nóbrega, com um selecionado grupo de professores: Antonio Gomide, Yllen Kerr, Georges Nasturel, Wolfgang Pfeiffer, Gian Domenico De Marchis e seu assistente Vittorio Sinaglia. Mais tarde vão juntar-se a esse grupo, ou substituir alguns deles: Helou Motta, Georges Nasturel, Mário Gruber, João Rossi e Livio Abramo.

Quirino da Silva - em artigo publicado em julho de 1952 - , entusiasmado com a recém-criada escola, exagerando na crítica à industrialização e creditando esse seu julgamento aos objetivos da EDA, ou ainda procurando estabelecer um debate com o Instituto de Arte Contemporânea IAC do MASP, escreveu:

Com o quase desaparecimento do artífice, veio, é claro, o desamor do homem pela matéria por ele usada.

A industrialização do trabalho na febricitante ganância de maiores lucros, desintegrou esse mesmo homem da sua verdadeira missão. O material, para ele não mais suscita aquele sincero afeto, aquele amor, mesmo, de que era impregnado todo o objeto por ele feito. Sim, porque esse objeto após longa e carinhosa permanência com o homem, tomava, naturalmente a sua personalidade, o seu feitio, sem com isso perder a sua nobreza de origem. Dava-lhe, antes, em virtude dessa afetuosa convivência entre ambos, uma
Desenhos de Abrahão Sanovicz

Escola de Artesanato

fonte: acervo de Diva Sanovicz
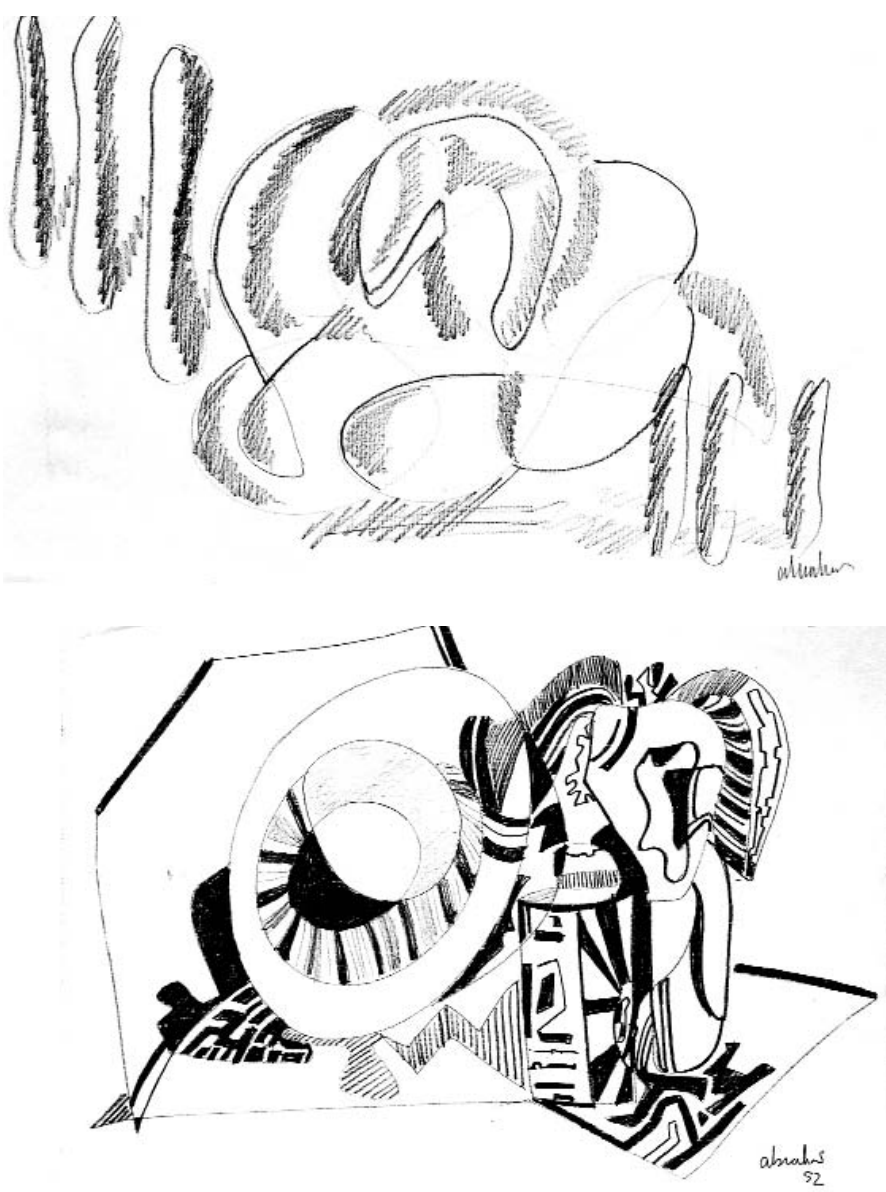
Desenhos de Abrahão Sanovicz

Escola de Artesanato

fonte: acervo de Diva Sanovicz

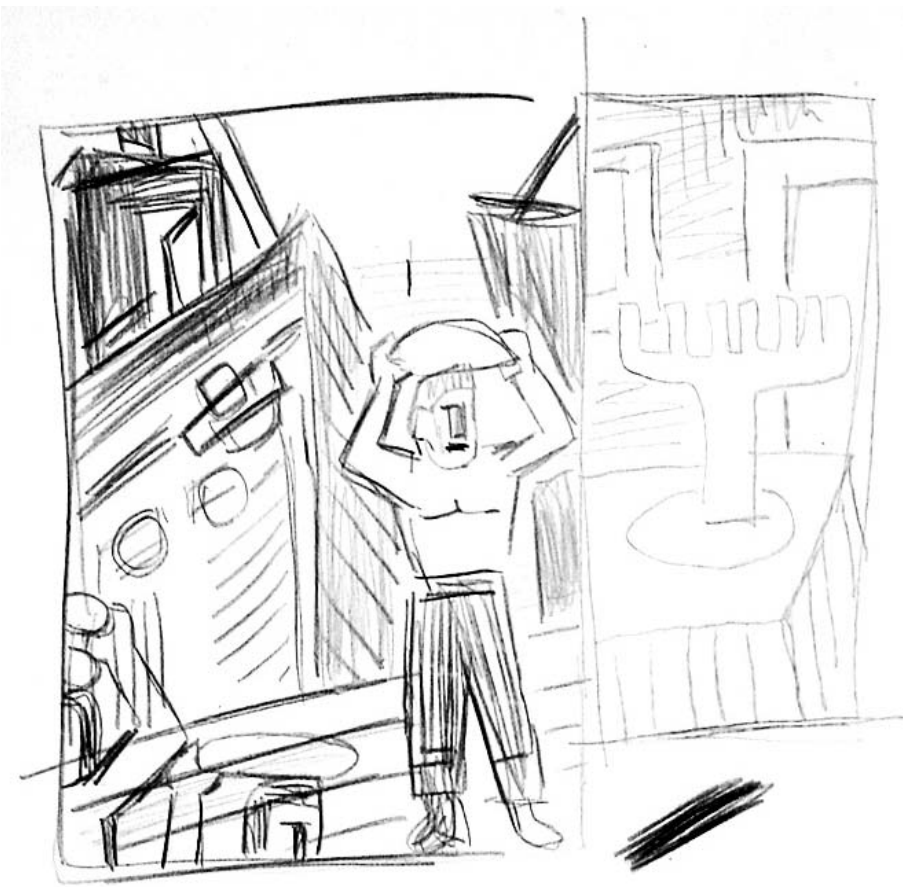

Elmose parou

alum -

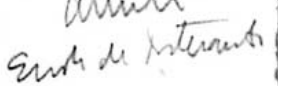

sedução e compreensão que, ainda hoje - apesar do tempo decorrido - se percebe na superioridade de um e na obediência de outro: o material e o homem se integravam, e se harmonizavam numa deliciosa poesia. Essa obediência do material não era, decerto conseguida pela rapidez das maravilhosas máquinas de hoje, as quais muito embora representem numerosa produção, desrespeitam a integridade da matéria, desvirtuando-lhe, sempre, o destino. Obrigando-a a serviços subalternos, enxovalhando-lhe, enfim, a sua nobreza.

Mais uma escola que forme um punhado de artífices - como a que já existe no Museu de Arte - vem como o bíblico ramo de oliveira, anunciar que muito em breve teremos artífices capazes de exumar esse amor pelo ofício e pela matéria usada (SILVA, Q. 1952)

Este não era o pensamento dos idealizadores da Escola de Artesanato, tanto que em entrevista para o jornal última Hora, Nelson Nóbrega declarou:

[...] despertar nos jovens o amor pelo ofício artístico e ao mesmo tempo dotá-los de uma sólida base de conhecimentos indispensáveis às suas futuras criações artísticas. É de nosso desejo cooperar com todos os que trabalham pela melhoria do nível de nossos meios artísticos, fazendo ao mesmo tempo, com que se desenvolva o sentido da estreita ligação entre as artes plásticas contemporâneas e as artes aplicadas. Os alunos recebem certificado de conclusão dos cursos após dois anos e já se prevê a instituição de cursos de especialização e cursos livres que serão organizados com o objetivo de difundir o gosto pelas artes (MARTINS, 1952).

A Escola de Artesanato teve ajuda financeira da Prefeitura de São Paulo, mediante convênio escolar que oferecia vinte 
e cinco bolsas de estudo por ano aos candidatos que aliassem à precária situação econômica aptidão e aplicação.

A EDA contava com dois cursos básicos: o de desenho e o de história da arte. O primeiro, ministrado por Antônio Gomide, contemplava o desenho geométrico, decorativo, ilustrativo, à mão livre, e de modelo vivo; o segundo, ministrado por Wolfgang Pfeiffer, quando os alunos entrariam em contato com as significativas realizações artísticas da humanidade, a fim de que aprendessem a responsabilidade que Ihes cabia na preservação e enriquecimento desse grande acervo espiritual.

Duas oficinas artesanais iniciaram suas atividades: a de cerâmica, dirigida por De Marchis, que se dedicava desde os estudos rudimentares da terra-cota aos trabalhos mais especializados em esmalte e porcelana; e a de artes gráficas, confiada a Yllen Kerr, que deveria desenvolver no aluno o gosto pela gravura em geral, dedicando-se mais à litografia, compreendendo ainda aulas de paginação de livros e jornais, tricromia e ilustração a cores.

A instituição passou por períodos de dificuldade io financeiras. Além disso, em 1958 o MAM muda-se para o Parque do Ibirapuera, Francisco Matarazzo insistindo em que a Escola se mudasse também. Alunos e professores, por sua vez, insistiam em continuar nas instalações originais.

No início de 1959, por essas e por outras, a diretoria do MAM resolve encerrar as atividades da Escola de Artesanato.

Entre os alunos - e aqui se inclui de Abrahão Sanovicz diversos importantes artistas por lá passaram, como: Antonio Henrique Amaral, Doroty Bastos, Flávio Império, Savério Castellano, entre outros.

Aracy Amaral, em Arte Para Quê?, quando trata da abertura do MAM, remete à matéria de Ibiapaba Martins no Correio Paulistano "Duas Entrevistas Oportunas", onde o jornalista comenta que, para a primeira diretoria empossada:

[...] o caráter "popular" do Museu de Arte Moderna, em contraposição ao elitismo que rodeava o Ambiente do MASP, evidencia-se na medida em que "qualquer pessoa" pode dele se associar "mediante módica mensalidade" e isso "sem distinção de classe" (MARTINS, 1958 apud AMARAL, 1987, p. 237).

Essa importante referência desperta o interesse para a reflexão sobre o caráter do Museu de Arte São Paulo - MASP e sobre o Instituto de Arte Contemporânea - IAC. 


\subsection{O Museu de Arte São Paulo - MASP}

Sobre a fundação do Museu de Arte São Paulo Assis

Chateaubriand, escreveu Renata Vieira da Motta:

A fundação do MASP só foi possível pela coincidência histórica de uma idéia e o aparecimento daqueles que a colocariam em prática: o encontro de Assis Chateaubriand com Pietro Maria Bardi e Lina Bo Bardi. Se a idéia de um novo museu de arte não era nova, remontando aos anos 1920 e configurando uma discussão mais ampliada nos anos 1930, o jornalista nordestino, dono dos Diários Associados - o Chatô - seria o primeiro a concretizá-la (MOTTA, 2003, p.18).

O casal Bardi, vindo da Itália, chegou ao Brasil no segundo semestre de 1946. Logo, Assis Chateaubriand convidou Pietro Maria para, junto com o jornalista Frederico Barata, estudar a criação de um museu que, por determinação do próprio Chateaubriand, deveria instalar-se em São Paulo, à Rua 7 de Abril, no Edifício dos Diários Associados, de autoria do arquiteto Jacques Pilon.

O MASP foi oficialmente criado em 10 de março de 1947, constituído por uma sociedade civil composta de trinta membros, a maior parte deles pertencente à "sociedade paulistana" da época: fazendeiros, industriais e banqueiros.

Inaugurado no dia 2 de outubro de 1947, ocupava metade do segundo andar daquele edifício, com projeto de adaptação do espaço realizado por Lina Bo Bardi.

No que se refere à constituição de seu acervo o MASP não se alinhava com as posições de combate aos museus tradicionais, nem tinha no Museu de Arte Moderna de Nova York - MoMA sua maior referência. O desafio era constituir um acervo o mais significativo de todas as expressões de arte do Brasil e do mundo. Por outro lado, insistia Bardi na idéia de criar um centro cultural atingindo e educando um público ampliado, rejeitando o modelo tradicional, dando ênfase aos departamentos não-curatoriais: biblioteca, publicações, exposições itinerantes, educativo.

Em 1950, o Museu de Arte São Paulo passou a ocupar mais três andares, dando margem a uma nova inauguração.

A este respeito as palavras de Renata Motta:

Desfrutando de mais espaço e tendo se estruturado nesses três primeiros anos, as iniciativas do MASP cresceram consideravelmente, incluindo as escolas de desenho industrial (o Instituto de Arte Contemporânea IAC), propaganda, jardinagem, dança, além dos seminários de cinema (MOTTA R., 2003, p. 23).

\subsection{O Instituto de Arte Contemporânea}

O no. 3 da revista Habitat, de 1951, na matéria "Instituto de Arte Contemporânea" noticiava a criação de uma Escola 
de Design no Museu de Arte São Paulo cujo objetivo era a formação de jovens que se dedicassem à arte industrial.

A congregação IAC contava com a participação de arquitetos e artistas: Alcides da Rocha Miranda, Clara Hartoch, Eduardo Kneese de Mello, E. Hanner, Elizabeth Nobiling, Enrico Bernachi, F. Kosnta, Giancarlo Palanti, Jacob Ruchti, Lasar Segall, Lina Bo Bardi, Pietro Maria Bardi, Oswaldo Bratke, Roberto Burle Marx, Rodolfo Klein, Thomas Farkas, Poty e Flávio Motta. Esses dois últimos haviam participado da curta experiência da Escola Livre de Artes Plásticas, também no MASP.

As referências do curso vinham da Bauhaus, por intermédio da adaptação à nossa realidade dos conteúdos formulados para o Instituto de Design de Chicago em 1937, por MoholyNagy e Walter Gropius, que havia idealizado a escola alemã.

Marlene Milan Acayaba, em Branco e Preto, esclarece que, o objetivo do IAC era que seus alunos:

Se mostrassem capazes de desenhar objetos, nos quais o gosto e racionalidade das formas correspondessem ao progresso e à mentalidade contemporânea. Para tanto era preciso desenvolver a consciência da função social do desenho industrial, contestando a reprodução fácil e nociva dos estilos superados e do diletantismo decorativo. E, ainda, destacar o sentido da função social que cada projetista, no campo da arte aplicada, deveria ter em relação à vida (ACAYABA, 1994, p.36).
O curso era dividido em duas etapas. Na primeira, o aluno recebia formação básica sobre cultura e conhecimentos técnicos e artísticos.

Para essa etapa do curso, a autora supracitada assim opina:

Essa primeira etapa, semelhante a qualquer curso de arquitetura, visava à formação de desenhistas industriais com a mentalidade de arquitetos. Isso porque o desenhista industrial deveria trabalhar da mesma forma que o arquiteto, pois, embora não projetasse prédios, projetaria rádios, automóveis, geladeiras etc., com o mesmo respeito pelos materiais, pela função e pela técnica, como aquele que o arquiteto empregava em seus projetos (ACAYABA, 1994, p.38).

$\mathrm{Na}$ segunda etapa, os alunos aplicavam esses conhecimentos à solução de projetos de equipamentos que deveriam ser produzidos industrialmente; projetos de comunicação visual; e desenvolviam experiências com a fotografia, com a publicidade e com o cinema.

Não se pretendia formar especialistas, mas desenvolver nos alunos a capacidade de resolver qualquer problema técnico ou artístico na área do desenho industrial.

À indústria brasileira não interessava absorver os profissionais formados pelo IAC, comprometidos em criar uma linguagem nacional. "Aos poucos as patentes de produtos internacionais eram adquiridas e desejadas por 
Cartaz da I Bienal

autor: Antonio Maluf

fonte: www.globo.com/biena

visitada em 12/12/2003

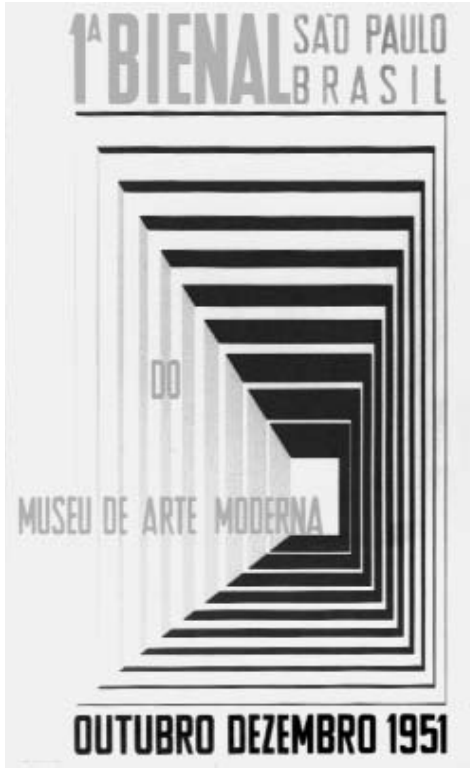

uma sociedade eternamente sequiosa do que se produzia fora" (ACAYABA, 1994, p.39).

Os alunos do IAC procuraram nas artes plásticas e desenho gráfico outros caminhos; porém ficaram para sempre marcados pelos conteúdos apreendidos no curso, dando a perceber certa "identidade de princípios" na produção profissional - ainda que muito diversificada desses antigos alunos. Freqüentaram o IAC: Alexandre Wollner, Antonio Maluf, Emilie Chamie, Ludovico Martino, Maurício Nogueira Lima, e muitos outros.

Os acontecimentos aqui relatados salientam a "efervescência cultural" em que se vivia na capital paulista quando Abrahão Sanovicz mudou-se para cá e logo procurou participar dessa efervescência. De igual modo esses fatos revelam o compromisso de muitos arquitetos na constituição de instituições que transformaram de maneira radical a vida cultural da cidade e do país, assim como a importante contribuição que tanto MAM, através da Escola de Artesanato, quanto o MASP com o Instituto de Arte Contemporânea, tiveram na formação de grandes artistas. 
Sobre esse momento da cidade, Aracy Amaral comenta:

Vivia-se em São Paulo em período de ebulição cultural, ambiente em que coexistiam vários críticos de arte oriundos da literatura, como Sérgio Milliet, José Geraldo Vieira, Geraldo Ferraz, Luiz Martins, da sociologia, como Lourival Gomes Machado, ou ainda do jornalismo e pintura, como Quirino da

Silva, ou simplesmente do jornalismo, como Ibiapaba Martins (AMARAL, 187, p.245).

Sobre a experiência da Escola de Artesanato e sobre a vida na cidade que o acolhia, declarou Abrahão Sanovicz ao pesquisador do Centro Cultural São Paulo, arquiteto Marcos

\section{Cartum:}

Quando cheguei, estava para acontecer a I Bienal de Arte de São Paulo (as primeiras bienais, por sinal, foram maravilhosas). A I Bienal foi no Trianon, um projeto feito por Luís Saia e Eduardo Kneese de Melo. Nessa época, ainda garoto, já manifestava muito interesse pelas exposições de arte organizadas, por exemplo, pelo MASP (ainda situado na rua 7 de Abrill. Então, tive oportunidade de acompanhar exposições, como a de Le Corbusier, Max Bill, Lasar Segall e Portinari. Havia ainda a revista "Habitat", da Lina Bo Bardi. Nessa época, o MASP criou o Instituto de Arte Contemporânea para a formação de artistas gráficos, um curso que já manifestava a preocupação com o design, mas relacionado com os aspectos bidimensionais. Havia uma equipe de europeus que aqui chegou no pós-guerra, agitando muito esse centro artístico que havia na 7 de Abril. Havia o pessoal da fotografia, estandes, cartazes etc. Veio muita gente para atuar nessas áreas durante as comemorações do IV Centenário da cidade, em 54. Era enfim, um novo mercado que se abria.

Nessa época, também, começavam a aparecer algumas galerias de arte moderna. Na praça da República, havia a galeria Domus e o pessoal da loja Ambiente. Eu, enfim, continuava freqüentar o curso de Edificações, quando o Museu de Arte Moderna abriu inscrições para uma nova escola chamada Escola de Artesanato montada na Praça da Roosevelt, uma iniciativa de Ciccilo Matarazzo. Essa escola tinha um sentido diferente do curso criado pelo MASP, que objetivava, na verdade, formar gráficos (um profissional que seria, por assim dizer, precursor do designer), além de outros cursos, como o de gravura e o de formação de artistas. Eram cursos livres. Já a Escola de Artesanato formava fundamentalmente gravadores e ceramistas. Acabei fazendo um teste para concorrer a uma vaga de bolsista; fui aprovado e comecei a freqüentar o curso (à noite). Era uma coisa maravilhosa devido ao ambiente de trabalho, ao contato com os colegas, muitos dos quais viriam a se tornar artistas importantes de São Paulo, além de grandes professores. Citaria, por exemplo, Yllen Kerr, que depois se tornou um excelente fotógrafo no Rio, o Mário Gruber, que já conhecia de Santos e o Lívio Abramo. Havia também os professores de Desenho Artístico: o Antonio Gomide, o Jorge Nasturel e o Pfeiffer, que dava aulas de História da Arte (SANOVICZ, 1997, p. 144). 


\section{Pássaro da Liberdade}

Em São Paulo, no período que estudava na Escola Técnica, de 1951 a 1953, Abrahão Sanovicz participou de um movimento juvenil sionista, socialista e kibutziano², o Dror ${ }^{3}$.

A apresentação do livro Pássaros da Liberdade, de autoria de Carla Bassanezi Pinsky, relaciona algum nomes que participaram do movimento:

O que é que têm em comum o maestro Isaac Karabtchevsky, o economista Paul Singer, o jornalista Alberto Dines, a psicanalista Anna Verônica Mautner, a pianista Clara Sverner, o ator Abrão Farc, o sociólogo Gabriel Bolaffi, o psiquiatra Richard Kanner, a joalheira Betty Loeb, o professor Bernardo Kucinski, além de serem cidadãos de destaque em suas áreas de atuação? O fato de terem pertencido, há quase cinqüenta nos, a um grupo de jovens socialistas radicais, o Dror, que negava os valores da sociedade burguesa em que viviam e pretendia socializar o mundo a partir de pequenas unidades agrícolas igualitárias, os kibutzim (PINSKY, 2000, capa).

Várias experiências e tradições deram conteúdo ideológico ao Dror: os sionistas socialistas europeus, a vida dos primeiros kibutzim, os movimentos juvenis e pioneiros no fim do Século XIX e início do XX; sobretudo o Wandervoge/4 como destacou o historiador e filósofo Dr. Nachman Falbel, amigo pessoal de Abrahão e companheiro deste movimento juvenil, cuja experiência relatou em entrevista ${ }^{5}$.

Os valores preconizados pelo Wandervogel atraíram grandes massas da juventude alemã: a volta à natureza, o combate ao desmatamento e à destruição das populações aborígines e do habitat selvagem; a crítica às aglomerações urbanas e conseqüente alienação do homem em relação à natureza; a educação através do trabalho prático; a valorização das atividades esportivas; e alteração nos costumes como não fumar, não beber, uma ética de vestuário (mas sem uniformes). Ao mesmo tempo, promovia valorização da idéia de que essa é a etapa da vida em que se deva experimentar total independência de ideologias ou credos.

Essa foi a matriz do movimento juvenil judaico que agregou a estes valores a problemática judaica, na medida em que surge o nacionalismo judaico, chamado "movimento sionista".

O Dror originou-se na Polônia, na década de 1910, e adquiriu maior relevância a partir da colonização judaica moderna da Palestina, fruto do entendimento de que a juventude constitui uma etapa de vida em si, independente e com valores próprios.

Relata-nos Pinsky:

À semelhança de jovens de outros paises, que, na segunda metade dos anos 40 e por toda a década de 1950, engrossaram as fileiras dos movimentos judaicos, eles fizeram-se herdeiros de uma tradição européia do início do século que engloba o sionismo socialista, os movimentos juvenis e os ideais 
pioneiros. Acreditando que o problema da discriminação contra os judeus seria resolvido com a participação destes em atividades produtivas dentro de um estado nacional judaico Israel - em colônias coletivas - os kibutzim -, os jovens do Dror politizaram-se, questionaram a ordem burguesa e os papeis a eles oferecidos pelo meio em que viviam e prepararam-se para uma nova vida na terra distante, buscando servir de exemplo para a criação de uma sociedade mais justa e igualitária no mundo (PINSKY, 2000, p.9)

No Brasil, o movimento surgiu primeiramente em São Paulo, em 1945, com o nome de Freiheit', que logo passou a ser chamado Dror e, em pouco tempo se espalhou para as comunidades jovens judaicas de outros Estados.

\section{Como descreve o citado Nachman Falbel:}

Em fins do mesmo ano de 1945, em 29 de dezembro, o Jornal Israelita, e no dia 31 a Aonde Vamos? publicavam nota sobre a fundação da Organização Juvenil Sionista Socialista Freiheit em

São Paulo, tradicional movimento europeu que já existia na Argentina desde 1934, na qual se informava a constituição de uma comissão provisória[...] O Dror, nome que substituiu o iídiche Freiheit, teria assim como os demais movimentos sniffim (filiais)em outras capitais do país, tornando-se um catalisador dos anseios da juventude judaica após a guerra. A história dos movimentos juvenis no Brasil ainda está por ser escrita, mas ela encerra um dos capítulos mais importantes que a juventude judaico-brasileira desempenhou na disseminação de ideais sociais, não somente no âmbito restrito de sua comunidade, mas na sociedade brasileira como um todo (FALBEL, 1996, p. 88 e 89)

Participavam do Dror crianças e jovens de 7 a 20 anos, organizados por faixas etárias. Adotou-se uma pedagogia apropriada para cada uma destas faixas, de maneira a prepará-los para viverem nas colônias agrícolas de Israel. Se, por um lado, deveriam estar habilitados a viver do próprio trabalho na agricultura, por outro, como a maior parte deles pertenciam a segunda ou terceira geração de emigrantes, deveriam estudar o hebraico, o folclore de seus antepassados e a geografia da "Terra de Israel". Para isso, os educadores do Dror desenvolviam métodos apropriados: organizavam excursões, acampamentos e seminários. Eventos que visavam a formação judaica, ideológica e espiritual dos jovens.

Muitos deles foram viver em Israel. Outros, no dizer de Falbel, "pela insistência dos pais ou por acreditarem que sem título universitário não sobreviveriam" ficaram no Brasil.

Abrahão Sanovicz foi um dos que ficou. Falbel salienta a importância do movimento como o "vírus" da militância e idealismo que se implantou na juventude e acompanhou o amigo Abrahão por toda a vida.

O jornalista Alberto Dines, na apresentação do livro de Carla Pinsky, sintetiza esse sentimento com precisão:

[...] foi talvez a passagem mais importante da minha vida. Mais de meio século depois, verifico que os outros têm a mesma sensação. Com Romain Roland no coração, estávamos convencidos de que o mundo melhor começaria a a partir de nós mesmos (PINSKY, 2000, capa). 


\section{O aprendizado da arquitetura}

\subsection{Origem}

A Faculdade de Arquitetura e Urbanismo da Universidade de São Paulo foi criada pela Lei $n^{\circ}$. 104, de 21 de junho de 1948, a partir do curso de arquitetura da Escola Politécnica ministrado desde 1894 formando engenheiros arquitetos.

A iniciativa resultou de um processo social marcado por debates, manifestações e movimentos, desenvolvido ao longo de várias décadas.

Vilanova Artigas comenta o panorama do ensino da arquitetura no Brasil no Século XIX no documento "Contribuição para o Relatório sobre o Ensino de Arquitetura", que encaminhou, em 1974, à Comissão de Ensino Superior da Organização das Nações Unidas para a Educação, Ciência e Cultura - UNESCO:

Em 1886 já dispúnhamos em São Paulo e no Rio de Janeiro de uma Escola Politécnica e da Escola de Belas Artes fundada pela Missão Francesa. Entretanto, não cumpriam o papel que delas se esperava. A Politécnica porque era exatamente teórica e a Belas Artes porque não dispunham de qualquer recurso para a instrução de arquitetos sobre o domínio da natureza com os recursos do conhecimento técnico já existente (ARTIGAS, 1993, p. 133).

Nesse mesmo documento, Artigas cita as preocupações colocadas pelo Instituto Politécnico Brasileiro, entidade criada no Rio de Janeiro em 1862, no ofício que encaminhou

ao Governo Imperial:

Dá-se ainda um outro fato que reclama também uma providência do Governo Imperial: é a notável disparidade dos respectivos cursos na Escola Politécnica e na Academia de Belas Artes ... naquela o curso não é contemplado com a precisa instrução prática, e nesta subsiste a ausência radical e a mais completa de certos conhecimentos científicos, atualmente indispensáveis ao engenheiro arquiteto, em conseqüência da diversidade de elementos, que a arte moderna aplica às construções(ARTIGAS, 1993, p. 133).

O ofício do Instituto Politécnico Brasileiro não teve qualquer repercussão prática.

Até o fim da primeira metade do Século $X X$, os cursos e escolas de arquitetura eram poucos, e o número de profissionais era muito pequeno.

Para consolidar seu papel na sociedade brasileira, os poucos arquitetos procuraram reunir forças, apoiando-se nos movimentos de arte moderna que começavam a acontecer no país.

A esse respeito, Artigas ilustra:

Daí o caminho que a Arquitetura brasileira teve que aceitar para restabelecer no Brasil o prestígio histórico da arte de projetar, o "caminho heróico" como já é costume chamá-lo entre nós. Alia- 
ram-se os arquitetos aos movimentos de arte moderna, aos pin-

tores, escultores, aos artistas da palavra(ARTIGAS, 1993, p. 134).

Assim, os acontecimentos artísticos ocorridos em São Paulo a partir de 1922, aliados à atuação de Lucio Costa, Gregori Warchavichik e Flávio de Carvalho, publicando manifestos ou escandalizando no dizer de Artigas (1993, p.133) "o provincianismo da época construindo casas modernas" deram importância à discussão sobre a formação do arquiteto.

Lucio Costa, nomeado em 1930 diretor da Escola de Belas Artes, tentou empreender uma reforma radical no currículo dessa instituição, convidando novos professores, como, por exemplo, Gregori Warchavchik, Leo Putz, Celso Antonio e A. Budeus. Porém, não obteve êxito, conforme relata Mindlin (1999, p. 26), "um incidente em sala de aula deu aos elementos reacionários o pretexto para demitir o jovem diretor em menos de um ano". Os alunos se organizaram numa greve em defesa das novas idéias artísticas e esboçaram a proposta de criação de uma escola independente.

Os protagonistas desses acontecimentos concorreram para a "descoberta" da arquitetura moderna brasileira.

A arquitetura brasileira já era reconhecida internacionalmente, por meio da exposição Brazil Builds, realizada em 1943, no Museu de Arte Moderna de Nova York e
Capa. fonte: MINDLIN, 1999 p. 11

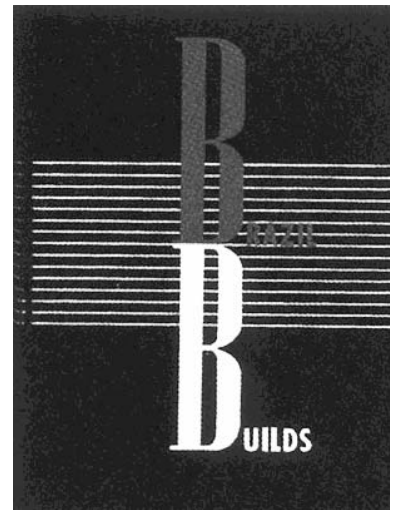

BRAZIL

BUILDS

ARCurticture NEW AND Oto 1652-1942

Primeiras páginas.

fonte: GOODWIN, 1943 p. 2 (acima), 3 e 5.
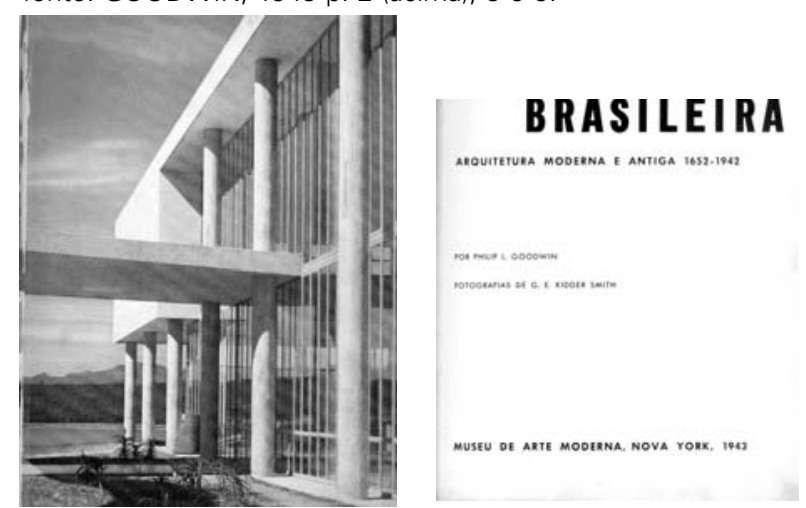
mediante o lançamento do livro de Phillip Godwin com mesmo nome. Os arquitetos brasileiros, agora prestigiados, começaram a discutir e planejar a educação e formação dos novos profissionais.

O I Congresso Brasileiro de Arquitetos, organizado pelo Departamento de São Paulo do Instituto de Arquitetos do Brasil, IAB-SP, realizado, portanto, em São Paulo, em janeiro de 1945, apontava, em suas conclusões, a urgente autonomia dos cursos de arquitetura em relação às escolas Politécnica e de Belas Artes.

O ensino da arquitetura deveria ser reformulado de maneira a garantir aos novos arquitetos uma formação compatível com o processo de modernização da sociedade brasileira, absorvendo questões relativas à industrialização e aos novos campos de trabalho que se abririam para esses profissionais.

Nesse contexto, o curso de Arquitetura da Escola Politécnica da Universidade de São Paulo deu lugar à Faculdade de Arquitetura e Urbanismo.

A história registra como principais protagonistas desse acontecimento: o professor Luiz Ignácio Romeiro de Anhaia Mello, fundador da FAU, e os irmãos Armando e Sílvio Álvares Penteado, doadores do edifício da Rua Maranhão, nº. 88, para a Universidade de São Paulo. A doação teve o objetivo precípuo de se constituir a Faculdade de Arquitetura

Julio Roberto Katinsky, em entrevista concedida à autora do presente estudo, aponta como heranças da Politécnica:

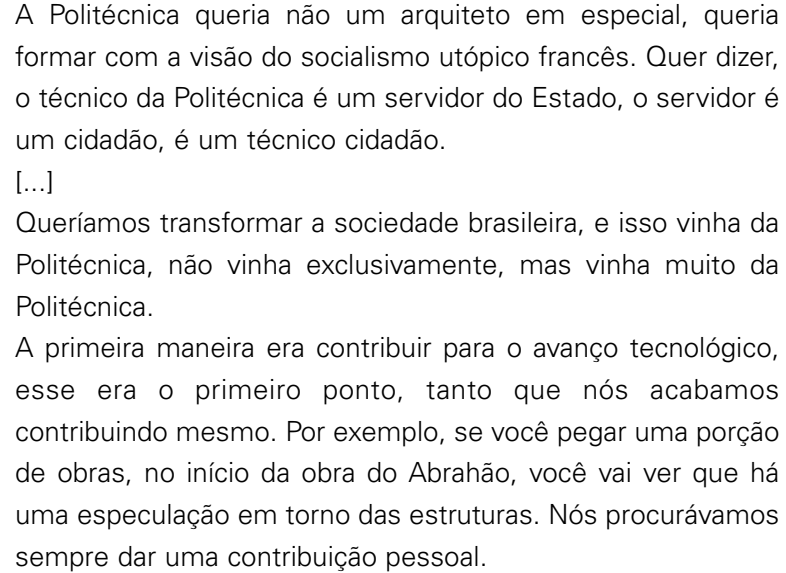

A primeira maneira era contribuir para o avanço tecnológico, esse era o primeiro ponto, tanto que nós acabamos contribuindo mesmo. Por exemplo, se você pegar uma porção de obras, no início da obra do Abrahão, você vai ver que há uma especulação em torno das estruturas. Nós procurávamos sempre dar uma contribuição pessoal.

O currículo da nova escola conservou o programa de ensino técnico que caracterizava o curso da Politécnica, incorporando a formação urbanística, também ministrada naquela escola, e disciplinas da Escola de Belas Artes: a plástica, modelagem, arquitetura de interiores, pequenas e grandes composições, entre outras.

Inicialmente, a organização da Faculdade previa a existência de dois cursos: o de graduação em arquitetura, 
com duração de 5 anos, e o de graduação em urbanismo, que se daria em 2 anos. Este último não chegou a ser implantado.

A estrutura do curso de arquitetura permaneceu basicamente a mesma de 1948 a 1962, ou seja:

$1^{\circ}$ ano: matemática superior; geometria descritiva e aplicações; arquitetura analítica; composição de arquitetura - pequenas composições; normografia; desenho artístico; e plástica.

$2^{\circ}$ ano: mecânica racional; materiais de construção; topografia - elementos da astronomia de posição; teoria da arquitetura; composição de arquitetura - pequenas composições; desenho artístico; e plástica.

$3^{\circ}$ ano: resistência dos materiais e estabilidade das construções; construções civis - organização dos trabalhos e prática profissional - higiene dos edifícios; física aplicada; mecânica dos solos - fundações; composições de arquitetura - grandes composições; composição decorativa; e plástica.

$4^{\circ}$ ano: concreto simples e armado; economia política estatística aplicada - organizações administrativas; ণ্ণী estruturas; composições de arquitetura - grandes composições; composição decorativa; e plástica. $5^{\circ}$ ano: história da arte e estética; arquitetura no Brasil; urbanismo; arquitetura paisagística; composições de arquitetura - grandes composições; composição decorativa; e plástica.

Apesar da importância atribuída à criação do curso de arquitetura, o conteúdo programático adotado não alcançou plenamente a expectativa de alguns de seus precursores.

Artigas, demonstrando tal inquietude, assim se expressou:

O currículo composto foi, inevitavelmente, uma somatória de disciplinas. O modelo de arquiteto que pretendíamos não podia ser compreendido. O amadurecimento deste modelo ainda precisava e talvez precise ainda algum esforço (ARTIGAS, 1993, p. 134).

\subsubsection{A Graduação de Abrahão Sanovicz: 1954}

\section{$-1958$}

Abrahão Sanovicz prestou vestibular em 1953. Na entrevista que concedeu a Marcos Cartum, comentou o vestibular:

Havia 152 candidatos para 30 vagas. Foram aprovados 37 que acabaram sendo absorvidos pela escola. Fiquei em $29^{\circ}$ lugar. No vestibular teve uma prova de desenho que consistia no seguinte: um vaso e um plano para serem desenhados. Com minha formação em desenho e gravura, acabei fazendo alguma coisa que preenchia todo o plano da folha, como um 
Ministério da Educação e Saúde.

Projeto dos arquitetos Lucio Costa, Oscar Niemeyer, Afonso Reidy, Carlos Leão, Jorge Moreira e Ernani Vasconcelos.

Consultor: Le Corbusier. 1937

fonte: GOODWIN, 1943 p. 106 e 110

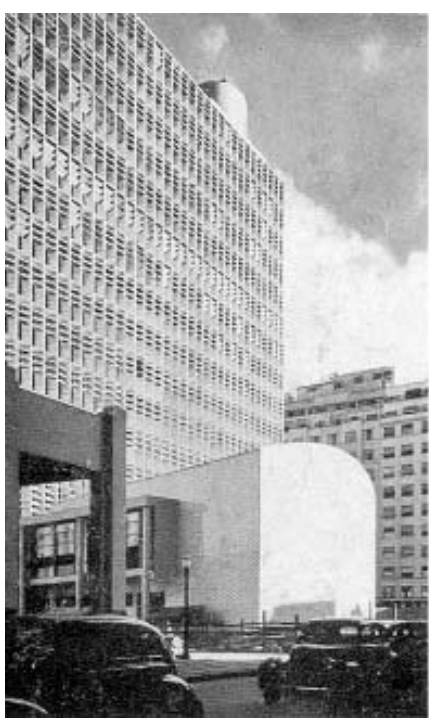

gravador que estivesse gravando a madeira. A minha nota fo 6,5 , e eu estranhei, porque achava que poderia obter uma nota melhor. Mas quando fui verificar as provas consideradas melhores, percebi que elas eram as mais simples em termos de solução de desenho. As melhores notas, enfim, foram para candidatos que haviam feito o cursinho da FAU, orientados pelos alunos dessa faculdade. Isso foi em 53 , mas já se podia notar que havia certa estrutura de encaminhamento numa direção. Há uma diferença muito grande entre o meio em que os orientadores são artistas, pintores e gravadores e o meio em que eles são arquitetos: uma diferença de diretrizes. Na

FAU, comecei a tomar contato com outro tipo de pessoas. Era uma escola aristocrática e, assim, entrei em contato com a aristocracia e com todo o tipo de conhecimento de que ela pode lançar mão. A FAU já contava com uma grande biblioteca, e a gente passava a maior parte do tempo nessa biblioteca (SANOVICZ, 1997, p. 144)

Para matricular-se era necessário apresentar o certificado de conclusão do Curso Técnico, que deveria ser obtido junto ao Ministério da Educação, no Rio de Janeiro. Lá Abrahão pôde conhecer as obras que tanto admirava no Brazil Builds: além do Ministério, visitou a Associação Brasileira de Imprensa e o Instituto de Resseguros do Brasil.

$\mathrm{Na}$ entrevista na qual relata o vestibular, Abrahão se refere aos colegas Ludovico Martino e Eduardo de Almeida que foram os melhores classificados na prova desenho.

Ludovico Martino freqüentou o curso do Instituto de Arte Contemporânea - IAC do MASP. Por adotar referências do curso da Bauhaus, o IAC tinha maior identidade com a 
orientação conceitual da FAU do que a Escola de Artesanato.

O fato confirma a asserção de Abrahão, sobre a diferença de abordagem feita no meio artístico e no arquitetônico.

Nas palavras de Lucio Costa:

[...] se arquitetura é fundamentalmente arte, não o é menos, fundamentalmente, construção. É, pois, a rigor, construção concebida com intenção plástica. Intenção esta que a distingue, precisamente, da simples construção.

Ela não atua, porém, essa intenção plástica, de uma forma abstrata, mas condicionada sempre por fatores de natureza variável de tempo e lugar, tais como a época, o meio físico e social, os materiais empregados, a técnica decorrente desses materiais, o programa, etc. Pode-se, assim, definir arquitetura como construção concebida com uma determinada intenção plástica, em função de uma determinada época, de um determinado meio, de um determinado material, de uma determinada técnica e de um determinado programa (COSTA, 1962, p. 112 e 113)

No ano de 1954, os calouros, quando começaram a cursar o primeiro ano, encontraram os alunos da Escola ainda muito ressentidos, porque, dois anos antes, tinham saído derrotados na chamada "greve Niemeyer".

Oscar Niemeyer que, na época, morava em São Paulo trabalhando no projeto do Parque do Ibirapuera, havia se candidatado a uma vaga de professor na Faculdade de Arquitetura e Urbanismo da Universidade de São Paulo, mas teve seu nome vetado pelo Conselho Universitário. Os alunos fizeram
Associação Brasileira de Imprensa $A B \mid$.

Projeto dos arquitetos Marcelo e Milton Roberto, 1938

fonte: GOODWIN, 1943 p. 113
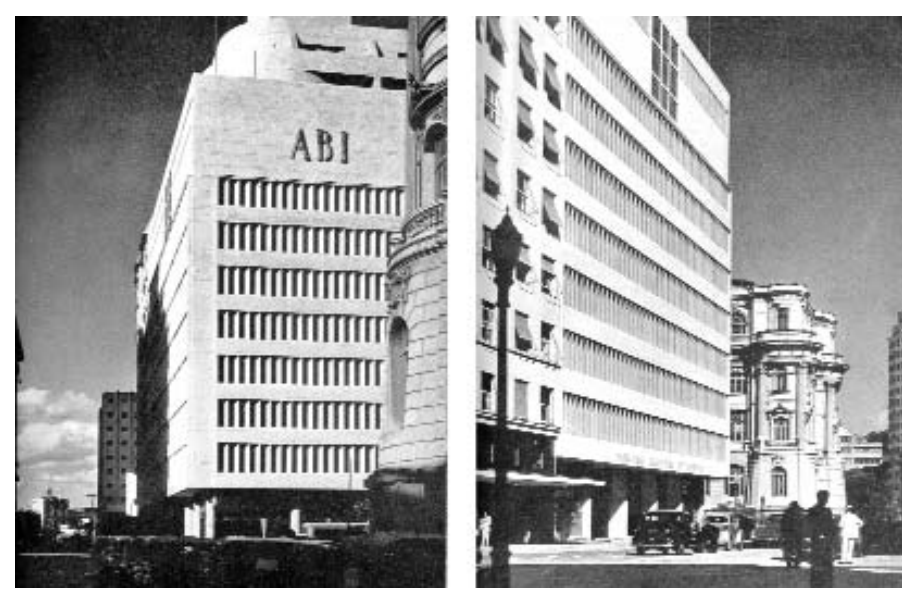

Instituto de Resseguros do Brasil

Projeto dos arquitetos Marcelo e Milton Roberto, 1942 fonte: MINDLIN, 1999 p. 225
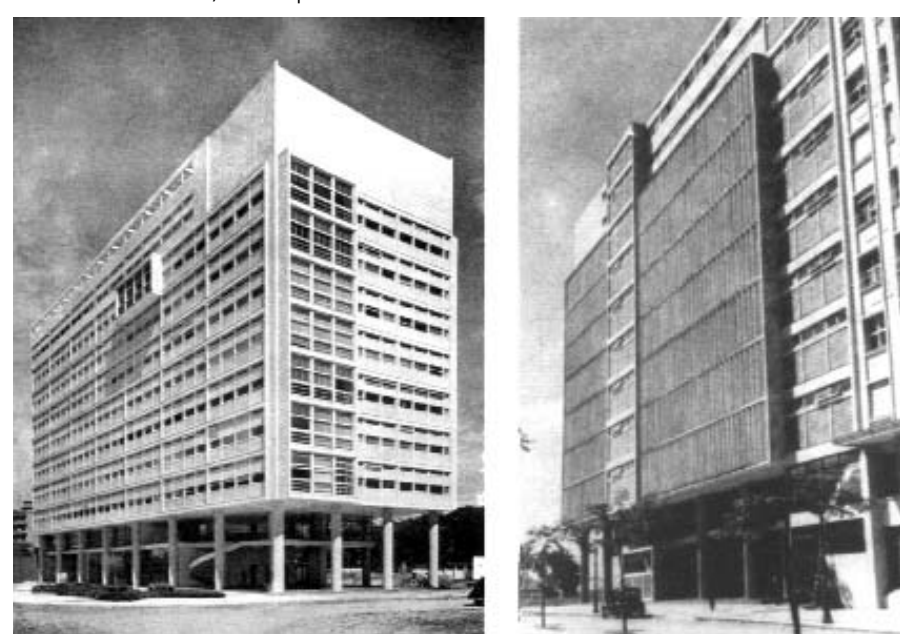
uma greve que se prolongou por três meses até que a Escola fosse ocupada.

Esse primeiro ano de escola foi bastante conturbado: os professores de projeto só tiveram suas recontratações efetivadas no meio do ano. Não puderam contar com a participação do professor Artigas, o qual, em 1953, tinha sido obrigado a voltar a dar aulas na Politécnica, retornando à FAU somente em 1956. Portanto, no primeiro semestre de 1954, só foram cursadas as cadeiras técnicas.

Iniciado o segundo semestre, morre, em agosto, o Presidente da República Getúlio Vargas. Uma greve geral da Universidade, contra o propósito de haver uma intervenção que prejudicasse a autonomia universitária, fez com que poucas atividades tivessem acontecido naquele ano.

A partir de 1955 os alunos começaram a se reorganizar em torno do GFAU, Grêmio da Faculdade de Arquitetura e Urbanismo da USP.

O GFAU, fundado no dia 5 de novembro de 1948, preocupado com a formação dos alunos, promovia atividades culturais complementares ao currículo da Escola, como, por exemplo viagens, exposições, mostras de cinema.

Na entrevista à Catharine Gati, Abrahão comenta:
Esse clima criava um interesse constante: tudo era novo e a vontade de aprender sem limite.

Nossa Escola era muito pequena, 150 alunos no total. A cada evento na cidade algum aluno sempre produzia um cartaz para divulgação na $F A U$, era quase uma disputa, cada um queria fazer o cartaz mais bonito.

Para a exposição do Volpi no Museu de Arte Moderna, fiz um cartaz com uma ilustração que lembrava uma das janelas que ele tinha desenhado, usando azul e cor-de-rosa, tão presentes na obra do artista.

Para os cartazes também tínhamos nossas referências, graças às publicações que encontrávamos na Biblioteca da FAU, a influência maior eram a dos cartazistas poloneses e do suíço Celestino Piatti (DPCA, 1987 e 1988) ${ }^{8}$
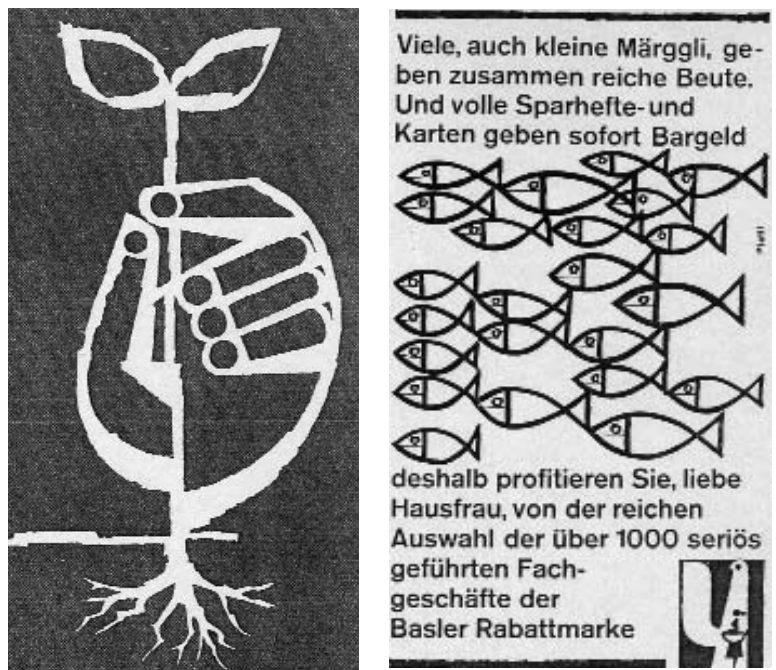

Logotipo da Associação dos Arquitetos Paisagistas Cartaz para uma Cooperativa

autor: Celestino Piatt

fonte: Graphis, n66, jul/ago 1956, p.315 e 320 
Os estudantes, interessados pelo estudo do folclore vinculado à cultura brasileira, a partir das idéias lançadas por de Mário de Andrade, Lucio Costa e Luís Saia, criaram o Centro de Estudos Folclóricos - CEF que, mais tarde, passou a se denominar Centro de Estudos Brasileiros - CEB. Este organismo influiu, sem dúvida, na constituição e na orientação do Departamento de História da FAU.

O Centro dedicava-se a atividades culturais e artísticas, tanto por meio de pesquisas, quanto pela documentação da arquitetura tradicional e da arquitetura que se produzia no Brasil naquele momento, assim como por publicações.

Sobre seu interesse, comentou Abrahão:

Faziam-se pesquisas, a partir das quais comecei a me indagar sobre a Arquitetura Moderna, querendo entender melhor o processo da arquitetura moderna no Brasil (até hoje a crítica da arquitetura moderna brasileira não é muito clara, como não era muito clara na nossa cabeça naquela época). Queríamos conhecê-la com maior profundidade. Acreditávamos que conhecendo melhor seu processo, isso nos ajudaria a caminhar um pouco mais à frente. Começamos então a fazer pesquisas em arquitetura, tomando a obra de Lucio Costa como ponto de partida.

\section{$[\ldots]$}

Eu e o Katinsky começamos a fazer o levantamento da obra de Lucio Costa desde o período neocolonial até o período imediatamente anterior à Brasília (que naquela época ainda não havia sido construída). Também foram com a gente Eduardo de Almeida e Ludovico Martino (por sinal, foram eles os que tiveram as melhores notas na prova de desenho a que me referi acima). Não existia xerox, portanto, tivemos que ir à sede do jornal "A Noite", no Rio, e ficamos manuscrevendo, copiando tudo o que havia sobre Aleijadinho, texto de Lucio Costa. Essa série de pesquisas, além do trabalho junto ao Grêmio, nos possibilitou conhecer, tomar contato com todos os grandes arquitetos da época. Fomos até o prédio do Ministério da Educação, onde um senhor alto, magro, que cuidava do Arquivo, nos atendeu. Explicamos que estávamos pesquisando a obra de Lucio Costa, e ele foi muito atencioso com a gente, fornecendo-nos um vasto material de pesquisa Esse senhor era simplesmente Carlos Drummond de Andrade (SANOVICZ, 1997, p. 145).

Nesse período, os alunos acreditavam que para entender a arquitetura que era produzida na época, no Brasil, deveriam buscar suas origens nos anos 1930. Nesse sentido, texto de Lucio Costa "Razões da Nova Arquitetura", de 1930, teve singular importância:

Na evolução da arquitetura, ou seja - nas transformações sucessivas por que tem passado a sociedade, os períodos de transição se têm feito notar pela incapacidade dos contemporâneos no julgar o vulto e alcance da nova realidade, cuja marcha pretendem, sistematicamente deter. A cena é, então, invariavelmente, a mesma: gastas as energias que mantinham o equilíbrio anterior, rompida a unidade, uma fase imprecisa e mais ou menos longa sucede, até que, sob a atuação de forças convergentes, a perdida coesão se restitui o novo equilíbrio se restabelece.

[...] 
Filia-se a nova arquitetura, isto sim, nos seus exemplos mais característicos - cuja clareza e objetividade nada tem do misticismo nórdico - às mais puras tradições mediterrâneas, àquela mesma razão dos gregos e latinos, que procurou renascer no Quatrocentos, para logo depois afundar sob os artifícios da maquilagem acadêmica - só agora ressurgindo, com imprevisto e renovado vigor. $E$ aqueles que, num futuro talvez não tão remoto como o nosso comodismo de privilegiados deseja, tiverem a ventura - ou o tédio - de viver dentro da nova ordem conquistada, estranharão, por certo, que se tenha pretendido opor criações de origem idêntica e negar valor plástico a tão claras afirmações de uma verdade comum

Porque, se as formas variam - o espírito ainda é o mesmo, e permanecem, fundamentais, as mesmas leis (COSTA 1962, p. $17,40$ e 41$)$.

Entre os alunos que, no período, se envolviam com a produção das publicações, além de Abrahão Sanovicz, estavam: Benedito Lima de Toledo, Gustavo Neves da Rocha Filho, João Walter Toscano, João Xavier, Julio Roberto Katinsky e Nestor Goulart Reis Filho.

O cuidado com o projeto gráfico destas publicações era evidente, como comentou Abrahão, continuando a entrevista com Catharine Gati:

A Biblioteca da Escola sempre foi uma maravilha, o que estimulava os alunos. Recebia as revistas como: "Stile / Industria", "L'Architecture D'Aujourd'hui", "Casabella", "Domus", "L'architettura", "L'Architettura, Cronaca e Storia" dirigida por Bruno Zevi, "Arts and Architecture", "Ghaphis",
"Gebrauch Graphik" e a "Du".

Nessas publicações eram apresentadas obras do nascente design do pós-guerra, o que despertou grande interesse por parte dos alunos da FAU pelo assunto.

A preocupação com o desenho gráfico já se demonstrava nas publicações editadas pelo GFAU, o cuidado que tínhamos com a qualidade gráfica, a procura do que era fundamental, essencial, colocado de uma forma direta, desenhado de uma forma direta e com a maior economia de meios, característica que se esboçava na Escola e, que começamos a desenvolver desde alunos. Identifico um certo ascetismo presente na minha obra com essas preocupações que iniciaram desde a nossa formação (DPCA, 1987 e 1988)

As publicações do Centro de Estudos Folclóricos - tidas como realização dos estudantes no sentido de complementar as atividades didáticas - inauguraram uma tradição que permanece até hoje, como, por exemplo: a revista Estudos; Coleção Depoimentos CEB; Publicação 1, 2, 3 ...;Tema; Boletins do CPEU (Centro de Projetos e Estudos Urbanos); Desenho; Ou; Caramelo; Cogumelo; Jornal do GFAU; 1:1.000; e muitas outras publicações.

Dessa primeira fase, três publicações foram aqui selecionadas para ilustrar os conteúdos de interesse e a atenção com o projeto gráfico.

A Publicação 5 do Centro de Estudos Folclóricos, de 1950, traz em sua primeira parte, "A ASCORAL e sua VI Secção", uma série de extratos traduzidos do livro Manière 
de Penser L'Urbanisme, de Le Corbusier. Segue-se a reprodução do texto de Artur Ramos, "Conceito de Folclore" e, por fim, apresenta a Carta de Atenas do Congresso Internacional de Arquitetura Moderna - CIAM de 1933.

A autoria do projeto gráfico não vem explicitada no volume, apenas uma referência à figura da capa que é de Mario Cravo.

O texto "O Neo-Plasticismo", de Piet Mondrian, originalmente publicado em 1920 e incluído em 1924 na coleção "Bauhausbücher", foi reeditado pelo GFAU em 1954, com tradução de Vilma De Katinszky. Dada a relevância do conteúdo, foi aqui reproduzido um pequeno trecho:

Se arte, por um lado é expressão plástica de nossa emoção estética, não podemos, por isto concluir que a arte seja apenas "a expressão estética de nossas sensações subjetivas".

Quer a lógica que a arte seja a expressão plástica de todo o nosso ser: que seja, pois a aparição plástica do não individual, o que lhe é a oposição absoluta e anuladora e, por outro lado, seja a expressão direta do universal em nós, isto é a aparição exata do universal fora de nós.

i⿱ $)$ Assim compreendido, o universal é o que é e permanece sempre: o mais ou menos inconsciente para nós, em oposição ao mais ou menos consciente - o individual, que se renova e se repete.
Publicação 5 do Centro de Estudos Folclóricos, de 1950 fonte: biblioteca da FAUUSP

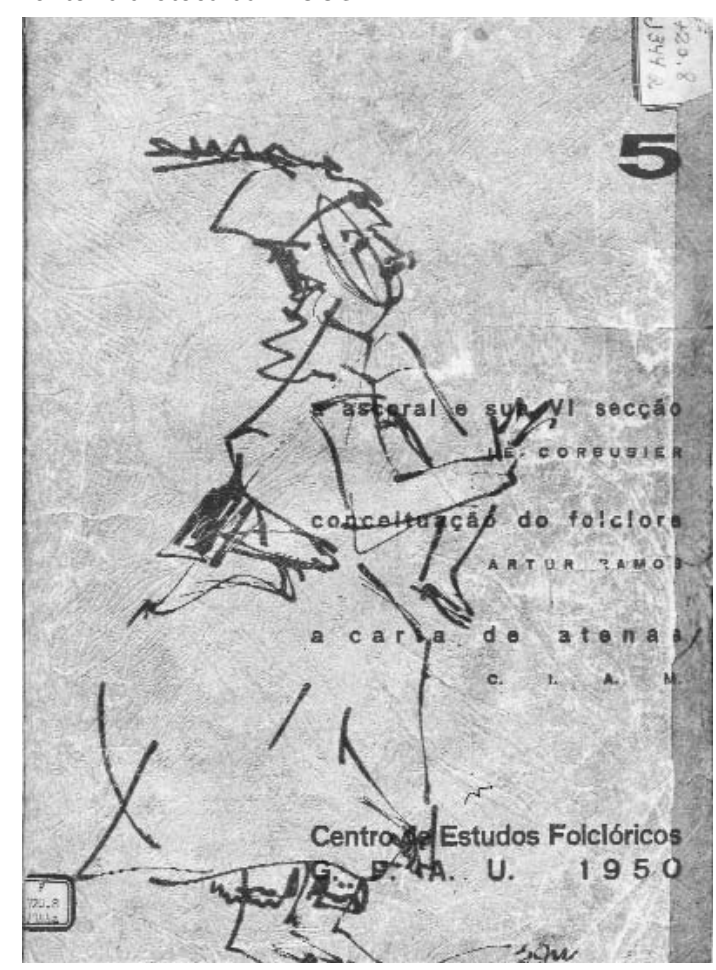



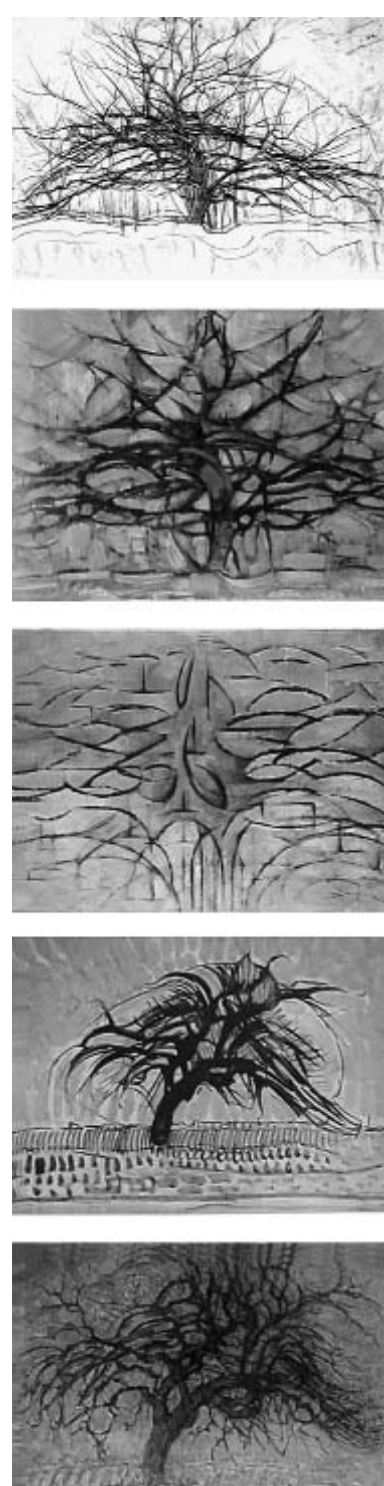

à esq

árvores de Piet Mondrian

fonte: $D u, n^{\circ} 2$, fev 1956, p.17 e 18

abaixo

Publicação GFAU, 1954

capa: Ludovico Martino

fonte: biblioteca da FAUUSP

\section{o neo-plasticismo}

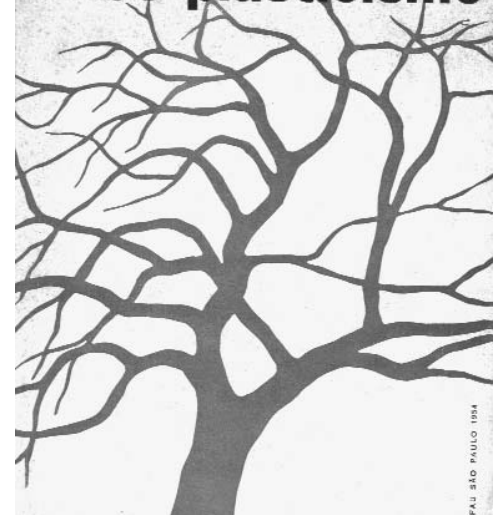

PIET MONDRIAN

\begin{abstract}
$[\ldots]$
É possível que na "totalidade do nosso ser" domine o individual ou o universal, ou ainda que o equilíbrio esteja próximo dos dois. É esta última possibilidade que nos permite sermos universal enquanto indivíduo: isto é exteriorizar o inconsciente conscientemente, É então que vemos e percebemos universalmente, pois nos elevamos acima do domínio do mais exterior (MONDRIAN, 1954, s.p., destaques no original).
\end{abstract}

Para a capa, como era costume, foi promovido um concurso entre os estudantes, sendo vencedor o projeto de Ludovico Martino. No projeto Ludovico Martino fez uma releitura de trabalhos de Mondrian.

O Centro de Estudos Folclóricos publicou, em 1955, o "Curso de Filosofia e História da Arte" e o "Anteprojeto do Serviço do Patrimônio Histórico e Artístico Nacional" de Mário de Andrade.

O Curso de Filosofia e História da Arte foi, inicialmente, ministrado na Universidade do Distrito Federal, em 1938. Da exposição na aula inaugural sobre "O Artista e o Artesão" foi extraído o seguinte trecho final:

Há uma incongruência bem sutil em nosso tempo. Na história das artes estamos num período que muito parece ter pesquisado, e que, no entanto, é dos mais afirmativos, dos mais vaidosos, dos menos humildes diante da obra de arte. Há por certo, em todos os artistas contemporâneos, uma desesperada, uma desapoderada vontade de acertar. Mas a 
inflação do individualismo, a inflação da estética experimental, a inflação do psicologismo, desnortearam o verdadeiro objeto da arte. Hoje, o objeto da arte não é mais a obra de arte, mas o artista. E não poderá haver maior engano.

Faz-se necessário urgentemente que a arte retorne às suas fontes legítimas. Faz-se imprescindível que adquiramos uma perfeita consciência, direi mais, um perfeito comportamento artístico diante da vida, uma atitude estética disciplinada, apaixonadamente insubversível, livre mas legítima, severa apesar de insubmissa, disciplina de todo o ser, para que alcancemos realmente a arte. Só então o indivíduo retornará ao humano. Porque na arte verdadeira o humano é a fatalidade (ANDRADE, 1955, s.p.)

A autoria da capa da publicação é de Abrahão Sanovicz e Julio Robeto Katinsky. As fotografias acrescentadas ao texto, no esforço para tornar mais claro o pensamento do autor, foram escolhidas no acervo da biblioteca da FAU, por Katinsky e Paulo Bastos.

Por essa época, a União Nacional de Estudantes - UNE organizou em Petrópolis um encontro sobre a imprensa universitária. Como o Grêmio da Faculdade de Arquitetura e Urbanismo da Universidade de São Paulo não editava um jornal, as publicações esparsas foram reunidas numa exposição. Com isso, os organizadores alteraram as características gerais do encontro, passaram a discutir, além dos conteúdos, os meios, o formato e a forma da imprensa universitária. Veio daí o que posteriormente se convencionou chamar "estilo GFAU".
Publicação GFAU, 1955

capa: Abrahão Sanovicz e Júlio Roberto Katinsky fonte: biblioteca da FAUUSP

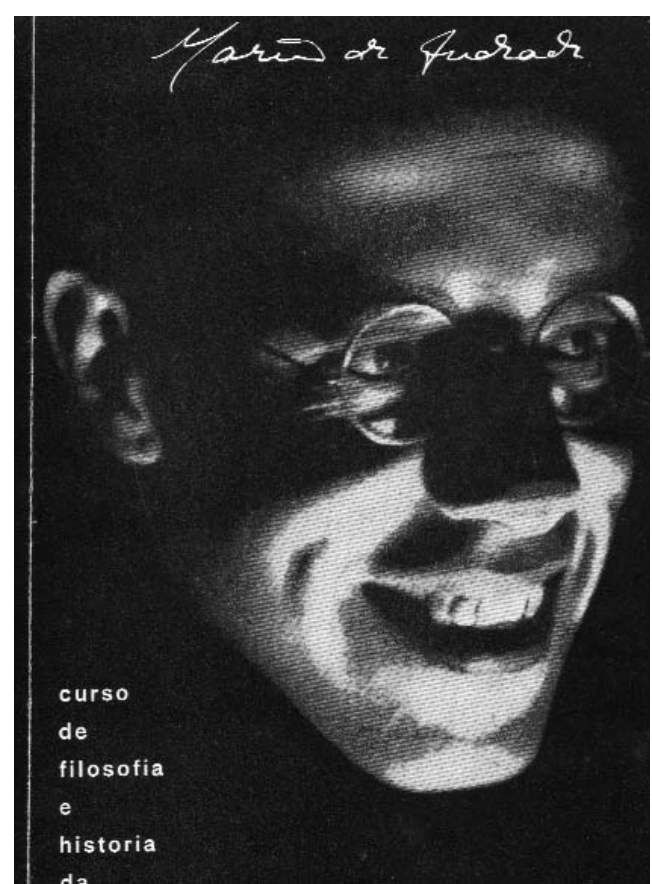




\subsection{Dois projetos}

Os documentos pesquisados, sobre os projetos que Abrahão realizou enquanto estudante, dão a entender os que ele se refere com mais entusiasmo: a "casa" que fez no $3^{\circ}$ ano; o projeto para um concurso patrocinado pela União Estadual dos Estudantes - UEE, em 1956, a Colônia de Férias em Campos do Jordão, em equipe com Julio Katinsky, $1^{\circ}$ lugar no concurso; um outro concurso, patrocinado pelo GFAU, em 1957, uma Colônia de Férias em Ilhabela, em equipe com João Rodolpho Stroeter, $3^{\circ}$ lugar; e, também, em 1957, o Núcleo Residencial para a Refinaria Presidente Bernardes, Município de Cubatão que representou a FAU no Concurso Internacional para Escolas de Arquitetura da IV Bienal do Museu de Arte Moderna de São Paulo, realizada nesse mesmo ano.

É de se lamentar que foram localizados registros de apenas dois destes projetos, a "casa", que preservou em seu acervo e o Núcleo Residencial para a Refinaria Presidente Bernardes, registrado em publicação especial da FAU. 


\section{A "Casa"}

fonte: acervo da biblioteca da FAUUSP

"O melhor projeto que fiz individualmente, como estudante, foi uma casa, para Cadeira de Técnicas das Construções, ministrada por Ariosto Mila", relata Abrahão à sua entrevistadora Catharine Gati.

A Cátedra de №. 9 da FAUUSP, sob responsabilidade do professor Ariosto Mila, continha os seguintes conteúdos programáticos: Técnica das Construções, Organização dos Trabalhos e Prática Profissional, Higiene dos Edifícios, Noções de Mecânica dos Solos e Fundações. Era ministrada em dois anos, no $3^{\circ}$ e no $4^{\circ}$, e abordava todas as etapas do projeto, desde a avaliação do terreno até a elaboração de editais para concorrência e contratos para obra.

O método de ensino estabelecia que a cada módulo teórico, correspondesse um exercício prático.

Analisando o programa da disciplina depreende-se que o objetivo, ao final do $3^{\circ}$ ano, era fornecer ao aluno elementos para executar de um projeto arquitetônico completo. No $4^{\circ}$ ano, o intuito era capacitar o estudante para resolver as questões da prática profissional e para a organização dos trabalhos.

O projeto de Abrahão foi elaborado para o primeiro

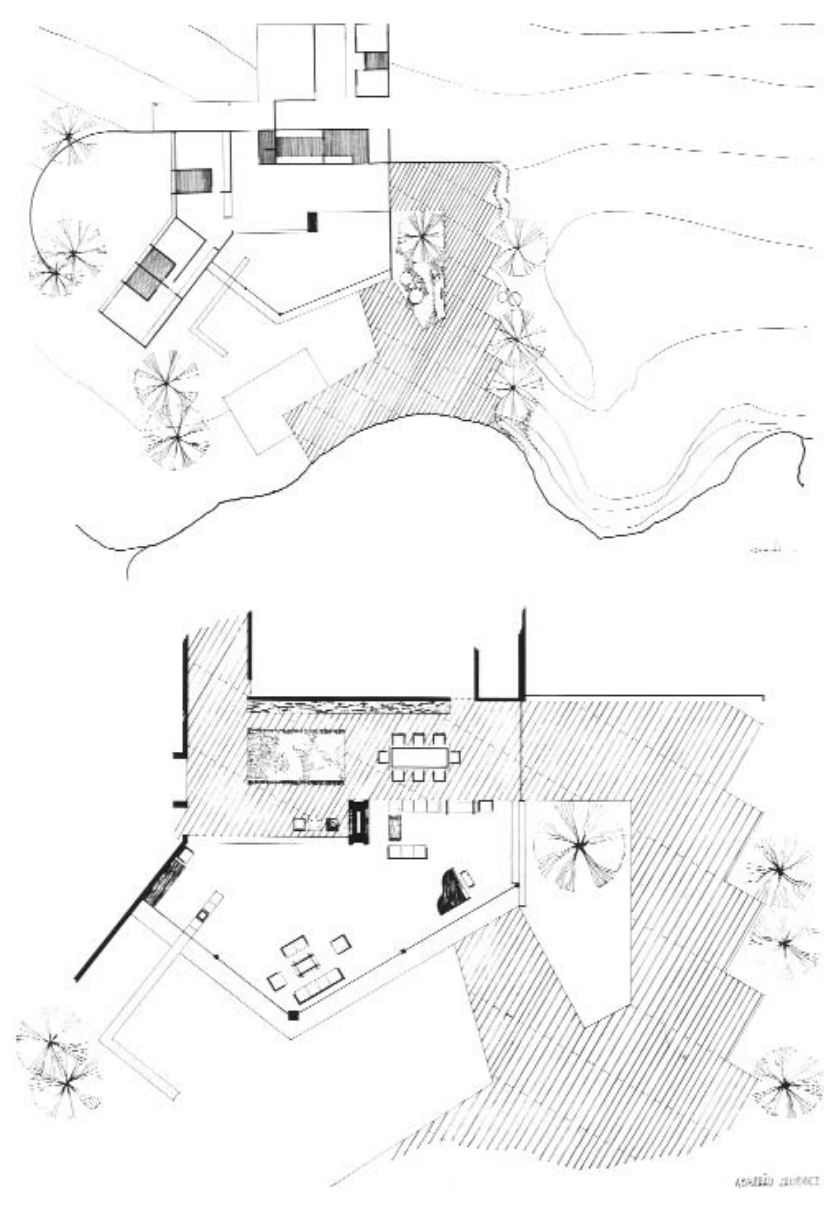




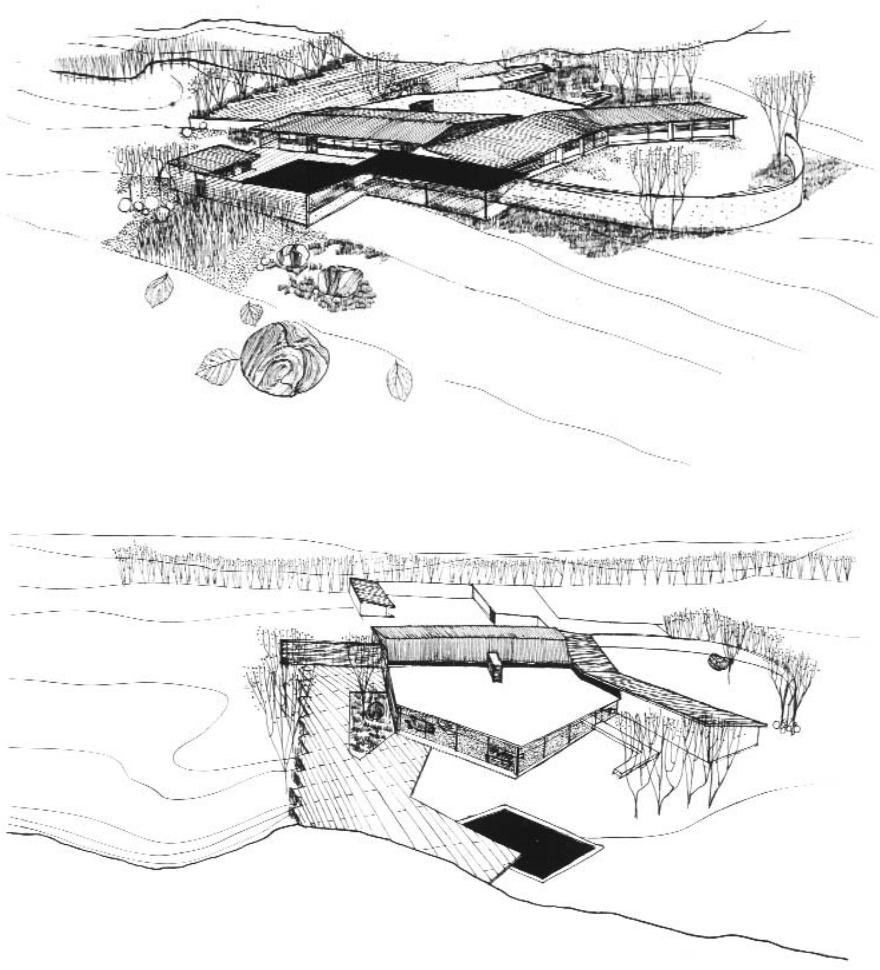

módulo da disciplina, "Planejamento Arquitetônico", onde eram discutidos os seguintes conteúdos:

- Do terreno: ocorrências superficiais; aspectos topográficos; natureza do solo; serviços de utilidade pública; aspecto econômico - noções sobre avaliação de terrenos.

- Leis e regulamentos: Código Civil - do direito de construir - das águas - do direito de condomínios.

- O programa: esquemas funcionais.

- Movimento de terra, adaptação das superfícies. Abertura de valas, processos de terraplenagem.

- Insolação: percurso aparente do sol. Diagramas, exigências legais. Dispositivos para controle da insolação.

O trabalho prático consistia na elaboração do anteprojeto de uma casa, dados um terreno e um programa de necessidades.

Seu projeto era assim delineado: um jogo de volumes, justapostos em ângulo; linhas que marcam a integração do espaço interno com o externo; um pequeno desnível; o recurso de paredes e muros que desenham os espaços desejados. Os desenhos, muito bonitos, fazem registrar a importância da Escola de Artesanato na sua formação. 


\section{O Núcleo Residencial para a Refinaria Presidente Bernardes fonte: FAUUSP, 1958}

O Regulamento do III Concurso Internacional para Escolas de Arquitetura da IV Bienal do Museu de Arte Moderna de São Paulo propunha como tema: o projeto para um núcleo residencial para os trabalhadores de um centro industrial, que empregasse de mil a duas mil pessoas. A proposta deveria prever, além da habitação, os serviços de recreação, educação, etc. A região onde implantar essa proposta seria definida pelos autores, necessariamente no país de onde procedia o trabalho.

A Faculdade de Arquitetura e Urbanismo da Universidade de São Paulo, contava no início com duas equipes, as quais, mesmo antes de começar o trabalho, e por iniciativa de Israel Sancoviski, resolveram fundir-se. O grupo ficou assim formado: Abrahão Sanovicz, Heberto Lira, Hélio Penteado, Israel Sancovski, Jaguanhara Toledo Ramos, Jerônimo Esteves Bonilha, João Carlos Rodolfho Stroeter, José Caetano Mello Filho, Julio Roberto Katinsky e Lúcio Grinover.

Procuraram, inicialmente, Luís Saia e Vilanova Artigas como orientadores do trabalho. O primeiro propôs um estudo urbanístico no bairro da Penha; Artigas, um núcleo habitacional para a Refinaria Presidente Bernardes, do Conselho Nacional do Petróleo.

Nessa época, o país vivia um clima de otimismo em relação ao seu próprio destino e um sentimento nacionalista em ascensão. Os alunos da FAU, sempre engajados nas causas progressistas de cunho nacionalista, elegeram a Refinaria Presidente Bernardes para implantação do projeto.

Desde o começo, o tema foi encarado como de planejamento, procurando sempre a integração do núcleo proposto ao complexo urbano de Cubatão.

Sendo um projeto de grande envergadura, os aspectos que necessariamente devessem ser desenvolvidos (demografia, clima, solo, processos e materiais de construção) foram aprofundados de modo suficiente para subsidiar a proposta até a fase de projeto que se comprometiam apresentar.

No caderno do projeto publicado pela FAUUSP, está registrado que a equipe afirmava ser a preocupação fundamental do trabalho discutir:

O processo da expansão gigantesca que o país atravessa, e os múltiplos problemas que enfrenta, devido ao fenômeno da industrialização, os quais ameaçam tornar obsoletas e inoperantes as estruturas tradicionais de nossas cidades (FAUUSP, 1958, s.p.). 

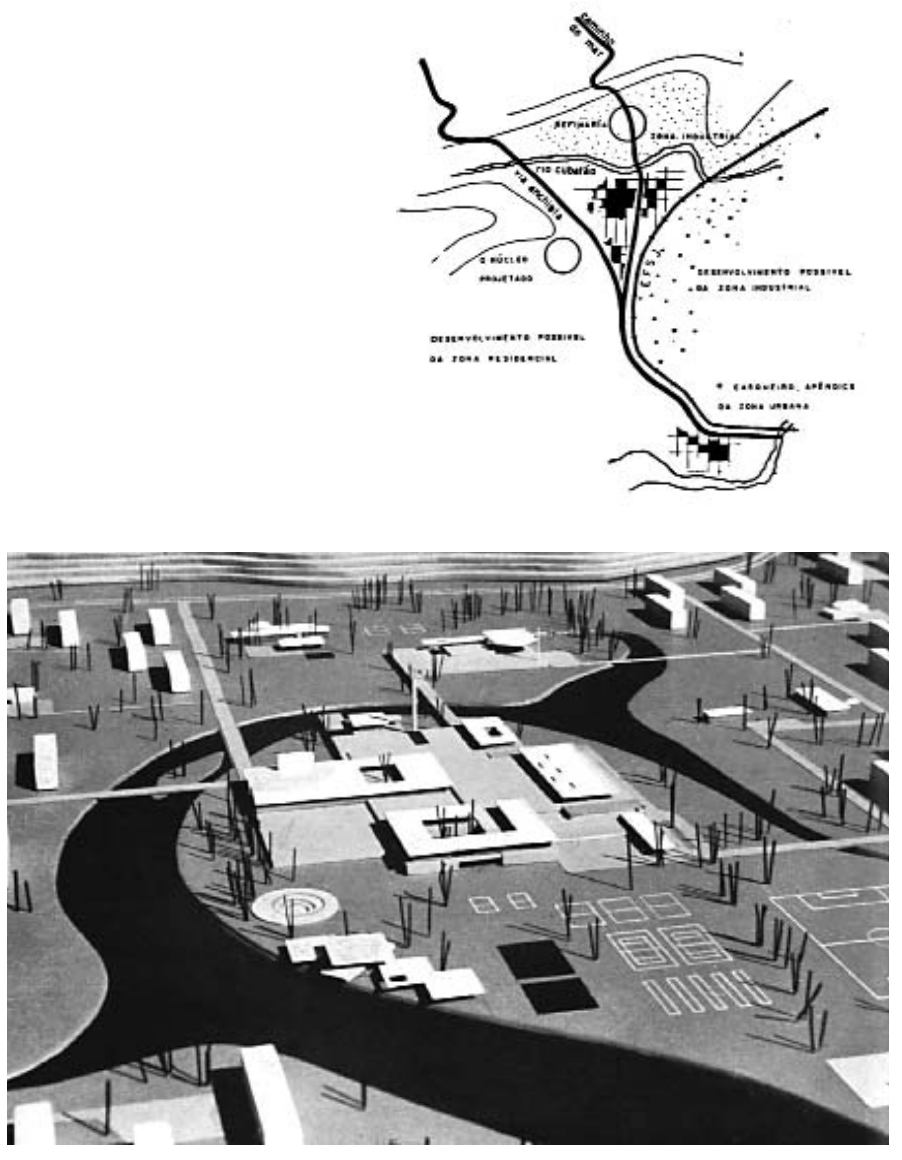

Justificavam eles a escolha de Cubatão pelo fato de ser um local onde o aparecimento das preocupações ocorreriam num intervalo de tempo bastante curto, e a escolha da Refinaria Presidente Bernardes, pelo impacto e significado de sua instalação, daria um impulso decisivo na industrialização do município.

A escolha da área onde implantar o núcleo e, de maneira mais ampla, a reflexão para onde Cubatão devesse se expandir, estava limitada a duas possibilidades: de um lado, os morros escarpados da Serra do Mar e, de outro, as áreas de mangue. Optaram pela ocupação dos manguezais, após serem resolvidas as questões de recuperação e de saneamento.

A proposta de apropriação dos manguezais previa a execução de pôlderes com cota 2,60m acima do mar.

O núcleo ficaria numa posição intermediária entre o centro do município e a zona industrial, ligado a ambos por transporte coletivo, como explicam no texto de apresentação do projeto:

A longa extensão em que se desenvolve a zona industrial exige a existência do transporte coletivo e afasta, desde logo, a possibilidade de localização ao lado de cada indústria, da respectiva vila-operária. Por outro lado, a vinculação direta desta à indústria é indesejável, por favorecer o controle e a alienação do trabalhador pela habitação. O operário deve antes ser um cidadão de Cubatão do que o morador de uma 
determinada vila operária (FAUUSP, 1958, s.p.).

O núcleo foi situado no lado oeste da Via Anchieta, entre o Morro Marzagão e o Morro Piassaguera, ocupando uma área de 144 hectares. A densidade bruta era de 65 habitantes por hectare (adotando o número de 1,4 funcionário por família - número utilizado pela Companhia Siderúrgica Paulista - COSIPA na época).

A proposta previa 8 "unidades de residência", cada uma com 13 edifícios de apartamentos e uma unidade de serviços com: jardim de infância, lavanderia, comércio diário, sala de reuniões e, eventualmente, restaurante.

Em cada "unidade de residência", os edifícios de apartamento foram agrupados em conjuntos de 3, 4 ou 5 edifícios, em torno dos quais o terreno seria pavimentado e ajardinado, estando previstas áreas para reuniões, descanso, exercícios e jogos. Esses conjuntos eram separados por bosques de eucaliptos que, além de drenar o solo, visavam tornar seu uso mais flexível e contribuir para a melhoria do microclima e para a criação de zonas de sombra. Os bosques eram destinados a passeios e, através deles, passavam os caminhos para pedestres e ciclistas que se dirigiriam ao centro.

A descrição do projeto das "unidades de residência" deixa
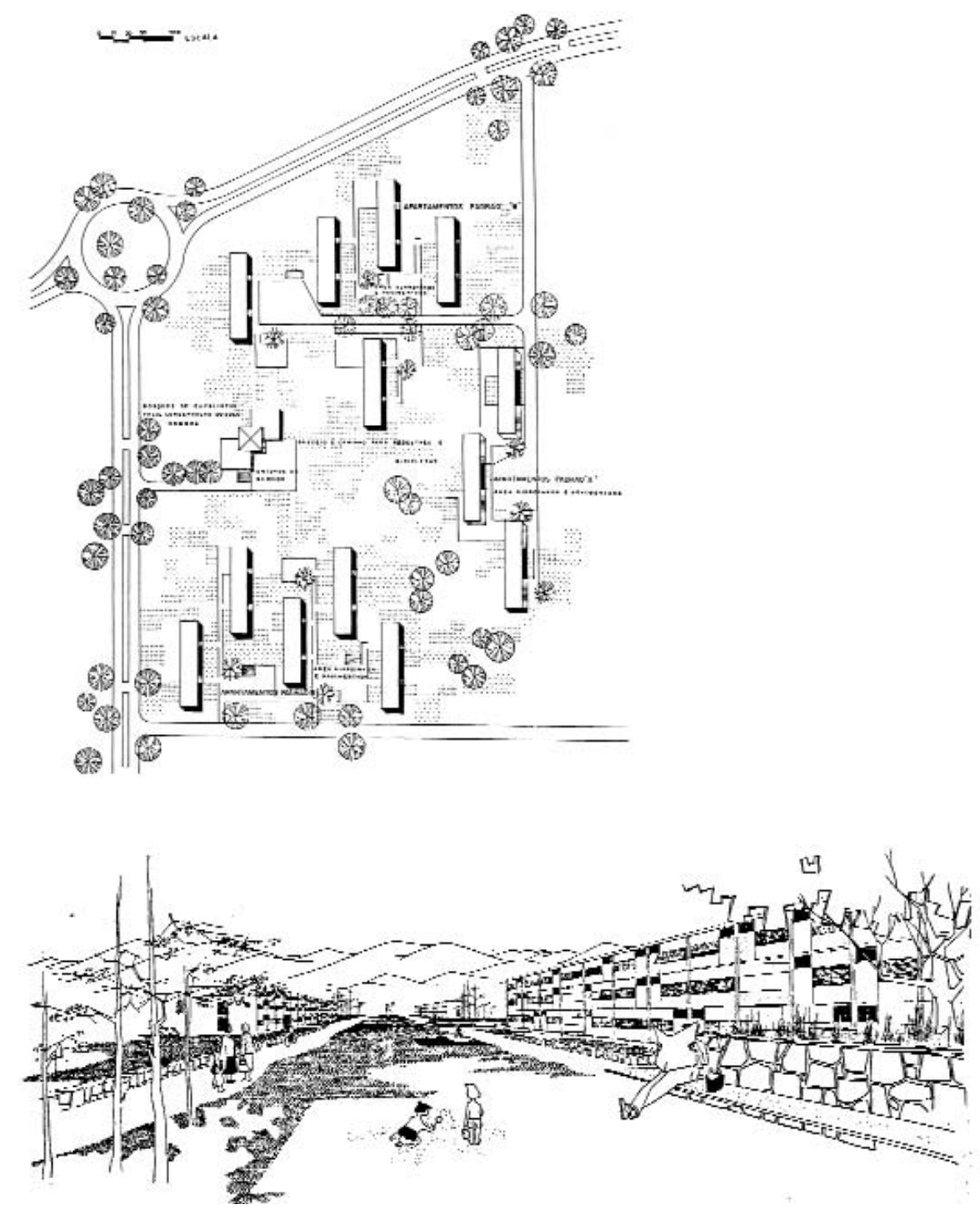

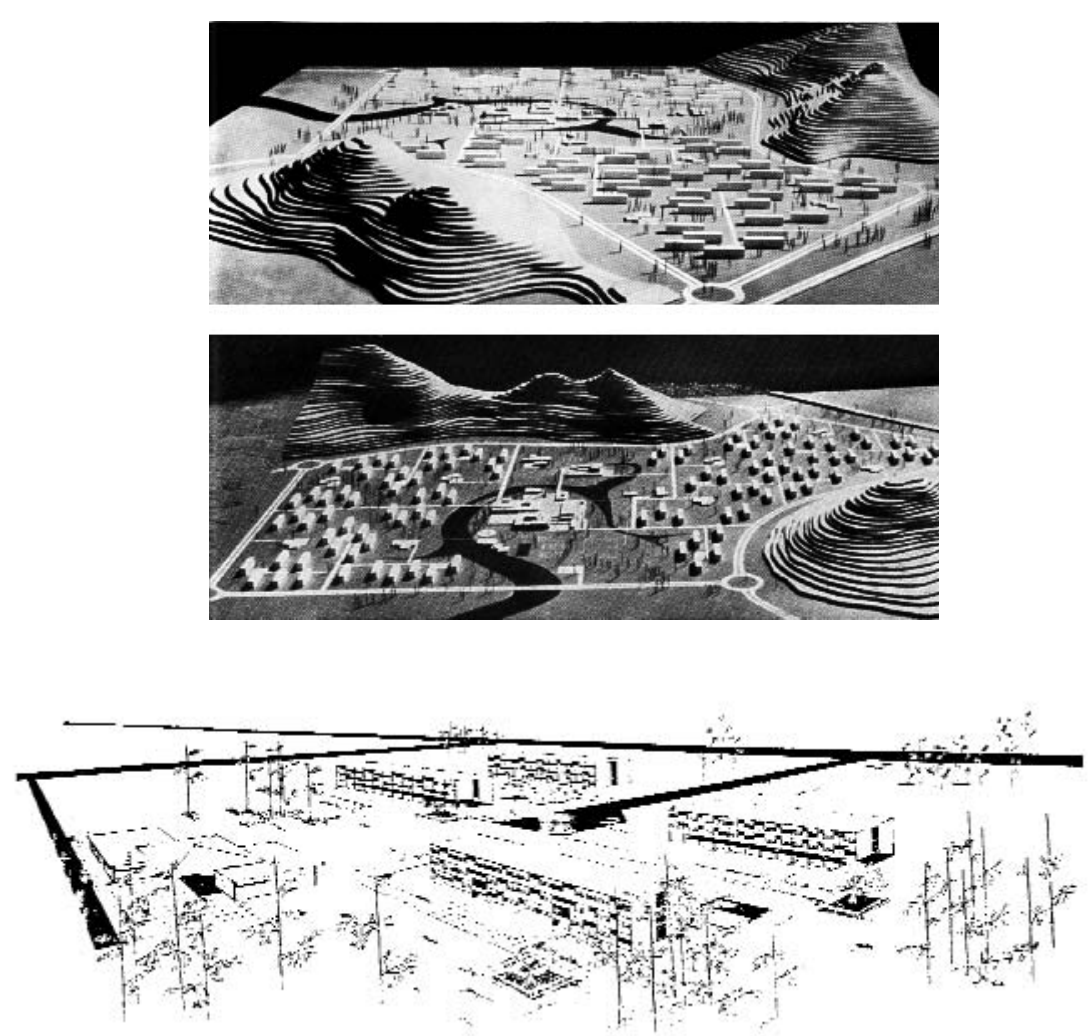
leira estava, nessa época, ensaiando seus primeiros passos.

A solução previa, para os apartamentos, um edifício com térreo em pilotis, mais três pavimentos. Assim, não seria necessária a instalação de elevadores. A construção seria industrializada, com modulação que pudesse acomodar satisfatoriamente famílias com diferentes números de membros.

O centro comunal iria reunir as atividades que caracterizam o espaço cívico (referência aos Congressos Internacionais de Arquitetura Moderna - CIAM's) e aquelas que surgem especificamente do aglomerado humano: lojas, mercado, cinema, igreja, biblioteca pública, centro de saúde, 
edifício de administração, clube náutico, teatro de arena ao ar livre, terminal de ônibus e escola primária.

O centro comunal foi localizado na península formada por um braço do estuário santista e se situa no centro do conjunto. A península é cercada em toda a volta, por pôlderes de largura variável, sobre os quais acontecem os passeios para pedestres.

Na proposta, o centro comunal está elevado e é constituído por três pequenas praças em níveis diferentes, interligadas por escadarias. As diversas atividades foram encaradas como igualmente importantes e apenas relações funcionais de aproximação determinaram a localização dos edifícios.

Algumas atividades não foram previstas por serem específicas da escala de cidade, como ensino secundário e industrial, hospital, etc.

Com este projeto, a Faculdade de Arquitetura e Urbanismo da Universidade de São Paulo recebeu - com outras três Universidades: École Speciale d'Architecture - Paris França, Faculdad de Arquitectura y Urbanismo de la Universidad Central da Venezuela e Waseda University Graduate School of Tokyo - o Primeiro Prêmio "Ex-Aequo" do III Concurso Internacional para Escolas de Arquitetura da IV Bienal do Museu de Arte Moderna de São Paulo, 1957.
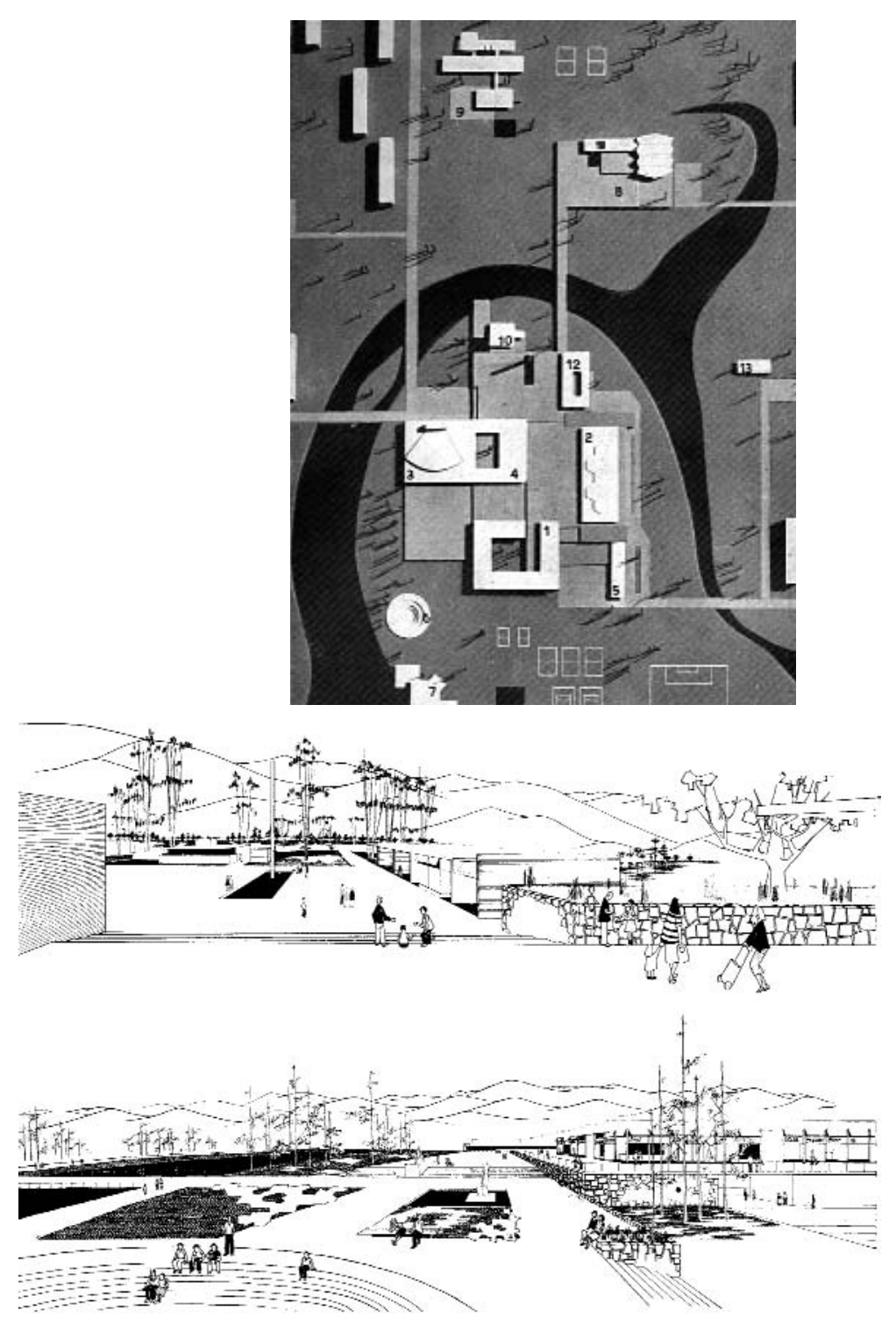


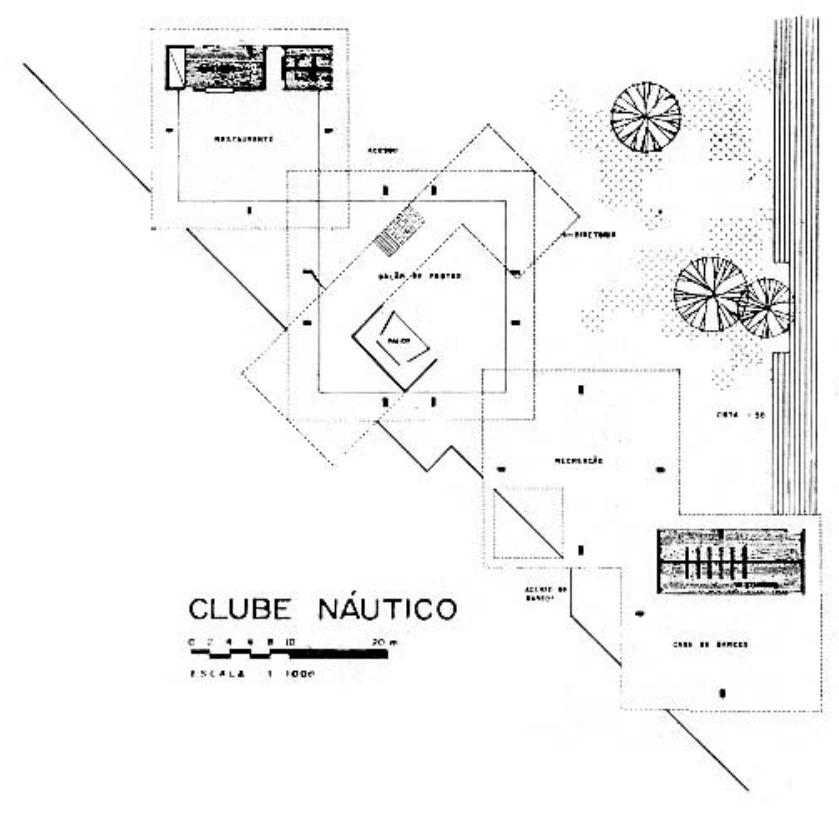

Sobre o projeto, comentou Julio Katinsky em entrevista com a autora do presente estudo:

Acatamos então a proposta do professor Artigas, e aí algumas teses foram importantes se desenvolver, digamos assim, bem característica do mundo paulista. Primeiro lugar: o conjunto habitacional tinha que ter um Centro Cívico, e quem definiu isso muito bem foi Hélio Duarte: o Centro Cívico tem que ter uma vida cultural e uma vida física, tudo misturado.

A outra coisa que foi muito importante, e nisso Abrahão deu uma grande contribuição foi a sistematização das fachadas dos edifícios. Foram feitos todos com três andares, além do pilotis, para não ter elevador.

A gente trabalhou nesse projeto com um entusiasmo louco. Para mim foi muito bom, eu desembaracei muito. Abrahão e eu ficamos responsáveis pelo projeto do clube náutico: todo mundo ficou impressionado, porque em vez de ser um retângulo, como todos os outros, resolvemos com uma articulação de quadrados, ficou muito bonito. E nós já estávamos estudando a obra do Oscar. Bom, é tudo um pouco ingênuo, trabalho de estudante.

Outra coisa muito bonita foi a maquete, foi tudo calculado, tão trabalhado: os blocos não foram pintados de branco, foram pintados num leve cor-de-rosa, porque diziam para nós que se fosse cor-de-rosa o contraste seria maior. As árvores são pregos, ficou muito bonito. A maquete foi feita pelos funcionários

Com o prêmio, Abrahão concorreu a uma bolsa concedida pelo Circolo Italiano de São Paulo para trabalhar em um escritório de desenho industrial em Milão, para onde foi logo que se formou. 


\section{NOTAS}

1 Para os azulejos do Ministério da Educação e Saúde "a técnica utilizada é a do baixo esmalte ou 'biscoito': a pintura é feita sobre o azulejo não esmaltado. Após o desenho sobre a superfície porosa, que absorve a tinta com extrema rapidez e exige uma elevada exatidão do traço, os azulejos de $15 \times 15 \mathrm{~cm}$ são armazenados e levados para o trabalho de esmaltagem e queima nas Indústrias Reunidas Francisco Matarazzo" in Itaú Cultural. Enciclopédia das Artes Visuais. Verbete Osiarte. www.itaucultural.org.br.

2 Relativo ao kibutz (plural kibutzim) comunidade autônoma com base em trabalho agrícola ou agroindustrial, caracterizada por uma organização igualitária e democrática, obtida pela propriedade coletiva dos meios de produção.

3 Dror significa "Pássaro da Liberdade", em hebraico. Movimento juvenil sionista e socialista fundado na década de 1910, originário da Polônia.

4 Wandervogel "pássaros errantes", em alemão, foi um movimento juvenil que surgiu no fim do Século XIX, com preocupações ecológicas, culturais, políticas e econômicas. Sua principal característica era a independência política, ideológica e religiosa, como comentou Falbel.

5 Entrevista de Nahman Falbel concedida à autora. Ver Volume 2 da tese.

6 Freiheit significa liberdade, em alemão.

7 Aonde Vamos? Revista judaica editada no Rio de Janeiro. E Jornal Israelita era ditado no Rio de Janeiro.

8 Celestino Piatti: nasceu em 1922 na Suíça, em Wangen, cidade próxima de Zurique, onde freqüentou por um ano a "School of Arts and Crafts", depois durante quatro anos trabalhou numa gráfica, onde aprofundou seus conhecimentos em artes gráficas. De 1944 a 1948 trabalhou no ateliê de Fritz Bhüler. No inverno de 1948 / 49 abre seu próprio ateliê em sociedade com sua mulher, a ilustradora Marianne Piatti-Stricker. O trabalho de Celestino Piatti marcou gerações de artistas gráficos. 


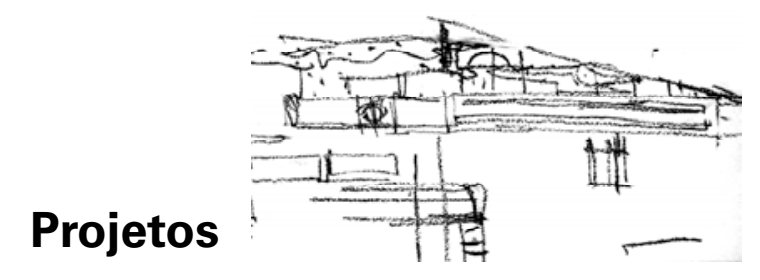

late Clube de Londrina

Desenho Industrial - A experiência no escritório de Marcello Nizzoli 1959

Centro Cultural e Teatro Municipal de Santos

Equipamentos Públicos e Sinalização para os Jardins de São Paulo - 1967/69

Estações de Piscicultura de Promissão e Salto Grande Residência Abrahão Sanovicz

Fórum de Bragança Paulista

Sede do Banespa Recife

\section{Quatro Escolas}

Grupo Escolar Embaúba

Ginásio Estadual em Santos

Escola Professor Caetano de Campos

Escola Estadual de Primeiro Grau Bairro 120

67 Edifícios de Apartamentos

165 Edifício Abaeté $\quad 167$

75 Edifícios residenciais, modulados e repetitíveis $\mathbf{1 7 5}$

75 Edifício Fiandeiras 181

85 Edifício Teixeira da Silva 191

95 Conjuntos Habitacionais 197

95 Conjunto Residencial Nova Cidade 201

105 Parque Habitacional CECAP Serra Negra 209

113 Parque Habitacional CECAP Sumaré 221

113 Vila Residencial da CESP Porto Primavera 229

121 Conjunto Habitacional Pascoal Melantônio e Conjunto

129 Habitacional Celso dos Santos 237

137 Casas Bi-Nucleares $\quad 247$

141 Residência André Mehes 253

145 Residência Maia Rosenthal 263 

O que é o ato de projetar?

E uma atividade tão criadora como qualquer outra atividade humana. Não tem nada de especial nem de excelso e se insere junto com as demais no processo vital, tendo algumas características específicas.

Cada vez que somos solicitados a resolver algum programa e temos de lançar os primeiros esboços no papel, o que fazemos? Procuramos montar algumas relações no cérebro. Para montá-las, contamos com certo estado de préconsciência do projeto. Elaborado neste estado e por um mecanismo próprio do cérebro, que é comum a todas as pessoas, ele atinge o estado da consciência. Rapidamente, pegamos um papel e um lápis e lançamos um pequeno esboço. Conhecemos bem o gesto simples de uma cruz que define uma cidade e que hoje é uma capital.

E muito difícil sermos observadores daquilo que estamos pensando e que ainda permanece no estado da préconsciência.

Porém na medida em que lançamos o esboço no papel, começamos a fazer perguntas para o mesmo, procurando respostas aos problemas propostos.

Na medida em que essas respostas atendem aos nossos desejos, paulatinamente temos a certeza daquele nosso primeiro ato intuitivo: se as respostas vierem certas, estamos atingindo nosso objetivo; se as respostas não vierem, ou pergunta está errada, ou o projeto precisa ser corrigido.

A partir da certeza que aqueles traços interpretam o projeto que nós tínhamos - interpretam um determinado acontecimento social a ser configurado no espaço, ancorado ou não - podemos então ampliar as escalas do projeto e usarmos todas as técnicas que conhecemos.

ato de projetar (a passagem do estado da pré-consciência para o estado da consciência do projeto) é por demais conhecido.

O projeto (resultado deste processo) é desconhecido, é a pesquisa (SANOVICZ, 1990, p. 110).
Com estas palavras Abrahão Sanovicz revela seu pensamento sobre o processo do projeto.

Os projetos apresentados procuram exprimir a trajetória do arquiteto e a diversidade de problemática que enfrentou. Mas, sobretudo, estão entre aqueles que melhor ilustram seu pensamento. 

late Clube de Londrina - 1959

Av. Higienópolis, Londrina, PR

fonte [desenhos] Toscano, 2002, p. 36 - 39 
O late Clube de Londrina, em 1958, procurou apoio do Instituto de Arquitetos do Brasil - IAB para promover um concurso de âmbito nacional para o projeto de sua sede.

A equipe constituída por Abrahão Sanovicz, João Walter Toscano e Julio Roberto Katinsky se inscreveu no certame.

O Clube se implantaria junto ao lago artificial formado pelo represamento das águas do Ribeirão Cambé.

Para um terreno de $123.660 \mathrm{~m}^{2}$, o programa de necessidades sugerido no edital estabelecia: administração - diretoria, secretaria, copa e sanitários; salão de baile; salão de jogos; biblioteca; salão de estar; restaurante; boliche; auditório; sanitários; vestiários com sala de fisioterapia; píer e abrigo para barcos; e esportes ao ar livre (quadras poliesportivas, piscinas e hipismo).

O júri, constituído pelo IAB, foi composto pelos arquitetos: Ernani de Vasconcelos, que participou do projeto do Ministério de Educação e Saúde, Eduardo Corona e Rubens Meister, que era de Curitiba, e tinha sido autor do projeto do teatro Guaíra, dessa cidade.

O melhor projeto selecionado foi o dos jovens arquitetos Abrahão Sanovicz, João Walter Toscano e Julio Roberto Katinsky. "Quando escolheram o projeto, acreditaram ser de um grupo carioca e se surpreenderam quando souberam que a equipe vencedora era composta por jovens e desconhecidos arquitetos paulistas" (DPCA, 1987 e 1988), comentou Abrahão. O mérito da escolha também pode ser avaliado pelas palavras de Toscano:

Concorremos com gente importante, como Sérgio Bernardes.

Os organizadores pensavam que era uma equipe mais experiente e quando chegamos ao aeroporto, três recémformados, eles perguntaram se éramos nós mesmos os autores do projeto, que não foi todo construído. A inspiração foi o late Clube de Pampulha, parecia um barco, pois estávamos ligados à arquitetura moderna brasileira. Esse projeto foi muito divulgado e obteve bastante repercussão na época (TOSCANO, J., 2003)

late Clube da Pampulha - Belo Horizonte, MG, 1942 projeto: Oscar Niemeyer

fonte: NIEMEYER, 1977, p. 47.

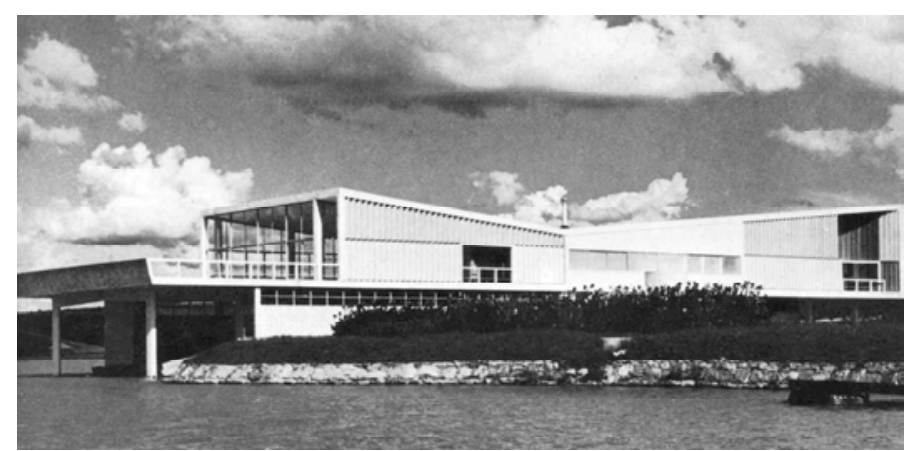

A proposta de implantação considerava a Avenida Higienópolis e a margem do lago como eixos principais para a implantação do empreendimento. O acesso natural, 
paralelo ao lago, definiu a localização do bloco principal, centralizador das atividades que constituem o núcleo do Clube, distribuídas em três pavimentos.

A cavaleiro do terreno, implantado perpendicularmente ao lago, esse bloco iria definir e organizar as diversas atividades.

Vislumbrava ainda o projeto: blocos edificados, elementos de circulação, espaços livres e esplanadas ordenariam os espaços externos.

Entre as quadras e a piscina, a meio caminho, um outro bloco pequeno semi-enterrado, previa a instalação dos vestiários para as atividades esportivas, das salas para fisioterapia e do salão de boliche. O bloco se abria para a esplanada, desenhada pelo edifício principal de um lado e piscina olímpica do outro.

Da praça de chegada à meia altura entre o térreo e o primeiro andar, o acesso ao prédio seria feito por rampas.

Nesse mesmo espaço térreo, a proposta localizava o bar e o restaurante, que também deveriam abrir-se para a esplanada; a sala de jogos (pingue-pongue e bilhar); os vestiários para as práticas do iatismo e hipismo; e o abrigo para barcos.

No primeiro andar, na chegada da rampa, o vestíbulo previsto seria o espaço de acolhimento e organização do programa definindo, em um lado, a administração, a biblioteca, a sala para jogo de cartas e os sanitários. No outro lado, separado por uma membrana curva, o salão de baile e o terraço coberto. No eixo de circulação horizontal, um segundo terraço, sobre o restaurante, se volta para a esplanada.

Um grande espaço estava desenhado no segundo andar: vestíbulo e salão nobre, divididos apenas por uma cortina pesada.

Nesse cenário, a circulação vertical interna seria resolvida com uma generosa escada helicoidal.

A solução construtiva para o bloco principal constitui-se em estrutura mista, ou seja: os pilares e as lajes são em concreto armado; a cobertura metálica apoiada em quatro pilares de concreto.

\section{Toscano comenta mais uma vez:}

A cobertura foi resolvida como um lençol atirantado, sustentado por sete cabos de aço engastados nas duas grandes vigas metálicas, que transferem os esforços para quatro cabos, dois ancorados na terra e outros dois ancorados no balanço da laje do salão de baile. Assim as quatro colunas de concreto da cobertura são solicitadas somente por esforços verticais (TOSCANO, J., 2002, p. 36) 
Sobre as referências de projetos além da mencionada por Toscano, Abrahão tece os seguintes comentários:

[...] as referências são muito evidentes: parece a síntese entre o pensamento do Oscar (Niemeyer) com algumas soluções do Artigas, como a "receita do pilar".

$[\ldots]$

Nossas preocupações fundamentais eram com a implantação e com a leveza do edifício, e nesse sentido dois projetos de Oscar Niemeyer nos impressionavam o do late Clube da Pampulha e uma casa que tínhamos visitado em 1958, um lençol com quatro pilares, em Pedro do Rio.

O projeto de Londrina tem muito da arquitetura carioca: a implantação perpendicular ao lago; o percurso no terreno até o edifício; o desenho dos pilares; a maneira como "mordem a laje"... (DPCA, 1987 e 1988).

Consultado, pessoalmente, para definir com suas próprias palavras o que era "receita de pilar", o professor Katinsky, preferiu responder delineando o desenho que apresentamos. Antes, porém, lembrou outra importante referência, que foi o late Clube do Rio de Janeiro.

Na pesquisa dessas referências apontadas pelos autores, outras tantas foram selecionadas e incorporadas, como se pode ver nas imagens que seguem.
Desenho de Julio Katinsky - "Receita de Pilar"

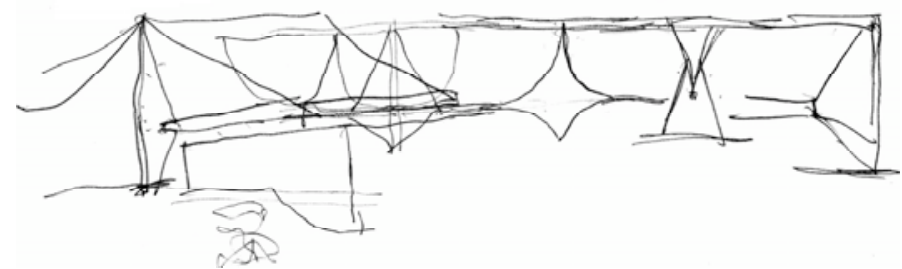

tate Clube Rio de Janeiro - Rio de Janeiro, 1945 projeto: Oscar Niemeyer fonte: NIEMEYER, 1977, p. 62

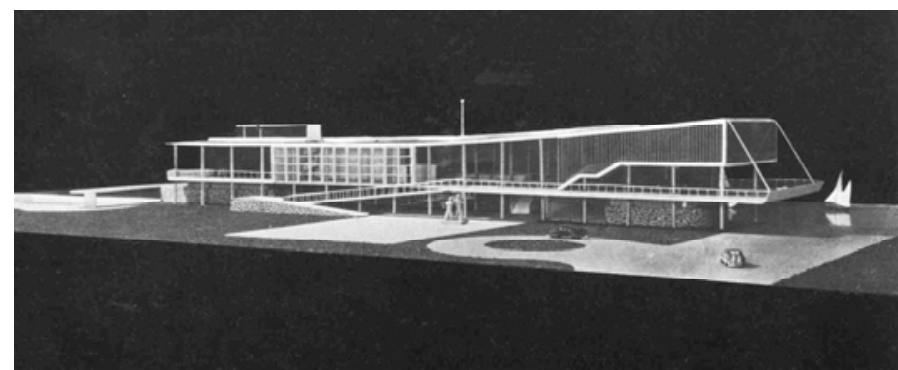



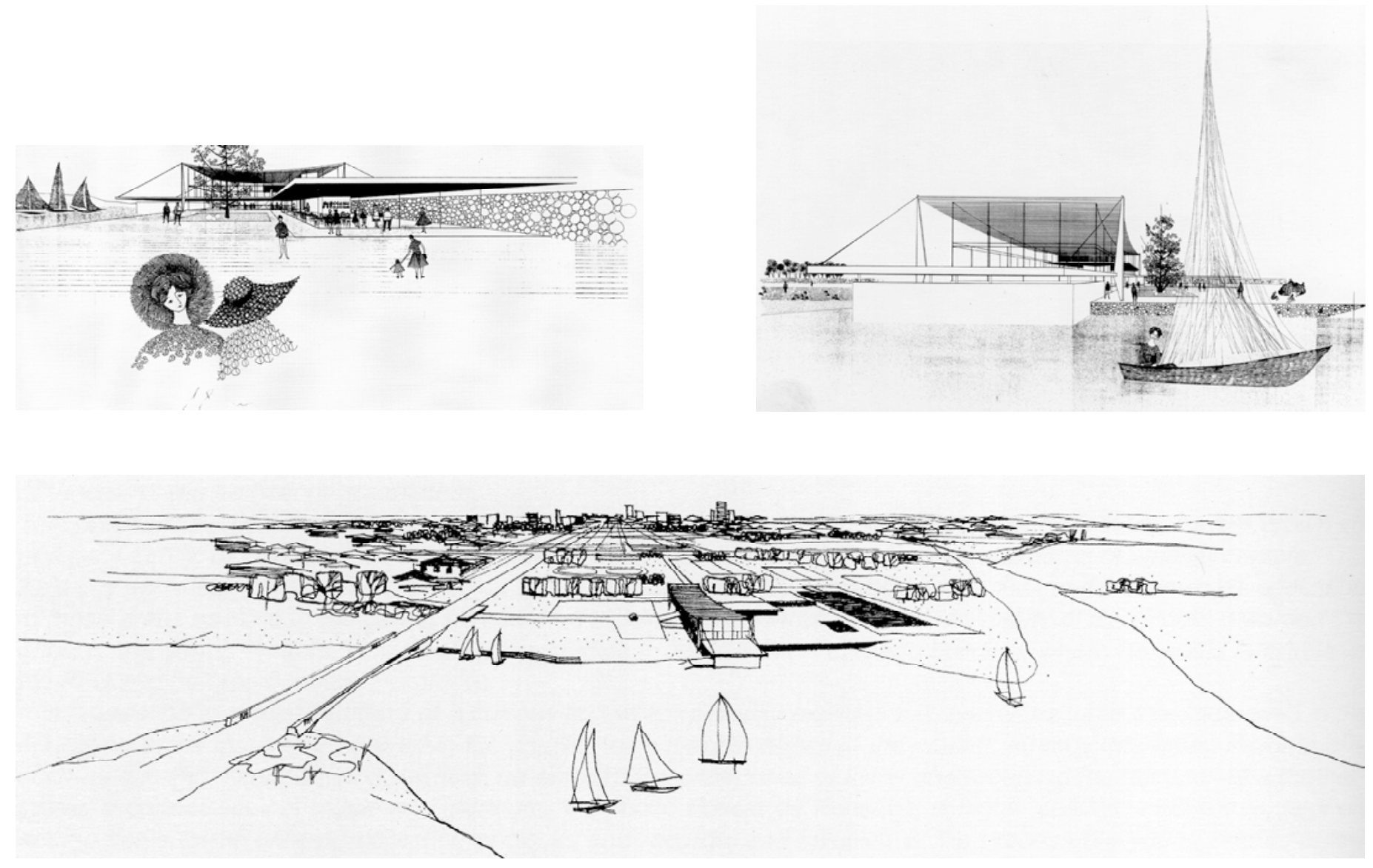


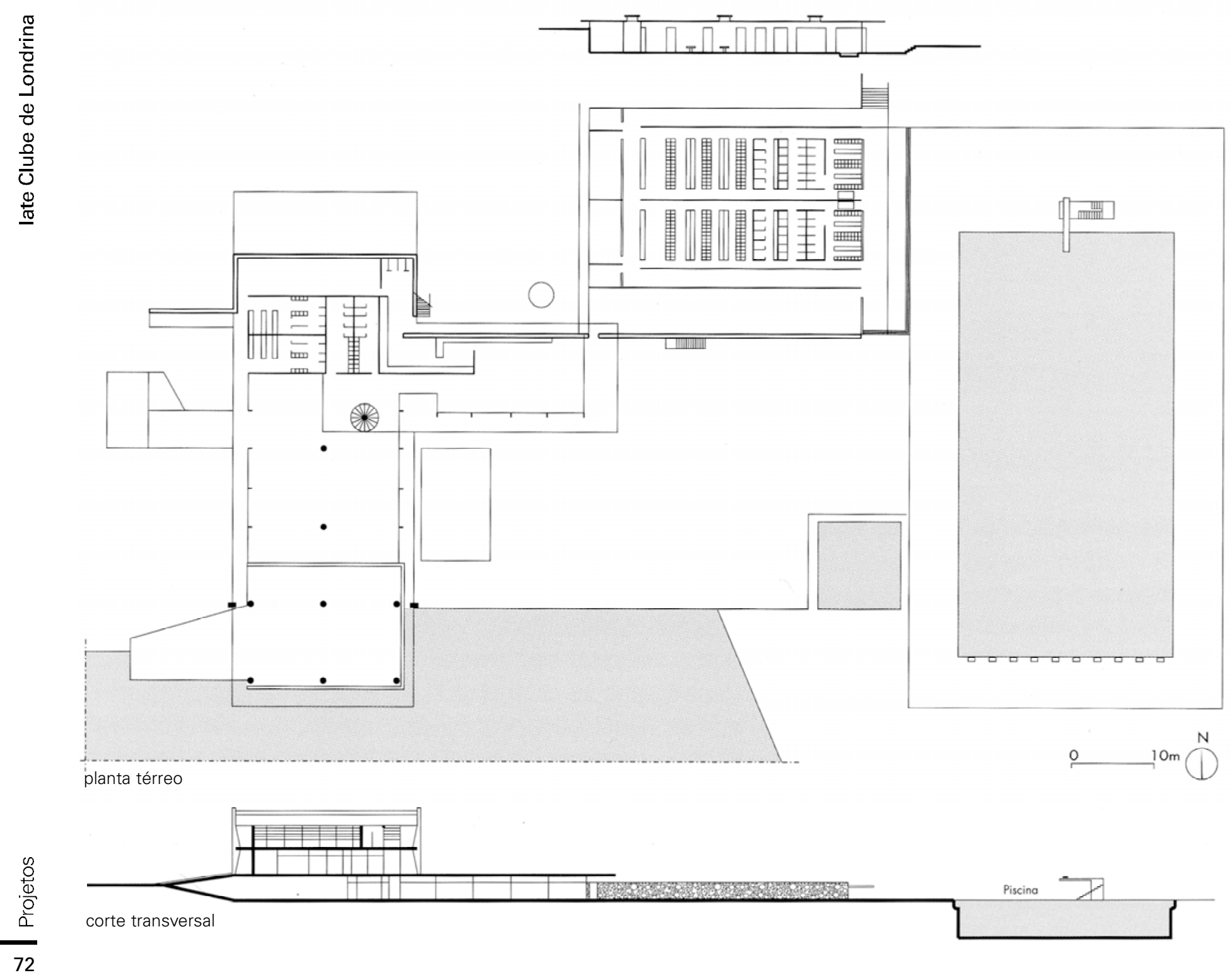




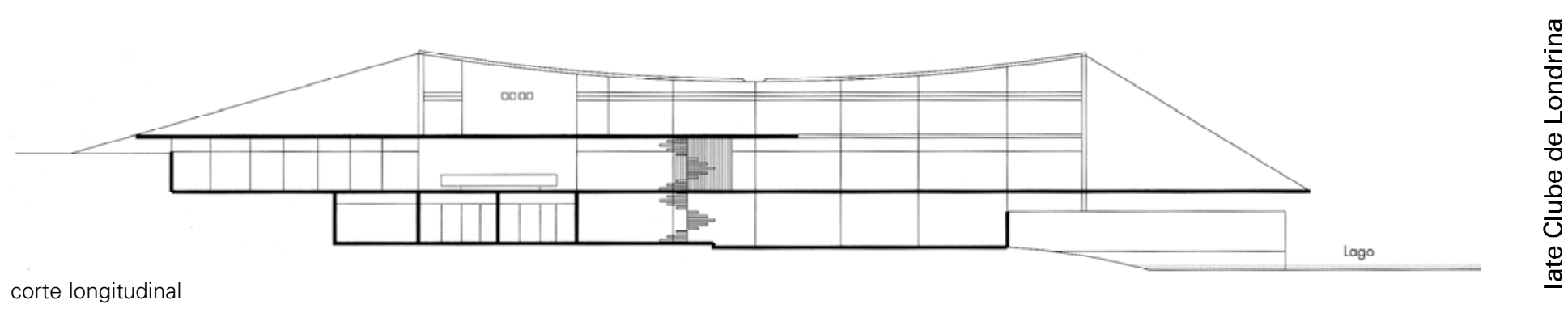

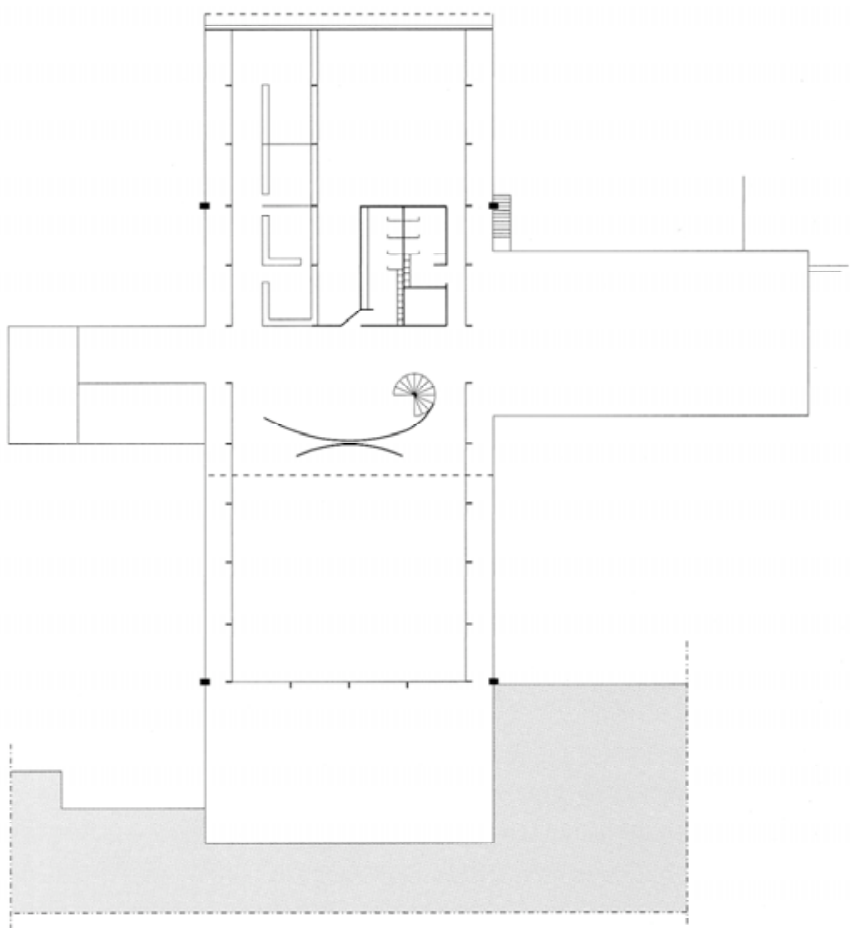

planta $1^{\circ}$. andar

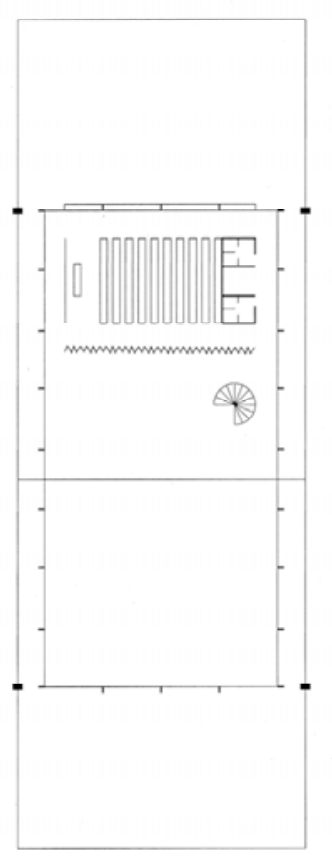

planta $2^{\mathrm{O}}$ andar 

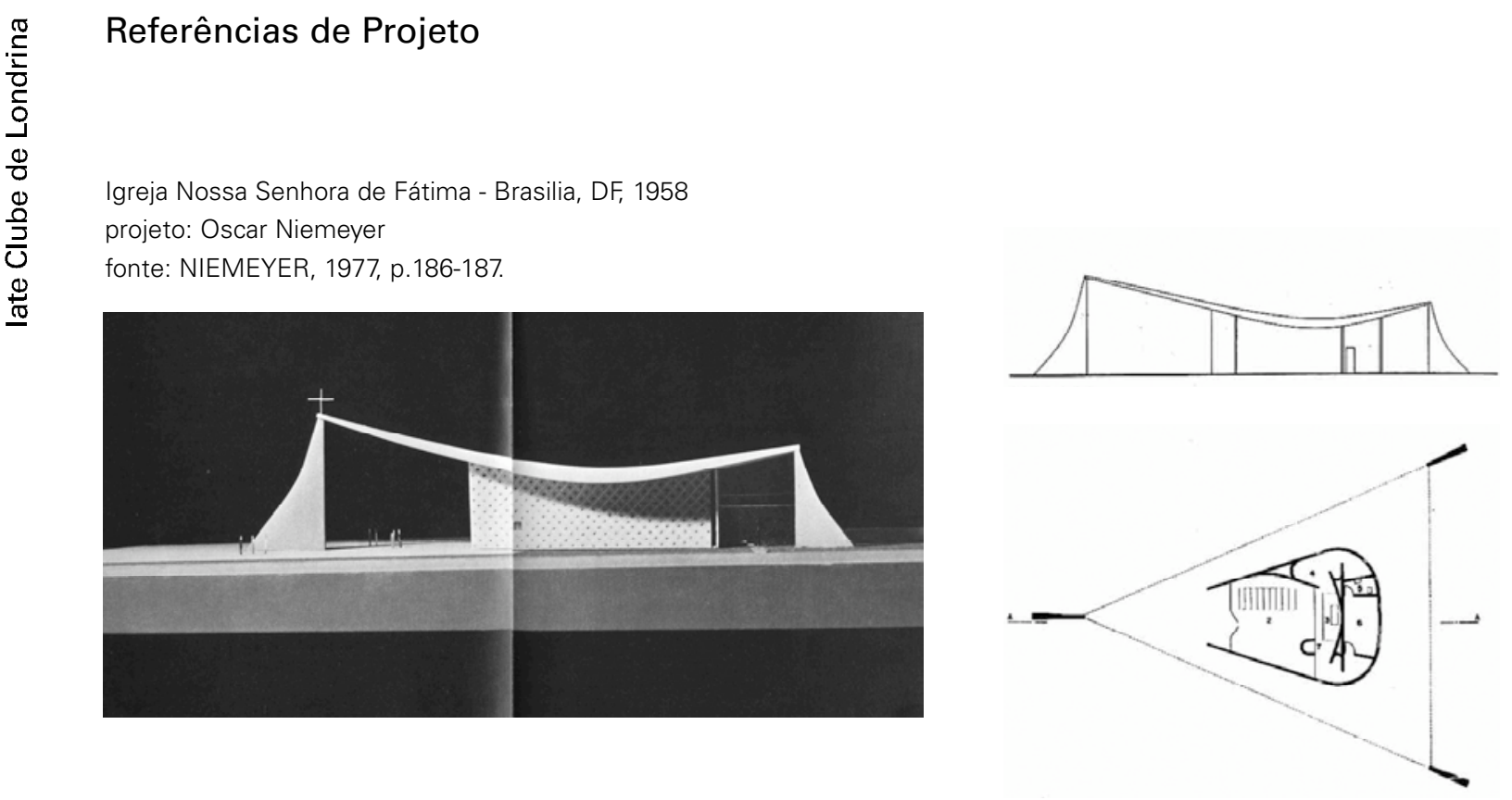

Residência Cavanelas - Rio de Janeiro, RJ, 1954

projeto: Oscar Niemeyer

fonte: NIEMEYER, 1977, p.124-125
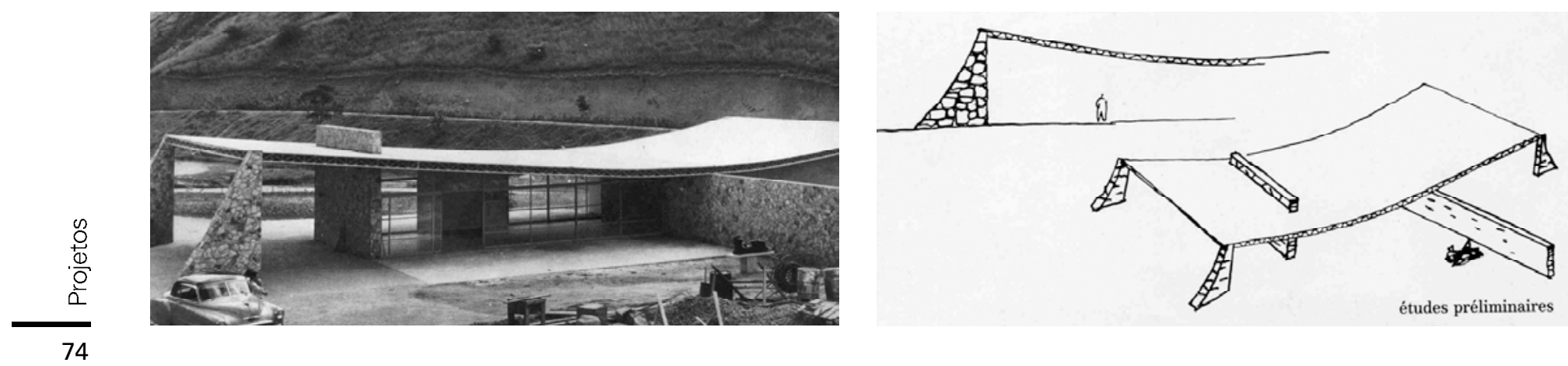
Desenho Industrial

A experiência no escritório de Marcello Nizzoli

1959

Milão, Itália

fonte [imagens] acervo da biblioteca da FAUUSP

[desenhos] acervo de Diva Sanovicz 
A equipe de estudantes da FAU recebeu, com outras três universidades, o já citado Primeiro Prêmio "Ex-Aequo" do III Concurso Internacional para Escolas de Arquitetura da IV Bienal do Museu de Arte Moderna de São Paulo, 1957. Abrahão Sanovicz, um dos componentes dessa equipe, recebeu uma bolsa, oferecida pelo Circolo Italiano, para estagiar num escritório de design em Milão.

Sobre seu interesse pelo desenho industrial, declarou para Marcos Cartum:

[...] essa história de desenhar objeto surgiu na FAU com um grande impacto. Os italianos começaram antes, tiveram a sabedoria de vender esse produto, não só para a Itália mas para o mundo. Eles publicavam insistentemente aquilo que produziam, lutando pela conquista do mercado. Nessa época, nós não entendíamos isso com essa profundidade, porque costumávamos apenas ver as figurinhas nas revistas. Mas atrás dessas figurinhas, atrás desse impacto editorial, havia um grande desejo de conquista mercadológica. E o que mais nos impressionava nisso tudo era o Olivetti Style, que foi marcante na época. Isso foi surgindo naturalmente na escola e, entre os alunos, havia certa preocupação em desenhar o objeto. Era até encantadora a proposta do ponto de vista social. A gente faria um objeto bem estudado, capaz de ser produzido, repetido, e ele ia ser usado indistintamente, vendido nas lojas, e tal. Seria gratificante entrar em uma casa onde se estivesse comendo com talheres que você havia desenhado! Havia um pouco esse sentido romântico que poderia ser melhor conduzido. Ficou só no romantismo, quando poderia haver maior objetividade. (SANOVICZ, 1997, p. 146)
O primeiro problema que teve que enfrentar foi procurar um profissional para acolhê-lo em Milão. Bramante Buffoni, artista gráfico radicado no Brasil, indicou o escritório do designer Marcello Nizolli, e foi onde Abrahão estagiou.

Marcello Nizzoli nasceu na cidade italiana de Boretto em 1887. Freqüentou o curso de pintura da escola de Belas Artes de Parma onde se formou pintor, no início do século XX

Graças à sua pesquisa sobre arte abstrata, aproximou-se do movimento racionalista.

Dedicou-se, inicialmente, à arte aplicada, desenhando mosaicos, tapeçarias, estamparia para tecidos e projetos de decoração.

No ano de 1923, participou da Mostra Internacional de Arte Decorativa da cidade de Monza, Itália, onde seu trabalho foi reconhecido. Por essa razão, foi trabalhar para as indústrias Campari, Fiat e Montecatini.

Sua trajetória artística e profissional registra ainda a colaboração com muitos arquitetos protagonistas da "nova arquitetura italiana", como, por exemplo, Terragni, Baldessari, Figini e Pollini.

Em 1940 foi convidado para trabalhar no escritório de publicidade da Olivetti como artista gráfico. Em pouco tempo tornou-se um de seus principais desenhistas 
industriais. São projetos de Nizzoli para Olivetti a calculadora Divisumma 24 (1956) e as máquinas de escrever Lexikon 80 (1946-1948), Lettera 22 (1950), expostas na coleção permanente de design do Museu de Arte Moderna de Nova York.

Além de suas próprias criações, elaborou relevantes projetos de arquitetura com os arquitetos G. M. Olivetti, A. Fiocchi e G. A. Bernasconi.

Devido ao extraordinário currículo desse artista que acolheu o brasileiro Abrahão Sanovicz, ele recebeu, em 1966, o título de Doutor Honoris Causa em Arquitetura do Politécnico de Milão.

Esse foi um pálido "esboço" biográfico de Marcello Nizzoli em cujo escritório Abrahão estagiou por seis meses.

Durante sua permanência na Itália, Abrahão teve oportunidade de estar em contato bem próximo com o trabalho de outros importantesdesigners italianos como, por exemplo, Gio Ponti, Marco Zonuso, os irmãos Costiglioni, Pinin Farina, "Nuccio" Bertoni, e Ettore Sottsass. A convivência com este ambiente nos leva a crer que influenciou de modo significativo o pensamento de Abrahão.

Com eleito, Bertoni assim expressa a essência do pensamento desses designers.
Divisumma 24, Lexikon 80 e Lettera 22 projetos: Marcello Nizzoli

fonte: www.olivetti.com e www.tribu-design.com

(acesso 11 de dez. de 2003)

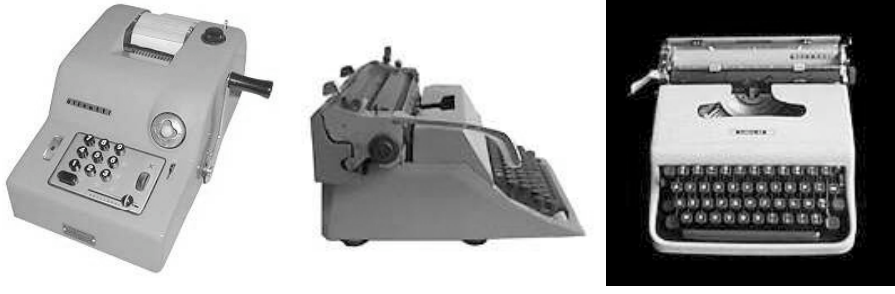

Todo o empreendimento humano é caracterizado por uma fase inicial de intensa concentração e grande criatividade. É o momento mais delicado e estimulante, é quando se cria a idéia, o projeto. Em seguida vem o desenvolvimento do projeto, os ensaios, a produção, as máquinas, os computadores, os robôs... No início de tudo, há somente o homem com seu pensamento, sua alma e seu profissionalismo, capaz de ter intuições grandes e frágeis, ao mesmo tempo simples e complexas (BERTONI, 2003, p. 7).

Cumpre registrar de igual modo que no estágio com Nizzoli, Abrahão participou do projeto de um interfone, uma máquina de café, um distribuidor de gasolina para Agip e algumas marcas para empresas estatais.

Dessa experiência comenta ele próprio:

E é interessante observar a relação do designer com a indústria na Itália. Existe por parte do empresário um interesse, um cuidado especial que vai desde a programação visual, passando pelos logotipos e papéis de carta da indústria, até o produto fabricado por ela. Citaria o exemplo da Olivetti. 
O Nizzoli trabalhava justamente para a Olivetti, que na época não tinha ainda um escritório próprio de design. Um dia, ele me apresenta a marca da máquina de escrever Underwood, pedindo para que eu fizesse uma nova marca, porque o presidente da Olivetti embarcaria no dia seguinte para Nova York, onde deveria adquirir $25 \%$ das ações da Underwood, e pretendia levar pronta a nova marca (SANOVICZ, 1997, p. 147).

Abrahão não só observou a maneira respeitosa como a indústria italiana tratava o design, mas também percebia a maneira como a sociedade italiana assimilava seus artistas, e isso, sem dúvida, marcou a partir daí suas manifestações. A esse respeito, na mesma entrevista ele afirma:

[...] você pega os artistas mais interessantes do Renascimento e percebe que isso é uma coisa que eles têm profundamente arraigado, que está no sangue. Para nós, assumir uma postura de artista fica algo difícil, quase esquisito. Para eles, é uma coisa normal; o artista não é diferente dos outros. Aqui, é visto como um ser diferenciado que passa pelo mundo como um iluminado, sempre soltando raios e coisas assim... Enfim, senti um choque muito grande, quando fui à Itália e percebi a diferença de tratamento num contexto social do que é ser um arquiteto e um artista lá, do que é ser um arquiteto e artista aqui. Completamente diferente. Lá, é algo normal, existe um espaço para ele. Quando se trabalha lá fora, sentindo o tipo de encomenda que lhe fazem, o tipo de relacionamento profissional e social que se estabelece, quando você volta, sente um imenso degrau. Sei lá... país novo, capitalismo selvagem, economia predatória, falta de critérios culturais, coisas desse gênero (SANOVICZ, 1997, p. 146).

Dos projetos desenvolvidos juntamente com Nizolli, foram localizados alguns croquis e as cópias heliográficas de suas versões finais. O material disponível orientou a apresentação desses preciosos documentos, destacando a importância do esboço no processo de pensar e resolver o projeto.

Uma exposição realizada em 1984 no Museu Lazar Segal - "A linguagem do Arquiteto: o Croquis" - tratou com muita propriedade o assunto.

Do catálogo dessa exposição extraímos um trecho do texto do arquiteto e professor Luiz Carlos Daher:

O esboço poderá crescer lenta ou rapidamente, definir-se compacto ou em formas distribuídas. Mas assim que a imagem lançada no papel se torna significativa, parece induzir a um movimento pendular, qualquer coisa de "equilíbrio instável permanente", se a expressão não for pedante ou pseudo-científica. Porque por um lado o esboço multiplica seus contornos: raramente é possível abarcar de imediato a multiplicidade de funções imposta pelo programa de necessidades. Mas por outro lado, o trabalhador da imagem deverá retornar ao esboço inicial para manter a relação dos detalhes com o todo: a satisfação das necessidades contingentes não pode prejudicar a integridade e a percepção primeira da imagem.

O retorno ao esboço aos novos espaços imaginados; e esta modificação por seu turno sugere novos contornos... processo é inesgotável, enquanto o arquiteto disser: - eis a imagem que importa materializar.

[...]

Deve haver, certamente, quem descreva melhor esse 
pensamento arquitetônico, no qual a lógica verbal interfere de forma ainda pouco esclarecida. Quando se observa o esboço vê-se a passagem do indeterminado para o determinado, do desejado pelo cliente para o desejado por ele e pelo arquiteto.

Ambos têm papeis representativos na sociedade onde o projeto aparece. Extrapolando, o esboço mostra aquilo que

uma sociedade formula no plano afetivo e intelectual; como Fernando Pessoa, o arquiteto pode dizer: "o que está em mim está pensando" (DAHER, 1984, s.p.).

Abrahão participou da exposição supracitada, apresentando os desenhos elaborados para o projeto de um conjunto habitacional em Porto Primavera. Deixou registrado seu pensamento:

O primeiro risco é sempre fruto da intuição.

Pode demorar bastante tempo para aparecer. Pode ser rápida gestação.

Projetado este primeiro esboço num papel, me torno observador do que está desenhado.

É menos penoso do que observá-lo dentro de minha cabeça. Como analista atento, passo a reconhecer o que propus.

Faço perguntas a este tosco croquis

Quanto mais completas são as respostas mais me convenço da exatidão da proposta.

É um processo de indagações e solução emergentes, até um ponto no qual o projeto adquire vida própria.

Ele como que ordena as soluções necessárias para seu aperfeiçoamento

A partir de então, sobra tempo para identificar quais projetos e situações anteriores me induziram a determinada solução.

O fato artístico / intuitivo é reconhecido e então explicitado.(SANOVICZ, 1984, s. p.). 


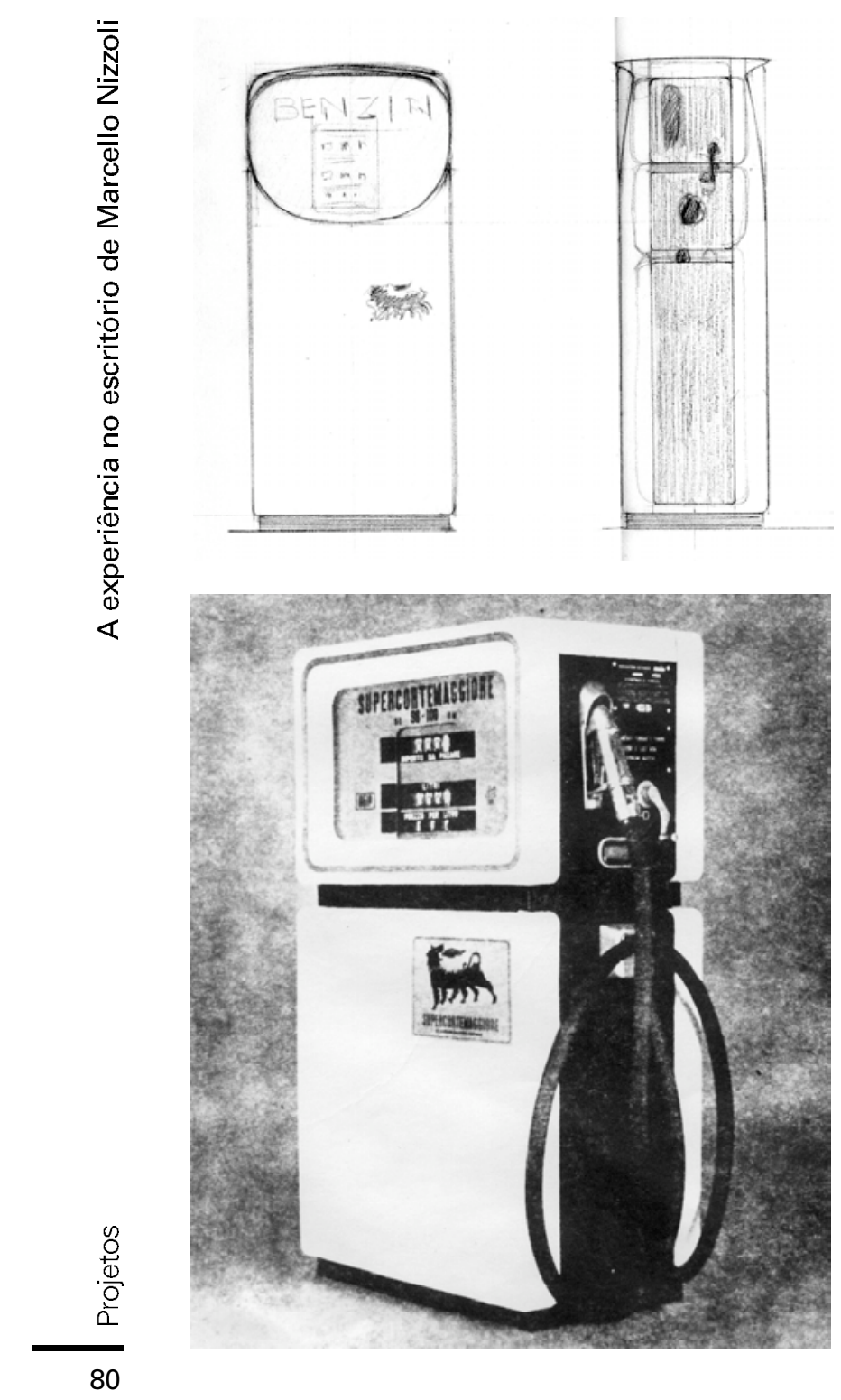



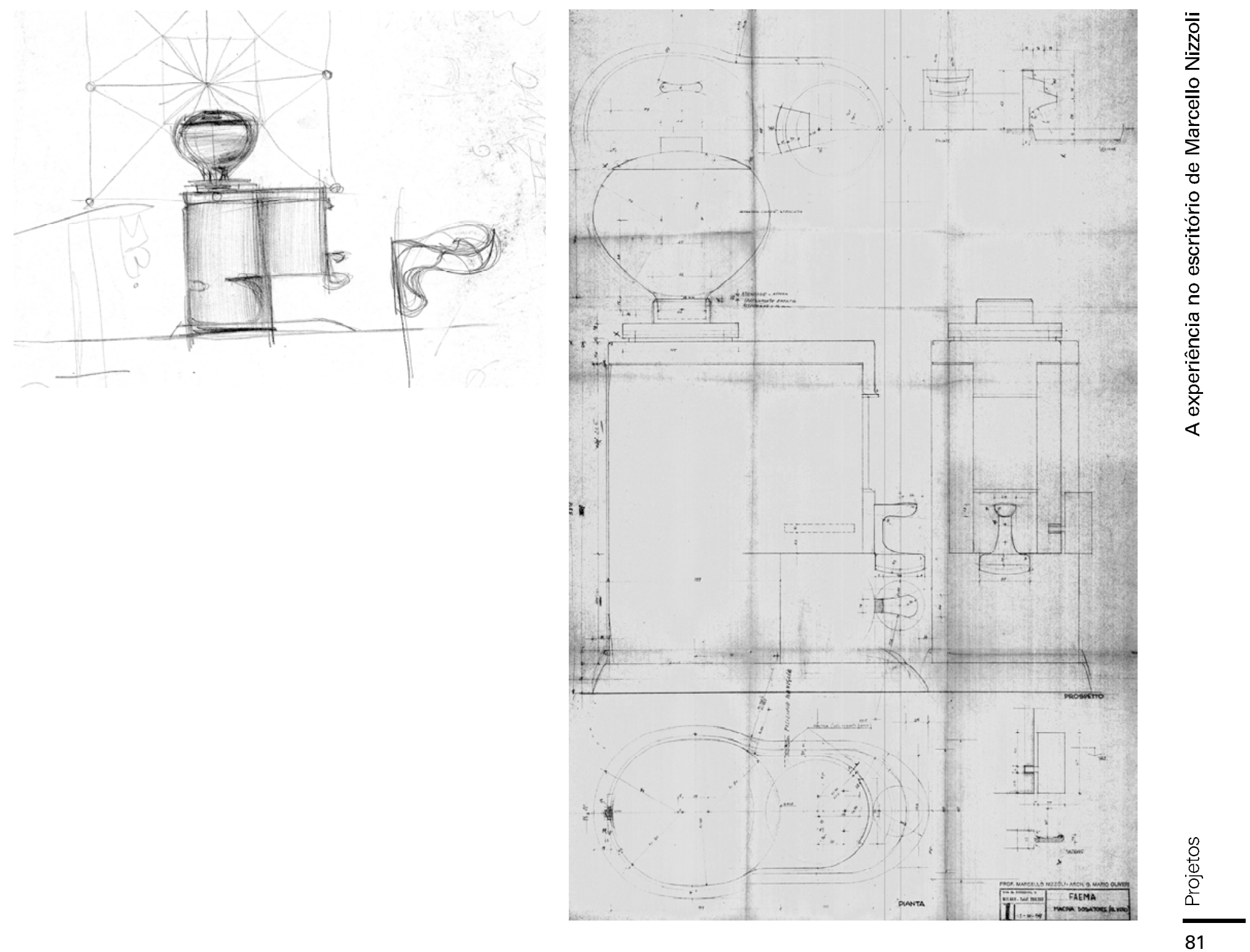

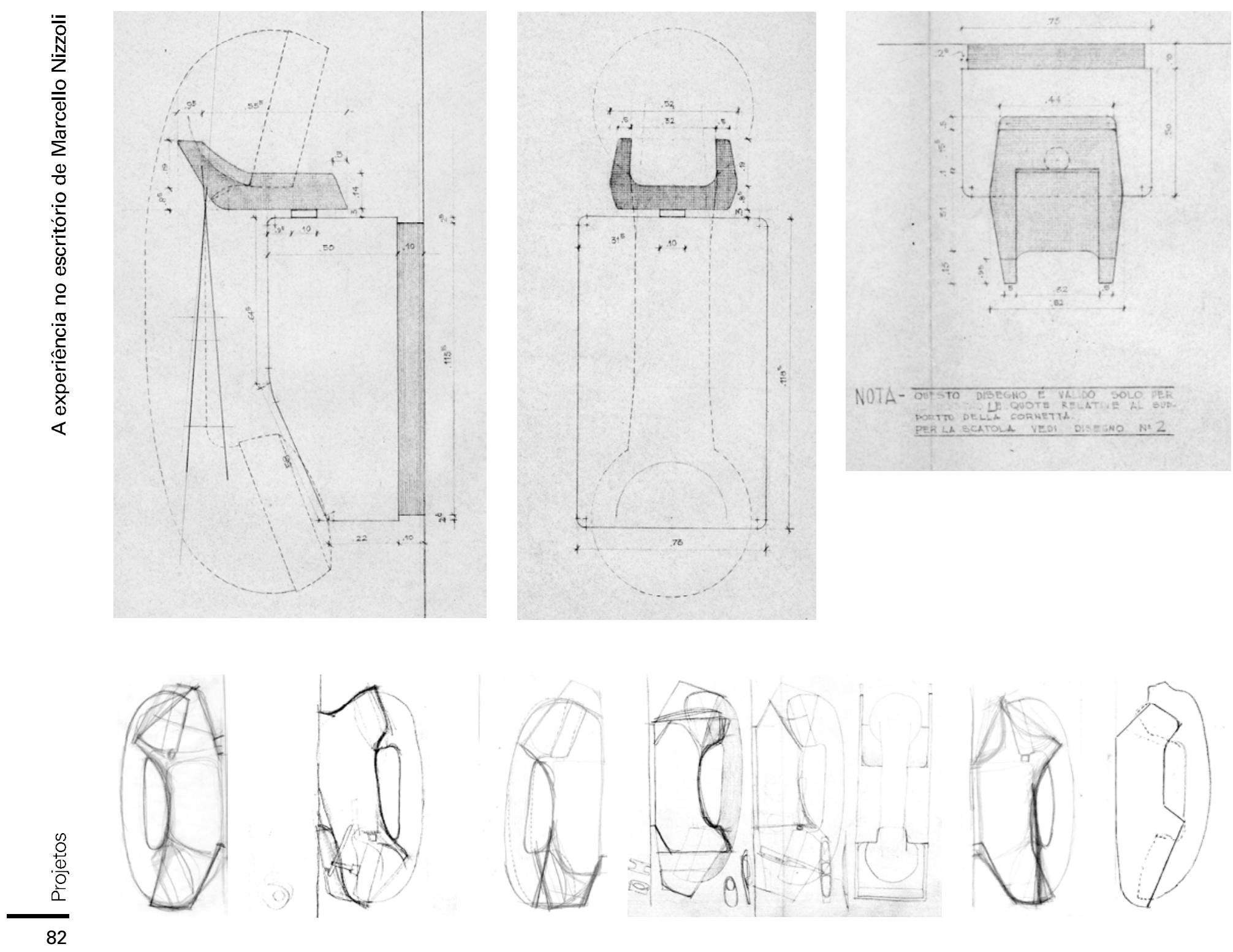

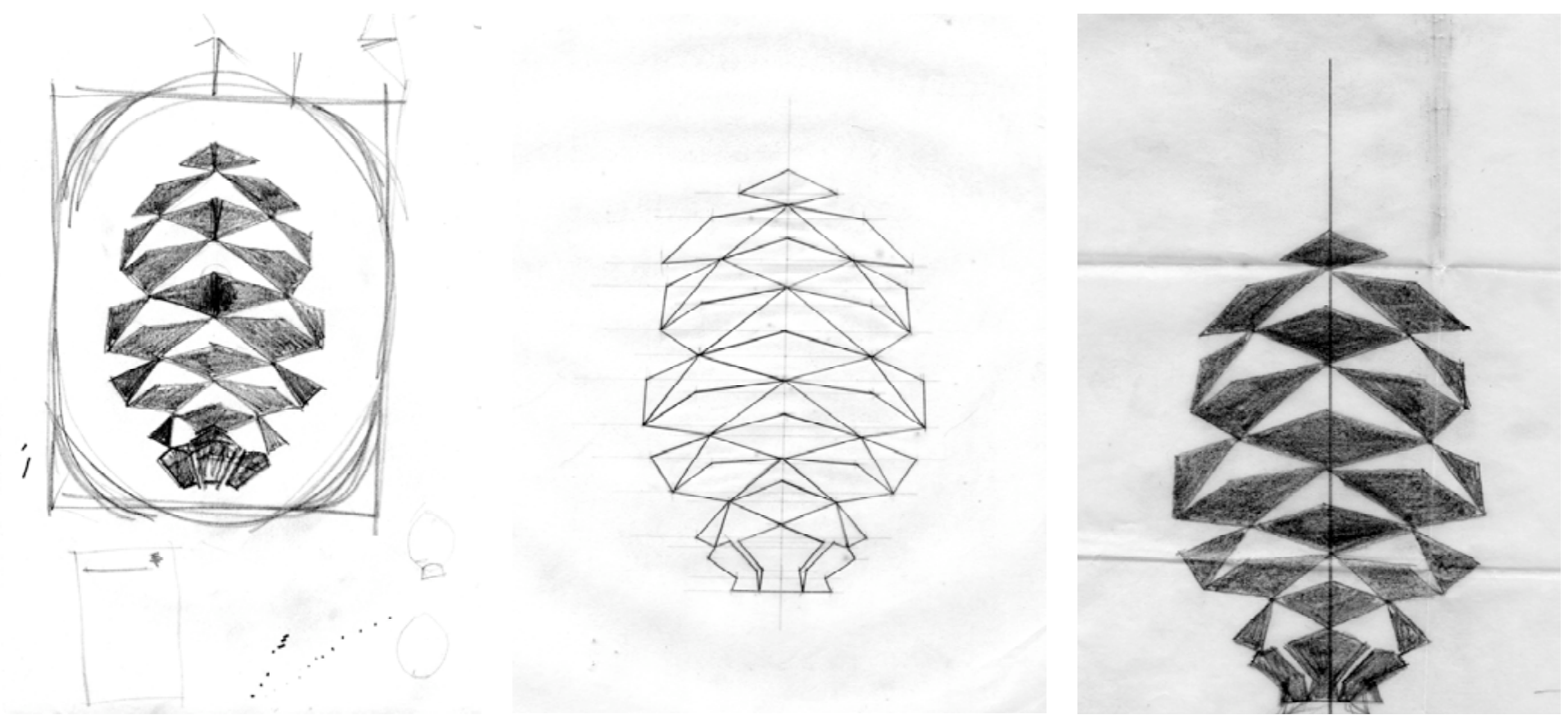

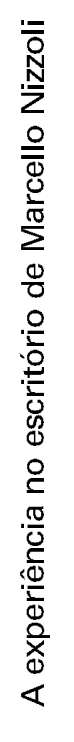

Referência

Pinha - Le Corbusier

fonte: L'architecture d'Aujourd'hui, número hors serie p.35.

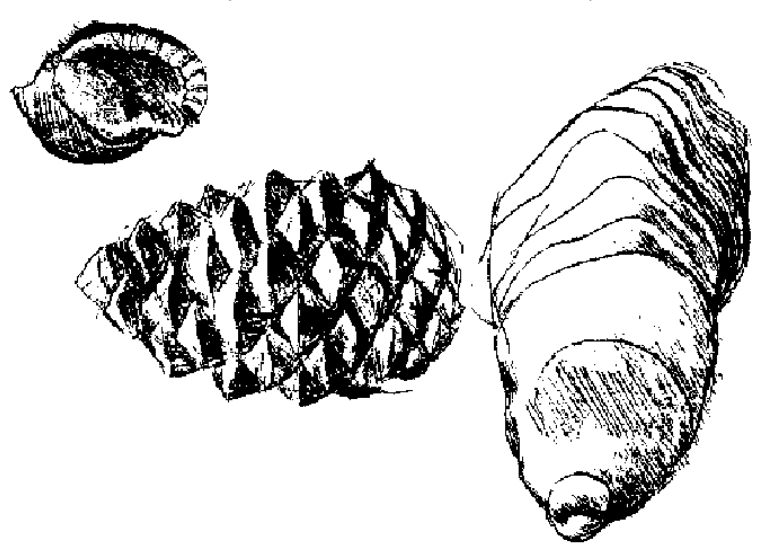



Centro Cultural e Teatro Municipal de Santos 1960/68

Avenida Senador Pinheiro Machado com Avenida Francisco Manoel

Santos, SP

fonte [desenhos|imagens] acervo da biblioteca da FAUUSP 
Os arquitetos Abrahão Sanovicz, Julio Roberto Katinsky e Oswaldo Corrêa Gonçalves são os autores do projeto de Centro Cultural e Teatro Municipal de Santos.

Oswaldo Corrêa Gonçalves nasceu em Santos em 1917. Foi o único de sua turma a se formar engenheiro arquiteto pela Escola Politécnica da USP, em 1941.

Foi professor da Faculdade de Arquitetura e Urbanismo da Universidade de São Paulo em 1954 e 1955, assistente de Ícaro de Castro Mello, na disciplina Grandes Composições.

Presidiu o Departamento de São Paulo do Instituto de Arquitetos do Brasil - IAB SP, de 1961 a 1963, entidade que ajudou a fundar e construir.

O artigo Documento, publicado no no. 59 da revista $A U$, foi dedicado à obra de Oswaldo Corrêa Gonçalves. O texto traz o seguinte destaque:

Se existem arquitetos que se caracterizam pela fidelidade, ao longo do tempo, à expressão de um ideário numa linguagem arquitetônica constante, outros há que, para expressar princípios que seguem com constância, empregam linguagens diversas, tornando menos imediata a correlação obra-autor. Oswaldo Corrêa Gonçalves pertence ao segundo grupo. A parceria freqüente com arquitetos de formação e geração diversas resultou num conjunto de obras que se apresenta ao olhar como um leque de projetos da mesma raiz, mas de florações diversas. Ao mesmo tempo, a convivência entre aquela geração de arquitetos imbuídos de intenções $e$ indagações afins propiciou o entrelaçamento de informações (e, por que não? de influências) recíprocas num processo que impulsionou - vivificando - a pesquisa e a produção modernas em São Paulo (DOCUMENTO, 1995, p.81-82).

A maneira de trabalhar acima descrita é ilustrada com um exemplo concreto: trata-se do convite que fez aos jovens arquitetos Abrahão Sanovicz e Julio Roberto Katinsky, para participarem com ele da elaboração do projeto do late Clube de Santos. Como anteriormente foi referido, Sanovicz e Katinsky, juntamente com Toscano, foram os vencedores do concurso de projetos para o late Clube de Londrina.

Assim pode ser descrito o projeto do late Clube de Santos: uma grande cobertura em concreto armado que se projetava sobre o mar, constituída por vigas-vagão invertidas, com vão de 50 metros e balanços de 20 num sentido, e 25 metros no outro, apoiadas sobre quatro pilares. Essa estrutura foi calculada pelo engenheiro Roberto Rossi Zuccolo. Infelizmente, todavia, o projeto não chegou à sua fase executiva.

Pela mesma época, Oswaldo foi convidado para elaborar o projeto do Centro Social do setor Politécnico e Praça Circundante, desenvolvido pela mesma equipe. Em seguida surge outro convite, agora o Teatro Municipal de Santos. Dessa feita, a mesma equipe enfrenta um programa bastante extenso. 
Oswaldo Corrêa Gonçalves, Abrahão Sanovicz e Julio Roberto Katinsky VI Bienal do Museu de Arte Moderna de São Paulo, 1961.

Exposição Internacional de Arquitetura com o projeto Centro Cultural e Teatro Municipal de Santos

fonte: acervo de Diva Sanovicz

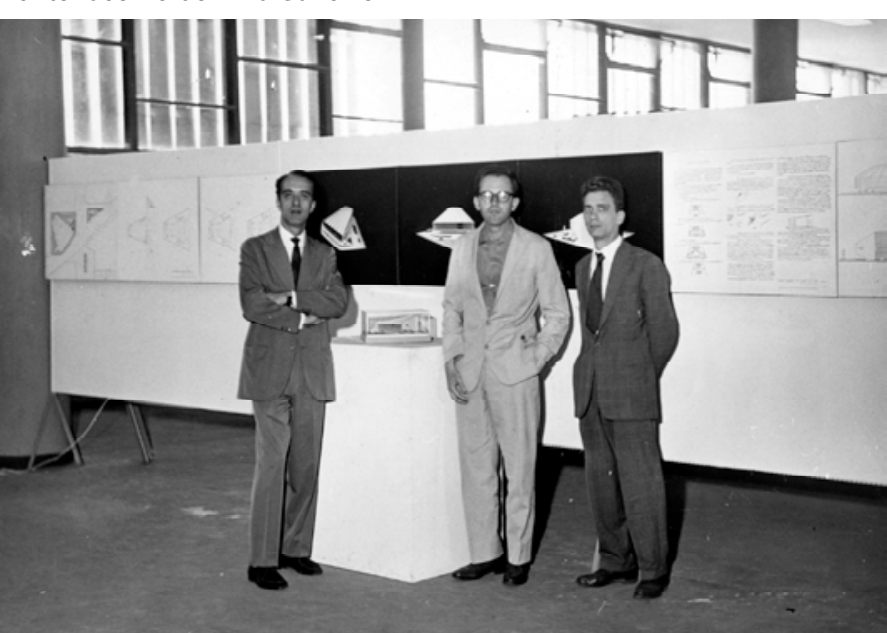

Em 1961, o crítico Sabato Magaldi fez uma matéria para a revista Habitat sobre o Teatro Municipal e Centro de Arte em Santos. Comentava ele na ocasião:

A construção do Municipal é de fato uma exigência para Santos. O antigo Coliseu não apresenta condições acústicas satisfatórias para o gênero declamado, e nem veio tendo boa conservação, a fim de que parecesse acolhedor para o público. O Independência, depois de curto serviço prestado ao teatro, transformou-se em cinema, negócio mais rendoso... O auditório do Centro Português prestou ótimas colaborações ao II Festival Nacional de Teatro de Estudantes, por exemplo, mas pelas próprias exigências da coletividade a qual pertence, não pode ter aproveitamento permanente (MAGALDI, 1961, p. 24)
Deve-se salientar que a carência da cidade era ainda maior e não existiam edifícios dedicados a outras manifestações artísticas. Dessa maneira, foram então incorporadas outras atividades ao programa do teatro, criando, assim, um centro artístico e cultural que compreendia:

a. teatro de comédia (tradicional), com 600 lugares

b. balé;

c. ópera de câmara;

d. teatro elizabetano, no qual a área de representação rodeia em parte a platéia;

e. teatro múltiplo com três palcos simultâneos representando-se cenas sincronizadas;

f. teatro de arena onde o palco é cercado pelas platéias; g. espaço para sessões cinematográficas de filmes de arte;

h. locais para exposição de artes plásticas, pintura, escultura, gravura, desenho, arquitetura, bem como preleções sobre artes, feitas por especialistas;

i. escola de balé.

O terreno reservado para a implantação do projeto localizava-se inicialmente na confluência da Avenida Ana Costa, Rua Alexandre Herculano e Avenida General Francisco Glicério. 
Como partido de projeto, todas as atividades foram reunidas num único bloco. Isso porque os autores tiveram a preocupação e o cuidado de integrar o edifício à praça que Ihe servia de suporte. Assim sendo, vindo de qualquer uma das ruas, atingia-se uma plataforma um pouco elevada, local das bilheterias, da administração e acesso para a sala de espera do teatro. Esta laje, prolongava-se até o jardim lateral, onde estaria o estacionamento, ficando a cavaleiro de um espelho d'água.

O segundo pavimento previa um espaço para exposições com a respectiva administração e os sanitários.

Iluminada e ventilada zenitalmente, a escola de balé foi projetada para ficar sobre a platéia.

A consultoria cenotécnica foi de Aldo Calvo e a do sistema eletroacústico de Igor Serenevsky.

A ampla caixa do palco foi desenhada de maneira a acomodar toda a parte mecânica, bem como as coxias laterais para o deslocamento dos cenários. No palco, dois giratórios permitiriam a troca instantânea dos cenários. Forro e paredes da platéia receberam tratamento de maneira a se obter o melhor rendimento acústico.

A estrutura, calculada pelo Escritório Técnico Feitosa Cruz e De Lucca, era constituída de seis grandes vigas que suportavam as cargas da cobertura e, parcialmente, da laje do museu, descarregando na parede do ciclorama e em pilares embutidos nas parede de fecho da platéia. A laje da sala de espera descansava sobre vigas em balanço, com secção variável, acompanhando o forro.

O fechamento do volume seria feito pelas empenas laterais e por paredes de vidro protegidas do sol por grelhas de alumínio.

A revista carioca Módulo, em sua edição nº 7, de julho de 1962, assim se refere ao projeto:

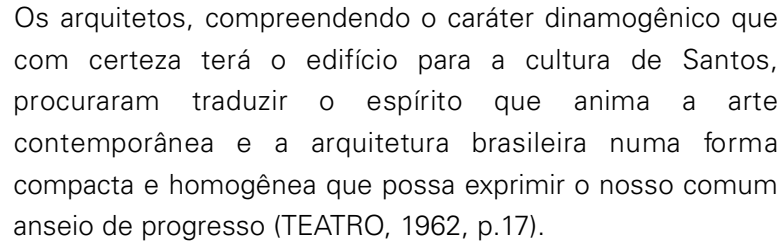

É importante consignar que o prefeito eleito em 1960, Luiz La Scala Júnior, grande entusiasta do projeto, morreu antes de assumir o cargo.

Por esse motivo o empreendimento foi interrompido e só foi retomado em 1968 - portanto, após longos oito anos em outro terreno bem maior, na Avenida Senador Pinheiro Machado com Avenida Francisco Manoel, e incorporando outras atividades no programa: um centro de vivência, bibli- 
oteca municipal e uma escola de arte.

Nesse novo cenário, o desafio do desenvolvimento do projeto ampliou de modo significativo os conhecimentos dos ainda jovens arquitetos. Desafios e conhecimentos expressados pelas palavras do próprio Abrahão:

Quando o projeto foi retomado tivemos que nos assenhorar de todas as técnicas intervenientes: cenotécnica; sistema de ar condicionado; instalações; estruturas protendidas; curvas de visibilidade; materiais de impermeabilização; tratamento de juntas de dilatação; além de nos aprofundar nas diferentes manifestações teatrais, como a ópera, o teatro shakespeareano e o elizabetano. Foi uma oportunidade de nos aprofundarmos em complexas e diferentes áreas do conhecimento (DCPA, 1987 e 1988).

Abrahão indicou como influências marcantes na elaboração dessa obra: o Teatro Nacional de Brasília, com suas vigas protendidas na cobertura; e o projeto que Vilanova Artigas apresentou para o concurso do Clube Paulistano, especificamente o edifício do auditório, um prisma chanfrado, um único apoio e a platéia em balanço.

A convivência com Oswaldo Corrêa Gonçalves, mereceu o seguinte comentário junto à Catharine Gati:

Ele teve uma grande confiança em dois jovens arquitetos nos dando a oportunidade de, no início da carreira, trabalharmos com problemas tão complexos. Oswaldo é um trabalhador incansável, sabe como perseguir o projeto, como levá-lo para frente, se cercar de todas as técnicas necessárias, resolver os entraves, e, isso tudo, aprendemos com ele (DCPA, 1987 e 1988). 


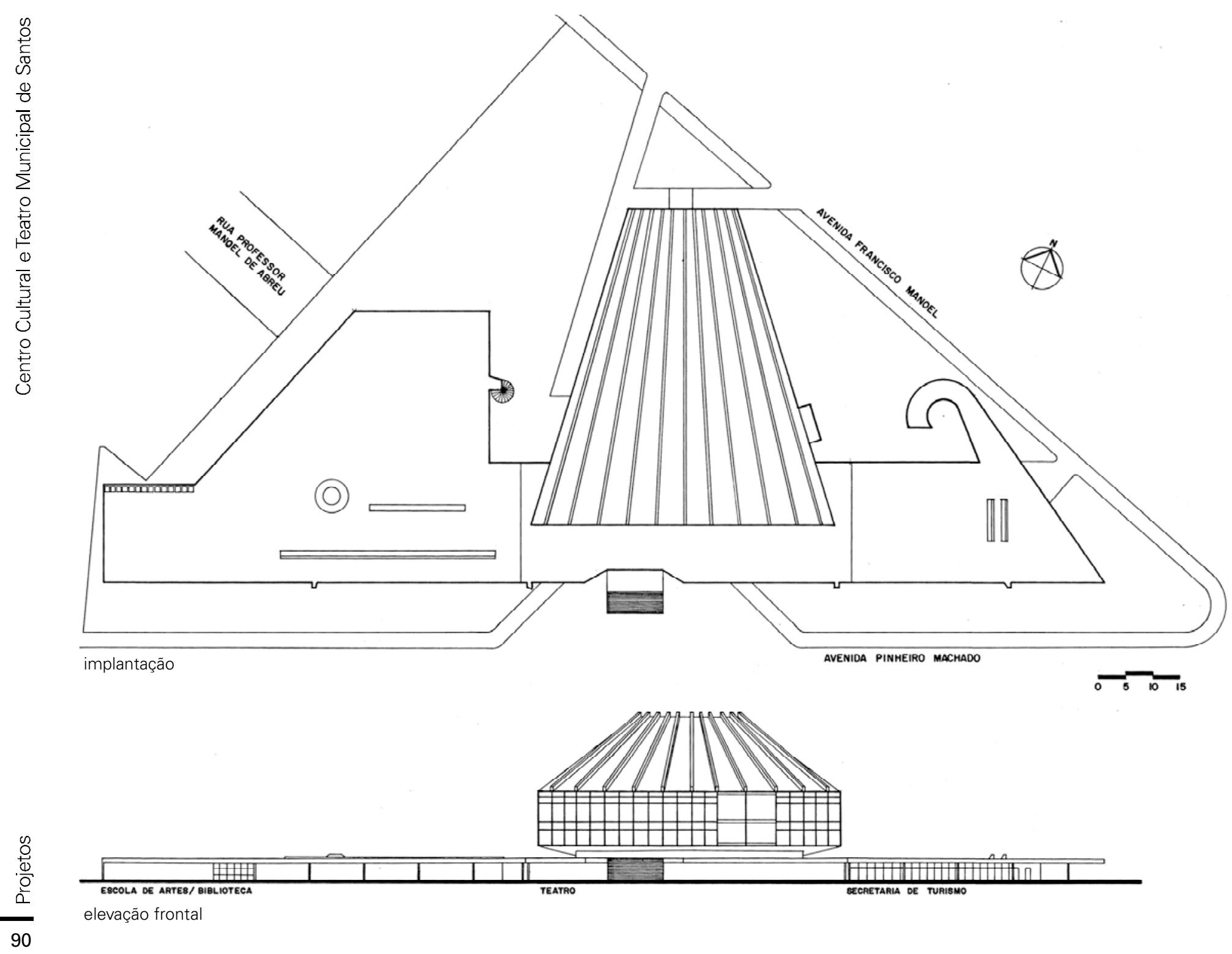



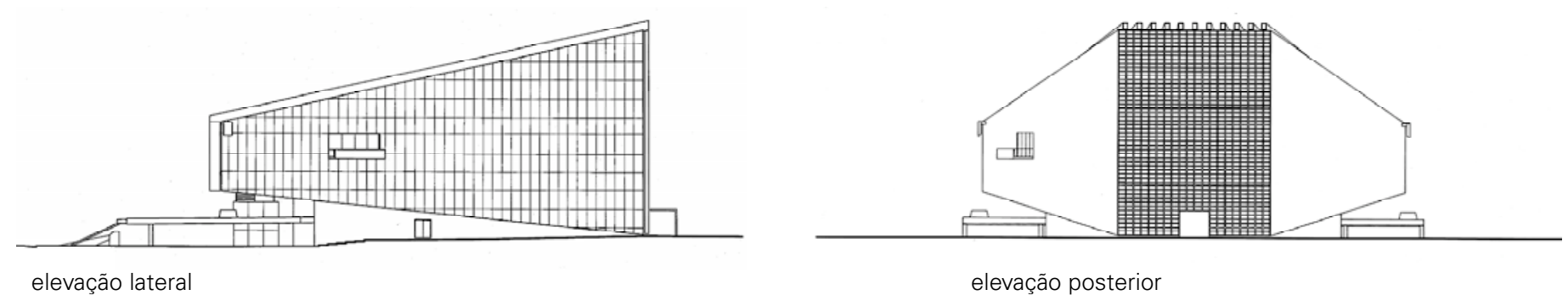

elevação posterior

Teatw Municifal

wnt?

Siti da platéré

$\frac{\frac{1960}{196.8}}{\frac{1948}{81}} \frac{00}{2}$

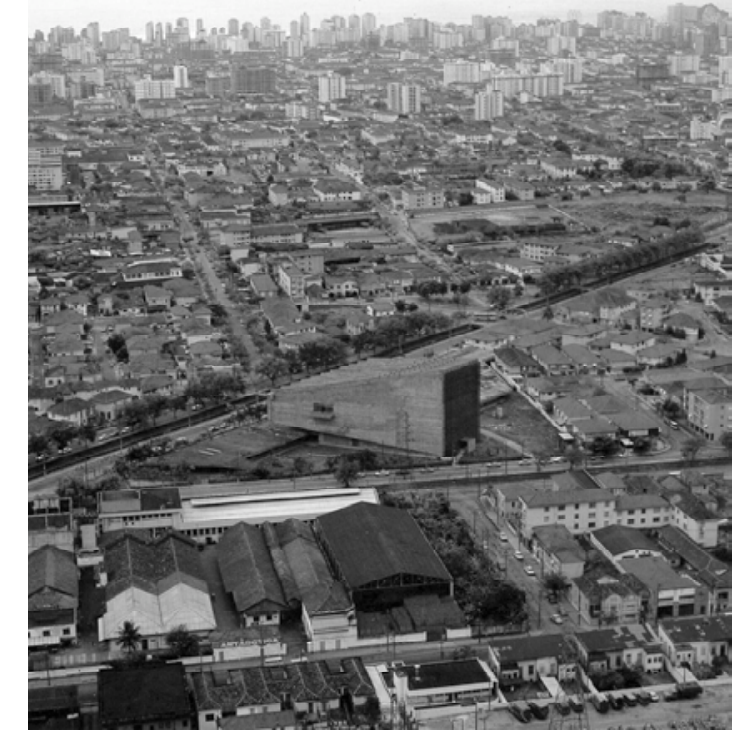

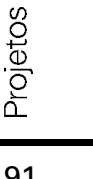



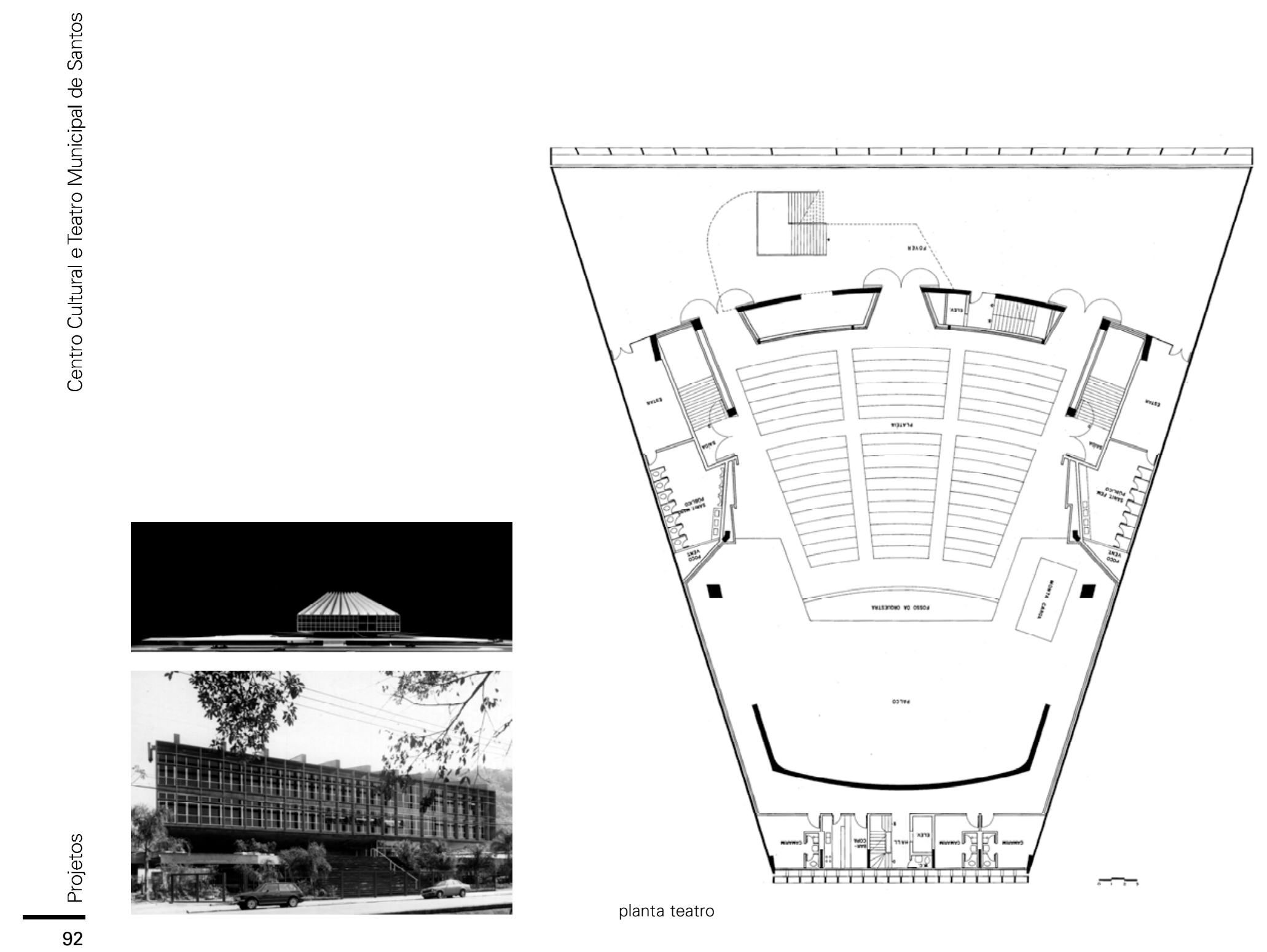

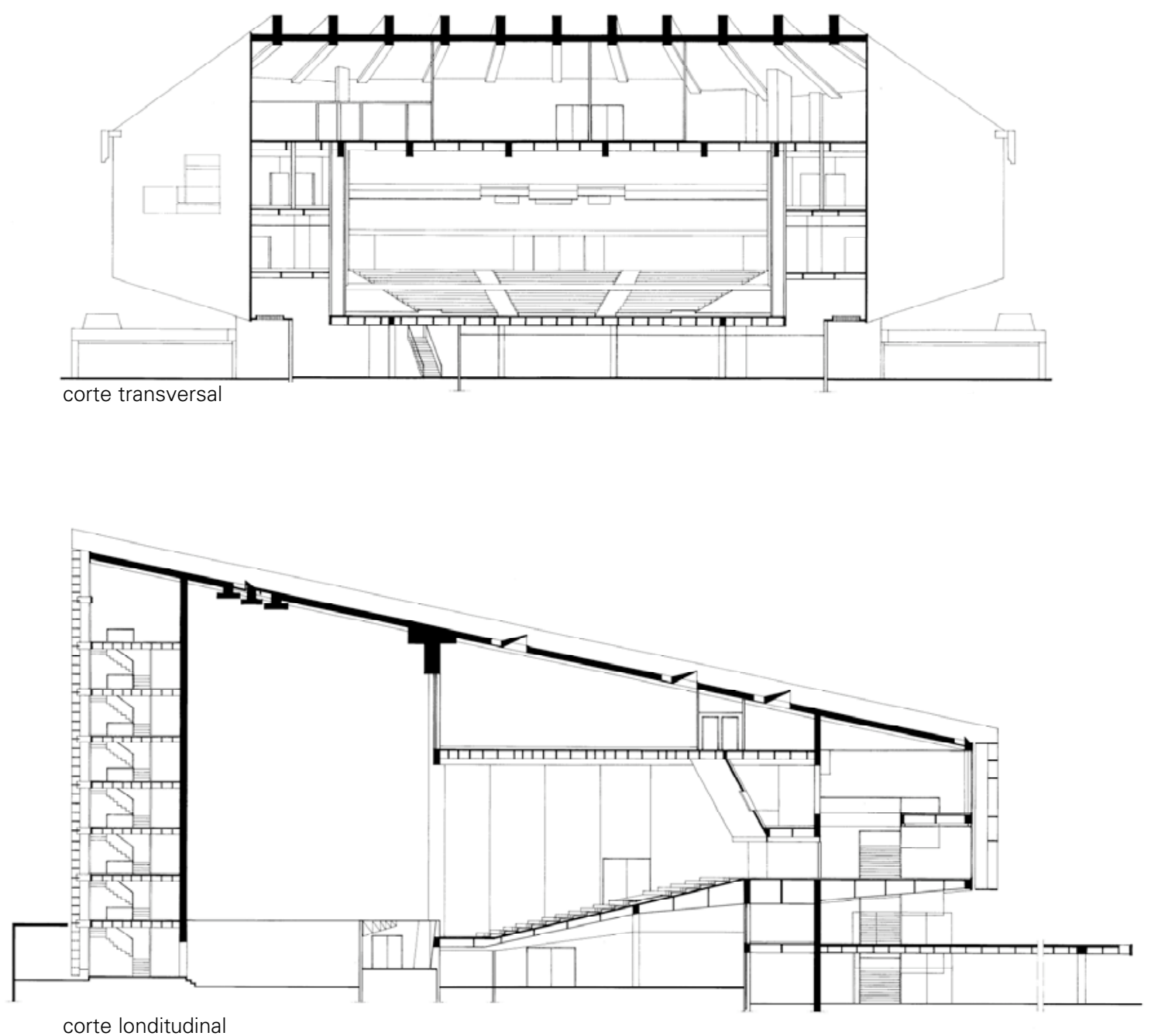

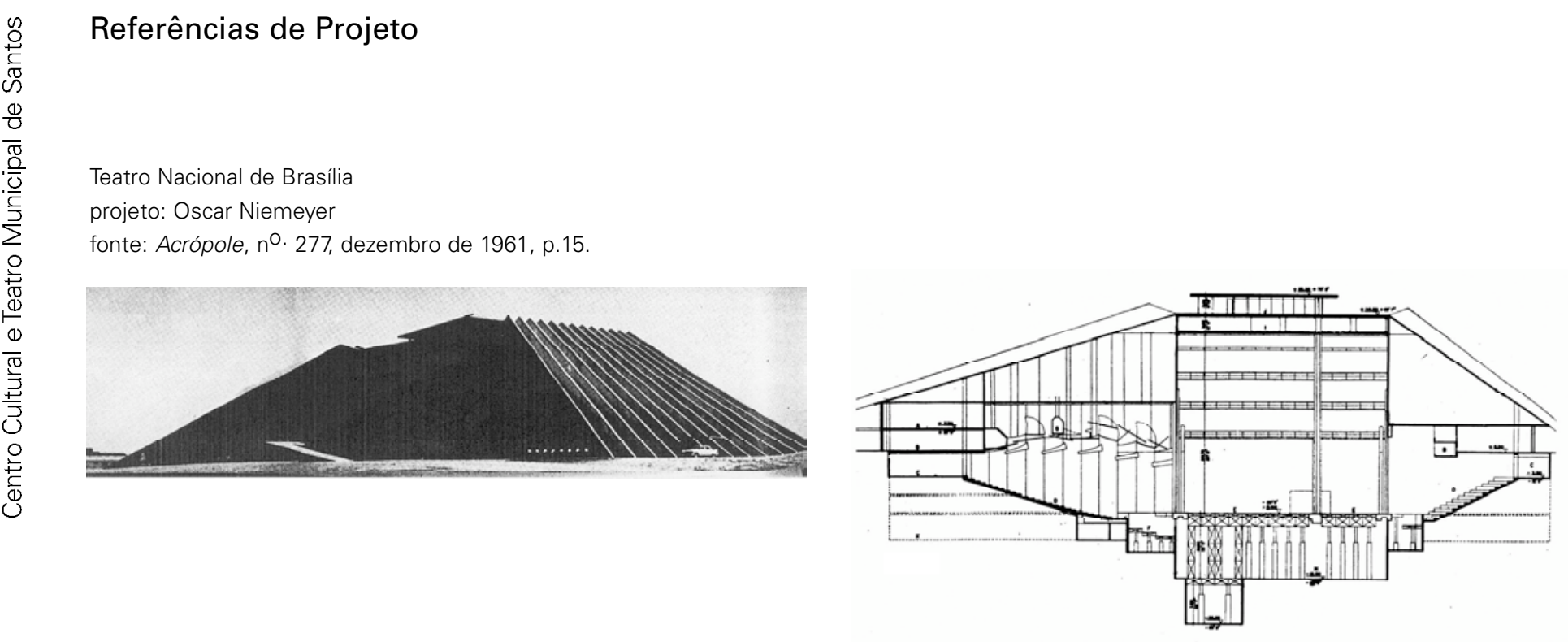

Concurso Clube Atlético Paulistano, 1957.

Auditório

projeto: João Batista Vilanova Artigas

fonte: acervo da biblioteca da FAUUSP
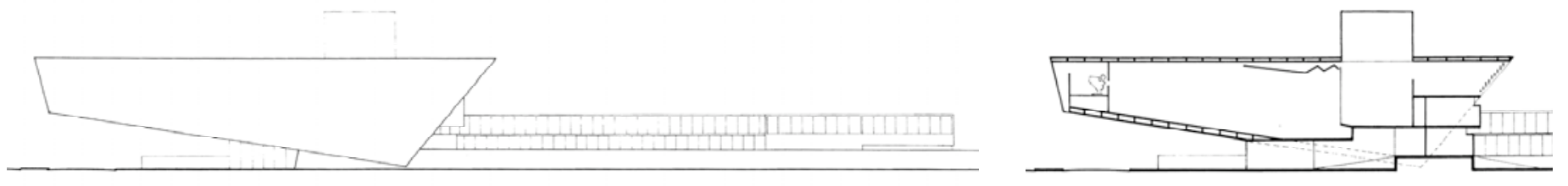

$\frac{\stackrel{\infty}{0}}{\frac{0}{0}}$ 
Equipamentos Públicos e Sinalização para os

\section{Jardins de São Paulo - 1967/69}

fonte [imagens|desenhos] acervo da biblioteca da FAUUSP 
A Divisão de Parques e Jardins da Prefeitura do Município de São Paulo convidou, em 1967, as arquitetas Miranda Magnoli e Rosa Kliass para elaborarem projetos de inúmeras praças na cidade.

Para o projeto dos equipamentos, elas convidaram Abrahão Sanovicz, professor da disciplina de desenho industrial da Faculdade de Arquitetura e Urbanismo da Universidade de São Paulo, alguns anos após ele ter passado pela experiência de estágio na Itália e ter podido estar em contato com expressivos designers. $\mathrm{Na}$ realidade a escolha se justificava porque era necessário projetar equipamentos que pudessem ser produzidos em escala industrial.

Para o desafio dessa nova empreitada, Abrahão convocou seu companheiro Julio Katinsky, o arquiteto Massayoshi Kaminura e o desenhista industrial Bramante Buffoni. Ambos, conheciam Buffoni desde estudantes, quando o convidaram como júri de um daqueles concursos internos para escolha de um cartaz ou capa de publicação.

Decio Bramante Buffoni, nasceu em Milão em 1890. Na Itália, trabalhou com Marcello Nizzoli, que recebeu Abrahão em seu escritório, conforme relatado anteriormente. Veio para o Brasil em 1955 onde realizou trabalhos de desenho industrial, artes gráficas e muitos murais.
A arquiteta Isabel Coelho, em sua dissertação de mestrado Painéis em Mosaico na Arquitetura Moderna Paulista: 1945 - 1964 observa:

Buffoni transita através de múltiplas técnicas, aliando o envolvimento com o lado artesanal da arte à criação plástica mais comprometida, "brincando" com a descoberta. Sem ser necessariamente um mosaicista, conseguiu algumas das mais importantes experiências em mosaico produzidas em São Paulo no período estudado. O percurso artístico estudado demonstra, afinal, uma livre, experimental, e ao mesmo tempo profunda preocupação técnica (COELHO, 2001, p. 206).

Cartazes desenhados por Bramante Buffoni fonte: Habitat, nO. 13, dezembro de 1953, p. 62
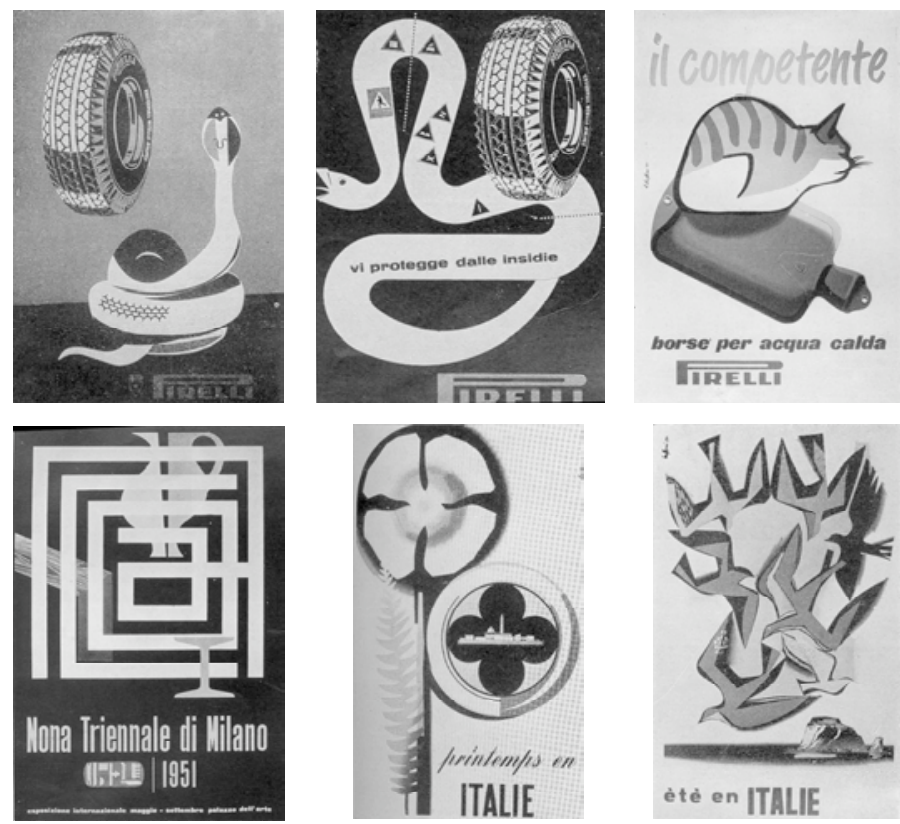

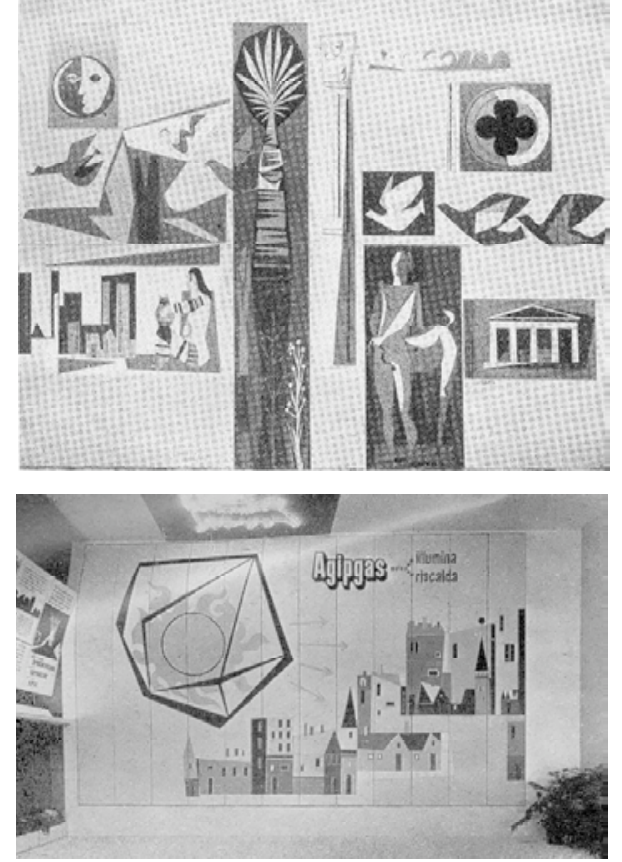

Painéis em mosaico desenhados por Bramante Buffoni fonte [acima] Habitat, $\mathrm{n}^{\mathrm{O}}$ 50, set/out de 1958, p.28

[abaixo] Habitat, n⿳. 13, dezembro de 1953, p.62.

A Prefeitura cedeu uma área de cerca de $200 \mathrm{~m}^{2}$ no Viveiro de Plantas Manequinho Lopes instalado no Parque Ibirapuera, para que as equipes responsáveis pelo projeto de paisagismo e desenho dos equipamentos urbanos trabalhassem. Durante dois anos - de 1967 a 1968 - todas as manhãs Abrahão, Buffoni, Katinsky e Massayoshi reuniamse nesse local.
Elaboraram quase uma centena de projetos de equipamentos públicos: bancos, postes de iluminação, lixeiras, taças, espelhos d'água, relógios, brinquedos para crianças, uma publicação sobre plantas brasileiræ, cartazes, elementos de sinalização e muitos outros.

Chamavam de "desing for the community".

Essa epopéia foi assim comentada por Abrahão:

[...] nem em Londres se enfrentou um programa como esse. Foi um trabalho muito interessante: nos preocupávamos em usar materiais e técnicas simples, soluções fáceis para ancoragem, elementos de fácil reposição e estocagem. O resultado do trabalho deveria ser algo que pudesse interessar a indústria dada a escala de aplicação. O projeto foi concluído, poucas peças foram produzidas, como de costume em nosso país

Foi uma reaproximação de nosso trabalho com os órgãos governamentais. Na época, discutíamos a validade de se trabalhar para um prefeito nomeado, entendemos que a relevância do programa superava esse tipo de relação, afinal as pessoas passam e os trabalhos ficam (DPCA, 1987 e 1988).

Além dos equipamentos públicos fizeram juntos dois outros projetos: de uma máquina de escrever para a Olivetti e um ventilador para a Aeromar. Os projetos foram concluídos e muito bem aceitos pelos contratantes, mas, sendo as duas indústrias multinacionais, não conseguiram a aprovação das matrizes para produzí-los. 


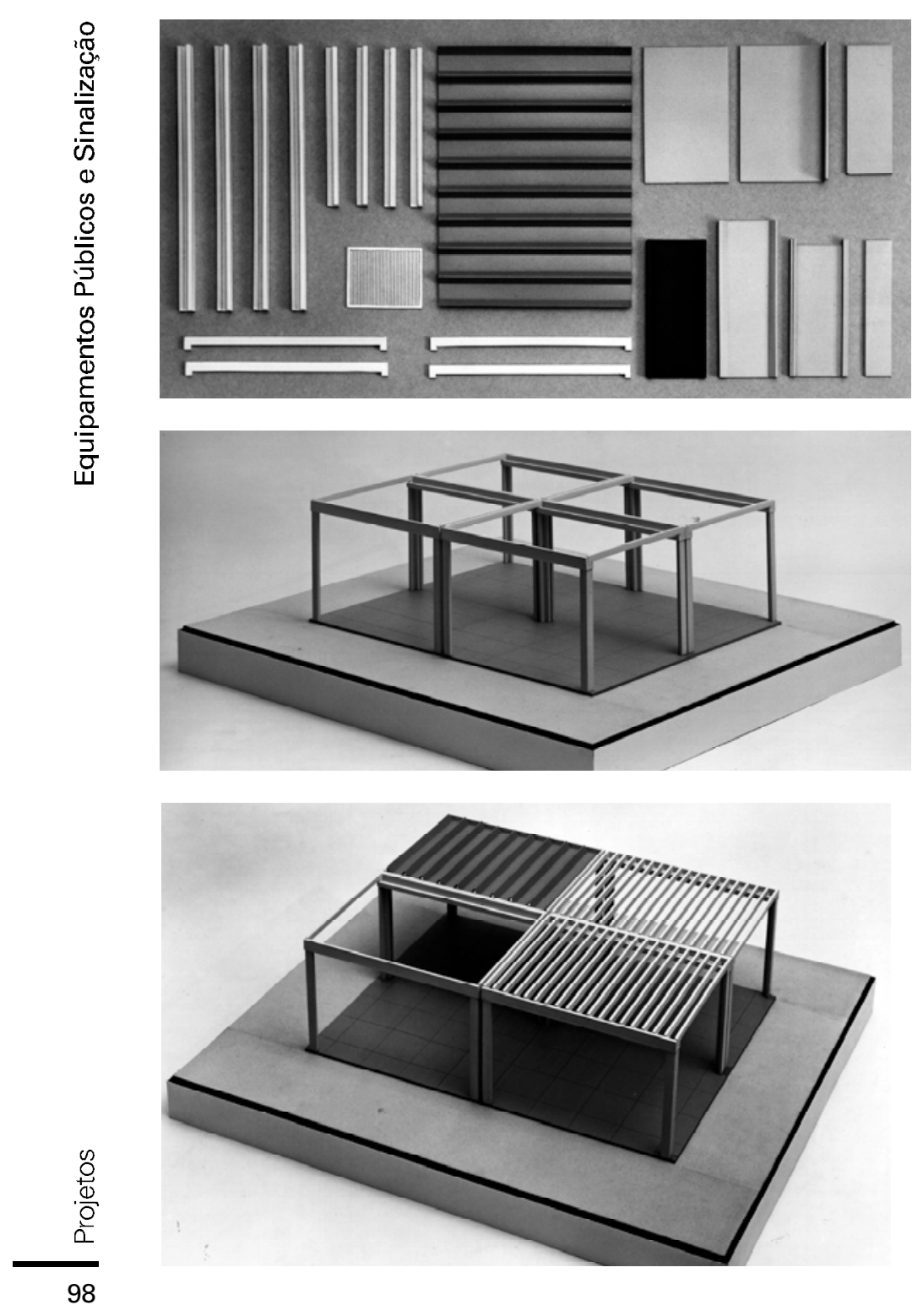



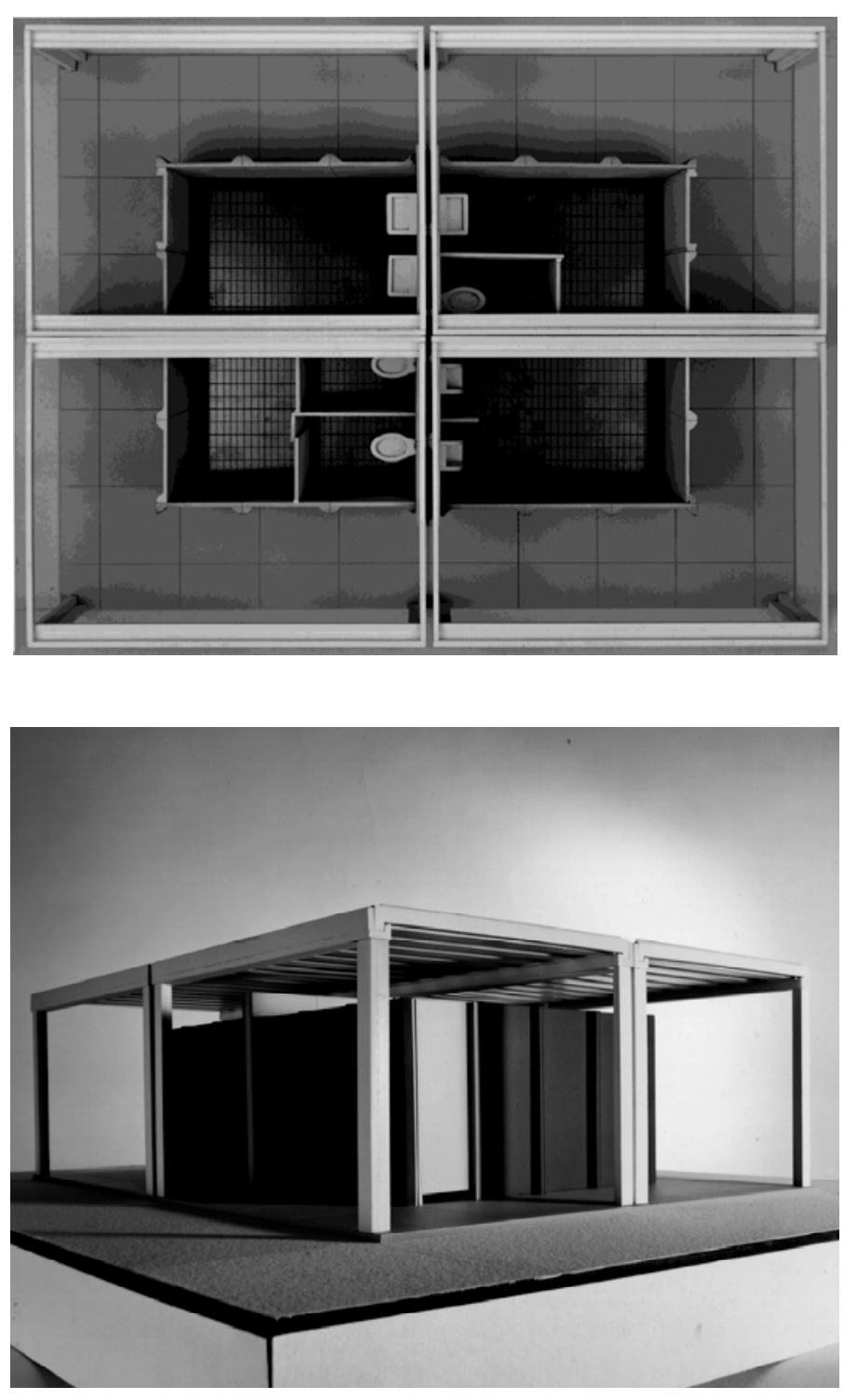


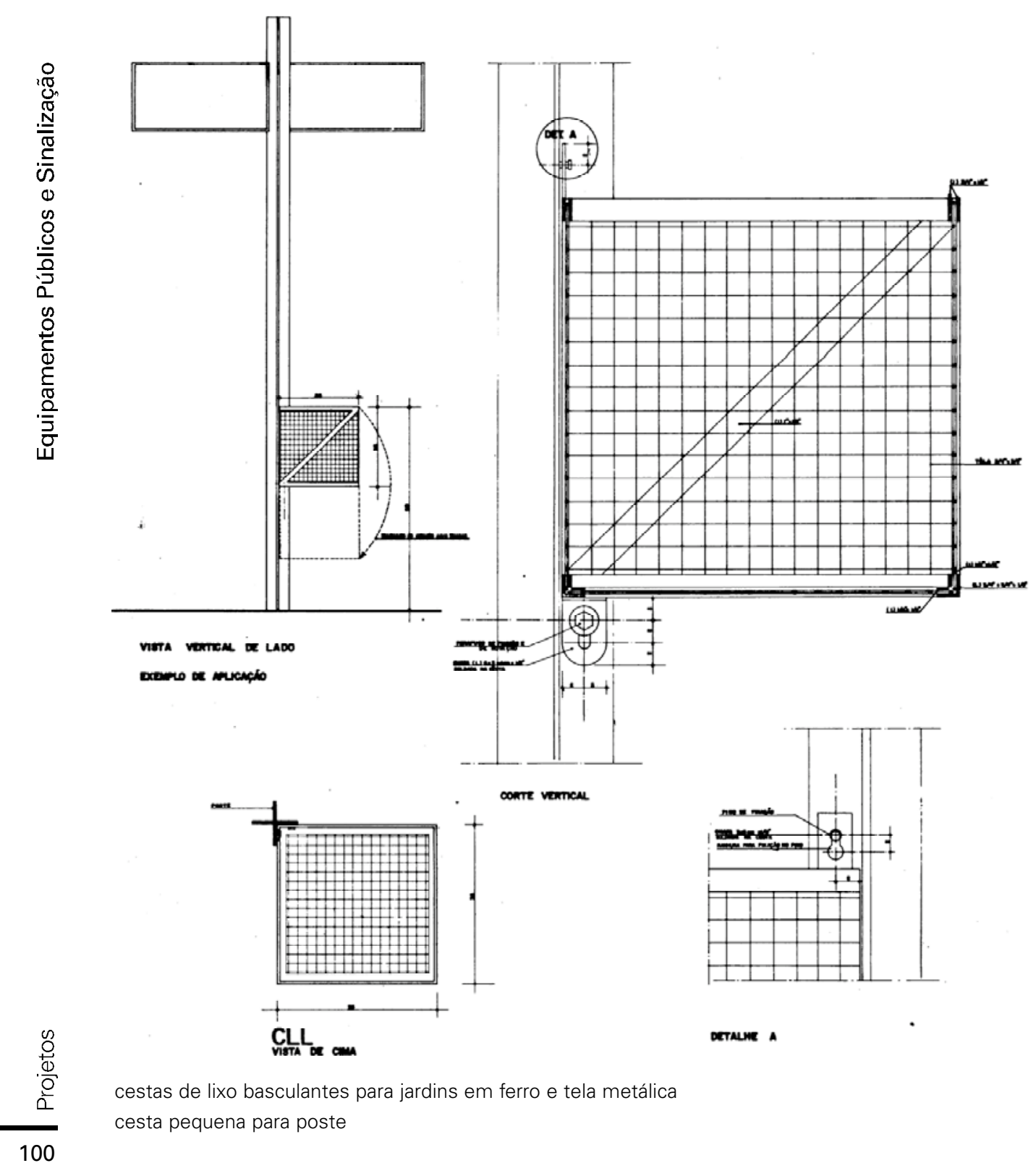




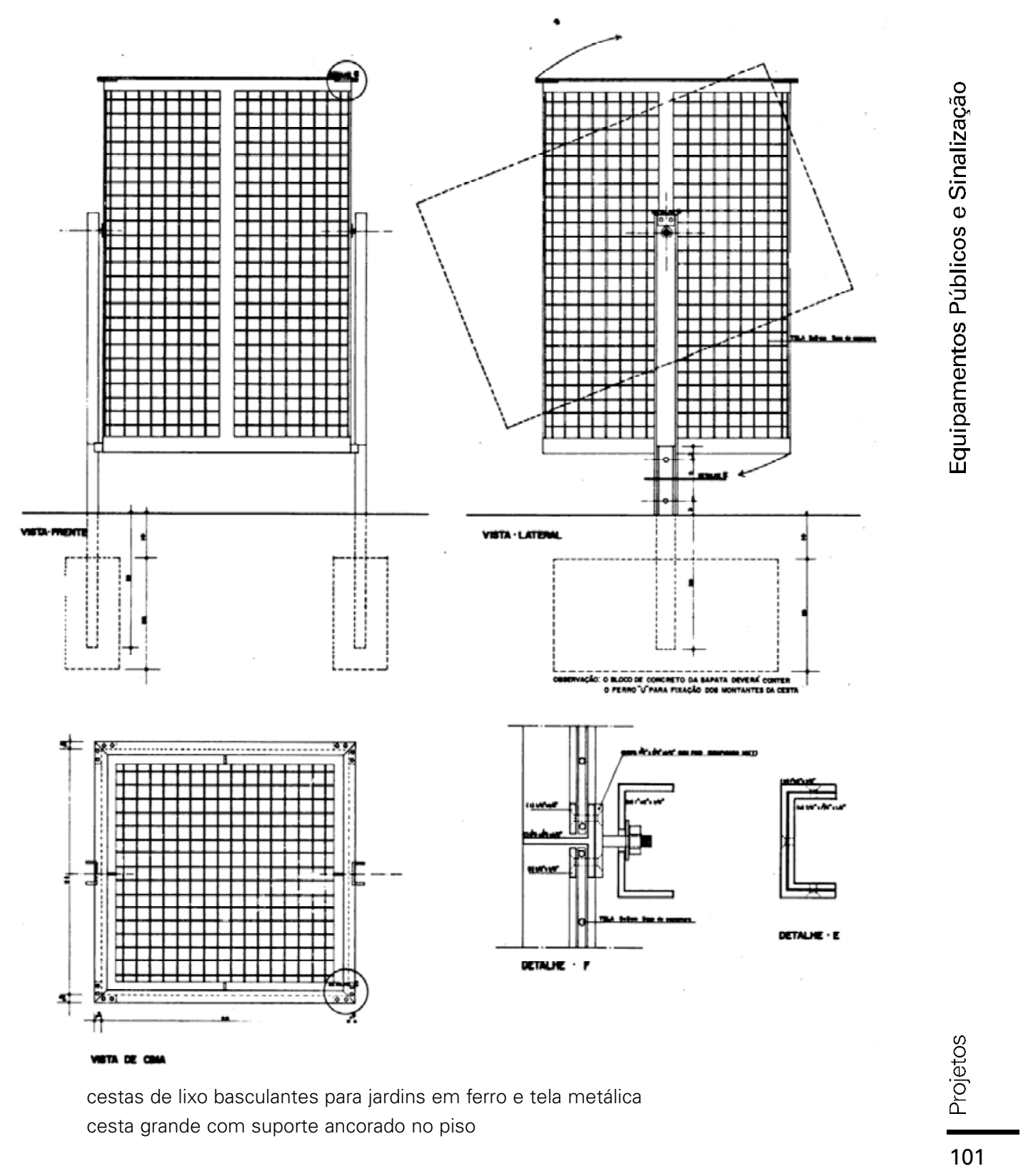




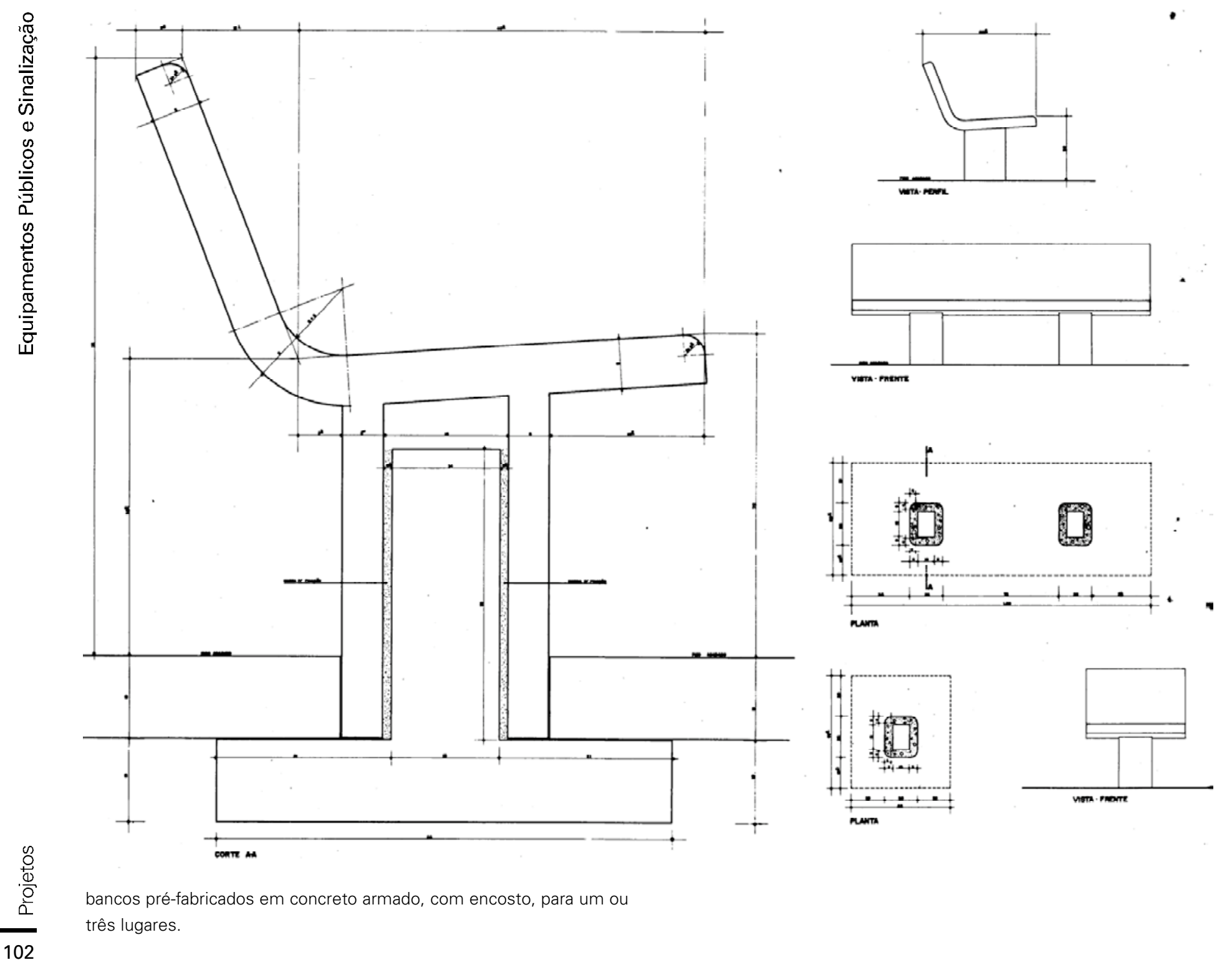



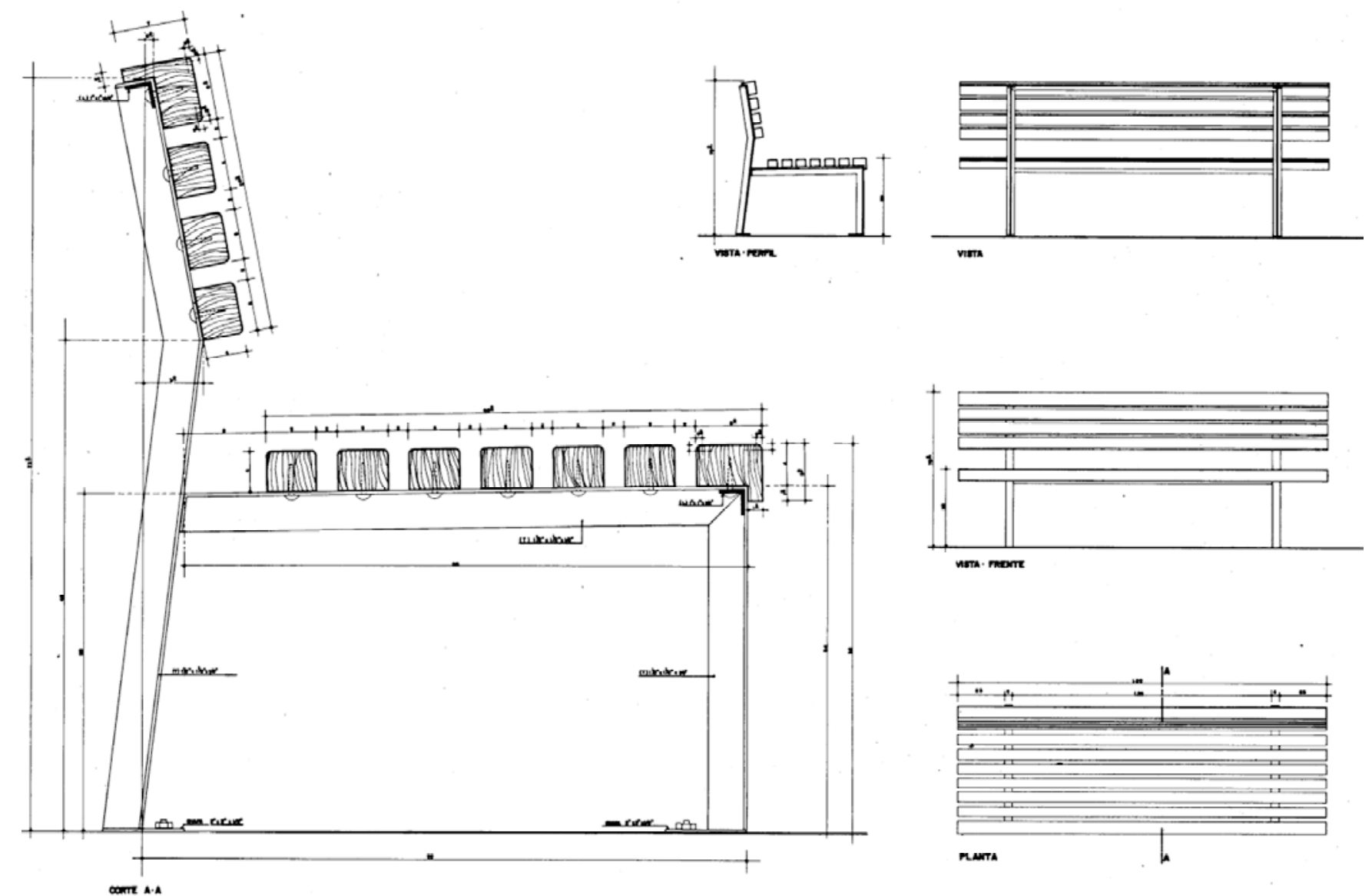

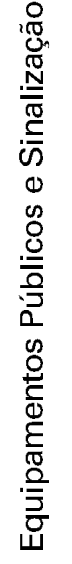

banco de ferro e madeira para três lugares

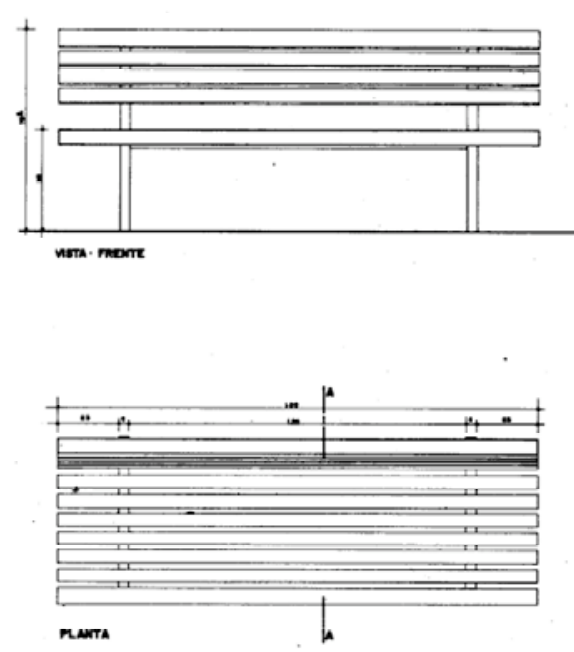




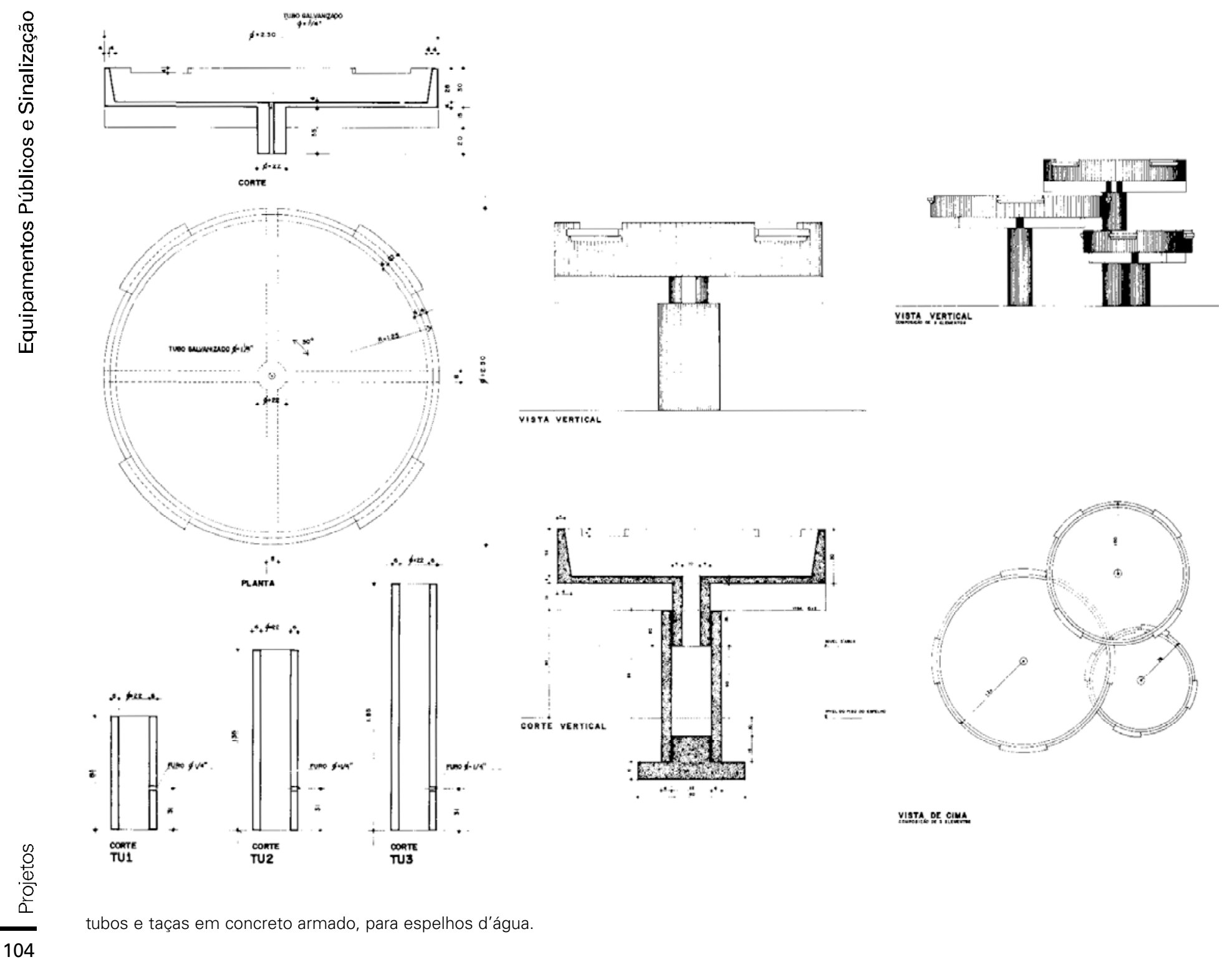


Estações de Piscicultura de Promissão e Salto

\section{Grande - 1972}

Estado de São Paulo

fonte [imagens] acervo do escritório Elito Arquitetos

[desenhos] acervo da biblioteca da FAUUSP 
No ano de 1972, Abrahão Sanovicz foi chamado pela Companhia Energética de São Paulo - CESP para elaborar dois projetos de estações de piscicultura a serem executados junto às represas de Promissão e Salto Grande, na região centro-oeste do Estado de São Paulo.

Tratava-se de um programa incomum, uma vez que abrangia elementos que fugiam da rotina profissional de Abrahão, tais como grandes tanques enterrados, com diferentes dimensões para abrigar os peixes em todo seu desenvolvimento. Desse modo deveria prever: ventilação constante, mas controlada; captação da água da represa e descarte; iluminação noturna especial que atraísse insetos; paisagismo com espécies frutíferas; e edificação para o laboratório.

As áreas disponíveis para implantar as estações eram muito grandes, cerca de $350.000 \mathrm{~m}^{2}$. Além de resolver o problema do número de tanques, era necessário solucionar a recomposição da paisagem.

Assim, foram definidos, em projeto, todos os processos e os procedimentos que a empreiteira deveria obedecer: desde a limpeza do terreno, a organização do canteiro e os métodos construtivos até a limpeza final da obra.

Como o programa dos laboratórios era o mesmo, servia para as duas estações, a implantação de ambos foi feita com um único projeto.

Os partidos adotados para as duas estações de piscicultura foram estabelecer um eixo principal em cada uma delas, a partir do laboratório, e dispor os tanques em ordem crescente nas suas dimensões, ao longo desses eixos.

$\mathrm{Na}$ estação de piscicultura de Promissão esse eixo é paralelo à barragem e à estrada estadual; e os tanques acompanham-no perpendicularmente, num desenho ordenado, sem competir com a paisagem ao redor.

A presença da estação é visível apenas por causa do edifício do laboratório e pela vegetação, principalmente a que sombreia os tanques e serve de alimentação para os peixes.

Na estação de piscicultura de Salto Grande, o eixo é também paralelo à estrada e à barragem; porém, os tanques foram dispostos de ambos os lados deste eixo, formando um desenho mais livre.

A topografia do terreno, mais movimentada, permite uma visão total do conjunto, a partir do patamar do laboratório, colocado a cavaleiro da estação.

Em cada um dos projetos, um grande lago, de desenho livre, conforma o conjunto e recebe as águas servidas dos tanques. 
Em ambas as estações, a captação de água para os tanques é por gravidade, feita desde a tomada de água instalada na barragem.

Por último cabe ainda ressaltar que os projetos não foram concebidos somente como estações reprodutoras de peixes, mas como áreas de lazer organizado.

Sobre um trabalho com programa tão "exótico", Abrahão observou:

A equipe com quem eu trabalhei nesses projetos era muito boa, assim, mesmo com um programa pouco freqüente, logo pudemos dominar totalmente o problema. Assim (brincando) bem assessorado, me tornei especialista em piscicultura.

Sempre digo que somos "especialistas gerais", não sabemos nada em profundidade, mas a responsabilidade pelo espaço construído deve ser sempre nossa. Qualquer que seja o programa, se bem apoiados por outros profissionais, temos sempre condições de, compreendendo o todo, nos assenhorarmos do problema e chegar à melhor solução (DPCA, 1987 e 1988 comentário de Catharine Gati).
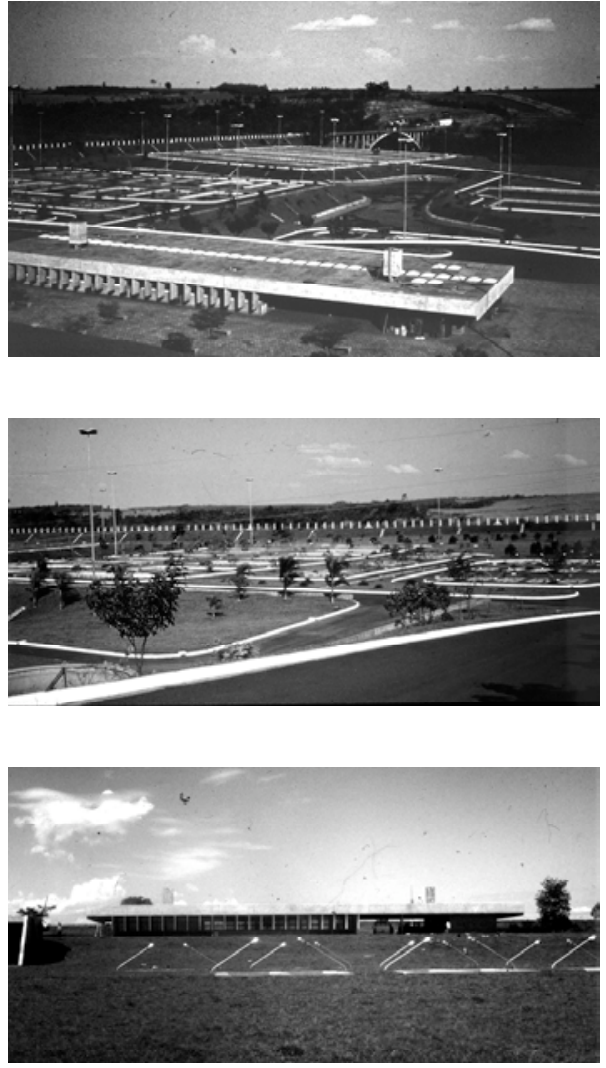


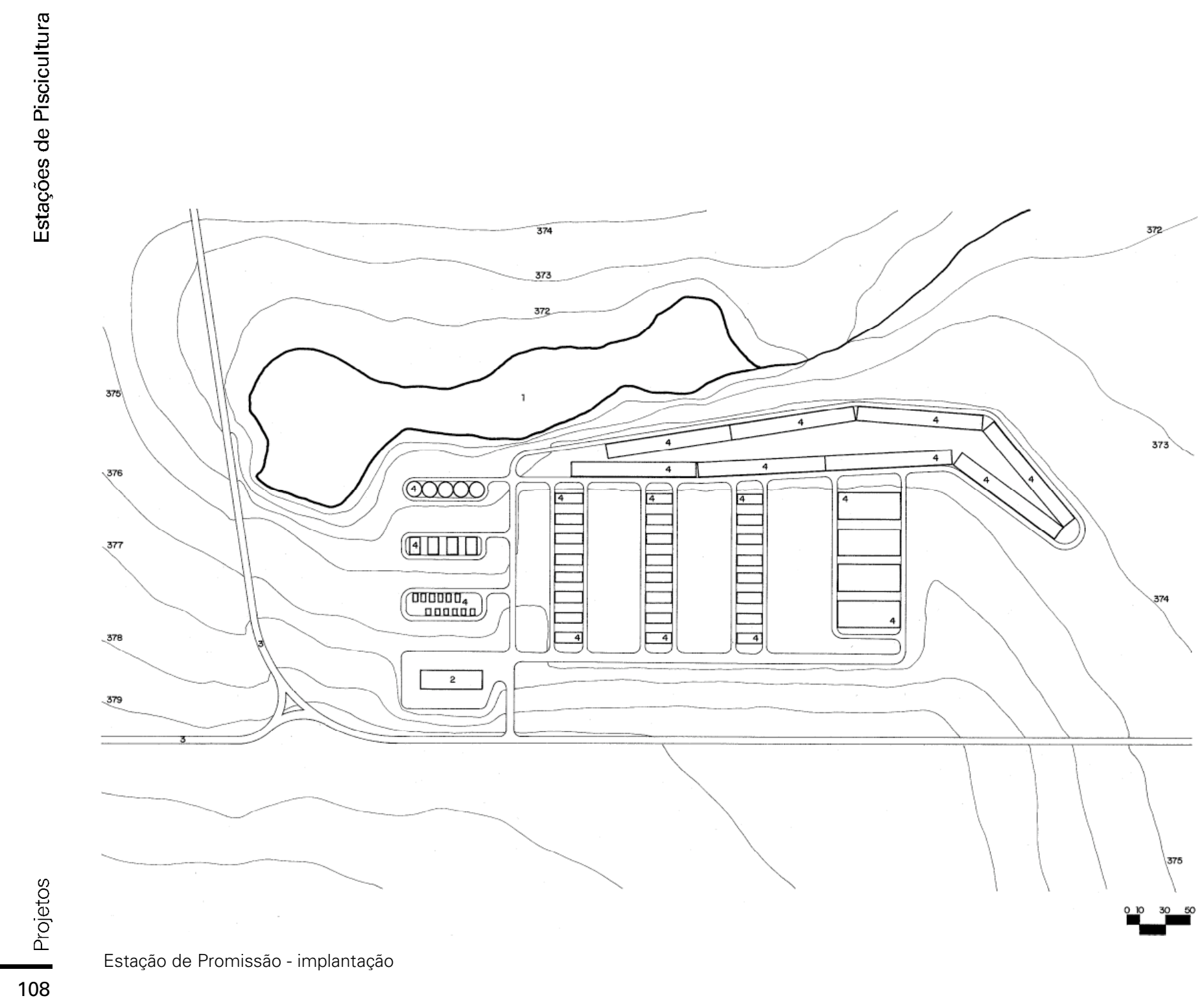




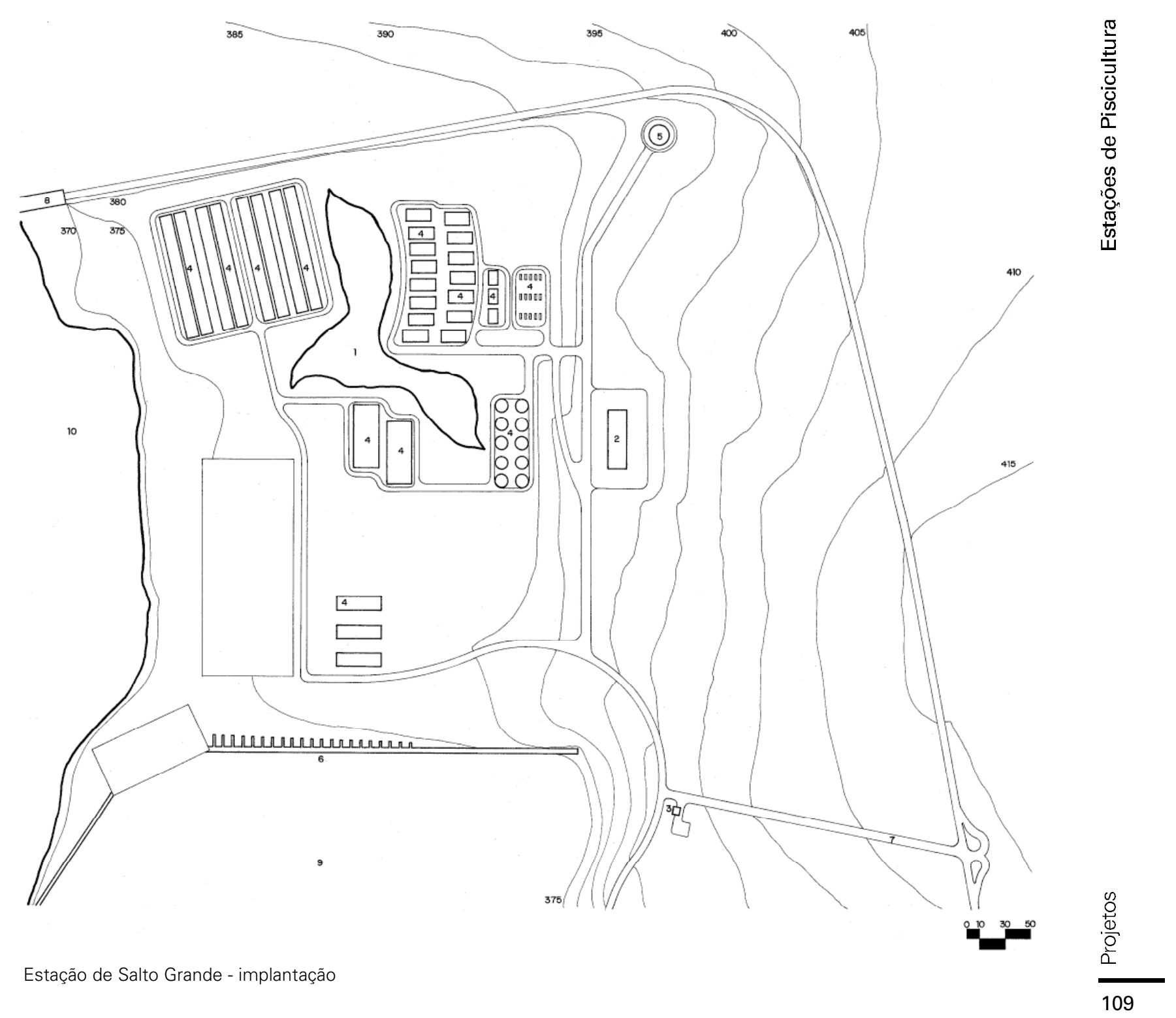



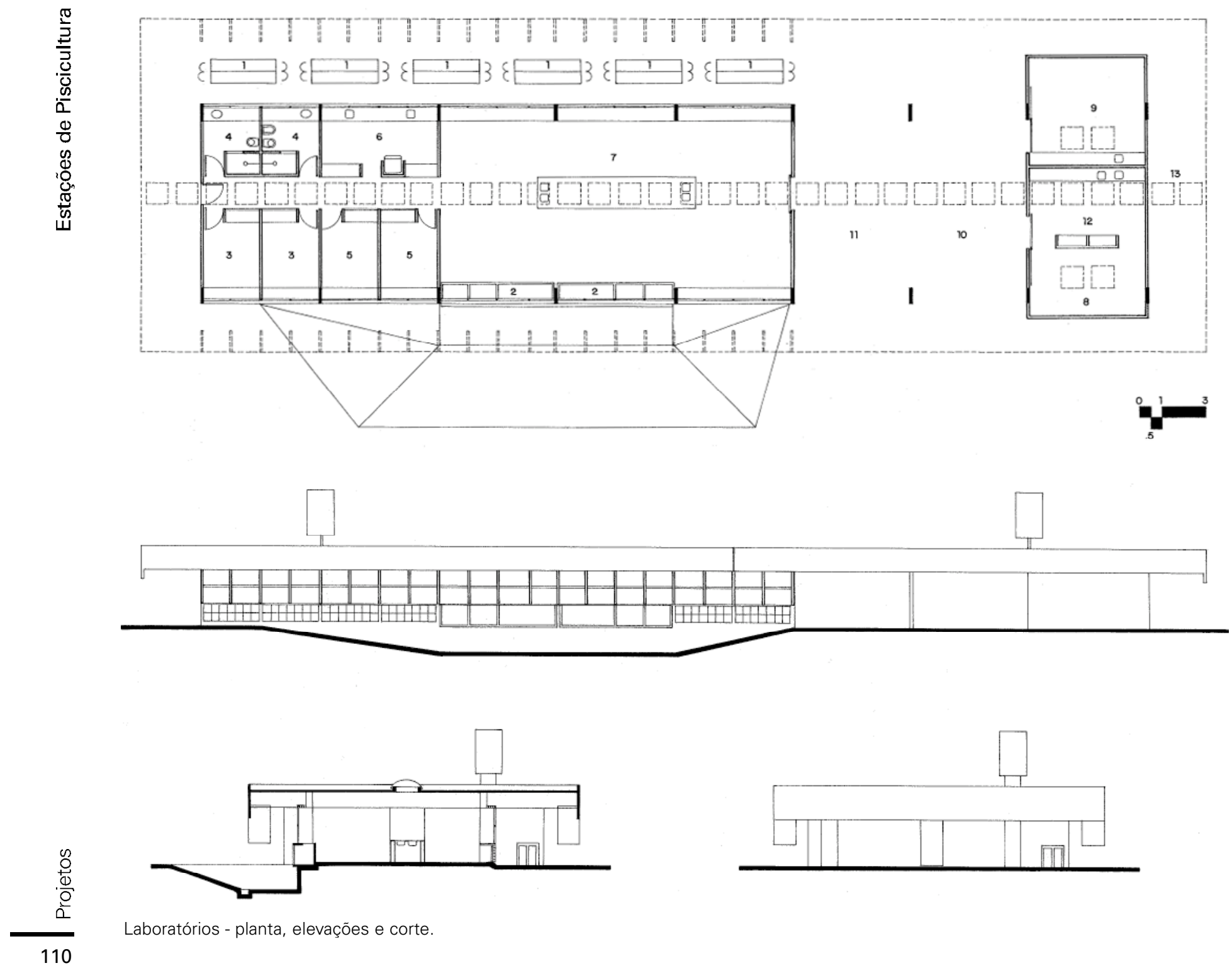

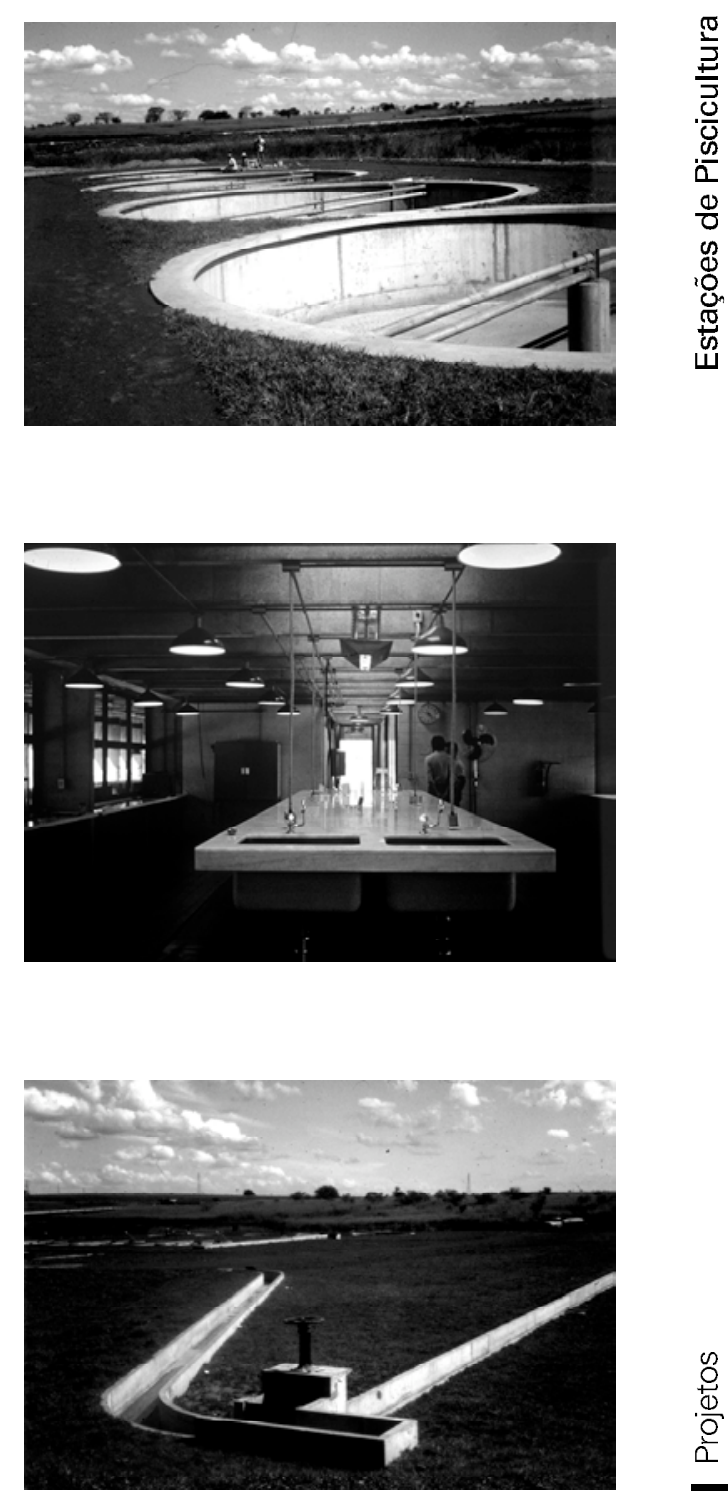

$\frac{\substack{0 \\ .0 \\ \frac{0}{2} \\ \frac{0}{2} \\ 111}}{2}$ 

Residência Abrahão Sanovicz - 1976/77

Rua Alexandre Marcondes Ferreira, 33

São Paulo, SP

fonte [imagens] acervo do escritório Elito Arquitetos

[desenhos] acervo da biblioteca da FAUUSP 
Em 1976 fiz o projeto da minha casa, é o fim de um processo. É uma caixa de concreto apoiada em 4 pilares, me lembra muito o primeiro projeto moderno que eu vi construído, a casa do Artigas na llha Porchat.

Ela é tudo que sempre admirei: planta livre; estrutura independente; conjugação dos espaços; pés direitos duplos; a escada uma escultura; terraços; compreensão da totalidade do espaço; implantação elevada; faz cantar os pontos de apoio. Aparece então o velho desenho: uma caixa pesadíssima que dá sensação de leveza. É toda vazada, não se sabe onde começa e onde acaba (DCPA, 1987 e 1988).

Com essas palavras Abrahão demosntra a essência do projeto que desenhou para sua família.

A casa da família Sanovicz, em três níveis, foi implantada num lote urbano tradicional e plano, no bairro do Butantã, área da várzea aterrada para a retificação do Rio Pinheiros.

Com uma projeção de $125 \mathrm{~m}^{2}$, insere-se no rol das casas em que a solução estrutural é dada por: quatro apoios, empenas de concreto $(0,15 \times 6 \mathrm{~m})$, e lajes tipo caixão perdido.

As empenas, no comprimento maior da planta, definem as aberturas no outro sentido. No nível do pilotis, um volume solto abriga a lavanderia e dependência de empregada. Sala e cozinha ficam no pavimento intermediário.

Para dar ao acesso principal - uma continuidade espacial com a área externa - vale-se de um aterro, desenhado no pilotis pelos muros de contenção, que apóia uma pequena parte do piso da varanda de chegada.

A cozinha e lavabo, num volume solto, paralelo a uma das empenas, a escada e o pé direito duplo qualificam e definem os ambientes.

No nível superior, um bloco fixo, constituído pelos dois banheiros, e divisórias leves permitem algumas possibilidades de ocupação.

Um agradável jogo de varandas, ora limitadas pelas paredes, mas descobertas, ora cobertas e abertas, reforçam a continuidade espacial interna.

Como referência, além da casa projetada por Artigas, Abrahão indica um projeto de 1933, de Figini \& Polini a "Casa de Figini" em San Martino, na Itália.

Quando as referências dos projetos nos são apresentadas, à primeira vista, chegamos a confundir os projetos. Analisando com mais atenção, percebemos que, aparentemente iguais, são muito diferentes. O que ocorreu foi o entendimento pelo arquiteto, da essência do espaço referencial.

A esse respeito, João Walter Toscano falando sobre seu projeto, elaborado em 1959, para a Faculdade de Filosofia de Itu observa: 
Em minha tese de doutorado, comparo esse projeto com

outros que ficaram em minha memória, como a obra de Reidy em Pedregulho, no Rio. É diferente, mas tem o jeito do espaço, a rampa que sobe em pé-direito duplo, elementos

vazados de um lado (TOSCANO, J. 2003).

Num diálogo muito interessante, reproduzido abaixo,

Abrahão comenta com Catharine Gati o que significou o

projeto da Residência Sanovicz:

Abrahão Sanovicz - É uma síntese, lição do estudante de arquitetura, arquiteto Abrahão Sanovicz.

Catharine Gati - É sua expressão amadurecida diante do projeto?

Abrahão - Acho que sim, é o reconhecimento da condição de ter uma linguagem própria.

Catharine - O que é muito bonito, porque você, que sempre declara suas referências, passa a ser referência.

Abrahão - Numa certa medida sim, mas aí tenho mais liberdade para recorrer a outras tantas referências. O trabalho

e o processo são sempre os mesmos, mas a partir desse

projeto com muito maior liberdade (DPCA, 1987 e 1988). 


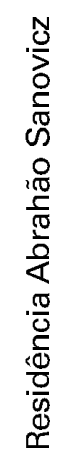
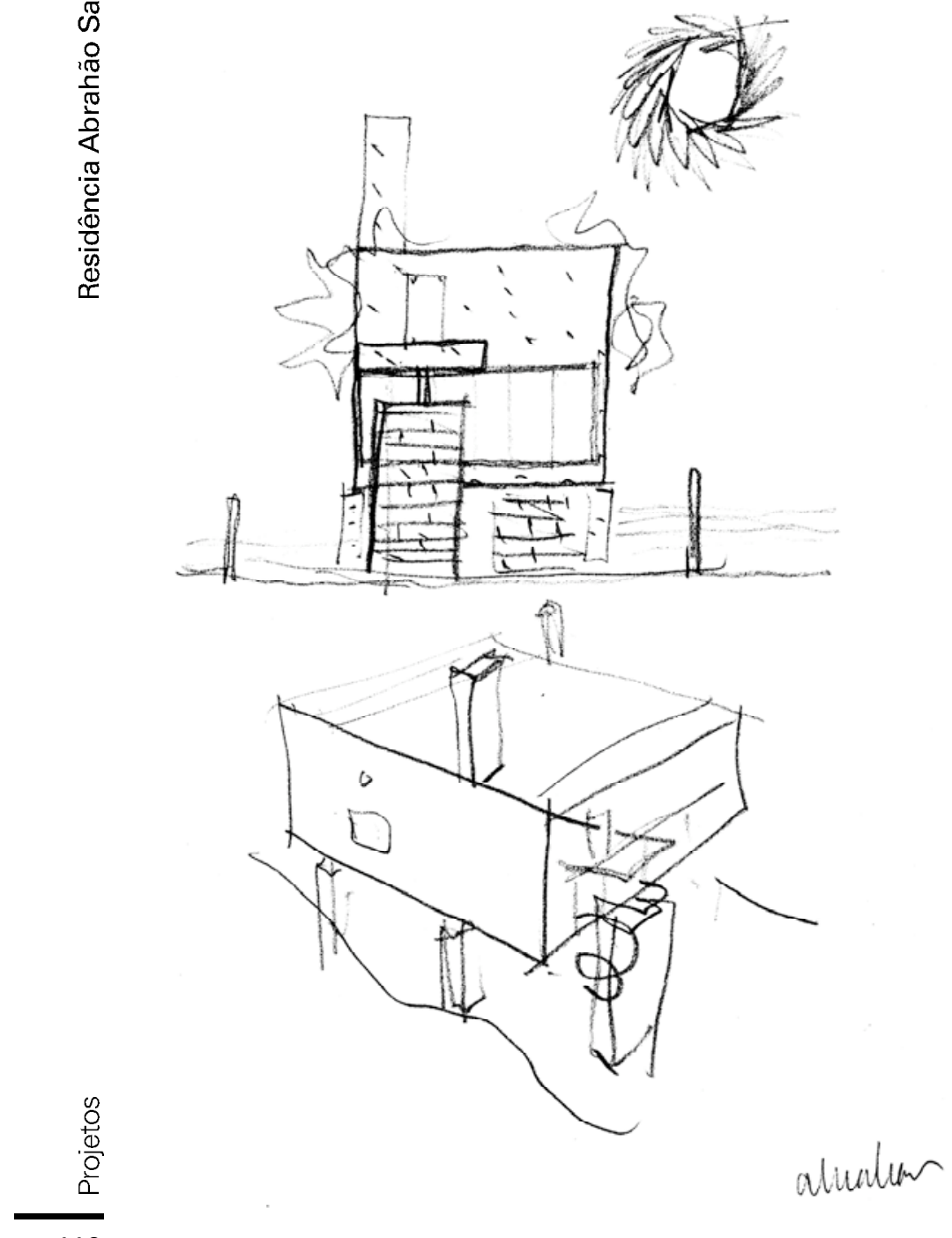

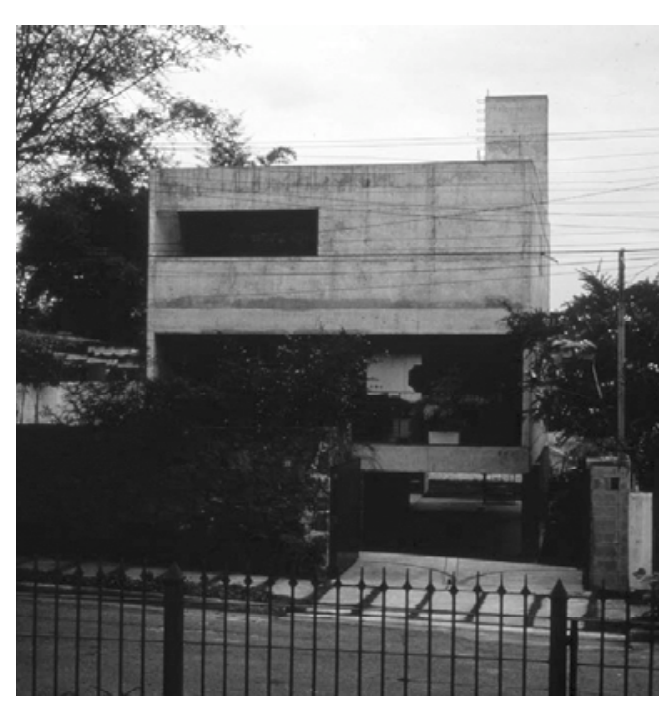




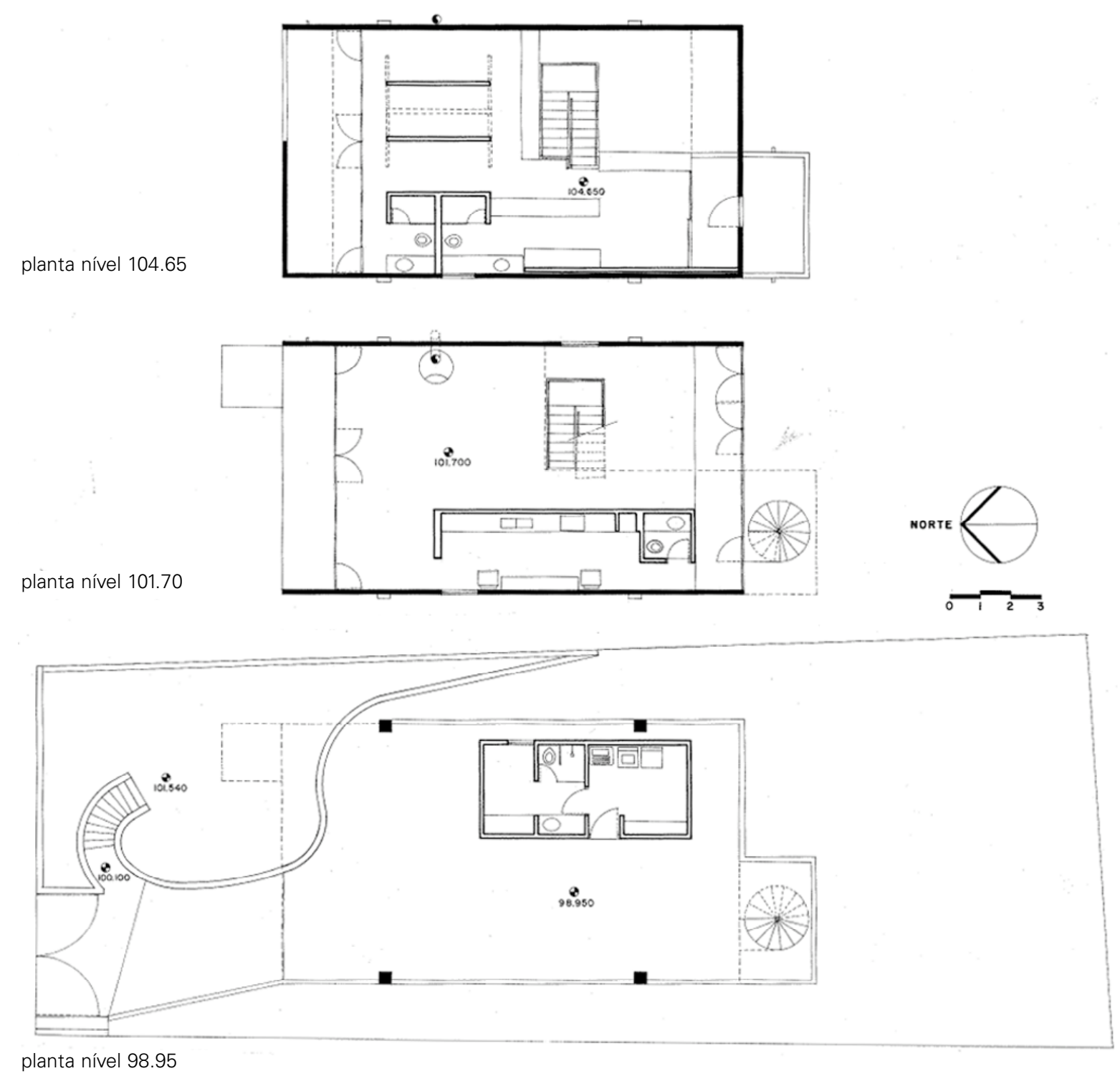

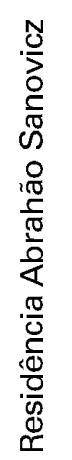

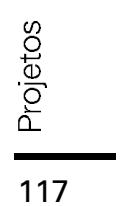




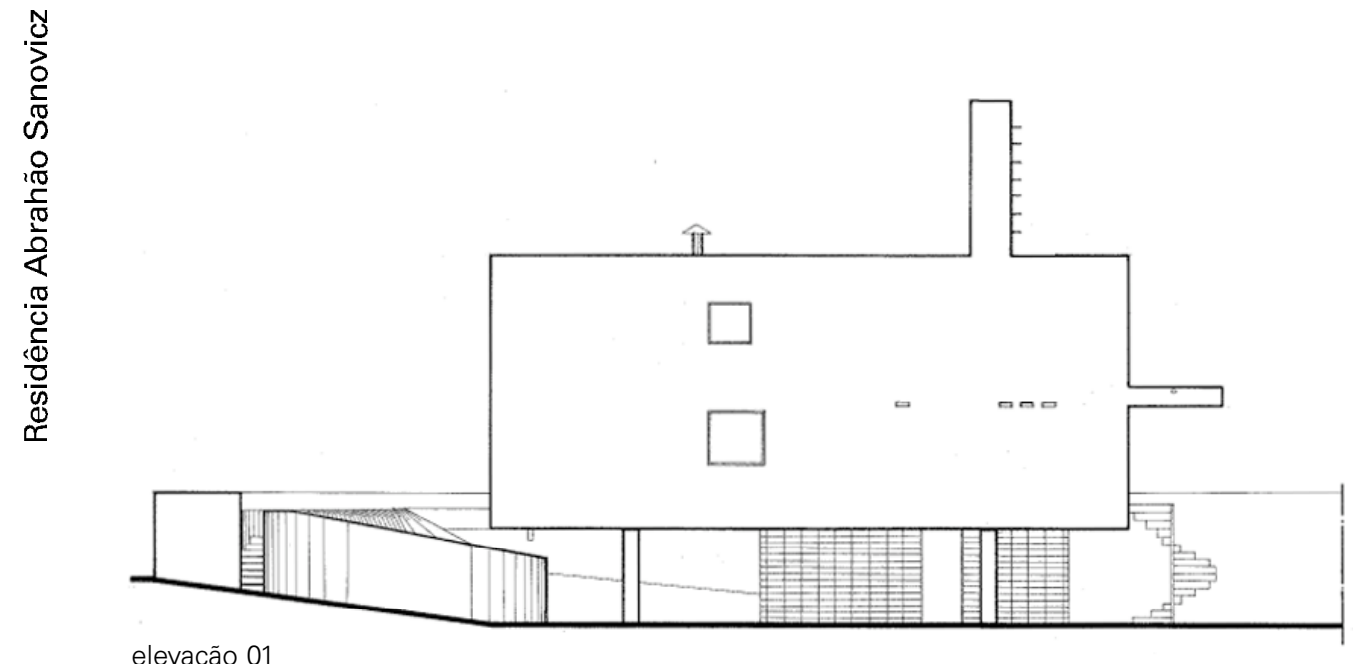

elevação 01

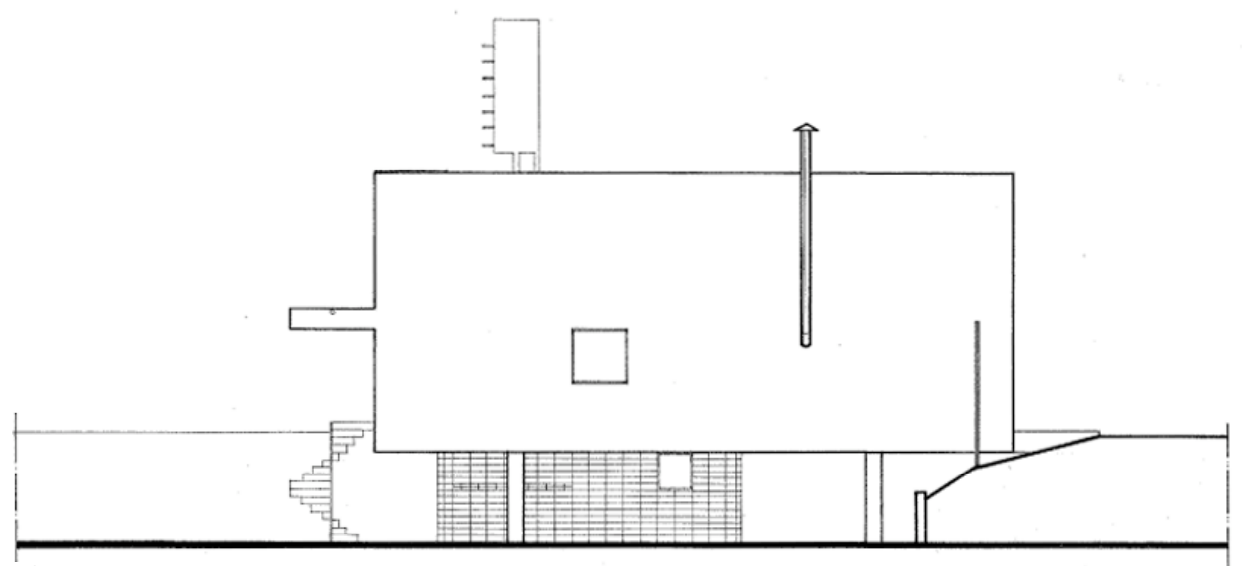

elevação 03

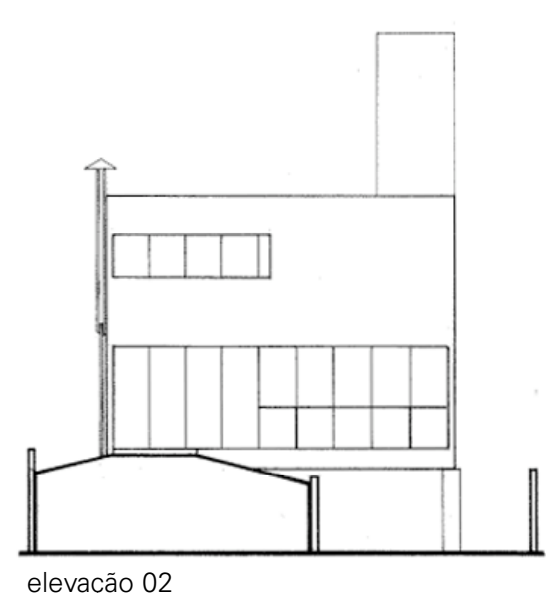

elevação 02

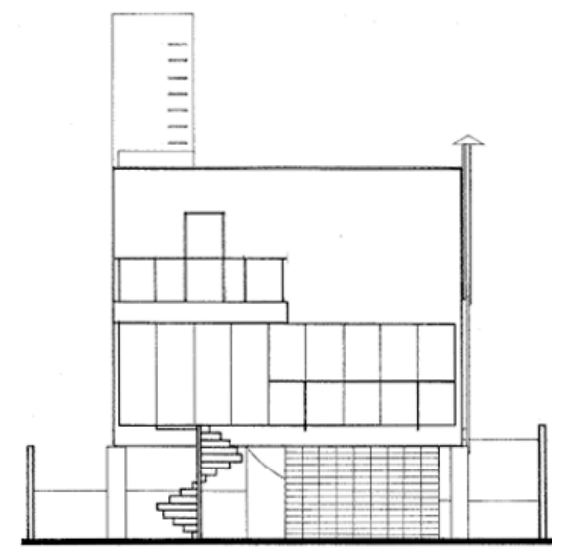

elevação 04 

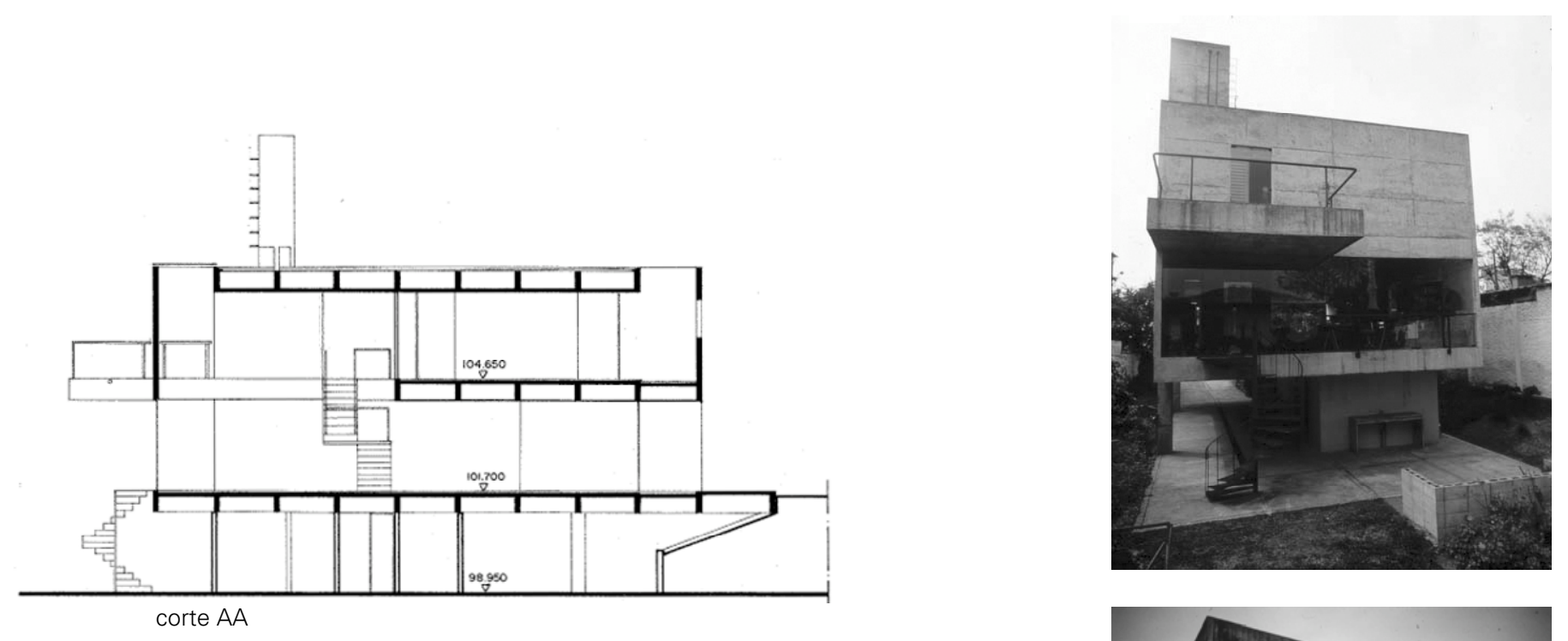

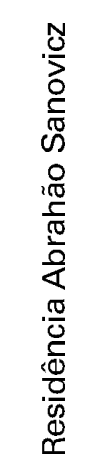
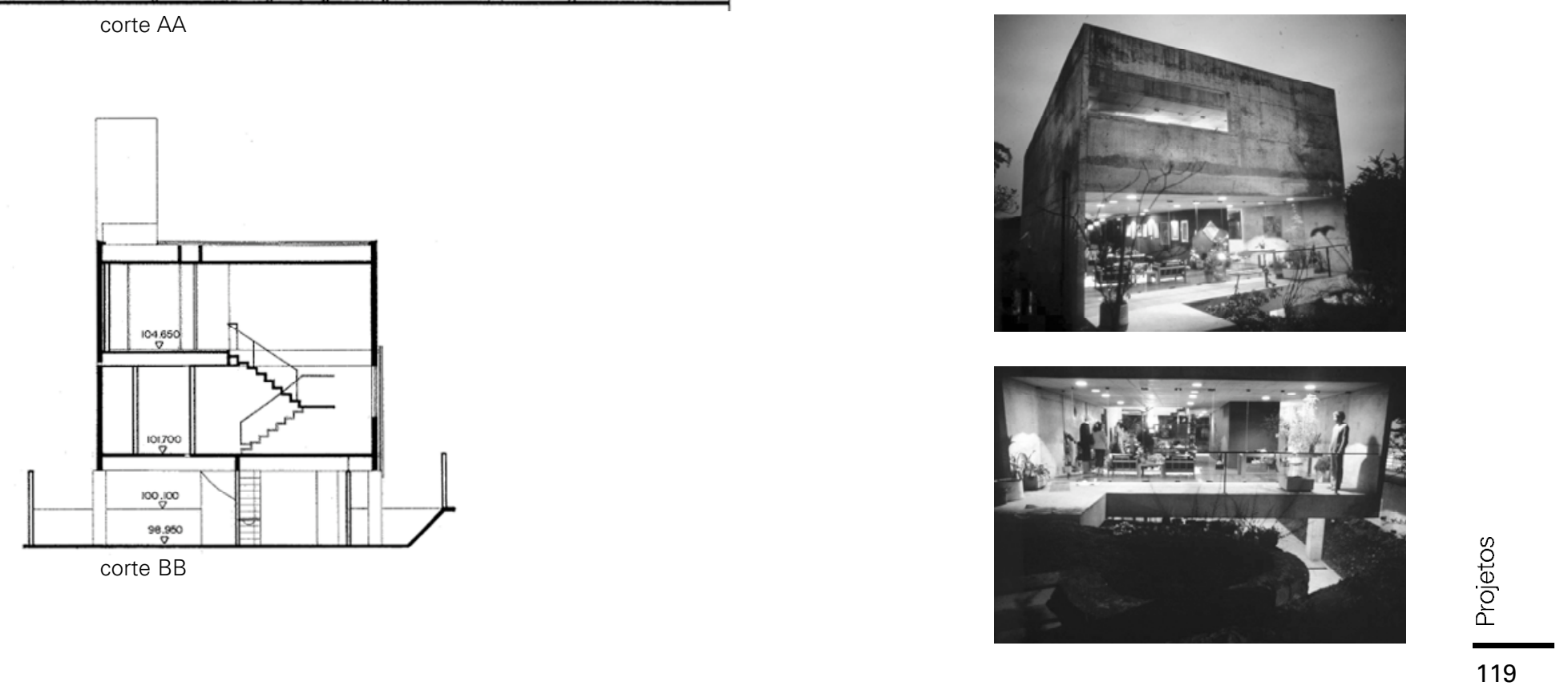

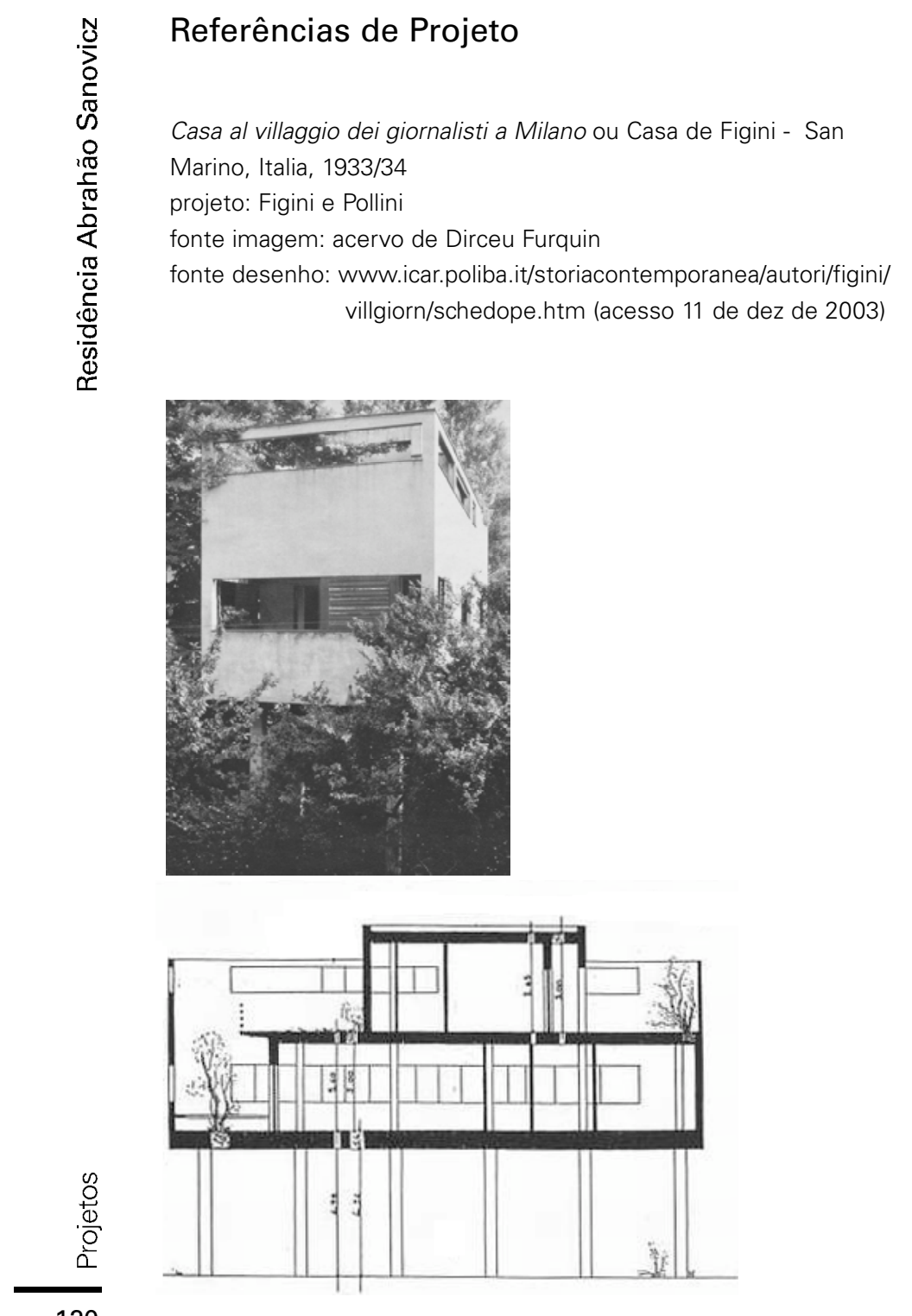

Casa Hirsh Shor - Ilha Porchat, Santos, SP, 1950 (demolida) projeto: Vilanova Artigas

fonte: acervo da biblioteca da FAUUSP
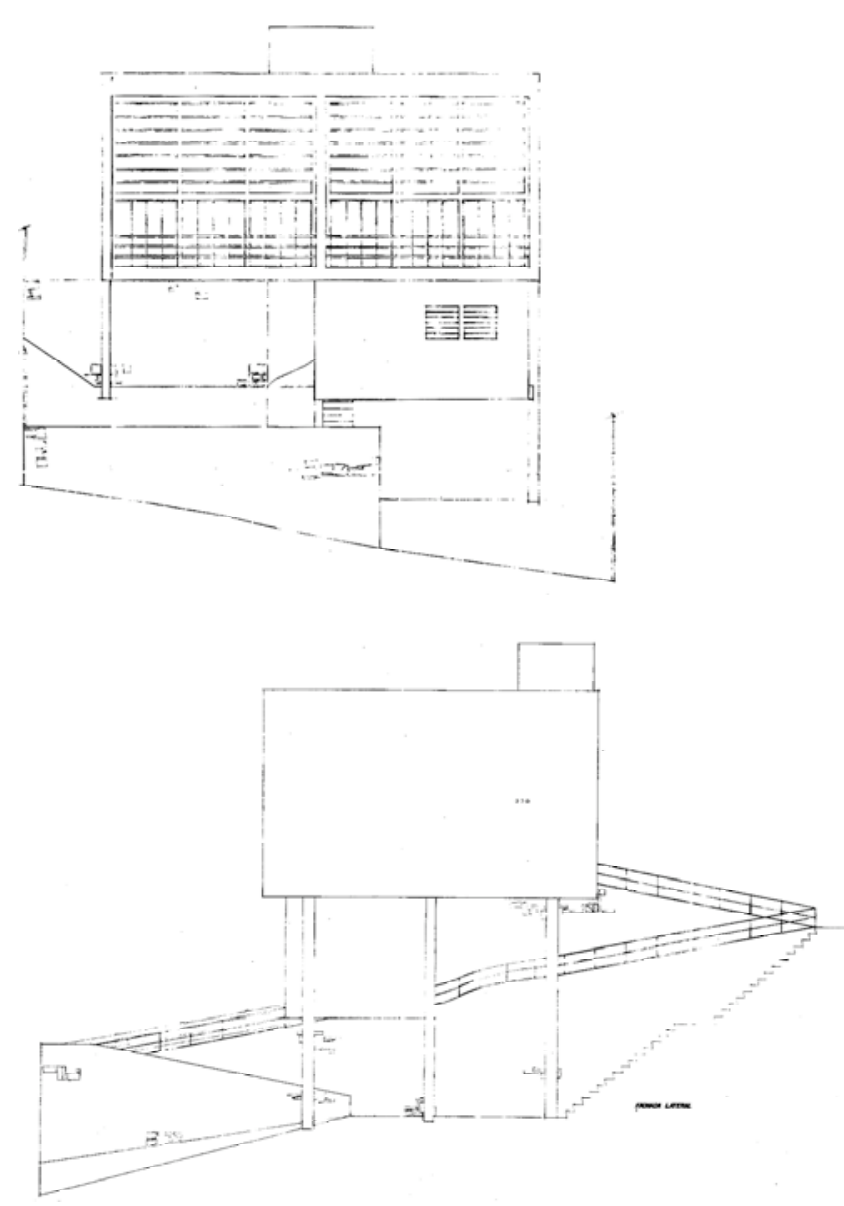
Fórum de Bragança Paulista - 1985

Bragança Paulista, SP

fonte [imagens] acervo do escritório Elito Arquitetos [desenhos] acervo da biblioteca da FAUUSP 
A realização desse projeto representou o encontro de trajetórias e vivências de vários arquitetos. Abrahão Sanovicz, líder da equipe, e à maneira de Oswaldo Corrêa Gonçalves, constituiu um consórcio de escritórios, convidando, inclusive, profissionais da região de Bragança Paulista, para com ele participarem da elaboração do projeto. A equipe assim formada contou com Affonso Risi Junior, Edson Jorge Elito, Leo Tomchinsky, João Carlos Monte Claro Vasconcellos e José Diaulas Pimentel de Almeida.

O programa previa: acessos (principal, de presos e para juízes); portaria; protocolo; administração; cartórios; posto bancário; salas para: assistência social (psicólogo e assistente social), assistência jurídica, testemunhas, oficiais de justiça, promotoria; salas de audiência; administração e almoxarifado; arquivo; biblioteca, sala de reunião, salão do júri, sala de jurados; cela; sanitários; vestiários; lanchonete; garagens; e vestíbulos de espera.

Com área de $2.000 \mathrm{~m}^{2}$, dois volumes abrigam o extenso programa. No maior estão as atividades de maior afluxo de público, no anexo, o salão do júri, cela e sala de jurados ficam no nível superior, e arquivo e garagem no térreo. Colocado a meio nível em relação outro, o anexo ao mesmo tempo em que toma partido da topografia do terreno, dá condições que se crie um pé direito maior no pavimento superior.

A circulação, a partir do acesso principal, é o elemento ordenador e que hierarquiza a ocupação do edifício e, ao mesmo tempo, facilita a compreensão do espaço.

A solução construtiva é a tradicional: fundações em estacas, estrutura de concreto moldada in loco, alvenaria de tijolos maciços aparentes, portas de madeira pintadas de várias cores, diferenciando funções de cada espaço, piso de ardósia e caixilhos basculantes, por questões de segurança.

$\mathrm{O}$ acesso principal, uma varanda com $7 \mathrm{~m}$ de pé direito e o fechamento do bloco anexo recebem um tratamento especial, paredes sinuosamente desenhadas executadas em tijolo maciço.

Este desenho, aliado à iluminação zenital dos espaços nos remetem ao projeto de Eero Saarine para a capela do Massachussets Institute of Technology MIT.

O jornalista José Wolf, na matéria da revista $A \cup$ de nº 43 , resume as intenções dos autores do projeto:

A gênese do projeto, do princípio até sua tradução final em espaço revela, em síntese, alguns pontos essenciais.

A "planta miesiana", ou seja, existe uma estrutura, não importa a modulação ou material empregado, que torna possível distribuir sobre ela os espaços de maneira solta para se 
atender ao programa de necessidade.

O segundo elemento é a caracterização espacial que não se

vê, mas se sente. Em outras palavras: uma arquitetura sem grande retórica. E com "economia de meios".

Há ainda aqui uma referência histórica, da própria Arquitetura

Moderna dos anos 40, quando teve início o uso de elementos

construtivos para se criar um "micro-clima" de conforto

ambiental, como brises soleils horizontais ou verticais,

varanda, utilizados pelos mestres.

Deve-se enfatizar também a generosidade dos espaços

internos, dos corredores amplos, de um projeto implantado

numa região de clima quente, espaços com ventilação nas

duas extremidades, para maior conforto do usuário

E, finalmente, a utilização do tijolo de barro maciço. Ele possui

uma característica particular na questão da manutenção, ao

eliminar a pintura, e, ao mesmo tempo, é "um material comum

no nosso cotidiano" (WOLF, 1992 p. 49 - 50).
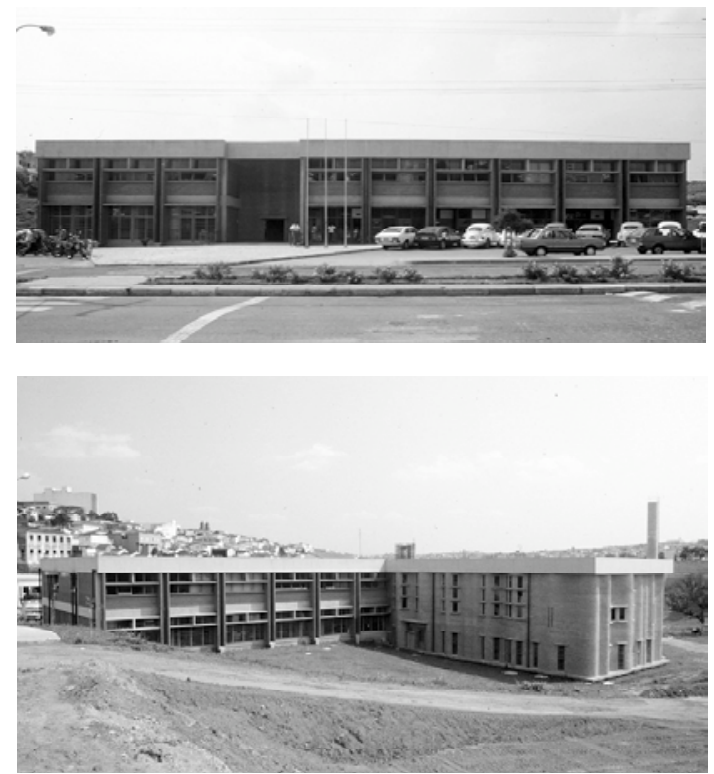


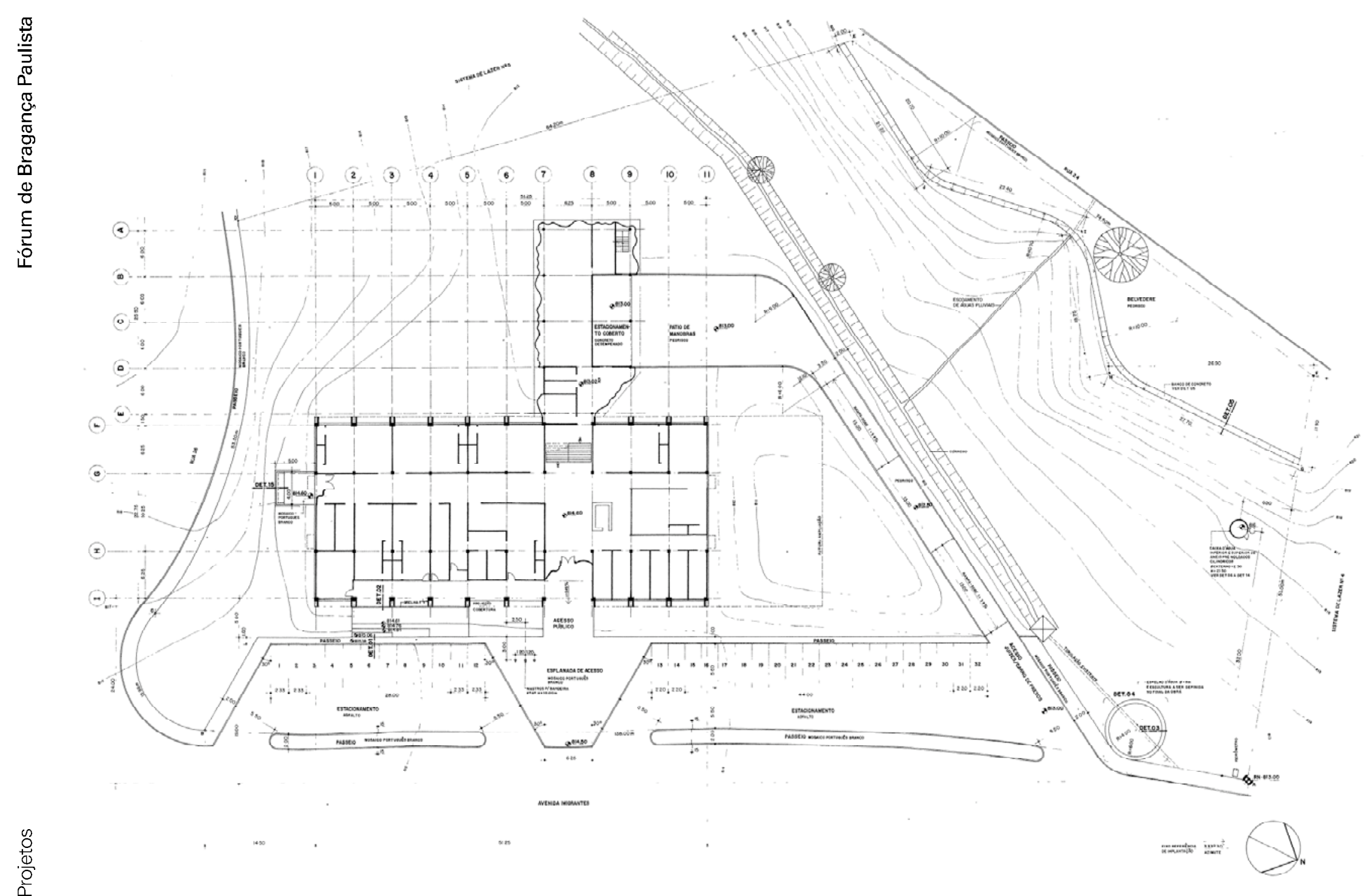

124 implantação 


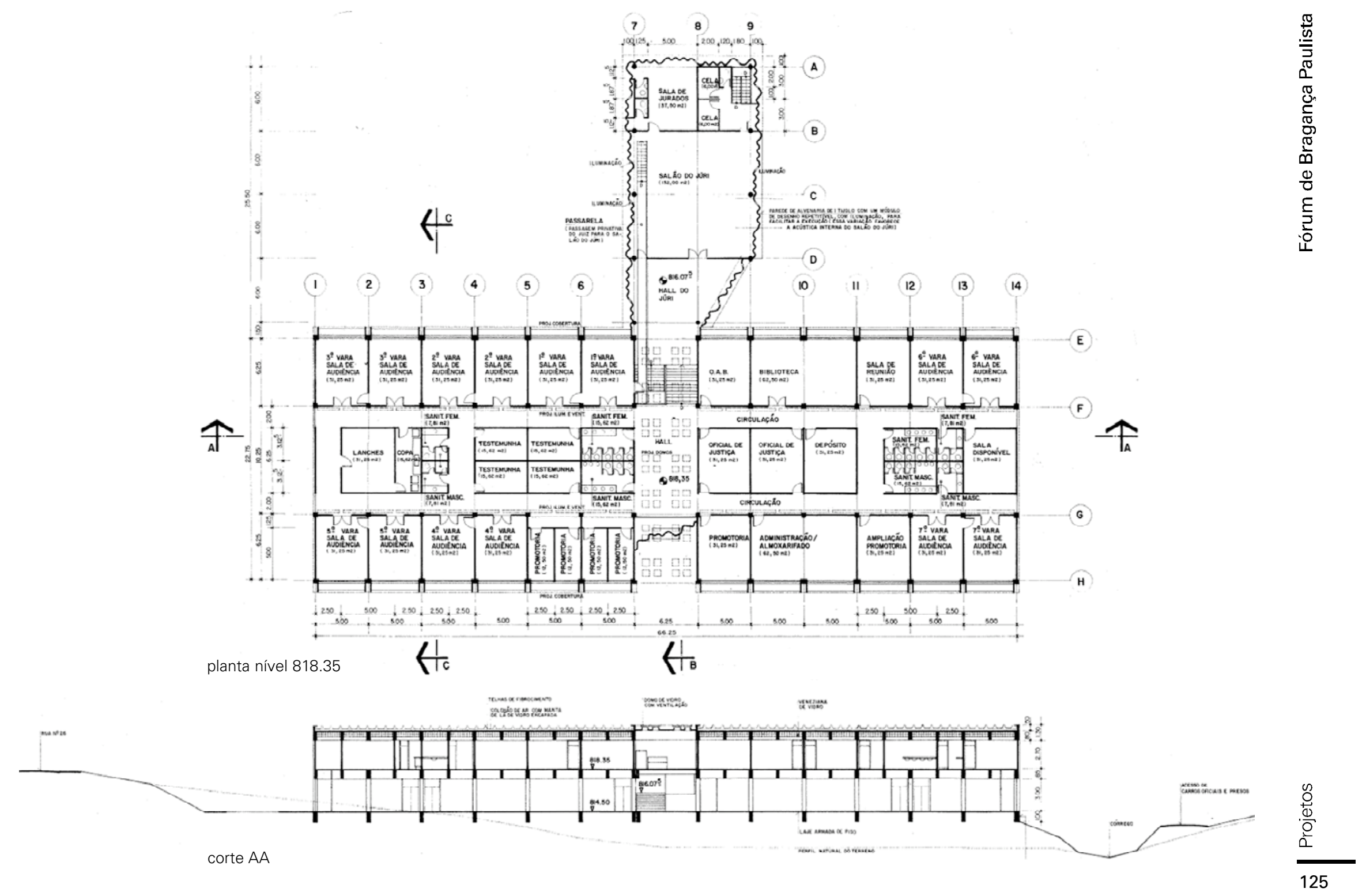



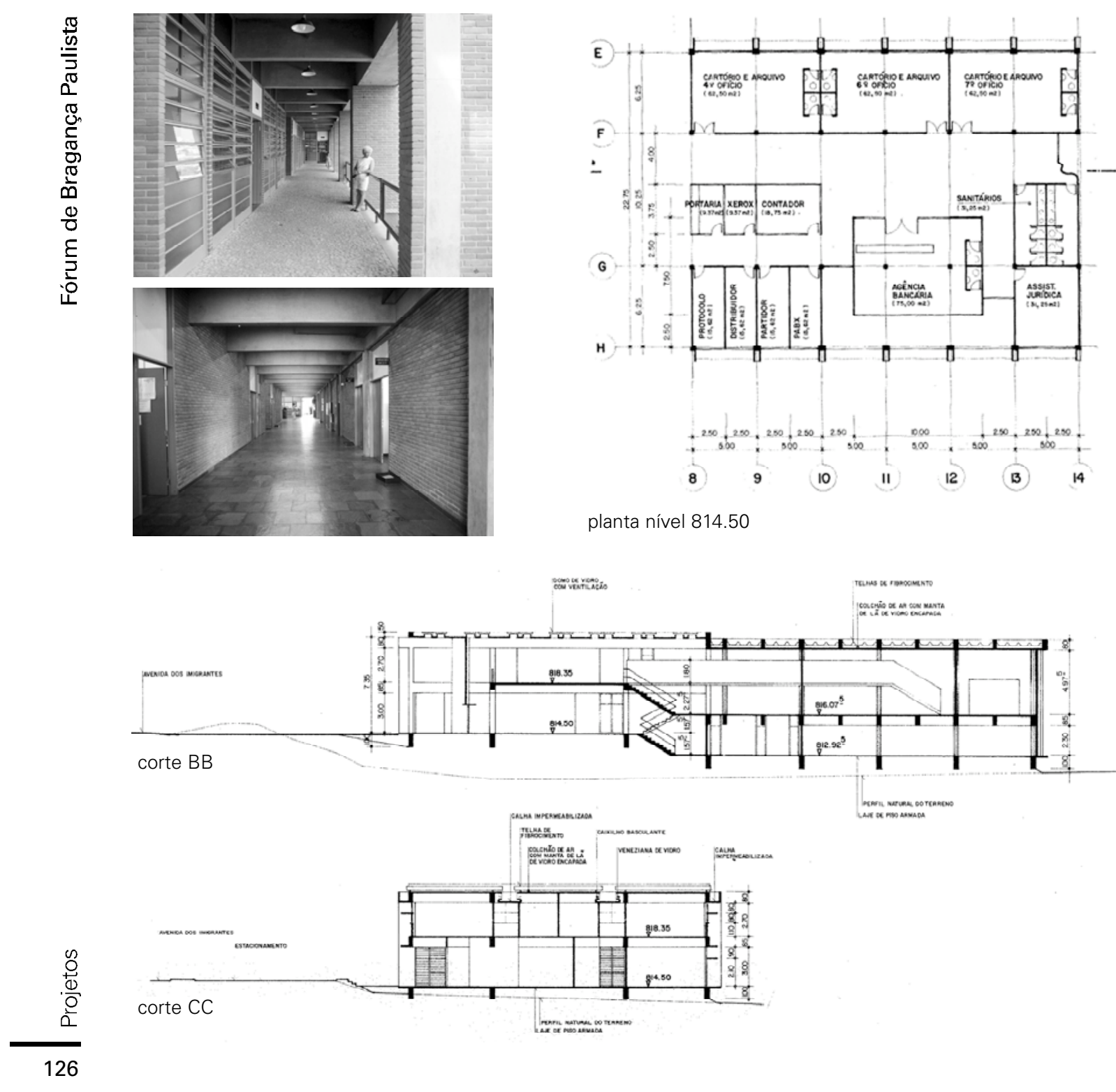


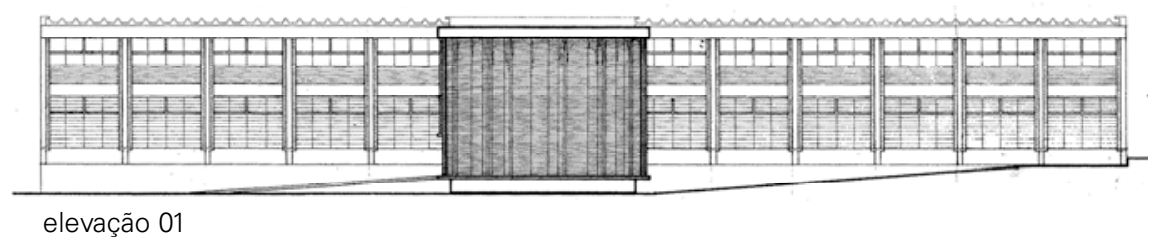

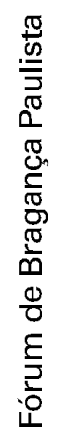

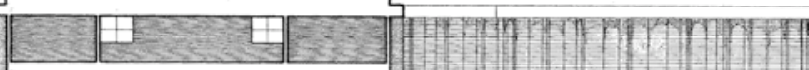

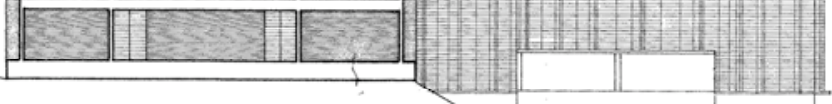

elevação 02

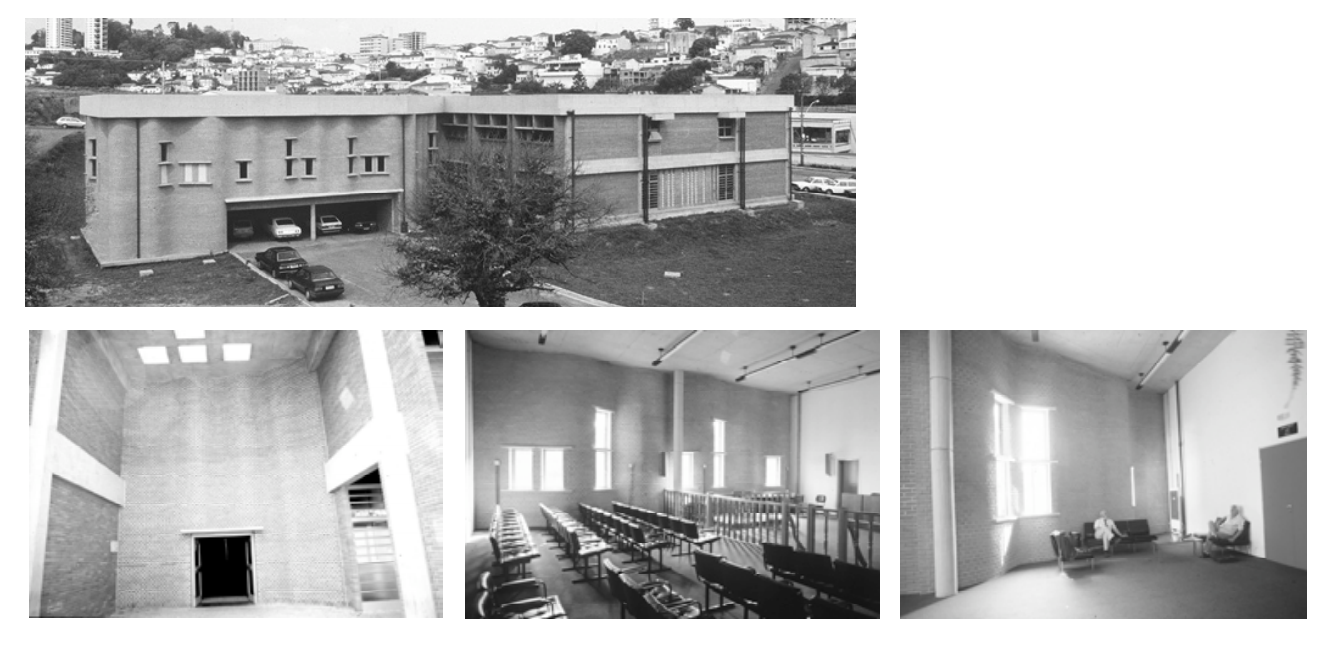



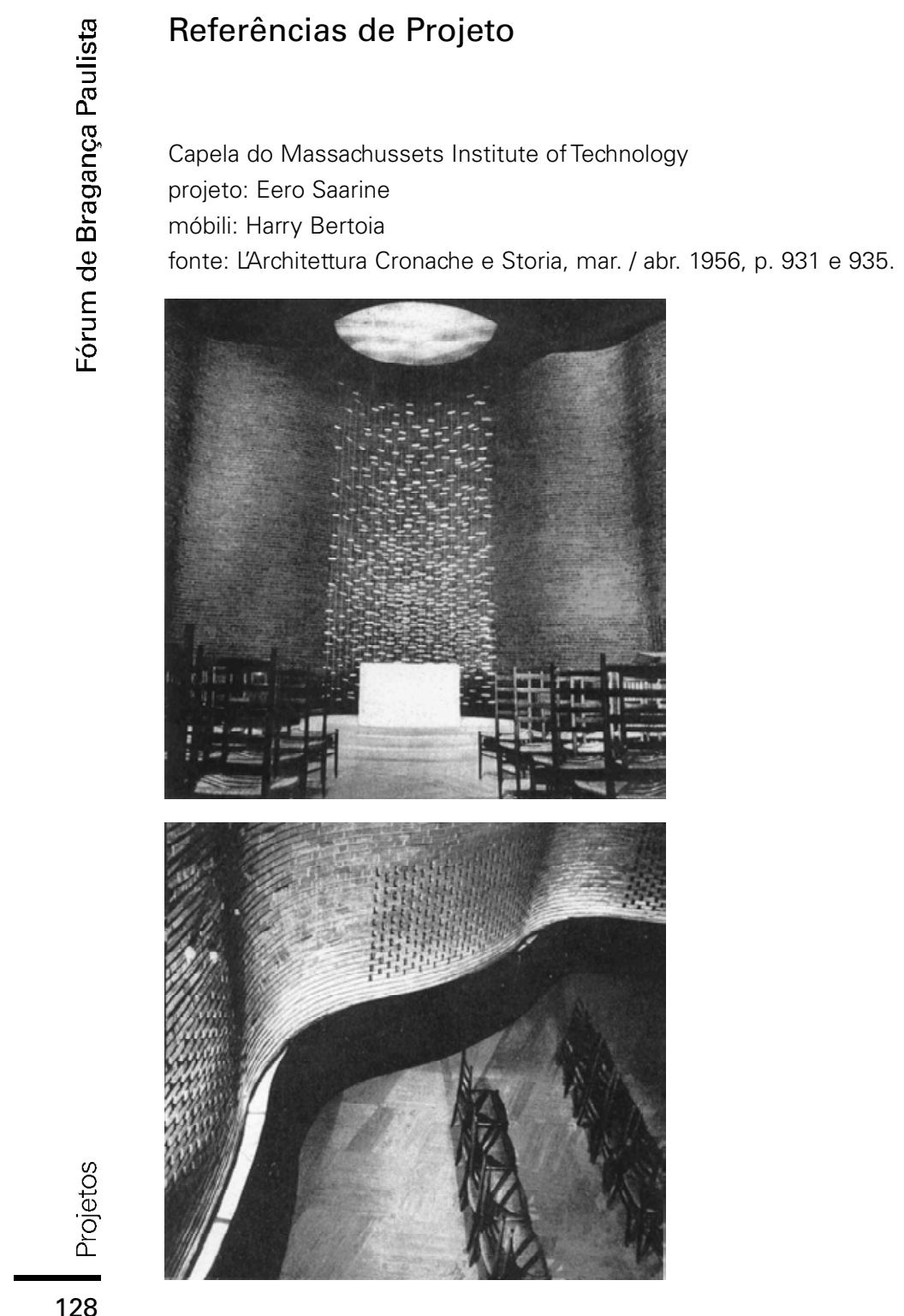


\section{Sede do Banespa Recife - 1986}

Avenida Conde da Boa Viagem com Rua do Hospício, Recife, PE fonte [imagens] acervo do escritório Elito Arquitetos

[desenhos] acervo da biblioteca da FAUUSP 
A matéria "Recorrendo à Linguagem da História Presente" da revista Projeto no 126 apresentou a obra para o edifício sede do Banco do Estado de São Paulo.

"Um projeto é o resultado de projeto ou projetos anteriores" (GOMES, 1989, p.78). Com esta afirmação usual de Abrahão Sanovicz, o jornalista Geraldo Gomes iniciou matéria.

A forma do terreno aliada às restrições impostas pela legislação municipal definiram o desenho da planta.

O edifício com área de 2.142,00 m², em três pavimentos, abriga, no térreo a agência bancária, parte dela com pédireito duplo; no mezanino ficam o atendimento a clientes especiais e área de suporte; no último pavimento, a sede regional.

Geraldo Gomes lembra que na década de 1980, os edifícios mais suntuosos que se construíram nas cidades brasileiras foram os bancos. A arquitetura evidenciava a crise por que passávamos.

No entanto, esse não era o caso da Sede Regional Banespa Recife, primeiro pela escala, depois pelas soluções encontradas por Abrahão.

Embora dotado de sistema de ar condicionado, as paredes externas do prédio constituem uma proteção real. As paredes levemente onduladas dominam as fachadas leste e sul, dão ao edifício uma certa graça, além de promover a reflexão dos raios solares.

No térreo, na fachada sul, a mais longa, uma pérgula de concreto surge, independente e solta do corpo do edifício, mas servindo a ele já que protege as janelas. É um elemento essencial do projeto, porque, junto ao pé-direito duplo, recoloca a escala.

O espaço interno é franco e de fácil apreensão visual.

Geraldo Gomes afirma:

Em suma, é um edifício ainda moderno, nestes tempos iconoclastas, como a demonstrar os sete fôlegos do modernismo. Prova também que novas receitas são prescindíveis para uma boa arquitetura. Ainda bem (GOMES, 1989, p.81).

Para o projeto para sede do Banespa na cidade do Recife, Abrahão contou com a colaboração da arquiteta Marilena Fajerstajn. 


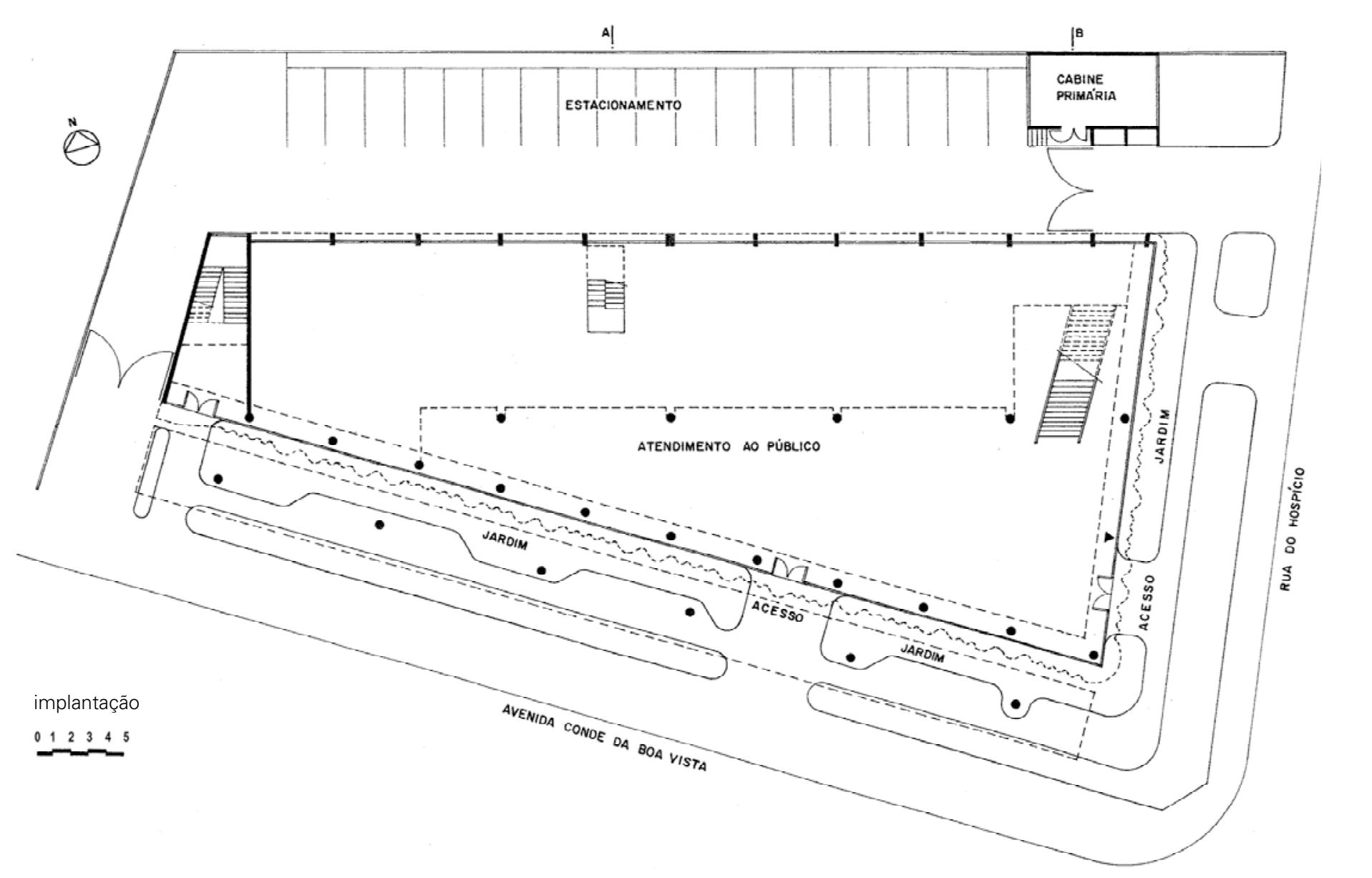

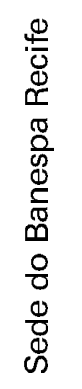




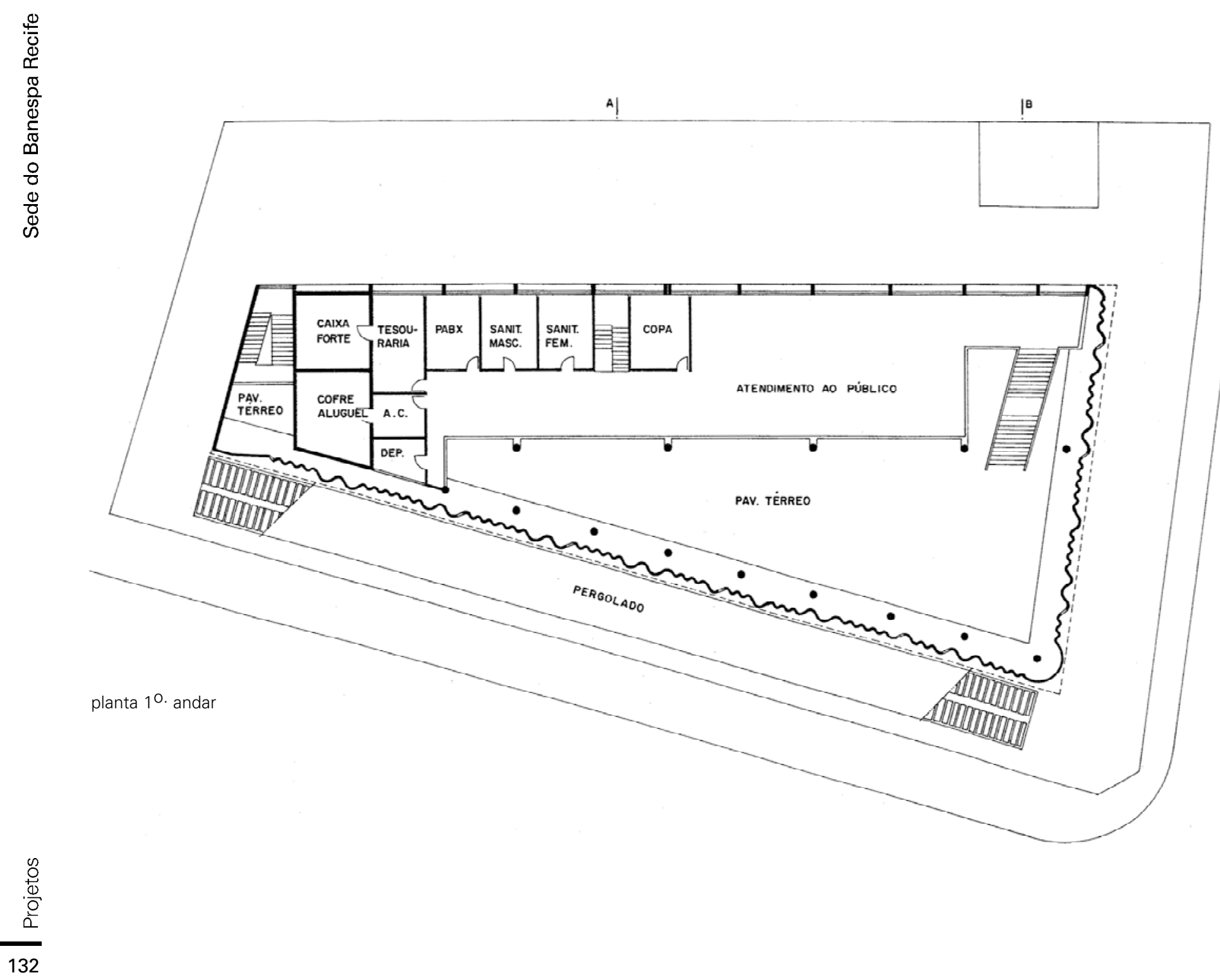




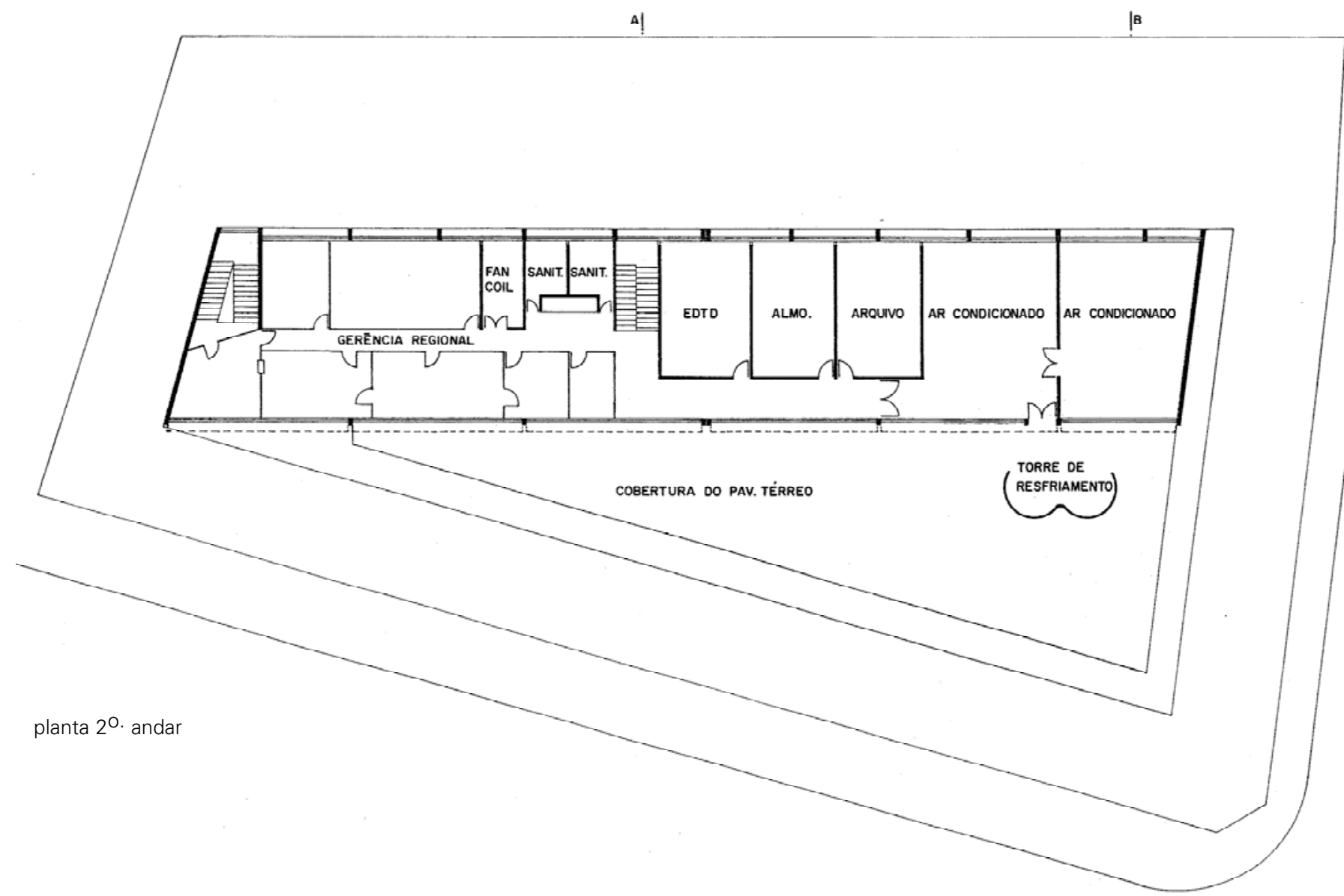



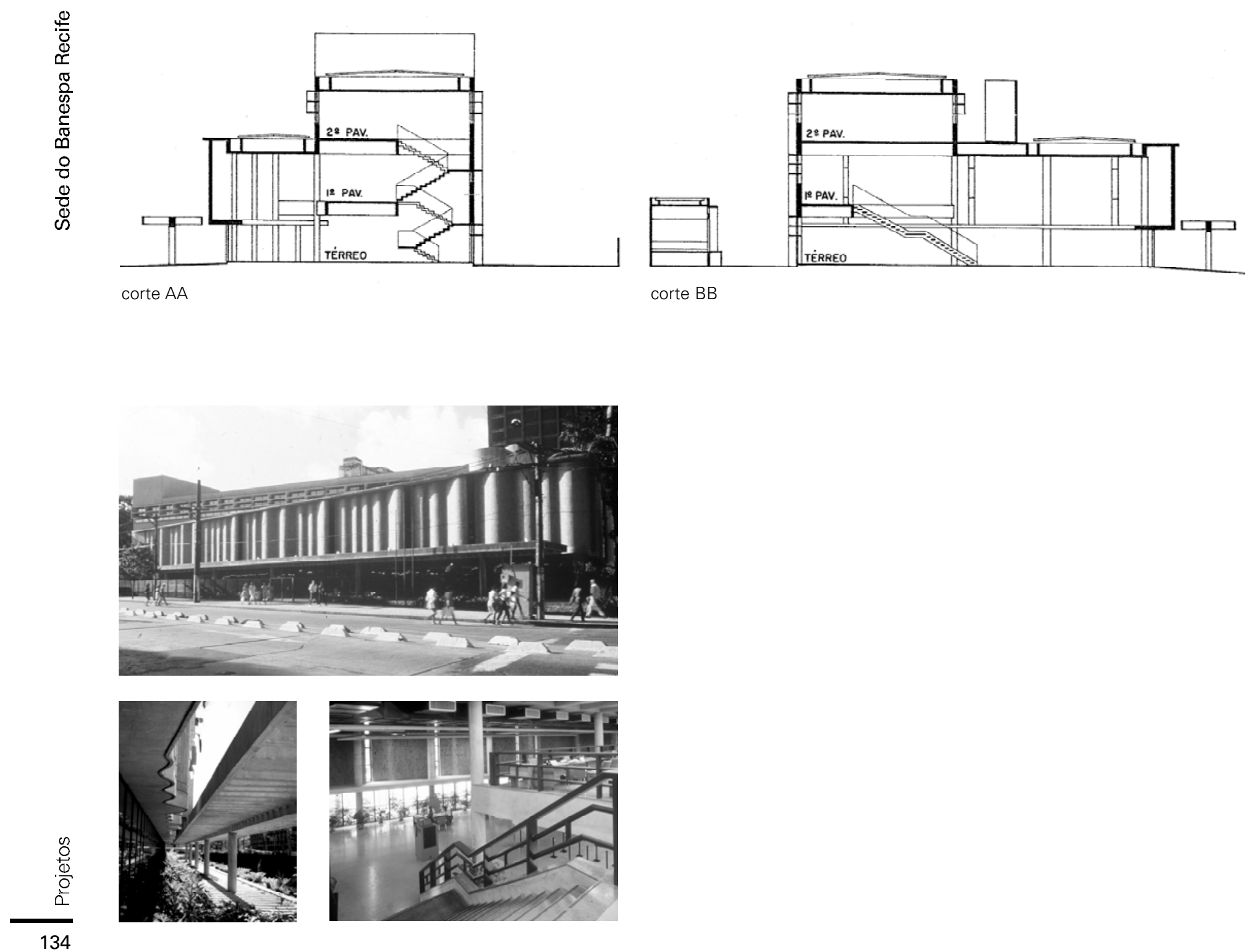


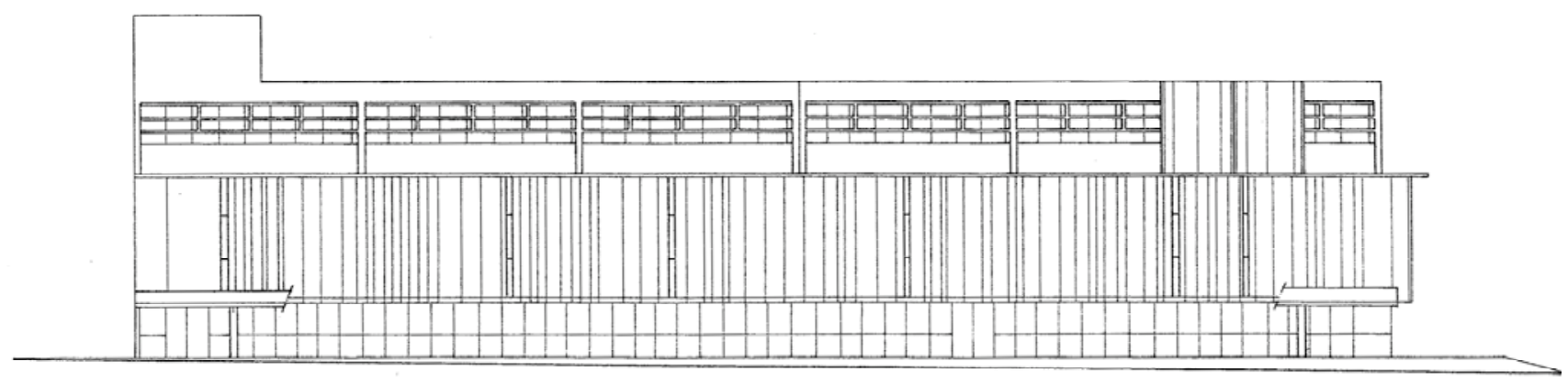



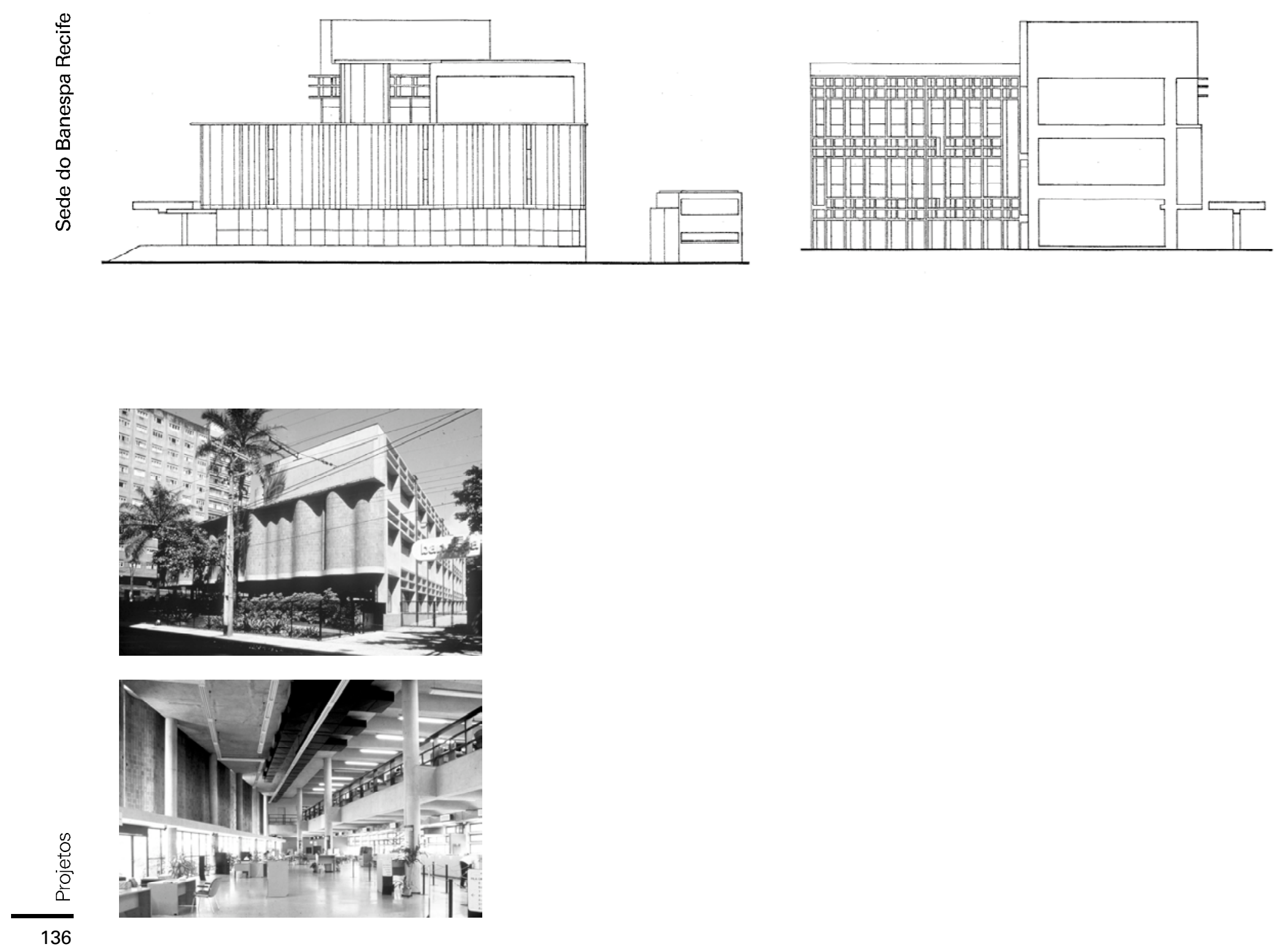
Quatro Escolas 
A convivência da Arquitetura Brasileira com a problemática da educação é cada vez maior e mais profundamente compreendida. Ela vai criando novas técnicas; assimila novos programas e se exprime cada vez com volumes mais claramente definidos e melhor propriedade poética. Sua experiência, que inclui também o conhecimento das vicissitudes e insuficiências do processo para o qual constrói novos espaços, se reflete nas formas que aos poucos vai selecionando para o seu repertório. Repertório poético do desejo humano do mundo subdesenvolvido de banir de seu universo o atraso cultural. Assim ela se modifica, se enriquece, rejeitando ou aproveitando verbos e adjetivos de concreto armado, empregados por ideários que já cumpriram o seu papel histórico (ARTIGAS, 1986, p. 114).

A construção escolar é um dos exemplos mais significativos da arquitetura paulista. Dos exemplos das obras da Primeira República aos recentes Centros Educacionais Unificados - CEUS, inúmeros arquitetos envolveramse com a problemática. Abrahão Sanovicz foi um deles, tendo realizado mais de cinqüenta projetos de escolas.

Entre eles, foram selecionados quatro que serão, a seguir, apresentados, dois do início da carreira de Abrahão, uma proposta elaborada com o arquiteto Paulo Mendes da Rocha, apresentada no concurso de projetos para a escola Caetano de Campos e um projeto realizado em 1991. A seleção procurou identificar os projetos, que trouxessem elementos que subsidiassem a discussão da pesquisa na área do projeto.
Nas entrevistas de Abrahão a Catharine Gati (DPCA, 1987 e 1988), quando se refere à escola onde estudou, o Grupo Escolar Cesário Bastos, construída em Santos no ano de 1911, o arquiteto salienta os aspectos simbólicos das escolas da Primeira República.

EE Dr. Cesário Bastos, 1911 projeto: Manuel Sabater fonte: CORRÊA, 1991, p. 163 e 169.
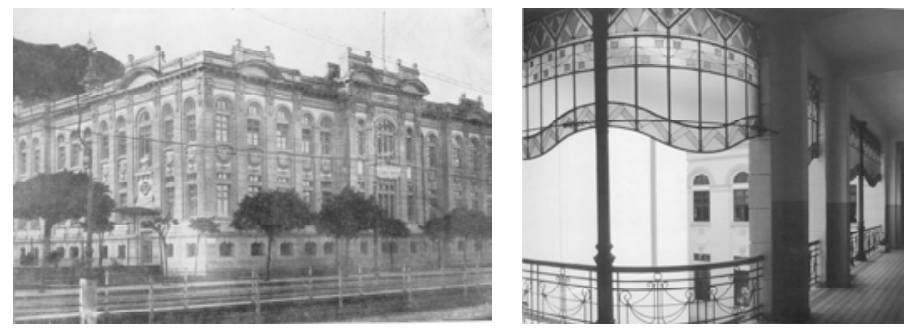

De fato, a história da edificação escolar no Brasil passa a ter expressão com a proclamação da República. As obras construídas nas primeiras três décadas do novo regime refletiam o ideal republicano, de afirmação da identidade nacional.

Vilanova Artigas, no artigo "Sobre Escolas ..." publicado na revista Acrópole em 1970 e posteriormente incluído na antologia Caminhos da Arquitetura Moderna, talvez seja o primeiro arquiteto brasileiro a desenvolver considerações 
abrangentes acerca da arquitetura escolar. Comenta o significado que este tipo de edificação teve no início do sistema republicano: "A Escola e o Relógio como que se transformaram em símbolos do ardoroso ideário republicano aparecendo nas praças mais novas em substituição da Igreja e do coreto" (ARTIGAS, 1986, p.110).

São de Artigas dois projetos considerados por Abrahão lições e modelos de arquitetura, o Ginásio de Itanhaém e o de Guarulhos.

Referências arquitetônicas assumidas por Abrahão - e por gerações de arquitetos - que sobre elas comentou:

Artigas antes de iniciar o projeto conversou com os responsáveis da Secretaria de Educação, queria saber o que pensavam sobre como educar um menino, como deveria ser o espaço da escola e quais os objetivos que tinham em relação à formação desse futuro cidadão.

Incorpora ao programa um auditório e propõe uma solução inusitada: o espaço flui; não há entrada ou saída; a estrutura de concreto é independente e lança mão da solução em pórticos; cria um sistema de caixilhos fixos, mas com ventilação permanente, respeitando o clima do litoral; racionaliza a construcãa e o emprego de materiais; e, convida Francisco Brenand, artista pernambucano, para executar um mural. A experiência de Itanhaém amadurece no projeto para o Ginásio de Guarulhos. Lá explicita o sistema construtivo e faz dele sua Arquitetura (DPCA, 1987 e 1988).
Ginásio de Itanhaém, 1959

Itanhaém, SP

projeto: João Baptista Vilanova Artigas

fonte: acervo da biblioteca da FAUUSP

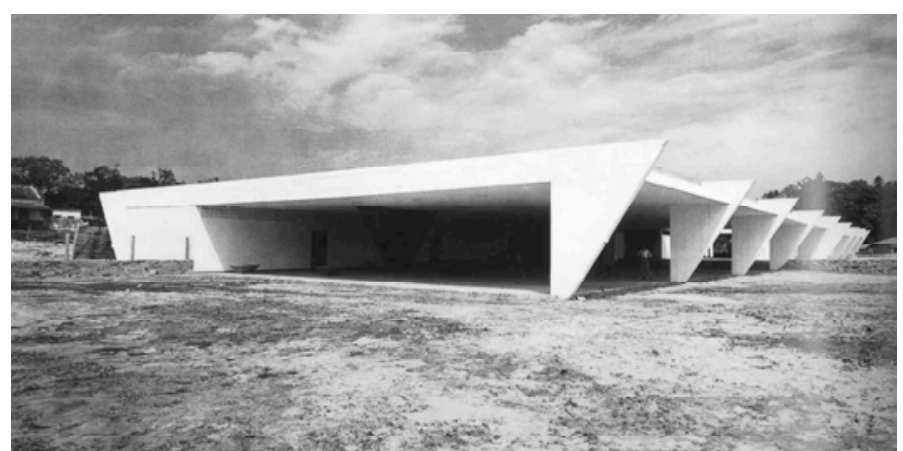

Ginásio de Guarulhos, 1960.

Guarulhos, SP

projeto: João Batista Vilanova Artigas

fonte: acervo da biblioteca da FAUUSP

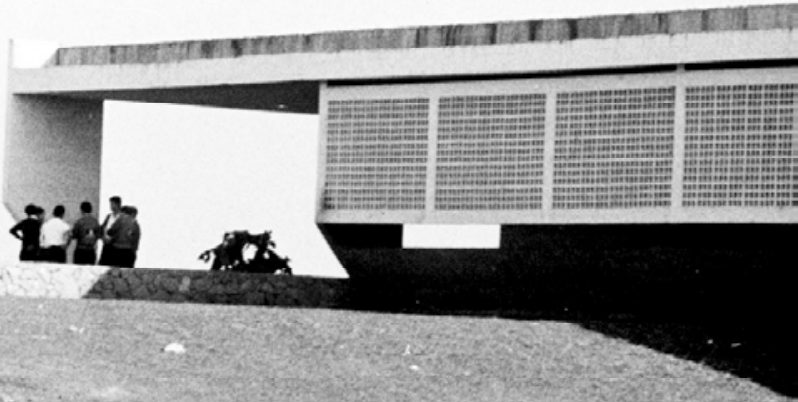

Uma outra referência importante, mas pouco estudada, é a arquitetura de Richard Neutra, especificamente a publicada em 1948, que reunia projetos do arquiteto para o 
programa de Educação e saúde do governo de Porto Rico:

Architecture of social concern in region of mild climate.

Plano para escola urbana com 8 salas de aula

projeto: Richard Neutra

fonte: NEUTRA, 1948, p. 89
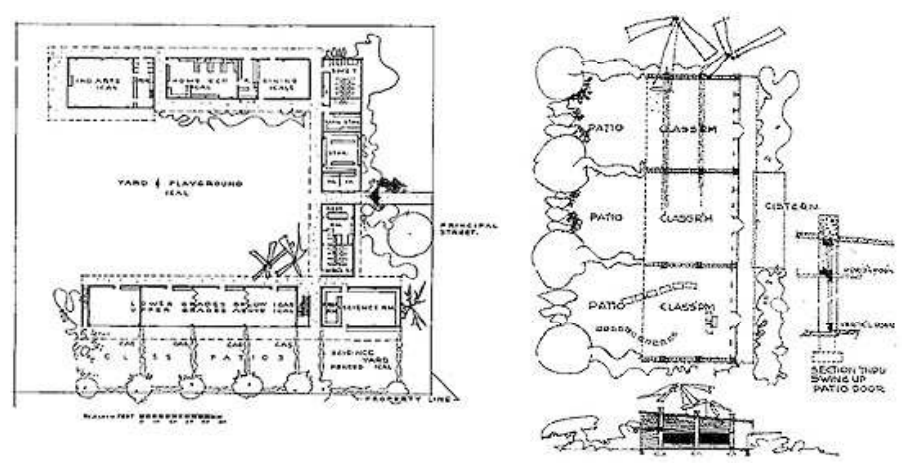

Recorrendo mais uma vez ao texto "Sobre Escolas ..." de

Vilanova Artigas:

Nessa procura de rumos, em cada fase da luta pela educação nacional, constroem-se escolas cuja arquitetura reflete, talvez melhor do que qualquer outra categoria de edifícios, as passagens mais empolgantes de nossa cultura artística; os recursos técnicos que tivemos à disposição; as idéias culturais e estéticas dominantes; tudo condicionado a um projeto nacional de desenvolvimento. Conhecendo estas passagens pode, a arquitetura brasileira, não só valorizar corretamente os sucessos dos pontos nodais de sua história, como escolher caminhos novos (ARTIGAS, 1986, p. 108). 


\section{Grupo Escolar Embaúba - 1959}

Avenida São Sebastião e Avenida São Benedito, Cajobi, SP fonte [desenhos] acervo da biblioteca da FAUUSP 
Abrahão Sanovicz e Julio Roberto Katinsky são os autores do projeto para o Grupo Escolar Embaúba.

No ano de 1949, foi elaborado o Plano de Ação do Governo Carvalho Pinto. Nele verifica-se a carência de construções escolares. O Governo convoca, então, os arquitetos para participarem da elaboração destes projetos, através do Instituto de Previdência do Estado de São Paulo IPESP.

O IPESP restringia o uso de materiais "telhados com telhas de barro ou de cimento amianto; paredes autoportantes, áreas mínimas" (DPCA, 1987 e 1988). O programa de necessidades estabelecido limitava-se a: 6 salas de aula; 1 sala para o pré-primário; gabinete dentário; sala de professores; secretaria; diretoria; recreio coberto; cozinha; e sanitários.

O terreno é estreito (36m) e bastante comprido (99m); fazendo frente para as duas avenidas paralelas. O projeto resolve o programa didático; administrativo e refeitório em três blocos distintos, articulados pelo quarto bloco que abriga a área de vivência.

Os elementos de fechamento da cobertura, em "asa de borboleta", dão unidade ao conjunto. de paredes executadas com tijolos trançados são elementos que caracterizam a edificação.

O projeto do Grupo Escolar Embaúba é do mesmo ano do Ginásio de Itanhaém de Artigas, já destacado por Abrahão:

No entanto, houve um projeto de um arquiteto, que por sua história profissional, conseguiu propor uma nova solução para o problema: o projeto de Artigas para o Ginásio de Itanhaém. Artigas mostrou que era possível e até mesmo a administração do IPESP se encantou com o resultado do projeto. A partir desta obra muitas outras interessantes foram realizadas pelo Instituto (DPCA, 1987 e 1988). 


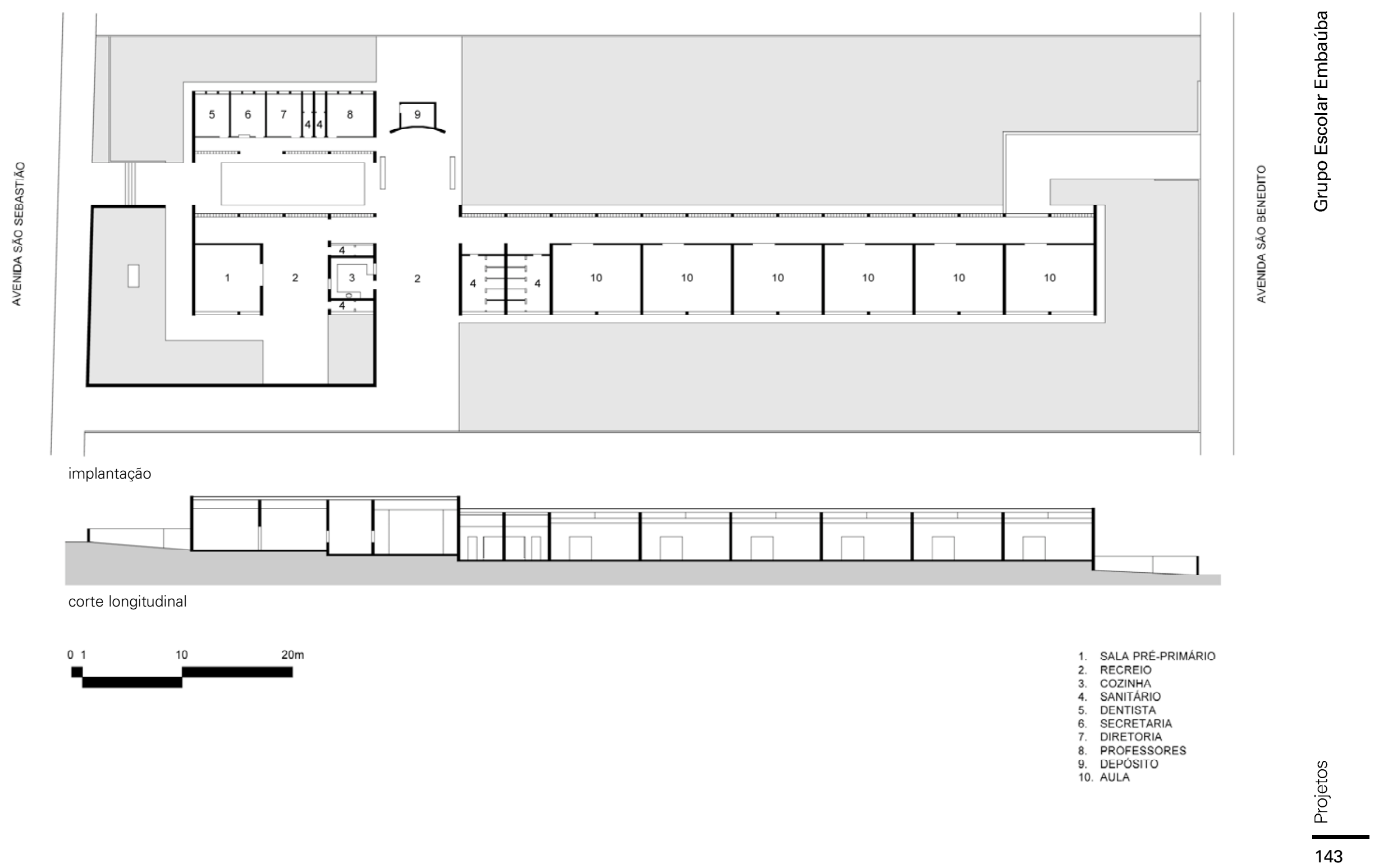




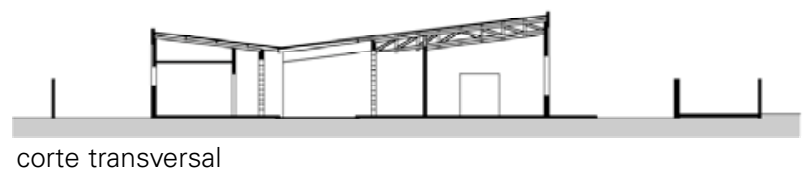

corte transversal

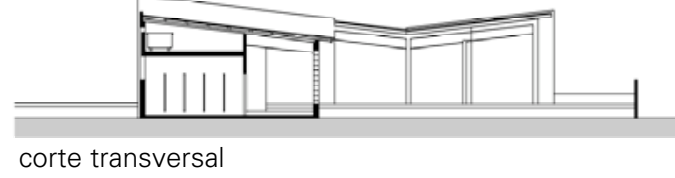

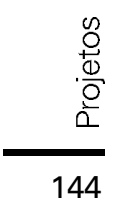


Ginásio Estadual em Santos - 1961

Rua Aristóteles Menezes, 367, Santos, SP

fonte [desenhos] acervo da biblioteca da FAUUSP 
O Instituto de Previdência do Estado de São Paulo IPESP, com as experiências dos Ginásios de Itanhaém (1959)

e de Guarulhos (1960), alterara os limites que impunha anteriormente.

O terreno é praticamente uma praça.

Com maior liberdade, Abrahão enfrentou para o Ginásio Estadual de Santos um programa que previa: 8 salas de aula; auditório para 46 lugares; secretaria; diretoria; sala de professores e do orientador; gabinete dentário; biblioteca; grêmio; copa; e sanitários.

O edifício, organizado em blocos lineares, tem o recreio coberto o local para onde convergem todas as atividades, como um espaço único, sob a mesma cobertura, em concreto armado.

As alvenarias são soltas da estrutura como volumes abrigados.

Sobre este projeto, Abrahão comentou suas referências:

[...] fiz um projeto para um Ginásio em Santos, era 1961 ou 1962, a planta tinha uma referência muito grande ao Ginásio de Itanhaém, do Artigas, já as fachadas lembravam a FAU, apesar de o prédio ser térreo. Julio olhou os desenhos disse que estavam muito bonitos, mas que era um pasticho (DPCA, 总 1987 e 1988) 1

(1) Julio Katinsky informou a autora não se lembrar desse comentário.
Edifîcio da FAU

fonte: acervo da biblioteca da FAUUSP

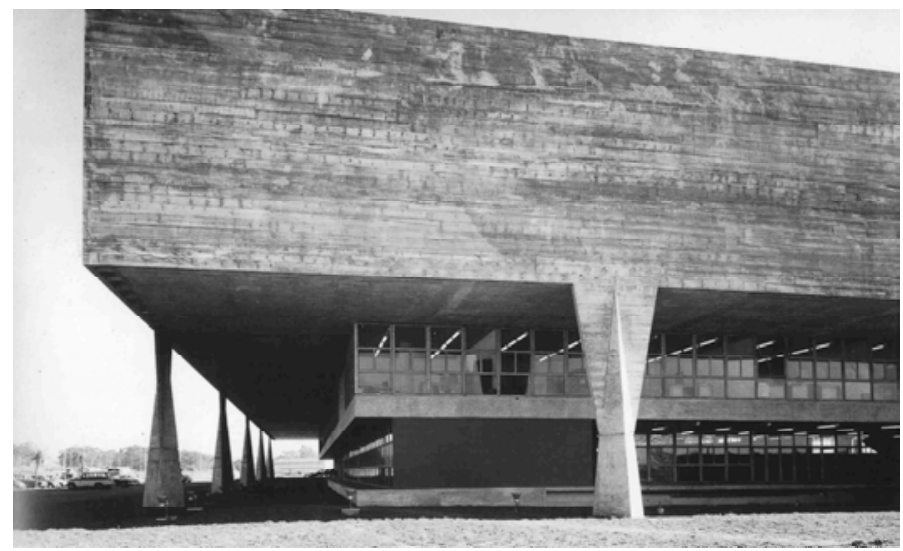

Planta do Ginásio de Itanhaém

fonte: acervo da biblioteca da FAUUSP
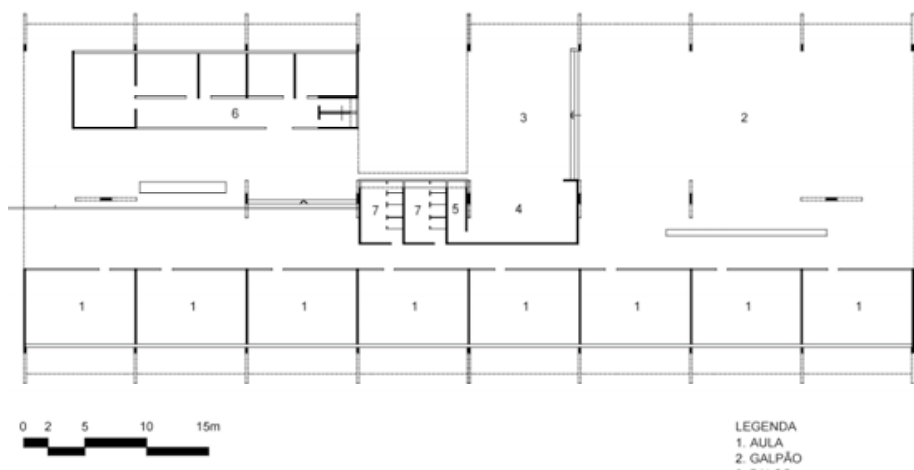

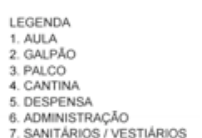




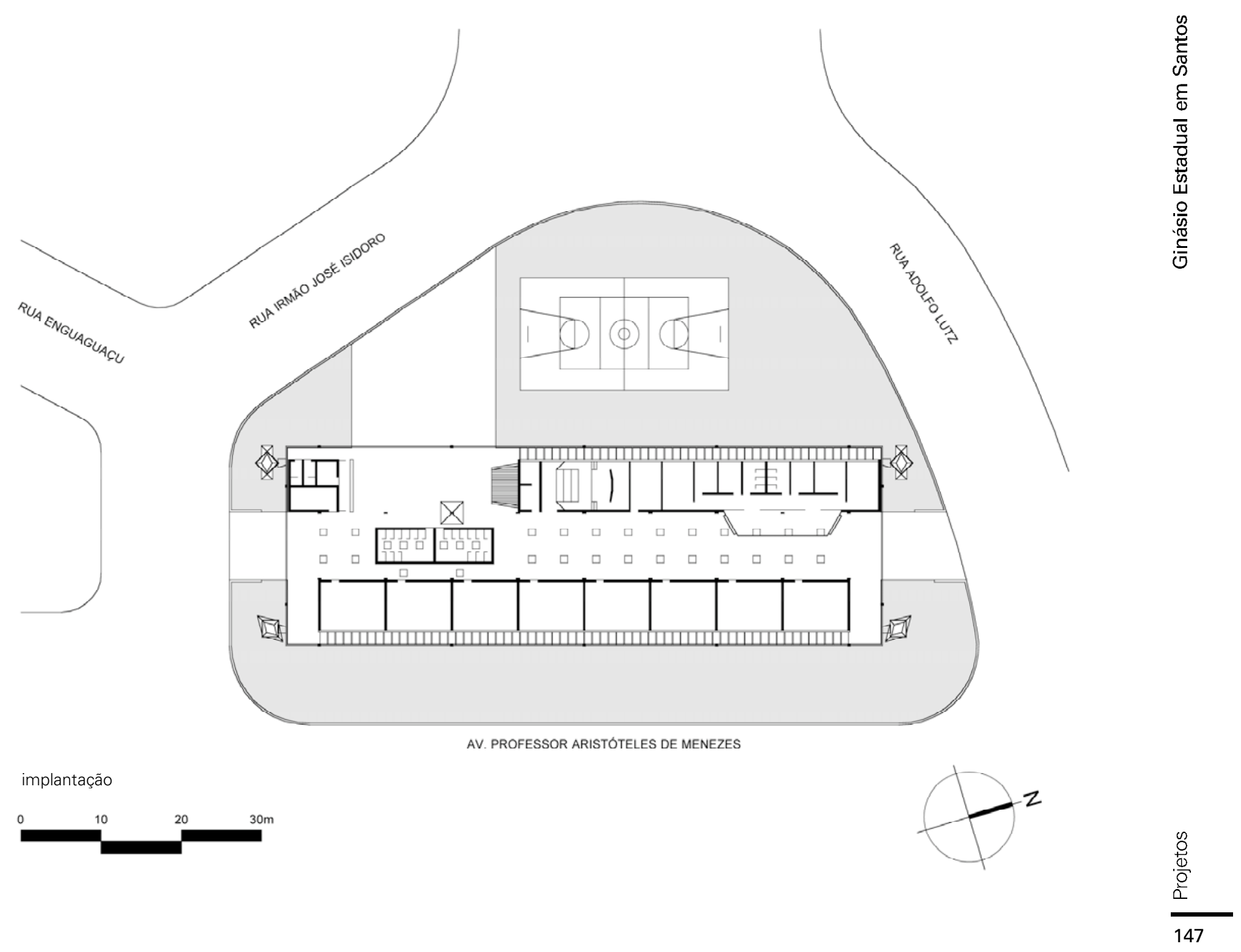



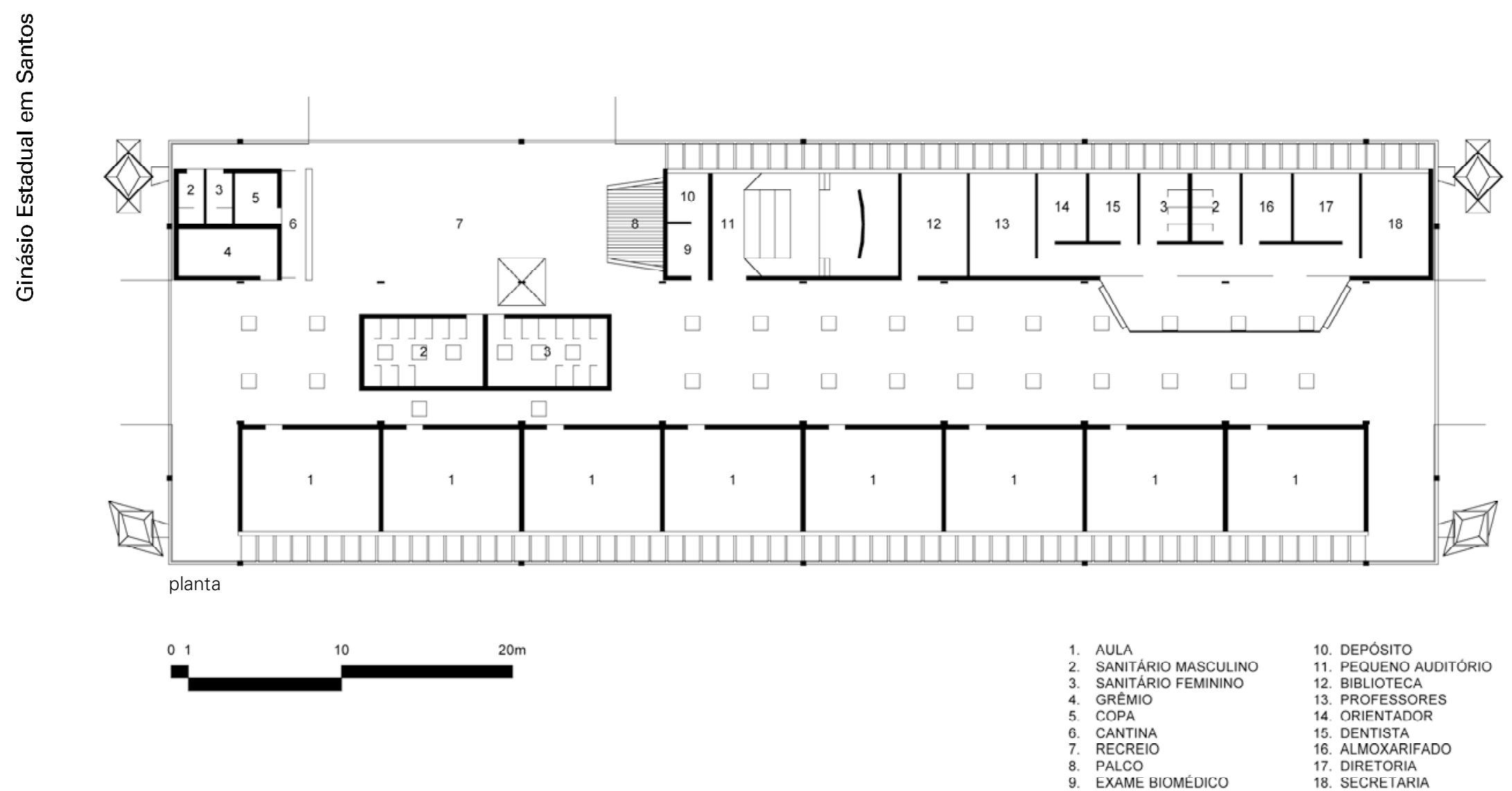

10. DEPÓSITO

UENO AUDITÓRIO

12. BIBLIOTECA
13. PROFESSORES

14. ORIENTADOR

15. DENTISTA
16. ALMOXARIFADO

78. DIRETORIA

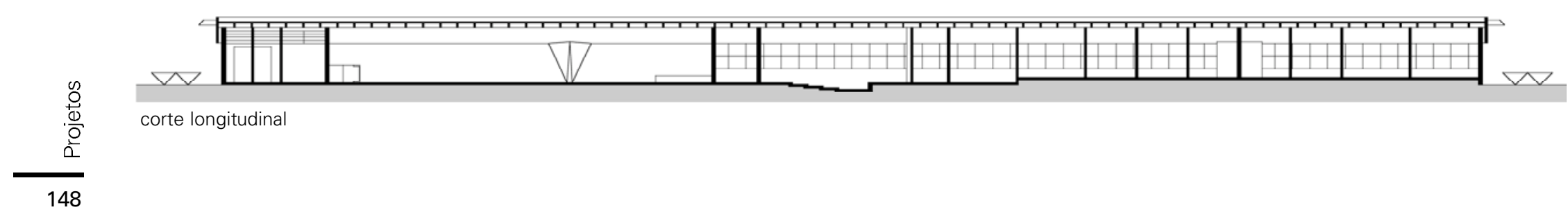



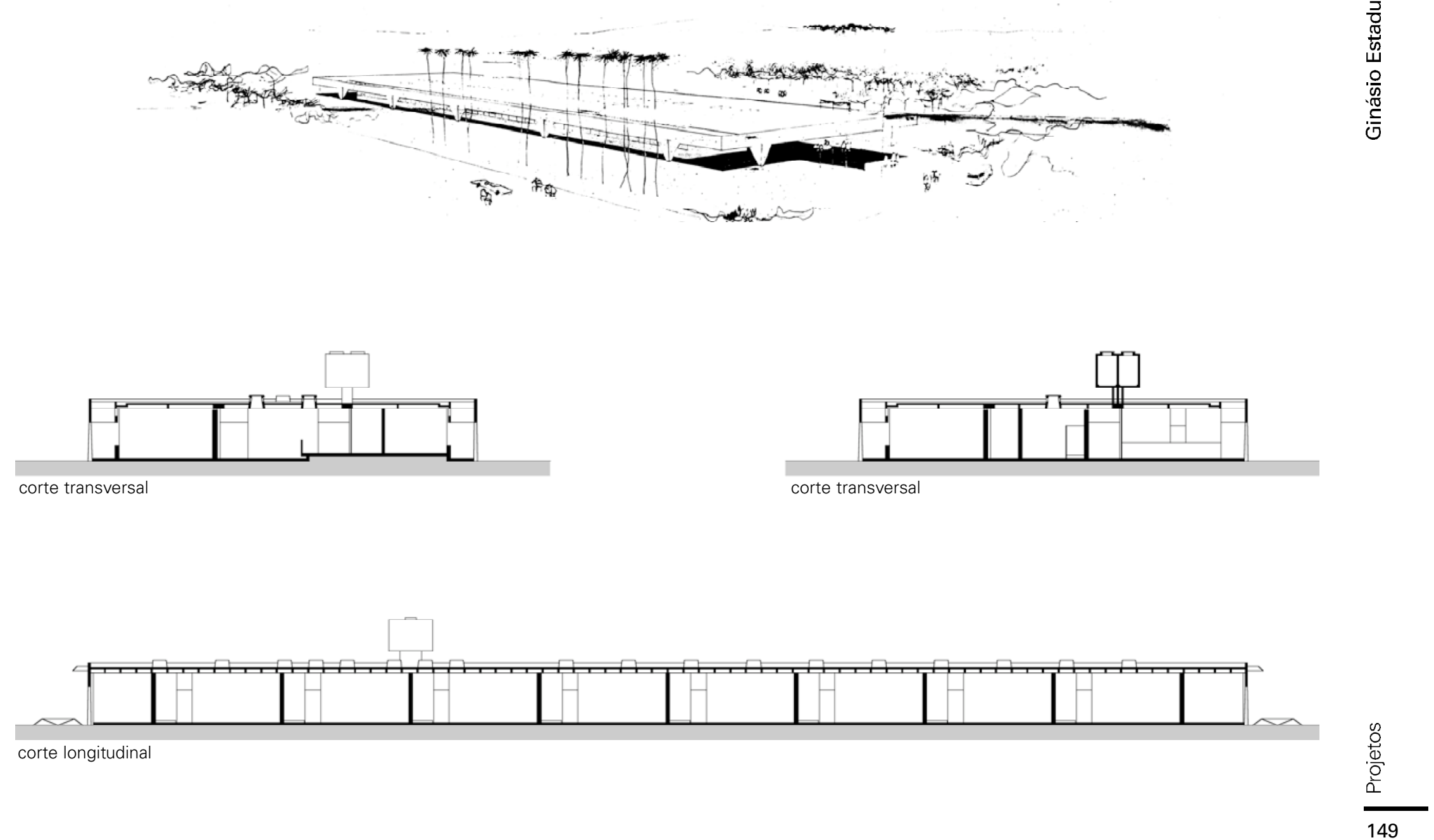


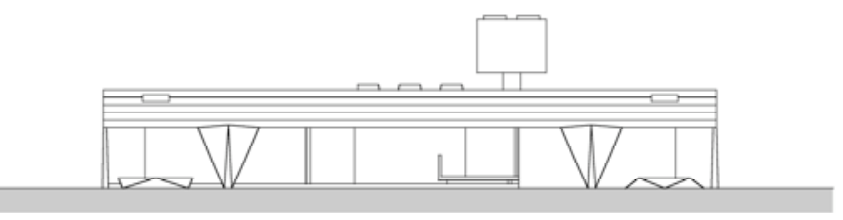

elevação norte

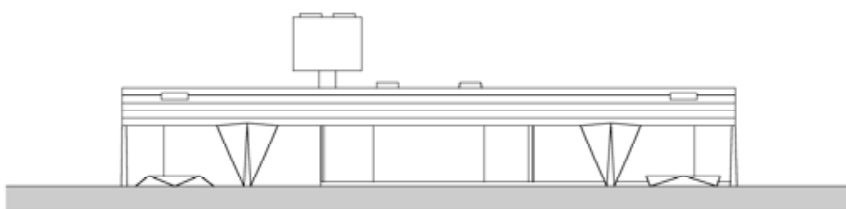

elevação sul

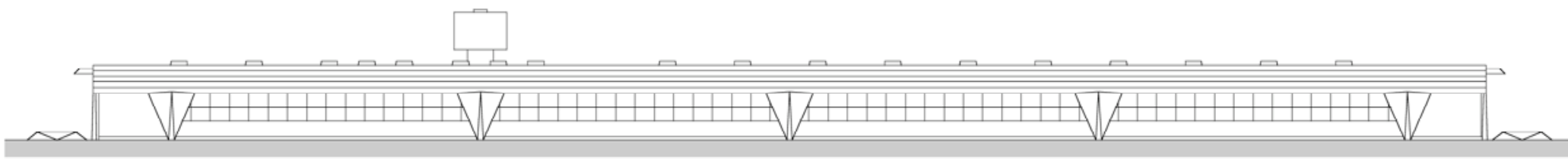
elevação leste

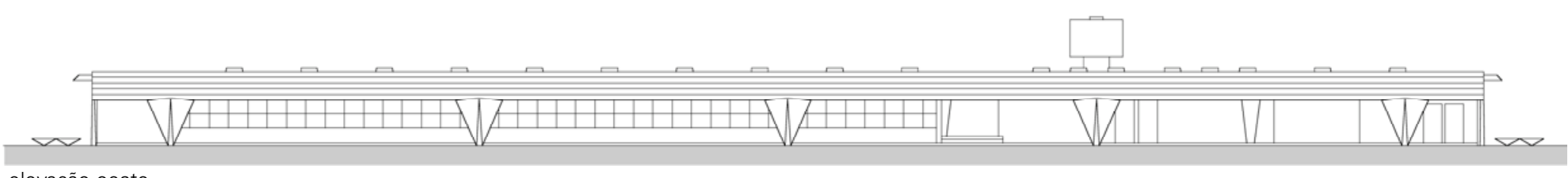
elevação oeste

$\frac{\stackrel{0}{0}}{\frac{0}{0}}$ 
Escola Professor Caetano de Campos - 1976

Rua Pires da Mota, São Paulo, SP

fonte [desenhos] acervo do escritório Paulo Mendes da Rocha 
No ano de 1976, a Companhia de Construções Escolares do Estado de São Paulo - CONESP convidou alguns arquitetos para participarem de um concurso fechado. $\mathrm{O}$ objetivo do concurso era a elaboração do projeto da Escola Professor Caetano de Campos.

Abrahão Sanovicz e Paulo Mendes da Rocha elaboraram juntos uma proposta.

O terreno, com cerca de $20.000 \mathrm{~m}^{2}$, tinha uma situação tal que, levou os arquitetos recomendarem a incorporação de terrenos adjacentes e o remanejamento de algumas vias.

O programa previa: pré-escola, primeiro grau, biblioteca e curso de formação de professores.

Na proposta de implantação o edifício ficava ao longo da Rua Pires da Mota, reservava uma faixa de área externa de modo a ampliar a via neste trecho, possibilitando, assim, um embarque e desembarque de alunos mais facilitado, além, do espaço para parada de ônibus.

O edifício divide-se, como que em blocos: a pré-escola; o primeiro grau; e formação de professores mais biblioteca. Uma galeria, elevada, organiza e une estes aparentes blocos. É ela que marca definitivamente o caráter do edifício.
Há alguns anos, participando com Paulo Mendes da Rocha do concurso para o novo Caetano de Campos, começamos estudando alguns projetos do Hannes Meyer, que tinham soluções muito interessantes, a escola quase uma praça. Chegamos a uma proposta. Foi quando entusiasmado exclamei: "faz tanto tempo que não faço um projeto com partido!" (DPCA, 1987 e 1988).

Sobre a experiência Abrahão comentou: 

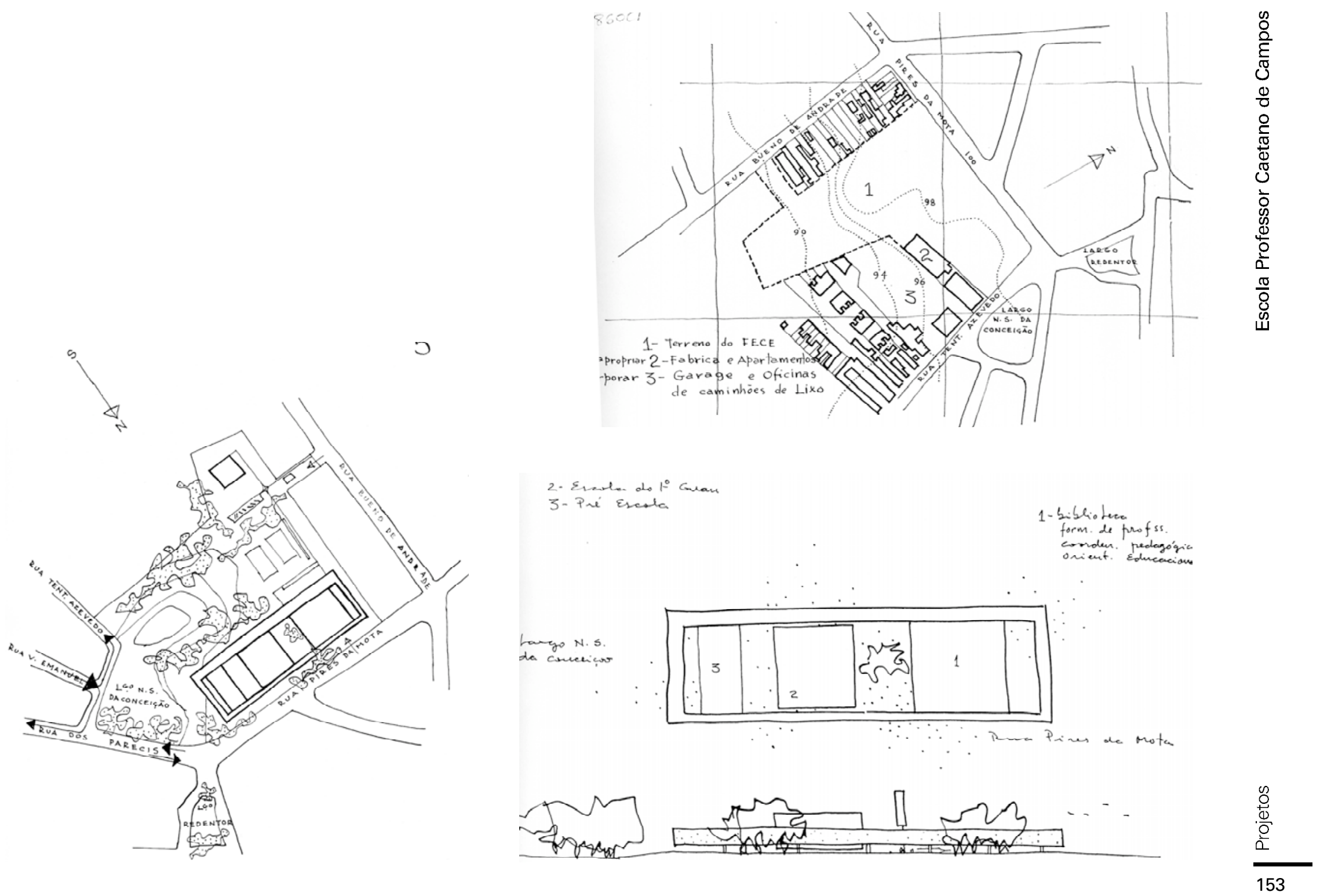

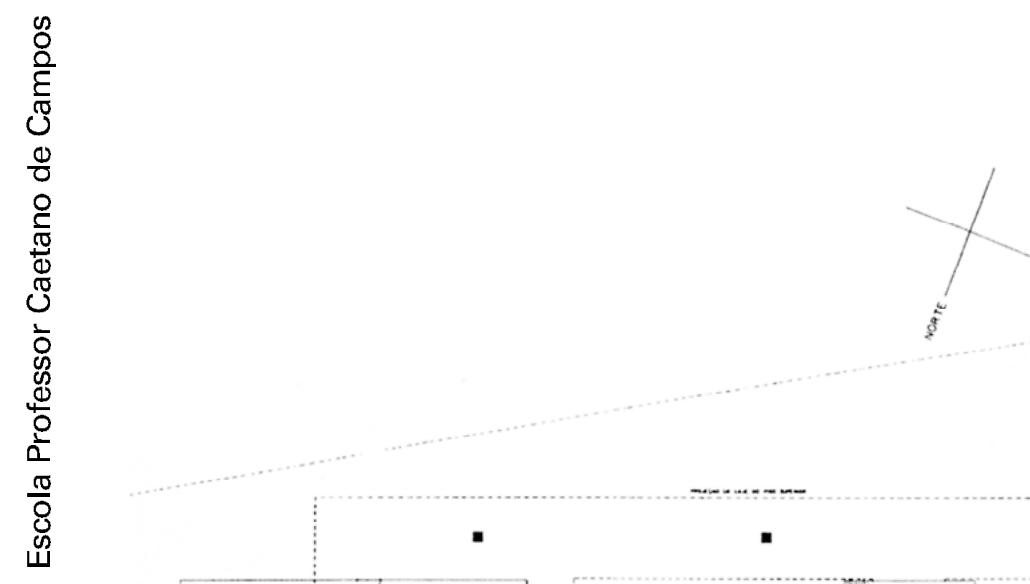

o

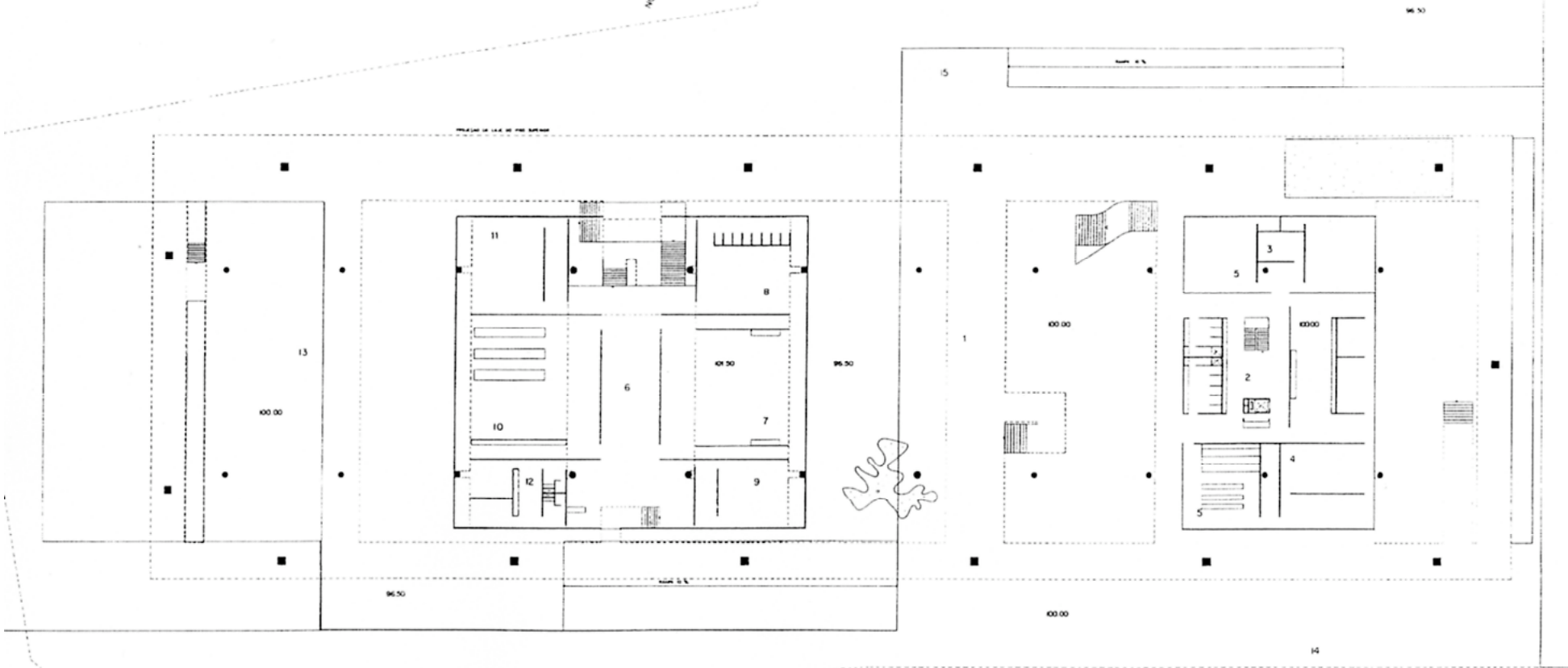

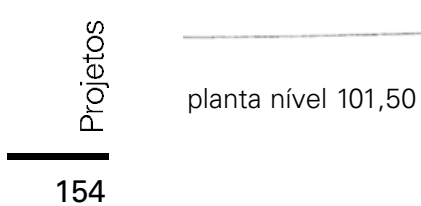




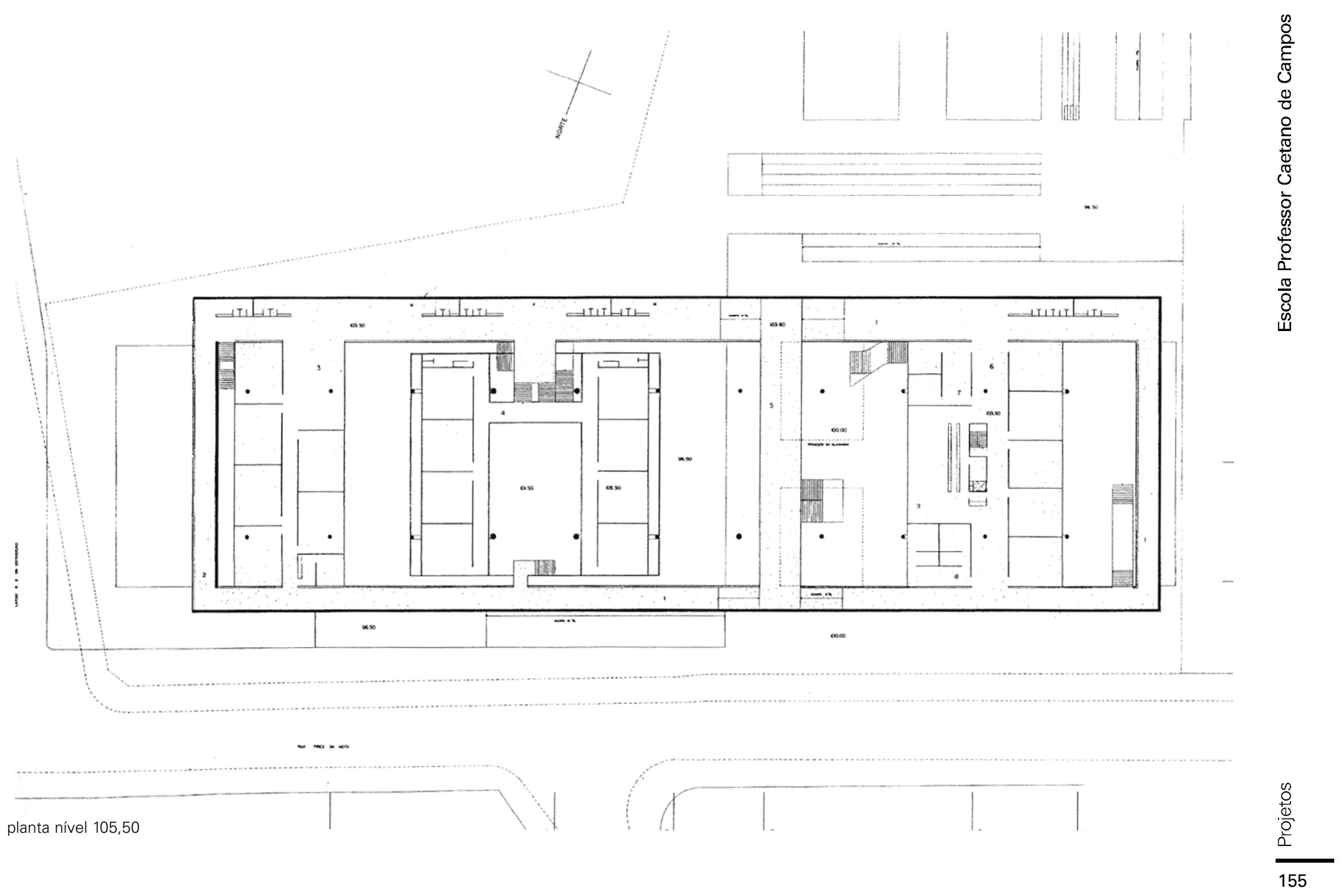




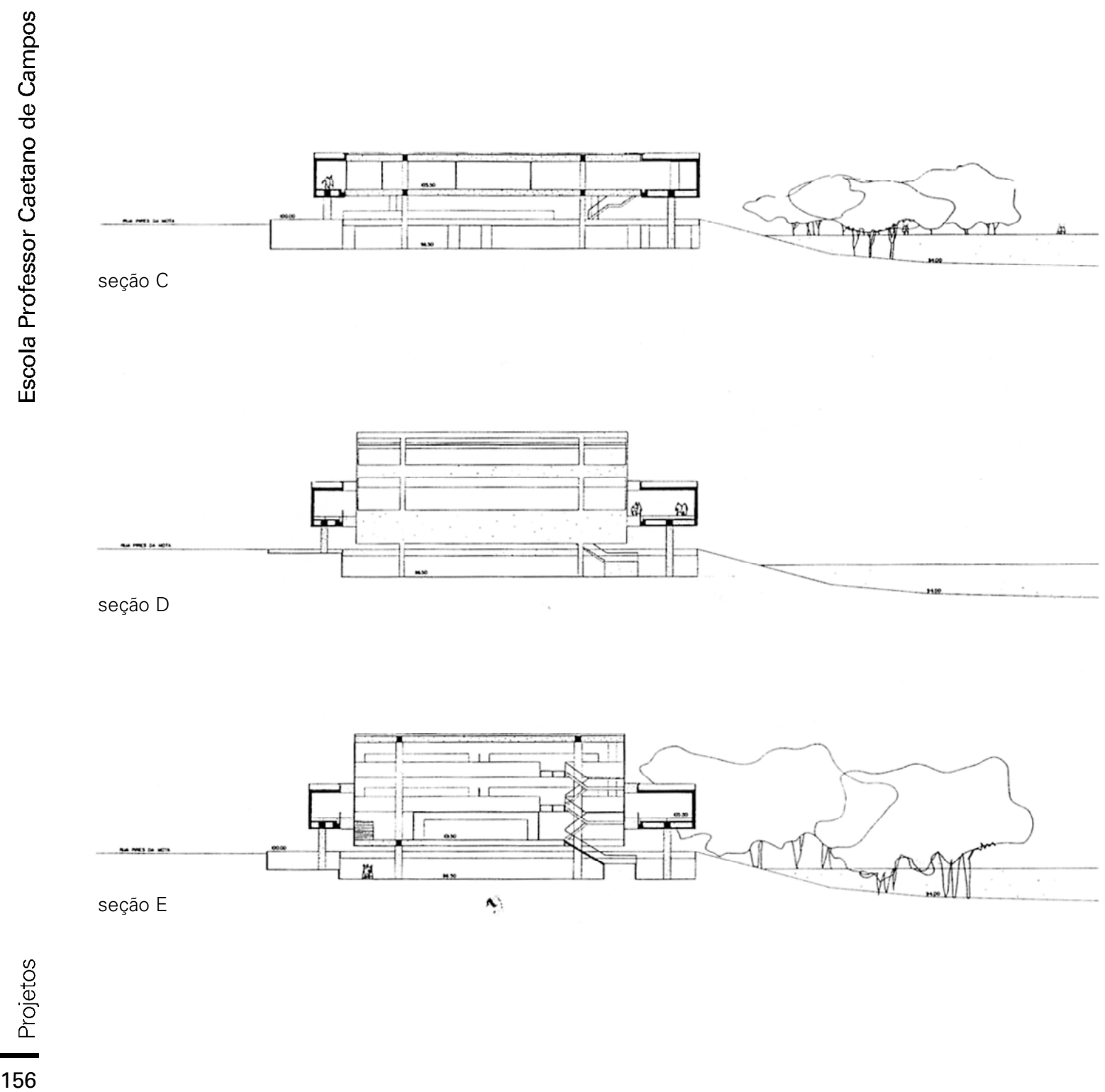




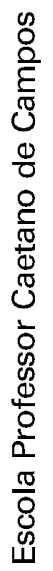

elevação norte - rua Pires da Mota
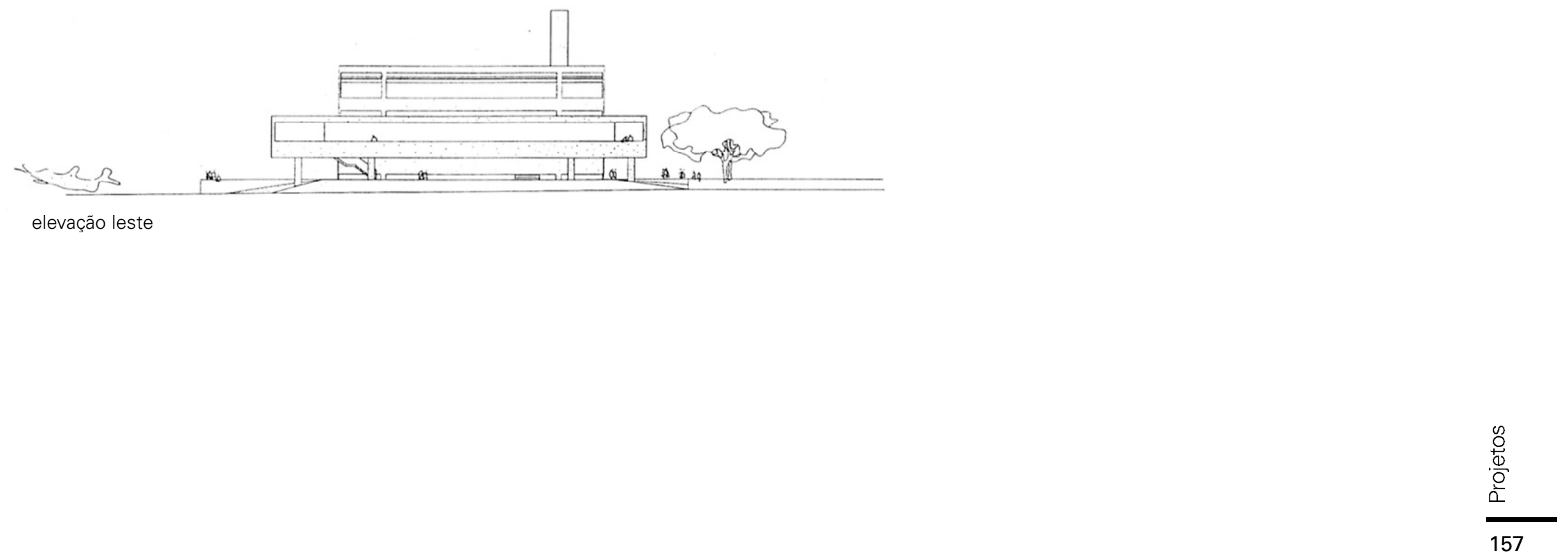

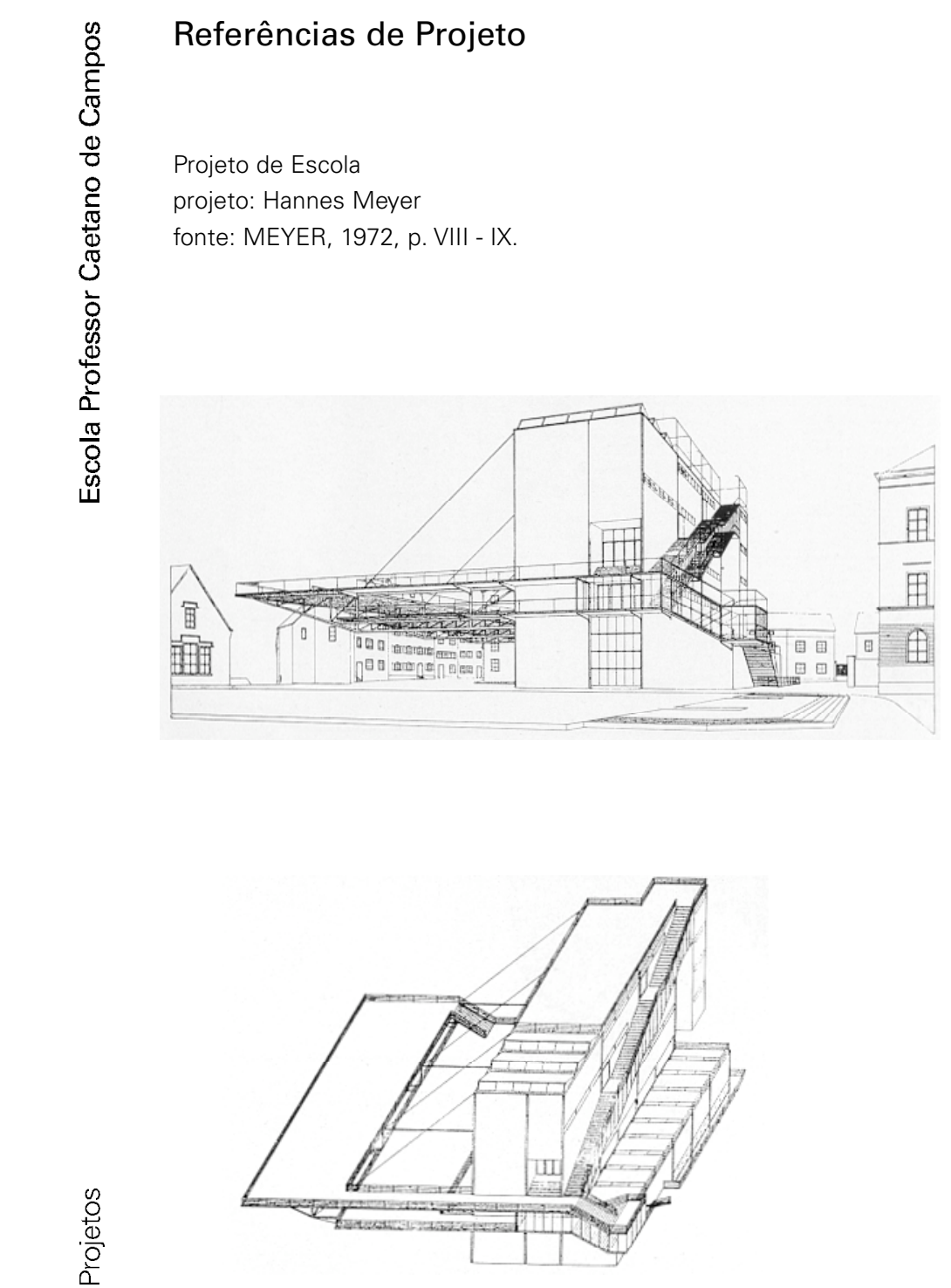
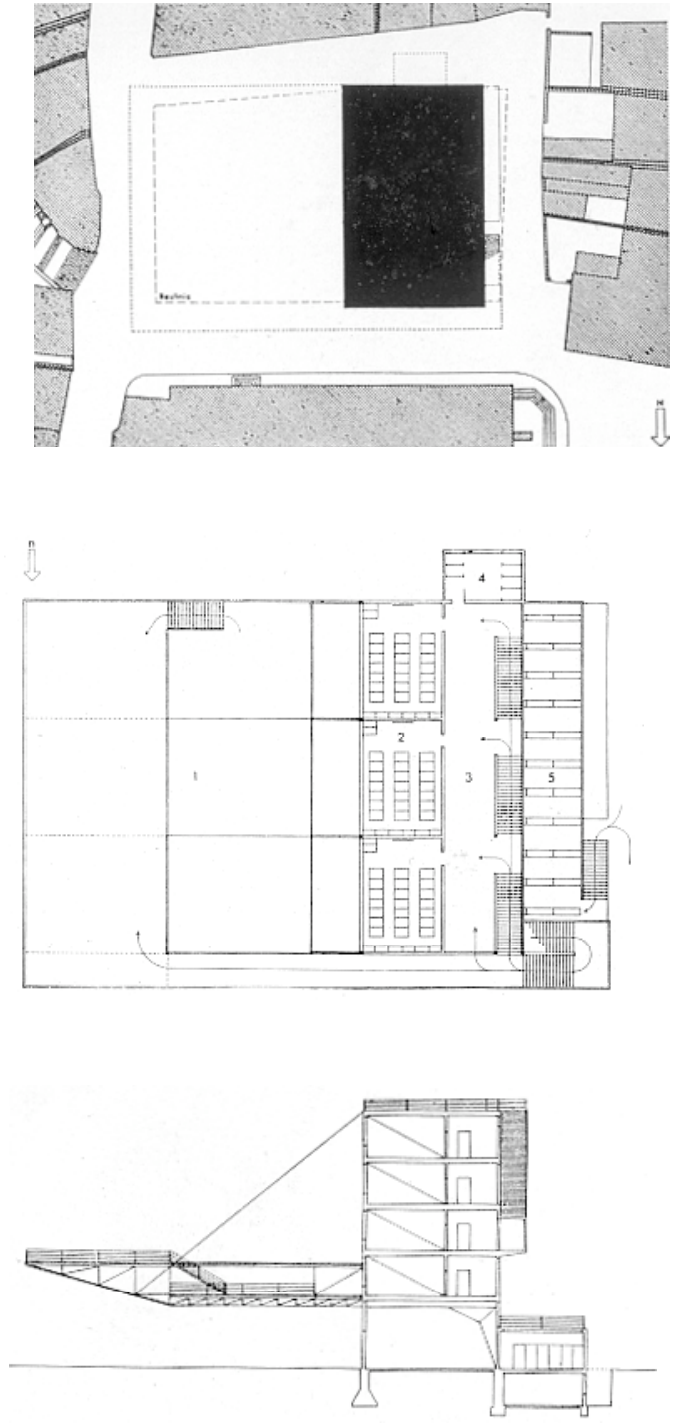
Escola Estadual de Primeiro Grau Bairro 120

$$
1991
$$

Santana do Parnaíba, SP

fonte [imagens] acervo do escritório Elito Arquitetos

[desenhos] acervo da biblioteca da FAUUSP 
Implantada em um terreno irregular de um morro, com área de $10.363,87 \mathrm{~m}^{2}$, em meio a uma paisagem típica de periferia, a Escola Estadual de Primeiro Grau Bairro 120 destaca-se pela maneira que se apropria das condições naturais do terreno.

O projeto teve como partido a construção de dois blocos distintos: o de salas de aula (em três pavimentos) e o de vivência, administração e zeladoria num único pavimento. A ligação ente os dois blocos é feita por meio de uma passarela que vai do recreio coberto para o nível intermediário das salas de aula.

As salas de aula estão voltadas para leste, aproveitando a insolação matinal.

O bloco mais baixo, ocupado com ambientes menores em seu perímetro tem, na parte central, um grande pátio, parte coberto parte descoberto, delimitando com estes vazios as áreas de usos diferenciados. As ligações deste bloco com as áreas externas são muito bem definidas, evitando assim as intervenções posteriores, que geralmente ocorrem, resultado dos cuidados adicionais com a segurança.

A solução construtiva adotada foi a da estrutura principal (vigas e pilares) em concreto, lajes mistas, alvenaria aparente de vedação e o telhado em telhas de fibrocimento.

A quadra de esportes, situada ao lado da entrada principal e separada dos blocos do edifício, pode ser ocupada pelos alunos sem prejudicar o andamento dos trabalhos pedagógicos. A caixa d'água cria um ponto de referência no conjunto.

O jornalista José Wolf, na matéria "Escolas -Arquitetura da Pedagogia" da revista AU no 62, escreveu:

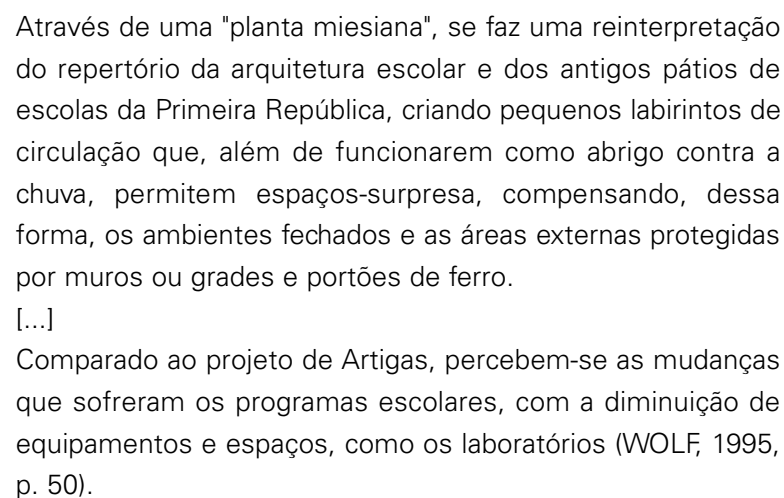

Percebe-se a referência ao projeto realizado com Paulo Mendes da Rocha, porém, com excesso de ascese, decorrência dos limites e restrições estabelecidos pela instituição contratante.

A partir do ano de 1987 a Fundação para o Desenvolvimento da Educação - FDE passou a ser a 
responsávd pelos recursos físicos da Secretaria de Educação

do Governo do Estado de São Paulo.

Sobre os programas escolares, Abrahão comenta:

Houve uma perda da dignidade do projeto, isto significa que os programas empobreceram, tanto os de caráter coletivo como individual.

Se verificarmos as publicações brasileiras dos anos 1930 aos 1960, constataremos que os arquitetos brasileiros puderam fazer um trabalho altamente criador, os programas eram os mais variados. A partir de então, constata-se um recuo nos programas e, conseqüentemente, uma perda da dignidade do projeto.

Se analisarmos as escolas dos anos 60 e as feitas mais tarde verificamos que os programas recentes se restringem ao mínimo. Os terrenos planos, disponíveis anteriormente, hoje, nos novos loteamentos, são as áreas destinadas aos equipamentos institucionais, normalmente as mais problemáticas e com pior topografia. Resta ao arquiteto, identificar dentro de limites tão adversos, a melhor solução para o projeto, não esquecendo ainda das restrições de ordem econômica.

Comparando os programas vemos que houve um certo recuo justificado por razões de ordem econômica e também pela quantidade de obras a realizar. (DPCA, 1987 e 1988).

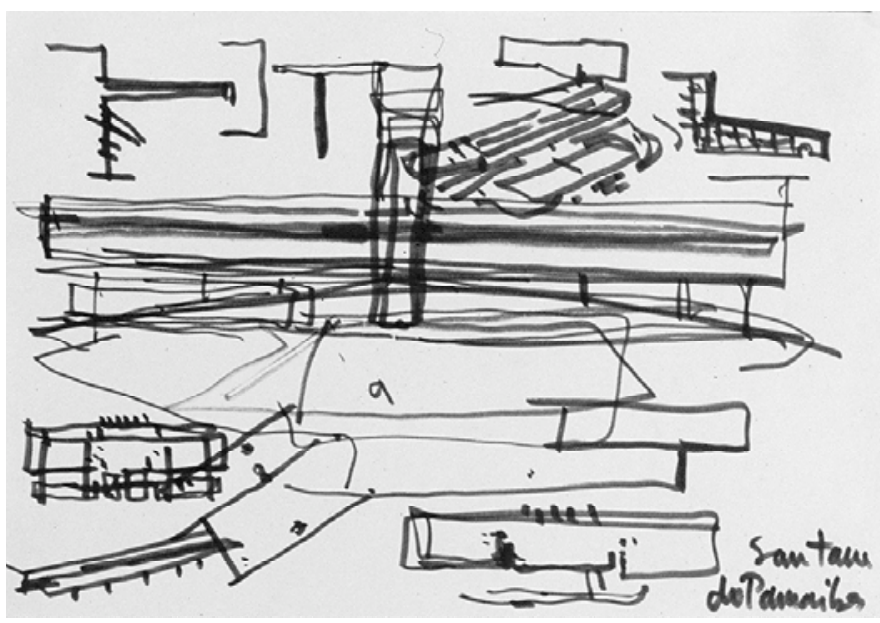




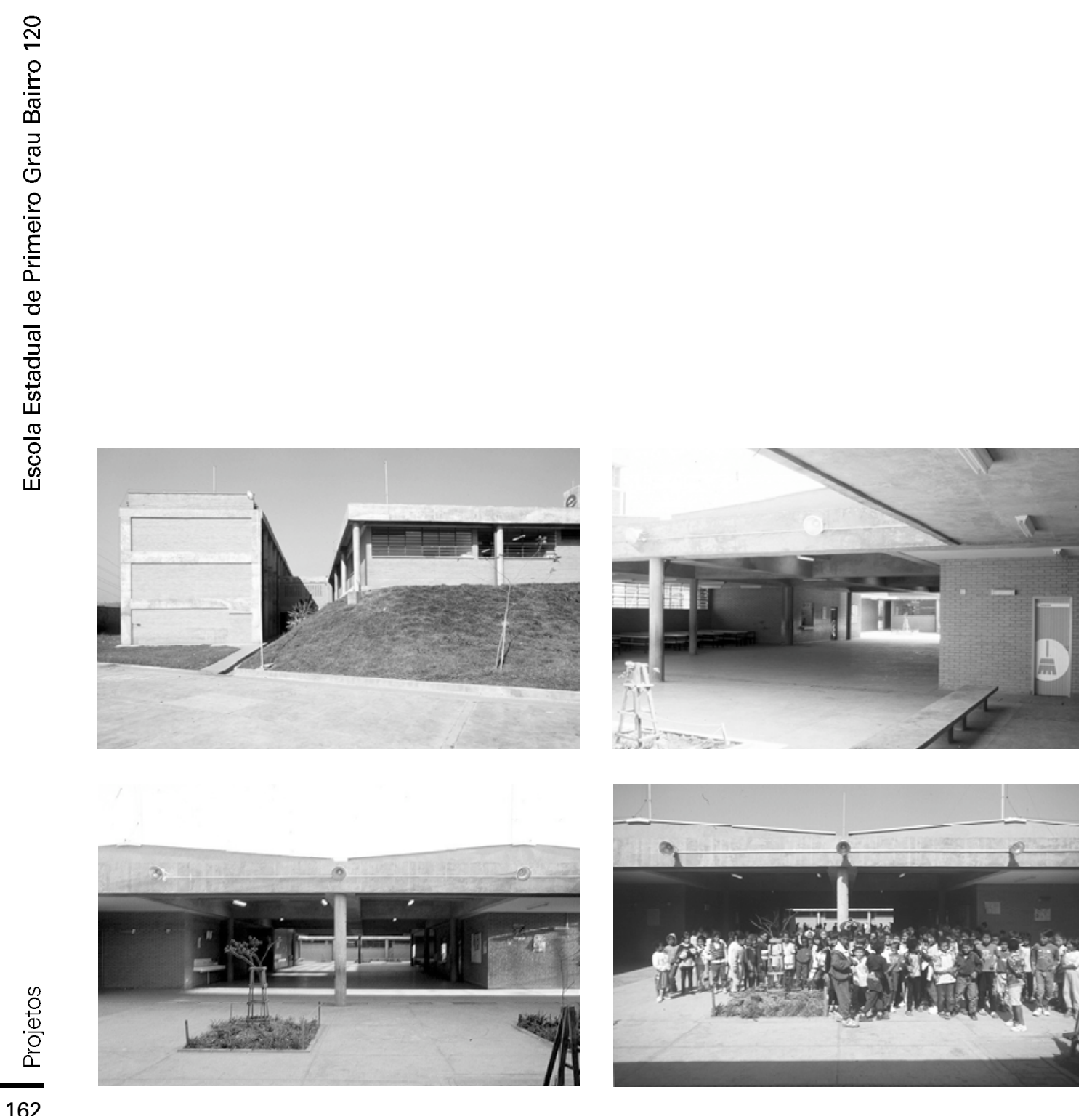




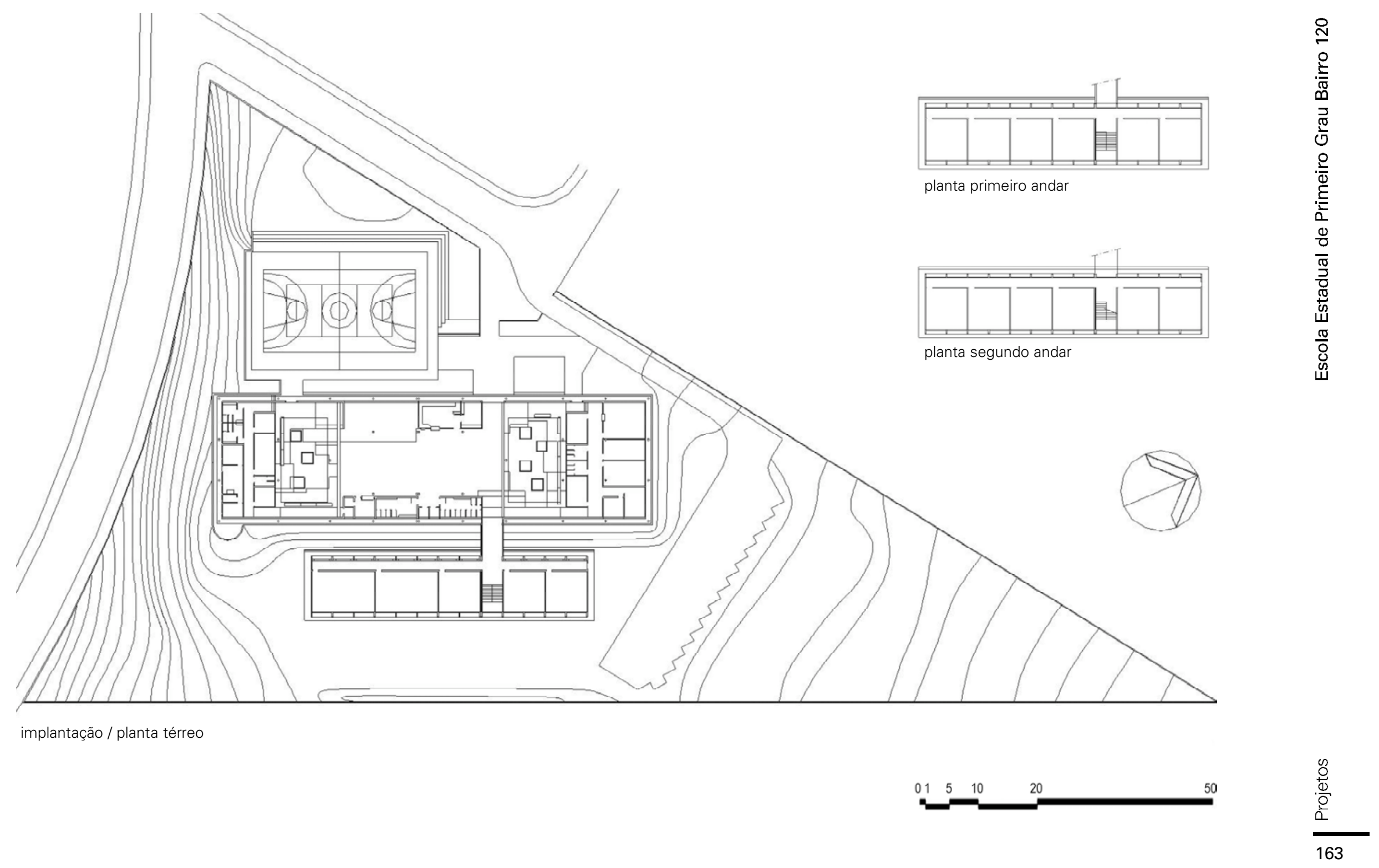



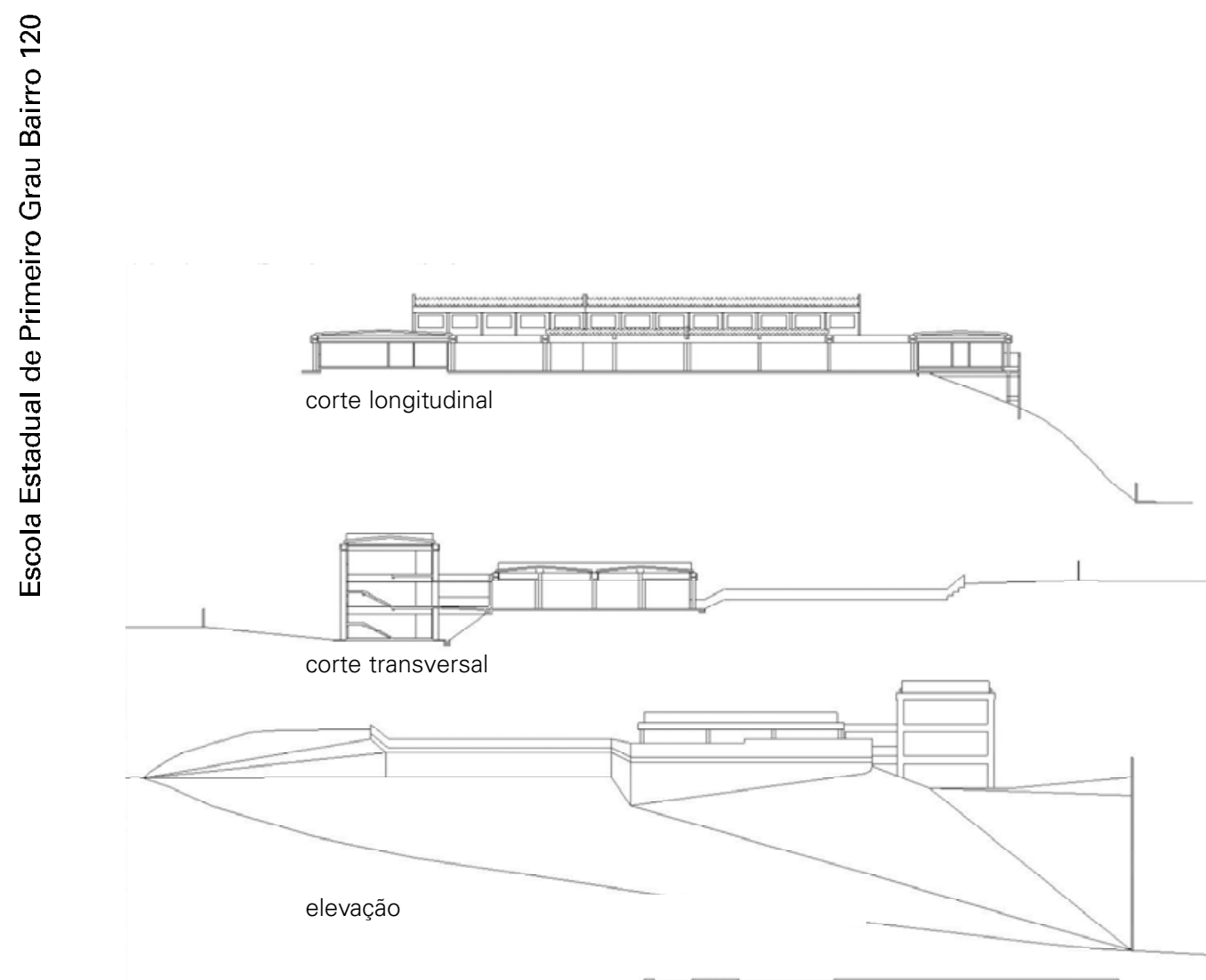

$\begin{array}{r}\frac{c}{2} \\ \frac{0}{0} \\ \frac{0}{0} \\ \hline 164\end{array}$ 


\section{Edifícios de Apartamentos}


Em 1963 Abrahão fez seu primeiro projeto para um prédio de apartamentos, o Edifício Abaeté na Rua Pará, na cidade de São Paulo, SP.

Começou a pesquisar, neste primeiro projeto alguns conceitos referentes à racionalização e industrialização da construção: estrutura regular e modulação rígida permitem otimizar os procedimentos no canteiro de obras; vedações estandardizadas possibilitam sua produção em grande escala; a utilização de painéis divisórios pré-fabricados concorre para uma obra limpa e rápida; etc.

A solução para tais preocupações, Abrahão vai desenvolver no projeto de 1969 para o Edifício Ubirama, na Rua Teixeira da Silva, 392, na mesma capital paulista. Retoma, depois, nos trabalhos que desenvolveu junto à Construtora Formaespaço, nos projetos para os modulares e conjuntos habitacionais.

As soluções foram aprimoradas nos projetos para os edifícios Fiandeiras e Teixeira da Silva (que não foi construído) e para os conjuntos habitacionais que realizou para o Governo do Estado e Prefeitura de São Paulo.

\section{Algum tempo depois, Abrahão comentou:}

O problema de nossa vida profissional é a falta de

continuidade. Com os Modulares estávamos continuando um trabalho que começou com a experiência da Pará, mas não há reflexão sobre este caminho (DPCA, 1987 e 1988). 


\section{Edifício Abaeté - 1963/68}

Rua Pará, São Paulo, SP

fonte [imagens] acervo do escritório Elito Arquitetos

[desenhos] acervo da biblioteca da FAUUSP 
Voltando ao Brasil (já no início dos anos 60), já que não era possível trabalhar em design, continuei fazendo projetos de arquitetura e, paralelamente, projetos gráficos.

Com todas essas experiências (frustradas), começamos a levar a idéia de design para a edificação. E o primeiro momento em que conseguimos fazer com que um novo tipo de caixilho fosse um produto seriado, foi no projeto para um edifício residencial em Higienópolis, São Paulo (SANOVICZ, 1997, p. 147, comentário do autor).

O projeto para o Edifício Abaeté coloca as premissas iniciais para a futura elaboração dos projetos posteriores. São elas: o cuidado com a modulação da estrutura, a redução e padronização dos caixilhos - detalhados e fabricados pelo escultor Luiz Sacilotto - e o uso do quebra-sol, produzido industrialmente

Implantado num terreno de $1.100 \mathrm{~m}^{2}$, o edifício com 16 andares de apartamento, térreo e garagem enterrada, tem $7.254 \mathrm{~m}^{2}$ de área total construída. Dois apartamentos por andar têm $200 \mathrm{~m}^{2}$ cada.

A estrutura é constituída por pilares na periferia e uma linha de apoio no centro. As lajes são do tipo caixão.

O volume central onde estão as circulações verticais, banheiros, e dormitório de empregada, organiza, no sentido maior o prédio: do lado noroeste, os quartos e, do lado sudeste, a área de serviço e a cozinha. A sala ocupa toda a extensão da fachada menor

Entre as lajes foram colocados caixilhos de piso ao teto.

\section{Como Abrahão observou:}

[...] não é uma fachada do Mies, porque os caixilhos ficam entre os pilares e vigas, já que a margem de erro nas nossas construções é muito grande, e, assim poderíamos fazer desaparecer possíveis desalinhamentos. Um desenho que se classificaria como feio, porque na arquitetura devemos ter grandes linhas (DPCA, 1987 e 1988).

Detalhe do Edifício Seagram 1954-1958 projeto: Mies van der Rohe

fonte: JOHNSON, 1960, p.205.
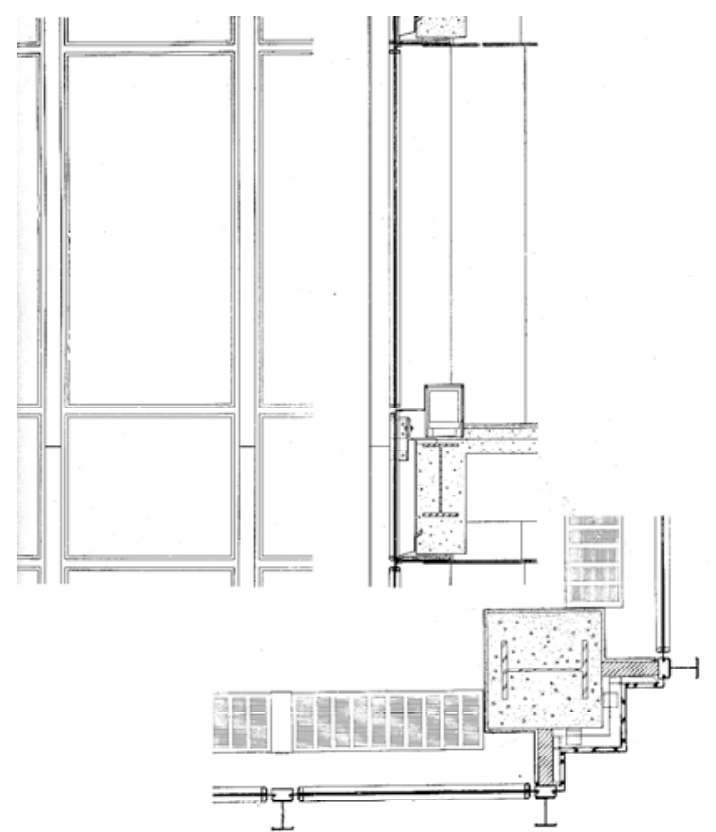
Trecho da fachada do edifício Abaeté

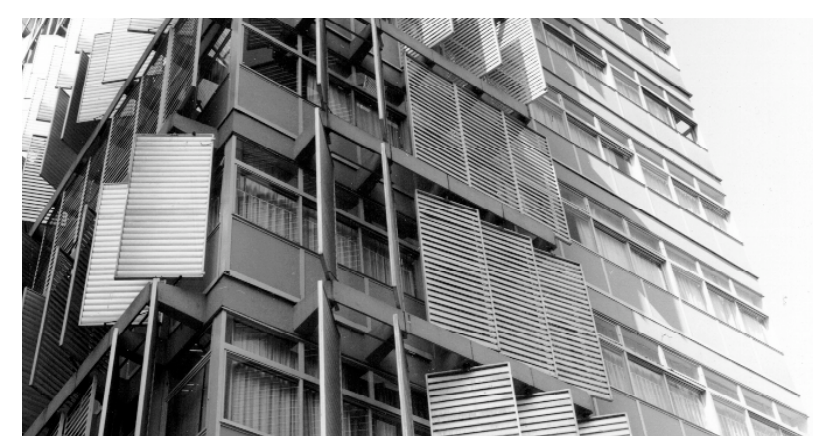

Abrahão, como de costume, submeteu o projeto às criticas de Julio Katinsky, que chamou a atenção para o resguardo de alguns ambientes. A observação do amigo veio confirmar a necessidade dos brises-soleils, que, se por um lado, protegem as fachadas mais sacrificadas pela insolação, por outro, funcionam como venezianas para os quartos. Uma outra solução foi a aplicação de chapas cegas de fibrocimento em substituição ao vidro, no pano que vai da altura do peitoril até o piso.

Interessante destacar que os brises são móveis. "Tudo foi feito no plano da sensibilidade, sem grandes cálculos: o sol se movimenta assim, portanto a melhor solução será tratar estas e aquelas porções da fachada ..." (DPCA, 1987 e 1988).

No mesmo ano de 1963 aconteceu a VII Bienal de São Paulo. Lá Abrahão conheceu a obra do premiado escultor concretista Yacov Agan, que apresentou na mostra peças que se movimentavam, formando várias composições.

\section{Obra de Yacov Agan}

fonte: Aujourd'hui, Paris, nº. 26, abril 1960, p. 22.
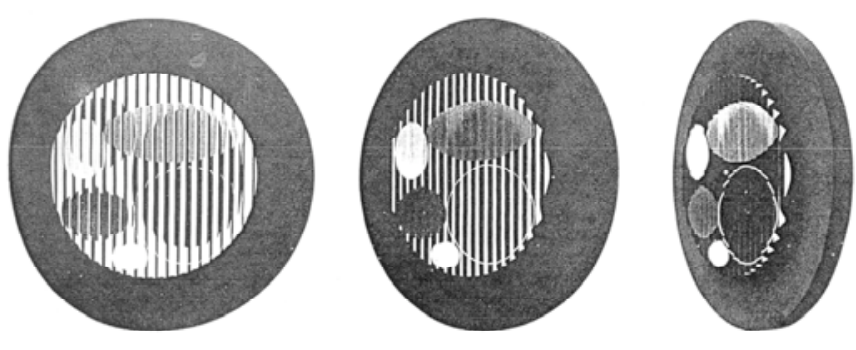

Entusiasmado, Abrahão comentou com um dos fundadores do Grupo Ruptura, o artista Waldemar Cordeiro, que com os brises móveis do Edifício Abaeté - que fazem com que a fachadas se alterem o tempo todo - faria um Agan gigantesco.

Projetado em 1963, o edifício da Rua Pará foi construído em 1968. Interessante que, apesar de ser uma obra tão importante e referencial para muitos estudantes e pesquisadores de arquitetura, só foi publicado em 1990 na revista Projeto $n^{\circ}$. 136, quando recebeu Menção Especial Categoria Habitação no concurso "O Fibrocimento na Arquitetura Brasileira".

No edifício Ubirama, projeto de 1969, um avanço na 

sobrepostos à fachada, requadrados em perfis de alumínio, o que resultou em melhor solução. Para utilizar o mesmo desenho de caixilho em diferentes ambientes, estes são divididos em panos de vidro, cego e veneziana nos quartos.

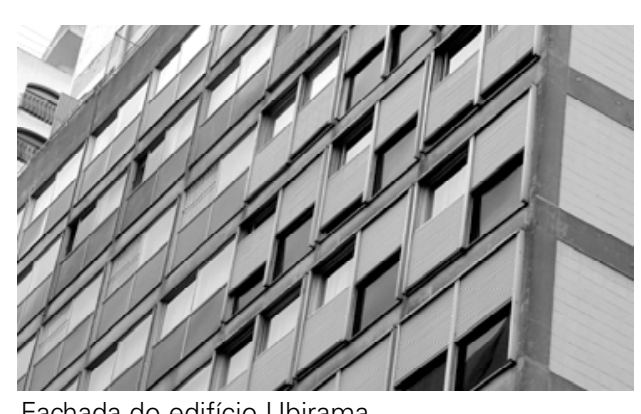

foto: Helena Aparecida Ayoub Silva 


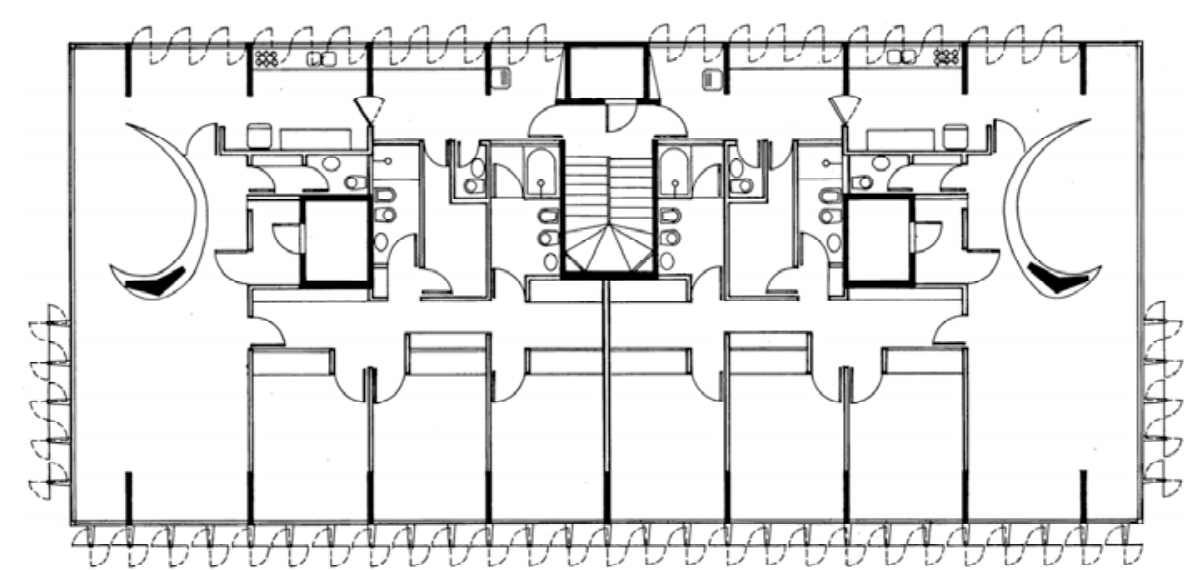

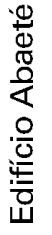

planta andar tipo

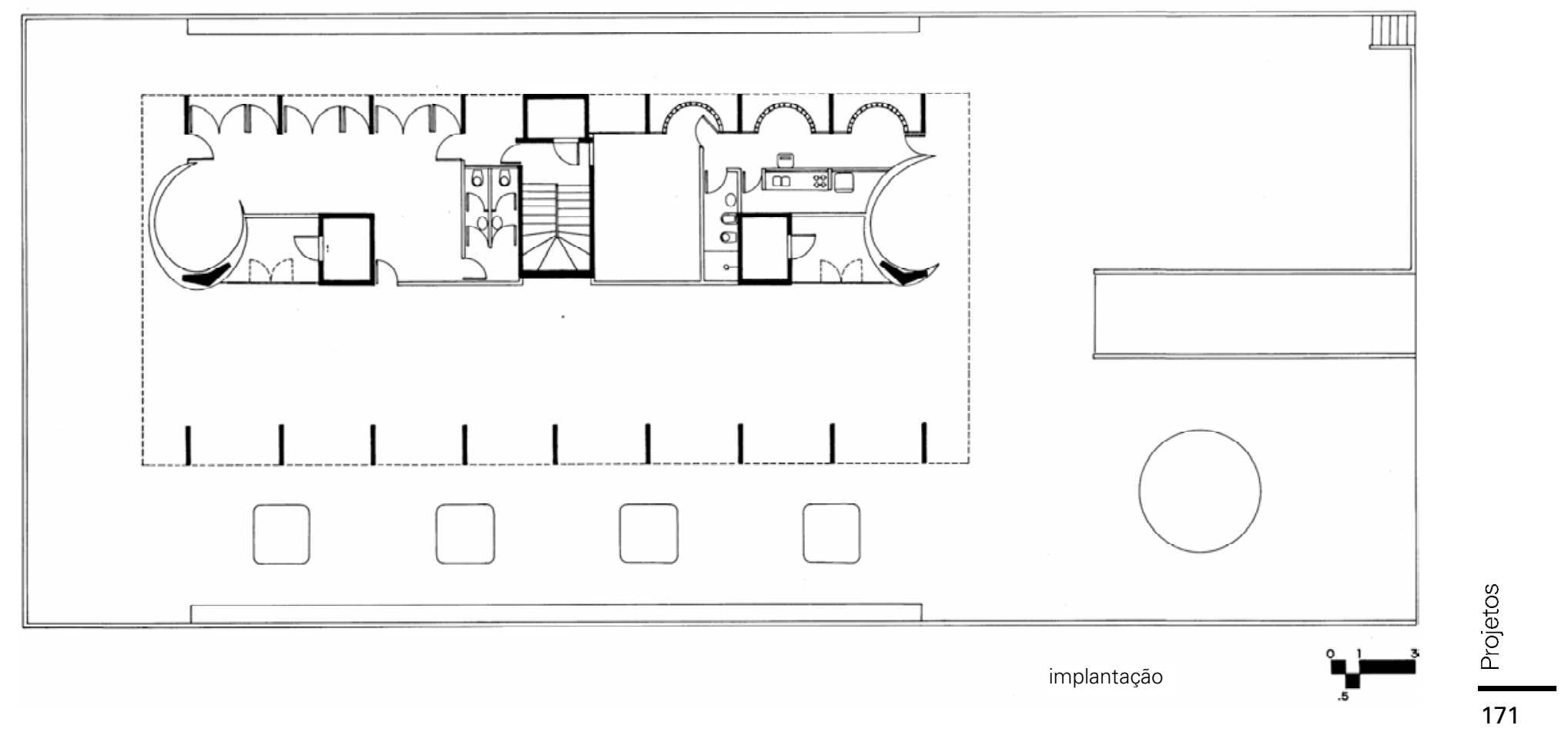



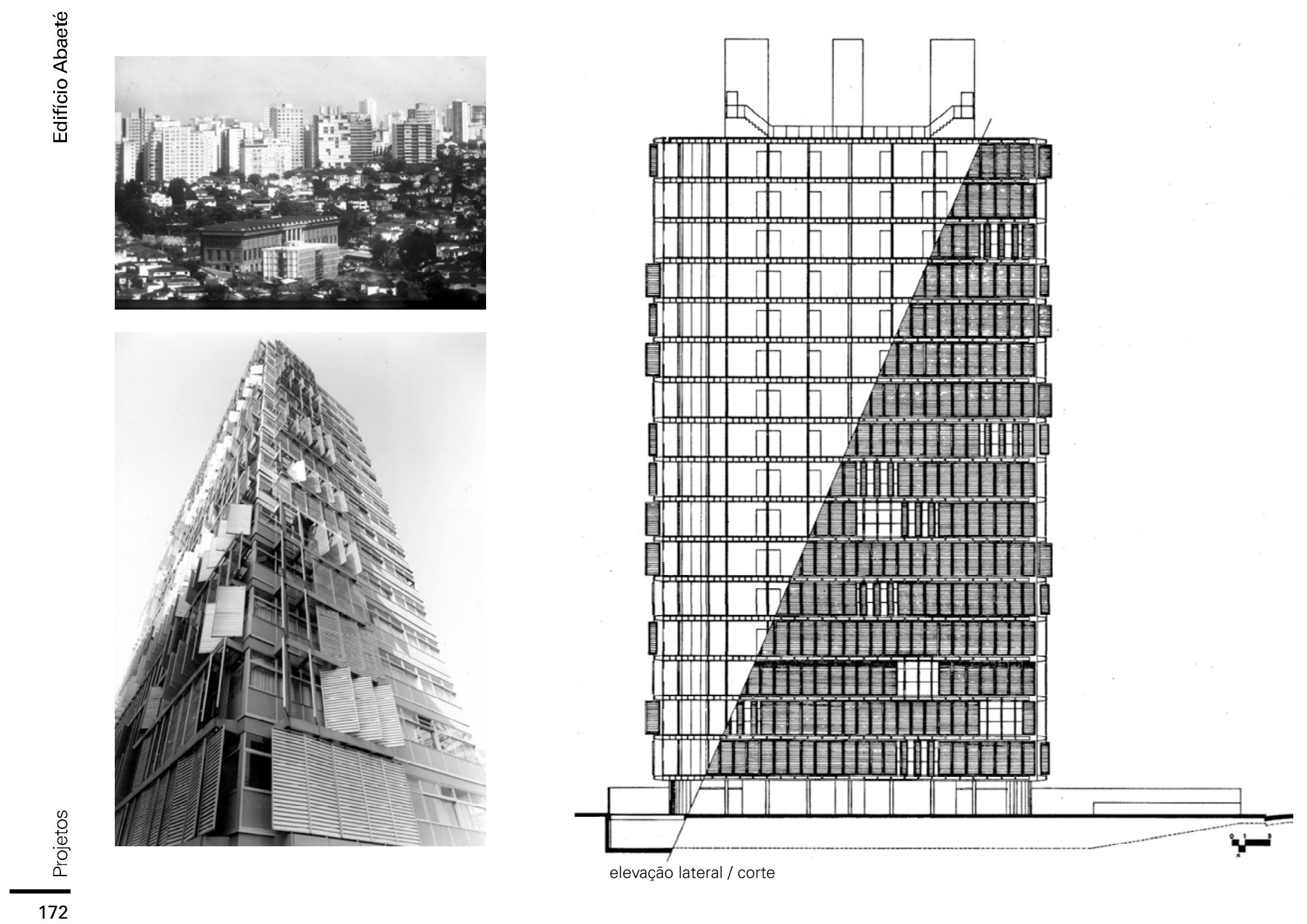

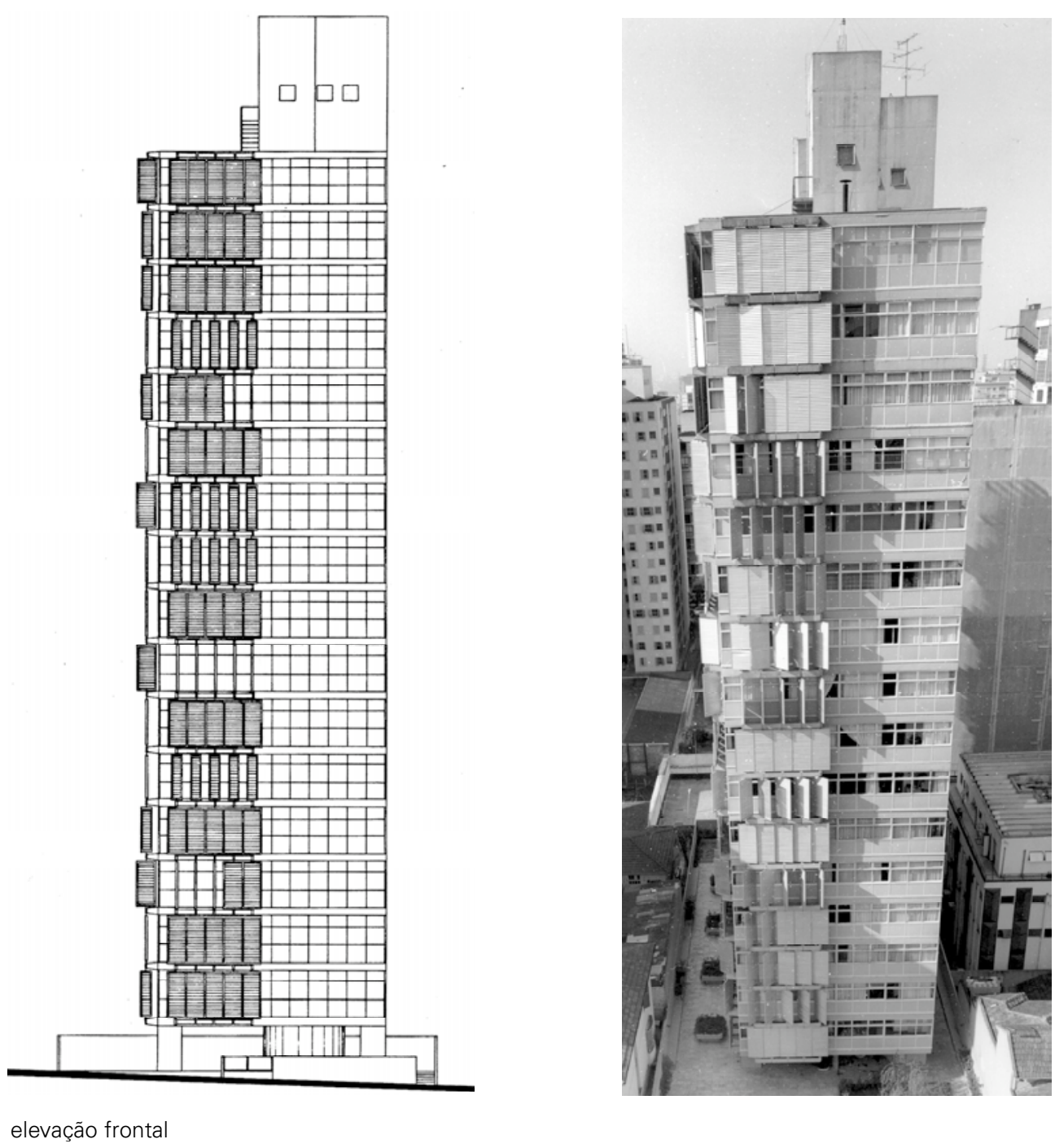

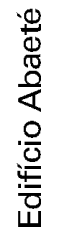

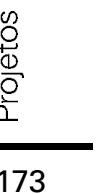



Edifícios residenciais, modulados e repetitíveis 1970/72

São Paulo, SP

fonte [imagens] acervo do escritório Elito Arquitetos

[desenhos] acervo da biblioteca da FAUUSP 
A Construtora Formaespaço, no fim da década de 1960, entusiasmada com as possibilidades que o Banco Nacional da Habitação - BNH colocava para o mercado imobiliário, convidou alguns arquitetos para elaborarem projetos de edifícios de apartamentos para a classe média. A Construtora colocava alguns condicionantes: as soluções de projeto contemplariam a previsão de que pudessem ser repetidos em diferentes terrenos; deveriam ser procurados métodos construtivos racionalizados e componentes industrializados de modo a tornar a construção mais econômica; e, os índices de aproveitamento deveriam ser menores que os estabelecidos pelas posturas municipais, já que a Construtora procuraria terrenos em bairros mais novos, portanto mais baratos.

Abrahão Sanovicz foi um dos arquitetos convidados. Quase sete anos após a experiência do Edifício Abaeté, poderia, então, retomar algumas experiências lançadas naquela obra.

Atendendo as normas estabelecidas pelo $\mathrm{BNH}$, de acordo com as faixas de financiamento, a Construtora definiu dois tipos de apartamento:

- maior com área útil de $125 \mathrm{~m}^{2}$, atenderia ao seguinte programa: sala, três quartos, dois banheiros, sendo um deles conjugado a um dos quartos, cozinha com pequena copa, área de serviço e quarto e banheiro para empregada. Para este tipo de apartamento previa-se um edifício com dois apartamentos por andar, de onze a quatorze andares, dependendo das dimensões do lote. A área total construída não deveria ultrapassar quatro vezes a área do lote. O térreo abrigaria as áreas comuns e de serviço do edifício e o subsolo a garagem.

- O menor teria área total útil de $75 \mathrm{~m}^{2}$, sendo seu programa: sala, três quartos, um banheiro, cozinha e área de serviço. O edifício comportaria dois apartamentos por andar, teria três pavimentos sobre pilotis, não necessitando, assim de elevador. Estes edifícios estariam localizados em regiões periféricas das cidades.

Da experiência anterior, Abrahão estabeleceu algumas premissas:

- Planta livre de pilares internamente, para possibilitar diferentes arranjos.

- Estrutura na periferia do edifício, com vãos que não solicitassem recursos sofisticados como a laje nervurada ou o caixão perdido.

- Circulação vertical no meio do edifício, de maneira a criar duas habitações por andar, simétricas. 
- A eliminação de corredores internos, resultando em um desenho que, a partir de um eixo paralelo à maior dimensão do apartamento, distribuísse de um lado, alinhados, quartos e serviço, e do outro, a sala livre e os banheiros quase como um volume "solto".

- Os pilares vigas e lajes concretados de uma só vez formam o arcabouço do prédio.

- Os vãos deixados entre as vigas-peitoril, permitiu que os caixilhos chegassem na obra praticamente prontos.

- As divisórias internas são executadas com painéis de gesso pré-moldados, com $7 \mathrm{~cm}$ de espessura, $50 \mathrm{~cm}$ de largura e o comprimento igual ao pé direito.

- As instalações hidráulicas foram reduzidas a poucas prumadas.

- A modulação estrutural, permitindo o reaproveitamento das formas e a padronização das dimensões das diversas partes da estrutura, de maneira a possibilitar que toda a ferragem, racionalizada, fosse produzida fora do canteiro.

No volume Sistematização Crítica da O bra de Arquitetura para Obtenção do Título de Livre Docente, Abrahão comenta:

A construção começa então a se tornar montagem de suas partes, num compromisso entre o sistema tradicional construtivo e as possibilidades industriais do mercado.

Os elementos de "acabamento" da obra são os normais do mercado.

Os elementos essenciais do projeto, racionalizados, possibilitam aos setores de planejamento de obra determinarem com precisão maior, os custos e os tempos de execução da mesma (SANOVICZ, 1997, p. 51).

Maria Isabel Imbronito apresentou à FAUUSP, em 2003, sua dissertação de mestrado, Três Edifícios de Habitação para a Formaespaço: Modulares, Gemini e Protótipo. Na dissertação, estudou a atuação da Construtora Formaespaço: o período em que surgiu e atuou e qual o conjunto edificado que realizou. Sobre os Modulares Maria Isabel afirma:

A apreciação dos edifícios Modulares e a descrição de sua construção evidenciam a imbricação do desenho industrial e arquitetura no trabalho de Abrahão Sanovicz. Revelam ainda que o desenvolvimento do sistema construtivo não se resolve enquanto condição desvinculada da arquitetura (IMBRONITO, 2003, p. 28). 


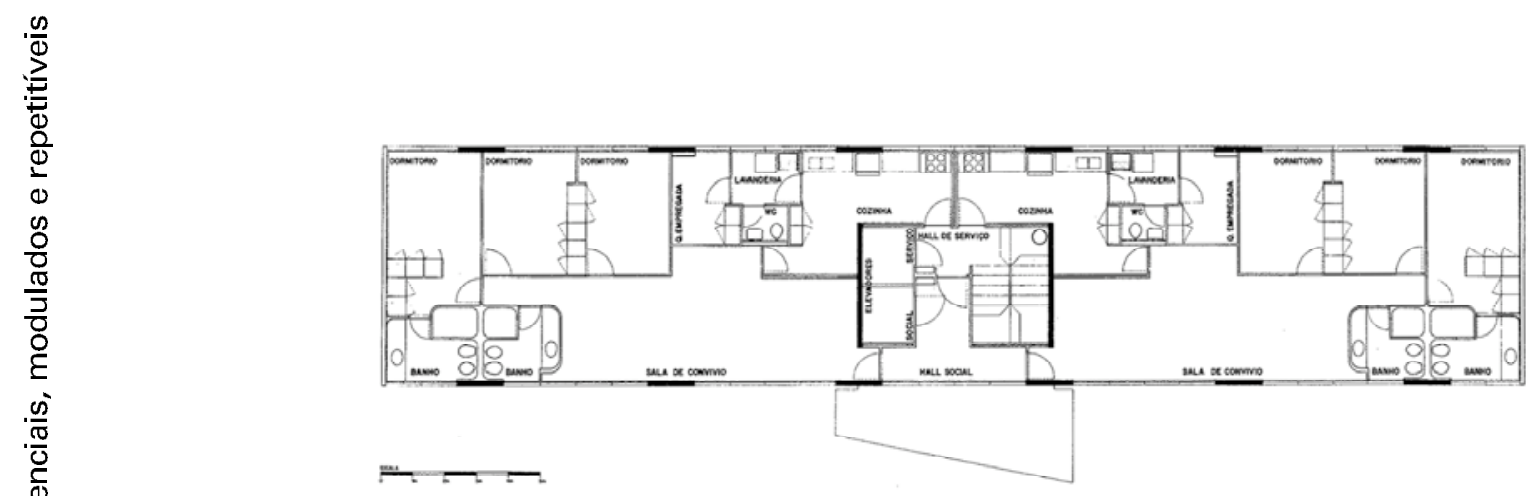

planta andar tipo

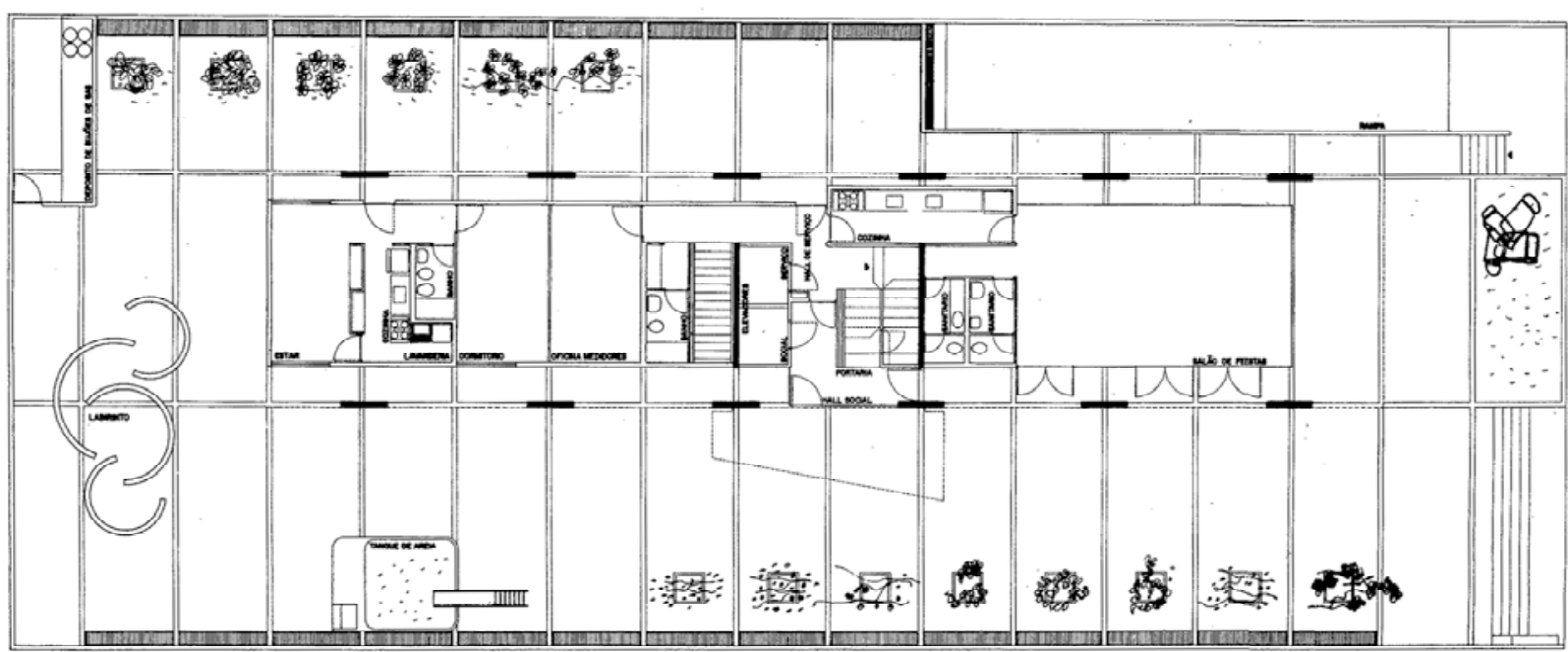

implantacão

$\frac{\frac{0}{0}}{\frac{0}{0} \frac{0}{0}}$ 

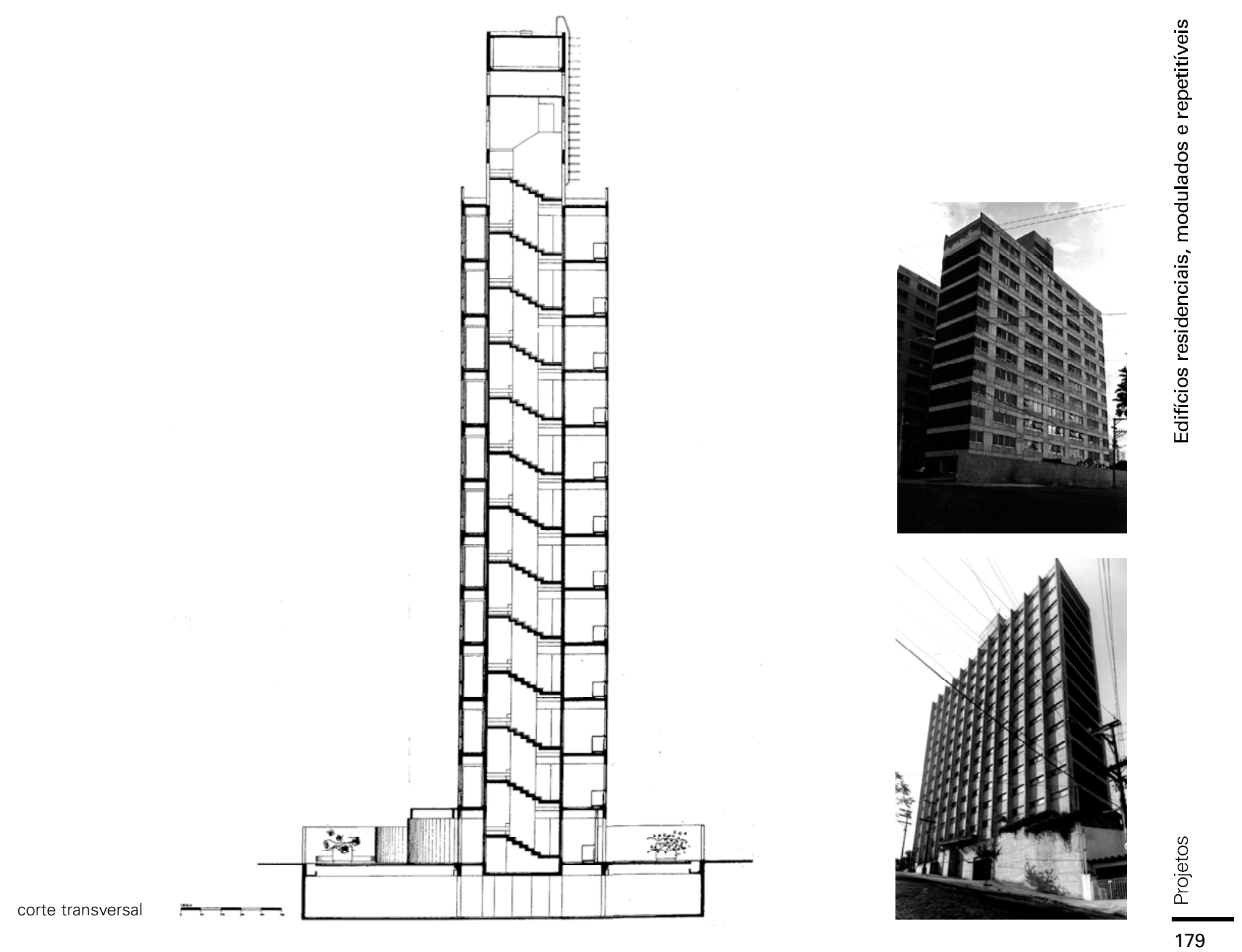

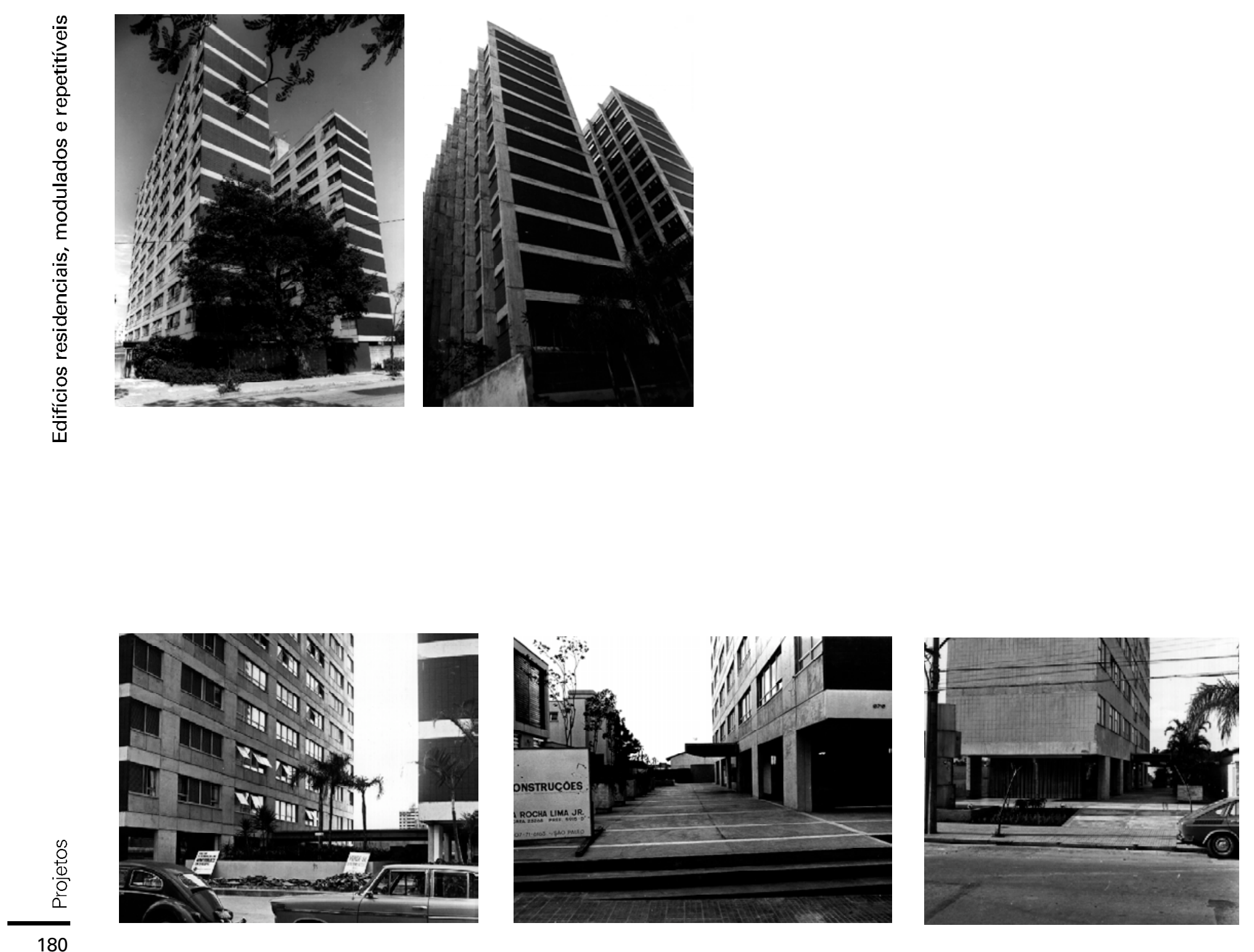


\section{Edifício Fiandeiras - 1972}

Rua Fiandeiras, São Paulo, SP

fonte [imagens] acervo do escritório Elito Arquitetos [desenhos] acervo da biblioteca da FAUUSP 
No conjunto de entrevistas que concedeu a Catharine Gati, Abrahão declara:

As experiências com os Modulares e os conjuntos habitacionais para a Formaespaço formam a primeira geração de projetos. Já o Fiandeiras é a segunda geração. Aí propus uma solução universal, um pré-moldado que resolvesse a vedação de todos os ambientes (DPCA, 1987 e 1988).

Também financiado pelo Banco Nacional da Habitação $\mathrm{BNH}$, para o projeto, a Construtora Carraresi - Dell'Acqua estabeleceu como programa, apartamentos de $90 \mathrm{~m}^{2} \mathrm{com}$ dois quartos.

Uma limitação foi colocada logo de início: o terreno onde foi implantado o Edifício Fiandeiras fazia fundos com o Córrego Uberabinha, canalizado no fim da década de 1990, dando lugar à Avenida Hélio Pellegrino.

$\mathrm{Na}$ época, nos períodos de chuva, o córrego sempre inundava os imóveis lindeiros. Por esse motivo, a garagem ocupa o nível térreo.

Uma laje elevada abriga o acesso principal, casa de zelador, salão de festas e área para o lazer infantil.

Acima deste piso, foram construídos oito andares com quatro apartamentos por andar.

A planta do prédio é quadrada, com a circulação vertical na sua parte central.
Abrahão resolveu com um único elemento pré-moldado, toda a vedação dos apartamentos, que têm poucas paredes internas, praticamente só nos volumes hidráulicos, o que dá margem a vários arranjos, já que se valeu de armários para dividir a sala dos quartos. 

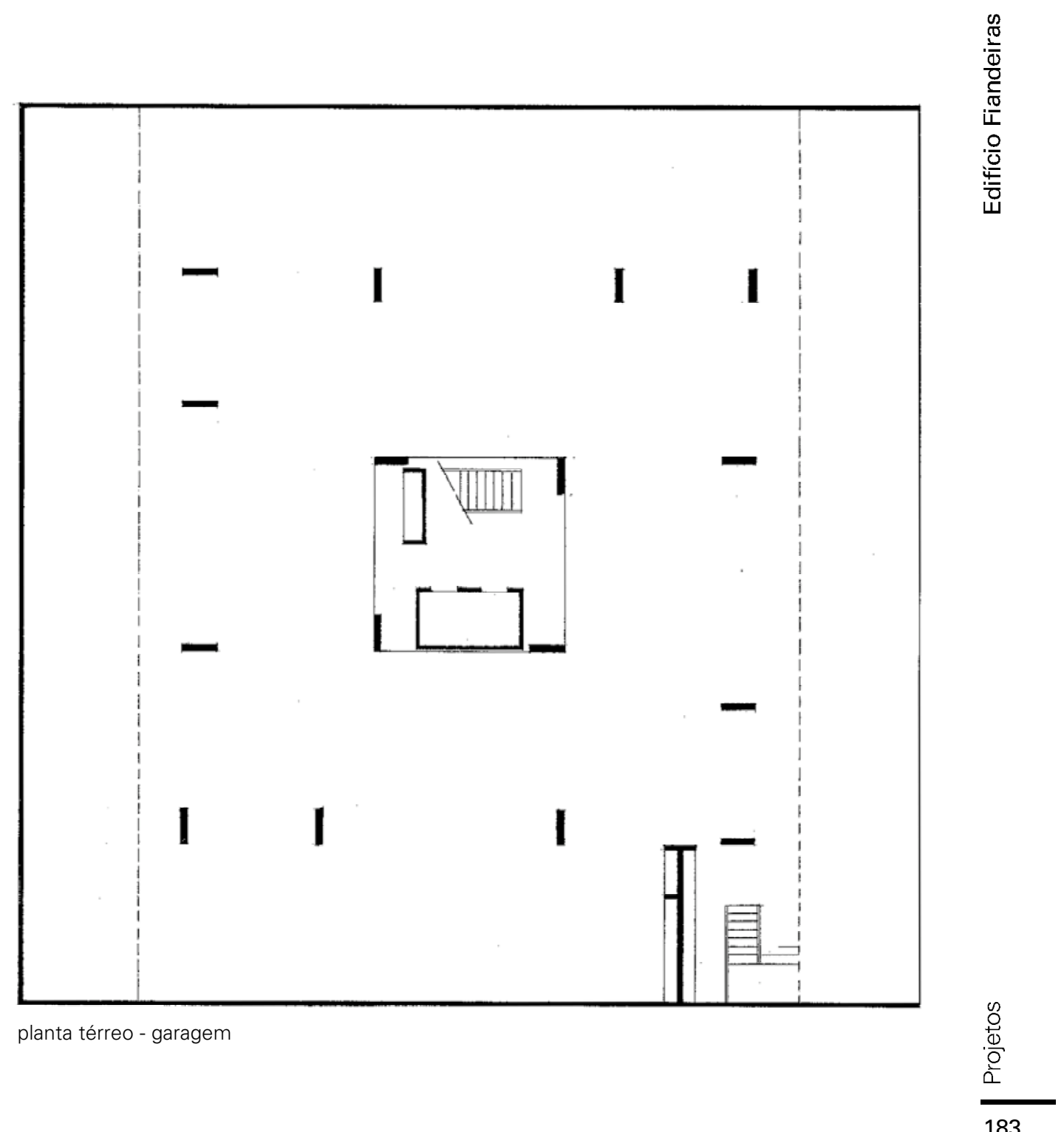


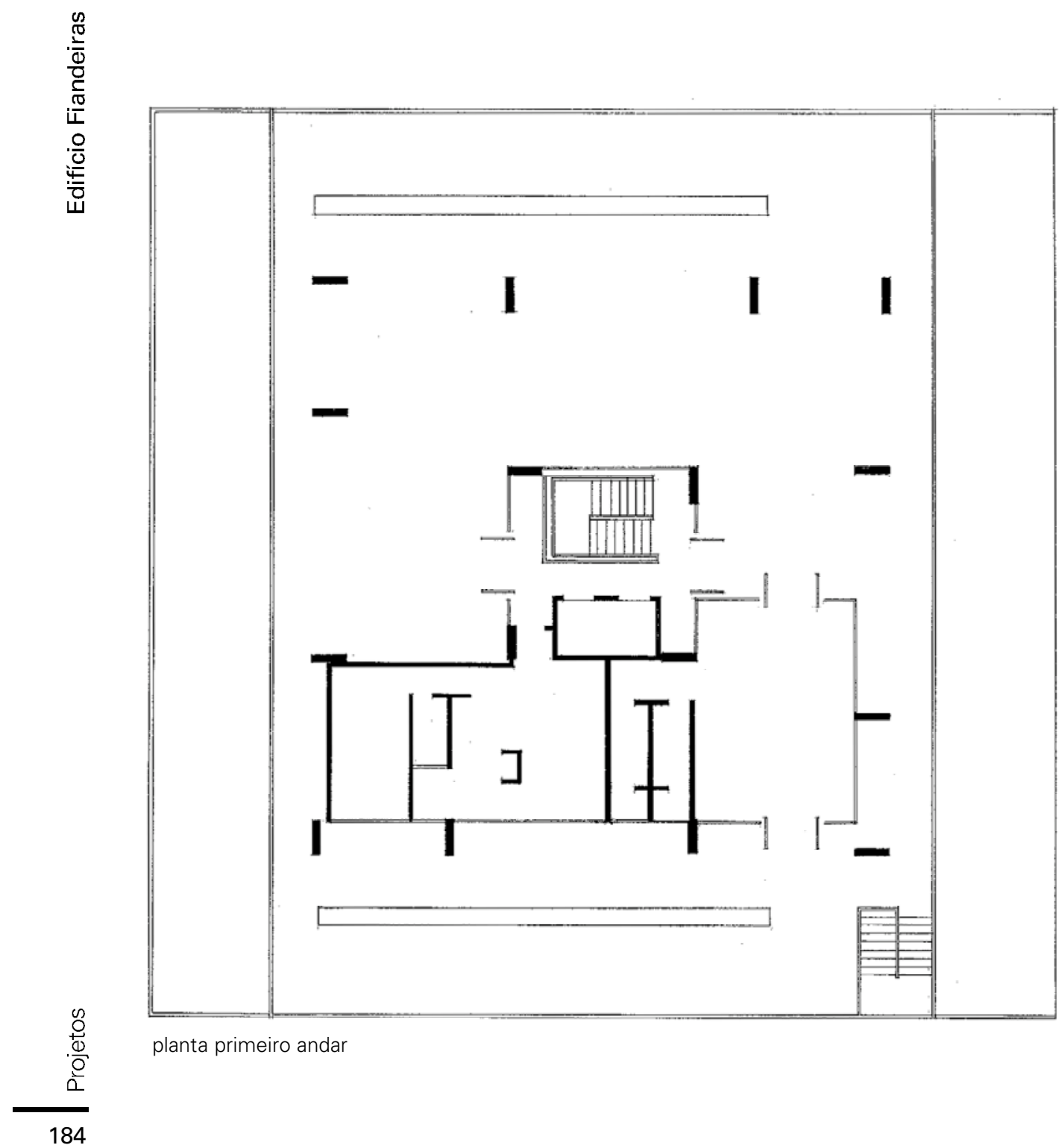




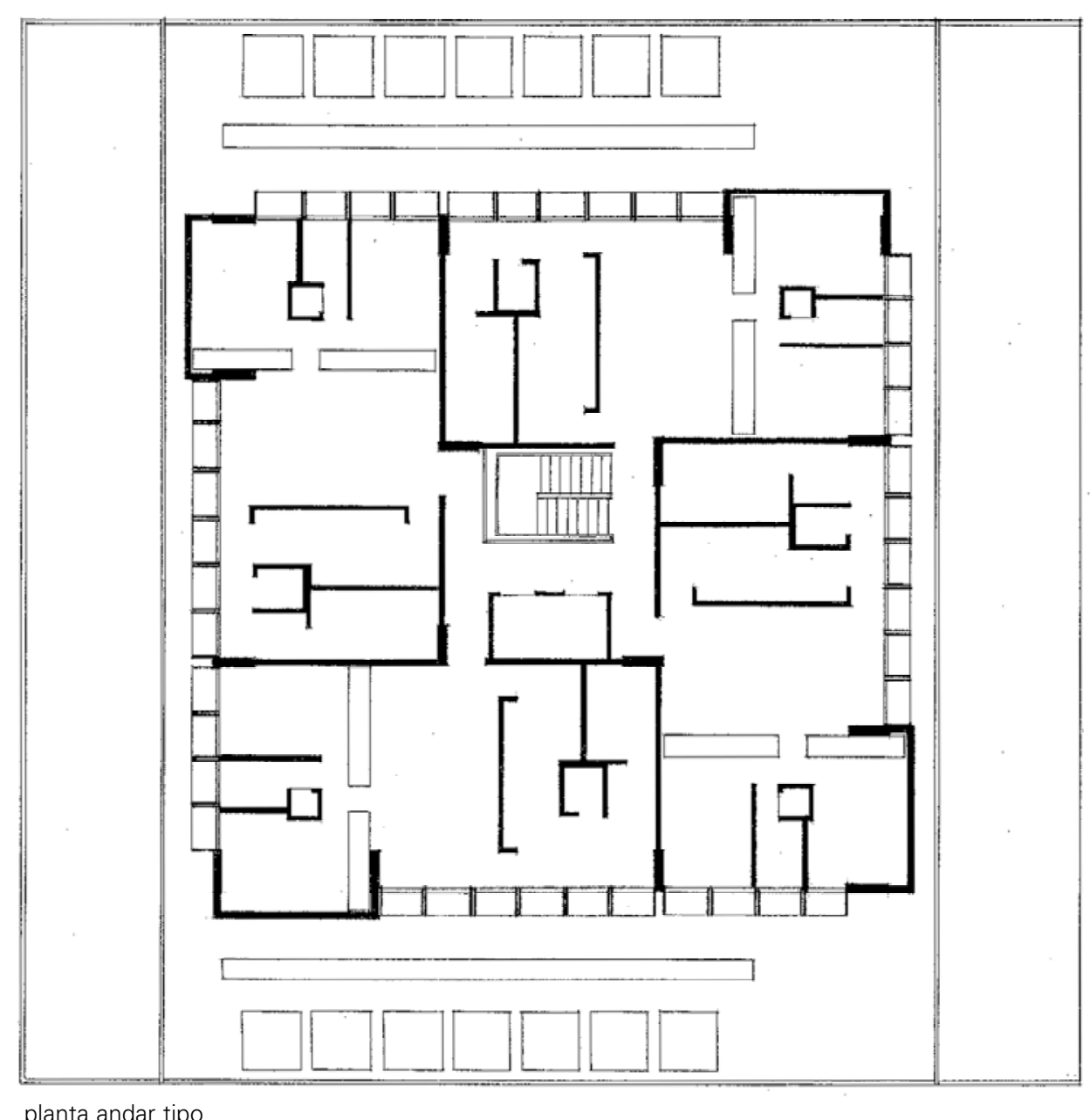




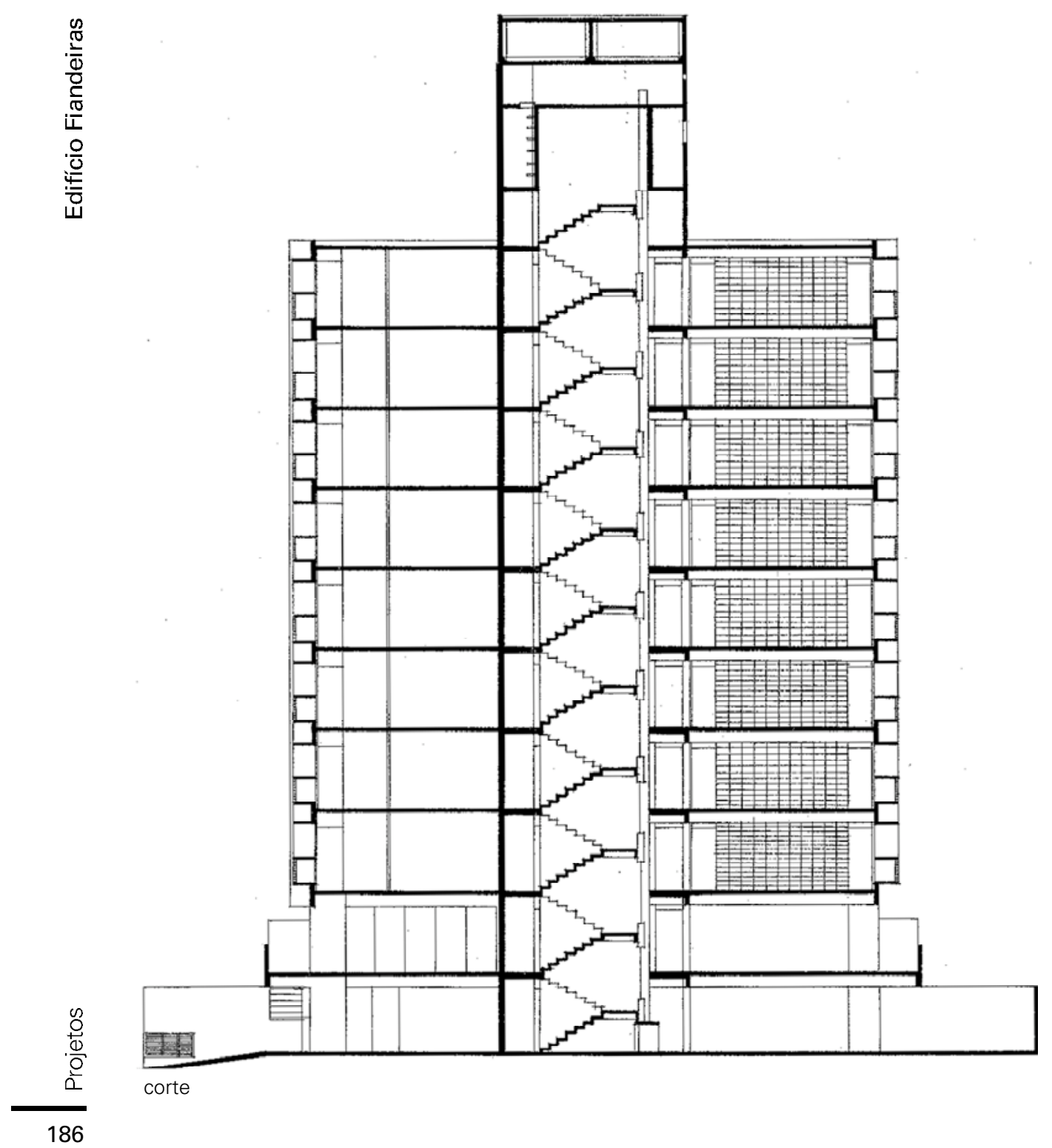




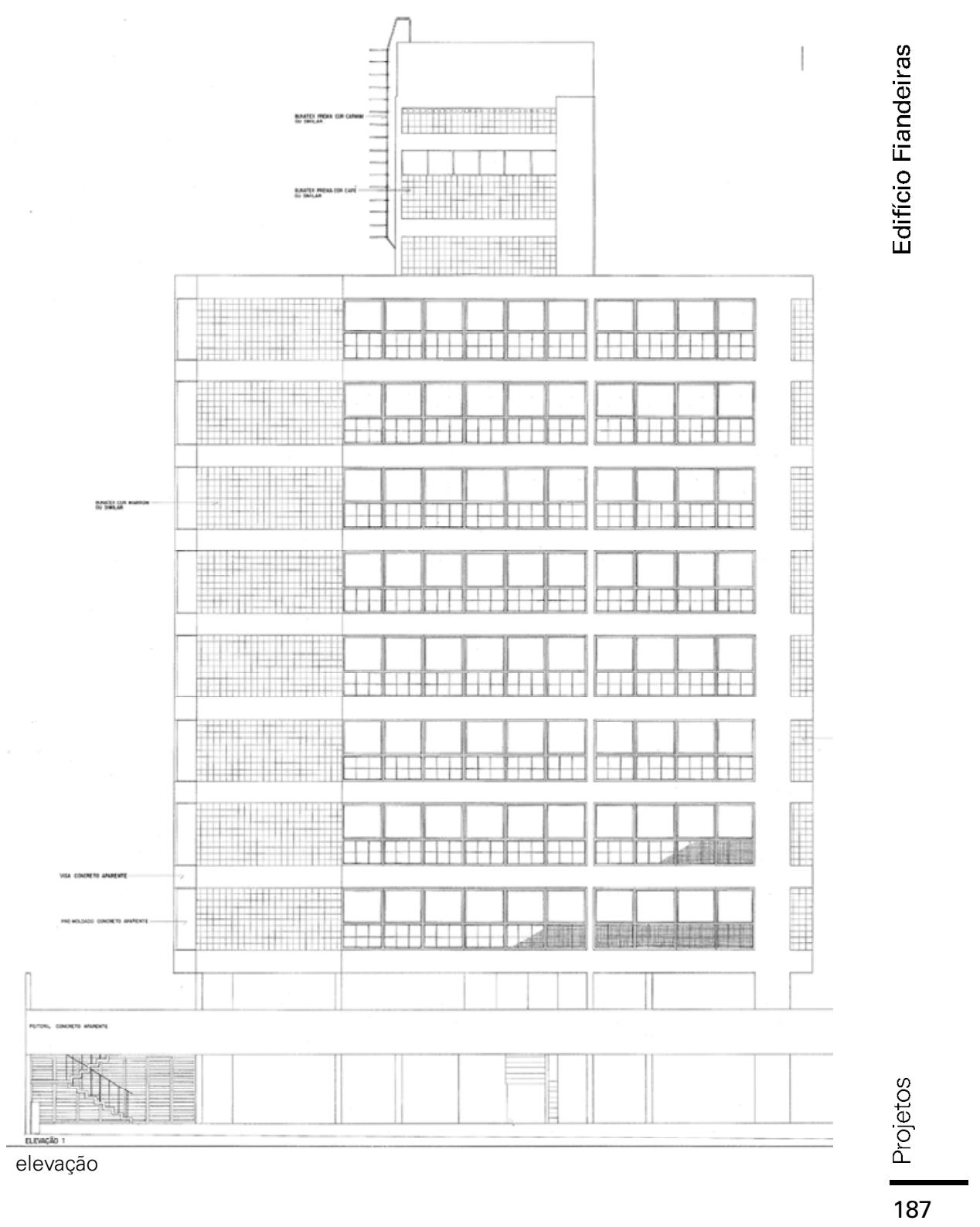




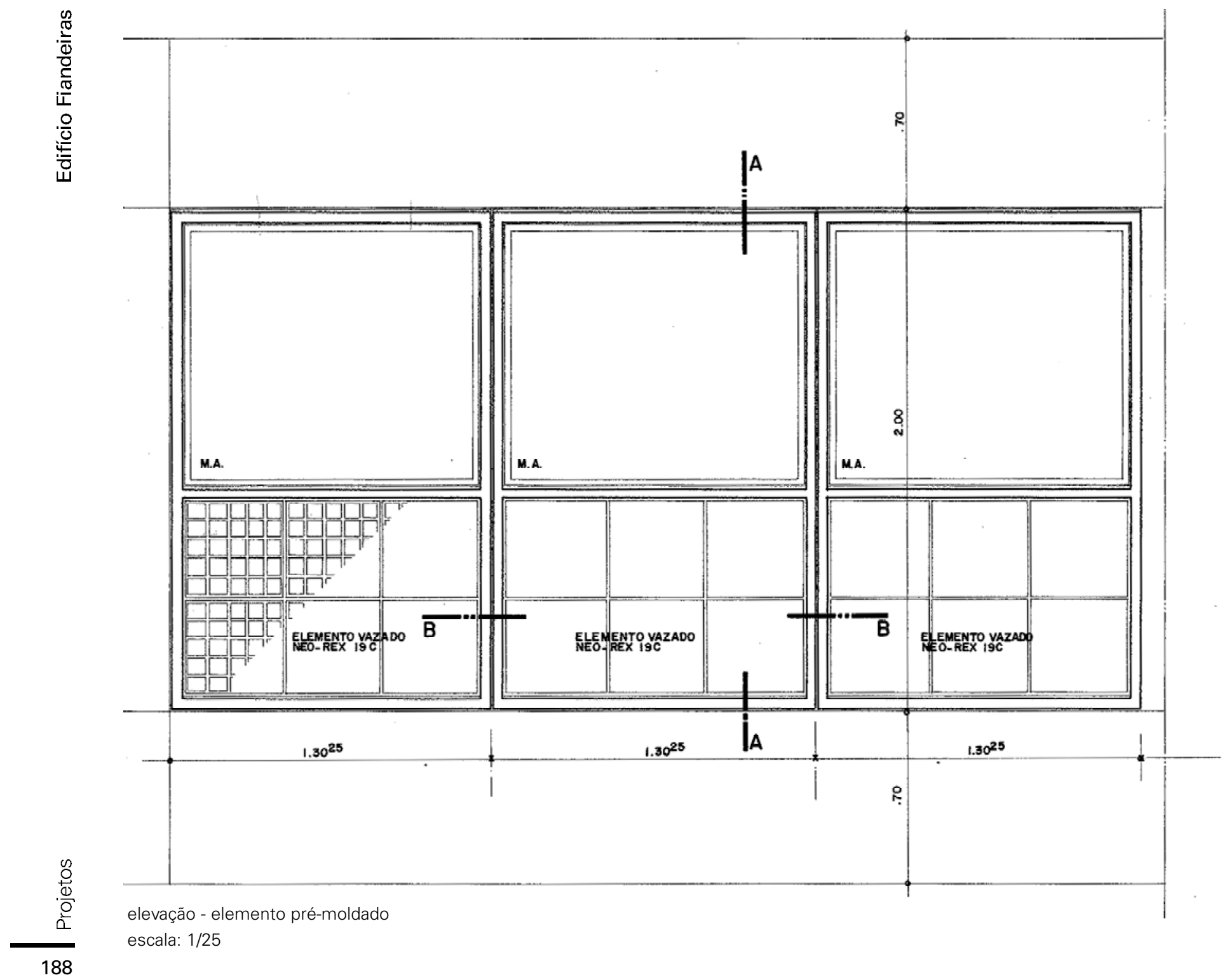




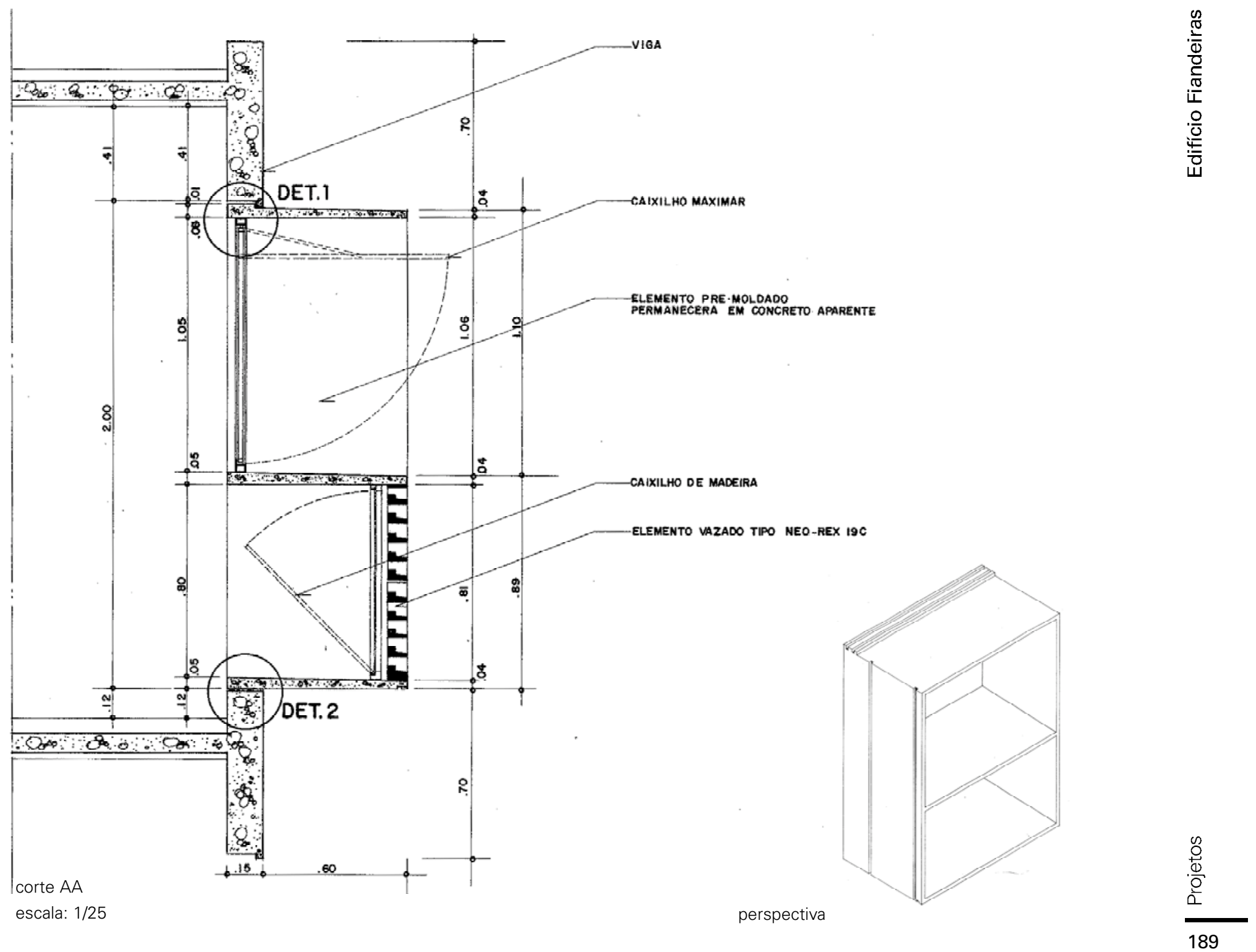



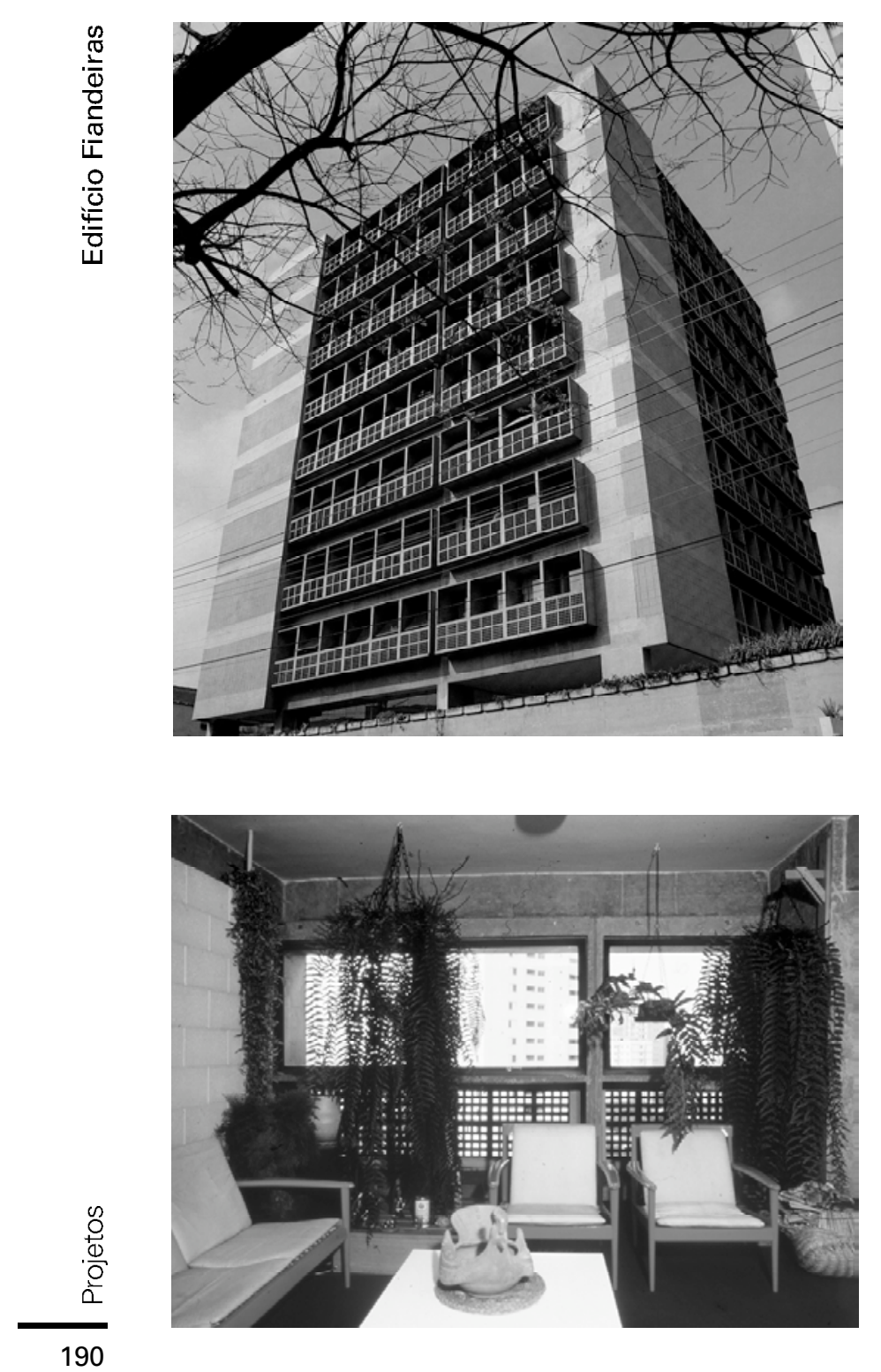


\section{Edifício Teixeira da Silva - 1974}

Rua Teixeira da Silva, São Paulo, SP

fonte [desenhos] acervo da biblioteca da FAUUSP 
O Edifício Teixeira da Silva não foi construído. Seria implantado em um lote de $300 \mathrm{~m}^{2}$, previa garagem no subsolo, no térreo o acesso principal e casa do zelador, nove andares com dois apartamentos de um quarto, com de $50 \mathrm{~m}^{2}$ de área útil cada. No décimo andar, o apartamento de cobertura ocupava o piso todo.

Uma planta tipo com $8,10 \mathrm{~m}$ por $14,75 \mathrm{~m}$ foi resolvida com uma estrutura em concreto armado muito simples. A parede da circulação vertical de um lado, e, do outro, no subsolo e térreo, duas colunas, substituídas, nos andares superiores, por pilares chatos embutidos nas paredes, suportam os esforços de vigas que apóiam as lajes maciças.

A planta do apartamento, tanto quanto no Edifício Fiandeiras, tem paredes construídas em alvenaria apenas nos blocos hidráulicos, restando sala e quarto em um espaço único. A sugestão do arquiteto era que, se necessário, um armário servisse como divisória.

Como resultado das experiências anteriores, apresentou uma evolução no desenho do caixilho que fecha as fachadas nordeste e sudoeste do piso ao teto.

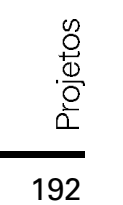



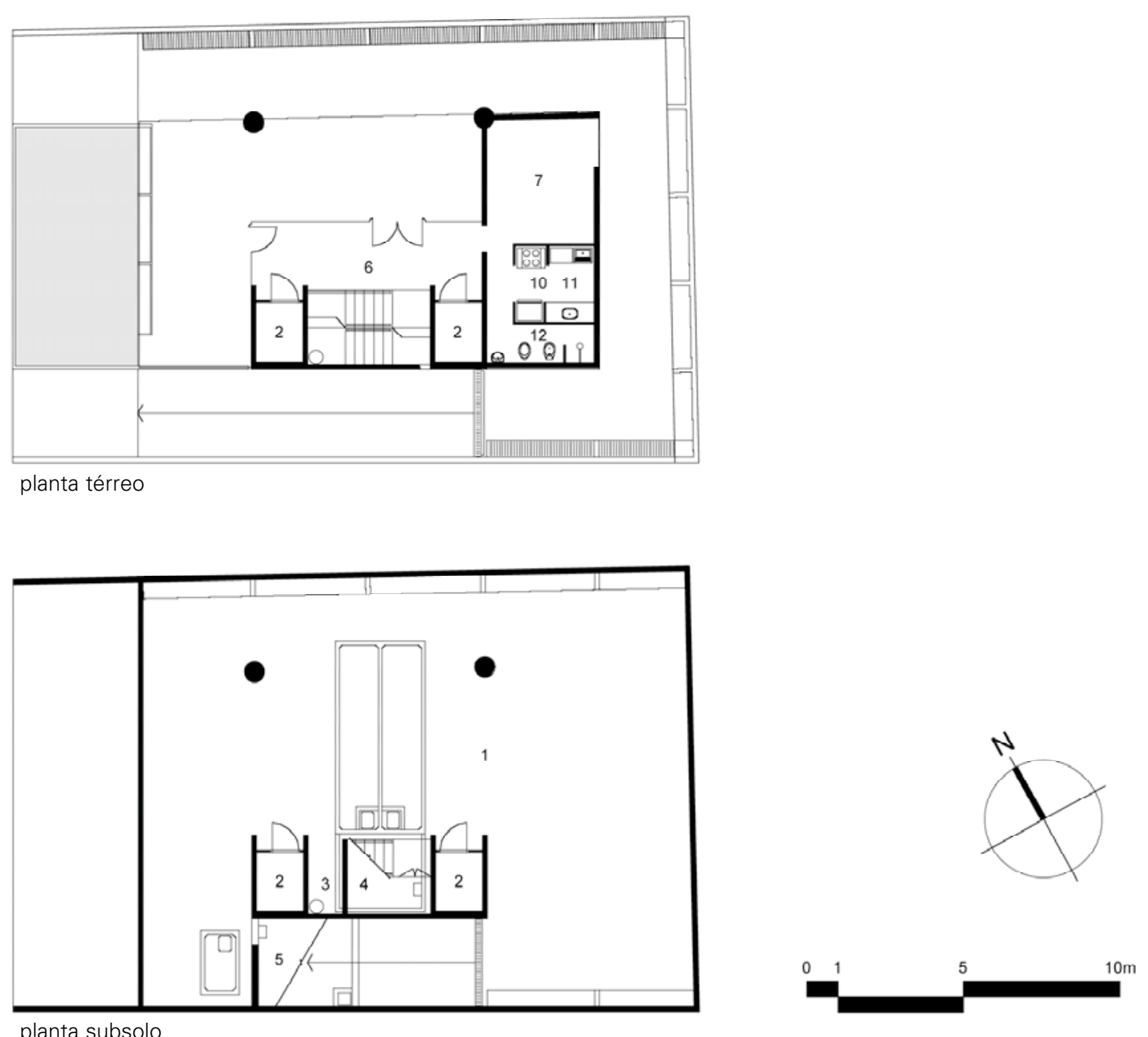

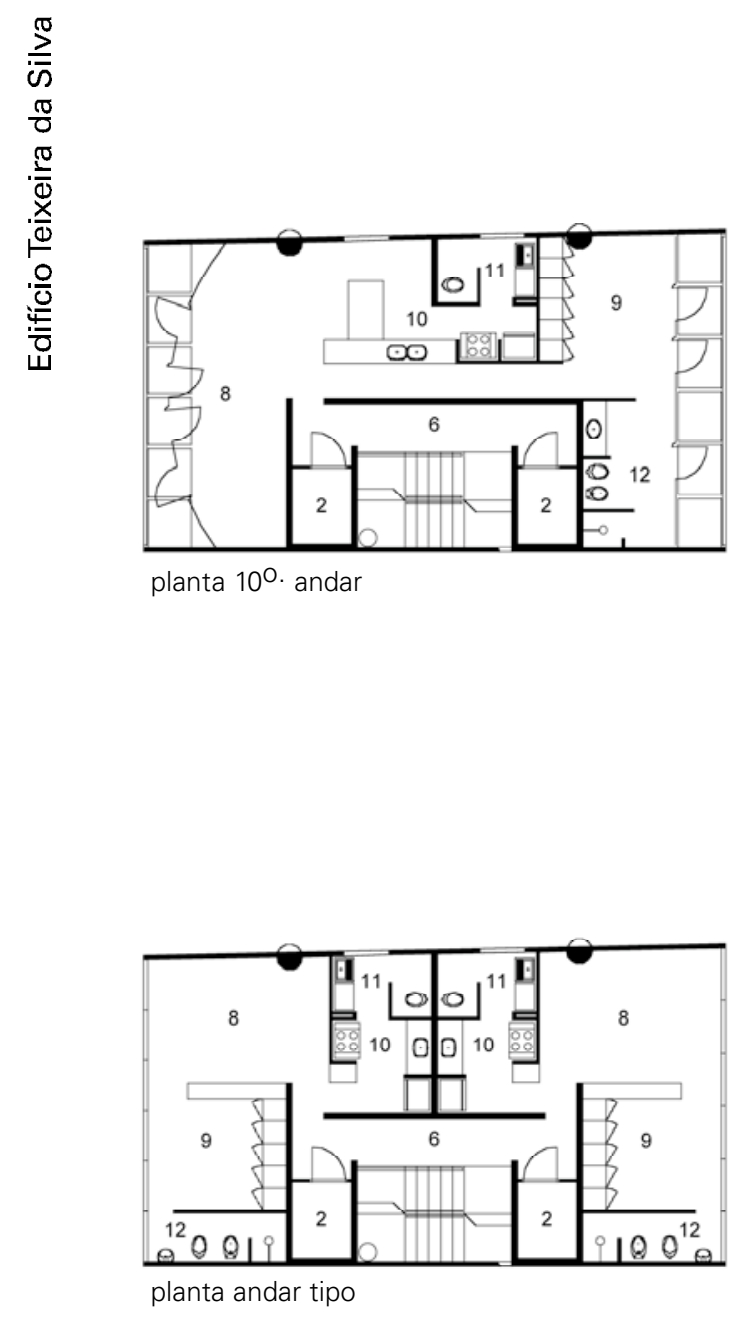

$\frac{\stackrel{0}{0}}{\frac{.0}{0}}$ 


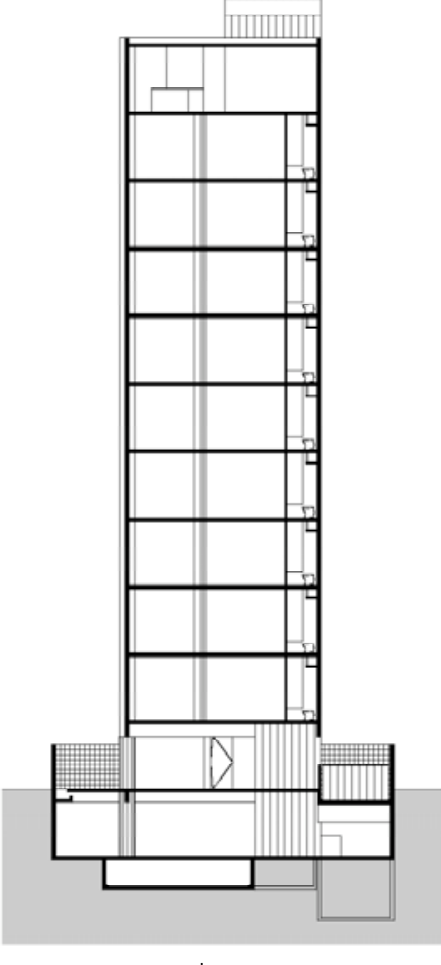

corte transversa

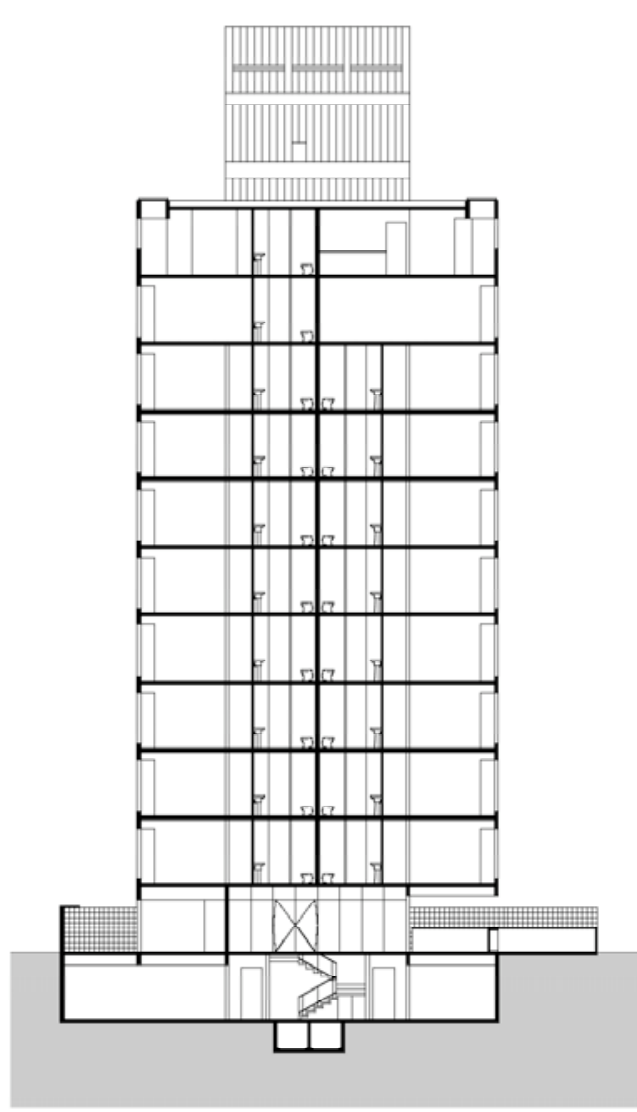

corte longitudinal

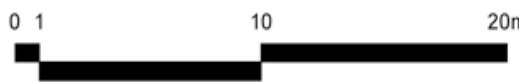




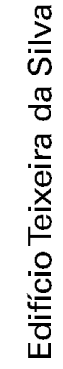

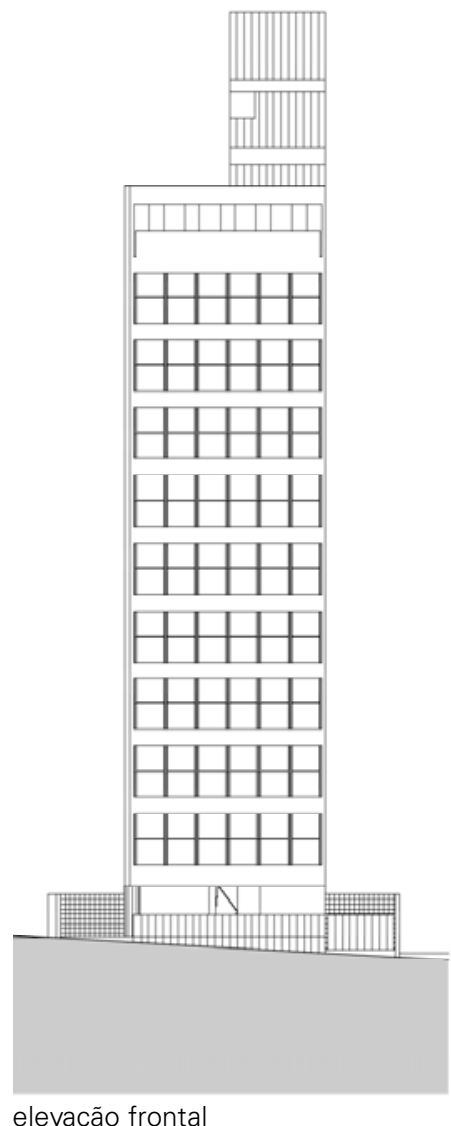

elevação frontal

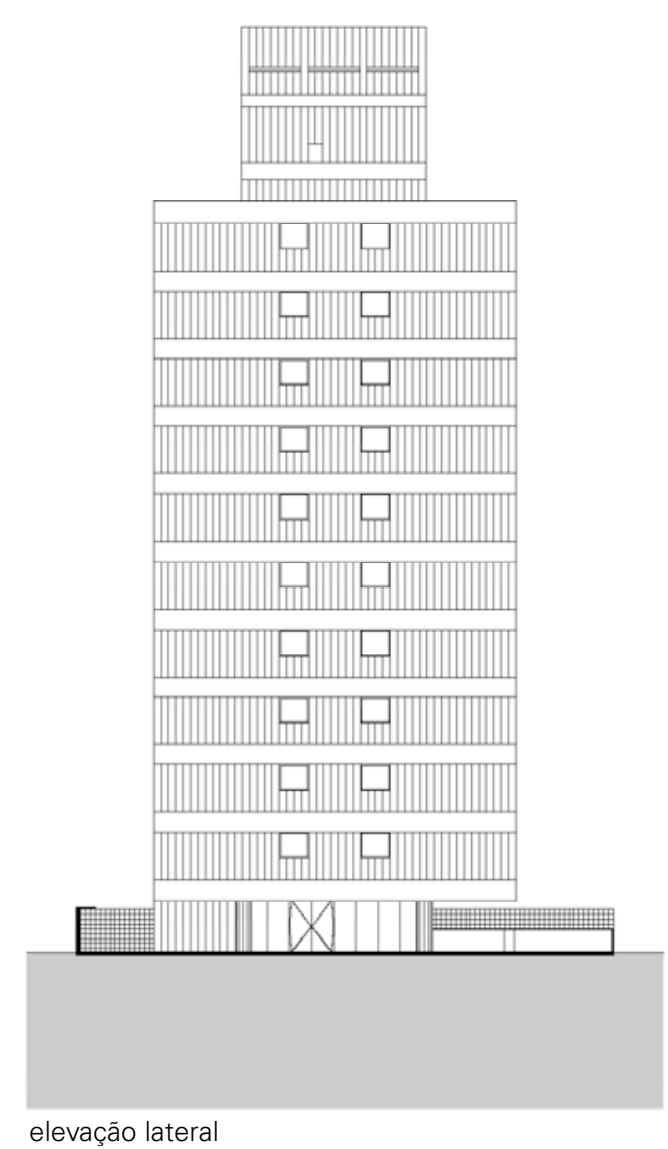

elevação lateral

$\begin{array}{r}\frac{8}{0} \\ \frac{0}{0} \\ \frac{0}{0} \\ \hline 196 \\ \hline 196\end{array}$ 
Conjuntos Habitacionais 
Abrahão Sanovicz realizou mais de uma dezena de projetos para conjuntos habitacionais.

Os primeiros foram para a Construtora Formaespaço. Destinavam-se à faixa de renda, estabelecida pelas linhas de financiamento do Banco Nacional da Habitação, em que a área máxima construída seria de $75 \mathrm{~m}^{2}$. Da experiência, destacou-se o projeto do Conjunto Habitacional Nova Cidade.

Num segundo momento, realizou os projetos para as cidades de Serra Negra e Sumaré, contratados pela Caixa Estadual de Casas para o Povo - CECAP.

Mais tarde, elaborou a proposta para a Vila Residencial de Porto Primavera, para a Companhia Energética de São Paulo - CESP.

Em 1995, realizou os projetos para os Conjuntos Habitacionais Pascoal Melantônio e Celso dos Santos, no plano de desfavelamento do Programa de Saneamento Ambiental da Bacia do Guarapiranga, contratado pela Secretaria de da Habitação e Desenvolvimento Urbano da Prefeitura do Município de São Paulo.

Sempre que Abrahão se manifestava sobre os seus projetos para os conjuntos habitacionais, apontava duas referências a partir das quais se dava a discussão inicial: as casas em renque de Mies van der Rohe e o Conjunto Habitacional Zezinho Magalhães Prado, sem dúvida, um marco da arquitetura brasileira.

Casas em renque

projeto: Mies van de Rohe

fonte: JOHNSON, 1960, p. 178 e 179
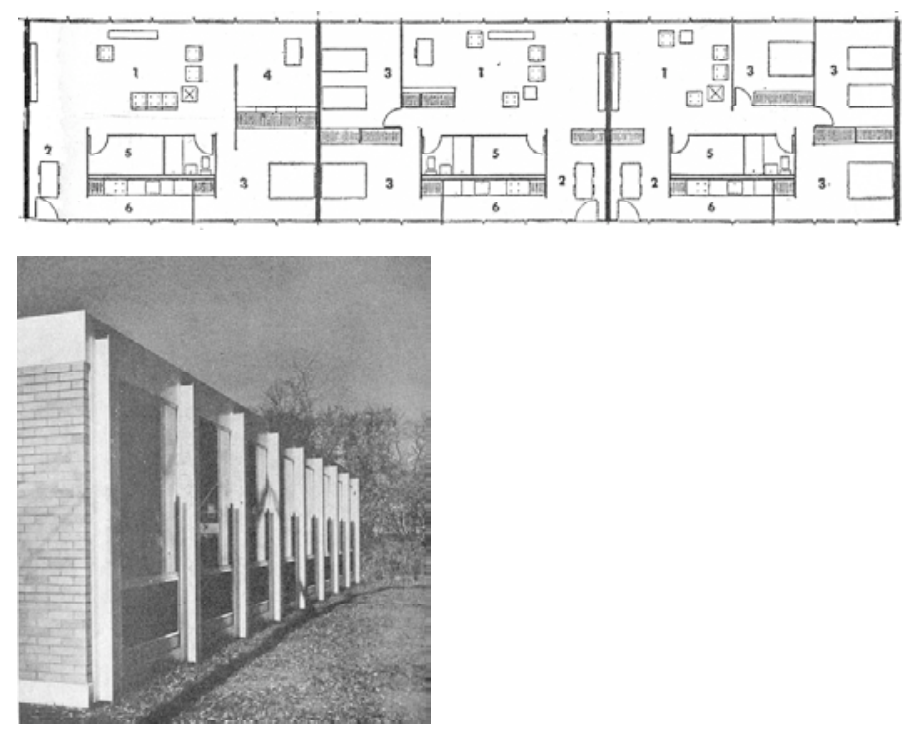

O Conjunto Habitacional Zezinho Magalhães Prado, contratado pela CECAP, em 1968, teve como coordenadores os arquitetos João Batista Vilanova Artigas, Fábio Penteado e Paulo Mendes da Rocha e, como colaboradores, Arnaldo Martino, Geraldo Vespaziano Puntoni, Giselda Cardoso Visconti, Renato Nunes e Ruy Gama. 
O projeto previa atender uma população de 55.000 pessoas num terreno de 130 hectares, junto à Via Dutra, em Guarulhos.

Portanto, além dos 10.600 apartamentos, o programa a ser atendido previa: oito grupos escolares; três ginásios; escola industrial; hospital geral; pronto-socorro; centro de saúde; posto de puericultura; estádio para 10.000 pessoas; dois cinemas; hotel; teatro; comércio; igreja; clube; entreposto de abastecimento; caixa de água e gasômetro.

Muitos outros profissionais fora convocados para compor a equipe e dar conta de programa tão extenso.

Num debate promovido pelo Centro de Estudos Brasileiros CEB, em 1968, o arquiteto Fábio Penteado, falou sobre o plano geral:

O conceito básico adotado no plano foi a abertura de áreas as mais generosas possíveis e nos entornos destas áreas a colocação, de maneira compacta, daquilo que no nosso projeto passou a se chamar de freguesia. Cada freguesia, densamente construída, mas em termos de ocupação de área razoavelmente satisfatória, passa a ser atendida por um conjunto de atividades cotidianas a uma distância de 150 metros.

$[\ldots]$

Estes 150 metros resultam num centro de abertura da freguesia para um espaço de comércio e outras utilizações, cada uma delas, por sua vez, se comunica com um grande espaço aberto que é para onde se convergem todos os movimentos.

A tendência deste plano é concentrar nesta grande área central, aberta, um grande movimento de toda a população do entorno (CUMBICA, 1973, s.p.).

Implantação do conjunto habitacional Zezinho de Magalhães Prado Guarulhos, SP, 1967

projeto: Fábio Penteado, João Batista Vilanova Artigas, Paulo Mendes da Rocha e equipe.

fonte: acervo da biblioteca da FAUUSP

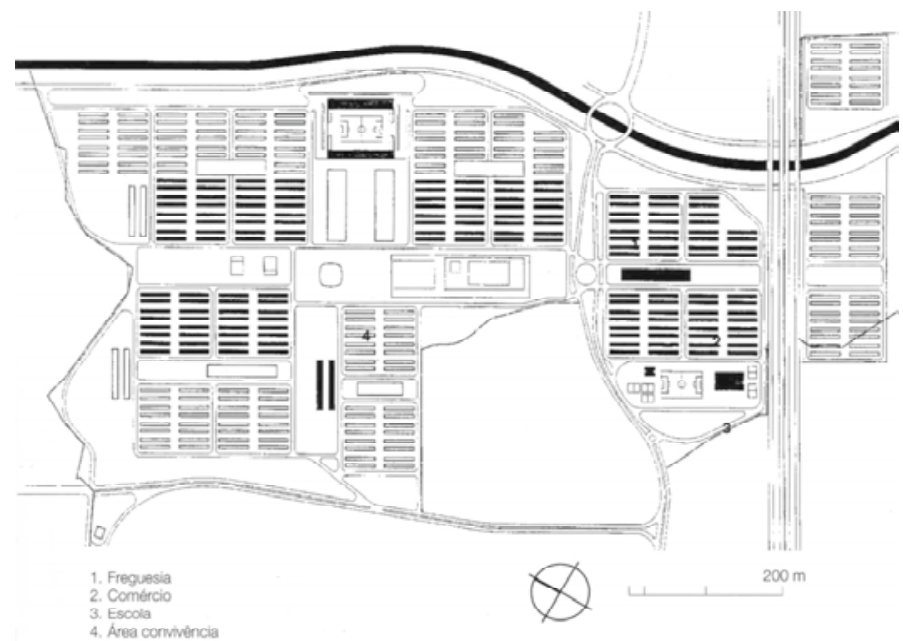

Os edifícios de apartamentos são sobre pilotis, prevendose utilizar as áreas ligadas aos planos de acesso de cada prédio para atividades recreativas, verdadeiros passeios que conduzem, naturalmente, ao comércio, à escola e aos pontos de ônibus. Era proposta da equipe que os pilotis seriam utilizados como estacionamento. 
Para todas as edificações a proposta era da industrialização e racionalização da construção ao máximo: formas deslizantes; esquadrias produzidas industrialmente; elementos pré-moldados para vedação ou circulação vertical, etc. Os arquitetos chegaram a projetar os fogões e geladeiras como elementos da construção.

Planta da unidade habitacional do conjunto Zezinho Magalhães Prado Guarulhos, SP, 1967

projeto: Fábio Penteado, João Batista Vilanova Artigas, Paulo Mendes da Rocha e equipe

fonte: acervo da biblioteca da FAUUSP

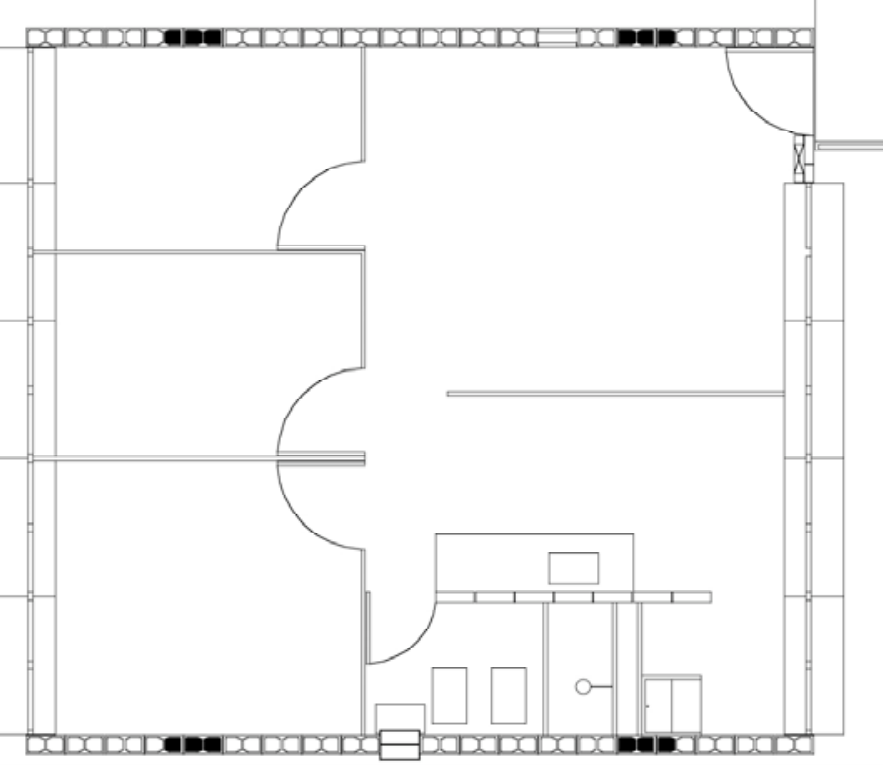

Mantendo uma coerência com suas preocupações iniciais, expressas nos primeiros projetos de edifícios habitacionais, Abrahão incorpora, em seus projetos para conjuntos habitacionais, as soluções adotadas Conjunto Habitacional Zezinho Magalhães Prado, relativas à industrialização e racionalização dos sistemas construtivos. 
Conjunto Residencial Nova Cidade - 1970

Jundiaí, SP

fonte [imagens] acervo do escritório Elito Arquitetos

[desenhos] acervo da biblioteca da FAUUSP 
A configuração do terreno, praticamente um triângulo, com o lado maior paralelo à Estrada de Ferro Santos - Jundiaí, e o acesso principal pelo vértice oposto, sugeriram a implantação dos blocos perpendicularmente ao lado maior, definindo, no centro do terreno uma grande área de lazer, ajardinada, com plena visão da Estrada de Ferro.

A área total do terreno é de $29.000 \mathrm{~m}^{2}$ e, nele, estão 144 unidades habitacionais divididas em 24 blocos.

O pavimento térreo de cada bloco foi destinado ao estacionamento de veículos dos moradores. Sobre o pilotis, três andares com dois apartamentos por andar, com $74 \mathrm{~m}^{2}$ úteis cada, respondem ao programa: sala, cozinha, área de serviços, banheiro e três quartos.

Os blocos sempre agrupados dois a dois e colocados paralelos e a meio nível um do outro, dividem a circulação vertical por escada.

O sistema construtivo é o mesmo para todo o conjunto. Consiste em uma estrutura de concreto armado, com pilares dispostos na periferia e lajes maciças suportadas por vigas altas aparentes que contraventam o sistema. O bloco hidráulico é unificado a cada prumada de apartamentos. As paredes internas são executadas em painéis pré-moldados de gesso.
Sobre este projeto Maria Isabel Imbronito comentou:

O conjunto inaugura o sistema estrutural que Abrahão Sanovicz utilizou nos edifícios modulares. As fachadas que contêm as aberturas são formadas pelos pilares e vigas de concreto. Aos vãos encaixam-se os caixilhos. (IMBRONITO, 2003, p. 23).

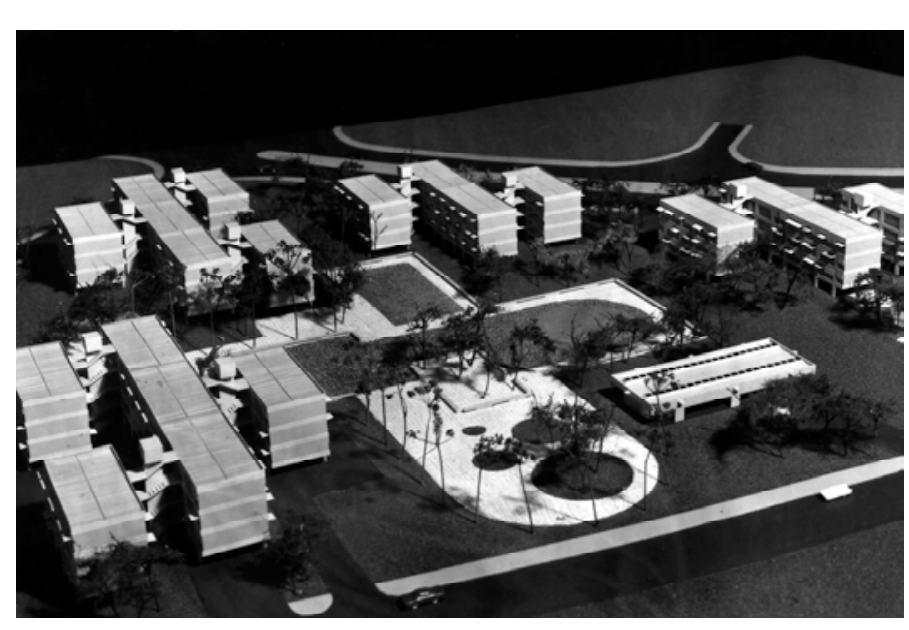




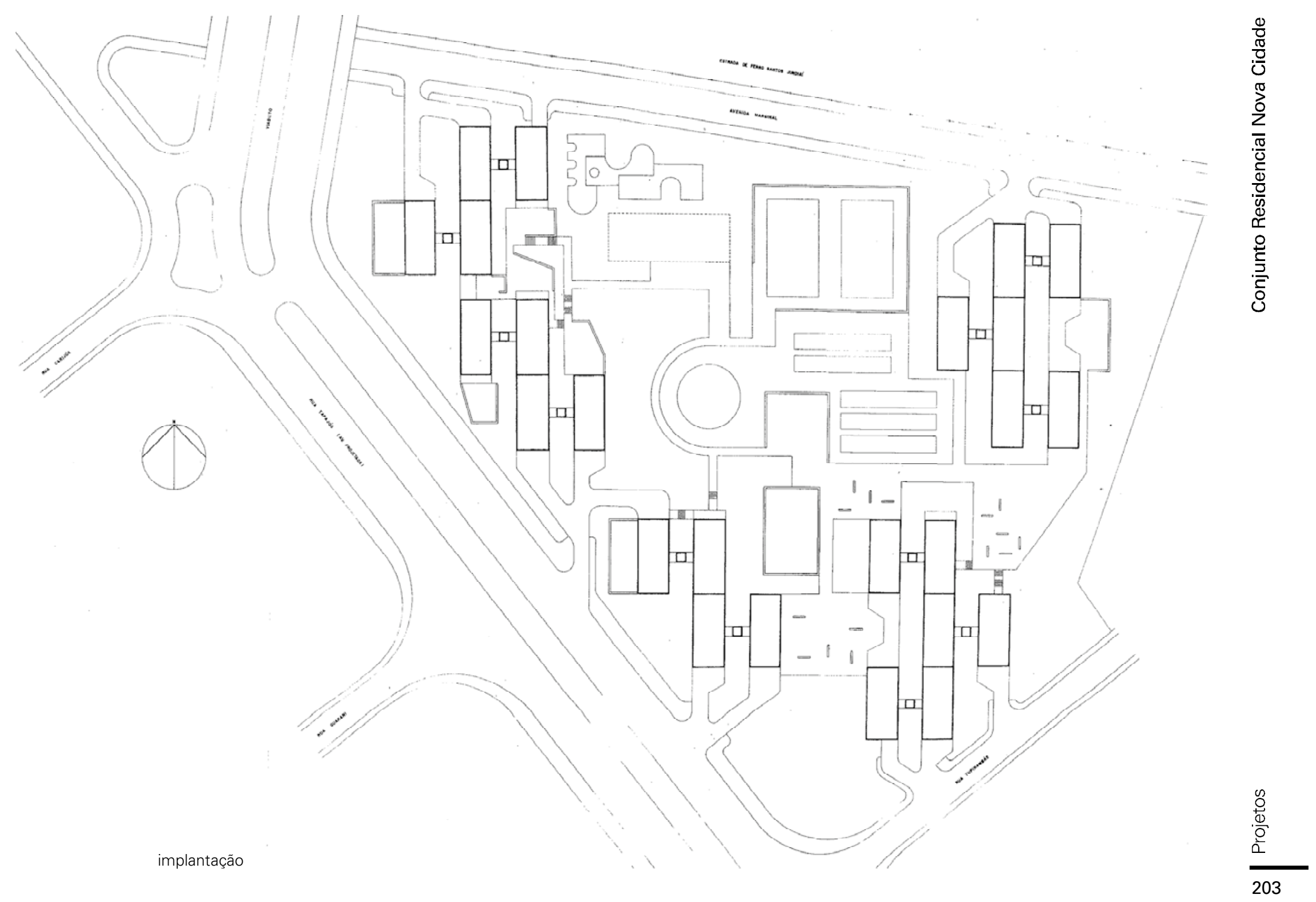



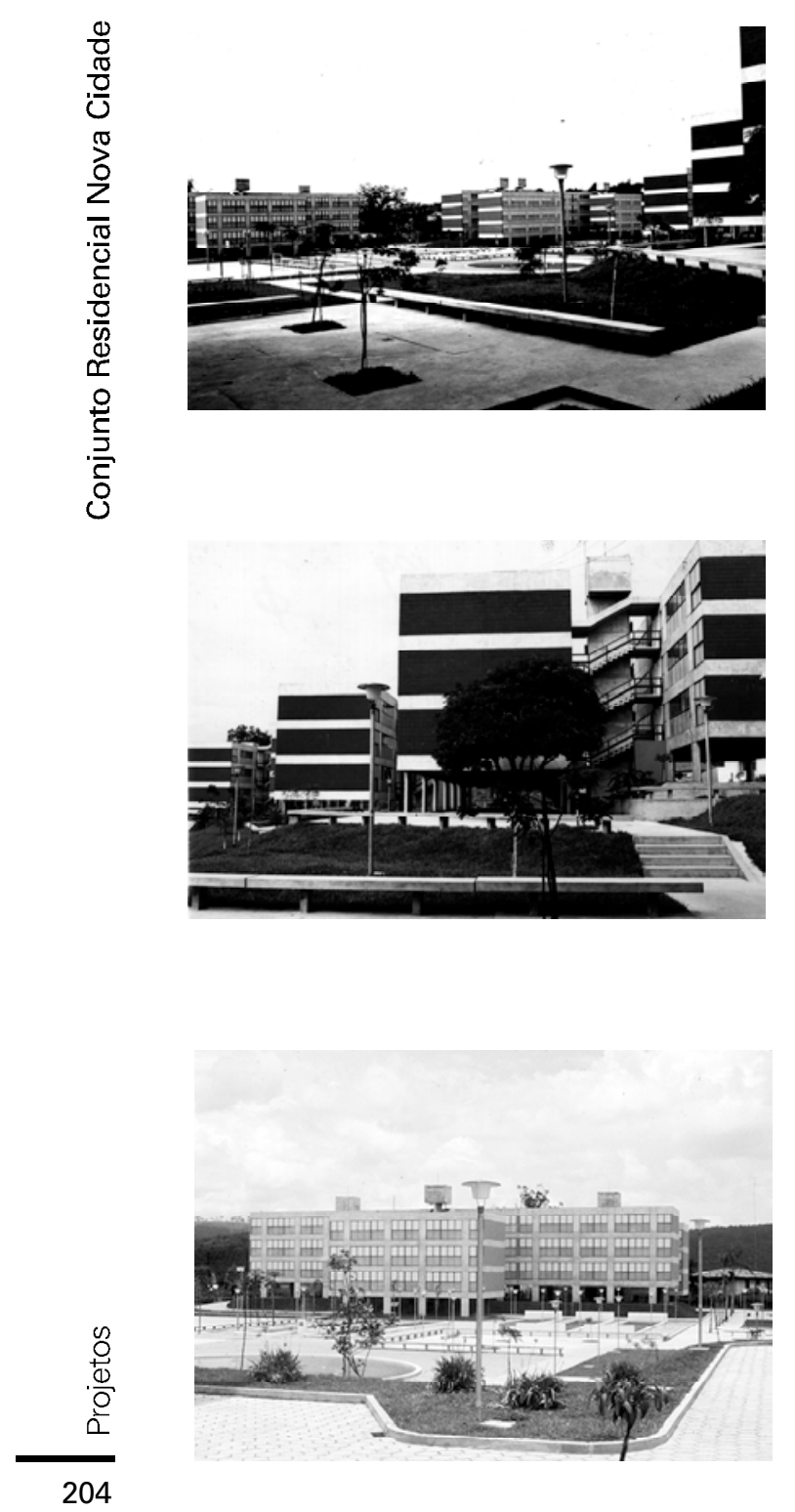


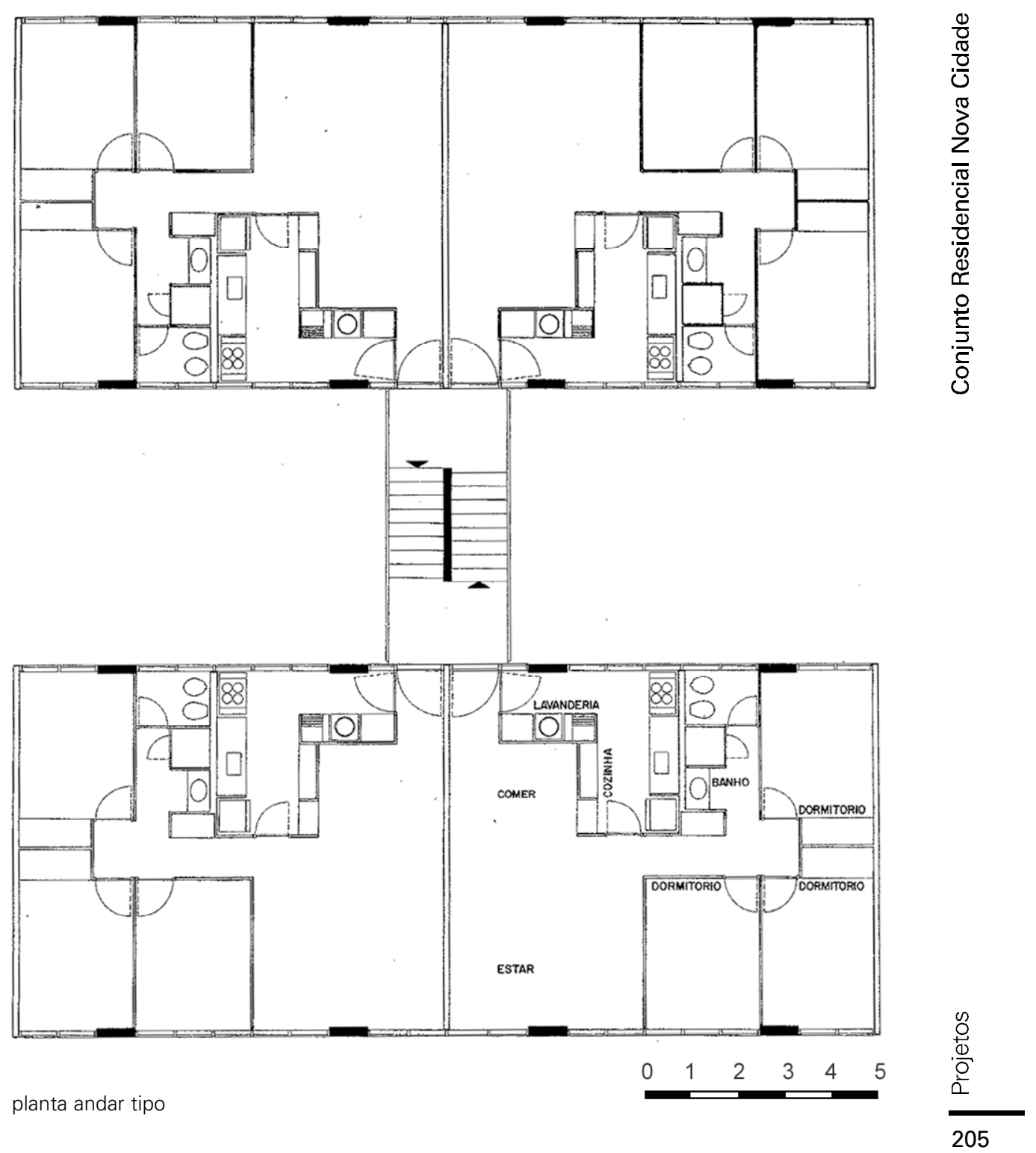




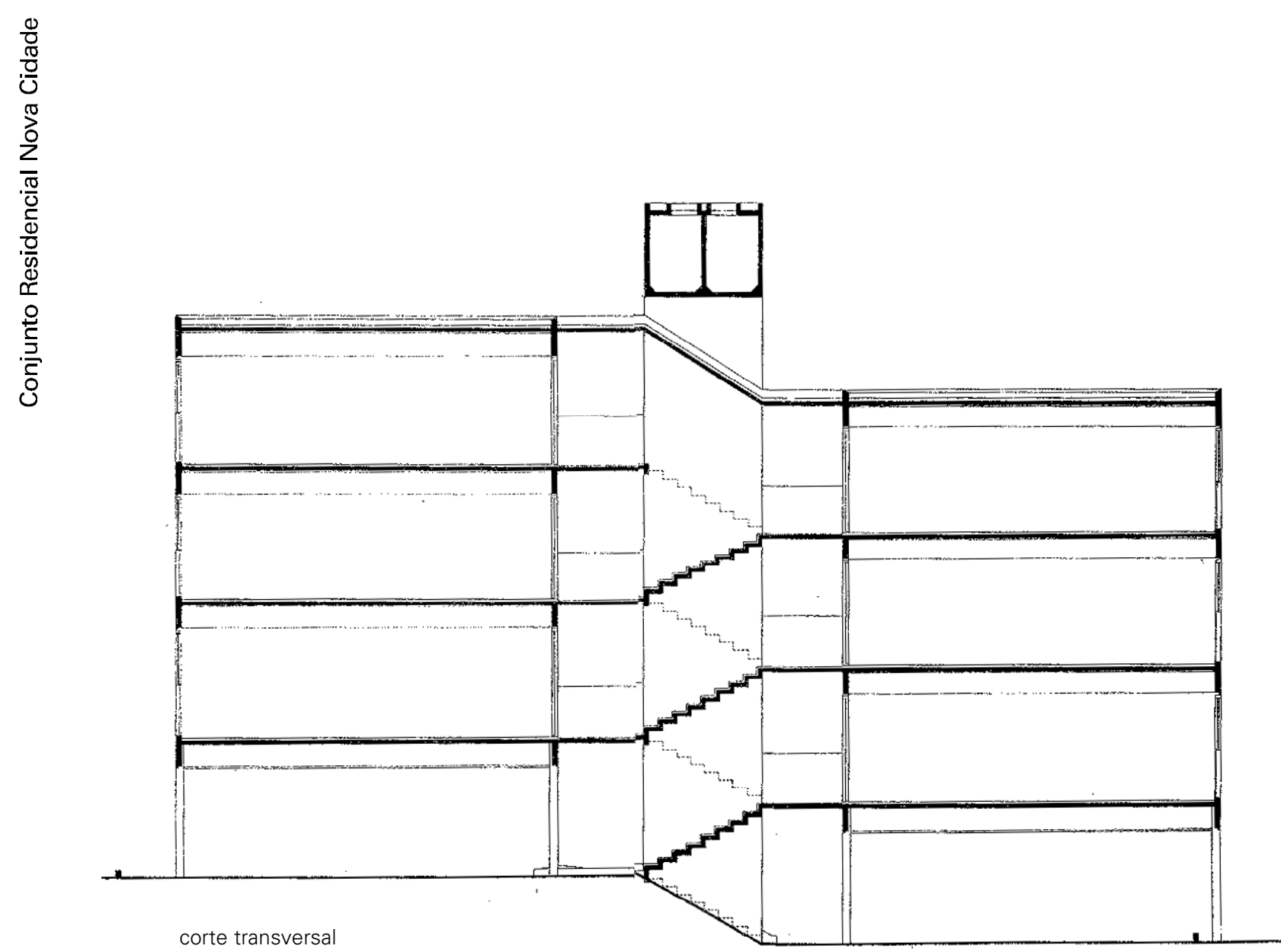

$\begin{array}{r}\frac{2}{0} \\ \frac{0}{0} \\ \frac{0}{0} \\ \hline 206\end{array}$ 

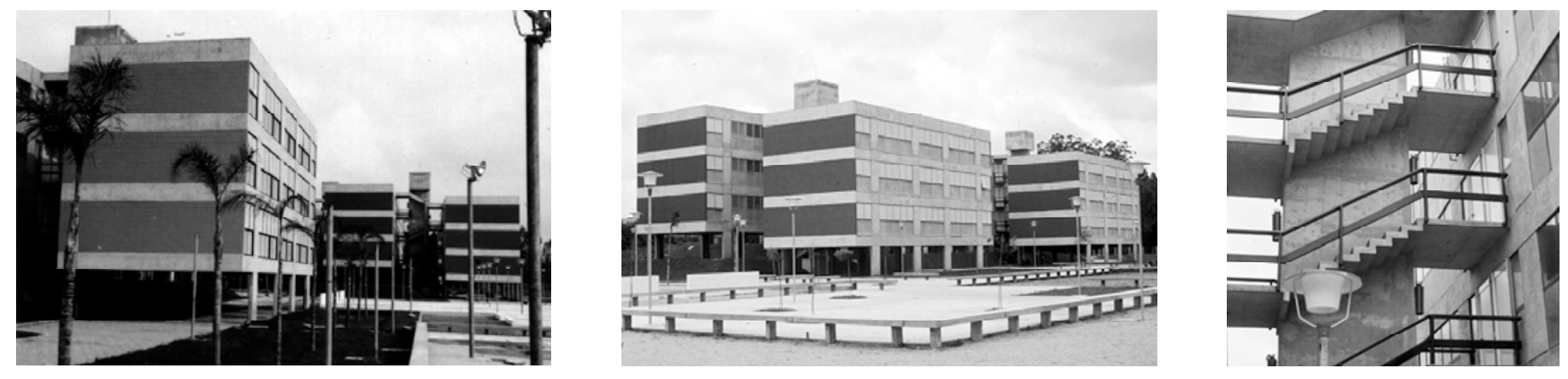

Parque Habitacional CECAP Serra Negra - 1975

Serra Negra, SP

fonte [imagens] acervo do escritório Elito Arquitetos

[desenhos] acervo da biblioteca da FAUUSP 
O projeto de Abrahão Sanovicz teve a colaboração do arquiteto José Carlos Olzon.

O terreno onde foi implantado o Parque Habitacional CECAP Serra Negra tem cerca de onze hectares. Fica a meia encosta, com acentuada declividade, em torno de $20 \%$. Extensa mata natural e nascentes foram preservadas.

Foram construídas 248 unidades habitacionais: 50 casas, em lotes isolados e 198 apartamentos divididos em sete blocos.

As casas foram implantadas na parte alta e regular do terreno, local originalmente mais plano. Ficam a cavaleiro do conjunto. Cada unidade tem $50 \mathrm{~m}^{2}$ de área útil sendo geminadas duas a duas. A solução contemplou dois quartos, banheiro e, conjugados, os espaços da sala, cozinha e área de serviços. Um volume solto, construído para envolver a geladeira, define as áreas da lavanderia e da sala.

Os apartamentos têm $60 \mathrm{~m}^{2}$ cada, com sala, cozinha, área de serviço, banheiro e três quartos voltados para o nascente.

O bloco hidráulico é concentrado a cada prumada de apartamentos. As vedações sob os caixilhos, inicialmente previstas como armários pré-moldados em argamassa armada, foram executadas no local.
Os blocos foram dispostos paralelamente às curvas de nível. Têm o térreo livre para estacionamento mais três andares de apartamentos. A circulação vertical, num volume externo ao bloco, serve a dois apartamentos por andar.

O projeto paisagístico de Fernando Chacel resgatou para as áreas alteradas do terreno a integração desejada com as partes preservadas. 

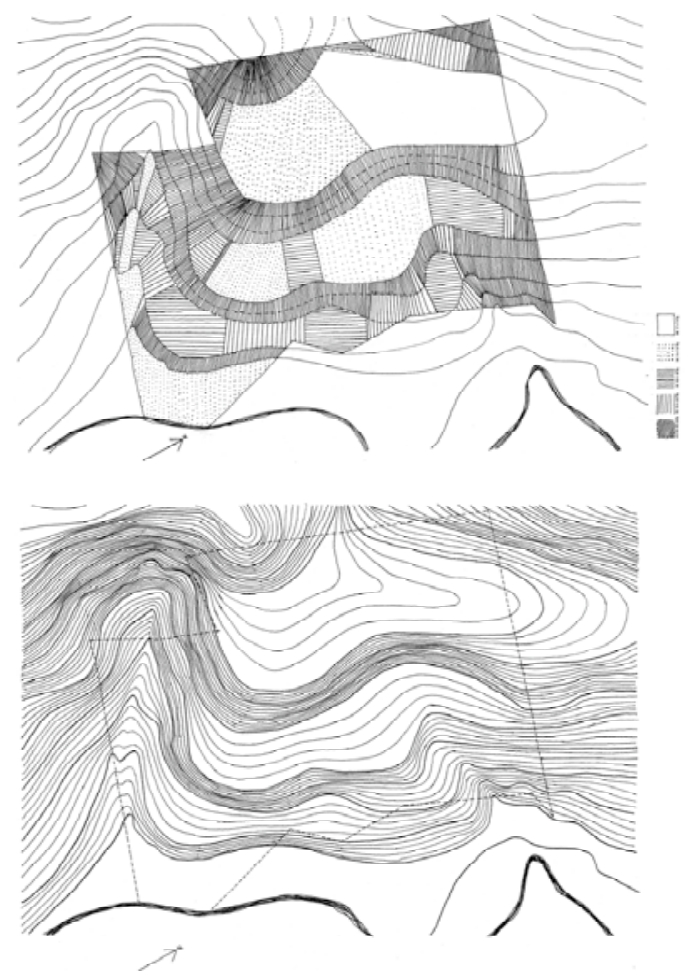

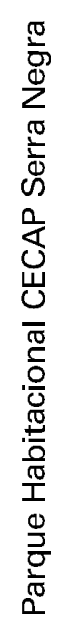

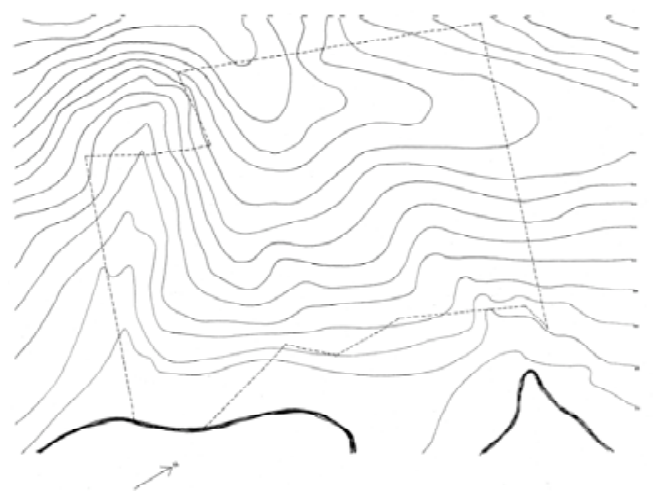



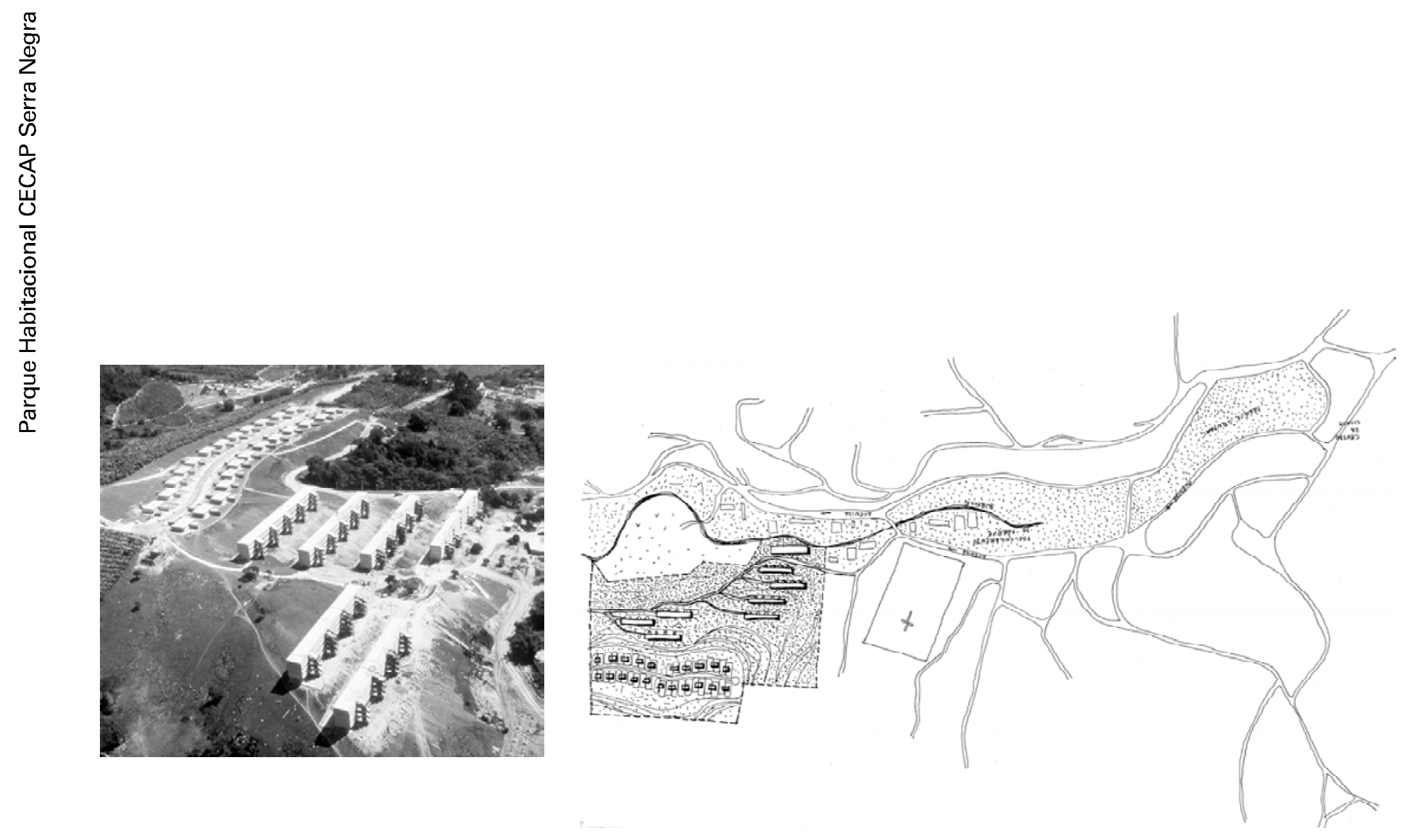

$\begin{array}{r}\frac{2}{0} \\ \frac{0}{0} \\ \frac{0}{0} \\ \hline 212 \\ \hline 212\end{array}$ 


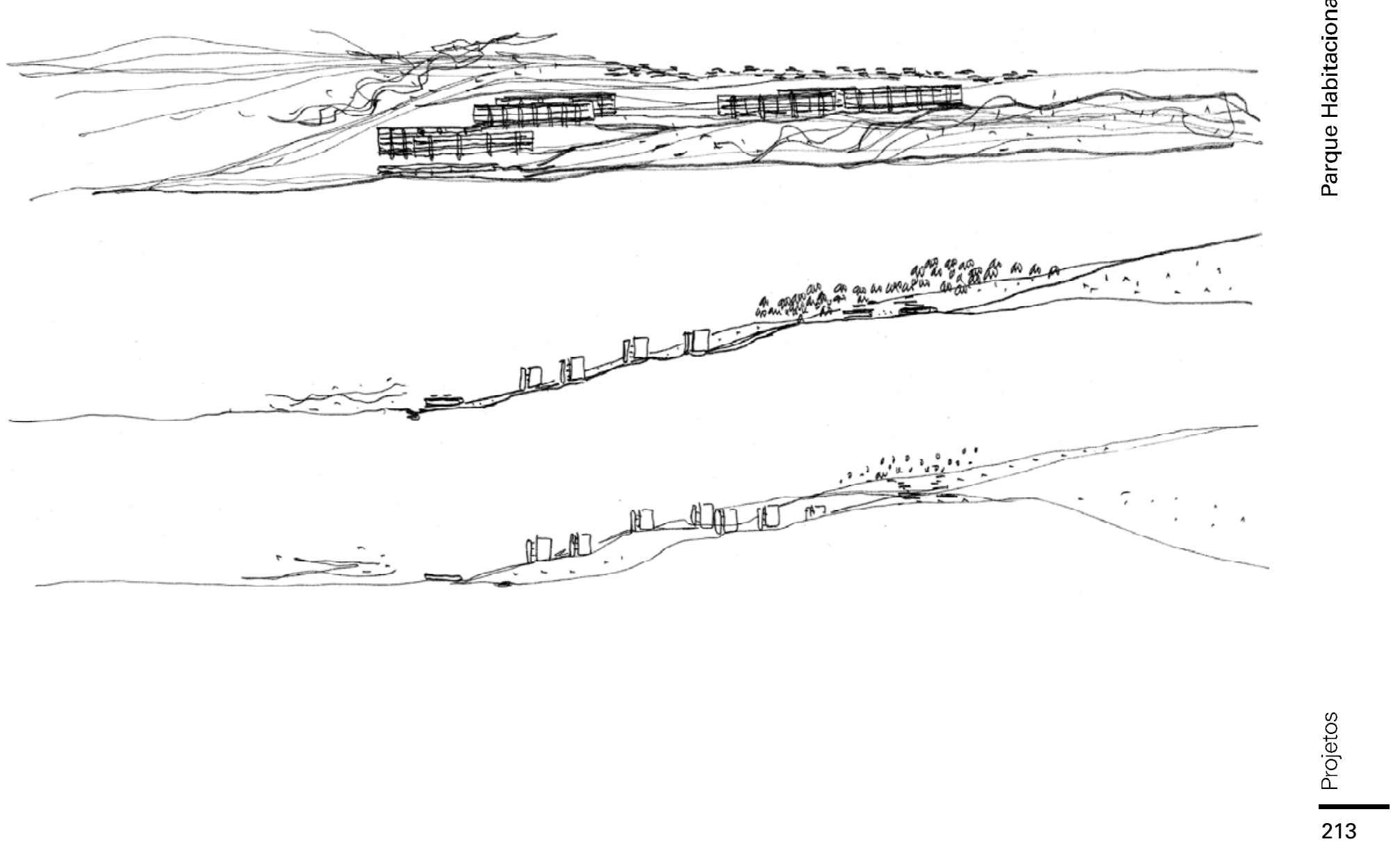




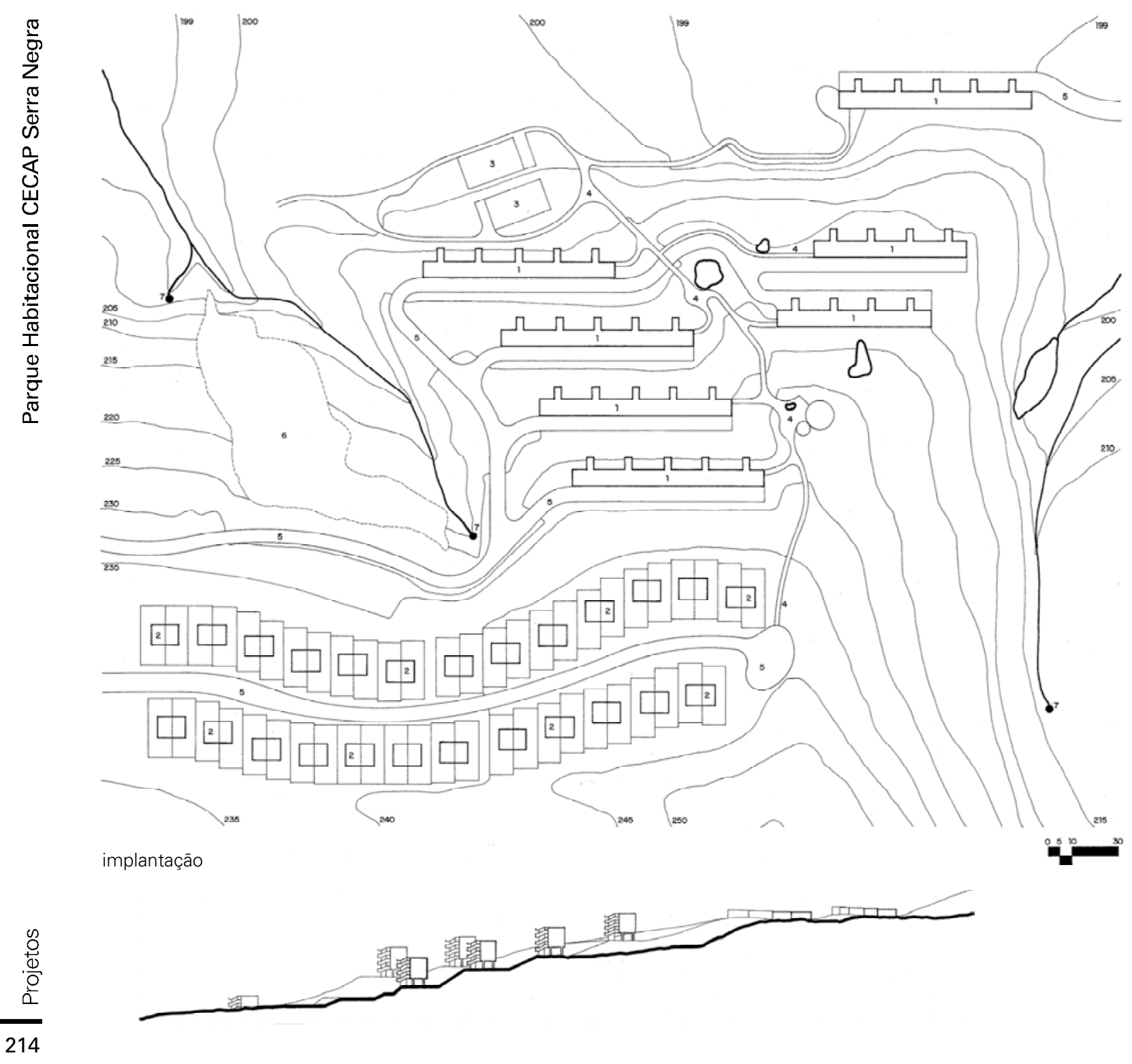



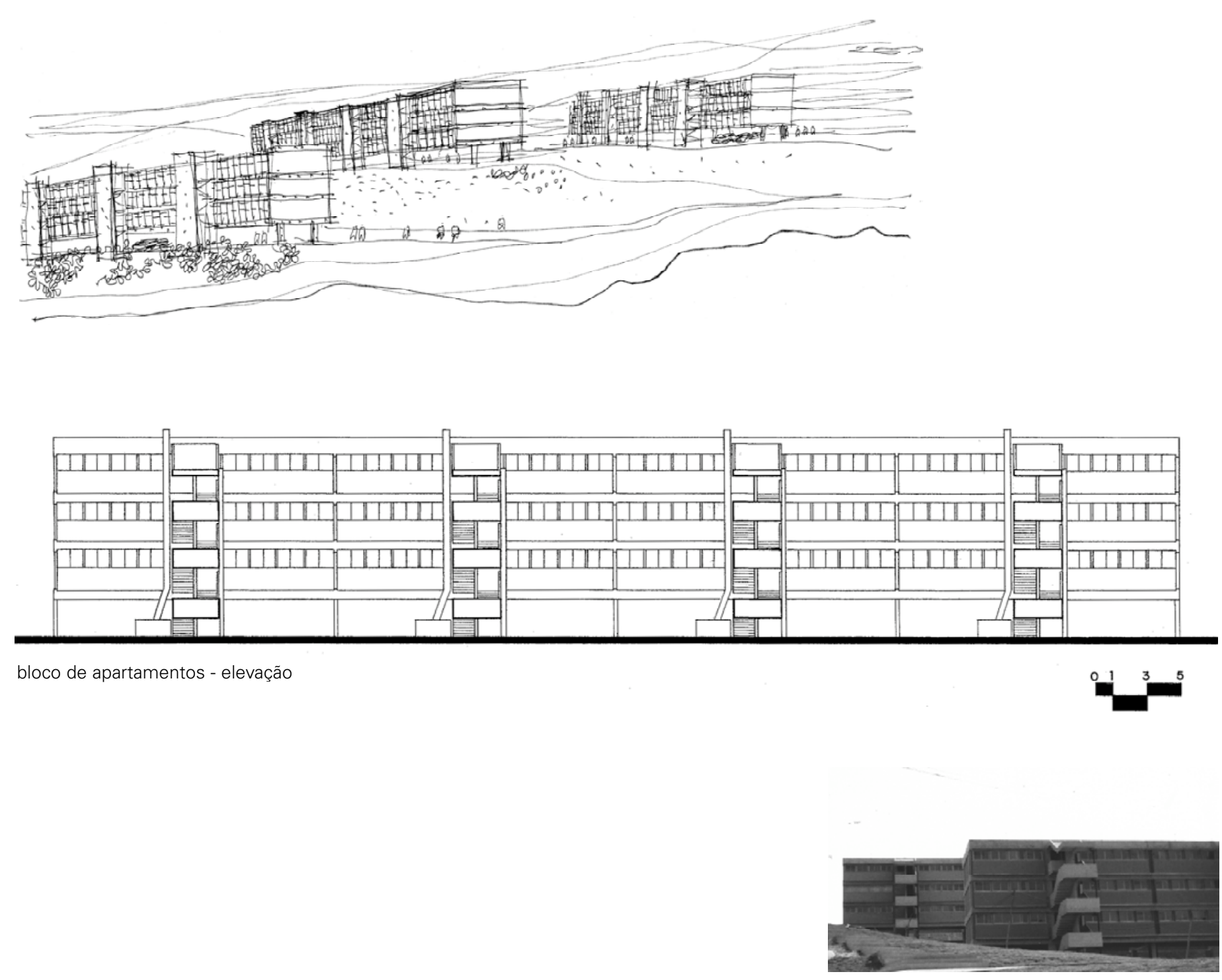


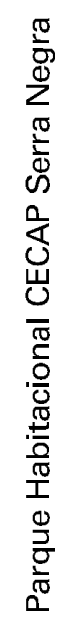
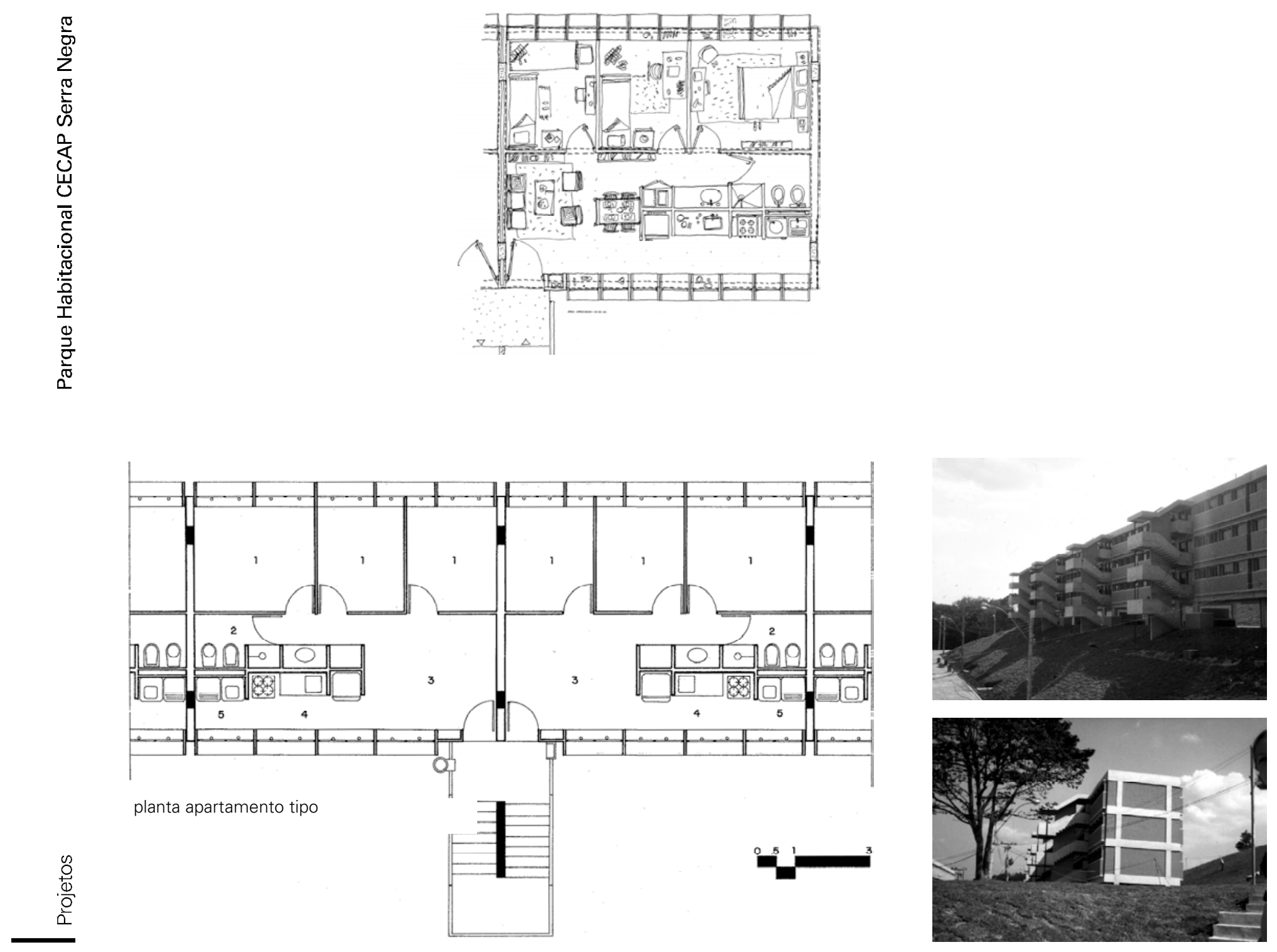

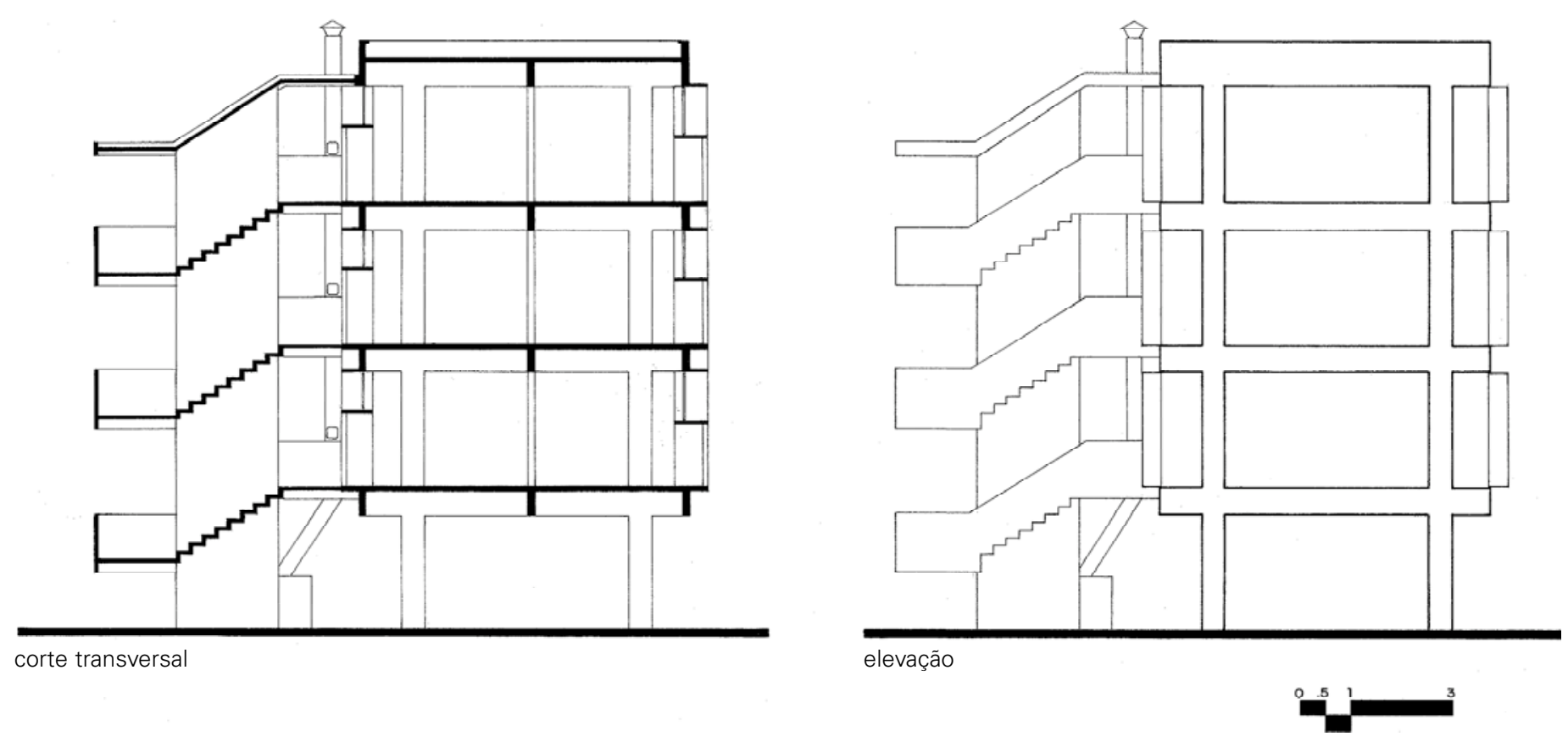

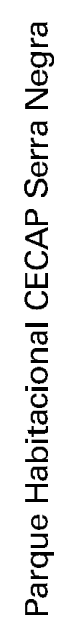



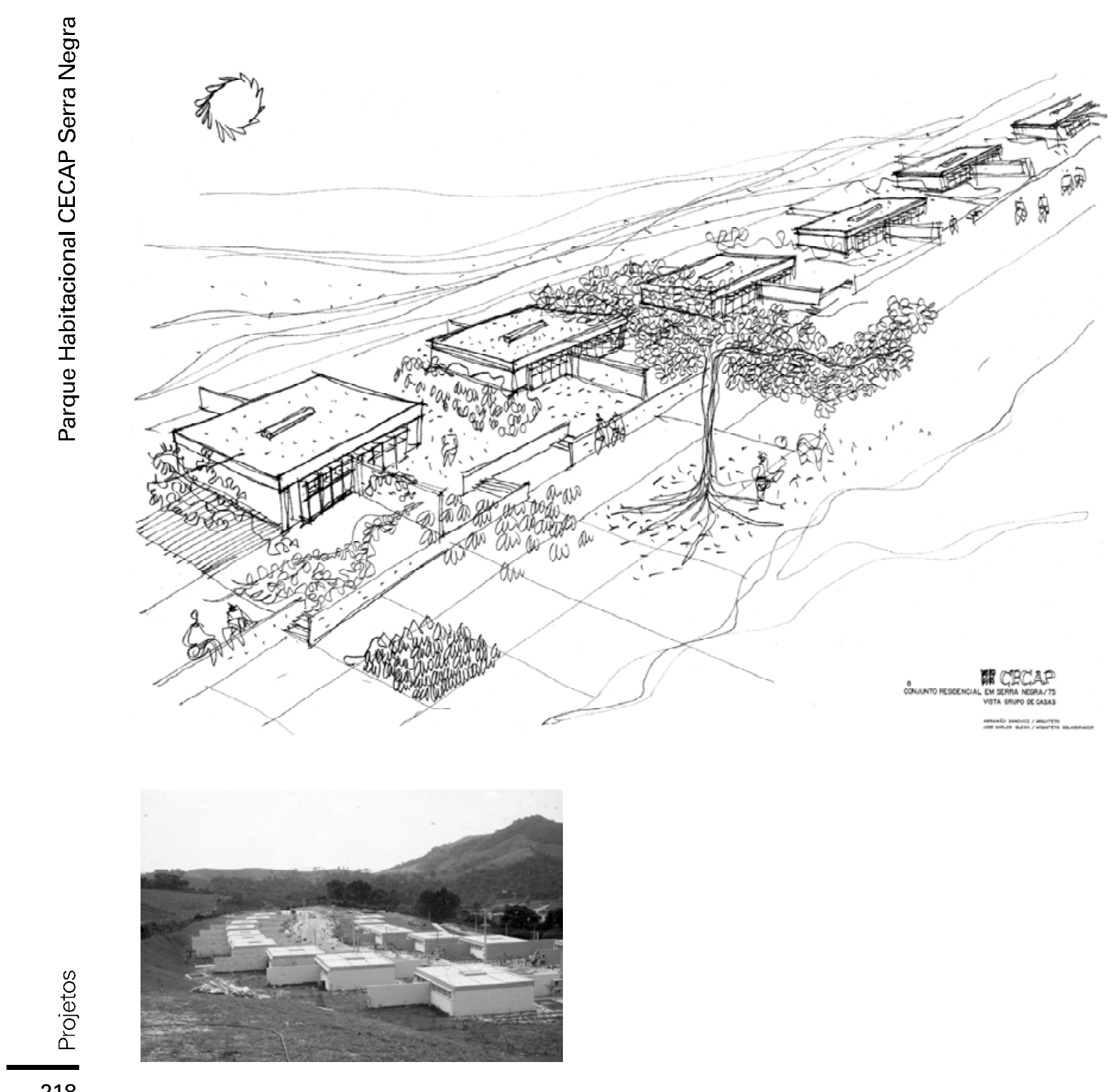

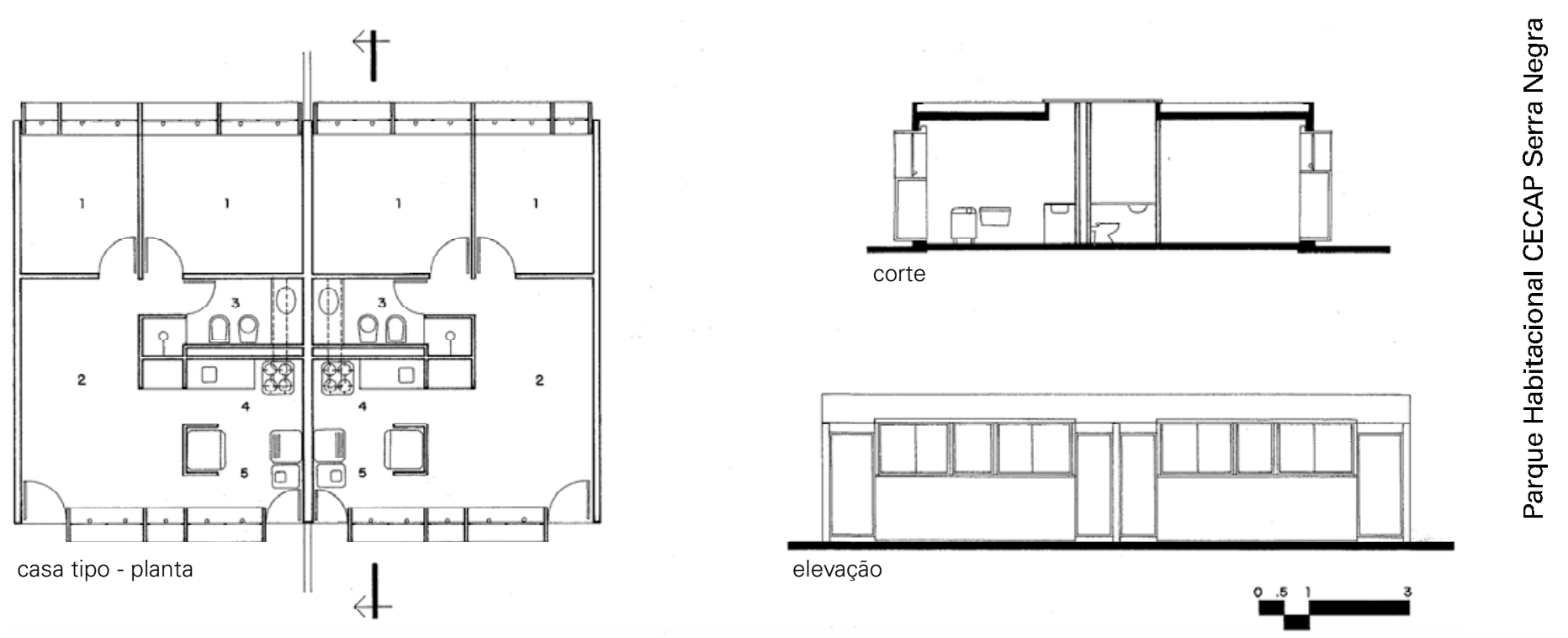

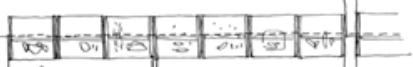
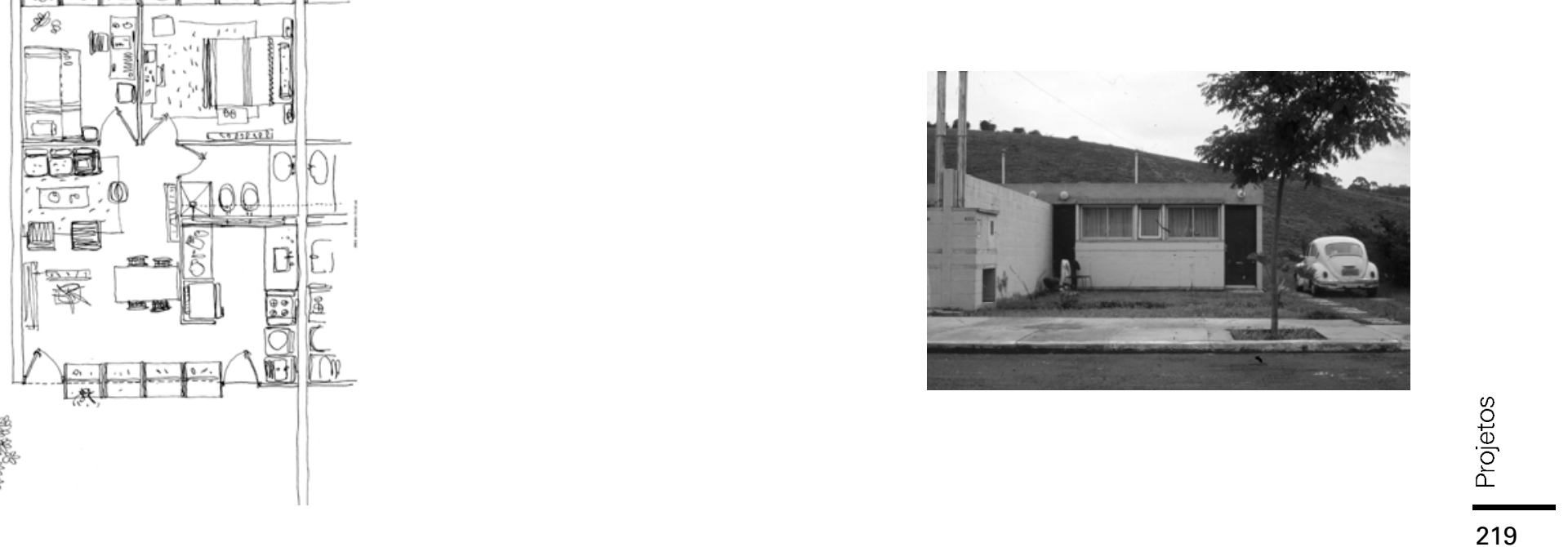

Parque Habitacional CECAP Sumaré - 1976

Sumaré, SP

fonte [imagens] acervo do escritório Elito Arquitetos

[desenhos] acervo da biblioteca da FAUUSP 
O Parque Habitacional CECAP Sumaré, não foi construído. O terreno previsto, ficava junto à avenida que liga o centro da cidade de Sumaré ao bairro de Nova Veneza. Com desenho triangular, é delimitado nos outros dois lados por um córrego e um lago. Fica a meia encosta, com acentuada declividade, em torno de $20 \%$.

Para o conjunto previam-se 180 unidades habitacionais com $81 \mathrm{~m}^{2}$ cada: 66 casas, em lotes isolados e 114 apartamentos divididos em três blocos.

A organização geral do Parque reunia um bloco de apartamentos e um conjunto de vinte a vinte e quatro casas, constituindo três núcleos, implantados sempre paralelamente às curvas de nível.

As casas são geminadas duas a duas. A solução contemplou quatro quartos, dois banheiros, sala, cozinha e área de serviços. Na parte central, a sala de um lado e o volume dos banheiros, cozinha e serviço, organizam uma planta que prevê, no outro sentido, dois quartos de cada lado.

Os apartamentos respondem ao mesmo programa das casas. Os quartos ficam todos numa mesma fachada. Neste caso, porém, o volume constituído por banheiros, cozinha e serviços fica posicionado longitudinalmente à sala.
Os blocos têm o térreo livre para estacionamento mais três andares de apartamentos. A circulação vertical, num volume interno ao bloco, serve a dois apartamentos por andar. 


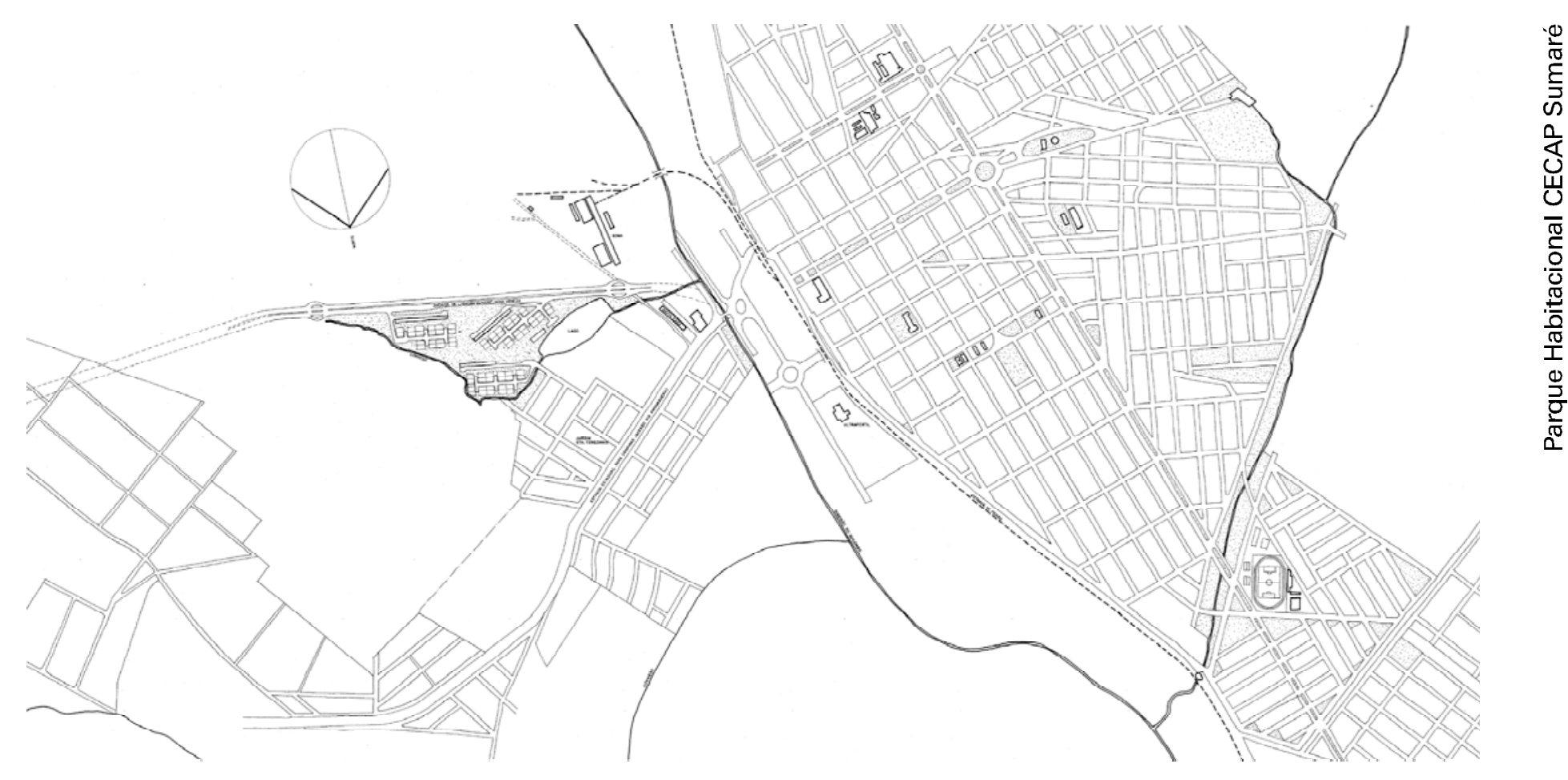

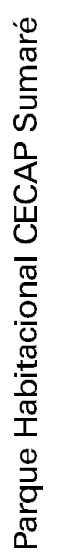

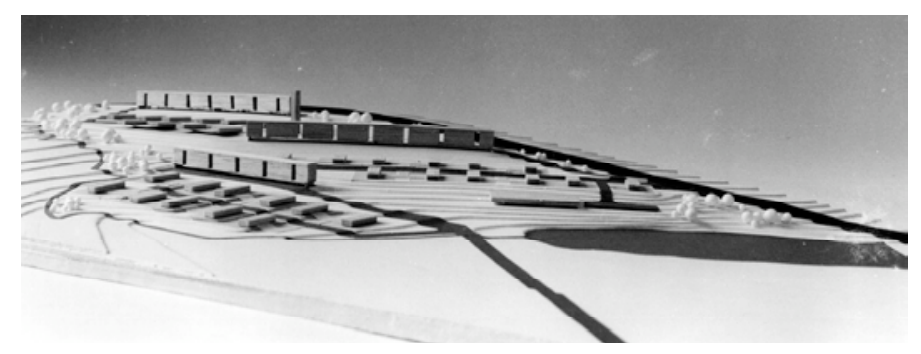




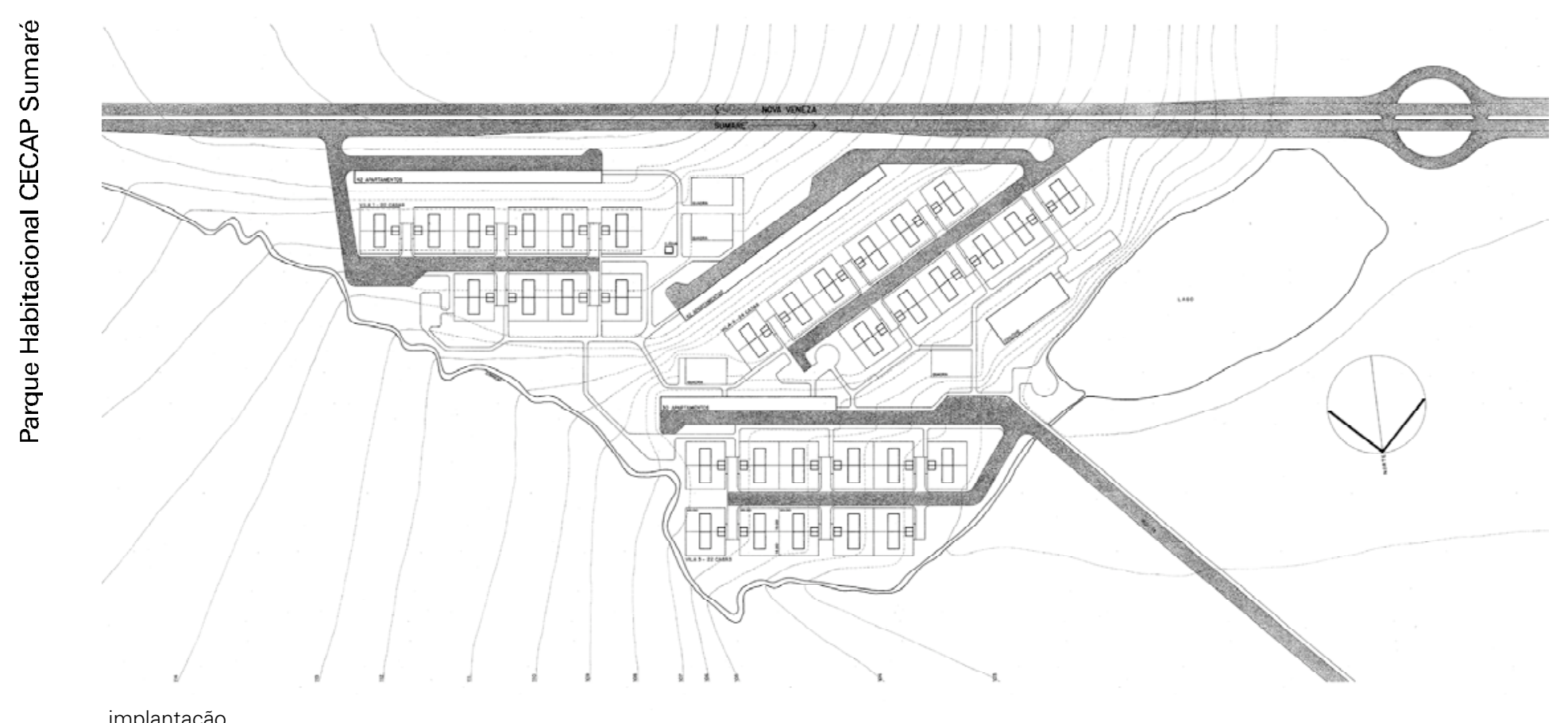

implantação

$\begin{array}{r}\frac{0}{0} \\ \frac{0}{0} \\ \frac{0}{0} \\ \hline 0 \\ \hline 224\end{array}$ 

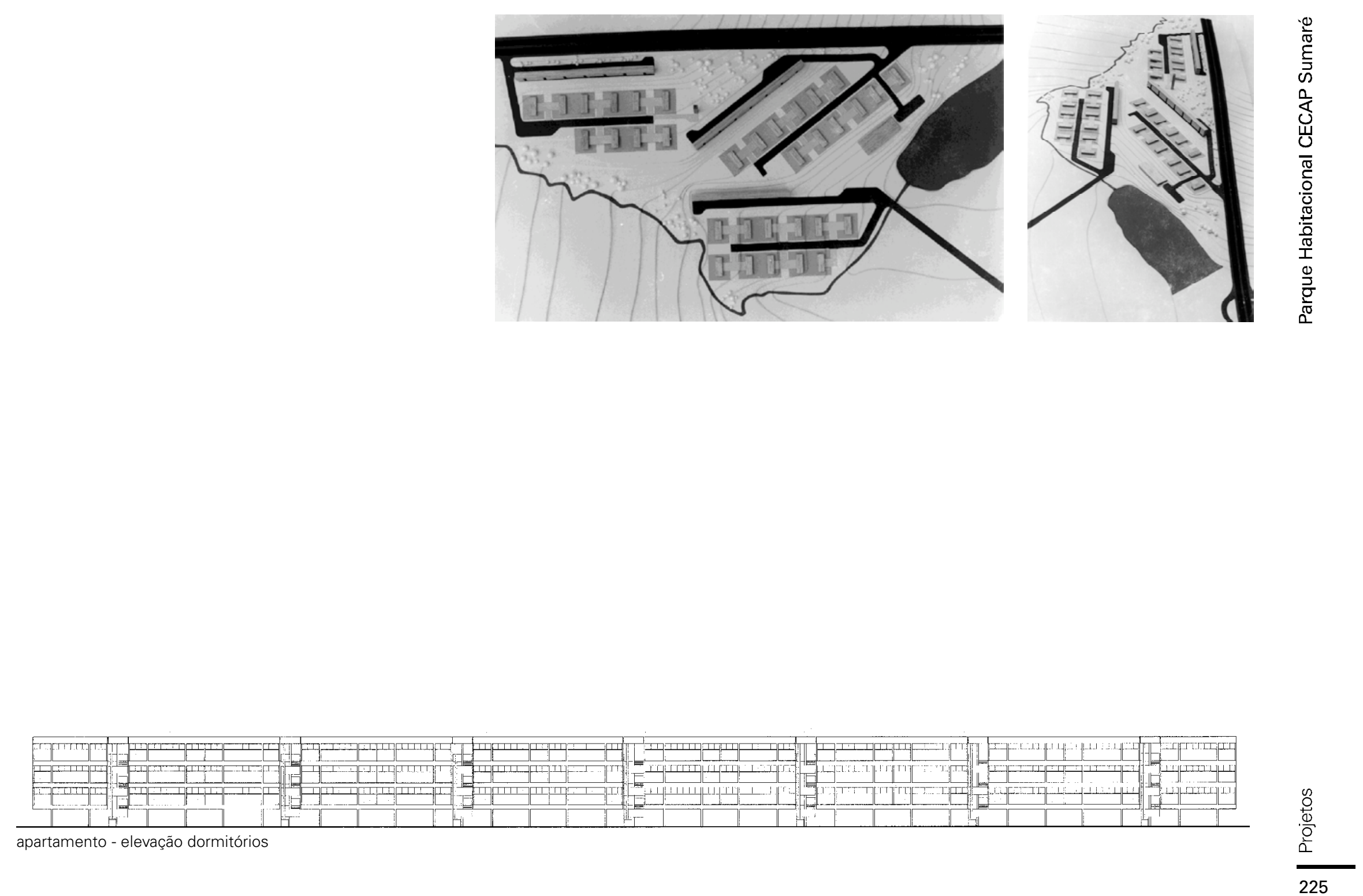


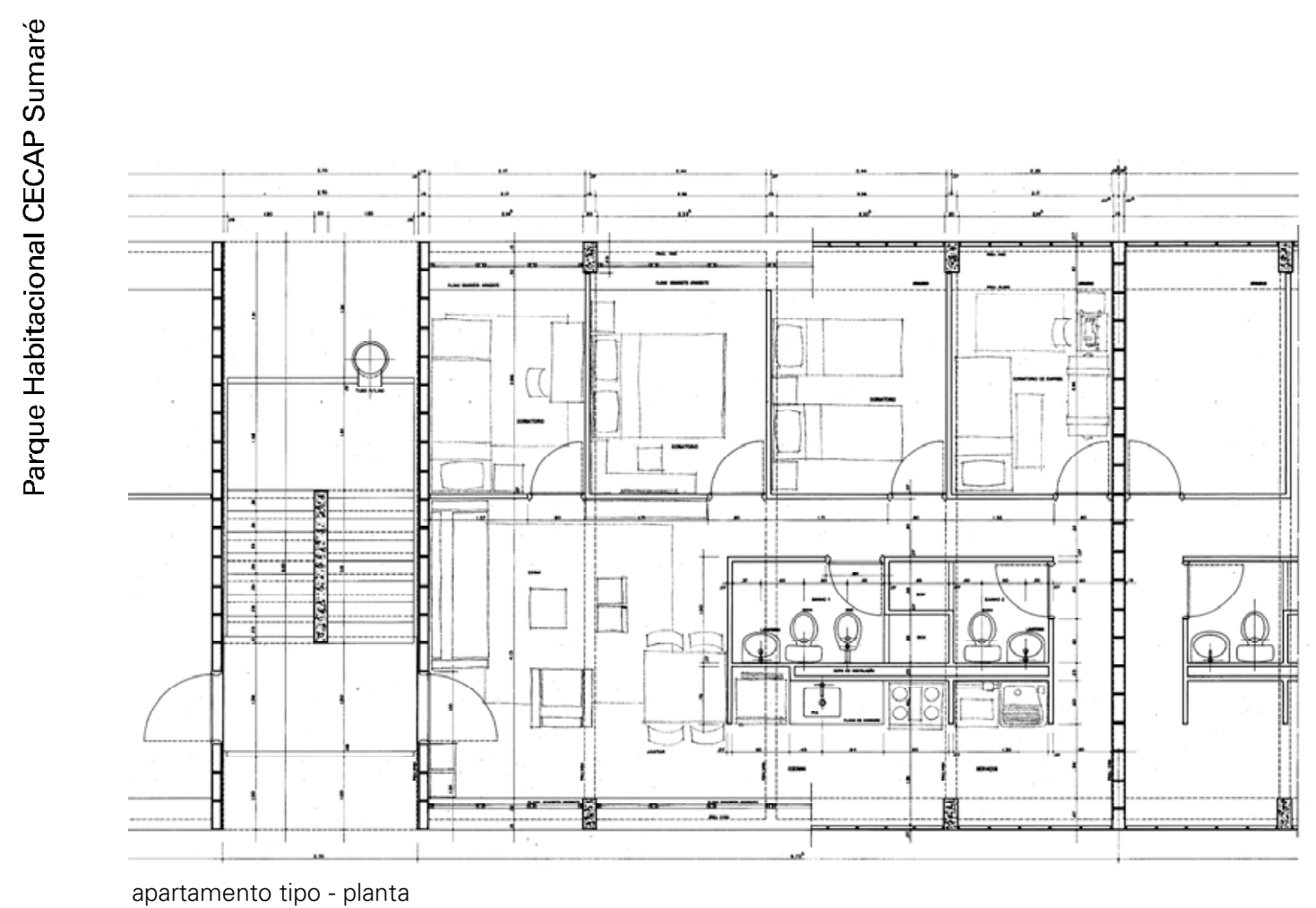

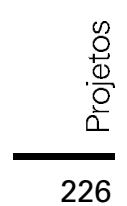




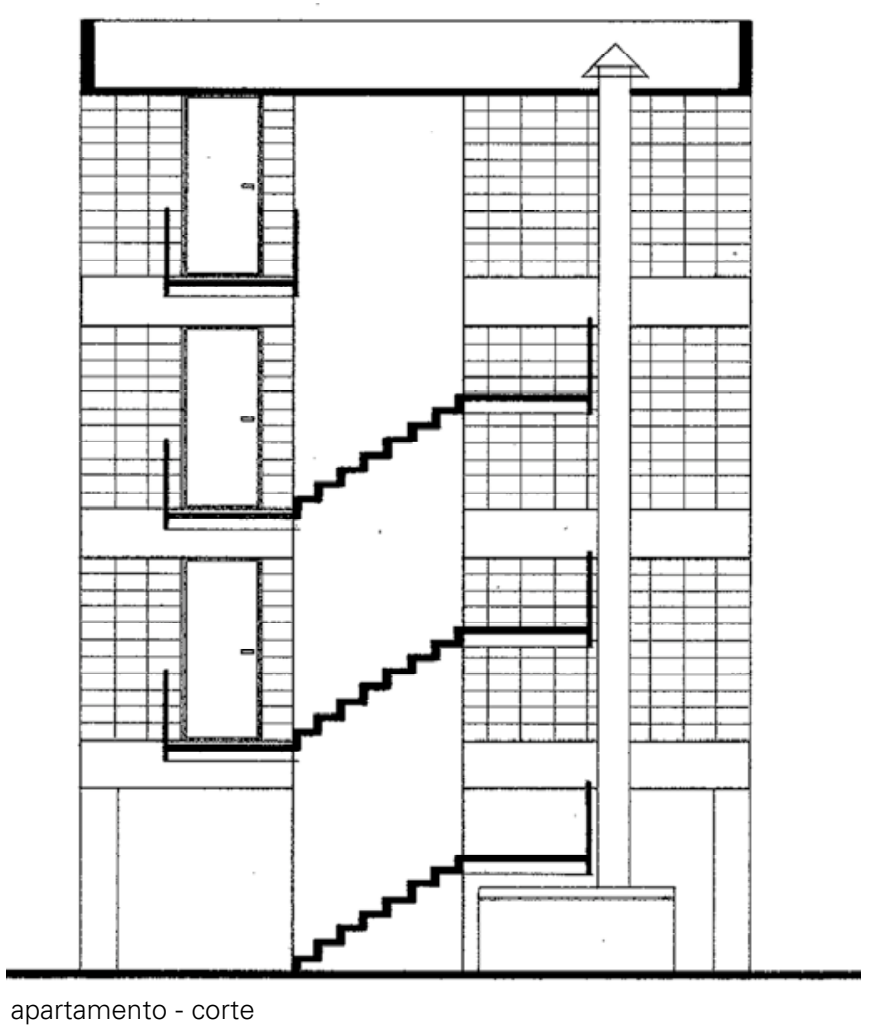

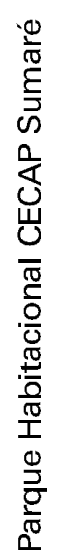

apartamento - corte 

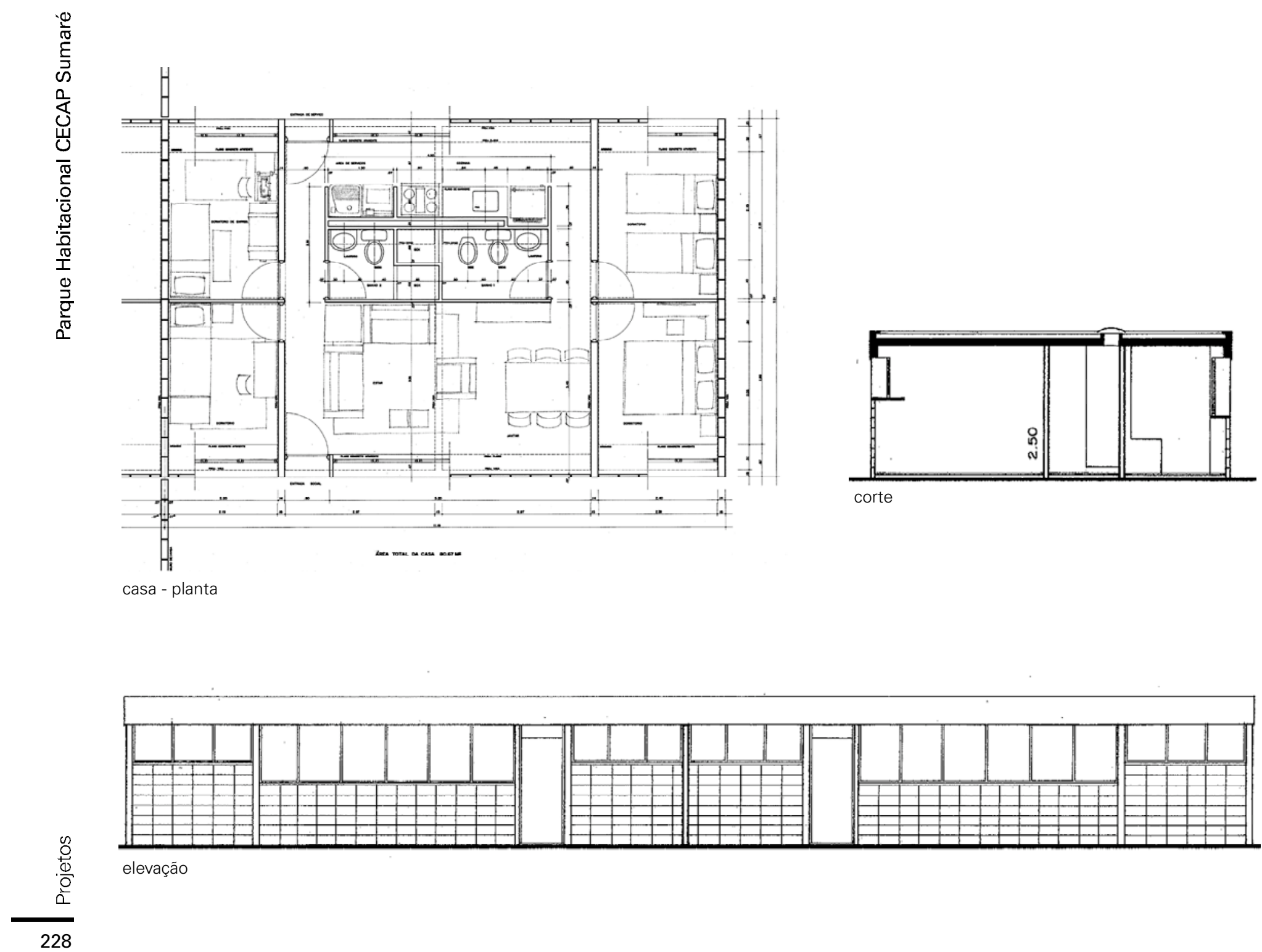
Vila Residencial da CESP Porto Primavera - 1979

Porto Primavera, SP

fonte [imagens] acervo do escritório Elito Arquitetos

[desenhos] acervo da biblioteca da FAUUSP 
O projeto de Abrahão Sanovicz teve a colaboração do arquiteto José Carlos Olzon.

O conjunto, que não foi construído, destinava-se à moradia dos funcionários especializados e dos profissionais estrangeiros que participariam da montagem da Usina de Porto Primavera. Previa 60 apartamentos divididos em cinco blocos e edifício de vivência comum.

O terreno, relativamente plano, possibilitou que a implantação dos blocos se acomodasse nos níveis do terreno, por meio de suaves rampas.

Nesse projeto também, o pilotis dos edifícios destinava-se ao estacionamento de veículos, contando com mais três andares de apartamentos. A circulação vertical, por escadas, serve dois apartamentos.

Como programa da unidade habitacional sala, três quartos, três banheiros, cozinha e área de serviço.

Foram previstos dois blocos hidráulicos: o primeiro, um volume solto, onde ficam dois banheiros, organiza de um lado a sala e do outro os quartos; o segundo, colocado no outro sentido, junto à entrada do apartamento, onde estão a cozinha, a área de serviços e o terceiro banheiro.

A solução estrutural foi projetada em concreto armado, com pilares na periferia e laje nervurada. 


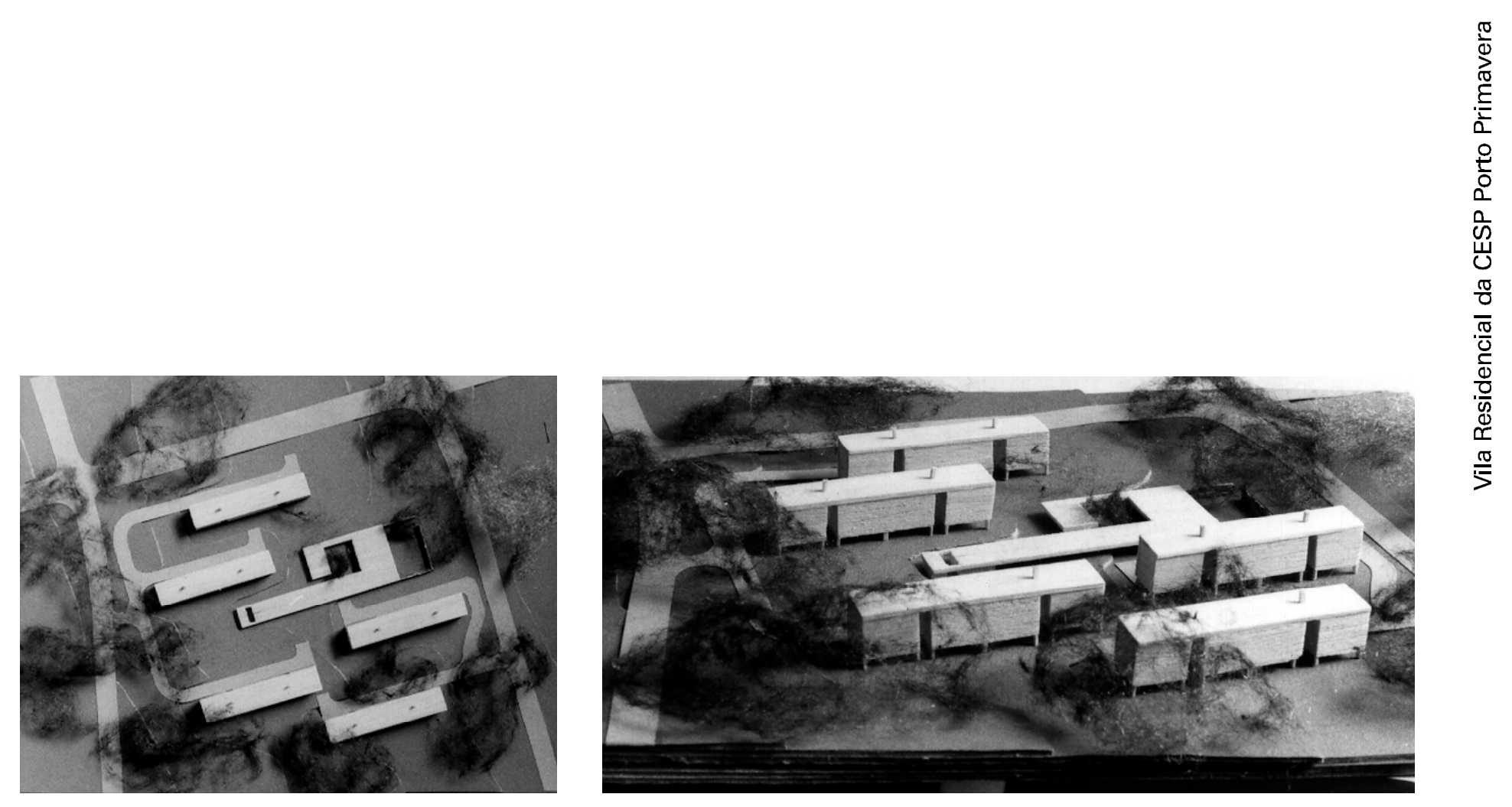

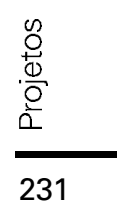




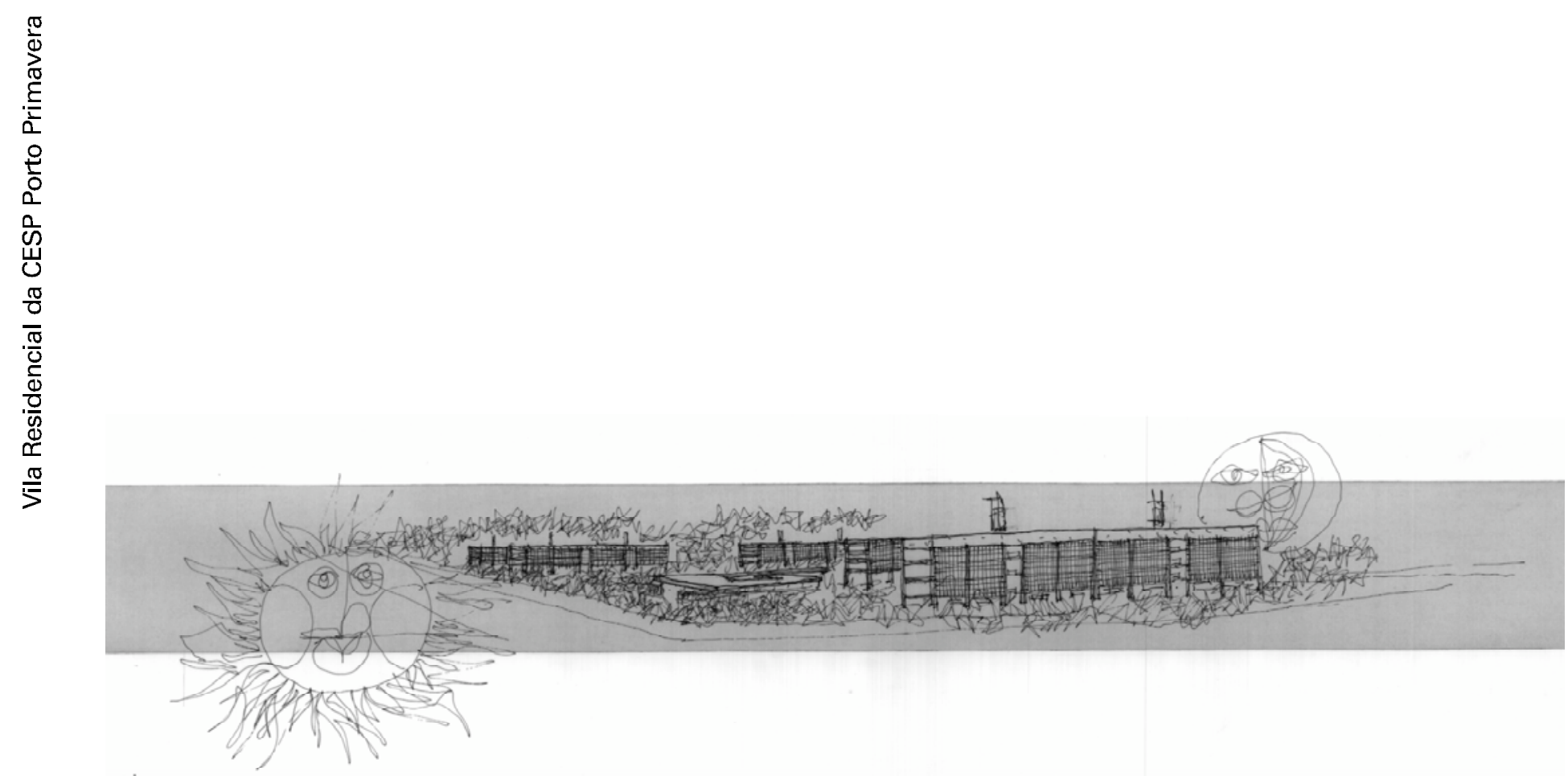

$\begin{array}{r}\frac{0}{0} \\ \frac{0}{0} \\ \frac{0}{0} \\ \hline \frac{10}{2} \\ \hline 232\end{array}$ 

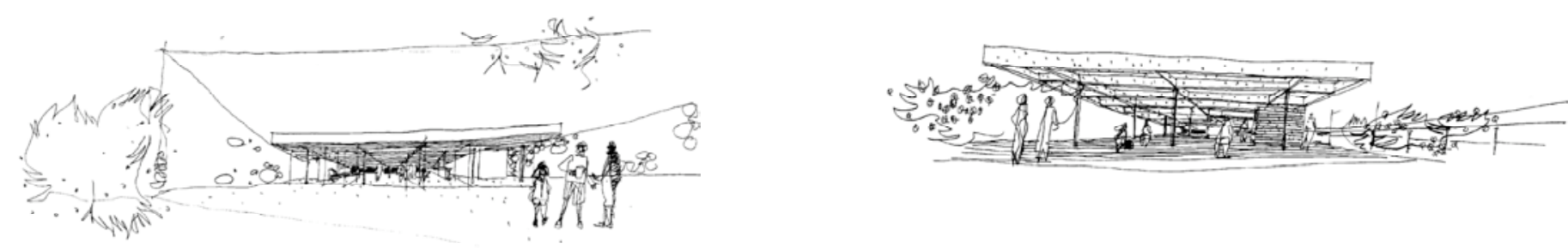

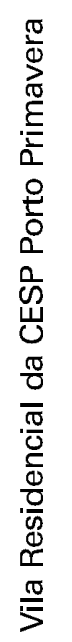
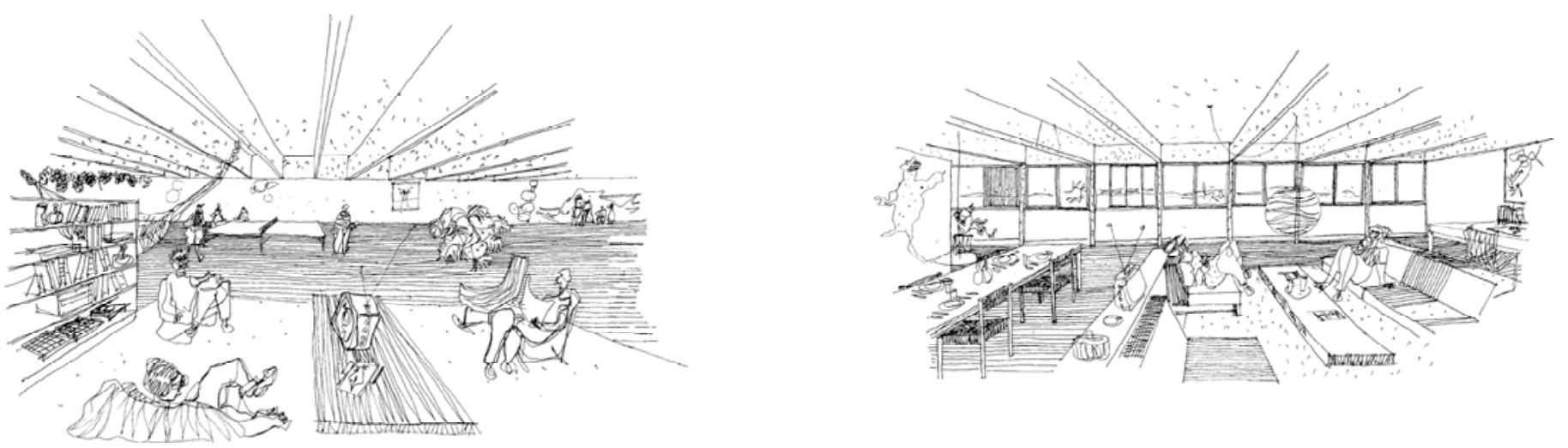

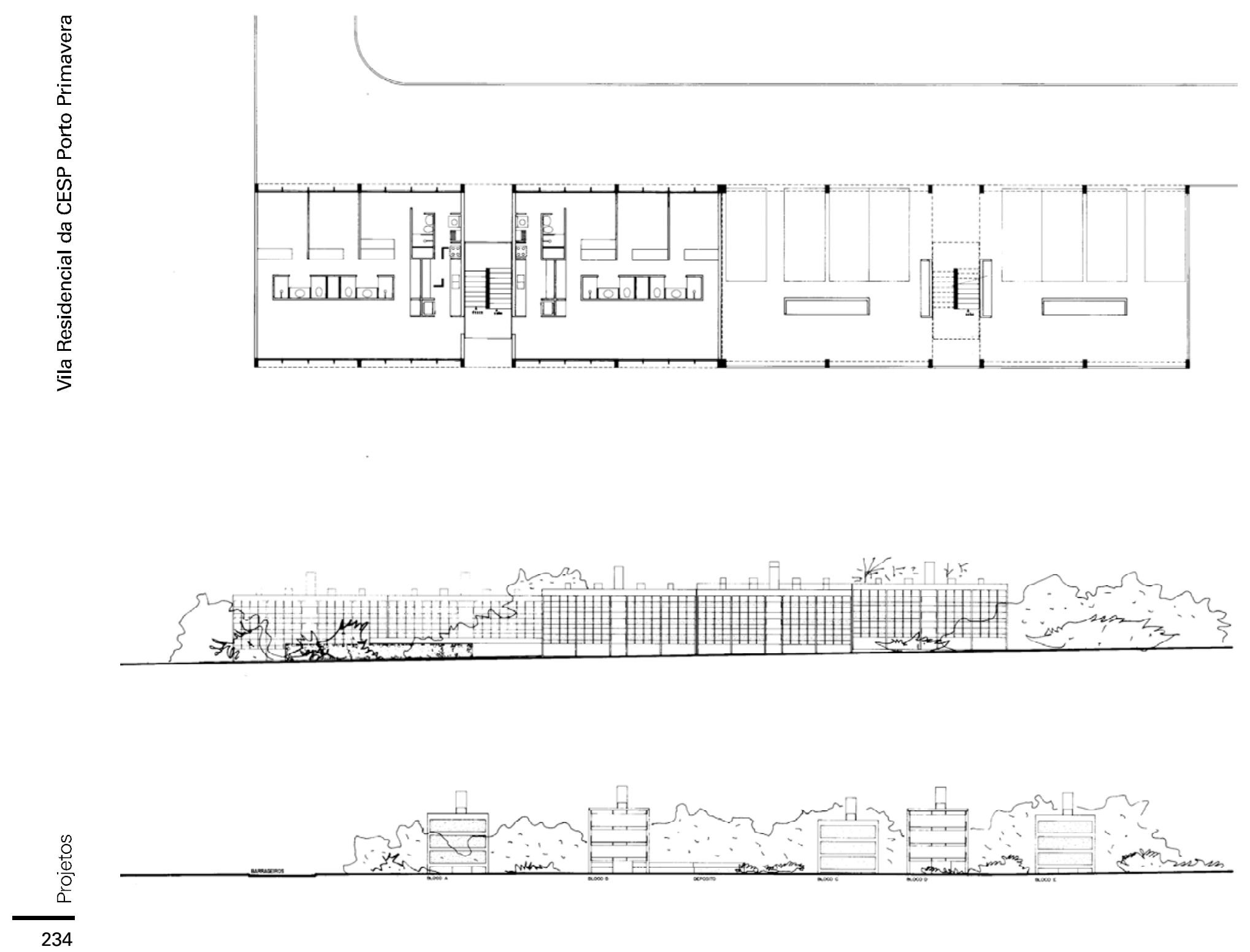

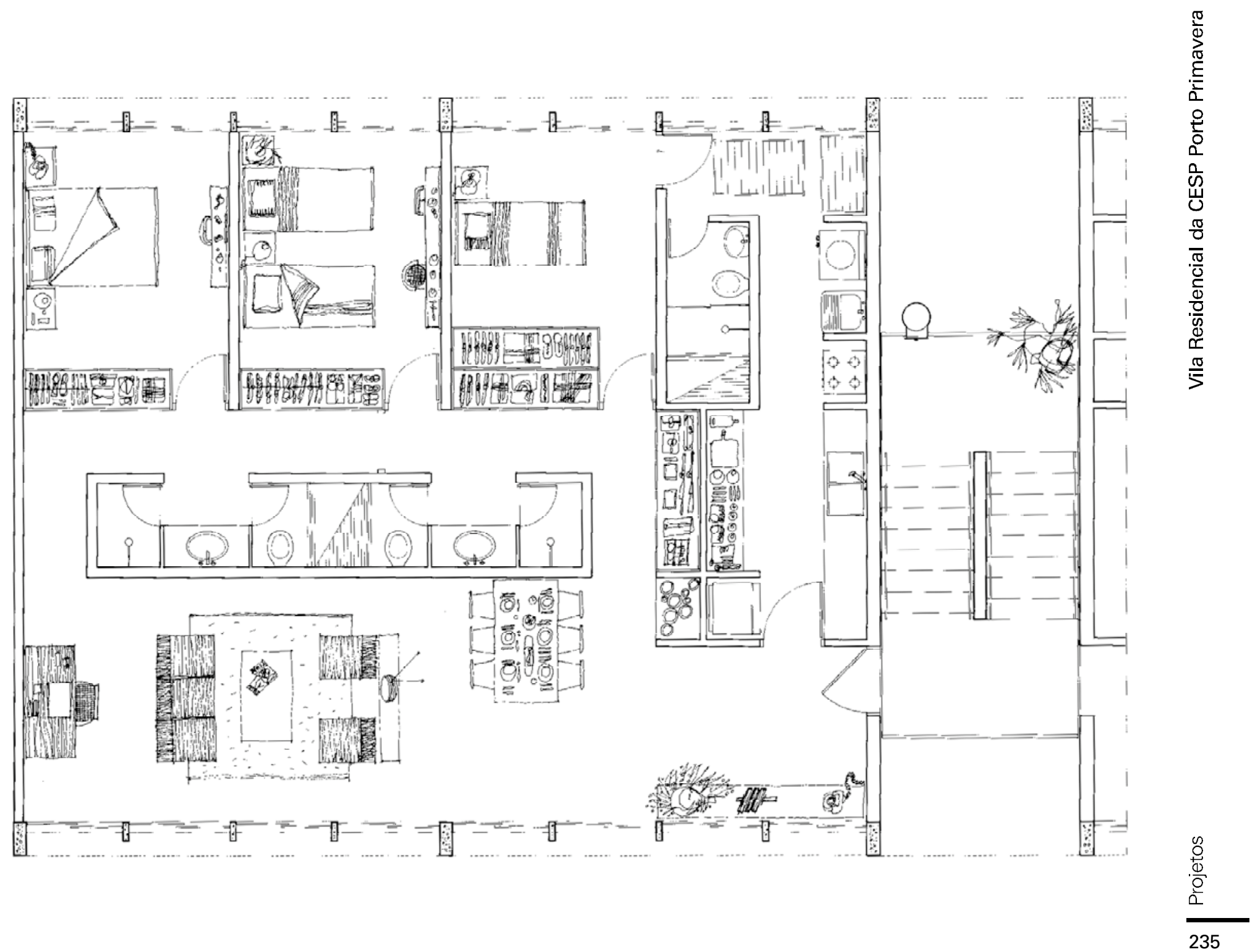



\section{Conjunto Habitacional Pascoal Melantônio}

Rua Pascoal Melantônio com Francisco Felippe Agosti, São Paulo, SP

\section{Conjunto Habitacional Celso dos Santos}

Avenida Celso dos Santos com Rua da Retificação, São Paulo, SP

1995

fonte [imagens] acervo do escritório Elito Arquitetos

[desenhos] acervo da biblioteca da FAUUSP 
O̊ Os projeto para os Conjuntos Habitacionais Pascoal Melantônio e Celso dos Santos foram realizados pela equipe de arquitetos composta por: Abrahão Sanovicz, Edson Jorge Elito, João Honório de Mello Filho, Luiz Guimarães Soares e Marcos José Carrilho.

O Programa de Saneamento Ambiental da Bacia do Guarapiranga previa o reassentamento de famílias que moravam em favelas ou lotes clandestinos nas áreas de proteção aos mananciais. Assim, estabelecia para o conjunto Pascoal Melantônio, a construção de 102 unidades habitacionais e para o Celso dos Santos 160. A área dos apartamentos em ambos os conjuntos é de $42,68 \mathrm{~m}^{2}$, compreendendo sala conjugada com a cozinha, dois quartos, banheiro e área de serviço.

Os terrenos eram pequenos e com acentuada declividade.

A proposta foi a mesma para os dois casos: concentrar todos os apartamentos em dois blocos, implantados contra as curvas de nível. Assim, criou-se um pavimento intermediário livre, no nível do acesso principal da rua, onde estão as áreas de uso comunitário e as prumadas de circulação vertical, por escadas. A partir do nível intermediário foram construídos quatro andares para cima e quatro andares para baixo, prescindindo do uso de elevadores.

O sistema construtivo adotado foi o da alvenaria armada em blocos de concreto estruturais, visando a utilização de técnica pouco sofisticada, custo reduzido e a rapidez de execução da obra. 
10
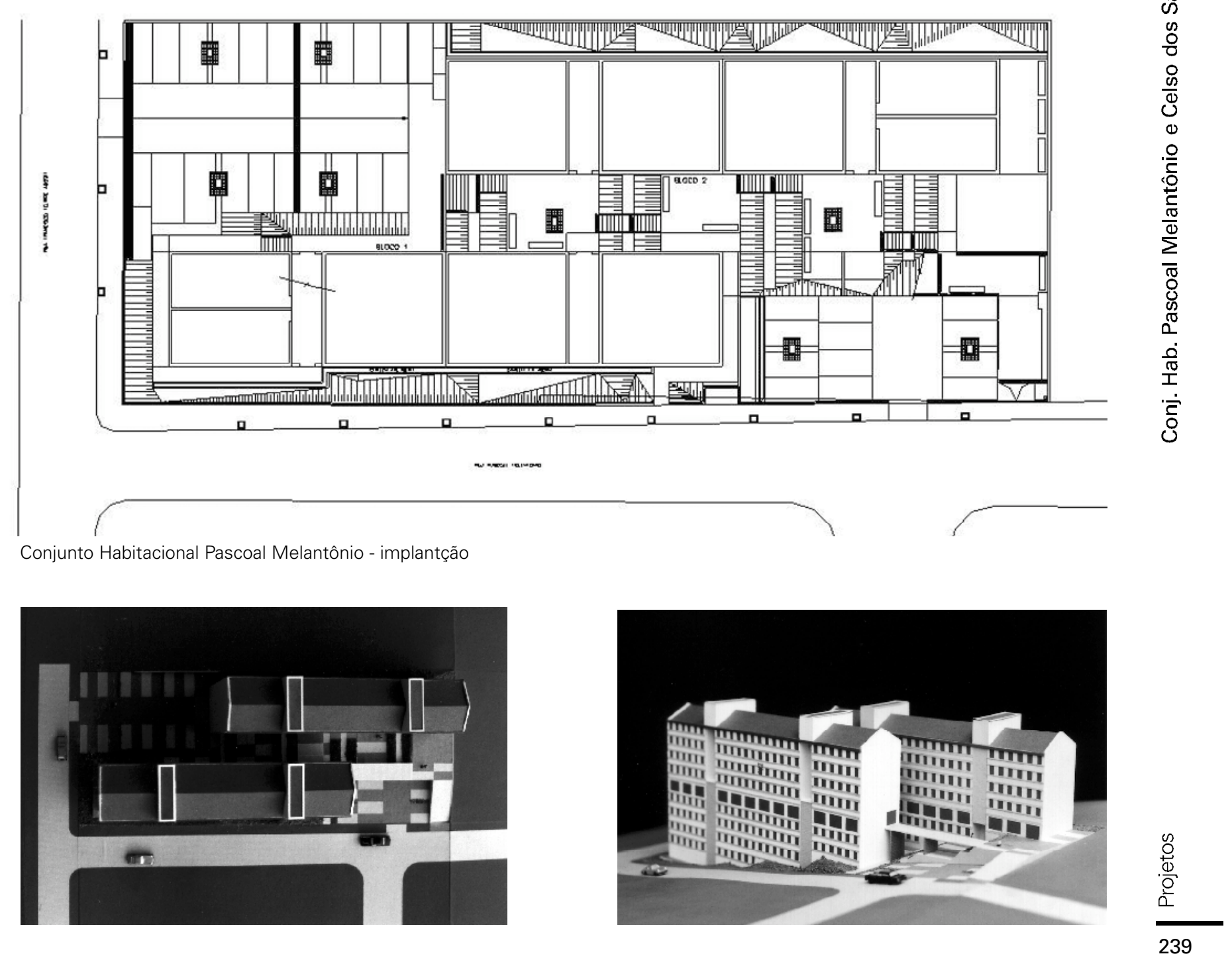


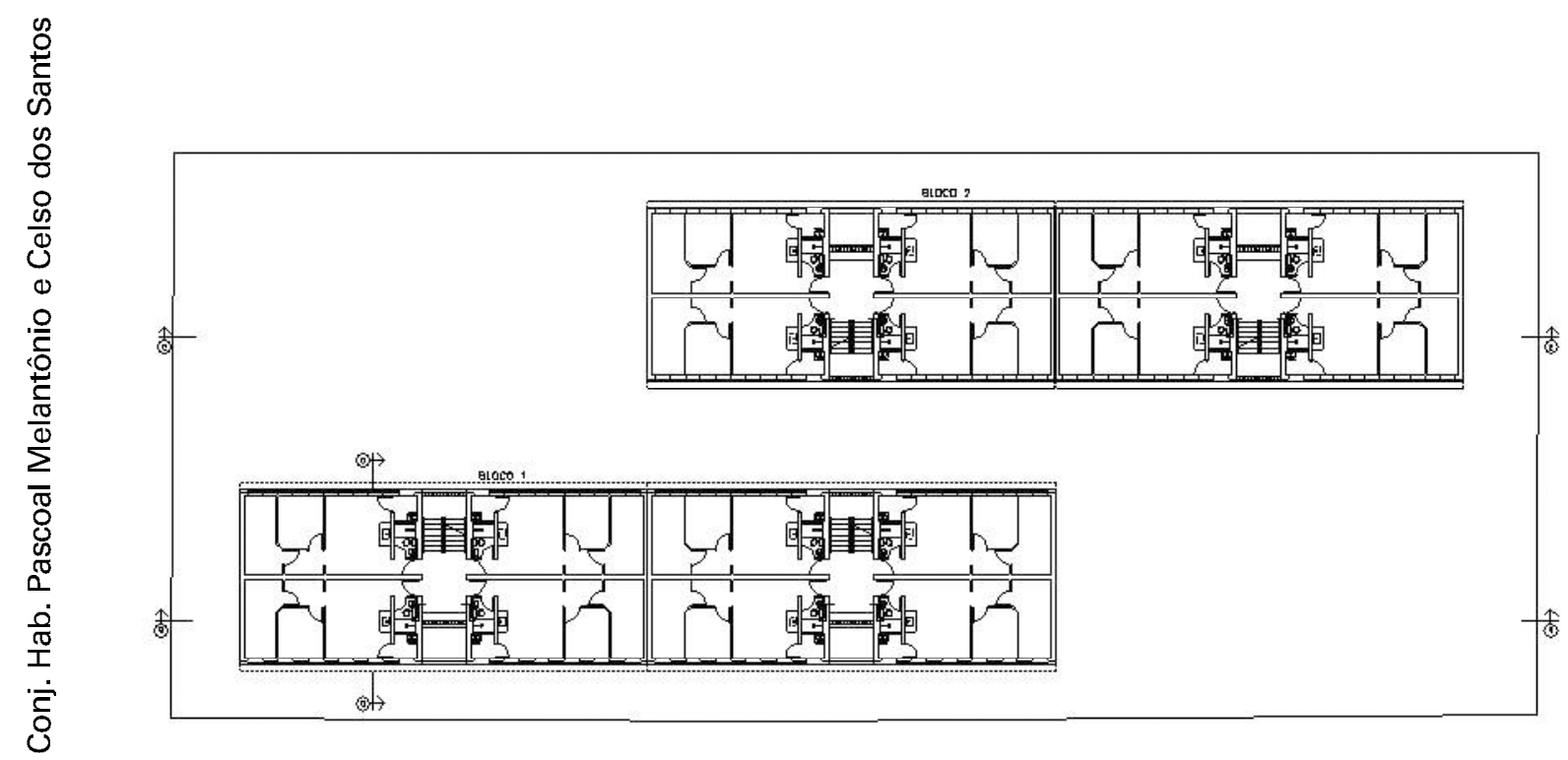

Conjunto Habitacional Pascoal Melantônio - planta andar tipo

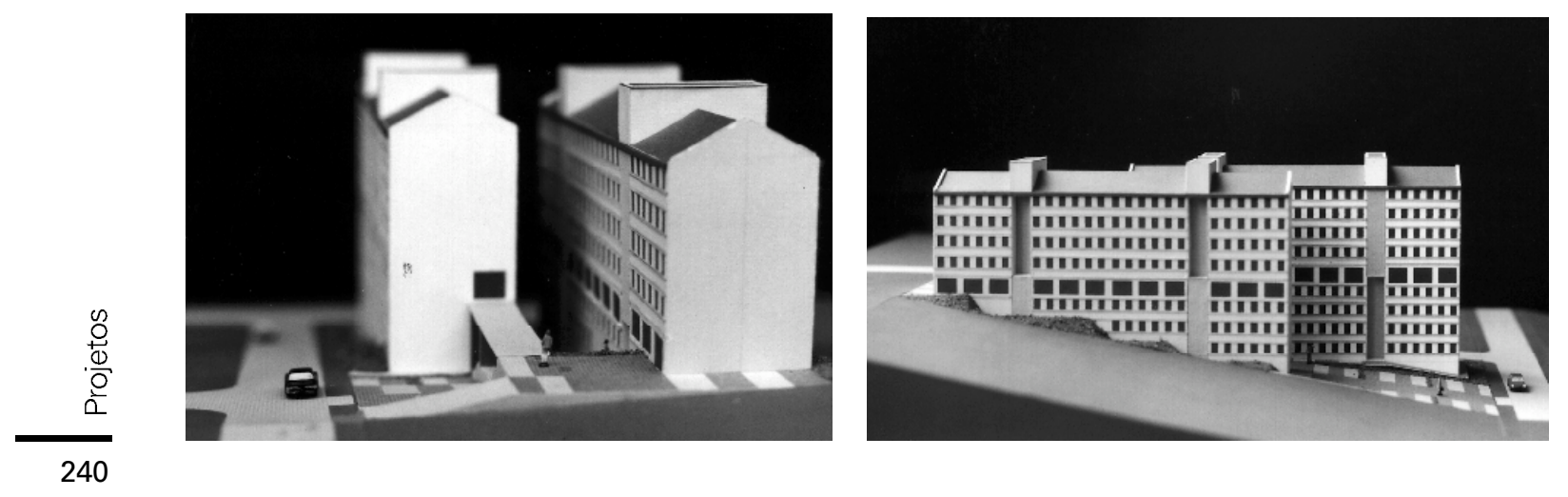



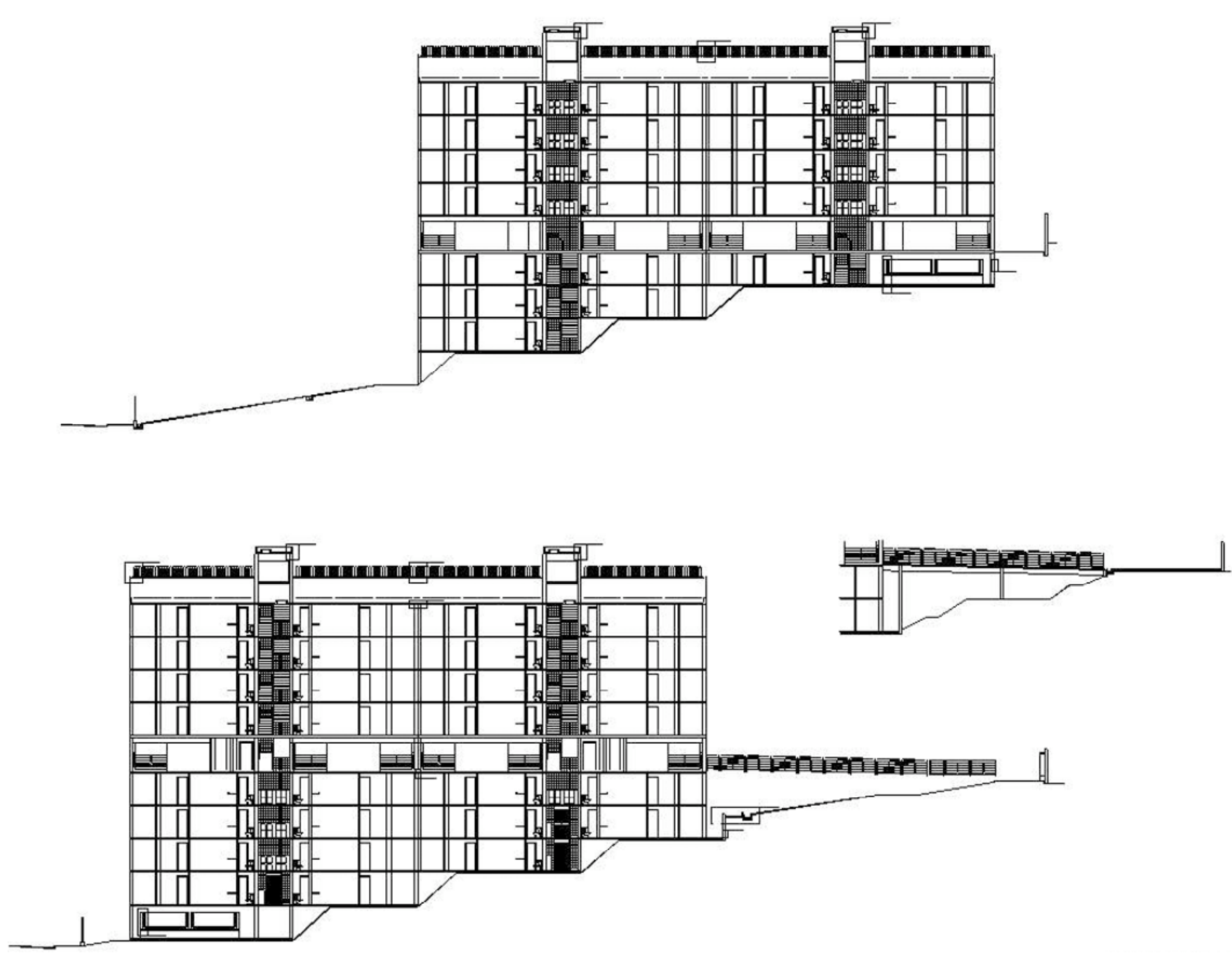

Conjunto Habitacionail Pascoal Melantônio - cortes 

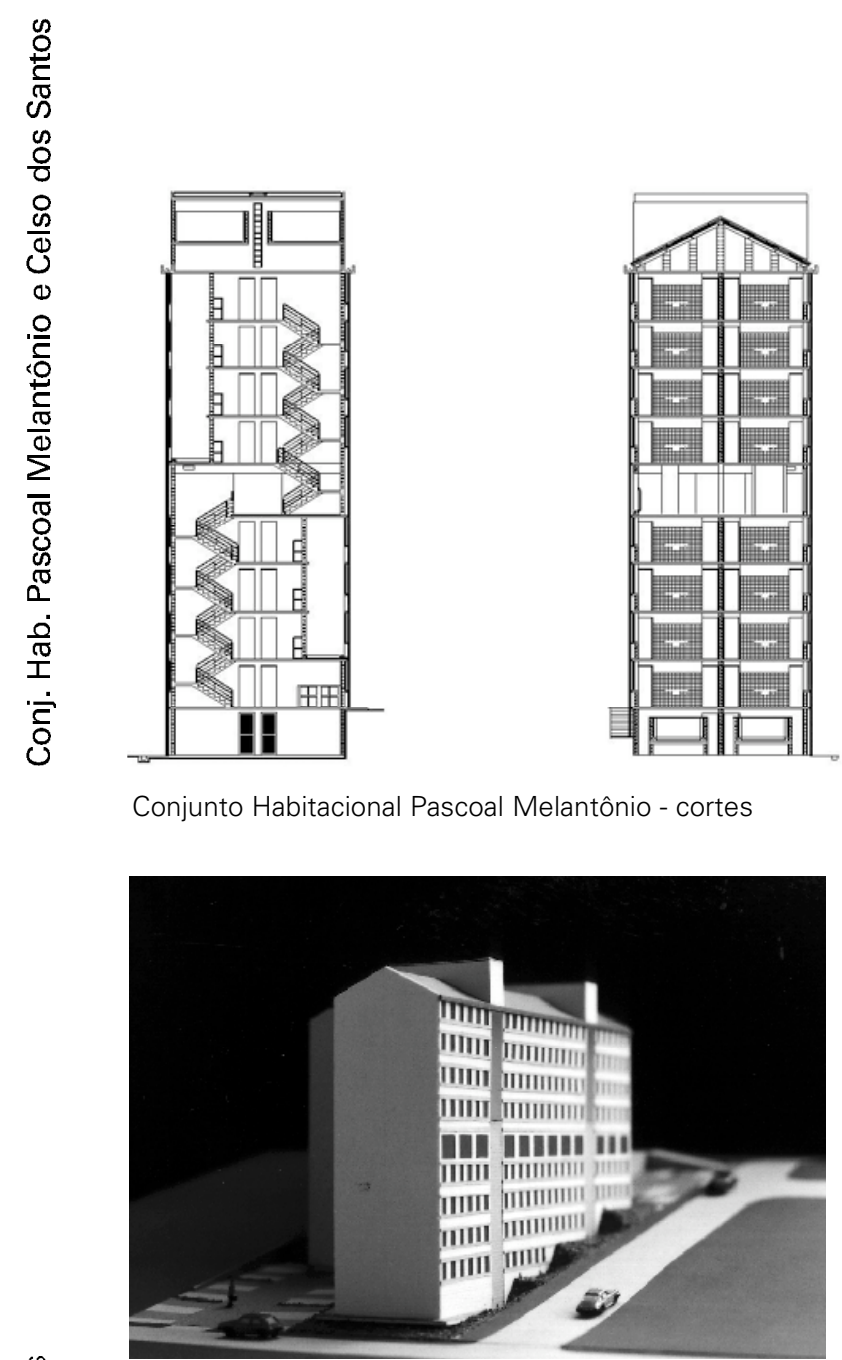

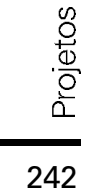




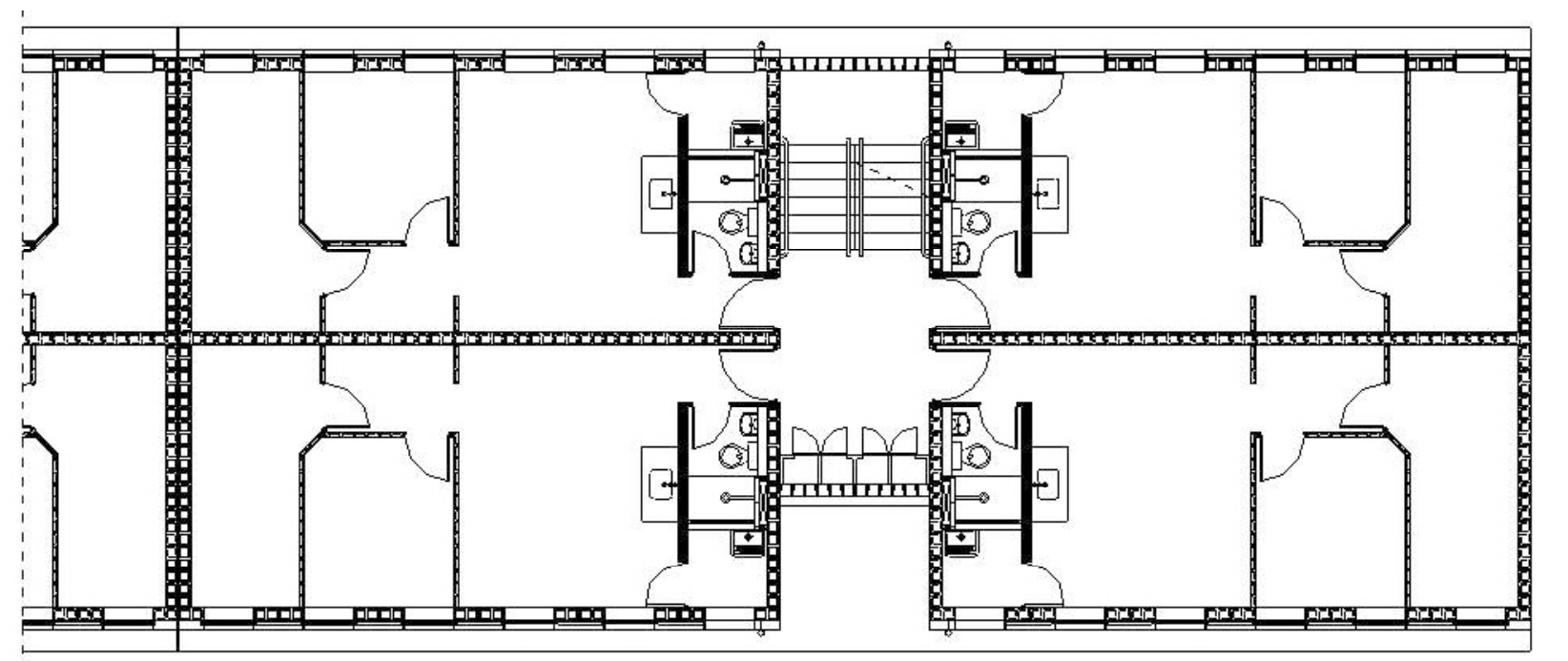

Conjunto Habitacional Pascoal Melantônio - planta apartamento tipo 


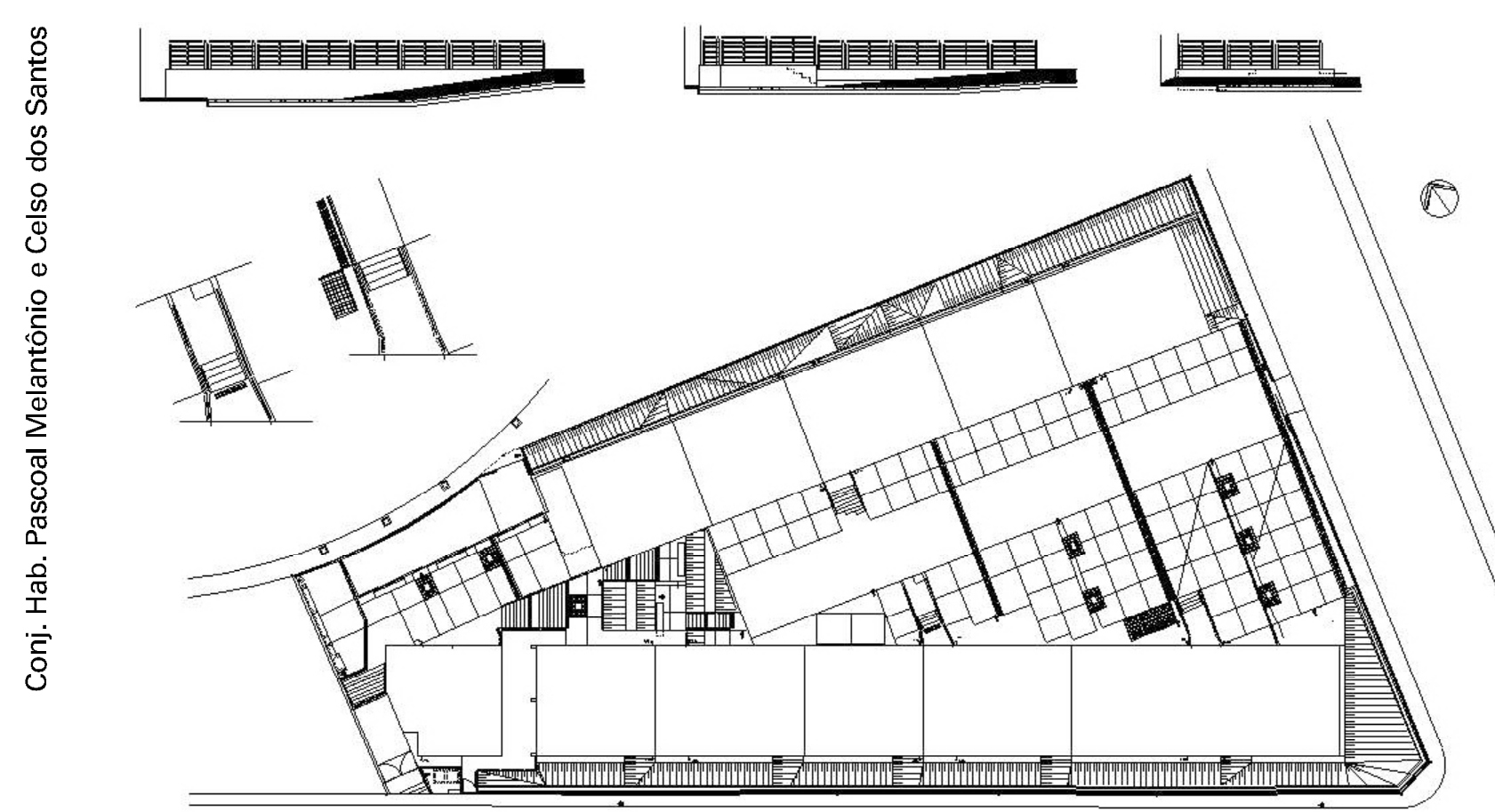

Conjunto Habitacional Celso dos Santos - implantação
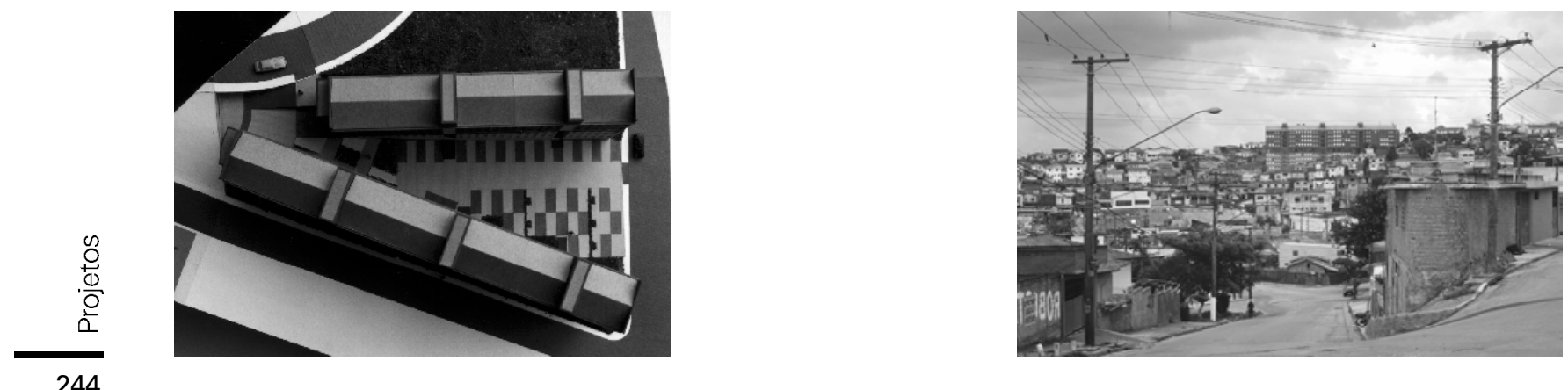


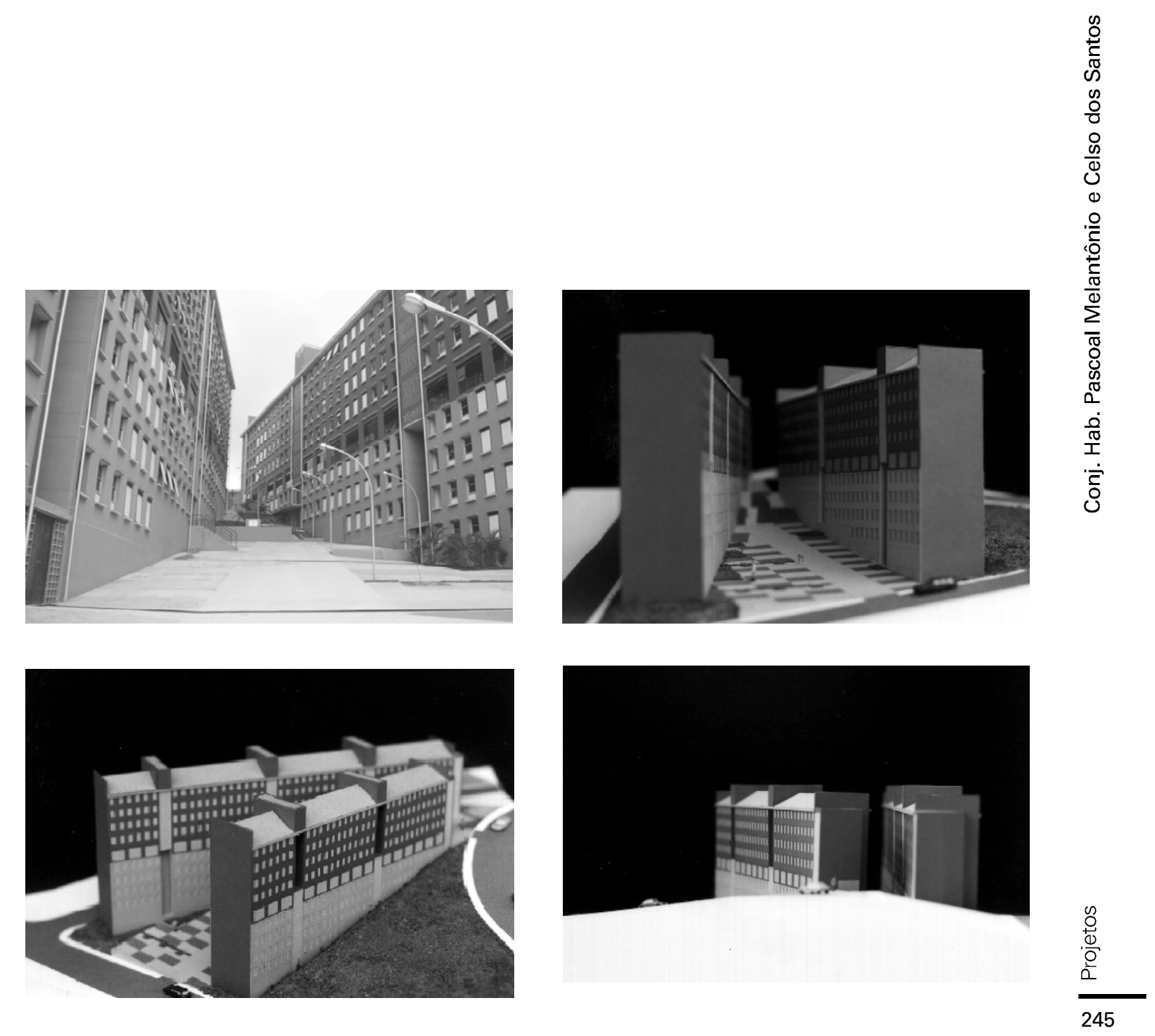




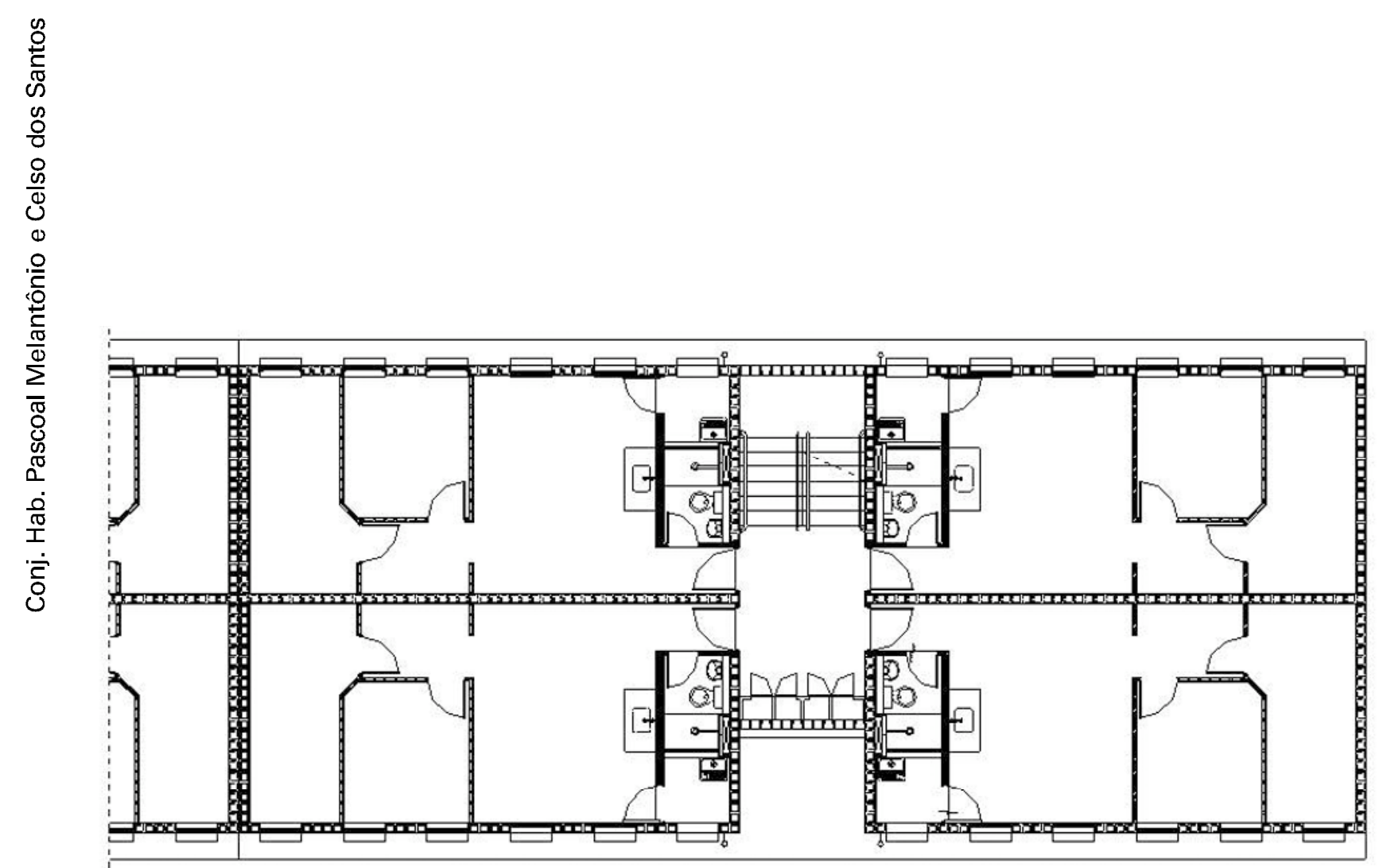

Conjunto Habitacional Celso dos Santos - planta apartamento tipo 
Casas Bi-Nucleares 
Nos projetos para as residências André Mehes, na cidade de São Paulo e Maia Rosenthal em Atibaia, Abrahão retoma

a proposta colocada pelo arquiteto Marcel Breuer, pela primeira vez, em 1944, com a Geller House I.

A proposta de Breuer era que a Geller House fosse o protótipo da casa pré-fabricada.

Esse projeto foi apresentado em um concurso promovido pela revista California Arts \& Architecture, que objetivava a construção de moradias no pós-guerra, para receber os soldados que voltavam do front. As propostas deveriam prever uma construção barata e que pudesse ser construída rapidamente.

O projeto de Marcel Breuer distinguia, por sua separação em dois volumes, as áreas "públicas e privadas", correspondentemente áreas diurnas e noturnas. As unidades separadas eram conectadas por um corredor. Na ala diurna estavam a sala e a cozinha, enquanto a outra acomodava os quartos.

Este foi o primeiro projeto bi-nuclear de Marcel Breuer, que passou a ser uma característica da sua obra.

A revista California A rts \&Architecture publicou as notas de Breuer sobre o projeto. Estes comentários fazem uma análise geral das funções da casa nas quais o sistema bi- nuclear é baseado:

Uma zona seria para vivência comum: comer, esportes, jogos, jardinagem, visitas, isto é, para uma vivência dinâmica do dia a dia. A outra, em uma ala separada seria para concentração: trabalhar e dormir. Os quartos são projetados e dimensionados para que sirvam também como área de estudo pessoal. Entre as duas zonas existiria um pátio externo, com plantas e flores: visualmente conectado às duas alas, da unidade ao conjunto. (DRILLER, 2000, p.149).

Segundo Driller (2000, p. 146) trata-se de "um documento mostrando uma crença tecnológica e de progresso social de certa forma ingênua". 
Geller House I em Nova York, 1944

projeto: Marcel Breuer

fonte: BREUER, 1962, p. 225

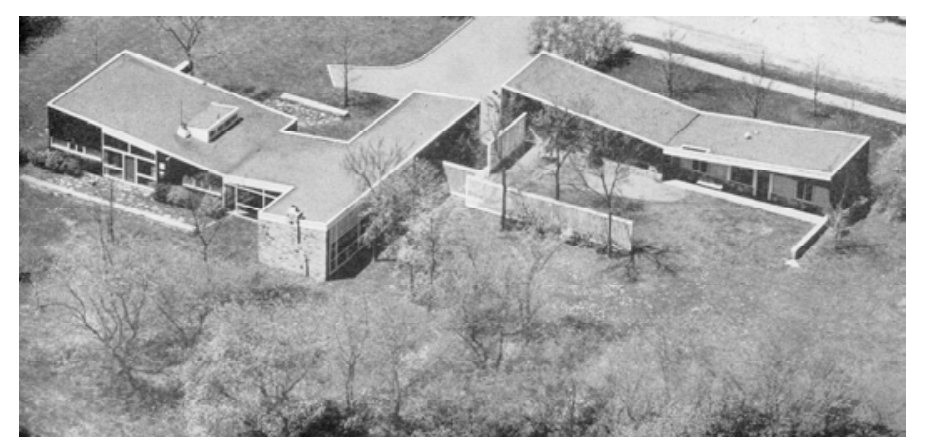

Robinson House, Williamstown, Massachusetts, 1946/47 projeto: Marcel Breuer

fonte: BREUER, 1962, p. 118

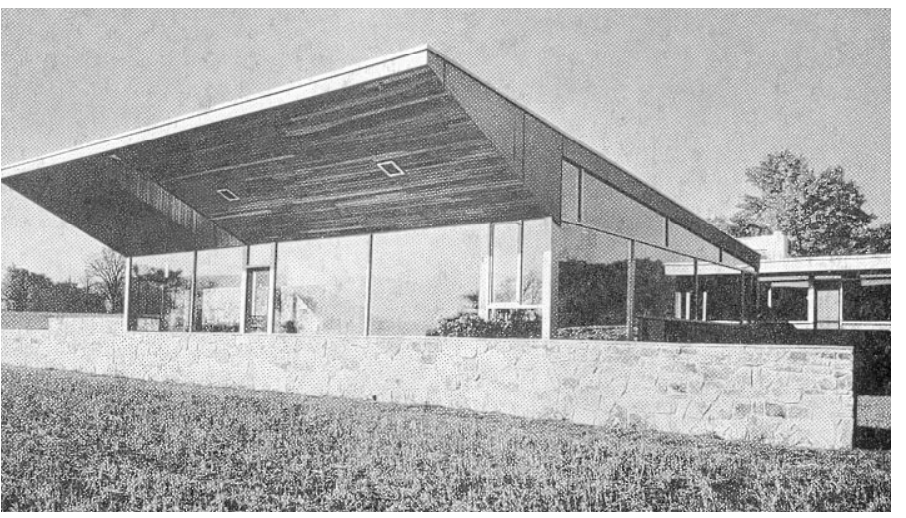

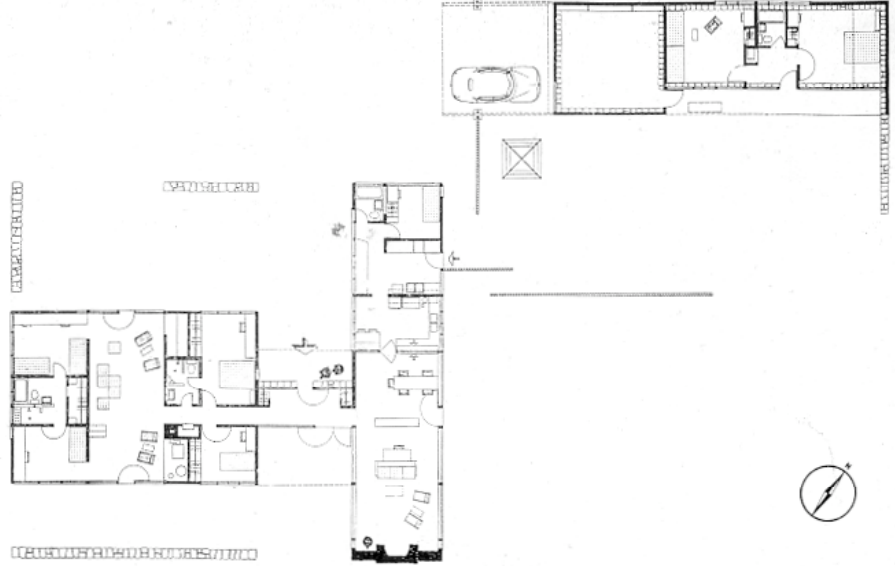

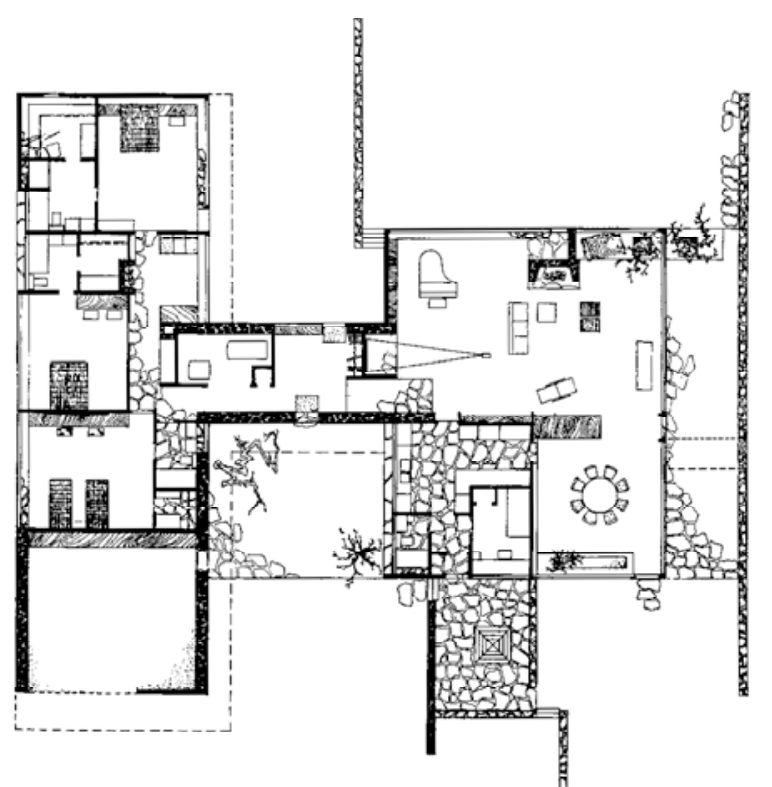


Clark House, Orange Connecticut, 1954

projeto: Marcel Breuer

fonte: BREUER, 1962, p. 193.
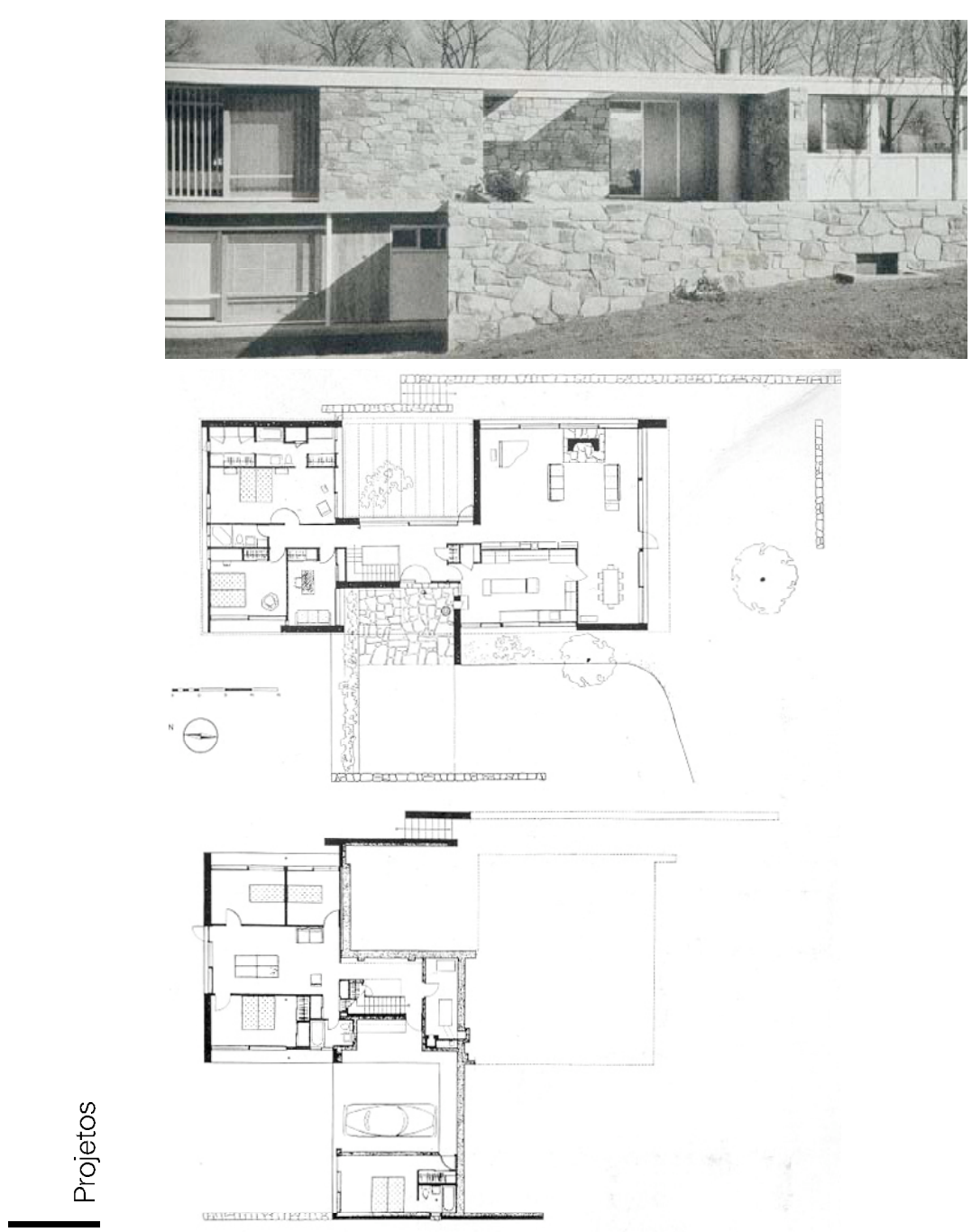

Grieco House, Andover, Massachusetts, 1954/55

projeto: Marcel Breue

fonte: BREUER, 1962, p. 190 e 191
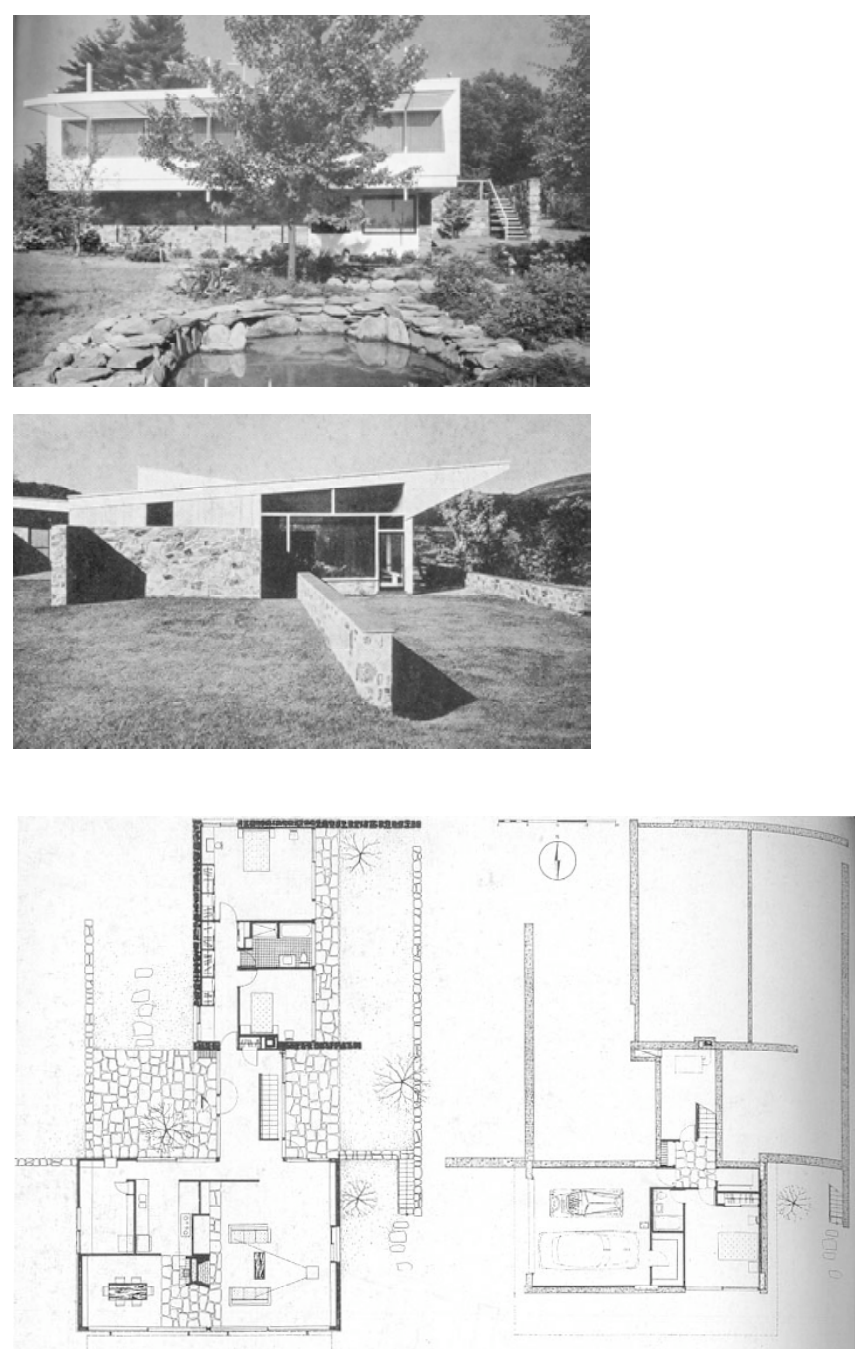
Starkey House, Duluth, Minnesota, 1954/55

projeto: Marcel Breuer

fonte: BREUER, 1962, p. 163.
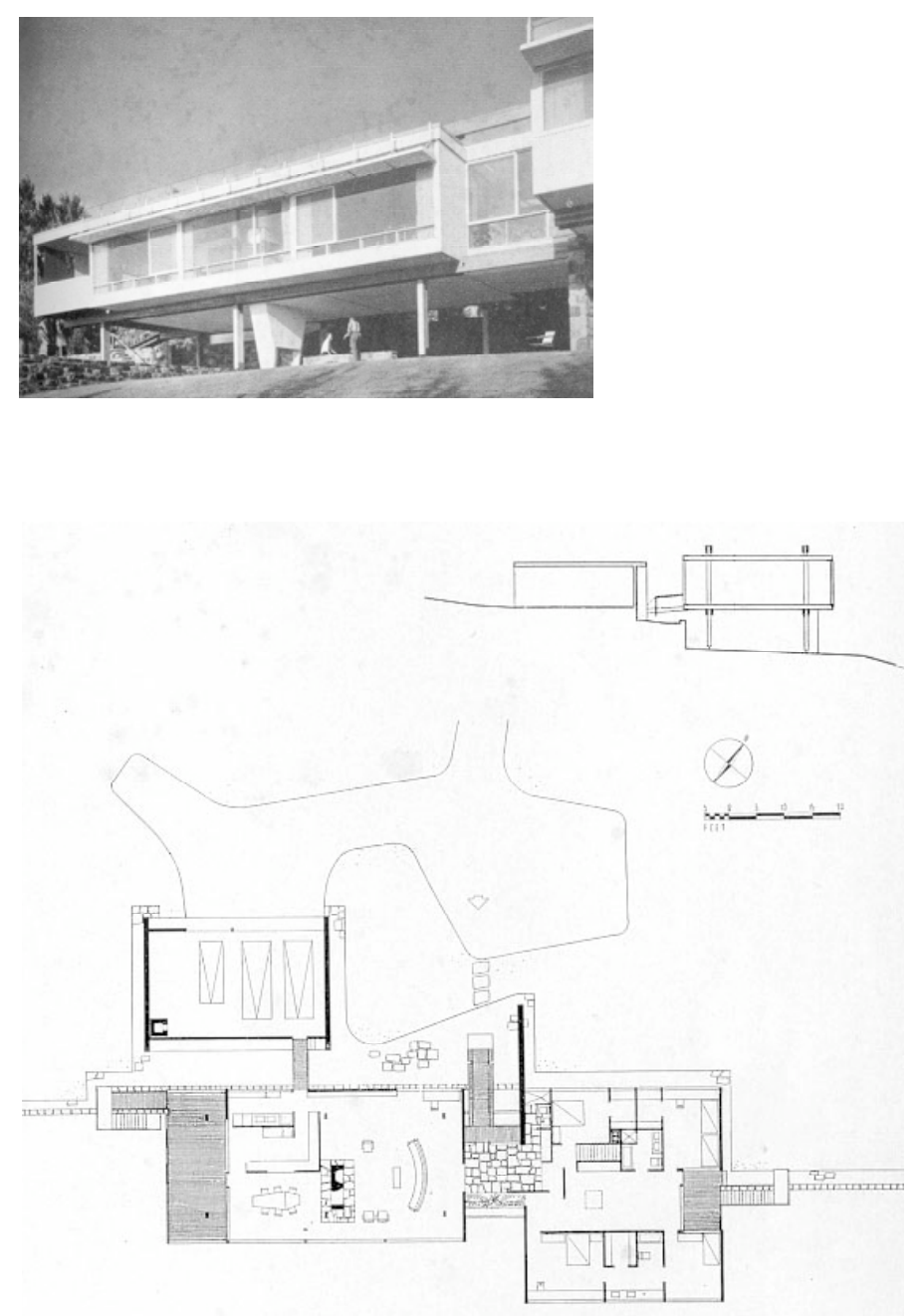

Hooper House, Baltimore, Maryland, 1959/60

projeto: Marcel Breuer

fonte: BREUER, 1962, p. 72 e 73
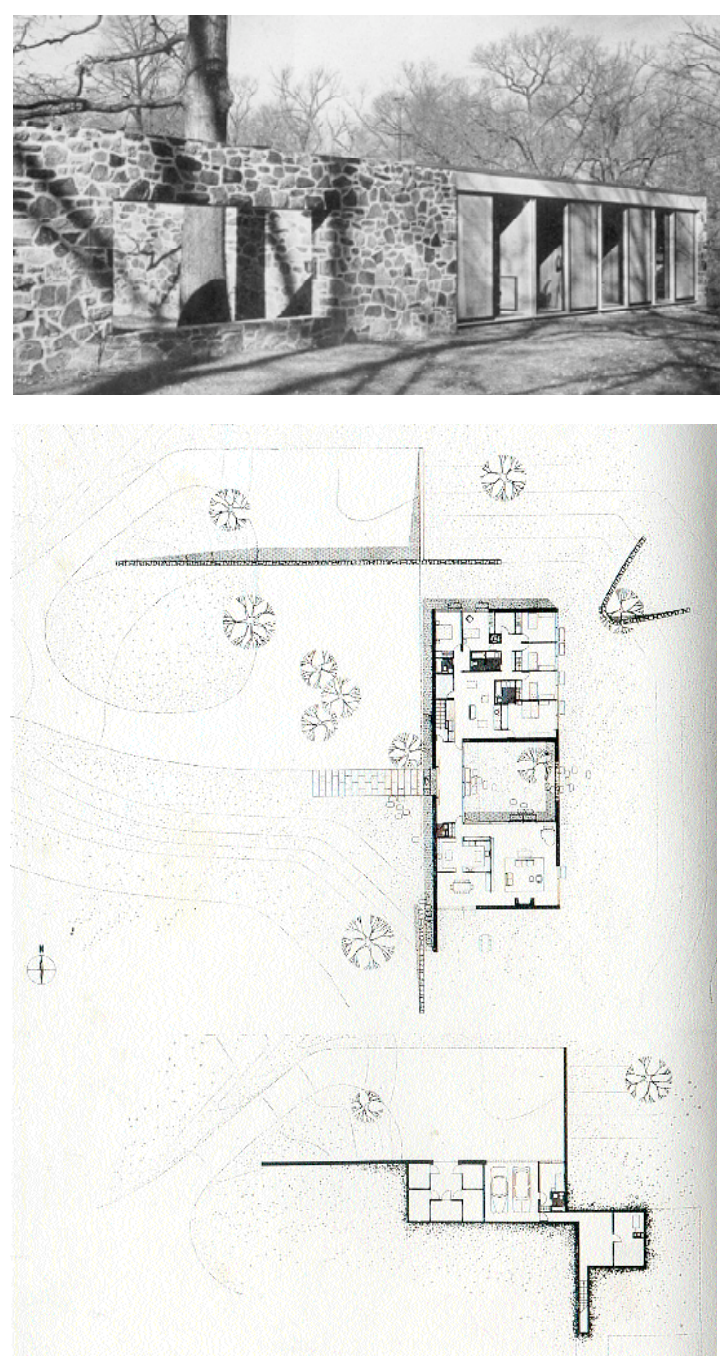
Casa Soriano, Greenwich, Connecticut, 1969

projeto: Marcel Breuer

fonte: PAPACHRISTOU, 1970, p. 182 e 183.
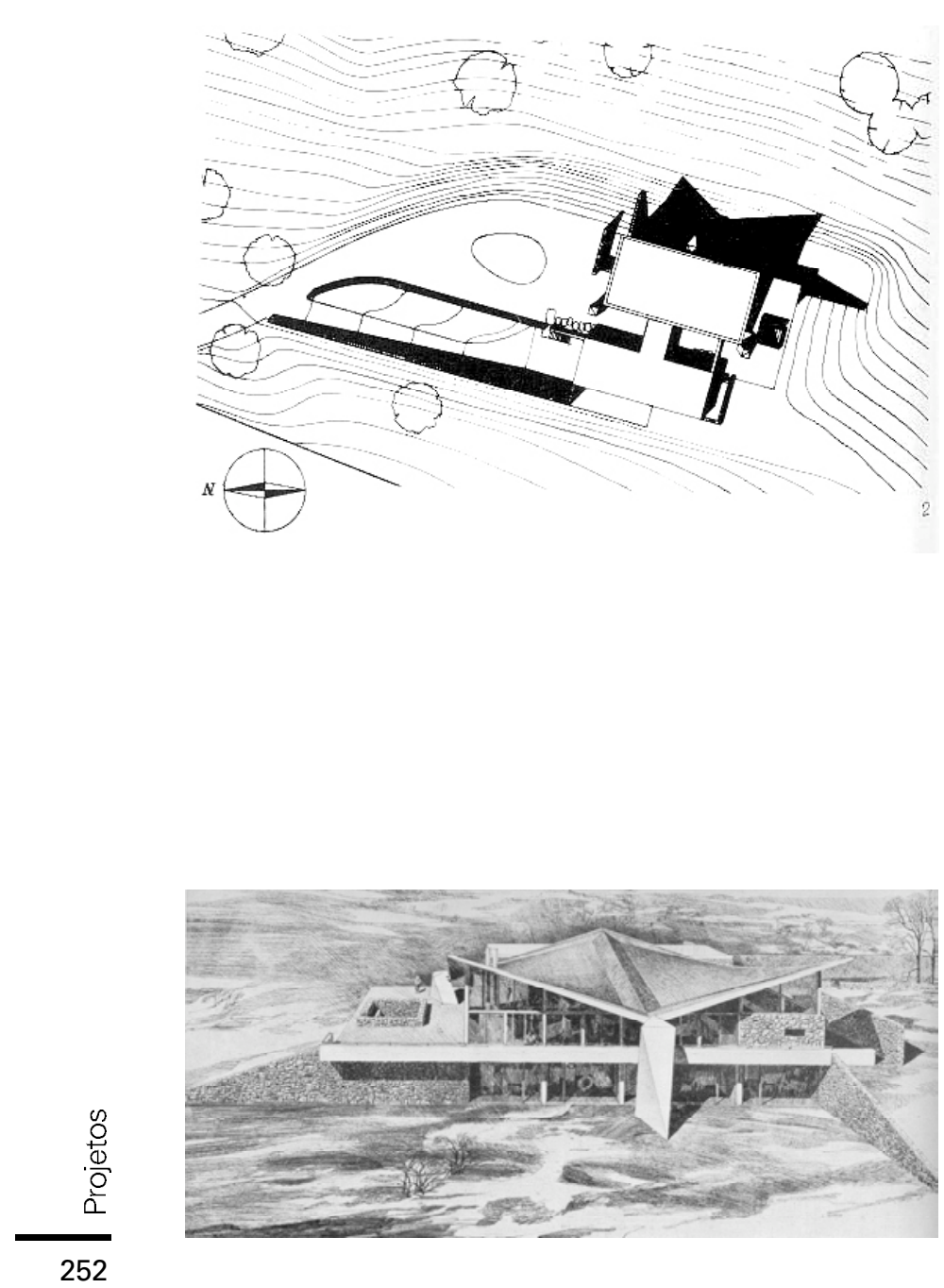

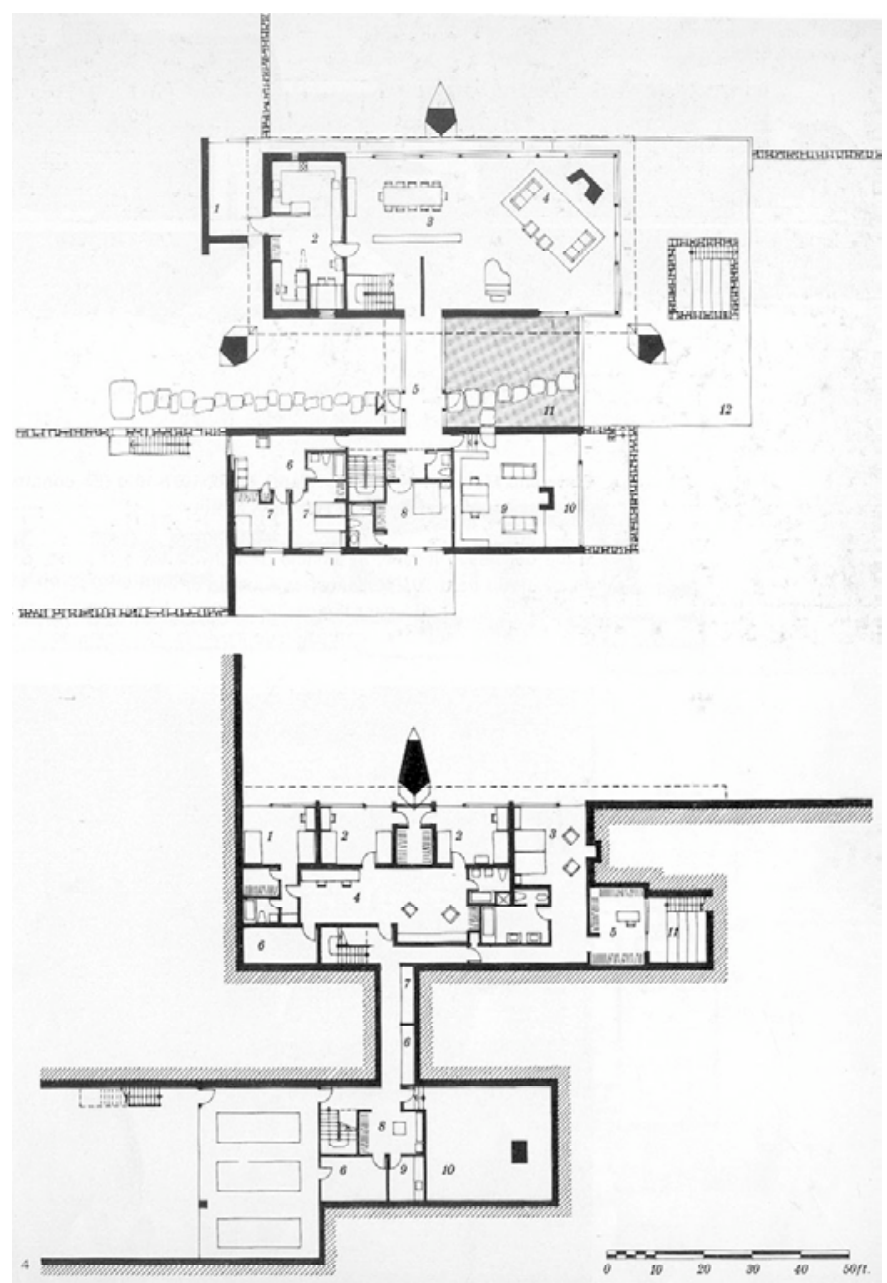


Residência André Mehes - 1973

Rua Berlioz, 440, São Paulo, SP

fonte [imagens] acervo do escritório Elito Arquitetos [desenhos] acervo da biblioteca da FAUUSP 
Abrahão resolveu o programa da casa em um único pavimento. Aproveitando a topografia, coloca sob o balanço da casa, abrigo de carros e depósito.

Com o alteamento do terreno e a proposta paisagística do arquiteto Fernando Chacel, promove uma continuidade espacial com a rua.

Dividida em duas alas, já que bi-nuclear, um volume irregular, que abriga os setores de serviço e dependências de empregada, faz contraponto ao volume regular dos quartos e sala.

A estrutura da casa, em concreto armado, caracteriza-se por lajes nervuradas, invertidas (tetos planos), apoiadas perifericamente em cortinas, também de concreto.

Os vedos externos constituem-se de panos de vidro e paredes de bloco de concreto.

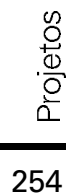
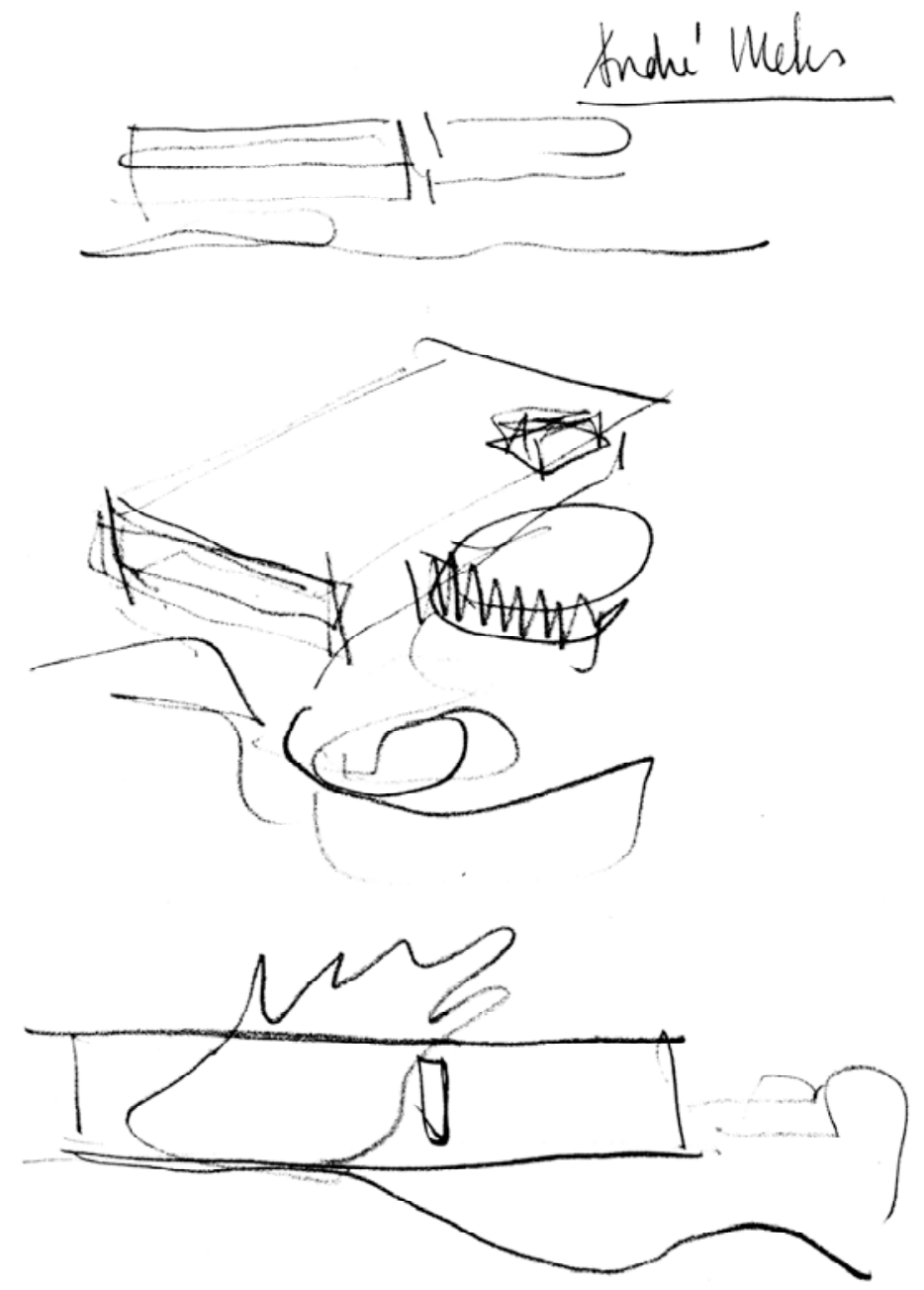


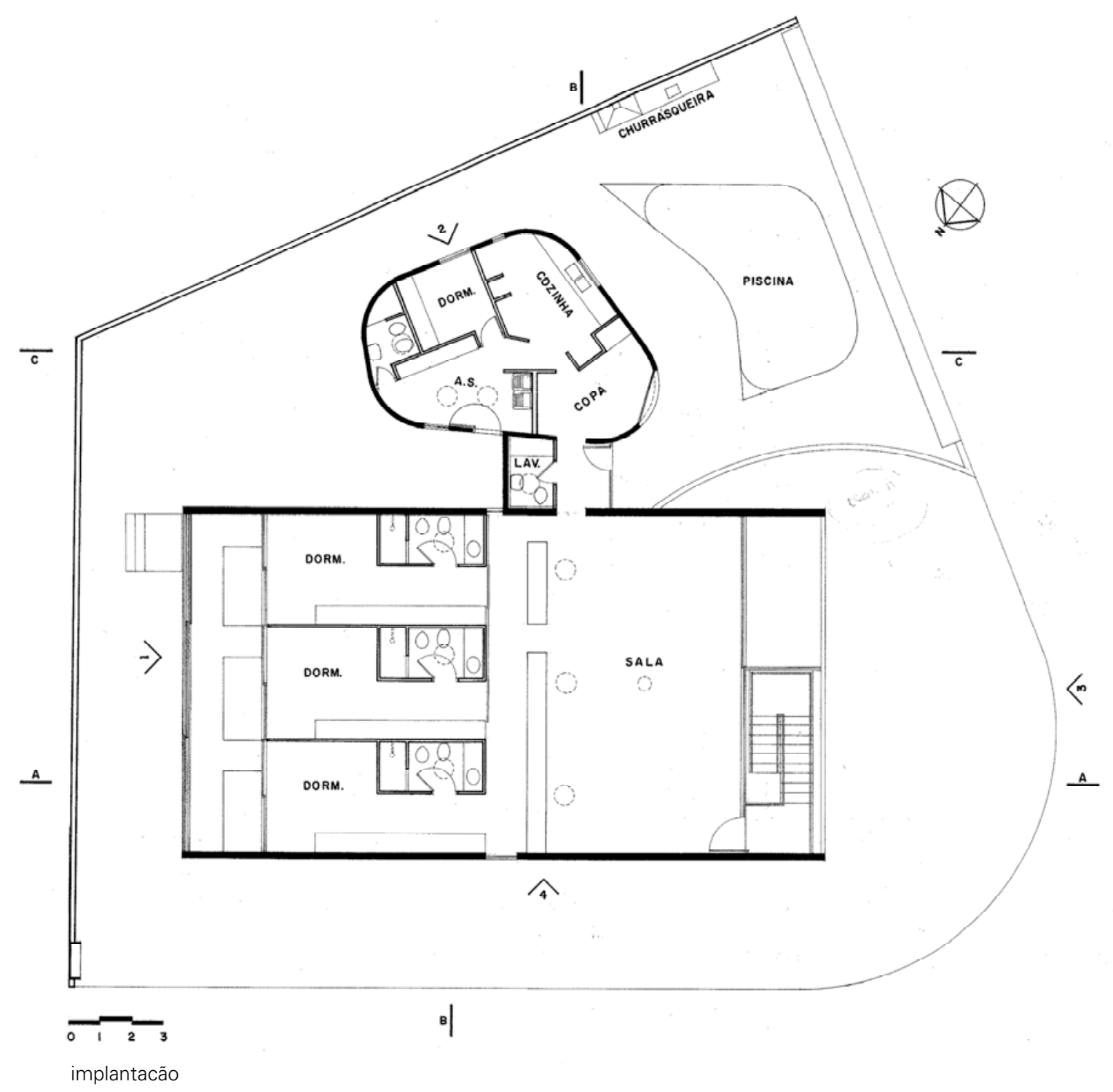

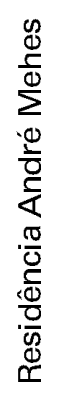

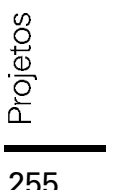




$$
D_{0}^{0}
$$



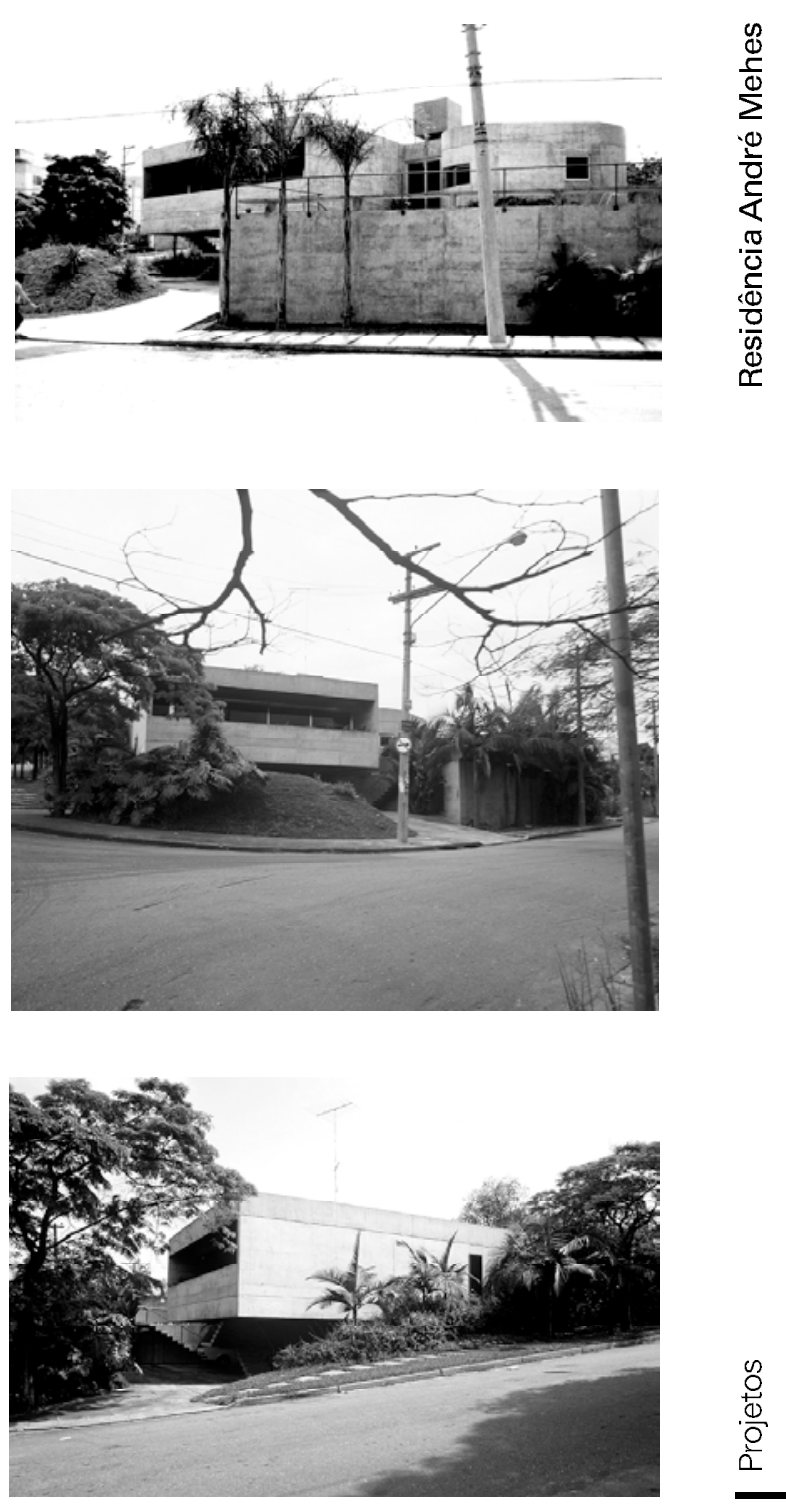

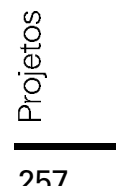



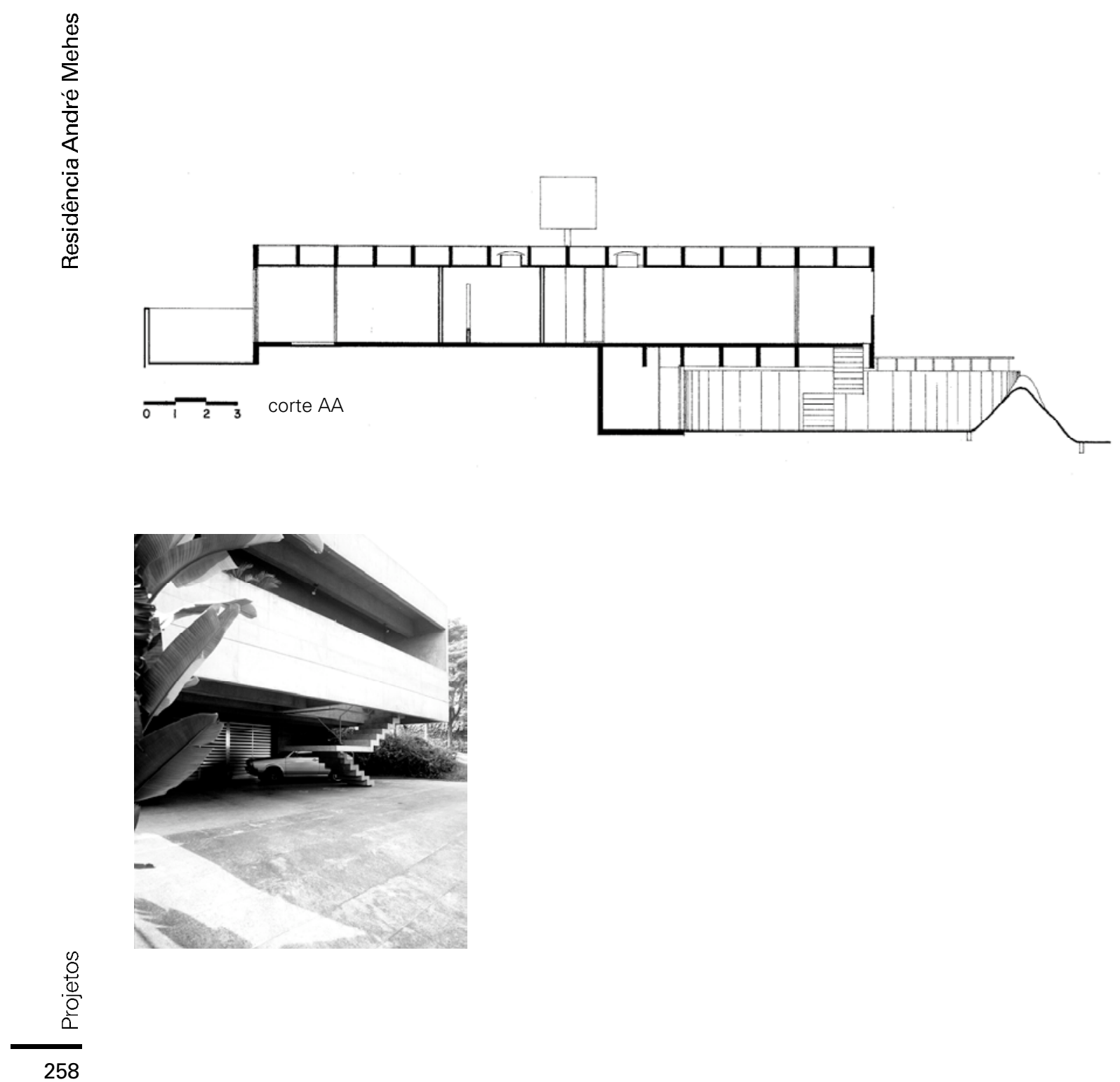


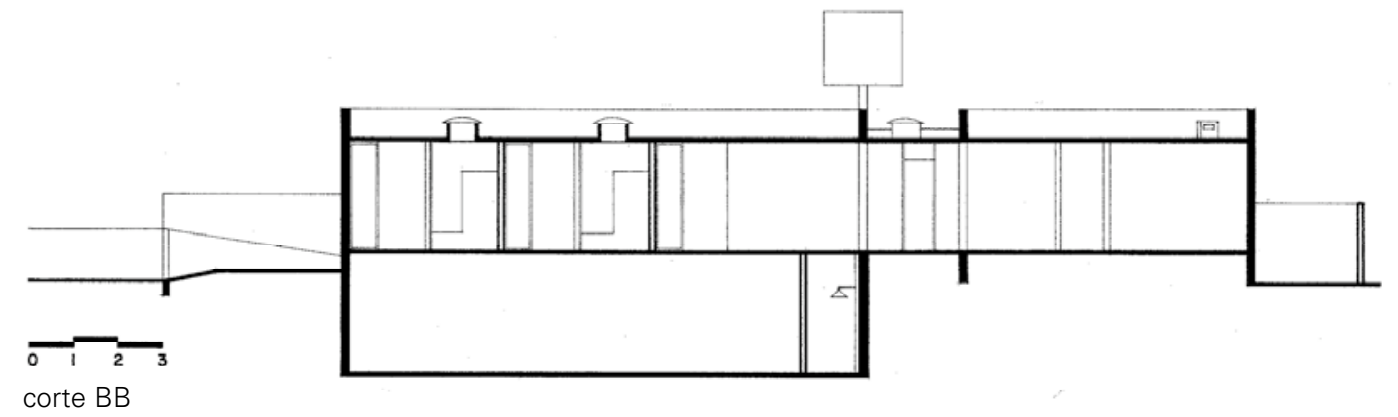

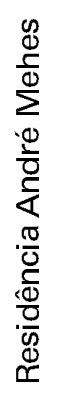

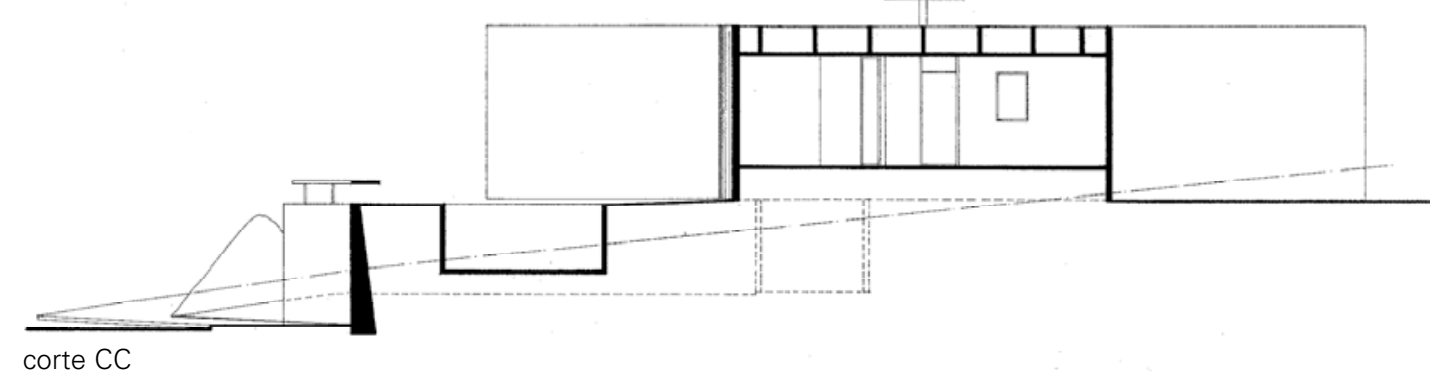



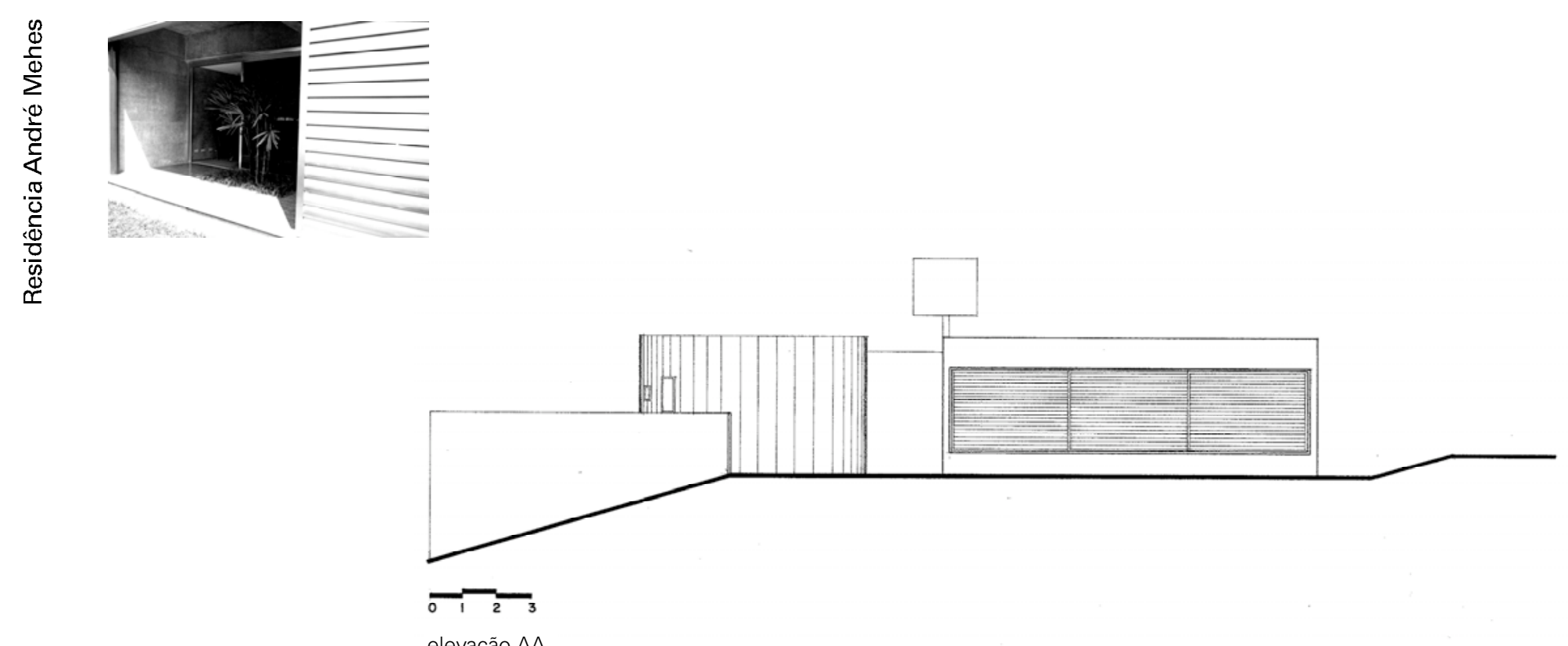

elevação AA

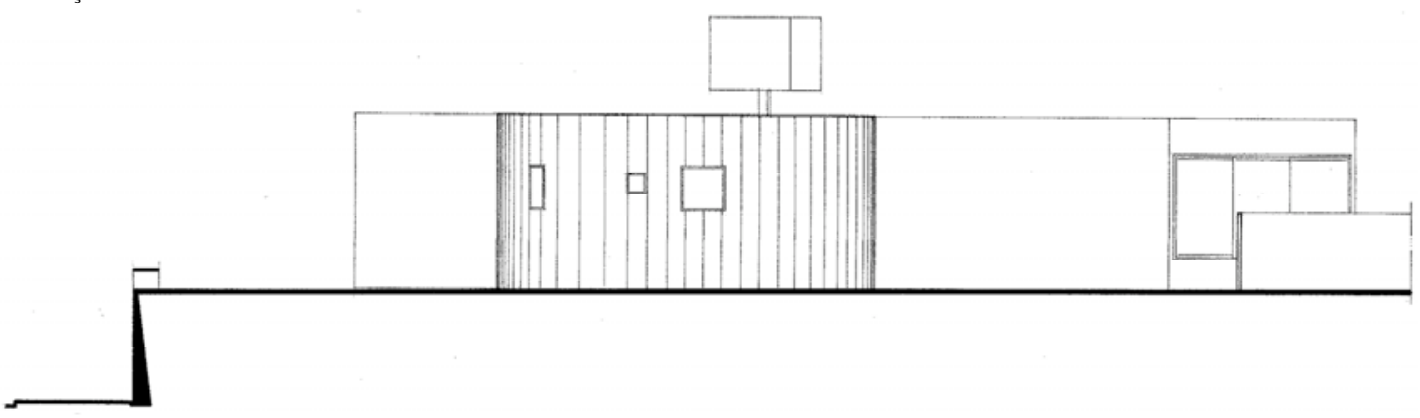

elevação BB

$\begin{array}{r}\frac{0}{0} \\ \frac{0}{0} \\ \frac{0}{0} \\ \frac{0}{0} \\ \hline 260\end{array}$ 

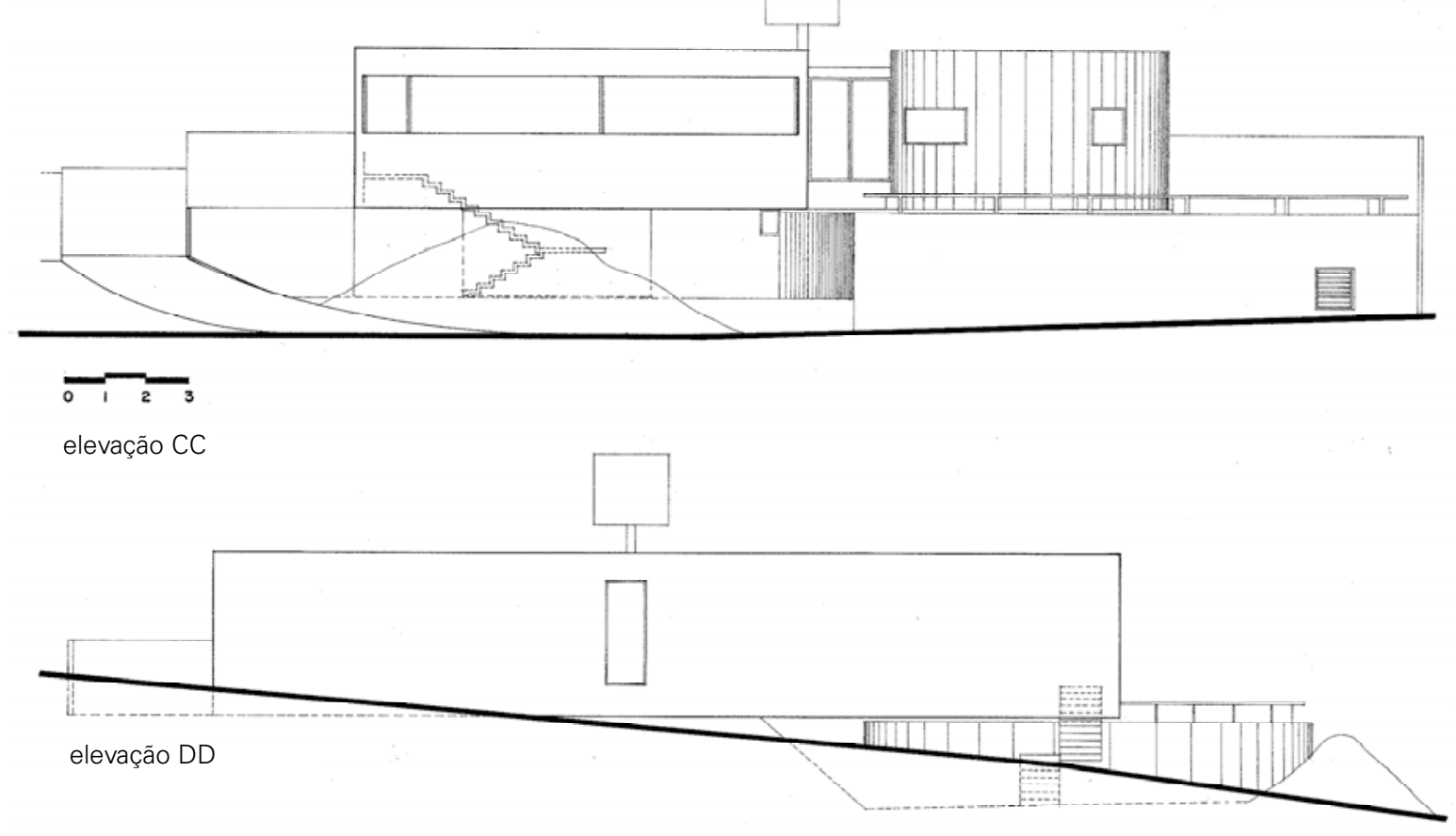

Residência Maia Rosenthal - 1980

Estância Parque Atibaia, Atibaia, SP

fonte [imagens] acervo do escritório Elito Arquitetos [desenhos] acervo da biblioteca da FAUUSP 

encosta.

Divide seus $315 \mathrm{~m}^{2}$ em dois núcleos. De um lado ficam três quatros, dependência de empregada e lavanderia. Do outro a cozinha, o quarto principal e a sala, que se abre para um pátio externo onde está a churrasqueira e a piscina.

A estrutura da casa, em concreto armado, caracteriza-se por lajes nervuradas, invertidas (tetos planos, protegidos por telhas de fibrocimento), apoiadas perifericamente em pilares de concreto embutidos nas paredes de alvenaria; quando nos vãos centrais, os pilares são em concreto aparente e sempre destacados dos vedos ou divisões internas.

Os vedos externos constituem-se de panos de vidro e paredes tijolo de barro aparente. Internamente as paredes de tijolo são revestidas.
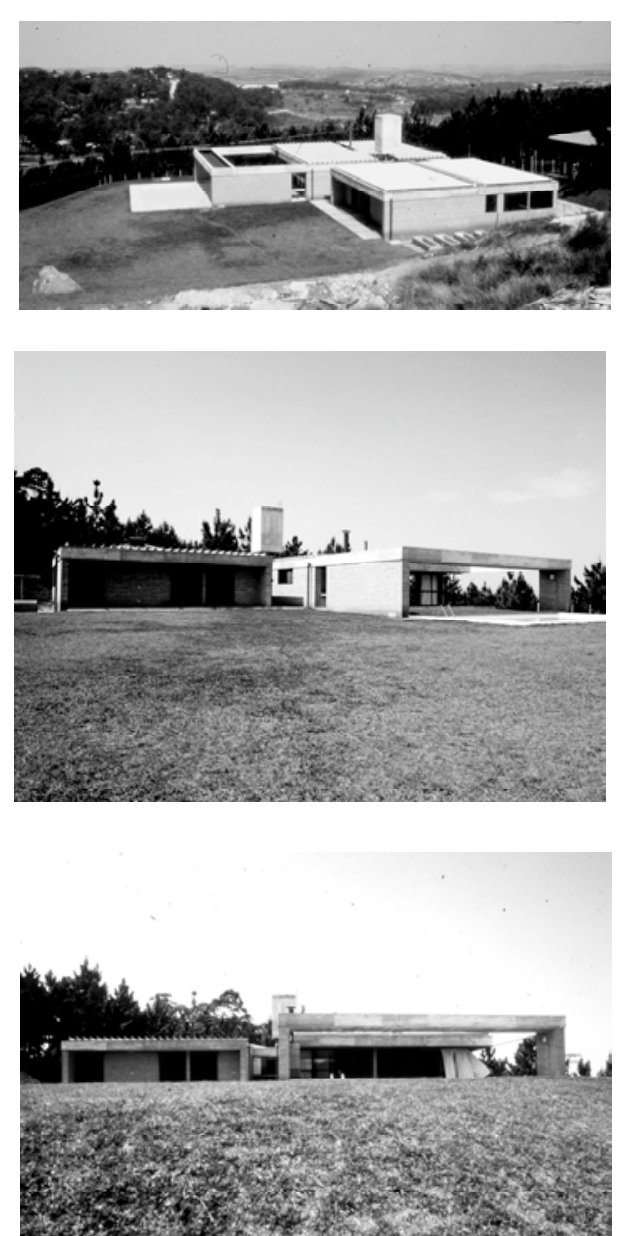


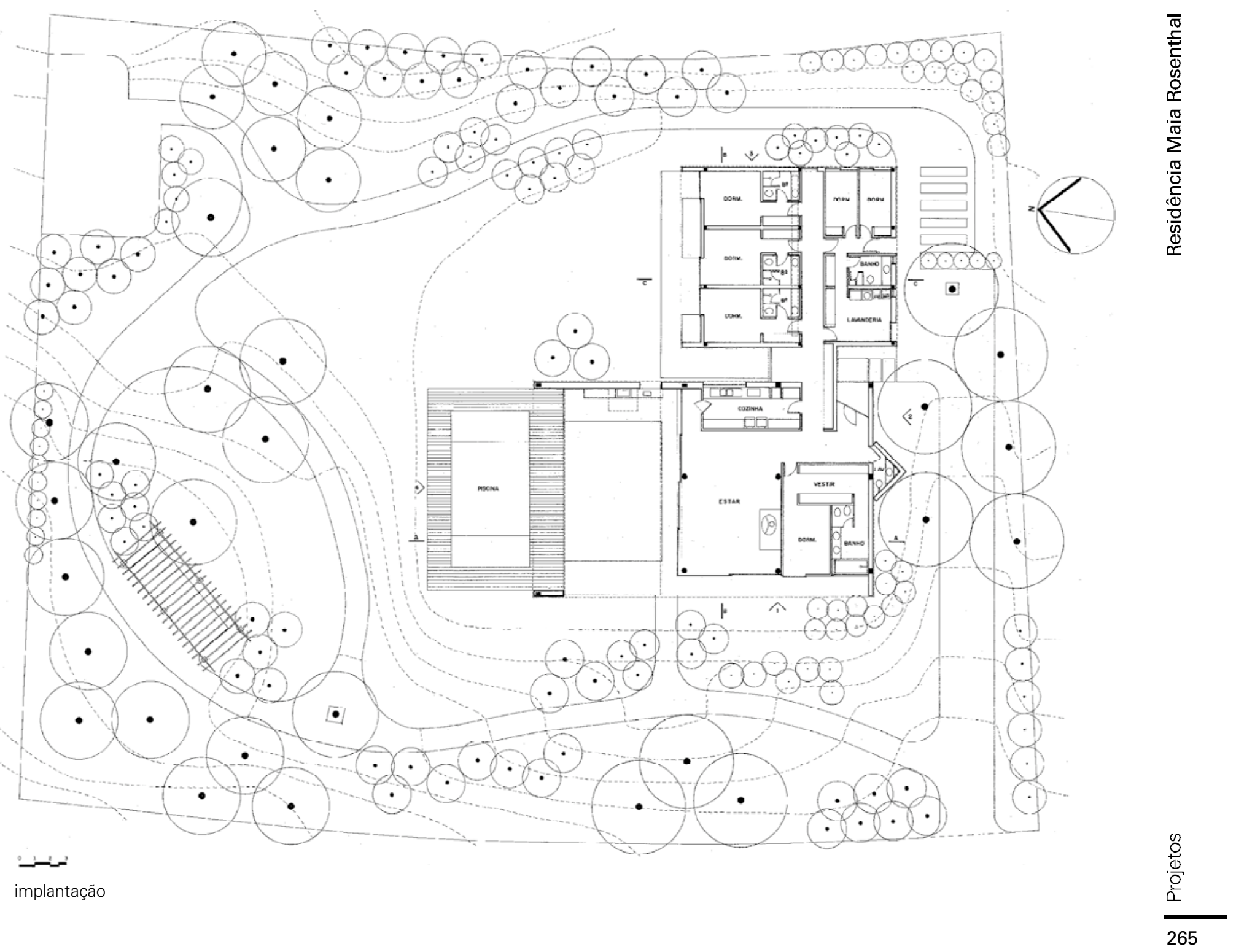



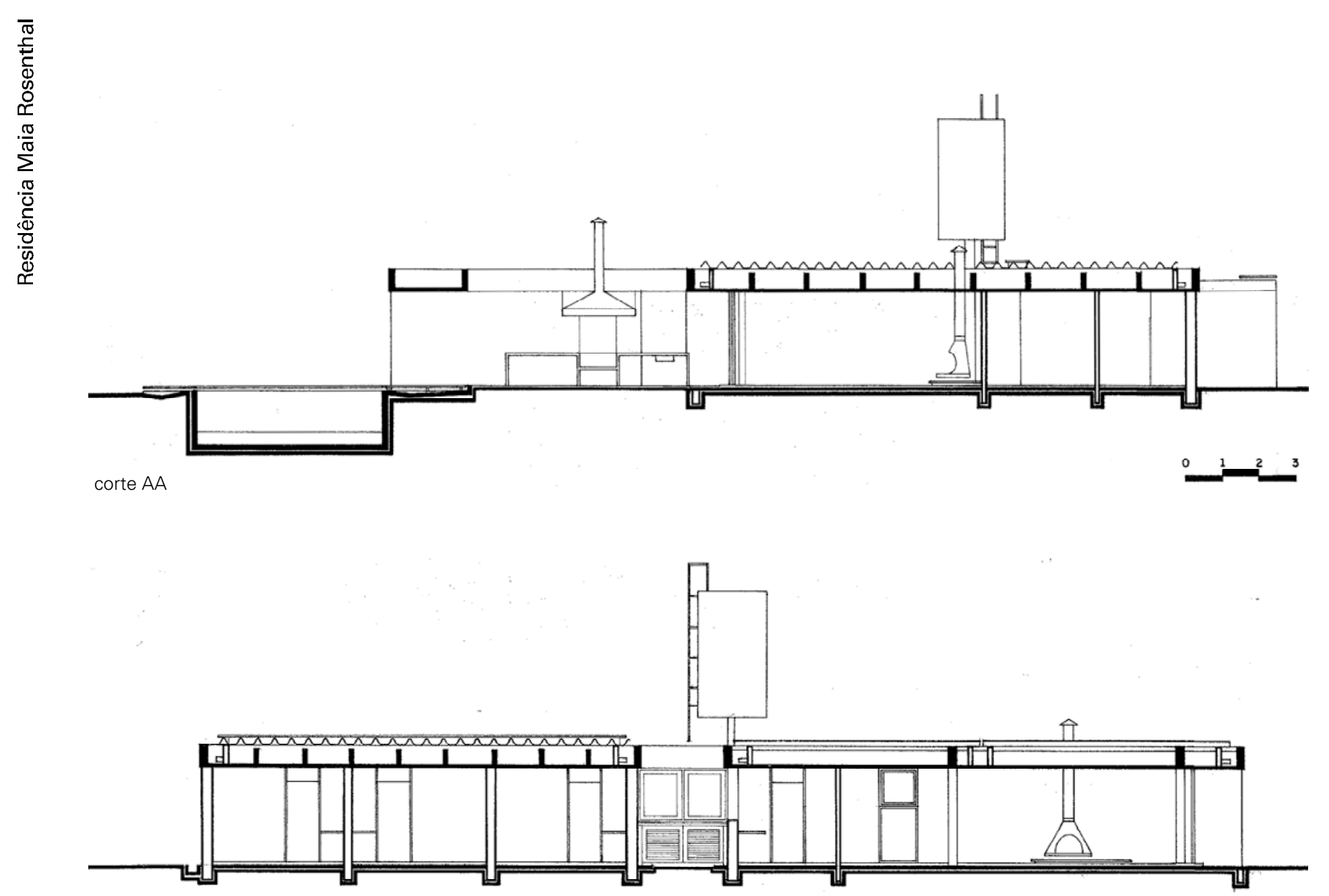

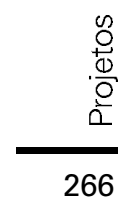



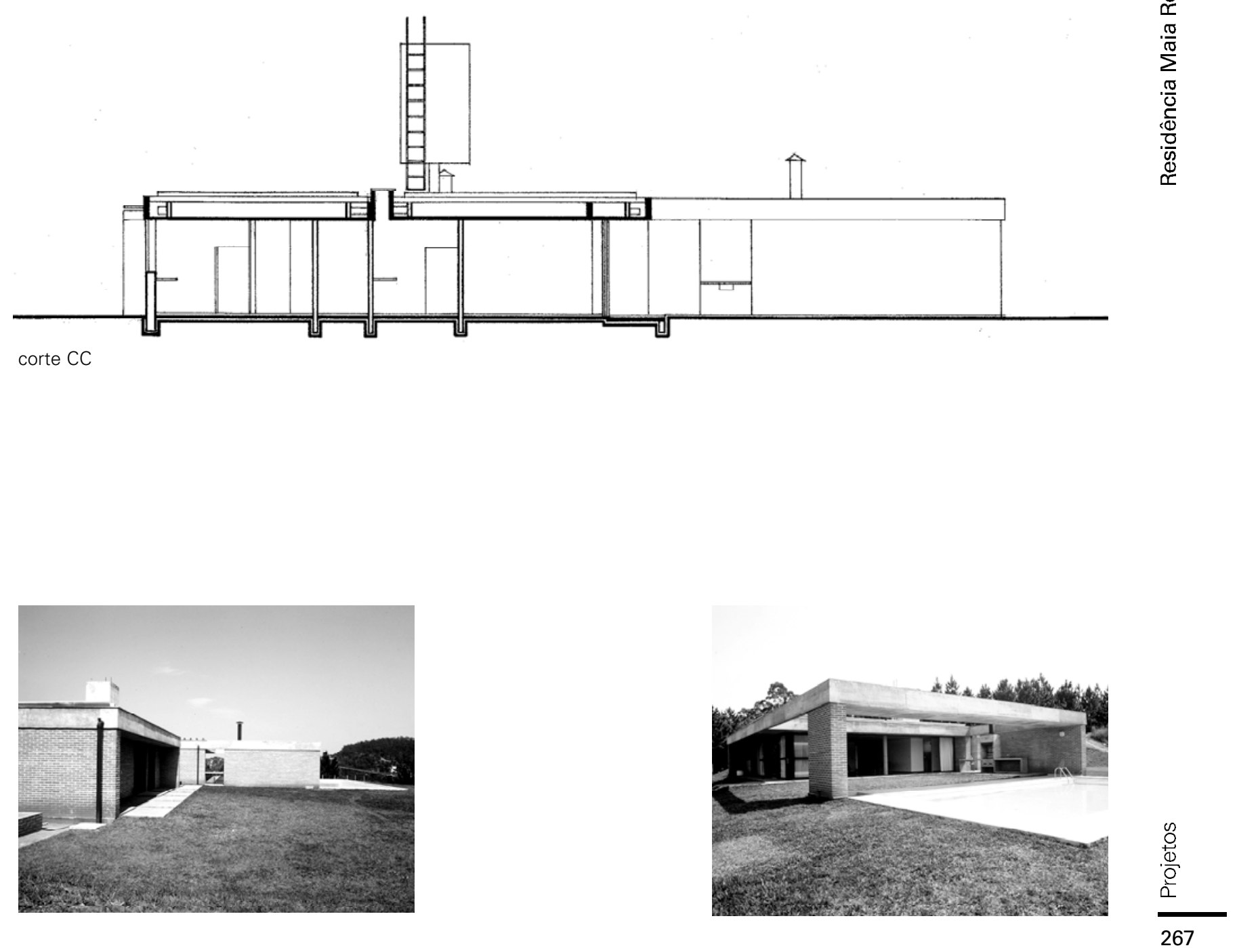

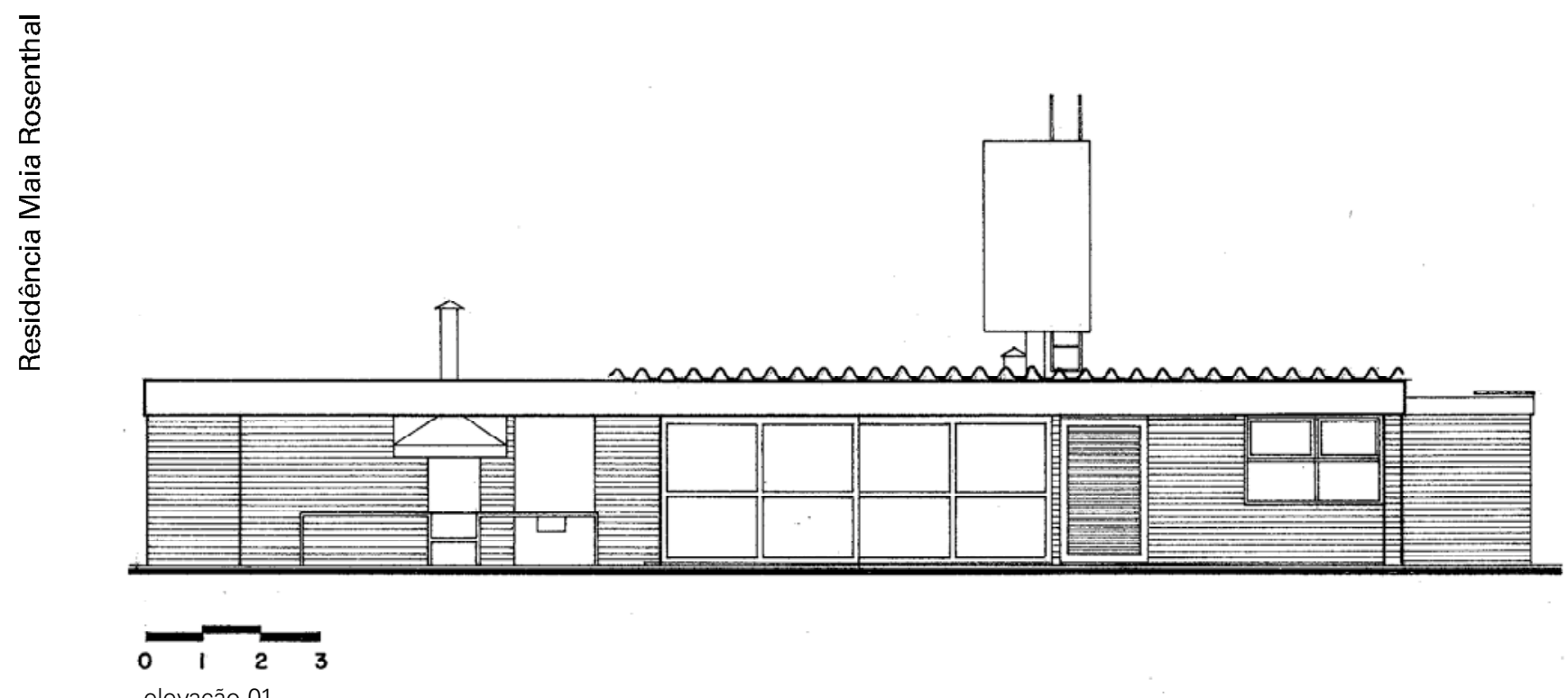

elevação 01

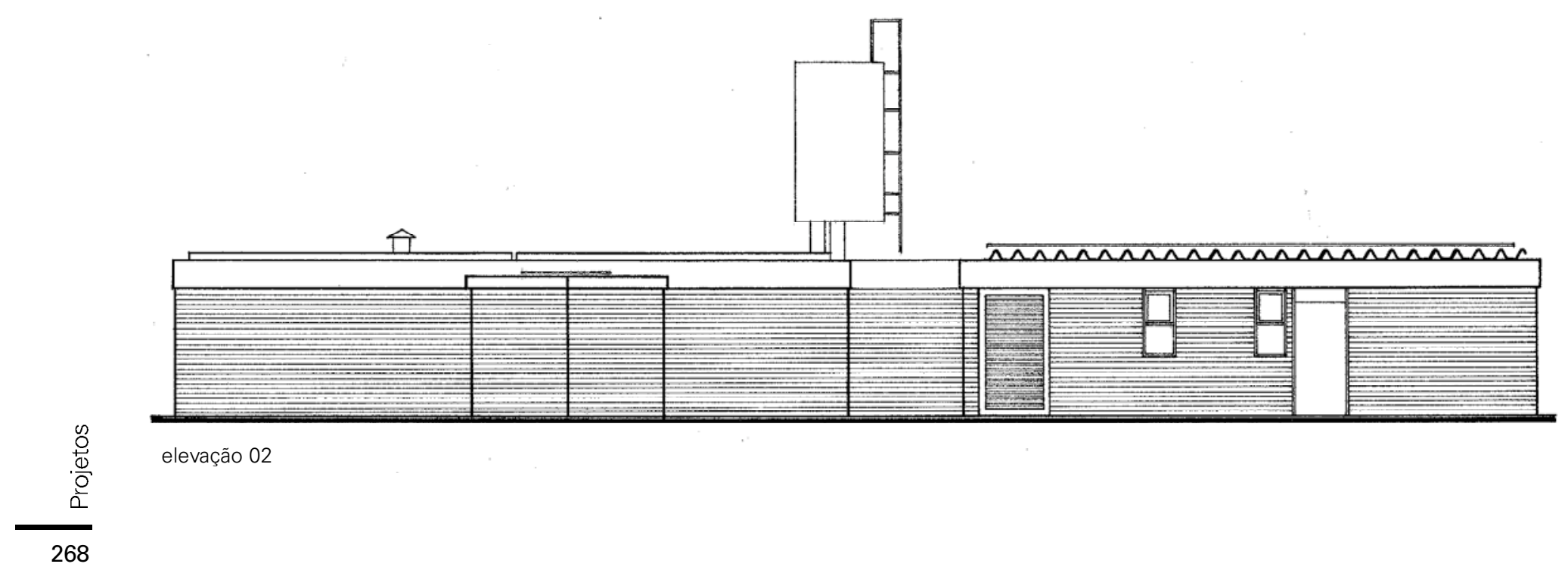



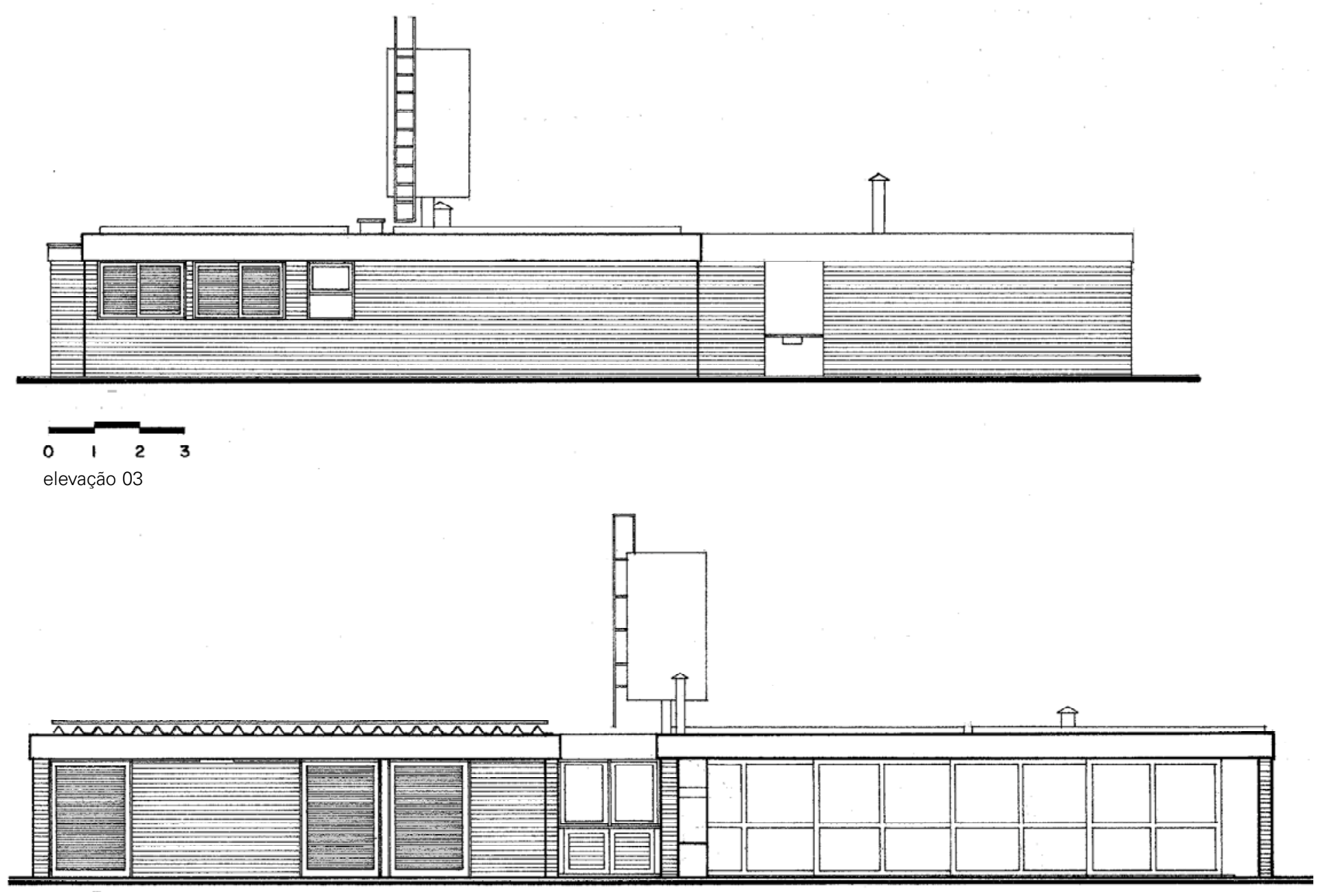

elevação 04 



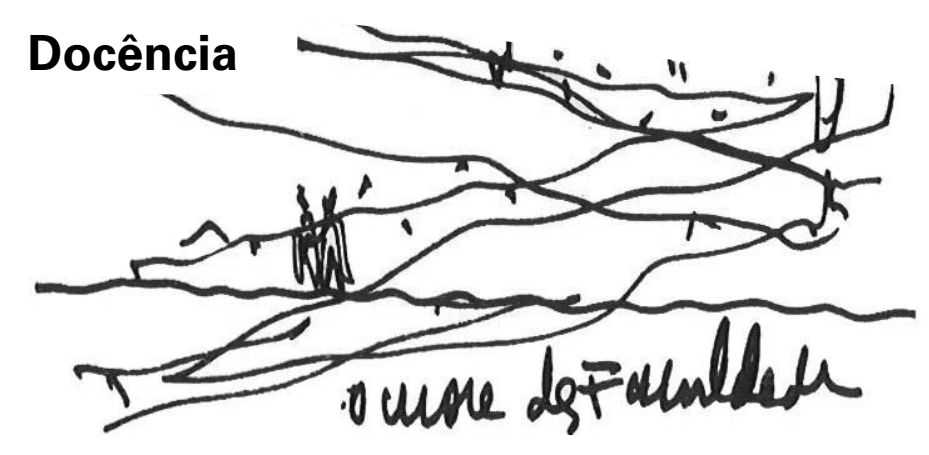




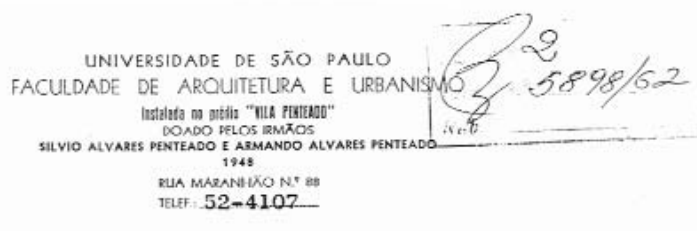

of. $\mathrm{GD} / 111$

$1 \mathrm{mc}$

São Paulo, 7 de março de 1962 .

Magnífico Reitor,

Permito-me solicitar se digne Vosa Magnificência de subeter a Excelentíssimo Senhor Governador do Estado submeter ao Excelentissimo Senhor Goferente a nomeação do Arqto ABRAHĀo VELVU SANOVICZ para o cargo de Assistente em comissão, ref. 53, do grupo I, da PP., do Quadro da Universidade de São Paulo, lotado nesta osição Decorati Secretaria. Tenho a honra de reiterar a Vossa
Magnificencia os protestos de minha elevada estima e consideração.

$$
\begin{aligned}
& \text { leacharf. } \\
& \begin{array}{l}
\text { Lourival GOMES MACHADo } \\
\text { Biretor }
\end{array}
\end{aligned}
$$

Exmo. Sr. Prof. Dr. ANTONIO BARROS DE ULHÔA CINTRA, Magnífico Reitor da Universidade de São Paulo.

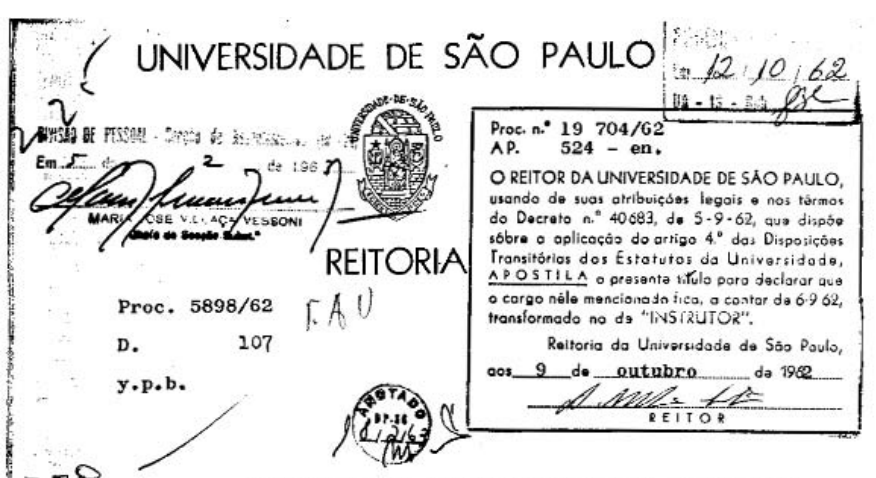

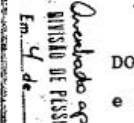

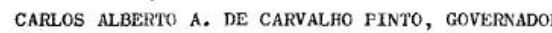
DO ESTADO DE SAO PAULO, usando de suas atribuições legais e nos têrmos do art. 38, item II, da C.L.F., nome i a O Arqt? ABRAHXo VELVU SANovicz para exercer, em comissão 管. - o cargo de Assistente, ref."53", do Grupo I, da PP., do Qua dro da Universidade de Säo Paulo, de 1o provimento, lotado - na Faculdade de Arquitetura e Urbanismo, junto à Cadeira

no 22 - "Composição Decorativa" -, da referida Faculdade. $A$ despesa correrá pelas verbas próprias do orçamento vigente.

Palácio do Govêrno do Estado de São Paulo, 9 le abri1 de 1962.

31 - Mr.

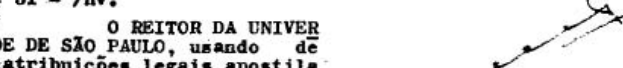

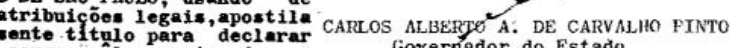

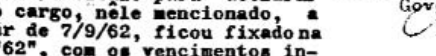

A. ULHOA CINTRA
Reitor

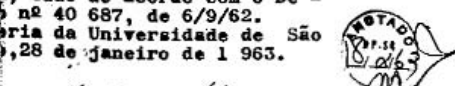

2. hue Le

A. ULHOA CINTRA Get.en: 3/. L-63

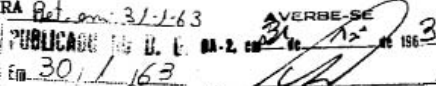


O ingresso de Abrahão Sanovicz no mundo acadêmico ocorreu da seguinte maneira: o diretor da Faculdade de Arquitetura e Urbanismo da Universidade de São Paulo, professor Lourival Gomes Machado, em ofício dirigido ao Magnífico Reitor Professor Antonio Barros de Ulhôa Cintra às folhas 02 do processo 5898/62 - datado de 7 de março de 1962, solicita a nomeação do arquiteto Abrahão Velvu Sanovicz para o cargo de assistente, lotado na Cadeira $\mathrm{n}^{\circ} .22$ "Composição Decorativa". A solicitação foi acolhida pelo Reitor e encaminhada ao Governador do Estado Carlos Alberto A. de Carvalho Pinto que assinou a nomeação em 9 de abril do mesmo ano.

O ano de 1962 marcou profundas mudanças no ensino da FAU como observou Abrahão na série de entrevistas a Catharine Gati:

A maioria dos professores titulares da FAU eram engenheiros vindos da Escola Politécnica, tanto que, nos primeiros anos o único diretor arquiteto, foi também seu fundador, Professor Anhaia Mello. O Conselho Universitário, que indicava os diretores da Escola, no início dos anos 1960, designou para o cargo um professor da Faculdade de Filosofia, professor de política, profundo conhecedor da história da arte, especialista em barroco mineiro, destacado intelectual que havia dirigido algumas bienais, Professor Lourival Gomes Machado, que tivera intenso contato com Mario de Andrade. Era o que a FAU poderia ter recebido de melhor.

O programa da FAU vinha do compromisso entre a Escola
Politécnica e a Escola de Belas Artes, numa somatória de conteúdos. Professor Lourival convocou os professores arquitetos para que reformulassem o programa de ensino, no sentido de atualizá-lo e de colocar a Escola à serviço do atendimento das novas necessidades colocadas pelo país. (DPCA, 1987 e 1988).

Cinco anos antes, mais precisamente em 1957, uma comissão formada pelos professores João Batista Vilanova Artigas, Rino Levi, Helio Duarte e Abelardo de Souza, foi encarregada de reformular o ensino da FAU, tendo como objetivo superar a tradição politécnica e compatibilizar a forma de ensino e os conteúdos com a realidade do país.

Os trabalhos desse colegiado provocaram forte reação por parte dos docentes ligados à Escola Politécnica, como lembra o professor Carlos Barjas Milan:

\begin{abstract}
[...] esta comissão, tendo em vista as dificuldades de uma reforma mais radical, que reconhecia necessária, propôs para aplicação imediata apenas a modificação na seriação das cadeiras do currículo oficial (MILAN. 1965, s.p.)
\end{abstract}

Assim, poucas alterações foram implantadas: uma série crescente de matérias de ordem cultural e uma série decrescente de matérias técnicas, estruturadas pelas disciplinas de projeto.

Além de poucas, essas alterações na estruturação do curso estavam longe de responder aos anseios de alunos e de 
professores arquitetos

Lourival Gomes Machado assumiu a direção da Escola no ano de 1962. Criou, então, as condições para que uma um novo projeto de ensino fosse implantado.

Sob a liderança do professor Artigas, se propôs a efetivar a "Reforma de 62", como ficou conhecida.

Sobre este processo e sobre a participação de Artigas, Abrahão comenta:

Voltando um pouco, depois da greve Niemeyer ${ }^{1}$ houve o afastamento de alguns professores, que foram mandados de volta para a Politécnica. O Artigas foi um deles. Não foi a primeira vez que o puseram de castigo. Quando voltou à FAU, em 56 ou 57, vivia um momento muito interessante: participara do concurso de Brasília que premiou Lucio Costa, depois participou do grupo de arquitetos que reformulou a Cidade Universitária e projetou o prédio da FAU. E foi justamente nessa época que ocorreu a reforma de ensino. Ele conseguiu entender o processo de modernização que o país estava precisando em matéria de ensino (SANOVICZ, 1997, p. 148).

Para a organização do ensino foram criados três departamentos: Projeto, História e Tecnologia. O Departamento de Projeto, por sua vez, era formado por quatro seqüências de disciplinas, compreendendo áreas de interesse e de atuação do arquiteto.

O professor Flávio Motta no texto "Subsídios para o Relatório sobre ensino de Arquitetura UIA2 UNESCO", descreve as áreas de interesse:

[...] subdividiu o campo de trabalho, sem anular as áreas de interesse recíproco, necessárias a uma visão de totalidade do arquiteto. São as seguintes áreas:

a) Comunicação Visual, cuja tônica recai sobre problemas da linguagem;

b) Desenho Industrial, onde dominam as preocupações sobre objetos, produtos e sistemas industriais;

c) Edifício, com a sistematização de problemas de construção, na área de edifícios e espaços habitáveis;

d) Urbanismo, e suas implicações com os problemas das cidades, metrópoles, paisagismo e ocupação territorial (MOTTA, F., 1993, p. 138)

Outra importante novidade incluída na reforma foi a criação do Museu, órgão encarregado de coordenar as atividades dos departamentos e divulgar a produção da Escola, promovendo, para tanto, exposições de arte e de projetos, debates acadêmicos e culturais e publicações.

Luiz Carlos Daher sintetizou a "Reforma de 62" nos seguintes termos:

Duas tradições vicejavam no país: a oriunda da Escola Politécnica de São Paulo e a da Escola de Belas Artes do Rio de Janeiro. A Reforma de 62, singelamente, ultrapassava essa dupla tradição, depois de décadas de batalhas acadêmicas e profissionais. Além disso, estabelecia, em definitivo, a noção do fazer, do projetar, como eixo, em torno do qual se organizam os diversos conhecimentos (DAHER, 1993, p. 156).

Com efeito, a "Reforma de 62" não só transformou 
radicalmente o ensino da $\mathrm{FAU}$, como serviu de referência para a formação de muitas outras escolas no país.

Toda essa trajetória de transformações acadêmicas também foi percorrida por Abrahão Sanovicz que participou ativamente dos processos de alteração do ensino, desde estudante, como atestam documentos arquivados na biblioteca da FAU.

Como acima referido, iniciou sua atividade docente na FAU em 1962. Sua primeira experiência, portanto, se engajava na nova estrutura de ensino proposta. Atuou na seqüência de Desenho Industrial, que tinha como professores os arquitetos Hélio de Queiroz Duarte, Marlene Picarelli e Lúcio Grinover, responsáveis pelo $1^{\circ}$ ano; Ernest Robert de Carvalho Mange, João Baptista Alves Xavier e Cândido Malta Campos Filho, responsáveis pelo $2^{\circ}$ ano; José Maria da Silva Neves, o próprio Abrahão Sanovicz e Luiz Gastão de Castro Lima, responsáveis pelo $3^{\circ}$ ano; e Roberto Cerqueira César, Luiz Roberto Carvalho Franco e Dario Imparato, responsáveis pelo $4^{\circ}$ ano.

Essa primeira experiência na nova estrutura de ensino está documentada na publicação Desenho Industrial 1962, que exprime, em sua introdução, os objetivos da sequência:
D.I. é o estudo do objeto e do seu uso. O raciocínio empregado na solução dos problemas de "Design" não é em absoluto estranho ao arquiteto, mas sim paralelo ao pensamento empregado: nos problemas de edificação e planejamento. O arquiteto na sociedade de hoje atua numa gama muito ampla de processos, abrangendo a produção industrial, identificando-se com ela e contendo em si o "Designer".

Este por sua vez, não deve ser confundido com o inventor, mas sim deve ser encarado e preparado como criador cujo espírito de análise e de síntese oriente com segurança as linhas de desenvolvimento do nosso D.I. O resultado dessa intervenção deverá ser um "Design" caracteristicamente brasileiro, ligado nitidamente ao nosso patrimônio artístico popular e erudito (FAUUSP, 1963)

A disciplina do $3^{\circ}$ ano, em cujo grupo de professores Abrahão estava incluído programou dois temas como trabalho prático para os alunos: jogo de xadrez e isqueiro.

O primeiro consistiu no reestudo de um jogo de xadrez, compreendendo: estudo do relevo de um jogo de xadrez existente; projeto das seis peças (rei, dama, bispo, cavalo, torre e pião); projeto do tabuleiro; projeto do estojo; projeto da embalagem; relevo e desenho do jogo proposto; apresentação visual do trabalho; maquete em tamanho natural e relatório.

Do resultado desse exercício os professores do grupo comentaram na publicação acima referida: 
Trabalhos dos alunos do $3^{\circ}$ ano - jogo de xadrez

em cima [da esq. para a dir.]

- Adauto Ribeiro da Silva | Ivan Romano Batistio |Mutsutaka Shimizu |

Paulo Rocha Queiroz | Wilson Rodrigues Netto | Yoiti Kataquiri

- Antonio Célio Silva | Ari Antonio da Rocha | Arnaldo Antonio Martino |

Carlos Henrique Heck | Conrado Jorge Heck | Marina Bernardini Donelli

- Carlos Augusto Welker | Célio Pimenta | Luisa Toscano | Maria Helena

C. de Abreu | Yasuko Tominaga | Antonio Domingos Battaglia

- Alfredo Benito Parlato | Armenio Iranik Arakelian | Eurico João Salviatil

Savério Henrique Castellano | Décio Verneck Moreira

embaixo [da esq. para a dir.]

- Adolpho Yutaka | Dora Heinrici | Helena Sula | Tetsuo Hori | Takudo Takada | Angela Maria T. Alma Filiset

- Ismael Gonzales | Jorge Alberto Silva Novo | José Ayrton Ferraz |

Mario Yoshinaga | Raul Guardia Sanchez | Vicente P. Borges Bicudo

- Adilson Costa Macedo | Danilo Bassani | Marta Mello Rosseto |

Massimo Fiocchi | Tetsuo Uema
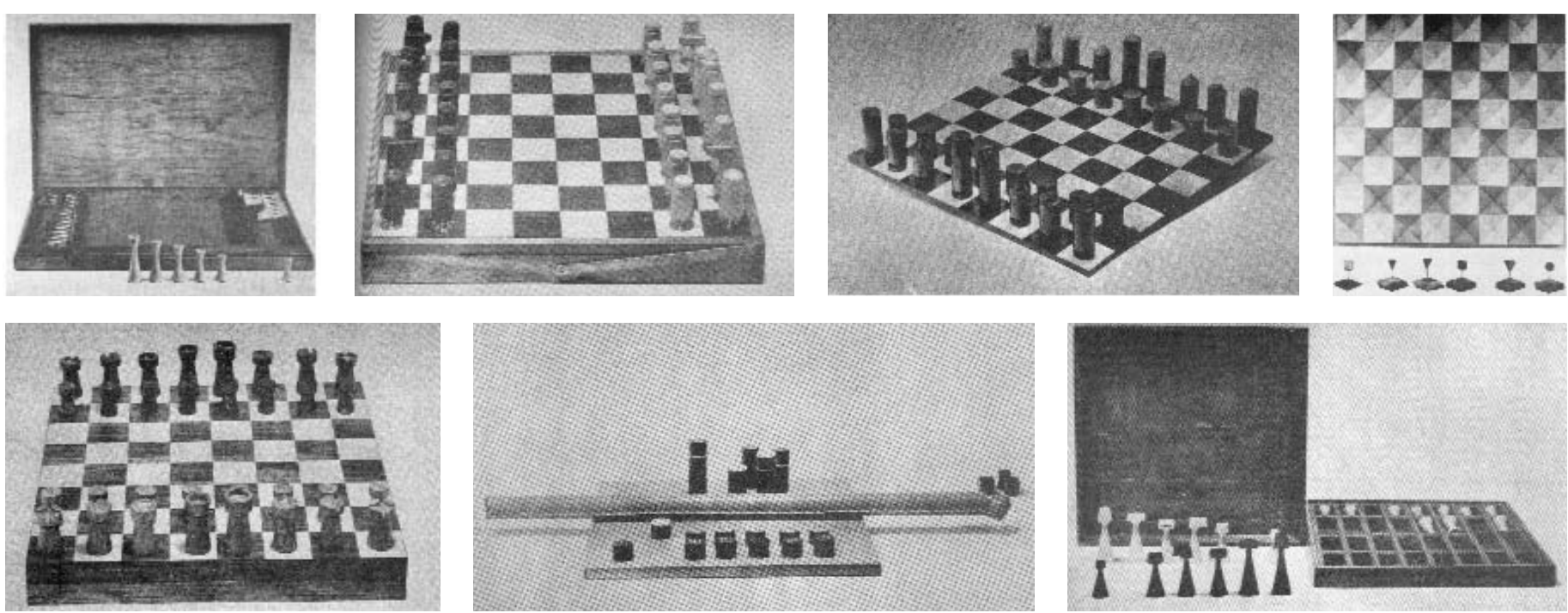
Como resultado final, constatou-se tendência geral de abandono das reminiscências artesanais de dar às peças formas figurativas correspondentes a seus nomes, completamente ultrapassadas pelos modernos conceitos de
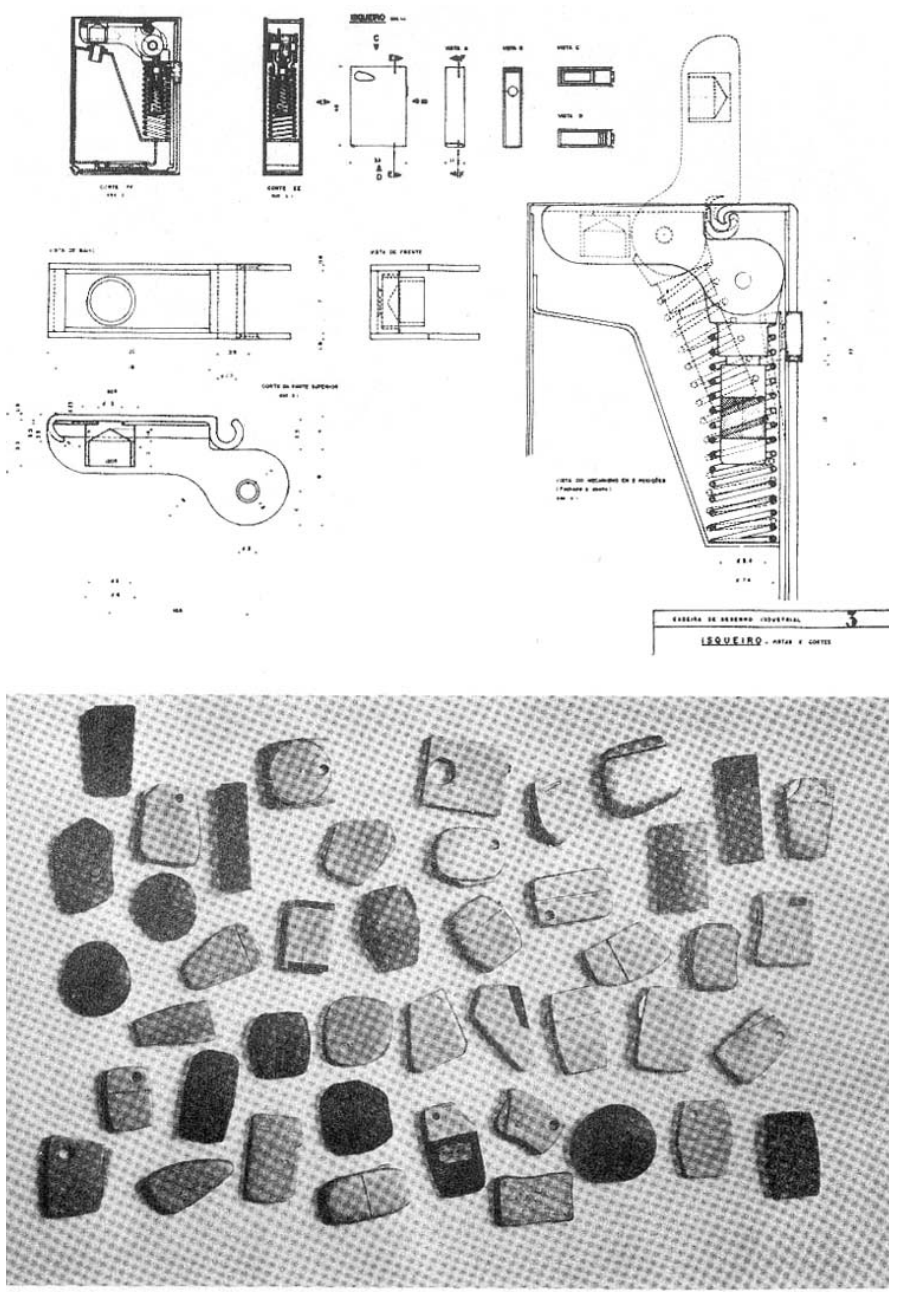

xadrez posicional deixando de considerá-lo como batalha e sim como jogo de relações.

Tomaram entre as peças características outras, como as de movimentação, apresentando maior coerência com as novas técnicas de produção.

Quanto ao aspecto de comunicação visual observa-se a necessidade de maior sedimentação do problema para obtenção de nível qualificado nos próximos exercícios. O resultado geral obtido é mérito dos alunos, cabendo didaticamente aos professores apenas a orientação e a preocupação da continuidade do trabalho (FAUUSP, 1963).

O segundo trabalho, definido pelos professores como bastante simplificado, consistia no projeto de um isqueiro a partir de um mecanismo existente. No caso, o objetivo era "caracterizar a distinção entre 'Design' e invenção mecânica" (FAUUSP, 1963).

Abrahão participou da seqüência de Desenho Industrial de 1962 a 1969.

Em 1969 a FAU mudou-se para a Cidade Universitária, tendo ampliado o número de vagas de oitenta para cento e cinqüenta alunos por ano.

Em abril de 1969, o Presidente da República, General Artur da Costa e Silva, amparado no Ato Institucional $n^{\circ} 5$, decretado em 13 de dezembro de 1968, que Ihe concedia o 
direito de por em recesso o Congresso Nacional, decretar intervenção em Estados e Municípios, suspender direitos políticos, proibir manifestações sobre assuntos políticos, aplicar o curioso princípio da liberdade vigiada e suspender a garantia do habeas-corpus, aposentou compulsoriamente, entre muitos outros professores e servidores públicos, João Batista Vilanova Artigas, Jon Maitrejean e Paulo Mendes da Rocha, professores da FAU.

As cassações aliadas às prisões dos também professores Sérgio Ferro e Rodrigo Lefèvre no início da década de 1970 fragilizaram muito a Escola.

A partir de 1970, Abrahão Sanovicz, após participar da a seqüência de Desenho Industrial, passou a integrar a que, mais tarde, passou a ser o Grupo de Disciplinas de Projeto de Edificações do Departamento de Projetos da FAUUSP. Diversos fatores concorreram para isso: o processo por que passava a Escola, algumas mudanças de objetivos na seqüência de Desenho Industrial e o entendimento de que a contribuição de Abrahão seria mais bem aproveitada na área de projeto.

No mesmo ano, Abrahão e o amigo Julio Katinsky participaram da estruturação da Faculdade de Arquitetura e Urbanismo de Santos - FAUS; o primeiro conceituando o curso de
Programação Visual e o segundo o curso de Desenho Industrial. Nessa Faculdade foi titular da Cadeira de Mensagem.

A experiência na estruturação e as atividades didáticas realizadas na FAUS resultaram no convite pelo Instituto de Arquitetura da Universidade de Brasília, em 1976, para que esses dois professores conceituassem os cursos de Desenho Industrial e Comunicação Visual dessa instituição.

O documento elaborado por Abrahão e Julio - resultante da conceituação realizada - foi publicado, em 1977, pela Associação Brasileira de Escolas de Arquitetura ABEA, sob o título Desenho Industrial e Programação Visual para Escolas de Arquitetura. Foi considerado pela Comissão de Ensino de Arquitetura e Urbanismo - CEAU, órgão do Ministério da Educação, documento de referência para discussão pelas escolas de arquitetura.

Nesse estudo, Abrahão introduz sua proposta delimitando, em relação à formação do arquiteto, a área de atuação da programação visual numa faixa compreendida pela sinalização viária ou rodoviária, de um lado e, de outro,

a propaganda. A partir dessa visão geral do problema, desenvolve e conceitua o curso e desenvolve as ementas para cinco disciplinas. 


\section{No texto ele expõe os objetivos gerais:}

O nosso desejo é formar um profissional mais completo, atento às indagações do meio social e apto a decifrá-las quando estuda a organização dos espaços, sua configuração e os meios do inter-relacionamento humano (SANOVICZ, 1977).

Em 1972, Abrahão apresentou sua tese de doutoramento com o título: Projeto e Produção - Por Uma Aproximação Metodológica. Nela apresentou doze projetos, isto é,aqueles que melhor definiam suas preocupações fundamentais.

A variedade de propostas que reuniu, demonstrando um acúmulo e uma diversidade de experiências, permite afirmar que há uma linha mestra orientando seu trabalho. Em suas palavras, essa linha se caracterizava:

Seja pelo valor social da arquitetura, dos modos de produzi-la; Seja pelas preocupações com o relacionamento dos valores plásticos;

Seja pelo sentido que assume, entre nós, a industrialização da moradia;

Seja, mesmo, o fenômeno da construção ligado ao pleno reconhecimento dos valores na paisagem (SANOVICZ, 1972).

Pela ordem cronológica, os projetos apresentados em sua tese são os seguintes:

- Núcleo Residencial para a Refinaria Presidente Bernardes, Cubatão, SP - 1957.

- Anteprojeto para Concurso do late Clube de Londrina, Londrina PR - 1959.
- Distribuidor de Gasolina Agip, realizado no estágio em Milão, Itália - 1959.

- Linha de Móveis para Escritório Escriba, São Paulo, SP $-1962$.

- Teatro Municipal e Centro Cultural de Santos, Santos, SP - 1960 e 1968

- Edificlo de Apartamento na Rua Pará, São Paulo, SP 1963.

- Projeto de Equipamento para Parques e Jardins do Município de São Paulo, SP - 1967 a 1969.

- Edifícios de Apartamentos Modulares, São Paulo, SP década de 1970

- Conjunto Habitacional Nova Cidade, Jundiaí, SP - 1970.

- Edifício de Apartamentos na Rua das Fiandeiras, São Paulo, SP - 1972.

- CESP - Estação de Piscicultura de Salto Grande, SP 1972.

- CESP - Estação de Piscicultura de Promissão, SP - 1972.

Os projetos comentados na tese, pela sua diversidade, pelos seus processos construtivos, pela sua possibilidade de realização, encerram um objetivo: a intervenção do arquiteto como elemento indispensável, que reúne e sintetiza todos os dados que se apresentam para uma correta solução, que 
atenda desde os mínimos atos individuais, até as complexas atividades comunitárias.

Concluindo, esse trabalho acadêmico Abrahão afirma:

A atividade do arquiteto não é rotineira.

A atividade do arquiteto não é especializada.

Esta atividade, que assume experiências anteriores, se renova a cada projeto.

A elaboração do projeto considera fatores reais de programa analisados e constantemente reelaborados.

A elaboração do projeto considera fatores econômicos, de possibilidades técnicas e tecnológicas de produção, instrumental humano e pelo homem dominado.

A elaboração do projeto considera fatores sociais.

As sínteses dos fatores acima considerados são formalizadas num produto final, onde se processam as atividades humanas. Sendo estas atividades infinitas, as formas das experiências estéticas são também infinitas, donde a riqueza das possibilidades é interminável.

O ideal é que possibilite a todo ser humano uma livre movimentação no espaço (configurando pela sociedade no seu atuar-se), onde pode e deve desenvolver sua atividade criadora, ou seja, libertar-se" (SANOVICZ, 1972).

Após a obtenção do título de doutor mediante a defesa de sua tese, continuou no Grupo de Disciplinas de Projeto de Edificação, ministrando sempre tanto as disciplinas obrigatórias do terceiro ano, quanto as optativas. Coordenou várias vezes o antigo Trabalho de Graduação Interdisciplinar - TGI, que correspondia ao atual Trabalho Final de Graduação - TFG.

Jamais deixou de participar ativa e criticamente, de todos os fóruns e processos de reestruturação do ensino da FAU.

No curso da pós-graduação, além do número de alunos que orientou, cumpre também destacar o curso que ministrou com o professor Flávio Motta "O Conhecimento Arquitetônico e a Construção", tendo como objeto a discussão da arquitetura dos anos 1950. Das aulas ministradas nesse curso restam ainda sessenta cassetes gravados que não foram transcritos até agora.

Em 1990, Abrahão foi convidado pela professora Bianca Bottero responsável pelo Corso de Composizione Architettonica, do Dipartimento do Programmazione, Progettazione e Produzione Edilizia do Politecnico di Milano, para, no período de 25 de abril a 14 de junho de 1990, participar do trabalho desenvolvido pelos alunos do ateliê de projetos.

Essa participação foi possível graças ao apoio da Fundação de Amparo a Pesquisa do Estado de São Paulo FAPESP que patrocinou a viagem.

A experiência adquirida na sua estada junto aos alunos desse ateliê levou-o a propor o estabelecimento de um intercâmbio entre o Politécnico de Milão e a FAU. Tal intercâmbio se baseou em algumas premissas discutidas com a direção do Politécnico e contidas no relatório que 
apresentou à FAPESP. São as seguintes:

1 - Os professores visitantes deviam trabalhar no ateliê acompanhando os exercícios dos estudantes, conjuntamente com os professores responsáveis pela disciplina, na escola visitada

2 - Os professores de ambas as escolas deveriam elaborar um elenco de programas, temas, métodos construtivos ou sistemas de projetos realizados por eles mesmos, para efetuarem seminários conjuntos com o objetivo de conhecer as respectivas obras.

3- Os professores de ambas as escolas deveriam realizar seminários onde seriam apresentados os exercícios dos alunos, os métodos usados para tanto e os produtos finais, para confronto, análise e discussão.

4- Os professores de ambas as escolas deveriam realizar durante o período de permanência um projeto de arquitetura em conjunto. Os programas deste projeto deveriam ser de complexidade tal que pudessem absorver vários professores, sendo os temas abrangentes e de interesse do país visitado (SANOVICZ, 1997, p. 184).

Assim propondo, ele acreditava que o intercâmbio, além da troca de experiência e aperfeiçoamento didático, não só abriria espaço para o início de uma crítica arquitetônica, em relação à universidade, como também proporcionaria independência no tocante à produção corrente no mercado. "A sistematização desta crítica - dizia ele - poderia ser rebatida à prática profissional e seu subsídio poderia trazer benefícios para a didática do projeto e para a qualidade da arquitetura" (SANOVICZ, p. 1997, p. 184).

Mais recentemente, ou seja, em 1997, Abrahão se inscreveu no concurso de Livre-Docência aberto junto ao Departamento de Projetos da FAUUSP. Para tanto, apresentou sua Sistematização Crítica da Obra de Arquitetura. Nela reuniu uma série de projetos e textos, seguindo uma ordem cronológica. Alguns projetos eram acompanhados de extensos memoriais, necessários na ocasião em que foram elaborados; outros, contendo apenas pequenos verbetes. Todos foram selecionados e organizados a partir do material existente, após criteriosa organização de arquivos.

Os desenhos incluídos na Sistematização eram, na sua quase totalidade, documentos de trabalho, guardados durante o processo de elaboração dos projetos.

A coletânea dos projetos e textos deixa claro que, para Abrahão Sanovicz, projetar e ensinar é única e mesma atividade.

O item Explicação Necessária introduz a tese. Nele, Abrahão sintetiza suas preocupações e o rebatimento na prática da arquitetura e do ensino. Assim redigiu ele:

A simplicidade procurada no projeto e no texto, como uma postura didática é ato normal para um professor, a fim de que o aluno possa avaliar o dito em sala de aula e a correspondente 
produção que informa e lastreia a atividade de ensinar.

Sobre os projetos, sempre os fiz com referências. Ato difícil de explicar quando nos bancos da escola, porém, com o caminhar da vida profissional, na maturidade, este processo torna-se claro. Os graus de liberdade se ampliam, o programa se enriquece a partir da "lista de necessidades", guardando do mesmo uma distância enorme. O material construtivo cada vez mais torna-se um meio, não um fim,o que me dá liberdade para interpretar cada programa com a linguagem específica necessária, sem sacrificar a coerência do conjunto dos projetos e textos elaborados ao longo desse percurso. O desenho como forma de linguagem. Sempre desenhei e continuo desenhando, somente passo o projeto para o papel quando já o tenho claro na minha cabeça. Não fico procurando a solução na folha branca. Projetando-o, consigo fazer todas as leituras que necessito para compreender a solução. E por que não, compreender-me também (SANOVICZ, 1977, p. 2).

Aulas ministradas, teses e dissertações, orientações a pósgraduandos, intercâmbios didáticos, reestruturação do ensino, e várias outras tarefas por ele realizadas no mundo acadêmico fazem parte de sua biografia de professor. Testemunha eloqüente dessa trajetória foram as atividades para comemorar o cinqüentenário da FAU que ilustraram com muita propriedade a atividade docente de Abrahão.

Com efeito, o primeiro dos eventos comemorativos foi a exposição de sua obra, realizada em 1997. Organizada pelos alunos, eles escolheram um professor, que, pela diversidade de atuação representasse, com fidelidade o "espírito da FAU".

Uma outra exposição deveria encerrar o conjunto de eventos pelo jubileu de ouro da Escola. O diretor da FAU, nessa época professor Julio Roberto Katinsky, convidou Abrahão para a curadoria desse último evento.

Previa-se que, na exposição, fossem apresentados trabalhos de arquitetos formados pela FAU. Selecioná-los era tarefa muito difícil. Para tanto Abrahão convocou cinco exalunos, subcuradores por cada década: Jon Maitrejean 1948 a 1958; Maria Helena Flynn - 1959 a 1968; Roberto Portugal Albuquerque - 1969 a 1978; Milton Braga - 1979 a 1988 e Fernanda Barbara - 1989 a 1998. Com eles identificou os projetos mais significativos elaborados pelos alunos formados em cada um desses períodos.

As duas exposições, - a que inaugurou e a que encerrou as comemorações do cinqüentenário - conseguiram apresentar a diversidade de atuação que tanto caracteriza o curso. Foram, as duas exposições, Aulas de Arquitetura do professor Abrahão Sanovicz.

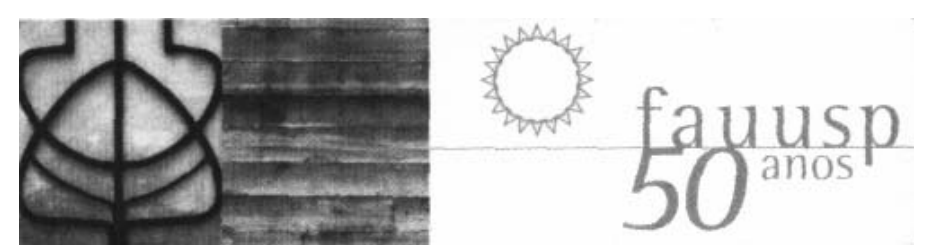


Texto de abertura da exposição do cinqüentenário da FAUUSP

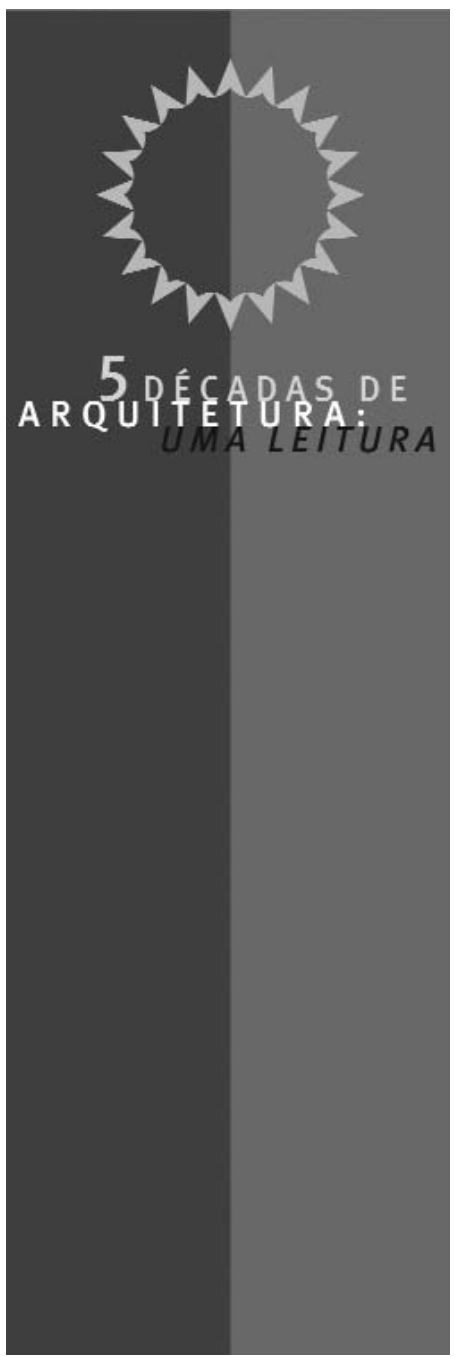

Público ou privado, a qualidade do espaço construido é patrimônio da comunidade e da nação. O projeto sempre é fruto de projeto ou projetos anteriores, leva em conta a história acumulada, logo, arquitetura é cultura ao lado das demais manifestações artísticas. Qual o objetivo - um desenho fisico para o espaço social nas suas diversas formas de intervenção.

O problema a resolver, então, é o da educação.

Educação na escola.

Educação dos órgãos responsáveis pela qualidade do espaço construido.

Educação da sociedade.

Donde, surge a qualidade dos programas.

Mudam-se as relaçōes sociais, mudam-se os desenhos dos espaços.

Uma crítica arquitetônica que seja exercida organicamente, isto é, a partir do interior do

projeto e da obra construída que balize os caminhos a trilhar terá como aspecto

fundamental não o edificio como objeto mas, sim o edificio e sua dimensão urbana.

Numa determinada época, com a distância do tempo vemos que os projetos se assemelham. Arquitetura se "democratiza".

A excepcionalidade herdada do movimento moderno, panfletário inclusive se dissolve e sua contribuição torna-se patrimônio universal.

O sentido de permanência da arquitetura faz com que todo esse processo tenha

obrigatoriamente um grande espaço de maturação, sendo o processo lento e contínuo. Năo nos assustemos se eu disser que em um futuro próximo, e até a médio prazo, 0 exercício da profissão e a sua linguagem não serão muito diversos daquela que apenas vimos apontada pelo movimento moderno entre as duas guerras. Seu repositório programático e formal é denso.

Sendo o exótico fruto de uma mercadologia esdrúxula na maior parte das vezes, tem a sua embalagem cobrindo a fraqueza ideológica do produto, alimentado por uma voraz necessidade editorial. Cabe neste caso menção especial ao tufão "pós-moderno" hoje apenas uma leve brisa.

Voltando ao inicio, é sempre um problema de educação. Esta é uma tarefa penosa e depende de um sistema econômico-social mais justo, o que nos deixa intranqüilos. $\mathrm{A}$ aparente confusão do desenho das cidades, não é da arquitetura, que é um meio - 0 objetivo é o bem-estar social através dos espaços qualificados.

Projetar è um ato tranqüilo.

Sua estética surge de uma postura ética.

E o que esperamos desta leitura.

A conferir 
Fotos da exposição do cinqüentenário da FAUUSP

fonte: acervo da biblioteca da FAUUSP

fotos: Odair Toledo
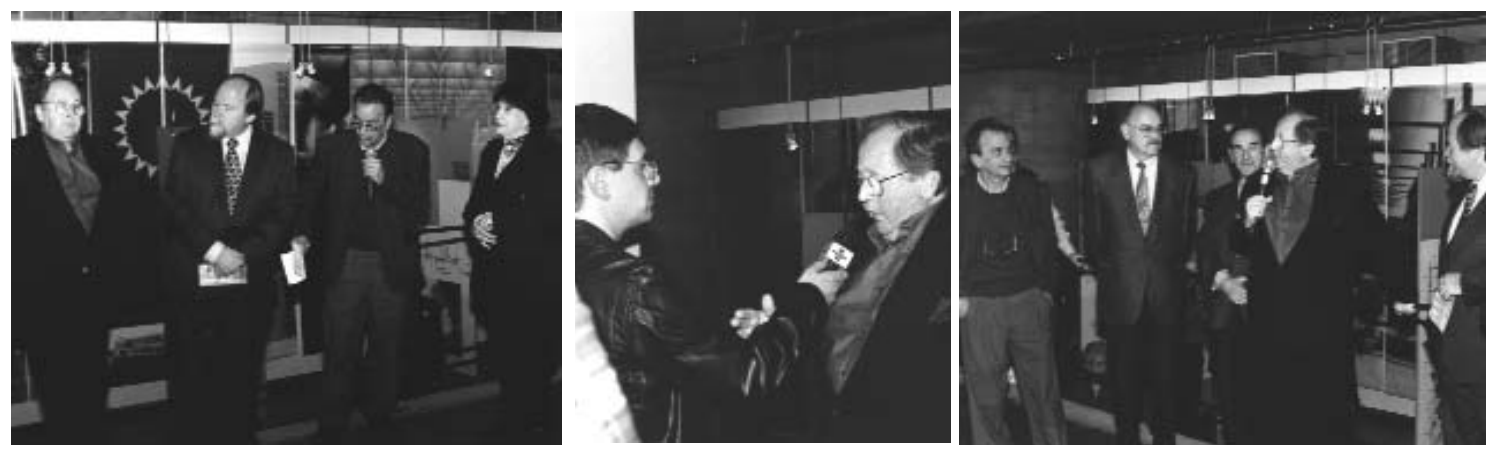

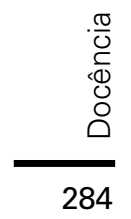




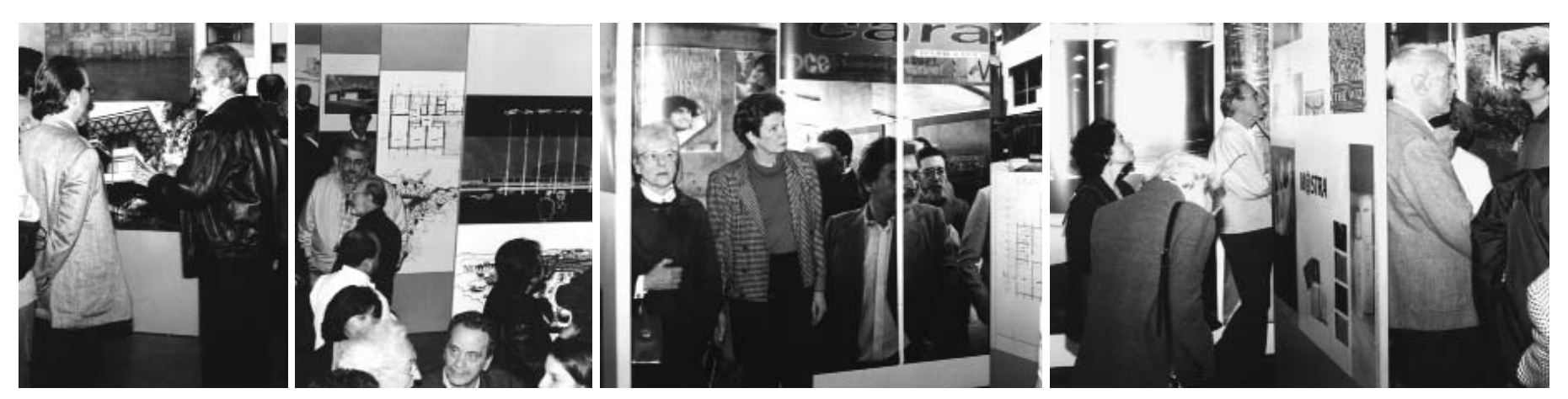




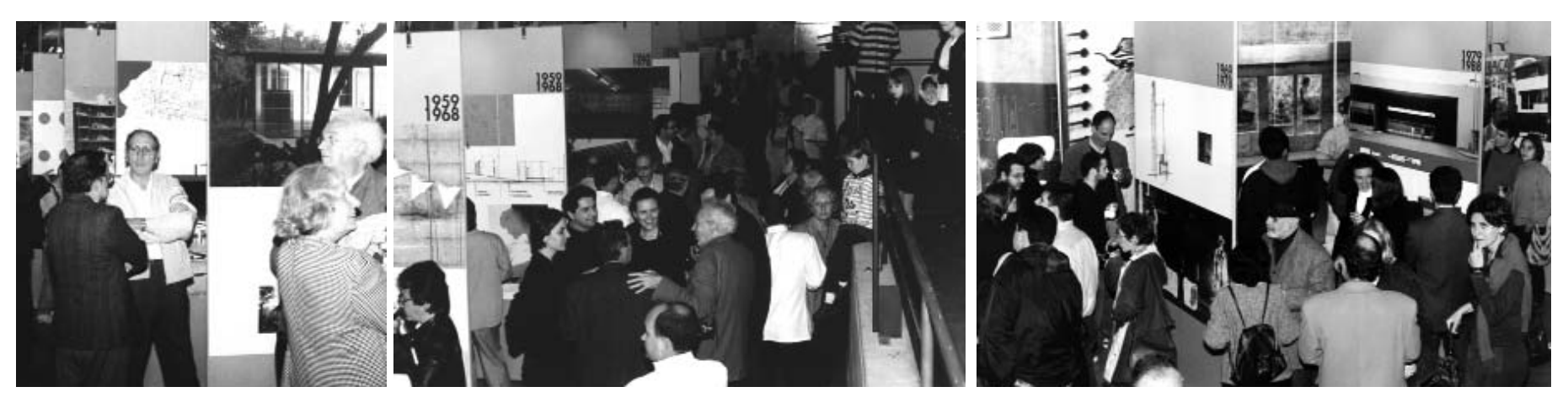

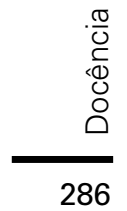




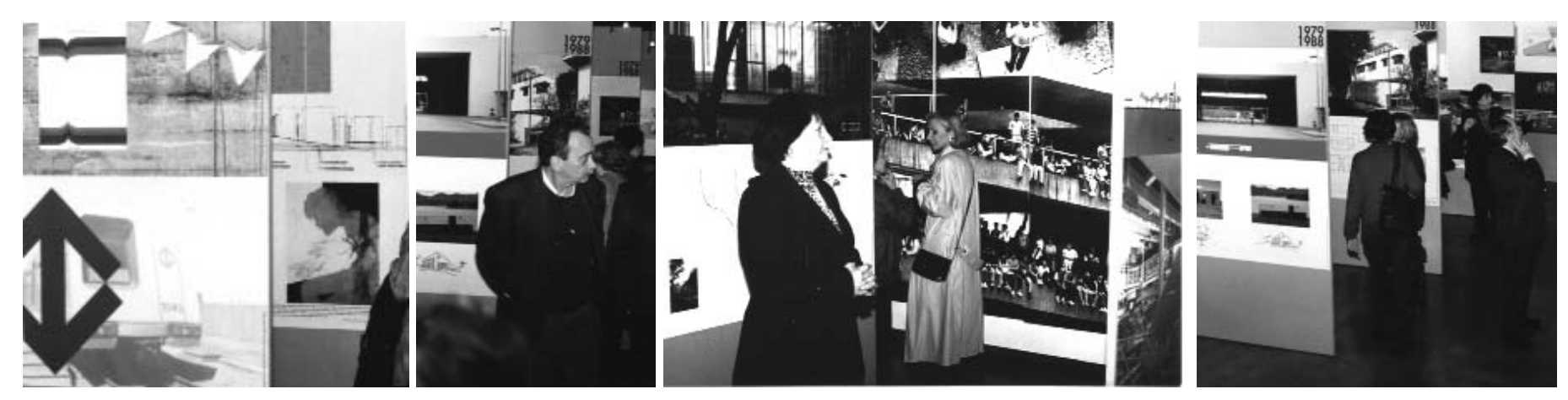

Notas:

1 Greve Niemeyer como citado no Capítulo Formação: Oscar Niemeyer candidatou-se, em 1952, a uma vaga de professor na Faculdade de Arquitetura e Urbanismo da Universidade de São Paulo, mas teve seu nome vetado pelo Conselho Universitário. Os alunos fizeram uma greve que se prolongou por três meses até que a Escola fosse ocupada.

2 UIA: União Internacional de Arquitetos 



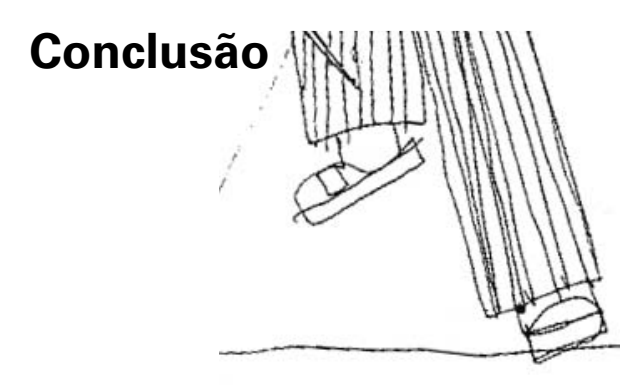


Um antigo provérbio latino, prenhe de sabedoria, assegura: Ars longa, vita brevis. "A arte é longa, a vida é curta".

Sabemos que o conteúdo de sabedoria de um provérbio traz consigo uma verdade que se relaciona com uma reflexão de natureza prática ou moral. Um dos atributos - se é que podemos dar esse rótulo - da verdadeira sabedoria é seu caráter universal cuja dimensão extrapola o tempo e o espaço e não se submete às rígidas leis dos calendários.

Estes comentários vêm a propósito do personagem em torno do qual foi desenvolvido o presente estudo: Abrahão Sanovicz. Com efeito, se esse provérbio é antigo e tem um caráter universal, a verdade que contém se aplica com incomum perfeição à figura daquele que deixou suas marcas na arquitetura em seu tempo de estudante, em sua carreira profissional e em suas atividades docentes.

Abrahão teve uma vida curta, todavia, foi tempo suficiente para deixar uma herança cujo patrimônio não se limitou aos aspectos culturais e arquitetônicos. Como se pode observar em seus projetos, ele fazia questão de demonstrar que a materialidade arquitetônica pode ser transformada pelo arquiteto em mensagem de humanismo.

Um comentário de Larousse (s/d., p. 46) a respeito do referido provérbio garante: "É um provérbio que será exces- sivamente triste se o sábio, o inventor não desejar que outra pessoa siga seus traços para continuar os seus trabalhos".

Tal comentário, com certeza não se aplica ao sábio arquiteto Abrahão Sanovicz. Conscientemente, ele deixava clara em suas obras e propostas a intenção de que outros profissionais seguissem seus traços, não tanto para continuar os seus trabalhos, mas, principalmente, para prolongar seus ideais de conteúdo social e humanístico.

Nesse pano de fundo de sua vida, fica evidente a constante procura de expressar seu ideal na explicitação dos processos de projeto. $\mathrm{E}$ isso ocorreu em toda a trajetória pessoal de Abrahão, a qual teve início já nos primeiros anos de estudante na Faculdade de Arquitetura e Urbanismo, e se estendeu pelo campo de suas atividades profissionais e pelo desempenho da docência na própria Faculdade.

A análise da trajetória delineada na presente pesquisa permitiu tirar as conclusões a serem expostas a seguir.

\section{Como estudante na FAU:}

- Viajou para o Rio de Janeiro com um grupo de colegas, para levantar a obra de Lucio Costa, seus projetos e textos. $\mathrm{O}$ objetivo era procurar entender, a partir desses documentos, como se deu o surgimento da arquitetura moderna no Brasil. 
E justificava: "Acreditávamos que conhecendo melhor seu processo, isso nos ajudaria a caminhar um pouco mais à frente" (SANOVICZ, 1997, p. 145);

- atuava no Grêmio da FAU (GFAU) e no Centro de Estudos Folclóricos na organização e elaboração de publicações sobre arte e arquitetura;

- fez parte da equipe que representou a FAU na IV Bienal Internacional do Museu de Arte Moderna, em 1957. A equipe deixou consignadas, na publicação que preparam com o registro do projeto para o Núcleo Residencial da Refinaria Presidente Bernardes, as intenções e reflexões havidas na elaboração do projeto.

2. Na fase após a graduação em arquitetura:

Uma vez formado arquiteto, as questões inicialmente colocadas se ampliaram, ficando cada vez mais forte sua característica de documentar o processo de trabalho, conforme se pode observar nos exemplos descritos a seguir.

No projeto para o late Clube de Londrina, tanto no memorial como em manifestações posteriores sobre essa obra, pôs em evidência a conceituação do problema e as intenções, e declarou os projetos e soluções formais adotados como referência para a proposta.
Da experiência em Milão, no escritório de Marcello Nizolli, trouxe farto material sobre os projetos de que participou. Esse material possibilitou percorrer os caminhos trilhados até a conclusão de cada desenho que objetivava realizar.

Os croquis e desenhos finais que recolheu durante esse estágio demonstram questões que mais tarde foram retomadas e aprofundadas na exposição em que Abrahão esteve presente com outros cinco arquitetos - Antonio Luis Dias de Andrade, Bruno Roberto Padovano, Eurico Prado Lopes, Minoru Naruto e Paulo Mendes da Rocha - "A Linguagem do Arquiteto: o Croquis", realizada em 1984 no Museu Lasar Segall. O material apresentado na mostra - coleção de croquis elaborados para cada projeto - são elementos que raramente vêm a público. São as primeiras idéias que, lançadas no papel, confirmam e orientam o percurso do projeto. Trazem elementos com os quais o arquiteto dialoga.

Para o Teatro de Santos, além das referências e dos esclarecimentos sobre o processo do projeto, sempre destacou a maneira como se deu a apropriação de novas áreas de conhecimento (mecânica cênica, estruturas protendidas, sofisticado sistema de ar condicionado). Outro importante aspecto ressaltado nos textos sobre o projeto refere-se ao aprendizado na convivência com um profissional mais 
experiente, o arquiteto Oswaldo Corrêa Gonçalves.

Com o projeto para os Equipamentos Públicos e Sinalização para os Jardins de São Paulo, um novo desafio: a elaboração de projetos para quase uma centena equipamentos que pudessem ser produzidos em escala industrial.

Dos elementos que marcaram esse trabalho destacam-se: a diversidade de abordagem; as considerações préestabelecidas pela equipe no que se refere à escolha de materiais e técnicas de simples execução e à facilidade de manutenção, de reposição e estocagem; a importância da realização de um trabalho que consideravam design of community; e a experiência de trabalho com Bramante Buffoni.

Nas manifestações sobre os projetos para as duas Estações de Piscicultura da CESP, Abrahão discute duas importantes questões: a crítica à especialização em arquitetura e o compromisso do arquiteto com espaço construído e sua responsabilidade por esse espaço.

A residência Abrahão Sanovicz é a síntese de tudo que sempre admirou e procurou cumprir: o espaço fluido, a planta livre, a estrutura independente.

No Fórum de Bragança, a experiência em liderar uma equipe formada por seis arquitetos e as novas experimentações formais são destacadas nos documentos sobre o projeto.
Para a sede do Banespa em Recife PE, a afirmação recorrente de Abrahão: "Um projeto é o resultado de projeto ou projetos anteriores" (GOMES, 1989, p.78).

Nas primeiras propostas de Abrahão para edifícios escolares, percebe-se a influência dos projetos dos ginásios de Itanhaém e de Guarulhos, de João Batista Vilanova Artigas. Em 1976, uma proposta inusitada para a Escola Professor Caetano de Campos, realizada com Paulo Mendes da Rocha, mais tarde retomada no projeto da Escola Estadual Bairro 120.

Nos projetos para os edifícios de apartamentos, identificam-se, seguramente, um processo e uma experimentação, que se iniciam com o Edifício Abaeté, na Rua Pará e se encerram com o Teixeira da Silva, compreendendo questões como a racionalização e industrialização da construção e a procura de elementos e componentes padronizados.

Para os conjuntos habitacionais, marcam as soluções encontradas: as referências ao Conjunto Zezinho Magalhães Prado, de Vilanova Artigas e equipe, e as referências às propostas elaboradas por Mies van der Rohe, aliadas às preocupações explicitadas nos projetos para edifícios de apartamentos.

Nas casas bi-nucleares, retoma as propostas adotadas por Marcel Breuer a partir de 1944 na Geller House I, adequando a uma nova realidade e a um outro programa. 
3. No exercício da docência:

O professor Abrahão Sanovicz sempre se pautou pelo compromisso em "estabelecer a integração entre o projeto e a produção - essa produção entendida como produção do projeto propriamente dito, com seus elementos gráficos e escritos, orientadores da obra a ser edificada" (SANOVICZ, 1997, p. 102) e pelo rebatimento de sua atividade de profissional do projeto no ensino e na pesquisa.

\section{Enfim ...}

Em todos os registros de seus projetos, constantemente buscou esclarecer o trajeto percorrido até a proposta final. De igual modo, procurou identificar aquilo que de um trabaIho anterior está presente na obra seguinte, declarando sempre as obras referenciais que ilustraram a solução. Tal atitude não foi pontual. Acompanhou-o durante toda a sua trajetória, caracterizando, portanto, um comportamento que sempre mereceu a admiração de todos.

Essa maneira de trabalhar e de registrar o caminho do projeto, tão característica de Abrahão Sanovicz, nos permite afirmar que, sem dúvida, projeto é pesquisa.

Entretanto, esta postura não é generalizada. Ela pressupõe um método, uma atitude consciente e deliberada anterior ao próprio projeto.

Abrahão construiu, ao longo de seu trabalho como arquiteto e professor de projeto, os mecanismos para registrar o fazer de sua obra de arquitetura, de modo a tornar, tanto sua postura como seus projetos, referências para muitos outros arquitetos. 



\section{Referência Bibliográfica}

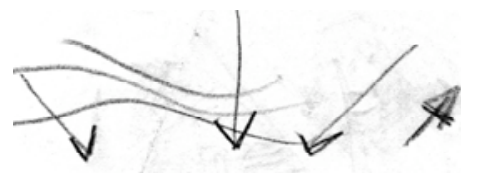



ACAYABA, Marlene Milan. Branco \& Preto: uma história de design brasileiro nos anos 50. São Paulo: Instituto Lina BO e P. M. Bardi, 1994.

ANDRADE, Mário. Curso de filosofia e história da arte. São Paulo: GFAU, 1955.

p. $154-156$

Essa paulista família. In: Revista do Instituto de Estudos Brasileiros nº. 10, São Paulo: Universidade de São Paulo, 1971,

ALMEIDA, Eduardo. In Catálogo da exposição de projetos, desenhos e gravuras de Abrahão Sanovicz. São Paulo, FAUUSP, 1997, s.p.

ALMEIDA, Paulo Mendes de. De Anita ao Museu. São Paulo: Perspectiva, 1976.

AMARAL, Aracy. Arte para quê? : a preocupação social na arte brasileira 1930-1970. São Paulo: Nobel, 1987.

ARTIGAS, João Batista Vilanova. Caminhos da Arquitetura. São Paulo: FVA: Pini, 1986.

1993.

Contribuição para o relatório sobre ensino de arquitetura. Sinopses Memória. São Paulo, FAUUSP, edição especial,

BERTONI, "Nuccio". In REGIONE PIEMONTI - ASSESSORATO ALLÁ CULTURA. Shape mission: car design in Turin e Piedmont. Piemonte: Regione Piemonti 2003.

BREUER, Marcel. Buildings and projects: 1921 - 1961. Stuttgart: Verlag, 1962.

COELHO, Isabel Ruas Pereira. Painéis em mosaico na arquitetura moderna paulista: 1945 - 1964. Dissertação de Mestrado Faculdade de Arquitetura e Urbanismo da Universidade de São Paulo. São Paulo: FAUUSP, 2001.

CORRÊA, Maria E. \& NEVES, Helia M. V. \& MELLO, Mirela G. - Arquitetura escolar paulista: 1890/1920. São Paulo, Fundação para o Desenvolvimento da Educação FDE, 1991. 
COSTA, Lucio. Sobre arquitetura. Porto Alegre: Centro de Estudantes Universitários de Arquitetura, 1962.

CUMBICA. Desenho. São Paulo: GFAU, nº. 4, matéria 5, maio de 1972.

DAHER, Luiz Carlos. O espaço arquitetônico brasileiro dos últimos 20 anos e a formação profissional do arquiteto. In: SINOPSES Memória. São Paulo: FAUUSP, edição especial, 1993, p. 156-164.

Sobre o desejo, digo, o desenho do arquiteto. In ASSOCIAÇÃO MUSEU LASAR SEGALL. A linguagem do arquiteto:o croquis. São Paulo: Museu Lasar Segall, 1984.

D’HORTA, Vera. MAM: Museu de Arte Moderna de São Paulo. São Paulo: DBA, 1995.

DOCUMENTO: Oswaldo Corrêa Gonçalves. AU. São Paulo: Pini, nº 59 p. 79 a 86, abr./mai.1995.

DPCA - Documentação sobre produtores culturais de arquitetura em São Paulo. Conjunto de entrevistas de Abrahão Sanovicz concedida à Catharine Gati, 1987 e 1988, inéditas. Ver síntese no Volume 2 da tese.

DRILLER, Joachim. Breuer Houses. Londres: Phaidon, 2000

FALBEL, Nachman. Manasdhe: sua vida e seu tempo. São Paulo: Perspectiva, 1996,

FAUUSP. Núcleo residencial para a Refinaria Presidente Bernardes. São Paulo: FAUUSP, 1958.

Publicação 8: seqüência de desenho industrial departamento de projetos. São Paulo: FAUUSP, 1963.

FERRAZ, Geraldo. Citado por LEITE, José Roberto Teixeira. 500 Anos da pintura brasileira: uma enciclopédia interativa. São Paulo: Log On Informática e Raul Mendes, 1999, verbete "Família Artística Paulista".

GOMES, Geraldo. Recorrendo à linguagem presente. Projeto nº. 126, p. 78-81, out. 1989.

GOMES, José Cláudio. A pesquisa no projeto de arquitetura e urbanismo: sete paradigmas. In SEMINÁRIO NATUREZA E 
PRIORIDADES DE PESQUISA EM ARQUITETURA E URBANISMO, São Paulo. Anais... São Paulo, FAUUSP, 1990 , p 29 e 30.

GONÇALVES, Lisbeth Rebollo. Sérgio Milliet, crítico de arte. São Paulo: Perspectiva: EDUSP, 1992.

GOODWIN, Philip. Brazil builds: architecture new and old, 1652 - 1942. New York: The Museum of Modern Art, 1943.

IMBRONITO, Maria Isabel. Três edifícios de habitação para a Formaespaço: Modulares, Gemini e Protótipo. Dissertação de Mestrado - Faculdade de Arquitetura e Urbanismo da Universidade de São Paulo. São Paulo: FAUUSP, 2003.

JOHNSON, Philip. Mies van der Rohe. Buenos Aires: Victor Leru, 1960.

LAMPRECHT, B. M. Richard Neutra: complete works. New York: Taschen, 2000.

LAROUSSE, M. Pierre. Flore latine des dames et gens du monde. Ou clef dês citations latines que l'on rencontre frequentement dans lês ouvrages dês ecrivants français. Paris: Larousse et Boyer, s/d.

LOURENÇO, Maria Cecília França. Museus acolhem o moderno. São Paulo: EDUSP, 1999.

MAGALDI, Sabato. Teatro municipal e centro de arte em Santos SP. Habitat São Paulo, nº 63 p. 24 a 29, maço de 1961.

MARINS, Ibiapaba. Menos "whisky" mais trabalho: reage à modorra o "Museu de Arte Moderna de São Paulo". Última Hora, São Paulo, 10 de setembro de 1952.

MEYER, Hannes. El arquitecto en la lucha de classes y otros escritos. Barcelona: Gustavo Gili, 1972, p. VIII e IX.

MILAN, Carlos Barjas. Várias Manifestações a propósito da arquitetura. Tema. São Paulo: GFAU, nº 1, maio de 1965.

MINDLIN, Henrique E. Arquitetura moderna no Brasil. Rio de Janeiro: Aeroplano, 1999.

MONDRIAN, Piet. O neo-plasticismo. São Paulo: GFAU, 1954. 
MOTTA, Flávio. Textos informes: a Família Artística Paulista. . In: Revista do Instituto de Estudos Brasileiros $\mathrm{n}^{\circ}$. 10, São Paulo: Universidade de São Paulo, 1971, p. 137-154.

Subsídios para o relatório sobre ensino de Arquitetura UIA - UNESCO. In: SINOPSES Memória. São Paulo: FAUUSP, edição especial, 1993, p. 138-155 (documento originalmente escrito em 1973).

MOTTA, Renata Vieira da. O MASP em exposição: mostras periódicas na 7 de abril. Dissertação de Mestrado - Faculdade de Arquitetura e Urbanismo da Universidade de São Paulo. São Paulo: FAUUSP, 2003.

NASCIMENTO, Ana Paula. MAM: museu para a metrópole: a participação dos arquitetos na organização inicial do Museu de Arte Moderna de São Paulo. Dissertação de Mestrado - Faculdade de Arquitetura e Urbanismo da Universidade de São Paulo. São Paulo: FAUUSP, 2003.

NEUTRA, Richard. Architecture of social concern in region of mild climate. São Paulo, Edanee, 1948.

NIEMEYER, Oscar. Niemeye r. Belmont-sur-Lausane: Alphabet, 1977.

PAPACHRISTOU, Tician. Marcel Breuer: Nuevas construcciones y proyectos. Barcelona: Gustavo Gili, 1970.

PINSKY, Carla Bassanezi. Pássaros da liberdade: jovens, judeus e revolucionários no Brasil. São Paulo: Contexto, 2000.

REGIONE PIEMONTI - ASSESSORATO ALLÁ CULTURA. Shape mission: car design in Turin e Piedmont. Piemonte: Regione Piemonti 2003.

SANOVICZ, Abrahão. A pesquisa na área de projeto. In SEMINÁRIO NATUREZA E PRIORIDADES DE PESQUISA EM ARQUITETURA E URBANISMO, São Paulo. Anais... São Paulo, FAUUSP, 1990, p 109 a 111 (Texto elaborado, originalmente, como base para discussão no Grupo de Disciplinas de Projeto de Edificações, 1985).

Atas de grupo de trabalho do DOP 1974 - intervenções. Apud KATINSKY, Julio Roberto. Desenho industrial. In: ZANINI, Walter (org.). História geral da arte no Brasil. São Paulo: Instituto Walter Moreira Sales: Fundação Djalma Guimarães, 1983, p. 915-951. 
KATINSKY, Julio Roberto. Desenho industrial e programação visual para escolas de arquitetura. Brasília: ABEA: MEC,

1977.

In ASSOCIAÇÃO MUSEU LASAR SEGALL. A linguagem do arquiteto:ocroquis. São Paulo: Museu Lasar Segall, 1984.

Projeto e produção: por uma aproximação metodológica. Tese de doutorado - Faculdade de Arquitetura e Urbanismo da Universidade de São Paulo. São Paulo: FAUUSP, 1972.

Sistematização crítica da obra de arquitetura. Tese apresentada para obtenção do título de Livre Docente da Faculdade de Arquitetura e Urbanismo da Universidade de São Paulo. São Paulo: FAUUSP, 1997.

SILVA, Quirino da. Visa a formar artífices a Escola de Artesanato. Diário da Noite, São Paulo 27 de junho de 1952.

SIMÕES, Inimá Ferreira. Salas de cinema em São Paulo. São Paulo: PW: SMC: SÉC, 1990.

TAFURI, Manfredo. In BUZZAR, Miguel Antônio. João Batista Vilanova Artigas: elementos para a compreensão de um caminho da arquitetura brasileira, 1938 - 1967. Dissertação de Mestrado - Faculdade de Arquitetura e Urbanismo da Universidade de São Paulo. São Paulo: FAUUSP, 1996.

TEATRO Municipal e Centro de Arte em Santos. Módulo. Rio de Janeiro, nº 7 (28) p. 16 a 20, julho de 1962.

TOSCANO, Odiléa. Fau Maranhão: formandos de 1958. In Catálogo da exposição de projetos, desenhos e gravuras de Abrahão Sanovicz. São Paulo, FAUUSP, 1997, s.p.

TOSCANO, João Walter. Entrevista. Projeto e Design. São Paulo, nº. 227, mar. 2003. Reproduzida na www.arcoweb.com.br/ entrevista/entrevista40.asp, acesso em 13 de out. 2003.

João Walter Toscano. São Paulo: UNESP: Instituto Takano, 2002.

WOLF, José. Fórum de Bragança Paulista SP: encontro de caminhos. AU. São Paulo: Pini, nº 43 p. 47-59, ago./set. 1992. 
Escolas - Arquitetura da Pedagogia. AU. São Paulo: Pini, nº 62 p. 48-54, out./nov. 1995.

SABAG, Haifa. Habitação. AU. São Paulo: Pini, nº 82 p. 75-86, fev./mar. 1999.

ZANINI, Walter (org.). História geral da arte no Brasil. São Paulo: Instituto Walter Moreira Sales: Fundação Djalma Guimarães,

1983.

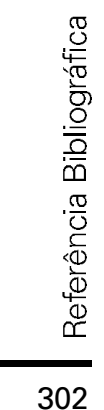




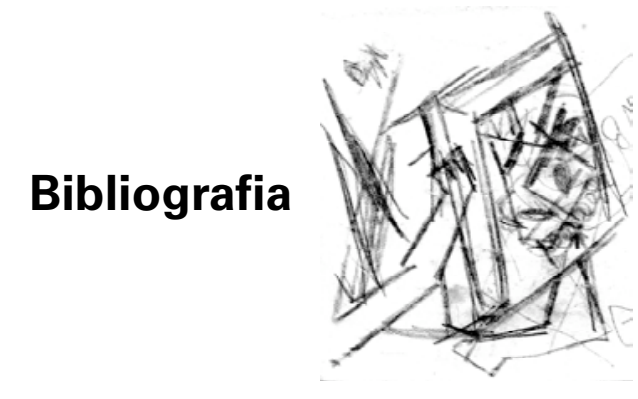





\section{REFERÊNCIA GERAL}

ABBAGNO, Nicola. Dicionário de filosofia. São Paulo: Mestre Jou, 1982.

ALMOYNA, Julio Martinez. Dicionário espanhol-portugês. Porto: Porto, 1974.

BINI, Edson. Dicionário técnico industrial inglês-português-inglês. São Paulo: Hemus, 1979.

CARVALHO, Olívio de. Dicionário francês-português. Porto: Porto, s/d.

Dicionário português-francês. Porto: Porto, 1974.

CORONA, Eduardo; LEMOS, Carlos. Dicionário da arquitetura brasileira. São Paulo: EDART, 1972.

CORRÊA, Roberto ; STEINBERG, Sary. Dicionário escolar francês-português / português-francês. Rio de Janeiro: FDE e MEC, 1986.

COSTA, Eunice; DOUCHCKIN, Tatiana. Thesaurus experimental de arquitetura. São Paulo: FAUUSP, 1982.

CUNHA, Antônio Geraldo da. Dicionário etimológico Nova Fronteira da língua portuguesa. Rio de Janeiro: Nova Fronteira, 1982.

DICTIONARE ENCYCLOPÉDIQUE POUR TOUS. Petit Larousse Ilustré. Paris: Larousse, 1977.

FARIA, Ernesto. Dicionário escolar latino-português. Rio de Janeiro: MEC, 1967.

FERREIRA, Aurélio Buarque de Holanda. Novo dicionário da língua portuguesa. Rio de Janeiro: Nova Fronteira, s/d.

FONTINHA, Rodrigo. Novo dicionário etimológico da língua portuguesa. Porto: Editorial Domingos Barreira, s/d.

GAMA, Ruy. Glossário. São Paulo: FAUUSP, 1982. 
LALANDE, André. Vocabulaire technique et critique de la Philosophie. Paris: PUF, 1980.

LEITE, José Roberto Teixeira. 500 Anos da pintura brasileira: uma enciclopédia interativa. São Paulo: Log On Informática e Raul Mendes, 1999

NASCENTES, Antenor. Dicionário etimológico da língua portuguesa. Rio de Janeiro: Francisco Alves, 1932.

SERPA, Osvaldo F. Dicionário escolar inglês-português, português-inglês. Rio de Janeiro: FDE \& MEC, s/d.

UNIVERSIDADE DE SÃO PAULO, FACULDADE DE ARQUITETURA E URBANISMO, BIBLIOTECA. Índice da arquitetura brasileira 1950/1970. São Paulo: FAUUSP, 1974.

Índice da arquitetura brasileira 1981/1983. São Paulo: FAUUSP, 1992.

ZANINI, Walter (org.). História geral da arte no Brasil. São Paulo: Instituto Walter Moreira Sales: Fundação Djalma Guimarães, 1983.

LIVROS

AGUILLAR, Nélson (org.). Bienal Brasil século XX. São Paulo: Fundação Bienal de São Paulo, 1994.

AMARAL, Aracy (coord.). Arte construtiva no Brasil: Coleção Adolfo Leiner. São Paulo: Companhia Melhoramentos, 1998.

Projeto construtivo brasileiro na arte. (1950 - 1962). Rio de Janeiro - São Paulo: MEC - FUNARTE, 1977.

ARGAN, Giulio Carlo. Projeto e destino. São Paulo: Ática, 2000.

ARTIGAS, João Batista Vilanova. A função social do arquiteto. São Paulo: Nobel, 1989.

ASSOCIAÇÃO MUSEU LASAR SEGALL. A linguagem do arquiteto: o croquis. São Paulo: Museu Lasar Segall, 1984. 
BARDI, Pietro Maria. Profile of the new brasilian art. São Paulo, Kosmos, 1970.

BENJAMIN, Walter. A modernidade e os modernos. Rio de Janeiro: Tempo Brasileiro, 2000.

BOLLNOW, Otto. Introdução a la filosofia del conocimiento. Buenos Aires: Amorrortu, 2001.

CLAYSSEN, Dominique. Jean Prouve. I'idée constructive. Paris, Dunod, 1983.

CORONA, Eduardo. Oscar Niemeyer: uma lição de arquitetura. São Paulo: FUPAM, 2001.

CORRÊA Maria Elizabeth; FERREIRA, Avany De Francisco; MELLO, Mirela Geiger. Arquitetura escolar paulista: restauro. São Paulo: FDE, 1998.

COSTA, Lucio. Lucio Costa: registro de uma vivência. São Paulo: Empresa das Artes, 1995.

FARIAS, Agnaldo (coord.). Bienal 50 anos: 1951 - 2001. São Paulo: Fundação Bienal de São Paulo, 2001.

FAUSTO, Boris. História do Brasil. São Paulo: EDUSP - FDE, 1995.

FAUUSP. Cadernos de Arquitetura 1. São Paulo: Pini: FUPAM, 2001.

FDE. Arquitetura escolar e política educacional. São Paulo: FDE, 1998.

FRIESEL, Sigue. Educação e Sociedade. Dror n5. Lishká Merkazit do Movimento Juvenil Dror, 1950.

HOBSBAWN, Eric. Era dos extremos. São Paulo: Companhia das Letras, 1995.

KAHN, Louis. Forma y diseño. Buenos Aires: Nueva Vision, 2003.

KOPP, Anatole. Quando o moderno não era um estilo e sim uma causa. São Paulo: Nobel: EDUSP, 1990. 
LA RECHERCHE EN ARCHITECTURE: UM BILAN INTERNACIONAL. Actes du colloque. Marselha: Parenthèses, 1986.

LOPES, Telê Ancona. Mariodeandradiando. São Paulo: Hucitec, 1996.

LÈVI-STRAUSS, Claude. Tristes trópicos. São Paulo: Companhia das Letras, 1996.

LOURENÇO, Maria Cecília França. Operários da modernidade. São Paulo: Hucitec / EDUSP, 1995.

MUSEU LASAR SEGALL. Desenho de Lasar Segall. São Paulo: Museu Lasar Segall, 1991.

NIEMEYER, Oscar. A forma na arquitetura. Rio de Janeiro: Avenir, 1978.

PLINIO. Textos de historia del arte. Madrid: Torrego, 2001.

PROUVE, Jean. Jean Prouve et Paris. Paris: Picard, 2001.

ROGGERO, Mario Federico. Il contributo di Mendelsohn allá evolucione della architettura moderna. Milão: Tamburini, 1952.

SEGAWA, Hugo. Arquiteturas no Brasil: 1900 - 1990. São Paulo: EDUSP, 1997.

SANOVICZ, Abrahão. A profissão e a criatividade no Brasil: caminhos da formação profissional ma universidade brasileira. In. Programa Oficial do XII Congresso Brasileiro de Arquitetos Lúcio Costa. São Paulo: IAB, 1991, p. 40.

O centro de cultura como programa: pequeno passeio. In Novo centro de cultura. Santos: PMS, 1991, p. 13 -14.

TAFURI, Manfredo. Projecto e utopia. Lisboa: Presença, 1985.

迹

$\frac{\bar{O}}{\overline{0}} \quad$ VALÉRY, Paul. Eupalinos ou o arquiteto. São Paulo: Editora 34, 1996. 
Introdução ao método de Leonardo Da Vinci. São Paulo: 34, 1998.

Variedades São Paulo: Iluminuras, 1999.

XAVIER, Alberto (org.) Depoimento de uma geração. São Paulo: Pini: ABEA: Fundação Vilanova Artigas, 1987.

ZAMBONI, Silvio. A pesquisa em arte: um paralelo entre arte e ciência. Campinas: Autores Associados, 2001.

\section{TESES ETRABALHOS DE GRAU}

ALMEIDA, Eduardo de. Habitação: consumo, produto, projeto. Tese de Doutorado - Faculdade de Arquitetura e Urbanismo da Universidade de São Paulo. São Paulo: FAUUSP, 1972.

ANELLI, Renato Luiz Sobral. Arquitetura e cidade na obra de Rino Levi. Tese de Doutorado - Faculdade de Arquitetura e Urbanismo da Universidade de São Paulo. São Paulo: FAUUSP, 1995.

BUZZAR, Miguel Antônio. João Batista Vilanova Artigas: elementos para a compreensão de um caminho da arquitetura brasileira, 1938 - 1967. Dissertação de Mestrado - Faculdade de Arquitetura e Urbanismo da Universidade de São Paulo. São Paulo: FAUUSP, 1996.

CORRÊA, Maria Luiza. Artigas: da idéia ao desenho. Dissertação de Mestrado - Faculdade de Arquitetura e Urbanismo da Universidade de São Paulo. São Paulo: FAUUSP, 1998.

NASCIMENTO, Myrna Arruda. Arquiteturas do pensamento. Tese de Doutorado - Faculdade de Arquitetura e Urbanismo da Universidade de São Paulo. São Paulo: FAUUSP, 2003.

SCHINCARIOL, Zuleica. Através do espaço do acervo: o MASP na 7 de Abril. Dissertação de Mestrado - Faculdade de Arquitetura e Urbanismo da Universidade de São Paulo. São Paulo: FAUUSP, 2000.

TOSCANO, João Walter. Arquitetura, experiência de um percurso. Tese de Doutorado - Faculdade de Arquitetura e Urbanismo da 
Universidade de São Paulo. São Paulo: FAUUSP, 1989.

VIÉGAS, Fernando Felippe. Conjunto Nacional: a construção do espigão central. Dissertação de Mestrado - Faculdade de Arquitetura e Urbanismo da Universidade de São Paulo. São Paulo: FAUUSP, 2003.

\section{PERIÓDICOS}

Artigos de Abrahão Sanovicz e sobre sua obra, organizados cronologicamente.

CAMPINAS, PAÇO MUNICIPAL E PARQUE - TERCEIRO PR MIO. Acrópole, São Paulo, n. 230, dez. 1957, p. 46 a 49. (Ainda estudante de arquitetura, Abrahão Sanovicz, fez parte da equipe colocada em terceiro lugar no concurso para o Paço Municipal e Parque da cidade de Campinas. A equipe, coordenada por Jorge Wilheim contava com a participação dos arquitetos Jorge Zalszupim, Roberto Coelho Cardoso, Rosa Grena Kliass, Wlademir Kliass e o engenheiro A. C. Vasconcelos, consultor estrutural).

ANTEPROJETO PARA O IATE CLUBE DE LONDRINA. Acrópole, São Paulo, n² 253, nov. de 1959, p. 18 a 20.

MAGALDI, Sabato. Teatro municipal e centro de arte em Santos SP. Habitat. São Paulo, nº 63 p. 24 a 29 , maço de 1961.

TEATRO MUNICIPAL DE SANTOS. Acrópole, São Paulo, nº 277, dez. 1961, p. 11 a 13.

ANTEPROJETO PARA ASSEMBLÉIA LEGISLATIVA DE MINAS GERAIS. Acrópole São Paulo, nº 283, junho de 1962 , p. 226 a 230. (Projeto de: Jorge Wilheim (coord.), Abrahão Sanovicz, Paulo Zimbres (arquitetos) e Miguel Juliano. Consultor estrutural: Aluisio Dávila).

TEATRO MUNICIPAL E CENTRO DE ARTES DE SANTOS. Módulo, Rio de Janeiro, nº 7 (28), junho de 1962, p. 16 a 20.

UMA CIDADE UNIVERSITÁRIA BRASILEIRA. Zodiac, Milão, n 11, 1963, p. 57 a 77.

$1^{\text {a }}$ EXPOSIÇÃO DE PRODUTOS INDUSTRIAIS BRASILEIROS DE BOM DESENHO. Produto e Linguagem, São Paulo, $\mathrm{n}^{\circ}$ 1, 1965 ,

p. 15. (Artigo sobre a contribuição de Abrahão Sanovicz, entre outros, para a realização do I Seminário sobre o Ensino do Desenho 
Industrial, a realização da I Exposição Nacional de Desenho Industrial e a primeira publicação cultural dedicada exclusivamente aos problemas do desenho industrial da ABDI - Associação Brasileirade Desenho Industrial. Abrahão participou da exposição com "Linha de Móveis 'Escriba' para Escritório").

CORONA, Eduardo. Equipamentos para jardins públicos. Acrópole, São Paulo, n 357, dez. de 1968 p. 34 a 40.

A ReCEITA PARA MORAR BeM. Projeto e Construção, São Paulo, n 9, ago. 1971, p. 35 - 39. (O artigo destaca a atuação da Construtora Formaespaço, consequentemente dedica parte do texto aos projetos de Abrahão Sanovicz para os Modulares e o Conjunto Habitacional Nova Cidade).

TEATRO MUNICIPAL CONCENTRARÁ ATIVIDADES CULTURAIS DE SANTOS. A Construção em São Paulo, São Paulo, nº. 1253, fev. 1972, p. $6-8$.

PROJETO DE CENTRO CUltuRAL NO CORAÇÃO DE PARIS. Dirigente Construtor, São Paulo, nº. 7, maio de 1973, p. 58 - 64.

CONJUNTO RESIDENCIAL EM JUNDIAÍ. Projeto e Construção, São Paulo, nº.31, jun. 1973, p. 49

ESTES PROJETOS PODEM MELHORAR A QUALIDADE DE NOSSOS PEIXES. Dirigente Municipal, São Paulo, nº. 8, dez. 1973, p. $26-30$.

O ANHANGABAú E A CIDADE, CONFORME ARTIGAS. A Construção em São Paulo, São Paulo, nº 1376, jun. 1974, p. 22 - 28.

URBANISMO - CONJUNTO HABITACIONAL EM JUNDIAÍ. CJ Arquitetura, São Paulo, nº. 3, dez. 1973 / jan. 1974 , p. 50 - 51.

PROJETO DE REORGANIZAÇÃO DO PARQUE ANHANGABAÚ E SUA EXTENSÃO PELA VIA ARTERIAL NORTE-SUL. Módulo, Rio de Janeiro, $n^{\circ} .42$, mar. / abr. / mai. 1976, p. 34 a 41.

UM CONSELHO: CASAS SIMPLES NA CIDADE COMPLICADA. Casa Vogue Brasil, São Paulo, abr. 1977, p. 97 e 98. 
ZEIN, Ruth Verde. As tendências e as discussões Pós - Brasília. Projeto, São Paulo, nº 53, jul. 1983, p. 78.

SABBAG, Haifa. Três gerações debatem arquitetura. A Construção em São Paulo, São Paulo, nº. 1872, dez. 1983 , p. 20 - 22.

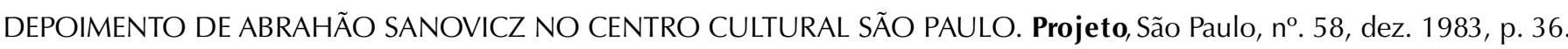

PERAZZOLO, Hélio. Morar diferente. Jornal da Tarde, São Paulo, 14 de julho de 1987.

PROJETO 15 ANOS. Projeto, São Paulo, nº. 102, ago. 1987, p. 75.

A VELHA ARQUITETURA PASSADA A LIMPO. Projeto, São Paulo, nº. 109, abr. 1988, p. 41 - 46. (Artigo sobre o projeto para o SENAC Tatuapé).

TURISMO DE MASSA: um princípio multiplicável para terminal. Projeto, São Paulo, nº. 109, abr. 1988, p. 46 - 48.

WOLF, José. Uma pedra no caminho ... escola paulista - depoimentos. AU, São Paulo, nº.17, abr. / mai. 1988, p. 55 - 56.

LIMITES INDEFINIDOS. Design \& Interiores, São Paulo, nº. 8, mai. / jun. 1988, p. 69 - 73. (Artigo sobre o projeto para o SENAC Tatuapé).

GOMES, Geraldo. Recorrendo à linguagem da história presente. Projeto, São Paulo, nº. 126, out. 1989, p. 78 - 81.

CASTROVIEJO, Alessandro; BOZZO, Cláudia. AU, São Paulo, no.26, nov. 1989, p. 54 - 59.

MACHADO, Lúcio Gomes. Arquitetura brasileira e os cinqüenta anos da Eternit. Projeto, São Paulo, nº 136, out. 1990, p. 92.

O CONCURSO GEORGES POMPIDOU. Caramelo, São Paulo: FAUUSP, nº.1, 1990, p. 26 - 35.

CONCURSO OPERA PRIMA - III PREMIAÇÃO PAVIFLEX DE TRABALHOS DE ARQUITETURA. Projeto, São Paulo, nº. 142, jun. 1991, p. 100 - 101. 
FÓRUM DE BRAGANÇA PAULISTA SP - encontro de caminhos. AU, São Paulo, nº.43, ago. / set. 1992, p. 47 - 49.

SENAC JUNDIAÍ. AU, São Paulo, nº.45, dez 1992 / jan. 1993, p. 54 - 59.

BUCCI, Ângelo; GRACIANO, José Robeto; TOSTA, Cristina. Três visões do Anhangabaú. Viva o Centro, São Paulo, nº. 7, dez. 1993, p. $23-27$.

O CROQUI DA PAIXÃO. Projeto, São Paulo, no. 180, nov. 1994, p. 49 - 67.

SANOVICZ, Abrahão. Crítica arquitetônica: recuperando a dignidade do projeto. In Projeto, São Paulo, nº 181, dez. 1994, p. 83.

Homenagem a Vilanova Artigas. In AU, São Paulo, no. 62, out. / nov. 1995, p. 29.

RECICLAGEM DE PROJETOS DE ESCRITÓRIOS RECEBE PROJETOS DE SETE ESCRITÓRIOS DE ARQUITETURA. Projeto Design, São Paulo, nº. 210, jul. 1997, p. $64-67$.

MOSTRA DE ARQUITETURA: Cinqüentenário da FAUUSP. AU, São Paulo, nº. 72, jun. / jul. 1997, p. 24.

WOLF, José; SOUZA, Marcos; SABBAG, Haifa. Habitação. AU, São Paulo, nº 82, fev. / mar. 1999, p. 75 - 86.

SANTOS, Maria Cecília Loschiavo dos. O traço criados de Abrahão Sanovicz. Projeto Design, São Paulo, nº. 210 , jun. 1999 , p. 12.

ESTÉTICA DOS MATERIAIS APARENTES. Finestra Brasil, São Paulo, nº. 2, jul. / set. 2000, p. 32 - 35. (Artigo sobre o projeto para o SESC Araraquara).

WOLF, José. Um lugar ao sol. AU, São Paulo, n. 92, out. / dez. 2000, p. 62 - 66. (Artigo sobre o projeto para o SESC Araraquara).

MOURA, Éride. Volumetria homogênea da fachada contrasta com riqueza espacial interna. Projeto Design, São Paulo, $\mathrm{n}^{\circ}$. 248, out. 2000, p. $71-75$. 
KATINSKY, Julio Roberto. Evocação de um Sanovicz, Abrahão. Revista da Pós. São Paulo: FAUUSP, dez. 2000 , p. 258 - 259.

WOLF, José. A epifania de Abrahão: viver pelo desenho. AU, São Paulo, no. 108, mar. 2003, p. 55 - 59.

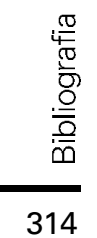


Escolas - Arquitetura da Pedagogia. AU. São Paulo: Pini, nº 62 p. 48-54, out./nov. 1995.

SABAG, Haifa. Habitação. AU. São Paulo: Pini, nº. 82 p. 75-86, fev./mar. 1999

ZANINI, Walter (org.). História geral da arte no Brasil. São Paulo: Instituto Walter Moreira Sales: Fundação Djalma Guimarães,

1983.

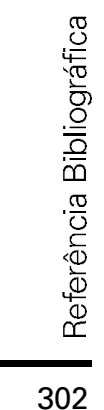




\section{Abrahão Sanovicz: o projeto como pesquisa}

Volume 2 | Anexos

Helena Aparecida Ayoub Silva

Tese apresentada à Faculdade de Arquitetura e Urbanismo

da Universidade de São Paulo para obtenção de grau de Doutor.

Orientador: Prof. Dr. Eduardo de Almeida

São Paulo, 2004 
simples peças da carpintaria - artesanato - do obrar artístico.

Assim, a pesquisa em projeto de arquitetura pode se va-

ler, ou não, pode convocar ou prescindir de saberes alheios e estranhos à fabricação artística do projeto, cuja natureza é sempre maior, ou menor, do que o conjunto do diversos saberes parcelares.

\section{3}

Do método da pesquisa

A natureza do objeto da pesquisa determina o seu método próprio de investigação . A pesquisa em arte nunca é direta e linear. Resultado de múltiplas determinações, o seu método é incerto, empírico, exploratório, errático tateante. Procede por aproximações e envolvimentos. Vai da análise à síntese e volta à analise. Mas pode partir de uma "iluminação" (Benjamim) e daí organizar uma (ou várias) linhas de análise. E, nem por isso é menos rigoroso e exato que o método da ciência.

Além do mais o método em projeto de arquitetura não é genérico, aplicável a todo e qualquer pesquisador. É procedimento individual, privado e particular na medida que cuida do singular e do especifico. Ele se faz e refaz a cada inves- tida que o pesquisador opera para desvelar o real.

Em termos de procedimento metodológico é sempre mais prudente deixar que ele flua do problema especifico que obsessiona o pesquisador colocando o método como conseqüência do objetivo a ser alcançado do que o contrário. Pois método é "caminho" a percorrer para se atingir um "objetivo".

4

\section{Da linguagem da pesquisa}

Como a linguagem do projeto é a linguagem não verbal, icônica, segue-se que a linguagem da pesquisa em projeto é a linguagem do discurso visual, não verbal. O que não quer dizer que não se possa usar do discurso verbal, ou mesmo, do discurso verbo-visual, mas que a linguagem privilegiada, enquanto comunicação preferencial da informação, é a do discurso icônico que se vale, se e quando necessário, de outras linguagem acessorias que venham esclarecer, reforçar ou iluminar um discurso cuja matriz é visual. 


\section{Sumário}

Introdução

Entrevistas

09

Depoimentos eTextos

81

Organização do Acervo de Projetos

117

Desenhos, Gravuras e Projetos

153

Imagens Referenciais

249 

- 直 

Este volume reúne documentos que deram suporte à pesquisa e que complementam as reflexões apresentadas na tese.

São textos e desenhos de relevante interesse e que, por suas peculiaridades, são de acesso limitado. Compreendem entrevistas, depoimentos e textos inéditos, ou publicados em edições esgotadas ou, ainda, em periódicos de circulação restrita, além de documentos e trabalhos do acervo pessoal do arquiteto.

São eles: informações sobre a formação, a atuação profissional e a obra de Abrahão Sanovicz; textos e depoimentos sobre o processo do projeto, considerados desde o início da pesquisa como fundamentais para condução dos trabalhos; proposta de organização do acervo de projetos; reunião de desenhos, gravuras e projetos de sua autoria; e imagens referenciais.

O material apresentado segue uma organização por categoria, existindo em cada uma delas, o ordenamento cronológico dos documentos.

\section{Entrevistas}

\section{Abrahão Sanovicz a Marcos Cartum}

O arquiteto Marcos Cartum, pesquisador da Divisão de Pesquisas do Centro Cultural São Paulo, entrevistou o arquiteto e professor Abrahão Sanovicz, em 1984. O enfoque principal da entrevista é a experiência do arquiteto com o desenho industrial, contudo, sem deixar de levantar aspectos importantes relativos à sua formação.

\section{Abrahão Sanovicz a Catharine Gati}

A arquiteta Catharine Gati, pesquisadora da Divisão de Pesquisas do Centro Cultural São Paulo, por meio do Centro de Documentação sobre Produtores Culturais de Arquitetura em São Paulo, realizou entre agosto de 1987 e novembro de 1988, nove sessões de entrevistas com Abrahão Sanovicz, abordando diferentes aspectos de sua formação e atuação profissional.

\section{Abrahão Sanovicz a José Wolf: Uma Pedra no}

\section{Caminho ... Escola Paulista}

$\mathrm{Na}$ procura dos fragmentos do discurso arquitetônico paulista, o jornalista José Wolf revisita a geração Artigas, procurando entender a identidade que caracterizou a obra 
destes arquitetos. Entrevistou, entre outros, Abrahão Sanovicz para Revista $A \cup$ n $^{\circ} 17$ em 1988.

Julio Roberto Katinsky a Helena Aparecida Ayoub Silva Em janeiro de 2001 o arquiteto e professor Julio Roberto Katinsky concedeu entrevista à arquiteta Helena Ayoub Silva, com o objetivo de relatar aspectos relevantes da formação profissional de sua geração.

\section{Nachman Falbel a Helena Aparecida Ayoub Silva}

Em julho de 2004, o historiador e professor Nachman Falbel concedeu entrevista à arquiteta Helena Aparecida Ayoub Silva, relatando a experiência que teve com Abrahão Sanovicz no movimento juvenil sionista socialista, o Dror.

\section{Depoimentos eTextos}

\section{Arquitetura e Desenvolvimento Nacional:}

Depoimentos de Arquitetos Paulistas

Em 1979, os grupos de trabalho do Instituto de Arquitetos do Brasil - Departamento de São Paulo "Análise da Produção Arquitetônica" e "Tecnologia" organizaram nos meses de maio e junho de 1979 um ciclo de depoimentos e debates, com a participação de várias gerações de arquitetos. Buscava-se com isso divulgar as experiências acumuladas de maneira a permitir o debate e a reflexão sobre os resultados alcançados.

A par da necessária avaliação dessas experiências, esperava-se que os depoimentos discutissem a mudança das condições de atuação dos arquitetos e que formulassem propostas que resultariam, ao conjunto dos arquitetos, uma atuação útil à sociedade e voltada para as necessidades da população.

Foram seis encontros, com a participação dos seguintes arquitetos:

1. Eduardo Kneese de Mello, Vilanova Artigas, Lina Bo Bardi e Oswaldo Bratke;

2. Salvador Candia, Ruy Gama, Rubens Alberto Botti, Pedro Paulo de Mello Saraiva, Miguel Juliano e Joaquim Guedes;

3. Abrahão Sanovicz, Rodrigo Lefèvre, Ubyrajara Gilioli, Araken Martinho e João Walter Toscano;

4. Luiz Gastão de C. Lima, Antônio Sérgio Bergamin Sérgio Zaratin e Siegbert Zanettini;

5. Alessandro Ventura, Sylvio Sawaya, Marlene Yurgel, Edgar Gonçalves Dente e Ermínia Maricato; e,

6. César Luiz Mazzacoratti, Wilhelm Rosa, Flávio Gordon, Luiz Fingerman e Joaquim Augusto de Mello. 
Diferentes posições sobre os problemas da categoria, a produção arquitetônica ou o desenvolvimento do país, revelaram o amplo quadro de inquietações em que os arquitetos se situavam perante os impasses com que se deparavam em sua função social.

\section{O Croquis}

O Museu Lasar Segall promoveu, em 1984, a exposição "A Linguagem do Arquiteto: o Croquis", trazendo para o público um tipo material que raramente é apresentado. Convidou seis arquitetos: Abrahão Sanovicz, que apresentou os desenhos para um conjunto habitacional em Porto Primavera, SP; Antonio Luis Dias de Andrade, com os desenhos de levantamento de aspectos da arquitetura da região do Vale do Paraíba; Bruno Roberto Padovano, com duas residências em Alphaville; Eurico Prado Lopes, com o Centro Cultual São Paulo; Minoru Naruto com desenhos de mobiliário urbano; e, Paulo Mendes da Rocha, que apresentou o plano piloto de urbanização das áreas marginais do Rio Cuiabá.

Dada a relevância dos temas abordados, são reproduzidos os textos de Abrahão Sanovicz e Luis Carlos Daher, que constam no catálogo da exposição.

\section{A Pesquisa em Arquitetura e Urbanismo}

A Faculdade de Arquitetura e Urbanismo da Universidade de São Paulo, organizou nos dias 29 e 30 de março de 1990 o seminário Natureza e Prioridades de Pesquisa em Arquitetura e Urbanismo, com apoio da FUPAM - Fundação para a Pesquisa Ambiental e FAPESP - Fundação de Amparo a Pesquisa do Estado de São Paulo.

O seminário tinha como proposta: discutir a natureza e os objetivos prioritários de pesquisa em Arquitetura e Urbanismo; delinear o panorama atual da pesquisa nessas áreas, avaliando-o, no sentido de informar a escolha de prioridades; e, contribuir para o esclarecimento e desenvolvimento da pesquisa sobre a organização do espaço em suas diferentes escalas.

Dos Anais deste seminário, dois importantes textos contribuíram fundamentalmente para o desenvolvimento da tese: "A Pesquisa na Área de Projeto", de Abrahão Sanovicz e "A Pesquisa no Projeto de Arquitetura e Urbanismo: Sete Paradigmas" de José Cláudio Gomes.

O texto de Arnaldo Martino "Pesquisa Enquanto Projeto" foi elaborado como base para discussão do Grupo de Disciplinas de projeto de Edificações do Departamento de Projetos da FAU. Dada a importância do texto, compõe este conjunto 
de trabalhos que abordam a questão do projeto e da pesquisa.

Crítica Arquitetônica - Recuperando a Dignidade do

Projeto

Texto de Abrahão Sanovicz, publicado na Revista Projeto no 181, p. 83 em dezembro de 1994 e posteriormente na Projeto Design n 215 de 1997. Passando por mais um dos períodos de escassez de trabalho, num desabafo, Abrahão se ressente da falta de crítica e de trabalho.

\section{E Pur Si Muove}

Em 1996, por iniciativa da Diretoria da FAUUSP, com apoio do GFAU e da Comissão de Graduação, foi organizada uma exposição dos trabalhos dos alunos. Abrahão Sanovicz elaborou o texto de apresentação, onde aborda aspectos relevantes da história da Escola.

\section{Estado da Profissão}

Entendendo que a perda do prestígio profissional é causada pela transformação do projeto, de fato cultural em mera mercadoria, sujeitando-se às empíricas regras de um marketing competitivo e oportunista, Abrahão Sanovicz se manifestou, em 1997, na Revista Palimpesto, editada pela Universidade Federal do Ceará.

\section{O que é o Projeto}

Prova escrita de Abrahão Sanovicz, apresentada no Concurso de Livre Docência junto à FAUUSP, realizada em 1997. Nela o professor sintetiza as considerações que formulou ao longo de sua vida profissional e docente.

\section{Décadas de Arquitetura: uma Leitura}

O professor Abrahão Sanovicz foi curador da exposição "Cinco Décadas de Arquitetura", realizada em 1998, no Museu Brasileiro da Escultura, comemorativa do cinqüentenário da FAUUSP. No texto de abertura da exposição, Abrahão faz a leitura desses 50 anos.

\section{Organização do Acervo de Projetos de}

\section{Abrahão Sanovicz}

Em 2003, a Biblioteca da FAUUSP recebeu, em doação, o acervo de projetos de Abrahão Sanovicz. No desenvolvimento da pesquisa, a classificação desse material foi fundamental para que se pudesse relacionar o percurso de trabalho de Abrahão. Neste volume é apresentado o resultado do ordenamento metodológico desenvolvido. 


\section{Reunião de Desenhos, Gravuras e Projetos}

Complementarmente à organização do acervo, foram fotografados e digitalizados inúmeros projetos, desenhos e gravuras. A seleção desse material considerou a importância e representatividade no conjunto da obra do arquiteto, além das condições das bases originais.

\section{Imagens Referenciais}

Abrahão Sanovicz, em todas as suas manifestações, sempre se reportou a suas referências arquitetônicas e artísticas. No desenvolvimento da pesquisa a reunião de muitas destas referências contribuiu para o maior e melhor entendimento de suas preocupações. As referências arquitetônicas comparecem no Volume 1 da tese. Neste volume estão apresentadas imagens citadas nos documentos que também o compõem.

Estes elementos possibilitaram identificar a gênese, evolução e prognóstico do objeto de estudo, ou seja, a obra do arquiteto e professor Dr. Abrahão Sanovicz, considerada a partir da reflexão daquela que foi sua principal tese "O Projeto como Pesquisa". 



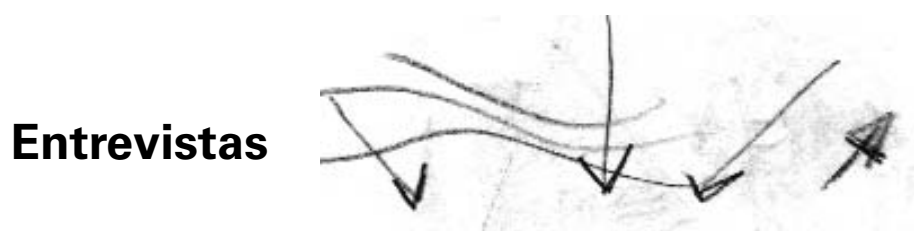

Abrahão Sanovicz a Marcos Cartum

Abrahão Sanovicz a Catharine Gati

Abrahão Sanovicz a José Wolf

Julio Roberto Katinsky à Helena Aparecida Ayoub Silva 68

Nachman Falbel à Helena Aparecida Ayoub Silva 



\section{Abrahão Sanovicz a Marcos Cartum}

Marcos Cartum (MC) - Como ocorreu sua formação esco-

lar e como você acabou se direcionando para a arquitetura?

Abrahão Sanovicz (AS) - Nasci em Santos em 1933. Em dezembro de 1950, com 17 anos de idade, tendo completado o curso ginasial, vim para São Paulo a fim de prestar exame para a Escola Técnica Federal (que formava técnicos em edificações, curso equivalente ao científico). Já trazia uma experiência de desenho, pois enquanto cursava o ginásio em Santos, fazia um curso noturno de desenho e, à tarde, trabalhava em um escritório de um desenhista onde cuidava de aprovação de plantas. E, dessa forma, fui pegando contato com esse lado profissional. Cheguei então a São Paulo, mas já com planos de fazer arquitetura (achava que com o curso profissionalizante poderia "queimar" etapas na formação em arquitetura). De fato, depois de concluir o curso de Edificações, prestei vestibular para a FAU e passei.

\section{MC - E o que o levou, na verdade, a essa decisão?}

AS - Quando cheguei, estava para acontecer a I Bienal de Arte de São Paulo (as primeiras bienais, por sinal, foram maravilhosas). A I Bienal foi no Trianon, um projeto feito por Luís Saia e Eduardo Kneese de Melo. Nessa época, ainda garoto, já manifestava muito interesse pelas exposições de arte organizadas, por exemplo, pelo MASP (ainda situado na rua 7 de Abril). Então, tive oportunidade de acompanhar exposições, como a de Le Corbusier, Max Bill, Lasar Segall e Portinari. Havia ainda a revista "Habitat", da Lina Bo Bardi. Nessa época, o MASP criou o Instituto de Arte Contemporânea para a formação de artistas gráficos, um curso que já manifestava a preocupação com o design, mas relacionado com os aspectos bidimensionais. Havia uma equipe de europeus que aqui chegou no pós-guerra, agitando muito esse centro artístico que havia na 7 de Abril. Havia o pessoal da fotografia, estandes, cartazes, etc. Veio muita gente para atuar nessas áreas durante as comemorações do IV Centenário da cidade, em 54. Era, enfim, um novo mercado que se abria.

Nessa época, também, começavam a aparecer algumas galerias de arte moderna. Na praça da República, havia a galeria Domus e o pessoal da loja Ambiente. Eu, enfim, continuava a freqüentar o curso de Edificações, quando o Museu de Arte Moderna abriu inscrições para uma nova escola chamada Escola de Artesanato montada na praça Roosevelt, uma iniciativa de Ciccilo Matarazzo. Essa escola 
tinha um sentido diferente do curso criado pelo MASP, que objetivava, na verdade, formar gráficos (um profissional que seria, por assim dizer, precursor do designer), além de outros cursos, como o de gravura e o de formação de artistas. Eram cursos livres. Já a Escola de Artesanato formava fundamentalmente gravadores e ceramistas. Acabei fazendo um teste para concorrer a uma vaga de bolsista; fui aprovado e comecei a freqüentar o curso (à noite). Era uma coisa maravilhosa devido ao ambiente de trabalho, ao contato com os colegas, muitos dos quais viriam a se tornar artistas importantes de São Paulo, além de grandes professores. Citaria, por exemplo, Yllen Kerr, que depois se tornou um excelente fotógrafo no Rio, o Mário Gruber, que já conhecia de Santos e o Lívio Abramo. Havia também os professores de Desenho Artístico: o Antonio Gomide, o Jorge Nasturel e o Pfeiffer, que dava aulas de História da Arte. Acontece que minha aproximação com a arquitetura, como disse, já havia começado antes de chegar a São Paulo...

\section{MC - Poderia falar sobre isso?}

AS - Em Santos, já conhecia as revistas "Acrópole" e "Habitat", e também a obra de Niemeyer, que já naquela é- poca (final dos anos 40), trazia todo esse carisma próprio dele (talvez, não fosse bem compreendido, mas já despertava a sensação de ser alguém que apresentava uma qualidade muito especial). Ele havia projetado a Pampulha, o Pavilhão da Feira de Nova York, além de outros projetos. Foi, enfim, quando eu conheci as primeiras obras modernas. Santos contava com alguma coisa moderna sendo construída. Assim, o que me chamou mais a atenção foram duas casas do Artigas, uma na ilha Porchat e outra na rua Castro Alves (isso, talvez, me tenha influenciado até hoje, a casa que projetei para mim, por exemplo, é justamente uma casa-caixote). Na ilha Porchat, havia também duas casas projetadas por Oswaldo Bratke. Como jovem, tinha toda essa inquietação e acompanhava tudo isso com muito interesse, as publicações, o que se construía, etc. Essa aproximação com a arquitetura se deu quase naturalmente. Apesar de sofrer uma grande dúvida a vida inteira entre seguir a vida de artista (ou seja, pintor ou desenhista) ou fazer arquitetura, acabei me definindo pela arquitetura.

\section{MC - E o exame na FAU?}

AS - Havia 152 candidatos para 30 vagas. Foram 
aprovados 37 que acabaram sendo absorvidos pela escola. Fiquei em $29^{\circ}$ lugar. No vestibular teve uma prova de desenho que consistia no seguinte: um vaso e um plano para serem desenhados. Com minha formação em desenho e gravura, acabei fazendo alguma coisa que preenchia todo o plano da folha, como um gravador que estivesse gravando a madeira. A minha nota foi 6,5 , e eu estranhei, porque achava que poderia obter uma nota melhor. Mas quando fui verificar as provas consideradas melhores, percebi que elas eram as mais simples em termos de solução de desenho. As melhores notas, enfim, foram para candidatos que haviam feito o cursinho da FAU, orientados pelos alunos dessa faculdade. Isso foi em 53, mas já se podia notar que havia certa estrutura de encaminhamento numa direção. Há uma diferença muito grande entre o meio em que os orientadores são artistas, pintores e gravadores e o meio em que eles são arquitetos: uma diferença de diretrizes. Na FAU, comecei a tomar contato com outro tipo de pessoas. Era uma escola aristocrática e, assim, entrei em contato com a aristocracia e com todo o tipo de conhecimento de que ela pode lançar mão. A FAU já contava com uma grande biblioteca, e a gente passava a maior parte do tempo nessa biblioteca.
MC - E como era o ambiente da FAU nessa época?

AS - Quando entrei na FAU, a escola se encontrava num período um tanto crítico, porque dois anos antes havia perdido uma greve chamada greve Niemeyer, isso em 52. A greve ocorreu porque Niemeyer havia se candidatado para professor da FAU na época em que se encontrava em São Paulo, projetando os prédios do $\mathrm{CNI}$ e o Ibirapuera. O Conselho Universitário, no entanto, não aceitou sua admissão por razões políticas. Então os alunos entraram em greve, que se prolongou por três meses, até a ocupação da escola.

E, assim, ao ingressar na faculdade, encontrei um clima de sentimento de perda. Os alunos haviam perdido a greve e a escola estava quase parada. Os professores de Projeto só foram recontratados no meio do ano. Do começo do ano até esse momento, só tivemos aulas das cadeiras técnicas. Quando a FAU começou a se movimentar novamente, aconteceu a morte de Getúlio e, com isso, o segundo semestre também ficou praticamente perdido. Além disso, houve nesse momento a intenção de se intervir na autonomia universitária, o que motivou outra greve geral universitária em São Paulo. De 55 em diante, a FAU começou a andar um pouco mais tranqüilamente e os 
alunos começaram a organizar eventos, trazendo propostas interessantes.

MC - E o que mudou em sua cabeça?

AS - Havia o Centro de Estudos Folclóricos que depois originou o Departamento de História. Faziam-se pesquisas, a partir das quais comecei a me indagar sobre a Arquitetura Moderna, querendo entender melhor o processo da arquitetura moderna no Brasil (até hoje a crítica da arquitetura moderna brasileira não é muito clara, como não era muito clara na nossa cabeça naquela época). Queríamos conhecê-la com maior profundidade. Acreditávamos que conhecendo melhor seu processo, isso nos ajudaria a caminhar um pouco mais à frente. Começamos então a fazer pesquisas em arquitetura, tomando a obra de Lucio Costa como ponto de partida. Participavam desse grupo de trabalho Gustavo Neves da Rocha Filho, Nestor Goulart Reis Filho, Julio Katinsky e Benedito Lima de Toledo. Eu e o Katinsky começamos a fazer o levantamento da obra de Lucio Costa desde o período neocolonial até o período imediatamente anterior a Brasília (que naquela época ainda não havia sido construída). Também foram com a gente
Eduardo de Almeida e Ludovico Martino (por sinal, foram eles os que tiveram as melhores notas na prova de desenho a que me referi acima). Não existia xerox, portanto, tivemos que ir à sede do jornal "A Noite", no Rio, e ficamos manuscrevendo, copiando tudo o que havia sobre Aleijadinho, texto de Lucio Costa. Essa série de pesquisas, além do trabalho junto ao Grêmio, nos possibilitou conhecer, tomar contato com todos os grandes arquitetos da época. Fomos até o prédio do Ministério da Educação, onde um senhor alto, magro, que cuidava do Arquivo, nos atendeu. Explicamos que estávamos pesquisando a obra de Lucio Costa, e ele foi muito atencioso com a gente, fornecendo-nos um vasto material de pesquisa. Esse senhor era simplesmente Carlos Drummond de Andrade.

\section{MC - Essa pesquisa, portanto...}

AS - Através dessas pesquisas, enfim, fomos nos inteirando sobre a arquitetura moderna brasileira. E descobrimos que essa pesquisa sobre Lucio Costa, na verdade, estava ocorrendo em vários lugares do país. Era preciso entender o processo, tínhamos que voltar aos anos 30. Ao mesmo tempo, a nossa turma, o pessoal que 
freqüentava a FAU, era muito inquieta e interessada. Nós tínhamos o mundo todo na Biblioteca. Havia revistas como a "Graphis", "L'Architecture d'Aujourd'hui", a "Stile \& Industria" etc. e, com isso, você ficava sabendo como era feita a arquitetura no resto do mundo e como se fazia a parte gráfica dessas publicações. Produzíamos cartazes, por exemplo. Volpi ia expor na MAM/SP, então fazíamos um cartaz para Volpi. Tivemos ainda a Semana Mario de Andrade (é importante lembrar a formação márioandradina de Luís Saia, que na época dirigia o Patrimônio Histórico, e de Artigas que, quando moço, fazia parte da família paulista, onde Mário ocupava o papel de carrochefe do movimento intelectual-artístico. A preocupação com toda essa matéria histórica, o estudo do folclore, a criação do Centro de Estudos Folclóricos, tudo isso tem raízes e ligações profundas com Mário de Andrade. O prédio da FAU, na rua Maranhão, era da família Álvares Penteado e foi doado para ser uma escola de Arquitetura. Os cartazes para essas exposições, a quais me referi, eram feitos de maneira muito primorosa (naquela época não havia letraset, e as letras eram recortadas uma por uma). Participamos de concursos de capas de revistas, de publicações etc.
MC - E o interesse pelo objeto, como surgiu?

AS - O interesse pelo objeto foi algo que surgiu ainda dentro da faculdade. Estava fortemente impressionado com o que as publicações traziam de fora. Havia uma revista norteamericana chamada "Arts \& Architecture" em que a casa era mostrada como um problema de design. Ela tinha um programa interessante chamado "Case Study House", pelo qual a cada ano era chamado um arquiteto para desenvolver o projeto de uma casa e, assim, iam publicando em seqüência todos os croquis, os projetos, os detalhes, até à obra.

Outra revista interessante era a "Stile \& Industria", que já mencionei. Ela publicava o que de melhor se fazia no design italiano. Os italianos, aliás, foram muito inteligentes nesse processo de promoção do design. Quer dizer, artistas quase por natureza (você pega os artistas mais interessantes do Renascimento e percebe que isso é uma coisa que eles têm profundamente arraigado, que está no sangue). Para nós, assumir uma postura de artista fica algo difícil, quase esquisito. Para eles, é uma coisa normal; o artista não é diferente dos outros. Aqui, é visto como um ser diferenciado que passa pelo mundo como um iluminado, sempre 
soltando raios e coisas assim. Aqui, talvez, essa imagem de "arquiteto-artista" tenha a ver um pouco com a experiência de Flávio de Carvalho. A dificuldade de se olhar o arquiteto de frente, de não diferenciá-lo dessa imagem de "artista", deve ter aí uma de suas origens históricas. Apesar do Flávio ter sido um grande desenhista, um grande pintor, não acho tão fundamental assim o trabalho dele de arquiteto. Acho mais importante o de desenhista, pintor e cenógrafo. Ele é menos conhecido pelo trabalho de pintor, mas considero de grande densidade - um belo Kokochka. Mas tinha essa atitude demolidora, e isso atrapalhou muito. Enfim, senti um choque muito grande, quando fui à Itália e percebi a diferença de tratamento num contexto social do que é ser um arquiteto e um artista lá, do que é ser um arquiteto e artista aqui. Completamente diferente. Lá, é algo normal, existe um espaço para ele. Quando se trabalha lá fora, sentindo o tipo de encomenda que lhe fazem, o tipo de relacionamento profissional e social que se estabelece, quando você volta, sente um imenso degrau. Sei lá... país novo, capitalismo selvagem, economia predatória, falta de critérios culturais, coisas desse gênero.

MC - E continuando...
AS - Sim, essa história de desenhar objeto surgiu na FAU com um grande impacto. Os italianos começaram antes, tiveram a sabedoria de vender esse produto, não só para a Itália mas para o mundo. Eles publicavam insistentemente aquilo que produziam, lutando pela conquista do mercado. Nessa época, nós não entendíamos isso com essa profundidade, porque costumávamos apenas ver as figurinhas nas revistas. Mas atrás dessas figurinhas, atrás desse impacto editorial, havia um grande desejo de conquista mercadológica. E o que mais nos impressionava nisso tudo era o Olivetti Style, que foi marcante na época. Isso foi surgindo naturalmente na escola e, entre os alunos, havia certa preocupação em desenhar o objeto. Era até encantadora a proposta do ponto de vista social. A gente faria um objeto bem estudado, capaz de ser produzido, repetido, e ele ia ser usado indistintamente, vendido nas lojas, e tal. Seria gratificante entrar em uma casa onde se estivesse comendo com talheres que você havia desenhado! Havia um pouco esse sentido romântico que poderia ser melhor conduzido. Ficou só no romantismo, quando poderia haver maior objetividade.

MC - E o mercado? 
AS - São Paulo já contava com algumas lojas que produziam móveis. Havia a Ambiente, o Tenreiro, o Branco e Preto (montada pelos arquitetos Miguel Forte, Roberto Aflalo, Jacob Ruchti, Plínio Croce, Carlo Fongaro, Cheng Hwa e Carlos Milan) e, inclusive, uma firma que produzia sem licença os desenhos do finlandês Alvar Aalto. Falava-se muito sobre a Bauhaus, psicologia da gestalt, mas ninguém sabia muito bem o que significava. As propostas levantadas pela Bauhaus foram estudadas e compreendidas num período posterior. Estava também começando a surgir a escola de Ulm (o Max Bill esteve em São Paulo no início dos anos 50 para convidar pretendentes para a escola que dirigia). Mas com Brasília em via de ser construída, todos nós queríamos de alguma maneira participar desse projeto...

\section{MC - Brasília?}

AS - O tipo de problema enfrentado pela FAU até esse momento era em escala muito reduzida, modesta. Problemas de urbanismo que surgiam, significavam, no máximo, uma quadra de área. Com Brasília, as escalas ficaram bem maiores. Era uma cidade inteira sendo projetada. A Bienal de 57, enfim, havia aberto um concurso para as escolas de Arquitetura, de âmbito internacional. Montamos uma equipe, com dez alunos (cinco do $4^{\circ}$ ano e cinco do $5^{\circ}$ ) e fizemos um projeto para o Núcleo Habitacional para funcionários da Refinaria de Cubatão. A equipe se inscreveu com esse projeto, e ganhamos o primeiro prêmio. Naquela época, a Bienal era de fato um acontecimento. O mundo inteiro comparecia. Os membros do júri eram Marcel Breuer, Kenzo Tange, Philip Johnson, Sílvio de Vasconcelos e Jacob Ruchti. Esse júri nos premiou, juntamente com outras três escolas (França, Japão e Venezuela). Sílvio Vasconcelos tinha dado um voto separado. Ele achava que o prêmio devia ser nosso, sem ser dividido com outras escolas. Ficamos chateadíssimos: ou o prêmio seria somente de nossa equipe ou a gente ia recusar a premiação. Lourival Gomes Machado (que depois se tornou diretor da FAU) era o diretor da Bienal. Durante um bate-papo em sua casa, ele nos convenceu que deveríamos receber o prêmio. Na hora da premiação, toda a equipe (os dez) foi receber o prêmio das mãos de Juscelino Kubitschek, o homem que estava construindo Brasília. Quase todos ganharam bolsa de estudos para o exterior (coisa rara naqueles tempos). Como não estava interessado em Planejamento (Urbanismo), abriu-se uma oportunidade de 
conseguir uma bolsa através do Circolo Italiano. Assim, solicitei uma bolsa para Milão, não para estudar, mas para trabalhar em algum escritório de desenho industrial. $\mathrm{O}$ único nome italiano conhecido no Brasil era o de Gio Ponti, que á havia passado por aqui. Porém, eu conhecia o trabalho de um gráfico maravilhoso chamado Buffoni, que havia vindo ao Brasil. Nessa ocasião, o chamamos para julgar os trabalhos gráficos de alguns alunos da FAU que haviam participado de um concurso de artes gráficas. Ele foi muito crítico, apontando, ao analisar trabalho por trabalho, todas as falhas técnicas. Quando ganhei a bolsa (eu e o Júlio Katinsky), consultamos o Buffoni que nos indicou o escritório de Marcelo Nizzoli, um designer que trabalhava para a Olivetti.

\section{MC - E como foi essa experiência em Milão?}

AS - Bem, antes de viajar para a Itália, resolvi participar de um concurso de projetos para o late Clube de Londrina (junto com Júlio Katinsky e João Toscano). Isso foi em 59. E nosso projeto foi vencedor. Nesse intervalo, o meu pedido de bolsa foi aprovado. E, assim, embarquei com minha esposa (havia casado há pouco tempo) para Milão, onde comecei a percorrer os escritórios de design da época. Procurei o Nizzoli, que me havia sido indicado pelo Buffoni, e foi lá que passei quase um semestre, colaborando no desenvolvimento de um projeto para interfone, um projeto para máquina de café e um distribuidor de gasolina, e algumas marcas para empresas estatais. Tive que voltar, porque meu filho estava para nascer. Mas, tudo que havia visto aqui, lá eu pude acompanhar de perto, vendo acontecer de fato. E é interessante observar a relação do designer com a indústria na Itália. Existe por parte do empresário um interesse, um cuidado especial que vai desde a programação visual, passando pelos logotipos e papéis de carta da indústria, até o produto fabricado por ela. Citaria o exemplo da Olivetti. O Nizzoli trabalhava justamente para a Olivetti, que na época não tinha ainda um escritório próprio de design. Um dia, ele me apresenta a marca da máquina de escrever Underwood, pedindo para que eu fizesse uma nova marca, porque o presidente da Olivetti embarcaria no dia seguinte para Nova York, onde deveria adquirir 25\% das ações da Underwood, e pretendia levar pronta a nova marca.

MC - E ao retornar ao Brasil? 
AS - Voltando ao Brasil (já no início dos anos 60), já que não era possível trabalhar em design, continuei fazendo projetos de arquitetura e, paralelamente, projetos gráficos. O primeiro trabalho que consegui pôr na rua, foi a primeira linha da Escriba, em 62, isso porque o José Serber era meu amigo de infância, e a Escriba (na época chamava-se PlayArte Decorações) desejava especializar-se em móveis para escritórios. Minha atuação maior como designer, enfim, foi na área de artes gráficas, executando principalmente logotipos. Hoje há campo para o designer, mas em 62, 63, era muito difícil você se impor como profissional nessa área, não havia mercado de trabalho. O nome Escriba, enfim, foi dado por Geraldo de Barros e o logotipo desenhado por Alexandre Wollner. Fizemos várias tentativas de desenhar objetos, mas não foram adiante. A experiência na Escriba, contudo, foi para mim um verdadeiro passaporte. O problema do designer é que ele não depende somente de seu projeto, mas requer um investimento por parte da indústria, depende de financiamentos para a pesquisa de desenvolvimento de produto, os riscos são muito grandes. Depois dessa experiência com móveis, fizemos uma linha de fogões, que não foi adiante, não saiu do projeto.
MC - Mas, com certeza, essas experiências abriram novos caminhos?

AS - Com todas essas experiências (frustradas), começamos a levar a idéia de design para a edificação. E o primeiro momento em que conseguimos fazer com que um novo tipo de caixilho fosse um produto seriado, foi no projeto para um edifício residencial em Higienópolis, São Paulo. Outra experiência importante foi quando, mais tarde, no início dos anos 70 (época do "milagre"econômico), tive a oportunidade de projetar um edifício modular com planta única, para ser reproduzido em pequena série. Quando comecei a projetar esses prédios, o mercado de trabalho acabava de se recuperar de uma grande estagnação. Nesse momento, havia terminado de fazer um trabalho interessante com Julio Katinsky e o Buffoni para a Prefeitura de São Paulo. Era um projeto de equipamentos para parques e jardins, bancos, floreiras, pisos, relógios, cabines telefônicas, paradas de ônibus, quadros de aviso, etc. No final, o projeto acabou sendo arquivado, tendo sido produzido apenas alguns bancos e um bebedouro. Nessa mesma época, fizemos um projeto para uma publicação sobre plantas brasileiras, que deveria ser distribuída nas escolas primárias. Por volta de 66, 
o Buffoni que estava desenvolvendo projetos para a Olivetti,

convidou a mim e ao Katinsky para fazermos juntos um projeto para uma máquina de escrever da Olivetti - a Studio 44, que seria produzida no Brasil. Também desenvolvemos o projeto de um ventilador que deveria ser produzido por uma multinacional, mas todos eles acabaram engavetados.

MC - E depois desses trabalhos?

AS - Aí começamos a projetar para a Formaespaço, cujo diretor pretendia construir um prédio modulado, que pudesse ser reproduzido. Fiquei entusiasmado com a idéia, que estava na minha cabeça já há alguns anos, desde 63. Enfim, os prédios estão aí, muito limpos, no sentido de terem apenas o essencial. Com esse projeto, eu tinha um protótipo, e estava finalmente conseguindo mostrar que era possível levar todo aquele conhecimento da arquitetura também para pessoas desconhecidas. Enfim, tínhamos feito uma coisa muito limpa, asséptica, visando fazer o mais econômico, mas mantendo a qualidade. Havia conseguido, finalmente, levar essa experiência para o edifício e pretendia ir adiante. $O$ interesse, enfim, que tínhamos em projetar objetos para a indústria foi se transferindo paulatinamente para a edificação.
Para nós, o projeto nunca é um trabalho terminado em si, ele é sempre fruto de trabalhos anteriores, ligados prospectivamente aos projetos que virão, nem que levem 20 ou 30 anos para serem retomados. É o sentido maior da palavra projeto. É tentar reconhecer um problema em sua forma mais simples, de maneira a que tenha um sentido didático. Todo o projeto é uma forma de aprendizado mesmo que o resultado não seja uma coisa brilhante. Com isso, pode-se entender como é que nos encontramos hoje, numa posição de desejos e vontades. Alguns projetos nos mostraram o que é possível fazer. Enfim, nos encontramos como um pianista que não consegue dar concertos, enquanto vai cada dia dedilhando seu instrumento. E eu digo que até o piano, muitas vezes, tiram da gente.

MC - Voltando à reforma de ensino que se processou na FAU em 62, quando se implantou essa nova mentalidade vinculada ao design, e que marcou sua geração, como você expôs claramente, poderia fazer um retrospecto de como ocorreu a implantação dessa reforma? E como se estabelece a conexão entre o design e o ensino?

AS - O Conselho Universitário, em 62, escolheu o professor de Política e História da Arte, Lourival Gomes 
Machado (formado pela Faculdade de Filosofia, e que havia sido diretor da Fundação Bienal por ser também um crítico de arte) para substituir o diretor da Faculdade de Arquitetura, o professor Anhaia Mello (professor de Urbanismo que desempenhou papel importante na formação da FAU-USP e que, inclusive, tinha sido prefeito de São Paulo, além de decano da universidade). Lourival sofreu toda uma influência de Mário de Andrade e da família paulista. Ele permaneceu pouco tempo na direção da escola, mas reuniu os professores e criou condições para que se fizesse uma reforma de ensino na FAU, que foi comandada pelo Artigas, que atravessava um período especialmente maravilhoso. Voltando um pouco, depois da greve Niemeyer houve o afastamento de alguns professores, que foram mandados de volta para a Politécnica. O Artigas foi um deles. Não foi a primeira vez que o puseram de castigo. Quando voltou à FAU, em 56 ou 57, vivia um momento muito interessante: participara do concurso de Brasília que premiou Lucio Costa, depois participou do grupo de arquitetos que reformulou a Cidade Universitária e projetou o prédio da FAU. E foi justamente nessa época que ocorreu a reforma de ensino. Ele conseguiu entender o processo de modernização que o país estava precisando em matéria de ensino. E criou três novos departamentos: Projeto, História e Tecnologia (e as quatro seqüências de projeto), introduzindo no currículo as palavras Desenho Industrial, Comunicação Visual, além de Projeto e Planejamento.

MC - Com certeza, uma inovação pioneira, em termos de Brasil...

AS - Artigas convidou uma garotada, que havia se formado alguns anos antes, com alguma experiência, criando condições para que todos eles fossem trabalhar na FAU, começando a formar um corpo de doutrina. Do ponto de vista do ensino superior, foi a primeira escola do Brasil que colocou o problema da formação de quadros para ministrar o ensino de desenho de objetos para a indústria, para se poder desenhar bidimensionalmente as informações, com o estudo necessário. Isto é, a parte da comunicação visual, que não se restringe somente à área da propaganda. Naquela fase desenvolvimentista em que estava entrando o país, era necessário formar quadros que pudessem preparar os objetos para a indústria, preparar os edifícios, os desenhos das cidades, porque já começava a mudar a relação cidadecampo. A nossa geração saiu da escala do edifício e 
começou a enfrentar todas essas novas escalas. $\mathrm{Na}$ Universidade, deveriam surgir as inquietações, que se transformariam depois em necessidades da vida prática. Antes da reforma, existiam cadeiras com intenções muito subjetivas, coisas como Composição Decorativa, Plástica. Com a reforma, pretendíamos também despertar a consciência de outras escolas, no sentido de poder formar profissionais dentro desses novos padrões.

MC - Na realidade, pretendia-se atingir todo o país?

AS - Essa reforma, na verdade, foi aceita em sua totalidade, por assim dizer, no eixo Rio-São Paulo, onde existia indústria. Porém, muitos não conseguiam conceber um curso de desenho industrial nas faculdades de arquitetura do Nordeste, por exemplo. Mas achávamos que, na realidade, para se fazer design, não era necessário ter uma indústria à disposição. Entendíamos o conceito de design como algo mais amplo. Podíamos, assim, fazer um design absorvendo toda a riqueza formal brasileira, pois temos todo um repertório popular a ser aproveitado. Esse grupo convidado a participar do processo de reforma da FAU tinha uma preocupação com o ensino, numa nova consciência profissional. Assim, pretendia-se formar entidades, através das quais fosse possível sensibilizar nosso futuro cliente, que era o industrial, por meio da Federação das Indústrias. Em 63, fomos para um congresso de design em Paris, como professores (Stroeter, Cauduro, Lucio Grinover e eu). Em seguida, fomos para UIm, visitando uma exposição de Design em Stuttgart, passando por Zurique, onde visitamos o estúdio de Max Bill. Retornando ao Brasil, entramos em contato com a Organização Internacional de Design e começamos a montar a Associação Brasileira de Desenho Industrial, que por desejo nosso deveria ficar junto com o IAB-Instituto dos Arquitetos do Brasil. De fato, ela começou no IAB, mas aos poucos foi se desligando. Acontece que ao lado de pessoas que estavam realmente interessadas em Desenho Industrial, surgiram outras com interesses paralelos. Conseguimos, apesar de tudo, formar um pequeno grupo, mas para que tivesse consistência seria necessário que se formassem profissionais e que a indústria, por outro lado, absorvesse a produção desses profissionais. Como mostrei, a Itália é um bom exemplo dessa ligação da indústria com o profissional, mas aqui isso não ocorreu. Na realidade, muito pouco se fez de design. O desenho da máquina, por exemplo, não foi feito. Fez-se apenas alguma coisa no setor 
do mobiliário. O móvel é uma coisa muito particular, pode ser desenvolvido semi-artesanalmente. Isso não ocorreu somente com o design. A arquitetura sofreu o mesmo processo. Por razões políticas, econômicas, sociais, não foi possível formar os quadros que se pretendia. A partir dos anos 60 , as coisas começaram a andar para trás, até que o país passou a atravessar uma crise e praticamente se parou de trabalhar. O desenho industrial não chegou a acontecer no país. O que vemos são coisas isoladas, episódicas. E isso veio a se refletir no ensino. Se na arquitetura, sentimos que houve uma quebra no processo de elaboração de temáticas, no design isso se fez sentir com mais força. Não quer dizer que os cursos deixaram de existir, mas o tipo de investigação que se passou a fazer dentro desses cursos, foi talvez uma investigação de sentido filosófico, uma análise de linguagem, fazendo um paralelo com a crítica literária. E começaram a incluir o estudo da semiologia, aspectos de comportamento, porque o lado prático não estava acontecendo. Porém, o compromisso aconteceu.

MC - Mas houve outras contribuições positivas?

AS - Outra contribuição importante da reforma foi, sem dúvida, a de ter criado condições para que se sistematizasse toda uma linguagem em três dimensões. E, além disso, fora do âmbito do edifício, como Brasília havia nos mostrado a dar o salto em escala, o Planejamento foi absorvido como investigação, o que representou um avanço para além do urbanismo. Naquele momento, em 62, nós afirmávamos que o arquiteto deveria ter uma visão completa do processo. Mesmo que se dedicasse na vida profissional somente ao desenho do edifício ou ao planejamento ou à comunicação visual, deveria conhecer todas as outras referências em relação ao espaço construído. Conhecendo o geral, teria condições de aperfeiçoar melhor o particular. Poderia ser um designer, mas com a consciência de todo o processo. A sabedoria desta postura está em que nenhuma dessas possibilidades poderia sobreviver isoladamente. Historicamente, nós tínhamos tido as experiências da Bauhaus, a partir das experiências históricas do Deutsche Werkbund que Gropius leva para a Bauhaus, onde o termo design era também levado pela mão dos arquitetos. Nós considerávamos, portanto, que o design, a comunicação, o edifício ou o planejamento não poderiam existir isoladamente. Então, a nossa escola estava se transformando em escola de design, no plano mais completo. 
MC - Você continua enfocando a questão da abrangência da formação do designer dessa maneira?

AS - Acho que o problema do design não está desligado do problema da arquitetura. Isso não quer dizer que nos anos 80 fosse necessário formar um arquiteto-designercomunicador, ainda que seja difícil fazer essa divisão. Se nos anos 60 era necessário, por razões históricas, pegar a Bahaus e trazer para o Brasil, se era necessário formar um profissional que pudesse pensar em todas as escalas, isso se justificava porque ainda não havia essa noção de que o trabalho devia ser entendido desde o planejamento até o objeto. Quer dizer que o planejador deve ter a cabeça ciclada para pensar em uma escala que vai de 1:50.000 e desce para 1:10.000 até 1:5.000. Ele vai até o momento em que ainda não é possível se colocar uma cota, quando começa a se colocar a cota, isso já pertence ao campo do arquiteto. De desenho urbano para o edifício. Vamos conversar melhor sobre essa questão de escala. Isso apareceu na minha cabeça quando começaram aquelas reuniões sobre planejamento no $\mathrm{IAB}$, nos anos 70, quando se vociferou, se transpirou planejamento por todos os lados. O resto ficou lá por baixo. Todo mundo pesquisou e, na faculdade, revirou-se favela pelo avesso, chegando-se à conclusão de que na favela havia favela, de que lá havia gente morando, que ela aumentava cada vez mais, que a favela era feita de restos de madeira, que as pessoas improvisavam aquelas soluções todas, até que se acabou achando um certo sabor na favela. Um estrangeiro que passasse por aqui, ficaria admirando a favela e tal (é claro que um ser humano, quando estabelece um cantinho para viver, procura pelo menos aquecer um ou outro ponto de seu entorno mais próximo)... Voltando ao problema das escalas. A cabeça desse pessoal de planejamento vai até uma certa escala. O pessoal de edifício parte de 1:5.000, que já é uma coisa rara, 1:2.000 ou 1:1.000, 1: 500, precisa colocar uma cotasinha, precisa detalhar um perfil, e vai descendo...1:100, 1:50. Quando começa o problema da pormenorização, da escala maior, 1:10, 1:5, 1:1, já se começa a pensar em produção em série, em coisas que dizem respeito à máquina, começa a pensar no objeto. E o objeto, em geral, é alguma coisa feita em escala natural. Aliás, a pormenorização tem uma escala ao contrário, é 2:1, coisa assim. Quem começa a pensar no objeto, começa muitas vezes a tomar contato com detalhes técnicos, materiais ou mecanismos nos quais precisa assentar sua lente de aumento para poder entender, coisa que o arquiteto passa por cima, porque para ele é um problema menor. Uma caixa de luz, por 
exemplo, como funciona lá dentro, não é nem tarefa dele. Quando alguém tiver que estudar o design de uma caixa de luz, como se monta e como se desmonta, como se coloca na parede etc., isso já é um problema de indústria, são coisas que só podem ser projetadas em escala natural. Até o modelo não é como a maquete do arquiteto, há uma diferença. A maquete exige sempre uma abstração. Aliás, o próprio projeto exige essa abstração; você pensa nele, e ele pode aumentar 100, 200 vezes, mas o objeto não. A noção de modelo exige uma escala natural.

Também no caso do pessoal da comunicação a coisa é feita em escala natural. E talvez acontençam certos tipos de trabalho em que essas coisas se interpenetram. Por exemplo, quando os americanos (acho que no MIT) fizeram um trabalho em que reduziram toda a ergonometria a ábacos, uma coisa maravilhosa. Esse trabalho feito pela universidade, que levou dez anos, foi orientado por um bom comunicador visual e um bom designer. Essas coisas podem acontecer em países ricos, em países periféricos raramente acontecem. Não há capital e não há cabeça. Para que isso seja possível, torna-se necessário que uma porção de gente tenha sua inteligência desenvolvida. E a inteligência aqui é desenvolvida em nível bacharelesco. Discursa-se muito, há idéias luminosas, faz-se um pouco de demagogia às vezes, mas a produção é muito pequena, produz-se pouco nesse sentido consultivo. Isso serve para eles afinarem melhor a produção deles. A luta pelo mercado é uma coisa muito séria, os românticos têm que aprender isso.

MC - Em relação às características que você menciona quanto ao design italiano, e que podem ser consideradas ideiais, como fica a perspectiva do design brasileiro?

AS - O europeu, por fruto da necessidade, aprendeu a não desperdiçar. Ele enfrentou guerras etc. e não desperdiça, isso é uma coisa impressionante. O sujeito fazia um desenhinho e isso valia, se não valesse naquele momento, um dia ia valer. A cabeça pensou, é trabalho. Esse desperdício, o valor do trabalho me impressionou muito. Vemos um pouco disso em nossos imigrantes, ao passo que em certos grupos, como se vê muito na FAU, há muito desperdício de trabalho e de tempo. Nada se acumula e isso me deixa chateado.

MC - Proporia a questão em outros termos. A produção para que aconteça, baseia-se na sensibilização do cliente. 
Há a necessidade de que quem disponha de recursos aposte no projeto. Quanto ao desenho industrial no Brasil, isso deixa de acontecer por não haver por parte do empresário a sensibilidade ou consciência necessária em relação à importância disso em seu produto. Parte da responsabilidade por esse quadro não recai no próprio profissional de design que não soube desencadear esse processo de conscientização?

AS - O empresário sabe muito bem o que é design. Ele viaja para o exterior todo o ano e sabe exatamente o que significa design. Acontece que ainda não chegou o momento dessas coisas serem exigidas pelo consumidor. A hora em que o mercado se transformar em um mercado de verdade, então ou ele se organiza ou rua. Isso aconteceu com o mercado de tecidos. A turma do tecido que não se reciclou, continuando a usar os mesmos teares dos tempos do pósguerra, caiu fora do mercado. O profissional que se reciclou está aí, suou muito. Se há um campo do design muito interessante porque leva em consideração a questão da moda; é o do tecido, que conta com uma organização de âmbito internacional. Começa pelo "pool" de empresas que trabalham com cores, tudo começa aí, passando pelos desenhistas de tecidos, os modelistas, etc. Eles estabelecem quais as cores da moda e só produzem isso. Começa na ponta da pirâmide, todos os anos. Então, a gente percebe que é um problema de mercado. Com certeza, é um processo que vai se iniciar aqui, quando se sentir necessidade, aí vai surgir esse profissional do design.

MC - Enquanto for mais barato copiar o produto de fora que desenvolvê-lo aqui...

AS - Mas copiar, não é assim tão fácil. Se fosse assim tão simples, copiar-se-ia tudo absolutamente. É difícil copiar. Quando o pessoal traz um produto para cá e tenta colocar tecnologia que nós temos aqui, sempre acontece alguma coisa. Cito um exemplo que tenho acompanhado de perto, no mundo dos plásticos. Pega-se um produto inglês ou escandinavo, alguém traz e mostra para um moldador para se fazer o molde. E surge uma dificuldade, sempre tem alguma coisa que não se consegue igualar, sempre é preciso redesenhar alguma coisa que não se consegue igualar. $\mathrm{Na}$ tecnologia, eles estão adiante, não é fácil.

MC - Há três coisas que você falou e que valeria a pena 
salientar pela sua importância. A primeira é a questão do artista, do designer italiano, daquele profissional que traz um "sentido" de arte aplicada muito evoluído (em decorrência de uma cultura que já traz isso enraizado desde, por exemplo, o Renascimento, para não ir muito longe). Outro ponto referese ao problema da falta de objetividade entre os arquitetos brasileiros durante a arrancada rumo ao design que acabou por se frustrar _ uma atitude romântica que turvou a caracterização de sua presença no mercado. E o terceiro ponto, a visão de que o problema do mercado quase que antecede qualquer discussão sobre design e seu comparecimento na indústria. Como você amarraria esses pontos, ainda pensando nas perspectivas do design brasileiro?

AS - Vamos ter que fazer um design brasileiro. Ou a gente faz parecido com o que empatizamos - o design italiano, o escandinavo - ou tentamos criar uma coisa que tenha o sentido de nosso contorno social, da textura social daqui. Em termos de gráfica, uma coisa que me deixava, e ainda me deixa entusiasmado, é a ilustração da literatura de cordel. Essas ilustrações revelam uma força tão grande, da qual é possível tirar algumas coisas. O pouco da cerâmica popular que se fazia por necessidade, os objetos de uso (a Lina Bo Bardi pegou muito bem isso tudo), as pipas, até o refugo da indústria que é reaproveitado, são coisas com um valor enorme e fruto da necessidade. A cerâmica tipo Vitalino começou a ser feita para as crianças brincarem e depois virou peça de museu, porque em um ou outro caso tinha qualidade artística. O Vitalino era um gênio cuja cabeça funcionava de uma forma diferenciada pela temática; ele sabia pegar o cotidiano etc. E a gente sempre trabalha a partir de exemplos. falei no caso específico do Nordeste, mas se pode falar do que vem da imigração do Sul ou da miscigenação de São Paulo ou das coisas das montanhas de Minas.

MC - Segundo seu pensamento, a questão que se polariza entre ser regional ou universal, a busca de uma linguagem supostamente brasileira versus a tendência de uma estética sem fronteiras, cosmopolita, se resolveria pelo incentivo à produção, que naturalmente reflete a cultura da qual se origina, sem que seja preciso um esforço externo...

AS - O que não existe é uma definição por decreto: "O design será brasileiro". Existe uma porção de coisas fortes, que são fruto da necessidade, e de onde a gente pode pinçar elementos que nos servirão de inspiração. Então, eu acho 
que nessa medida se atinge uma dimensão universal. Esse design que acaba surgindo é algo necessariamente brasileiro também. À semelhança do que se passa na pintura, que apesar de toda a influência, expressa uma temática brasileira. Por exemplo, o Rebolo é um pintor paulista. Morandi, um pintor italiano. Não se trata de compará-los para ver quem é melhor. Morandi pintava suas paisagens em Bolonha, suas garrafinhas cheias de poeira, preocupado em descobrir a cor atrás daquela história toda, às vezes explicitando o branco (o que deixava a gente meio deslumbrado), depois escurecia tudo aquilo, texturizava...Quando fazia seu pequeno trabalho, estava no fundo expressando um sentido universal. Não quero compará-lo com o Rebolo. O que sei é que o Rebolo olhava o Morandi com muita atenção. Se você pega as paisagens do Rebolo (um homem que não tinha nada de sofisticado, não era erudito, mas um cara de origem humilde, jogador de várzea, filho de imigrantes e que foi pintor de paredes), encontrará algo profundamente paulista. Ele documentou muito bem as matas do Morumbi, até no sentido de nos proporcionar uma leitura do que foi feito daquilo, que era uma mata maravilhosa. A cor dele é escura. É escura porque São Paulo sempre teve esse aspecto carregado. Quando vai ao Nordeste, é incrível, a tela explode e fica clara. A retina dele é obrigada a se fechar de tanta luz. Você vê isso em sua pintura. Rebolo é uma pintura paulista, como Volpi é uma pintura paulista (o pessoal do grupo Concreto tentou ver Volpi como um pintor concreto, mas ele não é um pintor concreto, é um pintor paulista, com origem semelhante à de Rebolo). Todo esse grupo da família paulista pintava de uma forma semelhante, um se adiantava mais, outro menos, mas é uma coisa que funcionou como um corpo único. A impressão que tenho é que eles se escudavam uns nos outros e, assim, avançavam juntos, isso acontece em qualquer manifestação... Um pintor pernambucano é outra coisa, fortemente marcado por esses aspectos da gravura popular e essa coisa toda...

Voltando à questão do design, acho que o dia em que surgir aqui um design, vai ter que partir da arte popular. Na Escandinávia foi assim também. Aí, a gente chama meia dúzia de sociólogos mais uns críticos e essas coisas todas e então vão descobrir, vão escarafunchar etc., porque eles só vêm depois; a gente faz e eles explicam, não é? Se a gente quiser explicar tudo também, acaba não fazendo nada, perde mais tempo explicando que fazendo, então o melhor é ir fazendo, depois se vê o que acontece. Também não acho ruim, é importante ter gente que faça como gente que 
explique. Então, esse é o tal do problema do design nacional. Depois que ele surgir, vamos descobrir o que informou essas coisas e elaborar um corpo de doutrina. Havia um pessoal aí preocupado que confundia o design de objeto com leitura do objeto, causando a maior confusão. Não se vende poesia a um homem de indústria, a não ser que você dedique a ele um livro de poemas e ele resolva pagar a produção, não é assim não. Esse negócio de eternas vanguardas é coisa de periferia. Se pegar outros lugares do mundo, Nova York, por exemplo, encontrará alguém que canta blues desde os anos 40 e que continua cantando. Tem o mercado dele, faz o melhor que sabe e cada vez melhor. Faz algumas modificações, mas continua sendo o mesmo blues. Neste país aqui, que chamam de periférico, há sempre a necessidade do panfleto e essas coisas não constroem, sabe? Não se joga a história pela janela.

Entrevista de Abrahão Sanovicz, concedida ao arquiteto Marcos Cartum, pesquisador da Divisão de Pesquisas do Centro Cultural São Paulo, em 1984. In SANOVICZ, Abrahão. Sistematização crítica da obra de arquitetura para obtenção do título de livre docente junto à Faculdade de Arquitetura e Urbanismo da Universidade de São Paulo, 1997. 


\section{Abrahão Sanovicz a Catharine Gati}

O Centro Cultural São Paulo CCSP, através do Centro de Documentação sobre Produtores Culturais de Arquitetura em São Paulo, realizou no fim da década de 1980 uma série de entrevistas.

Abrahão Sanovicz foi entrevistado pela pesquisadora e arquiteta Catharine Gati, em nove sessões, entre agosto de 1987 e novembro de 1988.

Estas entrevistas foram transcritas, mas nunca foram publicadas.

Procurou-se editá-las de maneira um tanto "livre" e, para garantir o conteúdo completo dos registros, uma cópia das transcrições foi depositada na Biblioteca da Faculdade de Arquitetura e Urbanismo da Universidade de São Paulo.

\section{Registro $01-18$ e 19 de agosto 1987}

Catharine Gati (CG) - Neste primeiro encontro vou listar algumas questões para que você discorra sobre elas na ordem que achar mais interessante:

- Por que você decidiu ser arquiteto?

- Na época em que tomou essa decisão que imagem tinha do arquiteto e que imagem tem hoje?
- Como estudante, quais os professores que te influen-

ciaram na FAU?

- O que é a arquitetura no seu entender?

- Qual o significado do projeto?

- Como você projeta?

- Gostaria que fizesse uma avaliação da sua produção, que falasse de um ou diversos projetos que são especiais para você.

- Você afirmou que está reformulando seu trabalho, fale um pouco sobre isso.

Abrahão Sanovicz (AS) - Fui obrigado a reformular meu trabalho, não que eu quisesse. Os últimos anos no país foram de uma dificuldade muito grande de trabalho, notadamente a partir de 1978.

Trabalhar com arquitetura em nosso país requer um esforço muito grande,a situação é de grande adversidade.

Nos países mais ricos a arquitetura faz parte do cotidiano a ponto de, pessoas que não são arquitetos se interessarem pela arquitetura, vivem esse processo como coisa que enriquece sua vida.

Nos últimos anos tem sido muito difícil conseguir um trabalho, realizá-lo e fazer com que seja construído de 
maneira mais eficiente.

Houve uma perda da dignidade do projeto, isto significa que os programas empobreceram, tanto os de caráter coletivo como individual.

Se verificarmos as publicações brasileiras dos anos 1930 aos 1960, constataremos que os arquitetos brasileiros puderam fazer um trabalho altamente criador, os programas eram os mais variados. A partir de então, constata-se um recuo nos programas e, conseqüentemente uma perda da dignidade do projeto.

Se analisarmos as escolas dos anos 60 e as feitas mais tarde, verificamos que os programas recentes se restringem ao mínimo. Os terrenos planos, disponíveis anteriormente, hoje, nos novos loteamentos, são as áreas destinadas aos equipamentos institucionais, normalmente as mais problemáticas e com pior topografia. Resta ao arquiteto, identificar dentro de limites tão adversos, a melhor solução para o projeto, não esquecendo ainda das restrições de ordem econômica.

Os trabalhos que foram feitos para o Instituto de Previdência do Estado de São Paulo IPESP, durante o plano de ação do Governo Carvalho Pinto, inicialmente, tinham como restrições definidas pelo contratante: telhados com telhas de barro ou de cimento amianto; paredes autoportantes, áreas mínimas. No entanto, houve um projeto de um arquiteto, que por sua história profissional, conseguiu propor uma nova solução para o problema: o projeto de Artigas para o Ginásio de Itanhaém.

Artigas mostrou que era possível e até mesmo a administração do IPESP se encantou com o resultado do projeto. A partir desta obra e muitas outras interessantes foram realizadas pelo Instituto.

Num levantamento recente feito pela Companhia de Construções Escolares do Estado de São Paulo CONESP para a manutenção e restauro de algumas dessas obras, verificouse que os projetos eram de altíssima qualidade.

Comparando os programas vemos que houve um certo recuo, justificado por razões de ordem econômica e também pela quantidade de obras a realizar.

O esforço da CONESP em sistematizar processos construtivos, componentes e materiais, foi muito importante, mas não conseguiram incorporar a esta iniciativa as melhores condições de projeto e de qualidade dos materiais. As obras construídas recentemente quando são inauguradas já estão velhas. Se compararmos essas obras com as escolas da Primeira República, como o Caetano de Campos ou o Grupo Escolar 
onde estudei em Santos, estes últimos estão perfeitos, com seus espaços generosos.

Vemos então que houve um retrocesso que não é da arquitetura, ela é um meio e não um fim, não se deve portanto dizer que a arquitetura está em crise.

Nossos colegas da CONESP lutam e lutaram desesperadamente para conquistar pequenas coisas, como a estrutura independente, por exemplo, mas isto é muito pouco se considerarmos as experiências anteriores.

Tomo como exemplo as escolas porque fiz muitos projetos escolares, principalmente nos últimos 10 anos, o que foi sempre um grande desafio. O diálogo que tinha com os colegas da CONESP era maravilhoso porque eles entendiam as propostas, ainda que fossem necessários alguns recuos.

Não me envergonho das implantações que fiz, ao contrário, todas elas foram feitas da melhor maneira possível, com as informações as mais detalhadas, revisões precisas, era aquilo que tínhamos à mão para fazer.

Outro fator que contribuiu para esta perda de dignidade foi a relação arquiteto - cliente, na medida em que foram montadas organizações empresariais, onde pelo excesso de processos burocráticos, não se reconhece mais a autonomia tanto do arquiteto como do cliente.
Hoje o arquiteto passou a se relacionar com o preposto do cliente, e essa relação cria conflitos, limita decisões, e vai dissolvendo, "aguando", o projeto.

A arquitetura é uma profissão tão digna, tão humana e tão normal, como qualquer outra atividade humana. Não acho que tenha nada de excelso, insere-se perfeitamente ao lado de outras atividades humanas no espaço cultural.

Dizendo isso pretendo modificar a imagem que tínhamos dos arquitetos até os anos 1960, herdada, possivelmente dos panfletários dos anos 20. Com a distância do tempo, percebese o esforço que foi, no período entre guerras, estabelecer e afirmar a profissão de arquiteto, foram necessárias manifestações panfletárias e até excêntricas, que hoje já não têm mais razão, ao contrário, hoje talvez até atrapalhem.

$\mathrm{O}$ arquiteto tem que considerar tudo o que é objeto da arquitetura: as técnicas; a construção; o programa; a natureza do solo; as condicionantes térmicas e acústicas; as condicionantes culturais, estéticas e éticas; e, a história da arquitetura que o informa.

Todo projeto é fruto do projeto ou projetos anteriores.

A arquitetura é uma profissão que se modifica em constante continuidade, tanto que, muitas vezes, percebemos que os projetos de determinado período ou 
geração se assemelham porque as condicionantes eram semelhantes.

CG - Como foi o debate da arquitetura nesse período? Até que ponto o amortecimento do debate contribuiu para o empobrecimento das propostas?

AS - O debate da arquitetura sempre foi vigoroso quando os programas e as soluções propostas eram vigorosos.

O maior debate que se dá entre arquitetos é através de seus projetos.

Por que se perdeu o hábito de debater?

Sobre o que debater se há tão pouco para mostrar.

CG - Como foi sua relação com o cliente individual, particular?

AS - Eu fiz muito poucas residências, minha maio atividade para cliente particular foi através dos prédios de apartamentos.

Em todos esses prédios moram arquitetos o que é motivo de orgulho para mim.
CG - Gostaria que você fizesse um pequeno histórico da colaboração com a Formaespaço.

AS - Com a Formaespaço havia uma relação familiar: um americano que quando veio para o Brasil casou com a prima de minha mulher. Dono de uma pequena firma construtora, uma pessoa muito inteligente, ativa e culta. Formado em literatura, não cursou arquitetura ou engenharia.

Quando aqui chegou, montou a construtora, pois sabia da importância da arquitetura. Entusiasmou-se com as possibilidades colocadas pelo Banco Nacional da Habitação $\mathrm{BNH}$, ou seja, levantar financiamento para construção de edifícios habitacionais. Colocou, de saída algumas premissas: gostaria de construir prédios que pudessem ser repetidos, alguma coisa que pudesse fazer a construção ser mais econômica, teria como público alvo a classe média, e procuraria terrenos em bairros mais novos, onde não precisasse usar o índice máximo de aproveitamento dos terrenos. Dizia: "Quero fazer alguma coisa que seja um design na construção"

Eu, por outro lado, tinha algumas experiências com design, umas deram certo, mas a maior parte não, porque não podemos afirmar que o design tenha grande expressão 
no Brasil.

Foi uma conjunção de interesses, àquela época (1968/1969), já achava que o único lugar onde se poderia aprofundar a experiência do design seria na construção. Fiquei animadíssimo.

A primeira experiência foi uma série de casas abobadadas, o Conjunto Jardim Prudência.

O partido desse conjunto, "o côncavo e o convexo", levou ao de uma casa para um dos diretores da Formaespaço: a parte côncava era dos dormitórios, a convexa a sala. Terreno na Granja Viana, o lugar é muito bonito, a parte da sala, leva para o espaço exterior.

A cobertura é um lençol com dois tímpanos, o partido era inovador porque ao contrário do que sempre fez Marcel Breuer que reunia sala e serviços num volume separado dos quartos, nesta casa, o volume separado era o dos serviços, com laje plana.

De certa maneira retomei este partido na residência André Mehes Filho, na Rua Berlioz, Alto de Pinheiros.

Com a obra do Conjunto Jardim Prudência, os construtores pretendiam "fazer dinheiro", enquanto isso, segui estudando o famoso "modular", o que levou quase sete meses.

A área do apartamento era a maior que se podia fazer, atendendo as normas do BNH, no máximo $160 \mathrm{~m}^{2}$ de área total, sendo $127 \mathrm{~m}^{2}$ de área útil. Tem três quartos, dois banheiros, sala (com três ambientes: jantar, estar e música) e serviços (cozinha, área de serviço, quarto e banheiro de empregada). Garagem para um carro, salão de festas e área para atividades das crianças.

Não usava o índice máximo de densidade estabelecido pela Prefeitura, pois assim, conseguia maior elegância dos prédios em relação ao terreno.

Eram terrenos relativamente baratos, os primeiros em Moema e, depois em Perdizes.

Sistematizei a estrutura, os pilares e vigas no perímetro externo já desenhavam a fachada.

As formas foram racionalizadas porque eram iguais de baixo até em cima, cada elemento estrutural tinha sempre o mesmo tamanho: vigas altas e lajes vencendo grandes vãos.

As paredes internas eram de gesso, uma técnica nova, tivemos assessoria de profissionais da Argentina, que tinham vasta experiência. Eram painéis de $7 \times 50 \mathrm{~cm}$, encaixados tipo macho-fêmea, com furos de $3 \mathrm{~cm}$ na longitudinal. Foi necessário elaborar um manual para obra: como colar, rasgar, embutir conduites, etc.

Havia um aspecto de pioneirismo, porque se adotava 
soluções não convencionais.

Com o primeiro prédio construído, era como se eu tivesse um protótipo feito em escala natural e sendo usado, com isso íamos aperfeiçoando a idéia. Fiz algumas alterações e poderia ter feito outras, mas essas empresas no Brasil, por má gestão ou mudança de enfoque, logo aparecem os problemas mais controvertidos, de repente invertem seu objetivo, que inicialmente tinha um caráter social e o desejo de construir algo que tivesse permanência.

Os processos econômicos ocorridos a partir dos anos 70, mais a ganância, a má gestão, a incapacidade técnica dos profissionais que intervinham na construção, ou o desamor o desconhecimento do objeto de seu trabalho, o fato é que essas firmas não agüentaram.

Pelo inusitado do projeto, comparado ao que se fazia na época, acredito que os modulares atendiam melhor.

Apesar do meu esforço, já que também era responsável pela execução da obra, não acho que foram bem construídos.

Muitas vezes passava os domingos nos stands de vendas e ouvia os compradores perguntando, por exemplo, como minha filha vai sair do quarto para ir ao banheiro de penhoar? (sobre as portas dos quartos que se abrem diretamente para a sala).
Quando projetamos uma obra assim, não se sabe quem é o cliente, o que é um risco. Mas tenho certeza de que estava fazendo arquitetura.

A força do projeto permanece e, com ela, questionava os estilos todos, que vendiam gato por lebre.

Quando comecei a desenvolver o projeto desenhei todas as vistas, pendurei nas paredes e disse: "Eu gostaria que qualquer colega meu olhasse esse projeto e dissesse: ' eu posso fazer a mesma coisa'" .

Com esse projeto quis me identificar com meus colegas, que cada um deles pudesse sentir que poderia fazer o mesmo. A idéia era de criar um processo, um embrião, se o país tivesse um ritmo econômico normal...

Não me agrada a idéia de que esses edifícios são pioneiros, seria mais interessante que tivéssemos um ritmo normal de trabalho.

O modular não deve ser encarado como projeto único, mas como um sistema que se desdobra, como no conjunto habitacional Nova Cidade, em Jundiaí, com unidades de 75 $\mathrm{m}^{2}$, prédios de três andares com a mesma linguagem.

A primeira geração dos modulares era totalmente despida, uma espécie de "pé-de-boi", referência ao Volkswagen, quando tiraram uma série de acessórios para 
barateá-lo. Depois houve uma segunda e terceira geração, quando apareceram caixilhos com quebra-sol, como no prédio da Pará (Edifício Abaeté à Rua Pará, Higienópolis, São Paulo SP).

A idéia norteadora era pensar um sistema que pudesse baratear a edificação e construir em larga escala. Devia-se, portanto, despir totalmente o edifício, e, à medida que fossem sendo construídos, poderiam ir incorporando outros elementos.

Depois dos modulares fiz algumas experiências com prémoldados no edifício Fiandeiras, que foi das últimas experiências em prédios de apartamentos para cliente particular.

Fiz alguns conjuntos habitacionais para o Caixa Estadual de Casas para o Povo - CECAP, nestas obras, é evidente a referência ao Zezinho Magalhães Prado, de Artigas, sobretudo a solução de planta, no entanto, implantados em terrenos com topografia bastante movimentada, não tiveram a implantação tão cartesiana como no Zezinho.

Essas minhas obras, por sua visibilidade, são mais conhecidas, mas, acredito que outros projetos realizados no interior do Estado representam uma produção mais densa.

Para analisar os modulares, seria interessante voltar para época da escola, especificamente, sobre um projeto que par- ticipei junto com uma equipe de estudantes e que representou a FAU na IV Bienal do Museu de Arte Moderna, em 1957

Os membros do júri eram: Kenzo Tange, Marcel Breuer, Philip Johnson, Silvio Vasconcelos e Jacob Ruchti. Daí a importância que era dada a estes concursos, jogávamos a vida nesses trabalhos.

CG - Voltando a nossas perguntas do início, que imagem você tinha da arquitetura e como era a FAU?

AS - Acho interessante relatar um pouco da minha experiência artística antes da FAU, como ela foi sendo substituída pelo interesse pela arquitetura, pela gráfica e o design. Voltei, recentemente, a fazer gravura, algo que devia a mim mesmo.

Por aí podemos ter uma idéia do que era a Escola, do movimento cultural. Eu e Flávio Motta fizemos interessantes experiências no curso de pós-graduação: uma série de seminários sobre os anos 50, Artigas, Lucio Costa. Foram feitas umas 60 fitas.

Importante falarmos sobre a vida cultural em São Paulo e sobre a imagem que tínhamos da FAU.

Com isso é mais fácil perceber minha atitude no trabalho, 
como fomos inventando nossa vida e como ela foi se transformando, tanto por contingências internas, nossas, como por contingências externas.

\section{CG - Há um poder transformador pela arquitetura?}

AS - Acredito que projetar, ou seja, o resultado do projeto encerra sempre uma intenção ideológica, que em determinadas condições ele tem uma capacidade transformadora.

Quando é que surge o partido novo que se diz transformador?

Quando o relacionamento social se transforma. Então, o arquiteto é intérprete dessa transformação. Por exemplo: desaparecimento do fundo de quintal pelo surgimento dos processos mecânicos de lavagem, secagem e tratamento químico das roupas, fez com que os partidos dos projetos se modificassem, além de liberar o tempo despendido para esses serviços, o que pode fazer com que a pessoa que se ocupava desses afazeres pudesse usar esse tempo numa atividade criadora. Não é o projeto que provoca essa mudança, ele absorve e propõe novas soluções.

Qual a grande contribuição de Mies van der Rohe?
A limpeza das paredes de uma edificação: a Farnsworth House é o máximo no mínimo, um retângulo com uma linha. Ele retira as paredes que dividem os ambientes, quando reconhece que não precisa mais dela, já que o relacionamento entre as pessoas também não, ou seja, o comportamento social se modificou, evoluiu. Destaca-se ainda nessa obra a concentração das instalações ,a simplicidade da planta.

A arquitetura é intérprete e ao mesmo tempo geratriz. Não existia a planta da Farnsworth antes. Interpreta na medida em que entende que as paredes não são mais necessárias e é geratriz porque cria as condições para que efetivamente estas relações aconteçam.

Se há uma coisa que me orgulho, e que é privilégio de um grupo que se formou naquela época, Katinsky (Julio Roberto Katinsky), Toscano (João Walter Toscano) e eu, a preocupação que sempre tivemos por uma arquitetura social, as casas, para mim são exercícios de estilo, experimento alguns partidos, reformulo outros, mas a maior parte de nosso trabalho, pelos próprios programas que obedecia, tinha uma grande preocupação social.

Alguém perguntou numa aula: "Como se reconhece se uma obra tem ou não qualidade? Se ela permanece ou é 
datada?".

Respondi: uso um critério muito simples, quer dizer, passo e olho a obra, se tenho vontade de vê-la novamente, e, cada vez que a vejo a vontade de revê-la aumenta, acho que esta obra interpretou bem seu tempo, portanto não é datada. A obra datada é aquela que depois de vê-la não interessa mais.

\section{Registro 02 - 2 de setembro de 1987}

Catharine Gati (CG) - São Paulo tem jeito?

Abrahão Sanovicz (AS) - Acho que existe uma grande diferença entre planejamento e desenho urbano. $O$ planejamento é feito numa escala 1:20.000 ou 1:50.000, onde não se pode pormenorizar, dimensionar, metrificar; ao passo que no desenho urbano você é obrigado a dimensionar.

São Paulo sofre por dois tipos de intervenções: de um lado a engenharia viária, que obedece a critérios fruto dos cálculos, e de outro, ao planejamento que trabalha a nível de diretrizes e conceitos, são dois extremos.

O desenho urbano, quantificado, levando em consideração todos os aspectos de cada região, intervenção feita passo a passo, medida, rigorosa, que não gera comoções, que não destrói a imagem da cidade, que pense no destino, no significado de cada ato para o usuário. É isso que nos falta.

Um bom exemplo é o da cidade de Hamburgo no pósguerra, parcialmente destruída, discutiu-se por dois anos o que era necessário fazer para reconstruí-la, de maneira que não sofresse descontinuidade a cada governo.

O trabalho deveria ser feito em diferentes níveis, em várias escalas, e estar tudo muito bem coordenado, já que são inúmeros os intervenientes: abastecimento, infraestrutura, transportes, mas isso não acontece.

Sempre existe uma sabedoria anterior no estabelecimento de um caminho. Trata-se de entender o projeto que está subjacente e explicitá-lo, o que exige uma visão bastante abrangente, uma grande experiência profissional e de vida.

\section{CG - Fale um pouco de seu trabalho.}

AS - A maior parte do meu trabalho é para o Governo do Estado de São Paulo. Cada gestão dura 4 anos, no primeiro planejam, segundo e terceiro, trabalham, no quarto, inauguram.

Se fizermos uma leitura dos projetos, programas, materiais empregados e linguagem, podemos identificar a 
situação econômica e sócio-política a cada momento da história brasileira.

Defino as importantes fases dessa história: a da formação e da experiência com a bolsa para um estágio em Milão, na Itália, que vai até meados de 1960; um período de crise, retoma-se a produção de 1967 a 1975; uma nova fase que vem com o "milagre" até 1978; uma forte crise até 1984; com um pequeno avanço neste último governo.

Seria interessante se a cada fase pudesse discorrer sobre os projetos realizados, mostrar uma espécie de gênesis de cada grupo de trabalhos mais significativos.

Antes, gostaria de falar que o mais importante foi a formação e, principalmente o espírito da FAU.

Importante para entender como cheguei na FAU foram as experiências na Escola Técnica e da formação artística na Escola de Artesanato do Museu de Arte Moderna MAM.

Na época, anos 50 (1950), São Paulo era uma maravilha, tinha uma escala ótima, com seus quase 3,5 milhões de habitantes. Já era uma metrópole, já não tinha mais a garoa, mas o movimento cultural era muito intenso: os novos museus, Museu de Arte Moderna MAM e Museu de Arte São Paulo MASP; a primeira Bienal; a criação da cinemateca. Era uma ebulição artística: a revistas estimulavam polêmicas sobre arte.
A vida cultural girava em torno da Praça da República.

Muito de arte se produziu no período, novas escolas, o grupo concreto, os tachistas, o rebatimento aqui das discussões que aconteciam nas escolas européias.

Acredito que esta explosão tenha sido preparada. Sempre encontramos, de alguma forma a figura de Mario de Andrade envolvido nessas manifestações.

São Paulo estava desprovincianizada: íamos à escola, depois a um museu, ao Teatro Municipal, uma nova peça no Teatro Brasileiro de Comédia TBC, o cinema brasileiro explodia com O Cangaceiro.

Os arquitetos em torno do Instituto de Arquitetos do Brasil $\mathrm{I} A B$ eram poucos, mas com uma produção muito interessante.

Mudei de Santos para São Paulo em 1950, depois de ter terminado o ginásio, para cursar o curso de nível médio, correspondente ao científico, na Escola Técnica Federal, onde fiz o Curso de Edificações que equivalia ao "geômetra" da Itália, era projetista, mas também tinha ligações com a obra.

Penso, às vezes que se tivesse feito científico poderia ter uma cultura geral mais ampla.

Antes, porém, com 13 ou 14 anos fiz um curso de desenho arquitetônico, queria ter uma profissão, gostava de desenhar e fui aconselhado por meus familiares, e acabei me 
profissionalizando. Na época era um mau aluno do ginásio, era importante logo ter uma profissão para ganhar a vida de maneira mais tranqüila... Descobri muito depois que a forma menos tranqüila de ganhar a vida é escolhendo a profissão de arquiteto.

CG - Já que gostava de desenhar, você não pensou que poderia ser artista?

AS - Pensei, tanto que, enquanto cursava a Escola Técnica, matriculei-me no curso de gravura da Escola de Artesanato do MAM, como bolsista, mas sempre ficava a dúvida: arte ou arquitetura. Cheguei até a pensar em fazer Belas Artes para aprender pintura.

Mesmo não sendo o melhor aluno, tanto o curso primário como o ginasial foram muito bons, o que se refletiu no meu aproveitamento na Escola Técnica, onde demonstrava uma grande curiosidade em relação à arquitetura e à arte, fiz o curso com certa facilidade. Era período integral e ainda conseguia me dedicar às noites ao curso de gravura no primeiro e segundo ano, e, no terceiro ano ao cursinho pré-vestibular.

A Escola de Atesanato funcionava numa casa doada por Cicillo Matarazzo na Praça Roosevelt. Forno e equipamentos foram também doados. A Prefeitura de São Paulo arcou com as bolsas.

No concurso para as bolsas, constituído de prova escrita e desenho, o Diretor da Escola, Nelson Nóbrega, apresentou aos candidatos a artista que selecionaria os bolsistas: uma senhora bonita, com o rosto todo maquiado com pancake branco, cabelo dividido ao meio, muito elegante. Era Tarsila do Amaral.

O primeiro professor de gravura foi Yllen Kerr, gravador italiano, mais tarde mudou-se para o Rio de Janeiro e dedicou-se à fotografia, morreu muito cedo. Era ótimo artista e professor, nos dava toda a liberdade.

Outros professores foram: Lívio Abramo; Mario Gruber, que já conhecia de Santos, um dos maiores artistas brasileiros, demonstra um profundo domínio das técnicas além de sempre fazer uma pintura temática, era professor de desenho artístico; Antonio Gomide, da "Família Paulista"; Georges Nasturel, pintor impressionista; e Wolfgang Pfeiffer, professor de história da arte.

Os três anos vividos em São Paulo, antes da FAU foram muito intensos. Ainda guardo os desenhos que fiz nessa época em uma pasta.

Continuei desenhando muito e sempre, quase compul- 
sivamente, no começo, ainda como estudante de arquitetura alguns colegas até diziam que eu dispersava. Ainda hoje sempre que posso afirmo que todos devemos pelo menos fazer um desenho por dia.

Passados mais de trinta anos, eu voltei a fazer gravura, período em que fiquei fazendo basicamente arquitetura e desenhando quase que sem compromisso. Com a volta para a gravura parece que resolvi alguma coisa que fiquei me devendo, e que tenho pago em módicas prestações: uma gravura por mês.

Em Santos, já tinha contato com alguma coisa de arquitetura moderna: trabalhava em um escritório de desenho arquitetônico e até fazia despacho de prefeitura. O escritório em que trabalhava, recebia as revistas "Acrópole" e "Habitat". Conhecia o projeto da Pampulha, as primeiras casas do Artigas e algumas obras de Oswaldo Bratke em Santos.

Vinha sempre à São Paulo para algum serviço, aprovação de projetos junto à Secretaria da Saúde, o que fazia com grande alegria, pois aproveitava para visitar o MASP e depois o MAM. Pude ver as exposições de Corbusier, Max Bill, Portinari, Segall, entre outras.

Para matrícula na FAU fui obrigado a apresentar o diploma da Escola Técnica, que deveria ser obtido junto ao
Ministério da Cultura no Rio de Janeiro, que já conhecia através do "Brazil Build's", o que me fez visitar também a ABI e o Instituto de Resseguros.

Entrei na FAU em 1954, mas sentia que, apesar de certa informação sobre arquitetura que trouxera da experiência no escritório de desenho em Santos e do Curso Técnico, me faltava estruturar e aprofundar esses conhecimentos. Isto só poderia ser possível através do espírito, da cultura, que só uma escola aristocrática poderia fornecer, afinal, inclusive, funcionava na antiga casa do Conde e Condessa Álvares Penteado. O ambiente, as pinturas do saguão já mudavam a maneira de como víamos o mundo.

Apesar de muito nova, a FAU já tinha história, tinha ocorrido a "greve Niemeyer" porque o Conselho Universitário, em 1951, não concordara com a contratação de Oscar Niemeyer como professor da Escola. Os alunos tomaram a FAU, que foi fechada por um tempo, Artigas voltou a dar aulas na Politécnica, como uma espécie de exílio. A Escola estava do avesso, ainda não se restabelecera da crise, enquanto os alunos, sobretudo os recém ingressos, sentíamos a necessidade de nos congregar: organizamos concursos de cartazes e exposições. Já havia uma tradição de publicações do Grêmio com a Revista Estudos e os textos 
editados pelo Centro de Estudos Folclóricos. Organizamos outras publicações, como a dos textos de Gropius.

Era importantíssimo descobrir como surgiu a arquitetura brasileira. Começamos estudar a obra de Lúcio Costa. Fomos ao Rio, entrevistamos o Mestre, estudamos todos os seus projetos, que passamos a conhecer profundamente, reunimos muitos documentos, mais tarde, parte deles foi cedida ao Xavier ${ }^{1}$ para a edição de "Sobre Arquitetura".

Tivemos ótimos professores, freqüentemente lembro das colocações feitas por eles. Os que mais me marcaram, foram:

- Archimedes Dutra, professor de desenho do $1^{\circ}$ ano, muito influenciou em minha formação como desenhista.

- Abelardo de Souza, professor de projeto, tinha Jon Maitrejean como assistente. Era o segundo ano que Jean lecionava, ele foi o primeiro aluno a voltar para a Escola.

- Renina Katz, convidada por Abelardo de Souza, era professora de plástica.

- Plínio Crocce, um "senhor trabalhador", sentava-se à prancheta conosco, e analisava profunda e demoradamente cada projeto.

- Professor Telemaco H. M. van Langendonck de estruturas.
- No $5^{\circ}$ ano, tínhamos os arquitetos mais importantes do Estado como professores, João Batista Vilanova Artigas e Rino Levi.

O melhor projeto que fiz individualmente, como estudante, foi uma casa, para Cadeira de Técnicas das Construções, ministrada por Ariosto Mila.

CG - Quais eram suas referências projetuais?

AS - Minha referência era a arquitetura moderna, a brasileira e a internacional. Às vezes "Artiguiana", bem comportada, as "casas caixote", uma forma mais sinuosa de Oscar Niemeyer, qualquer coisa à la Neutra, Mies ou Corbusier.

Depois de estudar Lucio Costa, precisávamos afirmar a arquitetura brasileira, esse era nosso ideário.

Por exemplo, se analisarmos o projeto para o concurso para o late Clube de Londrina, que fiz com João Toscano e Julio Roberto Katinsky, as referências são muito evidentes: parece a síntese entre o pensamento do Oscar (Niemeyer) com algumas soluções do Artigas, como a "receita do pilar".

Na FAU estudávamos com toda atenção os projetos dos Mestres, era essa, fundamentalmente, nossa preocupação. 
Tanto que podemos dizer que, primeiro, nosso trabalho teve grande influência de Le Corbusier e, depois, dos primeiros arquitetos modernos brasileiros.

Havia ainda o grupo dos Wrightianos, com quem brigávamos por não conseguirmos entender que a divisão entre a arquitetura orgânica e racionalista, naquela época, era puramente didática. Quando tive a oportunidade de conhecer a obra de Frank Loyd Wright e de Antonio Gaudi reconheci que eles estão entre os maiores artistas do século.

Se há um espaço que foi inventado, é sem dúvida alguma, o do Museu Guggenheim em Nova York.

(1) Alberto Xavier, aluno da Faculdade de Arquitetura e Urbanismo da Universidade do Rio Grande do Sul e com o apoio do Centro dos Estudantes Universitários de arquitetura, organizou e editou, em 1962, "Sobre Arquitetura" reunindo textos e obras do arquiteto Lúcio Costa.

\section{Registro 3 - 24 de setembro de 1987}

Abrahão Sanovicz (AS) -Voltemos à São Paulo, que nos anos 50 tinha uma escala muito boa, tudo girava em torno do centro da cidade. O Centro Velho tinha se deslocado para o Novo, em torno da Praça da República; a Avenida Paulista apenas despontava; a Rua Augusta começava a mostrar sua vocação.
Tudo convergia para o centro: o trabalho; as grandes escolas, inclusive a Universidade de São Paulo estava espalhada em torno do centro; os museus; os cinemas, principalmente aqueles que lançavam os filmes.

A vida cultural era muito intensa, havia um grande interesse, um surto de desenvolvimento.

Na realidade se vivia com pouco dinheiro e mesmo assim podíamos desfrutar dos espetáculos no Teatro Municipal, onde vi se apresentarem, entre outros, Arthur Rubinstein e Tito Gobbi.

Esse clima criava um interesse constante: tudo era novo e a vontade de aprender sem limite.

Nossa Escola era muito pequena, 150 alunos no total. A cada evento na cidade algum aluno sempre produzia um cartaz para divulgação na FAU, era quase uma disputa, cada um queria fazer o cartaz mais bonito.

Para a exposição do Volpi no Museu de Arte Moderna, fiz um cartaz com uma ilustração que lembrava uma das janelas que ele tinha desenhado, usando azul e cor-de-rosa, tão presentes na obra do artista.

Para os cartazes também tínhamos nossas referências, graças às publicações que encontrávamos na Biblioteca da FAU, a influência maior eram a dos cartazistas poloneses e 
do suíço Celestino Piatti.

A Biblioteca da Escola sempre foi uma maravilha, o que estimulava os alunos, recebia as revistas como: "Stile / Industria", L'Architecture D'Aujourd'hui", "Casabella", "Domus", "L'architettura", "L'Architettura, Cronaca e Storia" dirigida por Bruno Zevi, "Arts and Architecture", "Ghaphis", "Gebrauch Graphik" e a "Du".

Nessas publicações eram apresentadas obras do nascente design do pós-guerra, o que despertou grande interesse por parte dos alunos da FAU pelo assunto.

A preocupação com o desenho gráfico já se demonstrava nas publicações editadas pelo GFAU, o cuidado que tínhamos com a qualidade gráfica, a procura do que era fundamental, essencial, colocado de uma forma direta, desenhado de uma forma direta e com a maior economia de meios, característica que se esboçava na Escola e, que começamos a desenvolver desde alunos. Identifico um certo ascetismo presente na minha obra com essas preocupações que iniciaram desde a nossa formação.

A UNE organizou um encontro sobre a imprensa universitária no Quitandinha, Petrópolis, Rio de Janeiro. Já que não produzíamos um jornal no Grêmio da FAU, GFAU, reunimos as publicações numa exposição, o que fez com que os organizadores alterassem as características gerais do encontro, discutindo além dos conteúdos também a forma das publicações, o que chamaram de "o estilo GFAU".

Catharine Gati (CG) - De onde vinha todo esse entusiasmo, esse "fogo sagrado", como vocês chamavam?

AS - Vinha da possibilidade de participar da construção de um país, com grandes recursos naturais, e que começava a chamar a atenção do mundo.

A arquitetura brasileira conquistava posições de destaque no cenário internacional. Ser arquiteto, e arquiteto moderno, naquela época era coisa que nos orgulhava muito.

De um lado, o país, de outro a Escola que tinha suas bases no movimento moderno e em Mário de Andrade a figura máxima, nos estimulavam muito. Éramos a sétima turma da FAU, e tínhamos uma grande curiosidade para saber o que os colegas formados estavam fazendo, qual era o estilo que aflorava da Escola.

A maioria dos professores titulares da FAU eram engenheiros vindos da Escola Politécnica, tanto que, nos primeiros anos, o único diretor arquiteto foi também seu fundador, Professor Anhaia Mello ${ }^{1}$. O Conselho Univer- 
sitário, que indicava os diretores da Escola, no início dos anos 1960, designou para o cargo um professor da Faculdade de Filosofia, professor de política, profundo conhecedor da história da arte, especialista em Barroco Mineiro, destacado intelectual que havia dirigido algumas bienais, Professor Lourival Gomes Machado, que tivera intenso contato com Mario de Andrade. Era o que a FAU poderia ter recebido de melhor.

O programa da FAU vinha do compromisso entre a Escola Politécnica e a Escola de Belas Artes, num somatório de conteúdos. Professor Lourival convocou os professores arquitetos para que reformulassem o programa de ensino, no sentido de atualizá-lo e de colocar a Escola à serviço do atendimento das novas necessidades colocadas pelo país.

Com a liderança de Vilanova Artigas se propôs a "Reforma de 62"2 (1962), a partir do conhecimento das experiências de ensino realizadas na Europa, entre as duas guerras, notadamente a da Bauhaus, das inquietações e manifestações de alunos e professores e do entendimento do tipo de profissional que o país necessitava.

A reforma criou os três departamentos: Projetos, História e Tecnologia; o Museu ${ }^{3}$, organismo vivo encarregado de promover exposições, publicações e era também afeto à oficina de modelos. O Departamento de Projetos se dividiria em quatro seqüências: projeto, comunicação visual, desenho industrial e planejamento.

Criou-se também o Ateliê Interdepartamental ${ }^{4}$, onde alunos e professores pudessem desenvolver os grandes projetos em que estariam presentes todas as áreas do conhecimento.

A transformação da Escola foi muito grande e fica evidente a assimilação das inquietações e discussões por parte dos alunos ocorridas até 1960.

Era necessário reconhecer que os cursos universitários profissionalizantes deveriam estar aptos a atender às necessidades do país que buscava sua emancipação.

O projeto, em geral, é manifestação de soberania, deveria então, surgir a partir da Escola o projeto para a indústria, o edifício, o planejamento e a comunicação, e, os meios pelos quais se deveria fazer executar este projeto seria com a tecnologia mais apropriada.

(1) Luiz Inácio de Anhaia Mello

(2) O documento "Relatório de Atividades de 1962" apresenta no item 2.1.5 a criação de quatro departamentos: Composição, HistóricoCrítico, Ciências Aplicadas e Disciplinas Técnicas; e a criação de quatro linhas de desenvolvimento didático: expressão gráfica ou comunicação visual, desenho industrial, arquitetura de edifícios e planejamento. 
(FAUUSP, 1962).

(3) No mesmo documento, item II "Política de fins", é relatada a criação do Departamento do Museum, incumbido de coordenar as atividades curriculares, extracurriculares e complementares do ensino, visando estimular o interesse do aluno pelas artes gráficas, cenografia; pela miniatura de projetos através de modelos em gesso e madeira; pela arte fotográfica; e, pelo desenho industrial. (FAUUSP, 1962).

(4) Nos documentos consultados, disponíveis na Biblioteca da FAUUSP, o Ateliê Departamental Al só aparece em "Forum de Debates 1968 - Documentos e Relatórios das Comissões e Sub-Comissões", que coloca como objetivos do $\mathrm{Al}$ a promoção de trabalhos executados com a participação de professores e alunos, em atividades de pesquisa em arquitetura, que tenham caráter de trabalho interdepartamental. O Museu figura como órgão de direção executiva do Al (FAUUSP, 1968)

\section{Registro 4 - 28 de outubro de 1987}

Abrahão Sanovicz (AS) - O trabalho do arquiteto é a reflexão da situação. Cada projeto é a conseqüência de um programa que espelha essa situação. O projeto é a interpretação ou re-interpretação desse programa.

A "Reforma de 62" tratou basicamente do binômio soberania-emancipação, mas isso só ficou claro depois da divulgação do texto "O Desenho" de Vilanova Artigas. Onde, a partir da palavra "design" trabalha desde os aspectos históricos e etimológicos até seu rebatimento na construção do país.

A Reforma colocava uma nova perspectiva de se abrir o campo profissional para que o arquiteto pudesse enfrentar as questões do projeto em todas as escalas possíveis.

A Escola absorve as inquietações colocadas pelos estudantes e, ao absorvê-las, a intenção foi primeiro entendê-las, depois assumí-las e explicitá-las porque, no fundo, elas traduziam necessidades colocadas pela sociedade.

A questão soberania-emancipação pode ser entendida mais facilmente quando pensamos na arquitetura, já que o arquiteto tem condição plena de soberania em relação ao problema. É ele quem é obrigado a tomar decisões, para isso se acerca de todos os dados possíveis, existe, então o momento de reflexão em que todas as informações sobre o problema ficam retidas na cabeça do profissional, num estado latente, quase de pré-consciência. Aí ele projeta, ele joga para frente, fica então numa posição muito mais cômoda do que aquela de olhar para dentro de si. Passa a ser observador de um projeto que está diante dele. Espera-se que do croqui surjam as respostas às suas preocupações. Quanto mais respostas corretas vierem, mais certeza ele tem de que a interpretação que deu para o problema, naquele instante e de acordo com as possibilidades é a mais correta. Faz então outras perguntas, se as respostas continuarem corretas, se toma de confiança para seguir o trabalho em frente. Se as respostas não vierem, o trabalho está errado, ou a pergunta. 
Passada a fase da primeira síntese, do estado de préconsciência para o primeiro croqui, é aí que se dá a soberania, é ele quem comanda o projeto, neste momento se consegue reconhecer a personalização do projeto. Em todo projeto deveríamos poder localizar e destacar essa interpretação pessoal, que é resultado de inúmeros fatores: culturais, estéticos, econômicos, de conforto, etc.

Se pegarmos um caso particular e extrapolarmos para o universo todo da projetação, passamos a ter o domínio do processo.

Mas a soberania não basta, é preciso conquistar os meios pelos quais se possa materializar o projeto. É assim que se alcança a emancipação.

Esse mito soberania-emancipação estava esboçado na "Reforma de 62", na medida em que ampliava os horizontes dos arquitetos, já que poderiam intervir nas diferentes escalas. Surge, então, o Departamento de Projetos da FAU e as quatro seqüências: planejamento, projeto, design e comunicação visual (que deveria cuidar também dos aspectos de linguagem das demais seqüências). Este era o cerne da Reforma.

O texto do Flávio Motta sobre desenho, tanto quanto o do Artigas, ressaltava a questão da soberania. Era necessário formar profissionais que pudessem colaborar no desenvolvimento nacional, que se preocupassem com o desenho industrial brasileiro, pudessem instrumentar a indústria com seus projetos.

Esta era a tese, ambiciosa e necessária ao país. Era o momento que reunia condições para isso: existia o arcabouço teórico, a necessidade social, a inquietação dos jovens e a inquietação da indústria.

Houve certa comoção na época: certas cadeiras foram reformuladas, outras extintas. Colocados novos conteúdos e objetivos era necessário aprimorar a estrutura didática existente, adequá-la à ampliação do universo de trabalho e incrementar a crítica.

Pretendia-se que essa tese fosse levada para o resto do país, que se pudesse tomar consciências das possibilidades jacentes, poderíamos entender melhor todo o repositório formal brasileiro. Nos perguntávamos: que design sairá disso?

Por esse período, e não por acaso, Lina Bo Bardi montou na Bahia o Museu do Unhão, formado pelas peças de artesanato que recolheu no interior e sertão daquele estado. Dando-Ihes um caráter museológico, mostrava peças fruto de uma invenção que não era erudita, mas que mostrava a força do espaço que cercava aquele artista: era de lá que se 
alimentava para criar, determinado meio social, certa forma de vida, certa história.

O que se procurava com a Reforma era um salto qualitativo na arquitetura. O Departamento de Tecnologia teria a responsabilidade de fazer as coisas funcionarem. A crítica, teríamos através do Departamento de História e Crítica, que daria o respaldo histórico, mas faria a crítica do que se produzisse, criando assim uma consciência crítica.

Esperava-se ainda, no que se refere ao projeto do edifício, que dominando as técnicas construtivas existentes, pudéssemos criar novas técnicas de maneira a enfrentar a questão da construção em grande escala. Deveríamos considerar não só os aspectos construtivos mas também os equipamentos que compõem a edificação. Criou-se até uma terminologia: equipamentos ancorados e não ancorados. Os ancorados eram os equipamentos sanitários, as áreas molhadas; os não ancorados eram, por exemplo, o mobiliário.

\section{Catharine Gati (CG) - E o discurso formal?}

AS - A beleza é uma das funções, não é absoluta, mas tem história e não é fácil fazer com que as pessoas entendam esta afirmação, de fato a forma tem história, conseguimos lêla a cada época.

Se existe história e uma experiência acumulada, temos sempre que considerá-la, verificar as possibilidades técnicas e tecnológicas que podem levar a resultados que anteriormente não se conseguia e, depois pesquisar os comportamentos de ordem programática que levaram a soluções inesperadas até então. A forma final é o resultado de todos esses fatores, daí podermos dizer que todo projeto é resultado de projeto ou projetos anteriores, mas que deve passar pelo crivo daquele estado de pré-consciência, onde recebe uma interpretação que é pessoal e fruto da época que se está vivendo.

\section{CG - A discussão da forma não é pouco objetiva?}

AS - Seria pouco objetiva se você encarasse apenas a forma apreendida pelo primeiro olhar. Mas acredito que os melhores projetos são aqueles que melhor interpretam sua época, são aqueles que uma vez colocados no espaço você olha e tem vontade de voltar a olhá-los várias vezes. Eles permanecem. 
CG - Quando há uma ruptura em seu trabalho?

AS - Nem sempre sou capaz de perceber quando há uma ruptura e como ela se deu. Sempre trabalhamos num processo que avança nos vazios deixados por outros projetos.

Todo projeto resolve determinados problemas, mas sempre deixa em seu cerne espaço vazio para novas soluções. Isso é quase a interpretação da dinâmica da sociedade. Quando a arquitetura deixa de avançar é porque a sociedade está parada.

Infelizmente acho que vivemos uma fase em que a arquitetura não tem avançado. O relacionamento do arquiteto com o cliente e com o usuário ficou despersonalizado, não se discute mais os programas, atendemos simplesmente a índices quantitativos.

Há alguns anos, participando com Paulo Mendes da Rocha do concurso para o novo Caetano de Campos, começamos estudando alguns projetos do Hannes Meyer, que tinham soluções muito interessantes, a escola quase uma praça. Chegamos a uma proposta. Foi quando entusiasmado exclamei: "faz tanto tempo que não faço um projeto com partido!".

\section{Registro 5 - 21 de março de 1988}

Abrahão Sanovicz (AS) (lendo a transcrição dos registros anteriores)

Lucio Costa teve grande influência no nosso trabalho.

O movimento da arquitetura moderna no Brasil se deu a partir do Rio de Janeiro pelo chamado grupo carioca. Mesmo se considerarmos as obras de Warchavchik ${ }^{1}$ e Flávio de Carvalho, que são importantes referências da arquitetura moderna brasileira, mas que considero como manifestações isoladas que não frutificaram.

O Ministério de Educação e Saúde MES é sem dúvida o marco do início da arquitetura moderna no Brasil, que se estrutura a partir dos anos 30 (1930) e tem a primeira grande repercussão internacional com a exposição "Brazil Builds" de 1943.

No MES uma das mais destacadas qualidades foi a de liberar o térreo, com esta implantação não se rouba o espaço público. Neste projeto podemos encontrar já um pouco desenvolvido o germe da estrutura independente, a planta livre, mas é maravilhosa a esplanada que foi ganha com a simples solução de levantar o edifício.

Até hoje os dois grandes expoentes do grupo carioca, Lucio Costa e Oscar Niemeyer, octogenários, continuam 
com grande vitalidade de trabalho.

Lucio Costa, com muito cuidado, com um carinho todo especial, com uma dedicação especial à cultura tem balizado nos momentos certos o desenvolvimento da arquitetura brasileira.

Quando convidou Le Corbusier para o projeto do MES, não o fez por uma questão estética, mas porque Corbusier tinha desenvolvido conceitos universais que seriam muito benéficos para a arquitetura brasileira ${ }^{2}$.

Nos formamos enquanto se construía Brasília, que é coroamento de um processo e símbolo de um novo alento para o país, a bandeira do desenvolvimentismo liderada por Juscelino Kubitschek de Oliveira.

O ambiente de discussão sobre arquitetura, aqui em São Paulo, era muito intenso, apesar do pequeno grupo de arquitetos mais atuantes: Vilanova Artigas, Rino Levi ${ }^{3}$, Oswaldo Bratke, Ícaro de Castro Melo e Eduardo Kneese de Melo ${ }^{4}$. Estes arquitetos criaram as bases para constituição de nossas entidades representativas.

Esse grupo de arquitetos tinha esboçado uma linguagem, organizado o Instituto de Arquitetos do Brasil IAB e preparado os profissionais que participaram da constituição das novas escolas de arquitetura.
Catharine Gati (CG) - Como a sociedade via os arquitetos desse período, como você sempre diz: aqueles que prepararam o terreno para sua geração?

AS - Os arquitetos eram muito bem aceitos pela intelectualidade, como responsáveis pelo projeto e na relação com a produção da obra. Eles souberam fazer valer a sua presença, tanto que, em 1953, construíram o prédio do $\mathrm{IAB}^{5}$, que é um dos prédios mais bonitos da cidade.

Sem dúvida Brasília é o coroamento de um processo, e o grupo de arquitetos de São Paulo no final dos anos 1950 eram pioneiros na conquista da consolidação da profissão.

Acontece um fato que vem reforçar a necessidade do trabalho do arquiteto: Carvalho Pinto assumiu o Governo do Estado de São Paulo, visita Brasília, se encanta com as obras realizadas por Lucio Costa e Oscar Niemeyer, e, de volta, prepara o "Plano de Ação", coordenado por Plínio de Arruda Sampaio.

Para concretizar o Plano, lançou mão de verbas do Instituto de Previdência do Estado de São Paulo IPESP e convocou os arquitetos paulistas, que começam a trabalhar em maior escala. Foi quando começou a se constituir o que chamamos de "escola paulista". 
Isso só pode acontecer depois de Brasília, portanto, sem a "escola carioca" não existiria a "escola paulista".

Foi com o Plano de Ação que aconteceu uma importantíssima intervenção de Vilanova Artigas, o Ginásio de Itanhaém, lição e modelo de arquitetura.

Artigas antes de iniciar o projeto conversou com os responsáveis da Secretaria de Educação, queria saber o que pensavam sobre como educar um menino, como deveria ser o espaço da escola e quais os objetivos que tinham em relação à formação desse futuro cidadão.

Incorpora ao programa um auditório e propõe uma solução inusitada: o espaço flui; não há entrada ou saída; a estrutura de concreto é independente e lança mão da solução em pórticos; cria um sistema de caixilhos fixos, mas com ventilação permanente, respeitando o clima do litoral; racionaliza a construção e o emprego de materiais; e, convida Francisco Brenand, artista pernambucano, para executar um mural.

A experiência de Itanhaém amadurece no projeto para o Ginásio de Guarulhos. Lá explicita o sistema construtivo e faz dele sua Arquitetura.

Estes projetos dão as diretrizes para o desenvolvimento da chamada "escola paulista", que os jovens arquitetos logo absorvem e tocam em frente.
CG - É desse período o projeto do late Clube de Londrina?

AS - Em 1958 João Toscano, Julio Katinsky e eu ganhamos o concurso de projetos para a sede do late Clube de Londrina. Nossas preocupações fundamentais eram com a implantação e com a leveza do edifício, e nesse sentido dois projetos de Oscar Niemeyer nos impressionavam o do late Clube da Pampulha e uma casa que tínhamos visitado em 1958, um lençol com quatro pilares, em Pedro do Rio.

O projeto de Londrina tem muito da arquitetura carioca: a implantação perpendicular ao lago; o percurso no terreno até o edifício; o desenho dos pilares; a maneira como "mordem a laje"...

O concurso foi julgado em Londrina pelos arquitetos: Ernani de Vasconcelos que participou do projeto do MES, Eduardo Corona e Meister, que era de Curitiba. Quando escolheram o projeto, acreditaram ser de um grupo carioca e se surpreenderam quando souberam que a equipe vencedora era composta por jovens e desconhecidos arquitetos paulistas.

Interessante como esse projeto ilustra o que comentamos anteriormente: sem a "escola carioca" não existiria a "escola paulista". 
O projeto foi todo detalhado, apoiados pelas experiências de Frei Otto, resolvemos a exaustão todos os pormenores das estruturas tenseis.

Infelizmente o late Clube de Londrina não foi construído.

CG - Como vocês passaram desse projeto que tem referências tão explicitas, para a procura do caminho pessoal?

AS - Julio Katinsky e eu fomos sócios e, mesmo depois, fizemos alguns trabalhos juntos. A cada trabalho discutíamos e conceituávamos exaustivamente, o que resultou sempre trabalhos de grande densidade.

Além de ótimo profissional o Julio é um grande estudioso, acho até que todos nós nos beneficiamos dessa sua qualidade: ele coloca sempre as coisas em seu justo lugar. É uma das pessoas mais importantes para a Escola.

Oswaldo Correa Gonçalves nos convidou, no início dos anos 1960, para participarmos com ele do projeto de um iate clube em Santos, tínhamos acabado de ganhar o concurso de Londrina. Depois houve o projeto do Teatro, também em Santos.

Julio e eu fizemos, entre outros projetos, o da máquina de escrever da Olivetti e dos Equipamentos Públicos para São Paulo com o Buffoni6.

Mesmo quando não éramos mais sócios sempre consultei o Julio. Ele sempre sugeria ou criticava com muita propriedade. Por exemplo: fiz um projeto para um Ginásio em Santos, era 1961 ou 1962, a planta tinha uma referência muito grande ao Ginásio de Itanhaém, do Artigas, já as fachadas lembravam a FAU, apesar de o prédio ser térreo. Julio olhou os desenhos disse que estavam muito bonitos, mas que era um "pasticho"7.

Logo depois surgiu o projeto da Rua Pará, procurei uma solução mais contida, ortogonal e simples. O resultado me parece mais maduro, com estrutura de concreto e fachadas todas encaixilhadas, mas não é uma fachada do $\mathrm{Mies}^{8}$, porque os caixilhos ficam entre os pilares e vigas, já que a margem de erro nas nossas construções é muito grande, e, assim poderíamos fazer desaparecer possíveis desalinhamentos. Um desenho que se classificaria como feio porque na arquitetura devemos ter grandes linhas.

Mesmo sendo um edifício isolado, a intenção era procurar desenvolver alguns conceitos de industrialização e racionalização da construção: reaproveitamento de formas, painéis de vedação. 
Como os caixilhos iam de piso ao teto, Julio Katinsky chamou a atenção para o resguardo necessário em certos ambientes, o que veio a confirmar a aplicação dos brises-soleils.

Tudo foi feito no plano da sensibilidade, sem grandes cálculos: o sol se movimenta assim, portanto a melhor solução será tratar estas e aquelas porções da fachada.

Tinha ido visitar a uma exposição de um escultor concretista de Israel, Yacov Agam, suas peças tinham movimento. Comentei com Waldemar Cordeiro que iria fazer um Agam gigantesco: os brises da Pará são móveis, o que faz com que a fachada se altere o tempo todo.

Os caixilhos foram detalhados por Luiz Sacilotto, escultor concretista, que era dono de uma fábrica de caixilhos.

Bramante Buffoni fez o painel da entrada.

O prédio da Pará tem uma alta densidade de informações fruto da experiência concreta de novas soluções.

$\mathrm{Na}$ mesma época Paulo Mendes da Rocha tinha projetado o edifício ${ }^{9}$ da Haddock Lobo, discutimos um pouco as diferenças de postura: eu acreditava que quando se trata de construção em altura e com solução multiplicada, ou melhor, superposta, é fundamental a simplificação do canteiro e uma boa parte dos componentes deve ser feita fora e montada na obra.
(1) Gregori Warchavichk

(2) Num comentário paralelo AS relata uma experiência quando estava estagiando em Milão: "fui visitar um conjunto habitacional com uma colega italiana. Comentei que o espaço era interessante, mas me sentia cercado. Ela disse: 'vocês brasileiros são muito livres, tenho certeza que levantariam os edifícios no solo'. Foi muito interessante verificar que a arquiteta identificou o térreo livre como uma postura dos arquitetos brasileiros. E é bem correta esta identificação, o cuidado que temos com a implantação dos edifícios, o respeito pelo espaço circundante, com o domínio visual através do espaço livre.

(3) AS comenta a grande preocupação de Rino levi com a construção que pode ser comprovada na qualidade dos prédios que projetou.

(4) Para AS Eduardo Kneese de Melo foi o grande lutador pelas causas da profissão.

(5) Prédio do Departamento de São Paulo do IAB na Rua Bento Freitas com General Jardim.

6 Bramante Buffoni.

(7) Julio Katinsky esclareceu a autora dizendo que não se lembra desse comentário e acredita que pudesse ter sido feito por João Walter Toscano.

(8) Mies van der Rohe.

(9) Edifício Guaimbé.

\section{Registro 6 - 19 de março de 1988}

Abrahão Sanovicz (AS) - Gostaria de retomar uma presença que foi fundamental para minha formação que foi a do arquiteto Oswaldo Correa Gonçalves.

Ele tinha convidado Julio Katinsky e eu para fazermos o projeto de um iate clube em Santos. Era uma estrutura fenomenal, calculada pelo Zúccolo ${ }^{1}$ : uma grande cobertura 
em concreto armado que avançava sobre o mar; viga vagão invertida, apoiada sobre quatro pilares; a planta livre.

Oswaldo nos convidou também para fazer o Centro Social da Escola Politécnica e o Teatro Municipal de Santos.

Ele teve uma grande confiança em dois jovens arquitetos nos dando a oportunidade de, no início da carreira, trabalharmos com problemas tão complexos. Oswaldo é um trabalhador incansável, sabe como perseguir o projeto, como levá-lo para frente, se cercar de todas as técnicas necessárias, resolver os entraves, e, isso tudo, aprendemos com ele.

O primeiro projeto do Teatro foi implantado num terreno muito acanhado.

O convite para o projeto tinha sido feito pelo Secretário de Obras La Scala. Infelizmente, eleito Prefeito, Scala morreu sem tomar posse.

Em 1968 a Prefeitura de Santos resolveu retomar o projeto, mas em outro terreno, bem maior. O programa também foi ampliado: além do teatro, um centro de vivência, a biblioteca municipal, a escola de artes, enfim, um centro cultural.

Vejo como influências marcantes no projeto, o Teatro de Brasília, com suas vigas protendidas na cobertura, e o projeto de Vilanova Artigas para o concurso do Clube Paulistano A proposta de Artigas era muito inteligente, uma nova linguagem. O auditório tinha uma forma muito interessante, um prisma chanfrado: um apoio e o auditório em balanço, mas ancorado no chão. O Ginásio tinha um corte que lembrava o Museu de Caracas, porém com a cobertura em concreto, sobre vigas-vagão, mas sua planta não era quadrada como em Caracas, era circular, o volume, um tronco de cone, uma maravilha.

Quando o projeto do Teatro de Santos foi retomado tivemos que nos assenhorar de todas as técnicas intervenientes: cenotécnica; sistema de ar condicionado; instalações; estruturas protendidas; curvas de visibilidade; materiais de impermeabilização; tratamento de juntas de dilatação; além de nos aprofundar nas diferentes manifestações teatrais, como a ópera, o teatro shakespeareano e o elizabetano. Foi uma oportunidade de nos aprofundarmos em complexas e diferentes áreas do conhecimento.

A obra ainda não foi totalmente concluída, funcionam: o teatro, a escola de balé e o centro de exposições.

(1) Roberto Rossi Zuccolo.

\section{Registro 7 - 15 de abril de 1988}

Abrahão Sanovicz (AS) - Após o Golpe de 1964, ficamos 
quase sem trabalho, nem nos aproximávamos dos organismos governamentais à busca de novos contratos. Nesse período fiz alguns trabalhos de artes gráficas.

Em 1967, Miranda Magnoli e Rosa Kliass foram convidadas pela Divisão de Parques e Jardins da Prefeitura para elaborarem uma série de projetos de praças em São Paulo. Não tinha sentido desenhar equipamentos especiais para cada praça. Era necessário uma solução de projeto para que fossem produzidos em série.

Buffoni, Julio Katinsky, Massayoshi ${ }^{1}$, que é colaborador do Toscano, e eu ficamos responsáveis pela elaboração dos projetos destes equipamentos e de diversos elementos de comunicação visual.

A Prefeitura cedeu uma área de cerca de $200 \mathrm{~m}^{2}$ no Viveiro de Plantas Manequinho Lopes, onde, durante dois anos, todas as manhãs, essa equipe elaborou cerca de uma centena de projetos de equipamentos públicos para as praças de São Paulo: bancos (fizemos até um banco para gestantes) postes, taças, espelhos d'água, relógios, brinquedos para crianças, uma publicação sobre plantas brasileiras, cartazes, elementos de sinalização, e muitos outros.

Chamávamos de "desing for the community", nem em Londres se enfrentou um programa como esse. Foi um trabalho muito interessante: nos preocupávamos em usar materiais e técnicas simples, soluções fáceis para ancoragem, elementos de fácil reposição e estocagem. O resultado do trabalho deveria ser algo que pudesse interessar a indústria dada a escala de aplicação. O projeto foi concluído, poucas peças foram produzidas, como de costume em nosso país.

Foi uma reaproximação de nosso trabalho com os órgãos governamentais. Na época, discutíamos a validade de se trabalhar para um prefeito nomeado, entendemos que a relevância do programa superava esse tipo de relação, afinal as pessoas passam e os trabalhos ficam.

Além dos equipamentos públicos fizemos juntos dois outros projetos: de uma máquina de escrever para a Olivetti e um ventilador para a Aeromar. Os projetos foram concluídos e muito bem aceitos pelos contratantes, mas, sendo as duas indústrias multinacionais, não conseguiram a aprovação das matrizes para produzí-los.

O design parecia não avançar em nosso país, mesmo a experiência da Escriba, que foi uma linha de móveis para escritório e que ficou no mercado por um longo tempo, foi uma experiência isolada.

Na Escola também o curso de desenho industrial propos- 
to na Reforma de 62 (1962) começava a se descaracterizar.

Pensei que talvez devêssemos procurar o lugar do design brasileiro. Cada país descobriu como aplicá-lo com maior eficiência: os alemães no mundo dos objetos utilitários, os italianos dappertutto, os escandinavos no mobiliário, os ingleses nos equipamentos urbanos e os americanos disseminaram uma coisa chamada styling. Talvez nosso design devesse se voltar à construção, do desenho dos componentes à edificação.

Surge aí a experiência "Formaespaço". O programa estabelecido pelos construtores era um edifício que atendesse à classe média e a um determinado valor de construção que respeitasse os limites estabelecidos para financiamento pelo Banco Nacional da Habitação BNH, numa perspectiva futura, pensariam atingir faixas de renda mais baixas. Edifício deveria ter de onze a treze pavimentos, dois apartamentos por andar, em terrenos urbanos, mas localizados em bairros em vias de transformação.

A construção tinha que ser muito rápida, solicitaram então que procurasse uma solução modulada. Foi uma grande coincidência, porque, do ponto de vista teórico estava pensando que a construção seria a saída para o nosso design.

Comecei a estudar o problema, lembrei do tempo em que os arquitetos entregavam para os engenheiros as plantas sem estrutura e, estes últimos colocavam os pilares aleatoriamente, dentro das paredes, para não "atrapalhar a planta". Acostumados com os pilares chatos e compridos sabia que os engenheiros não poriam qualquer objeção a uma solução estrutural mieseana ${ }^{2}$ : modulada com pilares no perímetro da planta. Os lotes urbanos dessas regiões, Moema e Perdizes, tinham pouca frente e muita profundidade, para um lote de 15 x 45m era preciso adquirir três casas. A conformação dos lotes indicava que os prédios deveriam ser esticados, colocados lateralmente no terreno, circulação central, pilares na periferia, na pele, peitoris de concreto, o que deixava as fachadas praticamente prontas. A planta, depois de algumas tentativas, descobri que poderia fazer o terceiro quarto se abrindo para sala, com isso o prédio ficou com 7,5 m de largura, fino e elegante, com uma caixa d'água alta. Tinha o cerne do edifício da Rua Pará, era um redesenho em escala menor. Fiquei muito contente com o resultado, tinha conseguido configurar um produto que atendia às necessidades.

A legislação permitia construir quatro vezes a área do terreno, mas, tanto eu como os construtores preferimos um coeficiente menor, 2,9 vezes, assim poderíamos colocar no 
térreo algum equipamento coletivo.

Catharine Gati (CG) - O Edifício da Pará tem como característica marcante a utilização dos brises, como você resolveu o problema de orientação nos modulares?

AS - Como podíamos virar o edifício, sempre prevalecia a orientação dos dormitórios. Na sala e serviços usamos caixilho com vidro, para os dormitórios vidro e venezianas de correr que já eram feitas pela indústria, em plástico ou alumínio.

A indústria começava a produzir caixilhos com gaxetas de borracha que aproveitamos e aplicamos, sugerimos também os armários modulados.

Os banheiros eram revestidos com fórmica e as peças eram todas brancas. A exceção das áreas molhadas que tinham paredes em alvenaria, todas as outras divisões eram em painéis de gesso. O piso era cerâmico nas zonas molhadas e carpete em todo o resto. Não havia forro, lajes e vigas eram aparentes.

Interessante comparar com o que se estava construindo na mesma época, os modulares tinham a linguagem da arquitetura moderna, da escola paulista.
Quando fiz esses projetos sempre pensava que gostaria que, quando um colega meu passasse por um dos prédios, sentisse que faria a mesma coisa, que os prédios refletissem um interesse universal.

Foram executados vários prédios, mas a administração da Formaespaço passou para as mãos de pessoas que por ganância ou ignorância não entenderam a proposta e o processo. Também no canteiro tiveram muita dificuldade, mesmo sendo todas as peças retas e ortogonais, os técnicos que se ocupavam da construção eram inexperientes. Resultado: a construtora fechou.

Enquanto desenvolvia os Modulares fiz outros projetos para Formaespaço, apartamentos para moradores com menor poder aquisitivo, um conjunto habitacional em São Bernardo e o Nova Cidade em Jundiaí. Eram apartamentos de 70 m² $^{2}$ para moradores recém chegados da zona rural, com jardins de Burle Marx, espelho d'água e equipamentos comunitários.

Em Jundiaí, com prédios de três andares sobre pilotis, conseguimos uma projeção no terreno de 20 ou 22\%, sobrando praticamente $80 \%$ de área livre. É junto da linha do trem, para onde se voltam os edifícios que têm a mesma solução de estrutura e acabamento dos modulares.

As experiências com os Modulares e os conjuntos 
habitacionais para a Formaespaço formam a primeira geração de projetos. Já o Fiandeiras é a segunda geração. Aí propus uma solução universal, um pré-moldado que resolvesse a vedação de todos os ambientes.

São quatro apartamentos por andar com circulação central, cada unidade com dois quartos, poucas paredes internas, uma planta muito simpática que dá margem a vários arranjos, porque aí também usei armários para dividir os ambientes.

Acho que esses projetos não são datados, vejo neles um sentido de permanência. Samuel Szpiegel me disse: "O mais gozado é que esse seu trabalho é um clássico, não tem data".

Depois fiz os projetos para o CECAP, com grande influência do Zezinho Magalhães Prado, que tem uma planta modelo. O que fiz foi fazer um pequeno aperfeiçoamento na parte de serviço e usei a mesma planta com toda a tranqüilidade, como se estivesse me apropriando de qualquer outro elemento: uma janela, uma porta ...

Voltando à tese inicial, a saída é levar o design para o edifício. No fim 1987, fiz um projeto de desfavelamento para CDH no Jardim Calux³: 1200 habitações, 800 apartamentos e 400 casas. Os apartamentos tinham cerca de $37 \mathrm{~m}^{2}$, dois quartos sala, cozinha, banheiro e área de serviço, as casas com mesmo programa $40 \mathrm{~m}^{2}$

Há que se pensar não só os componentes da construção, mas equipamentos que sejam acoplados a esses espaços: a geladeira não pode ser a mesma, os armários a mesa. Esse tipo de edificação tem que ser totalmente repensado.

CG - Você sempre chama a atenção para o respeito ao cliente, como isso acontece nesses projetos onde o cliente é desconhecido?

AS - É nesse respeito que reconheço a arquitetura. Estudamos as referências, apresentamos soluções e é como se o seu risco não fosse só seu, mas fruto de uma experiência acumulada de arquitetura.

Você se sente fazendo parte de um processo. A sensação é muito agradável.

(1) Massayoshi Kamimura

(2) Como as de Mies van der Rohe.

(3) São Bernardo do Campo SP

\section{Registro 8 - 10 de novembro de 1988.}

Abrahão Sanovicz (AS) - O problema de nossa vida 
profissional é a falta de continuidade. Com os Modulares estávamos continuando um trabalho que começou com a experiência da Pará, mas não há reflexão sobre este caminho.

Em 1972 fui chamado pela CESP para elaborar dois projetos para as estações de piscicultura à beira das represas de Promissão e Salto Grande. Um programa exótico: grandes tanques enterrados, com diferentes dimensões para abrigar os peixes em todo seu desenvolvimento e com ventilação constante, mas controlada; a captação das águas; uma iluminação que atraísse insetos; o paisagismo que deveria prever espécies frutíferas que pudessem servir de alimento aos animais; e uma edificação para o laboratório.

Os terrenos muito grandes, com área de 300.000, $350.000 \mathrm{~m}^{2}$, era necessário, além de resolver o número de tanques a implantar, recompor a paisagem. Assim tínhamos que detalhar inclusive como a empreiteira deveria proceder para a limpeza do terreno, a organização do canteiro e a maneira de executar a obra, para minimizar as feridas na paisagem.

Catharine Gati (CG) - Fale sobre o projeto do laboratório.

AS - O mesmo projeto do laboratório foi usado nas duas estações de piscicultura, já que o programa era idêntico e muito simples: um salão com depósitos e frigoríficos; e acomodações para os biólogos.

A equipe com quem eu trabalhei nesses projetos era muito boa, assim, mesmo com um programa pouco freqüente, logo pudemos dominar totalmente o problema. Assim (brincando), bem assessorado, me tornei especialista em piscicultura.

Sempre digo que somos "especialistas gerais", não sabemos nada em profundidade, mas a responsabilidade pelo espaço construído deve ser sempre nossa. Qualquer que seja o programa, se bem apoiados por outros profissionais, temos sempre condições de, compreendendo o todo, nos assenhorarmos do problema e chegar à melhor solução.

Uma coisa gostaria de ressaltar: em Promissão a estação foi construída junto com a usina, por uma grande empreiteira, em Salto Grande, a usina era bastante antiga, foi contratada uma empreiteira menor. Os projetos foram resolvidos com os mesmos detalhes, e a diferença de execução foi muito grande, tanto que, passados alguns anos a estação de Salto Grande sofreu uma significativa reforma.

Muito me preocupa como vêm sendo executadas as construções, principalmente as contratadas pelo poder público, Se somos os responsáveis pela qualidade do espaço 
construído e não temos tido condições de alterar a maneira como vem sendo construído o patrimônio da Nação, é porque temos antes que refletir sobre o estado da nossa profissão e sobre como nossos governos têm tratado a questão.

Esta questão não se restringe à construção dos edifícios, mas se estende ao desenho das cidades, aos programas de habitação, não é um problema estético. Devemos, inclusive, discutir o significado dos investimentos do Estado, para exigir a qualidade máxima de todas as obras, o que vai exigir de nós um envolvimento muito maior na formação dos profissionais que respondam à essa exigência.

\section{Registro 9 - 29 de novembro de 1988.}

Abrahão Sanovicz (AS) - Junto com as Estações de Piscicultura fiz o prédio da Rua das Fiandeiras, depois minha casa de praia.

A casa é muito simples, poucos detalhes, praticamente um barracão, sala e cozinha integradas, três quartos com banheiros, quase sem janelas, já que o recuo lateral é sombreado por uma pérgula sobre um jardim, para onde é toda aberta. Ela não carrega para a praia os problemas da cidade.
Externamente é toda sisuda, fechada, mas quando se entra percebe-se toda aberta, o pergolado e o jardim passam a integrar tudo.

Fiz então a casa do André Mehes, no Alto de Pinheiro, o velho partido bi-nucleado: sala e quartos num bloco e serviços no outro, um redesenho da casa do Frank Gunther.

Catharine Gati (CG) - Por que você optou por este partido?

AS - Achava que a casa devia ser sala, quartos e banheiros, o serviço vai pouco a pouco saindo dela. Cheguei a pensar em colocar uma mesa quente na sala, as pessoas compram comida pronta...

CG - Nesse período, início dos anos 70 (1970), qual projeto você pode destacar como mais representativo?

AS - Foi uma época dura porque o país estava complicado, com a mentira do milagre, e que coincidiu com minha tese de doutoramento que fiz com muita dificuldade: juntei 12 projetos e falei sobre eles.

Aconteceu então de ser convidado pelo Artigas para 
trabalhar no projeto de reurbanização do Vale do Anhangabaú. Foi uma experiência incrível, porque assistia um grande arquiteto trabalhar, um homem que não procurava soluções, eles as elaborava e colocava com a naturalidade de quem vai enfrentando e trabalhando o espaço continuamente. É a interação do problema e da solução na cabeça do arquiteto.

O projeto indicava uma solução particular para o Vale, contida numa proposta maior para a cidade, ia do Rio Pinheiros ao Tietê.

A cada proposta, discutíamos os conceitos, por exemplo, como se vence o tráfego da avenida, com passarelas que então, não devem ser simples passagem, mas local de estar com isso aumenta-se a escala e o significado.

O projeto foi abandonado pelos poderes públicos. Mais tarde foi realizado um concurso público, com cujo resultado não consigo concordar: um enorme sacrifício para retirar os carros da superfície, procurando criar um lugar de encontro que nunca vai ser.

Fiz depois os projetos para o CECAP ${ }^{1}$, Serra Negra e Sumaré, que são praticamente o redesenho da experiência do Zezinho Magalhães Prado da equipe do Artigas.

Começam então, os projetos das escolas para a
CONESP2 2 A partir de 1976 fiz muitas escolas, tendo como parâmetro de projeto a sistematização de detalhes e componentes criada pelos técnicos da CONESP.

Em 1976 fiz o projeto da minha casa, é o fim de um processo. É uma caixa de concreto apoiada em 4 pilares, me lembra muito o primeiro projeto moderno que eu vi construído, a casa do Artigas na Ilha Porchat.

Ela é tudo que sempre admirei: planta livre; estrutura independente; conjugação dos espaços; pés direitos duplos; a escada uma escultura; terraços; compreensão da totalidade do espaço; implantação elevada; faz cantar os pontos de apoio. Aparece então o velho desenho: uma caixa pesadíssima que dá sensação de leveza. É toda vazada, não se sabe onde começa e onde acaba.

\section{CG - Poucas portas..}

AS - Sim, todos falam do fato de os banheiros não terem portas, mas junto aos quartos é um ambiente só. O Mario Botta faz a mesma coisa.

A solução dessa casa é muito semelhante à projetada por Figini \& Pollini, arquitetos do racionalismo italiano de 1927 na Vila dei Giornalist. 
É uma síntese, lição do estudante de arquitetura, arquiteto Abrahão Sanovicz ${ }^{3}$.

CG - É sua expressão amadurecida diante do projeto?

AS - Acho que sim, é o reconhecimento da condição de ter uma linguagem própria.

CG - O que é muito bonito, porque você, que sempre declara suas referências, passa a ser referência.

AS - Numa certa medida sim, mas aí tenho mais liberdade para recorrer a outras tantas referências. O trabalho e o processo são sempre os mesmos, mas a partir desse projeto com muito maior liberdade.

Fiz, depois, o projeto da Tecelagem Grisbi em Pirapora, Minas Gerais: em pré-moldado de concreto, uma preocupação muito especial com o clima.

Outros projetos interessantes foram o da Sede Regional do DER em Taubaté e o Centro de Farmacologia Clínica da Faculdade Paulista de Medicina, mas não foram construídos. Era 1978 e tivemos uma crise violenta, Paulo Maluf assume o governo do Estado e paralisa todas as obras.
Nesse período fiz algumas residências e o Terminal Rodoviário de Campos de Jordão, cuja construção ainda não terminaram, e alteraram bastante o projeto. $\mathrm{O}$ partido era bem interessante, mesmo tendo que obedecer à Legislação Municipal, que indica que as construções devem seguir o estilo suíço (nem na Suíça se faz mais essa arquitetura). Fiz uma série de concessões, mas o interessante foi separar o salão da gare num volume fechado, do embarque / desembarque, espaço aberto protegido por um muro de pedras.

Depois fiz outros projetos que gostaria de destacar:

- Uma casa em Itatiba para Arnaldo Goldman, triangular, com uma implantação muito simpática, uma planta com pouca área, mas com espaço grande.

- A reciclagem do Grande Hotel de Campos de Jordão.

- Residência Edgar Blucher.

- Residência Antero Aciero.

- Senac Tatuapé.

- O Terminal Turístico de Bertioga.

- Banespa Recife.

- Fórum de Bragança Paulista.

- O projeto de desfavelamento no Jardim Calux, São Bernardo do Campo. 
- O redesenho da Usina de Algodão de Aguaí.

- Dois projetos de restauro e reciclagem de lojas, em

Maceió e Recife.

(1) Caixa Estadual de Casas para o Povo

(2) Companhia de Construções Escolares do Estado de São Paulo.

(3) Referência ao título da publicação "Caderno de poesias do aluno Oswald de Andrade". 


\section{Abrahão Sanovicz a José Wolf: Uma Pedra no Caminho ... Escola Paulista}

Professor da FAU, onde se formou em 1958, Abrahão Sanovicz recorda. Certa vez, num seminário, ele também levantou a mesma questão a Lúcio Costa. Respondeu que não sabia se era escola carioca ou escola paulista, mas uma Arquitetura feita em São Paulo, outra no Rio. Vamos por aí (sugere Sanovicz); só assim podemos desmanchar alguns problemas de especificação.

Acontece o seguinte (explica): a arquitetura moderna, diria mais, contemporânea, feita em São Paulo, só acontece porque existiu uma experiência anterior feita no Rio. E é bom falar em reportagem, porque seria difícil um estudo mais introspectivo, pelo seguinte: no Brasil ainda se faz reportagem de arquitetura, não crítica; não temos essa tradição por falta, talvez, de recursos.

Voltando, então, ao início, a AU já levantou os dados da "escola carioca" ou da arquitetura feita no Rio, que se convencionou chamar de arquitetura moderna brasileira, algo que começou lá pelos anos 30, quando o Brasil começava a industrializar-se. Pode-se estar a favor ou contra, mas havia um projeto nacional capaz de criar todas as condições para esse processo. O grande maestro desse processo é, sem sombra de dúvida, Lúcio Costa. Seria difícil entender o Oscar sem ele; existe aí uma questão de precedência e uma questão de procedência. $E$ é bonito vêlos trabalhar juntos, às vezes até estremecidos. Mas, no fundo, os arquitetos dialogam através de seus projetos.Uma linguagem que pode ser do atelier, da cidade, pode ser interregional e até internacional.

Tudo isso, veja bem, acontece num período em que o mundo estava em guerra. Enquanto lá fora estavam destruindo, nós aqui estávamos construindo. E se você pegar a Arquitetura do Rio, verá: quase toda ela é feita para organismos governamentais, que começavam a criar seus espaços, suas estruturas. Como o MEC, que se tornou um prédio-padrão.

Mas, quando a gente entrou na escola, havia certo marasmo. Em 53, tinha havido o estouro do boom imobiliário, não havia trabalho. Aqui e no Rio também, tanto que tentaram trazer Niemeyer para a escola e não deixaram; depois ele foi convidado para o projeto do Parque do Ibirapuera. Nessa época, enfim, a gente procurava entender todo esse fenômeno, esse período moderno. O Katinsky e eu pedimos até para o Lúcio um roteiro, e ele apresentou três casas. Com elas, descobrimos um mundo.

Antes dessa crise (dando continuidade a seu relato), havia 
em São Paulo um conjunto de manifestações que não se pode ignorar, como o Oswaldo Bratke. O Bratke, o Rino Levi, o mais importante dessa época. Ele vem com uma tradição da escola italiana, aos poucos se transformou, inserindo-se no espaço da Arquitetura brasileira. E havia um grupo que gravitava em torno do Rino, o "Branco e Preto", com Miguel Forte, Jacob Ruchti, Ciampaglia, Croce, Aflalo, Cândia ou Milan, o mais jovem deles. Havia ainda alguns arquitetos europeus, vindos durante a Guerra, como Bernard Rudofsky, trazendo algum novo tipo de informação. O logotipo da Fotóptica, por exemplo, um símbolo bauhausiano. Havia também o Daniele Calabi, que faz algumas casas racionalistas italianas com pátio. Depois da Guerra, chegam a Lina, o Palanti. E, lutando pela organização da classe, estavam o Eduardo Kneese de Melo, Ícaro de Castro Melo, Oswaldo Correa Gonçalves, entre outros.

Esse era o panorama de nossa arquitetura, quando a gente entrou na escola.

Mas, de repente, acontecem o plano-piloto de Brasília e o surto desenvolvimentista, trazendo uma nova perspectiva. Brasília, então, é o coroamento de um processo que começou com projetos de edifícios isolados, onde se apontam certos aspectos de integração à cidade. O MEC, com sua área de projeção no térreo aberta, respeitando o espaço do pedestre. Então, a tal leveza (reflete Sanovicz) não é um problema formal, um fato estético.

Nunca a arquitetura se reduz a um fato estético, sempre traduz alguma intenção anterior, uma postura ética. O desejo de se projetar uma cidade contemporânea que já começava a se esboçar na obra desses arquitetos passa por Pampulha e se corporifica em Brasília. Ela absorve várias experiências anteriores, tem seus desdobramentos e rebate em São Paulo. Por que? Antes de Brasília, havia aqui uma produção variada, isenta de unidade, cada arquiteto procurando sua linguagem, um processo ainda em transformação.

Acontece que nessa meio-tempo se elege Carvalho Pinto. Ele prepara um Plano de Ação coordenado por Plínio Arruda Sampaio. Carvalho Pinto já tinha ido a Brasília, onde se encontrou com Juscelino, que Ihe mostrou o trabalho dos arquitetos. Ele entendeu esse fenômeno. Se quisesse ter o mesmo resultado, seria necessário usar os quadros que tinha em São Paulo. Foi uma época maravilhosa. Os arquitetos, de repente, tiveram de se preparar para um novo momento, que se iniciava com a construção de fóruns, escolas, etc.

O processo que havia acontecido no Rio ocorre, anos 
depois, em São Paulo. O Estado mostra-se o grande cliente e o trabalho fica mais ágil: em vez de você correr, com sua pastinha, capinando um projeto, era chamado para trabalhar.

E qual o desenho que se esboça, aqui?

A arquitetura feita em São Paulo é um desenho que pega essa experiência carioca e a desenvolve dentro de características regionais daqui. Ela procura seus aspectos programáticos, uma linguagem própria. E esse plano começa, via IPESP, com pedidos muito contidos para a construção de escolas. "Faça alvenaria de tijolo, tesouras de madeira, telhas de barro, no máximo, de fibrocimento". Um tipo de construção quase rural.

Mas (ressalta), no meio disso, aparece um projeto (a escola de Itanhaém), de Vilanova Artigas, abrindo certos graus de liberdade. A planta livre, as estruturas independentes, o grande vão. Uma semente? Como protótipo da arquitetura que acontece nessa época é, sem dúvida, um modelo. Ele começa, enfim, a mudar a linguagem. Sob alguns aspectos, contém influências do Museu do Reidy, no Rio. Ele coloca até uma ilustração, um painel de Francisco Brennand, um artista do Recife. O mesmo que ocorreu no MEC, quando se pegou um Portinari, um Bruno Giorgi. Há muitas semelhanças de atitudes, porém já com outra linguagem, de maior simplificação.

Em resumo, queria dizer que Artigas é um discípulo da "escola carioca", o grande discípulo de Oscar Niemeyer, no Brasil. Não no sentido de pegar aspectos formais, mas a essência, através de sua própria visão.

E como se dá essa transformação? Artigas faz uma inversão do processo, na medida em que começa a explicitar a arquitetura através de sua estrutura. Porém como meio, não fim; não se trata, portanto, de uma arquitetura do concreto.

O concreto é apenas um material à disposição. Ele começa a se explicitar através da estrutura. Tinha formação de engenheiro também, era da Póli. Ele trouxe isso mais a experiência da "escola carioca", de organização do espaço. Então, você vê essa continuidade espacial, na FAU, por exemplo. Onde começa, onde acaba?

Com sua formação filosófica, construída dentro desse "caldo cultural", sua convivência com os intelectuais, com um Mário de Andrade, Artigas regionaliza, cria uma linguagem paulista. E consegue, tanto é que a $A U$ está pesquisando isso. A partir desse projeto, abre-se uma nova perspectiva e todos os arquitetos mais jovens começam a projetar com base nele. Sua arquitetura, em termos de materiais, consegue também enxugar a experiência carioca. 
Faz-se um imóvel com pouco material, abole-se o revestimento, usa-se um piso só para todos os espaços, começa-se a usar o mínimo de tipo de caixilhos. O less is more também funcionou na simplificação dessa linguagem.

A nossa geração, enfim, pegou o bonde andando. Era uma época maravilhosa, como disse. Quando começamos a trabalhar, isso tudo já estava sistematizado, ao contrário do que aconteceu com outras gerações. Cada um de nós, dentro desse panorama, procurou absorver essa linguagem e desenvolvê-la através de seus projetos.

Vocês, então, foram discípulos de Artigas? Não, fomos seus alunos; porém, ele teve discípulos: o Sérgio Ferro, Rodrigo Lefévre, Flávio Império. O aluno absorve e continua a linguagem do mestre, enquanto o discípulo a absorve e a reelabora.

E hoje? Continuamos a andar (de bonde, diz Sanovicz, sorrindo). Cada um dentro de suas possibilidades.

Wolf, José. Uma Pedra no Caminho ... Escola Paulista in $A U$, São Paulo, n¹7, abril / maio, 1988 p. 55 e 56. 


\section{Julio Roberto Katinsky a Helena Aparecida Ayoub Silva}

Em 18 de janeiro de 2001 o Professor Doutor Julio Roberto Katinsky concedeu entrevista à Professora Helena Aparecida Ayoub Silva, com o objetivo de relatar aspectos relevantes da formação de sua geração na FAU.

Julio Katinsky (JK) - Eu preciso dar ir até o escritório do Edson Elito ${ }^{1}$, porque eu quero ver a obra mais recente do Abrahão. A obra antiga eu fiz uma parte com ele. Essa eu conheço bem, até digamos 1968/69, época que a gente estava fazendo a tese de doutorado. Mas depois, nos últimos dez anos, digamos assim, eu não acompanhei muito bem o que ele andou fazendo, de modo que eu gostaria de dar uma olhada com mais atenção. Ah! Eu falei para a Diva², e ela concordou: eu não vou fazer um trabalho sobre o Abrahão, eu vou fazer um trabalho sobre a minha geração. O Abrahão entrou porque ele era uma figura. Eu não vou fazer esse tipo de trabalho que o pessoal faz por ai. Fica exaltando a figura como se ele fosse um Michelangelo, quando na realidade ele não é. Quer dizer, fazer um negócio desse com o Oscar, que é um gênio, já é duro; imagine com o Abrahão, que é um bom arquiteto, mas guardadas as proporções, não foi um gê- nio. Mas se a gente reunir todos os arquitetos da sua geração nós podemos traçar um esboço dessa ideologia. Aliás, eu acabei de ler uma entrevista, peguei a terceira edição, a última edição do livro do Artigas, onde o Julinho Artigas acrescentou muito material inédito. E eu achei engraçado porque um pouquinho antes dele morrer, em 1984, ele falou umas coisas que ele nunca tinha falado: sobre o ataque ao movimento moderno, eu tinha me manifestado a respeito em 1987 no livro "Depoimentos de uma Geração". Artigas fala, até com mais contundência, de que no fundo o movimento moderno era atacado por ser considerado judaico e bolchevista.

Artigas sempre foi muito virulento, o pessoal do Rio foi bem mais generoso, brigou menos, desaforou muito menos.

Lembro que Artigas criticava muito o Bratke, o que era muito desagradável, porque aprendeu pra burro com o velho Oswaldo

O Bratke é um arquiteto típico de corte antigo: "eu faço a vontade do freguês"; "quer neocolonial? Eu faço".

Ele tinha um estilo moderno, mas moderado. A gente na FAU também criticava muito: às vezes a solução do projeto resultava num negócio muito liso no andar de cima, e umas pedras que a gente chamava de "canjica" em baixo, a cobertura, um telhado com uns cachorros. Esse era o estilo que ele 
fazia. Mas ele fazia qualquer um, era só pedir, mostrar na revista, que ele fazia. Quer dizer, não é o tipo de arquiteto que a Politécnica queria.

A Politécnica queria não um arquiteto em especial, queria formar com a visão do socialismo utópico francês. Quer dizer, o técnico da Politécnica é um servidor do Estado, o servidor é um cidadão, é um técnico cidadão. E eles cumpriram esse modelo na França? Depois de 1870 eles entortaram tudo, viraram reacionários, se fecharam. A defesa do Estado virou a defesa da burguesia. Mas até 1870 os engenheiros franceses eram todos socialistas. Os professores da Politécnica eram todos socialistas. Esse espírito de servir a cidade, servir o País permaneceu.

O Bratke, que se formou no Mackenzie, lá a formação é americana, formação de belas artes, é o patrão que decide, o arquiteto é somente um técnico como qualquer outro, entre os milhões de técnicos, e está lá para servir, que é a mentalidade da escola de belas artes.

Helena Aparecida Ayoub Silva (HAAS) - E a formação de vocês na FAU?

JK - Foi a do arquiteto-cidadão.
HAAS - Fica a impressão de que a FAU da tua geração é uma FAU que tinha forte ligação com o IAB.

JK - Tinha ligação com o problema da cidadania. Nós achávamos que iríamos participar de um processo no qual nós iríamos contribuir para o progresso do país. Nós evidentemente eu, o Abrahão... Nós não entramos na jogada do partidão. Tínhamos uma ligação muito forte com a arte moderna naquela época.

Acreditávamos no socialismo, que na época era uma crença geral: o mundo caminha para o socialismo, é só questão de tempo.

Queríamos transformar a sociedade brasileira, e isso vinha da Politécnica, não vinha exclusivamente, mas vinha muito da Politécnica.

A primeira maneira era contribuir para o avanço tecnológico, esse era o primeiro ponto, tanto que nós acabamos contribuindo mesmo. Por exemplo, se você pegar uma porção de obras, no início da obra do Abrahão, você vai ver que há uma especulação em torno das estruturas. Nós procurávamos sempre dar uma contribuição pessoal.

O segundo ponto importante era a necessidade de integrar a arquitetura à cidade. Então quando é um prédio só, 
um prédio em um lote, a gente resolve de maneira a ampliar os espaços urbanos, quer dizer: não contribuir para a ruacorredor, essa rua que é uma muralha, ou seja, de alguma maneira fazer com que essa rua penetre no espaço privado. Desenhar a cidade não era só fazer resolver a utopia, a cidade de 3.000.000 de habitantes, era também resolver um lote. Isso vem do Rio de Janeiro: um simples prédio muda toda uma quadra.

HAAS - Você lembra do projeto que vocês fizeram, enquanto estudantes, para representar FAU na IV Bienal?

JK - Claro! Isso aí já é superquadra de Brasília. Então, quando você recebia um terreno para fazer um projeto de um prédio, a luta era de alguma maneira caminhar nesse sentido: fazer prédio com pilotis e jardim entrando sob o prédio. Isso é típico na obra de Pedro Paulo Saraiva. O Paulo Mendes nessa coisa já não é tão impositivo, é mais paulista, mais privatista neste sentido. Nesse momento Pedro Paulo vai fazer uma série de edifícios para o Rubens Paiva e eles têm como referência o $5^{\mathrm{a}}$ Avenida.

A terceira coisa que nós tínhamos era a ligação com a vanguarda francesa. A Renina nunca me perdoou: ela era professora e nós éramos alunos, e ela se alinhava com o Realismo Socialista, aquela coisa de operários espancados na Praça da Sé, e nós dizíamos: "isso aí não é conosco", a gente estava fazendo edição do Mondrian, neoplasticismo.

Mário de Andrade criticou a arquitetura soviética na época, no Curso de Filosofia ele aproxima a arquitetura soviética da arquitetura nazista. Ficaram desesperados, o Partidão ficou desesperado, pois o Mário de Andrade era intocável para os intelectuais de esquerda. Como ele poderia aproximar o "realismo socialista" da estética nazista?

Nós éramos contra qualquer direção "a priorística" da atividade artística (lição do Mário)! Aí veio em 1956 (já tinha vindo) um informe do Kruschev condenando aquela arquitetura que a gente chamava de "Arquitetura de Bolo de Noiva", que depois vai ser valorizada pela mulher do Roberto Venturi.

O Lúcio Costa tem uma observação muito boa, muito inteligente sobre o Edifício da Universidade em Moscou, que nós nunca tínhamos percebido e ele percebeu. Ele foi à Rússia em 1963/64 e comentou que aquele prédio único era muito adequado para o clima. Já imaginou um tipo de universidade espalhada num campus, numa região onde a temperatura cai a menos $50^{\circ} \mathrm{C}$ ? Fazer tudo num só bloco é 
altamente inteligente, independentemente de toda aquela "bulostroca" que eles puseram em cima do prédio, a verdade é que aquele prédio se justifica. Num certo sentido o Minhocão tem um pouco esse espírito, é muito econômico o Minhocão.

As coisas mais ou menos caminhavam nesse sentido, e essas preocupações vão ser jogadas todas nesse projeto.

HAAS - E como essas preocupações aconteciam na FAU?

JK - Nós não tínhamos um Departamento de História, mas tínhamos já uma disciplina que primeiro foi do Lourival Gomes Machado e quando eu estava no fim do curso ficou sob a responsabilidade de Flávio Motta.

Flávio fez uma coisa muito inteligente e muito bonita, ele dava umas aulas de leitura de texto, à noite, fora do horário normal das aulas, então a gente ia à Faculdade, e ele convidava Mário Wagner para falar, então nós estávamos lendo Giedion "Espaço - Tempo e Arquitetura", claro nada mais que um capítulo ou dois.

E acho que foi um pouco com Flávio Motta que eu aprendi a ler, sempre gostei muito de ler, mas foi com Flávio que aprendi relacionar um texto com o outro. O Giedion falava muito em matemática barroca, então Flávio convidava o "Camargão"3 para falar sobre matemática, ele que era muito positivista, falava: "Que, matemática barroca? Isso não existe!" e, começávamos aí uma discussão

Ou quando ele chamou o Mario Wagner que além de economista era também sociólogo, e fez toda a amarração entre a sociedade renascentista e a perspectiva, uma coisa lindíssima.

As coisas aconteciam dessa maneira. Isso mais nossas preocupações, as colocações do Luís Saia sobre o folclore, a arquitetura popular brasileira, etc. coisas que vêm do Mário de Andrade, tanto que o cartaz do Centro de Estudos Folclóricos era um monte de losangos em vermelho e verde, me lembro bem! Era um cartaz para apresentar o Centro de Estudos Folclóricos, que tinha no centro esses losangos, arlequinal.

Estudar arquitetura para nós era viajar para Ouro Preto, Salvador e fazer slide, ninguém sabia o que era isso no Brasil, só nós em São Paulo que tínhamos o hábito de fazer slide o que possibilitou o início da slideoteca na FAU, que comprou os slides do Grêmio.

Os nossos professores, engenheiros que vieram da Politécnica, víamos todos como cientistas e ao mesmo 
tempo eles procuravam ter uma visão liberal, o mais que eles podiam, tanto que chegaram a indicar o Oscar Niemeyer, eles queriam trazer aqueles grandes arquitetos do Rio de Janeiro para dar aula na FAU; quem podou foi o "Camargão", mas também ficou muito mal visto na Universidade por causa disso. Ele deu um golpe...

Sobre este projeto lembro de algumas histórias interessantes: nós organizamos uma equipe e começamos a fazer o projeto. Da nossa equipe inicial participavam: eu, o Abrahão, o Hélio Penteado, o Heberto Lira, o Zé Caetano e o João Stroeter. Uma outra equipe se constituiu com: Lúcio Grinover, Israel Sancovski, Jaguanhara Ramos e Jerônimo Bonilha. Israel sugeriu que as equipes se juntassem assim, além de juntar forças, evitaríamos uma disputa indesejável para representar a FAU na IV Bienal. Era a "união da burguesia contra o imperialismo".

Então nós fomos consultar duas pessoas que, digamos assim, estavam meio marginalizadas na FAU: um era o Saia e o outro o Artigas, este tinha sido mandado embora para a Politécnica em 53, voltando só em 56.

O Saia nos propôs um estudo urbanístico para o bairro da Penha, aquela área que até hoje está mal ocupada. O Artigas colocou uma outra hipótese: nacionalismo em ascensão poderíamos enfrentar uma proposta para a refinaria que nem era da Petrobrás ainda era do Conselho Nacional de Pesquisa de Petróleo, que era Arthur Bernardes. Até hoje a Petrobrás é um símbolo brasileiro, imagine naquela época, era tudo!

Acatamos então a proposta do professor Artigas, e aí algumas teses foram importantes se desenvolver, digamos assim, bem característica do mundo paulista. Primeiro lugar: o conjunto habitacional tinha que ter um Centro Cívico, e quem definiu isso muito bem foi Hélio Duarte: o Centro Cívico tem que ter uma vida cultural e uma vida física, tudo misturado.

A outra coisa que foi muito importante, e nisso Abrahão deu uma grande contribuição foi a sistematização das fachadas dos edifícios. Foram feitos todos com três andares, além do pilotis, para não ter elevador.

A agente trabalhou nesse projeto com um entusiasmo louco, eu particularmente, para mim foi muito bom, eu desembaracei muito. Abrahão e eu ficamos responsáveis pelo projeto do clube náutico: todo mundo ficou impressionado, porque em vez ser um retângulo, como todos os outros, resolvemos com uma articulação de quadrados, ficou muito bonito. E nós já estávamos estudando aquela obra do Oscar. Bom, é tudo um pouco ingênuo, trabalho de estudante. 
Outra coisa muito bonita foi a maquete, foi tudo calculado, tão trabalhado: os blocos não foram pintados de branco, foram pintados num leve cor-de-rosa, porque diziam para nós que se fosse cor-de-rosa o contraste seria maior. As árvores são pregos, ficou muito bonito. A maquete foi feita pelos funcionários da FAU.

Nós ganhamos o prêmio máximo, e também aí é um outro capítulo, porque o Jacob Ruchti foi contra o nosso projeto, quem defendeu o nosso projeto foi Silvio Vasconcelos.

HAAS - Tem uma manifestação dele na ata de julgamento do concurso.

JK - Eu não sabia que ele tinha tido a coragem de enfrentar o júri. O Jacob era um cara, anticomunista, então tudo que vinha do Oscar era mal visto.

Ganhamos o prêmio máximo junto com a Universidade de Waseda e com a Faculdade de Paris, que por sinal o projeto deles tinha a mesma tese no Centro Cívico, igualzinho ao nosso. Agora Waseda, eu não me lembro o projeto. O Artigas elogiou muito o projeto de Waseda, quando fomos reclamar, "que absurdo, ganhar o prêmio 'ex- aequo' com os japoneses". Artigas respondeu: “ah, não é tanto assim, é um projeto poético".

Existe um pequeno detalhe que é importante, a Bienal seguindo orientação que acho que vinha do MoMA, fazia esses concursos de estudantes para pressionar as escolas de arquitetura, estava tudo em grande parte do mundo dominadas pelo pessoal mais acadêmico, claro! Então eles queriam mudar, aproveitavam a Bienal para fazer isso, quer dizer, quem ganhava o prêmio na Bienal era prestigiado e de fato você vê, de todos esses caras que estão aí, uma série deles virou professor.

Somos da geração do "finca-pé", nós percebemos que o combate ao movimento moderno era um combate que não era em relação aos aspectos negativos, era justamente aos aspectos positivos, e que nós tínhamos obrigação de defender essa coisa, isso foi muito claro, a minha geração furou o cerco. Aqueles arquitetos que você conhece procuraram exatamente fazer isso: defender todas aquelas teses que nós apresentamos no projeto para a refinaria.

HAAS - Como acontecia na FAU a discussão estética, por exemplo, sobre a proposta dos concretistas, do Mauricio Nogueira Lima? 
toda a população.

JK - Por que o Mauricio foi ser professor na FAU? Toda essa discussão acontecia lá. A preocupação forte do concretismo, do neoplasticismo, do estilo holandês, é exatamente essa. $\mathrm{O}$ interesse pelo mundo moderno pela adequação da estética com a ética, que domina toda a vanguarda do século da primeira guerra mundial, e que Mário de Andrade reproduz naquele texto maravilhoso dele em 1937 "O Artista e o Artesão", onde está presente toda esta problemática da ética e da estética dentro da cidade, que é o Schiller, que ele cita diretamente. Engraçado, eu tinha editado esse texto, que eu acho maravilhoso, e não tinha percebido essa ligação que ele põe explicitamente no texto: "A Educação Estética do Homem", estética no sentido da totalidade, da globalidade do ser humano e, portanto, obrigatoriamente democrático. Todo o pensamento iluminista é democrático e isso começa a ser combatido já na década de 1960. É muito esclarecedor o texto de Lucio Costa: "O Novo Humanismo Científico Tecnológico", ele vai lá no M.I.T. defender os iluministas. Quer dizer, a questão já não era mais atacar o Marx ou o Rousseau, o Diderot, e o D'Alambert, esse pessoal que fez a enciclopédia e tinha esse sentido do conhecimento universal, conhecimento democrático, conhecimento para
Nós na FAU, durante vinte anos agüentamos uma "estética atrasada", primeiro porque tinha suas referências na Belas Artes, depois pela crítica que contrapunha o projeto ao canteiro. Agora devemos recuperar essa estética da "solidariedade", mas em outra "chave", sem dogmatismos.

(1) O arquiteto Edson Elito foi, durante muitos anos, colaborador de Abrahão Sanovicz, permanecendo em seu escritório, até 2003, toda o acervo de projetos de Abrahão.

(2) Diva Sanovicz viúva de Abrahão Sanovicz.

(3) José Otávio Monteiro de Camargo. 


\section{Nachman Falbel a Helena Aparecida \\ Ayoub Silva}

Em 29 de julho de 2004, o Professor Dr. Nachman Falbel concedeu entrevista à Professora Helena Aparecida Ayoub Silva.

O Dr. Falbel é Professor Titular do Curso de História da Faculdade de Filosofia, Letras e Ciências Humanas da Universidade de São Paulo, amigo de Abrahão Sanovicz, participaram do movimento Dror na década de 1950.

Helena Aparecida Ayoub Silva (HAAS) - O que foi o movimento Dror?

Dr. Nachman Falbel (NF) - É movimento juvenil, um fenômeno muito próprio do judaísmo na Europa. Fruto de uma concepção de que a juventude constitui uma etapa em si, independente e com valores próprios. Na verdade, o que precedeu o movimento juvenil judaico foi um encontro inicial, também de jovens, na Alemanha no final do Século XIX chamado Wandervogel (pássaro errante, em alemão), que tinha como pensamento a volta à natureza, no sentido de se encontrar numa atmosfera mais limpa, não urbana, mais pura. Esses jovens tinham como slogan "A nossa falta de objetivos é a nossa força". Realmente, uma das características principais dos Wandervogel era a sua independência relativamente a qualquer organização política ou religiosa.

Essa concepção incluía um romantismo próprio, saudosista nos valores da idade média e, ao mesmo tempo, promovia a valorização da etapa da vida que se chamava juventude, como uma etapa que tem que ser vivenciada independentemente da fase adulta. Esta seria a matriz do movimento juvenil judaico que mais tarde surgiria, agregando a esses valores a problemática judaica, na medida que surge o nacionalismo judaico chamado movimento sionista.

A partir do I Congresso de 1897, com uma liderança já muito forte, começam a se destacar personalidades como Theodor Herzl reforçando o nacionalismo judaico que gerou várias correntes, porque, conceber a criação do estado judeu era um desafio do ponto de vista ideológico. Não havia nenhuma unidade nesse sentido. Havia várias posturas, várias concepções influenciadas pelas próprias ideologias da época no continente europeu. E, nesse sentido, o movimento juvenil acabou sendo na verdade ala juvenil de partidos que se constituíram a partir de correntes ideológicas e políticas, e que se formaram dentro do judaísmo, que atravessava essa 
fase de definição nacionalista na Europa. Esse fenômeno se pode entender estudando a história dos judeus no período e a partir daí é possível justificar a existência do movimento de jovens que se organiza com o padrão de Wandervogel, que antecedeu o segundo padrão, o movimento scoutico ${ }^{1}$ de Baden-Powell ${ }^{2}$. O escotismo também se preocupava com uma vida mais ligada à natureza, e, por outro lado, preparar o jovem para os desafios que estavam por vir, tendo autonomia frente aos obstáculos e às dificuldades que a vida oferece. Endurecer frente à vida, seria o termo, o que exige não só resistência espiritual, mas física.

Havia de certa forma alguma coisa muito próxima com o paramilitar, porque o movimento scoutico que teve origem inglesa, se inspirou também na experiência de Powell na guerra na África do Sul, mas formulou uma pedagogia e um sistema educativo. Então, esse fenômeno amplo, que dá o contexto para entender o movimento juvenil judaico, na medida em que os judeus se sentiram envolvidos com uma idéia nacionalista da formação de um estado próprio, após 2000 anos de exílio e diáspora.

Surge então o primeiro movimento, Hashomer Hatzair ${ }^{3}$, que significa "jovem guarda". Era inspirado diretamente nos dois paradigmas: Wandervogel e scoutico, com a mesma metodologia educativa, com a mesma organização interna, mas com uma matriz judaica, voltando-se para uma identidade religiosa nacional.

O nosso movimento, agora dando um grande salto, foi o Dror, que surgiu na Europa, no final dos anos 1920. De início, era a ala jovem do partido político sionista-socialista, isto é um nacionalismo que visava fundir duas ambições do ponto de vista político: criava o estado judeu, mas criava o estado judeu socialista.

Esse partido chamava Poalei Tsion (os operários de Sion), onde, naturalmente, a preocupação dos mais velhos era formar e preparar quadro de juvenis que estavam ligados à própria atuação do partido.

Mais tarde, os próprios jovens chegaram à conclusão de que eles deveriam criar um movimento com marca própria, seguindo uma doutrina pedagógica inspirada naquelas que conheciam do passado. Surge então o movimento Dror, também com uma sistemática próxima ao Hashomer Hatzair que o precedeu.

No Dror se adotou uma pedagogia apropriada para cada uma das diferentes faixas etárias, que começaram com meninos de sete anos até jovens entre 18 e 20 anos. A principal idéia era preparar esses jovens para irem à terra de Israel 
como membros voluntários em colônias agrícolas. Então, todo o preparo desse movimento era em função: da proletarização; tornar os jovens agricultores; e, habilitá-los a viver do trabalho próprio, criando as condições necessárias para a constituição de um futuro do estado judeu. Era a colonização.

Esse movimento de início chamou-se Freiheit, que significa liberdade em iídiche e alemão. No hebraico, o termo foi traduzido como Dror, que significa pássaro, andorinha; símbolo de liberdade.

Esse movimento surgiu em todo o mundo com as denominações bastante diferenciadas na Europa. Veio para a América do Sul nos anos 1930: na Argentina em 1934 e depois em 1945 se formou no Brasil.

Por esse movimento passaram milhares de jovens, ao lado de outros movimentos que tinham diferentes nuances ideológicas. Às vezes são sionistas-socialistas (mas o problema: que socialismo?, isto fazia muita diferença), marxistas, o nosso era filiado à social democracia, obviamente identificado com a social democracia austroalemã, a chamada II Internacional de Karl Kautsky, marxistas, mas não eram bolcheviques ou leninistas.

O Hashomer Hatzair, no decorrer do tempo, mudou de postura ideológica: começou como um movimento scoutico e foi se radicalizando e assumiu o ideário marxista leninista.

Depois, com as crises do comunismo, obviamente, eles também tiveram que se adaptar.

Este é o tipo de movimento que teve uma influência muito grande sobre a juventude judaica no Brasil, e fez com que muitos fossem viver em Israel em kibutzim, que era a sociedade representativa do sionismo socialista, para o qual o movimento educava. Eram filhos da classe média que caracterizavam muito a imigração judaica no momento em que ela se acentuou, e com isso podemos dizer que teve uma influência poderosa sobre as pessoas.

O movimento marcou profundamente mesmo aqueles que ficaram, porque, primeiro, os acontecimentos da juventude criam laços de amizade muito fortes, depois, porque era um movimento preocupado com cultura, ideologia, idéias.

Era um período decisivo para a formação do estado judeu após o holocausto, com representação ideológica muito grande e de fermentação espiritual, cultural e intelectual para os jovens que vivenciaram aqueles anos pós-guerra.

Isso deu de certa forma a esses jovens um cabedal extraordinário. Boa parte dos professores judeus saiu desses movimentos, porque era um fermento que levava a um interesse cultural muito grande, as pessoas abandonavam as 
escolas para ficarem nas bibliotecas. Isto aconteceu com o "China" 4 que era da minha geração.

HAAS - Quando Abrahão se engajou no movimento Dror?

NF - Quando veio estudar em São Paulo.

O movimento, na época, chegou ter até 1.200 membros, compreendendo várias camadas etárias, tinha um poder de atração muito forte, porque, de um lado, o impacto da guerra e o holocausto e, do outro a perspectiva da criação do estado judeu, atraíram e marcaram esses jovens que queriam dar alguma contribuição.

Foi um período formador de personalidades. Esse movimento juvenil foi a grande incubadora, nesse sentido, o "China" como nós todos, teve uma participação muito ativa no Dror, o que nos marcou profundamente.

No início da década de 1950 o movimento decidiu coletivamente que os mais velhos deveriam ir para Israel e abandonar os estudos. Foi um impacto muito doloroso, era uma verdadeira revolução na vida dos pais daqueles jovens, que tanto idealizaram a formação universitária de seus filhos. Muitos não conseguiram assumir a responsabilidade e tomar essa decisão, "China" foi um deles. Vencer a resistência dos pais e ainda superar a cultura de que "só se vence na vida com um título", foi tarefa impossível para muitos.

Mas, foi o movimento Dror que fez nascer o germe da militância político ideológica, que estava plantado no coração de todo esse pessoal. Quando o "China" decidiu ficar, passou para o movimento chamado Casa do Povo, que era nitidamente de esquerda. Coerente como sempre foi, não conseguiu mais permanecer no Dror, já que tinha tomado uma decisão pessoal e contrária à estabelecida pelo movimento.

"China" continuou a militância política porque o vírus já estava implantado. E eu acho que o movimento teve grande importância na vida dele, porque sempre foi um idealista. Tinha aquela auréola do militante permanente que ele nunca deixou de ser. Acho que esse registro é muito importante e que deve ser apontado num trabalho ligado à obra, biografia e a alma do "China".

HAAS - Como o Dror era organizado?

NF - Era organizado em camadas por faixas etárias: de 7 a 11 anos, de 11 a 14, de 14 a 17 e, de 17 a 20. Havia uma secretaria geral e diretórios locais, numa estrutura piramidal. 
Educadores desenvolviam métodos apropriados para atuar junto a cada faixa etária: realizavam excursões, acampamentos, seminários ideológicos, eventos que visavam a formação judaica, ideológica e espiritual dos jovens.

O aprendizado do hebraico, o conhecimento do folclore e da geografia da "Terra de Israel" eram meios de aglutinação desses jovens, que tinham um mesmo interesse. Através das canções e da literatura os aproximavam do novo Israel que estava nascendo.

A cultura hebraica estava se formando e esta era a maneira de preparar os jovens para viver naquele país, e, acima de tudo, fortalecer sua identidade judaica.

Já que pertenciam à segunda ou terceira geração de emigrantes, esses jovens já não falavam mais o língua dos pais, o iídiche da Europa Oriental, tinham assimilado os costumes e a cultura brasileiros. O movimento deveria oferecer todos os elementos necessários para que pudessem imigrar para Israel.

(1) Scoutico de scout, movimento escoteiro.

(2) Robert Stephenson Smyth Baden-Powell $(1857,1941)$, inglês, foi quem lançou o movimento do escotismo.

(3) Hashomer Hatzair, movimento juvenil judaico kibutziano (relativo ao kibutz, plural kibutzim; comunidade autônoma com base em trabalho agrícola ou agroindustrial, caracterizada por uma organização igualitária e democrática, obtida pela propriedade coletiva dos meios de produção) originário da Polônia, na região da Galitzia, em 1913. Em 1918, formou seu primeiro grupo destinado a emigrar para a Palestina com o objetivo de trabalhar na terra. Desde 1919, seus membros começaram a se estabelecer na terra de Israel, desempenhando um papel relevante no desenvolvimento dos kibutzim.

(4) China era como os amigos chamavam Abrahão Sanovicz. 



\section{Depoimentos e Textos}

Arquitetos de uma Geração

\section{O Croquis}

Abrahão Sanovicz

Luiz Calos Daher

A Pesquisa em Arquitetura e Urbanismo

Abrahão Sanovicz

Arnaldo Martino

José Cláudio Gomes
Por uma Crítica Arquitetônica

Pela Recuperação da Dignidade Perdida no Projeto 105

90

Pur Si Muove

O "Estado da Profissão"

108

110

O que é o Projeto

112

Cinco Décadas de Arquitetura 



\section{Arquitetos de uma Geração}

Abrahão Sanovicz

Cursamos a FAU-USP de 1954 a 1958 e agora, como observador, com alguma distância no tempo, posso afirmar que, através da Faculdade e da Universidade daqueles anos, minha geração se formou e adquiriu os elementos com os quais ela passou a atuar na vida profissional como arquitetos. A FAU era, desde a sua formação, uma escola moderna. Não foi preciso lutar como nossos colegas e vizinhos do Mackenzie (eram as duas únicas Faculdades no Estado), para termos o direito de riscar um projeto em linhas modernas. Tendo sua origem na Politécnica e montada como mais uma Faculdade na nossa Universidade, que naquela época já estava sensibilizada pelas obras de arquitetura brasileira, pode-se dizer que ela se iniciava com uma linguagem já existente. Nossa formação não vem da linha direta dos impactos do movimento europeu entre as duas guerras, hoje acervo universal. Porém, já se nutriu e profundamente, dos desenhos, dos programas, dos partidos, dos projetos e das obras executadas em nosso país pelas três gerações que nos antecederam e que continuam até hoje atuantes na produção arquitetônica, quando há projetos a fazer, bem entendido.
Porém, nada acontece tão linearmente, e passamos, as vezes, momentos difíceis. Quando ingressamos na FAU, entusiasmados com o projeto arquitetônico, cujo reconhecimento fazíamos através das revistas "Acrópole" e "Habitat", que tiveram na nossa geração uma importância muito grande (porque através delas conseguimos saber o que se estava projetando naquele momento) e estabeleceram uma espécie de diálogo muito gostoso para os arquitetos. Os arquitetos sempre dialogaram através dos seus projetos. Quando tive conhecimento dessas revistas, cursava, na época, uma escola técnica de edificações de grau médio.

Ingressamos na FAU entusiasmados e a escola ainda estava resfriada pelos acontecimentos de 1952, referentes à não contratação do arquiteto Oscar Niemeyer para a cadeira de grandes composições do $5^{\circ}$ ano. $\mathrm{O}$ ambiente era muito parado e acreditávamos, como alunos, ter de fazer algo para ajudar a tirá-la da inércia. O ano de 1954 foi de grande agitação política: o suicídio do Presidente Vargas e as suas decorrências. A partir de 55 e nos anos seguintes, através do Grêmio da FAU, fizemos uma pesquisa da obra do arquiteto Lúcio Costa, pois dizíamos: "Se tudo começou lá, vamos começar pelo princípio". Conseguimos chegar até o mestre, o que não era tão difícil assim, e modestamente ele nos deu 
não mais do que uma relação de três ou quatro projetos seus. Levantamos os mesmos e, de indicação em indicação, perguntando de um proprietário a outro, essa coisa toda, descobrimos um mundo de textos e projetos, que nosso Grêmio cedeu ao colega José Xavier, do Rio Grande do Sul, hoje professor da FAUUSP. Foi uma colaboração do nosso Grêmio ao seu livro "Sobre Arquitetura" que me parece ser a única edição que nós temos com textos completos de Lúcio Costa até Brasília. Por essa época se realizava o concurso de Brasília. A documentação sobre Brasília hoje é muito farta. Para nós, na escola, realmente foi um salto qualitativo. O grande fato era a ampliação da escala do arquiteto, isto é, desenhar uma cidade. Não era mais 1:100, 1:200, 1:50, $1: 20$, 1:1, era 1:1000, 1:2000, 1:5000 - que sei eu. Hoje, acho bom essa passagem de escala se ter dado quando éramos estudantes. Os modelos são melhor absorvidos assim, menos penosamente.

Foi com coragem, inclusive, que no ano seguinte enfrentamos a Bienal Internacional "Ex-Aequo", juntamente com mais quatro escolas. Racharam o prêmio entre quatro países. A Faculdade apresentava os frutos do seu ensino. Já havia, inclusive, experiência anterior na nossa escola. Nosso tema era um Núcleo Habitacional para 2 mil operários para a Refinaria de Cubatão, em 1957. Das quatro escolas que participavam - do Japão, da Venezuela, da França e nós - três tinham abordado assuntos de habitação ligados a Petróleo. Curioso. Mas é uma observação que fizemos na época. A biblioteca, inclusive, guarda até hoje publicação a respeito.

Falando em biblioteca, a nossa sempre foi a parte da Faculdade que mais estimamos. A escola, a nossa época, já se interessava pela caraterística e pelo desenho de objetos. Esse interesse era manifestado pelos alunos através dos concursos de capas de publicações, cartazes, e alguns modestos contatos com pequeníssimas indústrias para elaborar concursos de objetos. Isso - a mim, pessoalmente - me fez tentar uma bolsa de desenho industrial em Milão, que usufruí no segundo semestre de 1959.

São Paulo saía, por essa época, de uma violenta crise após o "boom" imobiliário de 1953.

Entusiasmado com as obras de Brasília, o Governo do Estado convocou arquitetos a colaborar num plano de ação, projetando obras - escolas principalmente - em substituição ao famigerado projeto padrão de então, cujos erros de implantação e de programas, superados, ainda hoje se pode constatar em várias regiões do nosso Estado. Essa foi uma época de forte estímulo cultural: as Bienais do Museu de Arte 
Moderna, os movimentos artísticos, em particular o movimento concreto liderado por Waldemar Cordeiro, já falecido; o Museu de Arte de São Paulo, onde entrávamos cheios de cuidado, dada a ordem ali reinante; o IAB, cuja ligação até física com a FAUUSP era fácil (bastava descer a Rua Major Sertório). Era e continua sendo fundamental essa ligação com o IAB porque temos um lugar onde podemos nos reunir. Isso foi muito bom, inclusive todo esse trabalho que a geração anterior preparou para nós, nos criou a bandeja onde a gente pudesse participar dos movimentos culturais aos quais o IAB, até hoje, continua se engajando.

Por essa época, a FAU dá um salto qualitativo: a implantação da "Reforma Artigas" em 62. É bom colocar assim em linhas gerais o que foi a "Reforma Artigas", pelo menos para aqueles que hoje são alunos das faculdades. O curso de projeto se estrutura em quatro sequências e a sequência passou a ser a unidade mínima de decisão dentro do departamento. Essas quatro sequências são as sequências de projeto, de planejamento (que reuniu Urbanismo e Paisagismo), de desenho industrial e de comunicação visual. A FAU passa a ter quatro departamentos: o de Projeto, que dizíamos ser a espinha dorsal do curso; o de História e Crítica, posteriormente História e Estética do Projeto, absorvendo o acervo do antigo Centro de Estudos Folclóricos do Grêmio da Faculdade; e os Departamento de Ciências e de Técnicas, hoje reunidos em um departamento único de Tecnologia.

Fazia-se necessário mostrar que o campo de atuação profissional estava para se ampliar e que se devia formar os quadros para enfrentar as tarefas que víamos necessárias: do objeto à cidade e à região, passando pelo edifício, suas formas de representação e informação necessárias para possibilitar uma eficiência de uso. (No que se refere ao curso de Desenho Industrial, essa experiência de 62, fizemos uma publicação dos trabalhos e ela se encontra depositada na biblioteca da FAU). O corpo docente se ampliou. A abertura de atuação significa educar vários tipos de profissional, fosse aquele que passava do geral ao particular, se assim o desejasse, fosse aquele que se fixasse num ou noutro campo, porém sem perder a visão do conjunto e perceber que sua atuação específica se insere num quadro geral. Esse projeto permanece até hoje porque os anos seguintes foram difíceis e de pouca possibilidade de atuação.

A escola sempre se nutre da atividade exercida no meio social e vice-versa. No meu caso pessoal, professor de desenho industrial, somente por volta de 1967/68 consegui 
realizar alguns projetos de equipamentos públicos para jardins de São Paulo, em colaboração com dois colegas meus, o pintor Buffoni, de formação européia, e o arquiteto Julio Katinsky. Eram cerca de 50 objetos e a gente denominava os projetos de desenho para a comunidade porque eram objetos de uso público e comum para inserir em jardins de São Paulo. Esses projetos, ainda hoje, continuam à espera de implantação. Somente poucos foram feitos. Como sempre, a gente faz uma publicação, deposita na FAU, essa coisa toda.

E vieram as cassações de 69. O nosso departamento se viu, de repente, sem a colaboração de três dos nossos melhores professores, em especial a sequência de projetos. Quero ressaltar que às vezes sucede a escola deixar de contar com a colaboração de professores que dela se afastam por motivos vários e até ocasionam renovação de quadros algumas vezes. Porém, era a primeira vez que isso acontecia dessa forma e na época, sem a visão de retorno. Foi uma violência. E daí por diante outras perdas se verificaram. Essa ausência até hoje é sentida. A escola perdeu substância e até hoje faz esforço para se reestruturar.

Os organismos chamados seqüências, aos quais eu tinha me referido como estrutura mínima, para se continuar a filo- sofia de ensino implantada em 1962, foram paulatinamente transformados em conjuntos de disciplinas com pouco poder de decisão como grupo, uma vez que a unidade mínima na Universidade de hoje é o Departamento. Em casos específicos, como o de ensino da arquitetura, o estatuto da Universidade não conseguiu ainda prever a continuidade da existência das seqüências. Tal fato, paulatinamente, foi enfraquecendo a visão de conjunto da escola, o que levou a nos concentrarmos cada vez mais nas nossas próprias disciplinas e cada um de nós na responsabilidade da condução dos nossos respectivos cursos, firmamos como meta de ensino aquilo no qual acreditamos. Razão pela qual eu assumo inteira responsabilidade pelos programas que norteiam minha atuação como professor do $3^{\circ}$ ano da disciplina de projetos. O que faz essa disciplina até hoje, é tentar estabelecer uma integração entre o projeto e a produção - essa produção entendida como produção do projeto propriamente dito, com seus elementos gráficos e escritos, orientadores da obra a ser edificada.

Por essa época surgiu na Faculdade, por razão estatuária, a necessidade de se fazer os concursos de doutoramento. Alguns de nós fizemos esse concurso para poder assumir a responsabilidade da condução de algumas disciplinas. Esses 
trabalhos estão na Biblioteca da FAU.

Entendemos que no nosso estágio atual de possibilidade da construção, esta se situa numa faixa na qual, de um lado, conta com o artesanato e as experiências de construção que passam, na maior parte das vezes, de uma para outra mão por transmissão oral do vasto repertório popular, isto é, não erudito, através dos usos e costumes; e de outro lado, do repertório industrial, quando possível - a nossa tecnologia. Durante esses anos todos fizemos os projetos que nos foi possível. Para a indústria, muito poucos; de programação visual, alguma coisa; edificações, a parcela maior. A parte de edificações foi a parcela mais significativa do trabalho de nossa geração, acredito eu, com algumas poucas incursões no urbanismo. Eu me refiro a alguns conjuntos habitacionais e, no meu caso em particular, posso até dizer que tive o privilégio, de prestar colaboração ao prof. Artigas no redesenho do Vale do Anhangabaú. Esse projeto é muito importante porque pega exatamente o centro da cidade, o eixo representativo da cidade. Foi elaborado numa faixa compreendida entre o Tietê e o Pinheiros e devolve ao Vale a sua condição original, ou seja, readquire o uso de Parque no centro da cidade. É curioso notar que esse projeto não lança mão de nenhuma desapropriação, se outros méritos não tivesse. É difícil a preservação; destruir é rapidíssimo. Vimos implosões até pela televisão.

Eu gostaria de me referir a uma experiência do início dos anos 70. Neste caso, uma experiência numa área das mais comprometidas, que foi a da especulação imobiliária. Consegui elaborar alguns projetos nos quais certa experiência de racionalização e possibilidade de posterior produção em série, aliada a um trabalho artesanal, foram elaborados. Tratava-se de levar a uma certa camada da população, usuários que não conhecíamos pessoalmente, pois eram apartamentos e casas para serem vendidos após o término da obra, aquela linguagem a que me referia anteriormente. Estas obras, boas ou más, aí estão, como tentativa de, no projeto e na produção, absorver as experiências, não só do projeto de edificação propriamente dito, mas de como o desenho industrial se funde com ela, uma vez que a pura e simples atividade de desenhar objetos para indústria, do guardanapo ao automóvel, parecem fechadas enquanto grande parte dos mesmos tiverem o seu poder de decisão numa esfera fora do nosso contexto social.

Com a preocupação de precisar melhorar a experiência acumulada, participamos da montagem do departamento de projetos da FAU-Santos, a convite de Oswaldo Gonçalves, e 
estruturamos a cadeira de mensagem. Posteriormente, a Universidade de Brasília pediu ao Katinsky e a mim que fizéssemos um trabalho sobre um curso de Programação Visual e Desenho Industrial. Isso foi publicado e lá procuramos deixar esclarecido como se dá o ato de projetar e os modelos que nós elegemos anteriormente para poder montar toda essa filosofia, fruto inclusive de nossa atividade de ensino em Santos.

Passamos tempos razoáveis e passamos tempos difíceis. Na realidade, os atuais são bem difíceis.

Acredito que somos uma geração de construtores, acredito que construímos quando estamos construindo. Quando nos falta trabalho, isso se reflete em nossas demais atividades. O processo todo e o projeto continuam aberto, à espera de realizações.

Acredito que estamos a meio caminho, até pela nossa faixa etária, e acredito que os muitos que somos hoje podem constituir a nossa força num país em que tudo está por ser projetado. Isto já ouvimos há bastante tempo e continuamos com a mesma convicção.

Eu dizia no início que nos nutríamos da experiência anterior de poucos. Trata-se de entender os processos pelos quais essa atuação se deu, com a precisão histórica necessária, e como levá-la adiante a camadas cada vez mais amplas do povo. Esses exemplos nos são muito caros. Não podemos, em hipótese alguma, nos dar ao luxo de jogá-los pela janela, pois são os modelos que mostram o que é possível e o que muitas vezes não é. Se às vezes os caminhos parecem fechados, temos que identificar suas possíveis aberturas. Não saberia dizer de outra forma. Acredito no projeto como uma das manifestações de soberania e como uma contribuição precisa ao projeto nacional, que se faz necessária. Arquitetura é um meio de vida, porém não é a própria vida.

Pergunta - Em que medida, nos dias de hoje, podemos dizer que o profissional de arquitetura está fazendo o encaminhamento de uma visão voltada para a investigação científica sistemática dentro das áreas do projeto, urbanização e planejamento regional? Quais as formas de participação neste campo?

Alguém aqui na mesa levantou o problema do que foi a investigação de planejamento feita em moldes científicos nesses 15 anos, a partir do plano Roberto Campos, e citou que tudo deu em papel pintado. É uma opinião muito 
pessoal minha, que moro aqui na cidade de São Paulo e conheço algumas regiões deste país - muito pouco passou do papel pintado. Na realidade, o que temos visto na nossa cidade não passa de engenharia municipal. Os traçados das ruas, das avenidas ligando vários extremos, o desenho do metrô que tem descaracterizado a nossa cidade. Isto não me parece ser uma investigação científica, mas um trabalho anticientífico, na medida em que passamos por uma certa região e, dois meses depois, meu Deus do Céu, a arrasaram. Eu tinha colocado, em referência ao trabalho do Anhangabaú, essa preocupação em se preservar o que é a memória da cidade, que nesse sentido até se pode preservar, chamar de científico, contra essa desurbanização. Por outro lado, voltando um pouco à referência aos modelos, nós podemos chamar no nosso caso, de desenho urbano, de urbanismo. No que se refere ao desenho urbano, temos visto muito pouca coisa. Nos últimos 15 anos, em matéria de desenho urbano, o que me chama ainda mais a atenção como significado, como forma de resolver e como programa é, a cidade de Brasília e, mais recentemente, a continuação do projeto do Rio de Janeiro em que se considera Copacabana e toda zona norte como dado existente e se mostra a expansão da cidade para a região da baía de Sernambetiba.
Parece-me que qualquer tentativa de desenho urbano nesse sentido terá que lançar mão, desde que se trate de desenho, ainda desses modelos.

Outros realmente não me chamam tanto a atenção talvez até por desconhecer sua importância. Faço, nesse sentido, uma distinção entre a investigação científica, de um lado, e o desenho urbano do arquiteto, do outro.

INSTITUTO DE AROUITETOS DO BRASIL, DEPARTAMENTO DE SÃO PAULO. Arquitetura e desenvolvimento nacional depoimentos de arquitetos paulistas. São Paulo: IAB SP, 1979, p. 57 a 59 


\section{O Croquis}

Exposição realizada no Museu Lasar Segall - 1984
O primeiro risco é sempre fruto da intuição.

Pode demorar bastante tempo para aparecer. Pode ser rápida gestação.

Projetado este primeiro esboço num papel, me torno observador do que está desenhado.

É menos penoso do que observá-lo dentro de minha cabeça.

Como analista atento, passo a reconhecer o que propus.

Faço perguntas a este tosco croquis.

Quanto mais completas são as respostas mais me convenço da exatidão da proposta.

É um processo de indagações e solução emergentes, até um ponto no qual o projeto adquire vida própria

Ele como que ordena as soluções necessárias para seu aperfeiçoamento.

A partir de então, sobra tempo para identificar quais projetos e situações anteriores me induziram a determinada solução.

O fato artístico / intuitivo é reconhecido e então explicitado.

SANOVICZ, Abrahão. S / Tit. In ASSOCIAÇÃO MUSEU LASAR SEGALL. A linguagem do arquiteto: o croquis. São Paulo: Museu Lasar Segall, 1984. 


\section{Sobre o Desejo - Digo, o Desenho - do Arquiteto}

Luiz Calos Daher

Além do desenho técnico, informando ao mestre-de-obra as dimensões e disposição dos materiais a serem empregados, o arquiteto utiliza vários instrumentos de representação do seu projeto. Um exemplo banal é o chamado desenho de apresentação, com o qual exibe ao cliente o aspecto geral da obra que pretende realizar. Menos persuasivo, existe o desenho em esboços didáticos, no qual o arquiteto representa as opções desenvolvidas ao resolver o programa de necessidades. Há quem registre, nesses desenhos ligeiros, inclusive as soluções não aproveitadas, caso notório de Oscar Niemeyer. E também há quem prefira explicar seus projetos com 'cortes' e 'plantas' esquemáticos.

Há também um tipo notável de desenho de observação, vez por outra necessário para compreender um sítio ou uma obra já existente, onde se prevê uma reforma, uma restauração, ou mesmo um projeto novo. Então o arquiteto inicia por um desenho de apresentação sensível dos espaços dados, arranjando sua sensibilidade para a intervenção. Mesmo certas maquetes, simples, feitas com papel e cartolina sobre a prancheta, no momento em que a equipe do arquiteto discute uma alternativa, podem ser consideradas desenhos de configuração do espaço desejado. Um modo de prefigurar.

\section{2}

Mas não se trata de estabelecer uma tipologia rigorosa desses saberes do arquiteto (mas que dele: da imaginação humana). O que se pretende é observar a germinação do tipo mais instigante de desenho, aquele que nasce do diálogo do arquiteto (sozinho ou em equipe) com o programa de necessidades para a criação de um novo espaço. Lançados os dados do problema arquitetônico, como é gerado o projeto?

Sabemos que na cumplicidade da imaginação com a mão que corre no papel manteiga, há um momento específico do pensamento. As formas iniciais surgem tateantes, o esboço fica mais forte quando o arquiteto escreve pequenos números, imprime no desenho indicações sobre a escala, as proporções daqueles rabiscos misteriosos. Minto: misteriosos para o leigo, porque para o autor são sinais que estavam apenas adormecidos à espera da sua hora. Assim parece quando o arquiteto consegue retirá-los do silêncio, num processo tranqüilo, ou sofrido ou prazeroso. 
O esboço poderá crescer lenta ou rapidamente, definir-se compacto ou em formas distribuídas. Mas assim que a imagem lançada no papel se torna significativa, parece induzir a um movimento pendular, qualquer coisa de "equilíbrio instável permanente", se a expressão não for pedante ou pseudo-científica. Porque por um lado o esboço multiplica seus contornos: raramente é possível abarcar de imediato a multiplicidade de funções imposta pelo programa de necessidades. Mas por outro lado, o trabalhador da imagem deverá retornar ao esboço inicial para manter a relação dos detalhes com o todo: a satisfação das necessidades contingentes não pode prejudicar a integridade e a percepção primeira da imagem.

O retorno ao esboço aos novos espaços imaginados; e esta modificação por seu turno sugere novos contornos... o processo é inesgotável, enquanto o arquiteto não disser: - eis a imagem que importa materializar.

Será tudo isso um momento da vida das formas, articulação incessante de estruturas multiplicadas e sintetizadas, encaminhada pela necessidade de ampliar os espaços: o espaço real, espaço imaginário, espaço social. Se seu trabalho frutificar no meio competitivo do mercado capitalista, o arquiteto verá nessas imagens realizadas uma continuidade de intenções e experiências. Poderá contemplar uma imagem como previsão em relação à outra.

Deve haver, certamente, quem descreva melhor esse pensamento arquitetônico, no qual a lógica verbal interfere de forma ainda pouco esclarecida. Quando se observa o esboço vê-se a passagem do indeterminado para o determinado, do desejado pelo cliente para o desejado por ele e pelo arquiteto. Ambos têm papeis representativos na sociedade onde o projeto aparece. Extrapolando, o esboço mostra aquilo que uma sociedade formula no plano afetivo e intelectual; como Fernando Pessoa, o arquiteto pode dizer: "o que está em mim está pensando".

\section{3}

Bem que se vê que o arquiteto não desenha sozinho porque não deseja sozinho. Não pode desenhar a partir de nada, não é miniatura de Deus. Antes que o lápis desça sobre o papel manteiga, já a evolução da ciência doou seus constrangimentos; a lei da gravidade, os materiais disponíveis e o orçamento possível são limites certos à fantasia. O triunfo é relativo: "O privilégio único da arquitetura, entre todas as artes, quer ela construa residências, igrejas ou embarcações, não é abrigar um espaço vazio conveniente e rodeá-lo de 
garantias, mas construir um mundo interior com espaço e luz determinados segundo as leis de uma geometria, de uma mecânica e de uma ótica que estão contidas, necessariamente, na ordem natural, mas com a qual a natureza não faz nada", diz Henri Focillon.

Na sociedade também lavra o desejo do privilégio, que ocupará seu espaço entre o esboço e a obra construída. O desenho "de execução" transmite informações para procedimentos de produção da obra, mas junto carrega a hierarquização do trabalho no canteiro. Levando em conta a divisão social do trabalho, esses desenhos são muitos: os desenhos técnicos do concreto, os desenhos com as indicações das instalações elétricas e hidráulicas, os desenhos com pormenores das vedações, das aberturas, dos equipamentos e revestimentos. Em situações excepcionais, a divisão do trabalho tende a diminuir. Por exemplo: a alvenaria armada dispensa a carpintaria e a armação do concreto, visto que a ferragem é arrumada pelo próprio pedreiro nos vazios dos blocos. Mas a tendência predominante é pela especialização das tarefas, ainda quando a maior parte dos componentes da construção se industrializa.

Nas construções pequenas, é possível constituir relações de trabalho amenas, porque as encomendas são mais pes- soais e os prazos mais elásticos. Lembraríamos várias residências construídas com cerca de meia dúzia de folhas de desenhos de execução, e número semelhante de operários. Mas nas construções maiores, os prazos rigorosamente ditados pelo mercado e a organização "racional" do trabalho (às vezes socialmente irracional) favorecem o anonimato da produção e o distanciamento dos produtores da significação dos seus gestos. Estranhamento. Tanto quanto se sabe, a reversão desse processo é uma tarefa de economia política, não exclusiva de economistas e políticos, e vem sendo possível nos países onde se visualiza um avanço nas relações de trabalho. Portanto, é inútil cobrar a conta em endereço errado, atribuindo aos arquitetos uma suposta cumplicidade com a geometrização opressiva nos canteiros. Quanto mais não fosse, porque a eles não interessaria desvalorizar os materializadores dos seus esboços. Não deve ser por acaso que a Comissão Julgadora da Premiação Anual do IAB / SP (Instituto dos Arquitetos do Brasil, seção São Paulo), agora em 1983, premiou dois jovens arquitetos (José Mario e Afonso Rizzi Jr.) cuja obra desempenha uma apropriação amorosa da experiência dos pedreiros no canteiro de obras. Os arquitetos, como todos os artistas, desejam agradar à mente e aos sentidos. E a má apropriação de qualquer trabalho nos 
湆 traz uma impressão prévia de desagrado, como lembrou ¿ Manoel Querino ao querido Flavio Motta.

DAHER, Luiz Carlos. Sobre o Desejo - Digo, o Desenho - do Arquiteto. In ASSOCIAÇÃO MUSEU LASAR SEGALL. A linguagem do arquiteto: 0 croquis. São Paulo: Museu Lasar Segall, 1984. 


\section{A Pesquisa em Arquitetura e Urbanismo}

Seminário realizado na FAUUSP - 1990

\section{A Pesquisa na Área de Projeto}

Abrahão Sanovicz

Em nosso país, temos de educar a todos, o tempo todo, para conquistar o direito de fazer um projeto. Projetar, hoje, é uma aventura.

Talvez nunca tenhamos discutido em profundidade o projeto como pesquisa

É um problema que ao final das contas, volta e meia surge nas faculdades e na cabeça dos arquitetos.

No momento, uma boa parte de nossas pranchetas estão desativadas, ou brancas. E isto é mau para o país. Na medida em que estamos trabalhando e que nossas pranchetas estão ocupadas, cada traço que fazemos significa trabalho para bastante gente. São os materiais que se usa, é a mão-de-obra empregada, o transporte necessário, a indústria ativada, coisas assim. Nosso trabalho é de ponta. Quando desenhamos dois traços, isto ativa toda uma população. É necessária a consciência do desdobramento dos mesmos. É um dos aspectos do nosso trabalho.
Por outro lado, projetos, uma vez construídos, são usufruídos pelas pessoas que os construíram, ou outras. $\mathrm{Na}$ maior parte das vezes, outras..

A partir da obra construída, pode ser feita a leitura de quais foram as condicionantes ideológicas que nos levaram a configurá-la. (Houve época quando dizíamos, condicionantes estéticas, filosóficas, sociológicas e essa coisa toda). Como artistas, intérpretes do contorno social, nós as traduzimos em espaços a serem construídos e tudo isso que estamos dizendo com palavras bonitas são os frutos dos mencionados traços.

Fazemos uma abstração para ser construída cem, duzentas vezes maior. É como se organiza a nossa cabeça. Se a organizamos bem, nossa formação está de parabéns; se há alguma falha neste sentido, tem de ser revista (a nossa formação ou a nossa cabeça).

Após a obra construída, passeamos no seu entorno, a apreciamos e dizemos: Que queríamos fazer aqui? Queríamos que as pessoas quando passassem sob esta passarela sentissem a referência daquela antiga entrada de estação. É como se disséssemos: "Isto tem passado, tem presente, tem futuro" - só para exemplificar. ${ }^{1}$

O que é o ato de projetar? 
É uma atividade tão criadora como qualquer outra atividade humana. Não tem nada de especial nem de excelso e se insere junto com as demais no processo vital, tendo algumas características específicas.

Cada vez que somos solicitados a resolver algum programa e temos de lançar os primeiros esboços no papel, o que fazemos? Procuramos montar algumas relações no cérebro. Para montá-las, contamos com certo estado de préconsciência do projeto. Elaborado neste estado e por um mecanismo próprio do cérebro, que é comum a todas as pessoas, ele atinge o estado da consciência. Rapidamente, pegamos um papel e um lápis e lançamos um pequeno esboço. Conhecemos bem o gesto simples de uma cruz que define uma cidade e que hoje é uma capital.

É muito difícil sermos observadores daquilo que estamos pensando e que ainda permanece no estado da préconsciência.

Porém na medida em que lançamos o esboço no papel, começamos a fazer perguntas para o mesmo, procurando respostas aos problemas propostos. Na medida em que essas respostas atendem aos nossos desejos, paulatinamente temos a certeza daquele nosso primeiro ato intuitivo: se as respostas vierem certas, estamos atingindo nosso objetivo; se as respostas não vierem, ou a pergunta está errada, ou o projeto precisa ser corrigido.

A partir da certeza que aqueles traços interpretam o projeto que nós tínhamos - interpretam um determinado acontecimento social a ser configurado no espaço, ancorado ou não - podemos então ampliar as escalas do projeto e usarmos todas as técnicas que conhecemos.

$\mathrm{O}$ ato de projetar (a passagem do estado da préconsciência para o estado da consciência do projeto) é por demais conhecido.

O projeto (resultado deste processo) é desconhecido, é a pesquisa.

Cada vez que nos encomendam um projeto, ficamos curiosos para saber o que vai surgir de nossas cabeças. Na distância do tempo e com o projeto já elaborado, dizemos: "É assim que pensávamos o uso deste espaço?". Fazemos a leitura do projeto e descobrimos alguns avanços, ou alguns recuos. Mas podemos descobrir outras coisas interessantes.

Projetar é sempre um ato individual, sempre alguém dá o partido do projeto e o seu desenvolvimento é um ato coletivo.

Como observadores percebemos as condicionantes anteriores e as informações que nos sensibilizaram e 
reconhecemos este ato individual, fruto de um pensamento coletivo, pois, em cada geração os projetos se assemelham.

Esse processo é comum a todos nós. O método para usar este mecanismo, cada um de nós tem o seu, porém, a pesquisa, efetivamente, está na configuração do projeto. Sendo pesquisa, não significa excepcionalidade, ao contrário, à medida que mais arquitetos se formam a atividade torna-se "democratizada": há um avanço, pela quantidade de arquitetos atuantes.

O movimento moderno tentou colocar um mundo novo e os projetos eram diferenciados. O esforço deles era muito maior e foram panfletários, inclusive. Porém, toda essa linguagem já esta assimilada e trata-se de ir à frente.

Pode-se avançar, como em outros ramos do conhecimento, desde que se reconheça o objeto do nosso trabalho - o projeto.

Assim sendo, é uma pesquisa e dela podemos tirar algumas conclusões. Uma pesquisa não é uma atividade diferenciada, mas sim pequenas partes que configuram o todo. É necessário desmistificar o desejo que temos em relação a este projeto, colocá-lo na sua justa medida e, repito, "democraticamente" ao lado das outras atividades humanas. Do contrário, vamos repetir o que alguns de nós fizemos até agora: tentamos fazer uma interpretação econômica, sem sermos economistas, tentamos fazer uma interpretação sociológica, sem sermos sociólogos, e assim por diante.

Temos que fazer a interpretação do projeto como arquitetos, e ao fazer sua leitura, o reconhecermos

(1) Exemplo destacado de um projeto do arquiteto João Valente, por ocasião da apreciação de sua dissertação de mestrado "Arquitetura e espaço Urbano", sendo orientador o Prof. Gian Carlo Gasperini.

SANOVICZ, Abrahão. A pesquisa na área de projeto. In SEMINÁRIO NATUREZA E PRIORIDADES DE PESQUISA EM ARQUITETURA E URBANISMO, São Paulo. Anais ... São Paulo, FAUUSP, 1990, p 109 a 111 (Texto elaborado, originalmente, como base para discussão no Grupo de Disciplinas de Projeto de Edificações, 1985). 


\section{Pesquisa Enquanto Projeto \\ Arnaldo Martino}

A pesquisa na Universidade formou-se e estabeleceu larga tradição e sistematização metodológica na área das ciências, onde os processos do desenvolvimento do conhecimento apoiam-se no método científico, na racionalidade, na lógica, na correlação entre causa e efeito.

$\mathrm{Na}$ arquitetura e no seu projeto, co-existem componentes científicos e artísticos e no estudo visando o seu desenvolvimento deverão co-existir diferentes formas de pesquisa.

Algumas destas formas de pesquisa, apoiadas mesmo na metodologia científica, tem contribuído para o aprimoramento da arquitetura e do seu ensino e realizadas com alto valor acadêmico.

Trataremos aqui de uma forma específica de pesquisa em arquitetura relacionada à ação do projeto.

\section{O Projeto como Processo de Descoberta de Conhecimento}

Ressalva-se que não se trata de qualquer projeto, ou ao seu significado restrito de representação projetiva de algo a ser construído, mas aquele projeto realizado como instru- mento de descoberta e vanguarda da produção cultural.

O termo projetar contém dois sentidos co-relacionados: Aquele ligado ao desígnio, ao intento e aquele de "atirar adiante", ou seja, lançar à frente novas idéias e soluções.

Pesquisa define-se como o conjunto de atividades que tem por finalidade a descoberta de conhecimentos novos, no domínio científico ou artístico.

O projeto elaborado com intenção criadora, percorre em seu caminho a indagação, o questionamento, o entendimento, a escolha, a proposta e a formalização das idéias enquanto expressão artística.

Estes caminhos embora pautados por sistematizados metodologias, envolvem grande número de dados e de novas situações e tem seus percursos dificilmente repetidos. Cada caso, cada projeto em arquitetura pode revelar-se um fato novo. A ação de projetar, a obra realizada, geram novos conhecimentos, que se acumulam como experiência e base para outros projetos.

Então, o projeto assim desenvolvido, isto é, que simultaneamente ao objetivo da obra, tem por finalidade a descoberta de novos conhecimentos e, enquanto processo (contínuo, plural, etc.) em arquitetura, deveria ser compreendido como uma das suas formas mais importantes 
e legítimas de pesquisa.

\section{A Arquitetura Enquanto Arte}

Define-se arquitetura como a arte de conceber e realizar (construir) os espaços edificados.

O objetivo da arquitetura é inventar os espaços para as atividades do homem: lugar, equipamento e abrigo adequados e belos.

Abrange todas as escalas destes espaços, do pequeno componente ao urbano.

$\mathrm{Na}$ concepção e apreciação da arquitetura simultaneamente intervêm: a finalidade (utilidade); a técnica e a estética. E porque ela não se restringe a exigências de ordem tecnológica ou programática, mas tem permanente compromisso com a procura da beleza, é uma arte.

A pesquisa enquanto projeto em arquitetura entendida como arte, necessita de outros métodos além do científico, porque as idéias, a concepção artística não podem limitar-se pela lógica linear e racional.

Não deve existir em arte uma teoria que preceda ou subjugue a prática (estas foram fórmulas do acadêmico e do totalitarismo).

A pesquisa voltada para a produção da arte está na própria experimentação da criação. Para tanto, a liberdade sempre será condição fundamental.

Os processos de criação inventam as soluções, as teorias tentam explicá-las (e são úteis no sentido de ampliar socialmente a sua compreensão).

As referências da arquitetura: o belo, o ideário, a técnica, são parâmetros dinâmicos, cujos conceitos, modelos e conhecimentos estão permanentemente se modificando. Portanto a pesquisa em projeto é condição essencial e intrínseca à idéia de contemporaneidade ou modernidade em arquitetura.

Admitindo-se que o projeto de arquitetura elaborado com o objetivo de descobrir novos caminhos e conhecimentos é uma das formas válidas da pesquisa em arquitetura, deve-se elaborar uma sistematização de sua apresentação como trabalho Universitário, ou seja, estas pesquisas centradas no projeto devem ser formalizadas em uma sistemática da exposição dos seus processos e resultados, explicitando as condições, as metodologias e reflexões que levaram às propostas apresentadas.

Desta forma se ampliará a sua compreensão e será mais facilmente possível somar as suas experiências ao trabalho coletivo de criação, tão importante em arquitetura. 


\section{O Projeto Enquanto Processo e Enquanto Proposta}

Ao projeto é inerente a proposta e pela qualidade e originalidade destas propostas um projeto pode vir a configurar-se como uma tese. Assim, o projeto enquanto processo pode estruturar-se como pesquisa. O projeto enquanto proposta original, defendida e comprovada pode constituir-se em uma tese.

A pesquisa em projeto em nosso meio, já ocorre no trabalho profissional de projetos cotidianamente realizados, cujos objetivos extrapolam à obra na medida que são de altíssimo valor artístico, técnico e cultural e têm contribuído com a sua experiência ao estudo e ao desenvolvimento da nossa arquitetura.

Estes trabalhos porém, tem ocorrido a maior parte das vezes de maneira individual e isolada e de difícil divulgação e assimilação pela coletividade. Cabe à Universidade superar estas deficiências, incorporando, documentando e divulgando estes trabalhos de reconhecido valor.

\section{Um Centro de Pesquisa em Projetos de Arquitetura}

A consciência da importância da pesquisa enquanto projeto e o volume da produção desenvolvida tornarão imprescindível a criação de um laboratório de projetos espaço adequado ao desenvolvimento deste estudos como parte integrante da FAU.

O Centro de Pesquisa em Projetos ensejará um trabalho interdisciplinar e de equipe de docentes e pesquisadores, com a participação de alunos como estagiários, e será dedicado à prestação de serviços à comunidade e à pesquisa pura, na forma de projetos experimentais e modernizadores, voltados ao desenvolvimento da Arquitetura e do Urbanismo.

Conclusão:

Ressalvado o valor das outras formar de pesquisa em Arquitetura, aqui procuramos desenvolver o conceito de pesquisa enquanto projeto, cuja importância vale agora relevar, pois faz parte da produção dos arquitetos professores e profissionais envolvidos com o ensino e a pesquisa na FAU, e cuja experiência desejamos sistematicamente integrada ao processo Universitário.

MARTINO, Arnaldo. Pesquisa enquanto projeto. Texto inédito elaborado como base para discussão no Grupo de Disciplinas de Projeto de Edificações, 1985 


\section{A Pesquisa no Projeto de Arquitetura e Urbanismo: Sete Paradigmas}

José Cláudio Gomes

Je ne cherche, je trouve.

Picasso

1

Do objeto da pesquisa no projeto.

O objeto é o projeto. Isto é: o operar artístico. O fazer de arte. Nem é a reflexão "sobre" o projeto, ou "a respeito" do projeto, mas a própria, fabricação de algo que, ao se constituir, reflete sobre o objeto constituído: sobre o projeto. Portanto, o objeto da pesquisa em projeto não pode ser algo que lhe seja externo ao próprio ato projetual (à sociologia do projeto, por exemplo, ou à economia política do projeto, etc.).

Além do mais, como o projeto ainda não é a coisa feita, o objeto construído, a obra realizada, mas apenas determinações enviadas ao canteiro para que o objeto se cumpra de acordo com o especificado, isto é, como o projeto é um simulacro da obra construída segue-se que a tarefa de pes- quisa em projeto é a de investigação das suas determinações internas, dos mecanismos internos ao próprio ato projetual. Assim, o objeto da pesquisa na área do projeto de arquitetura e urbanismo é a investigação dos elementos constitutivos do projeto, da forma como eles se articulam para, em determinadas situações específicas, constituírem o modelo a ser realizado na obra. $\mathrm{E}$, finalmente, o objeto da pesquisa em projeto é a indagação que o pesquisador remete, permanente, ao projeto e cuja resposta alimenta novas perguntas estabelecendo-se assim, um dialogo sem fim.

\section{2}

Da natureza da pesquisa em projeto

Mas este diálogo entre pesquisador e projeto é, permanentemente, atravessado por todo o tipo de indagações do saber humano, pelas ciências do homem, da natureza, da vida, desde que respondidas dentro do universo da arte.

A natureza da pesquisa em projeto de arquitetura não é interdisciplinar como comumente se afirma. É pesquisa especificamente disciplinar ente ao universo de um saber singular: do saber artístico. Os saberes parcelares não constituem um novo saber, por hipótese "interdisciplinar", mas são 
simples peças da carpintaria - artesanato - do obrar artístico.

Assim, a pesquisa em projeto de arquitetura pode se va-

ler, ou não, pode convocar ou prescindir de saberes alheios e estranhos à fabricação artística do projeto, cuja natureza é sempre maior, ou menor, do que o conjunto do diversos saberes parcelares.

\section{3}

Do método da pesquisa

A natureza do objeto da pesquisa determina o seu método próprio de investigação . A pesquisa em arte nunca é direta e linear. Resultado de múltiplas determinações, o seu método é incerto, empírico, exploratório, errático tateante. Procede por aproximações e envolvimentos. Vai da análise à síntese e volta à analise. Mas pode partir de uma "iluminação" (Benjamim) e daí organizar uma (ou várias) linhas de análise. E, nem por isso é menos rigoroso e exato que o método da ciência.

Além do mais o método em projeto de arquitetura não é genérico, aplicável a todo e qualquer pesquisador. É procedimento individual, privado e particular na medida que cuida do singular e do especifico. Ele se faz e refaz a cada inves- tida que o pesquisador opera para desvelar o real.

Em termos de procedimento metodológico é sempre mais prudente deixar que ele flua do problema especifico que obsessiona o pesquisador colocando o método como conseqüência do objetivo a ser alcançado do que o contrário. Pois método é "caminho" a percorrer para se atingir um "objetivo".

Da linguagem da pesquisa

Como a linguagem do projeto é a linguagem não verbal, icônica, segue-se que a linguagem da pesquisa em projeto é a linguagem do discurso visual, não verbal. O que não quer dizer que não se possa usar do discurso verbal, ou mesmo, do discurso verbo-visual, mas que a linguagem privilegiada, enquanto comunicação preferencial da informação, é a do discurso icônico que se vale, se e quando necessário, de outras linguagem acessorias que venham esclarecer, reforçar ou iluminar um discurso cuja matriz é visual. 
5

\section{Da pesquisa e do ensino}

O objeto, a natureza e os objetivos da pesquisa e do ensino são diversos.

A pesquisa busca, fundamentalmente, a produção de conhecimento novo, enquanto o ensino busca a transmissão para o aluno do conhecimento já elaborado. Além disto, institucionalmente, pesquisa e ensino têm tempos e ritmos diferentes: o ensino se pauta por horários, cronogramas, "timings" e sequenciamentos de complexidades crescentes, ao passo que a pesquisa se pauta por tempos e ritmos sujeitos a imprevistos e vicissitudes dificilmente programáveis.

Respeitadas estas especificidades da pesquisa e do ensino de projeto de arquitetura será sempre possível algum tipo de aproximação entre ambas atividades. Aproximação em termos de informação e de intercâmbio de noticias entre o universo do ensino e o da pesquisa, através do estabelecimento de sessões programadas, seminários, encontros, etc.

6

\section{Da pesquisa e da instituição}

Deverá a pesquisa em projeto estar, necessária e obri- gatoriamente, subordinada à instituição de ensino (Universidade) ou pesquisa (Centro de Pesquisa)? Será indispensável à produção de pesquisa em projeto de arquitetura a sua inserção no interior do universo acadêmico? É este universo o único, ou mais adequado, espaço para a produção de pesquisa em projeto de arquitetura? Em que medida pesquisas em arquitetura se desenvolveram, historicamente, fora dos quadros da Universidade ou dos Centros de Pesquisa institucionalizados? Em que medida será conveniente investigar-se formas e espaços alternativos para produção de pesquisa em projeto de arquitetura? Qual o real incentivo que a Universidade, enquanto instituição, traz à prática da produção de pesquisa em projeto?

\section{7}

\section{Da pesquisa e do exercício profissional}

O exercício profissional em projeto de arquitetura é o instante por excelência do envolvimento total do profissional com o real. Só por isto esta prática poderá qualificar a atividade de pesquisa inserindo-a, permanentemente, no real dos problemas sociais. Mesmo historicamente, ou principalmente, numa visada histórica, a teoria e a prática do 
ensino Universitário só pode encontrar o "material" de ensino no chão da realidade social e da prática profissional que lhe é conexa. Isto é: o trabalho do profissional de projeto é, historicamente, queiramos ou não, gostemos ou não, o "material", a "base", o "fundamento" para o ensino do projeto de arquitetura nas Instituições Universitárias.

Como conseqüência, não poderia a articulação pesquisa - profissão ser reformulada em novas bases?

GOMES, José Cláudio. "A pesquisa no projeto de arquitetura e urbanismo: sete paradigmas". In SEMINÁRIO NATUREZA E PRIORIDADES DE PESQUISA EM ARQUITETURA E URBANISMO, São Paulo. Anais ... São Paulo, FAUUSP, 1990, p. 29 e 30. 


\section{Por uma Crítica Arquitetônica}

\section{Pela Recuperação da Dignidade Perdida no}

\section{Projeto}

Abrahão Sanovicz

Curioso como a branca escuridão das pranchetas (ou como quiserem, a substituição dos "layers" de arquitetura por joguinhos de computador como passatempo), nos obriga a fazer um corte e projetar um painel da produção arquitetônica - mais desenho arquitetônico do que arquitetura, mercadologia ao invés de qualidade do espaço construído e menos riqueza programática.

"Eta" ofício complicado - um dia se acerta a mão, no outro não. Há sempre uma senoidal na produção global do arquiteto. Daí ao se analisar uma obra isolada de uma produção, resulta sempre uma conclusão parcial.

É curioso como tendo projetado tanto somos profissionais de um projeto só, embora haja aparente diversidade entre eles. Cada um trabalha no universo que conhece, o que mais gosta ou com qual melhor se identifica - este é o meu universo.

Houve uma perda de qualidade de arquitetura a partir do pós-guerra. O movimento pós-moderno surgiu no final dos anos 50, na Europa, como uma premonição do desequilíbrio deste violento final de século.

Com a perda gradual de qualidade de vida houve igualmente uma perda de qualidade no projeto. A diferença entre um país uniformemente pobre, porém de uma pobreza digna (se é que se pode chamar a pobreza de digna), e um país com enormes bolsões de miséria, é que no segundo caso não há desenho que resista, por mais belo que seja.

Ao fazermos um projeto, a passagem do estado de préconsciência para o estado da consciência é o momento da nossa contribuição pessoal. O antes e o após são informações, experiências, técnicas e tecnologias à disposição.

Logo, a crítica arquitetônica dando por reconhecidas as condicionantes visuais (o que se vê), aparelhada com sua linguagem impressionista, deve mergulhar fundo no espaço orgânico delimitado pelos contornos do projeto e suas referências, verificar se há uma correspondência humanística (palavra gasta mas de significado...), ir em frente, acreditar no progresso do tecido social, de suas possibilidades, eis o cerne da arquitetura a analisar. É a ótica do que chamamos bom desenho e necessita de grande esforço de expansão, pois trabalhamos ainda pelos vazios do apenas esboçado movimento moderno. As aparentes 
rupturas com a história escondem de um lado, falta de clareza ou talento como quiserem, informação, e do outro escondem interesses que se sobrepõem à qualidade do espaço construído, sendo ungido, o espaço e o produtor à sua frente como mercadoria passível de troca. Independente da sua propriedade pública ou privada a qualidade do espaço construído é patrimônio da comunidade e da Nação. Que belas seriam nossas cidades se fossem mais simples.

É doloroso elaborarmos uma crítica arquitetônica pois estamos analisando produtos e produtores, sendo difícil, fazendo com que na maior parte das vezes, cercados de alta retórica, plantas, cortes e fachadas, belas fotos e alguns créditos, se dê o nome de arquitetura.

O reconhecimento do exercício do objeto do nosso trabalho é uma atividade humana (já escrevi sobre isso antes, vide Revista Projeto $\mathrm{n}^{\circ}$ 109, "Pesquisa, um problema na cabeça dos Arquitetos", pág. 42).

Nada a temer quando oferecemos o fruto de nossas pranchetas para uma crítica mais profunda e não mero descritismo ou exaltação. Houve uma "democratização" da profissão. Esta expansão está gerando a apreciação de arquiteturas que aparentemente não se destacam na paisagem. Ao contrário, com ela dialogam, se prolongam e se acomodam.
Para muitos de nós até de difícil entendimento.

Volto ao já dito, não se trata de proezas tecnológicas de países melhor equipados. Eis o mistério - ou não mistério. Com menor ou maior equipamento, como reconhecer um espaço qualificado?

Todos precisamos do esforço coletivo para nos individualizarmos, e igualmente romper os engessamentos que fazem segurar a crítica e, pelo fator tempo, tornam o processo um atraso ( sempre é um processo, pois não se parou de riscar nunca).

Aqui há de se reconhecer o elo entre o histórico recente e a produção das sucessivas gerações a partir do movimento moderno. Há também de se reconhecer a confusão de leitura, criada pela mercadologia de um lado e pelo exótico do outro, algumas dessas manifestações até bem intencionadas, o que me obrigo a reconhecer sem concessões.

Espero esteja aberta a polêmica. Que cada um mostre os seus projetos e os seus desenhos, ou como quiserem os seus desenhos e o que o canteiro produziu.

Para as jovens gerações não basta mais o tubo embaixo do braço, carregado de informações sobre o papel. Sabem que ao(s) comitente(s) isto não basta. Projeto e produção tornam-se um só. Construir além de pré-pensar a construção, 
paulatinamente passa para o domínio da arquitetura. Obrigará a repensar programaticamente nosso ensino e nossas escolas. Será o renascimento delas - das escolas e do exercício profissional digno.

Mudam-se as relações sociais, mudam-se os projetos. É um processo e não é tão simples.

Qual a cara desta arquitetura emergente? Quais as linguagens dos projetos de programas especiais e os do cotidiano? - Do cotidiano sabemos; os especiais, certamente não serão excepcionais.

Ainda permanece a pergunta - são várias as caras desta arquitetura, há que garimpá-las, pois apesar da confusão criada pela mercadologia, arquitetura continua sendo questão da cultura.

Agrava o fato de se reduzir este processo de cultura a mera mercadoria de licitação, orientada por quem "não do ramo", como se pudesse adquirir qualidade do espaço em fardos, donde pela porta de pseudo moralidade da licitação, o projeto se torna a mesma mercadoria que a mercadologia oferece. Entre os dois um fio fino de equilibristas.

SANOVICZ, Abrahão. Por uma crítica arquitetônica: pela recuperação da dignidade perdida no projeto. Projeto, São Paulo, n. 181, dezembro, 1994, pg. 83 


\section{E Pur Si Muove}

Abrahão Sanovicz

... E ao ser criada foi batizada com o nome de Faculdade de Arquitetura e Urbanismo.

E, ao sair da Escola Politécnica carregou consigo a "cadeira" de Urbanismo. O que significa urbanização, atribuição do arquiteto. Neste quase meio século, a Escola tem uma história depositada. É impossível para quem investiga e assume a tarefa de formalizar, tridimensionalmente, o que sucede no espaço social, não sentir os conflitos que surgem na prancheta/computador.

Faz-se necessária, portanto, uma metodologia quanto ao específico das nossas atividades, específico que certamente não se basta com a imaginação criadora, qualidade inerente a todo ser humano.

As diversas transformações programáticas e os diversos ciclos de interesse para os quais se dirigiram a Escola, e os alunos, podem ser alinhados com as diversas fases sóciopolíticas que vive o país.

A partir de um grande interesse pela história e pela teoria de arquitetura, motivada ainda pelo impacto do movimento moderno entre as duas grandes guerras, por um lado, e o interesse pelo "folclore" do outro, na boa tradição marioandradina, a Escola passa a estudar o fenômeno Movimento Moderno no Brasil. E com ascese, ensaia uma continuação desse processo, através de seus vazios (problemas a resolver). Esboça-se então, uma linguagem própria. Uma postura ética lastreando a sua estética. E igualmente a preocupação com as habitações de menor custo - Casa Popular.

Mas, há uma industrialização acelerada do país e a necessidade de qualificar uma demanda que se esboça com Brasília, até a escala dos exercícios propostos aos alunos, se ampliam.

Pela matriz bauhausiana, o estudo do objeto, a ordenação de informações e o planejamento, englobando urbanismo e paisagismo, substituem "cadeiras artísticas" que se cursava dentro de grande dose de subjetividade.

A Escola alinha-se com a "nueva vision" de um mundo em transformação. E torna curriculum o que já era inquietação do corpo discente.

Com coragem, disposição, juventude e um mundo melhor como desejo na cabeça, seguimos em frente.

As brecadas se sucedem a partir dos anos violentos. E, em 1968 o sonho perdeu espaço para a realidade. A reforma de 62 durou até 69. "Sete anos". Não é pouco. A matriz 
(Bauhaus) durou quatorze.

Nesse período, da casa popular, o interesse passou para o mutirão. Invertia-se a proporção de população campocidade para cidade-campo, e se implantava o inchaço e a metástase urbana, com o desenvolvimento de enormes bolsões de miséria substituindo a pobreza uniforme, dos anos 40/50.

Da pobreza à miséria a qualidade programática se esgarça. O planejamento, com grande dificuldade, tenta acompanhar esta desordenada ocupação urbana que se espalha como se fosse mancha de óleo. Desinteressado pela sua emancipação, o parque industrial se desinteressa pelo estudo do objeto. Sem o amparo necessário de laboratórios à disposição (indústria e seus departamentos de pesquisa de produtos), o desenho industrial se volta para problemas de linguagem como que dizendo, se não posso produzir um concerto pelo menos pratico o solfejo ao piano.

A comunicação tem como vento a favor a propaganda, de um lado e a inquietação artística, do outro.

O tardio conhecimento dos ensaios pós-modernos e a aparente ruptura com a história próxima, lançam a Escola num empirismo que a transporta para os anos 90.

Com a queda das grandes ideologias começa-se, paulatinamente, a recolher os salvados dos diversos fogos e a reconstruir o enxoval já com as diversas linguagens que se queira exercitar. Afinal, são exercícios de aula. E esta exposição é, com certeza, uma primeira manifestação deste novo desejo..

Texto de Abrahão Sanovicz elaborado para a exposição conjunta dos trabalhos dos alunos da FAUUSP de Abrahão Sanovicz, em 1996. In SANOVICZ, Abrahão. Sistematização crítica da obra de arquitetura para obtenção do título de livre docente junto à Faculdade de Arquitetura e Urbanismo da Universidade de São Paulo, 1997, p.226. 


\section{O "Estado da Profissão"}

Abrahão Sanovicz

A perda do prestígio profissional causada pela transformação do projeto como fato cultural em mera mercadoria, sujeitando-se às empíricas regras de um marketing competitivo e oportunista, leva-me a tecer algumas considerações:

O étimo da palavra prestígio é magia, encanto, influência exercida por pessoa, coisa, instituições que provocam admiração ou respeito. Já a palavra profissão nos remete à palavra professar, reconhecer publicamente, adotar.

A perda dessa condição, redundando, significa a queda do reconhecimento público pela instituição, pessoa ou coisa que provoca ou provocava, no meio social, admiração ou respeito.

Retomando o parágrafo inicial, a arquitetura representa para nós um fato cultural porque qualifica o espaço edificado, balizado pela história acumulada. Assim penso eu.

É preciso entender o que sucede hoje, no chamado estado avançado de comercialização ou pós-cultura, quando a civilização é substituída pela comunicação e a informação transmitida por ondas, somente dialoga entre fonte emissora e receptora, com privilégio de poucos. A não ser que algum travesso fure essa onda.

A perda do prestígio gerou uma perda de qualidade na qual é espoliado o profissional e é espoliado o cliente quando da confecção da mercadoria projeto: a diferença consiste em que o primeiro sente a espoliação, o segundo nem sequer tem consciência dela.Tentamos educar o arquiteto para atender a uma demanda qualitativamente até, em certos estabelecimentos de ensino, mas não é feito esforço idêntico para aquele que está do outro lado da mesa, seja governo, seja semipúblico ou seja o privado, apesar de esta qualidade do espaço construído independente de quem tenha a sua escritura de posse ser patrimônio da Nação. Já escrevi várias vezes esta frase.

Longo caminho temos a percorrer novamente, ainda mais quando estamos também reivindicando, além do projeto, a coordenação técnica da obra, que é uma atividade preventiva e não uma tentativa de reparar eventuais erros de interpretação do desenho.

O resto já conhecemos...As pranchetas estão brancas, os computadores ociosos, etc,etc,etc,...

O que fazer? Educar o cliente, como?

Conscientizar os governos sobre uma legislação com 
regulamentação profissional que contemple igualmente os aspectos culturais do nosso ofício, bem como as relações econômicas do mesmo. No plano do ensino, alargar a formação profissional entendendo que projeto e produção é uma unidade. A ninguém mais satisfaz o rolo de papel debaixo do braço ou os disquetes na pasta.

Os organismos representativos da classe que hoje se encontram multiplicados, cada um com sua vocação de formação, seja profissional, mercadológica ou cultural, disputando os poucos espaços entre si, necessitam de um repensar a respeito dos objetivos comuns que possam nos levar a uma unidade de atuação nunca se esquecendo que para que haja a produção de uma estética é necessário uma atitude ética. Coletiva ou individualmente, pois, para nos individualizarmos, precisamos do coletivo.

SANOVICZ, Abrahão. Sistematização crítica da obra de arquitetura para obtenção do título de livre docente junto à Faculdade de Arquitetura e Urbanismo da Universidade de São Paulo, 1997, p.228. 


\section{O que é o projeto.}

Abrahão Sanovicz

O projeto é o conjunto de documentos - desenhos memoriais quantitativos e qualitativos, e normas de procedimento que ordenem a organização do canteiro de obras.

Os referidos documentos, desenhos, textos, ou outros quaisquer são o suporte de uma série complexa de decisões tomadas durante o ato de projetar.

E o que é o ato de projetar - é uma atividade tão criadora como qualquer outra atividade humana. Não tem nada de especial nem de excelso e, se insere junto com as demais no processo vital, tendo algumas características específicas.

Cada vez que somos solicitados a resolver algum problema e temos que lançar os primeiros esboços no papel, o que fazemos? Procuramos montar algumas relações no cérebro. Para monta-las, contamos com certo estado de préconsciência do Projeto. Elaborado neste estado e por um mecanismo próprio do cérebro, que é comum a todas as pessoas, ele atinge o estado da consciência. Rapidamente, pegamos um papel e um lápis e lançamos um pequeno esboço. Conhecemos bem o gesto de uma cruz que define uma cidade e que hoje é uma capital.
É muito difícil, somos observadores daquilo que estamos pensando e que ainda permanece no estado de préconsciência.

Porém, a medida em que lançamos o esboço no papel, começamos a fazer perguntas para o mesmo, procurando respostas aos problemas propostos. Na medida em que essas respostas atendem aos nossos desejos, paulatinamente temos a certeza daquele nosso primeiro ato intuitivo: se as respostas vierem certas, estamos atingindo nosso objetivo; se as respostas não vierem, ou a pergunta está errada, ou o projeto precisa ser corrigido.

A partir da certeza que aqueles traços interpretam o projeto que nós tínhamos - interpretam um determinado acontecimento social a ser configurado no espaço, ancorado ou não - podemos então ampliar as escalas do projeto e usarmos todas as técnicas que conhecemos.

O ato de projetar (a passagem do estado da préconsciência para o estado da consciência do projeto) é por demais conhecido.

O projeto (resultado desse processo) é desconhecido, é a pesquisa.

Cada vez que nos encomendam um projeto, ficamos curiosos para saber o que vai sair de nossas cabeças. Na 
distância do tempo e com o projeto já elaborado, dizemos: "É assim que pensávamos o uso deste espaço?". Fazemos a leitura do projeto e descobrimos alguns avanços, ou alguns recuos. Mas podemos descobrir outras coisas interessantes.

Projetar é sempre um ato individual, sempre alguém dá o partido do projeto e o seu desenvolvimento é um ato coletivo.

Como observadores, percebemos as condicionantes anteriores e as informações que nos sensibilizam e reconhecemos esse ato individual, fruto de um pensamento coletivo, pois em cada geração os projetos se assemelham.

Esse processo é comum a todos nós.

O método para usar esse mecanismo cada um de nós tem o seu, porém, a pesquisa, efetivamente está na configuração do projeto. Sendo pesquisa, não significa excepcionalidade, ao contrário, à medida que mais arquitetos se formam, a atividade torna-se democratizada; há um avanço pela quantidade de arquitetos atuantes.

O movimento moderno tentou colocar um mundo novo e os projetos eram diferenciados. O esforço deles era muito maior e foram panfletários, inclusive. Porém, toda essa linguagem já está assimilada e trata-se de ir em frente.

Pode-se avançar como em outros ramos do conhecimento, desde que se reconheça o objeto do nosso trabalho - o projeto.

Assim sendo, é uma pesquisa e dela podemos tirar algumas conclusões. Uma pesquisa não é uma atividade diferenciada, mas sim pequenas partes que configuram o todo. É necessário desmistificar o desejo que temos em relação a este projeto, colocá-lo na sua justa medida, repito, "democraticamente" ao lado das outras atividades humanas.

Do contrário, vamos repetir o que alguns de nós fizemos até agora: tentamos fazer uma interpretação econômica, sem sermos economistas, tentamos fazer uma interpretação sociológica, sem sermos sociólogos, e assim por diante.

Temos que fazer a interpretação do projeto como arquitetos e, ao fazer sua leitura, o reconhecermos.

Este texto sobre o que é ato de projetar, que explica a existência do conjunto de documentos necessários ao canteiro e que consta do volume "Sistematização Crítica da Obra de Arquitetura para Obtenção do Título de Livre Docente" é minha opinião elaborada sobre este processo.

Dependendo do grau de complexidade de cada projeto, são necessárias intervenções pontuais de outras técnicas, as quais reunimos sob o nome de "projetos complementares", sempre sob a coordenação do arquiteto autor do projeto, que verifica as intervenções e o grau de profundidade 
máxima, sempre exigidos.

Prever com a devida antecipação, que é a gênese da palavra projeto é sempre necessário, no geral e no particular de cada ato interveniente. Temos a certeza de que a obra acusará e devolverá o "insulto" de um ato mal pensado, não considerado ou julgado desnecessário.

Porém, aqui quero documentar uma característica do desenvolvimento de um projeto que não havia feito até então.

Trata-se do momento durante este processo em que se sente que o projeto adquire vida própria e ele começa a comandar de dentro, organicamente, o seu seguimento.

O projeto nos diz quais são os pormenores que necessita para a sua configuração total, tem vida própria. Está nos trilhos, como costumam dizer. É o segundo momento altamente gratificante do processo.

O terceiro é o canteiro. É onde acontece o pleno desempenho do projeto. No todo e nas suas partes, ordenando cronologicamente a sucessão de serviços desde a implantação da obra, preparo do solo, sua infra e superestrutura e os demais serviços, este conjunto de desenhos e textos orienta e permanece até a consecução final das atividades. O processo não para aí.

O projeto agora, já com suas diversas fases, acertos e modificações que se fizerem durante a obra, permanece como documento de consulta do histórico deste percurso.

Logo, concluímos que, o projeto é o início, o meio e não o final de um processo pois permanece como objeto de consulta durante a vida útil do construído, e pelo seu sentido de permanência. (O investimento, seja na menor célula, é sempre alto), podemos imaginar a vida útil não só da obra mas também do projeto.

Prova escrita, apresentada para obtenção do Título de Livre Docente junto à Faculdade de Arquitetura e Urbanismo da Universidade de São Paulo, 1997. 


\section{Cinco Décadas de Arquitetura}

Abrahão Sanovicz

Público ou privado, a qualidade do espaço construído é patrimônio da comunidade e da nação. O projeto sempre é fruto de projeto ou projetos anteriores, leva em conta a história acumulada, logo, arquitetura é cultura ao lado das demais manifestações artísticas.

Qual o objetivo - um desenho físico para o espaço social nas suas diversas formas de intervenção.

O problema a resolver, então, é o da educação.

Educação na escola.

Educação dos órgãos responsáveis pela qualidade do espaço construído.

Educação da sociedade.

Donde, surge a qualidade dos programas.

Mudam-se as relações sociais, mudam-se os desenhos dos espaços.

Uma crítica arquitetônica que seja exercida organicamente, isto é, a partir do interior do projeto e da obra construída que balize os caminhos a trilhar terá como aspecto fundamental não o edifício como objeto, mas, sim o edifício e sua dimensão urbana.
Numa determinada época, com a distância do tempo vemos que os projetos se assemelham. Arquitetura se "democratiza".

A excepcionalidade herdada do movimento moderno, panfletário inclusive se dissolve e sua contribuição torna-se patrimônio universal.

O sentido de permanência da arquitetura faz com que todo esse processo tenha obrigatoriamente um grande espaço de maturação, sendo o processo lento e contínuo.

Não nos assustemos se eu disser que em um futuro próximo, e até a médio prazo, o exercício da profissão e a sua linguagem não serão muito diversos daquela que apenas vimos apontada pelo movimento moderno entre as duas guerras. Seu repositório programático e formal é denso.

Sendo o exótico fruto de uma mercadologia esdrúxula na maior parte das vezes, tem a sua embalagem cobrindo a fraqueza ideológica do produto, alimentado por uma voraz necessidade editorial. Cabe neste caso menção especial ao tufão "pós-moderno" hoje apenas uma leve brisa.

Voltando ao início, é sempre um problema de educação. Esta é uma tarefa penosa e depende de um sistema econômico-social mais justo, o que nos deixa intranqüilos. A aparente confusão do desenho das cidades, não é da 
arquitetura, que é um meio - o objetivo é o bem-estar social através dos espaços qualificados.

Projetar é um ato tranqüilo.

Sua estética surge de uma postura ética.

É o que esperamos desta leitura.

Texto de apresentação da exposição "Cinco Décadas de Arquitetura", realizada no Museu Brasileiro da Escultura em comemoração ao cinqüentenário da Faculdade de Arquitetura e Urbanismo da Universidade de São Paulo, 1988. 


\section{Organização do Acervo de Projetos}

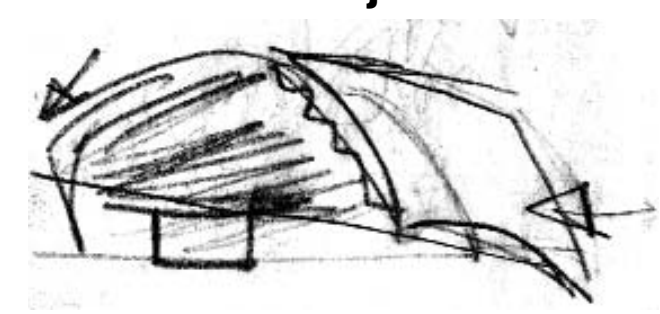





\section{Acervo de Projetos de Abrahão Sanovicz Uma Proposta de Organização}

A Biblioteca da FAUUSP recebeu, como acervo, a obra do Professor Abrahão Sanovicz, em 2003. São 59 caixasarquivo, 44 envelopes, 180 tubos e 6 projetos encaminhados no formato digital "plt", onde podem ser identificados os processos percorridos pelo arquiteto na busca da solução de quase todos os projetos. Abrahão tinha a qualidade de manter a memória de quase a totalidade de seus trabalhos.

O material de cada projeto do acervo é apresentado em diferentes suportes: cópias heliográficas, desenhos em papel vegetal, desenhos para publicação, fotolitos, desenhos em papel manteiga ou croquis, o verso de um envelope aberto, ou um pequeno guardanapo. Não há como organizá-los por projeto, enquanto material físico, o que só será possível depois de digitalizados.

O primeiro contato com esse material foi feito por tipo de embalagem onde estavam acondicionados, a partir daí elaborou-se uma tabela, por projeto, identificando a localização no acervo e levantando informações consideradas fundamentais para a organização da obra: ano do projeto; tipo; nome do projeto; local; e, observações quanto ao contratante, finalidade, equipe, e demais pormenores considerados importantes. 


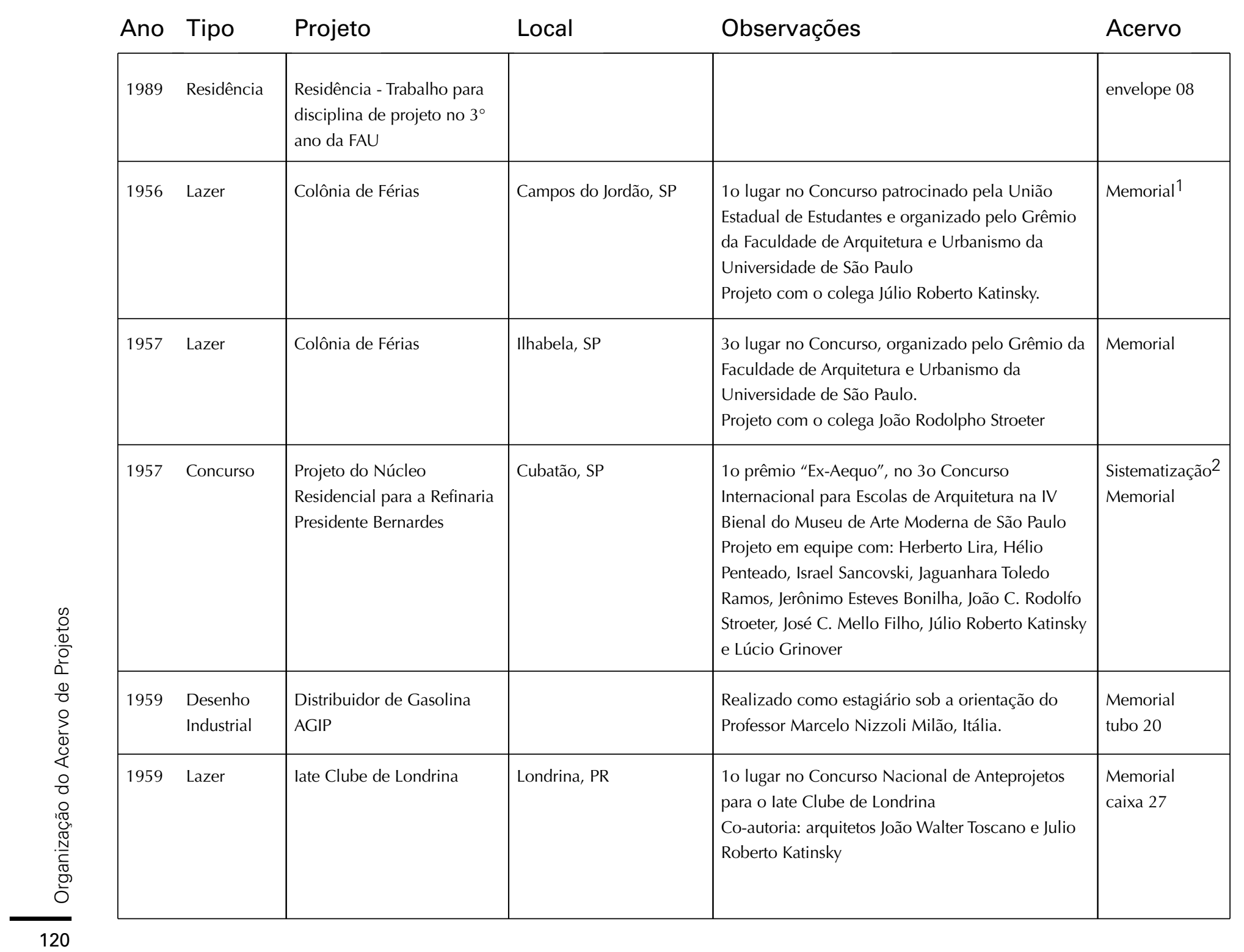




\begin{tabular}{|c|c|c|c|c|c|}
\hline Ano & Tipo & Projeto & Local & Observações & Acervo \\
\hline 1959 & $\begin{array}{l}\text { Edifício } \\
\text { Residencial }\end{array}$ & Condomínio Edifício Porto & $\begin{array}{l}\text { Rua Alexandre Martins, } \\
15 \text { no Bairro do Embaré, } \\
\text { Santos, SP }\end{array}$ & $\begin{array}{l}\text { Apartamentos para veraneio. } \\
\text { Co-autoria:arquiteto Julio Roberto Katinsky }\end{array}$ & $\begin{array}{l}\text { Memorial } \\
\text { tubo } 12\end{array}$ \\
\hline 1959 & Ensino & Grupo Escolar Embaúba & $\begin{array}{l}\text { Distrito de Cajobi, São } \\
\text { Paulo, SP }\end{array}$ & $\begin{array}{l}\text { Contratante: IPESP - Instituto de Previdência do } \\
\text { Estado de São Paulo } \\
\text { Co-autoria: arquiteto Julio Roberto Katinsky }\end{array}$ & Memorial \\
\hline $1960^{* *}$ & $\begin{array}{l}\text { Desenho } \\
\text { Industrial }\end{array}$ & Mimeógrafo & & ** década de 60 & tubo 20 \\
\hline $1960^{* *}$ & $\begin{array}{l}\text { Desenho } \\
\text { Industrial }\end{array}$ & Máquina de café & & ** década de 60 & tubo 20 \\
\hline $1960^{* *}$ & Indústria & Indústria de Papel Paraíba & $\begin{array}{l}\text { Vila Carmozina, Itaquera, } \\
\text { São Paulo, SP }\end{array}$ & $\begin{array}{l}\text { Contratante: Indústria de Papel Paraíba } \\
\text { Área total construída } 813,40 \mathrm{~m}^{2} \\
\text { ** década de } 1960\end{array}$ & tubo 33 \\
\hline $1960^{* *}$ & Apartamento & Prates & Rua Prates, São Paulo, SP & $\begin{array}{l}\text { Reforma com área total construída 130,00m² } \\
*_{* *}^{2} \text { década de } 1960\end{array}$ & tubo 33 \\
\hline $1960^{* *}$ & $\begin{array}{l}\text { Edifício } \\
\text { Comercial }\end{array}$ & Lojas IF & $\begin{array}{l}\text { Rua Barão de } \\
\text { Itapetininga, São Paulo, } \\
\text { SP }\end{array}$ & $\begin{array}{l}\text { Contratante: Lojas IF } \\
\text { Loja }+5 \text { andares de salões } \\
\text { ** década de } 1960\end{array}$ & tubo 33 \\
\hline $1960^{* *}$ & Escritórios & Sede da ABDI & $\begin{array}{l}\text { Rua Major Sertório com } \\
\text { Rua Araújo e Avenida } \\
\text { Ipiranga, São Paulo, SP }\end{array}$ & $\begin{array}{l}\text { Contratante: ABDI } \\
\text { ** década de } 1960\end{array}$ & tubo 33 \\
\hline $1960^{* *}$ & $\begin{array}{l}\text { Edifício } \\
\text { Residencial }\end{array}$ & Edifício Bela Cintra & $\begin{array}{l}\text { Rua Bela Cintra, São } \\
\text { Paulo, SP }\end{array}$ & $\begin{array}{l}\text { Contratante: Construtora Ambiente } \\
\text { Área total construída } 4.800,00 \mathrm{~m}^{2} \\
\text { ** década de } 1960\end{array}$ & tubo 33 \\
\hline
\end{tabular}




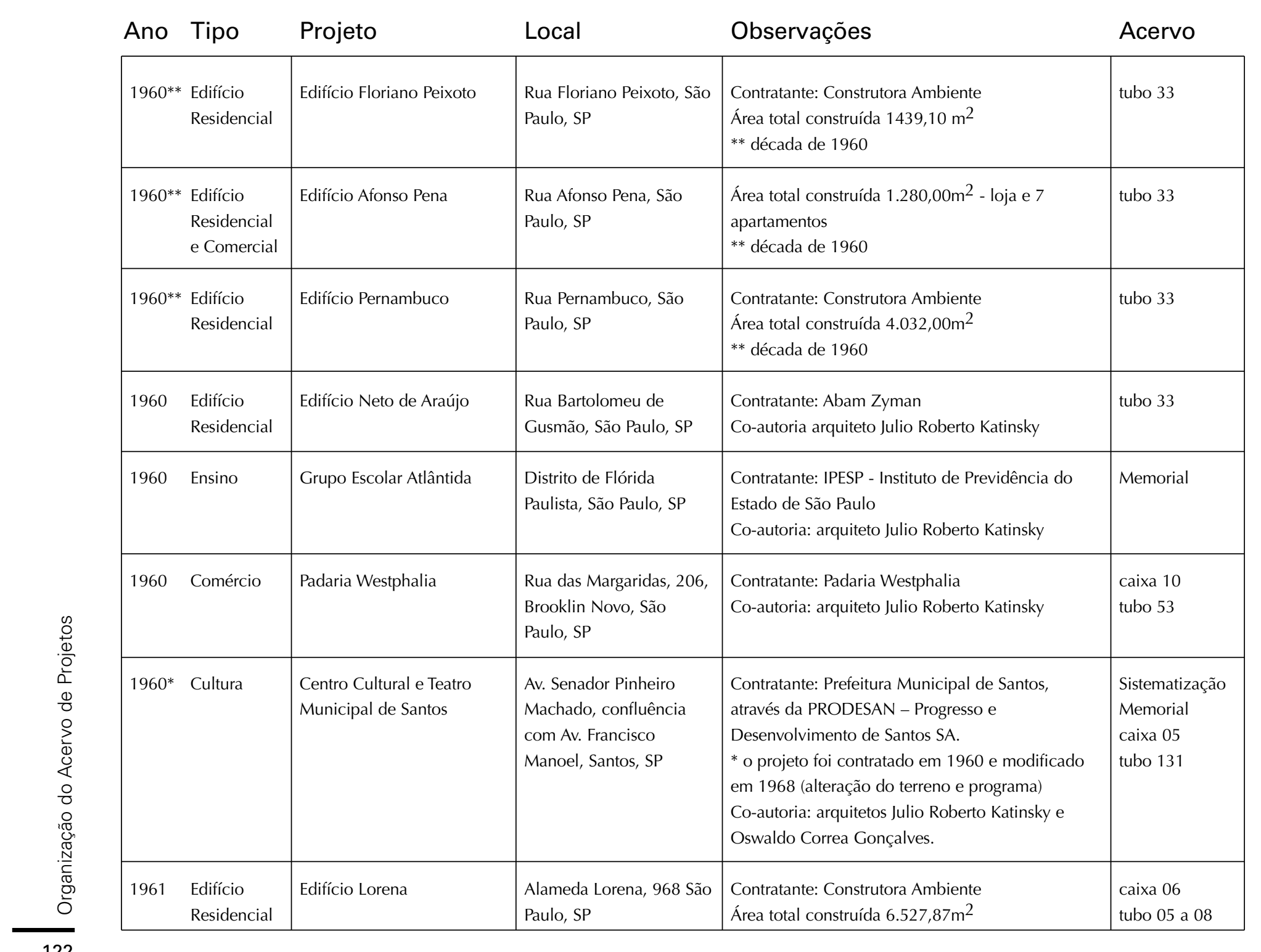




\begin{tabular}{|c|c|c|c|c|c|}
\hline Ano & Tipo & Projeto & Local & Observações & Acervo \\
\hline 1961 & $\begin{array}{l}\text { Desenho } \\
\text { Industrial }\end{array}$ & Linha de Mobiliário & & $\begin{array}{l}\text { Contratante: Móveis L’Atelier } \\
\text { Co-autoria: arquitetos Julio Roberto Katinsky }\end{array}$ & tubo 19 \\
\hline 1961 & $\begin{array}{l}\text { Instituição } \\
\text { Pública }\end{array}$ & Fórum de Guararapes & Guararapes, SP & $\begin{array}{l}\text { Contratante: IPESP - Instituto da Previdência do } \\
\text { Estado de São Paulo } \\
\text { Escultura de Luis Sacilotto }\end{array}$ & $\begin{array}{l}\text { caixa } 20 \\
\text { tubo } 32\end{array}$ \\
\hline 1961 & Ensino & Ginásio Estadual em Santos & $\begin{array}{l}\text { R. Aristóteles Menezes, } \\
367 \text { no Bairro do Macuco } \\
\text { Santos, SP }\end{array}$ & $\begin{array}{l}\text { Contratante: IPESP - Instituto da Previdência do } \\
\text { Estado de São Paulo }\end{array}$ & caixa 01 \\
\hline 1962 & $\begin{array}{l}\text { Instituição } \\
\text { Pública }\end{array}$ & $\begin{array}{l}\text { Centro Social do Setor } \\
\text { Politécnico }\end{array}$ & $\begin{array}{l}\text { Cidade Universitária } \\
\text { "Armando Salles de } \\
\text { Oliveira" São Paulo, SP }\end{array}$ & $\begin{array}{l}\text { Contratante: Universidade de São Paulo } \\
\text { Co-autoria: arquitetos Julio Roberto Katinsky e } \\
\text { Oswaldo Correa Gonçalves }\end{array}$ & Memorial \\
\hline 1962 & $\begin{array}{l}\text { Desenho } \\
\text { Industrial }\end{array}$ & Linha de Móveis & & $\begin{array}{l}\text { Contratante: ESCRIBA - Indústria e Comércio de } \\
\text { Móveis Ltda }\end{array}$ & $\begin{array}{l}\text { Sistematização } \\
\text { Memorial } \\
\text { tubo } 19\end{array}$ \\
\hline 1962 & $\begin{array}{l}\text { Desenho } \\
\text { Industrial }\end{array}$ & Linha de Móveis & & $\begin{array}{l}\text { Contratante: Móveis Alfa } \\
\text { Co-autoria: arquitetos Julio Roberto Katinsky }\end{array}$ & tubo 22 \\
\hline 1962 & $\begin{array}{l}\text { Desenho } \\
\text { Industrial }\end{array}$ & Projetor de Slides & & & tubo 20 \\
\hline $1962^{*}$ & $\begin{array}{l}\text { Desenho } \\
\text { Industrial }\end{array}$ & Linha de Fogões residenciais & & $\begin{array}{l}\text { Contratante: Indústria e Comércio DAKO do } \\
\text { Brasil S.A. } \\
\text { * e } 1963 \\
\text { Obs: projeto da parte externa dos fogões }\end{array}$ & $\begin{array}{l}\text { Memorial } \\
\text { caixa } 02 \\
\text { tubo } 09 \text { e } 10\end{array}$ \\
\hline 1962 & $\begin{array}{l}\text { Edifício } \\
\text { Residencial }\end{array}$ & Edifício Veiga Filho & $\begin{array}{l}\text { Rua Veiga Filho, São } \\
\text { Paulo, SP }\end{array}$ & $\begin{array}{l}\text { Contratante: Construtora Ambiente } \\
\text { Área total construída } 5.440,00 \mathrm{~m}^{2}\end{array}$ & tubo 33 \\
\hline
\end{tabular}




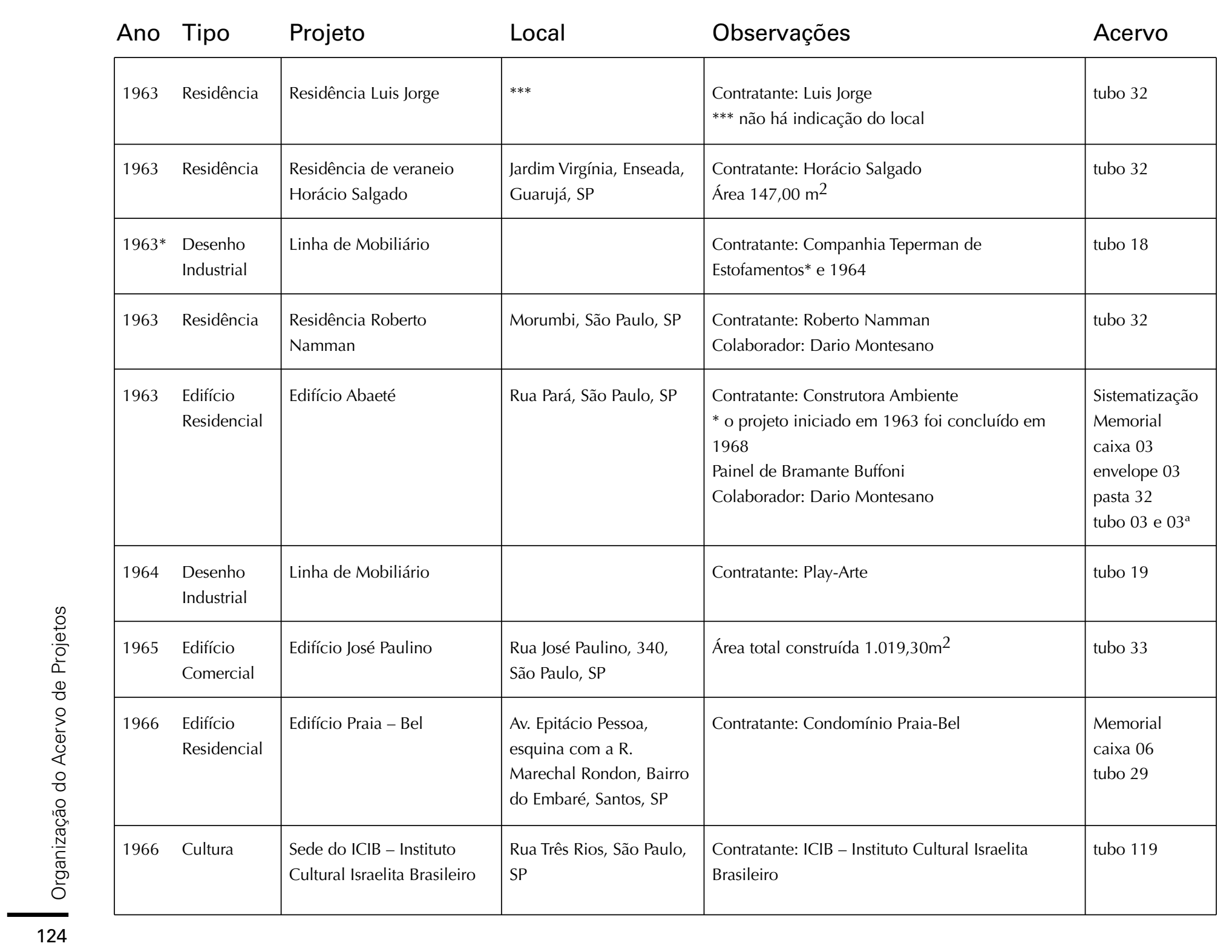




\begin{tabular}{|c|c|c|c|c|c|}
\hline Ano & Tipo & Projeto & Local & Observações & Acervo \\
\hline 1966 & $\begin{array}{l}\text { Desenho } \\
\text { Industrial }\end{array}$ & $\begin{array}{l}\text { Redesenho de Máquina de } \\
\text { Escrever }\end{array}$ & & $\begin{array}{l}\text { Contratante: Olivetti do Brasil S. A. } \\
\text { Co-autoria: projeto com arquiteto Julio Roberto } \\
\text { Katinsky e com o designer Bramante Buffoni }\end{array}$ & $\begin{array}{l}\text { Memorial } \\
\text { caixa } 02 \\
\text { tubo } 16 \text { e } 20\end{array}$ \\
\hline 1966 & $\begin{array}{l}\text { Desenho } \\
\text { Industrial }\end{array}$ & $\begin{array}{l}\text { Cruz e Elementos para } \\
\text { Decoração de Natal }\end{array}$ & & & tubo 20 \\
\hline 1966 & $\begin{array}{l}\text { Desenho } \\
\text { Industrial }\end{array}$ & $\begin{array}{l}\text { Componíveis Suporte para } \\
\text { Sistema de CV }\end{array}$ & & & tubo 20 \\
\hline 1966 & $\begin{array}{l}\text { Edifício } \\
\text { Residencial }\end{array}$ & Edifício Bandeirantes & $\begin{array}{l}\text { Rua Bandeirantes, São } \\
\text { Paulo, SP }\end{array}$ & Contratante: Construtora Ambiente & tubo 32 \\
\hline 1967 & $\begin{array}{l}\text { Comunicação } \\
\text { Visual }\end{array}$ & $\begin{array}{l}\text { Sistema de Sinalização para } \\
\text { Praça dos Andradas }\end{array}$ & $\begin{array}{l}\text { Praça dos Andradas, } \\
\text { Santos, SP }\end{array}$ & $\begin{array}{l}\text { Contratante: Jorge Wilheim Arquitetos Associados / } \\
\text { PRODESAN } \\
\text { Colaborador: Cláudio Farah }\end{array}$ & caixa 20 \\
\hline 1967 & $\begin{array}{l}\text { Comunicação } \\
\text { Visual }\end{array}$ & Símbolo para Rio Tietê & & Contratante: Jorge Wilheim Arquitetos Associados & tubo 21 \\
\hline 1967 & $\begin{array}{l}\text { Comunicação } \\
\text { Visual }\end{array}$ & $\begin{array}{l}\text { Símbolo para Cidade de } \\
\text { Joinville }\end{array}$ & & Contratante: Jorge Wilheim Arquitetos Associados & tubo 21 \\
\hline 1967 & $\begin{array}{l}\text { Comunicação } \\
\text { Visual }\end{array}$ & $\begin{array}{l}\text { Símbolo para Cidade de } \\
\text { Guarulhos }\end{array}$ & & Contratante: Jorge Wilheim Arquitetos Associados & tubo 21 \\
\hline 1967 & $\begin{array}{l}\text { Comunicação } \\
\text { Visual }\end{array}$ & $\begin{array}{l}\text { Símbolo para Cidade de } \\
\text { Natal }\end{array}$ & & Contratante: Serete SA Engenharia & $\begin{array}{l}\text { envelope } 04 \\
\text { tubo } 21\end{array}$ \\
\hline 1967 & $\begin{array}{l}\text { Comunicação } \\
\text { Visual }\end{array}$ & $\begin{array}{l}\text { Símbolo para Cidade de } \\
\text { Osasco }\end{array}$ & & Contratante: Serete SA Engenharia & $\begin{array}{l}\text { envelope } 05 \\
\text { tubo } 21\end{array}$ \\
\hline
\end{tabular}




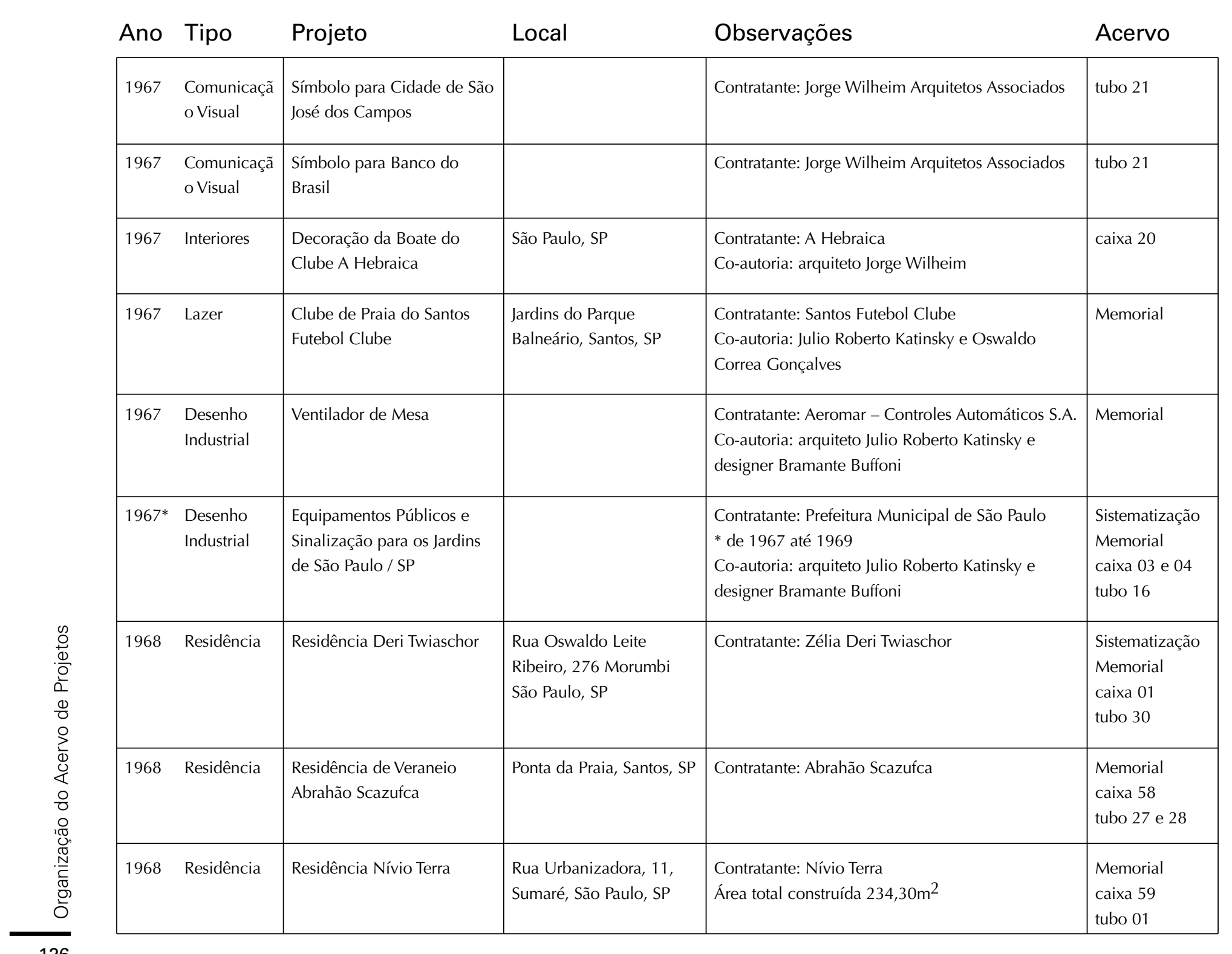




\begin{tabular}{|c|c|c|c|c|c|}
\hline Ano & Tipo & Projeto & Local & Observações & Acervo \\
\hline 1968 & $\begin{array}{l}\text { Conjunto } \\
\text { Habitacional }\end{array}$ & $\begin{array}{l}\text { Conjunto Habitacional São } \\
\text { Miguel }\end{array}$ & $\begin{array}{l}\text { São Miguel Paulista, São } \\
\text { Paulo, SP }\end{array}$ & $\begin{array}{l}\text { Contratante: Olga Garbin Pinto } \\
\text { Área de } 44.492,73 \mathrm{~m}^{2}\end{array}$ & $\begin{array}{l}\text { caixa } 59 \\
\text { tubo } 32\end{array}$ \\
\hline $1968^{*}$ & Interiores & $\begin{array}{l}\text { Especificação do mobiliário } \\
\text { para a Faculdade de } \\
\text { Arquitetura e Urbanismo da } \\
\text { Universidade de São Paulo }\end{array}$ & $\begin{array}{l}\text { FAUUSP Cidade } \\
\text { Universitária "Armando } \\
\text { Salles de Oliveira", São } \\
\text { Paulo, SP }\end{array}$ & $\begin{array}{l}\text { Convite: FAUUSP } \\
\text { * e } 1969\end{array}$ & Memorial \\
\hline 1969 & Ensino & Grupo Escolar em Dumont & Ribeirão Preto, SP & $\begin{array}{l}\text { Contratante: FECE - Fundo Estadual de Construções } \\
\text { Escolares }\end{array}$ & $\begin{array}{l}\text { Memorial } \\
\text { tubo } 33\end{array}$ \\
\hline 1969 & $\begin{array}{l}\text { Edifício } \\
\text { Residencial }\end{array}$ & Edifício Ubirama & $\begin{array}{l}\text { Rua Teixeira da Silva, } 392 \\
\text { - São Paulo, SP }\end{array}$ & $\begin{array}{l}\text { Contratante: Julio Cossoy Silva e Carmine Felice de } \\
\text { Março } \\
\text { Área total construída } 4.335,47 \mathrm{~m}^{2}\end{array}$ & $\begin{array}{l}\text { Memorial } \\
\text { tubo } 24,26 \text { e } 66\end{array}$ \\
\hline 1969 & $\begin{array}{l}\text { Conjunto } \\
\text { Residencial }\end{array}$ & Conjunto Jardim Prudência & $\begin{array}{l}\text { Rua Bolívia, Jardim } \\
\text { Prudência, São Paulo, SP }\end{array}$ & Contratante: Formaespaço S. A. Construções & $\begin{array}{l}\text { Sistematização } \\
\text { Memorial } \\
\text { caixa } 06 \\
\text { tubo } 13 \text { e } 26\end{array}$ \\
\hline 1969 & Residência & $\begin{array}{l}\text { Residência Franklin } \\
\text { Kuperman }\end{array}$ & $\begin{array}{l}\text { R. Faveiro s/ no, Jardim } \\
\text { do Embaixador, Campos } \\
\text { do Jordão, SP }\end{array}$ & Contratante: Franklin Kuperman & $\begin{array}{l}\text { Memorial } \\
\text { caixa } 58 \\
\text { tubo } 14 \text { e } 14 \mathrm{~A}\end{array}$ \\
\hline 1969 & $\begin{array}{l}\text { Conjunto } \\
\text { Residencial }\end{array}$ & $\begin{array}{l}\text { Conjunto Residencial } \\
\text { Jacatirão }\end{array}$ & $\begin{array}{l}\text { Rua Jacatirão, Chácara } \\
\text { Monte Alegre, São Paulo, } \\
\text { SP }\end{array}$ & $\begin{array}{l}\text { Contratante: Formaespaço S. A. Construções } \\
\text { Área total construída 569,22 m² }\end{array}$ & caixa 06 \\
\hline $1970^{* *}$ & Concurso & $\begin{array}{l}\text { Centro Comercial, Mercado } \\
\text { Municipal do Portão }\end{array}$ & $\begin{array}{l}\text { Rua das Palmeiras com } \\
\text { Av. Kennedy Curitiba, PR }\end{array}$ & $\begin{array}{l}\text { Promotor: IAB PR } \\
{ }^{* *} \text { década de } 1970\end{array}$ & tubo 17 \\
\hline
\end{tabular}




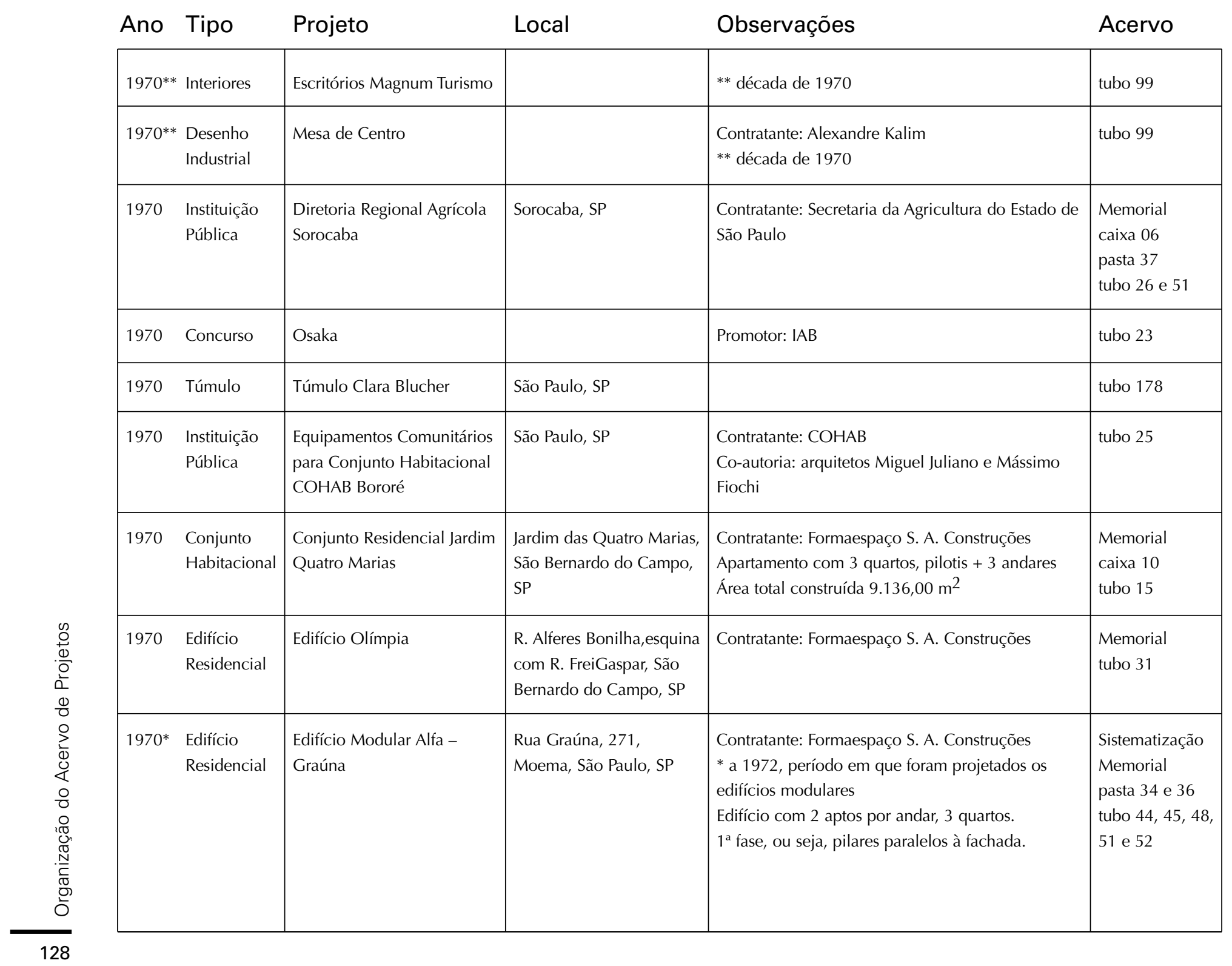




\begin{tabular}{|c|c|c|c|c|c|}
\hline Ano & Tipo & Projeto & Local & Observações & Acervo \\
\hline $1970^{*}$ & $\begin{array}{l}\text { Edifício } \\
\text { Residencial }\end{array}$ & $\begin{array}{l}\text { Edifício Modular Beta - } \\
\text { Divino Salvador }\end{array}$ & $\begin{array}{l}\text { Av. Divino Salvador, 863, } \\
\text { Moema, São Paulo, SP }\end{array}$ & $\begin{array}{l}\text { Contratante: Formaespaço S. A. Construções } \\
\text { * a 1972, período em que foram projetados os } \\
\text { edifícios modulares } \\
\text { Edifício com } 2 \text { aptos por andar, } 3 \text { quartos. } \\
1^{\text {a }} \text { fase, ou seja, pilares paralelos à fachada. }\end{array}$ & $\begin{array}{l}\text { Sistematização } \\
\text { Memorial } \\
\text { pasta } 34 \text { e } 36 \\
\text { tubo } 38,44,45, \\
48,51 \text { e } 52\end{array}$ \\
\hline $1970^{*}$ & Escritórios & Sede da Formaespaço & $* * *$ & $\begin{array}{l}\text { Contratante: Formaespaço S. A. Construções } \\
\text { *** não há indicação do local } \\
\text { Reforma }\end{array}$ & $\begin{array}{l}\text { caixa } 10 \\
\text { tubo } 11\end{array}$ \\
\hline $1970^{*}$ & $\begin{array}{l}\text { Edifício } \\
\text { Residencial }\end{array}$ & $\begin{array}{l}\text { Edifício Modular Gama - } \\
\text { Jurema }\end{array}$ & $\begin{array}{l}\text { Av. Jurema, 888, Planalto } \\
\text { Paulista, São Paulo, SP }\end{array}$ & 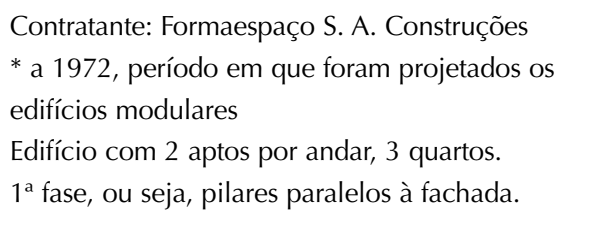 & $\begin{array}{l}\text { Sistematização } \\
\text { Memorial } \\
\text { pasta } 34 \text { e } 36 \\
\text { tubo } 40,44,48 \\
\text { e } 51\end{array}$ \\
\hline $1970^{*}$ & $\begin{array}{l}\text { Edifício } \\
\text { Residencial }\end{array}$ & $\begin{array}{l}\text { Edifício Modular Delta I e II } \\
\text { - Lavandisca }\end{array}$ & $\begin{array}{l}\text { Rua Lavandisca , 52, } \\
\text { Moema, São Paulo, SP }\end{array}$ & 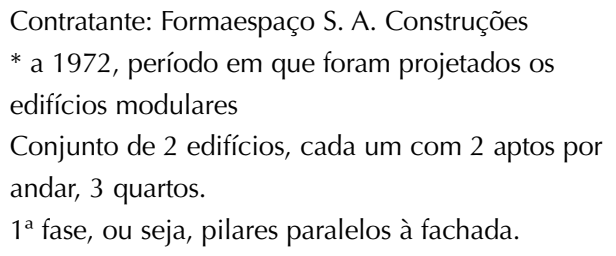 & $\begin{array}{l}\text { Sistematização } \\
\text { Memorial } \\
\text { pasta } 34 \text { e } 36 \\
\text { tubo } 41,44,48 \\
\text { e } 51\end{array}$ \\
\hline $1970^{*}$ & $\begin{array}{l}\text { Edifício } \\
\text { Residencial }\end{array}$ & $\begin{array}{l}\text { Edifício Modular Epsilon - } \\
\text { Lavandisca }\end{array}$ & $\begin{array}{l}\text { Rua Lavandisca, 622, } \\
\text { Moema, São Paulo, SP }\end{array}$ & 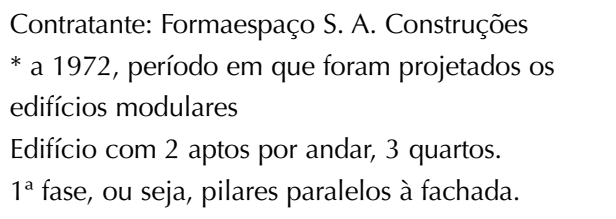 & $\begin{array}{l}\text { Sistematização } \\
\text { Memorial } \\
\text { pasta } 34 \text { e } 35 \\
\text { tubo } 41,44,48 \\
\text { e } 51\end{array}$ \\
\hline $1970^{*}$ & $\begin{array}{l}\text { Edifício } \\
\text { Residencial }\end{array}$ & $\begin{array}{l}\text { Edifício Modular Dzeta - } \\
\text { Irerê }\end{array}$ & $\begin{array}{l}\text { Rua Irerê, 976, Planalto } \\
\text { Paulista São Paulo, SP }\end{array}$ & $\begin{array}{l}\text { Contratante: Formaespaço S. A. Construções } \\
\text { * a 1972, período em que foram projetados os } \\
\text { edifícios modulares } \\
\text { Edifício com } 2 \text { aptos por andar, } 3 \text { quartos. } \\
1^{\text {a }} \text { fase, ou seja, pilares paralelos à fachada. }\end{array}$ & $\begin{array}{l}\text { Sistematização } \\
\text { Memorial } \\
\text { pasta } 34 \text { e } 36 \\
\text { tubo } 41,44,48 \\
\text { e } 51\end{array}$ \\
\hline
\end{tabular}




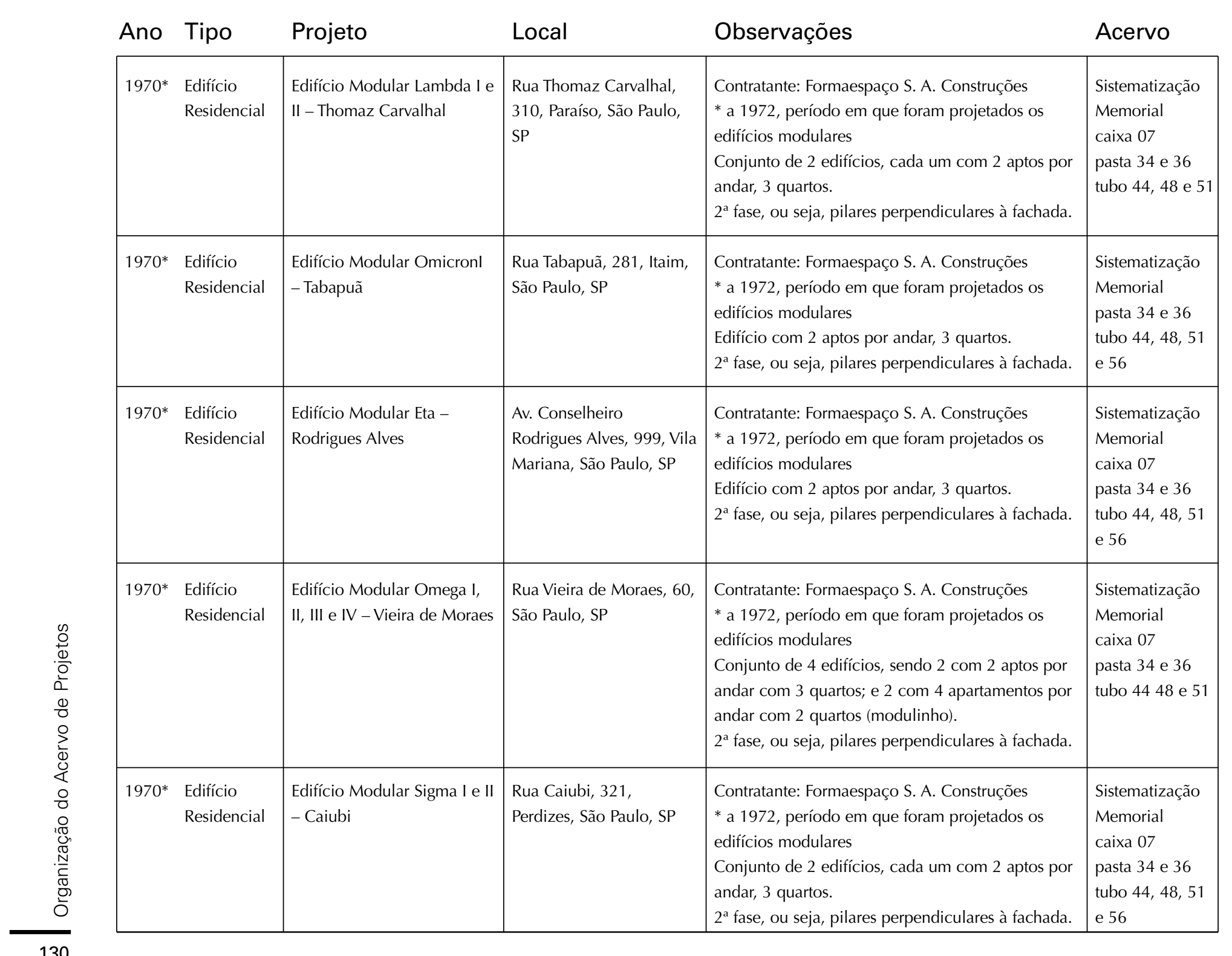




\begin{tabular}{|c|c|c|c|c|c|}
\hline Ano & Tipo & Projeto & Local & Observações & Acervo \\
\hline $1970^{*}$ & $\begin{array}{l}\text { Edifício } \\
\text { Residencial }\end{array}$ & $\begin{array}{l}\text { Edifício Modular Vega - } \\
\text { Campevas }\end{array}$ & $\begin{array}{l}\text { Rua Campevas, 313, } \\
\text { Perdizes, São Paulo, SP }\end{array}$ & 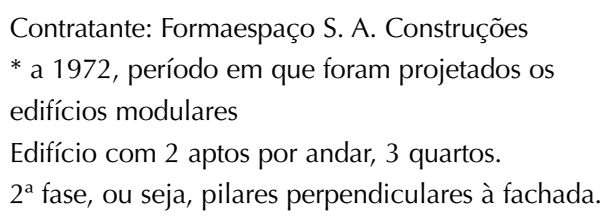 & $\begin{array}{l}\text { Sistematização } \\
\text { Memorial } \\
\text { caixa } 07 \\
\text { pasta } 34 \text { e } 36 \\
\text { tubo } 44,48 \text { e } 51\end{array}$ \\
\hline 1970 & $\begin{array}{l}\text { Conjunto } \\
\text { Habitacional }\end{array}$ & $\begin{array}{l}\text { Conjunto Habitacional } \\
\text { Nova Cidade }\end{array}$ & Jundiaí, SP & Contratante: Formaespaço S. A. Construções & $\begin{array}{l}\text { Sistematização } \\
\text { Memorial } \\
\text { pasta } 38 \text { a } 40 \\
\text { tubo } 26,31,47 \\
\text { e } 51\end{array}$ \\
\hline 1970 & Residência & Residência Frank Gunter & $\begin{array}{l}\text { Via Raposo Tavares, Km24, } \\
\text { Granja Viana, Cotia, SP }\end{array}$ & Contratante: Frank Gunter & $\begin{array}{l}\text { Memorial } \\
\text { tubo } 54,55 \text { e } 67\end{array}$ \\
\hline 1971 & Concurso & $\begin{array}{l}\text { Centro de Artes do Plateau } \\
\text { Beaubourg }\end{array}$ & Les Halles, Paris, França & Co-autoria: arquiteto Paulo Mendes da Rocha & Memorial \\
\hline 1971 & Interiores & $\begin{array}{l}\text { Stand Câmara Brasileira do } \\
\text { Livro na Frankfurter } \\
\text { Deutsche Messe }\end{array}$ & $\begin{array}{l}\text { Frankfurt, Alemanha } \\
\text { São Paulo, SP }\end{array}$ & Contratante: Câmara Brasileira do Livro & $\begin{array}{l}\text { Memorial } \\
\text { caixa } 58 \\
\text { tubo } 38\end{array}$ \\
\hline 1971 & Túmulo & Túmulo Jacob Wolfenson & & & tubo 178 \\
\hline 1971 & $\begin{array}{l}\text { Edifício } \\
\text { Residencial }\end{array}$ & Edifício Granja Julieta & $\begin{array}{l}\text { R. Madre Rita Amada de } \\
\text { Jesus, } 79 \text { - Granja Julieta, } \\
\text { São Paulo, SP }\end{array}$ & Contratante: Formaespaço S. A. Construções & Memorial \\
\hline 1972 & Residência & Residência Mário Penteado & $\begin{array}{l}\text { Rua Gabriel Calfat, } \\
\text { esquina com Rua Afonso } \\
\text { Pena Júnior, Jardim } \\
\text { Leonor, São Paulo, SP }\end{array}$ & Contratante: Mário Penteado & Memorial \\
\hline
\end{tabular}




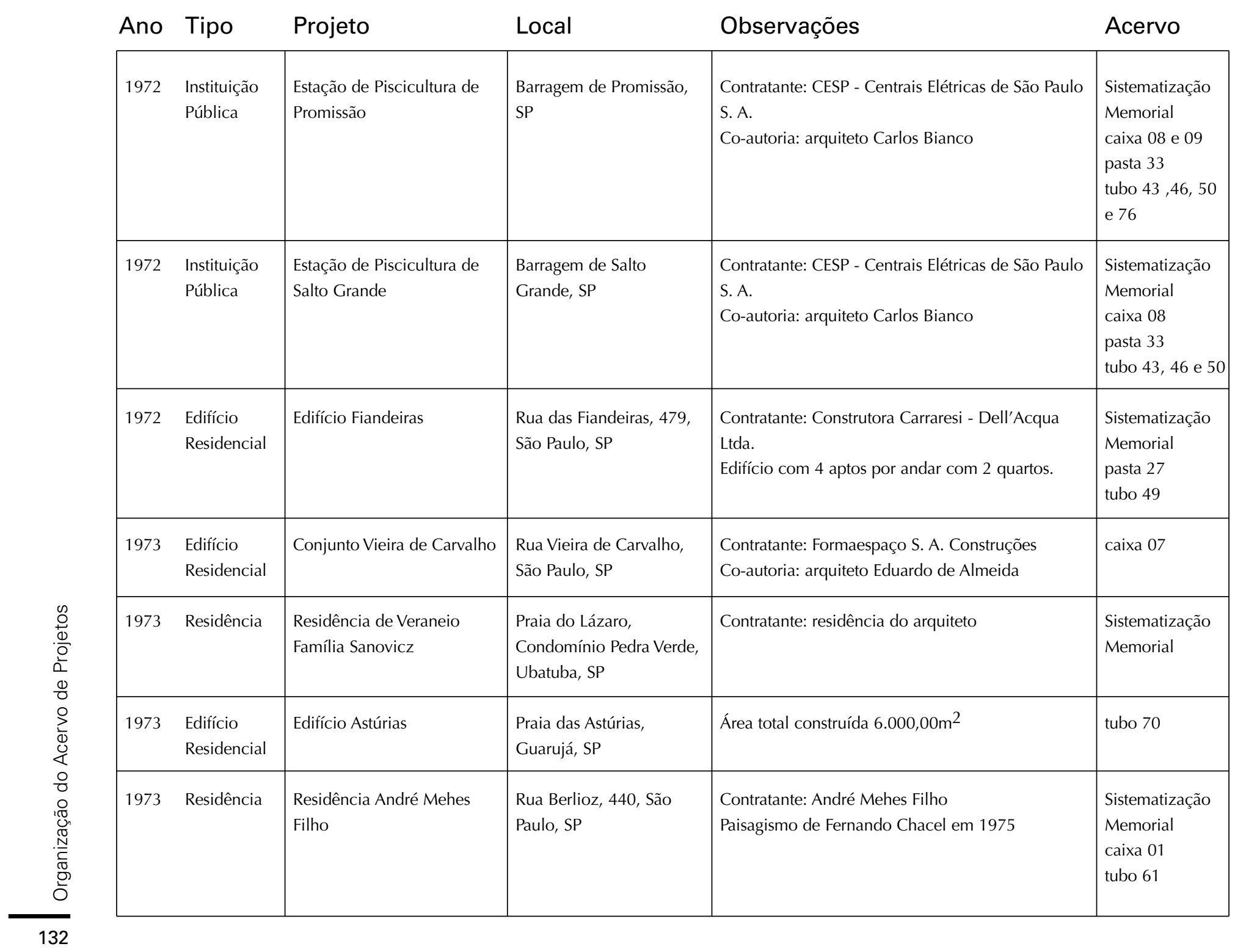




\begin{tabular}{|c|c|c|c|c|c|}
\hline Ano & Tipo & Projeto & Local & Observações & Acervo \\
\hline $1973 *$ & $\begin{array}{l}\text { Instituição } \\
\text { Pública }\end{array}$ & $\begin{array}{l}\text { Sub-regional Agrícola } \\
\text { Região de Guaratinguetá }\end{array}$ & Guaratinguetá, SP & $\begin{array}{l}\text { Contratante: Secretaria da Agricultura do Estado de } \\
\text { São Paulo } \\
\text { * e } 1974\end{array}$ & $\begin{array}{l}\text { Sistematização } \\
\text { Memorial } \\
\text { caixa } 10 \\
\text { tubo } 71\end{array}$ \\
\hline $1973 *$ & $\begin{array}{l}\text { Instituição } \\
\text { Pública }\end{array}$ & $\begin{array}{l}\text { Sub-regional Agrícola } \\
\text { Região de Botucatu }\end{array}$ & Botucatu, SP & $\begin{array}{l}\text { Contratante: Secretaria da Agricultura do Estado de } \\
\text { São Paulo } \\
\text { * e } 1974\end{array}$ & $\begin{array}{l}\text { Sistematização } \\
\text { Memorial } \\
\text { caixa } 10\end{array}$ \\
\hline $1973^{*}$ & $\begin{array}{l}\text { Instituição } \\
\text { Pública }\end{array}$ & $\begin{array}{l}\text { Sub-regional Agrícola } \\
\text { Região de Catanduva }\end{array}$ & Catanduva, SP & $\begin{array}{l}\text { Contratante: Secretaria da Agricultura do Estado de } \\
\text { São Paulo } \\
\text { * e } 1974\end{array}$ & $\begin{array}{l}\text { Sistematização } \\
\text { Memorial } \\
\text { caixa } 10\end{array}$ \\
\hline $1973 *$ & $\begin{array}{l}\text { Instituição } \\
\text { Pública }\end{array}$ & $\begin{array}{l}\text { Sub-regional Agrícola } \\
\text { Região de Andradina }\end{array}$ & Andradina, SP & $\begin{array}{l}\text { Contratante: Secretaria da Agricultura do Estado de } \\
\text { São Paulo } \\
\text { e } 1974\end{array}$ & $\begin{array}{l}\text { Sistematização } \\
\text { Memorial }\end{array}$ \\
\hline $1973^{*}$ & $\begin{array}{l}\text { Instituição } \\
\text { Pública }\end{array}$ & $\begin{array}{l}\text { Sub-regional Agrícola } \\
\text { Região de Santa Fé do Sul }\end{array}$ & Santa Fé do Sul, SP & $\begin{array}{l}\text { Contratante: Secretaria da Agricultura do Estado de } \\
\text { São Paulo } \\
\text { * e } 1974\end{array}$ & $\begin{array}{l}\text { Sistematização } \\
\text { Memorial }\end{array}$ \\
\hline $1973 *$ & $\begin{array}{l}\text { Instituição } \\
\text { Pública }\end{array}$ & $\begin{array}{l}\text { Usina de Beneficiamento de } \\
\text { Algodão em Aguaí SP }\end{array}$ & Aguaí, SP & $\begin{array}{l}\text { Contratante: Contratante: Secretaria da Agricultura } \\
\text { do Estado de São Paulo } \\
\text { * a } 1978\end{array}$ & $\begin{array}{l}\text { Memorial } \\
\text { caixa } 11,12 \text { e } 13 \\
\text { tubo } 37,58 \\
112,113 \text { e } 114\end{array}$ \\
\hline 1974 & $\begin{array}{l}\text { Instituição } \\
\text { Pública }\end{array}$ & $\begin{array}{l}\text { Sub-regional Agrícola } \\
\text { Região de Campinas }\end{array}$ & Campinas, SP & $\begin{array}{l}\text { Contratante: Secretaria da Agricultura do Estado de } \\
\text { São Paulo }\end{array}$ & tubo 73 \\
\hline 1974 & Residência & $\begin{array}{l}\text { Residência de Veraneio } \\
\text { Wautraut Helene Lay }\end{array}$ & $\begin{array}{l}\text { Praia da Fortaleza, } \\
\text { Ubatuba, SP }\end{array}$ & Contratante: Wautraut Helene Lay & $\begin{array}{l}\text { Memorial } \\
\text { caixa } 59 \\
\text { tubo } 72\end{array}$ \\
\hline
\end{tabular}




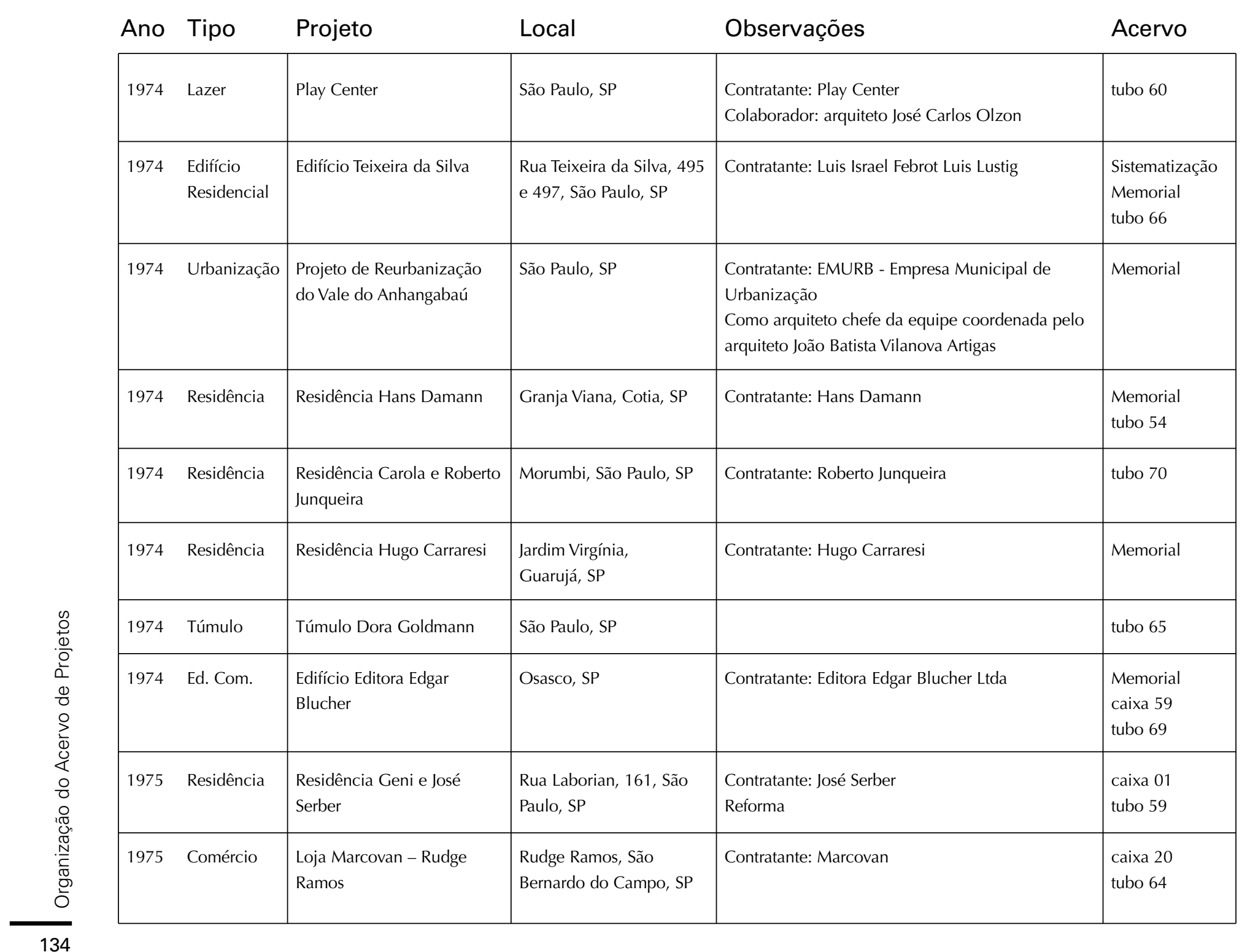




\begin{tabular}{|c|c|c|c|c|c|}
\hline Ano & Tipo & Projeto & Local & Observações & Acervo \\
\hline 1975 & $\begin{array}{l}\text { Conjunto } \\
\text { Habitacional }\end{array}$ & $\begin{array}{l}\text { Parque Habitacional CECAP } \\
\text { Serra Negra }\end{array}$ & Serra Negra, SP & $\begin{array}{l}\text { Contratante: CECAP - Caixa Estadual de Casas para } \\
\text { o Povo } \\
\text { Colaborador: arquiteto José Carlos Olzon }\end{array}$ & $\begin{array}{l}\text { Sistematização } \\
\text { Memorial } \\
\text { caixa } 14,15 \text { e } 16 \\
\text { pasta } 24 \\
\text { tubo } 77\end{array}$ \\
\hline 1976 & Residência & Residência Gordon & São Roque, SP & $\begin{array}{l}\text { Contratante: Gordon } \\
\text { Reforma }\end{array}$ & $\begin{array}{l}\text { caixa } 01 \\
\text { tubo } 78\end{array}$ \\
\hline 1976 & $\begin{array}{l}\text { Conjunto } \\
\text { Habitacional }\end{array}$ & $\begin{array}{l}\text { Parque Habitacional CECAP } \\
\text { Sumaré }\end{array}$ & Sumaré, SP & $\begin{array}{l}\text { Contratante: CECAP - Caixa Estadual de Casas para } \\
\text { o Povo }\end{array}$ & $\begin{array}{l}\text { Sistematização } \\
\text { Memorial } \\
\text { caixa } 16 \\
\text { pasta } 22 \\
\text { tubo } 79\end{array}$ \\
\hline 1976 & Concurso & $\begin{array}{l}\text { Escola Caetano de Campos - } \\
\text { Pré-Escola, Primeiro Grau e } \\
\text { Escola de Formação de } \\
\text { Professores }\end{array}$ & $\begin{array}{l}\text { Rua Pires da Motta, São } \\
\text { Paulo, SP }\end{array}$ & $\begin{array}{l}\text { Promotor: IAB SP } \\
\text { Co-autoria: arquiteto Paulo Mendes da Rocha }\end{array}$ & \\
\hline 1976 & Túmulo & $\begin{array}{l}\text { Túmulo Pauline Della } \\
\text { Gordon }\end{array}$ & São Paulo, SP & & \\
\hline 1976 & $\begin{array}{l}\text { Comunicação } \\
\text { Visual }\end{array}$ & Logotipo Escola Planalto & & Contratante: Escola Planalto & tubo 65 \\
\hline 1976 & $\begin{array}{l}\text { Comunicação } \\
\text { Visual }\end{array}$ & Logotipo AMERIPAK & & Contratante: AMERIPAK & tubo 65 \\
\hline 1976 & Interiores & $\begin{array}{l}\text { Stand Câmara Brasileira do } \\
\text { Livro na Frankfurter } \\
\text { Deutsche Messe }\end{array}$ & Frankfurt, Alemanha & Contratante: Câmara Brasileira do Livro & $\begin{array}{l}\text { Memorial } \\
\text { tubo38 }\end{array}$ \\
\hline
\end{tabular}




\begin{tabular}{|c|c|c|c|c|c|c|}
\hline & Ano & Tipo & Projeto & Local & Observações & Acervo \\
\hline & 1976 & Ensino & EEPG Parque Fernanda & São Paulo, SP & $\begin{array}{l}\text { Contratante: CONESP - Companhia de } \\
\text { Construções Escolares do Estado de São Paulo } \\
20 \text { salas de aula, área construída de } 2.481,00 \mathrm{~m}^{2}\end{array}$ & $\begin{array}{l}\text { Memorial } \\
\text { caixa } 16 \\
\text { tubo } 90\end{array}$ \\
\hline & 1976 & Ensino & EEPG Vila Maracanã & São Paulo, SP & $\begin{array}{l}\text { Contratante: CONESP - Companhia de } \\
\text { Construções Escolares do Estado de São Paulo } \\
12 \text { salas de aula }\end{array}$ & $\begin{array}{l}\text { Memorial } \\
\text { caixa } 16 \\
\text { tubo } 90\end{array}$ \\
\hline & 1976 & Ensino & EEPG Bairro Savoy & Itanhaém, SP & $\begin{array}{l}\text { Contratante: CONESP - Companhia de } \\
\text { Construç̃es Escolares do Estado de São Paulo } \\
8 \text { salas de aula }\end{array}$ & $\begin{array}{l}\text { Memorial } \\
\text { caixa } 16 \\
\text { tubo } 90\end{array}$ \\
\hline & 1976 & Ensino & EEPG Jardim Beval & Barueri, SP & $\begin{array}{l}\text { Contratante: CONESP - Companhia de } \\
\text { Construç̃̃es Escolares do Estado de São Paulo } \\
7 \text { salas de aula, área construída de } 791,80 \mathrm{~m}^{2}\end{array}$ & $\begin{array}{l}\text { Memorial } \\
\text { caixa } 17 \\
\text { tubo } 90\end{array}$ \\
\hline & 1976 & Urbanização & $\begin{array}{l}\text { Urbanização de gleba em } \\
\text { São Roque }\end{array}$ & $\begin{array}{l}\text { Km } 48 \text { da Estrada de } \\
\text { Ibiúna São Roque, SP }\end{array}$ & Contratante: Planova & $\begin{array}{l}\text { Memorial } \\
\text { caixa } 58\end{array}$ \\
\hline \multirow{3}{*}{ 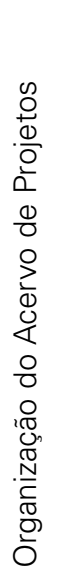 } & 1976 & $\begin{array}{l}\text { Desenho } \\
\text { Industrial }\end{array}$ & $\begin{array}{l}\text { Linha de móveis de } \\
\text { escritório }\end{array}$ & & $\begin{array}{l}\text { Contratante: Forene S. A. Móveis do Nordeste } \\
\text { Colaborador: José Carlos C. Olzon } \\
\text { Consultor: Michel Arnoult }\end{array}$ & \begin{tabular}{|l} 
Sistematização \\
Memorial \\
caixa 19 \\
envelope 14 \\
tubo $74,75,75$ \\
A, 85 e 137 .
\end{tabular} \\
\hline & 1976 & Comércio & Loja Forene & $* * *$ & $\begin{array}{l}\text { Contratante: Forene S. A. Móveis do Nordeste } \\
\text { *** não há indicação do local } \\
\text { Reforma }\end{array}$ & tubo 85 \\
\hline & $1976^{*}$ & Residência & Residência Família Sanovicz & $\begin{array}{l}\text { Rua Alexandre } \\
\text { Marcondes Machado, } 33 \\
\text { Butantã, São Paulo, SP }\end{array}$ & $\begin{array}{l}\text { Contratante: residência do arquiteto } \\
\text { * e } 1977\end{array}$ & \begin{tabular}{|l} 
Sistematização \\
Memorial \\
pasta 28
\end{tabular} \\
\hline
\end{tabular}




\begin{tabular}{|c|c|c|c|c|c|}
\hline Ano & Tipo & Projeto & Local & Observações & Acervo \\
\hline 1977 & $\begin{array}{l}\text { Conjunto } \\
\text { Residencial }\end{array}$ & $\begin{array}{l}\text { Unidades residenciais no } \\
\text { Patrimônio do Carmo }\end{array}$ & $\begin{array}{l}\text { Lotes } 173,175 \text { e } 302, \\
\text { setor B, Patrimônio do } \\
\text { Carmo. Ibiúna, SP }\end{array}$ & & $\begin{array}{l}\text { Memorial } \\
\text { caixa: } 07 \\
\text { tubo } 88\end{array}$ \\
\hline 1977 & Ensino & EEPG Saco da Ribeira & $\begin{array}{l}\text { Rua Particular, Sítio São } \\
\text { Benedito, Ubatuba, SP }\end{array}$ & $\begin{array}{l}\text { Contratante: CONESP - Companhia de } \\
\text { Construções Escolares do Estado de São Paulo } \\
6 \text { salas de aula }\end{array}$ & $\begin{array}{l}\text { Memorial } \\
\text { caixa } 58\end{array}$ \\
\hline 1977 & Ensino & EEPG Santa Bárbara & $\begin{array}{l}\text { Rua do Flamengo, com } \\
\text { Rua Espanha e Rua } \\
\text { Portugal, Americana, SP }\end{array}$ & $\begin{array}{l}\text { Contratante: CONESP - Companhia de } \\
\text { Construções Escolares do Estado de São Paulo } \\
6 \text { salas de aula }\end{array}$ & $\begin{array}{l}\text { Memorial } \\
\text { caixa } 58\end{array}$ \\
\hline 1977 & Indústria & $\begin{array}{l}\text { Indústria de Tecelagem e } \\
\text { Malharia Grisbi }\end{array}$ & $\begin{array}{l}\text { Pirapora, MG e Camaçari, } \\
\mathrm{BH}\end{array}$ & Contratante: Grisbi Nordeste S. A. & $\begin{array}{l}\text { Sistematização } \\
\text { Memorial } \\
\text { caixa } 18 \\
\text { tubo } 80 \text { a } 83103 \\
\text { e } 104\end{array}$ \\
\hline 1977 & $\begin{array}{l}\text { Comunicação } \\
\text { Visual }\end{array}$ & $\begin{array}{l}\text { Logotipo para Indústria de } \\
\text { Tecelagem e Malharia Grisbi }\end{array}$ & & Contratante: Grisbi Nordeste S. A. & envelope 07 \\
\hline 1977 & Ensino & EEPG Vila Cristina & $\begin{array}{l}\text { Rua Vicente de Paula } \\
\text { Lima, Serrana, SP }\end{array}$ & $\begin{array}{l}\text { Contratante: CONESP - Companhia de } \\
\text { Construções Escolares do Estado de São Paulo } \\
6 \text { salas de aula }\end{array}$ & $\begin{array}{l}\text { Memorial } \\
\text { caixa } 58\end{array}$ \\
\hline 1977 & Inst. Ensino & EEPG Jardim Itamaraty & Mogi-Guaçu, SP & $\begin{array}{l}\text { Contratante: CONESP - Companhia de } \\
\text { Construções Escolares do Estado de São Paulo } \\
11 \text { salas de aula, área total construída } 1.718,56 \mathrm{~m}^{2}\end{array}$ & $\begin{array}{l}\text { Memorial } \\
\text { caixa } 17 \\
\text { tubo } 90\end{array}$ \\
\hline 1977 & Residência & $\begin{array}{l}\text { Residência Josif e Zélia Deri } \\
\text { Twiaschor }\end{array}$ & Campos do Jordão, SP & $\begin{array}{l}\text { Contratante: Josif e Zélia Deri Twiaschor } \\
\text { Área total construída de } 240,37 \mathrm{~m}^{2}\end{array}$ & $\begin{array}{l}\text { caixa } 59 \\
\text { pasta } 12 \\
\text { tubo } 84\end{array}$ \\
\hline
\end{tabular}




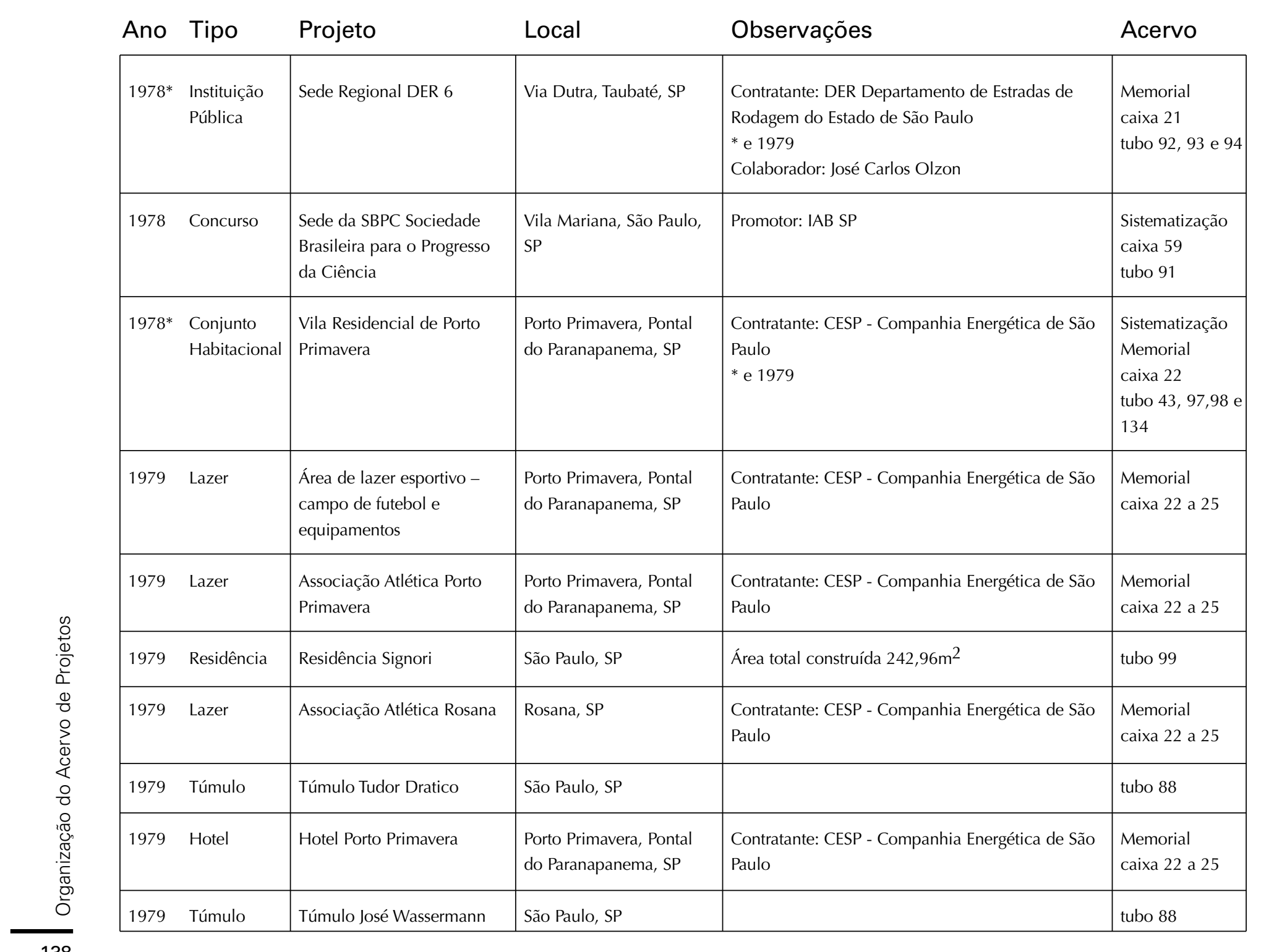




\begin{tabular}{|c|c|c|c|c|c|}
\hline Ano & Tipo & Projeto & Local & Observações & Acervo \\
\hline 1979 & $\begin{array}{l}\text { Edifício } \\
\text { Residencial }\end{array}$ & Edifício Santo André & Rua Itaipava, São Paulo, SP & Área total construída $1.992,00 \mathrm{~m}^{2}$ & tubo 99 \\
\hline 1979 & Residência & $\begin{array}{l}\text { Residência Fernando } \\
\text { Gonçalves }\end{array}$ & $\begin{array}{l}\text { Alameda Equador, 541, } \\
\text { Alphaville, Barueri, SP }\end{array}$ & $\begin{array}{l}\text { Contratante: Fernando Gonçalves } \\
\text { Reforma } \\
\text { Colaborador: José Carlos Olzon }\end{array}$ & $\begin{array}{l}\text { Memorial } \\
\text { tubo } 99\end{array}$ \\
\hline 1979 & Residência & $\begin{array}{l}\text { Residência Fernando Ramos } \\
\text { Gonçalves }\end{array}$ & $\begin{array}{l}\text { Alameda Equador, } 541 \\
\text { Alphaville, Barueri, SP }\end{array}$ & Contratante: Fernando Ramos Gonçalves & $\begin{array}{l}\text { caixa } 27 \\
\text { tubo } 117\end{array}$ \\
\hline $1980^{* *}$ & Residência & Cobertura Bety e Júlio & $\begin{array}{l}\text { Rua Ministro Godoy, 627, } \\
\text { São Paulo, SP }\end{array}$ & $\begin{array}{l}\text { Contratante: Bety e Júlio } \\
\text { ** década de } 1980 \\
\text { Reforma }\end{array}$ & $\begin{array}{l}\text { caixa } 27 \\
\text { tubo } 120 \text { e } 128\end{array}$ \\
\hline $1980^{* *}$ & $\begin{array}{l}\text { "Comunicação } \\
\text { Visual }\end{array}$ & Logotipo Clube da Gravura & & ** década de 1980 & tubo 161 \\
\hline $1980^{* *}$ & $\begin{array}{l}\text { Desenho } \\
\text { Industrial }\end{array}$ & $\begin{array}{l}\text { Elementos pré-moldados de } \\
\text { concreto }\end{array}$ & & Contratante: Reago Indústria e Comércio S.A. & tubo 177 \\
\hline 1980 & Saúde & $\begin{array}{l}\text { Centro de Farmacologia } \\
\text { Clínica da Escola Paulista de } \\
\text { Medicina }\end{array}$ & $\begin{array}{l}\text { Rua Pedro de Toledo, São } \\
\text { Paulo, SP }\end{array}$ & Contratante: Escola Paulista de Medicina & $\begin{array}{l}\text { Memorial } \\
\text { tubo } 36\end{array}$ \\
\hline 1980 & Residência & Residência Maia Rosenthal & $\begin{array}{l}\text { Estância Parque Atibaia, } \\
\text { Atibaia, SP }\end{array}$ & $\begin{array}{l}\text { Contratante: Maia Rosenthal } \\
\text { Área total construída de } 314,25 \mathrm{~m}^{2}\end{array}$ & $\begin{array}{l}\text { Sistematização } \\
\text { Memorial } \\
\text { tubo } 129\end{array}$ \\
\hline 1980 & Residência & $\begin{array}{l}\text { Residência Raul } \\
\text { Wassermann }\end{array}$ & $* * *$ & $\begin{array}{l}\text { Contratante: Raul Wassermann } \\
\text { *** não há indicação do local }\end{array}$ & caixa 59 \\
\hline 1981 & Concurso & $\begin{array}{l}\text { Reurbanização do } \\
\text { Anhangabaú }\end{array}$ & São Paulo, SP & Promotor: IAB SP & tubo 123 a 127 \\
\hline
\end{tabular}




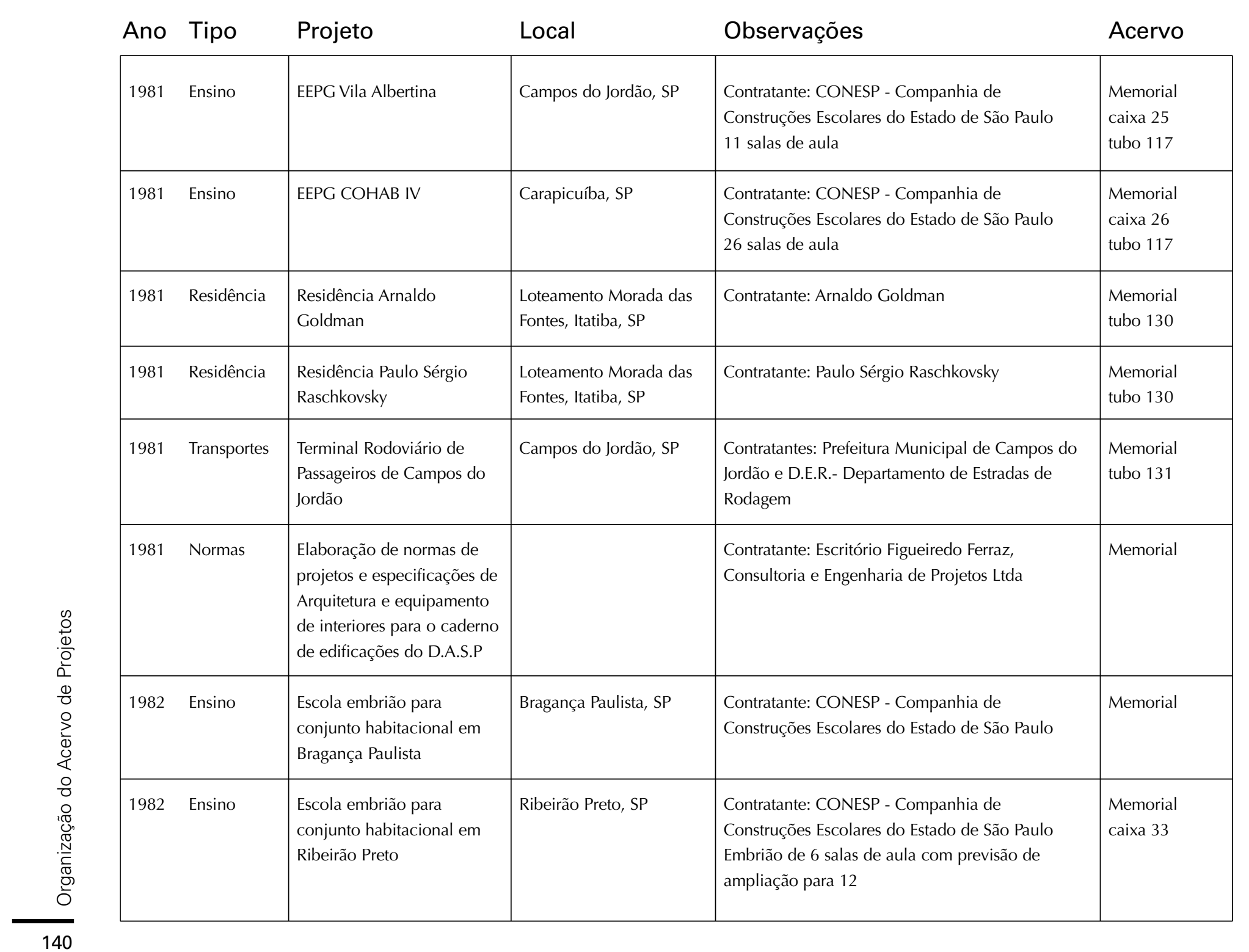




\begin{tabular}{|c|c|c|c|c|c|}
\hline Ano & Tipo & Projeto & Local & Observações & Acervo \\
\hline 1982 & Ensino & $\begin{array}{l}\text { Escola embrião para } \\
\text { conjunto habitacional em } \\
\text { Barueri }\end{array}$ & Barueri, SP & $\begin{array}{l}\text { Contratante: CONESP - Companhia de } \\
\text { Construções Escolares do Estado de São Paulo }\end{array}$ & Memorial \\
\hline 1982 & Ensino & $\begin{array}{l}\text { Escola embrião para } \\
\text { conjunto habitacional em } \\
\text { Cotia }\end{array}$ & Cotia, SP & $\begin{array}{l}\text { Contratante: CONESP - Companhia de } \\
\text { Construções Escolares do Estado de São Paulo }\end{array}$ & Memorial \\
\hline 1982 & Residência & $\begin{array}{l}\text { Residência Paulo Sérgio } \\
\text { Raschkovsky }\end{array}$ & $\begin{array}{l}\text { Rua Jesuíno Maciel, } \\
\text { 1.479, São Paulo, SP }\end{array}$ & Contratante: Paulo Sérgio Raschkovsky & Memorial \\
\hline 1982 & $\begin{array}{l}\text { Agência } \\
\text { Bancária }\end{array}$ & BANESPA Lindóia & Lindóia, SP & $\begin{array}{l}\text { Contratante: BANESPA - Banco do Estado de São } \\
\text { Paulo }\end{array}$ & $\begin{array}{l}\text { Memorial } \\
\text { caixa } 27 \\
\text { tubo } 135\end{array}$ \\
\hline 1982 & Residência & $\begin{array}{l}\text { Residência Cilene e Raphael } \\
\text { d’Amico }\end{array}$ & São Paulo, SP & $\begin{array}{l}\text { Contratante: Raphael d’Amico } \\
\text { Reforma }\end{array}$ & tubo 132 \\
\hline 1982 & Interiores & Stand Reago & $\begin{array}{l}\text { Parque Anhembi, São } \\
\text { Paulo, SP }\end{array}$ & $\begin{array}{l}\text { Contratante: Reago Indústria e Comércio S.A. } \\
\text { Il Feira Nacional da Habitação }\end{array}$ & $\begin{array}{l}\text { Memorial } \\
\text { tubo } 132\end{array}$ \\
\hline 1983 & $\begin{array}{l}\text { Associação } \\
\text { Profissional }\end{array}$ & $\begin{array}{l}\text { Sede do Sindicado dos } \\
\text { Engenheiros no Estado de } \\
\text { São Paulo }\end{array}$ & $\begin{array}{l}\text { Rua Genebra, São Paulo, } \\
\text { SP }\end{array}$ & $\begin{array}{l}\text { Contratante: SEESP - Sindicado dos Engenheiros no } \\
\text { Estado de São Paulo } \\
\text { Reforma }\end{array}$ & caixa 10 \\
\hline 1983 & Ensino & $\begin{array}{l}\text { EEPG Conjunto } \\
\text { Habitacional dos } \\
\text { Metalúrgicos do } \mathrm{ABC}\end{array}$ & Ipiranga, São Paulo, SP & $\begin{array}{l}\text { Contratante: CONESP - Companhia de } \\
\text { Construções Escolares do Estado de São Paulo } \\
14 \text { salas de aula } \\
\text { Colaborador: Fausto C. de Lima }\end{array}$ & $\begin{array}{l}\text { Memorial } \\
\text { caixa } 28\end{array}$ \\
\hline 1983 & Serviço & Consultório Dr. Jorge Kignel & $\begin{array}{l}\text { Rua Oscar Freire, 465, cj. } \\
\text { 11, São Paulo, SP }\end{array}$ & $\begin{array}{l}\text { Contratante: Dr. Jorge Kignel } \\
\text { Reforma }\end{array}$ & tubo 149 \\
\hline
\end{tabular}




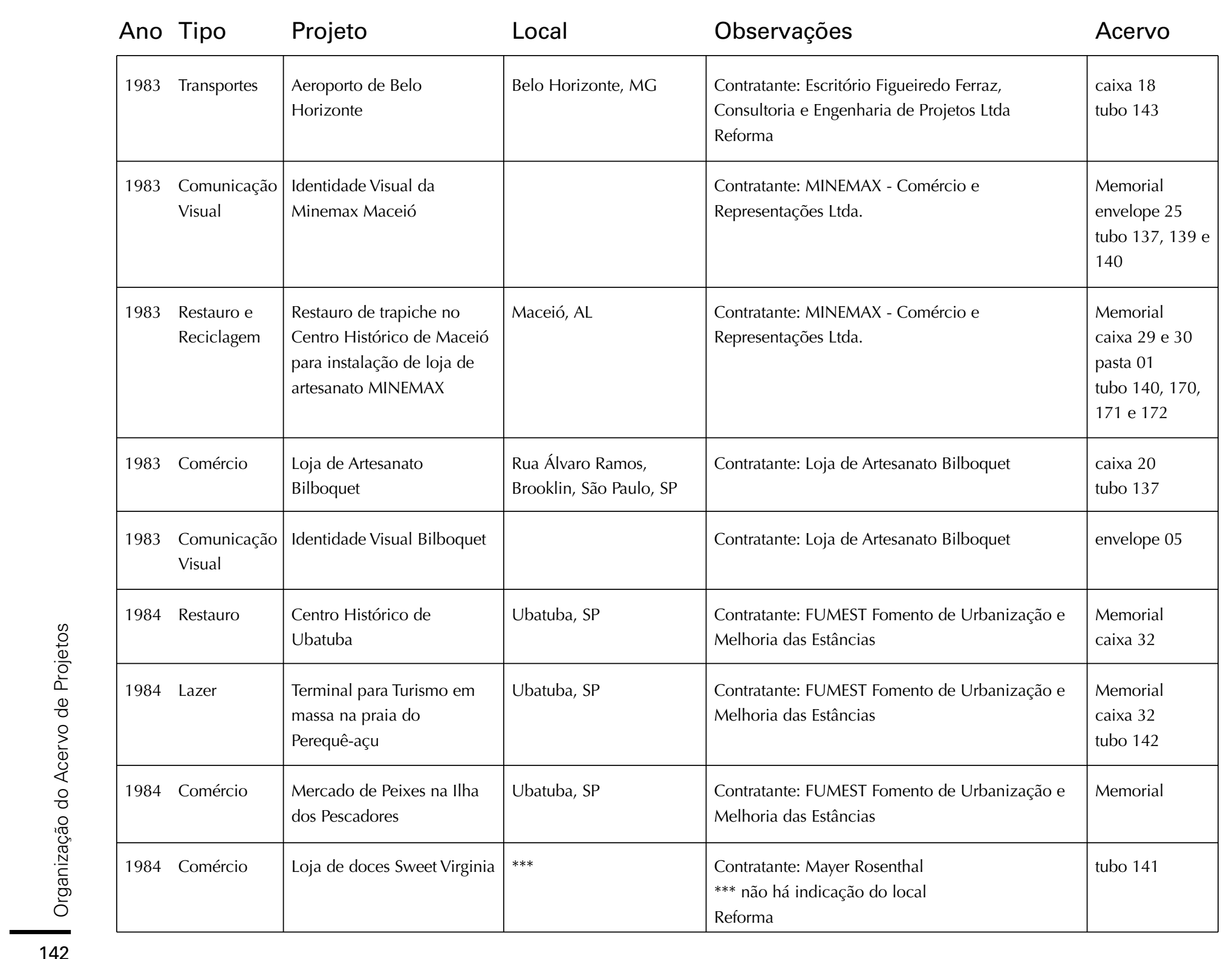




\begin{tabular}{|c|c|c|c|c|c|}
\hline Ano & Tipo & Projeto & Local & Observações & Acervo \\
\hline 1984 & Ensino & EEPG Jardim Maria Helena & Barueri, SP & $\begin{array}{l}\text { Contratante: CONESP - Companhia de } \\
\text { Construções Escolares do Estado de São Paulo }\end{array}$ & $\begin{array}{l}\text { Memorial } \\
\text { caixa } 27 \\
\text { tubo } 117 \text { e } 118\end{array}$ \\
\hline 1984 & Ensino & EEPG Jardim Pombeba & $\begin{array}{l}\text { Vila Fátima - São Vicente, } \\
\text { SP }\end{array}$ & $\begin{array}{l}\text { Contratante: CONESP - Companhia de } \\
\text { Construções Escolares do Estado de São Paulo }\end{array}$ & Memorial \\
\hline 1984 & Residência & Residência Antero Aceiro & $\begin{array}{l}\text { Rua 4, Quadra F, Lote } 4 \\
\text { Loteamento Dom } \\
\text { Henrique II - Cotia, SP }\end{array}$ & Contratante: Antero Aceiro & $\begin{array}{l}\text { Memorial } \\
\text { tubo } 149 \text { e } 153\end{array}$ \\
\hline 1984 & Reciclagem & $\begin{array}{l}\text { Conjunto Grande-Hotel, } \\
\text { Projeto de Balneário e } \\
\text { Centro de Convenções }\end{array}$ & Campos do Jordão, SP & $\begin{array}{l}\text { Contratante: FUMEST Fomento de Urbanização e } \\
\text { Melhoria das Estâncias }\end{array}$ & $\begin{array}{l}\text { Memorial } \\
\text { caixa } 38 \\
\text { pasta } 23 \\
\text { tubo } 145 \text { a } 148\end{array}$ \\
\hline 1984 & Concurso & $\begin{array}{l}\text { Biblioteca Pública do Rio de } \\
\text { Janeiro }\end{array}$ & Rio de Janeiro, RJ & Promotor: IAB RJ & tubo 144 e 149 \\
\hline 1984 & Concurso & Memorial a Getúlio Vargas & Rio de Janeiro, RJ & Promotor: IAB RJ & $\begin{array}{l}\text { envelope } 13 \\
\text { tubo } 144\end{array}$ \\
\hline 1984 & Ensino & EEPG Jardim Itaquiti & Barueri, SP & $\begin{array}{l}\text { Contratante: CONESP - Companhia de } \\
\text { Construções Escolares do Estado de São Paulo } \\
11 \text { salas de aula }\end{array}$ & $\begin{array}{l}\text { Memorial } \\
\text { caixa } 17\end{array}$ \\
\hline $1984^{*}$ & Ensino & EEPG Jardim Cabuçu & Guarulhos, SP & $\begin{array}{l}\text { Contratante: CONESP - Companhia de } \\
\text { Construções Escolares do Estado de São Paulo } \\
\text { * e } 1985\end{array}$ & Memorial \\
\hline $1984^{*}$ & Ensino & EEPG Jardim das Rosas & $\begin{array}{l}\text { Espírito Santo do Pinhal, } \\
\text { SP }\end{array}$ & $\begin{array}{l}\text { Contratante: CONESP - Companhia de } \\
\text { Construções Escolares do Estado de São Paulo } \\
\text { * e } 1985\end{array}$ & $\begin{array}{l}\text { Memorial } \\
\text { tubo } 149 \text { e } 152 \\
\text { Sistematização }\end{array}$ \\
\hline
\end{tabular}




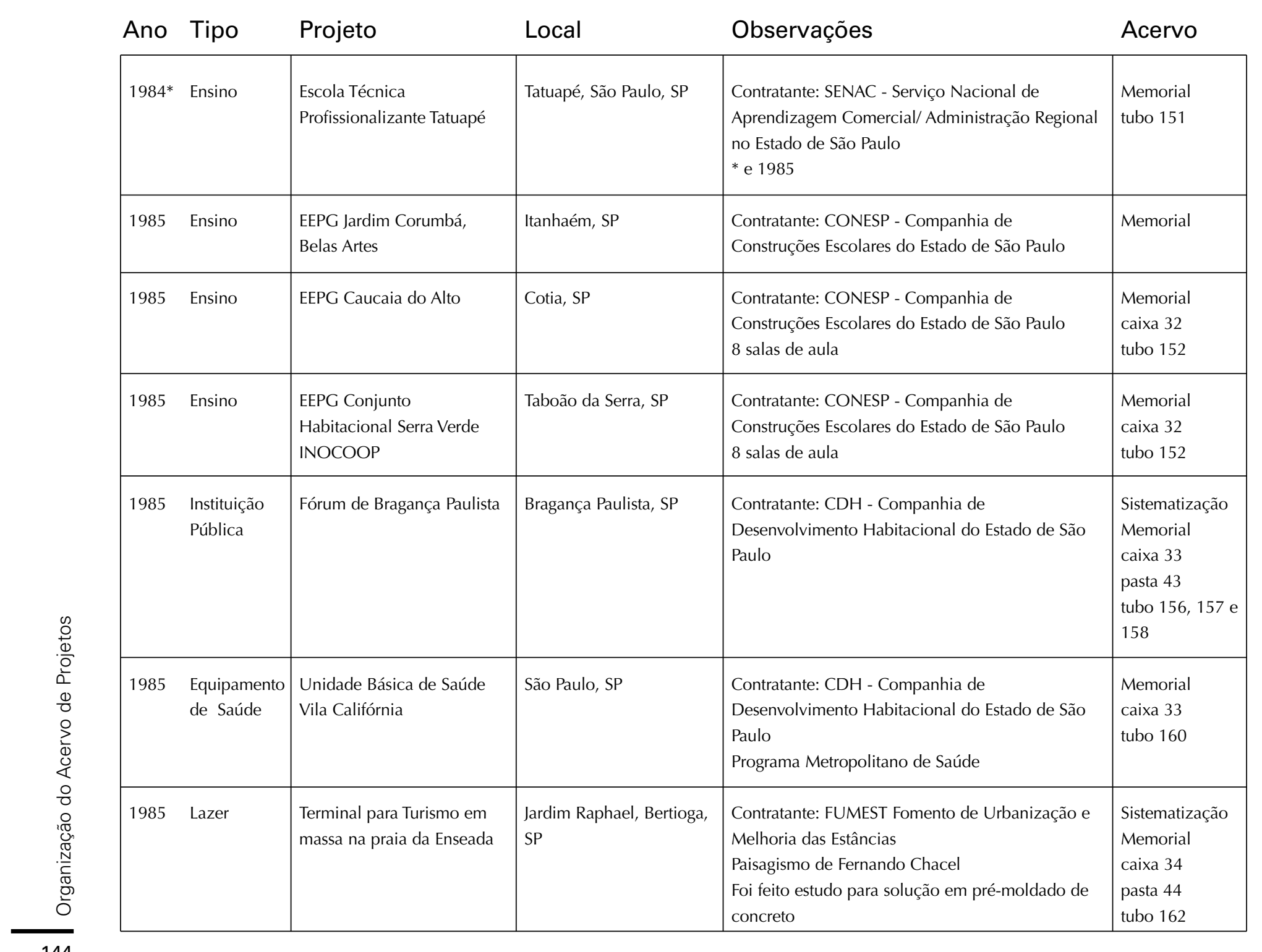




\begin{tabular}{|c|c|c|c|c|c|}
\hline Ano & Tipo & Projeto & Local & Observações & Acervo \\
\hline 1985 & Residência & Residência Edgard Blücher & $\begin{array}{l}\text { Rua Desembargador } \\
\text { Mamede, 185, Jardim } \\
\text { América, São Paulo, SP }\end{array}$ & Contratante: Edgard Blücher & $\begin{array}{l}\text { Memorial } \\
\text { tubo } 154 \text { e } 155\end{array}$ \\
\hline 1986 & Ensino & EEPG Jardim São Fernando & Ferraz de Vasconcelos, SP & $\begin{array}{l}\text { Contratante: CONESP -Companhia de Construções } \\
\text { Escolares do Estado de São Paulo } \\
10 \text { salas de aula }\end{array}$ & $\begin{array}{l}\text { Memorial } \\
\text { caixa } 33 \\
\text { tubo } 159\end{array}$ \\
\hline 1986 & Ensino & $\begin{array}{l}\text { EEPG Distrito Raposo } \\
\text { Tavares }\end{array}$ & $\begin{array}{l}\text { Vargem Grande Paulista, } \\
\text { SP }\end{array}$ & $\begin{array}{l}\text { Contratante: CONESP -Companhia de Construções } \\
\text { Escolares do Estado de São Paulo } \\
6 \text { salas de aula }\end{array}$ & $\begin{array}{l}\text { Memorial } \\
\text { caixa } 33\end{array}$ \\
\hline 1986 & Ensino & EEPG Jardim Campos & $\begin{array}{l}\text { Jardim Bartira. São Miguel } \\
\text { Paulista, São Paulo, SP }\end{array}$ & $\begin{array}{l}\text { Contratante: CONESP -Companhia de Construções } \\
\text { Escolares do Estado de São Paulo }\end{array}$ & $\begin{array}{l}\text { Memorial } \\
\text { tubo } 159\end{array}$ \\
\hline 1986 & Serviços & Estacionamento Cuiabá & $\begin{array}{l}\text { Praça Alencastro, Cuiabá, } \\
\text { MT }\end{array}$ & Contratante: Construtora Wysling Gomes Ltda & tubo 161 \\
\hline 1986 & Saúde & $\begin{array}{l}\text { Unidade Básica de Saúde } \\
\text { Vila Paranavaí }\end{array}$ & Mauá, SP & $\begin{array}{l}\text { Contratante: } \mathrm{CDH} \text { - Companhia de } \\
\text { Desenvolvimento Habitacional do Estado de São } \\
\text { Paulo } \\
\text { Programa Metropolitano de Saúde }\end{array}$ & $\begin{array}{l}\text { Memorial } \\
\text { caixa } 33 \\
\text { tubo } 161\end{array}$ \\
\hline 1986 & Ensino & EEPG Jardim São Nicolau & $\begin{array}{l}\text { Rua Aníbal Falcão, Jardim } \\
\text { Aurora, Itaquera, São } \\
\text { Paulo, SP }\end{array}$ & $\begin{array}{l}\text { Contratante: CONESP -Companhia de Construções } \\
\text { Escolares do Estado de São Paulo } \\
18 \text { salas de aula }\end{array}$ & $\begin{array}{l}\text { Memorial } \\
\text { caixa } 36 \\
\text { tubo } 163\end{array}$ \\
\hline 1986 & $\begin{array}{l}\text { Agência } \\
\text { Bancária }\end{array}$ & BANESPA Recife & $\begin{array}{l}\text { Rua Conde da Boa Vista } \\
\text { Com Rua do Hospício } \\
\text { Recife, PE }\end{array}$ & $\begin{array}{l}\text { Contratante: BANESPA - Banco do Estado de São } \\
\text { Paulo } \\
\text { Área total construída de } 2.371,70 \mathrm{~m}^{2}\end{array}$ & $\begin{array}{l}\text { Memorial } \\
\text { caixa } 34 \text { e } 35 \\
\text { pasta } 29 \\
\text { tubo } 164,165 \\
166\end{array}$ \\
\hline
\end{tabular}




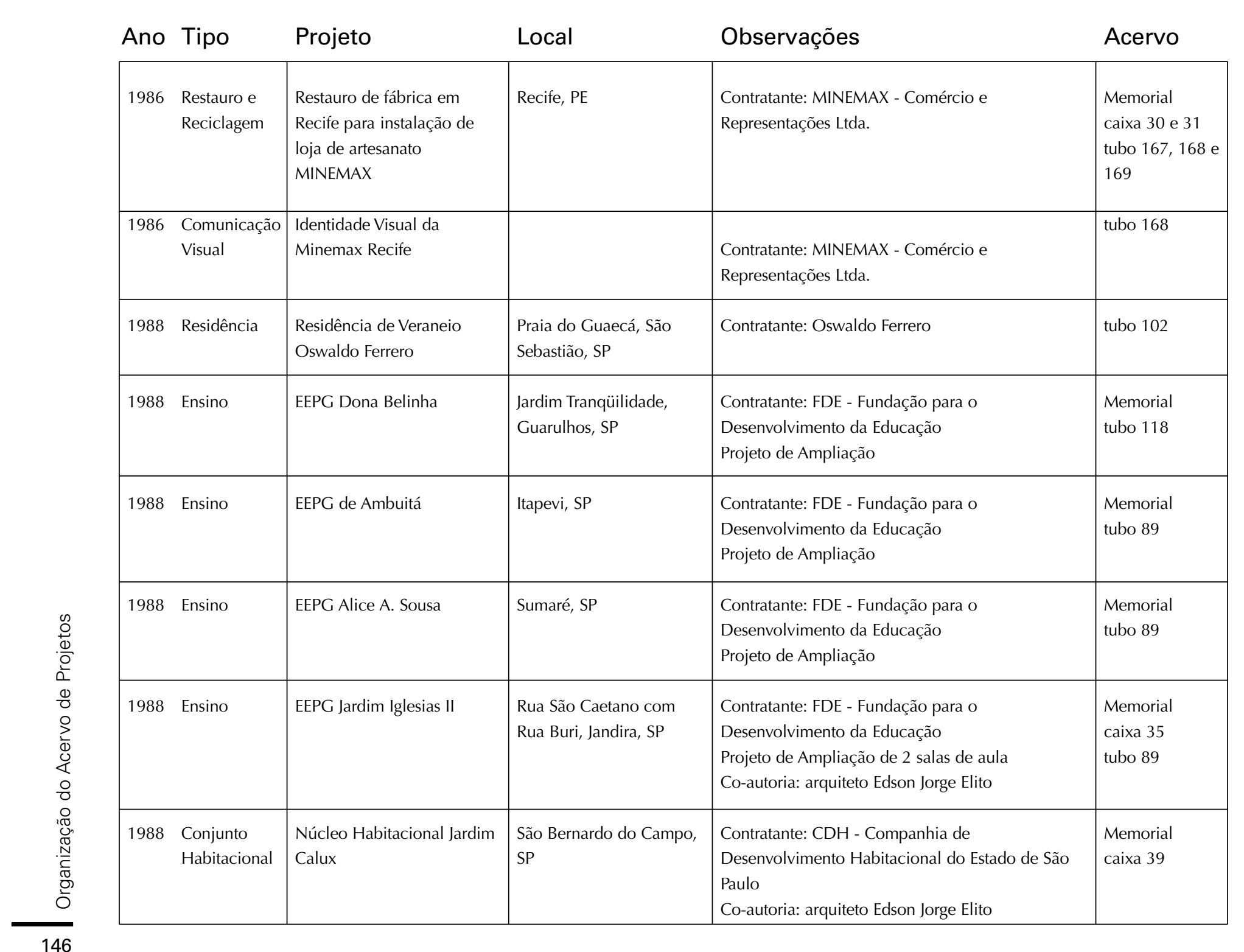




\begin{tabular}{|c|c|c|c|c|c|}
\hline Ano & Tipo & Projeto & Local & Observações & Acervo \\
\hline 1988 & Ensino & EEPG Canal 8, Cristo Rei & São José do Rio Preto, SP & $\begin{array}{l}\text { Colaborador: arquiteto Luiz Soares } \\
\text { Contratante: DOP - Departamento de Edifícios e } \\
\text { Obras Públicas }\end{array}$ & $\begin{array}{l}\text { Memorial } \\
\text { tubo118 }\end{array}$ \\
\hline 1988 & Ensino & $\begin{array}{l}\text { EEPG Conjunto } \\
\text { Habitacional Solo Sagrado }\end{array}$ & São José do Rio Preto, SP & $\begin{array}{l}\text { Contratante: DOP - Departamento de Edifícios e } \\
\text { Obras Públicas }\end{array}$ & $\begin{array}{l}\text { Memorial } \\
\text { tubo } 118\end{array}$ \\
\hline 1988 & Ensino & EEPG Jardim Saltense & Salto, SP & $\begin{array}{l}\text { Contratante: DOP - Departamento de Edifícios e } \\
\text { Obras Públicas } \\
4 \text { salas de aula e previsão de ampliação para } 10\end{array}$ & $\begin{array}{l}\text { Memorial } \\
\text { caixa } 36 \\
\text { tubo } 89\end{array}$ \\
\hline 1988 & Ensino & $\begin{array}{l}\text { EEPG Conjunto } \\
\text { Habitacional Nosso Teto }\end{array}$ & Catanduva, SP & $\begin{array}{l}\text { Contratante: DOP - Departamento de Edifícios e } \\
\text { Obras Públicas }\end{array}$ & $\begin{array}{l}\text { Memorial } \\
\text { tubo } 89\end{array}$ \\
\hline 1988 & Ensino & $\begin{array}{l}\text { EEPG Jardim Novo } \\
\text { Horizonte }\end{array}$ & Sorocaba SP & $\begin{array}{l}\text { Contratante: DOP - Departamento de Edifícios e } \\
\text { Obras Públicas }\end{array}$ & Memorial \\
\hline 1988 & Ensino & EEPG Vila Nova Esperança & Sorocaba, SP & $\begin{array}{l}\text { Contratante: DOP - Departamento de Edifícios e } \\
\text { Obras Públicas }\end{array}$ & $\begin{array}{l}\text { Memorial } \\
\text { tubo } 95 \text { e } 96\end{array}$ \\
\hline 1988 & Ensino & EEPG Jardim Guaíba & Sorocaba, SP & $\begin{array}{l}\text { Contratante: DOP - Departamento de Edifícios e } \\
\text { Obras Públicas }\end{array}$ & $\begin{array}{l}\text { Memorial } \\
\text { tubo } 96\end{array}$ \\
\hline 1988 & $\begin{array}{l}\text { Instituição } \\
\text { Pública }\end{array}$ & $\begin{array}{l}\text { Usina de Beneficiamento de } \\
\text { Algodão em Aguaí }\end{array}$ & Aguaí, SP & $\begin{array}{l}\text { Contratante: Secretaria da Agricultura do Estado de } \\
\text { São Paulo }\end{array}$ & $\begin{array}{l}\text { Memorial } \\
\text { tubo } 37,71 \text { e } 73\end{array}$ \\
\hline 1988 & Residência & Residência Elza Marba & $\begin{array}{l}\text { Jardim Europa - Campos } \\
\text { do Jordão, SP }\end{array}$ & $\begin{array}{l}\text { Contratante: Elza Marba } \\
\text { Área total construída } 186,58 \mathrm{~m}^{2}\end{array}$ & $\begin{array}{l}\text { Memorial } \\
\text { tubo } 107,108 \text { e } \\
138 .\end{array}$ \\
\hline 1988 & Ensino & EEPG Bairro do Cajurú & Sorocaba, SP & $\begin{array}{l}\text { Contratante: DOP - Departamento de Edifícios e } \\
\text { Obras Públicas }\end{array}$ & $\begin{array}{l}\text { Memorial } \\
\text { tubo } 121\end{array}$ \\
\hline
\end{tabular}




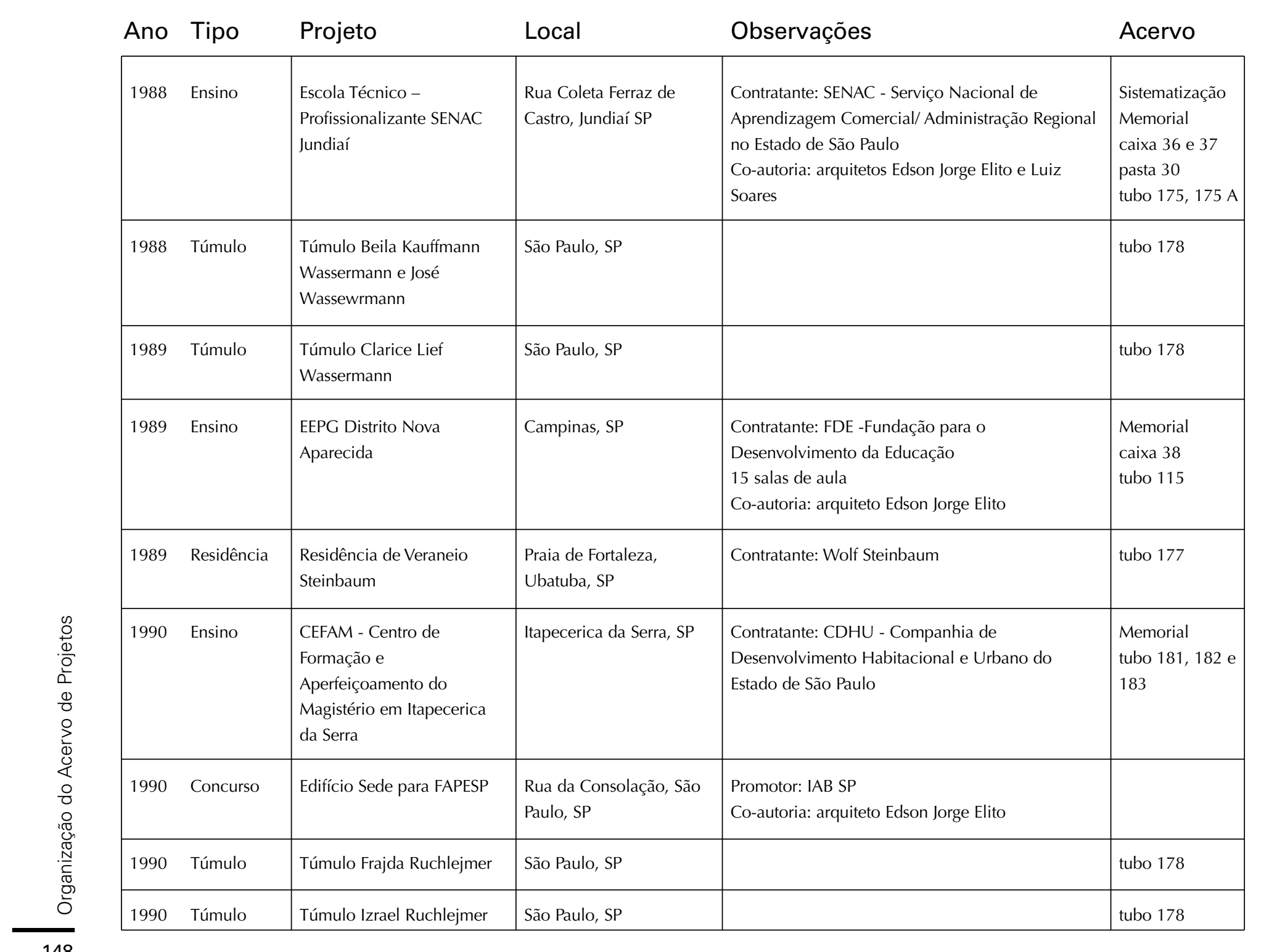




\begin{tabular}{|c|c|c|c|c|c|}
\hline Ano & Tipo & Projeto & Local & Observações & Acervo \\
\hline 1991 & Ensino & $\begin{array}{l}\text { EEPG Prof. Guines A. } \\
\text { Morales }\end{array}$ & Neves Paulista, SP & $\begin{array}{l}\text { Contratante: FDE -Fundação para o } \\
\text { Desenvolvimento da Educação } \\
12 \text { salas de aula } \\
\text { Co-autoria: arquiteto Edson Jorge Elito }\end{array}$ & $\begin{array}{l}\text { Memorial } \\
\text { caixa } 38 \\
\text { tubo } 186\end{array}$ \\
\hline 1991 & Urbanização & Loteamento em Salto & Salto, SP & $\begin{array}{l}\text { Contratante: } \mathrm{CDHU} \text { - Companhia de } \\
\text { Desenvolvimento Habitacional e Urbano do } \\
\text { Estado de São Paulo }\end{array}$ & $\begin{array}{l}\text { Memorial } \\
\text { tubo } 179\end{array}$ \\
\hline 1991 & Interiores & $\begin{array}{l}\text { Conjunto Restaurante, } \\
\text { Lanchonete, Cozinha e } \\
\text { Refeitório, no Edifício } \\
\text { Escolar Técnico- } \\
\text { Profissionalizante - SENAC } \\
\text { Moda e Beleza }\end{array}$ & $\begin{array}{l}\text { Av. Francisco Matarazzo, } \\
\text { São Paulo, SP }\end{array}$ & $\begin{array}{l}\text { Contratante: SENAC - Serviço Nacional de } \\
\text { Aprendizagem Comercial } \\
\text { Reforma } \\
\text { Co-autoria: arquiteto Edson Jorge Elito }\end{array}$ & $\begin{array}{l}\text { Memorial } \\
\text { caixa } 40 \text { e } 41 \\
\text { tubo } 180\end{array}$ \\
\hline 1991 & Ensino & EEPG Bairro 120 & Santana de Parnaíba, SP & $\begin{array}{l}\text { Contratante: FDE -Fundação para o } \\
\text { Desenvolvimento da Educação } \\
14 \text { salas de aula } \\
\text { Co-autoria: arquiteto Edson Jorge Elito }\end{array}$ & $\begin{array}{l}\text { Sistematização } \\
\text { Memorial } \\
\text { caixa } 40\end{array}$ \\
\hline 1992 & Ensino & $\begin{array}{l}\text { EEPG Conjunto } \\
\text { Habitacional Ipatinga }\end{array}$ & Sorocaba, SP & $\begin{array}{l}\text { Contratante: FDE -Fundação para o } \\
\text { Desenvolvimento da Educação }\end{array}$ & $\begin{array}{l}\text { Memorial } \\
\text { tubo } 187 \text { e } 18 \varepsilon\end{array}$ \\
\hline 1992 & $\begin{array}{l}\text { Restauro } \\
\text { Ensino }\end{array}$ & $\begin{array}{l}\text { EEPSG Conselheiro } \\
\text { Crispiniano }\end{array}$ & $\begin{array}{l}\text { Av. Timóteo Penteado } \\
\text { com Rua Nossa Senhora } \\
\text { Mãe dos Homens, } \\
\text { Guarulhos, SP }\end{array}$ & $\begin{array}{l}\text { Contratante: FDE -Fundação para o } \\
\text { Desenvolvimento da Educação } \\
\text { Restauro da Escola do arquiteto João Batista } \\
\text { Vilanova Artigas e ampliação }\end{array}$ & $\begin{array}{l}\text { Sistematização } \\
\text { Memorial } \\
\text { caixa } 41\end{array}$ \\
\hline 1992 & Serviços & $\begin{array}{l}\text { Sede da AFAEL - Associação } \\
\text { dos Fabricantes de Alumínio }\end{array}$ & São Paulo, SP & $\begin{array}{l}\text { Contratante: AFAEL } \\
\text { Reforma, área construída 1.006,74 m² }\end{array}$ & tubo 62 \\
\hline
\end{tabular}




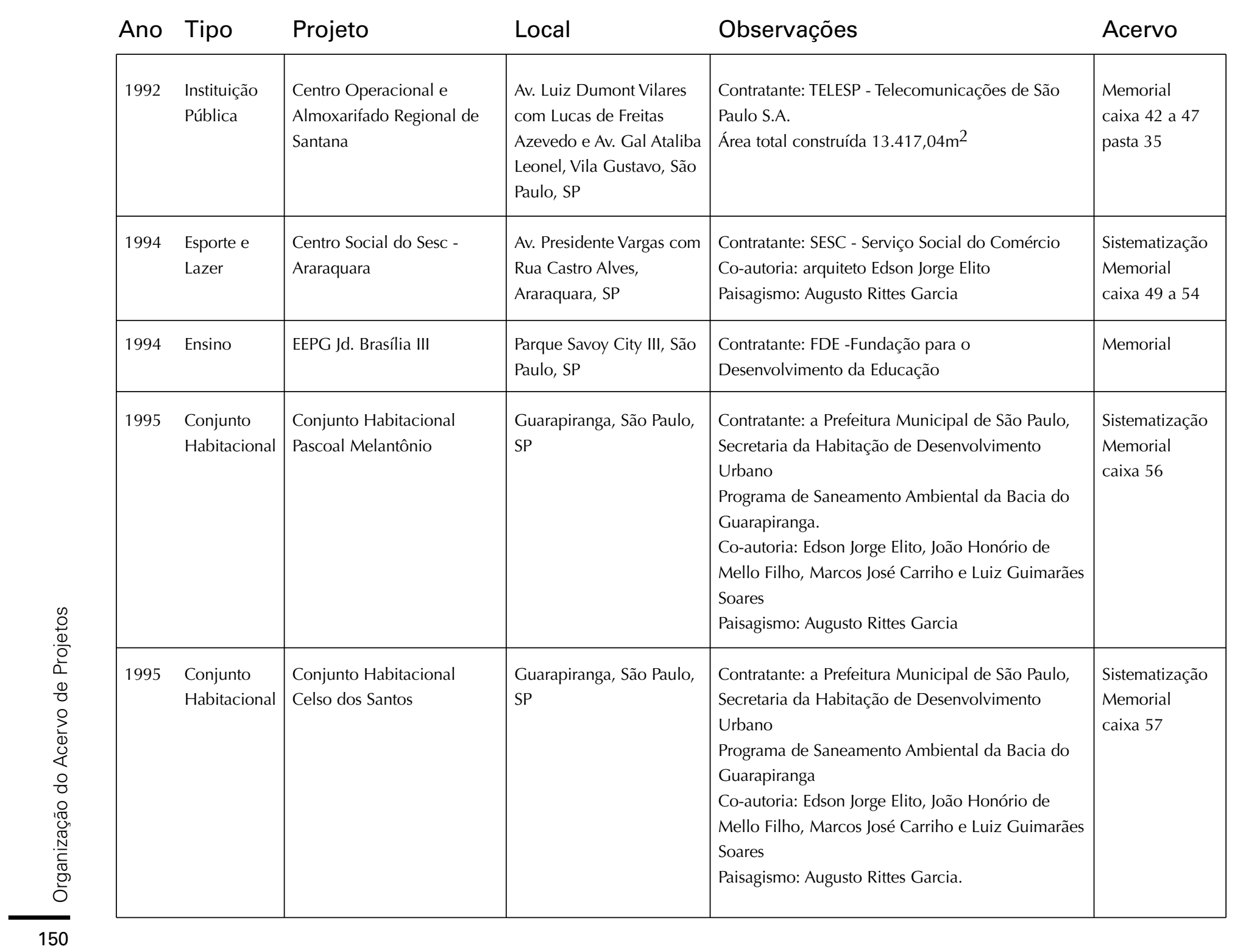




\begin{tabular}{|c|c|c|c|c|c|}
\hline Ano & Tipo & Projeto & Local & Observações & Acervo \\
\hline $1996 *$ & Ensino & $\begin{array}{l}\text { EEPSG Prof. José Quevedo, } \\
\text { Bairro do Cajurú }\end{array}$ & Sorocaba, SP & $\begin{array}{l}\text { Contratante: FDE - Fundação para o } \\
\text { Desenvolvimento da Educação } \\
\text { *e } 1997\end{array}$ & Memorial \\
\hline $1996^{*}$ & Ensino & EEPG Parque Piratininga II & Itaquaquecetuba, SP & $\begin{array}{l}\text { Contratante: FDE - Fundação para o } \\
\text { Desenvolvimento da Educação } \\
8 \text { salas de aula - área total construída } 1.734,84 \mathrm{~m}^{2} \\
\text { Co-autoria: Edson Jorge Elito } \\
{ }^{*} \text { e } 1997\end{array}$ & Memorial \\
\hline 1998 & $\begin{array}{l}\text { Instituição } \\
\text { Pública }\end{array}$ & Poupa Tempo Campinas & $\begin{array}{l}\text { Avenida Francisco } \\
\text { Glicério, Campinas, SP }\end{array}$ & $\begin{array}{l}\text { Contratante: Companhia de Processamento de } \\
\text { Dados do Estado de São Paulo - PRDESP } \\
\text { Área total construída } 3581,51 \mathrm{~m}^{2} \\
\text { Reforma } \\
\text { Co-autoria: Edson Jorge Elito }\end{array}$ & Memorial \\
\hline
\end{tabular}

(1) Memorial para Obtenção do Título de Livre Docente

(2) Sistematização Crítica da Obra para Obtenção do Título de Livre Docente

Alguns projetos que não têm registro de data, local e contratante, estão listados na próxima tabela. 


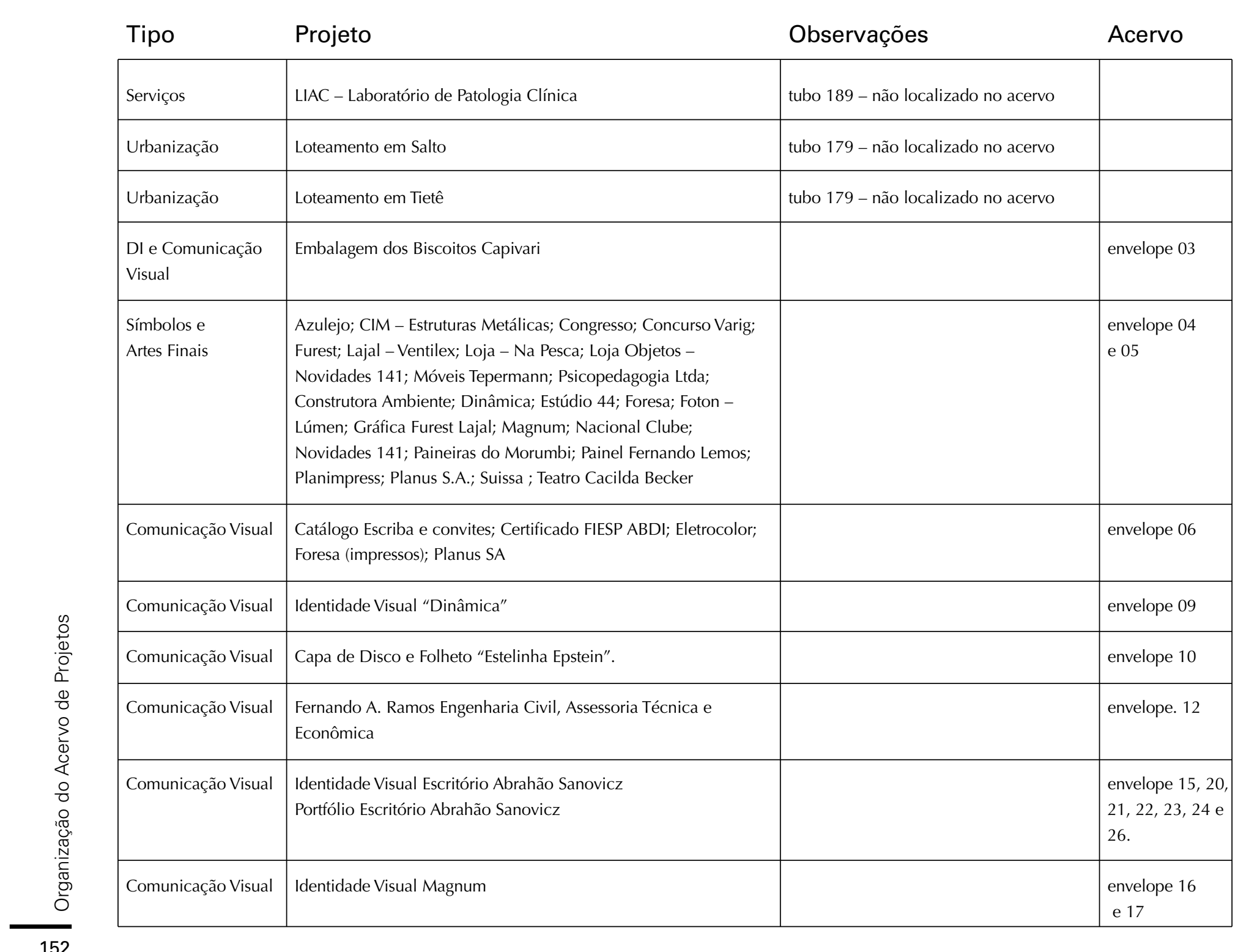




\section{Desenhos | Gravuras | Projetos}

\section{Desenhos}

Escola de Artesanato do MAM

Desenhos de reunião

Desenhos a pastel $\quad 168$

Outros desenhos

Gravuras

192

Projetos

199 



\section{Desenhos da Escola de Artesanato do MAM}

fonte de todos os desenhos: acervo de Diva Sanovicz
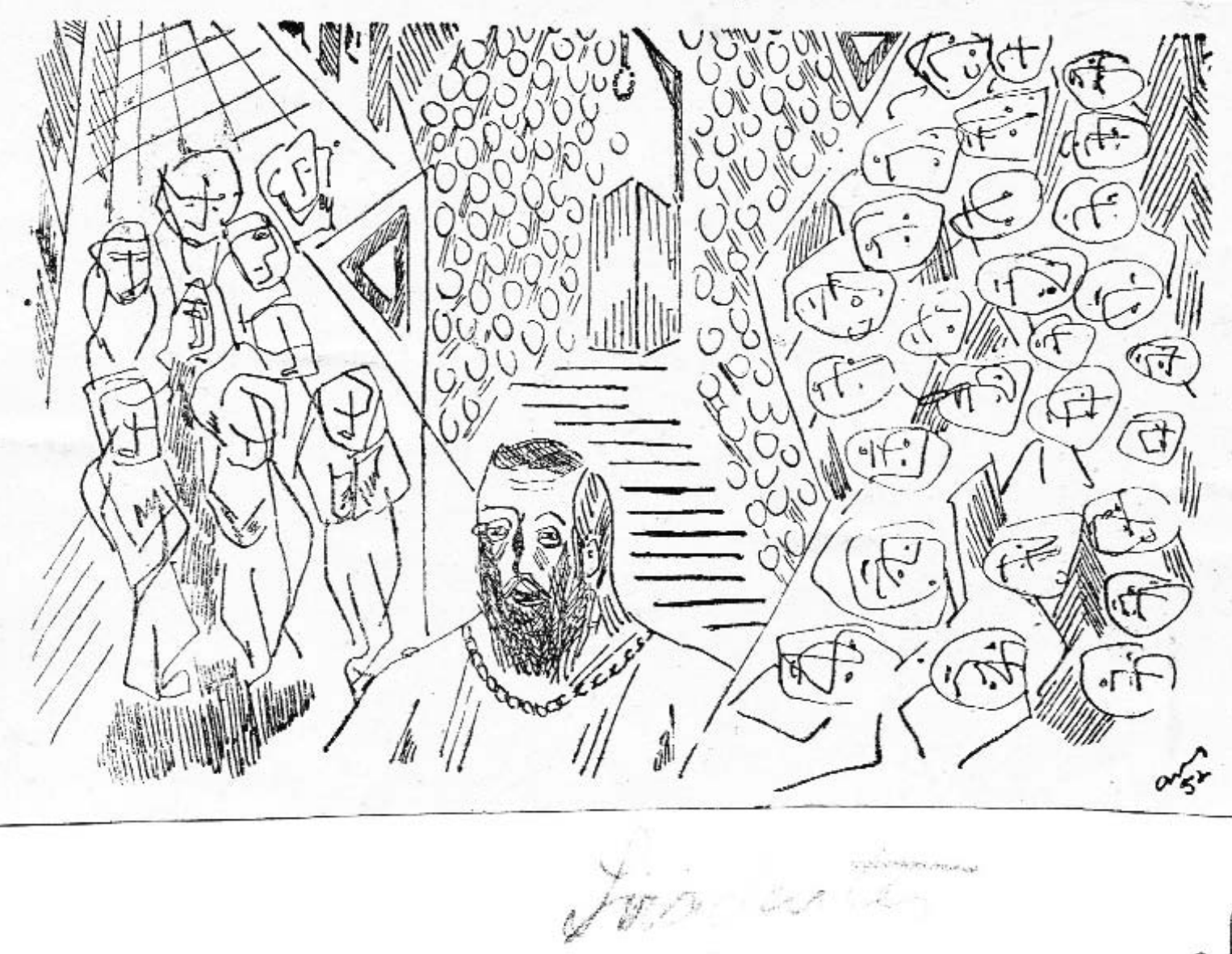


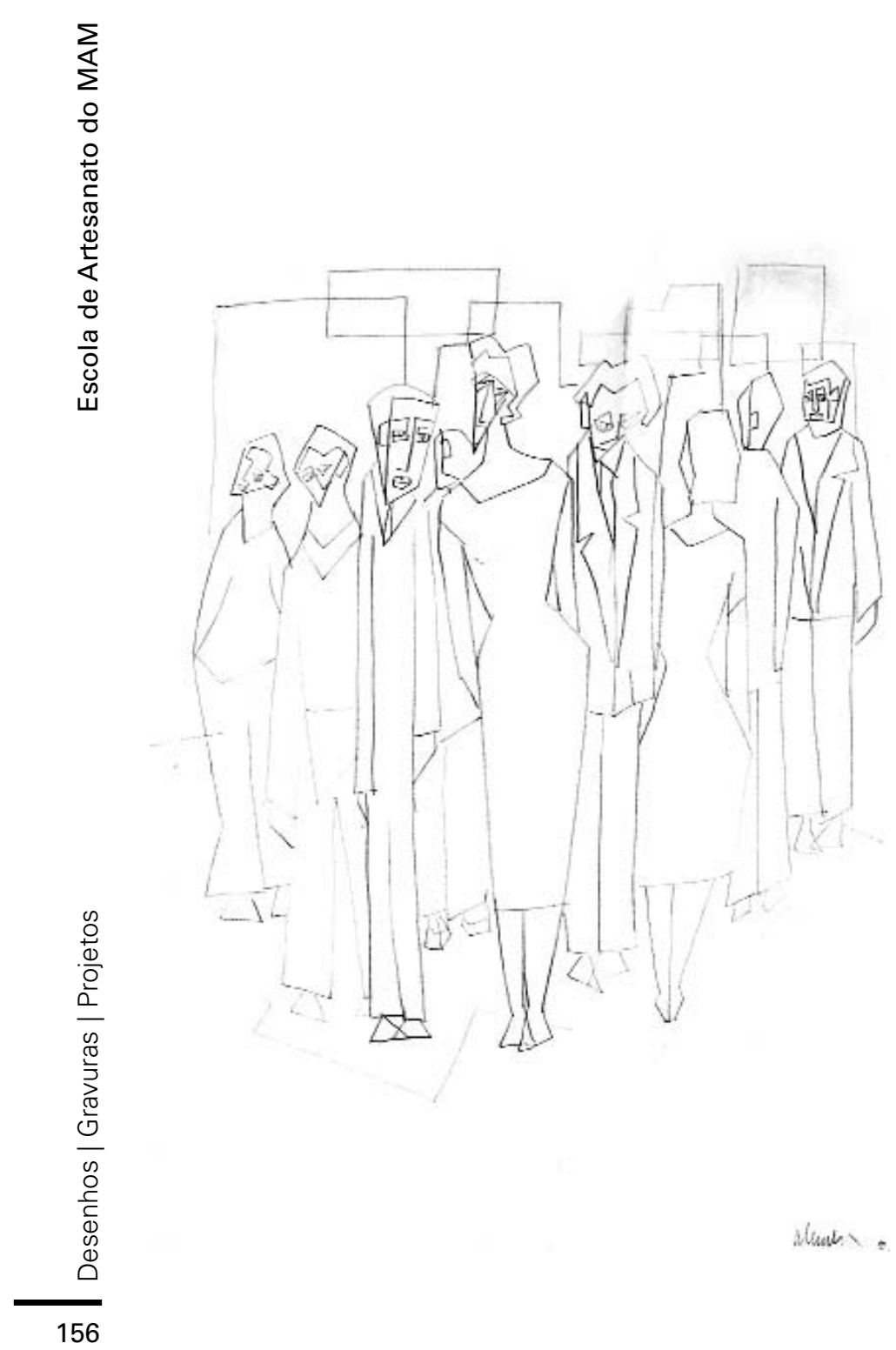



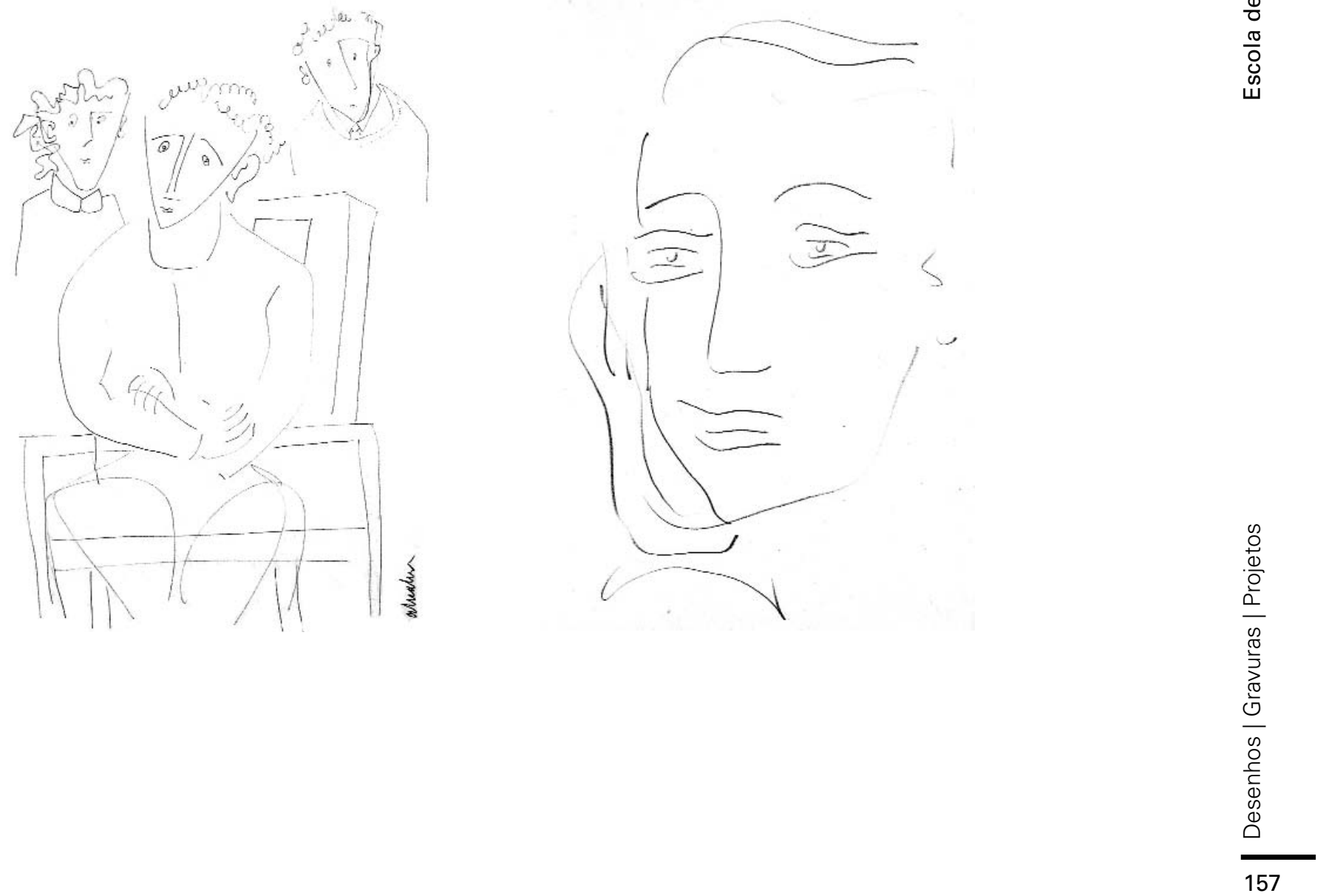

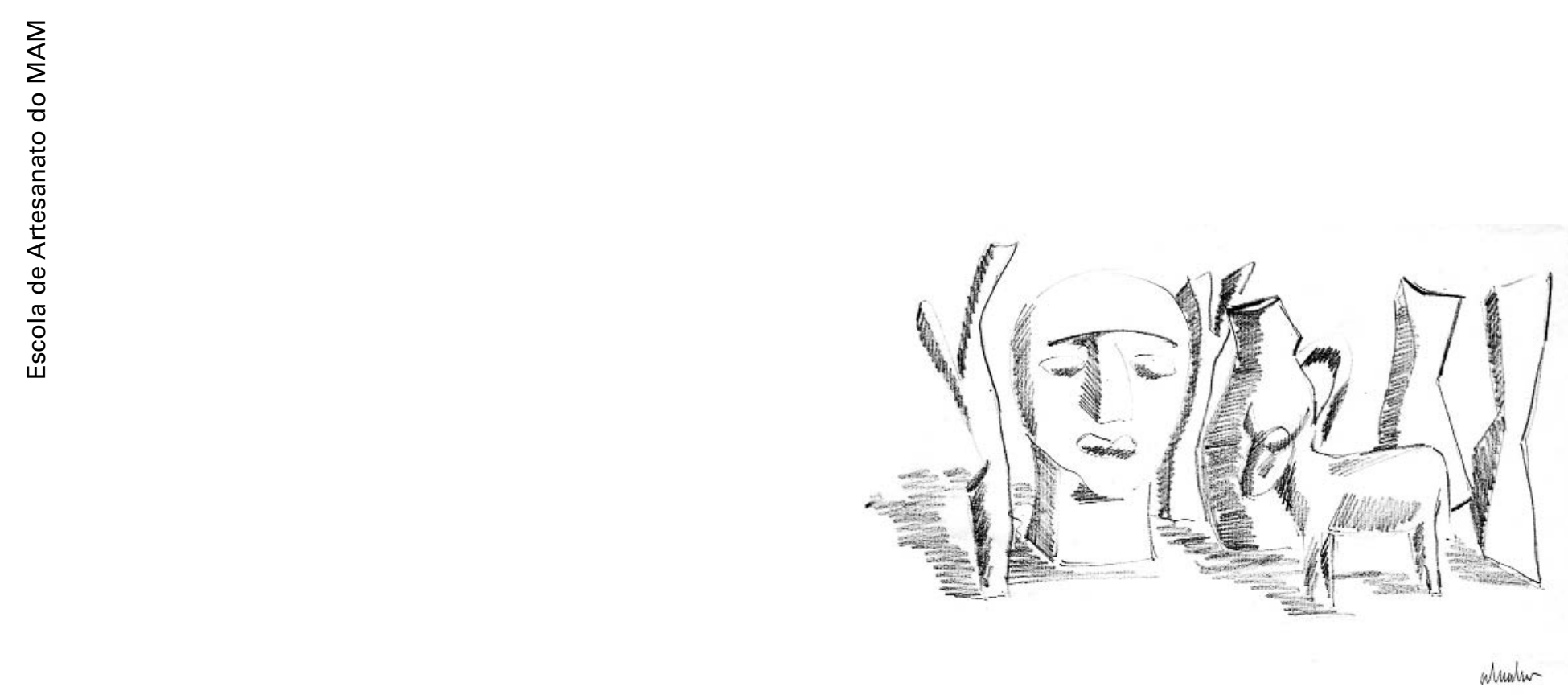

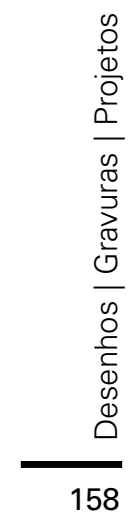

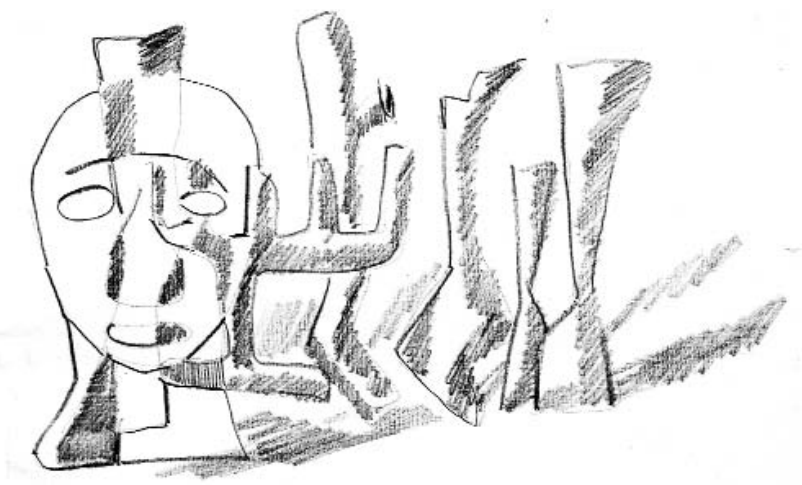




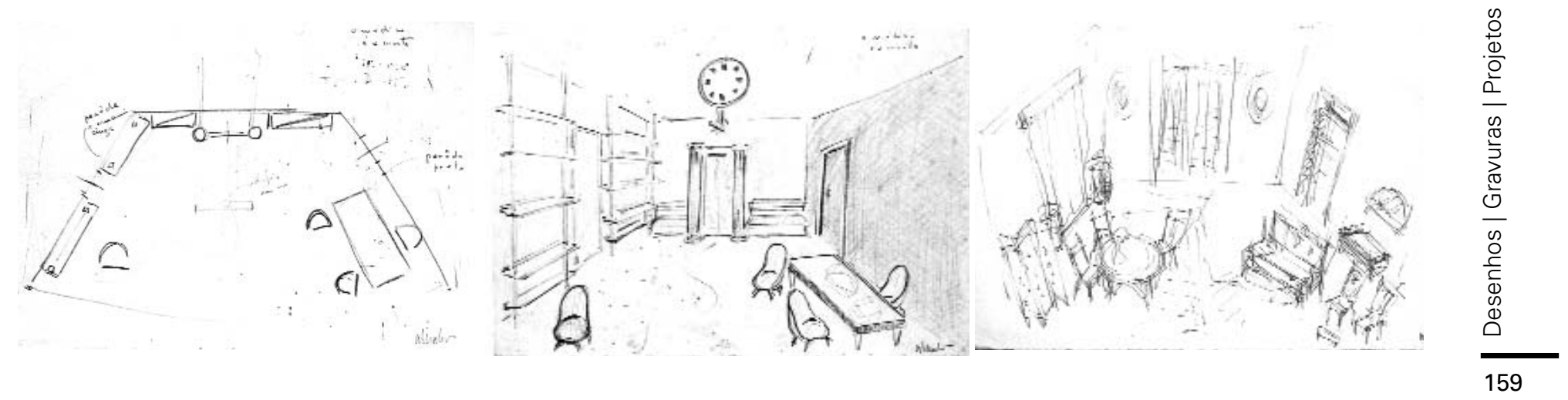



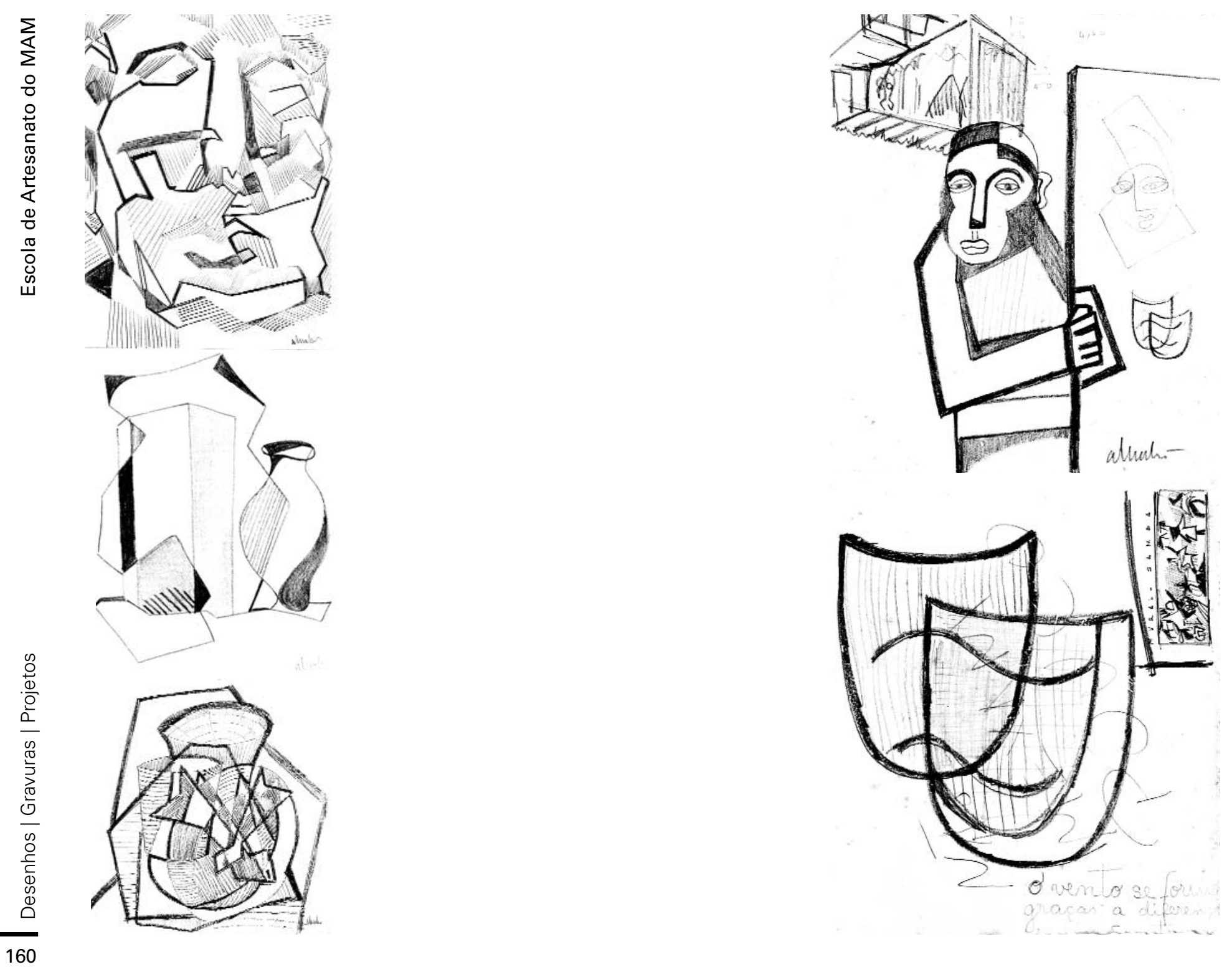


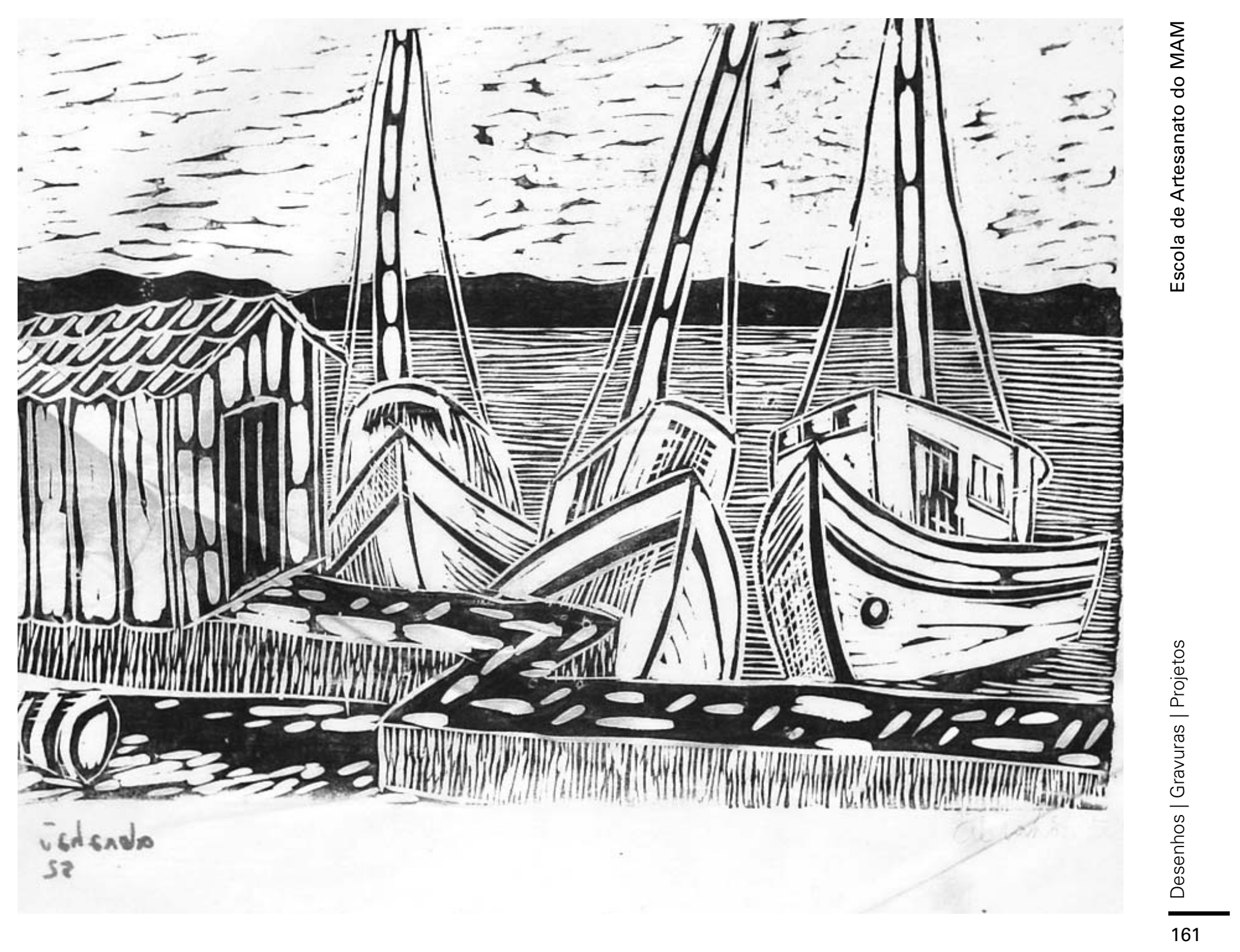


$\frac{0}{2}$
$\frac{\pi}{5}$
0
0
0
0
0
0
$\frac{1}{5}$
0
0
0
0

\section{Desenhos de reunião}

fonte de todos os desenhos: acervo de Diva Sanovicz

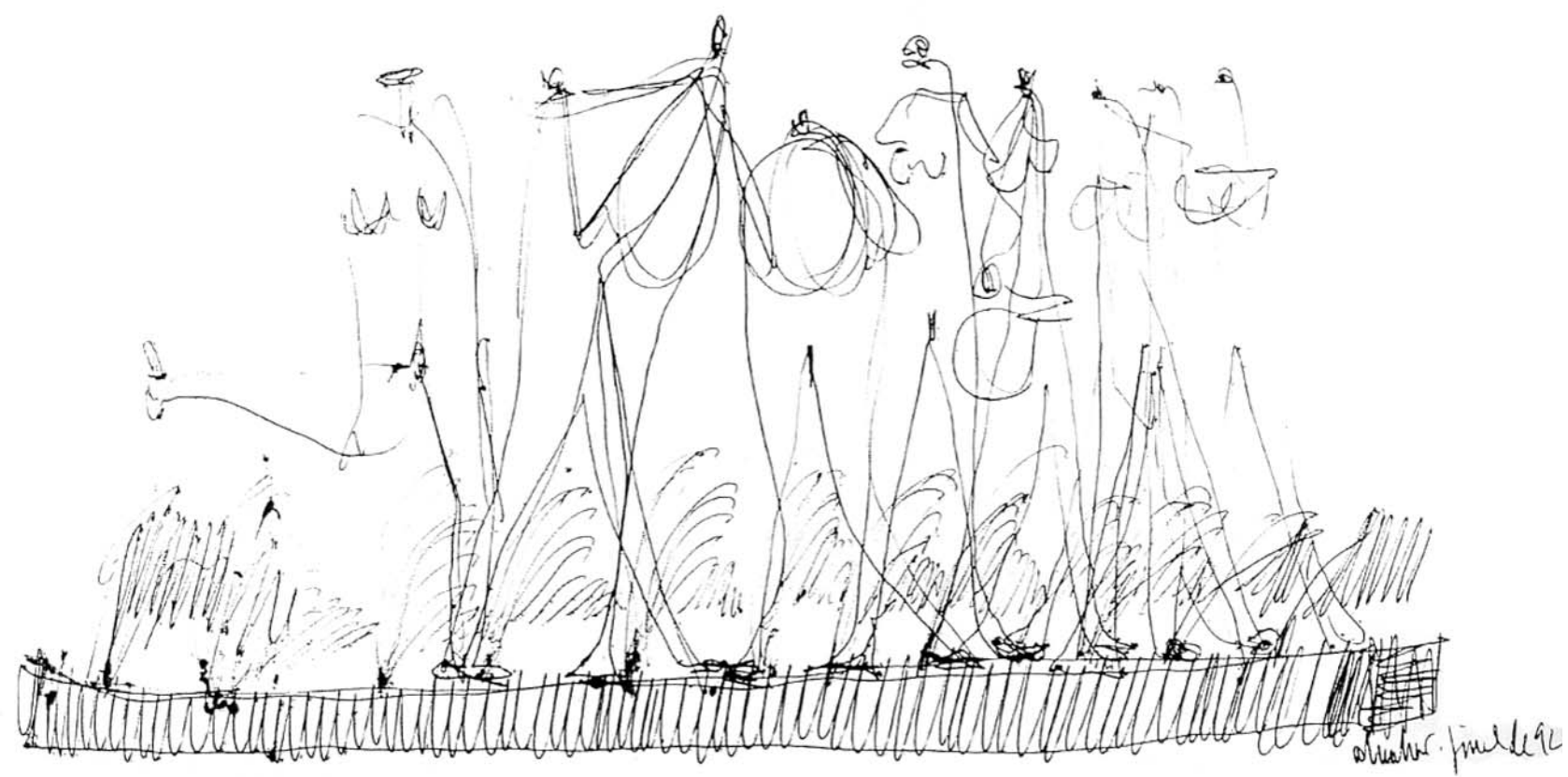




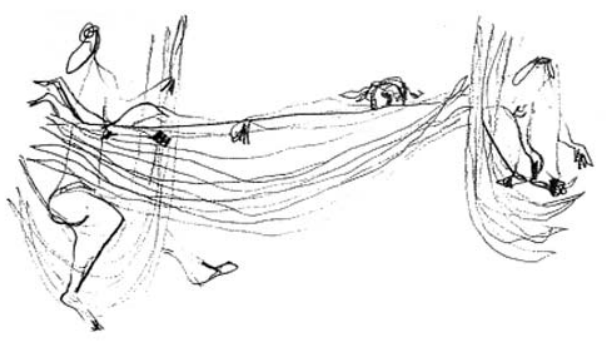

0
$\frac{0}{5}$
$\frac{1}{5}$
0
0
0
0
0
0
$\frac{1}{5}$
0
0
0
0
0

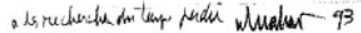
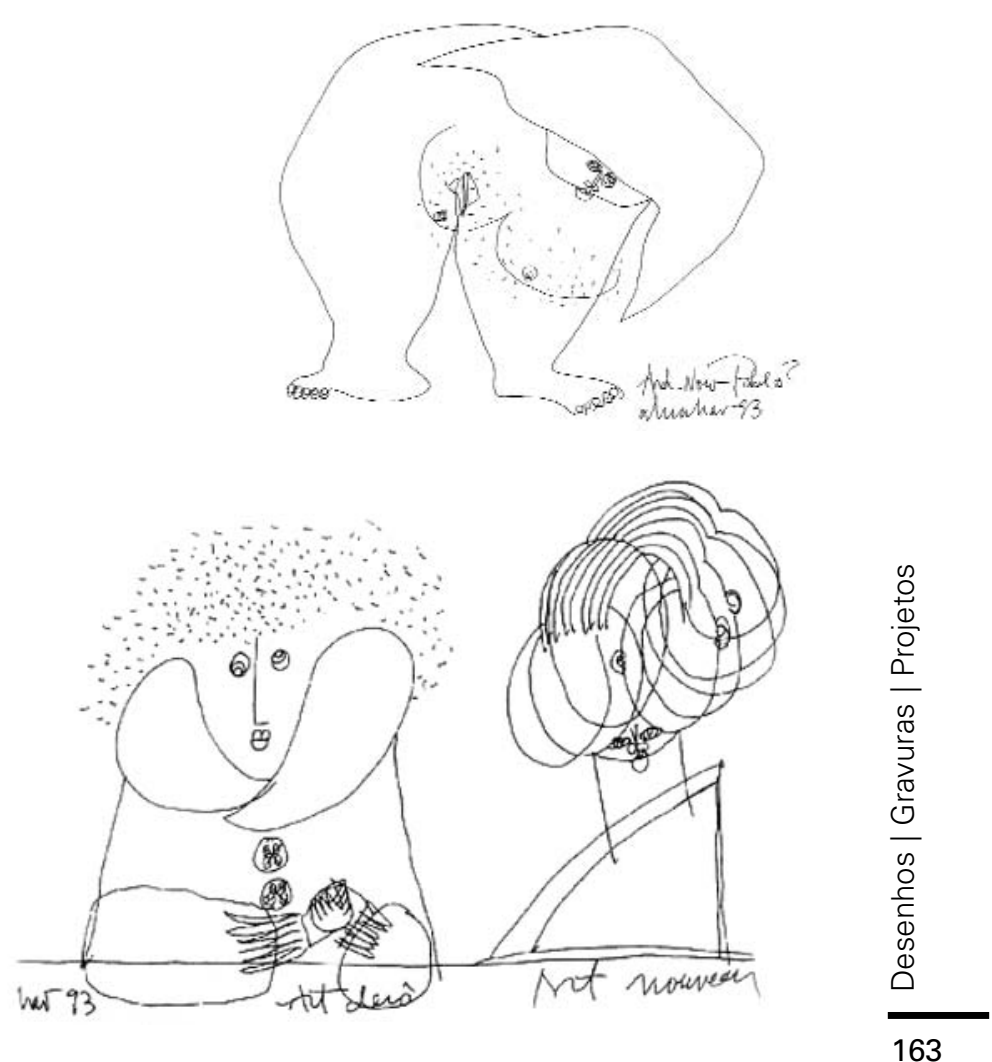


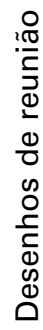

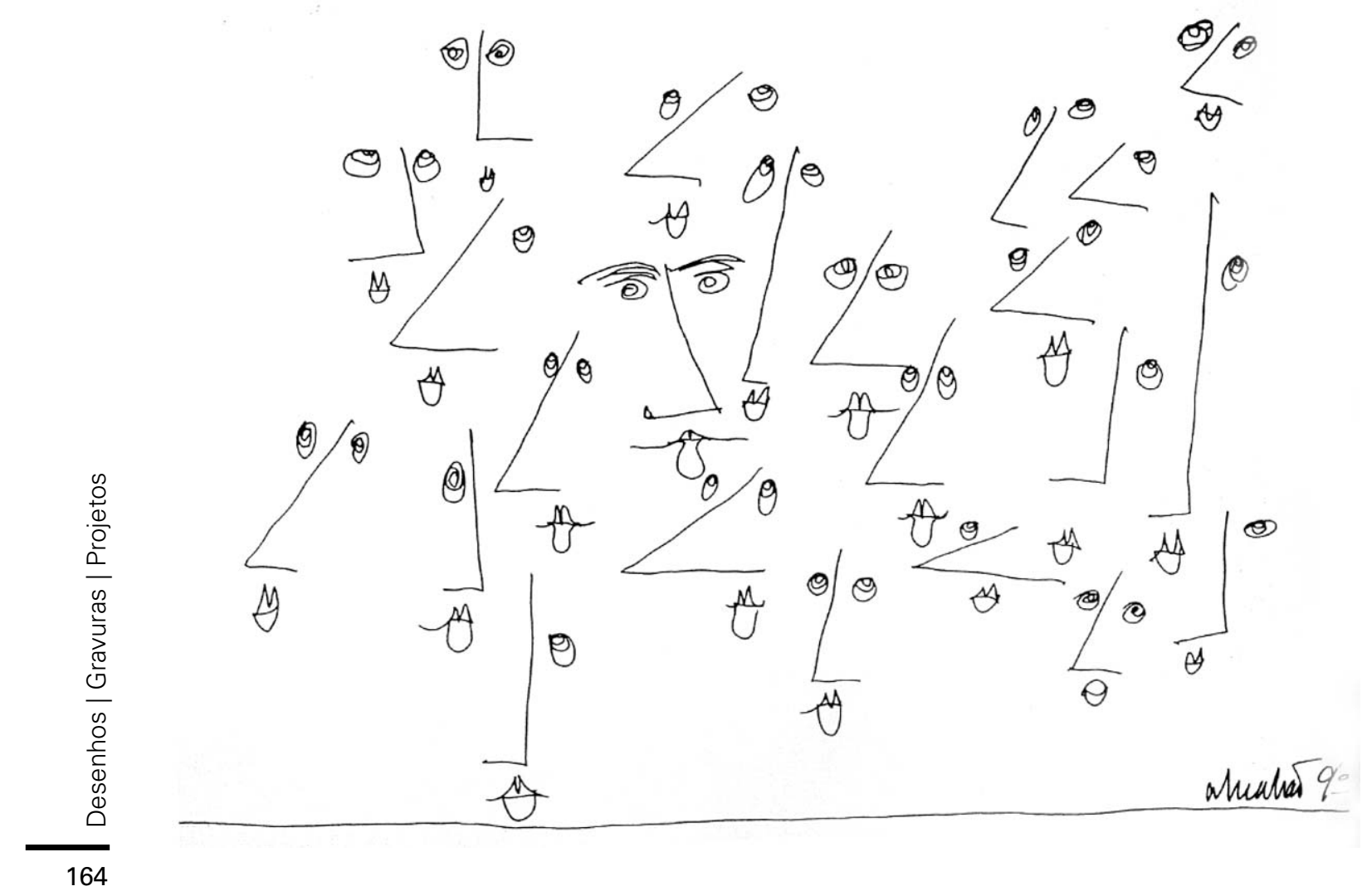




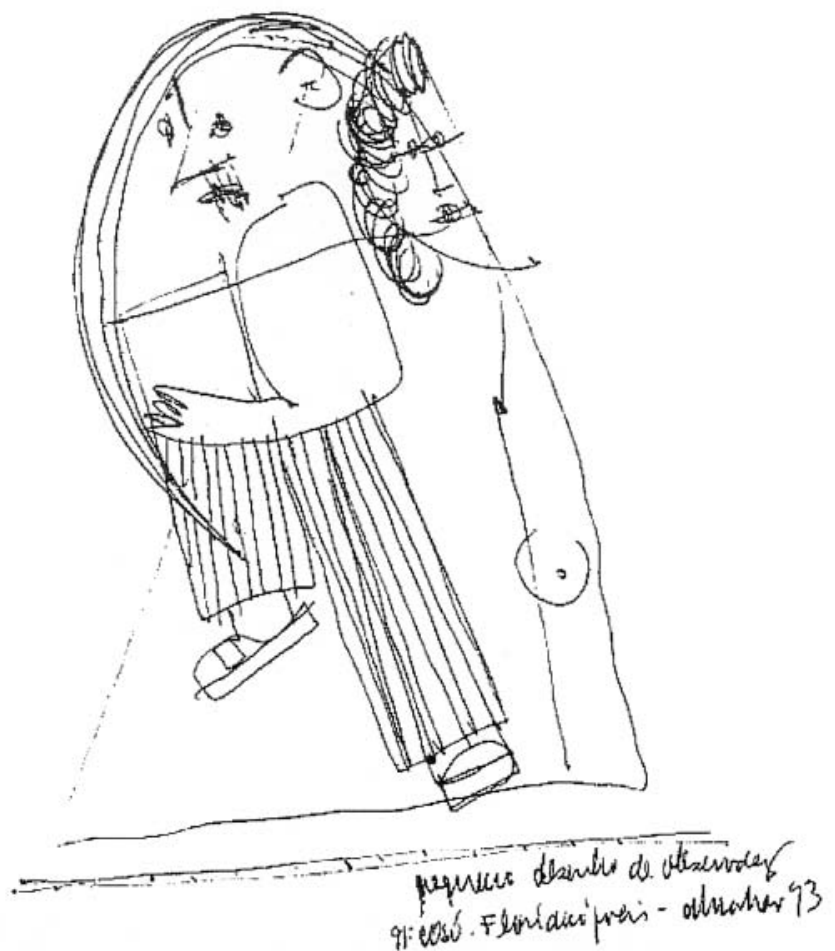

0
$? \frac{\pi}{5}$
0
0
0
0
0
0
0
$\frac{0}{0}$
0
0
0
0
0
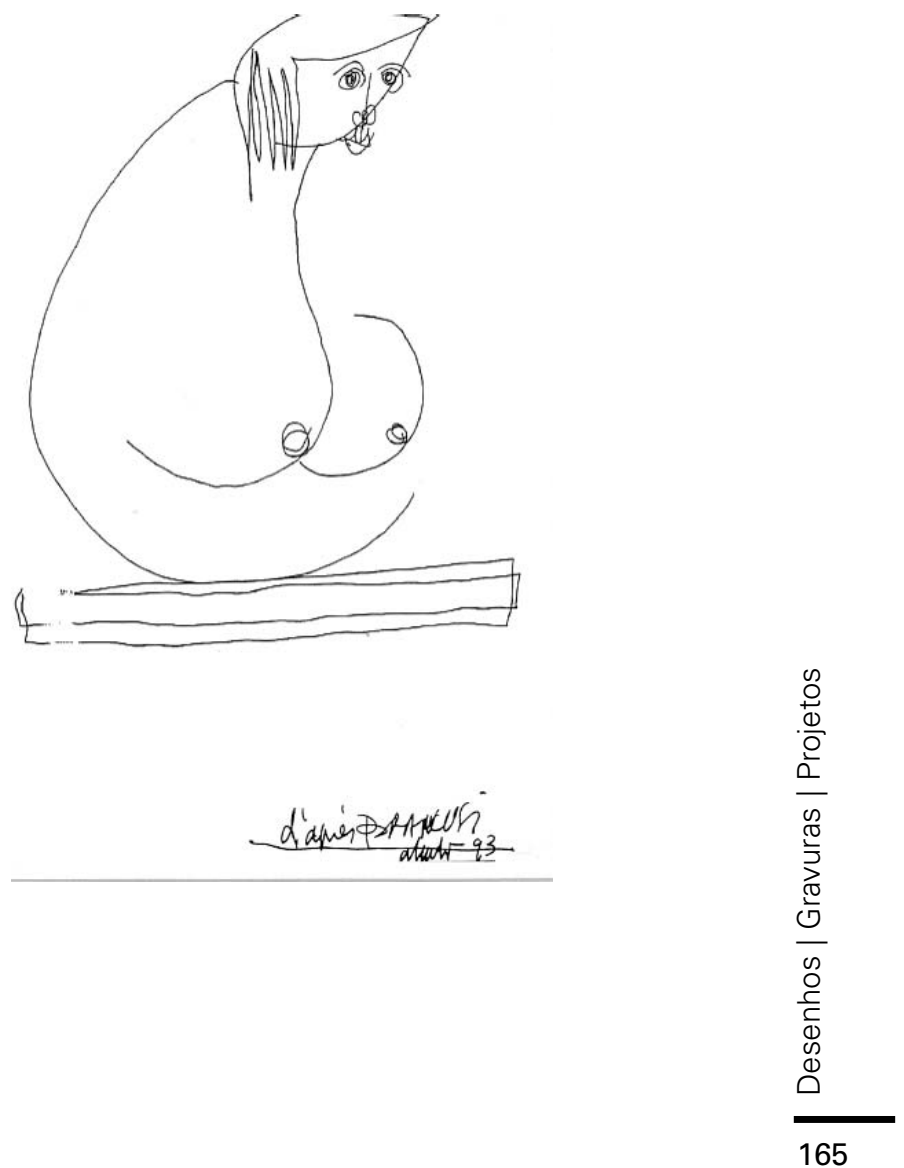


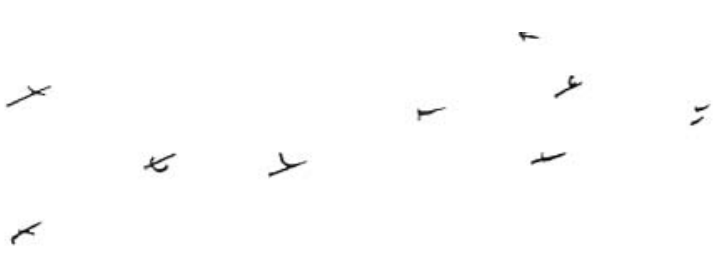

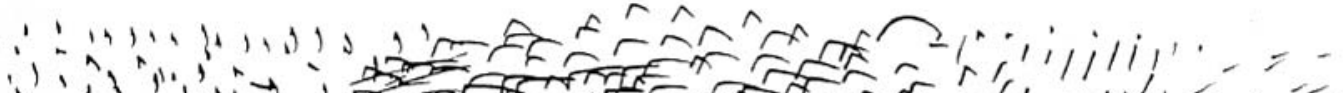

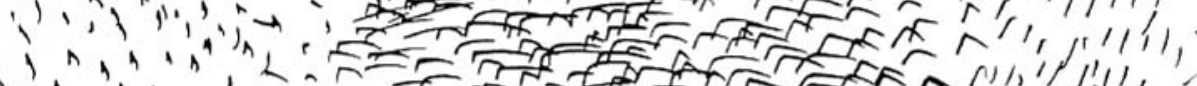

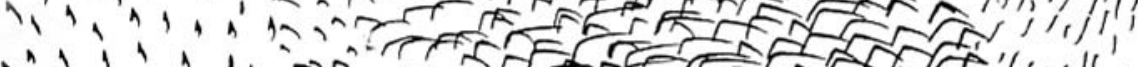

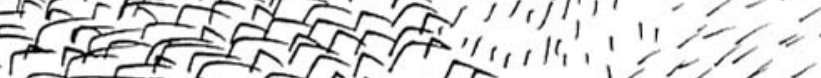

in पर

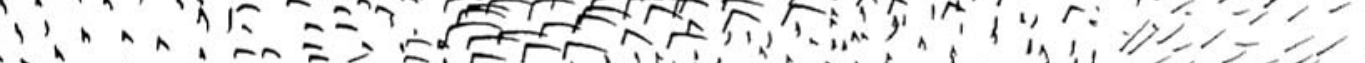

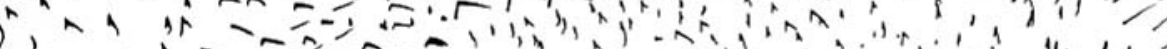

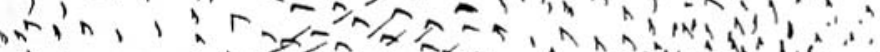

')

(1)

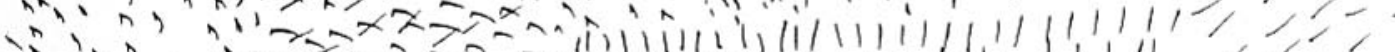

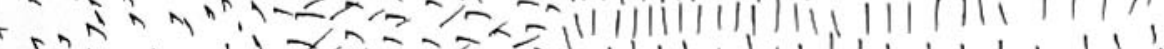

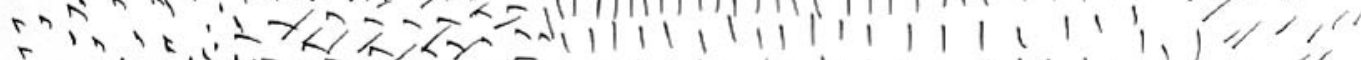

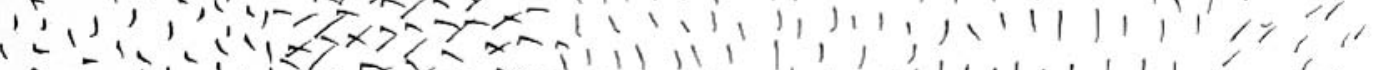

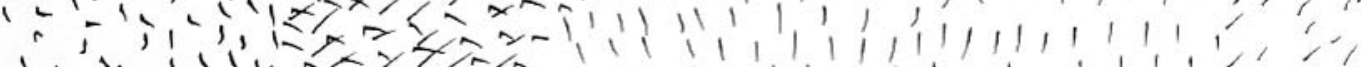

( 


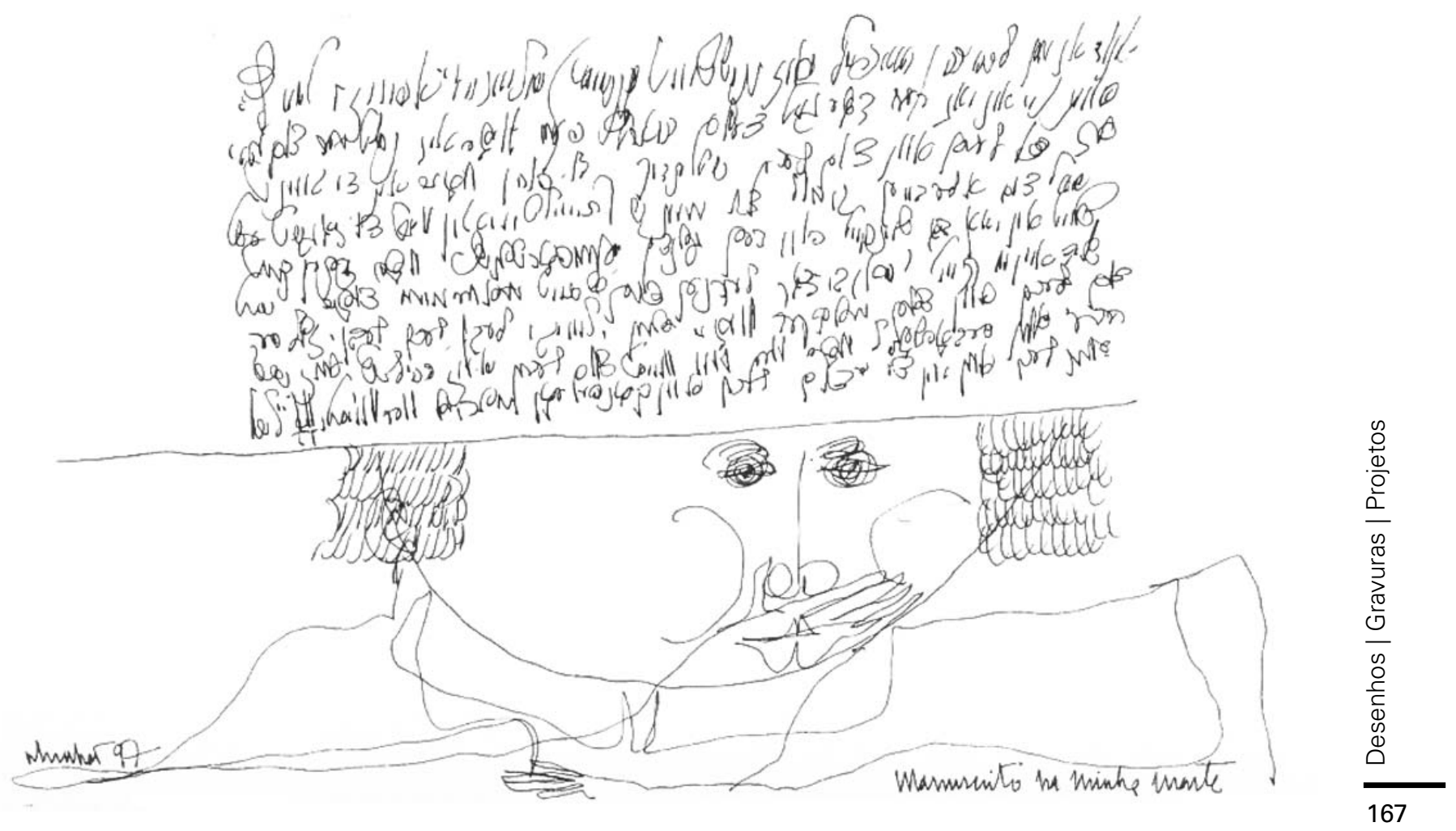




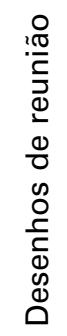

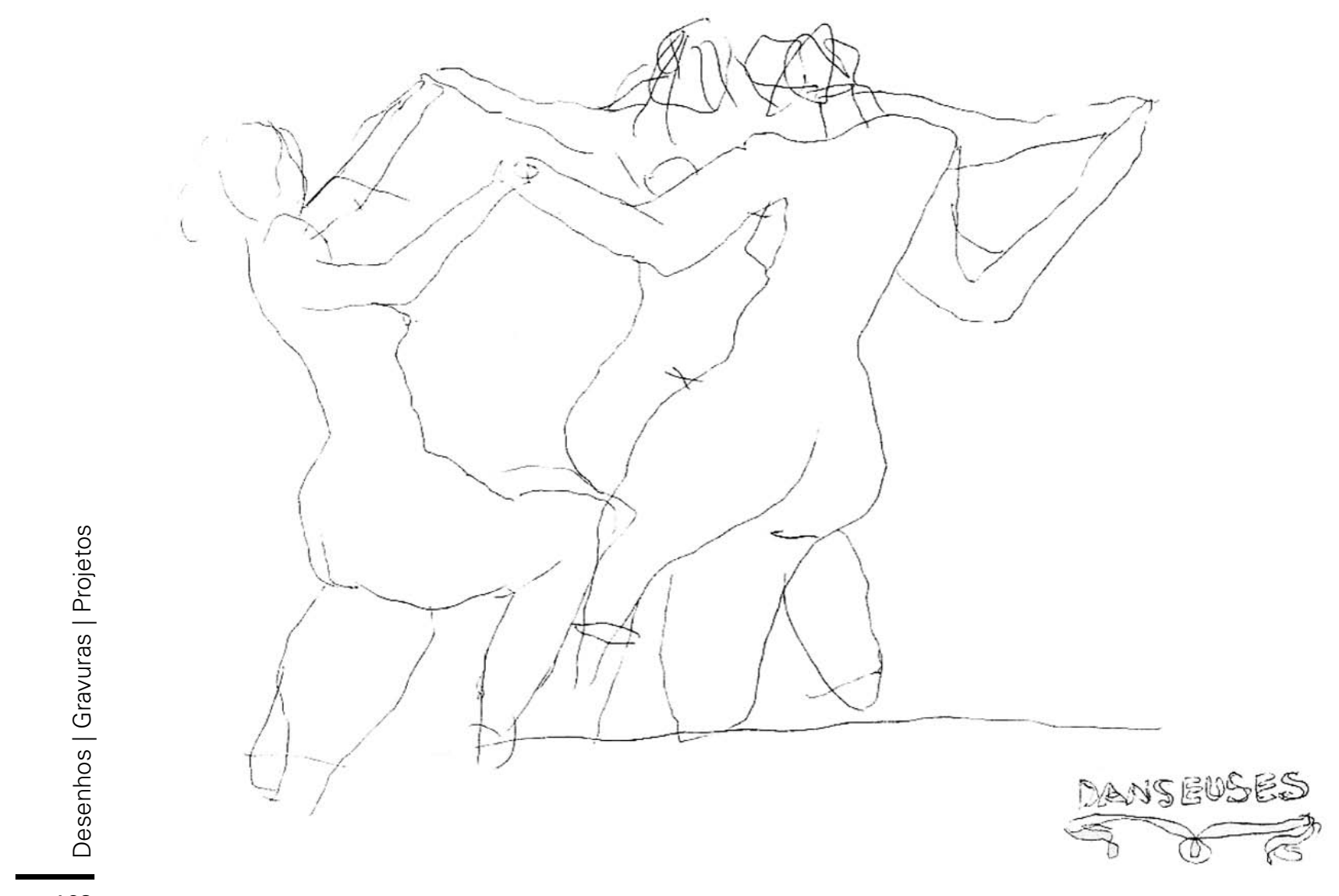




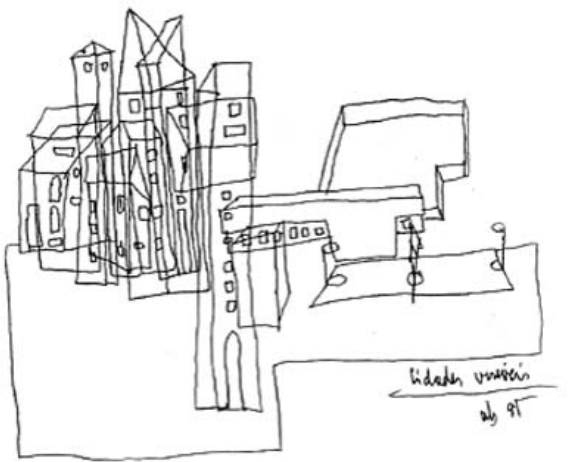

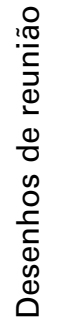

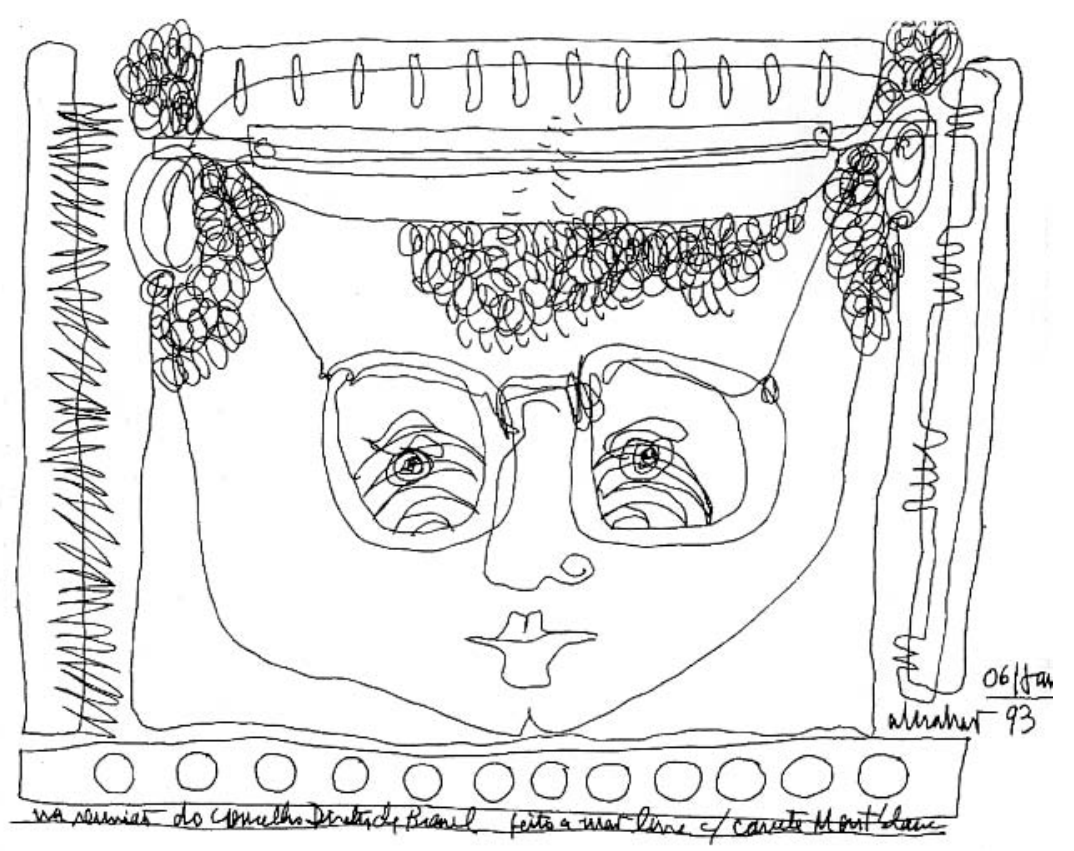


Desenhos a pastel

fonte de todos os desenhos: acervo de Diva Sanovicz
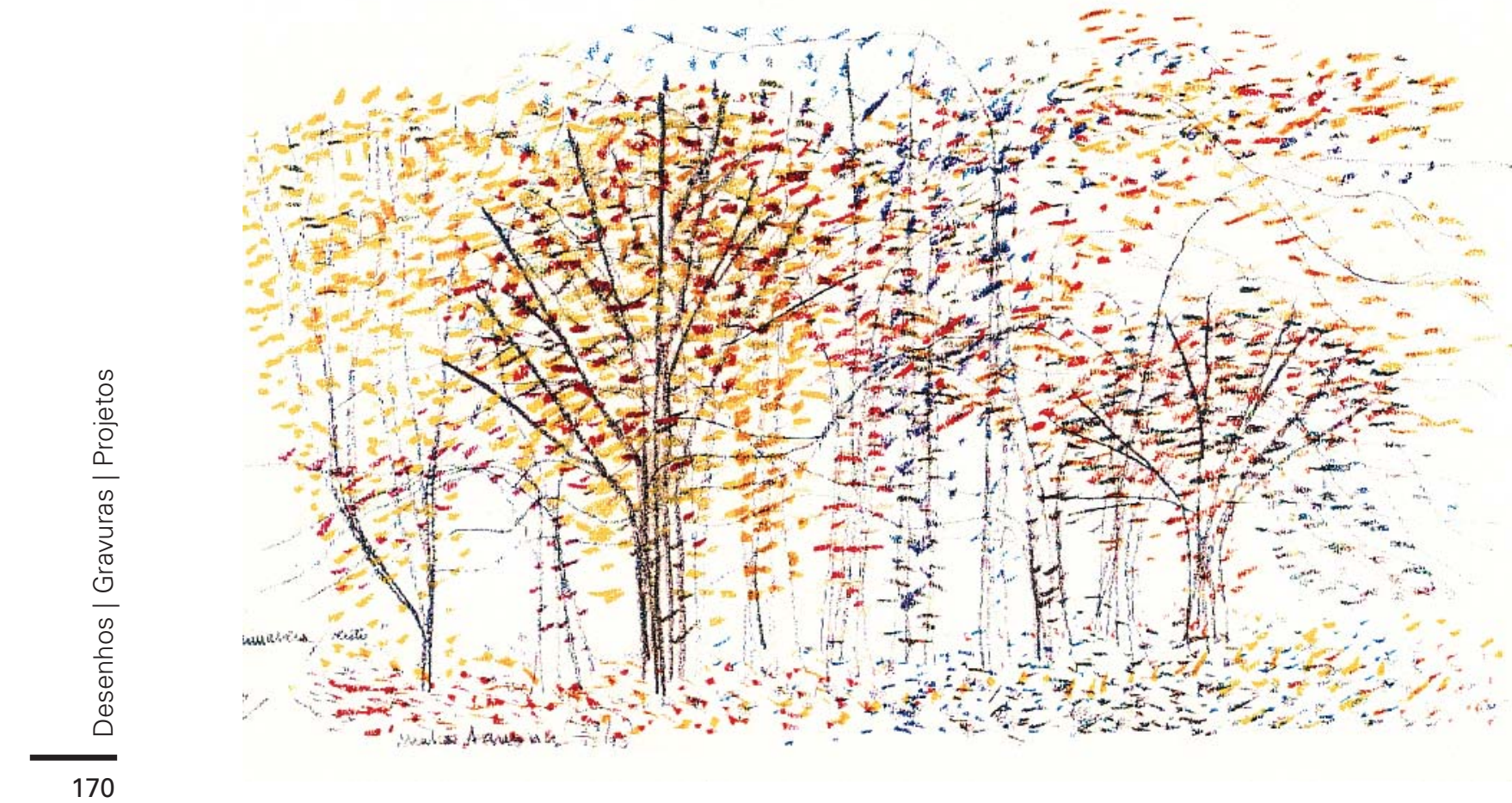

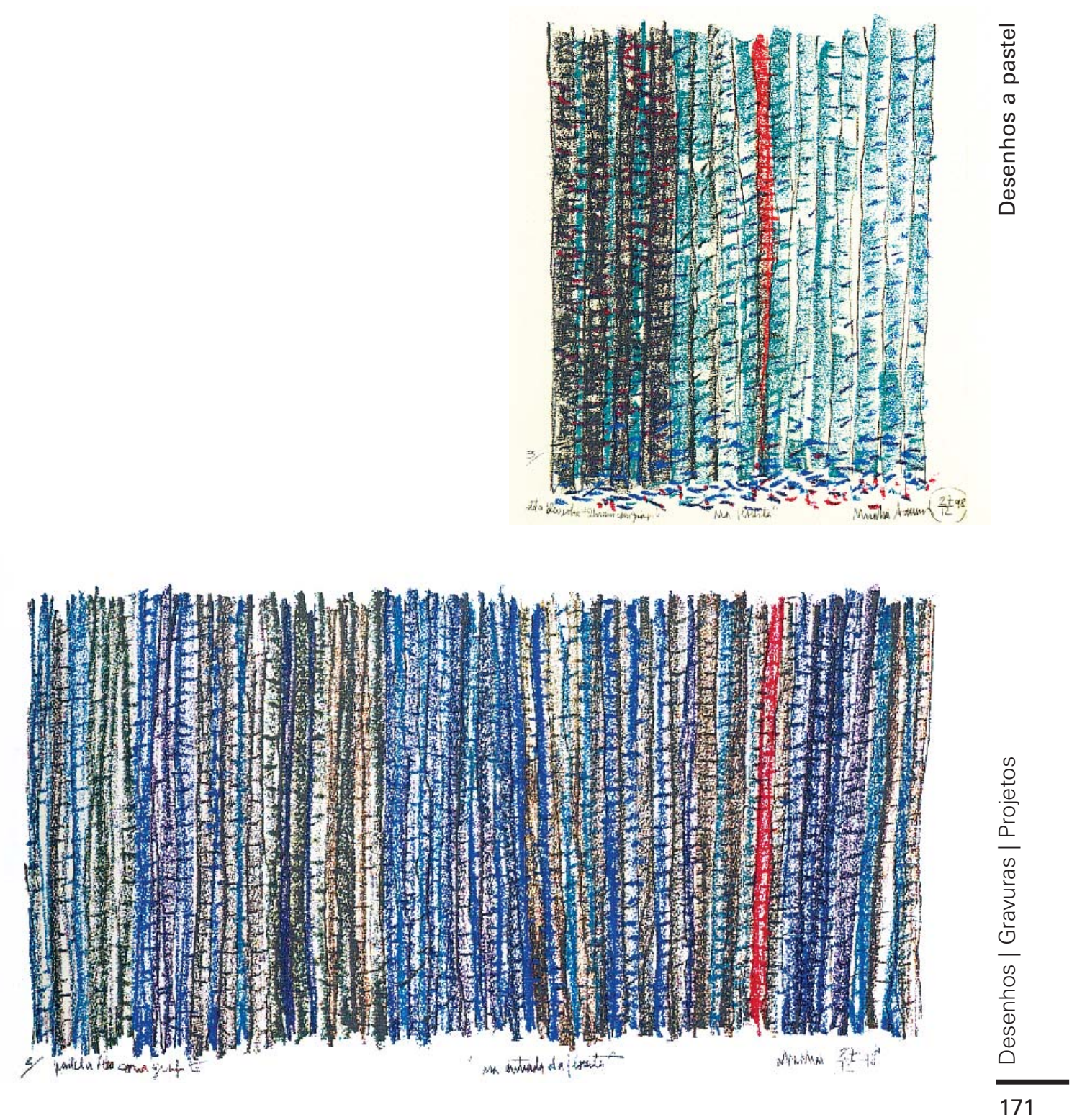
$\bar{\Phi}$
0
0
0
0
0
0
0
0
$\frac{0}{c}$
0
0
0
0
0

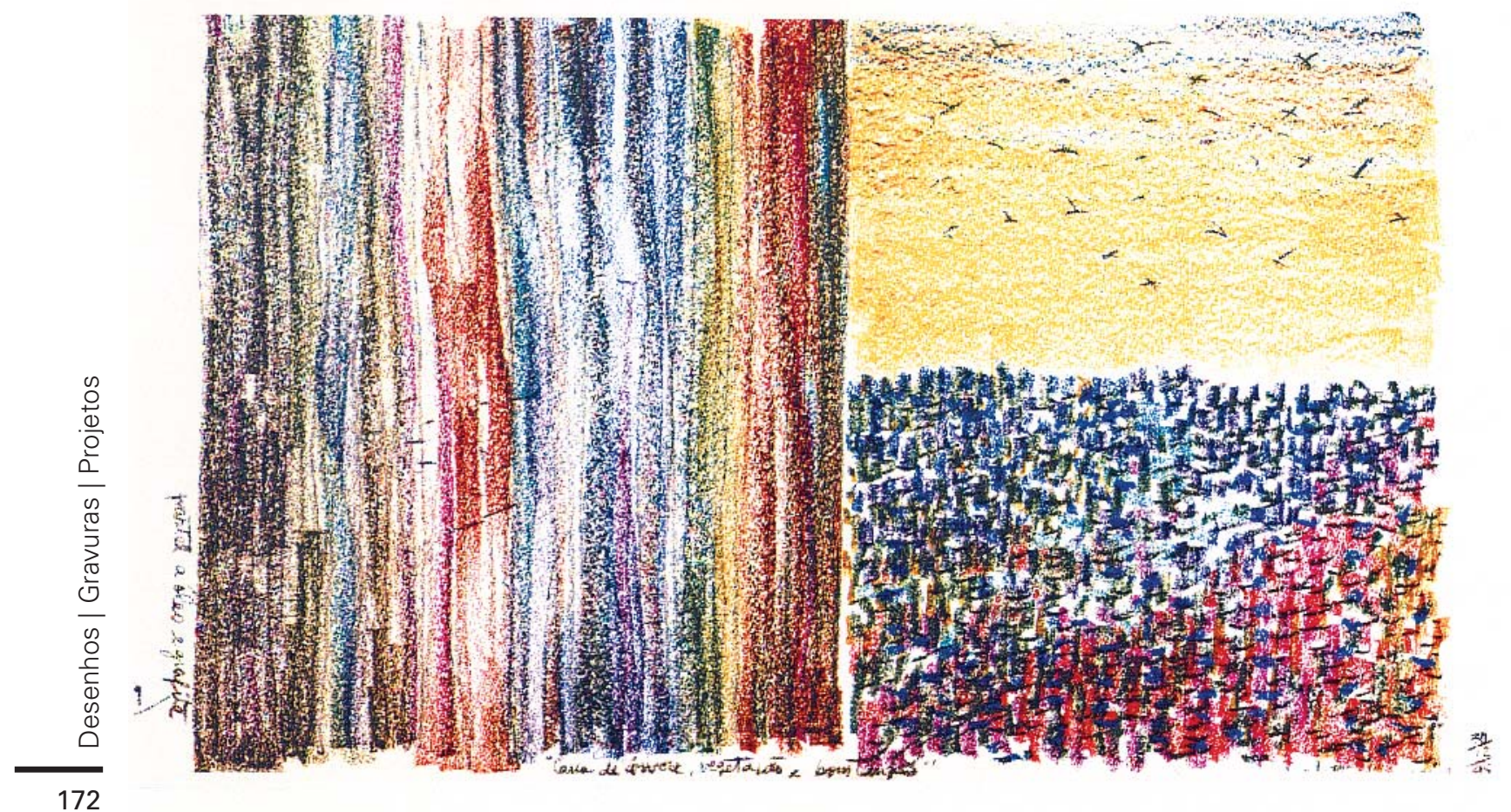




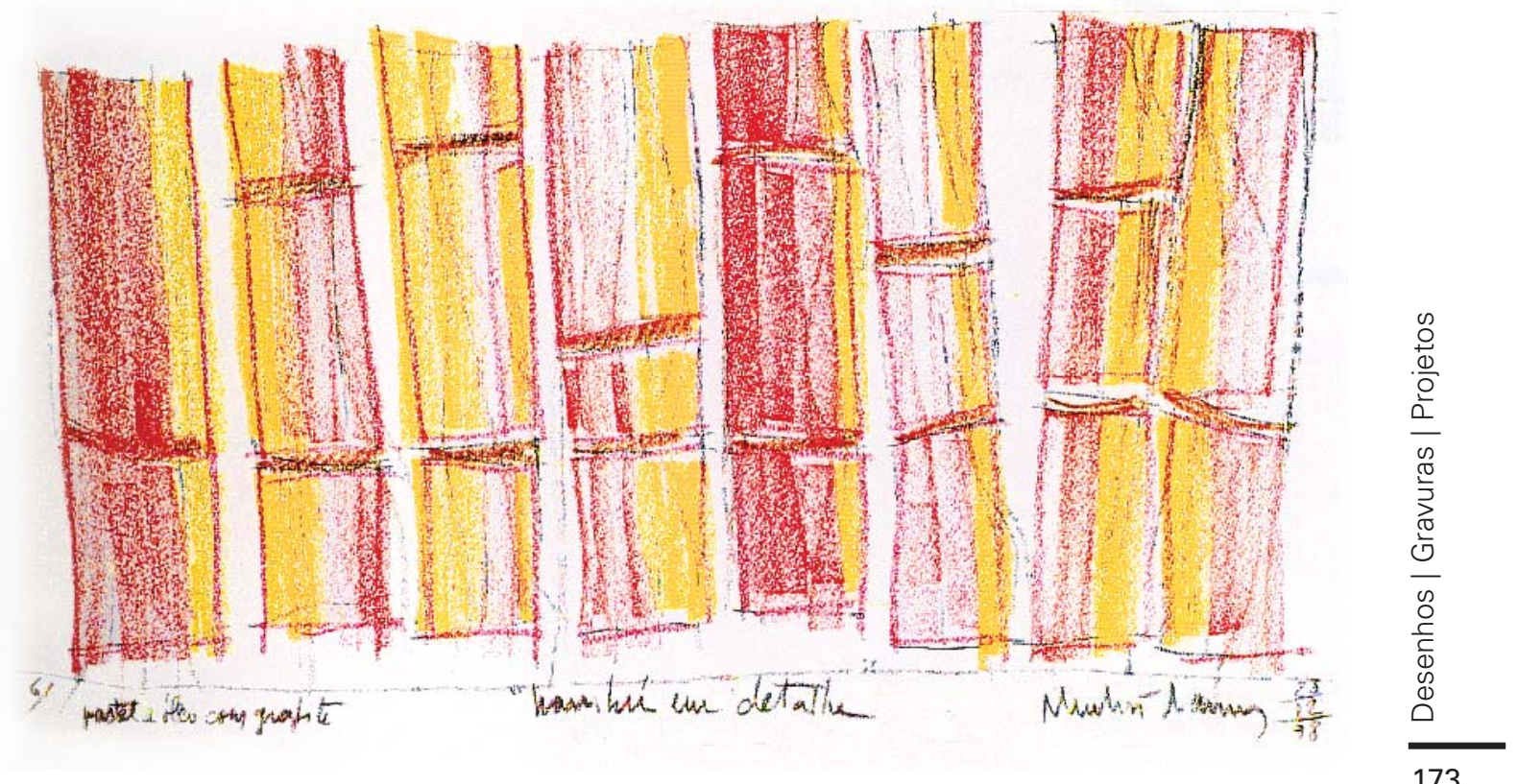




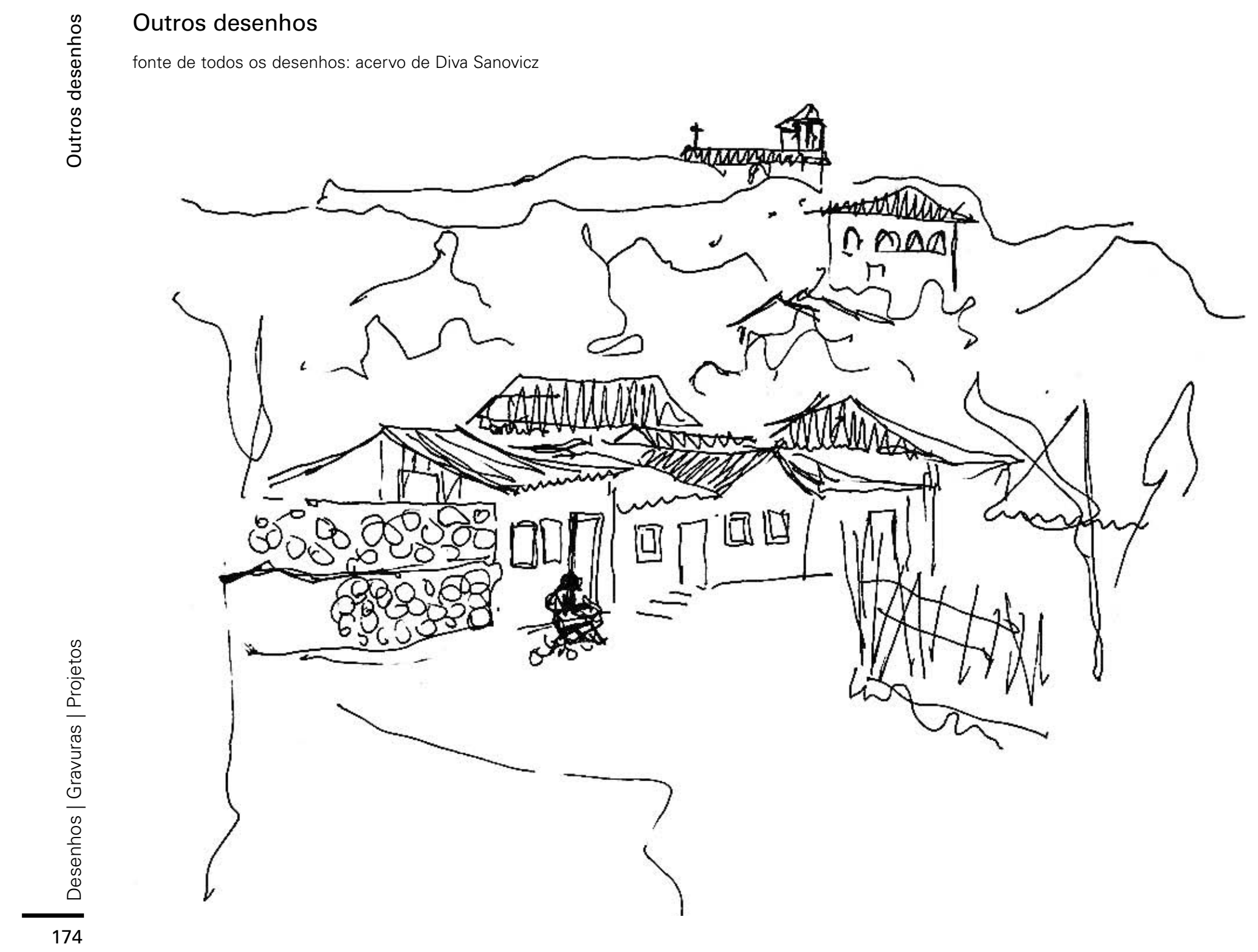



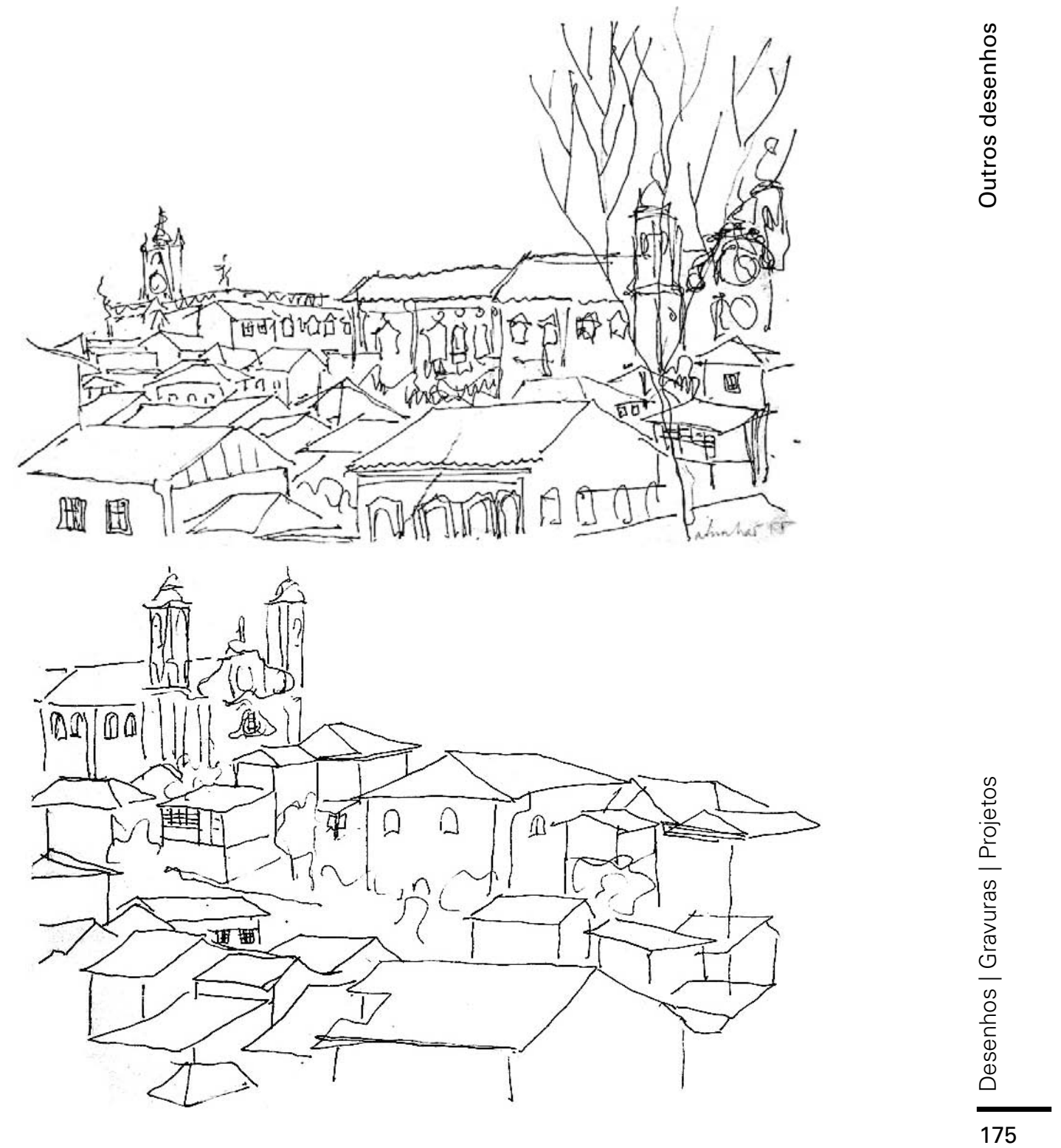
0
0
0
0
0
0
0
0
0
0
0
0
0
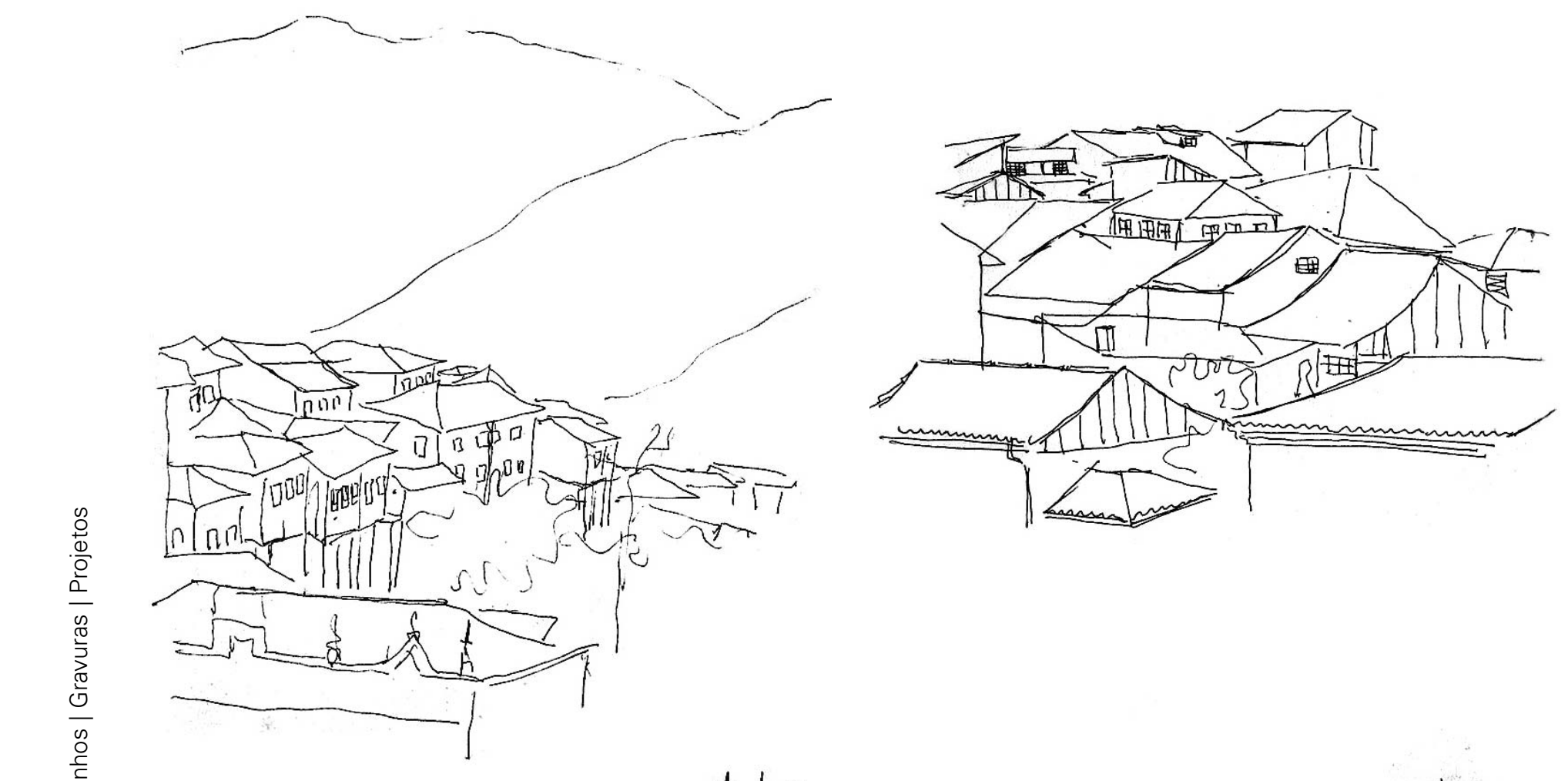

Whatum

aluutur 

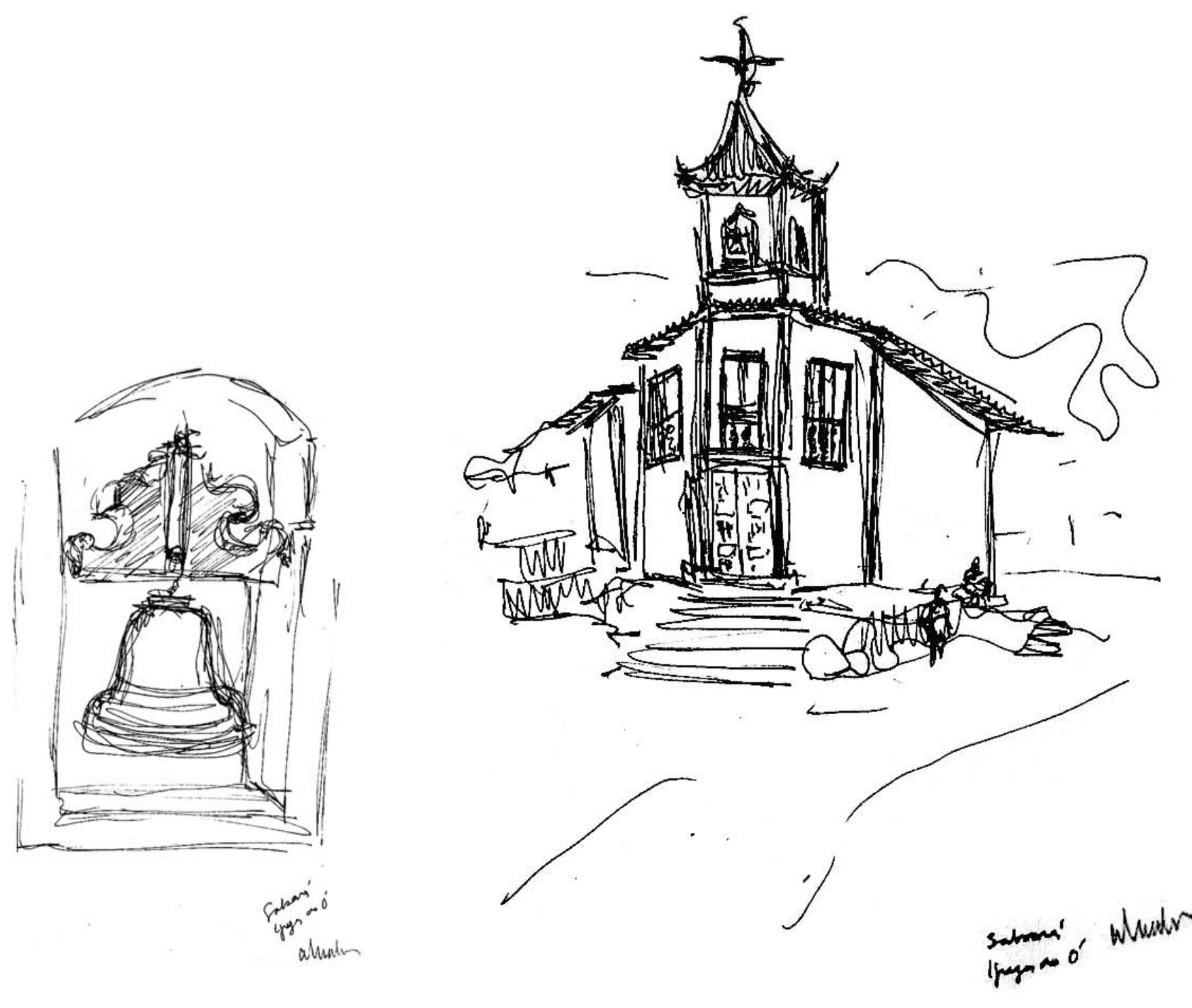

0
0
0
0
0
0
0
0
0
0
0
0
0
0

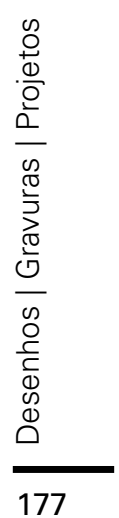



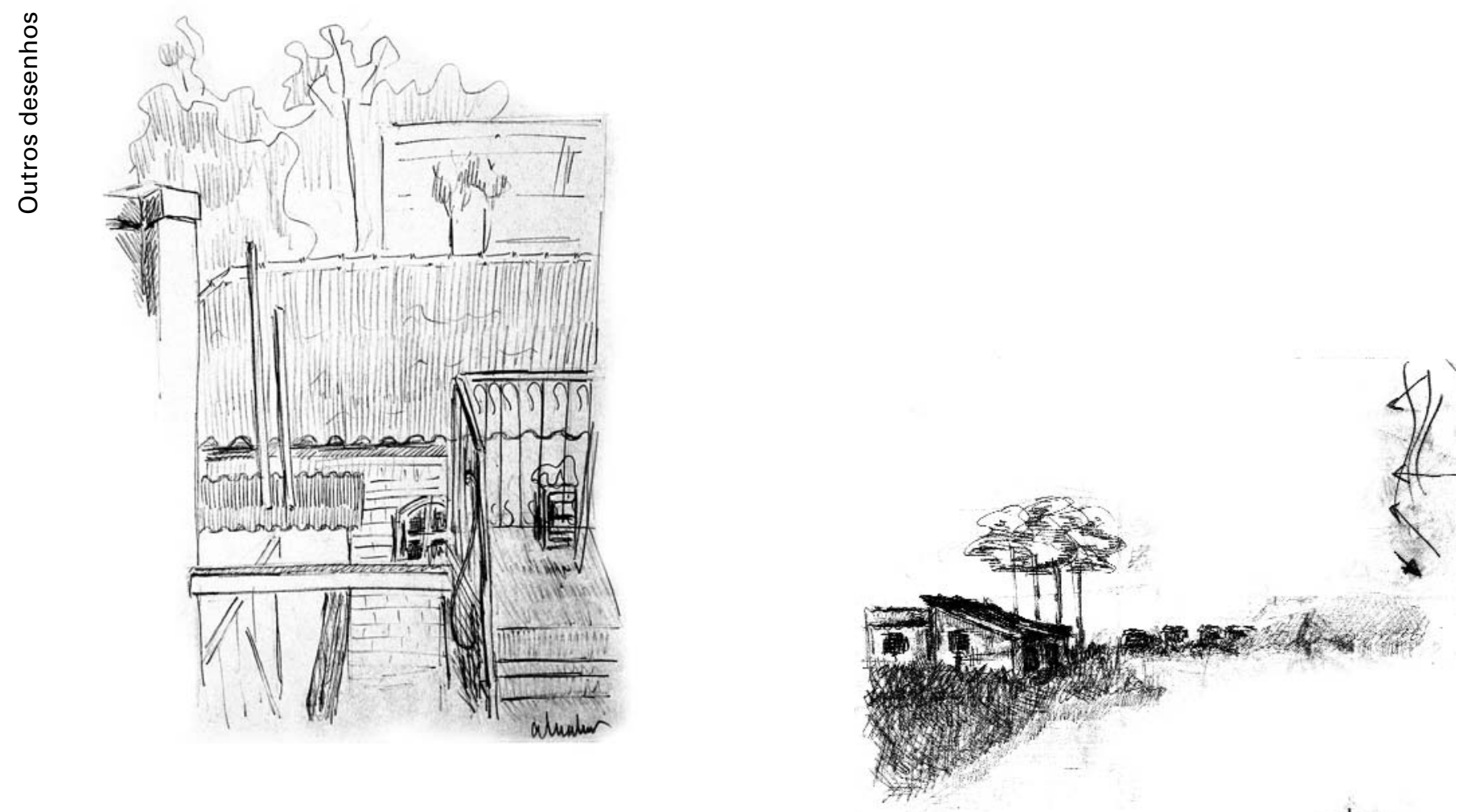

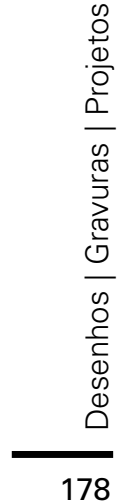

aluahn-

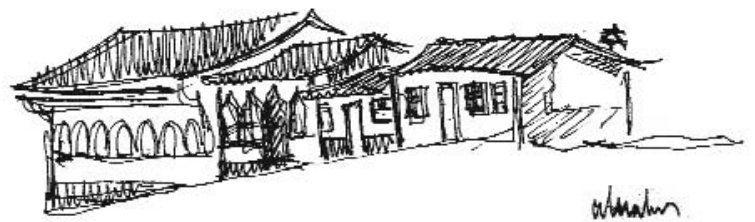



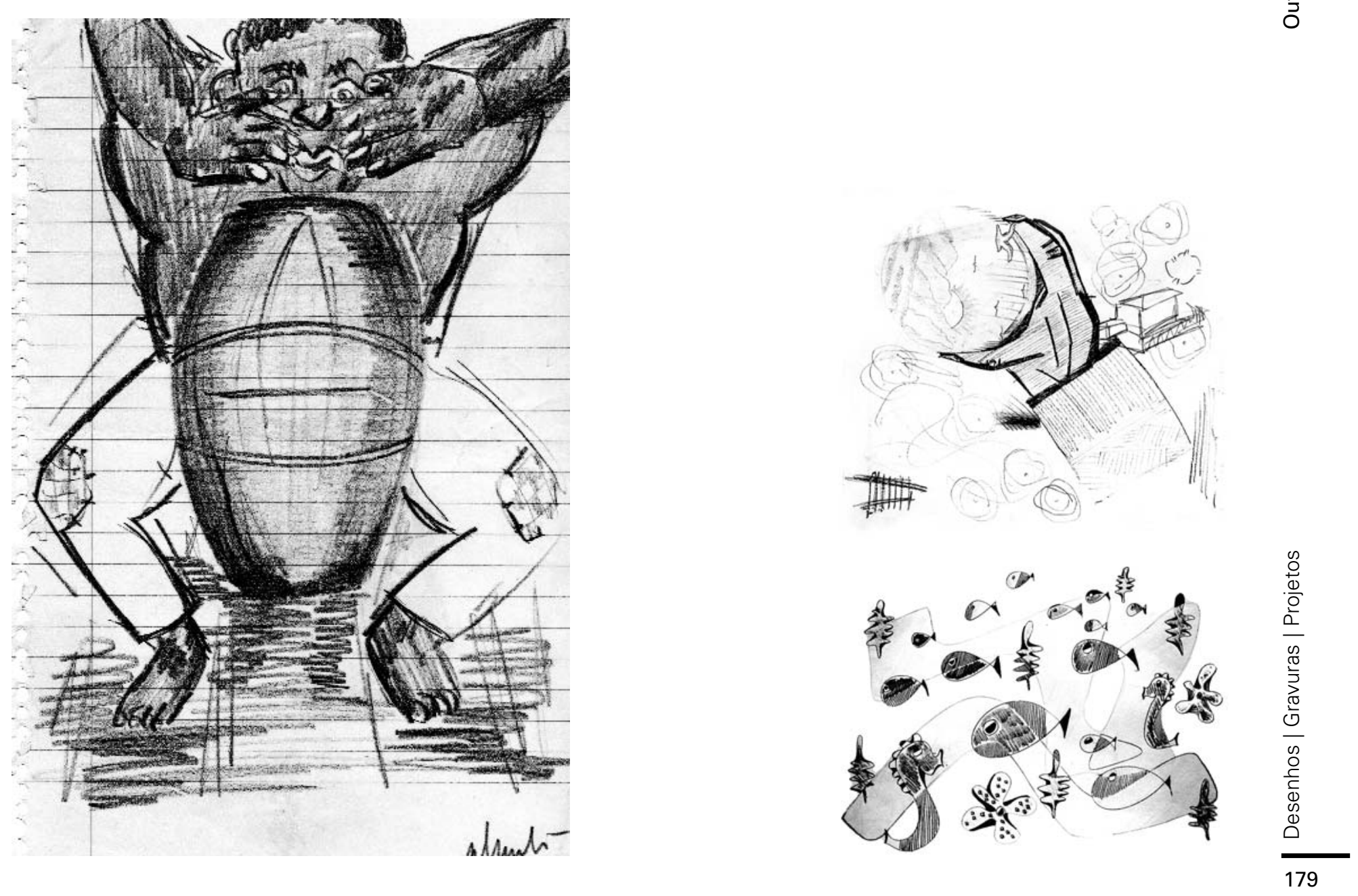


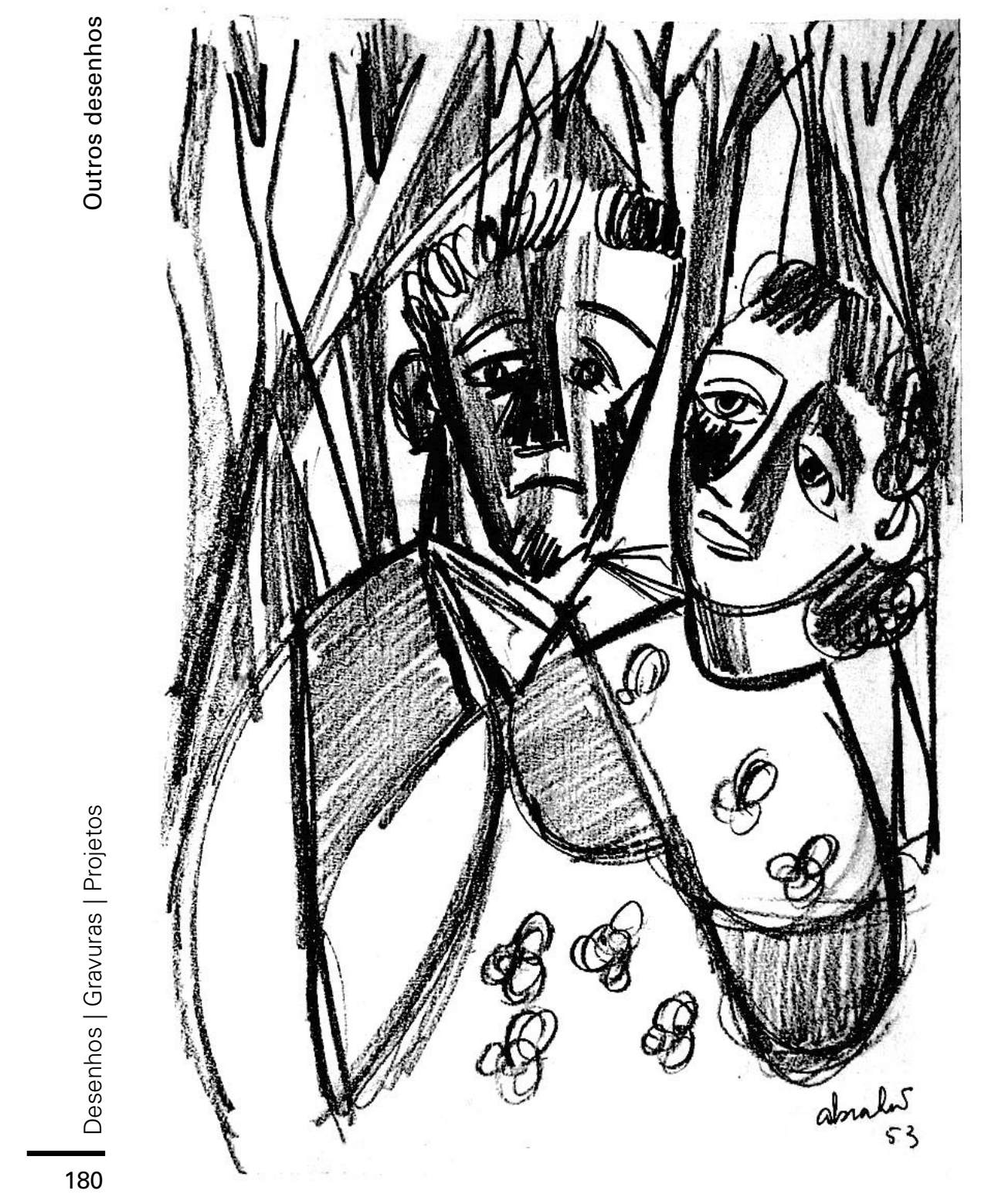



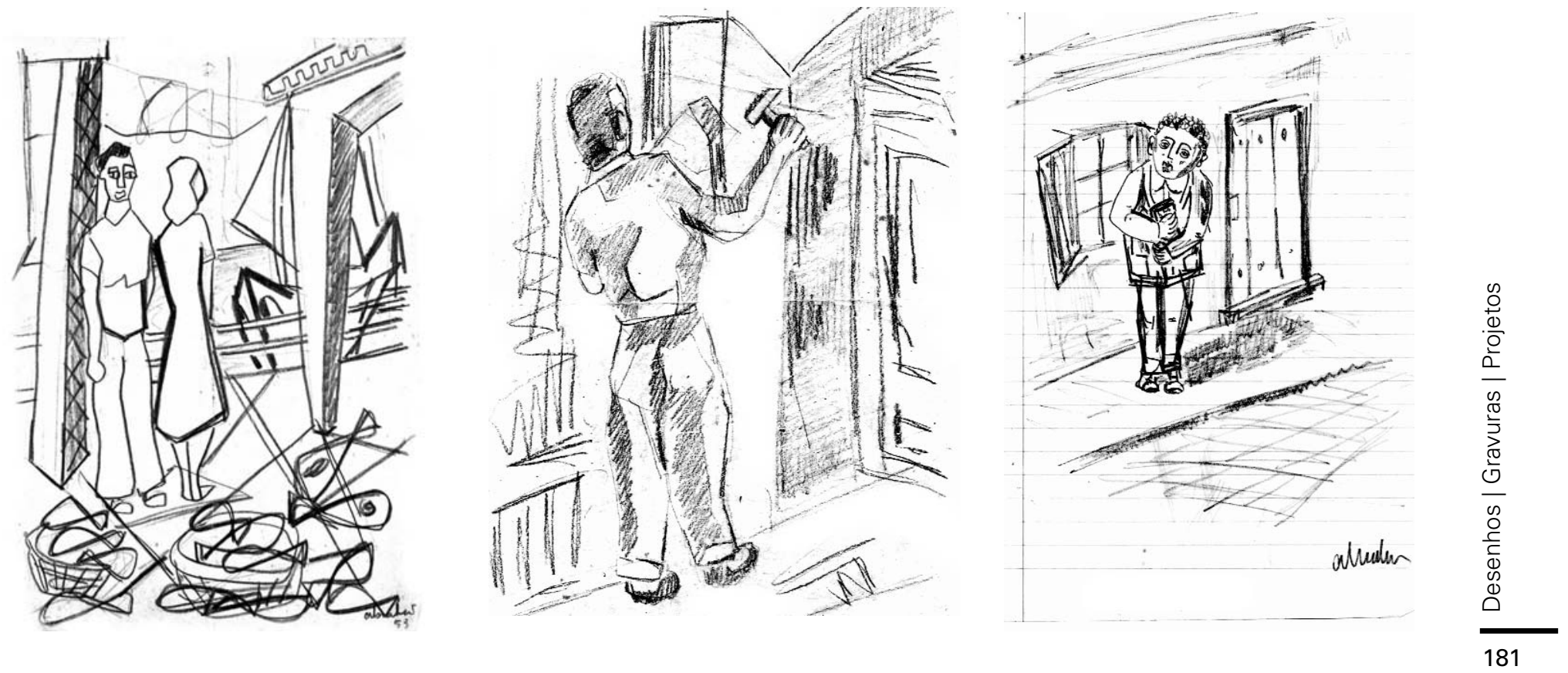



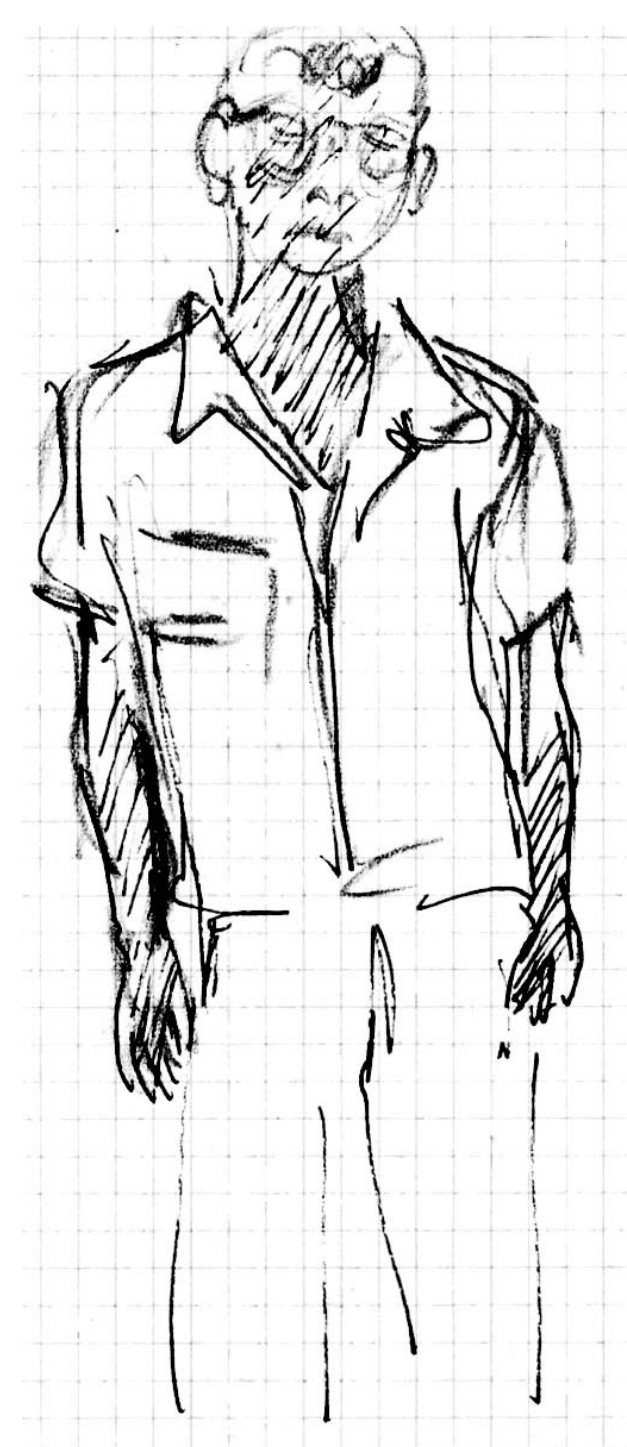

0
0
0
0
0
0
0
0
0
0
0
0
0
0
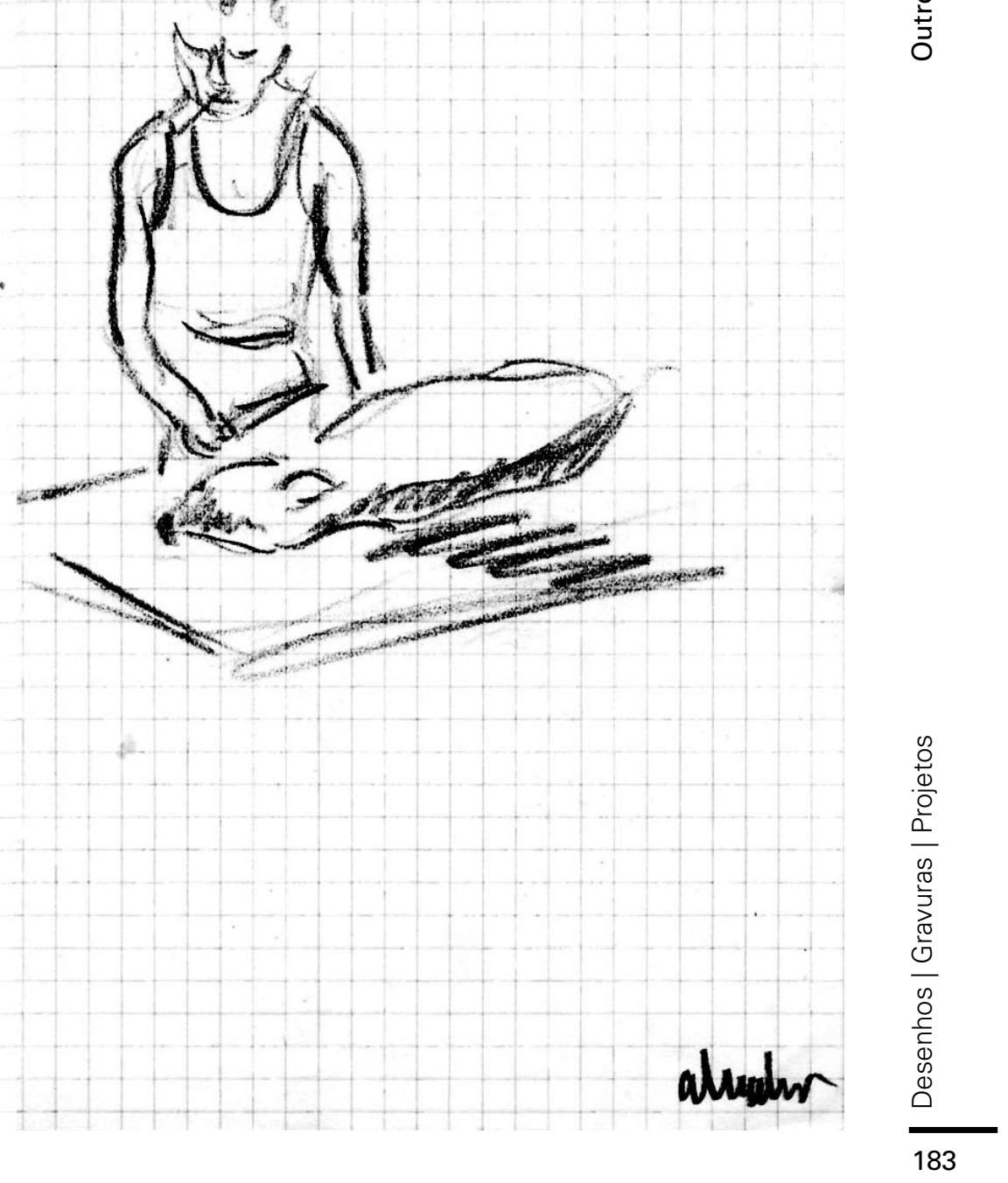



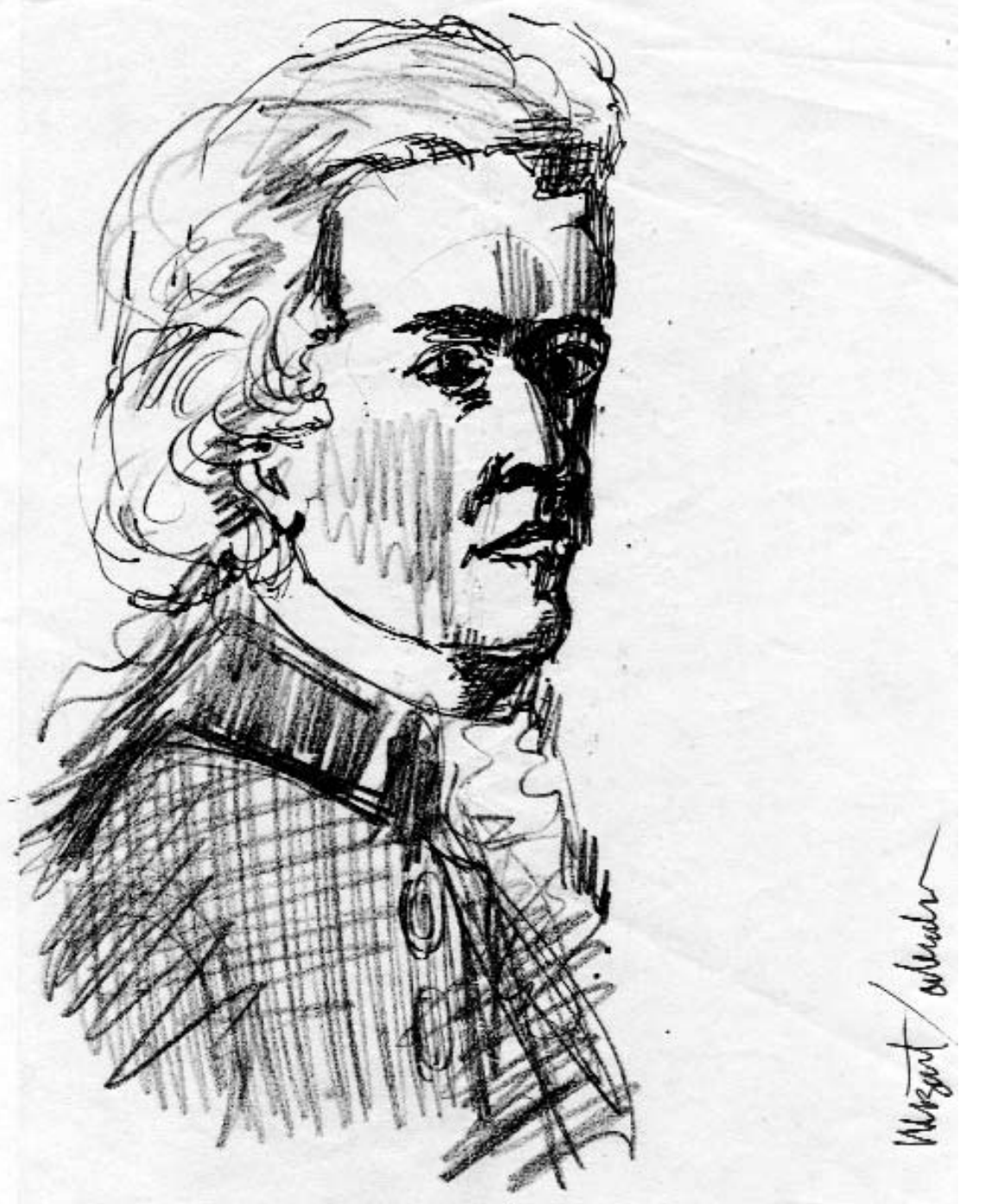




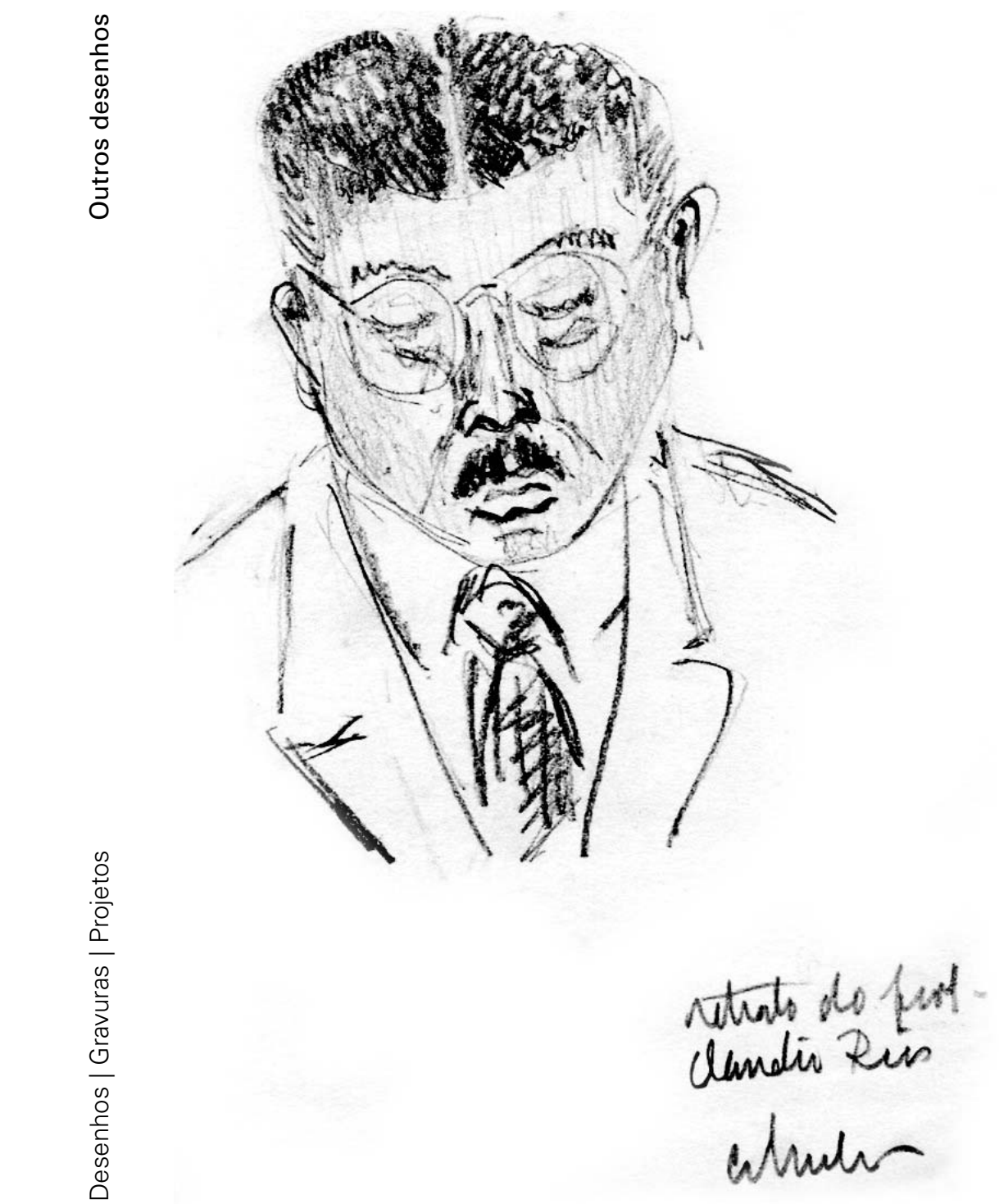




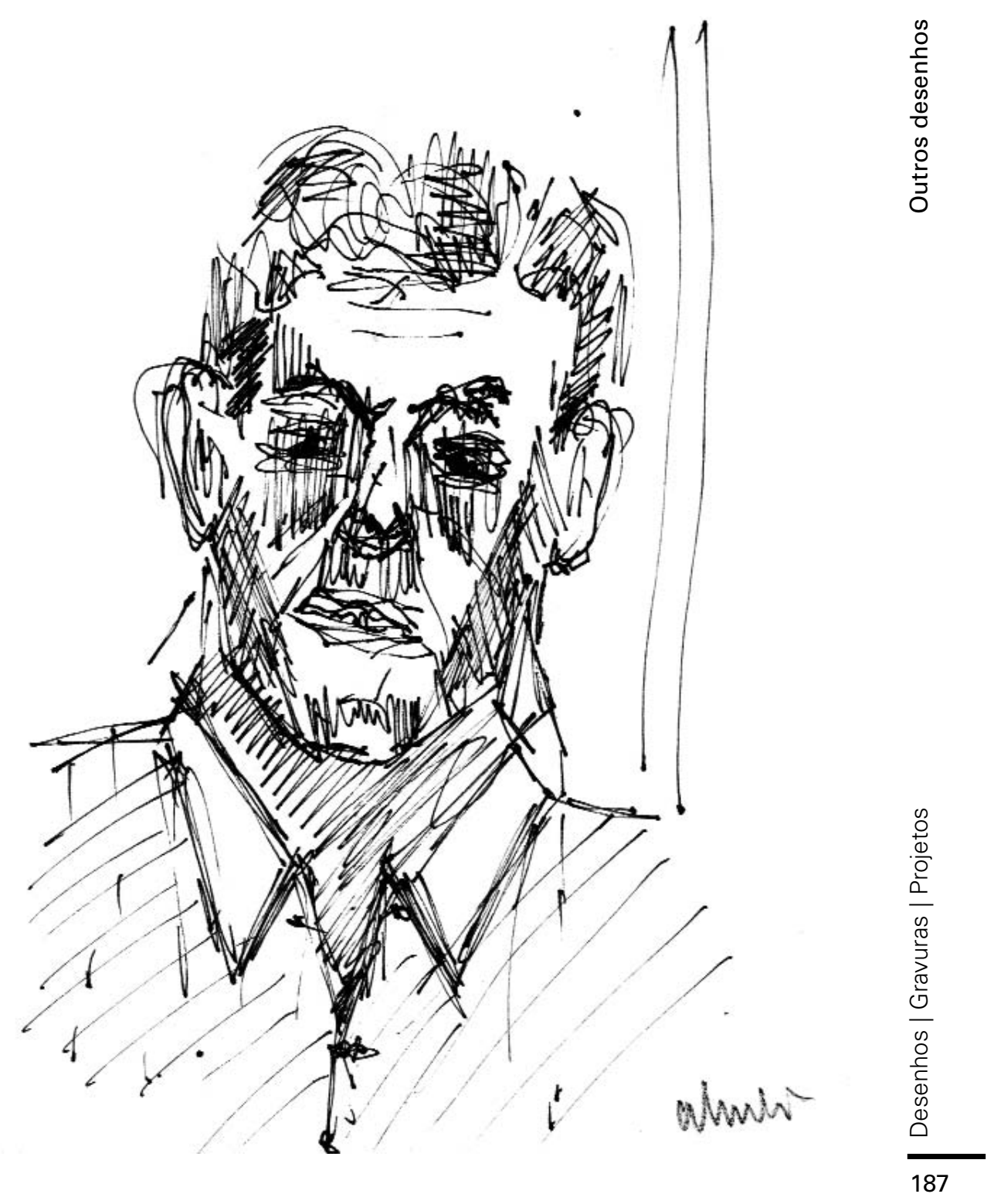


0
0
0
0
0
0
0
0
0
0
0
0
0

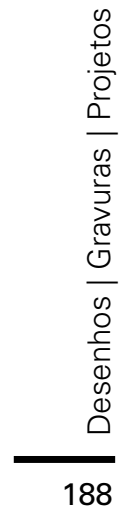

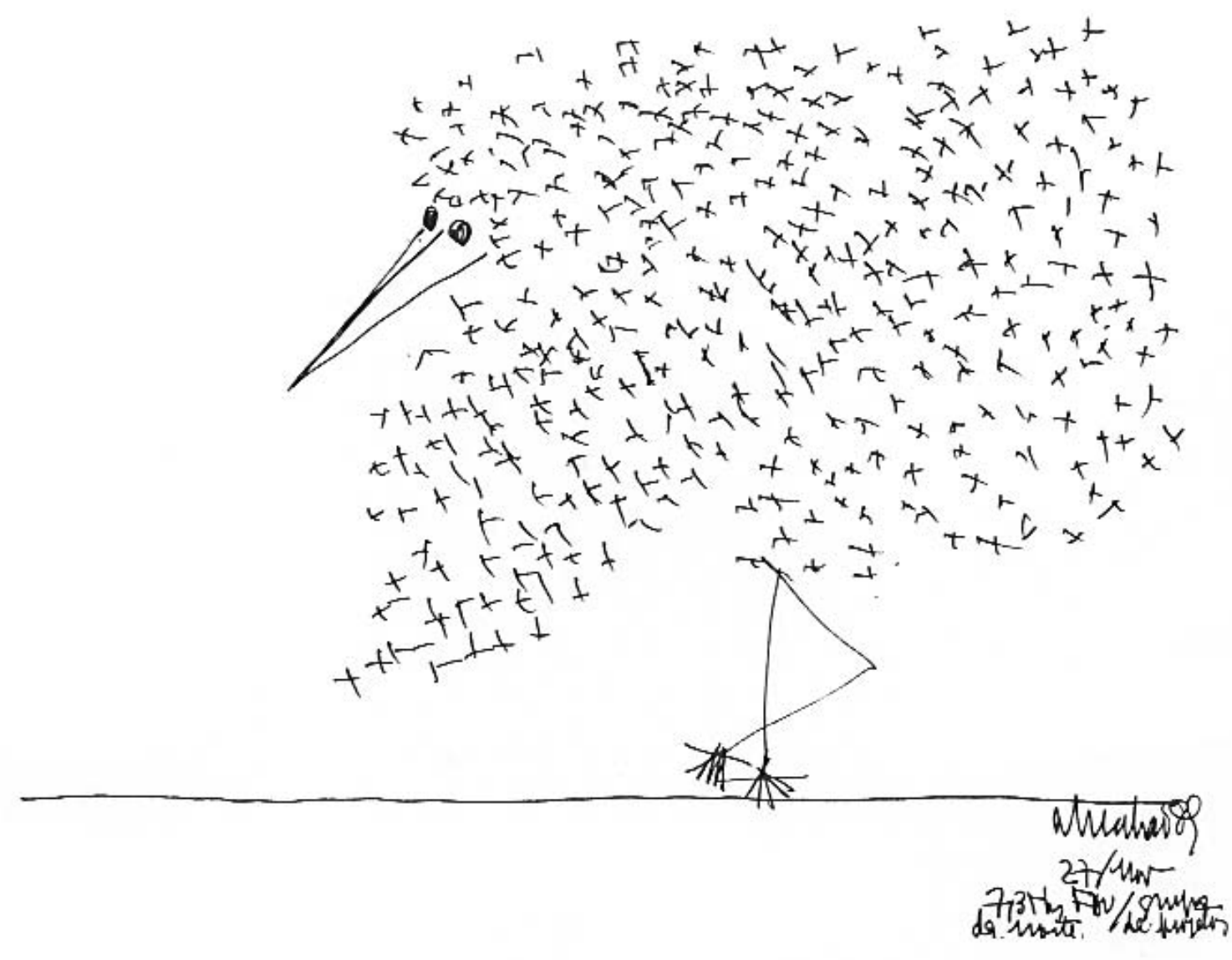




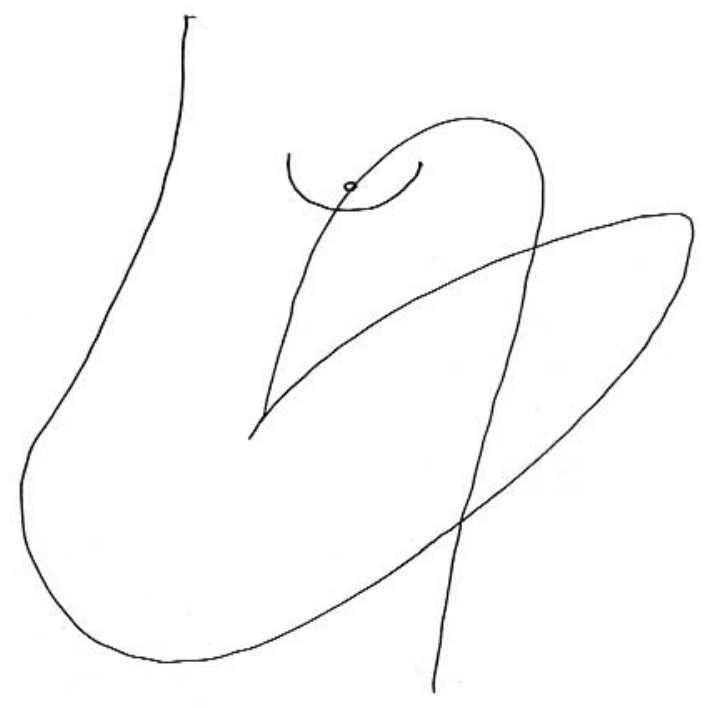

0
0
$\frac{1}{1}$
0
0
0
0
0
0
0
0
0

\section{$\frac{\text { less is more }}{\text { d'apuis Mies atum } 93}$}

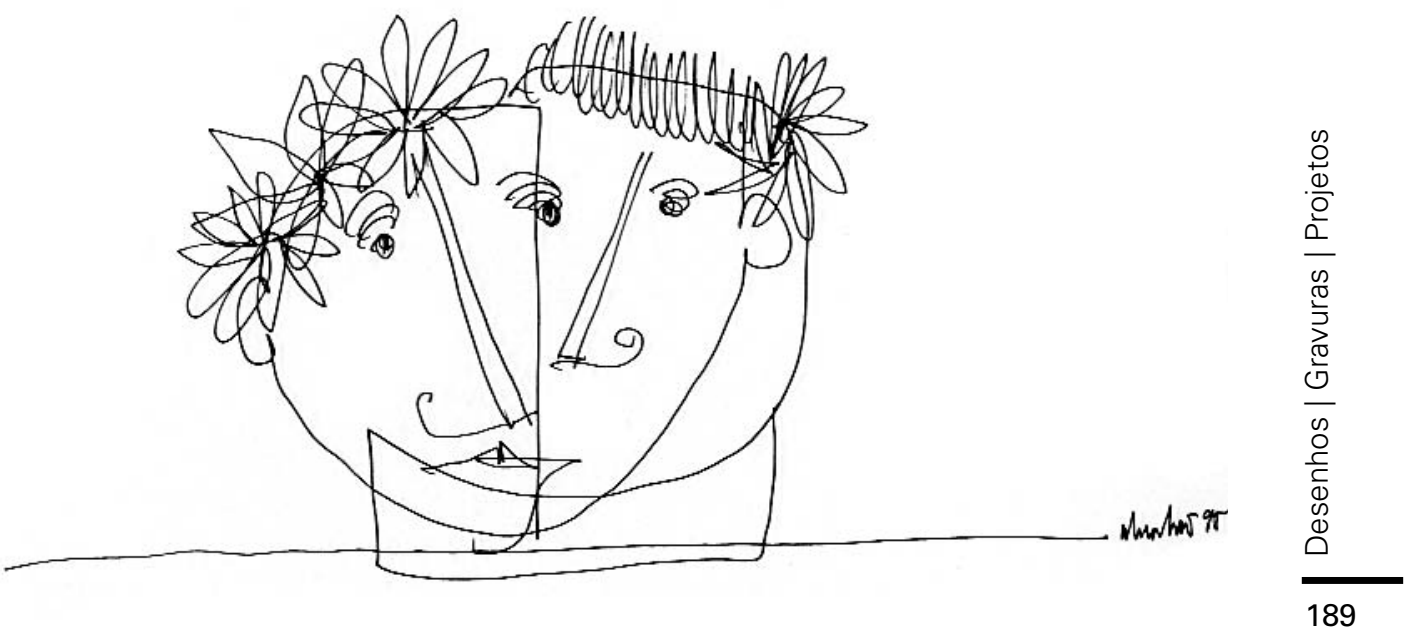




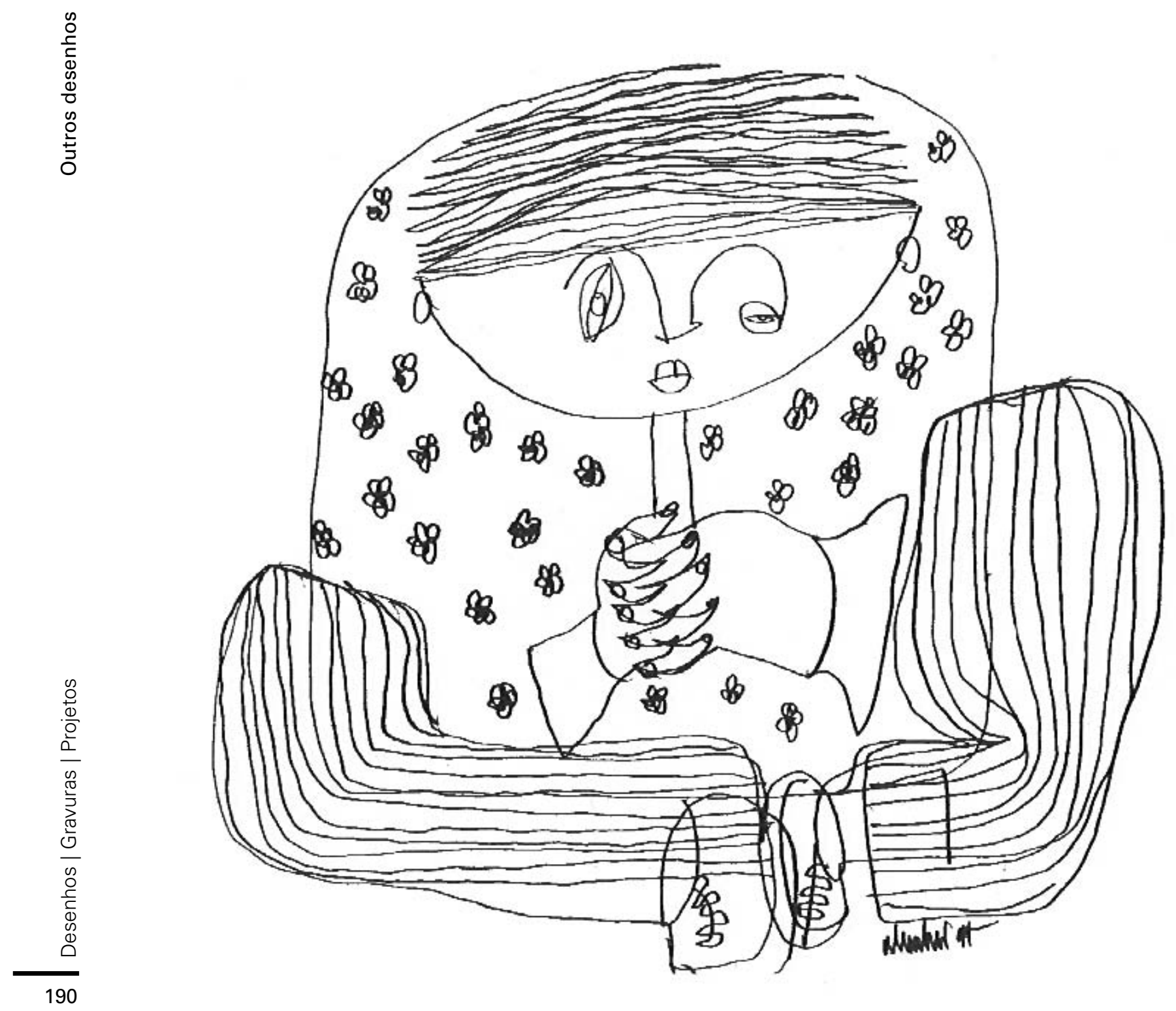



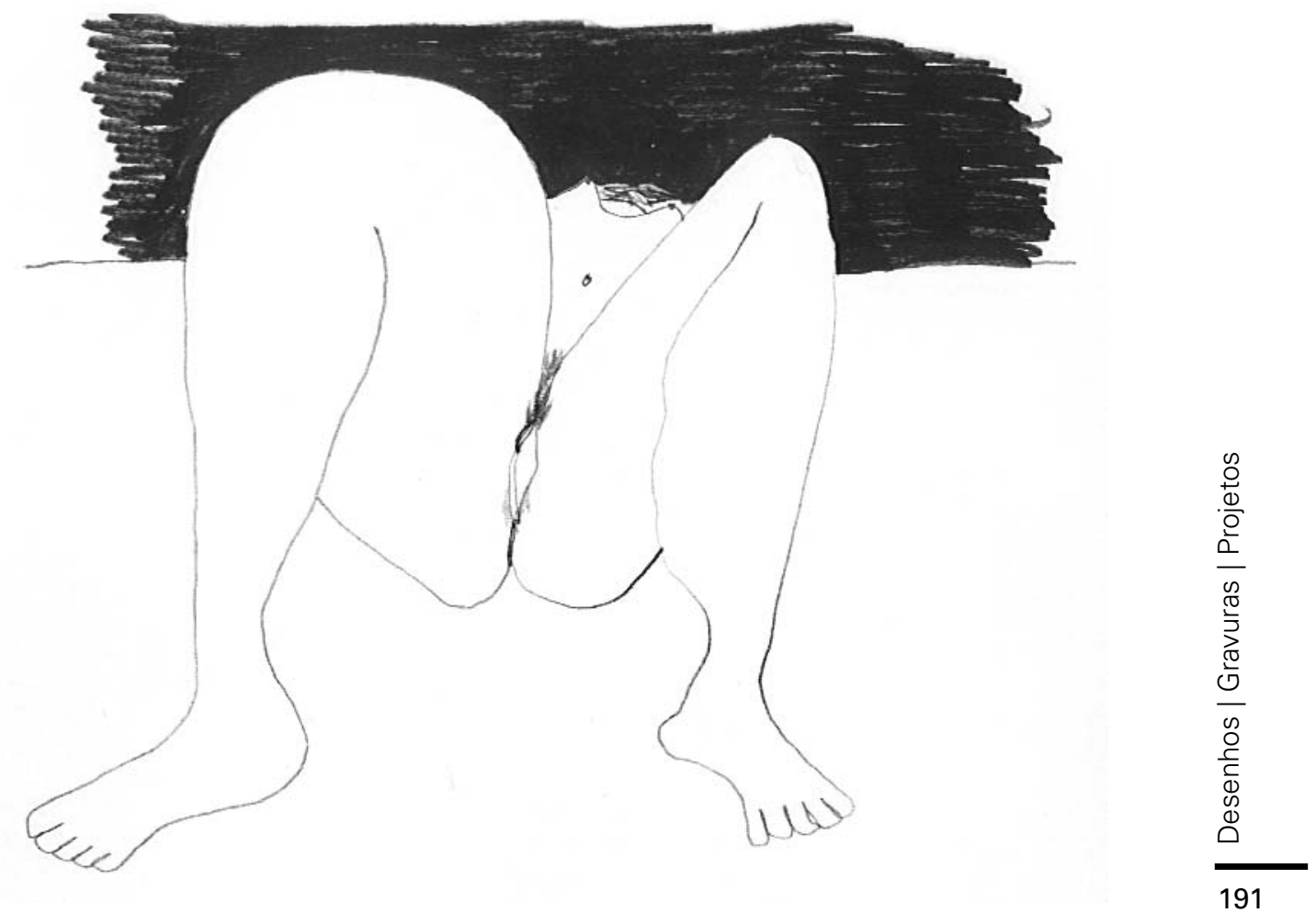


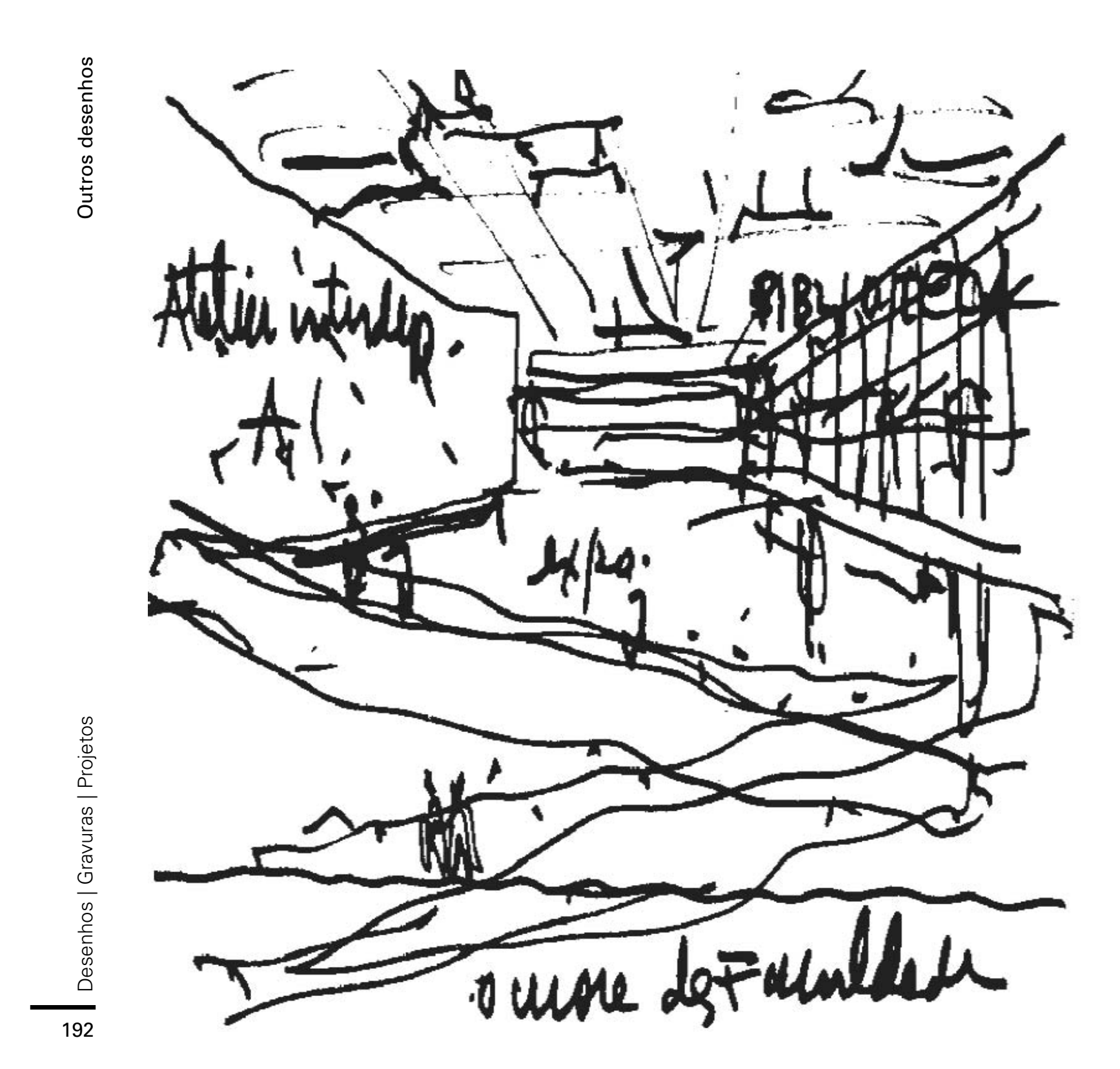




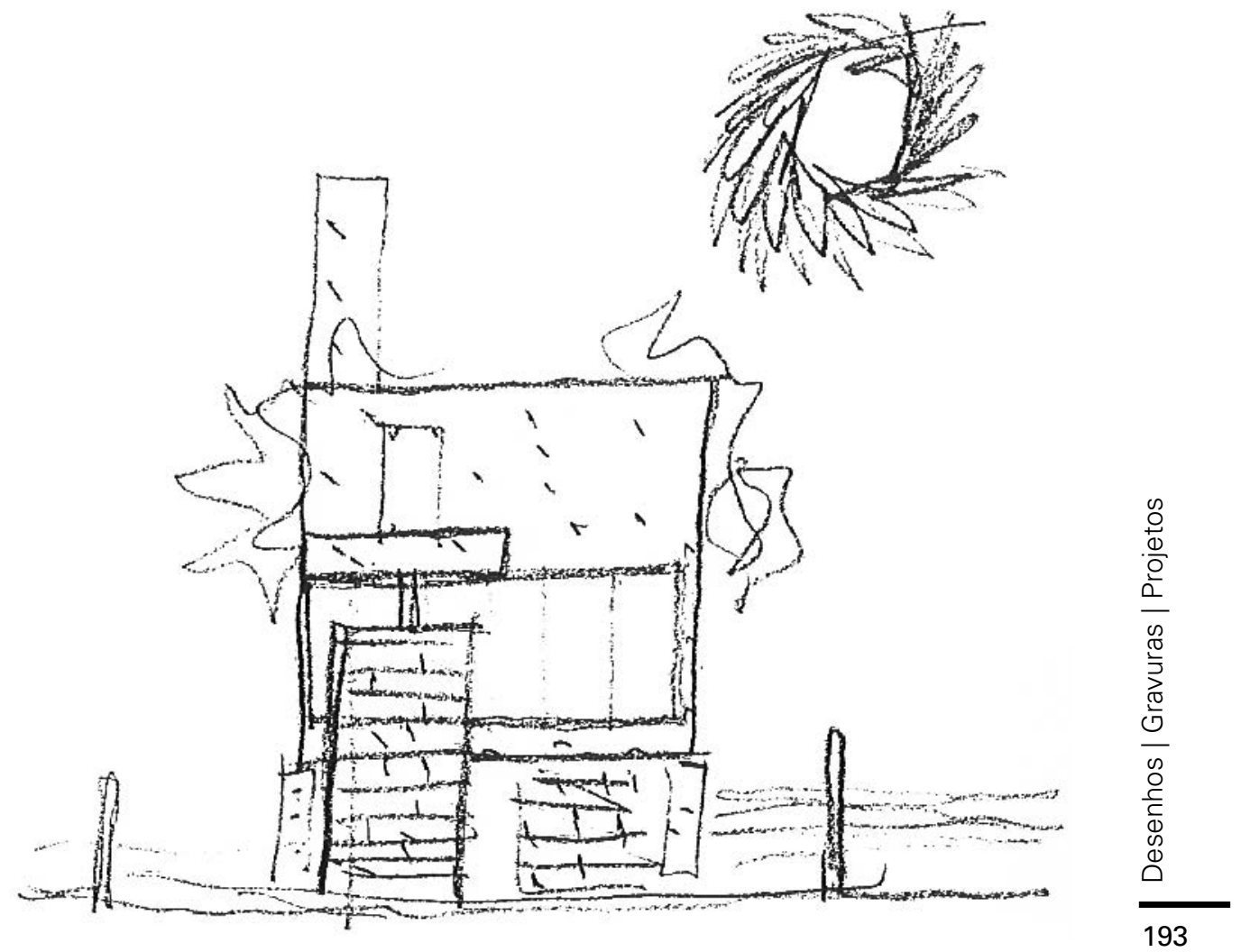




\section{Gravuras recentes}

fonte de todas as gravuras: acervo de Diva Sanovicz

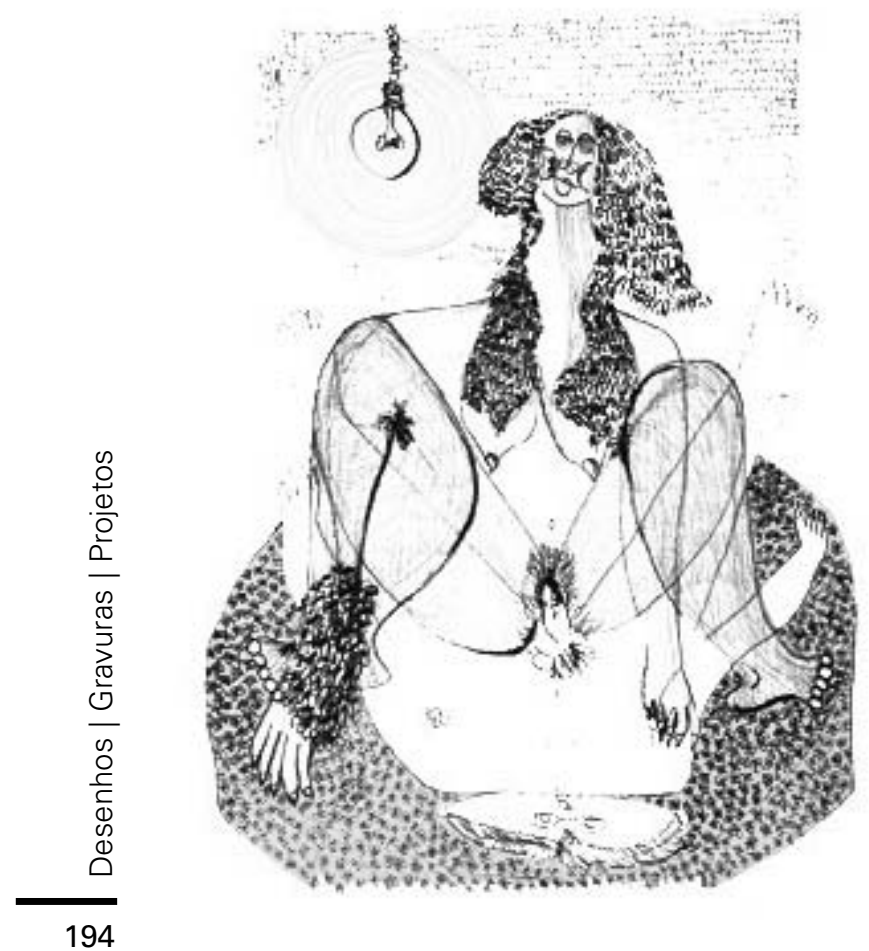




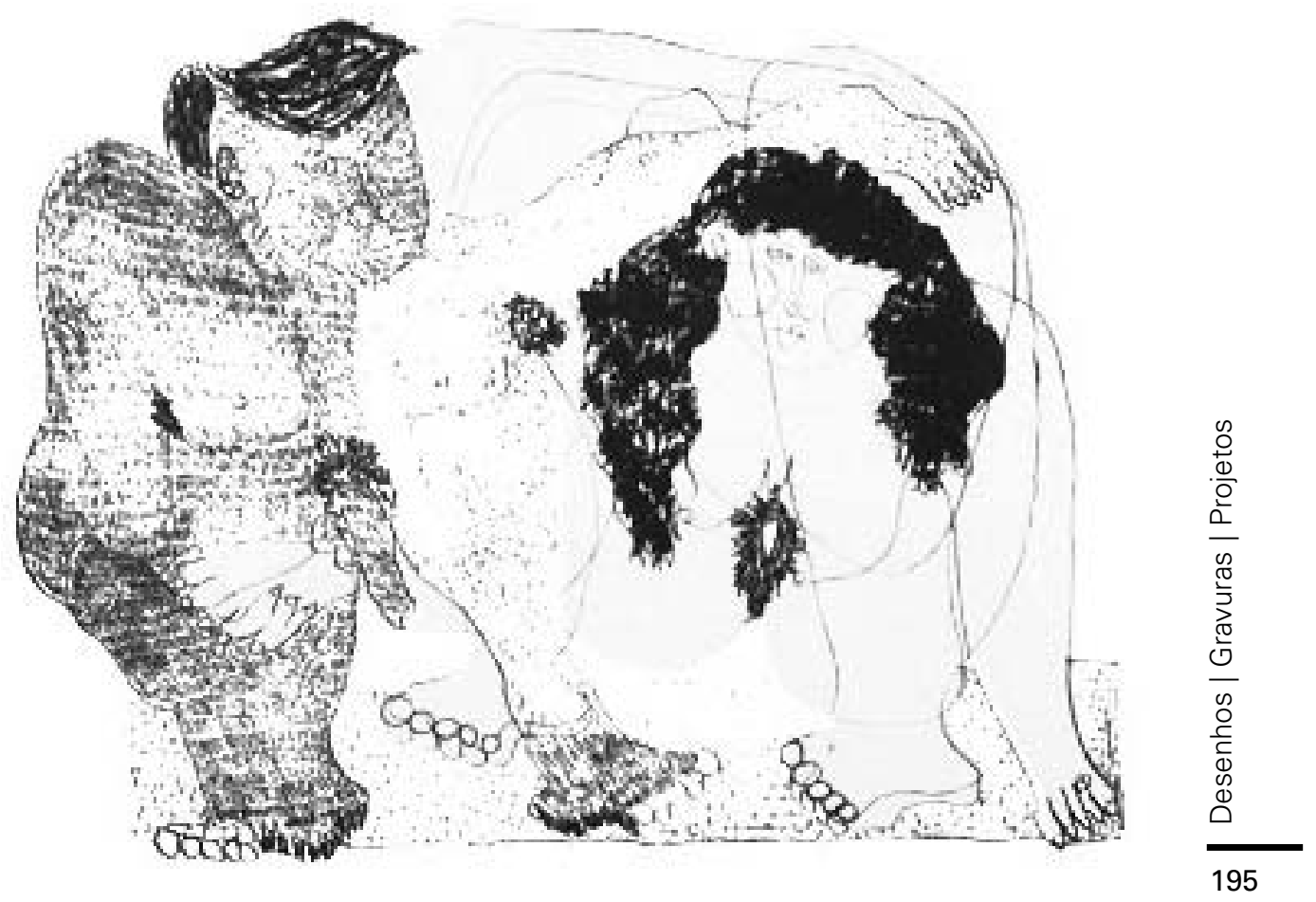




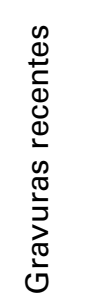

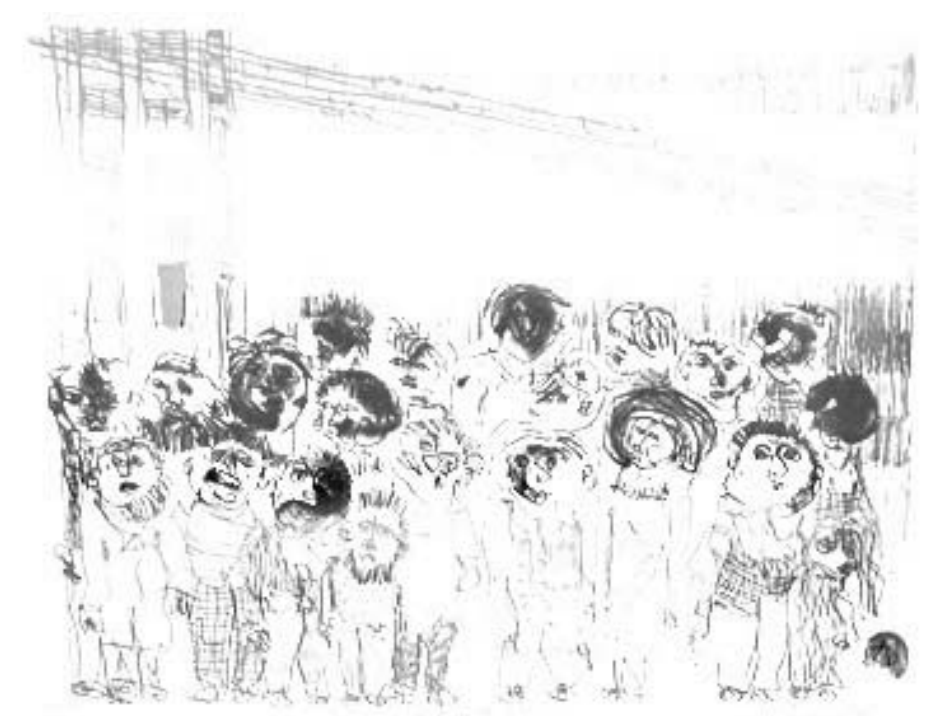

$\begin{array}{r}\frac{0}{0} \\ \frac{0}{0} \\ \frac{0}{0} \\ \frac{0}{0} \\ \frac{0}{5} \\ \frac{0}{0} \\ \frac{0}{0} \\ \frac{0}{0} \\ \frac{0}{0} \\ 0 \\ 0 \\ 0 \\ 0 \\ \hline 196\end{array}$

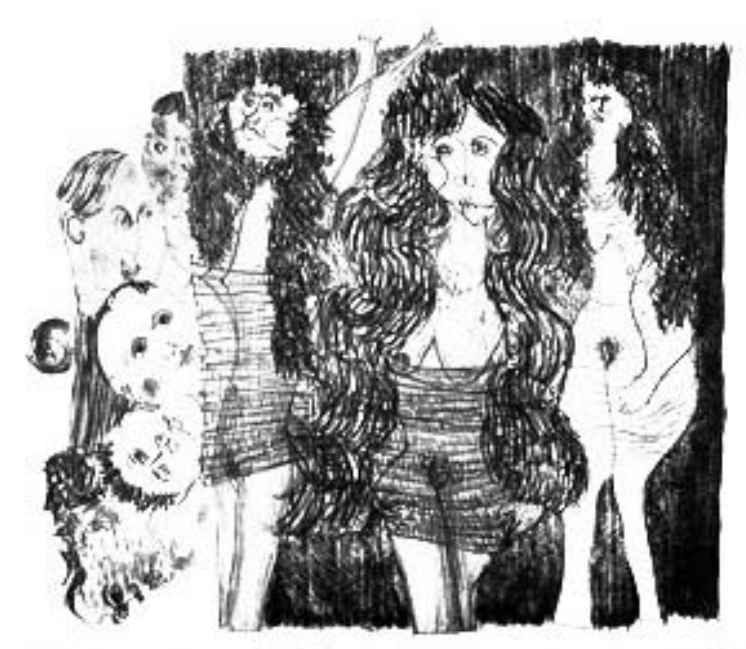



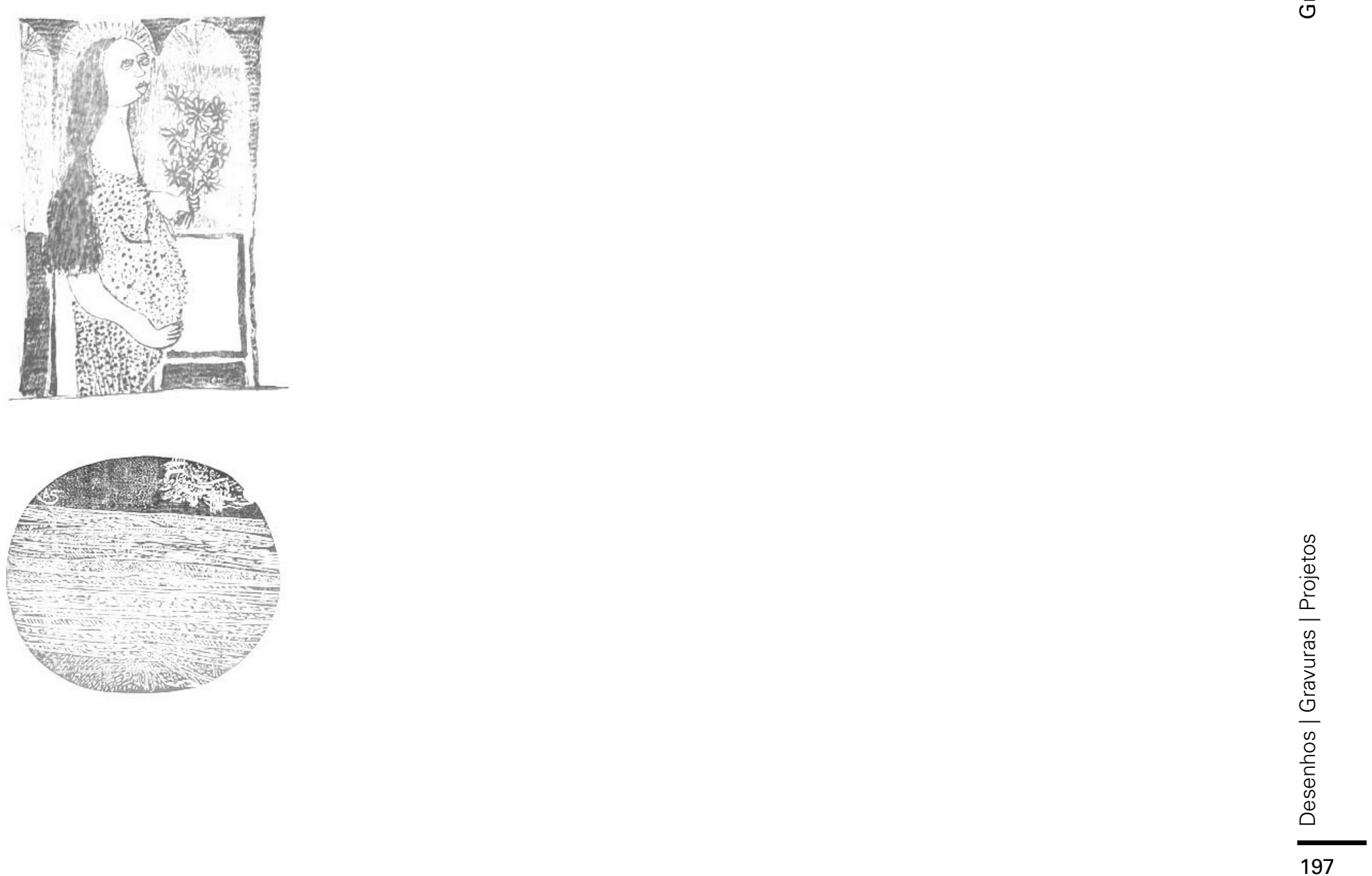


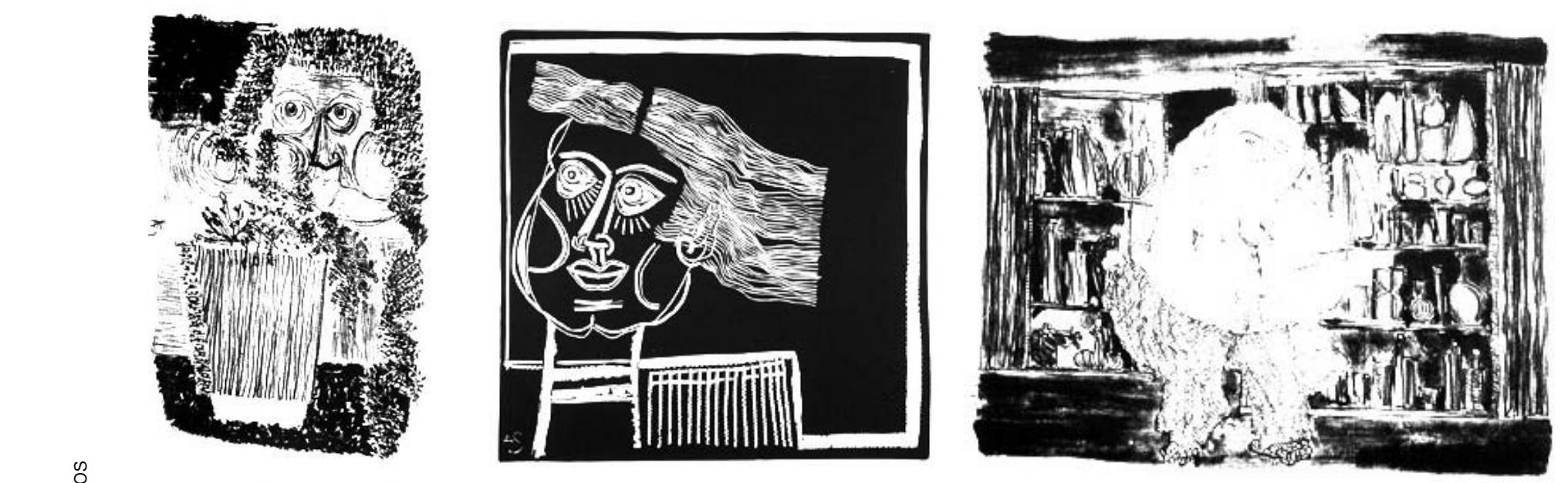




\section{Projetos}

Centro Social da Escola Politécnica da Universidade de São Paulo - 1962

fonte [imagens|desenhos] Zodiac n¹1, 1963 p. 63 a 66

Por Abrahão Sanovicz, Julio Roberto Katinsky e Oswaldo Correa Gonçalves

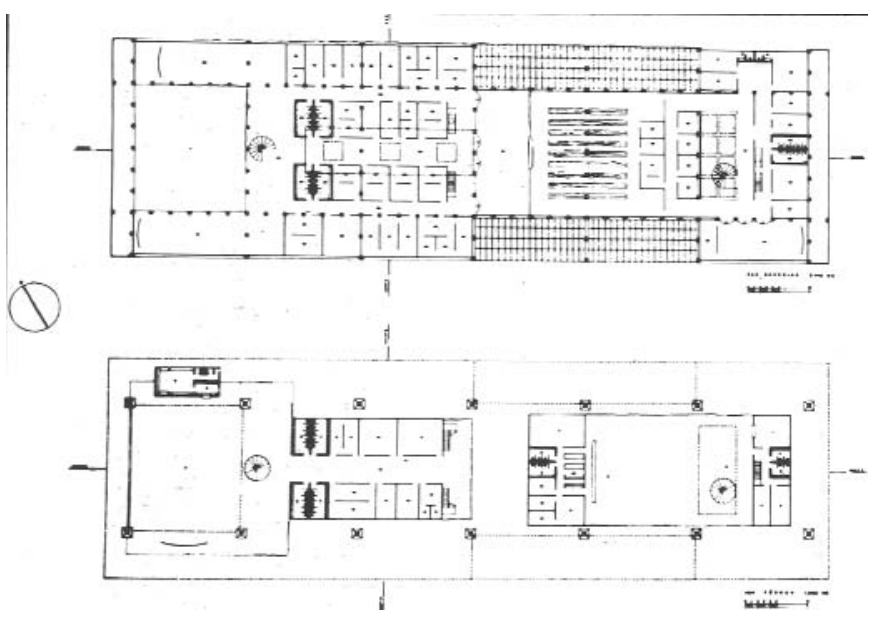

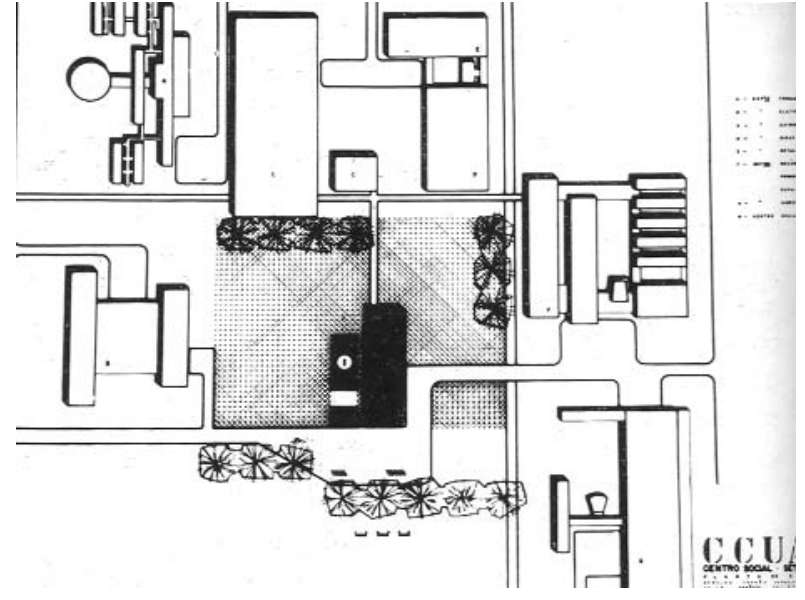
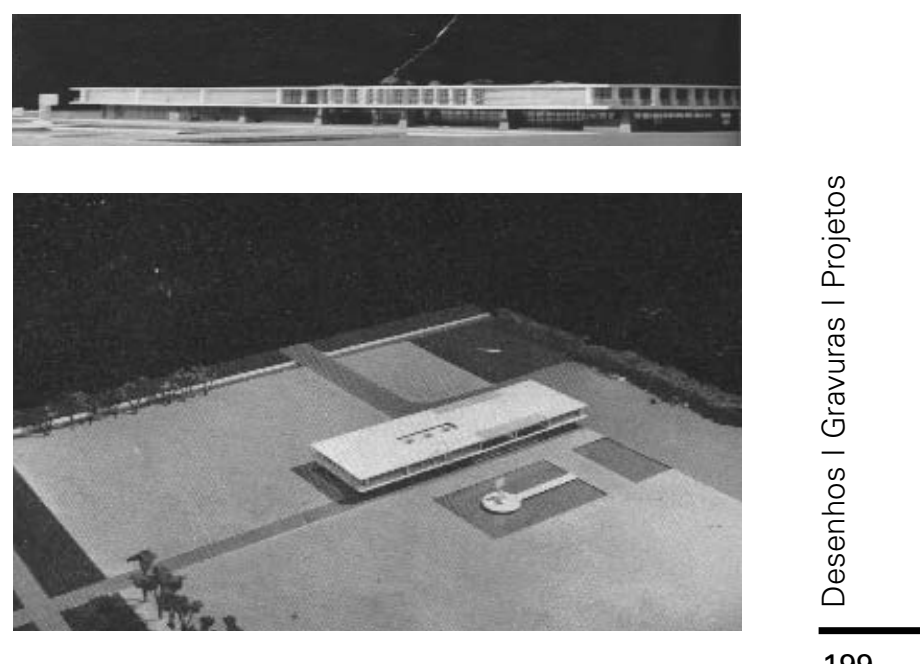
Linha de Móveis para Escritório - 1962

Contratante: Escriba - Indústria e Comércio de Móveis Ltda. - SP

fonte [imagens] acervo escritório Elito Arquitetos

Conjunto de mesas e estantes para escritórios.
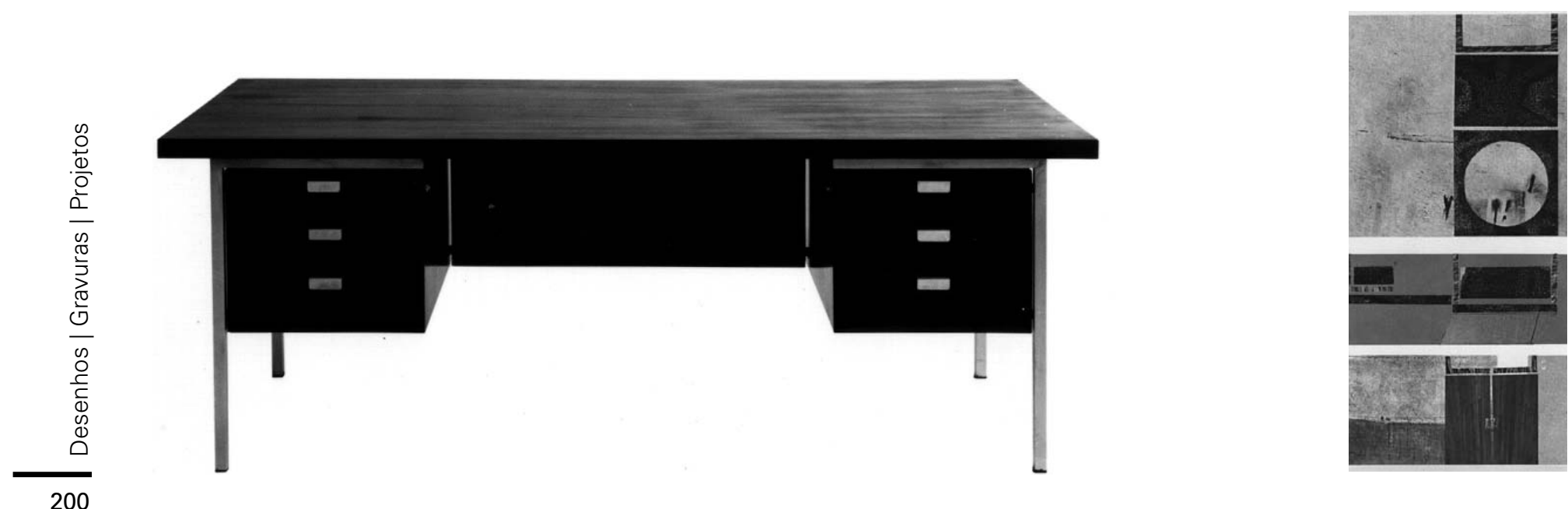

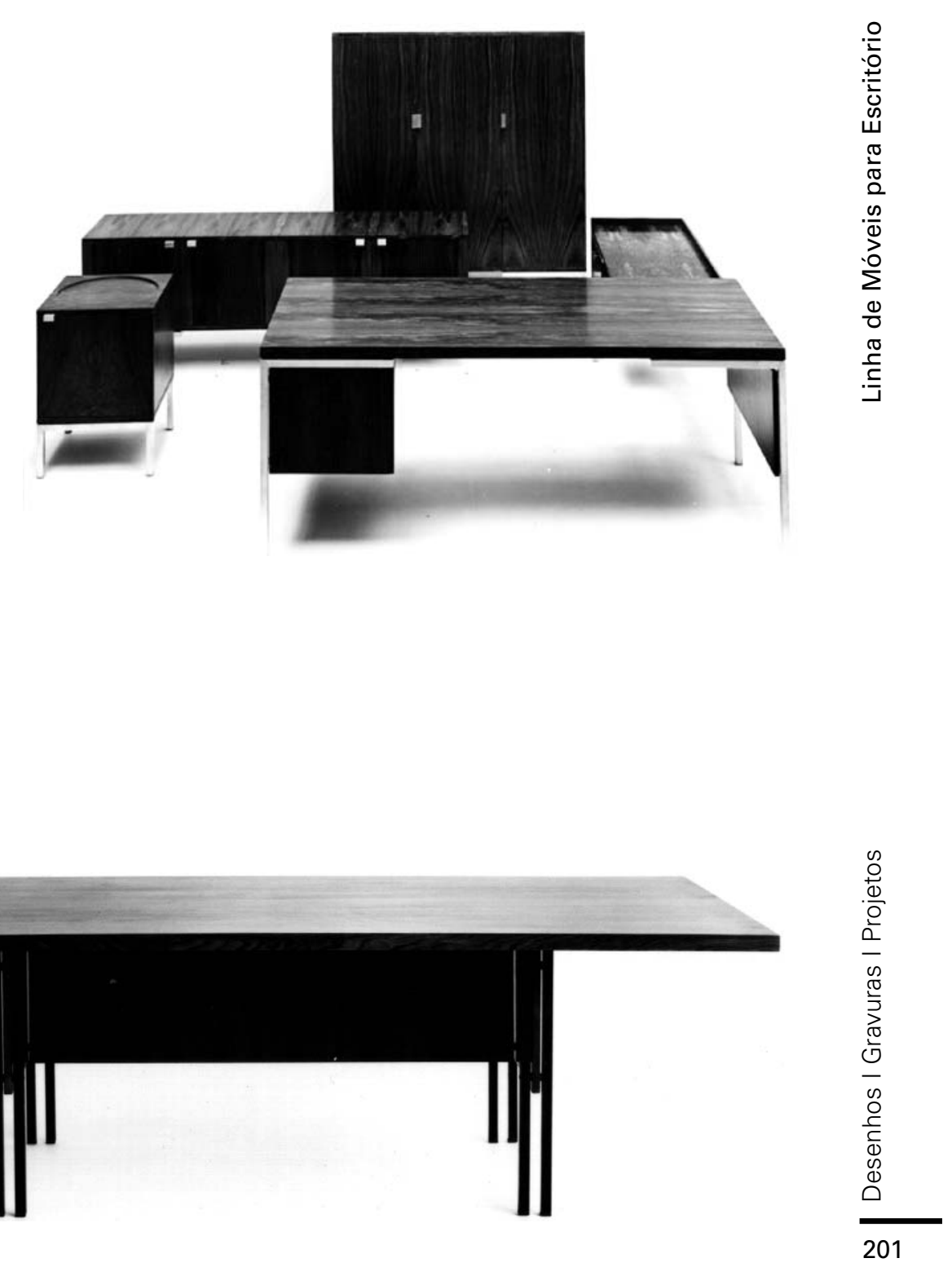
Residência Zelia Deril Twiaschor - 1968

Rua Osvaldo Leite Ribeiro, 276 - São Paulo - SP

fonte [desenhos] acervo biblioteca FAU USP

[imagens] acervo escritório Elito Arquitetos

Edificacão em dois pavimentos. Ao nível do acesso da rua, a sala de estar, com local para música, o recanto de refeições e servicos.

No pavimento inferior, os quatro dormitórios e banheiros, com

acesso ao jardim, em cota inferior à da rua.
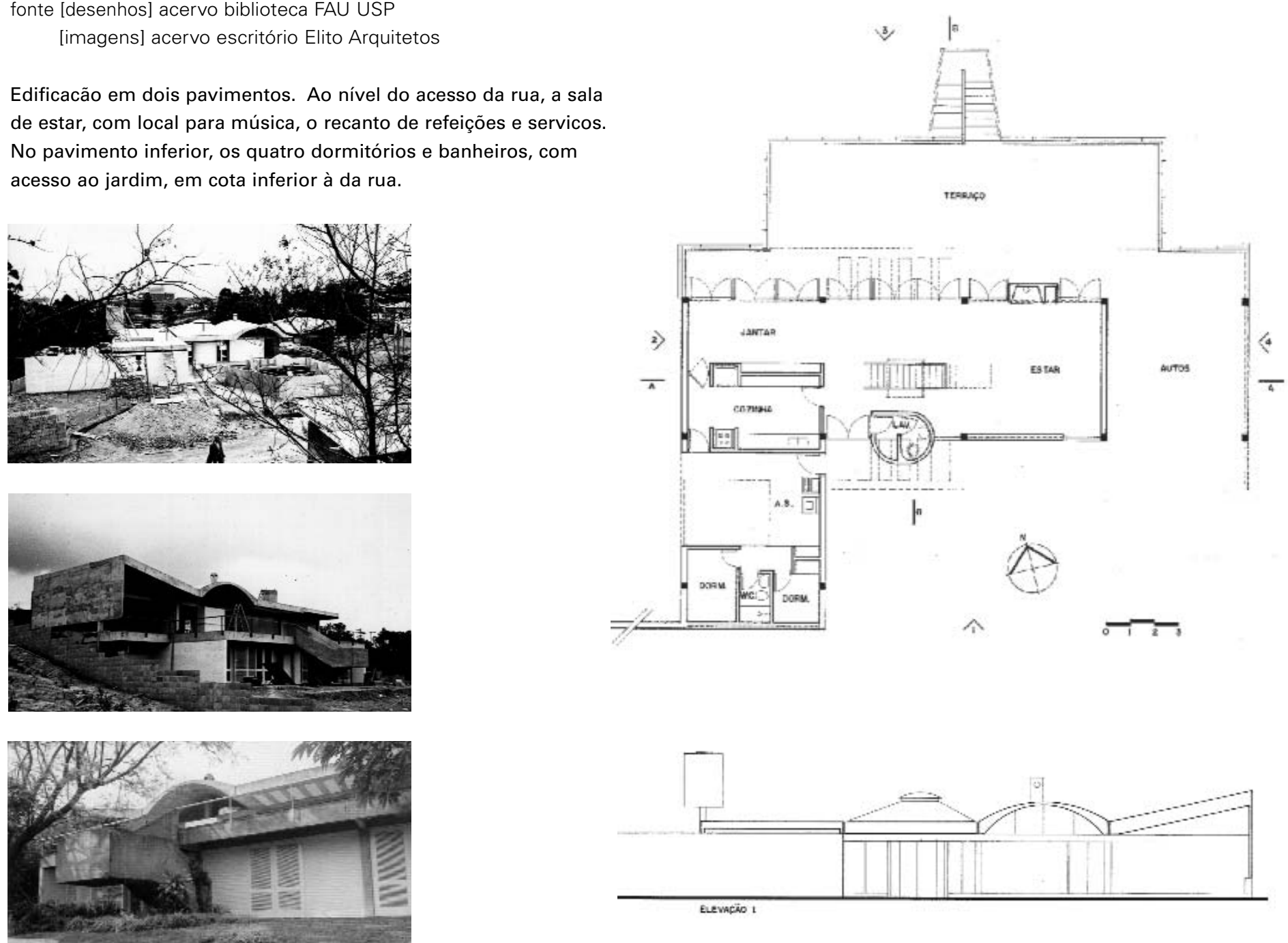

ELevecio 1 

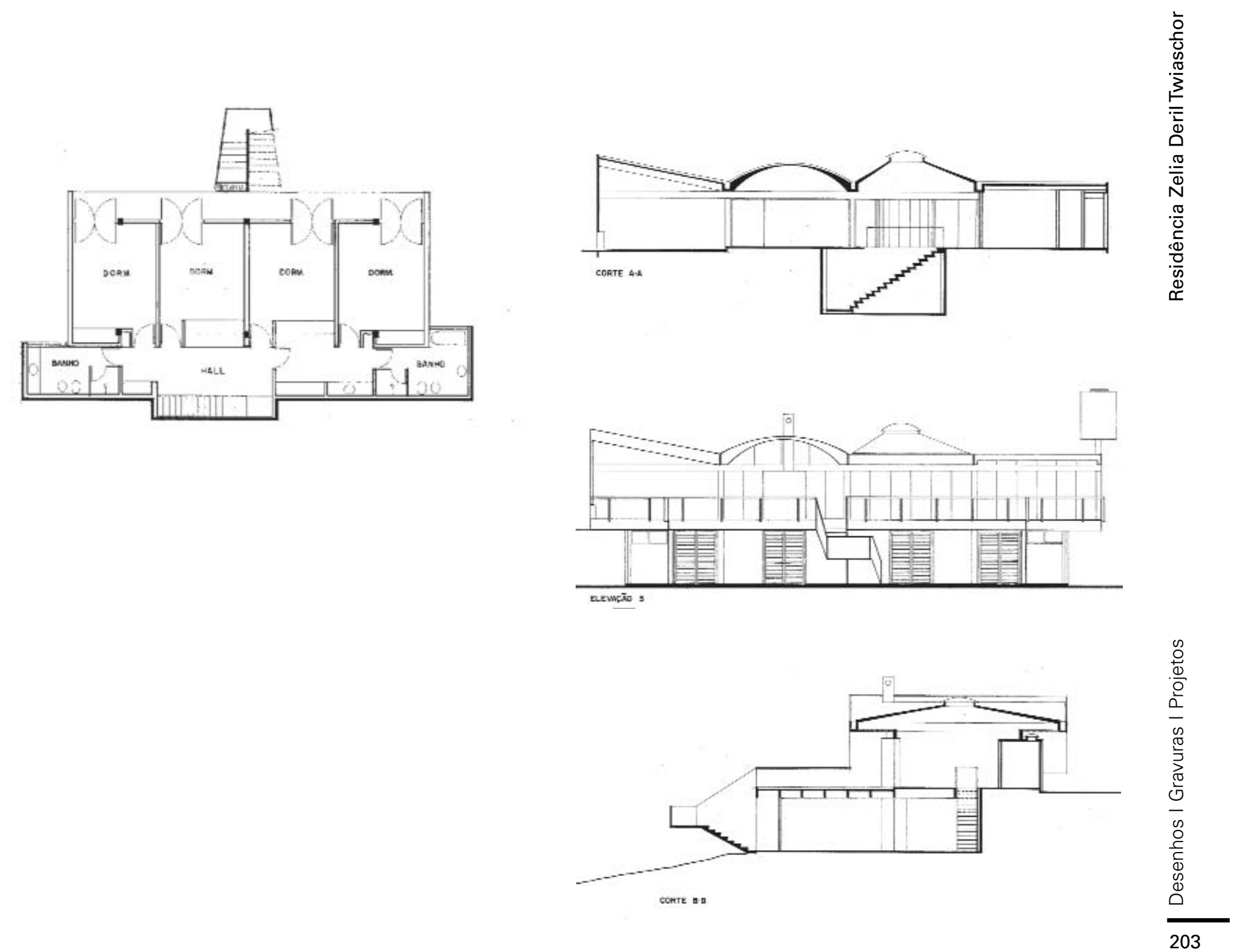
Conjunto Residencial - 1969

Rua Bolívia - Jardim Prudência - SP

Contratante: Formaespaco S.A. Construcōes

fonte [desenhos] acervo biblioteca FAU USP

[imagens] acervo escritório Elito Arquitetos

Conjunto de 22 residências padrão. Área de cada residência:

$154 \mathrm{~m}^{2}$, em dois pavimentos. No pavimento térreo, garagem,

servicos, estar, refeições e cozinha. No pavimento superior, três

dormitórios e dois banheiros.

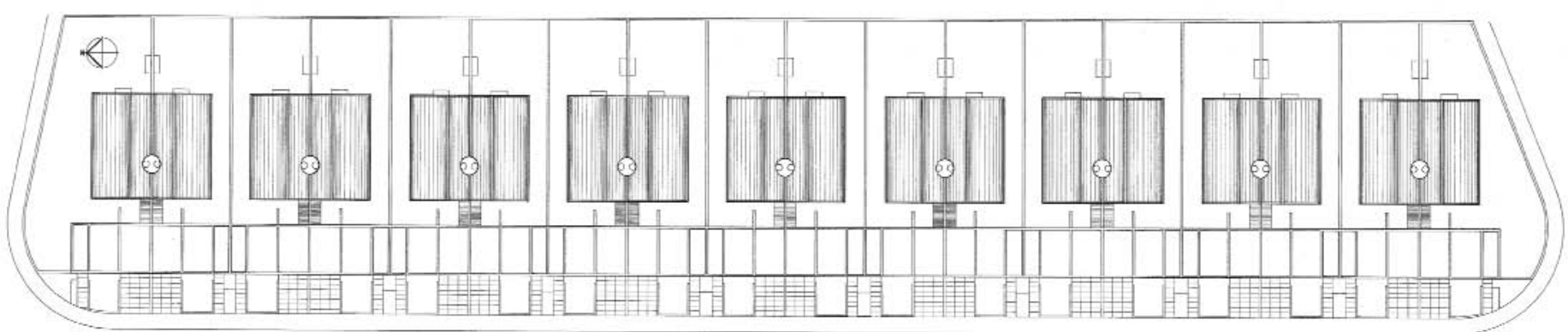

PLANTA Geral do CONJUNTO

RUA BOLIVIA

- -

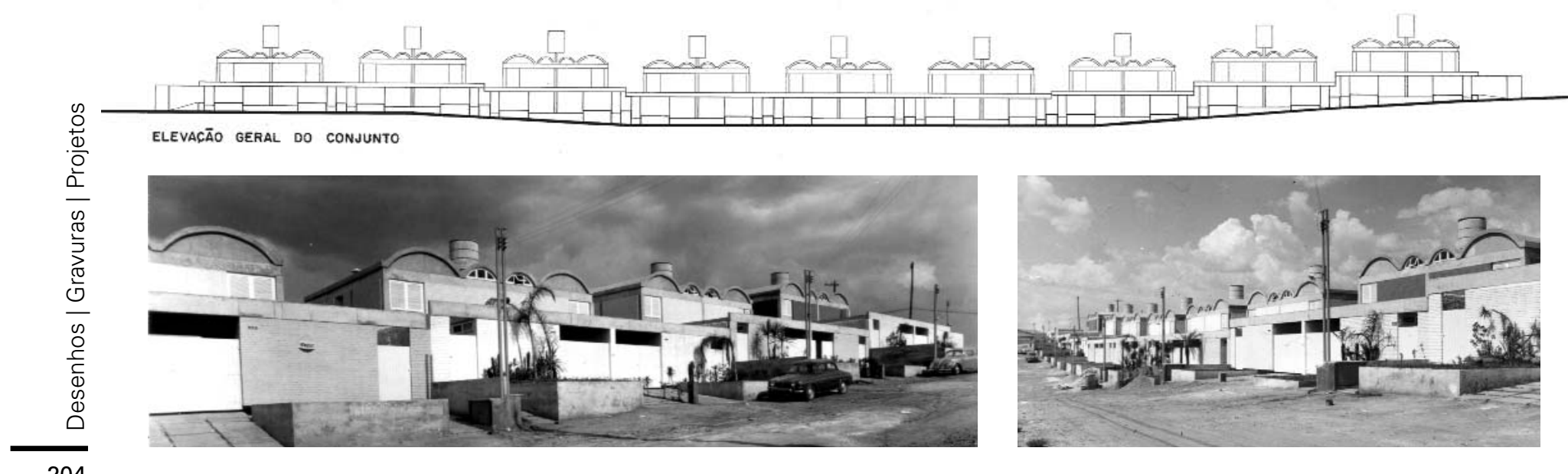



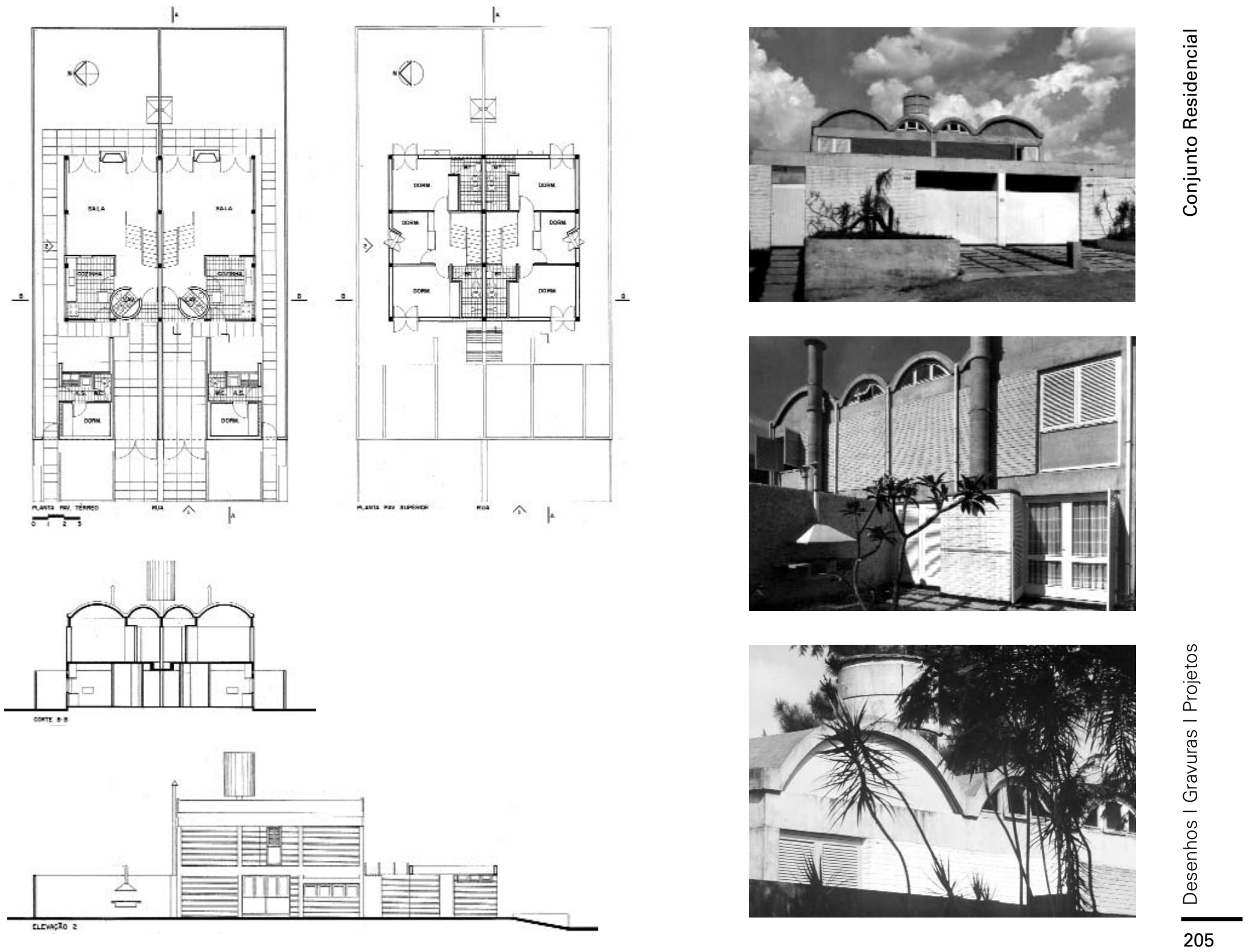
Centro Cultural Georges Pompidou - 1971

Concurso em Paris, França

fonte [desenhos | imagens] acervo Paulo Mendes da Rocha

Por Abrahão Sanovicz e Paulo Mendes da Rocha

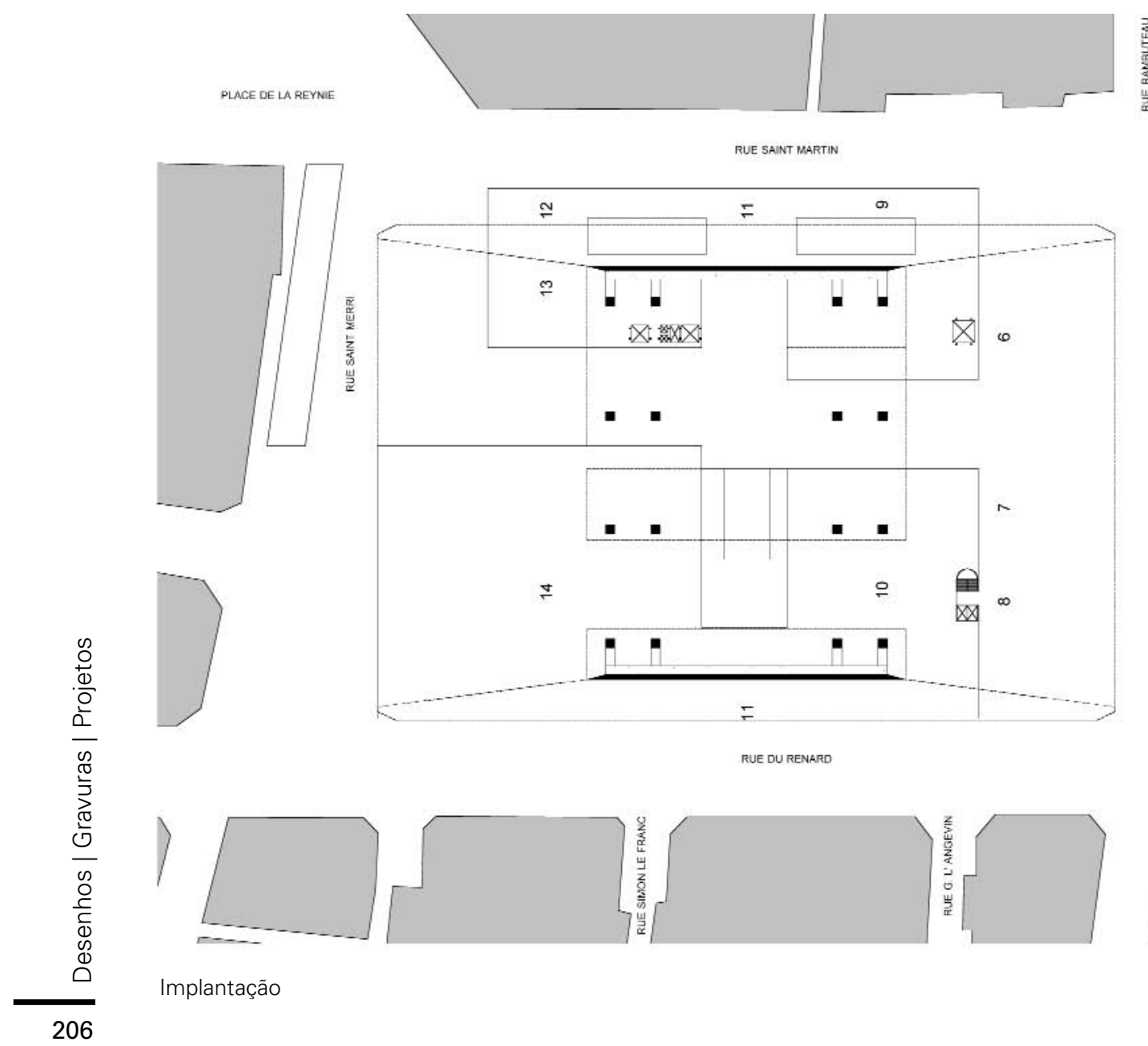

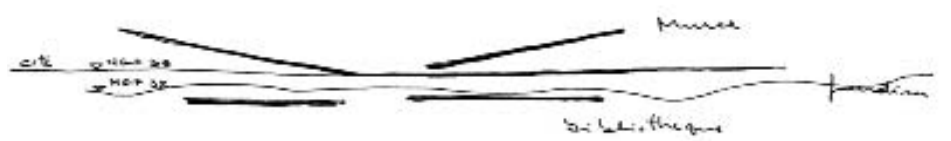
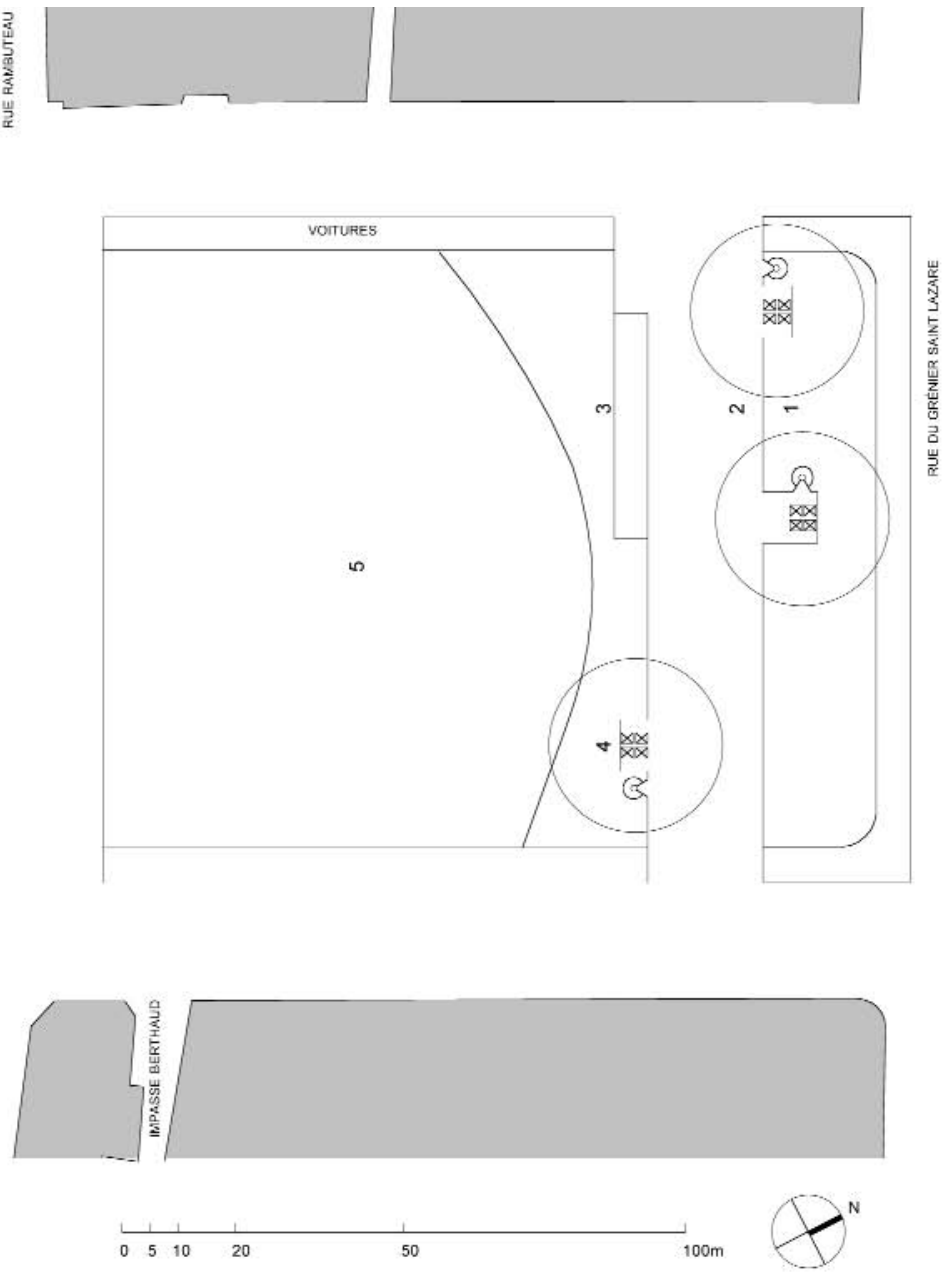


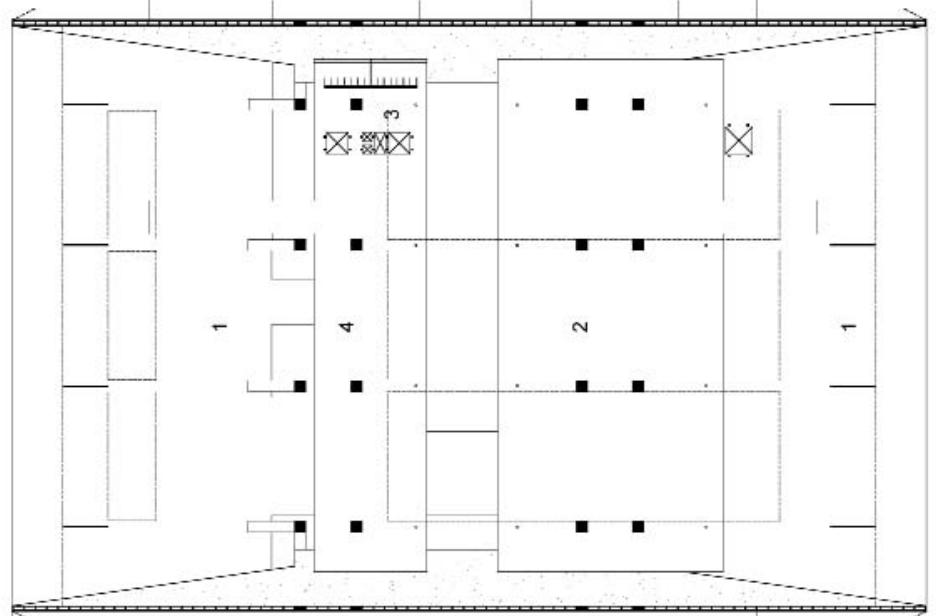

Planta do Museu

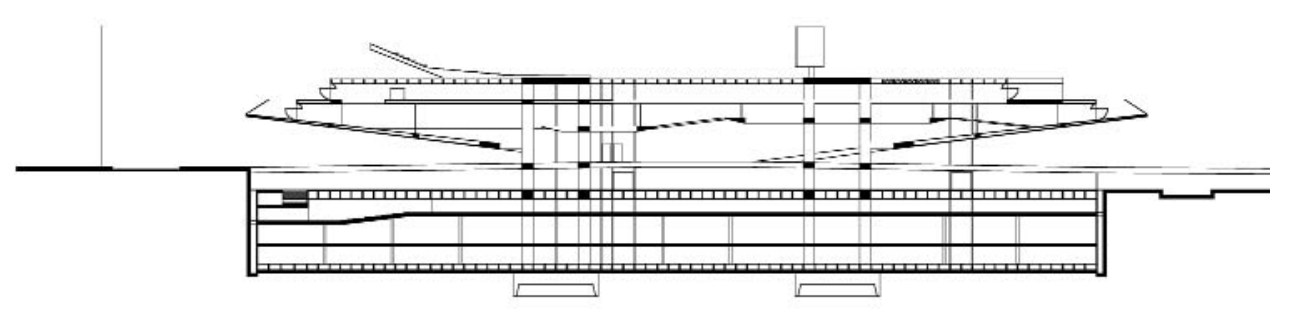

1- torres de escritórios

2- galeria comercial

3- terraço do café

4- hôtel des artistes

5- jardim

6- monta-cargas

7- ônibus

8- acesso administração

9- acesso Rue de Rambuteau

10- jardim da biblioteca

11- metrô

12- acesso estacionamento

13- táxi

14- acolhimento, jardim da biblioteca,

cantina e cafeteria

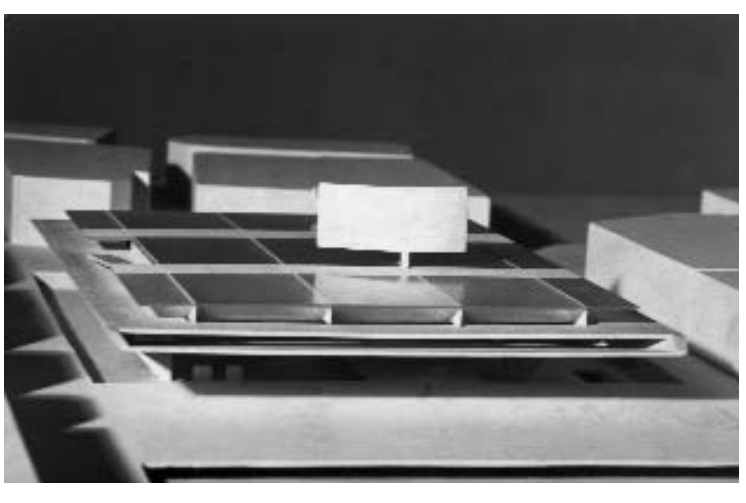


Residência de veraneio Família Sanovicz - 1973 Ubatuba - SP

fonte [desenhos] acervo biblioteca FAU USP

[imagens] acervo escritório Elito Arquitetos
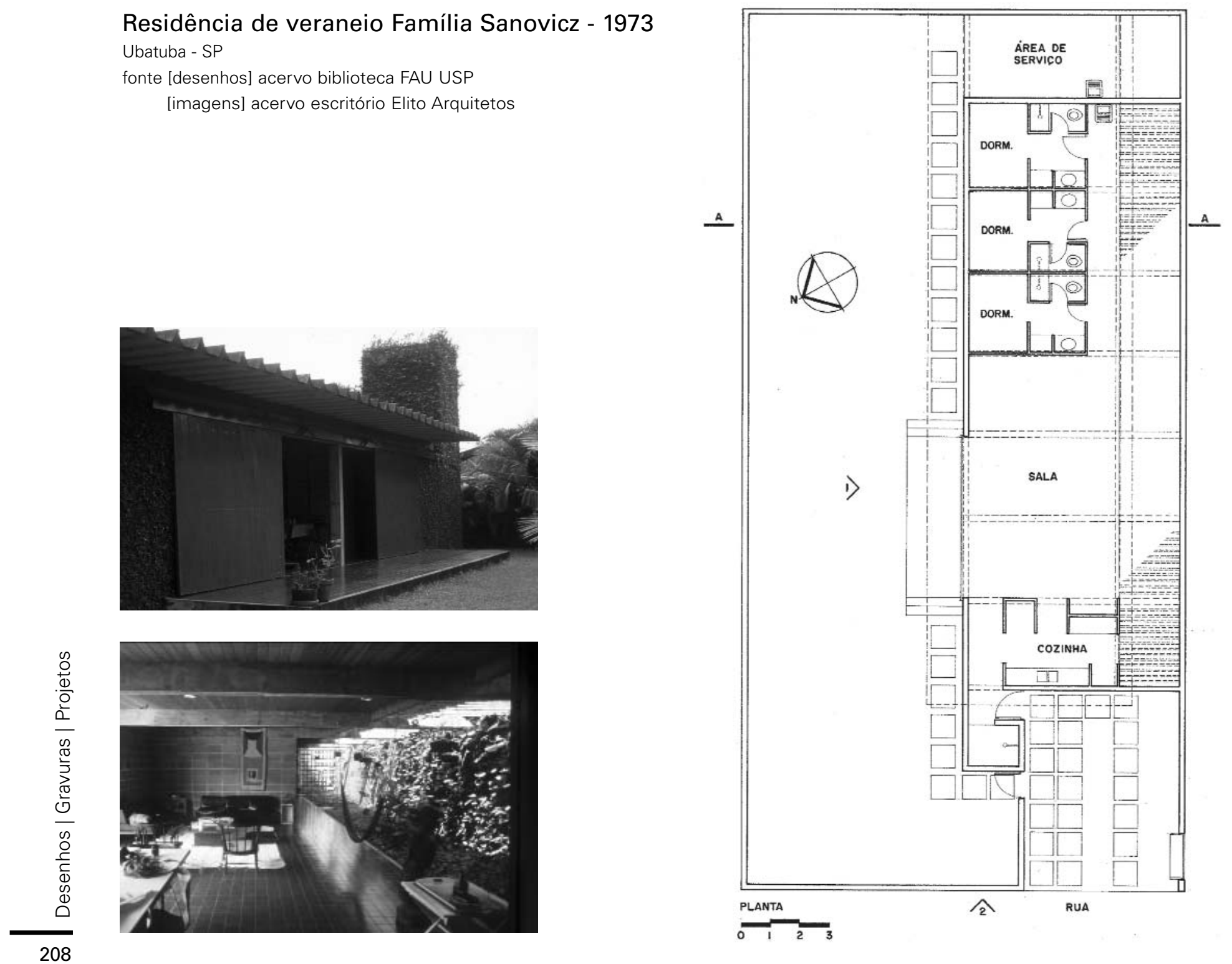

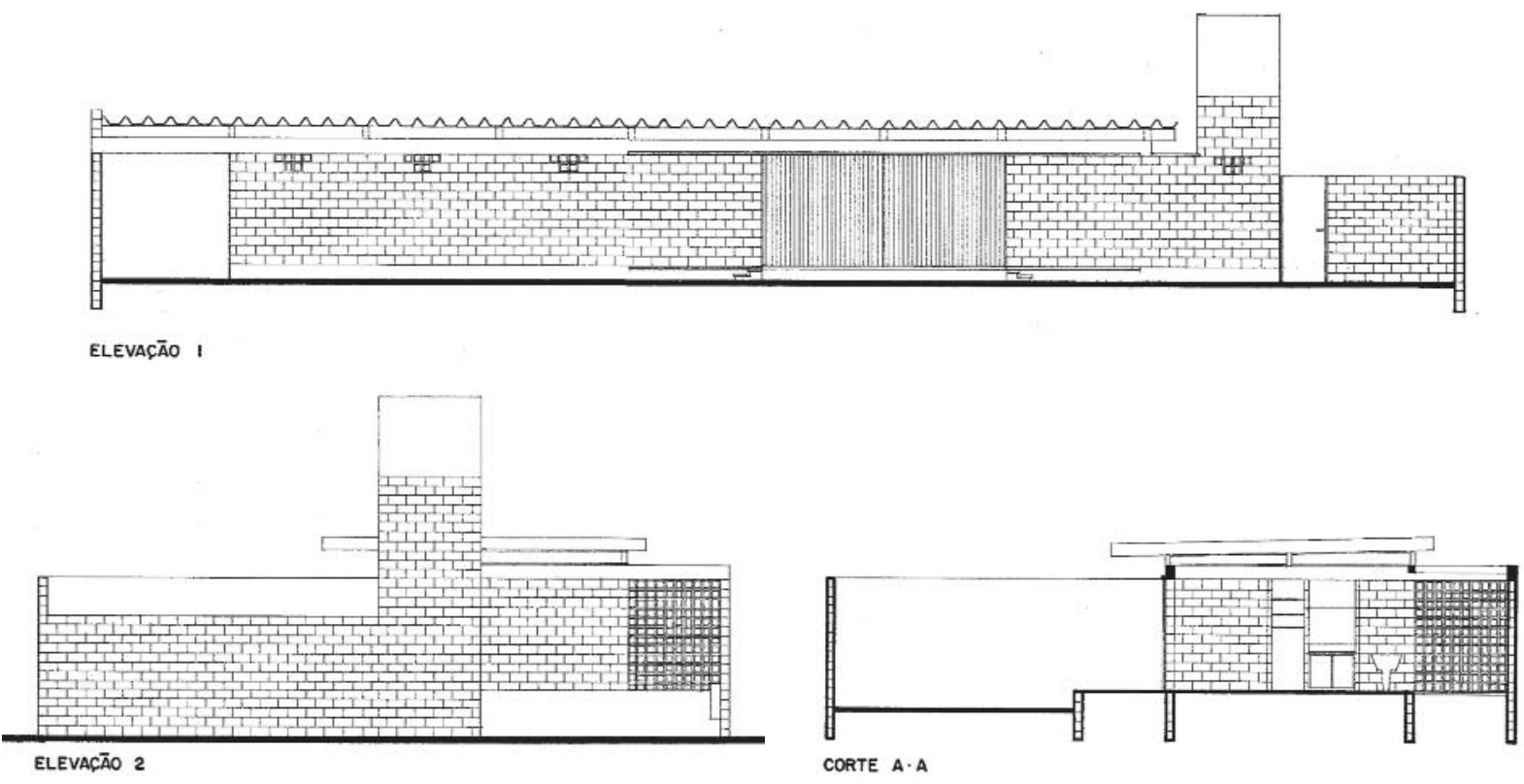
Quatro Sub-Regionais Agrícolas Padrão - 1973/1974

Guaratinguetá, Botucatu, Catanduva e Santa Fé do Sul - SP

Contratante: Secretaria da Agricultura do Estado de São Paulo

fonte [desenhos] acervo biblioteca FAU USP

[imagens] acervo escritório Elito Arquitetos

Edificacões em dois pavimentos. Pavimento térreo: espaco para

exposições especializadas, depósito de sementes e servicos gerais

Pavimento superior, sobre pilotis: sala dos técnicos, administração,

laboratórios e servicos gerais.
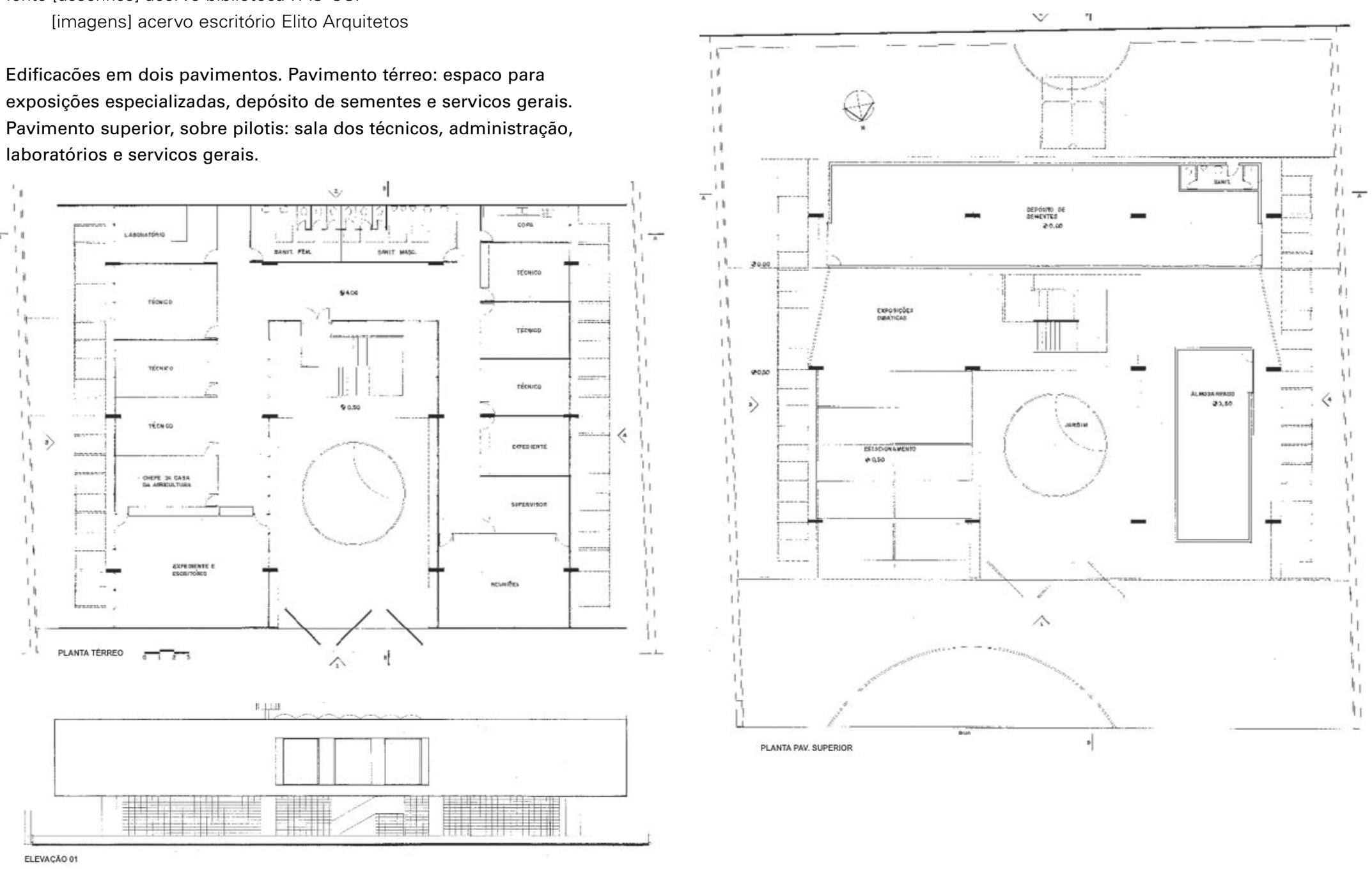

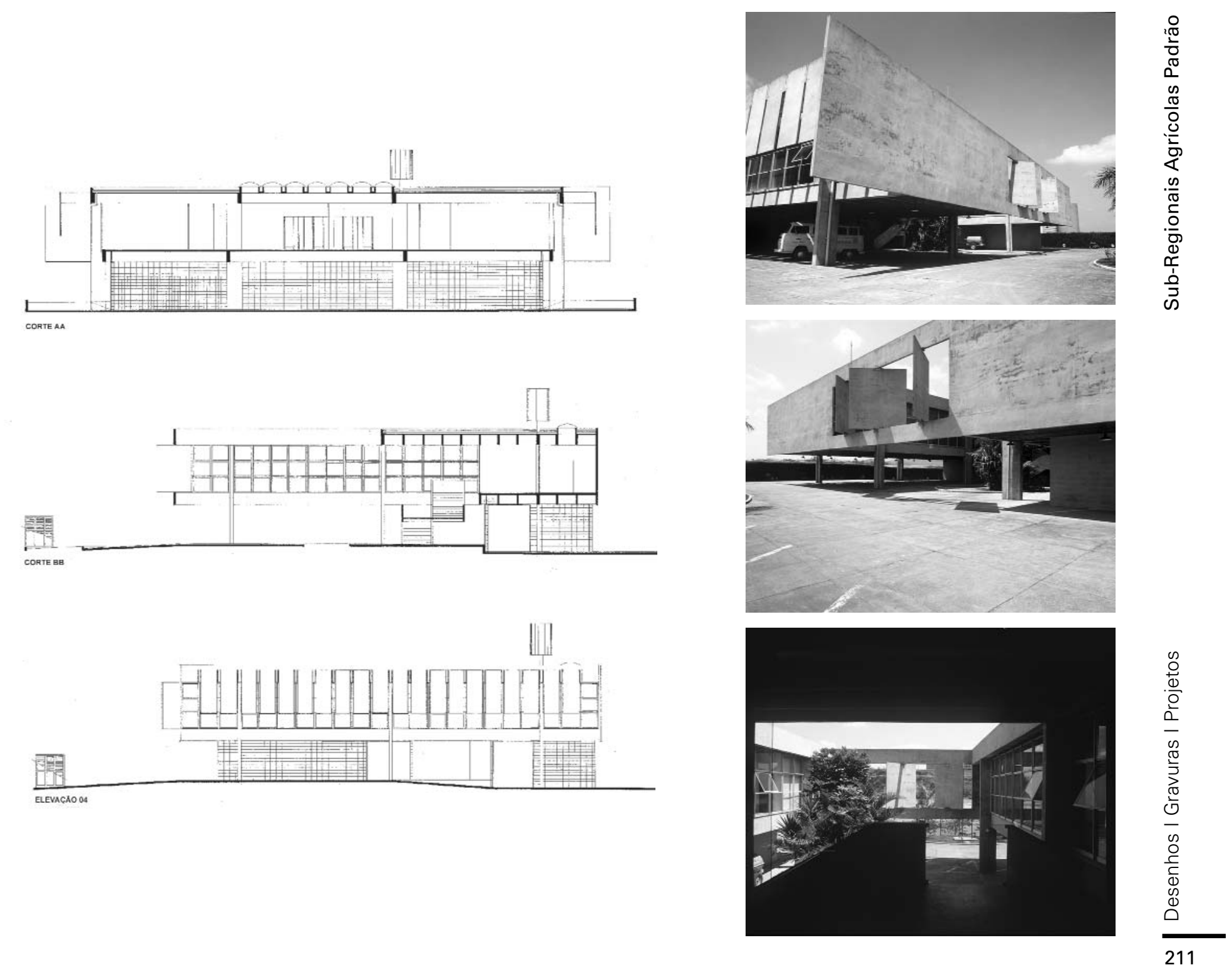
Usina de Beneficiamento de Algodão - 1973/1978

Aguaí - SP

Contratante: Secretaria da Agricultura do Estado de São Paulo

fonte [desenhos] acervo biblioteca FAU USP

[imagens] acervo escritório Elito Arquitetos

Conjunto de edifícios destinados à portaria e controle,

administração, tulha, casa de máquinas, depósito de fardos,

depósito de sacaria, laboratório com deslintamento químico

depósito de sementes, vestiários e reservatórios d'água.
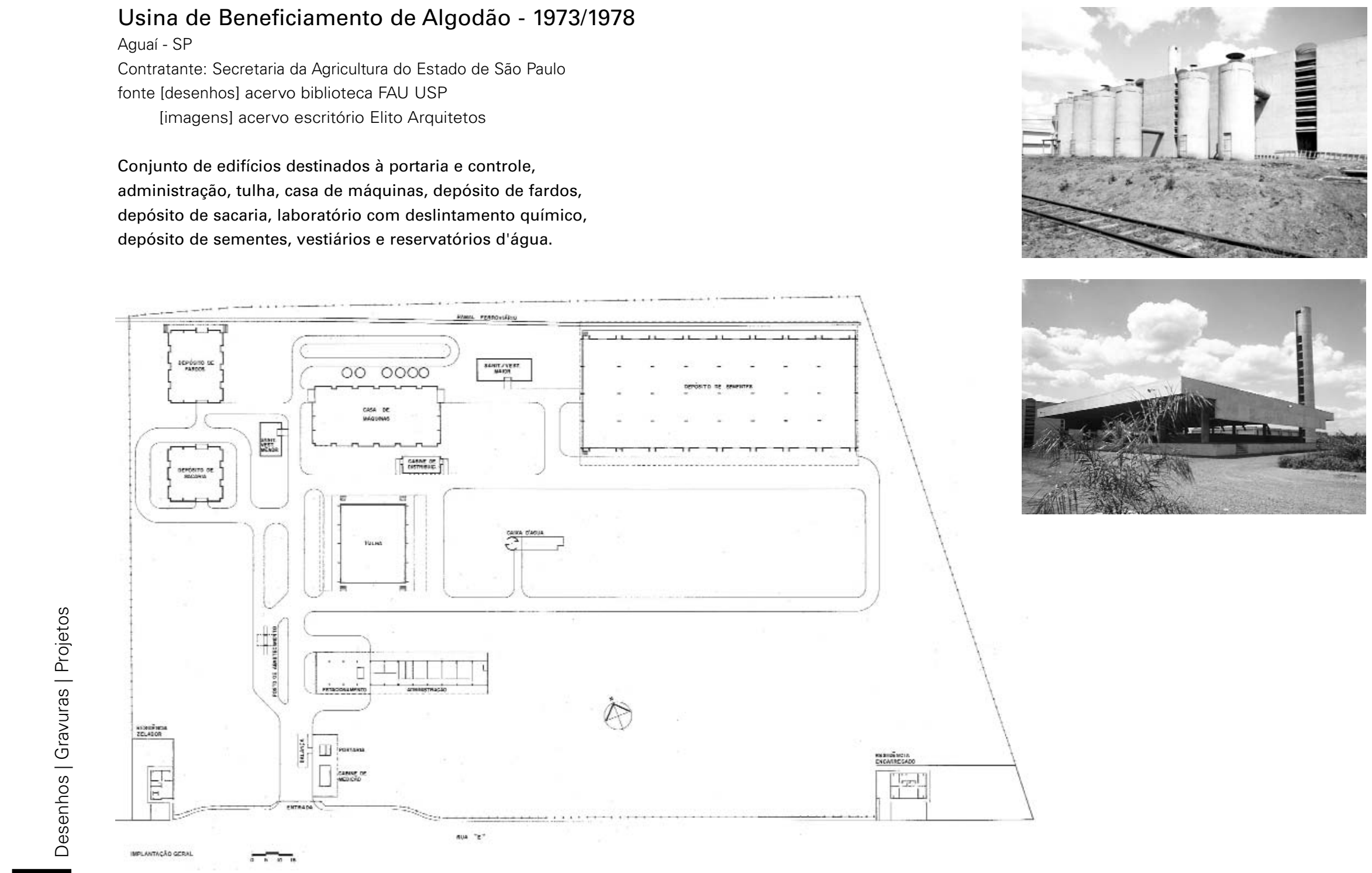

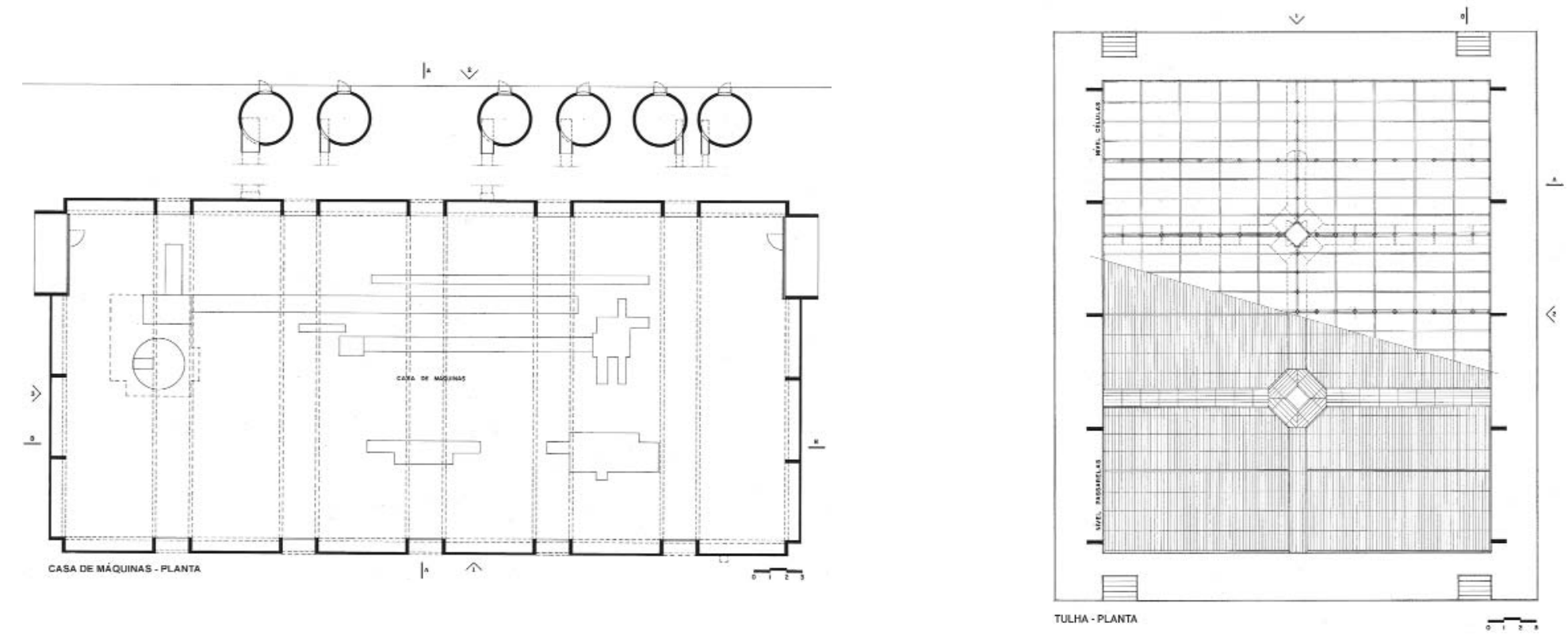

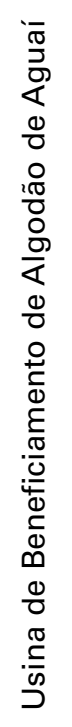
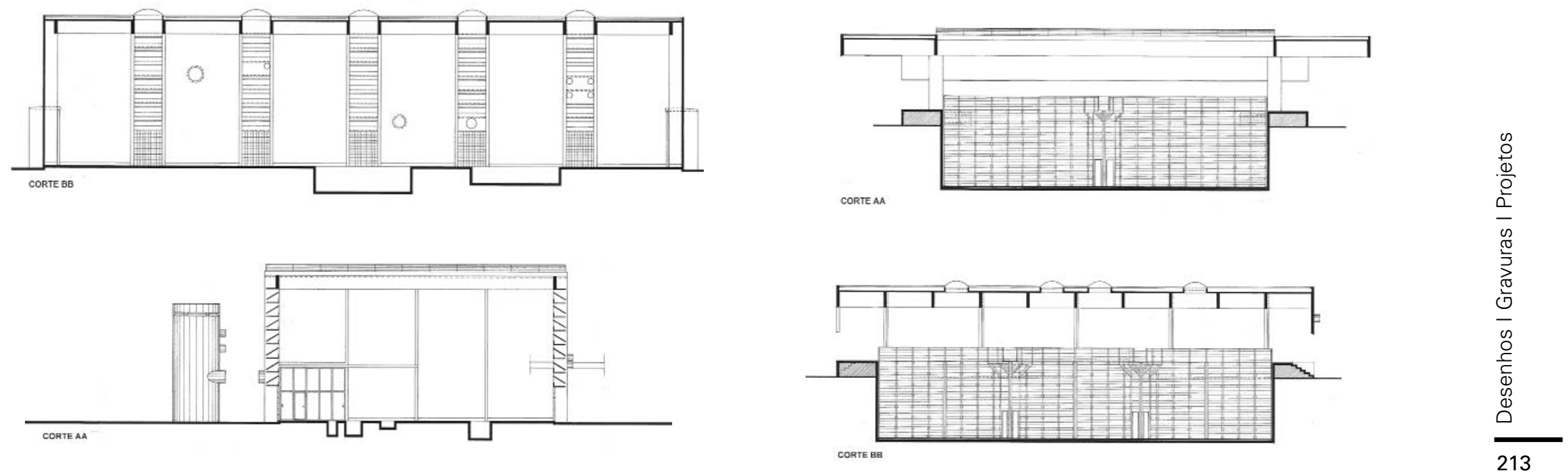
Reurbanização do Vale do Anhangabaú - 1974

São Paulo - SP

fonte [desenhos] acervo biblioteca FAU USP

Por João Batista Vilanova Artigas, Abrahão Sanovicz, Marlene

Yurgel, Harue Yamashita e Eduardo de Jesus Rodrigues
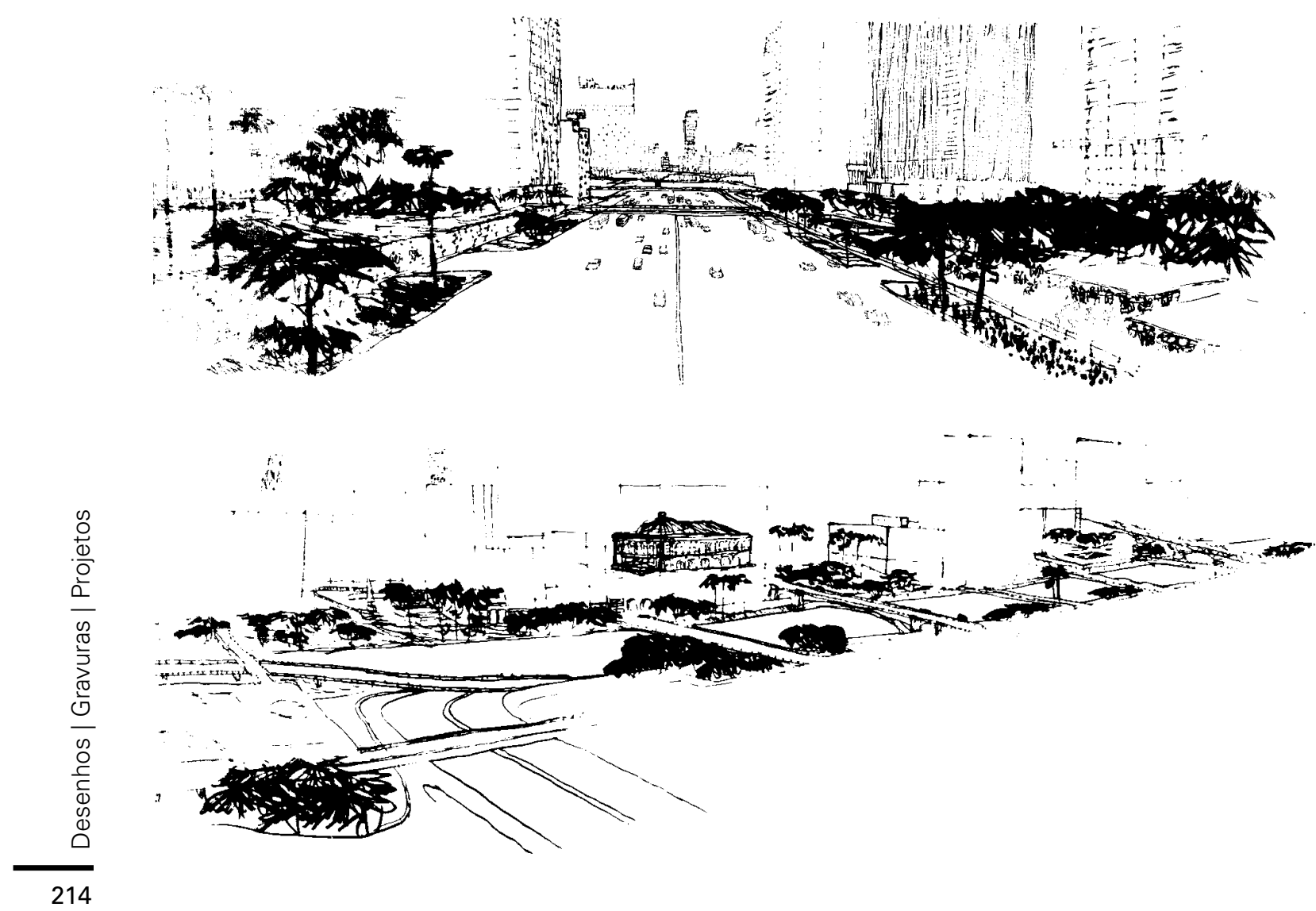

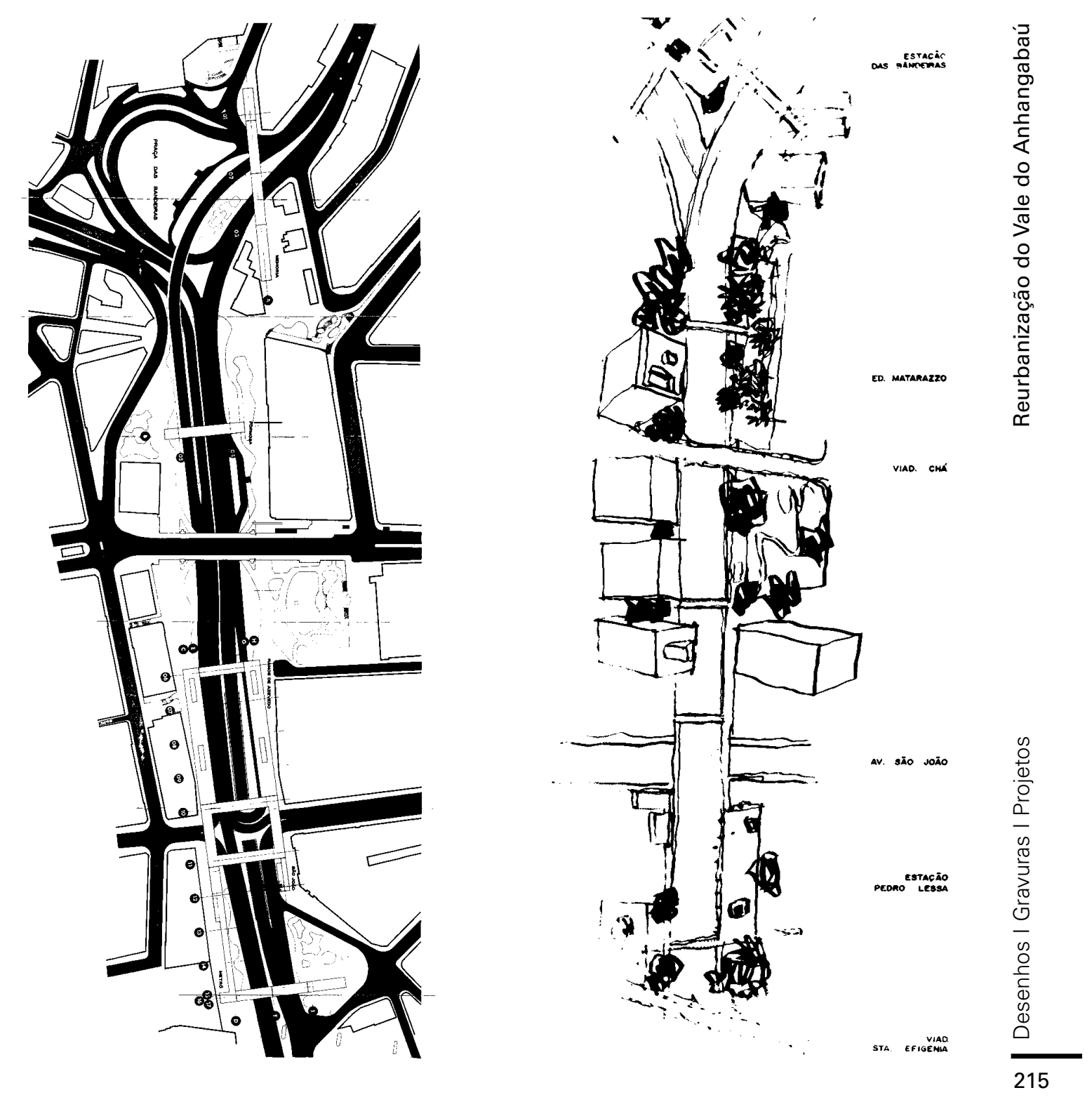
Linha de Móveis para Escritório - 1976

Contratante: Forene S.A. Móveis do Nordeste

fonte [imagens] acervo escritório Elito Arquitetos

Mesas de trabalho, de reunião e auxiliares, armários componíveis

e gaveteiros volantes.
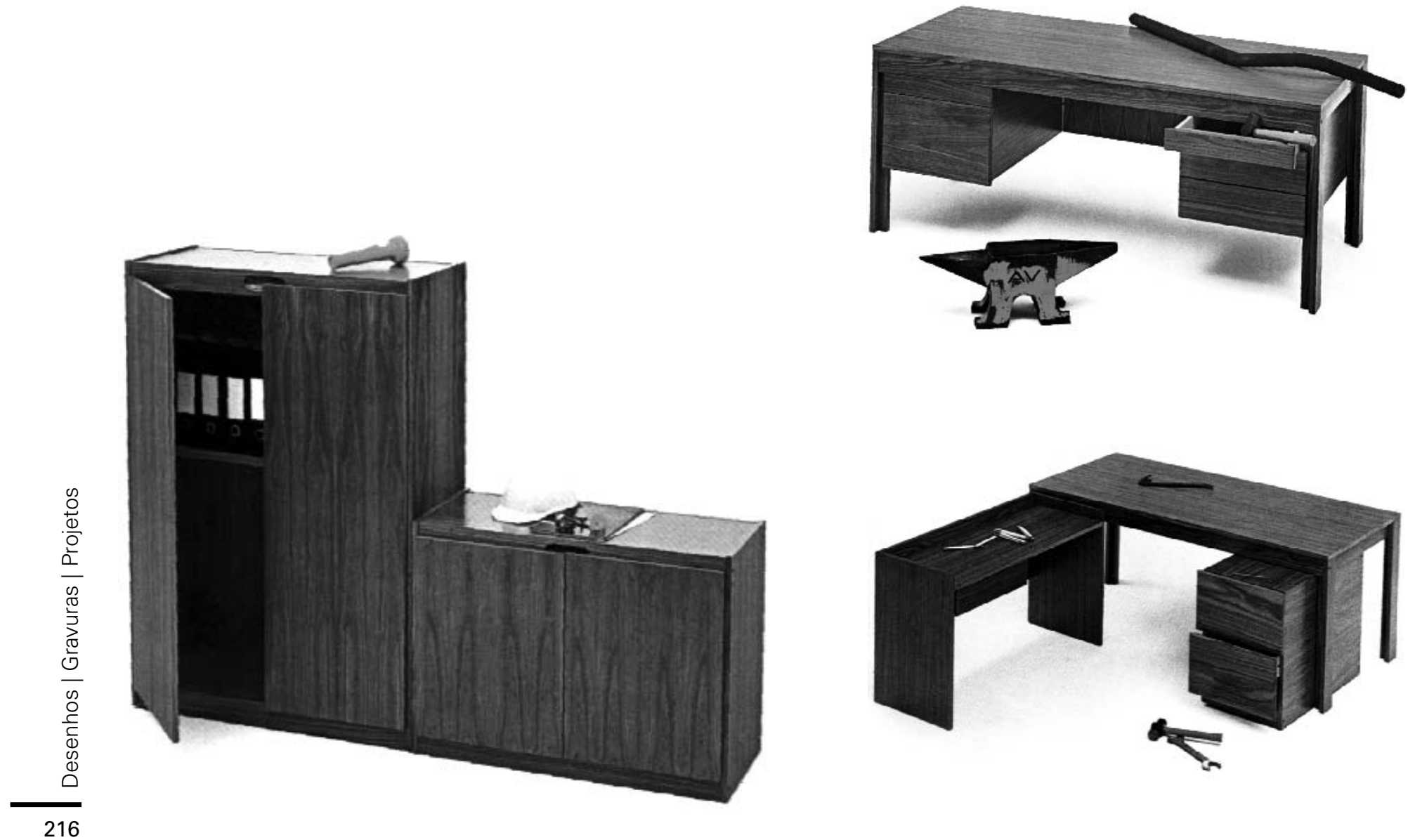
Unidade de Tecelagem da Grisbi Nordeste S.A. - 1977

Pírapora - MG

Contratante: Grisbi S.A. Indústrias Têxteis - SP

fonte [desenhos] acervo biblioteca FAU USP

[imagens] acervo escritório Elito Arquitetos

No bloco principal ficam a tecelagem e tinturaria

com servicos anexos; as edificacões de apoio destinam-se à

administração, restaurante, e ao conjunto portaria e controle da fábrica.
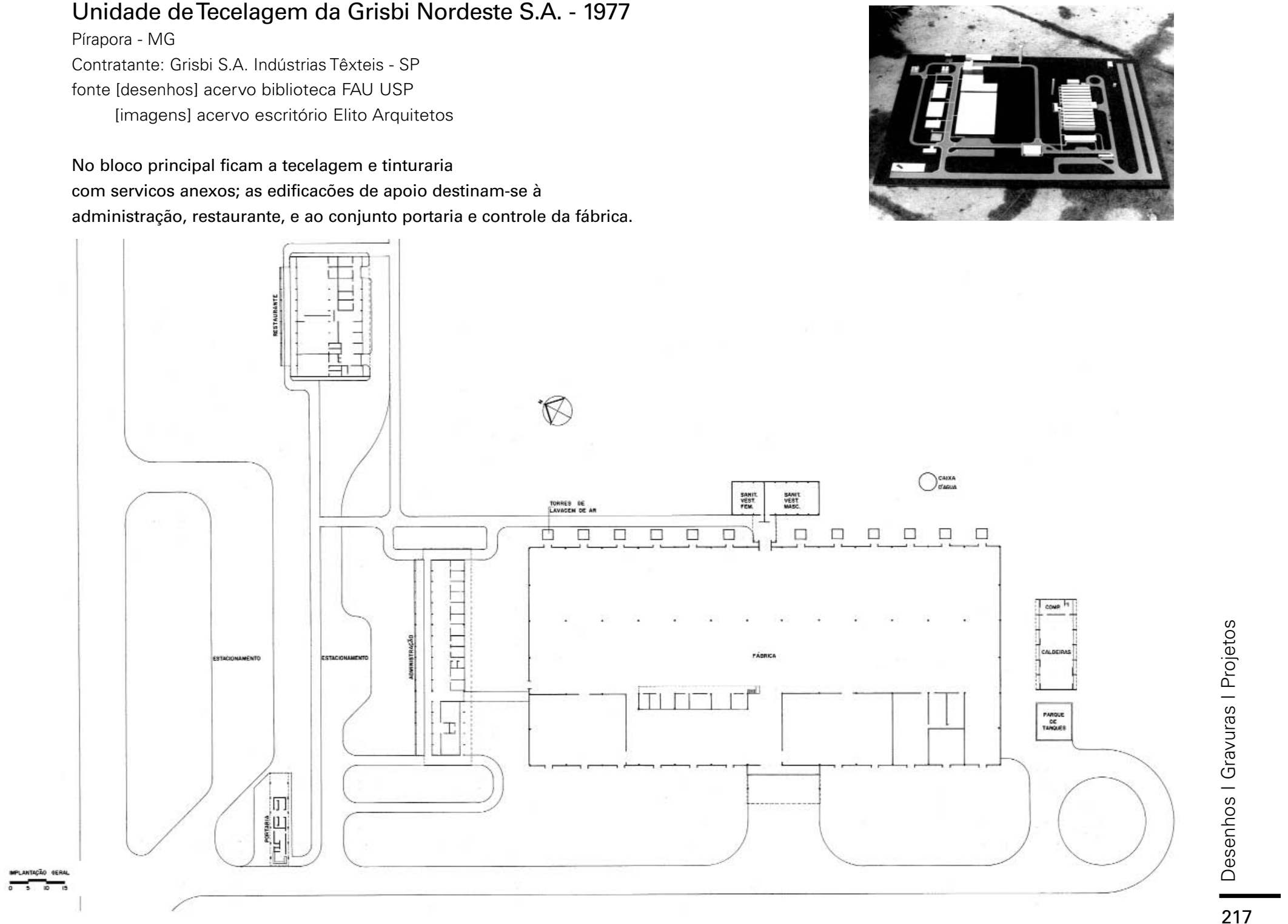

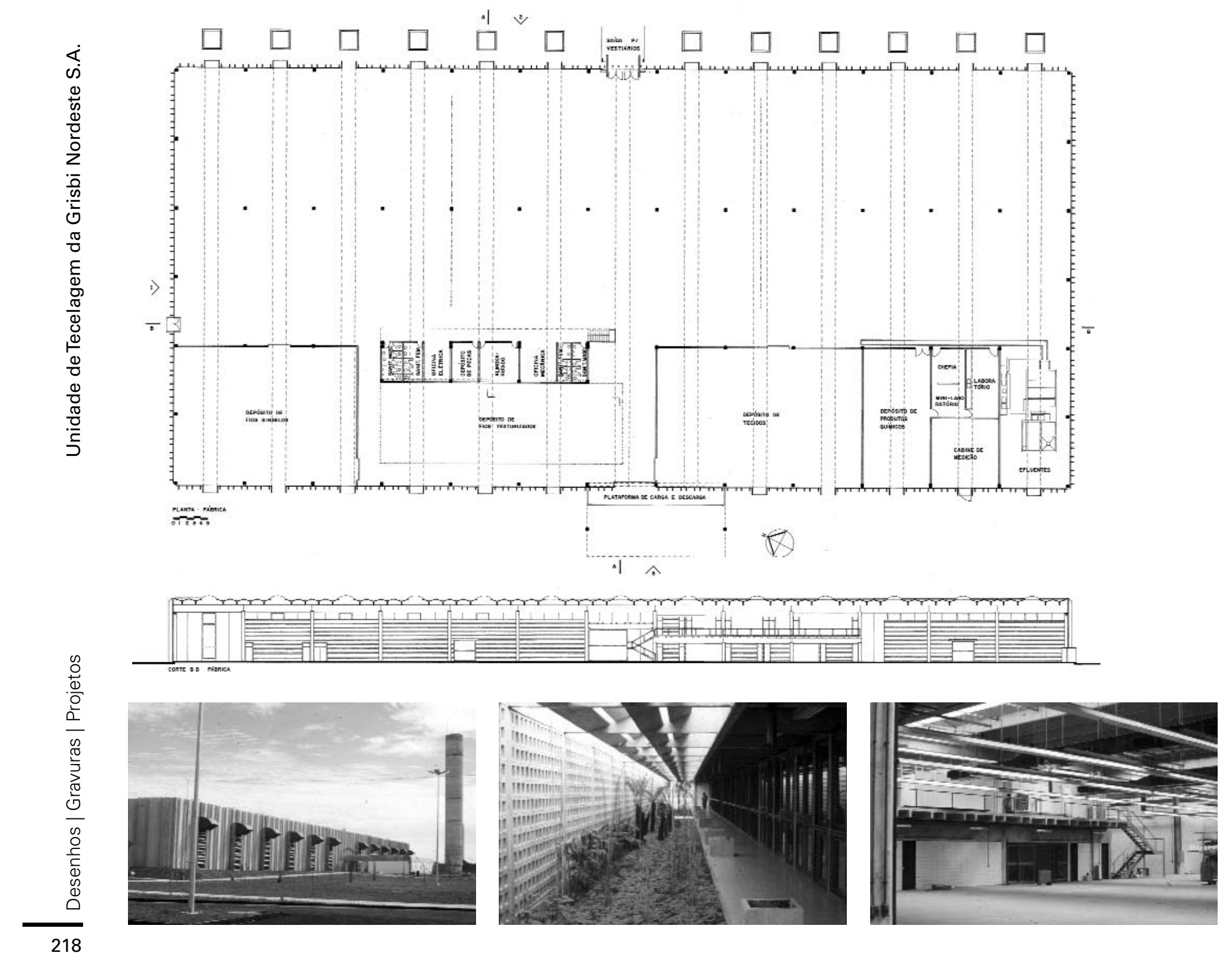


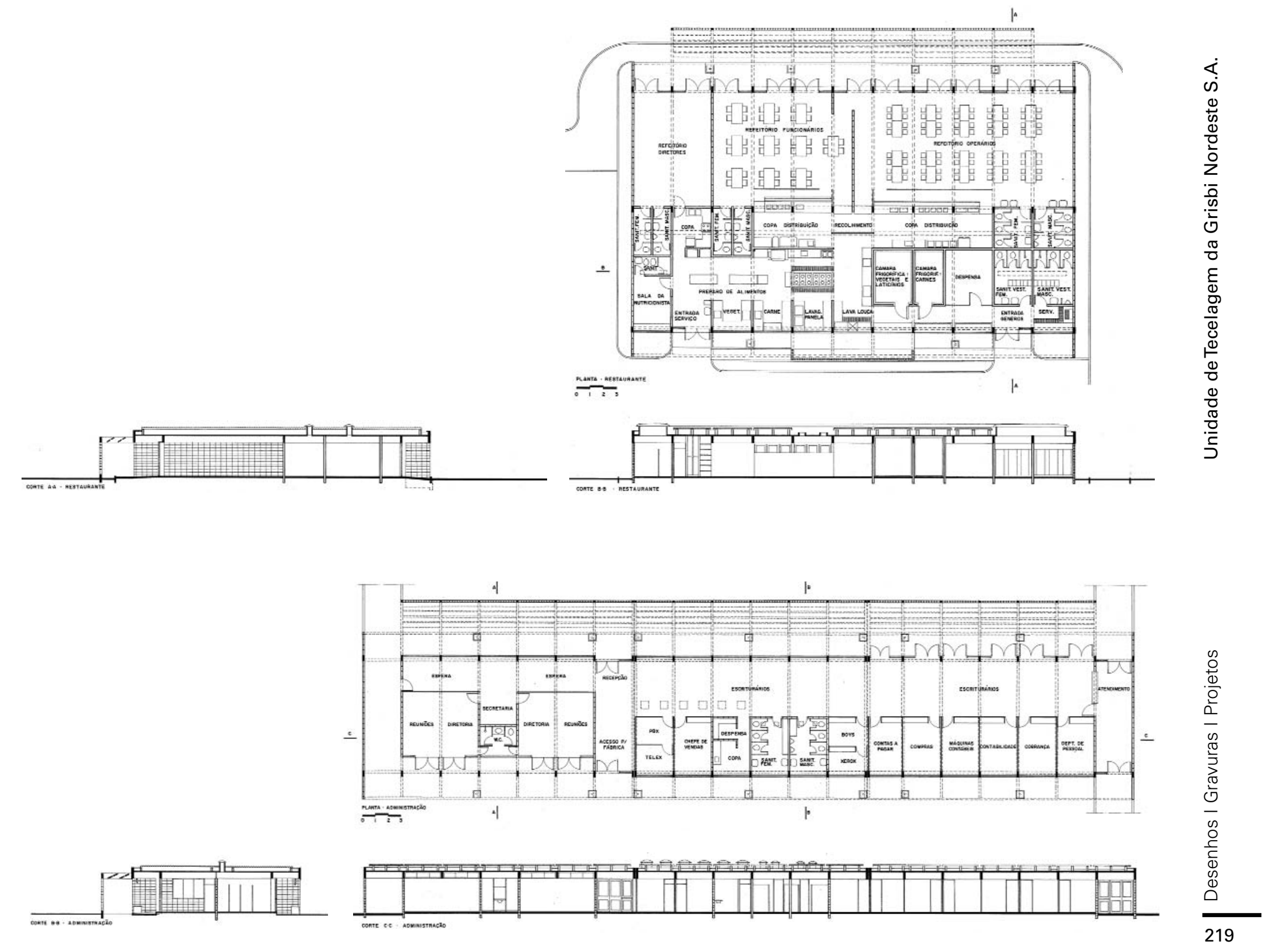


Sede da Sociedade Brasileira para o Progresso da Ciência (SBPC) - 1978

Concurso em São Paulo - SP

fonte [desenhos] acervo biblioteca FAU USP
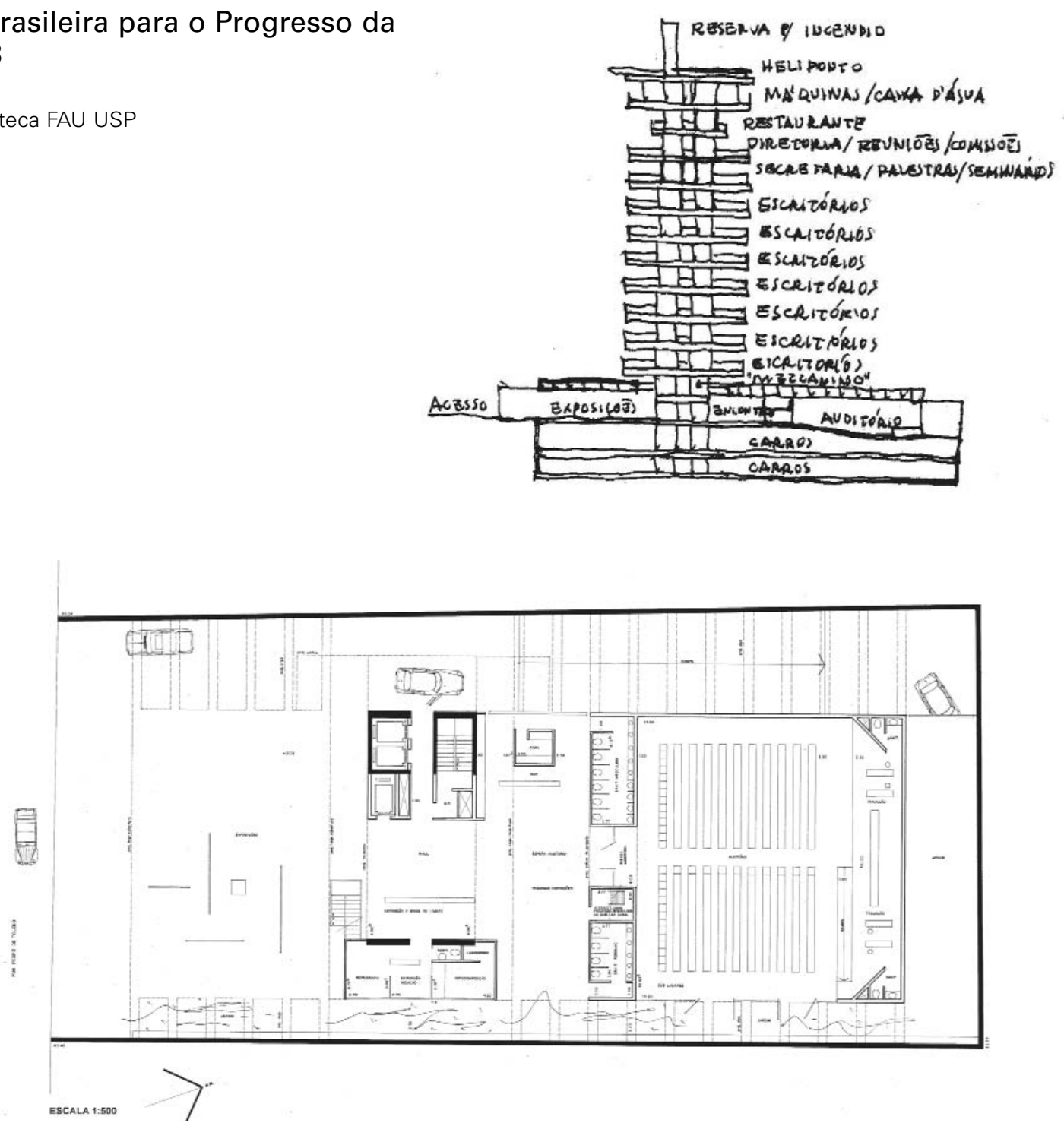

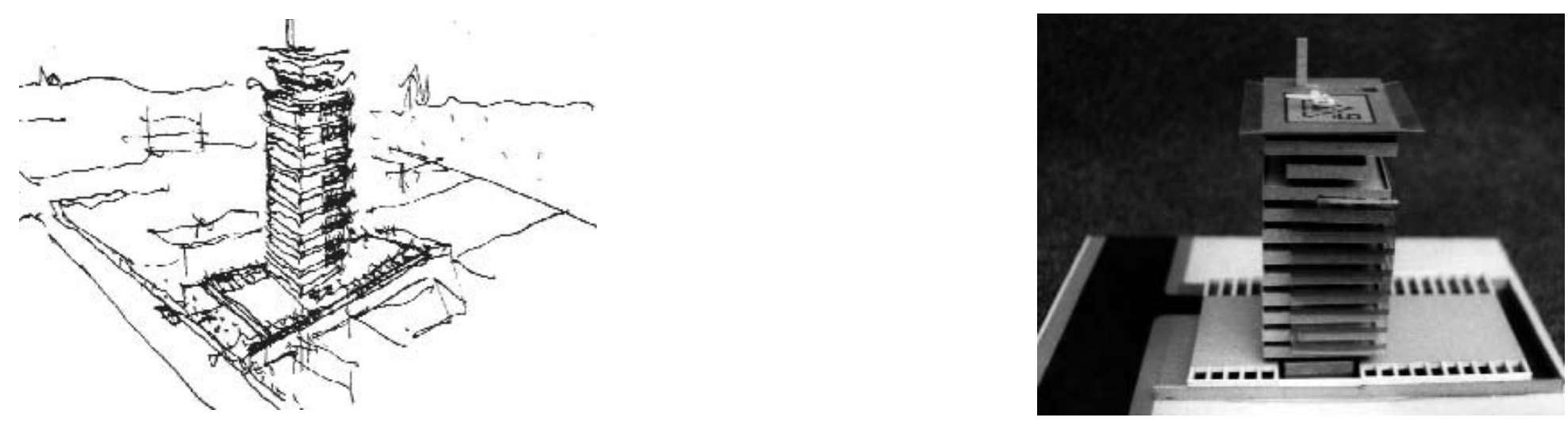

0
0
0
0
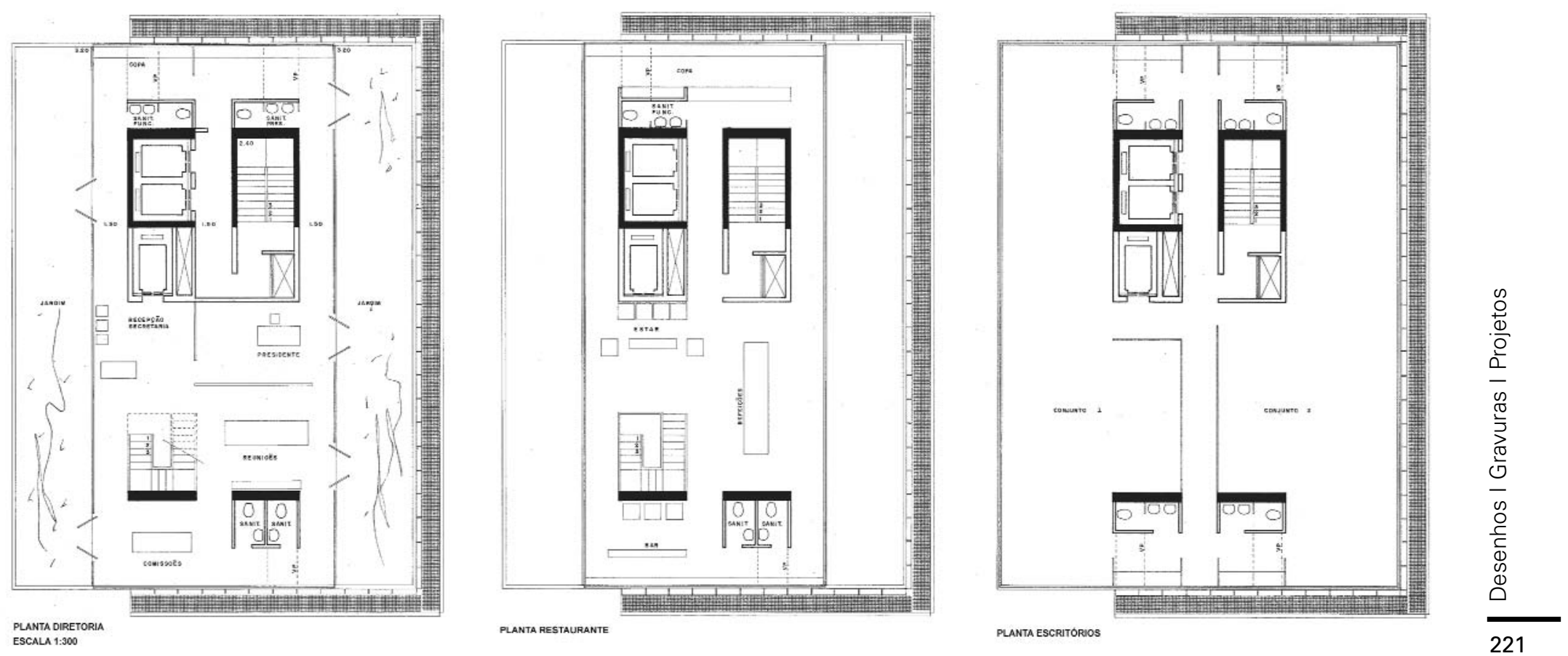

PLANTARESTRUPRANTE 
SENAC Tatuapé - 1984/1985

São Paulo - SP

fonte [desenhos] acervo biblioteca FAU USP

[imagens] acervo escritório Elito Arquitetos

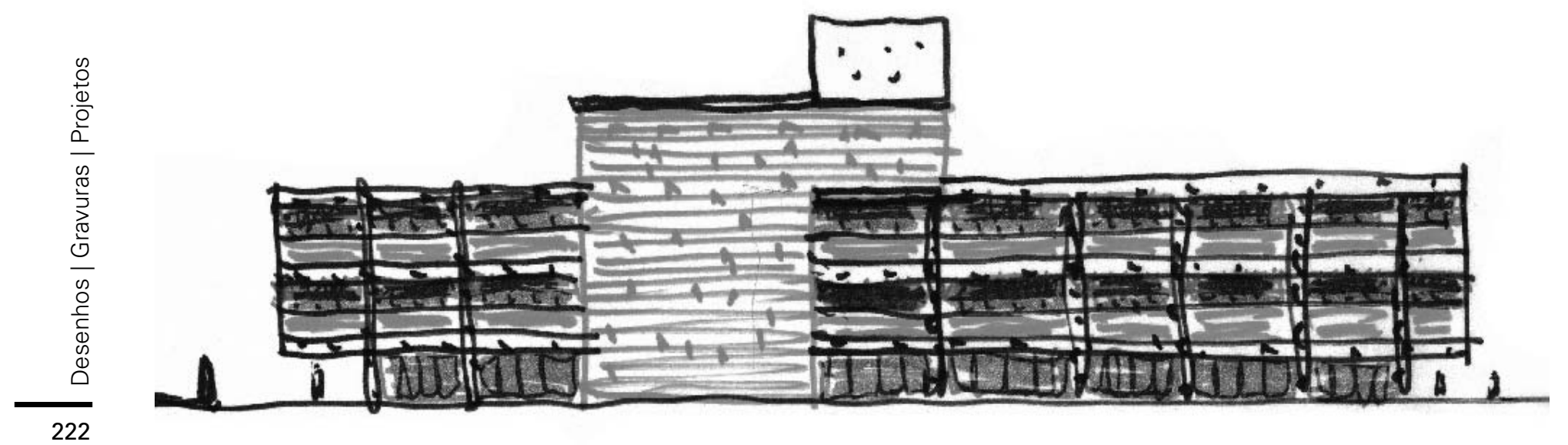



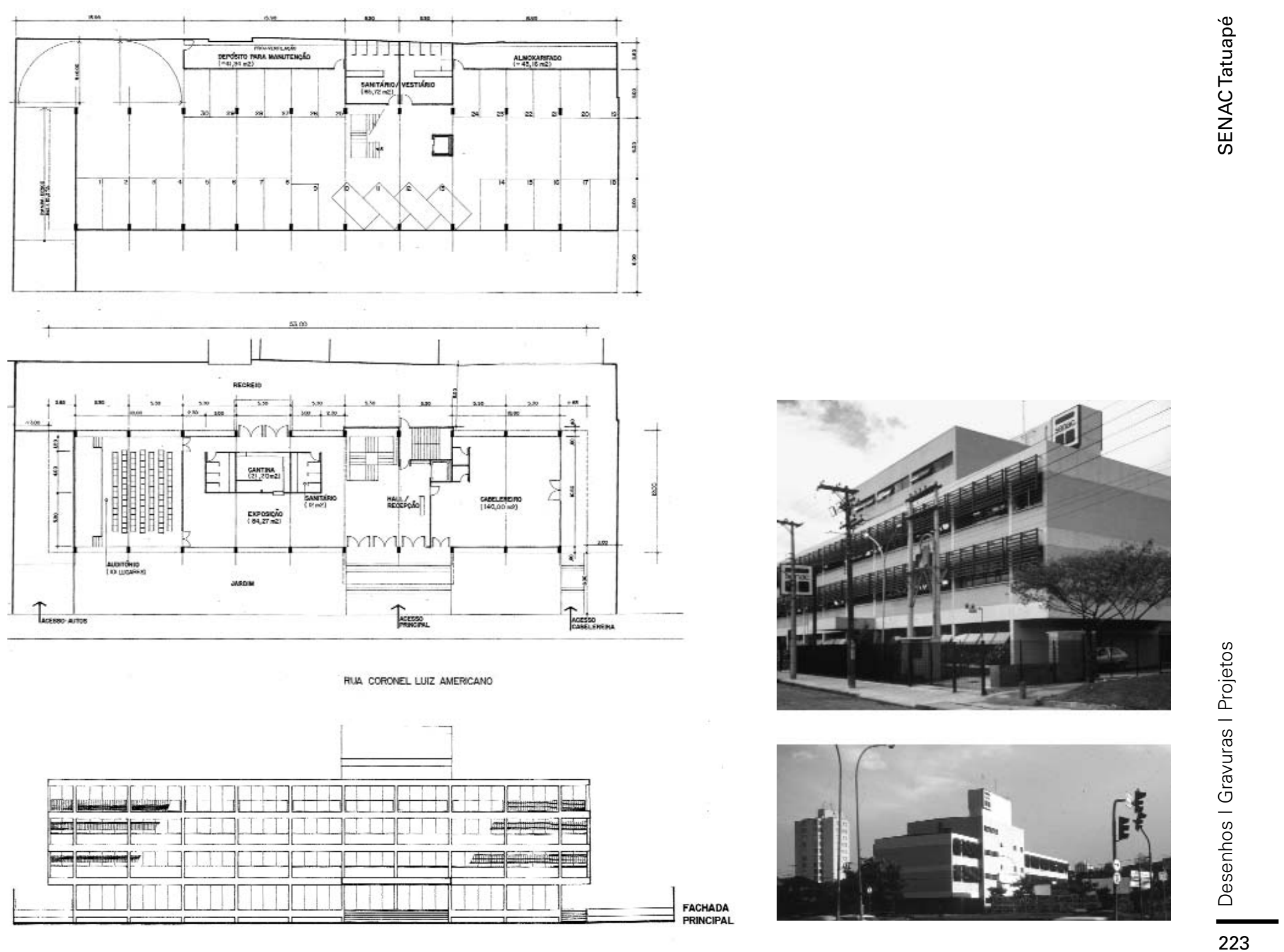

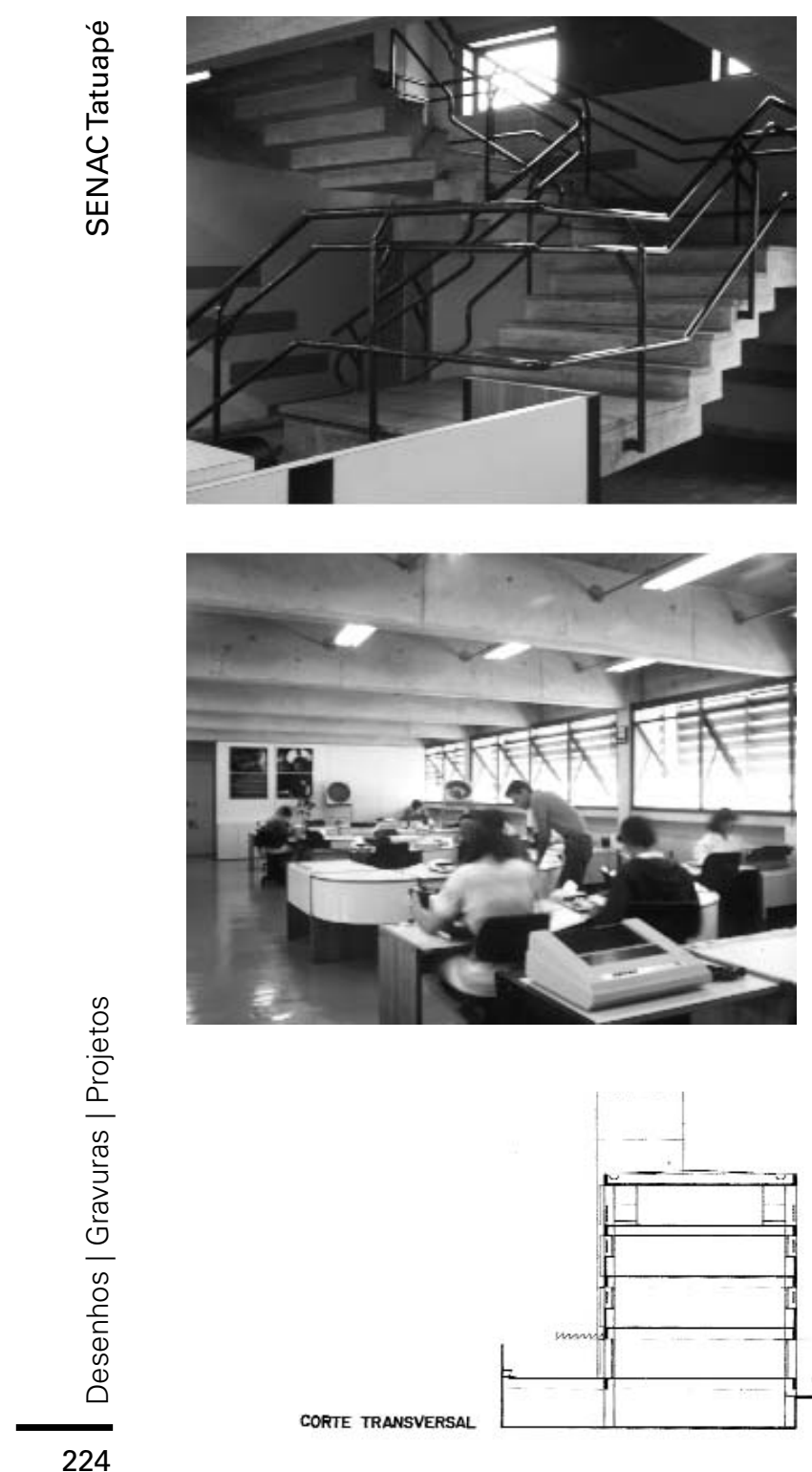
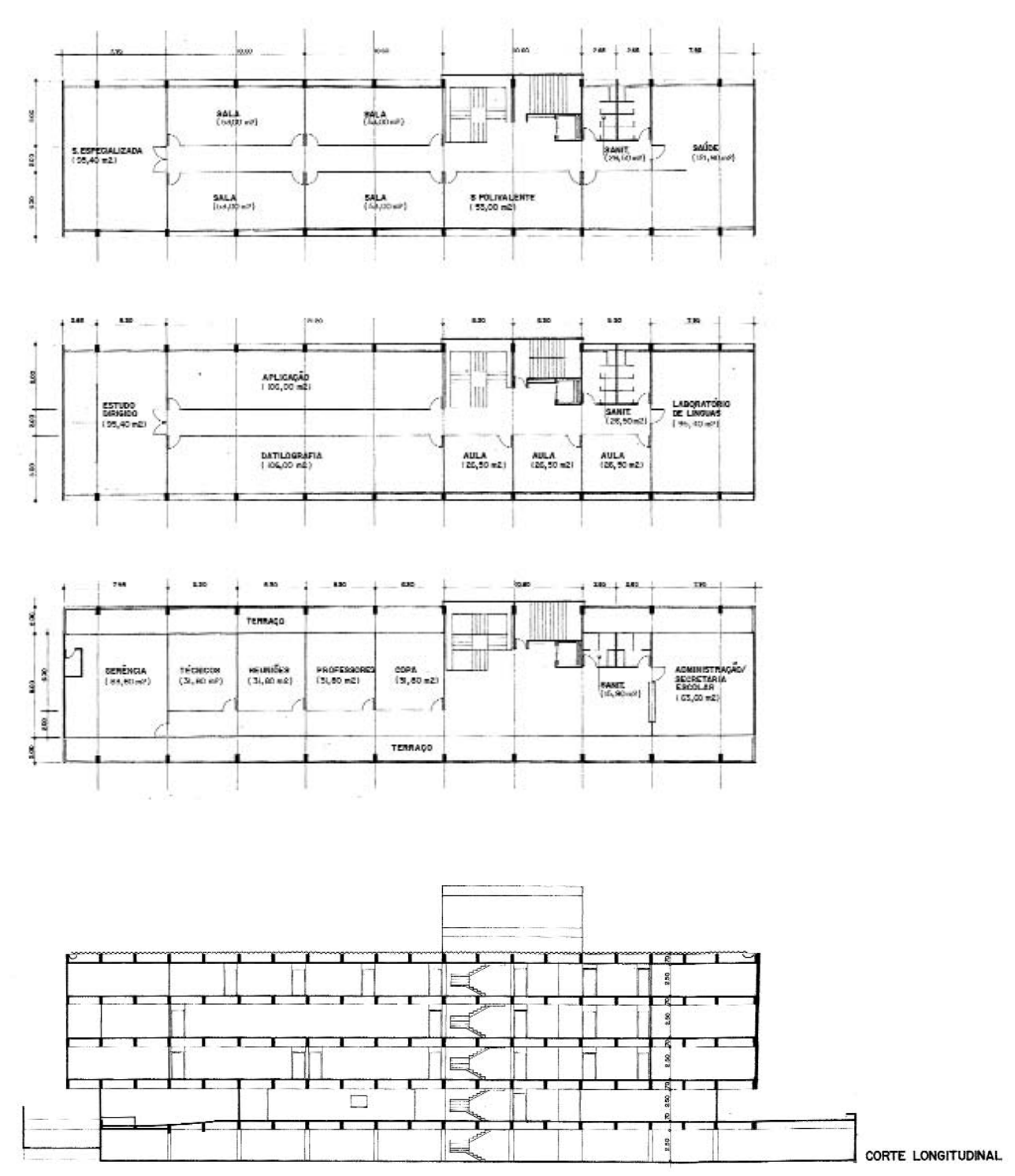


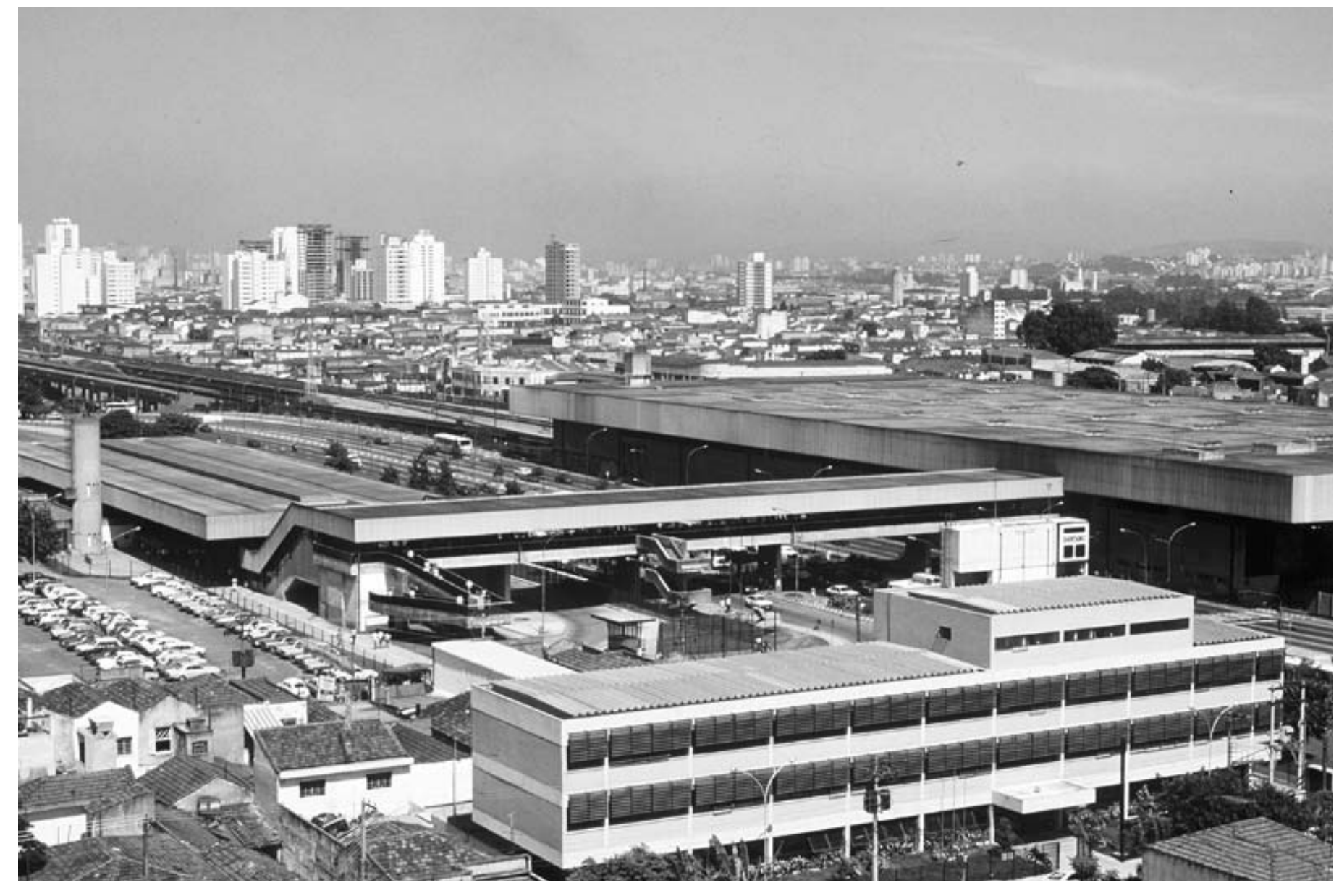


Terminal de Turismo de Massa de Bertioga - 1985 Bertioga - SP

fonte [desenhos] acervo biblioteca FAU USP

[imagens] acervo escritório Elito Arquitetos
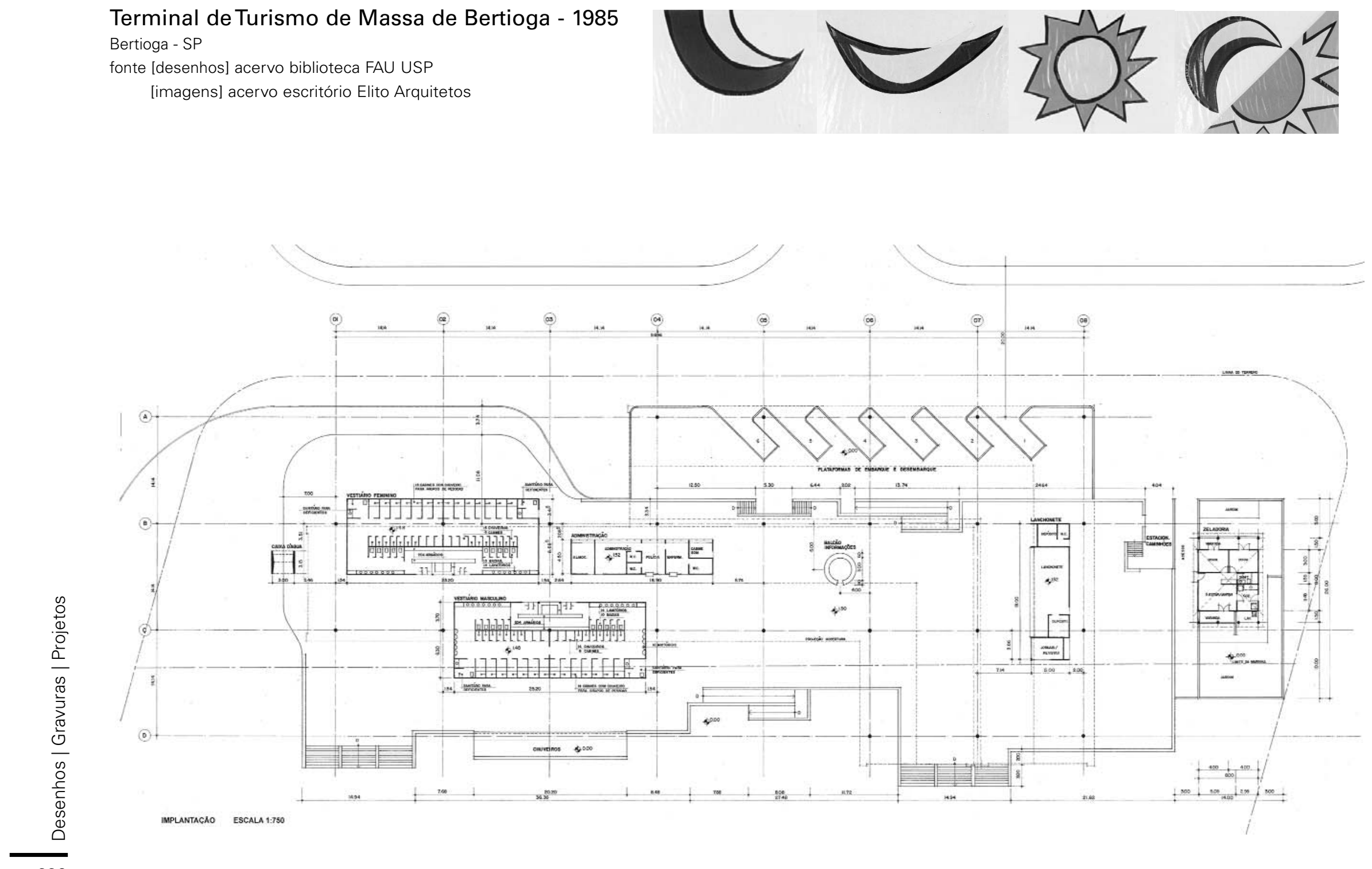


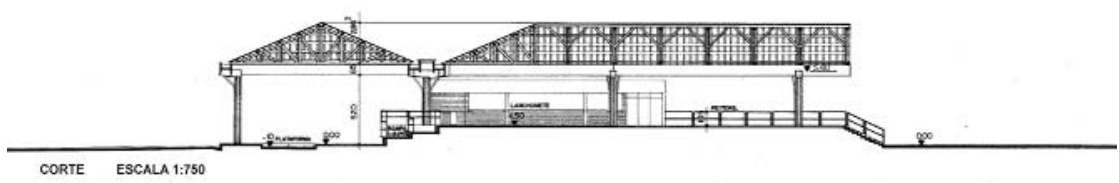
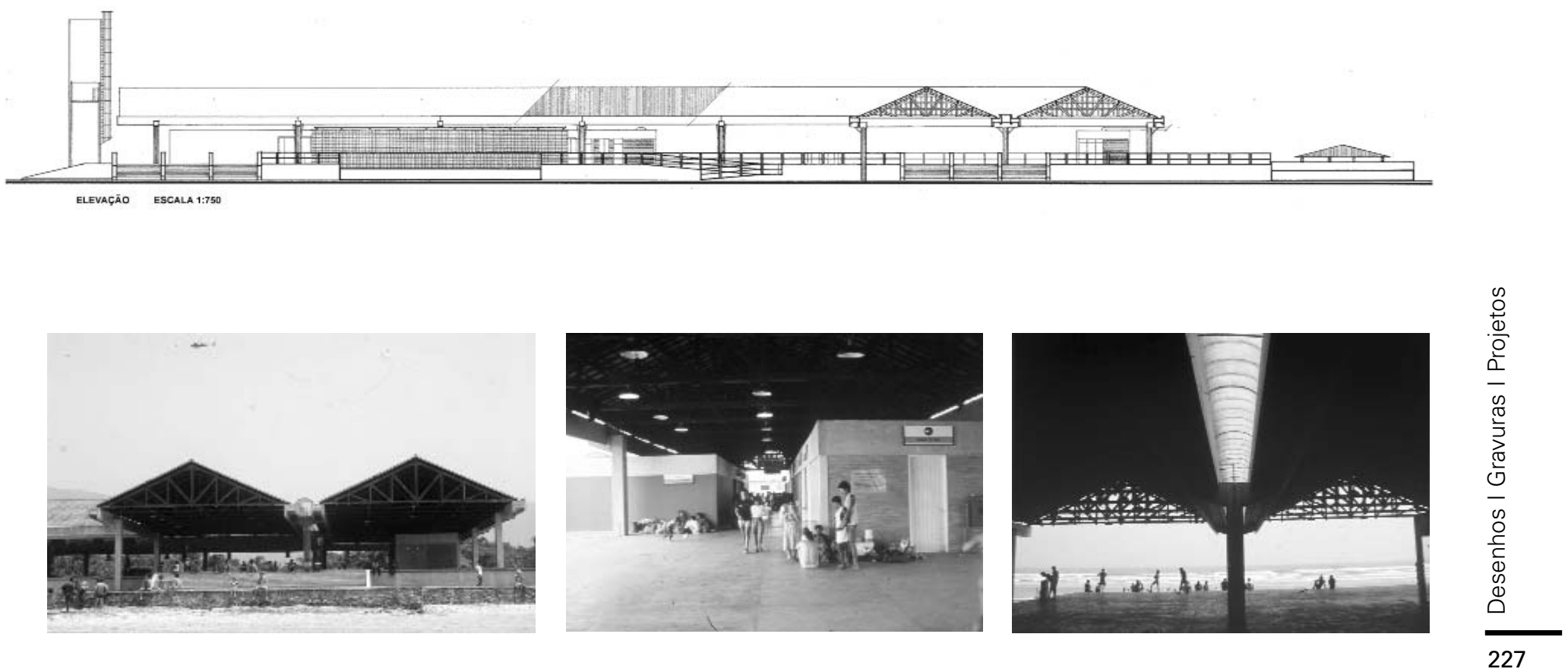
Terminal deTurismo de Massa de Ubatuba - 1985

Ubatuba - SP

fonte [desenhos] acervo biblioteca FAU USP
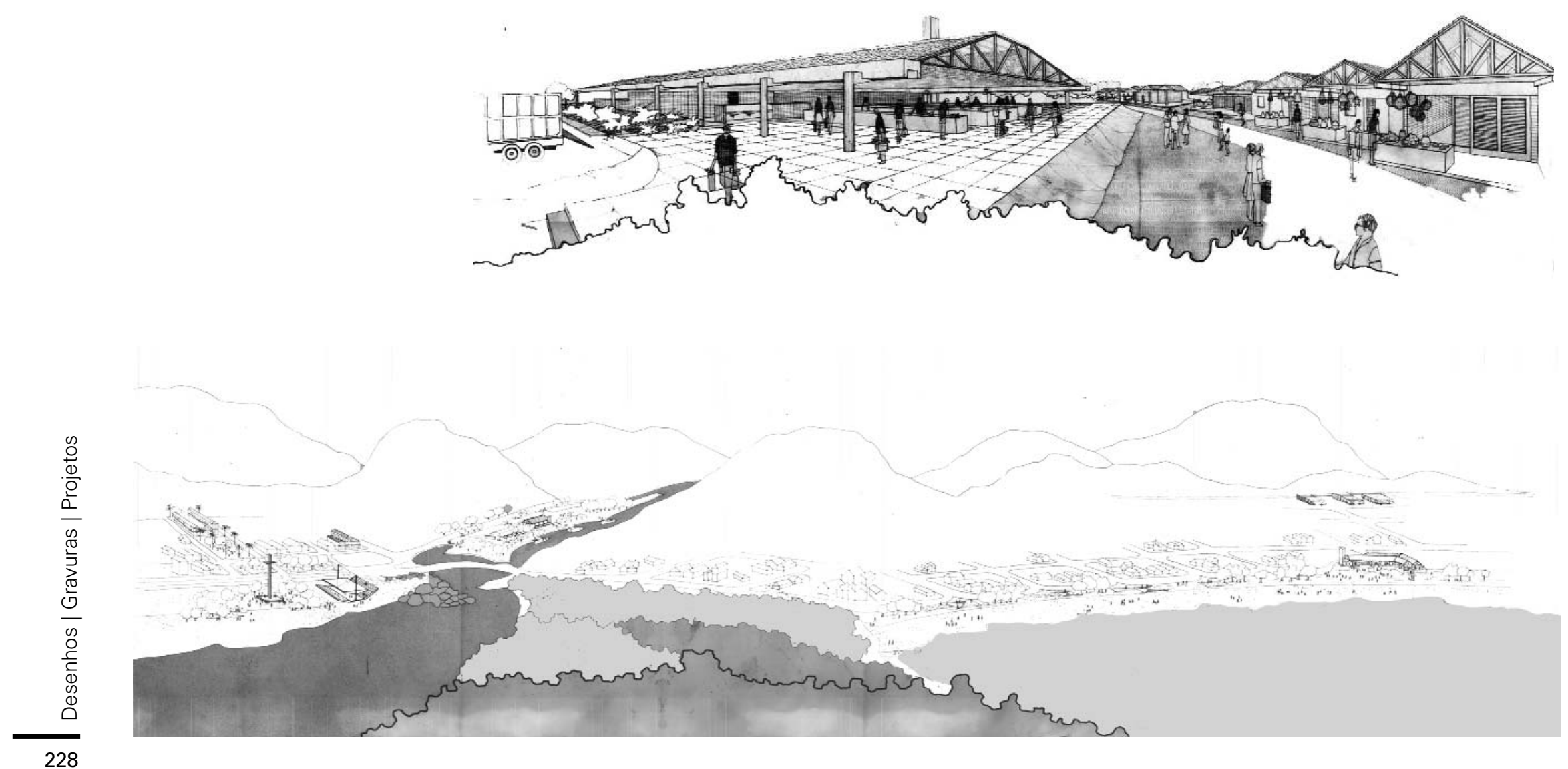


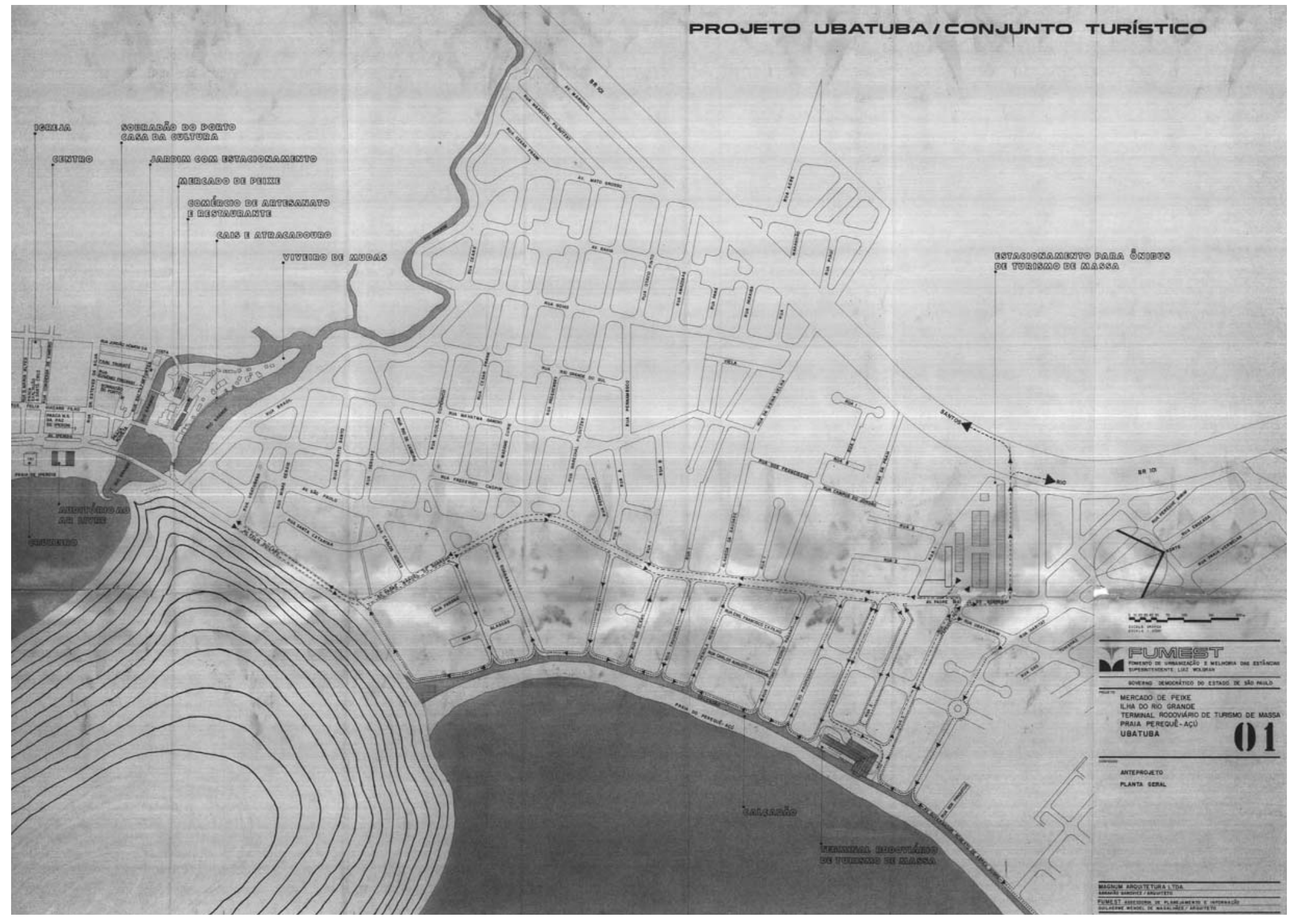




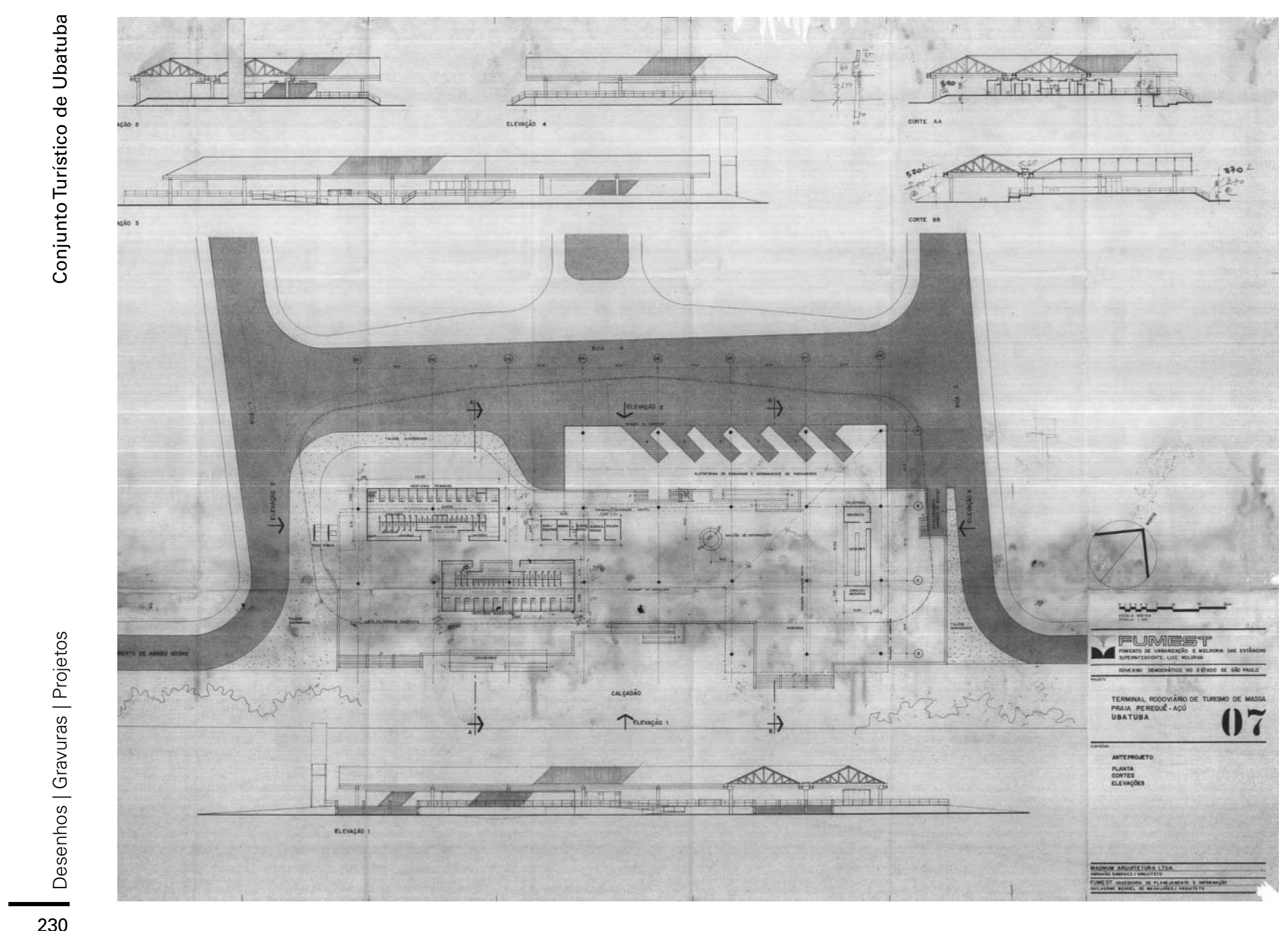




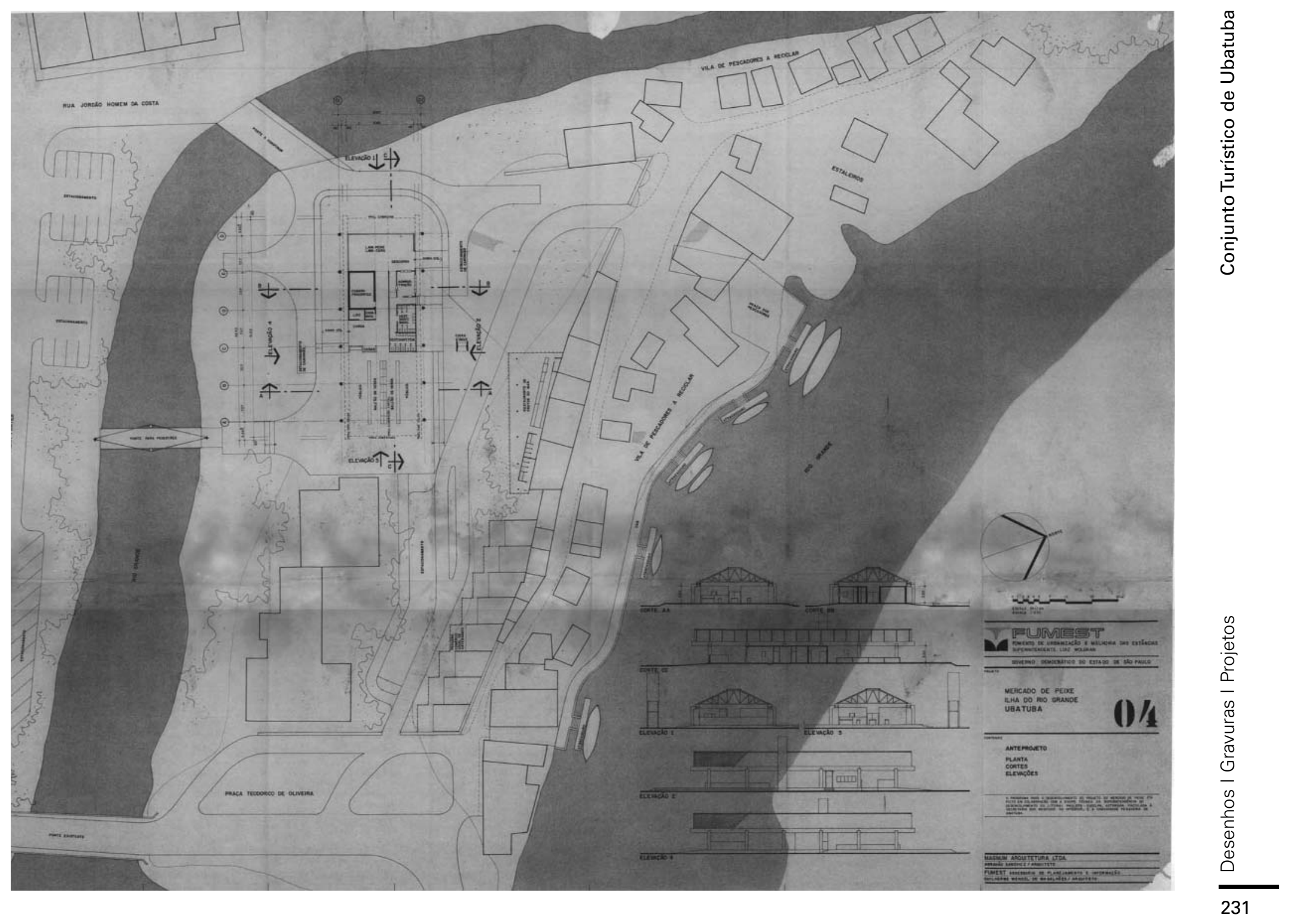


SENAC Jundiaí - 1988

Jundiaí - SP

fonte [desenhos] acervo biblioteca FAU USP

[imagens] acervo escritório Elito Arquitetos

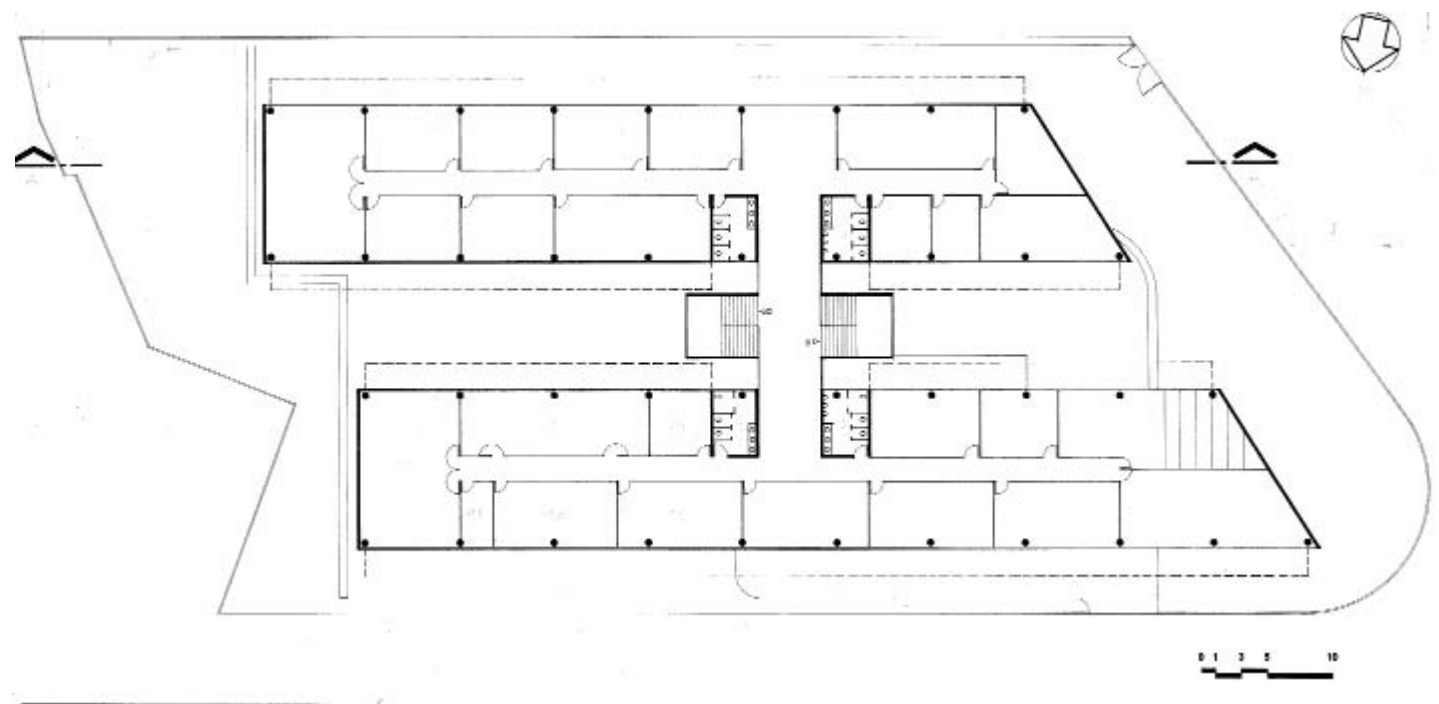

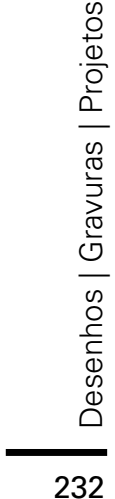
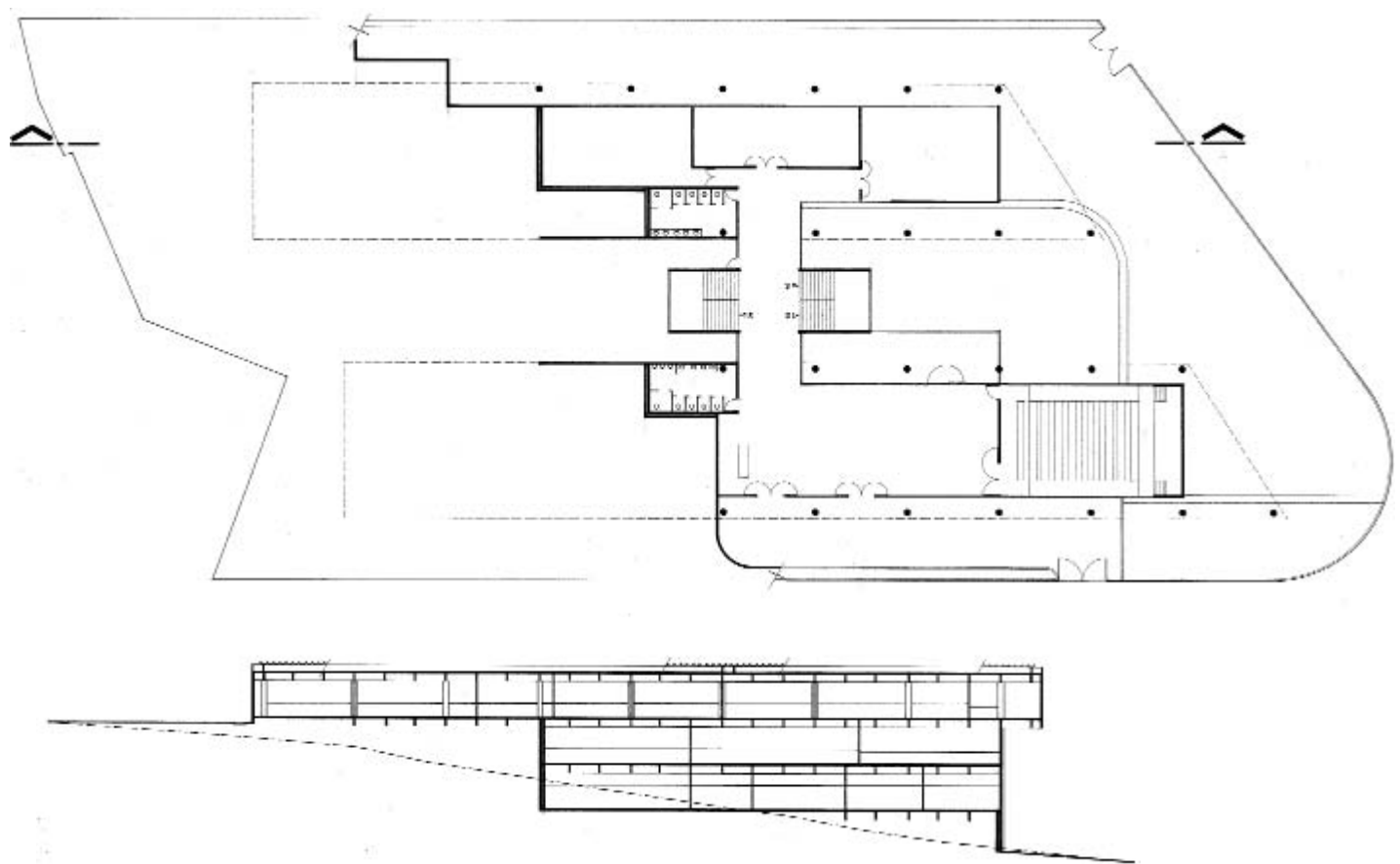


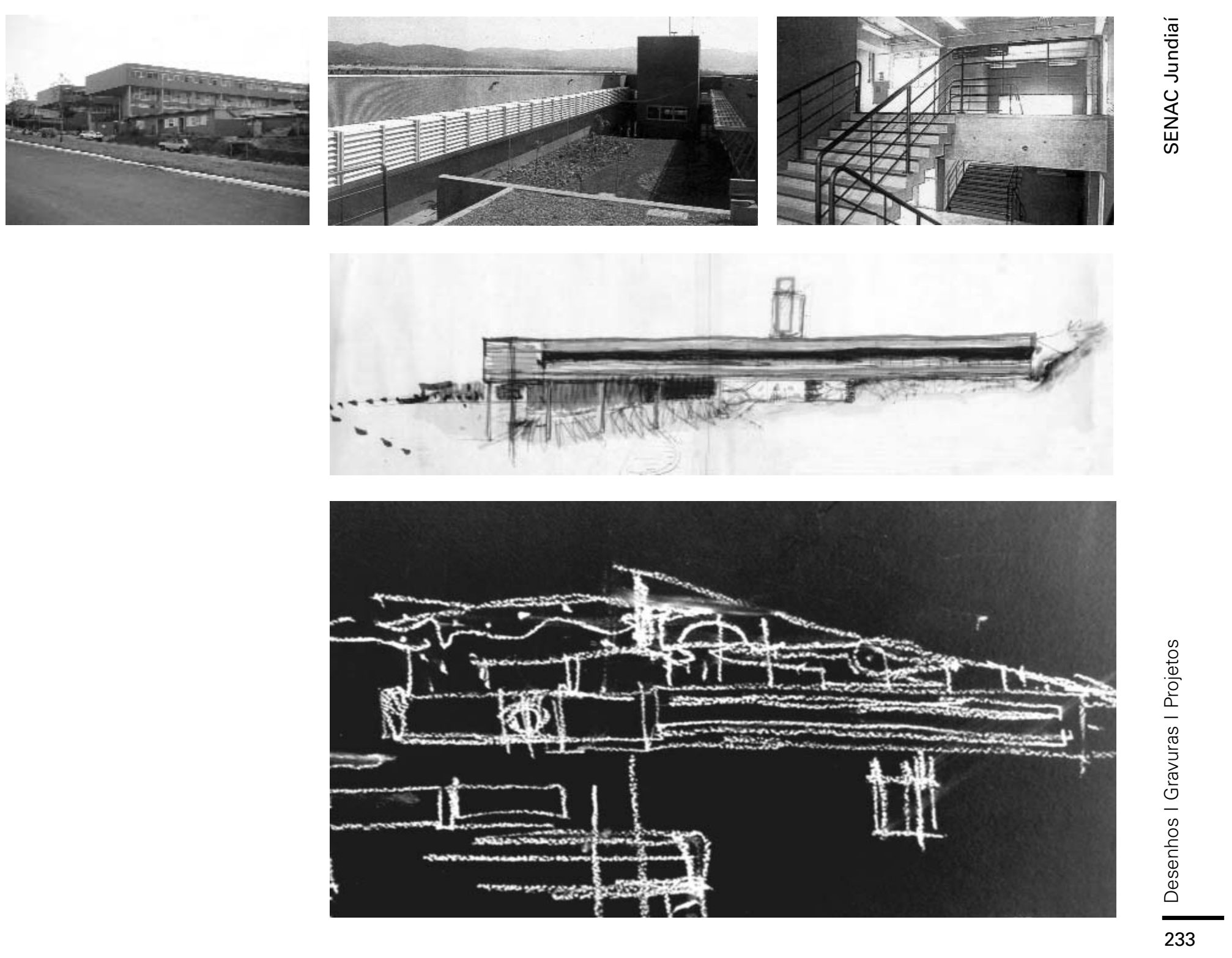


Sede da FAPESP - 1990/1991

Concurso em São Paulo - SP

fonte [desenhos] acervo biblioteca FAU USP

[imagens] acervo escritório Elito Arquitetos

[perspectivas] Vallandro Keating

Por Abrahão Sanovicz e Edson Jorge Elito
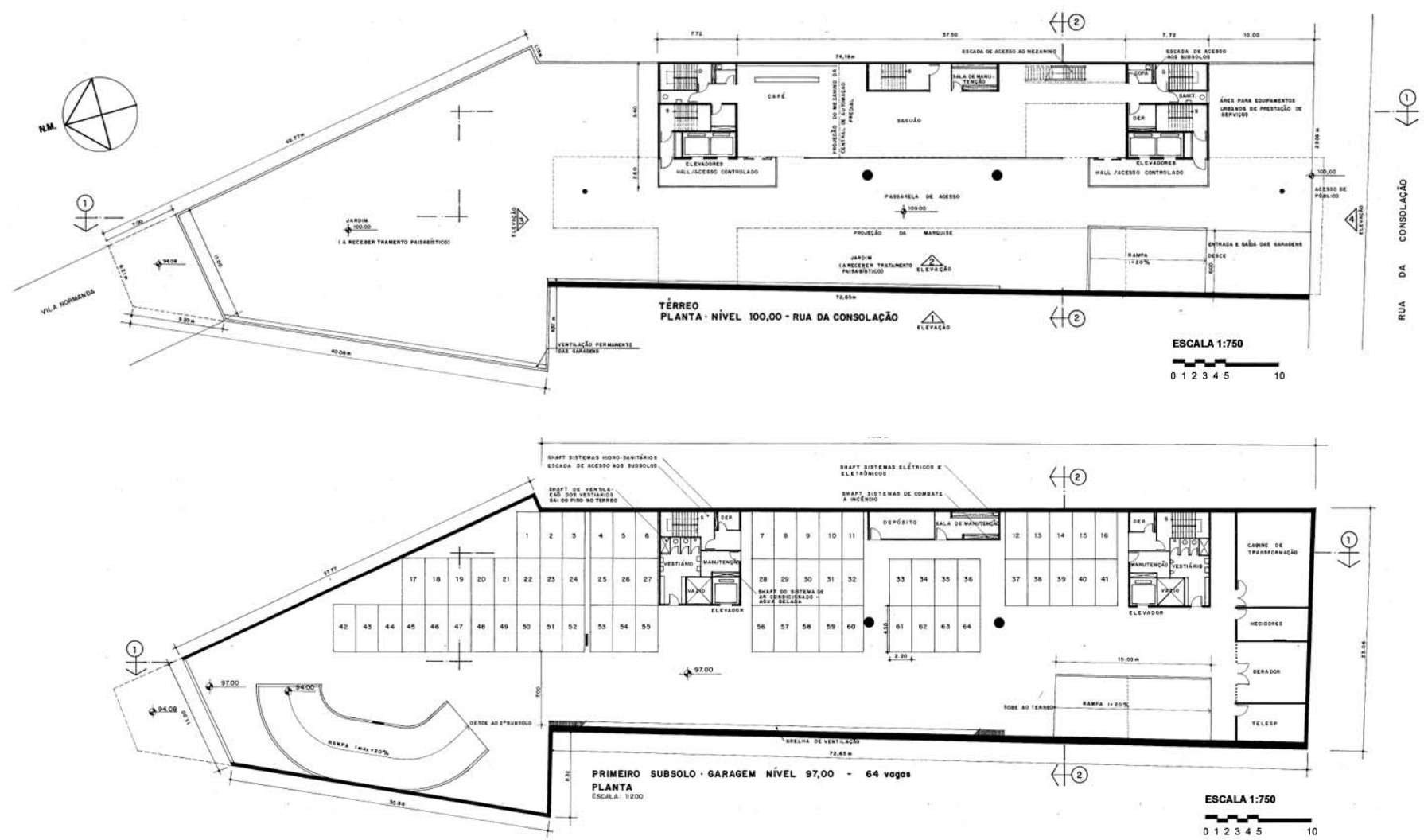

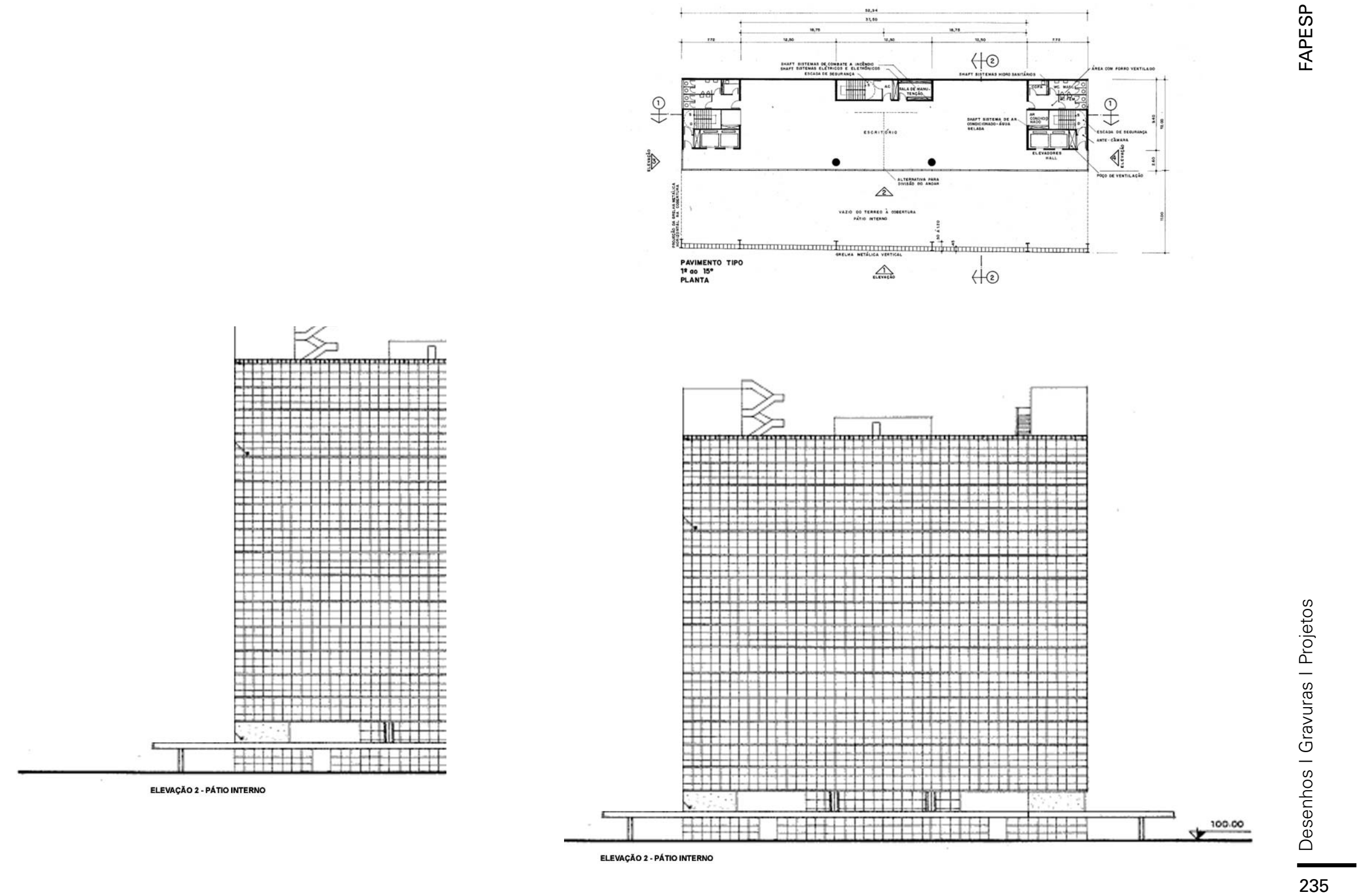


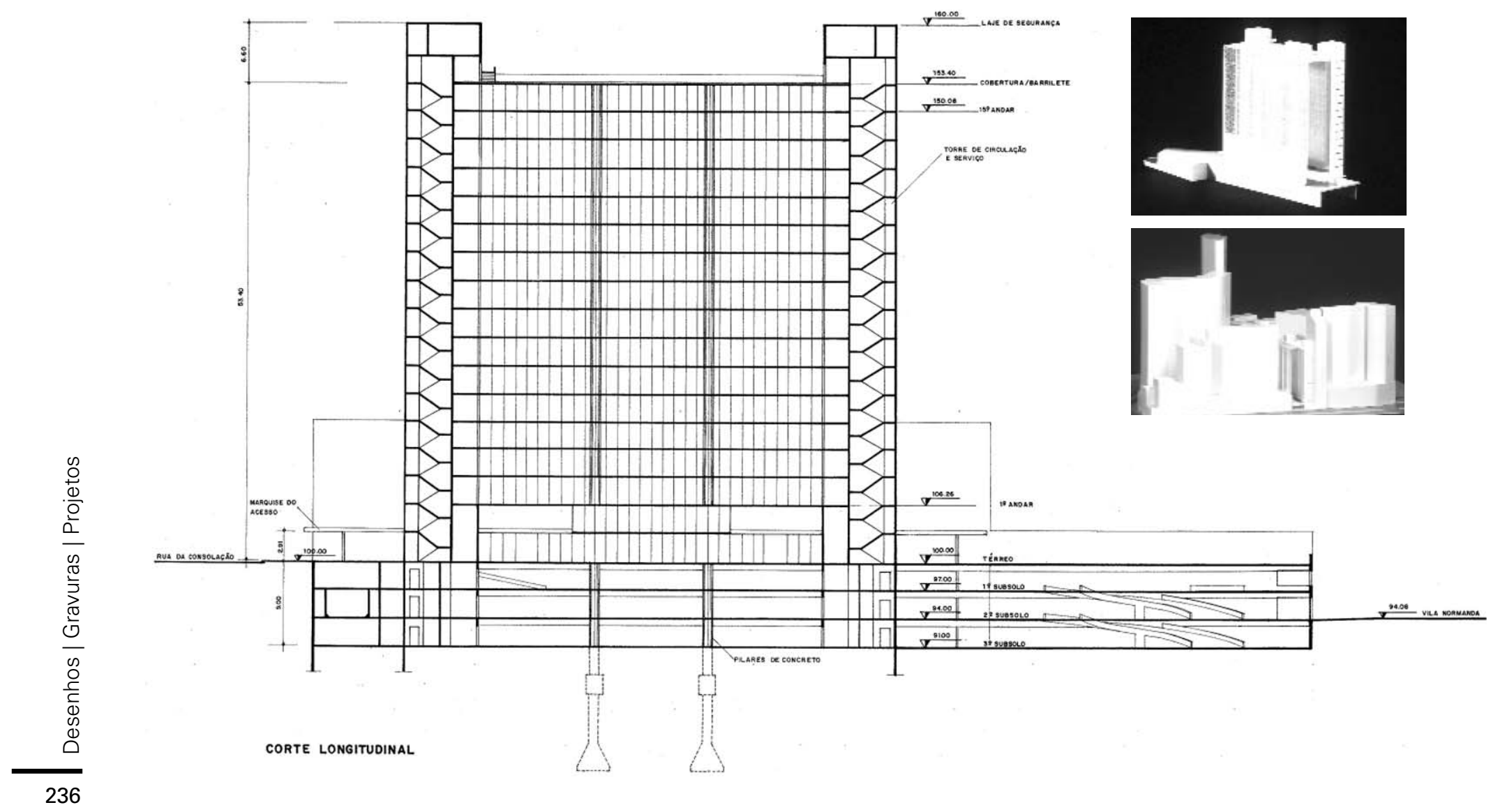



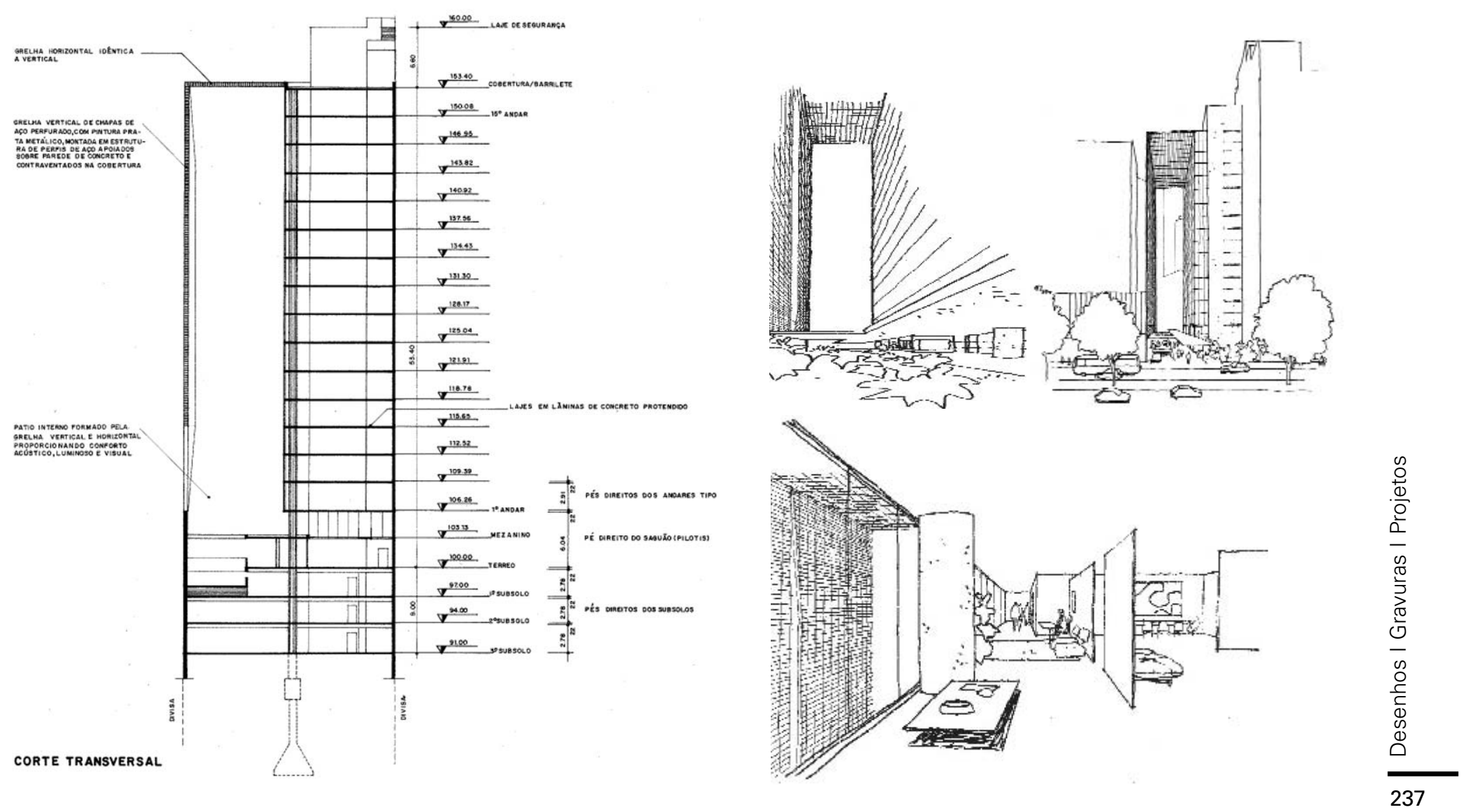
Escola Estadual Conselheiro Crispiniano - 1992

Guarulhos- SP

fonte [desenhos] acervo biblioteca FAU USP

[imagens] acervo escritório Elito Arquitetos

Restauro e ampliação da obra de João Batista Vilanova Artigas

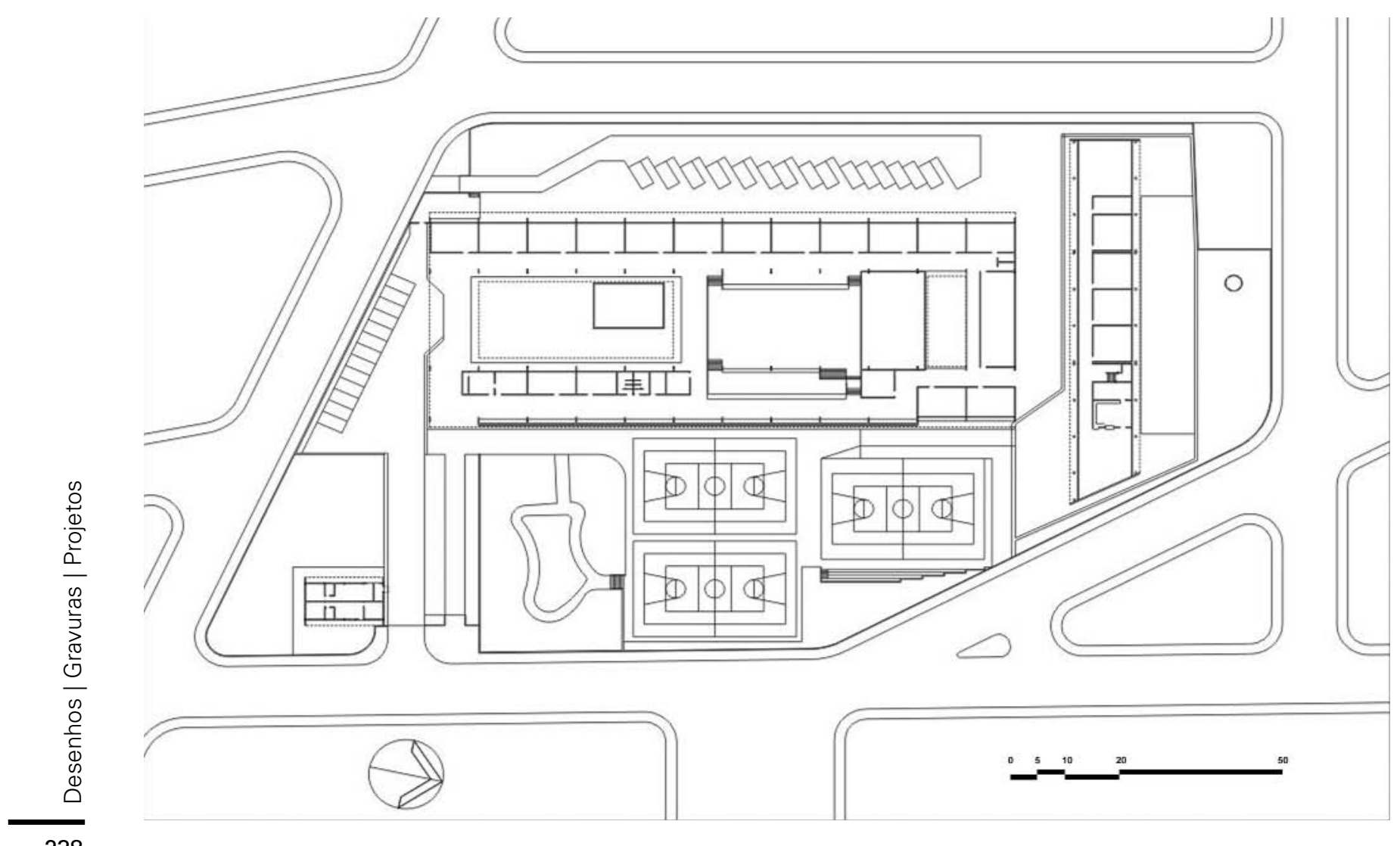

238 

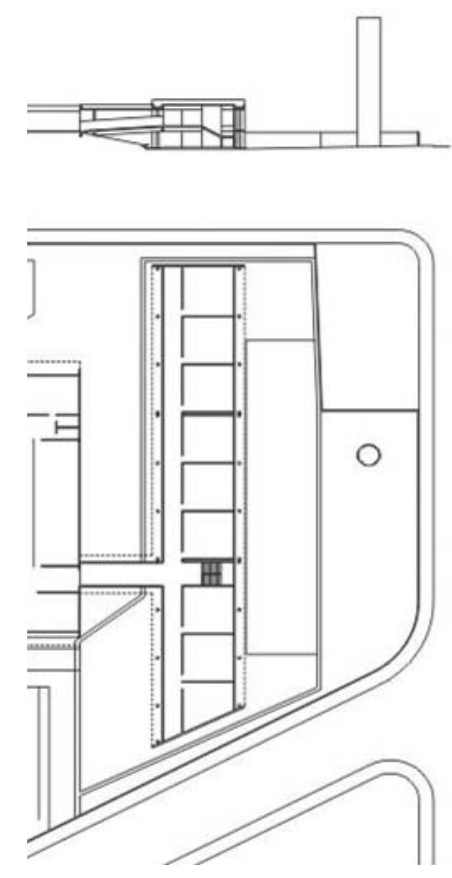

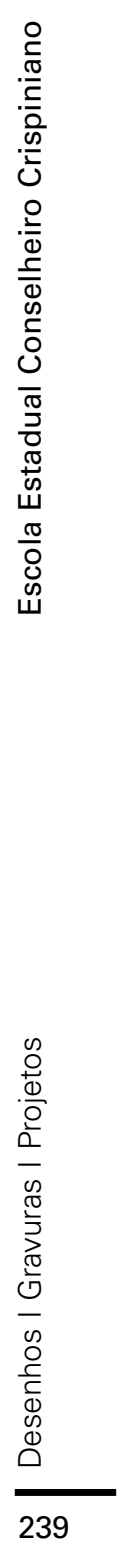

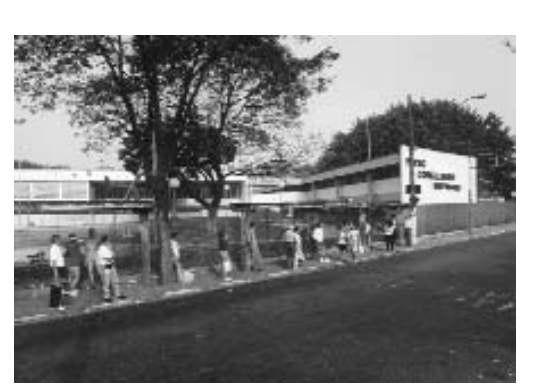
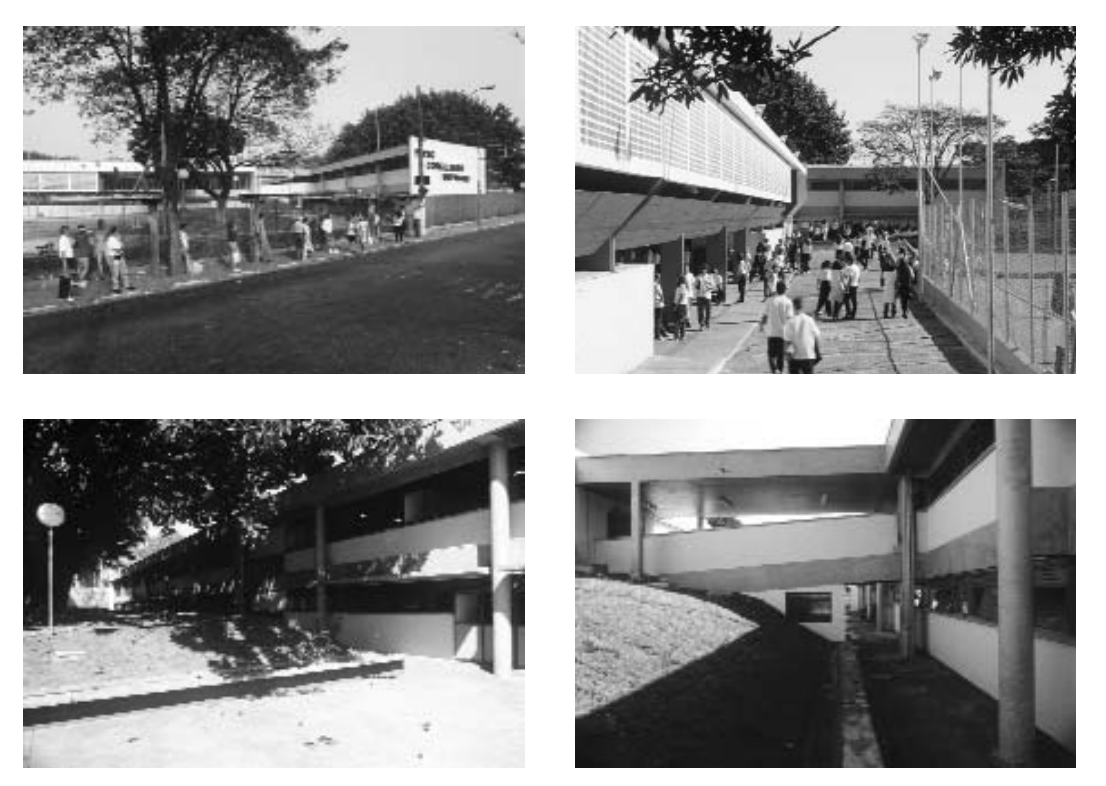
SESC Araraquara - 1994

Araraquara - SP

fonte [desenhos] acervo biblioteca FAU USP

[imagens] acervo escritório Elito Arquitetos

Por Abrahão Sanovicz e Edson Jorge Elito
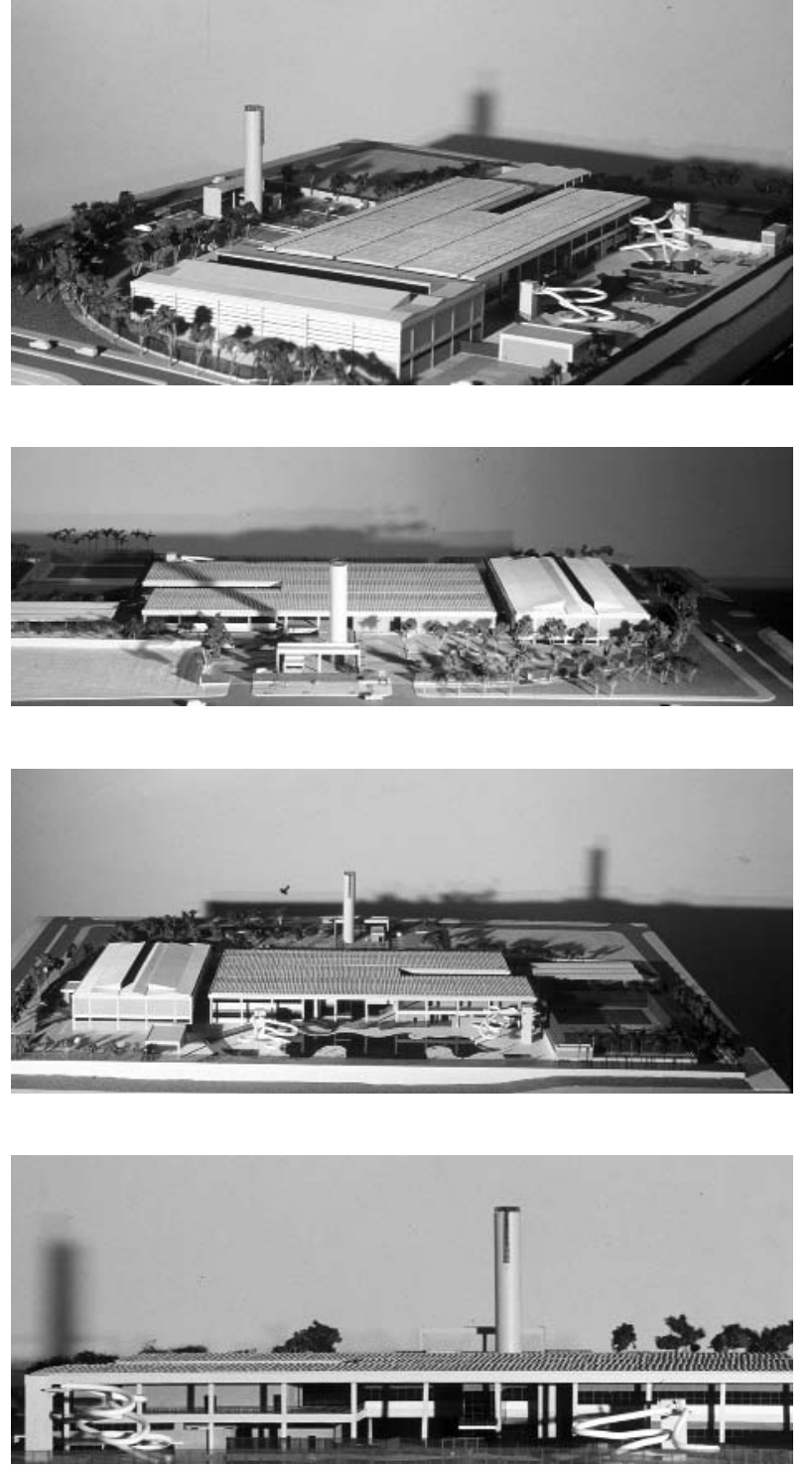


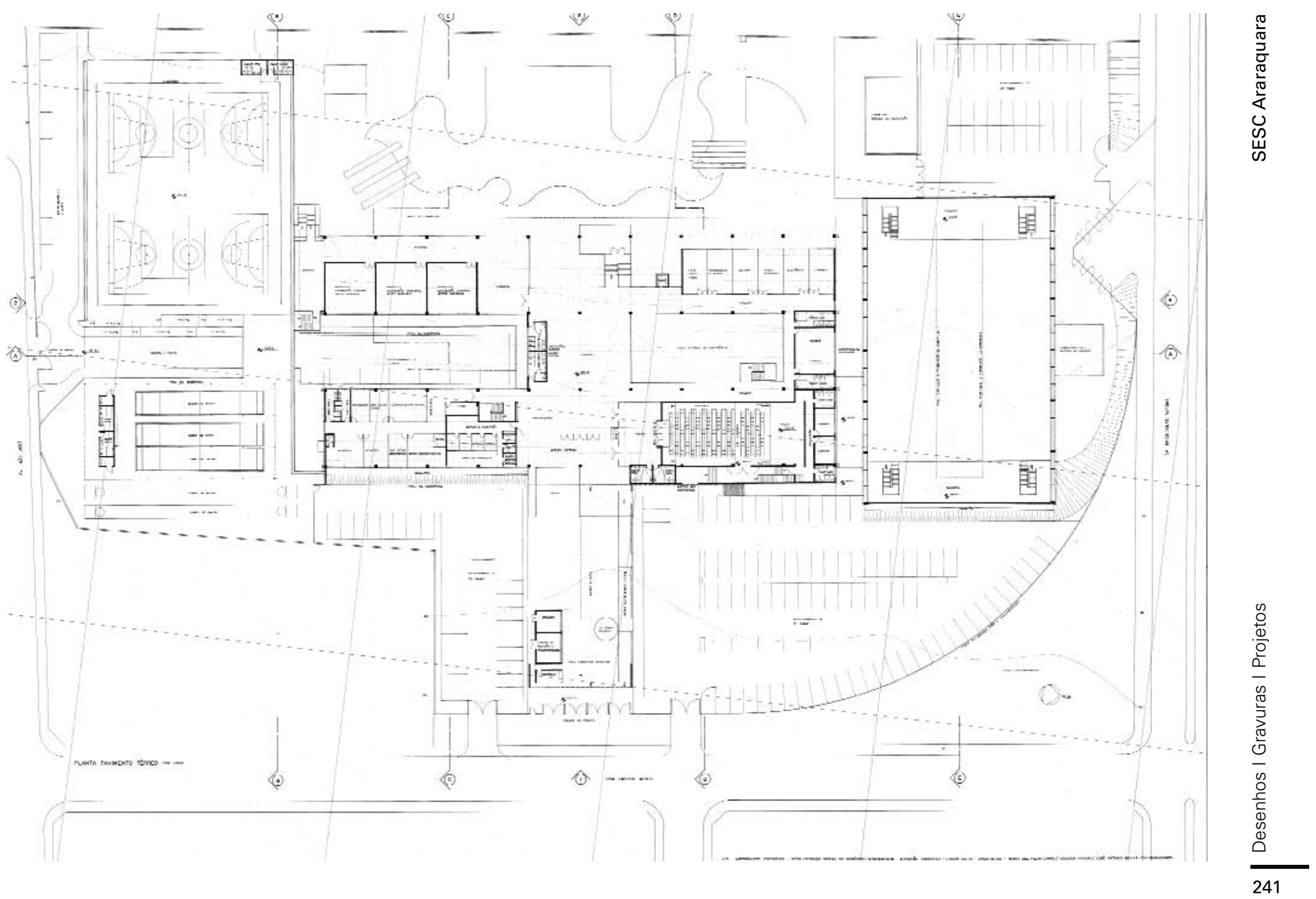




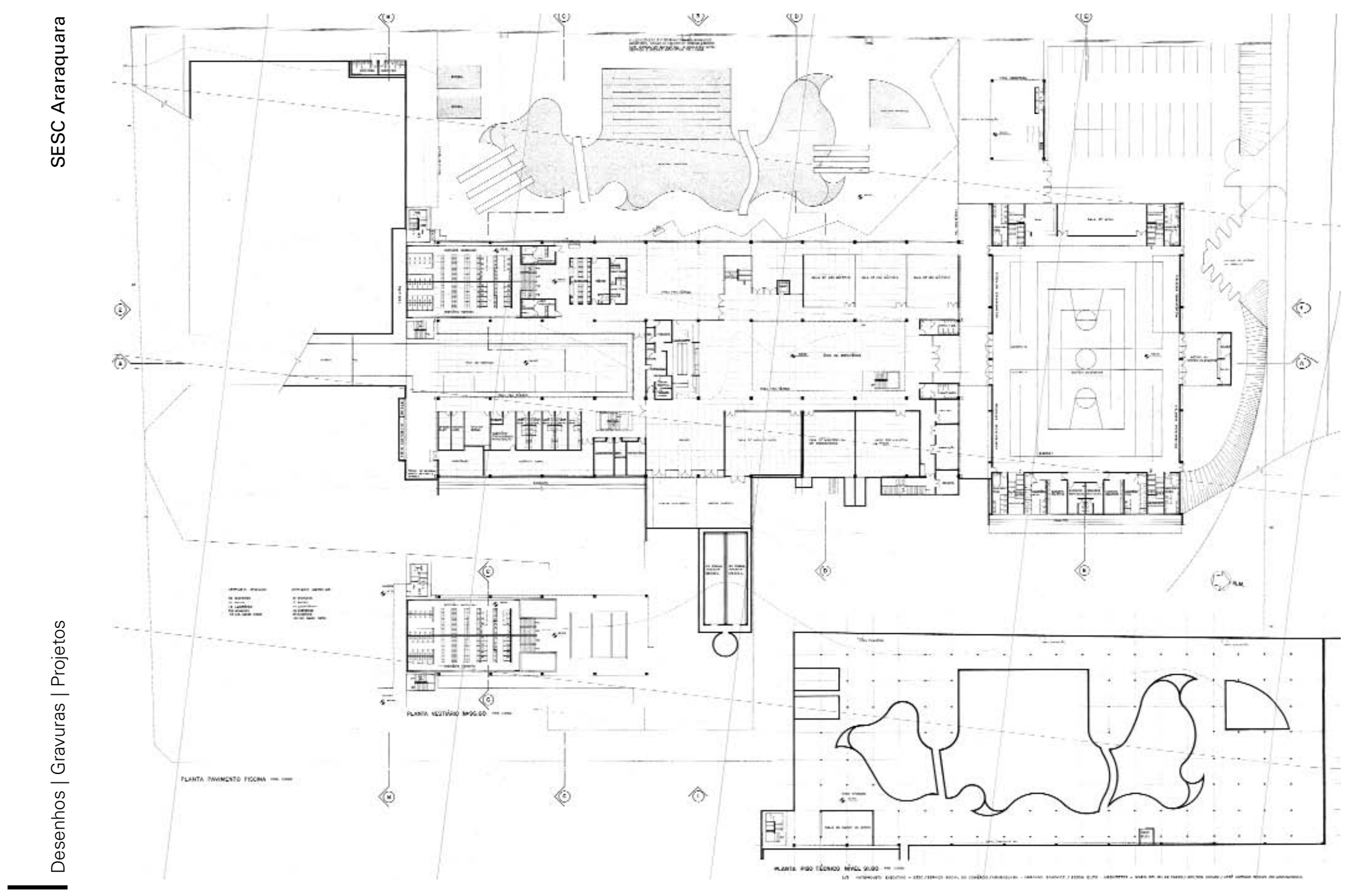




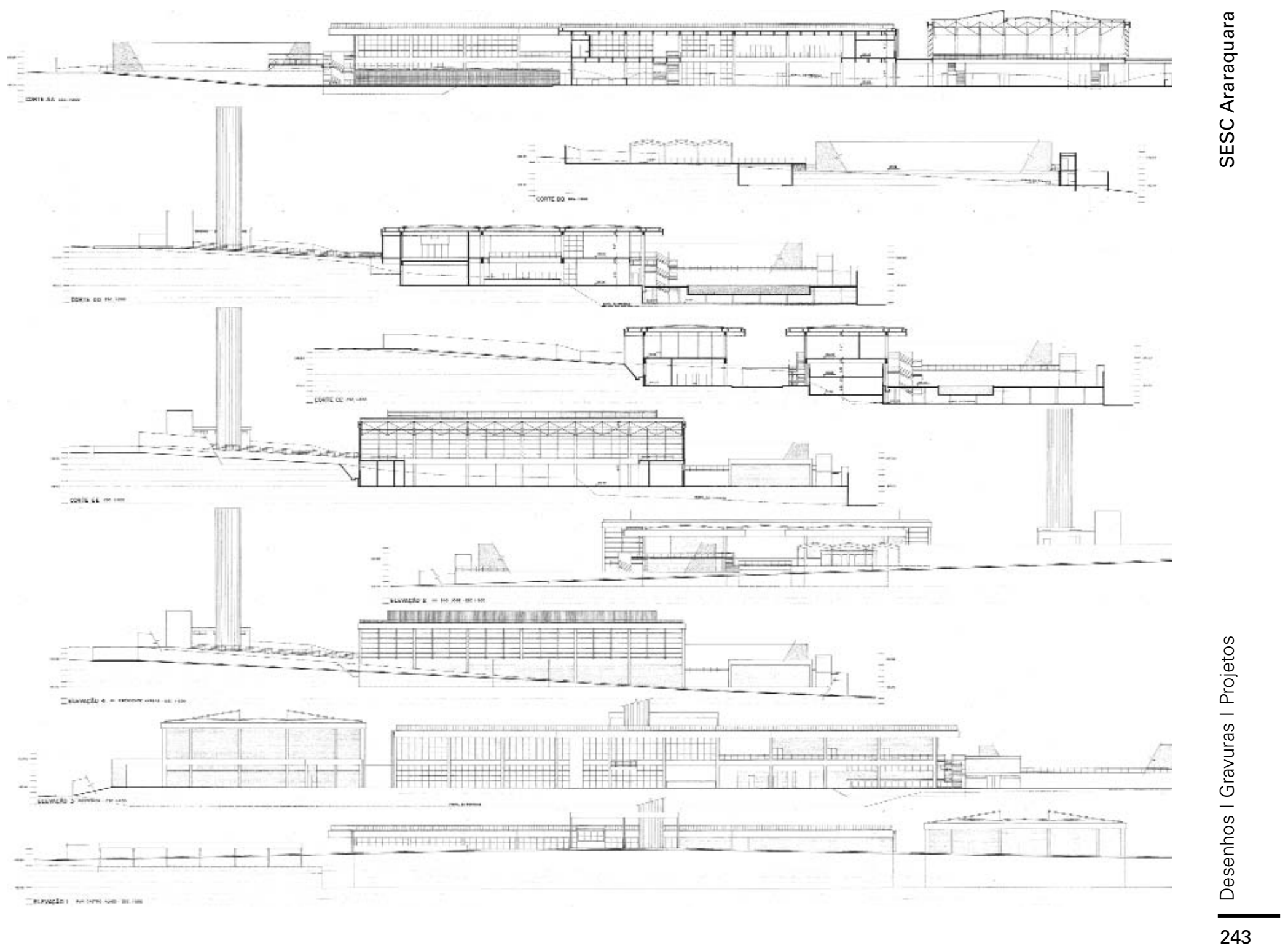


Escola Estadual Parque Piratininga II - 1997 Itaquaquecetuba - SP

fonte FUNDAÇÃO PARA O DESENVOLVIMENTO DA EDUCAÇ̄̃O.

DIRETORIA DE OBRAS E SERVIÇOS - Escolas estaduais de $1^{\circ} \mathrm{grau}$

projetos arquitetônicos 96/97. São Paulo, FDE, 1997
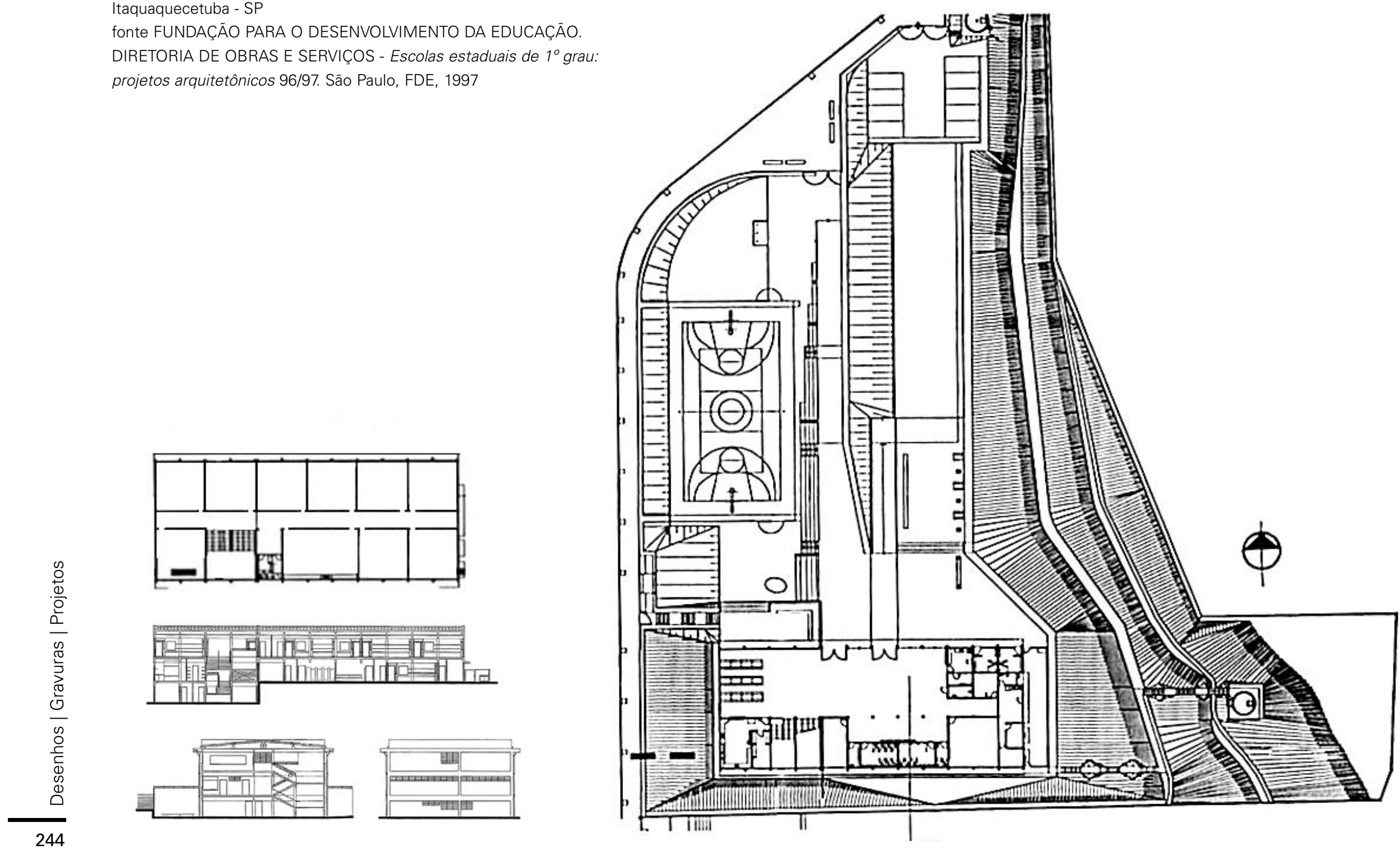
Comunicação Visual

Diversos, s/d

fonte [imagens] acervo biblioteca FAU USP

\section{$\Phi$}

Teatro Cacilda Becker

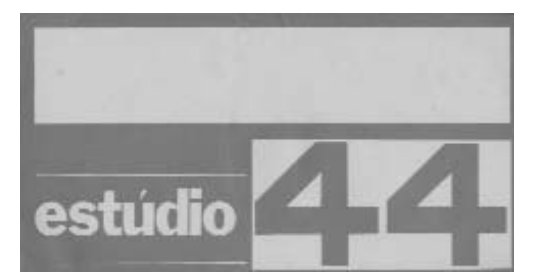

Estúdio 44

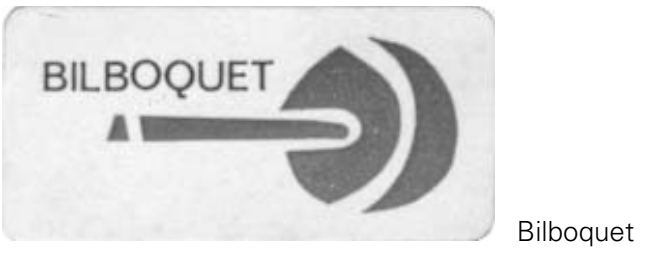

든므듬ㄱ
$0.000(0)(0)$

planus s.a.

oja de Pesca

Planus S. A.

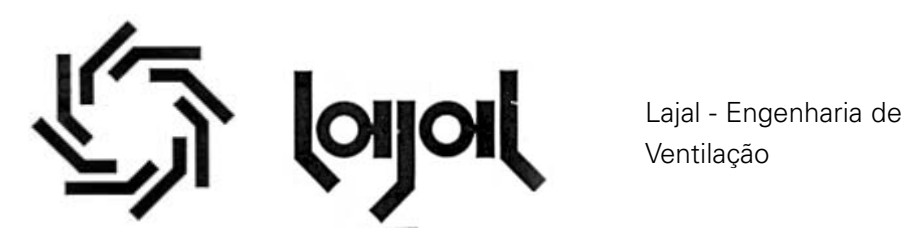

\section{Eeftcaser}

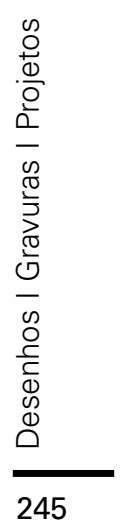




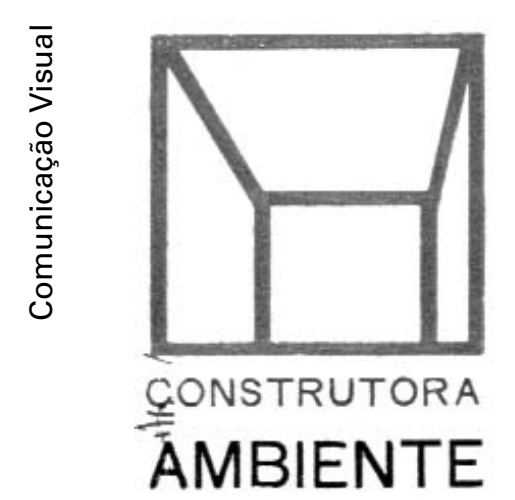

Construtora Ambiente

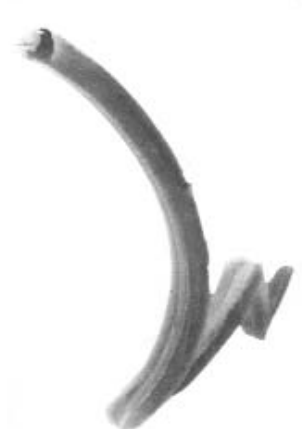

Nacional Clube

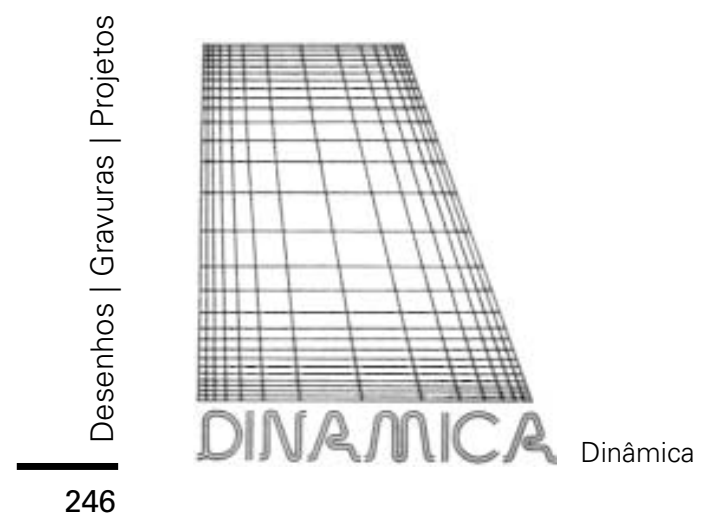

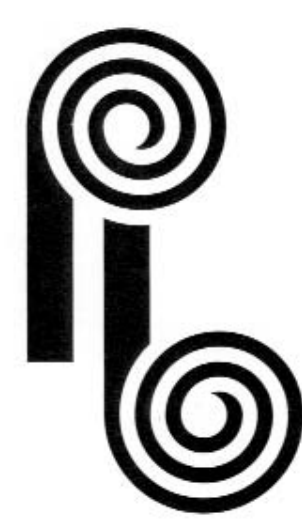

Planimpress

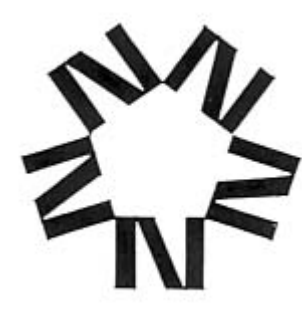

Plano Urbanístico e de

Desenvolvimento de Natal - RN

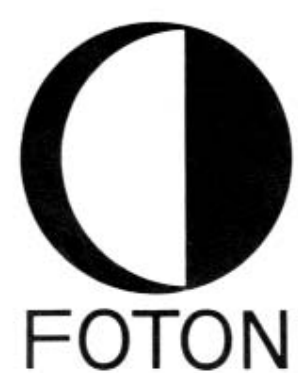



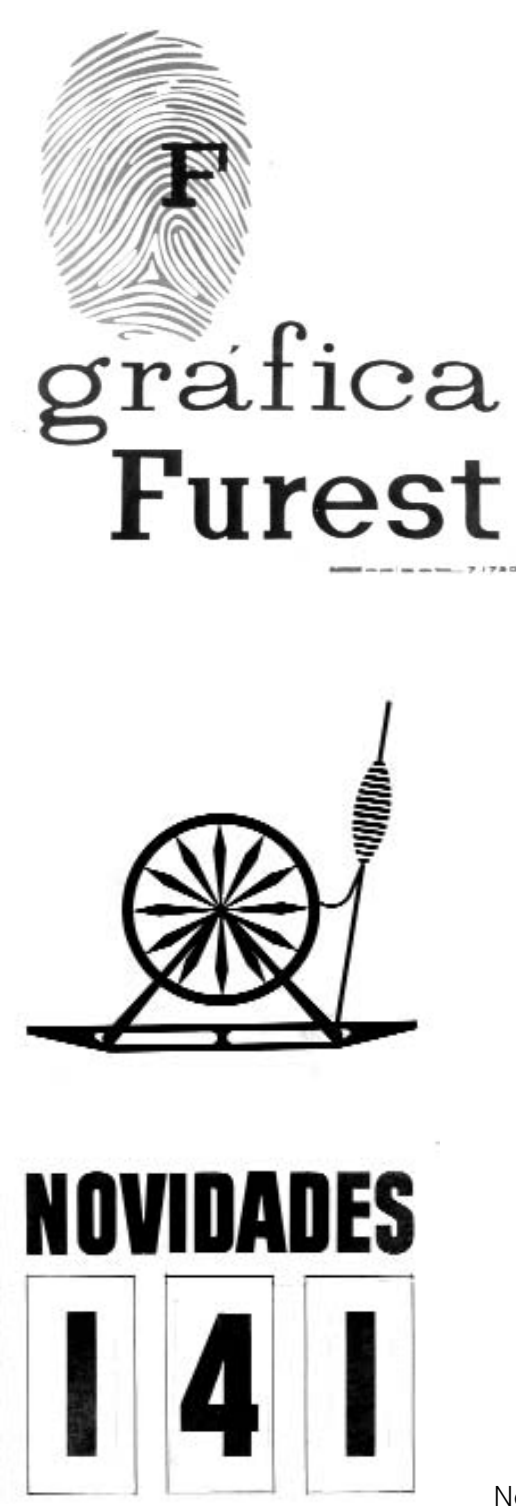

Jólas | RELóglos | PRESENTES

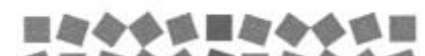

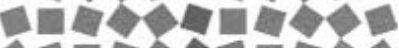

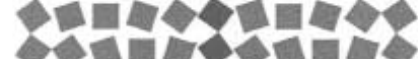

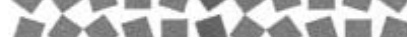
E 1 -

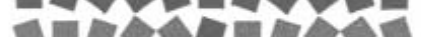

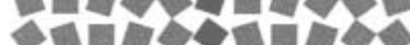

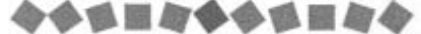

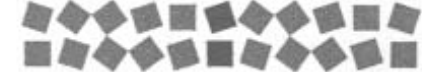
SUISSa

RUA FREI GASPAR 83 | SANTOS SP | 25462

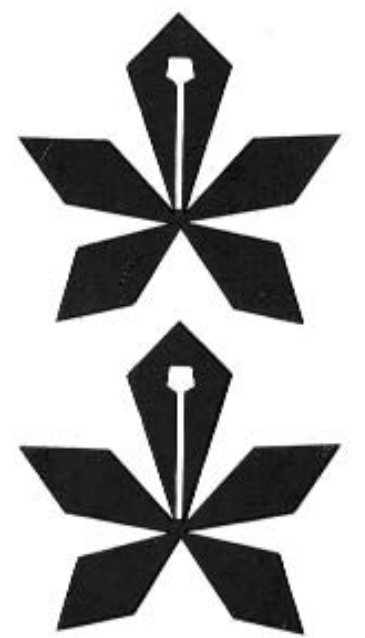





\section{Imagens Referenciais}

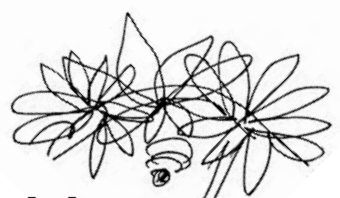

\section{Professores da Escola de Artesanato do MAM}

Publicações da FAUUSP

258

Cartazes

265

Revistas

273 

Professores da Escola de Artesanato

Nelson Nóbrega (diretor da Escola de Artesanato)

fonte: Itaucultural - www.itaucultural.org.br

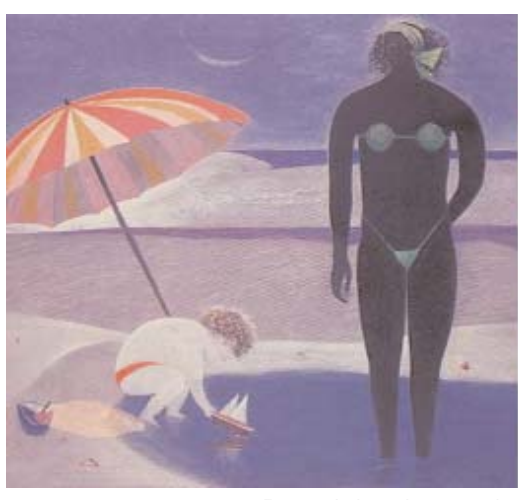

Barquinho de papel

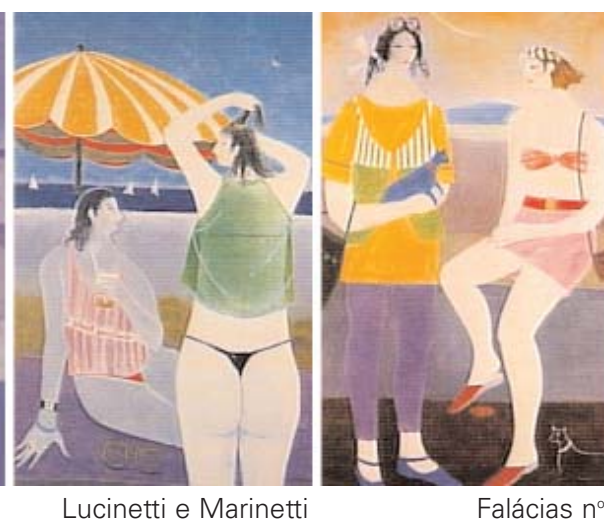

198

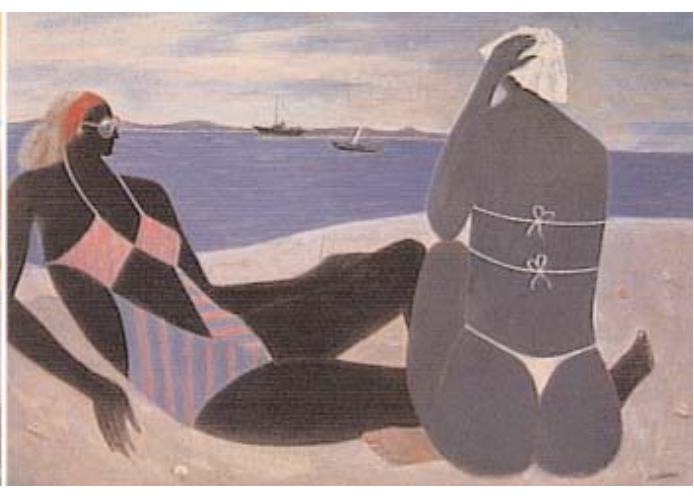

Duas figuras na praia 

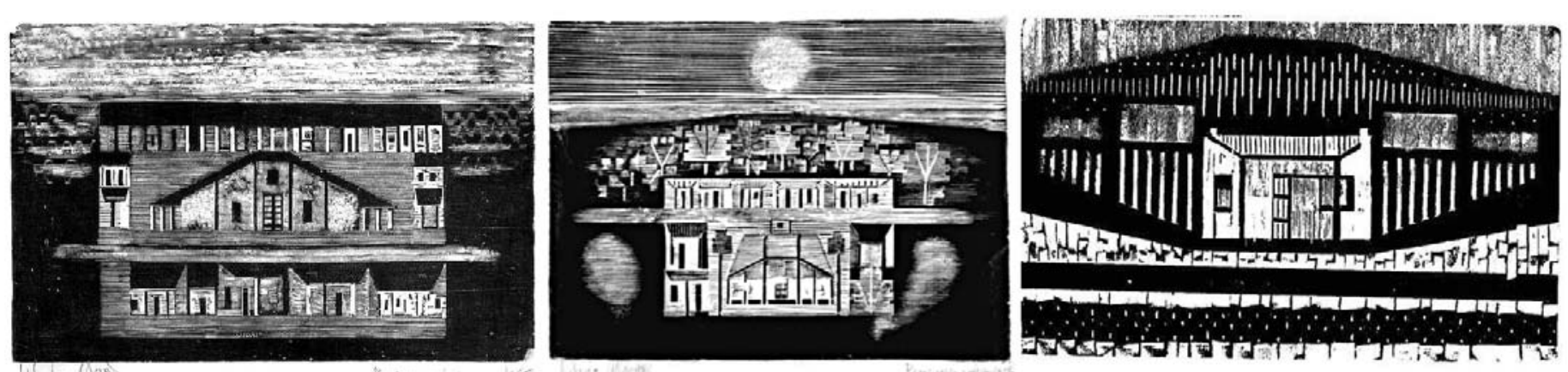

Paraguai - onírico2

Paraguai - onírico

Paraguai - sinfonia

1965

1957

1965 


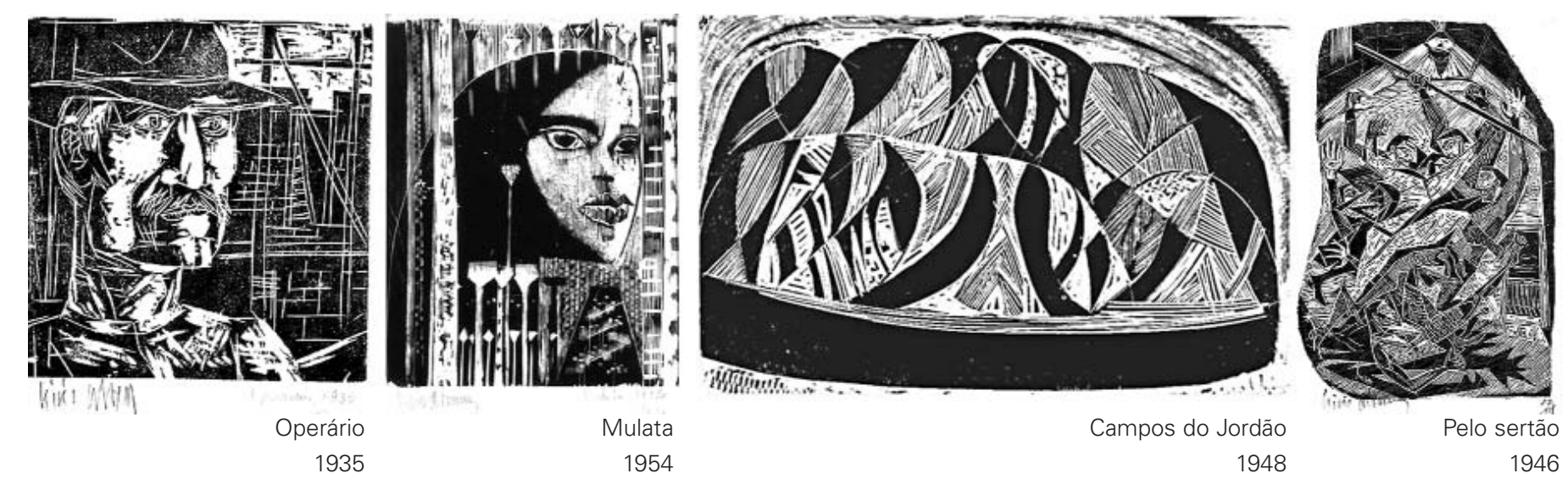




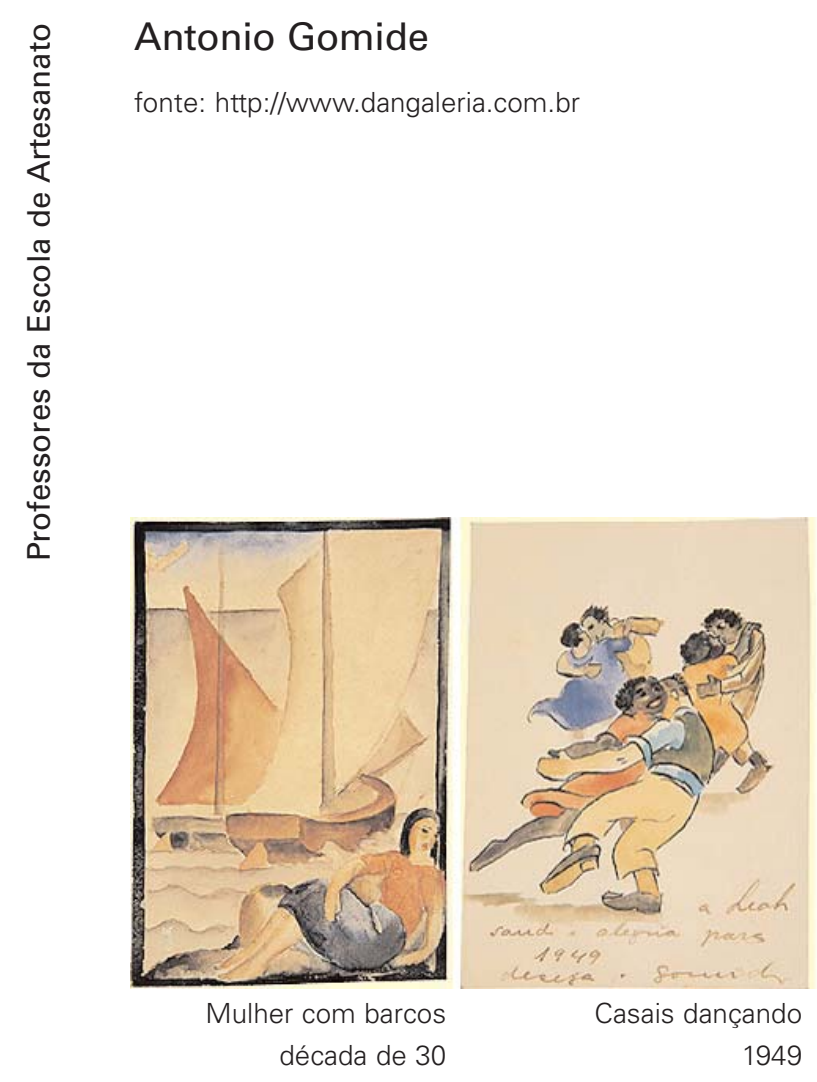

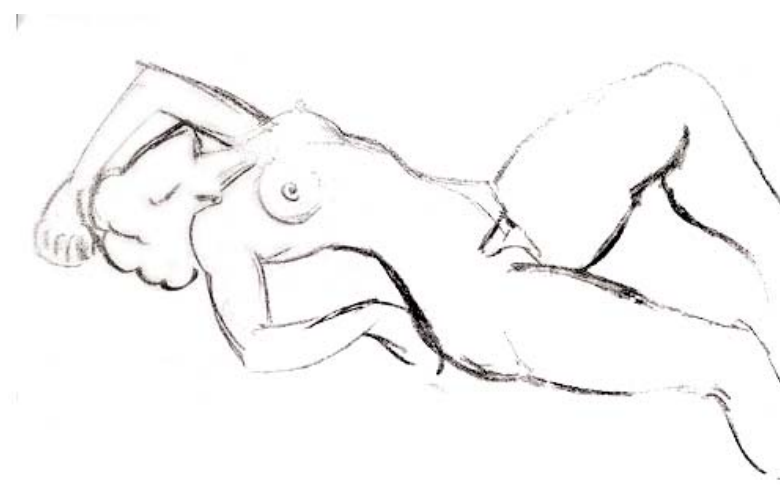

Nu feminino recostado

sem data

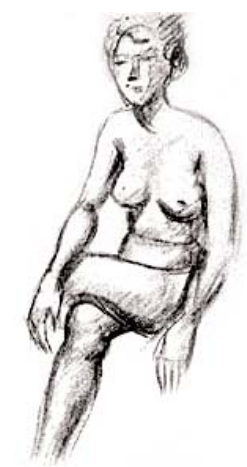

Figura feminina sentada

sem data

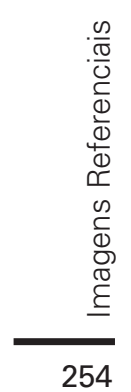



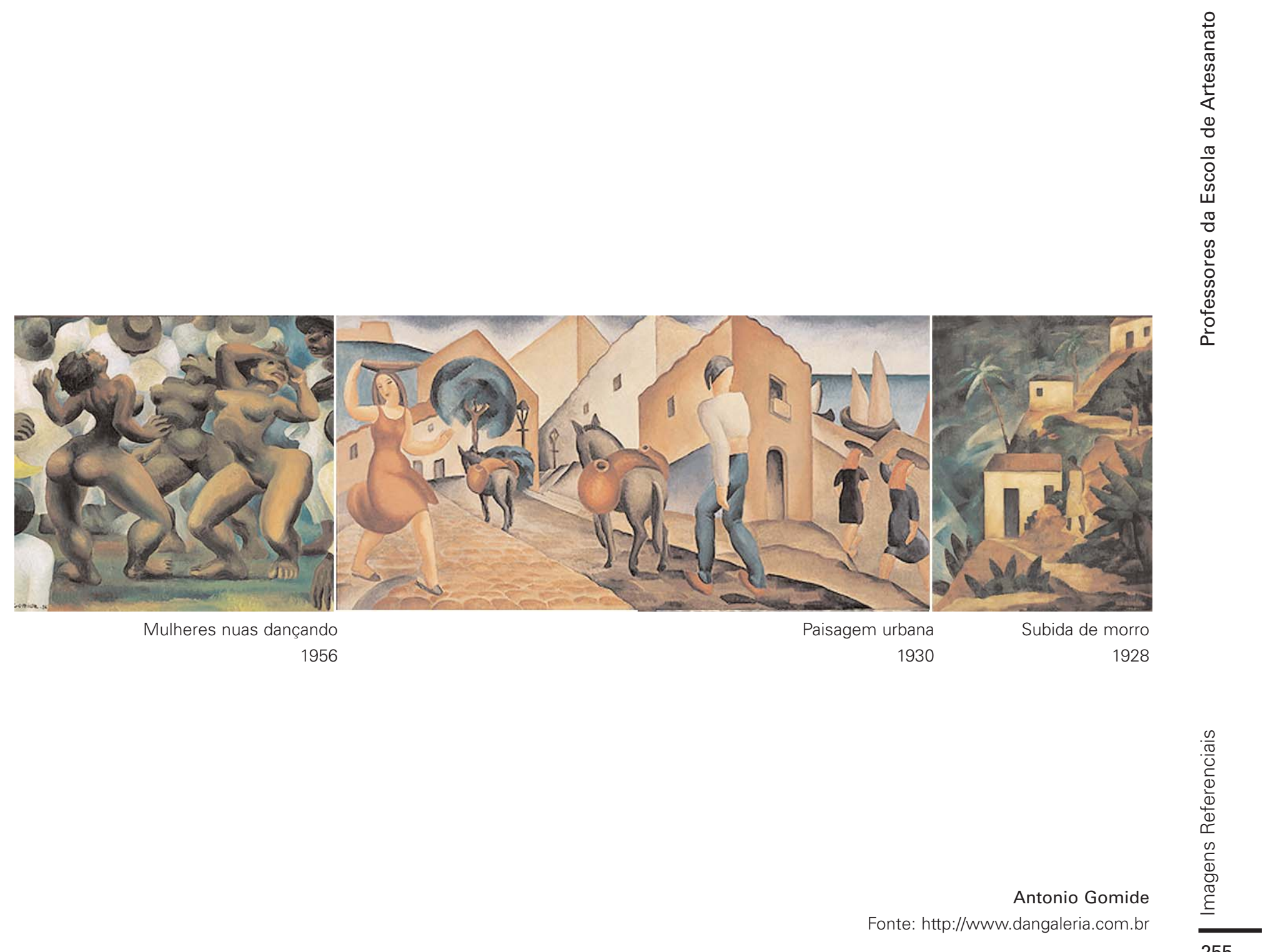


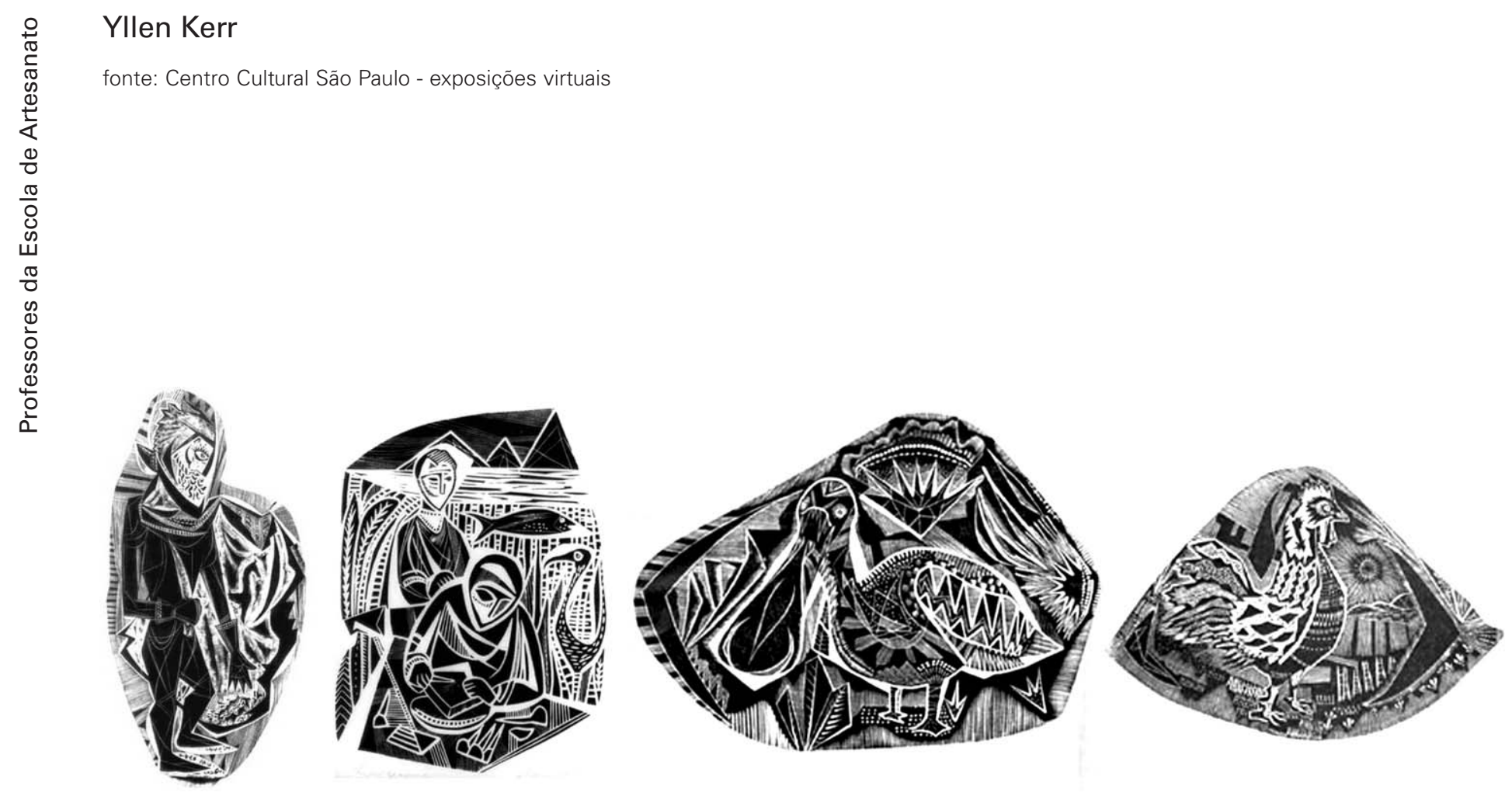

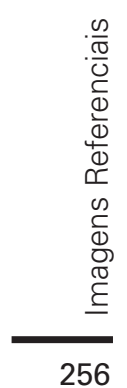




\section{Mário Gruber}

fonte: Itaucultural - www.itaucultural.org.br

www.mac.usp.br

www.arteartistas.com.br

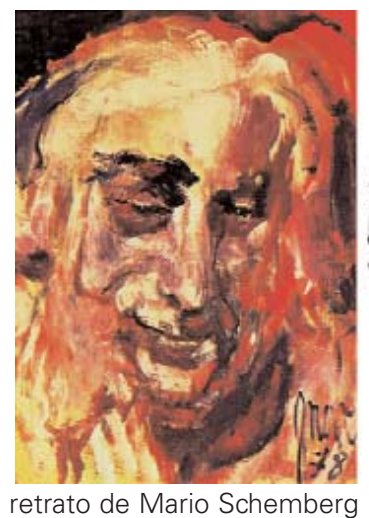

1978

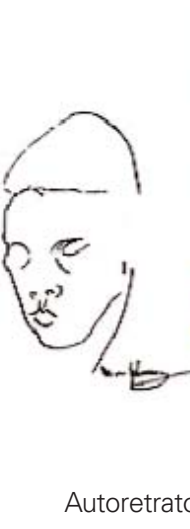

sem data

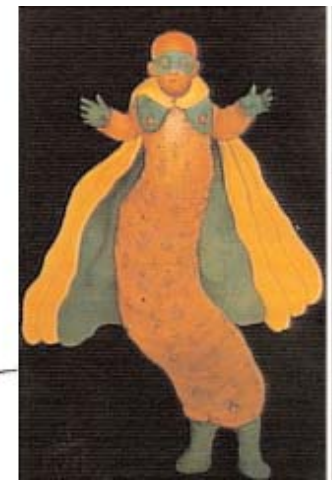

Libélula

1979

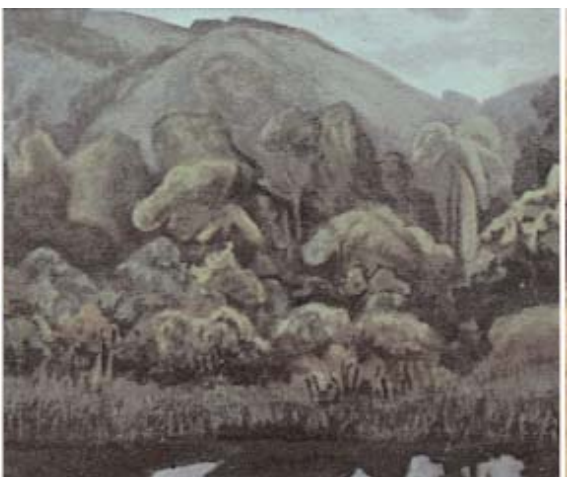

Barra do Una

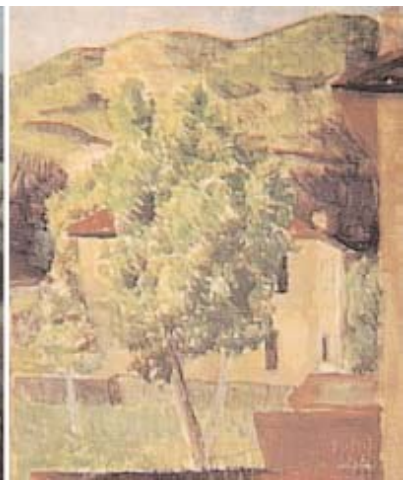

Morro Santa Terezinha

194

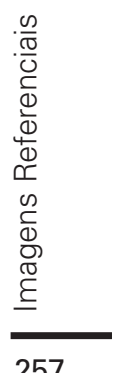




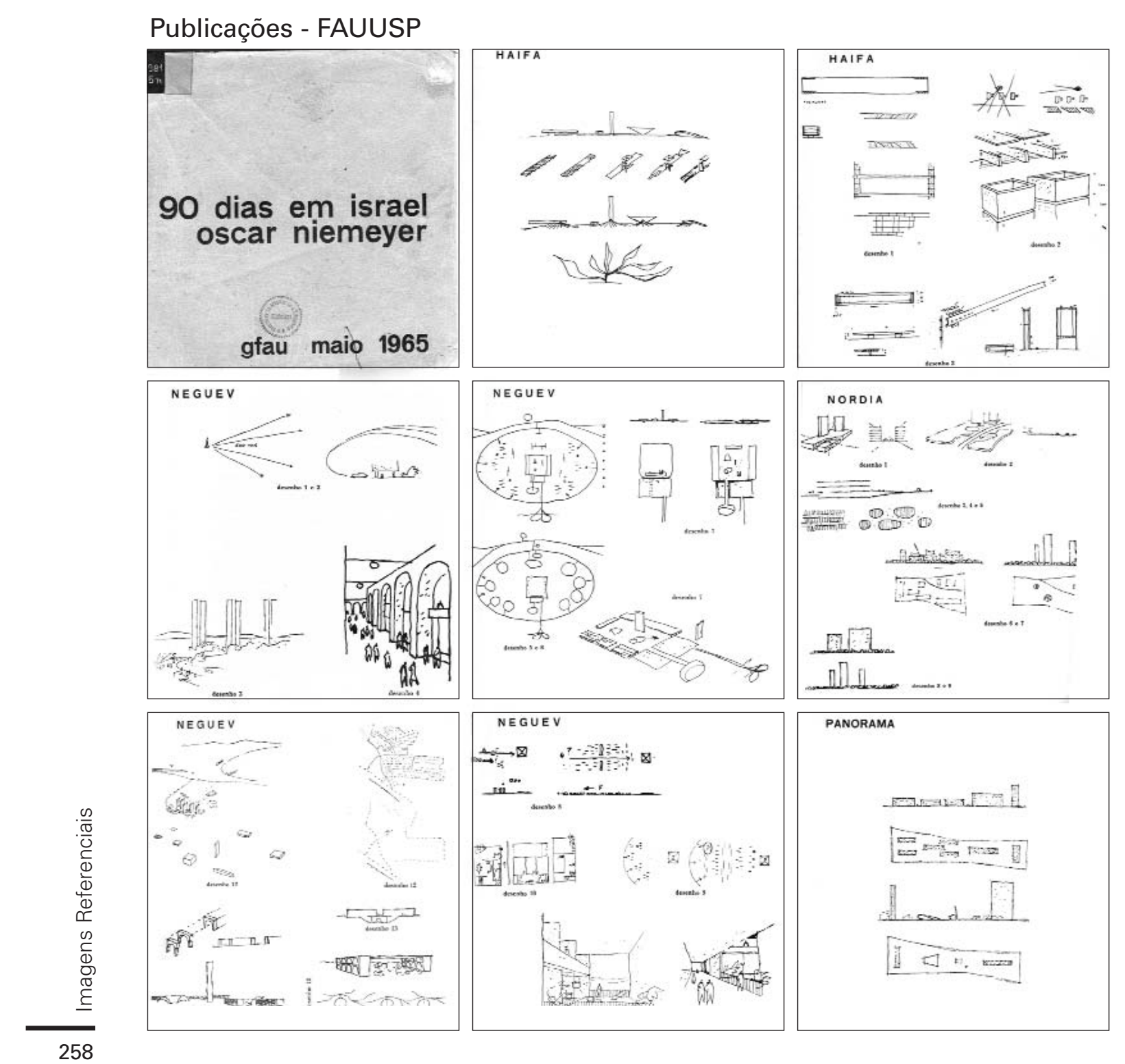




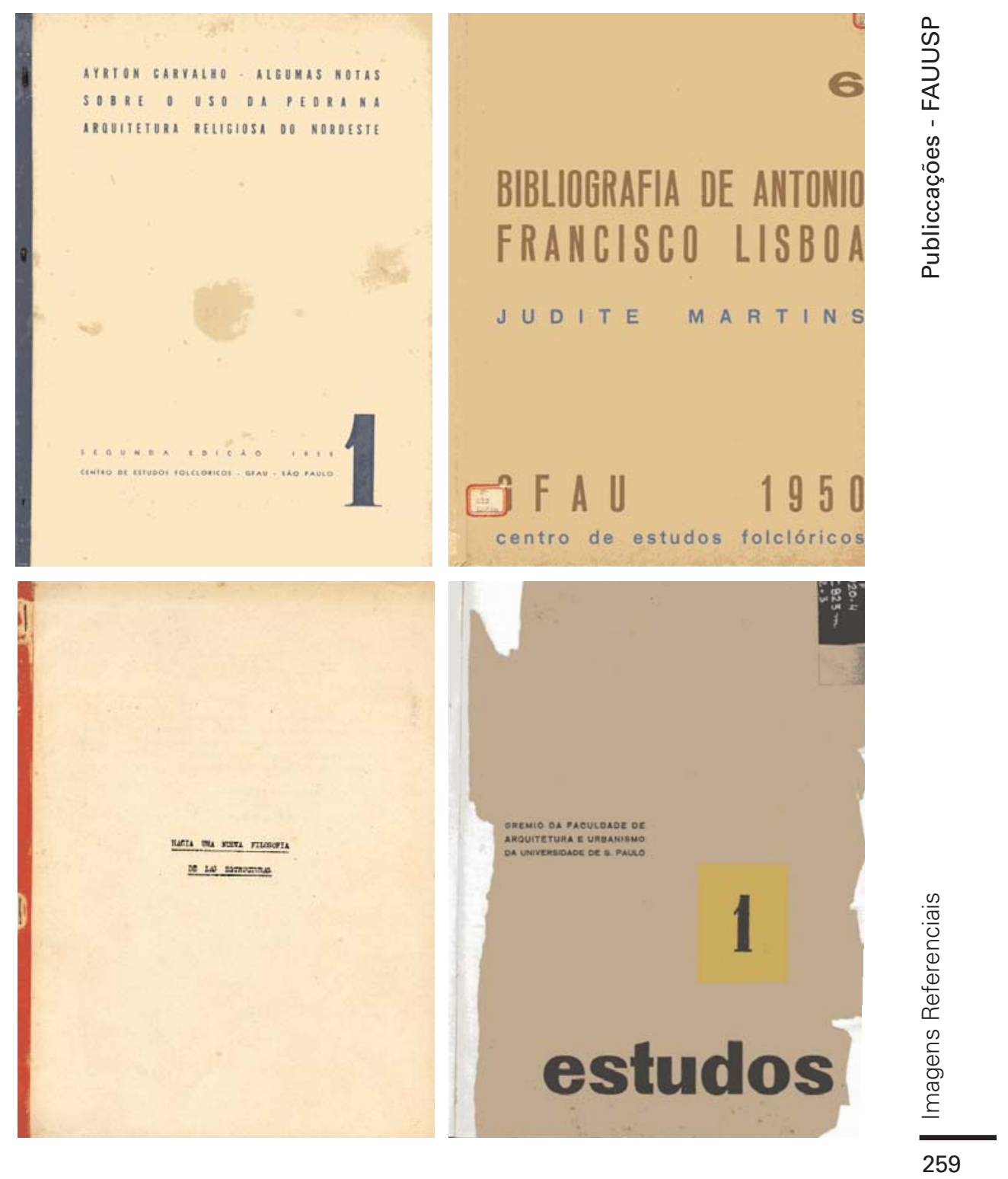




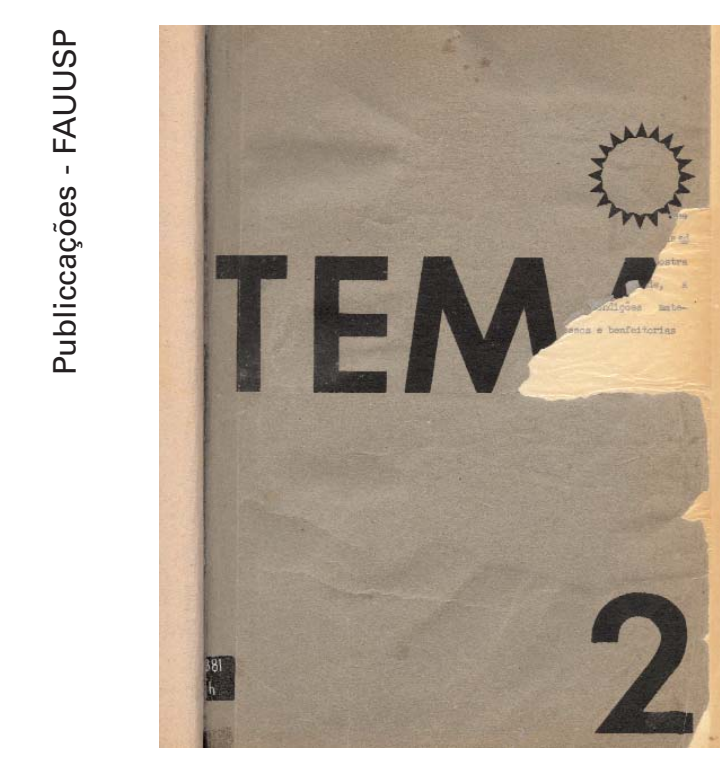

w a t e r gropius

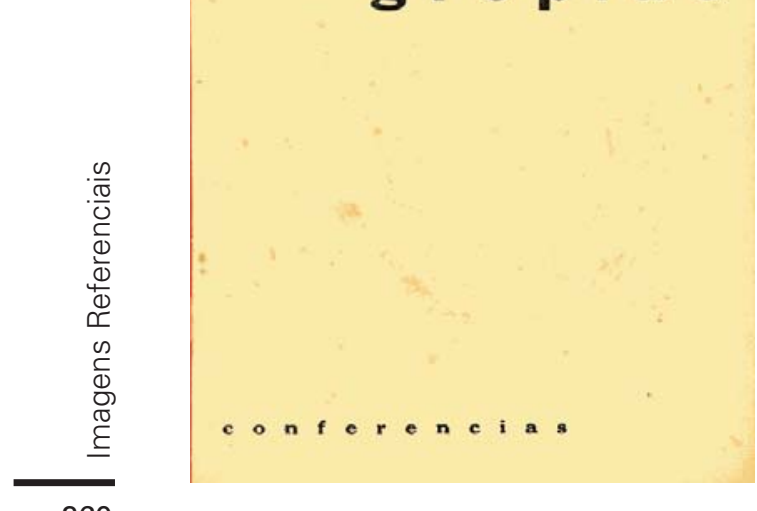

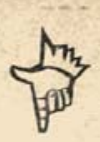

DEPOIMENTOS-1
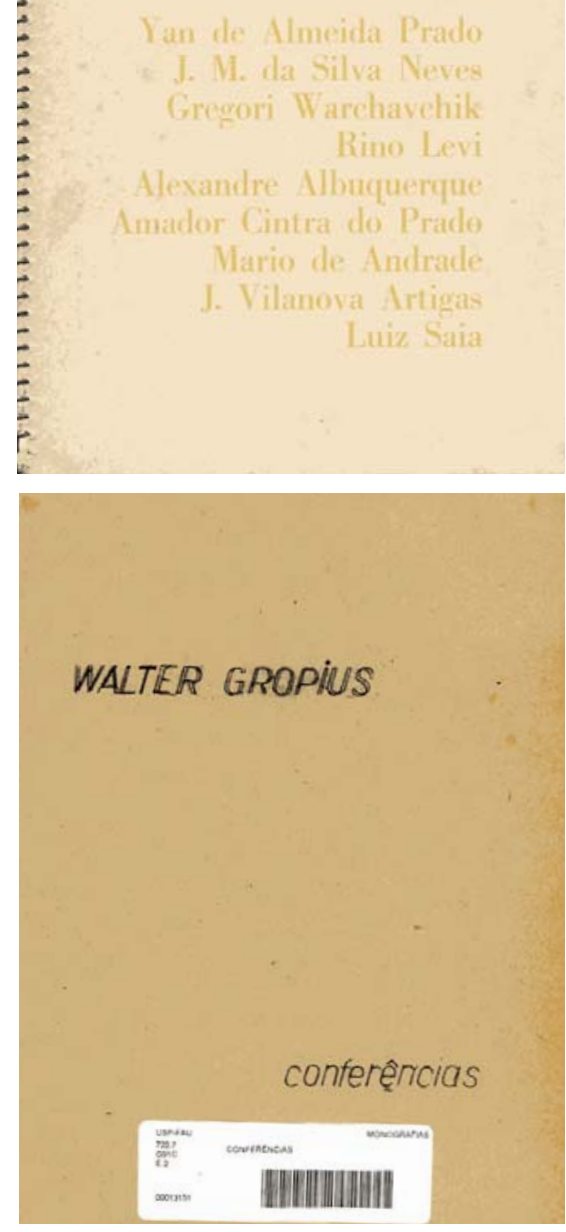
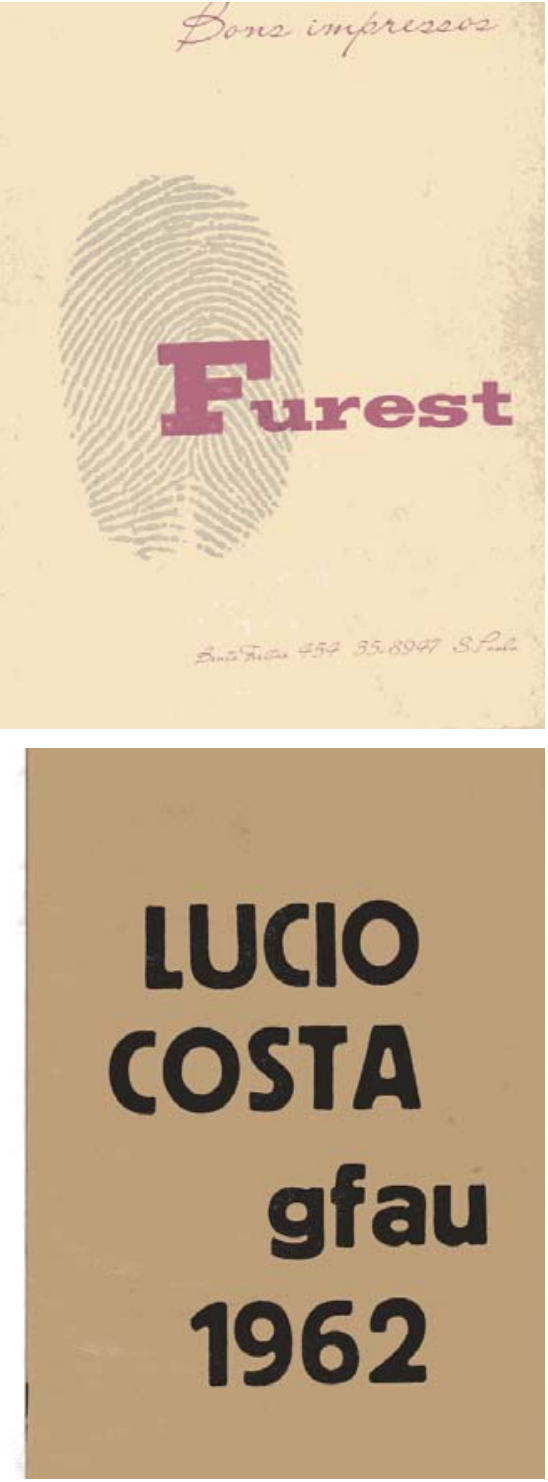

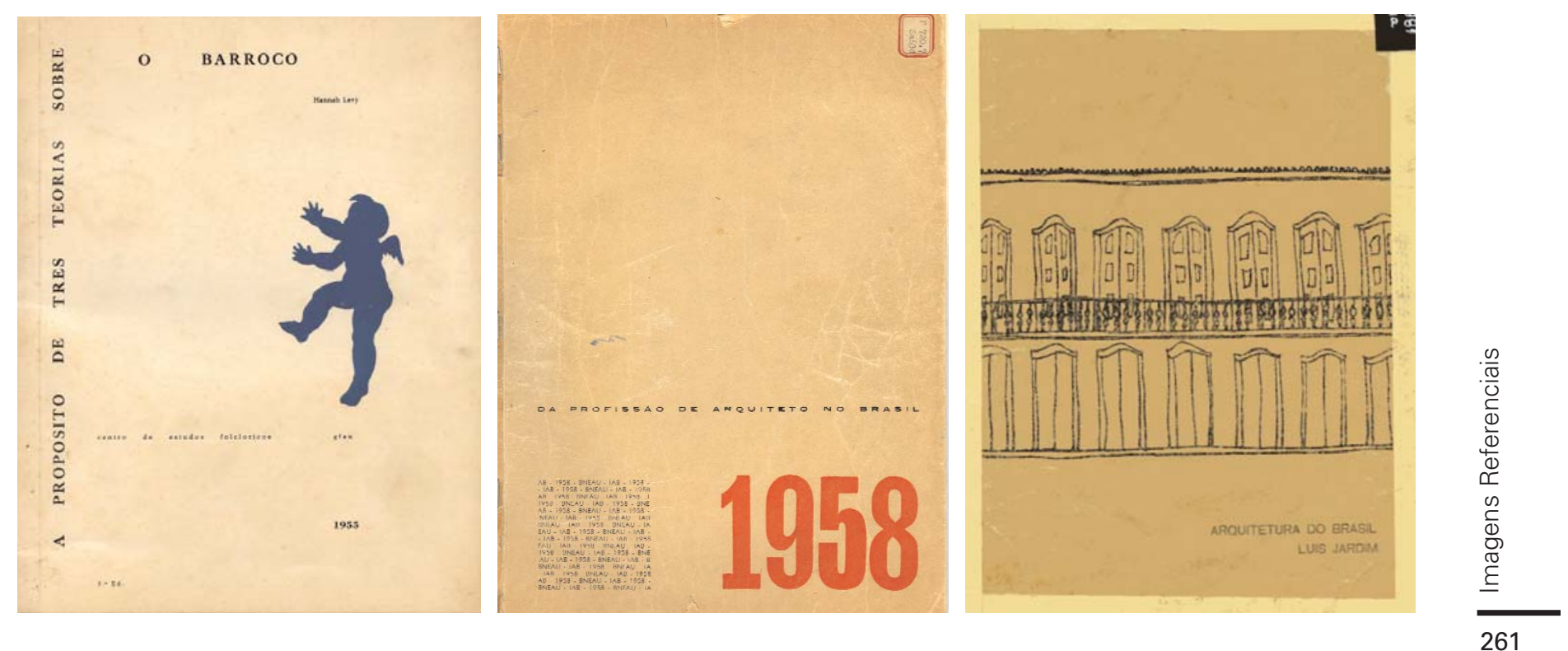


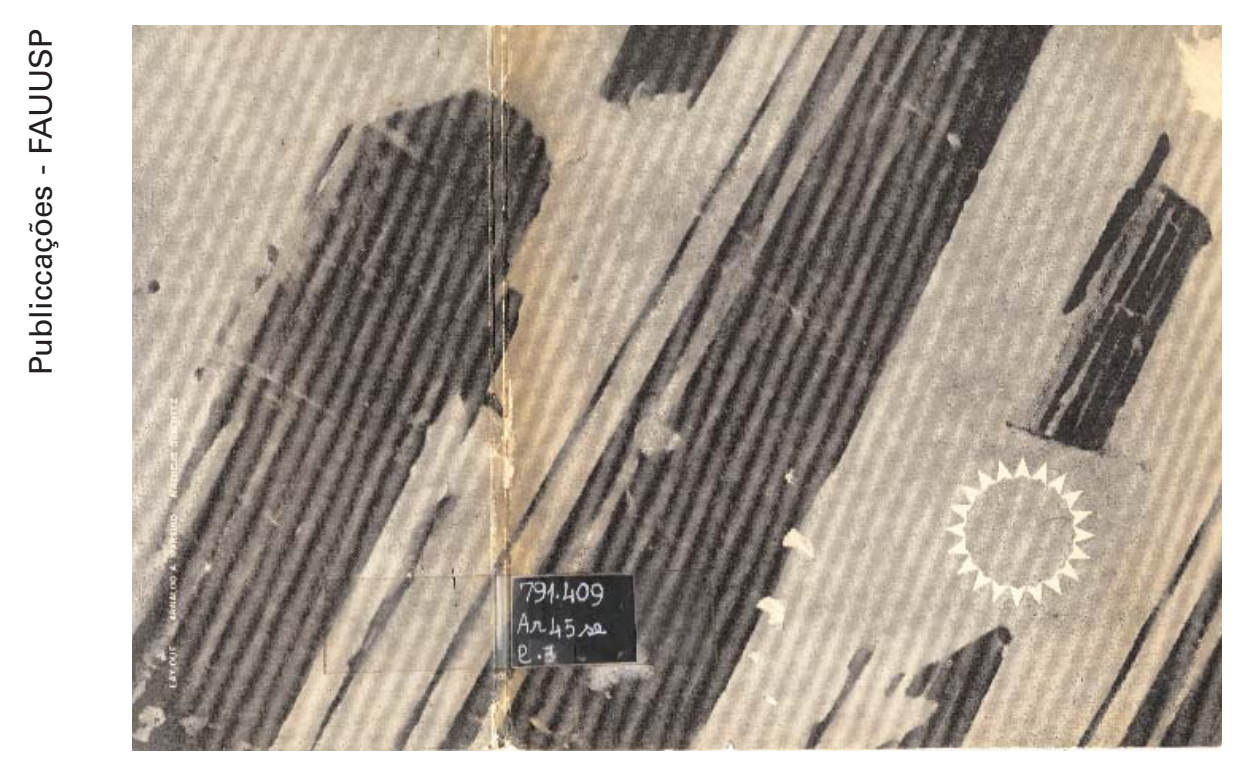

\section{GFAU 1}

$\odot \odot$

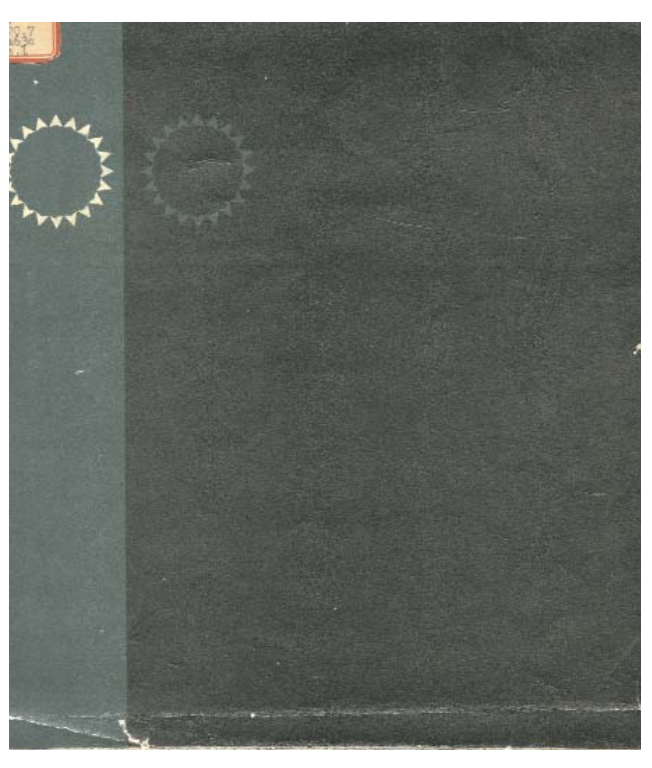



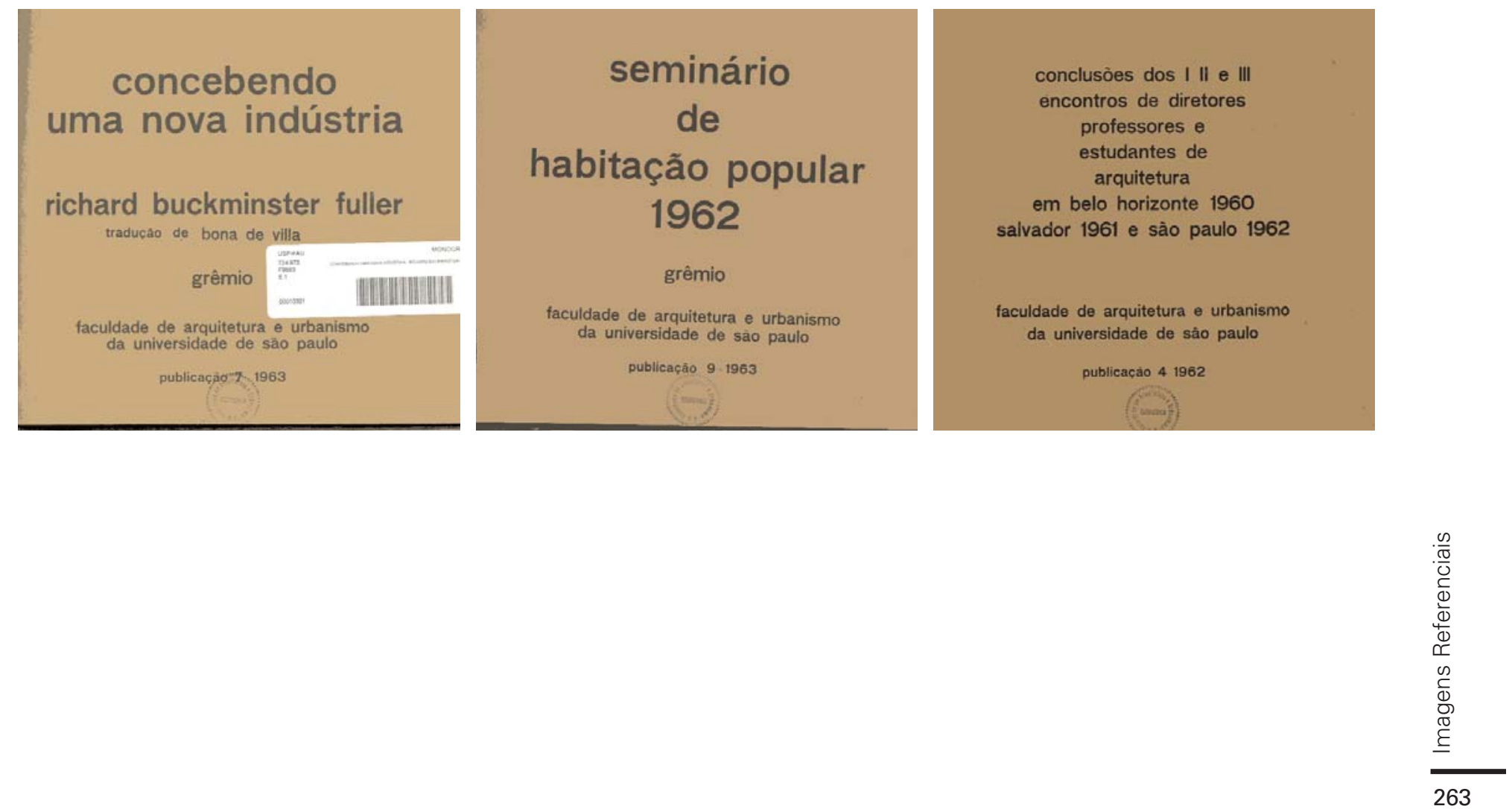


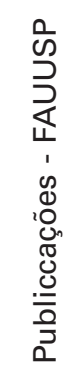

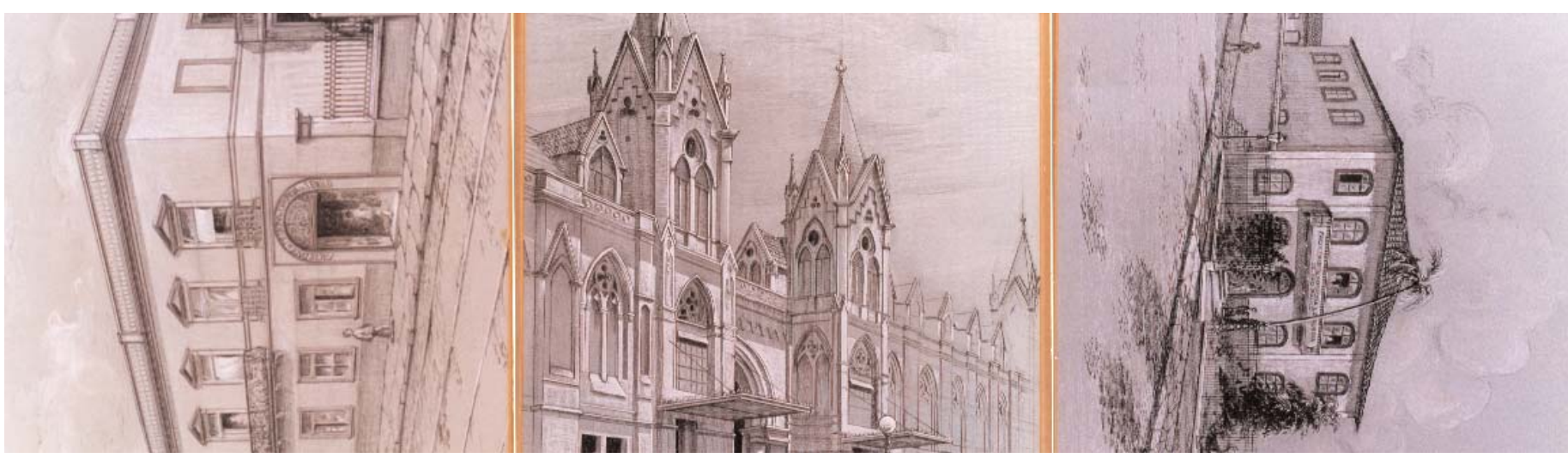

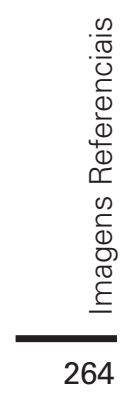




\section{Cartazes}

Celestino Piatti

fonte: Graphis, nº 66 jul.ago 1956 p.314-325

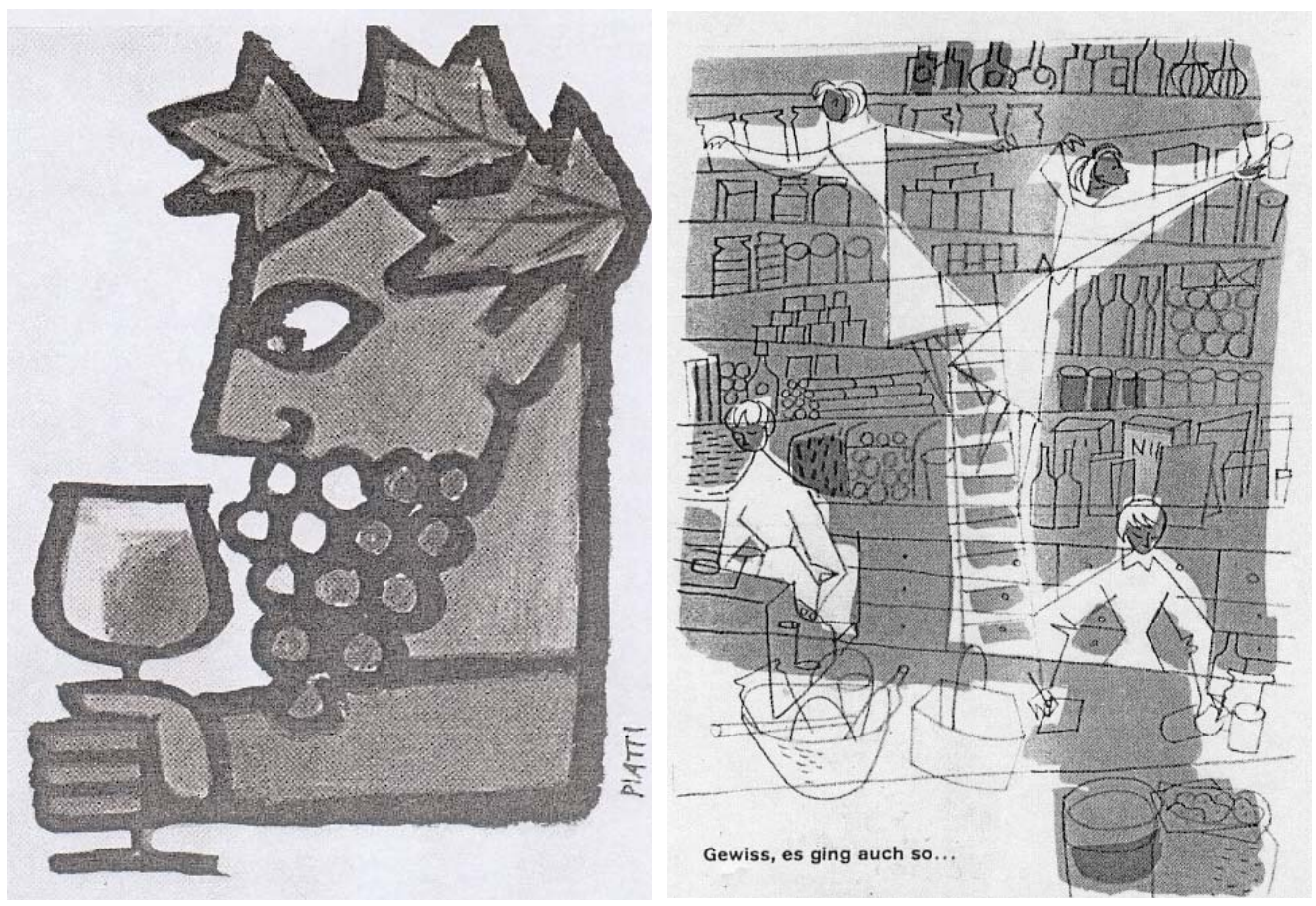




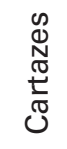
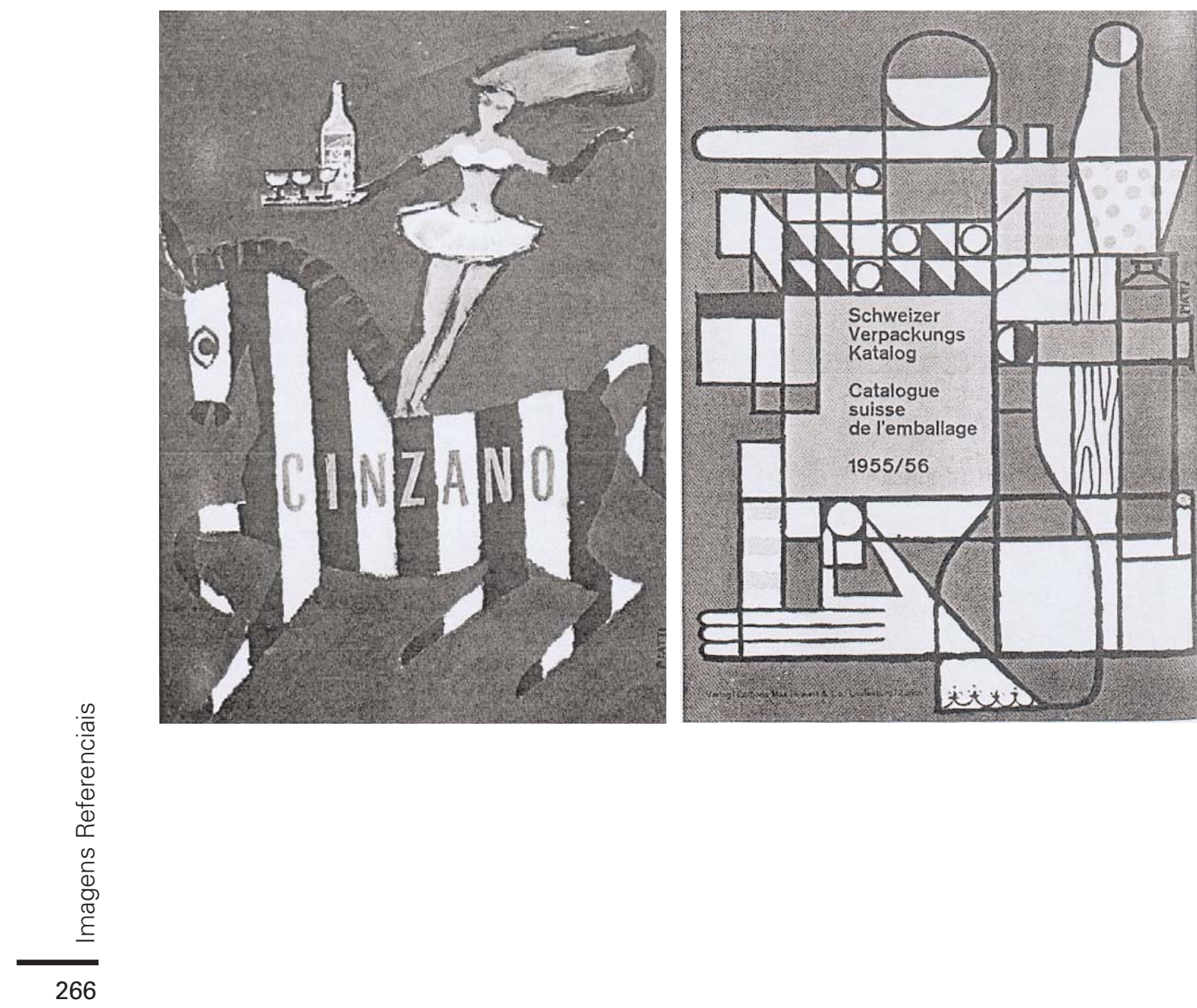

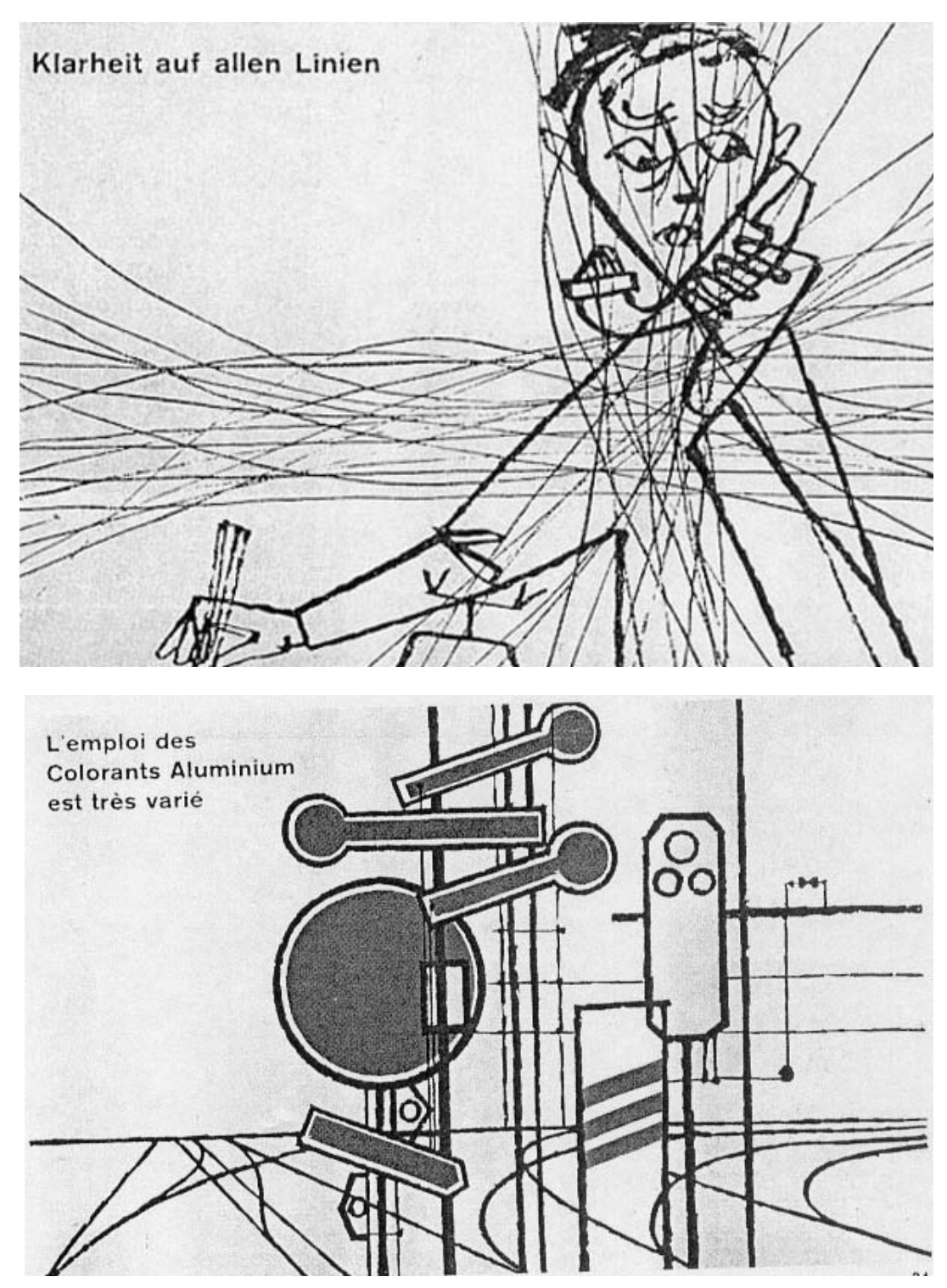

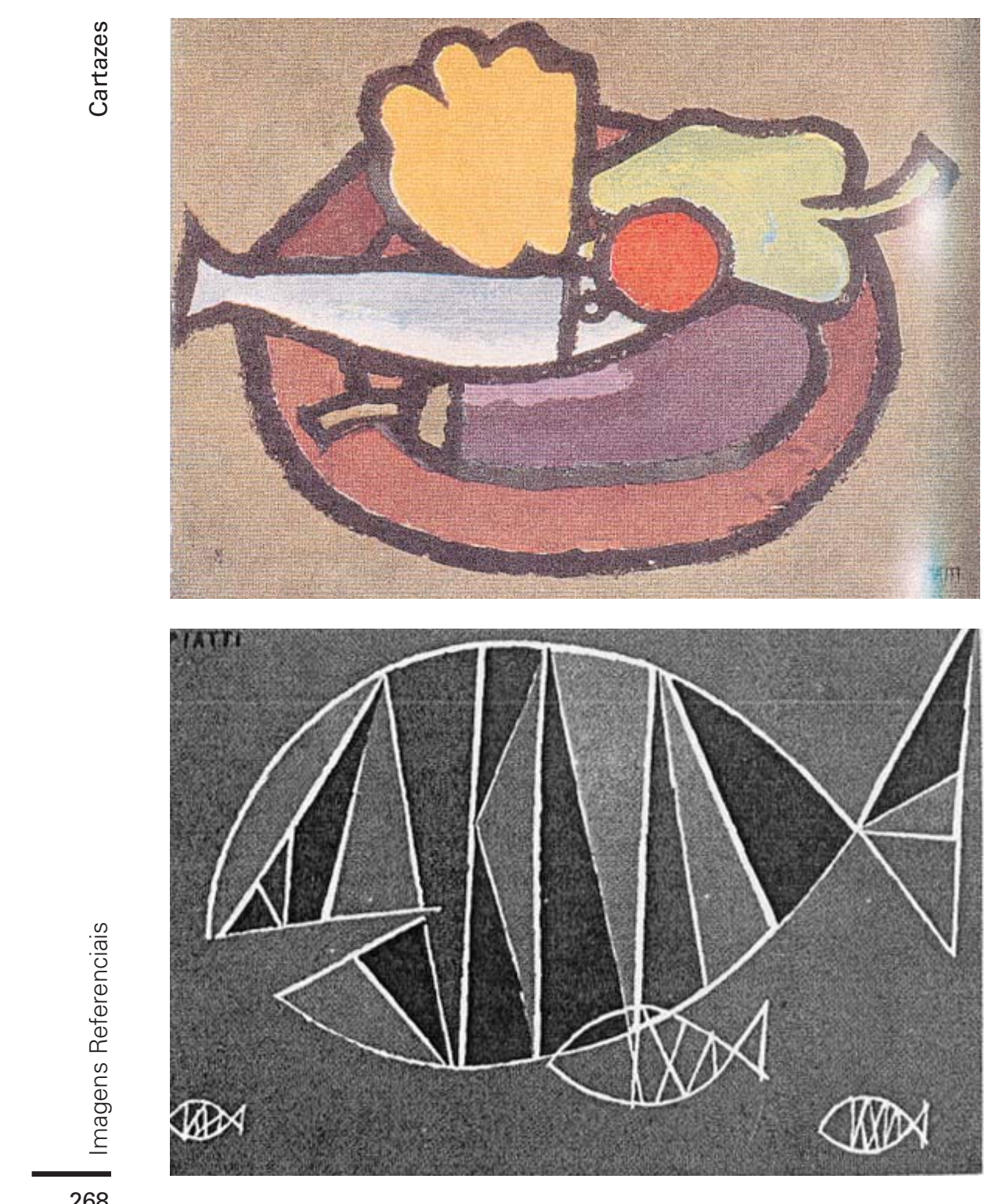

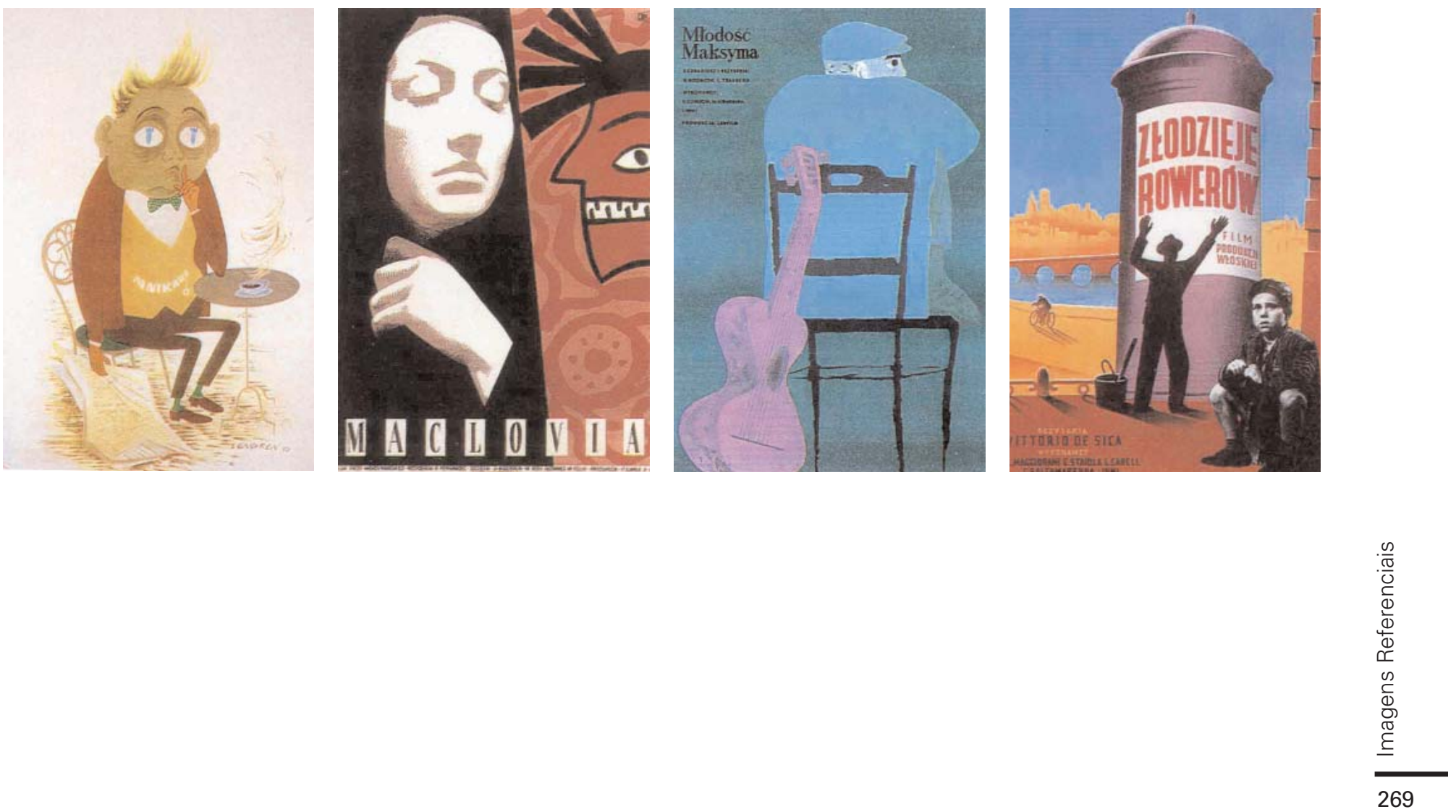
0
$\mathbb{N}$
$\mathbb{N}$
$\frac{5}{\pi}$
0
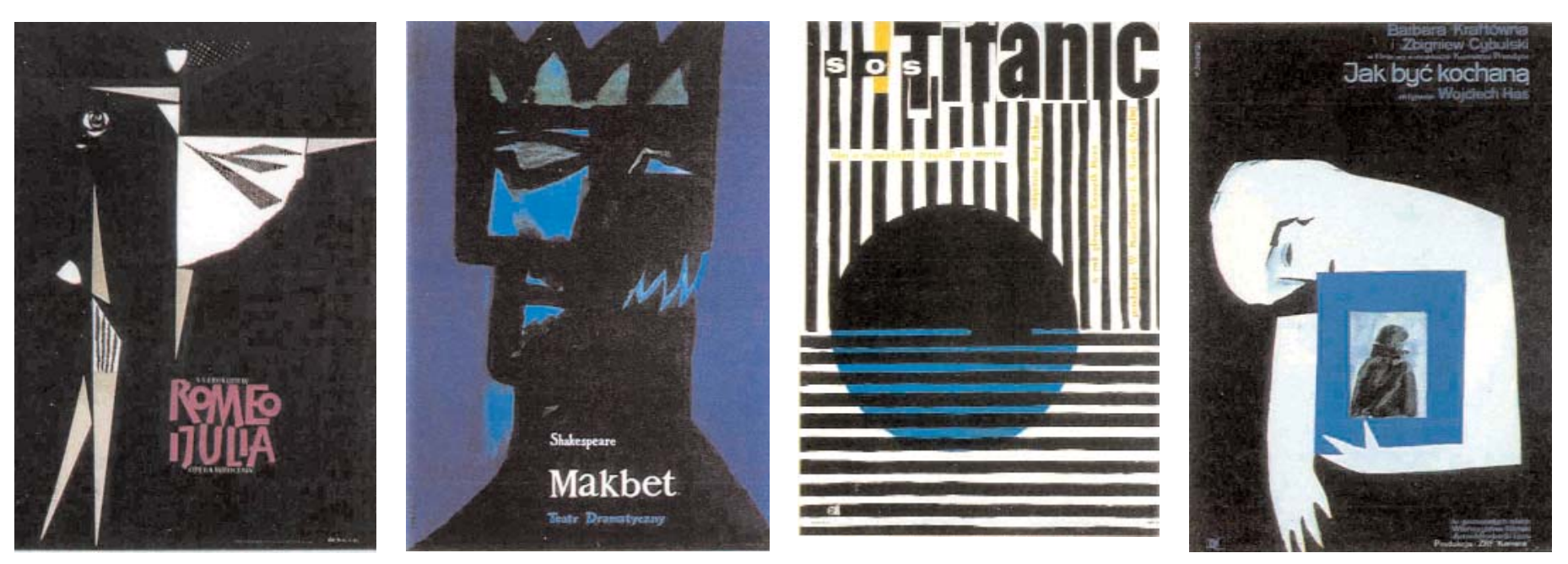

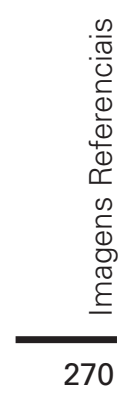



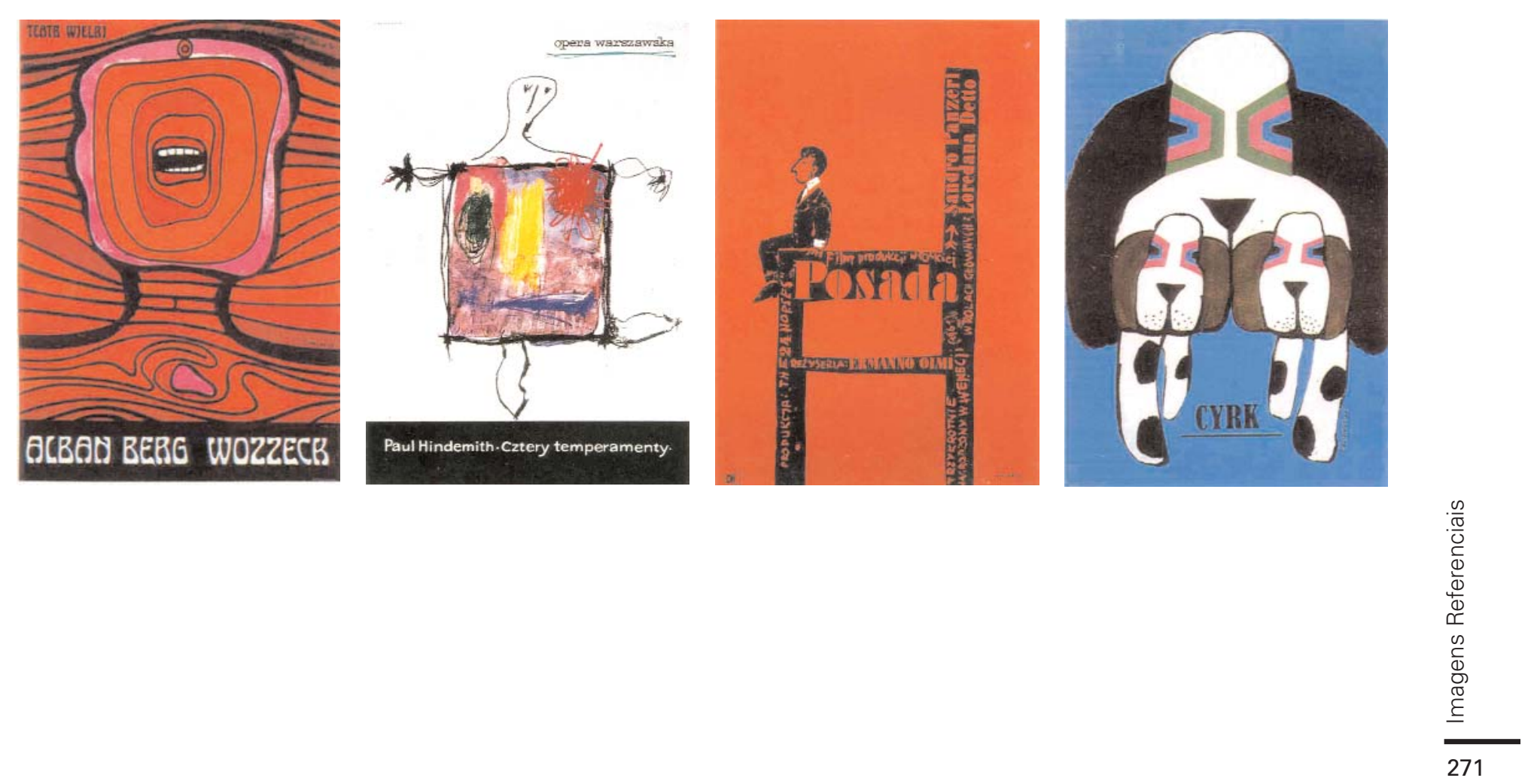


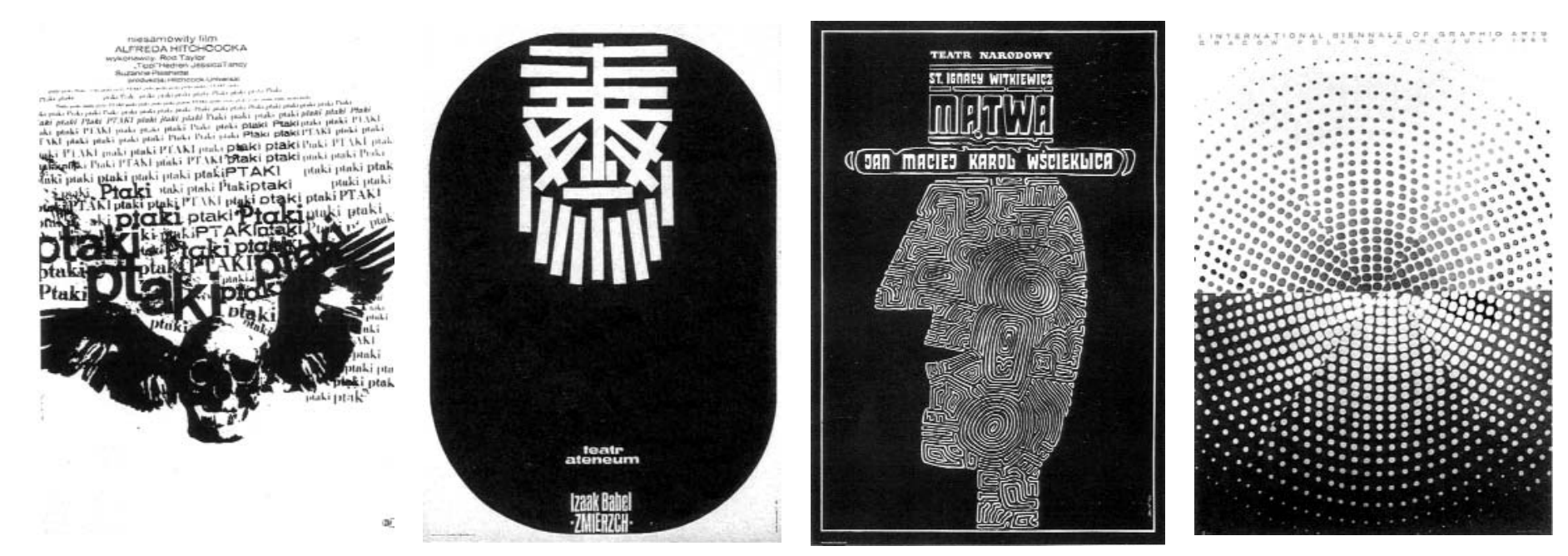

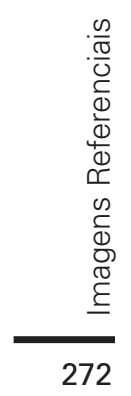


Arts \& Architecture

vol. 72 n 1 - jan 1955 capa e matéria Bertoia

vol. $74 \mathrm{n}^{\circ} 1$ - jan 1957

vol. $74 n^{\circ} 7$ - jul 1957
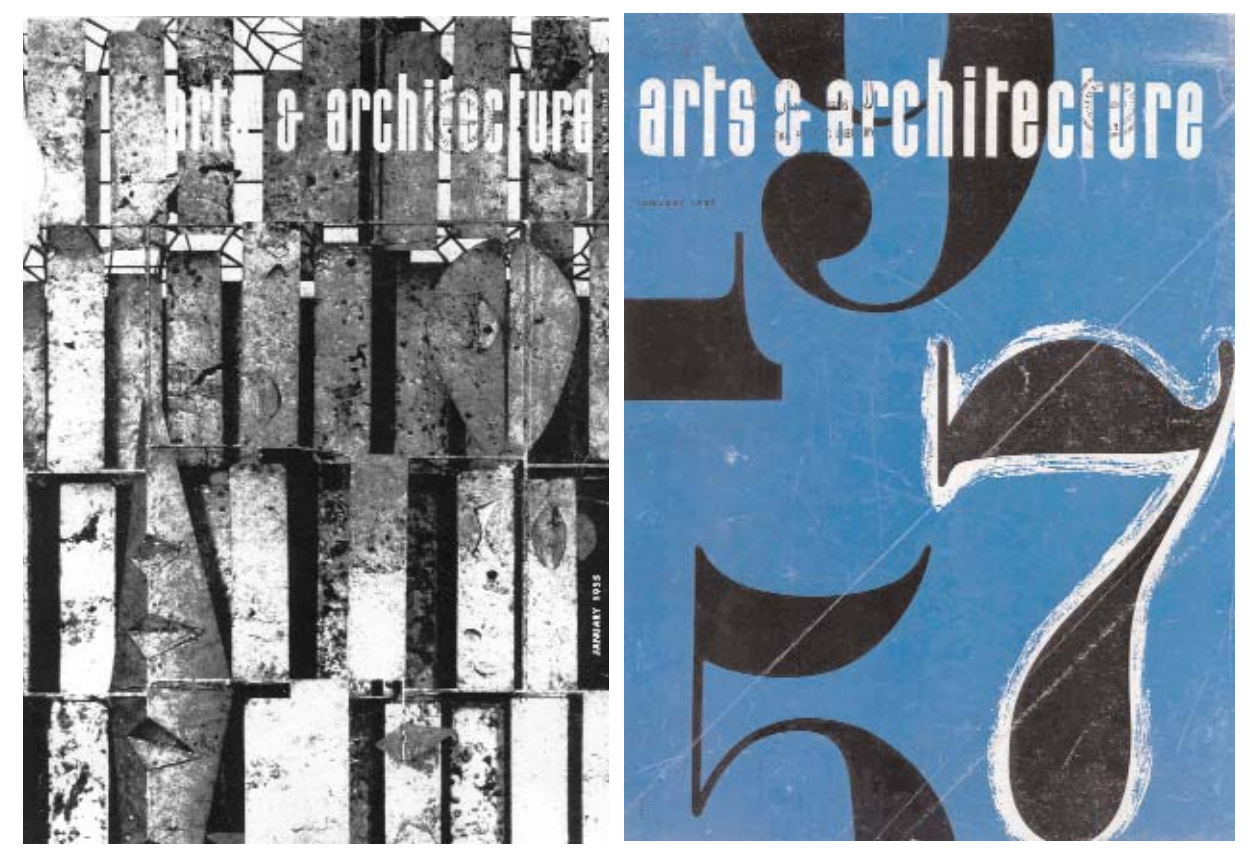

arts o architecture:

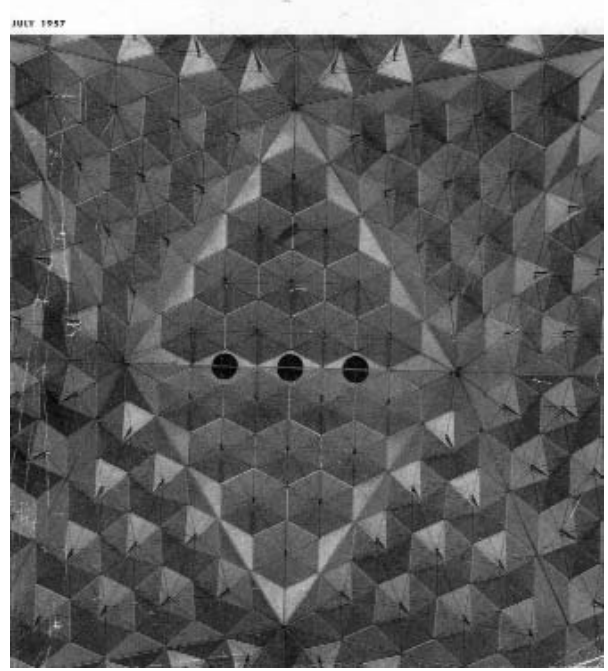




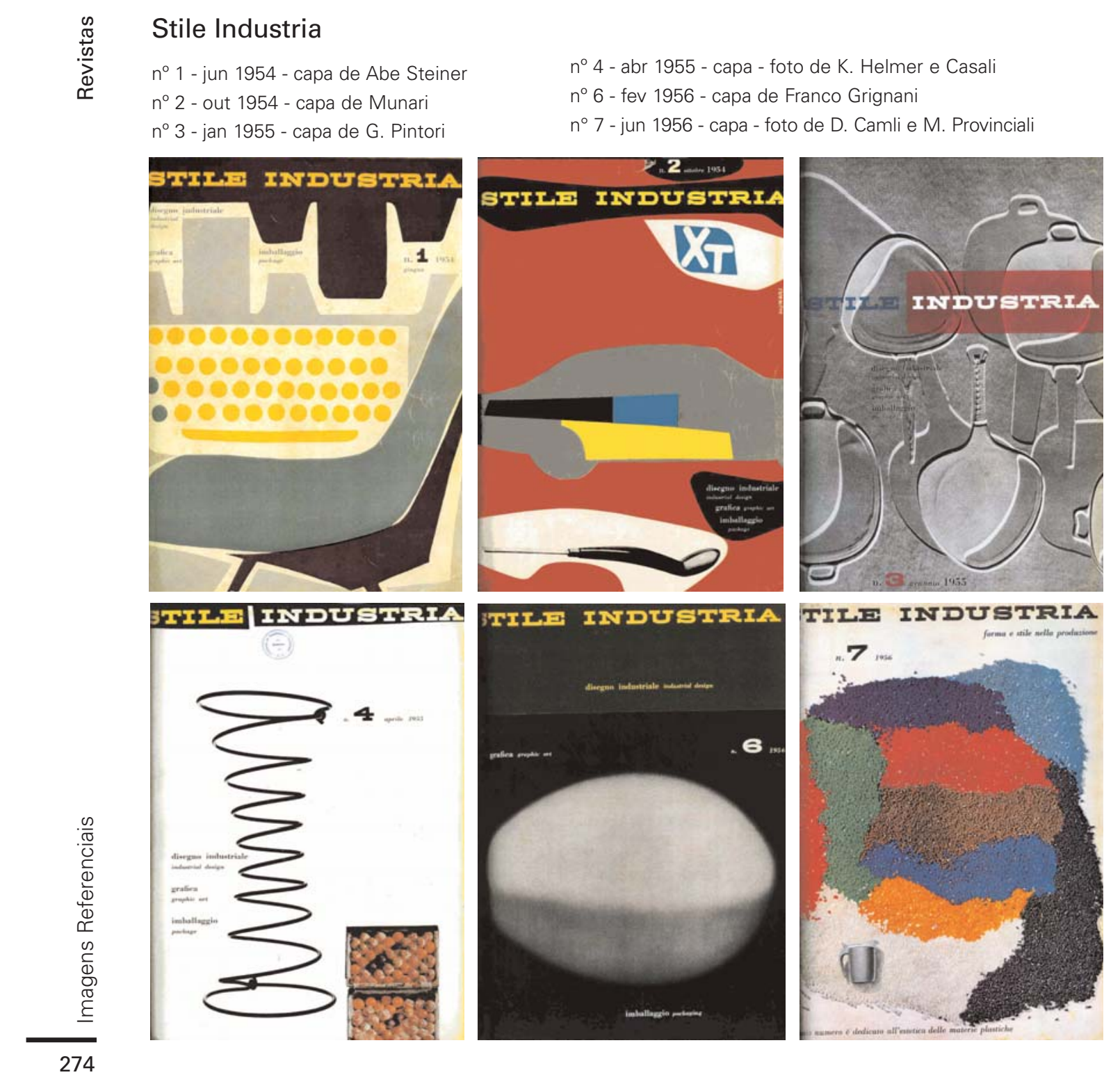


L'architettura cronache e storia

n 4 - nov/dez 1955 capa motivo abstrato por Marcelo Nizzoli

n 5 - jan/fev 1956 - capa motivo inspirado no velódromo olímpico de Roma por Marcelo Nizzoli

n 6 - mar/abr 1956 - capa motivo inspirado no Arco de Richet e Curvilenee pág.929 Saarinen pág. 931 a 935
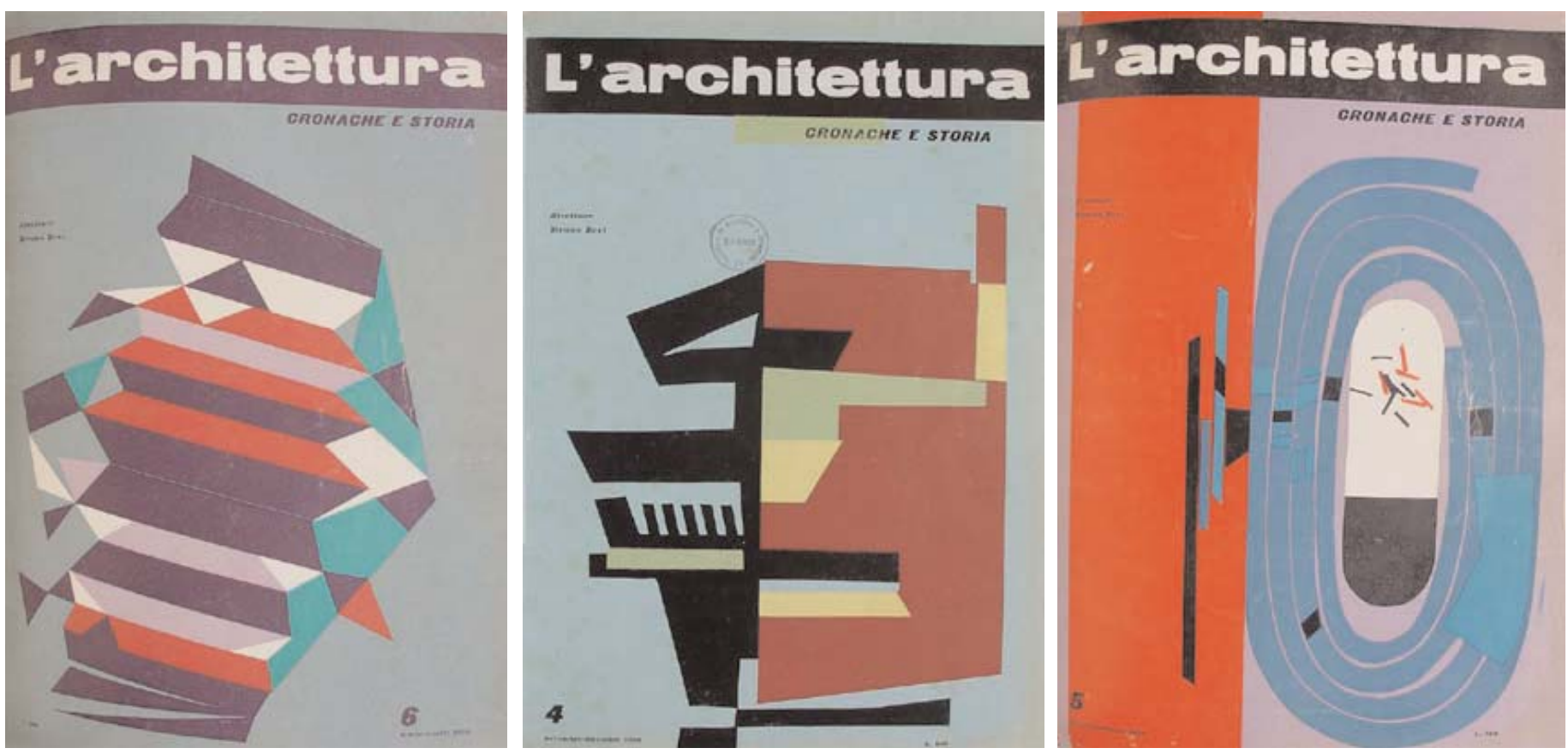

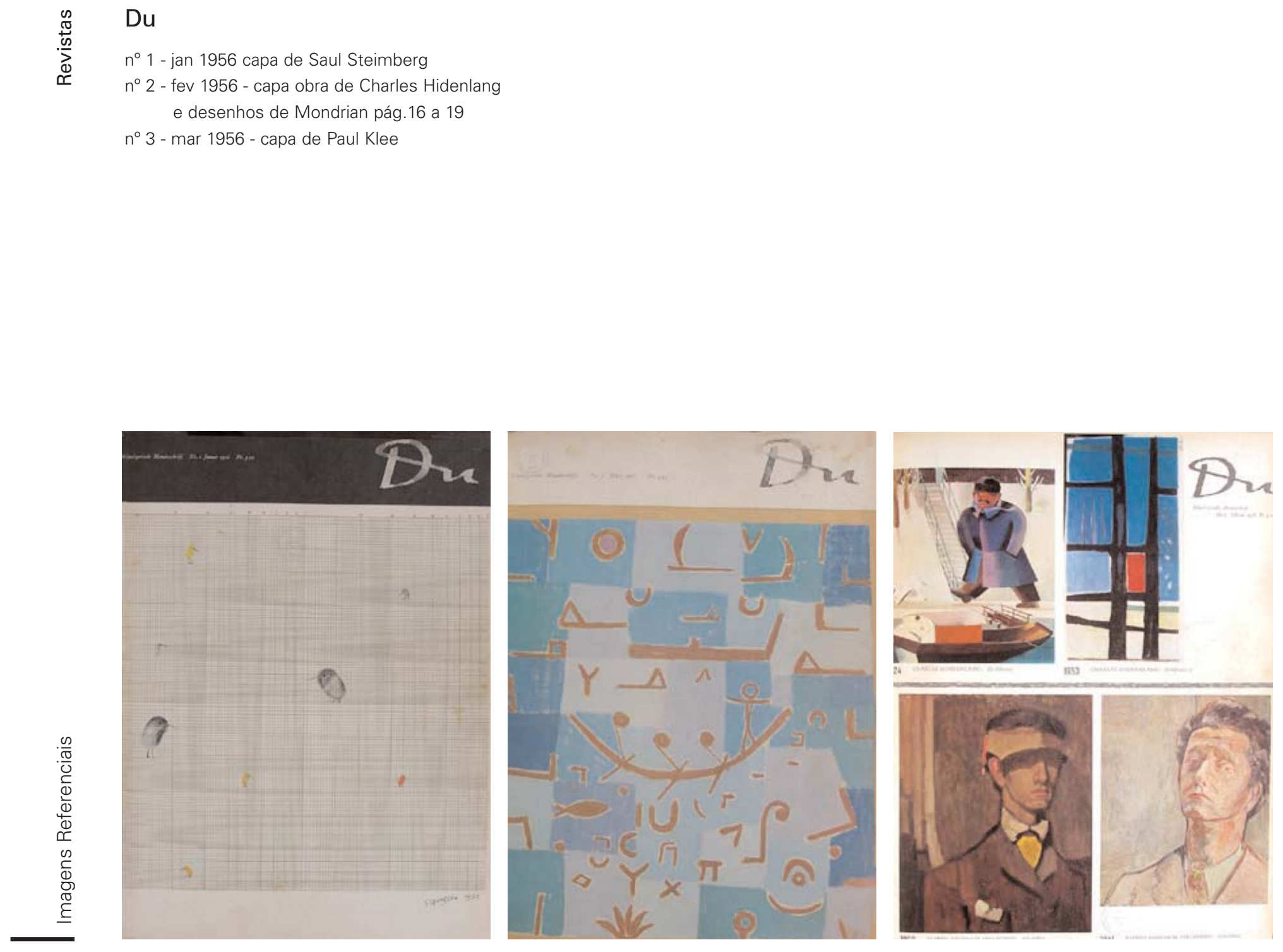

276 


\section{Graphis}

070 - mar/abr 1957 capa de Rudolph de Harak no 71 - mai/jun 1957 - capa de Phillipe de Lesser no 72 - jul/ago 1957 - capa de Celestino Piatt no 73 - set/out 1957 - capa de Le Corbusier
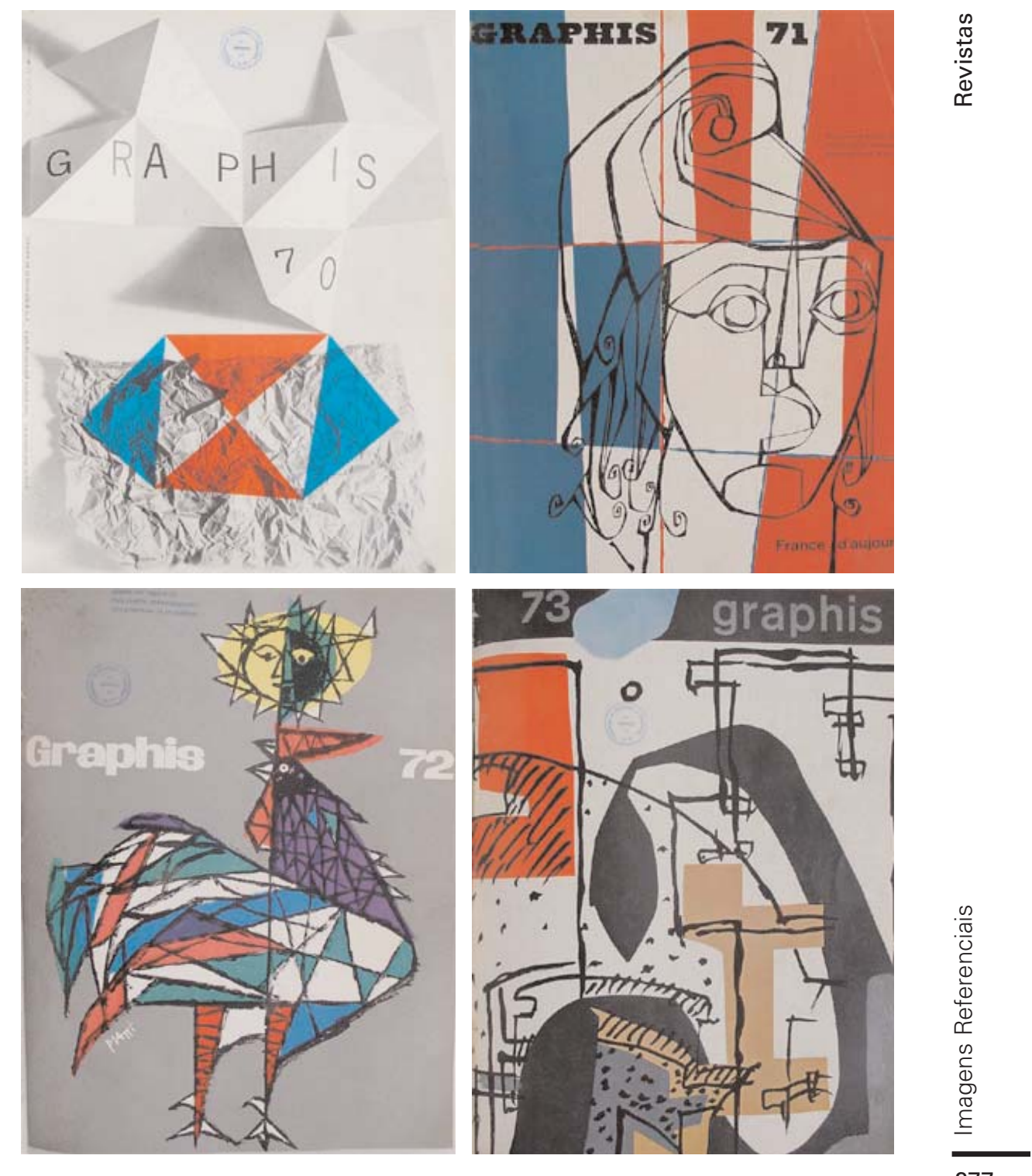
Habitat

$n^{\circ} 20$ - jan/fev 1955

$n^{\circ} 21$ - mar/abr 1955

no 22 - mai/jun 1955

no 24 - out 1955
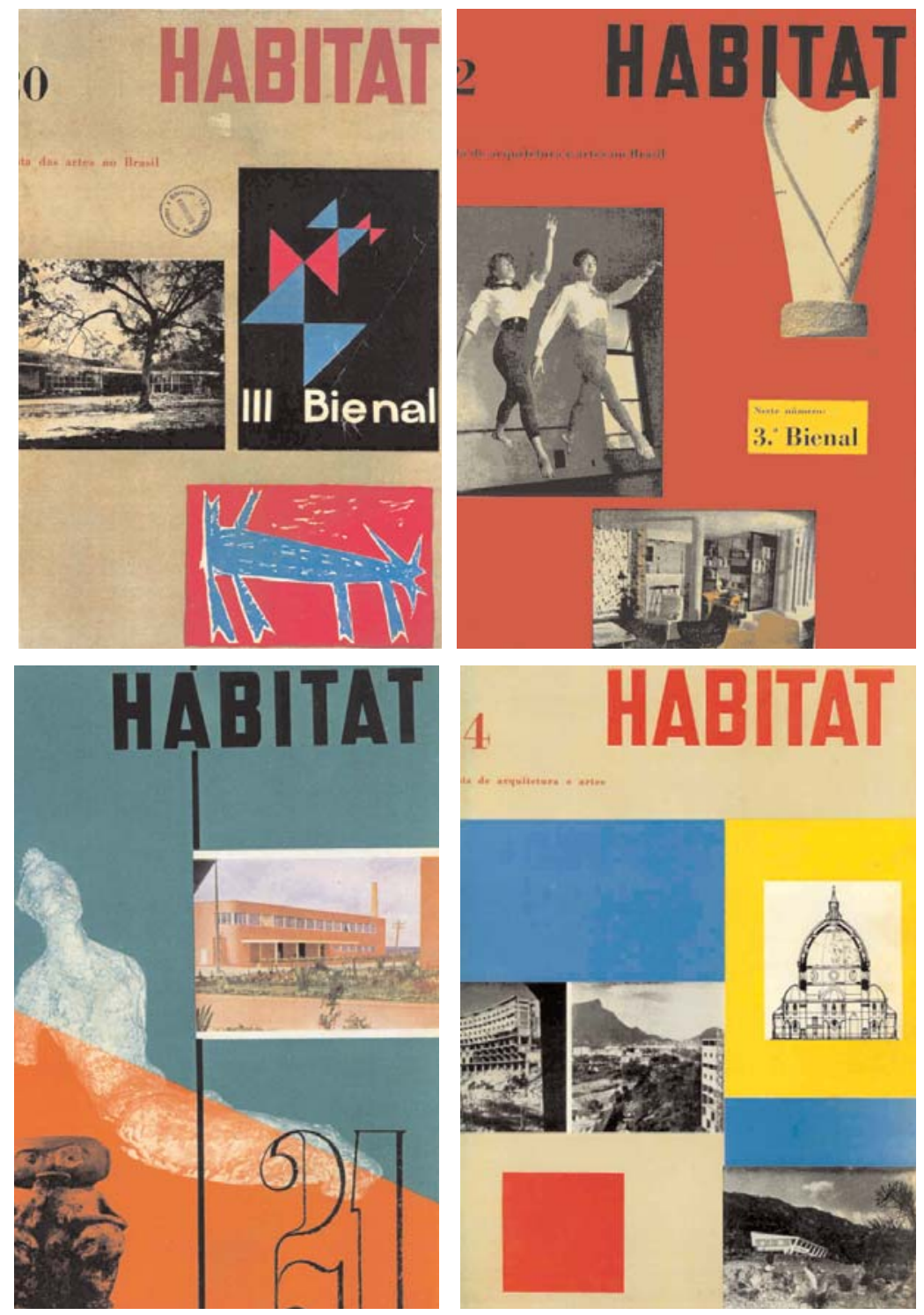

$\underset{\substack{0 \\ 0}}{\substack{50 \\ 0}}$

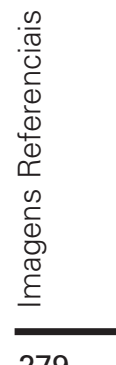



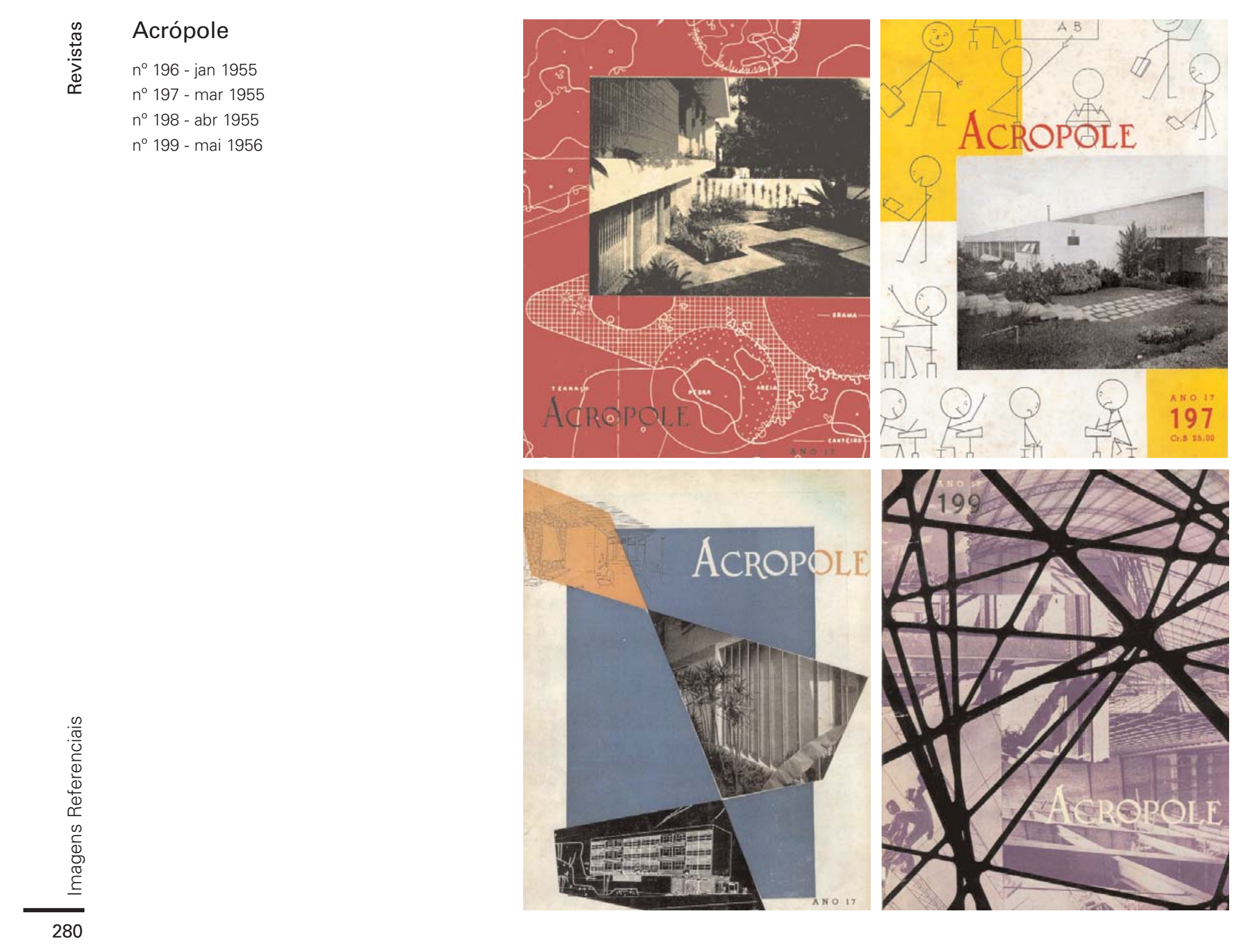
Módulo

no 1 - mar 1955

$n^{\circ} 2$ - ago 1955

$n^{\circ} 3$ - dez 1955

no 4 - mar 1956

\section{MOOULOMODULO}
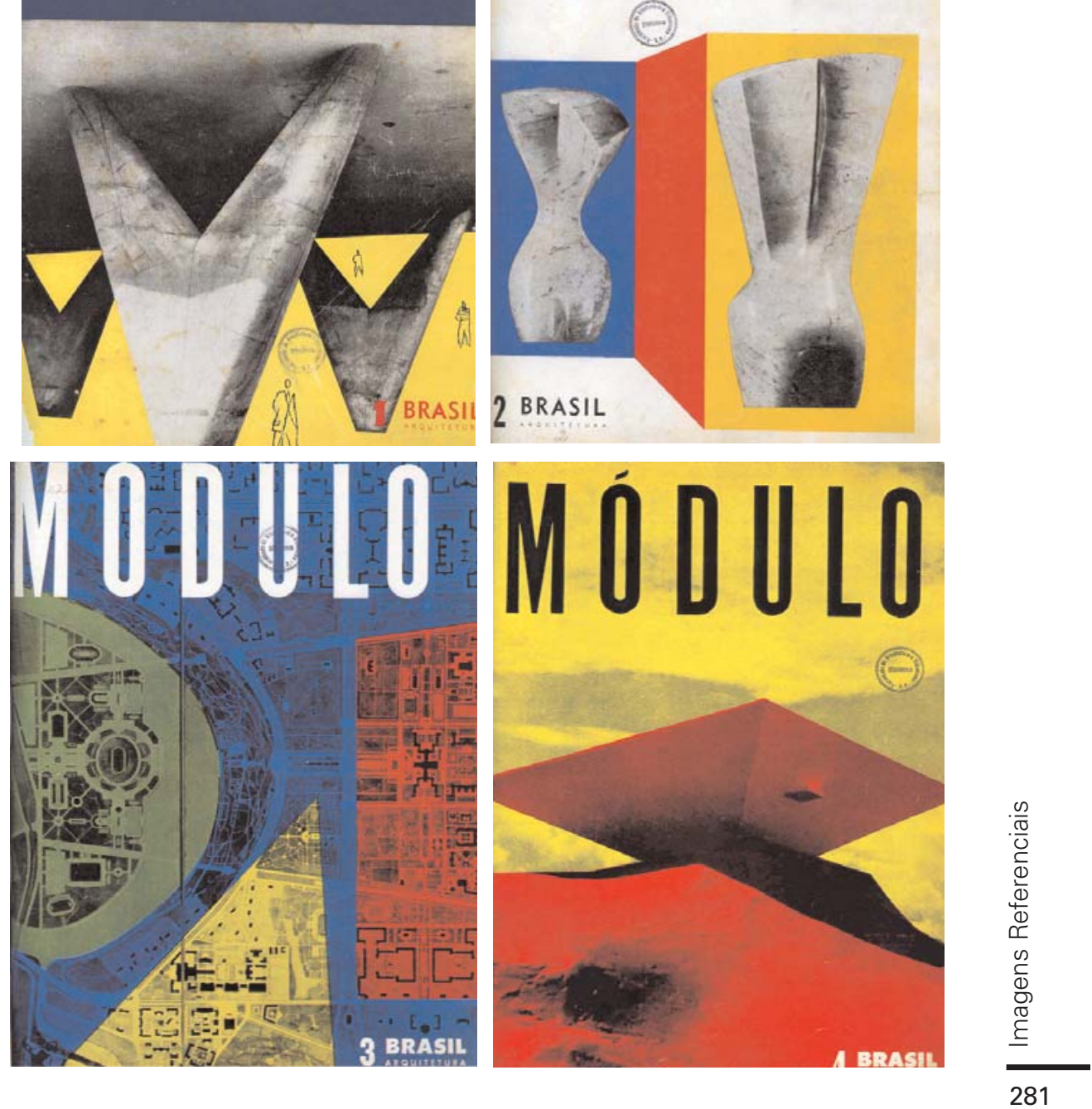